\title{
Van kolonie tot koninkrijksdeel : de staatkundige geschiedenis van de Nederlandse Antillen en Aruba van 1634 tot 1994
}

Citation for published version (APA):

van Aller, H. B. (1994). Van kolonie tot koninkrijksdeel : de staatkundige geschiedenis van de Nederlandse Antillen en Aruba van 1634 tot 1994. [Doctoral Thesis, Maastricht University]. WoltersNoordhoff. https://doi.org/10.26481/dis.19940908ha

Document status and date:

Published: 01/01/1994

DOI:

10.26481/dis.19940908ha

Document Version:

Publisher's PDF, also known as Version of record

Please check the document version of this publication:

- A submitted manuscript is the version of the article upon submission and before peer-review. There can be important differences between the submitted version and the official published version of record.

People interested in the research are advised to contact the author for the final version of the publication, or visit the DOI to the publisher's website.

- The final author version and the galley proof are versions of the publication after peer review.

- The final published version features the final layout of the paper including the volume, issue and page numbers.

Link to publication

\footnotetext{
General rights rights.

- You may freely distribute the URL identifying the publication in the public portal. please follow below link for the End User Agreement:

www.umlib.nl/taverne-license

Take down policy

If you believe that this document breaches copyright please contact us at:

repository@maastrichtuniversity.nl

providing details and we will investigate your claim.
}

Copyright and moral rights for the publications made accessible in the public portal are retained by the authors and/or other copyright owners and it is a condition of accessing publications that users recognise and abide by the legal requirements associated with these

- Users may download and print one copy of any publication from the public portal for the purpose of private study or research.

- You may not further distribute the material or use it for any profit-making activity or commercial gain

If the publication is distributed under the terms of Article $25 \mathrm{fa}$ of the Dutch Copyright Act, indicated by the "Taverne" license above, 


\section{Van kolonie tot Koninkrijksdeel}


Dissertatie-serie vakgroep Staatsrecht

Rijksuniversiteit Groningen

Redactie:

prof. mr. D.J. Elzinga 


\section{VAN KOLONIE TOT KONINKRIJKSDEEL}

De staatkundige geschiedenis van de Nederlandse Antillen en Aruba van 1634 tot 1994

\section{Proefschrift}

ter verkrijging van de graad van doctor aan de Rijksuniversiteit Limburg te Maastricht op gezag van de

Rector Magnificus Prof. dr. H. Philipsen volgens het besluit van het College van Dekanen in het openbaar te verdedigen op donderdag 8 september 1994 om 16.00 uur.

door

HENDRINA BERNARDA VAN ALLER

geboren te Ede 
Promotor: Prof. mr. C. Flinterman

Co-promotor: mr. dr. A.B. van Rijn (UNA)

Beoordelingscommissie:

Prof. mr. F.A.M. Stroink (voorzitter)

Prof. mr. drs. D.J. Elzinga (RUG)

Prof. mr. A.H.A. Soons (RUU)

Prof. mr. J.E. Spruit

Deze uitgave is tot stand gekomen, mede dankzij de financi ële steun van:

PRINS BERNHARD FONDS NEDERLANDSE ANTILLEN EN ARU BA

Copyright 1994 Wolters-Noordhoff bv Groningen, The Netherlands.

Alle rechten voorbehouden. Niets uit deze uitgave mag worden verveelvoudigd, opgeslagen in een geautomatiseerd gegevensbestand, of openbaar gemaakt, in enige vorm of op enige wijze, hetzij elektronisch, mechanisch, door fotokopieën, opnamen, of enige andere manier, zonder voora fgaande schriftelijke toestemming van de auteursrechthebbende.

Voorzover het maken van kopieën uit deze uitgave is toegestaan op grond van artikel 16B Auteurswet 1912 juncto het Besluit van 20 juni 1974, Stb. 351, zoals gewijzigd bij het besluit van 23 augustus 1985, Stb. 471 en artikel 17 Auteurswet 1912 , dient men de daarvoor wettelijk verschuldigde vergoedingen te voldoen aan de auteursrechthebbende. Voor het overnemen van gedeelte(n) uit deze uitgave in bloemlezingen, readers en andere compilatiewerken (artikel 16 Auteurswet 1912) dient men zich eveneens tot de auteursrechthebbende of de uitgever te wenden. 


\section{Verantwoording en dankbetuiging}

Het hoofdthema van deze studie is de staatkundige ontwikkeling van de Nederlandse Antillen en Aruba van 1634 tot heden. Op onderdelen is de geschiedenis daarvan beschreven door B. de Gaay Fortman, H.W.C. Bordewijk, J.A. Schiltkamp, R.A. Römer, A. Kasteel, W.H. van Helsdingen, C.Ch. Goslinga en vele anderen. Het verbindende element daarin ontbrak echter. Deze studie voorziet daarin.

De geschiedenis van de koloniale staatkundige ontwikkeling is zoveel mogelijk chronologisch weergegeven. Op sommige onderdelen is dat niet gebeurd, of omdat een bepaalde samenhang moest worden aangegeven, of omdat het betreffende onderwerp niet paste in een bepaalde tijdsperiode. Ten behoeve van het onderzoek naar de koloniale geschiedenis is ondermeer gebruik gemaakt van de indeling van de onderzoeksresultaten in bepaalde tijdsperioden, waarin zich bijzondere staatkundige ontwikkelingen voordeden.

Een voorbeeld van een 'afwijkende' indeling is de behandeling van de slavernij, die zich over meerdere tijdsperioden uitstrekt en dus niet ondergebracht kon worden in én tijdsperiode. Daarom wordt de slavernij in zijn geheel apart behandeld.

Over het algemeen zijn staatsrechtelijke werken, hoewel vaak wetenschappelijk buitengemeen verantwoord, niet ingericht om een levend beeld te scheppen van de dagelijkse politieke praktijk. Die praktijk leidt veelal tot leerstellige overzichten in staatsrechtelijke handboeken en geleerde verhandelingen. Het kan anders, zoals Kasteel en Goslinga laten zien. Bij lezing van hun werken kan men zich identificeren met de toen voor velen geldende werkelijkheid. Dit draagt bij tot een beter inzicht in de ontwikkeling van het staatsrecht. Deze werkwijze heb ik willen benaderen.

Daar deze studie moest worden uitgevoerd naast de dagelijkse werkzaamheden als wetenschappelijk medewerker Arubaans Staatsen Bestuursrecht aan de Universiteit van Aruba, was het niet mogelijk uitgebreid onderzoek te doen in het Algemeen Rijksarchief in Nederland of het Centraal Historisch Archief in Curaçao. Derhalve is gebruik gemaakt van alle beschikbare bronnen, literatuur en voor de recente ontwikkelingen eveneens van de artikelen in de plaatselijke 
pers. De staatkundige en politieke ontwikkelingen vinden daarin hun neerslag.

Mijn erkentelijkheid en dank gaan uit naar mijn promotor Prof. mr. C. Flinterman en mijn co-promotor mr. dr. A.B. van Rijn. Ook de leden van de Beoordelingscommissie Prof. mr. drs. D. J. Elzinga, Prof. mr. A.H.A. Soons, Prof. mr. J.E. Spruit en Prof. mr. F.A.M. Stroink wil ik danken voor hun steun en betrokkenheid.

In het bijzonder wens ik mijn collega mr. dr. M. Tratnik te bedanken voor het geduld dat hij opbracht om de concepten van het manuscript met buitengewoon grote nauwlettendheid te lezen en opbouwende kritiek te leveren. Dit geldt eveneens voor dr. H.E. Coomans, Maritza Coomans-Eustatia en drs. J.E. van Aller. Mr. dr. L.G.H. Hesselink verleende onontbeerlijke ondersteuning, waarvoor ik hem dankbaar ben.

Prof. mr. J.E. Spruit, lid van de Beoordelingscommissie, zeg ik speciaal dank voor de onderhoudende opmerkingen en de niet aflatende ondersteuning, die leidden tot subtiele verbeteringen van het manuscript. Eveneens wil ik mijn bijzondere erkentelijkheid uitspreken voor de jarenlange betrokkenheid en ondersteuning van Prof. mr. H.C.F. Schoordijk.

Veel dank ben ik verschuldigd aan de directrice en medewerksters van de Biblioteca Nacional van Aruba: Alice van Romondt, Susan de Lange, Betty Goeloe, Miriam Malmberg en Iraís Sanjatsung-Nava. Zonder hun steun en bereidwilligheid om het benodigde materiaal te zoeken en ter beschikking te stellen was mijn werk aanmerkelijk veel moeilijker geweest.

Eveneens wil ik mr. B. Nieuwenhuizen, directeur van het Kabinet van de Gouverneur van Aruba van 1989 tot juli 1993, bedanken. Zijn hulp in het verkrijgen van onvindbare rapporten was onontbeerlijk. Mijn dank gaat uit naar mr. P.D.O. Denz, die mij zijn persoonlijk archief ter beschikking stelde, eveneens dank ik mr. N.E. Henriquez voor zijn bereidwilligheid om mij inzage te verlenen in zijn archiefstukken.

Tevens wil ik mijn erkentelijkheid uitspreken voor de medewerking van mevrouw G.E.M. Maduro-Hassell, hoofd van het Nationaal Historisch Archief van Aruba, evenzeer wil ik de medewerkers van het Historisch Archief bedanken voor hun inzet. Ook drs. L. Alofs heeft mij ter zijde gestaan, met name in mijn zoektocht naar 'stukken' en naar de juiste definities.

Voor de ondersteuning van het College van Curatoren van de Univer- 
siteit van Aruba en speciaal van de rector van de Universiteit van Aruba, mr. drs. P. Pronk, wil ik mijn grote waardering en erkentelijkheid uitspreken.

Al mijn collega's ben ik dankbaar voor hun medewerking en opbeurende woorden. De bibliothecaresse van de universiteitsbibliotheek Felecita Loefstok-Croes wist altijd weer de noodzakelijke literatuur te vinden, al moest het hele eiland worden afgezocht. De heer $\mathrm{H}$. Hoepel was steeds bereid kopieerwerkzaamheden van unieke manuscripten te verrichten, ook al ontbrak hem de benodigde tijd.

Niet onvermeld mag blijven de onmisbare wetenschappelijke en feitelijke steun van Prof. mr. D.H. de Jong, mr. dr. A.E. Harteveld en Prof. mr. drs. D.J. Elzinga van de Rijksuniversiteit Groningen om de uitgave van dit proefschrift mogelijk te maken. De 'laatste loodjes' werden zoveel aangenamer door de spitsvondige en vooral waardevolle suggesties van mr. dr. A.E. Harteveld.

Mevrouw M. Pruissen-Kik, secretaresse van de vakgroep Staatsrecht van de Faculteit der Rechtsgeleerdheid van de Rijksuniversiteit Groningen, wil ik in het bijzonder bedanken voor het drukklaar maken van de tekst.

Voor het verzamelen van de benodigde fondsen wil ik Prof. mr. J.E. Spruit en mr. drs. P. Pronk in het bijzonder dank zeggen.

Ten slotte wil ik speciaal mijn dank betuigen aan mijn studenten uit Aruba, de Nederlandse Antillen, Suriname, Nederland en andere delen van de wereld. Van hen heb ik veel geleerd over de vroegere en huidige staatkundige en politieke situatie in de Nederlandse Antillen en Aruba. Zij tekenden voor mij de zo inspirerende dagelijkse staatkundige, politieke en bestuurlijke werkelijkheid. Daardoor kon $i k$ het verleden en heden beter begrijpen.

Aruba, juni 1994 


\section{Inhoudsopgave}

Gebruikte afkortingen XIII

Opbouw van het onderzoek 1

Inleiding 1

De probleemstelling van het onderzoek 4

De criteria voor evaluatie 6

Verantwoording van de methode 7

De indeling in tijdvakken 14

Korte inhoud 19

De Nederlandse kolonisatie van de West 21

Inleiding 21

2.2

De 'Nederlandse Antillen' 25

Overzicht Nederlands koloniaal bestuur Benedenwinden en Bovenwinden 27

Motieven voor de Europese expansie in de Nieuwe Wereld 32 Economische ontwikkeling 39

De West-Indische Compagnie 51

De periode 1634 tot 1792 (I) 52

De Tweede West-Indische Compagnie (1674-1792) 59

De Raad: samenstelling en bevoegdheden 62

2.6.2 Committé tot Zaken van de Coloniēn en Bezittingen (1795-1801) 82

2.6.3 De Raad der Amerikaansche Coloniën en Bezittingen (1801-1806) 83

2.7 Geen revolutie in de koloniën 86

2.8 Het tijdperk van de drie koloniën, de periode 1815-1828 (III) 87 
De slavernij in de Nederlandse koloniën 111

De slavernij 111

Behandeling van de slaven in de Nederlandse koloniën 113

De afschaffing van de slavernij 118

De slavenopstand op Curaçao 126

Samenvatting en conclusie 136

De periode van koloniale stabilisatie 1865-1936 (VI) 141

Regeringsreglement 1865141

Decentralisatie 149

Kannibalisme en kiesrecht op Curaçao 152

De nieuwe rechterlijke organisatie 155

Modernisering van de Rechterlijke Organisatie 159

Banden met het vasteland 164

4.6 .2

Verkoop van Curaçao aan Venezuela 169

4.7

De overval van Urbina 171

Grondwetswijziging 1922172

De Commissie Staal (1922) 178 de Nederlandse Antillen 204 
Commissie De la Try Ellis (1946) 223

Parlementaire Commissie Kropman (1947) 227

Commissie Van Helsdingen (1946) 229

Aruba en de autonomie 231

Eerste Ronde Tafel Conferentie 233

Commissie Van Poelje (1948) 235

Grondwetswijziging 1948238

\section{Verantwoordelijk bestuur 247}

6.1

De nieuwe rechtsorde 247

Nederlandse Antillen (1950) 249

De ERNA: geen zelfstandigheid voor de eilanden 264

Het hoogste gezag, wettelijke regelingen, fundamentele rechten en wijziging van het Statuut 283

De verhouding Staten-Regering-Gouverneur 286

Toetsing van de formele wet aan het Statuut 292

Toepassing van de Algemene Maatregel van Rijksbestuur op grond van grove verwaarlozing 294

Evaluatie Statuut 298

De Staatsregeling van de Nederlandse Antillen (1955) 302 Samenvatting en conclusie 304

Oorzaken en gevolgen van 30 mei 1969311 en verdere onderzoeken 329 
Het mislukken van de West-Indische federatie 349

Verdere vertraging van het proces tot de

Antilliaanse onafhankelijkheid 351

Onafhankelijkheid van Suriname 355

Samenvatting en conclusie 357

Economische en politieke ontwikkelingen 442

De ontbinding van de Staten van Aruba in 1988447

De samenwerking tussen Aruba en de Nederlandse Antillen 452

De Arubaanse Statenverkiezingen van 8 januari 1993458

Politieke ontwikkelingen in de Antillen 460

Modellen en meningen 461

De Gaay Fortman, Van der Grinten en Hoetink 461

De Werkgroep Dip en de Werkgroep Herstructurering

Nederlandse Antillen 466

Minderheden en meerderheden 472

De mislukking van een eilanden federatie 473

Wie vertolkt de mening van het volk 475 
Schets voor een Gemenebestconstitutie voor het

Koninkrijk der Nederlanden 478

9.10

9.11

9.12

9.13

9.14

9.15

9.16

9.17

9.18

9.19

9.20

10

10.1

10.2

10.3

10.4

10.4 .1

10.4 .2

10.4 .3

10.4 .4

10.4 .5

10.4 .6

10.5

Eilanden Unie 481

Associatieconstructie en samenwerking 483

Elk eiland een Status Aparte 486

Onafhankelijkheid, kroongewest en decentralisatie 487

Federale staatsvormen 494

Vergelijking staatsrechtelijke organen

Nederlandse Antillen, Aruba en Nederland 496

Het kiesstelsel 498

Het schrappen van artikel 62 Statuut 502

Nederlandse en Antilliaanse opvattingen over

de Koninkrijksverhoudingen 505

De Toekomstconferentie 510

Samenvatting en conclusie 516

Een les uit het verleden: een (con)federale structuur 525

De evaluatie-criteria 525

Een prognose 527

Een oplossing op termijn: de staatsrechtelijke federatie 537

De rechtsstaat, democratie en deugdelijk bestuur 545

De controle op het bestuur 549

De bescherming van de burger tegen overheidshandelen 550

Het recht op inspraak 551

Preventief en repressief toezicht en spontane vernietiging 552

Nieuwe vormen van hoger toezicht 553

Criteria voor hoger toezicht 556

Slot 563

Summary 567

Bronnen 587

Geraadpleegde literatuur 595

Personenregister 619

Zakenregister 625 


\section{Lijst van afkortingen}

$\begin{array}{ll}\text { AA } & \text { Ars Aequi } \\ \text { AB } & \text { Afkondigingsblad } \\ \text { AEP } & \text { Arubaanse Eenheidspartij } \\ \text { AD'86 } & \text { Accion Democratico '86 } \\ \text { ADN } & \text { Accion Democratico Nacional } \\ \text { AHATA } & \text { Aruba Hotel \& Tourism Association } \\ \text { A.J.V. } & \text { Antilliaanse Juristen Vereniging } \\ \text { ALM } & \text { Antilliaanse Luchtvaart Maatschappij } \\ \text { AMvB } & \text { Algemene Maatregel van Bestuur } \\ \text { AMvRB } & \text { Algemene Maatregel van Rijksbestuur } \\ \text { APV } & \text { Algemene Politieverordening } \\ \text { ASP } & \text { Accion Social Progresista } \\ \text { AV } & \text { Algemene Vergadering (van de VN) } \\ \text { AVP } & \text { Arubaanse Volkspartij } \\ \text { a.w. } & \text { aangehaald werk } \\ \text { art. } & \text { artikel } \\ \text { artt. } & \text { artikelen } \\ \text { ATIA } & \text { Aruba Trade \& Industry Association } \\ \text { AV } & \text { Algemene Vergadering van de Verenigde Naties } \\ \text { AVP } & \text { Arubaanse Volkspartij } \\ \text { AVV } & \text { Arubaanse vrijgestelde vennootschap } \\ \text { BC } & \text { Bestuurscollege (van een Eilandgebied) } \\ \text { B en W } & \text { Burgemeester en wethouders } \\ \text { C.A.B. } & \text { College van Algemeen Bestuur } \\ \text { CDA } & \text { Christen Democratisch Appel } \\ \text { CFW } & \text { Curaçaosche Federatie van Werknemers } \\ \text { COP } & \text { Curaçaosche Onafhankelijke Partij } \\ \text { CPIM } & \text { Curaçaosche Petroleum Industrie Maatschappij } \\ \text { CSM } & \text { Curaçaosche Stoomvaart Maatschappij } \\ \text { CMPA } & \text { Compañia Mexicana de Petroleo et Aguila SA; ook } \\ & \text { wel Arend Petroleum Maatschappij genoemd, of in } \\ \text { CPP } & \text { het Engels: 'Eagle' } \\ \text { CPU } & \text { Curaçaosche Protestantse Partij } \\ \text { CORONA } & \text { Curaçaosche Politieke Unie } \\ \text { CZW } & \text { Convergencia Royalista Nacional } \\ \text { D66 } & \text { Stafafdeling Constitutionele Zaken en Wetgeving van } \\ & \text { het Ministerie van Binnenlandse Zaken. } \\ & \text { Democraten 66 } \\ \end{array}$


DP

DPB

DSSE

EEG

ERNA

EVL

e.v.

FISSA

FOL

FTA

GBS

G.C.T.A.

GEA

GG

GHvJ

GPB

GS

GT

GW

HvJ

HR

IMF

ISS

IOUWA

jo

JPB

KABNA

KABNAA

KB

KP
Democratische Partij

Democratische Partij Bovenwinden

Departement Staatkundige Structuur Eilanden, dit was een landsdienst gevestigd op Aruba. De eilandelijke tegenhanger op Curaçao was het Bureau Staatkundige Structuur Curaçao (1981). Op Aruba was dat de afdeling Wetgeving en Constitutionele Zaken van de Eilandelijke Dienst Algemene en Juridische Zaken $(A J Z)$. Deze dienst was de eilandelijke poot van het landelijk departement Juridische en Algemene Zaken (JAZ)

Europese Economische Gemeenschap

Eilandenregeling Nederlandse Antillen

Eenvormige landsverordening

en verder

Full Internal Self Government Sint Maarten

Frente Obrero y Liberashon 30 di Mei

Federacion di Trahadornan di Aruba

Gouvernementsblad Suriname

Gemengde Commissie Toekomst Antillen

Gerecht in eerste aanleg

Gouverneur-Generaal

Gemeenschappelijk Hof van Justitie van de Nederlandse Antillen en Aruba (vanaf 1 januari 1986)

Groot Placcaat Boek

Gedeputeerde Staten

Geldende Tekst

Grondwet

Hof van Justitie van de Nederlandse Antillen (tot 1 januari 1986)

Hoge Raad

Internationaal Monetair Fonds

Institute of Social Studies

Independent Oil Union Workers of Aruba

juncto

Jurisprudentiebundel Antilliaanse en Arubaanse rechterlijke uitspraken Van Aller/Van Rijn

Kabinet van Nederlands Antilliaanse Zaken (tot 1 januari 1986)

Kabinet van Nederlands Antilliaanse en Arubaanse Zaken (na 1 januari 1986)

Koninklijk Besluit

Katholieke Partij 


$\begin{array}{ll}\text { KR } & \text { Koloniale Raad } \\ \text { KvK } & \text { Kamer van Koophandel } \\ \text { KVP } & \text { Katholieke Volkspartij } \\ \text { KWG } & \text { Koninkrijkswerkroep } \\ \text { LB h.a.m. } & \text { Landsbesluit houdende algemene maatregelen } \\ \text { LTU } & \text { Landsverordening Toelating en Uitzetting } \\ \text { MASA } & \text { Movimiento pa Adelante Social Antillano } \\ \text { MAN } & \text { Movimiento Antia Nobo } \\ \text { MEP } & \text { Movimiento Electoral di Pueblo } \\ \text { m.n. } & \text { met name } \\ \text { MSR } & \text { Ministeriële Samenwerkingsraad } \\ \text { MULO } & \text { Meer Uitgebreid Lager Onderwijs } \\ \text { MvA } & \text { Memorie van Antwoord } \\ \text { MvT } & \text { Memorie van Toelichting } \\ \text { NA } & \text { Nederlandse Antillen } \\ \text { NJ } & \text { Nederlandse Jurisprudentie } \\ \text { NJB } & \text { Nederlands Juristenblad } \\ \text { NP } & \text { Nos Patria } \\ \text { NVP } & \text { Nationale Volkspartij } \\ \text { NVP-U } & \text { Nationale Volkspartij-Unie, een verbinding met de } \\ \text { NWIG } & \text { URA (1971) } \\ & \text { Nieuwe West-Indische Gids sinds 1950 de opvolger } \\ \text { o.a. } & \text { van De West-Indische Gids (WIG) } \\ \text { OLA } & \text { onder andere } \\ \text { OM } & \text { Organisacion Liberal Arubiano } \\ \text { OvJ } & \text { Openbaar Ministerie } \\ \text { OvR } & \text { Officier van Justitie } \\ \text { PAN } & \text { Ordre van Regieringe } \\ \text { PAN } & \text { Partido Aruba Nobo } \\ \text { PAPU } & \text { Partido Provinsial of Provincie Antilliaanse Nederlan- } \\ \text { PAR } & \text { ders } \\ \text { PB } & \text { Partido di Pueblo } \\ \text { PBU } & \text { Publicatieblad } \\ \text { PDB } & \text { Partido Boneriano Uni } \\ \text { PPBU } & \text { Partido Progresista Boneriano Uni } \\ \text { PD } & \text { Partido Demokrat (Papiamentse naam van de Demo- } \\ & \text { cratische Partij) } \\ \text { Partido Democratico Arubiano } \\ \text { Partido Democratico Boneriano } \\ \text { Petroleos de Venezuela SA } \\ \text { Procureur-Generaal } \\ \text { Partido Independiente Arubiano } \\ \end{array}$




$\begin{array}{ll}\text { PNP } & \text { Partido Nashonal di Pueblo (Papiamentse naam voor } \\ \text { POB } & \text { NVP) } \\ \text { PPA } & \text { Partido Obrero Boneriano } \\ \text { PPB } & \text { Partido Patriotico Arubiano } \\ \text { PPBU } & \text { Partido Patriotico Boneriano } \\ \text { PSD } & \text { Partido Progresista Boneriano Uni } \\ \text { pp. } & \text { Partido Socialista Democratico } \\ \text { p. } & \text { pagina's } \\ \text { PAP } & \text { pagina } \\ \text { PAPU } & \text { Partido Autentico di Pueblo } \\ \text { PDO } & \text { Partido di Pueblo } \\ \text { POB } & \text { Partido Demokrat Outentiko } \\ \text { PPB } & \text { Partido Obrero Boneriano } \\ \text { PPL } & \text { Partido Progresista Boneriano } \\ \text { PPN } & \text { Partido Popular Liberal } \\ \text { PPN } & \text { Partido Patriotico Nacional } \\ \text { PPR } & \text { Partido Patriotico Nobo } \\ \text { PRO } & \text { Politieke Partij Radicalen } \\ \text { PRP } & \text { Partido Revolucionario Obrero } \\ \text { RR } & \text { Partido Radical di Pueblo } \\ \text { PS } & \text { Regeringsreglement } \\ \text { PSD } & \text { Provinciale Staten } \\ \text { RM Themis } & \text { Partido Social Democraat } \\ \text { RTC } & \text { Rechtsgeleerd Magazijn Themis } \\ \text { PvdA } & \text { Ronde Tafel Conferentie } \\ \text { RUBA } & \text { Partij van de Arbeid } \\ \text { RvA } & \text { Reformistanan Uni pa Bienestar di Aruba } \\ \text { RvS } & \text { Raad van Advies } \\ \text { RUG } & \text { Raad van State } \\ \text { RUL } & \text { Rijksuniversiteit Groningen } \\ \text { RUU } & \text { Rijksuniversiteit Limburg } \\ \text { SI } & \text { Rijksuniversiteit Utrecht } \\ \text { Soponata } & \text { Partido Social Independiente } \\ \text { SPA } & \text { Sociedade Portugesa de Navios Tanques Ltda } \\ \text { SWR } & \text { Sint Maarten Patriotic Alliance } \\ \text { Stb. } & \text { Samenwerkingsregeling } \\ \text { Stcr. } & \text { Staatsblad } \\ \text { TAR } & \text { Staatscourant } \\ \text { TvO } & \text { Tijdschrift voor Antilliaans Recht } \\ & \text { voor1-1-1975:Tijdschrift voorOverheidsadministra- } \\ \text { TOSM } & \text { tie } \\ & \text { Topoverleg Sint Maarten } \\ & \end{array}$




$\begin{array}{ll}\text { ULO } & \text { Uitgebreid Lager Onderwijs } \\ \text { UA } & \text { Universiteit van Aruba } \\ \text { UD } & \text { Union Democraat } \\ \text { UNA } & \text { Union Nacional Arubiano } \\ \text { UNA } & \text { Universiteit van de Nederlandse Antillen } \\ \text { UPB } & \text { Union Patriotico Boneriano } \\ \text { URA } & \text { Union Reformista Antilliano } \\ \text { USA } & \text { United States of America } \\ \text { vgl. } & \text { vergelijk } \\ \text { VN } & \text { Verenigde Naties } \\ \text { VN } & \text { Vrij Nederland } \\ \text { VOC } & \text { Verenigde Oost-Indische Compagnie } \\ \text { VS } & \text { Verenigde Staten } \\ \text { vs } & \text { versus } \\ \text { VVD } & \text { Volkspartij voor Vrijheid en Democratie } \\ \text { WESCAR } & \text { Werkspoor Caribbean } \\ \text { WIC } & \text { West-Indische Compagnie } \\ \text { WIG } & \text { De West-Indische Gids } \\ \text { WIPM } & \text { Windward Islands Peoples Movement } \\ \text { WIPP } & \text { Windward Islands Peoples Party } \\ \text { z.j. } & \text { zonder jaartal } \\ \text { z.p. } & \text { zonder plaatsnaam } \\ \text { z.u. } & \text { zonder uitgever }\end{array}$





\section{Opbouw van het onderzoek}

Het Koninkrijk der Nederlanden bestaat sinds 1 januari 1986 uit drie landen: Nederland, de Nederlandse Antillen en Aruba. De landen regelen zelfstandig hun eigen aangelegenheden. Sinds Aruba de Status Aparte kreeg, de Antilliaanse constellatie verliet en als land in het Koninkrijk werd opgenomen, is het verband van de Nederlandse Antillen aan erosie onderhevig geweest. Sinds het begin van de jaren negentig wenst Curaçao ook een aparte status, deze wens is versterkt door de Nederlandse toezegging dat Aruba niet langer onafhankelijk hoeft te worden. Curaçao wil niet langer verantwoordelijk zijn voor de kleine eilanden: Bonaire, Sint Maarten, Saba en Sint Eustatius. Sinds 1986 worden weer verhitte discussies gevoerd over de toekomstige staatkundige verbanden van de Nederlandse Antillen. Daarbij hield Aruba zich afzijdig, daar het eiland zonder de andere eilanden van de Nederlandse Antillen aan zijn ontwikkeling begon. De afspraak tussen Nederland, de Nederlandse Antillen en het eiland Aruba was dat na 10 jaren Status Aparte, Aruba onafhankelijk zou worden. Dat was de prijs die Aruba moest betalen voor een aparte status, los van de Nederlandse Antillen. Dit werd vastgelegd in art. 62 van het Statuut, de geschreven constitutie van het Koninkrijk der Nederlanden.

Naar aanleiding van de Toekomstconferentie gehouden in maart 1993 en de te verwachten vervolgconferenties is de toekomstige staatkundige structuur van het Koninkrijk der Nederlanden weer actueel. De staatkundige structuur heeft altijd een belangrijke rol gespeeld in de staatkundige geschiedenis van de Nederlandse Antillen en Aruba. Vanwege de kleinschaligheid van elk eiland en ook van de landen spelen die ontwikkelingen zich dichter bij de burger af. De discussies over de Toekomstconferentie leidden tot grote meningsverschillen tussen Nederland, de Nederlandse Antillen en Aruba. Ook intern waren de Nederlands-Antilliaanse en Arubaanse politici verdeeld over de in te nemen standpunten op de Toekomstconferentie. De oorzaak hiervan was dat premier Lubbers die de Toekomstconferentie voorzat, aangaf dat Nederland deugdelijk bestuur in de Nederlandse Antillen 
en Aruba een voorwaarde achtte voor de onderhandelingen over een nieuwe staatkundige structuur van de Nederlandse Antillen. Nederland wenste over behoorlijk bestuur te praten, de Nederlandse Antillen en Aruba wilden over een nieuwe Koninkrijksstructuur spreken en wensten dat niet te koppelen aan 'deugdelijk bestuur'.

Gelijktijdig met de discussies over de Toekomstconferentie, kreeg Sint Maarten wegens jarenlange verwaarlozing van het eigen bestuur te maken met een maatregel van Koninkrijkstoezicht. ${ }^{1}$ Deze maatregel hield in, dat vanwege het Koninkrijk streng toezicht vooraf zou worden uitgeoefend op het overheidshandelen van Sint Maarten. Het toezicht op het overheidshandelen in Sint Maarten had normaal gesproken moeten worden uitgeoefend door de landsregering. Daar echter de zittende landsregering de steun nodig had van de politieke leiders van Sint Maarten, kwam er van ingrijpen van de landsregering in het overheidshandelen van Sint Maarten niet veel terecht. Het slechte bestuur op Sint Maarten is dus ook te wijten aan de landsregering en de Staten van de Nederlandse Antillen. De AMvRB leidde begrijpelijkerwijs bij de politici tot grote ontevredenheid. Nederland werd kolonialisme verweten. De invoering van de AMvRB voor Sint Maarten geeft aan dat de nieuwe interpretatie van het Statuut de autonomie van het Koninkrijk overzee aanmerkelijk kan beperken. ${ }^{2}$

Te verwachten valt dat voorlopig de meest ingrijpende verande-

1 Algemene Maatregel van Rijksbestuur (AMvRB), Besluit van 2 februari 1993, houdende enkele tijdelijke voorzieningen in het bestuur van het eilandgebied Sint Marten van de Nederlandse Antillen, Stb. 1993, 72. Zie voor de vóórgeschiedenis van de invoering van de maatregel: Van Aller, college staatsrecht 18 november 1992 , naar aanleiding van het Koninklijk bezoek aan Aruba, Universiteit van Aruba.

2 Oostindie (1992). Hirsch Ballin bracht in de 'Schets' in 1990 naar voren dat Aruba niet meer onathankelijk behoefde te worden. De Nederlandse Antillen zouden gesplitst moeten worden in een Bovenwinds- en Benedenswinds deel. Curaçao zou toezicht moeten houden op Bonaire en Sint Maarten op Saba en Sint Eustatius. Oostindic meende dat de 'Schets' van Hirsch Ballin rekolonisatie inhoudt en vroeg zich af of strenger toezicht op de overzeese Koninkrijksdelen wel past in de opzet van het huidige Statuut, waarin de Landen autonoom hun eigen aangelegenheden behartigen. Bovendien is hij van mening dat impliciet de gevolgen van de 'Antillianisering' sinds de jaren '70 als teleurstellend worden gekwalificeerd door Hirsch Ballin. De kwaliteit van het landsbestuur en het eilandsbestuur zou te wensen over laten. Indien de invloed van Nederland in de West zal toenemen, zou dat kunnen leiden tot toenemende spanningen. Oostindie voorspelt een verdere desintegratie van de Nederlandse Antillen. De vorm waarin dat zal gebeuren zal, volgens hem, nog een harde strijd opleveren. Het nieuwe Statuut zal de West meer integreren in het Koninkrijk, dan voorheen het geval was. Het artikel besluit met de essentie van de vraag waarom de Nederlandse Antillen en Aruba (nog) niet onathankelijk willen worden: "The Dutch presence will guarantee a relatively favourable, economic profile, territorial integrity and stable democracy". Ook al zal de Nederlandse invloed toenemen, dan hoeft dat geen rekolonisatie in te houden, daar met rekolonisatie wordt bedoeld verrijking van het moederland en daarvan is allang geen sprake meer.

2. Opbouw van het onderzoek 
ringen in de Koninkrijksverhoudingen zich zullen voordoen op het beheersmatige niveau en niet op het staatsrechtelijke niveau. De Nederlandse regering en het Nederlandse parlement zijn de mening toegedaan, dat een staatsrechtelijke structuur alleen kan functioneren als er sprake is van behoorlijk bestuur en daaraan ontbreekt het nu juist in de Nederlandse Antillen en Aruba.

Omdat behoorlijk bestuur, volgens Nederland, ontbreekt en het eilandgebied Curaçao en het Land de Nederlandse Antillen gezamenlijk een schuld hebben opgebouwd van 2.5 miljard gulden liet Nederland op de Toekomstconferentie van maart 1993 weten, dat de deugdelijkheid van bestuur, de rechtszekerheid en het financieel beheer van de Nederlandse Antillen en in mindere mate Aruba, aanzienlijk zouden moeten verbeteren, voordat Nederland een nieuwe staatkundige structuur zou willen bespreken.

Bovendien bleek dat Nederland niet zou aarzelen AMvRB's in te voeren, indien er niet met spoed verbetering zou optreden in het overheidshandelen. Deugdelijk bestuur bleek van overheersend belang te zijn geworden. Begrijpelijk is dat wel, daar Nederland te kampen heeft met een ernstige recessie en grote werkloosheid, dus ook let op het geld dat wordt uitgegeven aan het Koninkrijk overzee. Nu de Arubaanse onafhankelijkheid van de baan lijkt, neemt de Nederlandse behoefte toe om orde op zaken te stellen in het Koninkrijk overzee. Dit was politiek noodzakelijk om het nieuwe beleid ten opzichte van het Koninkrijk overzee in Nederland te legitimeren.

Daar voor de toekomstige staatkundige structuur werkbare en vooral realistische oplossingen moeten worden gevonden, is het van belang het verleden te bestuderen en te onderzoeken, welke modellen werden voorgesteld en waarom zoveel modellen niet werkten in de praktijk.

Vele auteurs hebben in het verleden gedeelten van de staatsrechtelijke geschiedenis van de voormalige Nederlandse kolonie 'Curaçao en onderhorigheden' in kaart gebracht. Niemand heeft echter de staatkundige geschiedenis in het verleden geanalyseerd om vast te kunnen stellen of invloeden van het Nederlandse bestuur uit de koloniale tijd en de langzame ontwikkeling naar een parlementaire democratie, thans nog knelpunten kunnen opleveren voor de huidige en gewenste staatkundige structuur van de Nederlandse Antillen en Aruba.

Het belang van dit onderzoek is drieërlei. Ten eerste wordt systematisch informatie verzameld over het ontstaan van het staatkundig systeem van de Nederlandse Antillen en Aruba en wordt nagegaan welke factoren invloed hebben uitgeoefend op het ontstaan van de parlementaire democratie in de voormalige kolonie. Ten tweede wordt bestudeerd hoe deze factoren een specifieke ontwikkeling van het 
staatkundig en politiek verband in de Nederlandse Antillen en Aruba tot gevolg hadden en hoe deze ontwikkeling ten slotte leidde tot het uit elkaar vallen van het Antilliaanse verband. Ten derde kunnen uit het voorgaande conclusies worden getrokken die behulpzaam kunnen zijn bij het doen van aanbevelingen voor de huidige staatkundige structuur van het Koninkrijk der Nederlanden. Een belangrijk voordeel van deze aanpak is dat de staatkundige geschiedenis van de Nederlandse Antillen en Aruba zo in historisch perspectief verduidelijkt kan worden. Daar deze aanpak niet eerder werd ondernomen voor het geheel, ontbrak een algemeen inzicht in de staatkundige vormgeving van de Nederlandse Antillen en Aruba en de invloed van het Nederlands bestuur daarop. Dit onderzoek kan daarin voorzien.

Doel van het onderzoek is het beschrijven, analyseren, systematiseren en interpreteren van het Nederlands-Antilliaanse en Arubaanse staatsrecht in relatie tot de relevante staatkundige geschiedenis van Nederland. Door de uitkomsten van het onderzoek kan meer inzicht worden verkregen in de factoren waarmee bij het kiezen van oplossingen voor de staatkundige toekomst van de Nederlandse Antillen en Aruba rekening moet worden gehouden. De antwoorden op de probleemstelling van het onderzoek kunnen in hun onderlinge samenhang uitsluitsel geven over de staatkundige en bestuurskundige problemen van de Nederlandse Antillen en Aruba, waarmee het Koninkrijk thans worstelt. Tevens kunnen op grond van de conclusies van het onderzoek aanbevelingen worden gedaan voor een nieuwe staatkundige structuur van het Koninkrijk.

\section{De probleemstelling van het onderzoek}

Bij de vraag wat het probleem is dat zal worden onderzocht, komt vooral aan de orde of een helder omschreven probleemstelling gemaakt kan worden. De helderheid wordt bevorderd wanneer het probleem als een vraag wordt gesteld, waarop een antwoord moet komen. Dit betekent dat veelal de vraag de vorm krijgt van boe een bepaald probleem opgelost moet worden. Het onderwerp van het onderzoek en de bijbehorende vraagstelling worden in drie fasen geformuleerd. Het blootleggen van de redenen waarom iets een probleem is, helpt niet alleen om de probleemstelling scherper te formuleren, maar tevens om aan te geven aan welke criteria de oplossingen moeten voldoen. Omdat de onderzoeker bij het oplossen van een probleem veelal met meerdere partijen te maken heeft, is het van essentieel belang vast te stellen of partijen het probleem op dezelfde of verschillende wijze zien. Als een probleem verschillend 
gezien wordt, kan dit een probleem op zich vormen. De probleemstelling voor het onderzoek wordt als volgt geformuleerd:

1. Wat is de invloed geweest van het Nederlands koloniaal bestuur en de Nederlandse staatkundige ontwikkeling op de huidige staatkundige structuur van de Nederlandse Antillen en Aruba?

2. Welke invloeden uit het verleden hebben geleid tot de Status Aparte van Aruba en hoe beīnvloedde vervolgens de toekenning van de Status Aparte aan Aruba de staatkundige structuur van Aruba en de Nederlandse Antillen binnen het Koninkrijk?

3. Zijn uit het voorgaande conclusies te trekken en aanbevelingen te doen voor een algemeen aanvaarde toekomstige staatkundige structuur van de Nederlandse Antillen en Aruba?

Veel problemen hebben verschillende aspecten, die gedeeltelijk via de voorgaande vragen aan de orde zijn gesteld. Deze gegevens kunnen op verschillende manieren worden gegenereerd, bijvoorbeeld door middel van verkenning van de literatuur. De vraag naar de oorzaken van het probleem loopt vooruit op het opstellen van een verklarend model. Een goede manier om eenvoudige verklaringen op te stellen voor een probleem is een dubbele vraag te stellen: waardoor wordt het probleem veroorzaakt en via welk proces brengen de oorzaken het probleem tot stand? De vraag naar de oplosbaarheid van het probleem heeft vooral betrekking op de vraag waarom partijen voor wie het probleem een probleem is zelf het probleem nog niet opgelost hebben. Kan men het niet of wil men het niet? Ook moet de onderzoeker zich de vraag stellen of het wenselijk is om het probleem op te lossen. Binnen de probleemstellingsfase wordt de hele toepassingsen oplossingscyclus in miniatuur doorlopen. Daarnaast zal bij de uitwerking van het probleem tot probleemstelling blijken dat sommige antwoorden die bij een bepaalde vraag naar voren komen, tevens als antwoord voor andere vragen dienen. De uiteindelijke formulering van de probleemstelling blijft beperkt tot een duidelijke omschrijving wat het probleem is, voor wie het een probleem is en wat de belangrijkste aspecten zijn.

Onderzocht zal worden welke factoren hebben bijgedragen tot de staatkundige structurering van een koloniale maatschappij, welke knelpunten dat opleverde en welke specifieke factoren thans nog een rol spelen bij de staatkundige herstructurering van het Koninkrijk der Nederlanden.

De onderlinge relaties tussen de verschillende aspecten worden idealiter aan de hand van een theoretisch model opgesteld. Om geschikte antwoorden op de onderzoeksvragen te kunnen geven, moet 
zoveel mogelijk bekend zijn over de gehanteerde begrippen en hun onderlinge relaties of samenhang. ${ }^{3}$ De begrippen en hun onderlinge relaties die bij de onderzoeksvragen een essentiële rol spelen zijn: de kolonisatie, de opbouw van de staatsorganen, de verdeling van overheidsmacht en de scheiding van machten, de invloed van het Nederlandse bestuur op het bestuur van de kolonie en de inbreng van de bevolking van de kolonie in het lokale bestuur. Uit de onderlinge samenhang van de gehanteerde begrippen kunnen ook de evaluatiecriteria worden afgeleid.

Op grond van de geformuleerde probleemstelling wordt onderzoek gedaan naar de economische ontwikkeling van de koloniën, de opbrengsten voor het moederland, de rechtsbedeling, de invloed van de burgers in het bestuur, de verdeling van macht over de verschillende bevolkingsgroepen, de mate van naleving van mensenrechten in de koloniale tijd en de post-koloniale periode en de ontwikkeling van een koloniale maatschappij naar een parlementaire democratie. Van belang in de post-koloniale periode is de ontwikkeling van het zelfbeschikkingsrecht, zoals geformuleerd door de Verenigde Naties en de specifieke interpretatie van het zelfbeschikkingsrecht door Nederland, de Nederlandse Antillen en Aruba.

De genoemde begrippen met hun onderlinge relaties worden bestudeerd tegen de achtergrond van de West-Europese ontwikkeling van het staatsrechtelijk denken en de invloed die het Nederlandse staatsrechtelijk systeem heeft gehad op de staatsrechtelijke ontwikkeling in het Caraibisch deel van het Koninkrijk.

De criteria voor evaluatie

Het onderzoeksmateriaal, voorgestructureerd zoals hierboven omschreven, wordt vervolgens bestudeerd aan de hand van een aantal thema's of criteria voor evaluatie. Die criteria zijn ontleend aan belangrijke staatsrechtelijke beginselen, die naar voren kwamen bij het analyseren van de probleemstelling. Die thema's zijn:

- de invloed van het Nederlands bestuur op het bestuur van de kolonie;

- de opbouw van de staatsorganen en de binding van de staat aan het recht;

- de verdeling van de overheidsmacht;

- het zoeken van het juiste evenwicht tussen ordening van de

3 Hakkenberg (1981) pp. 126-133; Veen (1985). 
samenleving en individuele vrijheid;

- de verhouding burger-bestuur, waarbij inspraak van de burgers in het bestuur, het naleven van de mensenrechten en de rechtsbescherming van de burger tegen de overheid van belang zijn;

- tevens werden klasseverschillen, kleurverschillen en de invloed van de slavernij bij de toekenning van politieke rechten, plichten en privileges in elke periode onderzocht.

De starre, sterk gesegmenteerde koloniale samenleving heeft grote invloed gehad op de moderne Antilliaanse en Arubaanse maatschappij en is daaruit nog niet verdwenen. Ook heeft de machtsverdeling binnen die maatschappij en het ingevoerde kiessysteem het ontstaan van het politieke patronagesysteem bevorderd. De gevolgen daarvan waren belangrijke agendapunten op de Toekomstconferentie van maart 1993.

Niet in alle perioden kwamen dezelfde verschijnselen in gelijke mate voor. De werking van het stemrecht en de ontwikkeling van de parlementaire democratie konden pas na 1936 worden onderzocht, evenals het daarmee gelijktijdig ontstaan van het patronagesysteem, dat grote overeenkomst vertoont met een 'aangepast' feodaal systeem. De politiek in de Nederlandse Antillen en Aruba kent een eigen ontwikkeling door de sterke nadruk op persoonlijke relaties en de neiging tot politisering van elk vraagstuk.

De ontwikkeling van de parlementaire democratie vond in de Nederlandse Antillen pas plaats tussen 1936 en 1954, honderd jaar na diezelfde ontwikkelingen, onder gunstiger omstandigheden, in het moederland. Het overplaatsen van een aangepast Nederlands parlementair systeem in de voormalige kolonie bracht specifieke problemen met zich mee, die tot op de huidige dag hun invloed laten gelden.

\section{Verantwoording van de methode}

Nadat de probleemstelling van het onderzoek is geformuleerd en de onderzoekscriteria zijn vastgesteld, zal de te hanteren onderzoeksmethode ${ }^{4}$ moeten worden gekozen.

De staat kan bestudeerd worden vanuit een sociologisch of politicologisch standpunt, vanuit een juridische opvatting of vanuit een staatsfilosofische opvatting. De staatsrechtwetenschap bestudeert het wezen en functioneren van de staat en omvat meerdere perspectieven. De staat kan daartoe op verschillende manieren wetenschappe- 
lijk worden benaderd. Indien vanuit een juridische opvatting naar de staat wordt gekeken gaat het niet om de feitelijke macht binnen de staat, maar om de juridische bevoegdheidstoedeling binnen de staat. ${ }^{5}$

De benadering van de staat kan sociaal-wetenschappelijk van aard zijn. Bij een dergelijke benadering wordt niet in de eerste plaats gelet op gedragsregels, maar op gedragspatronen. De socioloog heeft niet het juridisch 'behoren of moeten' tot onderwerp van onderzoek maar de maatschappelijke werkelijkbeid, het sociale 'zijn'.

Sociale wetenschap toegepast op politieke processen pleegt men politicologie te noemen. Deze wetenschap houdt zich bezig met de sociale interacties waardoor bindende beleidsbeslissingen tot stand komen. Dit brengt mee de bestudering van karakteristieken van personen die in het politieke proces een rol spelen, van de stabiliteit van politieke stelsels, van de invloed van politieke partijen op de besluitvormingsprocessen en van de betekenis van pressiegroepen etc. ${ }^{6}$ Vooral sinds de Tweede Wereldoorlog is de bestuurskunde of bestuurswetenschap in opkomst. Deze in Amerika vanuit de sociologische benadering ontstane wetenschap (public administration) concentreert zich op het openbaar bestuur en poogt dat via een interdisciplinaire benadering te onderzoeken.

De wijsgerige benadering van de staat of de staatsrechtfilosofie vraagt naar het waarom van de staat. ${ }^{7}$ Een belangrijke vraag is of en waarom de staat aanspraak kan maken op gehoorzaamheid aan regels. De staatsrechtfilosofie onderzoekt niet de legaliteit van het overheidshandelen (daarmee wordt bedoeld overeenkomstig de geldende regels optreden), maar de legitimiteit daarvan te weten de uiteindelijk rechtvaardiging van die regels. Politieke theorieēn hangen meestal nauw samen met staatsfilosofische opvattingen. Ook als zij wetenschappelijk gezien verouderd zijn, oefenen zij vaak nog een grote invloed uit, bijvoorbeeld omdat de inrichting van het staatsbestel door een dergelijke theorie beïnvloed kan zijn. Montesquieu's trias leer en de Amerikaanse constitutie zijn daar een voorbeeld van. De ideeennwereld van waaruit leidende politici denken is vaak ook gekleurd door bepaalde theorieen over hoe de staat zou behoren te functioneren. De volgende methoden om de staat te bestuderen kunnen

s Van der Pot/Donner/Prakke (1989) p. 199 e.v. Van der Pot-Donner geeft op genoemde bladzijden een goed overzicht van de methoden die sinds 1782 zijn toegepast op de beoefening van het staatsrecht en het daardoor op een specifieke wijze beschrijven van de staat.

6 Sabine en Thorston (1973); Van der Land (1953).

Deze gedachtengang is uiteengezet in drie dialogen van Plato. Zie daarvoor: Plato, Verzameld werk (1980) I-V, II, De Staat, pp. 69-517, De Staatsman, pp. 519-611, IV, De Wetten, pp. 93-613; Friedrich (1963). 
worden gehanteerd:

1. de sociologische benadering van de staat bestudeert hoe bepaalde groeperingen binnen het staatsbestel zich gedragen en wat voor invloed dat heeft op de politieke ontwikkeling. Met name is van belang welke groepen binnen de staat de macht hebben, welke redenen daarvoor zijn en welke strategieën noodzakelijk zijn om die macht te behouden;

2. de wijsgerige benadering van de staat onderzoekt welke rechtvaardiging bestaat voor het staatsgezag, de morele gronden van gehoorzaambeid aan het staatsgezag worden geëxpliciteerd;

3. de politicologische methode onderzoekt de strijd om de macht in de staat, welke middelen van machtsvorming toegepast worden door de groepen die de macht hebben of willen verkrijgen, hoe groepen hun macht uitoefenen en welke gevolgen dat heeft. Ook wordt gekeken naar de gezaghebbende toedeling van waarden binnen de staat. De politicologie bestudeert de staat als een centrum van beslissingen, die het maatschappelijk leven beïnvloeden en waarvan de naleving kan worden afgedwongen. ${ }^{8}$

De staat vanuit het juridisch perspectief bekeken leidt tot bestudering van het staatsrecht op de volgende manieren: ${ }^{9}$

4. de juridisch-dogmatische methode past de logica toe in combinatie met de rechtswetenschap. Deze methode kan tot een volledig begrijpen van het staatsrecht leiden. Vanuit de rechtsregels (inductief) worien algemenere leerstukken afgeleid, die leiden tot bepaalde conclusies. Die conclusies kunnen weer oplossingen aandragen voor nieuwe rechtsvragen. Deze methode is gericht op het beschrijven, analyseren, systematiseren en interpreteren van het geldende of positieve recht. De functie van de rechtsdogmatiek is het bereiken van normatieve oordelen. Empirischtheoretische wetenschappen hebben een geheel andere functie, dan het bereiken van normatieve oordelen. Deze wetenschappen ontwikkelen uitspraken met het doel te verklaren. Dit betekent dat bepaalde feiten duidelijk kunnen worden aangemerkt als de oorzaken of voorwaarden voor een andere reeks van feiten. De empirie richt zich op de waarneembare feiten en niet op waarden

Merton (1986); Kuypers (1976); Therborn (1982); Rosenthal e.s. (1977).

Staatsrechtconferentie 1982; Staatsrechtconferentie 1983. 
en normen. ${ }^{10}$

5. de historisch-juridische methode verklaart het positieve recht vanuit de geschiedenis. Het wordt onmogelijk geacht het huidige constitutionele recht te begrijpen zonder onderzoek te hebben gedaan naar de historische achtergronden. Bestaande rechtsvragen worden volgens die methode beantwoord door de ontstaansgeschiedenis van de specifieke regel te bestuderen. Vrijwel alle staatsrechtelijke handboeken hanteren deze methode;

6. de historisch-systematische methode gaat uit van een beschrijving van het bestaande recht en de opbouw van het groeiende recht. Onderzoek volgens deze methode vindt plaats aan de hand van bepaalde grondregels die systematisch in verleden en heden op bepaalde verschijnselen procesmatig worden toegepast. Het staatsrecht zou zich, volgens deze methode, moeten richten op het ontwikkelen van systematische begrippen en universeel geldende regels die toegepast kunnen worden om situaties en oplossingen te toetsen. Belinfante ${ }^{11}$ formuleerde een aantal regels waaraan elke staatsorganisatie zou moeten voldoen:

- geen orgaan heeft een bevoegdheid zonder grondslag in de wet of de Grondwet (legaliteitsbeginsel);

Naar de mening van $H$.Th.J.F. van Maarseveen, zijn de jaren negentig het decennium van de ethiek. Het recht is wel basis voor het gedrag, maar biedt niet langer een ethisch perspectief. Het recht vormt geen morele categorie meer maar is teruggekeerd naar de oude plaats van amoreel en gebrekkig ordenings- en sturingsmechanisme. De juristen zijn de regel- en schakeltechnici van een openbaar nutsbedrijf. In de behoefte van de samenleving aan normatieve oriëntaties en dat is niets anders dan een behoefte aan gebods-en verbodsregels, blijkt buiten het recht om voorzien te gaan worden, NRC Handelsblad, Weekeditie, 20 april 1993. Van Maarseveen is steeds de mening toegedaan geweest dat het menselijk handelen binnen het staatsrecht centraal staat. Daardoorheeft hij een vernieuwende invloed gehad op het staatsrechtelijk onderzoek. Hirsch Ballin heeft een klassieke opvatting van het staatsrecht. Volgens Hirsch Ballin is de gelding van het staatsrecht dat een bepaalde rechtsorde in het leven roept bij gebrek aan een aanwijsbare erkenningsregel begrepen in het feitelijke bestaan van die rechtsorde. Omdat de burgers die ordening accepteren is er sprake van een rechtsordening. Naar zijn mening eindigt de taak van de staatsrechtwetenschap, daar waar de geldende constitutionele rechtsnormeneen rechtsuetrekking niet nader bepalen, zie: Hirsch Ballin (1991) pp. 93-116, met name de pp. 104-111. Tevens is Hirsch Ballin de mening toegedaan, dat het morele gehalte van de maatschappij ernstig is afgenomenen dat een 'ethisch reveil' noodzakelijk is. Hirsch Ballin is van mening dat een wettelijke regeling de burger tot gehoorzaamheid kan aanzetten en tevens dan de noodzakelijke rechtsorde constitueert. Hij heeft in zijn hoedanigheid van minister van Nederlands-Antilliaanse- en Arubaanse Zaken steeds duidelijk gemaakt dat hij van de Nederlandse Antillen en Aruba "deugdelijk bestuur" verwachtte. Van Maarseveen is van mening dat wettelijke regelingen door de toenemende bureaucratie en ondoorzichtigheid geen aanspraak meer kunnen maken op gehoorzaamheid. Zie ook: Van Maarseveen (1971); Staatsrechiconferentie 1982; Staatsrechtconferentie 1983.

Belinfante en De Reede (1987) pp. 20-25. 
- over de uitoefening van elke bevoegdheid moet verantwoording worden afgelegd (ministeriële- en parlementaire verantwoordelijkheid);

- de verantwoording is alleen verschuldigd over de toegekende bevoegdheid.

7. de systeemtheoretische methode is afkomstig uit de biologie en natuurwetenschappen. Het recht wordt gezien als een beslissingssysteem, met in elkaar grijpende onderdelen. Bestudeerd wordt hoe het rechtssysteem werkt, waarom bepaalde onderdelen wel werken en bepaalde onderdelen niet. De rechtswetenschap heeft de taak bij te dragen tot een zodanige ordening van dit beslissingssysteem, dat de kans dat het systeem optimale beslissingen produceert het grootst is, terwijl voldaan blijft aan eisen van rechtsstatelijkheid en democratie. Hiertoe is het van belang het gedrag van mensen (bijvoorbeeld politici) empirisch te onderzoeken om informatie te krijgen hoe het systeem functioneert;

8. de normatieve methode onderzoekt hoe het recht behoort te worden toegepast, wat heeft de wetgever bedoeld met een bepaalde regeling en welke invloed hebben veranderende waarden en normen op het recht. Recht wordt gezien als een concretisering van waarden. De belangrijkste menselijke waarde is de vrijheid. Met dit beginsel als leidraad moet het geldend recht worden beschreven, de rechtsvinding en interpretatie plaatsvinden en de rechtsvorming voortgang vinden.

Uit enerzijds de elementen van de grondregels die de basis vormen van de westerse democratie en anderzijds de geschiedenis, die aan een staatsbestel ten grondslag ligt, volgt de methodiek van de bestudering. Om de instellingen, het concrete stelsel van bevoegdheden en controles te begrijpen moet het worden gezien als resultaat van een historische groei. Daarom moet ook de methode van bestuderen voor zover die gericht is op verklaring van wat is, een historische zijn. Om het heden te begrijpen is het nodig het bestaande stelsel kritisch te analyseren volgens zekere systematische maatstaven. Die systematische maatstaven zijn de grondbeginselen en criteria waaraan een staatsinrichting moet voldoen. Die waarden en normen variêren echter naar tijd en plaats.

In dit onderzoek is de historisch-juridische onderzoeksmethode gecombineerd met de historisch-systematische methode. De toegepaste onderzoeksmethode is in hoofdzaak de historisch-juridische methode. Begonnen wordt immers met het verzamelen van alle mogelijke gegevens uit de literatuur, het documentenmateriaal, het lezen van 
boeken en tijdschriftartikelen en rapporten over het betrokken onderwerp. Vaak hadden de verschaffers van deze informatie een aantal waarnemingen verricht of onderzoekingen gedaan, waardoor reeds een gestructureerd beeld ontstond van het onderzoeksgebied. Ook wordt de historisch-systematische methode toegepast omdat bepaalde evaluatie-criteria systematisch in verleden en heden op bepaalde verschijnselen worden toegepast.

Tevens wordt de staatsrechtelijke theorie getoetst aan de staatsrechtelijke praktijk. Het onderzoek is derhalve voor een deel ook toetsingsonderzoek. Nagegaan wordt of een veronderstelde wetmatigheid overeenkomt met de verschijnselen in de werkelijkheid. Geen enkele hypothese is strikt bewijsbaar. Een hypothese moet bruikbaar zijn. Dit houdt in dat uit een hypothese bruikbare voorspellingen moeten kunnen worden afgeleid, die een grote kans hebben om uit te komen.

De redenen voor die combinatie zijn, dat een probleemstelling die uitsluitend geformuleerd is om de staat als rechtssysteem te bestuderen, leidt tot vertekening van de werkelijkheid omdat het menselijk handelen en het politieke systeem de juridische systemen en wettelijke regelingen in sterke mate vorm geven en beïnvloeden. Een probleemstelling die alleen vraagt naar de historische groei van de staat leidt tot passieve beschrijving van wat bestaat. Het alleen maar toetsen van het staatsbestel aan abstracte beginselen leidt tot uniformering van alle staatsstelsels zonder rekening te houden met de wordingsgeschiedenis en de volksaard. Begrip en kritiek moeten samengaan. Beschrijving van het bestaande staatsrecht vanuit het verleden en opbouw van het groeiende staatsrecht vanuit het heden, is de taak van de staatsrechtwetenschap, waarbij het relevante menselijk handelen binnen de juridische context niet verwaarloosd mag worden. Het staatsrecht is immers grotendeels de uitkomst van politieke en sociale processen en dient te worden benaderd vanuit verschillende fundamentele uitgangspunten. Het onderzoek is dus naast descriptief, ó6k verklarend van aard.

De waarden en normen die in de loop van de tijd het (staats)bestuur in de kolonie bepaalden, kunnen methodologisch worden gereconstrueerd uit de feiten. De feitelijke ontwikkelingen bepalen tevens de waarden en normen van het staatsgezag. Op deze manier kan ook de kloof tussen zijn en behoren worden overbrugd. ${ }^{12}$ 'Ware' 
wetenschappelijke uitspraken kunnen, op zichzelf genomen, niet worden gehanteerd als normerende oordelen, maar zij zijn nodig om de werkelijkheid waarop normerende oordelen betrekking hebben, in voldoende mate te 'kennen' en zij kunnen bepalend zijn voor de vorming van een (normatief) oordeel of het zinvol is geldende rechtsnormen of rechtsdogmatische oordelen tegen de druk van een afwijkende werkelijkheid in al dan niet te handhaven. ${ }^{13}$

Om vast te kunnen stellen of de vraagstellingen, zoals geformuleerd in de probleemstelling van het onderzoek eenduidig beantwoord kunnen worden, moet onderzoek worden gedaan naar de ontwikkeling van de staatkundige organen en de politieke besluitvormingsprocessen in Nederland, de kolonie, de latere Nederlandse Antillen en Aruba, vanaf de koloniale tijd tot heden. Als de ontwikkelde verklaring voldoende aanknopingspunten voor het vinden van werkbare oplossingen biedt, is per definitie het juiste verklaringsniveau gevonden en is een 'vruchtbaar' theoretisch model gevonden. Een plausibele verklaring is in eerste aanleg niet meer dan een verklaring waar met het gezonde verstand geen al te grote gaten in geschoten kunnen worden. In het ontwikkelde onderzoeksmodel worden de kernbegrippen uit verschillende theorieên gebruikt als ingangen voor het opstellen van verklaringen voor de gesignaleerde problemen.

Een van de vragen was of het koloniale bestuurssysteem nog steeds van invloed is op de huidige staatkundige ontwikkelingen in de Nederlandse Antillen en Aruba. Indien die vraag duidelijk beantwoord kan worden en naast de bovengenoemde invloeden, ók de bevolkingsopbouw, klasseverschillen, cultuurverschillen en werking van het politiek bedrijf als erfenis van het koloniaal systeem een rol zouden hebben gespeeld in de staatkundige ontwikkeling van de Nederlandse Antillen en Aruba, dan zou moeten worden aangetoond dat die factoren ook nu nog van invloed zijn op het staatkundig en politiek proces.

Indien de onderzoeksvragen de vooronderstellingen die daaraan ten grondslag liggen zouden kunnen bevestigen dan zouden daaruit conclusies kunnen worden getrokken met betrekking tot de te ver-

gewonnen (a posteriori). Dan zijn er de oordelen die bedoelen uit te drukken of iets wenselijk is of goed. Dit zijn oordelen ona thankelijk van de ervaring (a priori, sollen of behoren). Alle kennis begint met de ervaring, maar stamt niet uit de ervaring. Kennis a priori en a posteriori zijn streng gescheiden. Ook de metafysica kan aan dezelfde wetmatige methodes onderworpen worden als de denkmethoden warmee de empirie wordt bestudeerd; Kant, Prolegomena (1979); Van Aller (1992) p. 54 e.v. Zie cok Staatsrechtconferentie 1983, p. 54 e.v.

Staatsrechtconferentie 1983, p. 30. 
wachten knelpunten, mogelijkheden en onmogelijkheden over de gewenste staatkundige structuur, die onderwerp van bespreking vormt.

$\mathrm{Nu}$ de Nederlandse Antillen en Aruba niet meer op korte termijn onafhankelijk behoeven te worden, houdt dat in, dat een aantal problemen waarmee het Koninkrijk kampt op de komende conferentie moeten worden besproken. De evaluatie van de hypotheses zoals verwoord in de onderzoeksvragen van de probleemstelling kunnen een bijdrage leveren aan voorspellingen die realistische oplossingen voor de bestaande problemen bieden.

In met name de derde fase worden observaties en analyses verricht in de onderzochte staatsrechtelijke praktijk, zoals de wensen van de eilanden voor een staatkundige structuur en de reacties op de Toekomstconferentie. Vanuit de eerder waargenomen verschijnselen ontstond een zekere verwachting omtrent de samenhang van die verschijnselen. Die samenhang vormt de grondslag voor de toetsingscriteria en de wijze waarop de onderzoeksresultaten worden gegroepeerd, geinterpreteerd en geëvalueerd. Sommige feiten vertonen in hun onderlinge samenhang een structuur. Terwille van de overzichtelijke indeling is daarom naast de evaluatie-criteria ook een classificatiesysteem ontworpen in tijdvakken op grond waarvan het onderzoeksmateriaal verder gestructureerd en bewerkt wordt.

Door het bestuderen van regelingen, menselijke gedragingen, politieke besluitvorming en structuren kunnen wetmatigheden worden gevonden die invloed hebben uitgeoefend vanuit het verleden, op de hedendaagse staatkundige ontwikkeling van de Nederlandse Antillen en Aruba. Voorzover menselijke gedragingen in dit proces van staatkundige vormgeving een overheersende rol speelden, zijn die in de historisch-juridische context eveneens meegewogen.

De loop der staatsrechtelijke en geschiedkundige gebeurtenissen werd door Bordewijk ${ }^{14}$ onderverdeeld in vijf tijdvakken tot de invoering van het Regeringsreglement van 1865. Deze indeling werd overgenomen en voortgezet, omdat het vanuit een staatsrechtelijk oogpunt een verhelderende indeling is en in de genoemde tijdvakken steeds bepaalde staatsrechtelijke veranderingen tot stand kwamen. De aanvulling van de indeling in de tijdvakken VI $t / m$ IX is van mijn hand. Door deze indeling te maken werd de te bestuderen stof op grond van de gefaseerde probleemstelling al op een bepaalde wijze 
geordend. Die indeling sluit goed aan op het onderwerp van onderzoek en is als volgt.

De West-Indische eilanden werden sinds hun verovering van omstreeks 1634 tot 1792 gekoloniseerd door een privaatrechtelijk orgaan met publiekrechtelijke bevoegdheden: de beide West-Indische Compagnieën (WIC), die verantwoording waren verschuldigd aan de Staten-Generaal van de Republiek der Verenigde Nederlanden. Deze periode is van belang omdat het bewind van de WIC het latere bestuur diepgaand beīnvloedde.

II.

\section{Periode 1792-1815, revolutie en restauratie}

Vanaf 1792 werd de kolonie vanuit het moederland geregeerd, het bestuur werd ter uitvoering opgedragen aan een Raad der Colonien. De Raad kon slechts in functie blijven tot 1795. Nederland werd onder invloed van de Franse revolutie de Bataafse Republiek (17951806). De nieuwe republiek droeg het bestuur van de koloniēn op aan een Committé. In 1801 werd dit Committé weer vervangen door een Raad. Koning Lodewijk Napoleon maakte een einde aan de collegiale bestuursvorm in de periode dat de Bataafse Republiek het Koninkrijk Holland (1806-1810) werd. De koloniën kwamen onder het bestuur van de Koning. Er werd daartoe in 1806 een Ministerie van Koophandel en Koloniën ingesteld (vanaf 1808 het Ministerie van Marine en Koloniën).

Van 1810-1813 was Nederland bij Frankrijk ingelijfd en werden de koloniën vanuit Parijs bestuurd.

In 1816 vielen de eilanden weer direct onder het beheer van de Nederlandse staat. Omdat de koloniën vanuit Nederland werden geregeerd waren de regelingen betreffende de koloniën in de Nederlandse Grondwetten vanaf 1815 van grote betekenis voor de WestIndische kolonie. De Koning oefende het opperbestuur over de koloniën uit. De koloniën werden namens de Koning bestuurd door een Gouverneur. De Koning had de uitvoerende macht in Nederland, maar oefende over de koloniēn tevens de wetgevende machit uit. De kolonie Curaçao en de kolonie Sint Eustatius kregen ieder een eigen 
Regeringsreglement. De rechtspraak zou onafhankelijker van het bestuur gaan optreden.

IV.

Periode 1828-1845, samenvoeging tot én kolonie

Om de bestuurskosten van de koloniën te verlagen en de opbrengsten voor het moederland te verhogen werden in 1828 de kolonie Suriname, Curaçao en Sint Eustatius samengevoegd tot éńn kolonie. Het was een bureaucratisch systeem, de meeste bestuursbesluiten van de kolonie Curaçao en Sint Eustatius moesten worden goedgekeurd door de Gouverneur-Generaal in Paramaribo.

V.

Periode 1845-1865, tijdperk van de twee koloniën

Daar de samenvoeging niet tot vermindering van de bestuurskosten leidde, werd de samenvoeging in 1845 weer ongedaan gemaakt. De kolonie Curaçao en onderhorigheden en de kolonie Sint Eustatius en onderhorigheden kwamen voor het eerst onder één bestuur.

In de periodes van 1815 tot 1865 had de Koning het opperbestuur over de koloniën, dit hield naast bestuur ook wetgeving in. De koloniale verhoudingen werden beïnvloed door de toenemende macht van de Nederlandse volksvertegenwoordiging en het ontstaan van de ministeriële verantwoordelijkheid, waardoor de Koning niet meer alleenheerser was in de koloniën. Economische motieven speelden een belangrijke rol om de kosten van het instandhouden van de kolonie te verlagen. De slavernij werd tegen het eind van deze periode in 1863 afgeschaft. De slavenarbeid vormde een belangrijke factor in de koloniale economie.

VI.

Periode 1865-1936, koloniale stabilisatie

In deze periode vroegen de koloniën regelmatig om meer invloed in de eigen huishouding, maar Nederland was niet genegen dat toe te staan, ook al werd het Nederlandse voornemen daartoe al verwoord in het Regeringsreglement van 1865.

VII. Periode 1936-1950, geleidelijke dekolonisatie

De Tweede Wereldoorlog en de internationale opvattingen over dekolonisatie leidden tot de regeling van de eigen huishouding door 
de voormalige koloniën. Vanaf 1922 hebben vele staatscommissies en deskundigen staatkundige modellen voorgesteld. In die voorstellen werd niet altijd rekening gehouden met de omstandigheden ter plaatse en de wensen van de bevolking. Tussen 1936 en 1950 ontwikkelde zich het parlementair stelsel in de Nederlandse Antillen.

VIII.

Periode 1950-1986, verantwoordelijk bestuur

In het begin van periode VIII was de belangrijkste gebeurtenis de invoering van het Statuut. Met de invoering van het Statuut werd de dekolonisatie voorlopig voltooid. Tussen 1950 en 1986 droeg het bestuur en de volksvertegenwoordiging van de voormalige kolonie, zelf de verantwoordelijkheid voor de eigen huishouding, met de mogelijkheid van ingrijpen van de Koninkrijksregering door middel van preventief en repressief toezicht. Hiervan werd spaarzaam gebruik gemaakt.

Vanwege de ongeregeldheden in Willemstad in 1969 moest Nederland mariniers sturen om de orde te handhaven, dit ingrijpen leidde internationaal en nationaal tot grote kritiek op Nederland. Nederland achtte toen het tijdstip gekomen om Suriname en de Nederlandse Antillen naar de onafhankelijkheid te begeleiden. Suriname werd in 1975 onafhankelijk.

De Nederlandse Antillen wensten de onafhankelijkheid niet. Aruba wilde als dichtst bevolkste eiland na Curaçao al sinds de jaren veertig 'los van Curaçao'. Nederland wenste echter dat de Nederlandse Antillen als geheel onafhankelijk zouden worden, daar een eilandenverband meer kans zou hebben economisch de onafhankelijkheid te overleven, dan één eiland op zichzelf. Uiteindelijk kreeg Aruba in 1986 de Status Aparte, hetgeen leidde tot verdere desintegratie van het verband van de overblijvende eilanden.

IX.

Periode 1986-1993, het zoeken naar een nieuw Koninkrijksverband

Na de Status Aparte van Aruba werd op de Nederlandse Antillen koortsachtig gezocht na een geherstructureerd staatkundig verband. De eilanden konden niet tot overeenstemming komen over een vorm die elk eiland tevreden stelde.

In 1990 liet de minister van Nederlands-Antilliaanse en Arubaanse Zaken, Hirsch Ballin in zijn 'Schets voor een Gemenebestconstructie' weten dat Aruba niet meer onafhankelijk zou behoeven te worden in 1996. De onafhankelijkheid zou voor onbepaalde tijd van de agenda kunnen worden geschrapt. Een opdeling van de voormalige Antillen 
van zes eilanden in twee of drie landen zou onvermijdelijk zijn. Dit versterkte de wens van Curaçao om ook een aparte status te krijgen. Deze wens paste weer in de Antilliaanse interpretatie van de uitoefening van het zelfbeschikkingsrecht dat elk eiland heeft.

Alle eilanden van de Nederlandse Antillen kregen tot hun verbazing, onder voorwaarden, de Status Aparte door Nederland aangeboden op de Toekomstconferentie van maart 1993. Dit was een ingrijpende afwijking van het Nederlandse beleid van de laatste jaren. Het nieuwe beleid is erop gericht, de kwaliteit van het lokale bestuur te vergroten. De professionalisering van het overheidsbeleid door Nederland moet leiden tot vergroting van de efficiency van het overheidsapparaat van de (ei)landelijke voorzieningen en moet helpen de economische basis van de eilanden te verbreden.

De kleine eilanden accepteerden een toenemende Nederlandse invloed nog wel, maar Aruba en Curaçao verzetten zich daar met hand en tand tegen. Voor Nederland waren de eilanden steeds meer een bestuurskundig probleem geworden, dat om efficiënte oplossingen vroeg. De vergrote Nederlandse invloed leidde tot een toename van wrevel en onenigheid over bestuurlijke bevoegdheden, financiën, beleid en cultuurverschillen. De bestuurlijke problemen vallen niet op te lossen door alleen maar een nieuwe staatkundige structuur in te voeren.

Met de conclusies voortvloeiend uit het onderzoek kunnen de drie onderzoeksvragen, zoals geformuleerd in de gefaseerde probleemstelling worden beantwoord. Om die conclusies te kunnen trekken en de aanbevelingen te doen wordt de probleemstelling getoetst aan de praktijk op grond van de evaluatie-criteria. De gevolgtrekkingen lijken overeen te komen met de laatste ontwikkelingen. Tijdens de Toekomstconferentie van maart 1993 beloofde Nederland de Antilliaanse eilanden, onder zekere voorwaarden een aparte status binnen het Koninkrijk. Het referendum gehouden op Curaçao in november 1993 wees uit dat de bevolking van Curaçao massaal koos voor een 'Antillen van de Vijf'. Dit in tegenstelling tot de wens van de politici op Curaçao die vrijwel unaniem voor de status aparte van Curaçao opteerden. Hierdoor ontstond een ontwikkeling in tegengestelde richting. Een gezamenlijk Antilliaans verband werd weer (tijdelijk) bespreekbaar. 
Elk hoofdstuk begint met een korte beschrijving van de te behandelen stof en eindigt met een samenvatting van de belangrijkste conclusies aan de hand van de onderzoeksvragen en de evaluatie-criteria met gebruikmaking van de uiteengezette methode en vormgegeven op grond van de indeling in tijdvakken.

Hoofdstuk II beschrijft de kolonisatie en bestuursstructuur van de Nederlandse kolonie in West-Indië, onder het beheer van de WestIndische Compagnie en de Nederlandse staat vanaf het begin van de kolonisatie tot 1865 . De periodes I t/m V worden in hoofdstuk II uiteengezet.

Omdat de slavernij in de koloniên bestaan heeft van 1634 tot 1863 en derhalve grotendeels parallel liep met de perioden $\mathrm{I} \mathrm{t} / \mathrm{m} \mathrm{V}$ is gekozen voor een apart hoofdstuk (III) waarin de oorzaken en gevolgen van de slavernij worden behandeld.

Hoofdstuk IV beschrijft periode VI, de staatkundige ontwikkeling van de kolonie vanaf het Regeringsreglement van 1865 tot en met 1936.

Hoofdstuk V behandelt periode VII vanaf 1936 tot 1950, het tijdvak van de geleidelijke dekolonisatie.

Hoofdstuk VI, VII, VIII houden zich bezig met de periode 1950 . 1986 (VIII), de periode waarin het verantwoordelijk bestuur verder vorm krijgt.

Hoofdstuk VI beschrijft het ontstaan en invoeren van de nieuwe rechtsorde in het Koninkrijk, die werd aangekondigd in de rede van de Koningin Wilhelmina van 7 december 1942. De Tweede Wereldoorlog is van groot belang geweest voor de economische ontwikkeling van de Nederlandse Antillen en Aruba. Aandacht wordt besteed aan het bestaande onbehagen en de gevoelens van achterstelling van Aruba ten opzichte van Curaçao. De nieuwe wetgeving en de gevolgen daarvan komen uitgebreid aan de orde. Met de invoering van de Eilandenregeling Nederlandse Antillen (1950/1951), het Statuut (1954) en de Staatsregeling van de Nederlandse Antillen (1955) wordt deze periode afgesloten.

Hoofdstuk VII begint met de onlusten in 1969 en beschrijft periode VIII tot 1986. Het Nederlandse streven naar onafhankelijkheid van de voormalige koloniën en de Antilliaanse weerzin daartegen worden beschreven. Hierdoor krijgt ook het weer oplaaiende Arubaanse afscheidingsstreven nader reliëf. De politieke strijd om de Status Aparte van Aruba wordt vanuit vele gezichtspunten bezien, evenals de herstructurering van 'de Antillen van de Vijf'.

Hoofdstuk VIII beschrijft in extenso de ingewikkelde staatkun- 
dige weg die moest worden afgelegd door Nederland, de Nederlandse Antillen en Aruba om de gewenste Arubaanse afscheiding uit het Antilliaanse verband te bewerkstelligen. Dit hoofdstuk legt de nadruk op de Arubaanse optiek. De noodzakelijke wetswijzigingen, nieuwe wettelijke regelingen en politieke strubbelingen met betrekking tot de Status Aparte van Aruba worden nader toegelicht.

Hoofdstuk IX beschrijft de economische, staatkundige en politieke ontwikkelingen van de Nederlandse Antillen en Aruba na 1986. In dit hoofdstuk wordt periode IX behandeld, het zoeken naar een nieuw Koninkrijksverband. Vele geopperde staatkundige modellen komen aan de orde met bun voordelen en nadelen.

Door de uittreding van Aruba uit het Antilliaanse staatsverband werd het verdere samenwerkingsverband tussen de overblijvende Antilliaanse eilanden sterk ondermijnd en dreigde geheel uit elkaar te vallen. Deze middelpuntvliedende krachten werden versterkt door de opstelling van Hirsch Ballin in zijn 'Schets'.

Ten slotte bevat hoofdstuk X de eind-conclusies uit de voorgaande hoofdstukken, benevens een aantal aanbevelingen. De gevolgtrekkingen uit de hierboven genoemde specifieke tijdvakken worden nader geanalyseerd en vervolgens gerelateerd aan de evaluatie-criteria. 


\section{De Nederlandse kolonisatie van de West}

Hoofdstuk II beschrijft de kolonisatie en bestuursstructuur van de Nederlandse kolonie in West-Indië, onder het beheer van de WestIndische Compagnie, een privaatrechtelijke onderneming en de Nederlandse staat vanaf het begin van de kolonisatie tot het Regeringsreglement van 1865. De in de inleiding genoemde periodes $I \mathrm{t} / \mathrm{m} \mathrm{V}$ worden in dit hoofdstuk behandeld. Omdat de West-Indische Compagnie en de Republiek economische motieven hadden om tot kolonisatie over te gaan, stonden invloed van de bevolking van de kolonie en gelijke rechten voor de burgers uiteraard niet voorop. Het bestuur was sterk centralistisch en ambtelijk met weinig invloed van de burgerij op het bestuur van de kolonie. Tevens wordt aandacht besteed aan de rechtspraak, die in handen was van het koloniaal bestuur.

De economische ontwikkeling van de kolonie wordt beschreven, omdat de economie van grote invloed is geweest op de staatkundige ontwikkelingen in de kolonie. De kolonisatie heeft tot doel het verbeteren van de economische positie van het moederland. Op grond van dat uitgangspunt blijkt de belangstelling van de koloniserende mogendheid voor de rechtspositie van de oorspronkelijke bevolking dan ook gering. Om een goed overzicht van de economische ontwikkeling te krijgen en omdat niet apart op dit onderwerp wordt teruggekomen, zal die ontwikkeling beschreven worden tot in de huidige tijd.

De Nederlandse staatkundige geschiedenis van de Nederlandse Antillen en Aruba begint met de komst van de Spanjaarden en hun ontdekkingsreizen. In de $15 \mathrm{de}$ eeuw werden de eerste grote ontdekkingsreizen gemaakt door de Portugezen. De invloed van de Renaissance leidde tot een hernieuwde belangstelling voor de natuurwetenschappen en de wens om nieuwe zeevaartroutes te ontdekken naar India en het Oosten. Dit was noodzakelijk omdat de Kruistochten de routes overland moeilijk begaanbaar hadden 
gemaakt. Bovendien konden deze reizen nu ook ondernomen worden omdat navigatie-instrumenten waren ontwikkeld. ${ }^{1}$

De aanleiding tot de Spaanse ontdekkingsreizen was tevens economisch van aard, de strijd van Spanje tegen de Moren was voor de Spaanse schatkist uitputtend geweest en herstel van de financiële positie was dan ook uiterst urgent. De uitstraling van het katholicisme naar andere volken en de zucht naar godsdienstige macht, die de ontdekkers op hun reizen overzee vergezelden, waren mede aanleiding tot de koloniseringsdrang. Wat echter nog belangrijker bleek, was de koortsachtige wens om goud, edelstenen en specerijen te vinden om de lege schatkist te vullen en het Heilige Graf en Jeruzalem te bevrijden van de ongelovigen. ${ }^{2}$

Columbus wilde een korte zeeweg naar Indië vinden om de expansie-politiek van Spanje te ondersteunen. Op zijn eerste tocht ontdekte hij naast San Salvador eveneens Cuba en Hispaniola, het tegenwoordige Santo Domingo-Haïti. Hispaniola werd het centrum van de Spaanse ontdekkingsreizen. Tussen 1492 en 1502 betwistten de Spanjaarden en Portugezen elkaar de controle van de zeevaartroutes en de gebieden die ze benoemden en vervolgens koloniseerden. ${ }^{3}$

Curaçao werd volgens de overlevering ontdekt door Alonso de Ojeda, die in 1499 de Noordkust van het zuidelijk continent verkende. De drie Bovenwindse eilanden werden door Columbus ontdekt op zijn tweede tocht naar de Nieuwe Wereld, die plaatsvond in 1493. Sint Maarten werd waarschijnlijk door Columbus ontdekt op zijn tweede reis.

De Nederlandse expansie in het Atlantisch gebied leidde tot de definitieve doorbreking van het Iberische monopolie van kolonisatie van de Nieuwe Wereld en van handel op westelijk en zuidelijk Afrika. Nederlanders ondernamen tot het einde van de 16 de eeuw geen zelfstandige reizen naar Portugees West-Afrika, Brazilië en het Spaans Caraibisch gebied. Zij deden hun Afrikaanse en Amerikaanse zaken via tussenpersonen in Antwerpen, Lissabon en Sevilla. Toen de Nederlandse opstand tegen Spanje was overgegaan in een onafhankelijkheidsoorlog, brachten kooplieden uit de Noordelijke Nederlanden ondanks het verzet van hun Iberische collega's eigen duurzame handelsrelaties tot stand met West-Afrika, het Caraibisch gebied en de noordoostkust van

Williams (i970) pp. 13-17.

Granzotto (1992) pp. 256 en 315; Naipaul (1987).

Attali (1992) p. 205. 
Amerika. Na het aflopen van het Twaalfjarig Bestand met de Iberische dubbelmonarchie deden zij een poging het Portugese Zuidatlantische imperium te veroveren, dat bestond uit Afrikaanse steunpunten voor de handel in goud, slaven en ivoor, en het suikerproducerende Braziliē.

Het instrument van dit imperiale streven was de West-Indische Compagnie (WIC), waaraan in 1621 het monopolie voor handel en kolonisatie in het Atlantisch gebied was verleend. De WIC was een vereniging van kooplieden. Door een dergelijk verband kon de onderlinge concurrentie worden beteugeld, tevens kon door de gezamenlijke inspanning de handelsvloot van oorlogsschepen worden voorzien tegen de zeeroverij. De voornaamste taak van de WIC was zoveel mogelijk oorlogsbuit op de Spanjaarden veroveren. Daarnaast zou de WIC door krachtige oorlogsvoering gebieden onderwerpen in de Nieuwe Wereld, om vervolgens met de produkten uit die landen handel te drijven. Het voeren van oorlog bleef de voornaamste bezigheid van de eerste WIC, handel drijven was van ondergeschikt belang. De tweede WIC slaagde er evenmin in een bloeiende handel tot stand te brengen. ${ }^{4}$

Nederland was een koloniale mogendheid van aanzienlijke importantie. In de $16 \mathrm{de}$ en $17 \mathrm{de}$ eeuw was Nederland een leidende natie in de wereld, vooral voor wat betreft de handel en de scheepvaart. Nederland stichtte in de $16 \mathrm{de}$ en $17 \mathrm{de}$ eeuw koloniën in Zuid-Oost Azië en in het Caraibisch gebied. In 1596 kwamen de eerste Nederlanders op Java aan. De Verenigde Oost-Indische Compagnie (VOC) werd opgericht om de veroverde gebieden uit te breiden en te besturen. In het begin van de 19de eeuw nam de Republiek der Verenigde Nederlanden de bezittingen in Nederlandsch-Indië over van de VOC, zoals ook zou gebeuren met de bezittingen van de West-Indische Compagnie (WIC).

De WIC bestuurde de veroverde gebieden in West-Indië. In Suriname zetten de Nederlanders voor het eerst in 1613 voet aan wal. Het eiland Curaçao werd in 1634 door de Hollanders op de Spanjaarden veroverd, die het van 1499 tot 1634 hadden beheerst. De staatkundige geschiedenis van Suriname is sterk verweven met die van de Nederlandse Antillen en Aruba. De ontwikkeling van de West-Indische koloniën, is bepaald door de volgende factoren:

de ligging van de (Nederlands)-Antilliaanse eilanden, met name ten opzichte van het vasteland van Zuid-Amerika en de

Van Brakel (1908) pp. 31-36; Kesler, De WIG, 3, 1921, pp. 65-78; De Gaay Fortman, De WIG, 1a, 1919, pp. 441-457; Van den Boogaart (1982) p. 113. 
zeevaartroutes, de gunstige ligging van Suriname op de zeevaartroute naar de Afrikaanse Slavenkust en de ontwikkeling van Suriname op de Wilde Kust, ${ }^{5}$ als plantagekolonie, - de ontwikkeling van de koloniale mogendheden in Europa en het gedeeltelijk daarvan afgeleide economische nut van de Antilliaanse eilanden en Suriname voor Nederland.

De Spanjaarden zagen niet zoveel in deze eilanden, er viel nauwelijks iets te verbouwen en edele metalen werden er niet aangetroffen. Ook tijdens het bewind van de WIC dacht men eraan de kolonie Curaçao maar op te geven. Door de belangrijke haven die Curaçao bezat werd daarvan afgezien. Bovendien lag Curaçao gunstig ten opzichte van de andere Nederlandse bezittingen, in Brazilië, Amerika en Ghana, tevens vormde Curaçao een goede doorvoerhaven voor goederen en slaven.

In de begintijd van de eerste WIC sprak men in het moederland van de West-Indische bezittingen, daartoe werden toen ook naast de Slavenkust van West-Afrika, Nieuw-Holland (Braziliē), Nieuw-Nederland (New-York), de Wilde Kust (Suriname en Berbice) en de huidige Nederlandse Antillen en Aruba gerekend. De bezittingen op de Amerikaanse kust omvatten Nieuw-Nederland in het Noorden en Nieuw-Holland (Recife, Pernambuco) in het Zuiden. Voordat Braziliē verloren ging, was Curaçao in én bestuurlijk verband met Nieuw-Holland opgenomen, met de val van Recife in 1654 kwam hieraan een einde en werd Curaçao opgenomen in één bestuurlijk verband met Nieuw-Nederland. ${ }^{6}$

s De Wilde Kust stond ten tijde van het gezag van de WIC bekend als het reusachtige gebied tussen de Amazone en de Orinoco. Suriname kwam pas in 1674 definitief onder het gezag van de Republiek van de Verenigde Nederlanden. Omdat Suriname in eerste instantie door de Engelsen werd gekolonialiseerd, werd het plaatselijk bestuur - gezien de Engelse traditie - overgelaten aan de ingezetenen. De volksinvloed op het bestuur is daarom in Suriname veel groter geweest, dan in de kolonie Curaçao en onderhorigheden. Suriname kreeg bij het Regeringsreglement van 1865 een mede-wetgevend orgaan, de Koloniale Staten, waarvan 9 van de 13 leden verkozen werden. Volksinvloed in het bestuur kwam in de kolonie Curaçao en onderhorigheden pas gedeeltelijk tot stand bij de Curaçaosche Staatsregeling van 1936. Algemeen kiesrecht werd pas ingevoerd bij de Staatsregeling van de Nederlandse Antillen van 1948. In Suriname waren de suikerplantages de belangrijkste bron van inkomsten. Ook werd er tabak, koffie, cacao en katoen verbouwd. Kunst (1981) p. 72 e.v. en pp. 90-93.

- Dat was geografisch handiger, omdat de zeilverbinding Nieuw-Holland/Brazilië heel omslachtig was. Zeilen van Pernambuco naar Curaçao ging altijd, maar in omgekeerde richting was Braziliē alleen bereikbaar via West-Afrika; Lagerberg (1989) pp. 191-197. 
Aruba en de Nederlandse Antillen ${ }^{7}$ kunnen worden onderscheiden in de Eilanden boven de Wind en de Eilanden beneden de Wind. De Bovenwindse eilanden Saba, Sint Eustatius en Sint Maarten liggen negenhonderd kilometer noordoostelijk van de Benedenwindse eilanden.

De Benedenwindse eilanden Aruba, Bonaire en Curaçao, liggen

Antillen is de verzamelnaam voor de eilanden, die gelegen zijn tussen het vasteland van Noord Amerika en dat van Zuid-Amerika, en die van de Caraibische Zee en de Golf van Mexico, tezamen ook wel Amerikannse Middelzee genoemd. De Antillen kunnen worden onderverdeeld in drie groepen:

de Bahama Eilanden tussen Hispaniola en Florida;

de Grote Antillen, bestaande uit Cuba, Jamaica, Hispaniola (staatkundig verdeeld in Haĩti en de Dominicasnse Republiek) en Puerto Rico;

de Kleine Antillen, dit is de boog van talrijke kleine eilanden tussen Puerto Rico en de noordkust van Zuid-Amerika, waarvan onder andere de Nederlandse Antillen deel uitmaken.

Op de oude Italiaanse wereldkaarten zag men ten westen van Europa énn doorlopend watervlak tot aan de oostkust van Aziē, daarin waren getekend figuren van geweldige draken, monstermensen en -dieren. En ergens ten zuidwesten van lerland, in de eindeloosheid van die Oceasan, zag men een eilandje met de naam Brasil en nog een groep eilandjes: de Antillia. Het is onbekend hoe men aan die wetenschap kwam. Toch waren het de Noormannen die omstrecks 900 al ontdekkingstochten ondernamen vanuit Usland en Groenland. Zij stichtten koloniën op de Canadese kust en hebben ook New Foundland en Labrador bezocht. De Uslander Erik de Rode ontdekte Groenland. Zijn zoon Leif Erikson landde omstreeks 1000 op de kust van Noord-Amerika. Het is onbekend hoe het verloop van deze Noorse expedities is geweest. Wel vond men in Ontario bewijzen van hun aanwezigheid in de vorm van Vikingzwaarden en bijlen. In Minnesota is een steen gevonden met het opschrift in runenschrift: '1362, Acht Zweden en twee en twintig Noren op een ontdekkingsreis van Wijnland door het westen. Wij gingen uit vissen. Toen wij thuiskwamen vonden wij tien man, rood van bloed. Verlos ons van den boze. Wij hebben tien van onze mensen, aan zee om op onze schepen te passen, veertien dagreizen van hier'. De Noormannen noemden Amerika Wijnland, omdat zij er druiven groeiend in het wild asntroffen; Williams (1970) p. 18; Van Hulzen (1946) pp. 7 e.v.; Grote Winkler Prins Encyclopedie in 25 delen, Elsevier, Amsterdam/Brussel, 1983, deel 23, pp. 192193, 195.

De naam Antillen schijnt afgeleid te zijn van een eiland 'Antillia', gelegen in de oceaan tussen Europa en Indiē, waarvan men in de 15de eeuw dacht, dat het in de zevende eeuw zou zijn 'gekoloniseerd door de aartsbisschop van Porto en zes bisschoppen met andere christenen, mannen en vrouwen, vee en koopwaren.' Dit moet ongetwijfeld het 'eiland van de zeven steden' zijn, wasrvan de ontdekking wordt toegeschreven aan de Portugese bisschoppen, of 'het eiland van de Heilige Brandon' van de lerse monniken in de zesde eeuw. Attali (1992) p. 118. De Portugezen dachten dat er tussen de Azoren en het vasteland van Azië een land lag, dat zij 'Antilhas' noemden (tegenoverliggend land of eiland in de verte?). Jaarlijks verlieten schepen de haven van Lissabon op zoek nasr dat fabelachtige land, dat toch op de kaart van Toscanelli (1471) getekend was als liggend tussen Europa en Azië; De Haan (1940) pp. 3 en 15. 
ongeveer zeventig kilometer uit de kust van Venezuela. De onderscheiding in Bovenwindse en Benedenwindse eilanden is overgenomen van de Spanjaarden, die ook thans nog van de 'Islas de sota vento' en de 'barlo vento' spreken in verband met de passaatwind. Op beide groepen eilanden waait vrijwel het gehele jaar de noord-oostpassaat. ${ }^{8}$ Ten opzichte van de kuststrook tussen de Golf van Paria en het schiereiland Paraguaná (Venezuela) liggen alle eilanden tussen Trinidad en Puerto Rico namelijk barlo vento of bovenwinds.

De Engelsen spreken daarentegen van Windward (dit is Bovenwindse) en Leeward (dit is Benedenwindse) islands met Dominica op de grens, zodat de eilanden ten zuiden hiervan in het Nederlands en Spaans Bovenwinds worden genoemd en in het Engels Benedenwinds. De Spanjaarden bekeken de eilanden vanaf de vastelandskust en de Engelsen, zoals zij langs Dominica zeilend de Kraal binnenvoeren. ${ }^{9}$

De staatkundige verbrokkeling van de Antillen is in hoofdzaak toe te schrijven aan het feit dat de Antillen in het verleden als koloniaal bezit werden opgedeeld tussen vele Westeuropese landen en (in een later stadium) door de Verenigde Staten. Er kon geen groei naar een grotere Antilliaanse eenheid plaatsvinden, daar elke kolonie allereerst banden onderhield met het moederland. Het resultaat is een aantal politieke verbanden met een uiteenlopende internationale oriëntatie, maar met een veelal overeenkomstige sociaal-economische structuur en problematiek, hoofdzakelijk als gevolg van de plantage economie, die eeuwenlang voor deze gebieden kenmerkend is geweest en dat ten dele nog is. ${ }^{10}$

De oorspronkelijke bewoners van zowel de Bovenwindse- als Benedenwindse eilanden waren Indianen. Omstreeks 600 na Christus staken leden van het Arowakken (Indianen) volk uit de

- De Jong (1988) p. 5.

9 Hartog (1964) pp. 26-27. Dit verschil in wijze van benoeming heeft evenwel tot gevolg, dat de Nederlands-Antilliaanse Bovenwindse eilanden- door de Engelssprekende bewoners zelf toch ook Windward islands worden genoemd. Deze eilanden worden omringd door de Britse Benedenwindse eilanden (Leeward islands) zoals Anguilla, Sint Kitts en andere. In de Nederlandse, Franse, en Spaanse literatuur duidt men met de term Benedenwindse eilanden, de eilanden aan, die voor of in de nabijheid van de Zuidamerikasnse kust liggen. In de Engelse literatuur bedoelt men daarentegen met de Leeward Islands de noordelijke groep van de Kleine Antillen.

10 Encyclopedie (1985) pp. 25 en 26. 
kuststreken van Venezuela" (de Vaste Kust), over naar Aruba, Curaçao en Bonaire. ${ }^{12}$ Bovenwinden

De Benedenwindse eilanden stonden van 1499 tot 1634 onder Spaans gezag. ${ }^{13}$ Van 1634 tot 1792 stond de kolonie bestaande uit Curaçao en onderhorigheden (Aruba en Bonaire) en Sint Eustatius met onderhorigheden (Nederlands deel van Sint Maarten en Saba) onder het gezag van de beide West-Indische Compagnieën. Van een staatkundige relatie kan in de periode 1634 tot 1 januari 1792 moeilijk worden gesproken, aangezien gedurende dit

11 Venezuela werd vernoemd naar Venetiē, omdat de Spaanse ontdekker Pincon de waterrijke omgeving van de Orinocodelta veel vond lijken op Venetië; Van Hulzen (1946) pp. 12 e.v.

12 Daal (1988) pp. 18-20: In omstreeks 200 v. Chr. kwamen volken met grote overeenkomsten in taalgebruik en cultuur de Orinocorivier afzakken naar de deltagebieden in het costen van Venezuela. Gekenmerkt naar hun gemeenschappelijke taal kregen zij de naam 'Arowakken'. Het Arowak volk reisde per kano ('cayuco' of 'piragua'). De Arowakken die omstreeks $600 \mathrm{n}$. Chr. uit de kuststreken van Venezuela naar Aruba, Bonaire en Curaçao trokken, behoorden wat de taal betreft tot het Arowakkenvolk. Zij maakten deel uit van de stam der Caquetios, met een centraal opperhoofd op het schiereiland Paraguaná, de 'Cacique'. Vergelijk Versteeg (1991) p. 7: "Waarschijnlijk kwamen de eerste Indianen al omstreeks 4000 jaren geleden (2000 v. Chr.) naar Aruba. Dat concluderen we uit dateringen van terreinen waar Indianen in die tijd op Curaçao gewoond hebben. Heel waarschijnlijk is dat zulke groepen toen ook op Aruba woonden. Want Aruba ligt veel dichter bij het vasteland [Venezuela] dan Curaçao en is dus met kleine bootjes gemakkelijker te bereiken." Goslinga (1979) pp. 4-12, zegt dat Curaçao ook wel het Giganteneiland werd genoemd, omdat Vespucci (tijdens de ontdekkingsreis van De Ojeda in 1499) onder meer Curaçao aandeed. De daar aangetroffen Indiaanse bewoners bleken van uitzonderlijke lengte te zijn. Gould (1980) pp. 13-25, stelt dat in de Middeleeuwen ervan werd uitgegaan, dat in Patagonië een reuzen-mensenras leefde. Magelhaen zou ze zelf gezien hebben tijdens zijn wereldreis in 1520, toen hij aanlegde in San Julian. Hij noemde ze Patagoniërs naar de leguanenleren moccasins, die ze droegen. Twee reuzen had hij in de ijzers laten slaan om mee te nemen naar Europa, maar ze stierven tijdens de terugreis. Drake zag deze reuzen-inwoners ook toen hij in 1578 aanlegde in San Julian. Straat Magelhaen scheidt Argentinië van Tierra del Fuego. Patagonië is een geografische omschrijving van een grondgebied gelegen tussen de Rio Negro en Straat Magelhaen, dus met inbegrip van het noordelijk deel van Argentinië en Chili. Kapitein Byron bezocht met zijn schip de Dolfijn, Straat Magelhaen in 1764 en zag de reuzen met eigen ogen. Hij bezocht een stamnederzetting en beschreef hetgeen hij gezien had. Hun lengte wordt aangegeven tussen de 6 en 9 voet. Een voet is 12 inches of $0,3048 \mathrm{~m}$.

13 Wispelweij (1961) p. 9 merkt vroom op dat de grootste betekenis van de Spaanse Tijd voor deze eilanden is geweest, dat de Spanjaarden de Indianen het christendom hebben gebracht. 
tijdvak de kolonie Curaçao werd beheerd door de Eerste en Tweede West-Indische Compagnie. Beide delen der kolonie hadden een apart bestuur met een Directeur (later Gouverneur genoemd) op Curaçao en een Commandeur (later weer Gouverneur) op Sint Eustatius. Deze functionarissen werden ieder terzijde gestaan door een Raad van Politie (ook wel als Policie gespeld). Ook hadden beide delen van de kolonie een eigen regeringsreglement.

Op de andere eilanden werd de Directeur of Gouverneur (Generaal) vertegenwoordigd door een Commandeur of vice-Commandeur (later Gezaghebber genoemd). De Commandeur werd eveneens bijgestaan door een Raad van Politie. Het opperbestuur over beide Compagnieên werd uitgeoefend door de Staten-Generaal van de Republiek der zeven Verenigde Nederlanden. De Directeuren van de WIC, kregen hun instructies van de StatenGeneraal. Zij leidden de kolonie met naast zich een Raad van Politie, die zich zowel bezighield met bestuur als met rechtspraak.

Het octrooi, uitgegeven door de Staten-Generaal aan de WIC, bevatte de regels die de WIC in acht moest nemen met betrekking tot handeldrijven en oorlogvoeren. De Ordre van Regieringe van 1629 was een nadere uitwerking van het octrooi ten behoeve van bestuur en rechtspraak in de overwonnen gebieden. Suriname is tijdens de koloniale tijd vrijwel steeds een aparte kolonie geweest.

De handelscompagnieën ontstonden na de Middeleeuwen toen de betrokken overheid bepaalde gevaren voor de handel niet kon bedwingen. Zo ontstond de Compagnie op de Levant en bestond haar Directie uit een aantal kooplieden benoemd door het bestuur van Amsterdam in 1625 wegens de Barbarijsche zeeroverij en kapingen van Nederlandse handelsschepen. De betrokken handelstak regelde zodoende haar eigen problemen als de overheid dat niet kon. Deze compagnieèn droegen zorg voor de veiligheid van de handel en de behartiging van de belangen van de bedrijfstak in den vreemde. De West-Indische Compagnie was een onderneming van kooplieden, die een aantal ondernemingen met een bepaalde tak van handel verenigde. ${ }^{14}$ Bovendien had deze organisatie het

14 Voor een overzicht van het ontstaan van de compagnieēn zie ook: Van der Heijden, Handboek voor de naamloze en besloten vennootschap, bewerkt door W.C.L. van der Grinten (1989) pp. 1-16. Van der Heijden/Van der Grinten spreken wel over de Verenigde Oost-Indische Compagnie, maar noemen de WIC niet. De WIC was trouwens volgens hetzelfde principe van de commenda participatie ingericht als de VOC. De VOC en de WIC waren min of meer een NV bekleed met publiekrechtelijke bevoegdheden. Beide compagnieēn waren 
monopolie van de handel in een bepaald gebied gekregen van de Staten-Generaal en werd zij eveneens bekleed met overheidsbevoegdheid, namens de Staten-Generaal uit te oefenen in de veroverde gebieden. De Compagnie vervulde dus een deel van de staatstaak in de veroverde gebieden. Wel hadden de Staten-Generaal zich het recht voorbehouden de belangrijkste bestuursambtenaren in de te veroveren gebieden te benoemen. Bovendien kwamen de meeste ondernemingen van de WIC in nauw overleg met de regering van de Republiek tot stand. Na verloop van tijd werd de handel op de gebieden die onder het octrooi van de Compagnie vielen tegen recognitie (betaling) voor een ieder opengesteld. De slavenhandel reserveerde de WIC voor zichzelf. ${ }^{15}$

In 1792 werd de WIC opgeheven en werden de koloniēn direct bestuurd door de Staten-Generaal, die daartoe de Raad der Coloniën in het leven riepen. Op dit tijdstip begon de staatsrechtelijke relatie tussen de (latere) Nederlandse Antillen en Nederland. Deze Raad kon slechts tot 1795 functioneren, toen de Bataafse Republiek tot stand kwam. De Bataafse omwenteling vond plaats, omdat na de 'verlatinge' van de landsheer, het privaat- en publiekrecht en de rechterlijke organisatie tot 1795 in grote lijnen gelijk was gebleven aan die uit de latere Middeleeuwen. Dit leidde tot grote ontevredenheid onder een deel van de bevolking.

De functies in de rechtsprekende colleges werden vervuld op grond van het behoren tot een bepaalde stand, edelen, meetellende geërfden of stedelijke regenten. De verlichte ideeên uit de $18 \mathrm{de}$ eeuw brachten een verandering teweeg in de vanzelfsprekendheid van een op standenindeling berustende staatsinrichting. ${ }^{16}$

De Raad van Colonien maakte plaats voor het Committé tot Zaken van de Coloniën en Bezittingen op de Kust van Guinea en America. De Bataafse Republiek werd in 1806 vervangen door het Koninkrijk Holland. De Minister van Koophandel en Koloniën had toen de verantwoordelijkheid voor het bestuur der koloniēn. ${ }^{17}$

tevens een door de overheid geoctrooieende mastschappij, toegerust met een handelsmonopolie en werkzaam ten algemene nutt.

is Van Brakel (1908) pp. XXI-XXIV, 31-36, 46; Menkman, De WIG, 26, 1944, pp. 97-110. In dit artikel heef Menkema een document opgenomen uit het Algemeen Rijksarchief, daterend uit de bescheiden van de WIC van 1642. Het betreft een 'ordre' van Liebergen hoe 'de negotie van negros voor Loando, St. Paulo op Curaçao soude behooren te derigeren mijns bedunckens onder verbeteringhe'. Voor het eerst is hier sprake van de inrichting van een slavendepot op Curaçao; zie ook Menkman, De WIG, 17, 1935, pp. 11-26.

16 De Monté ver Loren en Spruit (1982) pp. 248-261.

17 De Hullu, De WIG, 4, 1922, pp. 387-398. 
Van 1810 tot 1813 was Nederland bij Frankrijk ingelijfd en werden de koloniën vanuit Parijs bestuurd.

Van 1815 tot 1828 bestonden er drie koloniën, Suriname onder een Gouverneur-Generaal, Curaçao en onderhorigheden (Bonaire en Aruba) onder het gezag van een Gouverneur-Generaal en twee Commandeurs. De Bovenwinden: Sint Eustatius en onderhorigheden (Sint Maarten, Nederlands gedeelte en Saba) stonden onder het gezag van een Gouverneur en twee Commandeurs. In 1828 werden met het oog op bestuurlijke bezuinigingen, de drie koloniēn verenigd onder een Gouverneur-Generaal in Paramaribo.

Bij $\mathrm{KB}$ van $1815^{18}$ werden voor de koloniēn drie regeringsreglementen gearresteerd. Een 'Reglement op het beleid van de Regering, het Justitiewezen, den Handel en Scheepvaart in Suriname', evenals eenzelfde reglement voor Curaçao en onderhorige eilanden en voor Sint Eustatius en onderhorige eilanden. Deze reglementen konden pas in 1816 feitelijk ingevoerd worden, omdat Engeland eerst in dat jaar Curaçao ontruimde. De term reglement was niet nieuw. In de $17 \mathrm{de}$ en $18 \mathrm{de}$ eeuw waren in de republiek der Verenigde Nederlanden al regeringsreglementen van kracht geweest. Curaçao en onderhorige eilanden stonden onder het uitvoerend gezag van de Gouverneur-Generaal. De geheel afzonderlijke kolonie Sint Eustatius, Saba en Sint Maarten stond onder het gezag van een Gouverneur. Sint Maarten was een min of meer zelfstandig onderdeel in deze constellatie. Er was voorts maar voorzien in één Raad van Politie, voor de kolonie Curaçao en onderhorigheden, die met de Gouverneur-Generaal moest samenwerken om de welvaart van de ingezetenen te bevorderen. Onder 'policie' verstond men destijds bestuur. De Raad van Politie bestond uit 7 leden, 3 ambtelijke leden; de Gouverneur(Generaal), de Raad-Fiscaal en de Raad-Contrarolleur met adviserende stem en 4 'der meest gequalificeerde ingezetenen'.

De Raad behandelde de huishoudelijk aangelegenheden van Curaçao onder het oppergezag van de Gouverneur-Generaal. Artikel 35 van genoemd Regeringsreglement specificeert de taken

18 Reglement op het beleid van de Regering, het Justitiewezen, den Handel en Scheepvaart op Curaçao, en onderhoorige Eilanden, gearresteerd bij Koninklijk besluit van 14 September 1815, 58, in Bordewijk (1911) Bijlage V, pp. 165-181. Zie ook Reglement op het Beleid der Regering, het Justitiewezen, den Handel en Scheepvaart op de Eilanden Sint Eustatius, Sint Martin en Saba, vastgesteld bij Koninklijk Besluit van 14 September 1815, 58, in Bordewijk (1911) Bijlage VI, pp. 181-193. 
van de Raad nader. De Raad had de opperdirectie over kerken, armen en andere publiekrechtelijke administraties, over wezen, minderjarigen en toezicht behoevende personen, over de politie van stad en eiland, over de gebouwen, wegen, straten, veren, publieke marktplaatsen en bank van lening. In artikel 36 worden nog genoemd de vrijlating van slaven en alles aangaande Aruba en Bonaire. Beschikkingen van de Raad in belangrijke aangelegenheden golden slechts voorlopig en hadden de goedkeuring nodig van het Departement van Koophandel en Koloniën te 's-Gravenhage. ${ }^{19}$ De Gouverneur-Generaal van de kolonie Curaçao en onderhorige eilanden werd op Bonaire en Aruba vertegenwoordigd door een 'Commandeur'. ${ }^{20}$

De Gouverneur (voordien Commandeur) op Sint Eustatius en de Commandeur op Sint Maarten (waaronder Saba werd begrepen) werden bijgestaan door een Raad van Politie. In 1820 werd de titel Gouverneur-Generaal gewijzigd in Gouverneur. Evenals in de kolonie Curaçao en onderhorige eilanden was ook op de eilanden Sint Eustatius en Sint Maarten de Raad van Politie belast met huishoudelijke aangelegenheden van de eilanden onder het oppergezag van de Gouverneur-Generaal. ${ }^{21}$

In 1824 werden voor Bonaire en Aruba afzonderlijke Reglementen van administratie en bestuur vastgesteld. Daaruit blijkt duidelijk dat de Commandeur op zijn eiland vrijwel almachtig was en dat invloed van de bevolking op het bestuur geheel ontbrak. Deze reglementen zijn niet uitdrukkelijk afgeschaft, maar moeten sinds 1865 als stilzwijgend vervallen worden beschouwd. ${ }^{2}$ Van 1828 tot 1845 hadden de drie samenstellende delen van de kolonie elk een eigen regeringsreglement en er was ook nog een overkoepelend regeringsreglement voor de gehele kolonie.

De huidige omvang van de gebiedsdelen van de Nederlandse Antillen en Aruba dateert van 1814/1816, toen deze na de Napoleontische tijd door Engeland werden teruggegeven. Na de terugkeer van de Oranje's uit ballingschap behelsden de Grondwetten van 1814 en 1815 een artikel waarin de macht van de Soevereine

Hartog (1961) pp. 668-669.

De term Commandeur is waarschijnlijk afkomstig van de benaming die gebruikt werd voor de Vlootannoerder, of gezaghebber van een bool. Zie Artikel XXXVII van de Ordre van Regieringe: 'Soo wanneer eenighe Schepen vande reyse sullen wederkeeren, allen de Generaels ofle Commandeurs over Vlooten, Schip ofte Schepen'.

Kunst (1981) pp. 237-242.

Bordewijk (1911) p. 40. 
Vorst, respectievelijk van de Koning over de koloniën en bezittingen van Nederland in andere werelddelen zo omschreven werd, dat hij bij uitsluiting (zonder de Staten-Generaal) het opperbestuur had..$^{23}$ Van 1828 tot 1845 werden de kolonie Suriname, Curaçao en onderhorigheden en Sint Eustatius en onderhorigheden samengevoegd. Dit gebeurde om te bezuinigen op de bestuurskosten.

In 1845 werd de administratieve vereniging weer ongedaan gemaakt, omdat een dergelijke bestuurseenheid toch niet zo goed en voordelig werkte als verwacht werd. Naast de kolonie Suriname kwam in 1845 de kolonie Curaçao en onderhorigheden tot stand, inhoudende de zes Nederlands-Antilliaanse eilanden, zodat deze voor het eerst onder één bestuur kwamen. Het bestuur van Curaçao en onderhorigheden zou worden uitgebreid tot de Bovenwinden. Op Curaçao zetelde de Gouverneur met een Koloniale Raad. Hij had de algemene leiding over de kolonie en regelde ook de plaatselijke aangelegenheden van Curaçao. De andere eilanden werden als 'onderhoorigheden' onder het opperbestuur van een Gezaghebber bestuurd, die terzijde werd gestaan door een Raad van Politie. Er kwam én regeringsreglement voor Curaçao en onderhorigheden. De basis voor de huidige Staatsregeling van de Nederlandse Antillen was het Regeringsreglement (uitgevaardigd bij wet en niet meer bij KB) van 1865 .

Motieven voor de Europese expansie in de Nieuwe Wereld

Vanaf 1450 streefden Portugese- en Italiaanse handelslieden en zeevaarders ernaar, naast het vinden van nieuwe zeeroutes, ook goud, goedkope specerijen en kaneelsuiker te vinden. In 1453 was Constantinopel door de Turken ingenomen en was voor Genua de specerijenroute via de Oriënt afgesneden. Bovendien werden binnen het internationale ruilverkeer de handelstransacties met goud betaald. De behoefte aan goud en zilver steeg met het toenemen van de handel. Heel Europa had zilver nodig, maar de ertsaders in Bohemen, Saksen en Tirol waren bijna uitgeput. Er moesten oorlogen worden gefinancierd en schepen uitgerust. Aan het eind van de $15 \mathrm{e}$ eeuw overtrof de vraag naar goud verreweg het aanbod. Goud zou te vinden zijn, volgens de verhalen van Marco Polo, in Cathay (China) en Cipango (Japan). Ptolomaeus had al gewaarschuwd dat goud alleen maar gevonden kon worden 
in verre en hete landen. Geldschieters financierden ontdekkingsreizen in de hoop dat er goud zou worden gevonden. ${ }^{24}$ Met de val van Constantinopel ontstond de wens om een zeeweg naar Indië en China via het westen te vinden. ${ }^{25}$

Portugal richtte zich op de ontdekking van Afrika en Aziē en zou zich pas omstreeks 1549 bezig gaan houden met Braziliē. Spanje koloniseerde Zuid-Amerika. ${ }^{26}$ Isabella van Castilië huwde Ferdinand van Aragón in 1468, door hun huwelijk voorkwamen zij dat hun rijken uiteen vielen. Zij bevrijdden in 1492 het Iberisch schiereiland van het laatste Moorse bolwerk. Die oorlog werd noodzakelijk geacht, omdat het om een heilige oorlog ging, de christelijke oorlog tegen de islam. Koningin Isabella en haar echtgenoot vonden verbreiding van het Christendom zo belangrijk, dat andere godsdiensten niet werden geduld. Daarom moesten in 1492 alle Joden, die zich niet tot het christendom bekeerden, vóór 1 juli 1492, met achterlating van hun goud het land verlaten. Isabella was tevens van mening, dat zij de ongedoopte zielen overzee tot het christendom moest brengen en in dat streven van Isabella zou Columbus een belangrijke rol spelen. Spanje ontwikkelde zich tot een natie met het zwaard en het kruis in de hand. De expansie van het Castilliaanse rijk was, in de traditie van de kruistochten, ook een uitbreiding van Gods rijk op aarde.

Columbus werd in 1451 in Genua geboren. Hij vertrok op zesentwintigjarige leeftijd naar Portugal. In 1480 bevestigde het verdrag van Alcobaça dat Afrika en de streken die gelegen zijn ten zuiden van Kaap Bojadar aan Portugal behoorden, en de Canarische eilanden aan Castiliē. In 1492 diende Columbus zich aan bij het Hof van Ferdinand van Aragón en Isabella van Castilië met zijn lang gekoesterde droom om een kortere, westelijke doorvaart naar Indië te vinden. God had hem in een droom geopenbaard hoe hij de ongedoopte zielen via het westen kon bereiken. Dit sprak koningin Isabella aan, zij financierde tenslotte in 1492 zijn eerste ontdekkingsreis. Over het algemeen wordt aangenomen dat Columbus voor het eerst voet aan wal zette in de Nieuwe Wereld op

Bedoeld wordt Ptolomaeus Claudius (ca 100-170). Alexandrijns astronoom, geograaf, wiskundige en muziektheoreticus. Tot de $16 \mathrm{de}$ eeuw heeft zijn 'Geographia' of 'Cosmographia', een gids voor het maken van kaarten invloed uitgeoefend op ontdekkingen en de cartografie. In de renaissance was er grote belangstelling voor zijn Geographia, Grote Winkler Prins Encyclopedie in 25 delen, deel 18, Elsevier, Amsterdam/Brussel, 1982, p. 462. Granzotto (1992) pp. 11-19; zie ook Naipaul (1987). 
een van de eilanden van de Bahama's, Watling (San Salvador), volledige zekerbeid bestaat daar echter niet over. ${ }^{27}$

De ontdekking van de Nieuwe Wereld werd in Europa, als bron van ongekende rijkdom met geestdrift begroet. De Spanjaarden spoedden zich hun soevereiniteit over de nieuw verworven gebieden veilig te stellen. Kort na Columbus' eerste tocht naar Amerika (1492) eiste echter de energieke Portugese koning Juan II diens ontdekkingen op. Hij baseerde zijn eis op het tussen Portugal en Spanje gesloten verdrag van Alcobaça (1480). Dit was het eerste Europese verdrag geweest dat aanspraken op overzeese bezittingen tot onderwerp had. De 'Katholieke koningen' wendden zich in verband met dit conflict tot Paus Alexander VI. De positie van de pausen was aan het eind van de Middeleeuwen reeds verzwakt, maar zij hadden vanaf de 14de eeuw uitspraken gedaan over de bekering van de heidenen en andere koloniale aangelegenheden. De paus deed dat uit de apostolische volheid van zijn macht en wees het Caraibisch gebied aan Spanje toe. De motivering van de paus was, dat hij het goede voornemen van de Spaanse vorsten om de inboorlingen in het pas ontdekte gebied in de goddelijke barmhartigheid te laten delen en tot het katholieke geloof te brengen, wilde aanmoedigen. De pauselijke bullen hadden Afrika als apostolische concessie toegekend aan de Portugese Kroon en de Castilliaanse Kroon kreeg 'de onbekende gebieden, die nog ontdekt worden in de toekomst [...]'. Zuid-Amerika werd aan koningin Isabella geschonken.

In 1508 verleende een nieuwe bul de Spaanse Kroon levenslang het recht op alle tienden die geĩnd werden in Zuid-Amerika, het felbegeerde universele patronaat over de kerk in de Nieuwe Wereld impliceerde het recht van de koning op alle kerkelijke inkomsten. ${ }^{28}$ Met het verdrag van Tordesillas (1494) verdeelden de vorsten van Spanje en Portugal, onder het toeziend oog van Paus Alexander VI, de wereld simpelweg onder elkaar. De getrokken demarcatielijn werd enigermate bijgesteld ten gunste van Portugal. Hierdoor kon Portugal aanspraak maken op Braziliē,

27 Granzotto (1992) pp. 162-206, zie met name de kaart op p. 194; Attali (1992) pp. 119-133. Gould (1980) pp. 66-94, geeft aan dat behalve San Salvador (Watling) volgens geleerden ook Cat, Gran Turk, Mayaguana en Samana (ook wel genoemd Samana Cay en/of Atwood's Cay) aanspraak maken op het eerste bezoek van Columbus aan de Nieuwe Wereld. Hij haslt daartoe alle bekende en onbekende standaardwerken aan. Hij komt zelf naar voren met een nieuwe claim, te weten Santa María de la Concepción, dat vlak bij Watling ligt. De nasm San Salvador werd sinds het begin van de zeventiende eeuw gebruikt om zowel Cat als Watling aan te duiden.

Galeano (1980) p. 26. 
hetgeen in 1500 gebeurde. $^{2)}$ Ferdinand en Isabella van Spanje hadden de koloniën als nieuw erfelijk bezit van de Kroon ingelijfd. Reeds in het tweede jaar na de ontdekking van Amerika door Columbus legde koningin Isabella in Spanje aan een commissie van juristen en theologen de vraag voor of Indianen in slavernij gebracht konden en mochten worden. Deze vraag werd ontkennend beantwoord. Indianen waren vrije mensen. ${ }^{30}$ Dit gold echter niet voor negers, zij werden wel in slavernij gebracht, zij werden niet als vrije mensen beschouwd.

In 1526 werd de Spanjaard Juan Martinez de Ampués benoemd tot 'encomendero' (bestuurder) van de drie Benedenwindse eilanden. Hij hield zich bezig met de handel in slaven op het vasteland, bij de plaats 'Santa Ana de Coro', waar de tot het christendom bekeerde cacique Manaure van de Caquetios, vijandige Indianen aan de Spanjaarden uitleverde. De kolonisatie van Curaçao had in eerste instantie de verovering van de kust van het vasteland tot doel. Omdat de meeste aandacht van de Spanjaarden en later de Hollanders naar Curaçao uitging, konden de Indianen op Aruba zich relatief lang handhaven. Volgens een telling in 1806 woonden er in dat jaar nog 550 Indianen. $^{31}$ De Ampues $^{32}$ verkreeg na

Kunst (1981) pp. 15-19.

30 De vader en de broer van Bartolomé de Las Casas, een dominicanenpater, waren bemanningsleden op de derde reis van Columbus. $\mathrm{Zij}$ waren in Hispañola gebleven. In 1510 werd Bartolomé de Las Casas als eerste priester aangesteld in het Nieuwe Land. Hij was in eerste instantie van mening dat de Indianen gekerstend moesten worden en was niet tegen slavernij. In 1520 ging hij daar anders over denken. Hij meende dat er geen natuurlijke slaven zijn, noch kunnen zijn. Ook kunnen er geen mensen bestaan zonder vrijheid en rechten of volkeren zonder soevereiniteit. Karel V verklaarde dan ook in 1530, op advies van De Las Casas, dat Indianen niet in slavernij mochten worden gebracht. Een Pauselijkc brief van Paus Paulus Il (1537) onderschreef deze gedachtengang. Indianen zijn geen apen, maar mensen, zo stelde zijn herderlijk schrijven. Dit betekende welhast dat De Las Casas met zijn standpunt de negers ongewild tot slavernij veroordeelde. Ondanks de erkenning van de kerk dat Indianen ook mensen waren ging, wat tegenwoordig als genocide wordt aangeduid, onverminderd door. In totaal kwamen in een tijdsbestek van vijftig jaar vijfenzeventig miljoen Amerikaanse Indianen om, terwijl slechts tweehonderdveertigduizend Spanjaarden zich daar vestigden. In vier eeuwen werden er meer dan dertien miljoen Afrikanen als slaven nasr Amerika gebracht om de Indianen die waren uitgeroeid te vervangen. Arali (1992) p. 230; Saja-Molins (1988) p. 28; Schiltkamp (1972) p. 9: art. 87 van de Instructie voor Brazilië van 23 augustus 1636 vermeldı dat Brazilianen en Indianen niet tot slaven mochten worden gemaakt, maar net als andere inwoners moesten worden behandeld. Attali (1992) pp. 228-230. 
lang aandringen in 1525 toestemming om het eiland Curaçao weer te bevolken. Hij wilde Curaçao gebruiken om de uitvoer van rode slaven van daan te organiseren. Curaçao was in bestuurlijk opzicht ondergeschikt aan het Spaanse bestuur (de audiencia) ${ }^{33}$ van Santo Domingo en in kerkelijke aangelegenheden aan het bisdom Coro (Venezuela). Een deel van de weggevoerde Indianen kreeg toestemming om naar Aruba en Curaçao terug te keren. Na de verovering van de Benedenwinden door Nederland, werden de staatsrechtelijke en kerkrechtelijke betrekkingen met het vasteland verbroken. De economische betrekkingen tussen Venezuela en Curaçao bleven echter bestaan. ${ }^{34}$

Columbus droeg door zijn ontdekkingsreizen veel bij tot de 'conquista' van Latijns-Amerika door de Spanjaarden en Portugezen en indirect aan de dood van miljoenen overwonnen Indianen en negerslaven. De goudkoorts had de 'conquistadores' zo in hun greep dat een meedogenloze jacht werd gemaakt op de natuurlijke rijkdommen van de overwonnen Indianen. Er werden grote hoeveelheden goud en zilver gevonden op de hoogvlakte van Mexico en hoog in het Andesgebergte (Potosi). Hernando Cortéz ontdekte in 1519 voor Spanje de fabelachtige rijkdom van de Azteekse schatten van Montezuma. Vijftien jaar later kwam in Sevilla het gigantische losgeld aan, én vertrek vol goud en twee vol zilver, dat Francisco Pizarro de Inca Athualpa liet betalen alvorens hem te wurgen. Veel Indianen van Dominica pleegden zelfmoord, om

32 Juan Martinez de Ampués (of Ampies), was vóór hij zich naar West-Indië begaf, kapitein in het Castiliaanse leger en maakte als zodanig een veldtocht mee in Italiē. Met een réal cédula (koninklijke ordonnantie) van 19 mei 1511 werd hij aangesteld tot factor op het eiland Hispaniola. In 1526 benoemde Karel V Juan de Ampués tot factor over Curaçao, Aruba en Bonaire. De eilanden moesten op vreedzame wijze worden gekoloniseend. Hij bevolkte de onbewoonde eilanden met vreedzame Arowakken, die op Hispaniola waren terechtgekomen en trachtte de Indianenjagers ervan te weerhouden om Curaçao, Aruba en Bonaire te bezoeken. De Ampués sloot een verdrag met de cacique Manaure in Venezuela. De overeenkomst verzekerde De Ampués van een regelmatige aanvoer van Indiaanse krijgsgevangen. Hij stichtte op het vasteland de stad Santa Ana de Coro (Coro), om een gunstige uitvoerhaven te hebben voor de te vervoeren Indiaanse slaven en Venezuela verder te koloniseren. Encyclopedie (1985) pp. 22 e.v.; Goslinga, De WIG, 37, 1957, pp. 169-187; Goslinga (1979) pp. 13-19; De la Try Ellis (1981) pp. 131-153: hierin wordt ook een uitleg gegeven van het begrip Encomienda. Het hield een vorm van dwangarbeid in van Indianen in de Nieuwe Wereld. Alonso de Ojeda zou Curaçao hebben bezocht in 1499 en in 1507. In 1499 was ook Amerigo Vespucci daarbij aanwezig.

31 De Audienca Real was een plaatselijk bureau van de koninklijke lndische Raad in Madrid, het was de hoogste Spaanse bestuurs- en toezichthoudende instantie in de Amerikaanse kolonies; Bartolomé de Las Casas (1969) p. 139, noot 29. Encyclopedie (1985) p. 186; Daal (1988) p. 28; Van Soest (1980) pp. 3-6. 
maar niet in handen van de veroveraars te vallen. ${ }^{35}$

Columbus deed de Bovenwindse eilanden aan op zijn tweede ontdekkingsreis in 1493. De Bovenwinden waren toen al niet meer bewoond. In 1499 zeilde vervolgens een expeditie onder leiding van Alonso de Ojeda, met onder andere Amerigo Vespucci aan boord naar de Nieuwe Wereld. De Spanjaarden gingen aan land op Bonaire en Curaçao en troffen er toen Indianen aan. De Benedenwindse eilanden werden sindsdien van tijd tot tijd door de Spanjaarden bezocht, om Brazil-hout ${ }^{36}$ te kappen en om er Indianen weg te voeren, om te werken op de suikerrietplantages van Hispaniola. ${ }^{37}$ Aangezien er geen edele metalen te vinden waren, verklaarde de nieuwe onderkoning van Hispaniola ${ }^{38}$ (thans de Dominicaanse Republiek), Diego Colón (de zoon van Columbus), de eilanden in 1513 tot 'Islas inútiles'. In datzelfde jaar werd de gehele bevolking (ongeveer 2000 Caquetios Indianen) van Aruba, Curaçao en Bonaire weggevoerd om op de vier suikerplantages van Hispaniola te werken.

Toen Karel V, Heilig Rooms Keizer en Koning van Spanje, ${ }^{39}$ in 1555 te Brussel afstand deed van de troon ten gunste van zijn zoon Filips II, gebeurde dat in tegenwoordigheid van afgevaar-

Galeano (1980) pp. 21-25 en 31-37. Tussen 1503 en 1660 werd 185.000 kilo goud en 16.000 .000 kilo zilver naar Spanje vervoerd. Het koninkrijk betaslde hiermede haar, meestal buitenlandse schuldeisers. In 1543 was $65 \%$ van de totale koninklijke inkomsten bestemd voor de jaarlijkse afbetaling van de schulden. Het rijke imperium had een arm moederland.

36 Ook wel Brasia genoemd (Haematoxylon brasiletto) of brazil, kampèchi, logwood, stokvishout, plantesoort uit de familie der Caesalpiniaceae. Gedoornde loofverliezende boom, met meestal een zeer grillig gevormde stam, Encyclopedie (1985) p. 94.

37 Bij het verdrag van Rijswijk van 1679 bevestigde Spanje de Franse bezelling van een deel van haar kolonie Hispaniola. Deze Franse kolonie in Hispaniola werd Saint-Dominigue genoemd. In 1804 werd het Franse gedeelte van Hispaniola, Saint-Dominigue onathankelijk. Voortaan werd Saint-Dominigue Haitti genoemd. Hispaniola is een belangrijk centrum geweest van de suikerrietplantage industrie. Tenslotte werd de Spaanse kolonie Hispaniola, de Dominicaanse Republick. Het Spaanse gedeelte van Hispaniola verklaarde zichzelf onafhankelijk van Spanje in 1821. In 1822 annexeerde Haîti de voormalige Spaanse kolonie, Hispaniola bleef onder het gezag van Haïti tot 1844 . Toen verklaarde het zichzelf onafhankelijk van Haîti als de Dominicaanse Republiek; Williams (1970), pp. 81, 254 en 415. Hispaniola wordt ook wel op de Spaanse manier aangeduid als Hispañola. Attali (1992) pp. 226-228. Van de driehonderdduizend Indiaanse inwoners van Hispañola, die er woonden, toen Columbus er aankwam waren er in 1510 nog vijftigduizend over en in 1540 nog duizend. Een ton suiker stond gelijk aan het leven van een slaaf. Spanje heeft met het koloniseren van Zuid-Amerika miljoenen Indianen uitgeroeid, benevens de cultuur van de Azteken en de Inca's. 
digden van de 17 Nederlandse gewesten. De nieuwe Spaanse Koning was niet gecharmeerd van zijn noordelijke onderdanen, die vergaande privileges genoten en een té grote zelfstandigheid aan de dag legden. Het noorden was bovendien overwegend protestant, een doorn in het oog van de katholieke vorst. Tegen de maatregelen die Filips II nam om zijn gezag te versterken kwamen de Nederlanden in opstand. Het verzet van de gewesten diende niet alleen het belang van de Calvinisten, maar ook dat van de adel, de stadsbestuurders en de kooplieden. ${ }^{40}$ De opstand was ontstaan door een juridisch verschil in opvatting over het wezen van de soevereiniteit tussen de heer en de Staten van zijn gewesten. Filips II wilde een eenwenlange staatsrechtelijke traditie doorbreken en een eenheidsstaat vormen onder zijn absoluut gezag. Dit konden de Staten van de gewesten niet accepteren, daar het hun bevoegdheden ernstig zou beperken. Dit conflict zou leiden tot de afzwering van de landsheer in $1581 . .^{41}$

Onder leiding van Willem van Oranje groeide de opstand uit tot de Tachtigjarige Oorlog (1568-1648).

Filips II slaagde erin de zuidelijke gewesten gewapenderhand te onderwerpen; de zeven noordelijke gewesten, in volle bloei door handel, nijverheid en scheepvaart, scheidden zich af en sloten zich aaneen in de Unie van Utrecht (1579). Dit verdrag regelde de gemeenschappelijke verdediging tegen de Spanjaarden, maar liet de zelfstandigheid van de gewesten intact. In 1581 werd de landsheer van zijn gezag vervallen verklaard; dit werd in een plechtige oorkonde het 'Plakkaat van Verlatinge' neergelegd. De gewesten die zich aaneen gesloten hadden in de Unie van Utrecht hielden de strijd vol en werden tenslotte onafhankelijk (1648). De opstandige (Noord) Nederlanders hadden hun onafhankelijkheid in grote mate aan de economische bloei te danken, opgebouwd door de zeevaart en handel. In het midden van de 16de eeuw was naar schatting een vierde deel van de mannelijke bevolking van Holland betrokken bij de overzeese handel, de scheepvaart en de visserij. Met een vloot van zo'n 300 vissersschepen en 75000 zeelieden was de visserij de belangrijkste bron van inkomsten. Voor het conserveren van de vis was zout nodig. En dat vormde een groot probleem. De oorlog met Spanje en de daaruit voortvloeiende 'generale arresten' (het verbod van handel in zout met vijandige gebieden) van de Spaanse Kroon brachten namelijk de aanvoer van zout

4 Goslinga (1971) pp. 1-89.

4 De Monté ver Loren en Spruit (1982) pp. 203-216.

38. De Nederlandse kolonisatie van de West 
uit het Iberisch schiereiland nagenoeg tot stilstand. De enorme behoefte stimuleerde de Nederlanders in steeds grotere aantallen de zee te bevaren op zoek naar zout. ${ }^{42}$

De Nederlanders vonden het felbegeerde zout in het Caraibisch gebied, met name op Punta de Araya, een schiereiland van het vasteland van Venezuela, halverwege het eiland Margarita en de stad Cumaná. De Hollanders tartten de Spaanse aanwezigheid met de bouw van pieren en loodsen, waar het gewonnen zout werd opgeslagen. De Hollandse expedities hielden zich behalve met verboden zoutwinning ${ }^{43}$ ook met smokkel en piraterij bezig. Dit betekende een schending van de 'generale arresten'.

Spanje nam dan ook maatregelen en zond in 1605 een Armada uit om de Spaanse soevereiniteit kracht bij te zetten. De illegale zoutvaart werd echter voortgezet totdat tijdens het Twaalfjarig Bestand (1609-1621), Spanje en Portugal de zouthandel weer hervatten. In 1622 hervatten de Hollanders de illegale zoutvaart weer. Ondanks regelmatige overvallen van de Spanjaarden werd de zoutwinning voortgezet tot 1640 , sinds 1622 op het eiland Tortuga (Venezuela). De Hollanders richtten in 1630 hun aandacht op Sint Maarten, vanwege de zoutpannen daar en een goede haven. Het onbewoonde eiland werd in 1631 bezet. In juli 1633 verscheen een Spaanse vloot voor de kust. De Hollanders gaven zich over en tot het eind van de Tachtigjarige Oorlog was er een permanent Spaans garnizoen op Sint Maarten gevestigd. ${ }^{44}$

\section{Economische ontwikkeling}

De bewindhebbers van de WIC besloten Curaçao in bezit te nemen 'om te hebben een bequaeme plaetse, daar men sout, hout ende anders mocht becomen, ende van de selve plaetse den viant in West-Indiēn te infesteren. ${ }^{45}$ Als producent van zout, verfhout en andere handelsprodukten bleek Curaçao slechts geringe waarde te bezitten. Meer betekenis had het eiland, althans tot het einde van de Tachtigjarige oorlog, als marinebasis van waaruit de Spaanse schepen en gebieden konden worden aangevallen. De WIC was ondermeer geïnteresseerd in de zilverschatten die vanuit het Amerikaanse vasteland op transport naar Spanje werden

\footnotetext{
Daal (1988) pp. 33-35.

Naipaul (1987) pp. 81 e.v.

Goslinga (1971) pp. 116 e.v.

Renkema (1981) p. 7.
} 
gesteld. Deze van staatswege georganiseerde kaapvaart moest de Spaanse oorlogsmacht verzwakken en tegelijkertijd de oorlogsreserves van de strijdende Nederlanden aanvullen. Niet alleen was Curaçao uitvalsbasis voor de vloot, maar ook vormde het een depot waar een deel van de veroverde buit, door middel van kaapvaart verworven, kon worden verzameld. Voor de kaapvaarders bestond bovendien de gelegenheid om er hun schepen te herstellen en de scheepsvoorraden aan te vullen. Na sluiting van het vredesverdrag tussen Spanje en de Nederlanden in 1648 richtte de WIC zich in plaats van op de kaapvaart meer op handeldrijven. ${ }^{46}$

Toen de Spanjaarden in 1634 het eiland verlieten, werd hun voorbeeld gevolgd door de Indianen, die tijdens het Spaanse bestuur op verschillende plaatsen op het eiland voedingsgeu assen hadden verbouwd en vee hadden gehouden. Hierdoor was de WIC genoodzaakt zelf zich op de landbouw toe te leggen of particuliere 'coloniers' aan te trekken. Na een aarzelend begin vol tegenslagen in de eerste decennia na 1634 kwam er omstreeks 1660 vaart in de aanleg van de door de Compagnie geëxploiteerde plantages. In dezelfde tijd werden verschillende terreinen op Curaçao aan particulieren ter bebouwing toegewezen of door hen eenvoudig in beslag genomen. Voor de bevoorrading van schepen, voor de voedselvoorziening van de op Curaçao verblijvende soldaten en compagniesambtenaren en om te voldoen aan de wens van de WIC handelsprodukten te verkrijgen, was het noodzakelijk dat op het eiland enige akkerbouw en veeteelt tot ontwikkeling kwam.

Curaçao, toevertrouwd aan de zorg van de Kamer Amsterdam van de WIC, was na de verovering in 1634 eerst een steunpunt voor de oorlogsvloten en de kaapvaart, later werd het een doorvoorhaven voor de clandestiene slaven- en goederenhandel op de nabijgelegen Spaanse bezittingen. Naast voedselgewassen werden op het eiland suiker, indigo en tabak verbouwd, maar dit bleek toch bijzaak. Op Bonaire verbouwden enkele tientallen slaven onder een blanke opzichter mais voor Curaçao of hielpen zout laden bestemd voor Nederland. De Bovenwinden waren Zeeuwse patroonschapskolonies. Op Aruba, dat nauwelijks was bewoond, werden paarden gefokt. Tussen 1674 en 1791 namen de handelscontacten af en nam de landbouw toe waardoor de slavenbevolking eveneens toenam. ${ }^{47}$

\footnotetext{
$4 \quad$ Römer-Kenepa (1983) p. 3.

47 Van den Boogaart (1982) pp. 137 en 158.
} 
Pas omstreeks 1650 begon de plantagegeschiedenis van Curaçao. De groeiende betekenis die het eiland kreeg als centrum voor de slavenhandel, maakte het noodzakelijk het aantal compagnieplantages voor de verbouw van voedselprodukten uit te breiden. Over het algemeen werden de plantages verwaarloosd en kostten ze meer dan ze opbrachten. De compagniesplantages op Curaçao werden na 1717 al niet meer door de WIC zelf beheerd; ze waren op é́n uitzondering na, aan particulieren in huur gegeven. Na de opheffing van de WIC in 1791 werd door de Raad van Koloniën besloten alle compagniesplantages op Curaçao te verkopen. Omstreeks dezelfde tijd waarin begonnen werd met de aanleg van de compagniesplantages ontstonden ook de eerste plantages van particulieren.

Toen Braziliē in 1654 afgestaan moest worden aan de Portugezen kwamen zeventig Joodse kolonisten uit Braziliē naar $\mathrm{Cu}$ raçao. $\mathrm{Zij}$ kregen toestemming van de autoriteiten om zich op Curaçao te vestigen en hun kennis over het verbouwen van gewassen in de praktijk te brengen.

Ook compagniesbeambten en vrije personen legden plantages aan. Er werd kleine maïs (sorghum), oorspronkelijk uit Afrika afkomstig verbouwd, evenals grote maīs 'mashi grandi', bonen, pinda's, rankvruchten en groenten, zoals rode biet, rammenas, radijs, wortelen en spargies. Ook werden oranjeappels, kokosnoten, china-appels, schupappels, pompelmoes, granaatappels, starappels, dadels, mispels, knippen, tamarinde, wilde druiven, zure limoenen, zoete limoenen, citroenen, zurezakken, goyabes, geelpruimen, Spaansche pruimen, casjoe, mango, advocaatappels, wilde amandels, mamajes, papayes, vijgen, broodbomen, bananen, bakobes en pomme de rose verbouwd en aangeplant. ${ }^{48}$ Als handelsgewassen werden indigo, suikerriet, tabak, katoen en verfhout verbouwd.

In de 19de eeuw was hier weinig meer van over. Directeur Van Raders (1836-1845) probeerde de landbouw te intensiveren door stapelprodukten te verbouwen. De katoen had echter veel te lijden van rupsen en insekten. De teelt van de andere vermelde handelsgewassen mislukte eveneens door een tekort aan regenwater, al of niet gepaard gaande met insektenplagen. Bij indigo speelde ook het ontbreken van winstgevende afzetmogelijkheden een rol. $^{49}$

4 Renkema (1981) pp. 7, 13-15 en 25 e.v., 30 e.v.

49 Renkema (1981) pp. 333-336. 
De economische situatie in Nederland was na de Napoleontische oorlogen niet rooskleurig. De handel had veel geleden. Koning Willem I nam maatregelen om Curaçao te ontwikkelen als een belangrijke handelsbasis in het Caraibisch gebied. Deze ontwikkeling werd echter belemmerd door de excentrische ligging van Curaçao en het feit dat Nederland pas in 1828 een handelsverdrag sloot met de Republiek Gran Colombia. Ook kwam Van den $\mathrm{Bosch}^{50}$ om het bestuur te reorganiseren en werden de drie koloniën in 1828 onder één bestuur geplaatst. Desondanks bleef de handel met de vaste kust een kwijnend bestaan leiden, de landbouwprodukten die werden verbouwd waren slechts toereikend voor de eigen consumptie. De geringe landbouw die er was, liep door de afschaffing van de slavernij nog meer terug. Verfhout ${ }^{51}$ en divi-divi ${ }^{52}$ peulen werden tot de Eerste Wereldoorlog in grote hoeveelheden uitgevoerd. Op Curaçao en Bonaire was in de 19de eeuw ook zout een belangrijk exportartikel. ${ }^{53}$ Op Curaçao, Bonaire en Aruba werd geprobeerd de cochenille-cultuur ${ }^{54}$ te ont-

so Commissaris-Generaal Van den Bosch werd door Koning Willem I naar de koloniën gezonden om orde op zaken te stellen en om met het oog op bezuinigingen in de bestuurskosten de koloniën samen te voegen tot één kolonie. De samenvoeging van de latere Nederlandse Antillen en Suriname duurde van 1828 tot 1845 .

s1 Renkema (1981) p. 274, noot 99 en p. 36. Verthout werd in de 17 de eeuw met scheepsladingen tegelijk naar Nederland verzonden, waar het werd gebruikt voor de bereiding van rode verfstof. In de laatste decennia van de 19de eeuw werd verfhout voor ongeveer $f$ 50,- per ton naar New York verkocht, maar in het begin van de 20 ste eeuw was er geen markt meer voor het produkt. Brazilië zou genoemd zijn naar het verthout (of stokvishout), dat er in grote hoeveelheden voorkwam; De Haan (1940) p. 17.

52 De economische waarde van de watapana- of divi-divipeul werd al voor de komst van de Nederlanders door de Spanjaarden erkend. Uit de divi-divipeulen werd looistof gewonnen. In het begin van de 19 de eeuw werden de produkten van de divi-diviboom voor verschillende doeleinden aangewend. Het hout werd veel gebruikt bij het branden van kalk, van de takken werden geselroeden gemaakt en de peulen werden op kleine schaal voor het looien van leer gebruikt. In 1837 werd bekend dat de peul ook een blauwe kleurstof en een geneeskundige stof bevatte. Omstreeks 1868 daalde de prijs van de divi-divi peulen sterk. Belangrijke winsten werden met de export van dit produkt nooit bereikt; Renkema (1981) pp. 36-40.

s3 Renkema (1981) pp. 53-62.

s4 Cochenilletuin, nopalerie of nopaltuin. In 1836 deed op Curaçao, Bonaire en Aruba de teelt van de nopalcactus (Nopalea cochenillifera) of French prickle zijn intrede. Op deze cactus leeft de cochenilleluis (Dactylopius coccus), die een karmijnrode kleurstof levert, Encyclopedie (1985) p. 109; Renkema (1981) pp. 77-83. 
wikkelen en werden er alo $e^{55}$ en katoencultures aangelegd. Alleen de aloë en de divi-divi hadden succes. De economie trok echter pas wat aan toen met de fosfaatwinning in 1871 werd begonnen. Na 1870 bezochten meer schepen de haven. De enige voorspoedige handel was echter het leveren van wapens aan de jonge republieken in de regio. Ook de gebeurtenissen op de vaste wal, met name in Venezuela, waren van invloed op de handelsbetrekkingen. Tijdens de moeilijkheden onder president Antonio Guzmán Blanco gingen in het Nederlandse parlement stemmen op om Curaçao aan Venezuela te verkopen (1876).

In 1915 opende de vestiging van de Curaçao Oil Company Ltd op Curaçao (Shell) - later herdoopt in de Curaçaose Petroleum Industrie Maatschappij (CPIM) - haar poorten, terwijl voor het transport van de ruwe olie van Maracaibo (Venezuela) naar Willemstad de Curaçaosche Stoomvaart Maatschappij (CSM) werd gesticht. De Koninklijke Shell-groep begon met de exploratie van aardolie bij het Meer van Maracaibo. Daar het meer voor diepgaande zeeschepen ontoegankelijk was werd de ruwe olie met kleine schepen naar de uitstekende haven van Curaçao vervoerd en daar geraffineerd. Aan het begin van de jaren tachtig is de Shell Curaçao gestart met een rigoureus bezuinigingsprogramma; ze heeft haar bezigheden aan het eind van de jaren tachtig gestaakt. Thans ontwikkelt een Venezolaanse oliemaatschappij activiteiten op Curaçao. De bijdrage van de olieindustrie aan de nationale economie is in de loop der jaren sterk verminderd. ${ }^{56}$ De toeristenindustrie heeft zich sterk ontwikkeld, met name op Curaçao, Bonaire, Aruba en Sint Maarten en is van groot belang voor de economie.

Aloë kwam reeds lang, in verschillende soorten, in het wild voor op de Benedenwindse eilanden. De bladeren van de plant werden gebruikt om stenen vloeren en tegels te schrobben of om mahoniehout schoon te maken en te laten glanzen; de stengel van de bloem was handig bij het repareren van omheiningen. Uit de bladeren werd een bepaalde soort koeken, de 'Koekoe Indiaan' gemaakt. De aloëgom of hars werd opgevangen en gekookt. De ingedikte en gestolde vloeistof werd in de 19de eeuw naar Londen of Liverpool verscheept, was het werd gebruikt voor de bereiding van medicijnen of bij de bereiding van bier, wasbij het een surrogaat vormde voor hop. De geringe afzetmogelijkheden en de grote prijsschommelingen op de wereldmarkt leidde ertoe dat de produktie van aloëhars in de jaren 60 van de 19de eeuw werd beëindigd. Thans is op Aruba een cosmeticafabriek gevestigd die schoonheidsprodukten vervaardigd van de aloëhars, grotendecls bestemd voor de Arubaanse- Antilliaanse- en Amerikaanse markt; Renkema (1981) pp. 83-87.

Zie voor een overzicht van de economie van Curaçao: Van Soest (1976); Van den Boogaart (1982) p. 223. 
De economische ontwikkeling van Aruba, Bonaire en de Bovenwinden verliep minder opvallend. De WIC gebruikte Bonaire en Aruba aanvankelijk als Compagnieplantages. Pas omstreeks 1770 kregen inwoners van Curaçao en Bonaire toestemming zich op Aruba te vestigen. Zij begonnen er plantages, die dankzij slavenarbeid levensvatbaar bleken.

Op Aruba werd de paardenfokkerij uit de Spaanse tijd door de WIC voortgezet. Paarden werden uitgevoerd naar Cuba en Jamaica. Ook leverde Aruba vlees aan de Compagnie in Curaçao. Vandaar de naam 'rancho' (vleesleverancier). Deze naam leeft nog voort in de naam van een wijk in Oranjestad. Rancho en paardenuitvoer leverde Aruba in de tijd van de WIC een schraal bestaan op. Omdat Aruba 'leeftogt' voor Curaçao leverde, was er tot het eind van de $18 \mathrm{de}$ eeuw geen vrije kolonisatie toegestaan. Daarom waren er ook nauwelijks slaven op Aruba, in tegenstelling tot Curaçao. ${ }^{57}$

Aruba is lange tijd een arm eiland geweest met weinig inwoners. Van 1824 tot 1915 is er goud gewonnen. Goud werd voor het eerst in 1824 in Rooi Fluit aangetroffen. Reeds in het begin van de vorige eeuw werd dit gemakkelijk winbare (alluviale) goud praktisch geheel afgegraven. Sinds 1839 vond goudwinning plaats door de ontginning van kwartsaders waarin het oorspronkelijke goud in fijnverdeelde vorm voorkomt. De mijnbouwactiviteiten vonden tot 1916 plaats, voor het laatst door de Aruba Goud Maatschappij. De ruines van goudsmelterijen te Bushiribana en Balashi getuigen van deze periode. De goudwinning op Aruba is nooit erg rendabel geweest. Volgens de officiële gegevens werd van 1824 tot 1916 in total $1338,63 \mathrm{~kg}$ goud geproduceerd, tegen de huidige goudprijs een waarde van ongeveer 20 miljoen dollars. In 1946 werd door de Aruba Combined Goldfields Ltd., een uitgebreid opsporingsprogramma uitgevoerd, maar dat leidde niet tot hernieuwde goudwinning. In 1986 toonde een Canadese groep investeerders belangstelling voor goudwinning op Aruba. Aan de Canarub Development NV werd toestemming verleend voor het onderzoeken van de ertsrestanten van de goudsmelterij te Balahsi. Op grond van een rapport zullen opsporingsonderzoeken worden verricht. Tot op heden (1994) heeft dat nog niets opgeleverd. ${ }^{58}$

Verder leefden de inwoners van de veeteelt en de paardenfokkerij. Fosfaat werd op Aruba voor het eerst in 1874 ontgon-

\footnotetext{
ת Hartog (1961) pp. 55, 60, 75, 76.

* Contactplan (1989) pp. 113 en 114.
} 
nen, de ontginning werd beëindigd in 1914. Grote veranderingen op Aruba traden in met de komst van de Lago Oil and Transport Company in $1924 .^{59} \mathrm{Er}$ werden verladingshavens en raffinaderijen aangelegd voor de in Venezuela gewonnen olie. Olie bracht Curaçao en Aruba grote welvaart. In 1985 sloot de Lago haar raffinaderijen, die in 1991 weer gedeeltelijk opgestart zijn door de Amerikaanse oliemaatschappij Coastal.

Bonaire was voor de WIC van belang als plantage, voor de winning van zout en verfhout, de veeteelt en maïscultuur. Er woonden weinig mensen. Behalve slaven werden er gestraften van de andere eilanden bij de zoutwinning te werk gesteld. Van 18101815 werd Bonaire gedeeltelijk aan particulieren verhuurd. Van 1816-1868 was Bonaire Gouvernementsplantage. Aan het begin van de 19de eeuw zorgden de zoutwinning en de verwerking van de divi-divi peul voor inkomsten. Vanwege de verslechterde economische situatie na 1868 emigreerden de arbeiders van Bonaire naar Venezuela en Suriname en vanaf de jaren twintig in toenemende mate naar Curaçao en Aruba, waar de olie-industrie werkgelegenheid bood. Bonaire verkrijgt thans voor een deel zijn inkomsten uit de zoutwinning en de toeristen "industrie".

Het Spaanse gezag werd door het Nederlandse gezag vervangen op Sint Eustatius in 1636 en op Saba in 1640. Beide eilanden werden gekoloniseerd als patroonskolonies, er werd tabak verbouwd en er werden slaven verhandeld op Sint Eustatius. De WIC zag erop toe dat veroverde landen werden gekoloniseerd of vanwege het Gouvernement of door patroons of zelfstandige boeren (coloniërs). Aan de coloniërs werden door de Raad bepaalde stukken grond ter bebouwing toegewezen. De Directeur ${ }^{60}$ zag toe op de verdeling van het land. Gronden die al in gebruik waren door Indianen en Compagniesslaven mochten niet worden toegewezen. Een (kapitaalkrachtige) patroon kreeg als stichter van een kolonie grote gebieden van een kolonie in leen, benevens de lage jurisdictie (heerlijkheid) daarover. ${ }^{61}$ Door zijn heerlijkheid was

9) Encyclopedie (1985) pp. 190-193; Wispelweij (1961) pp. 44-47.

$\infty$ Het ambt van Directeur, Commandeur en Gouverneur waren alle van zowel militaire als civiele aard. Tegen het einde van de $18 \mathrm{de}$ eeuw werd vanwege het aanzien van het ambt tegenover de opperhoofden van de Engelse en Franse koloniēn, de titel van de hoogste gezagdrager in de kolonie: Gouverneur; Van Grol (1980) p. 27.

61 Zie: De Monté ver Loren en Spruit (1982) pp. 42, 43, 138-148, met name p. 143. 
hij ambachtsheer, ook al heette hij hier patroon. Zo'n kolonie werd daarom een patroonschap genoemd.

Heerlijkheid hield in de bevoegdheid tot rechtspraak, zij het met uitzondering van het halsrecht, de rechtspraak over leven en dood. De Staten-Generaal legden deze vorm van bestuur vast in kolonisatie charters, ${ }^{62}$ analoog aan de indijkingsoctrooien uit de 15de eeuw door de graaf verleend aan een indijker, toen er land uit zee moest worden gewonnen. Aanvankelijk was een patroonschap alleen mogelijk voor aandeelhouders van de WIC. De patroons hadden de verplichting een bepaald aantal personen (minstens 50) naar het nieuwe gebied over te brengen. De patroon was een leenman van de WIC die op haar beurt weer in een leenverhouding stond tot de Staten-Generaal. Deze patroons verbonden zich bepaalde delen van de veroverde gebieden op hun kosten en voor hun risico te ontginnen en te beplanten met bepaalde gewassen, zoals bijvoorbeeld suikerriet, indigo of tabak en naast de landbouw ook de veeteelt te bedrijven. De patroons hadden ook coloniërs in dienst, die tegen loon als landarbeider werkten.

De patroon sprak recht in zijn gebied, zijn functie kwam overeen met die van de schout in de oud-Nederlandse betekenis. Het gerecht van de patroon was een vierschaar van coloniërs onder voorzitterschap van de kapitein of het opperboofd (commandeur) van zijn patroonschap. Van vonnissen door de koloniale schepenbank gewezen kon in hoger beroep worden gekomen bij de Commandeur en de Raden van Politie. Een bank van schepenen bestond uit burgers, daartoe door een kiescollege voorgedra-

62 Het gaat hier om het Zeeuwsche charter van 8 Maart 1628 bestemd voor de de kust van Guyana en de Kleine Antillen en het Amsterdamse Charter van 7 juni 1629 bestemd voor Nieuw-Nederland, of het Placcaat van 1630, het jaar waarin de charters werden gedrukt. Beide regelingen beoogden uitbreiding en intensivering van landbouw en veelteelt en de uitbreiding met nieuw terrein door een staatsrechtelijke colonisator of patroon. Ook moest de productie worden opgevoerd in bestaande gebieden en werden deze gebieden onder een Commandeur en een Raad geplaatst of door individuele colonisatores beheerd. Ook werden gebieden wel onder leiding van een meester, baas of patroon in privaatrechtelijke zin geplaatst, dan wel onder het beheer van zelfstandige coloniērs gesteld. De patroon moest ook zijn kolonie tegen indringers beschermen en indien nodig oorlog voeren. Kolonisatie buiten de patroonschappen stond onder direct gezag van de WIC. Meesters en zelfstandige coloniërs kregen land in concessie zonder heerlijkheid en betaalden daarvoor 10 stuivers per morgen. Een coloniër had een cultuurrecht, maar ook een cultuurplicht. De Antilliaanse eilanden waren door de Staten-Generas in haar geheel in concessie gegeven aan de WIC, die onderdelen daarvan uitgaf in concessies aan koloniestichters uit de koopmanswereld en kavels akkergrond in concessie gaf aan individuele landbouwers; Van Grol (1980) pp. 18-24. 
gen en benoemd door de overheid. De Directeur of Commandeur ter plaatse kon de schepenbank voorzitten. De schout had in het oud-Nederlandse recht ook een functie als openbaar aanklager. Deze werd op grond van het Regeringsreglement van 1629 in de kolonie uitgeoefend door een advocaat-fiscaal, zijn vervanger werd schout genoemd en was hoofd van politie. Civiele zaken werden berecht door drie gedelegeerde commissarissen uit het College van de Raad. Voor Curaçao en Sint Eustatius was er uitsluitend revisie of appel bij de Staten-Generaal mogelijk. ${ }^{63}$ In 1683 kwamen Saba en Sint Eustatius onder het bewind van de WIC.

Onder invloed van de oorlogsomstandigheden van 1688 tot 1713 bleef de economische situatie van Sint Eustatius precair. Van de Bovenwindse eilanden was vooral Sint Eustatius na 1768 een welvarend eiland, omdat het een belangrijke schakel werd in de Europees-Amerikaanse handel. Door de Amerikaanse vrijheidsoorlog profiteerden vooral Sint Eustatius en Curaçao van de leveringen aan de Amerikanen. Het werd een grote opslagplaats van goederen voor de 13 Staten, die tegen Engeland in opstand waren gekomen. Na de Amerikaanse Declaration of Independence was Sint Eustatius in 1776 de eerste plek ter wereld waar een saluut aan de Amerikaanse vlag werd gebracht. In de daarop volgende jaren werd het eiland een belangrijk wapendepot voor de NoordAmerikanen in hun vrijheidsstrijd tegen de Engelsen. Door de hulp aan de opstandelingen haalden de Nederlanders zich de vijandschap op de hals van de Engelsen. De Engelse Admiraal Rodney werd daarop naar Sint Eustatius gestuurd en eiste de overgave. Omdat het eiland onverdedigbaar was moest men zich wel overgeven. Als wraak voor de Nederlandse steun aan de Amerikaanse opstandelingen werd Sint Eustatius geplunderd en in de as gelegd. Talrijke Nederlandse schepen werden geconfisceerd en het bezit van de bewoners werd verbeurd verklaard. Tevens werden vele bewoners, vooral slaven en Joden, gedeporteerd naar omliggende eilanden. ${ }^{64}$

Aan het begin van de 19de eeuw is geprobeerd de katoenteelt op Sint Eustatius te introduceren, maar door lage prijzen in het buitenland en schade door insekten mislukte dat. Ook op Sint Eustatius ontwikkelde het toerisme zich in de jaren tachtig van deze eeuw in positieve zin.

63 Van Grol (1980) p. 29; Schiltkamp (1972) pp. 28-39.

Kunst (1981) p. 174. 
De Fransen vestigden zich in 1627 op Sint Maarten. Hun enige motief om zich daar te vestigen was piraterij. De Fransen handhaafden hun nederzetting tot 1640 , toen de Nederlanders erin slaagden het eiland in te nemen en er een eigen kolonie te stichten. De Nederlanders werden al gauw weer verdreven door de Spanjaarden, die er een fort bouwden om te voorkomen dat een andere natie zich op het eiland zou vestigen. In 1648 realiseerden de Spanjaarden zich dat de Engelsen, Fransen en Nederlanders waardevoller eilanden bezet hielden en besloten Sint Maarten te verlaten.

Het oudste Nederlandse verdrag werd gesloten op 23 maart 1648 op de berg Concordia tussen Robert de Lonvilliers, Gouverneur van het eiland Saint Martin, namens de Koning van Frankrijk en Martin Thomas, Commandeur van het eiland Sint Maarten, namens de Staten-Generaal van de Republiek der Verenigde Nederlanden. ${ }^{65}$ Dit verdrag wordt nog jaarlijks op 11 november (de verkeerde dag) herdacht. De originele exemplaren van het verdrag zijn niet meer aanwezig in de Franse, Antilliaanse of Nederlandse archieven. Wel bestaan er nog de 18de eeuwse afschriften. Men heeft niet kunnen vaststellen of het verdrag van 1648 is bekrachtigd door de regeringen van de ondertekenaars. De doelstellingen van het verdrag zijn echter in de praktijk vrijwel steeds nageleefd.

$\mathrm{Na}$ de officiële verdeling van Sint Maarten tussen de Fransen en de Nederlanders, werd aan de status quo niet wezenlijk getornd. Nadere Frans-Nederlandse verdragen in 1734, 1785, 1795 en 1839 bevestigden de tweedeling. De basis van het verdrag van 1648 wilde men in 1839 zoveel mogelijk in stand laten. De argumentatie was dat voorzover bekend het verdrag van 1839 van Franse zijde nooit was bekrachtigd, dus kon het ook niet in werking zijn getreden. Daarom is het verdrag van Concordia in feite nog steeds van kracht. ${ }^{66}$ De overeenkomst van 1839 legde

6s Articles accordez entre les Commandans pour le Roy en l'Isle de Saint Martin et les Holandois demeurans dans ladite Isle, Statuut voor het Koninkrijk der Nederlanden, Schuurman en Jordens, deel III (1988) pp. 500-502.

66 Hartog (1964) pp. 80-81. Hartog meldt als legende over de verdeling van Sint Maarten het volgende: 'De Fransen en Nederlanders kwamen overeen, dat het gedeelte van het eiland, hetwelk aan elke partij zou worden toegekend, zou worden bepaald door een loop-wedstrijd. Op zeker punt beginnend, zou elke partij in tegengestelde richting het eiland omlopen. Waar zij elkander zouden tegen komen, zou men een denkbeeldige lijn trekken naar het punt van vertrek. De Nederlanders liepen langzamer dan de Fransen, maar marcheerden langs de kant met de zoutpannen. Zo gebeurde het, dat Nederland een kleiner, doch, naar de maatstaven van die tijd gemeten, rijker deel kreeg. Frankrijk kreeg daaren- 
bovendien vast dat het aan de bewoners van beide gedeelten toegestaan was te vissen langs de gehele kust en dat de zoutvijvers gemeenschappelijk bezit zouden zijn, waarbij het zout dat gewonnen werd, zowel aan de Franse als aan de Nederlandse kant van het eiland onder het belastingrecht zouden vallen. Ook in de tijd dat Sint Maarten onder Engels gezag stond van maart 1801 tot december 1802 en van februari 1810 tot februari 1816 bleef dit zo. $^{67}$

De Fransen dachtten er in 1843 en 1849 wel over om het Nederlandse deel van Sint Maarten te annexeren. Tezelfdertijd zouden dan ook Saba en Sint Eustatius aan de Fransen moeten worden overgedragen. De Fransen zouden dan de kosten op zich nemen voor de slavenemancipatie. De reden hiervoor was dat de slavernij in de Franse koloniën in 1848 werd afgeschaft. In de Nederlandse koloniën zou dat tot 1863 duren. De slaven op het Nederlandse deel van Sint Maarten vluchtten naar het Franse deel. Hun meesters kwamen hierdoor in de problemen. Er ontstonden spanningen tussen het bestuur van Frans- en Nederlands Sint Maarten. Tussen de Franse en Nederlandse regering zijn hierover echter geen stukken gewisseld of besprekingen gevoerd. ${ }^{68}$

Sint Maarten was in het begin van het Nederlands bestuur een patroonskolonie. Tot omstreeks 1735 ging er weinig om op Sint Maarten. De bevolking bestond voor het grootse deel uit arme planters. Er werd indigo verbouwd en wat aan landbouw en veeteelt gedaan. Commandeur John Philips startte de zoutwinning op Sint Maarten. Vanaf 1742 namen het scheepvaartverkeer en de verbouw van suikerriet aanzienlijk toe.

Voortdurende vlagwisselingen op Saba (12), Sint Maarten (16) en Sint Eustatius (22) bleven deze eilanden echter teisteren tot hun definitieve restitutie aan Nederland bij de vrede van

tegen het grootste stuk.' Hartog spreekt er ook zijn verbazing over uit dat noch de Franse noch de Nederlandse regering zich kennelijk over het verdelingsverdrag van 1648 hebben uitgesproken. Artikel 8 van het verdrag regelt het voorleggen van de grensverdeling aan de generaal der Fransen en de Gouverneur van Sint Eustatius. Of dat ooit gebeurd is, is onbekend. Eerst in 1756 en $1764 \mathrm{kreeg}$ de grensscheiding enige vorm en pas in 1772 werd de Commandeur van Sint Eustatius door de WIC aangeschreven 'om de grenspalen van Sint Martin met de Franse opperhoofden te reguleren', Hartog (1964) p. 87. Hartog heeft hier kennelijk gebruik gemaakt van: Oudeschans Dentx, De WIG, 13, 1931 pp. 163 164 en De WIG, 15, 1933, pp. 280-281; zie ook Encyclopedie (1985) p. 483.

6. Paula (1992) p. 11 . 
Londen (1816). ${ }^{69}$

Ook de Bovenwindse eilanden kregen de terugslag te verwerken van de economische recessie in Nederland (1816). Een verbetering van de economische situatie van de Bovenwinden slaagde niet. Alleen Sint Maarten had tussen 1835-1850 een goede zoutopbrengst. Er heerste grote armoede. In de jaren 1919-1920 was de bevolking op Sint Maarten zeer ontevreden, omdat de mening overheerste dat het eiland achtergesteld werd. Er werd in de plaatselijke pers propaganda gemaakt voor onafhankelijkheid en er was sprake van een eigen Raad van de Bovenwindse eilanden. In de jaren twintig vond ook van de Bovenwinden emigratie plaats naar Curaçao en Aruba in verband met de werkgelegenheid in de olie industrie. Sint Maarten krijgt een groot deel van haar inkomsten thans uit de toeristen industrie. De vestiging van een tankopslag- en overslagbedrijf in 1981 heeft veel bijgedragen tot de economische bedrijvigheid.

Omstreeks 1700 was op Saba alle grond in cultuur gebracht, er werd koffie, katoen, suikerriet en andere voedingsprodukten verbouwd. Er waren op Saba in 1715 vier rum stokerijen en een schoenenindustrie. Er werden kustvaartuigen gebouwd en de visserij speelde een belangrijke rol. Ook Saba had te lijden van de Engelse en Franse aanvallen tussen 1795 en 1816 en de slechte economische situatie in Nederland na 1816. Dat verbeterde pas na 1945 toen Saba meer toegankelijk werd, omdat er een weg werd aangelegd en in 1963 een vliegveld. ${ }^{70}$ Ook op Saba is het toerisme tot ontwikkeling gekomen. Met name veel Nederlanders balen thans op Saba hun rijbewijs. Aan dit rijbewijstoerisme heeft Nederland inmiddels een einde gemaakt. ${ }^{71}$ Sinds 1 januari 1993 dienen Europese Nederlanders (en buitenlanders) ten minste 184 dagen in Aruba of de Nederlandse Antillen gewoond te hebben en in het bezit te zijn van een Antilliaans of Arubaans rijbewijs om

69 Een overzicht van alle vlagwisselingen op de eilanden met een opgave van de belangrijke bestuursfunctionarissen en geldende titulatuur is te vinden in Hartog (1964) pp. 705-725.

to Encyclopedie (1985) pp. 198-206; zie voor een overzicht van de economische en politieke situatie in de koloniën: Plante Fébure (1918) pp. 121-195 en Knappert (1932).

71 Het rijbewijstoerisme is een belangrijke bron van inkomsten voor alle Antilliaanse eilanden. Op Aruba kan men slechts het rijbewijs halen, als men ingezetene is. De verkeerssituatie wijkt op Saba, Sint Marten en Sint Eustatius nogal af van die in Nederland: het is er veel minder druk, NRC Handelsblad, 18-8-1992. 
De Hollandse expedities naar het Caraïbisch gebied kregen na het Twaalfjarig Bestand een geheel ander karakter met de oprichting van de West-Indische Compagnie. Deze onderneming werd op 3 juni 1621 ingesteld door de Staten-Generaal en opgezet met het doel handel te drijven, de kaapvaart, 'den Koning van Spanje met alle middelen afbreuk te doen ${ }^{73}$ en bezittingen te verwerven. De WIC verkreeg op 3 juni 1621 voor de tijd van vierentwintig jaar, het octrooi ${ }^{74}$ (monopolie) van alle handel en scheepvaart van de westkust van Afrika tussen de Kreeftskeerkring en Kaap de Goede Hoop tot de kusten van Amerika tussen New Foundland en de Straat Magalhaen, inclusief Zuidland (Australië). Hiermee was de WIC in feite de tegenhanger van de Verenigde Oost-Indische Compagnie (VOC).

De Republiek beschouwde de WIC in de eerste plaats als een instrument in de strijd tegen de Spanjaarden en verleende de WIC verstrekkende volmachten om nieuw grondgebied te verwerven, oorlog te voeren en vrede te sluiten, weliswaar voor eigen rekening en risico. Voor de duur van het octrooi was het de grondslag voor de soevereiniteit, die de WIC namens de Staten-Generaal uitoefende in het veroverde gebied. ${ }^{75}$

In 1674 besloten de Staten-Generaal de WIC op te heffen en een nieuwe, meer bescheiden onderneming te stichten onder dezelfde naam, maar met een sterk gewijzigd octrooi. ${ }^{76}$ De tweede WIC had het vanaf het begin van haar oprichting moeilijk. Met de Engelsen waren er onenigheden omdat deze Sint Eustatius en Saba bezet hielden, onder het voorwendsel de eilanden tegen de

72 Besluit houdende wijziging van het Wegenverkeersreglement, Stb. 1950, K377 is met ingang van I januari 1993 gewijzigd, blijkens het advies dat de Raad Van State op het ontwerp heeft gegeven, Kabinetsmissive van 26 mei 1992, no. 92.004571.

73 Van Grol (1980) p. 10.

74 Octroy, Bij de Hooge Mogende Heeren Staten Generael verleent aen de WestIndische Compagnie, in date den derden Juni 1621, in: Kunst (1981) p. 323 e.v.; Jonkers, De WIG, 34, 1953, Pp. 113-153.

75 Het octrooi is eenmal verlengd, in 1647 . Het op 31 december 1672 afgelopen octrooi van de (Eerste) West-Indische Compagnie werd tot 1674 nog enige keren provisorisch verlengd; Kunst (1981) pp. 47 en 83.

76 Het bestuur van de tweede WIC was kleiner (de Heeren X) en de hoofdparticipanten hadden meer invloed. Hel octrooi van 1674 werd verlengd in 1700, 1730 en 1762 , de laatste keer tot 31 december 1791 . 
Fransen te beschermen. Sint Maarten bleef nog bijna dertig jaar afwisselend Frans en Engels gebied. De tweede WIC werd langzamerhand meer administratiekantoor, dan inspirerende handelsonderneming. Het octrooi van de Tweede WIC eindigde in 1792.

De staatkundige geschiedenis van de Nederlandse Antillen laat men meestal aanvangen in 1792 . Dit lijkt mij echter niet juist want er was voordien wel degelijk sprake van een staatkundige ontwikkeling. Als argument voor het tegendeel wordt aangevoerd dat voor die tijd de eilanden immers werden geëxploiteerd door de WIC, die een privaatrechtelijke onderneming was.

Op 1 november 1624 hadden de Staten-Generaal een Regeringsreglement vastgesteld voor het pas veroverde Braziliaanse grondgebied. ${ }^{n}$ De Nederlandse Antillen en Aruba maakten van 1634 tot 1792 deel uit van het gebied, waarover na elkaar de beide WestIndische Compagnieen in naam van de Staten-Generaal het gezag uitoefenden. Deze periode kenmerkte zich door een grote stabiliteit. Het bestuur werd gevoerd volgens 'Order en Reglementen van de Compagnie'. 'Tot betere directie van zaken' van de Compagnie en 'onverminderd haar octrooi', hadden de Staten-Generaal na de verovering van de Capitania Bahia een regeringsreglement voor de 'Braziliaanse conqueste' vastgesteld op 1 november 1624 . Op 13 obtober 1629 werd dat regeringsreglement voor Nederlands Brazilië gewijzigd in een algemeen regeringsreglement voor geheel Nederlands Amerika of West-Indië, met de titel: 'Ordre van Regieringe soo in Policie als Justitie in de Plaetsen verovert ende te veroveren in West-Indiën' ${ }^{78}$ De Staten-Generaal hadden daarin in een vroeg stadium een algemene basis voor het recht gegeven. Deze hoogste regeling werd herhaaldelijk gewijzigd. Het octrooi gold tot 1792 , de Ordre verviel met het invoeren van de nieuwe wetgeving in 1869 . Op grond van het octrooi van de Staten-Generaal oefende de WIC overheidsbevoegdheden uit in de

\footnotetext{
$\pi \quad$ Ordre van Regieringe soo in Policie als Justitie in de 'plaetsen verover ende te veroveren in West-Indiēn, In den date den 13 October 1629'. Op 26 april 1636 stelden de Staten-Generaal een ordonnantie vast op 'het bewonen en cultiveeren der Landen' in de Braziliaanse conqueste. Het kolonisatiereglement van 1624 en de bestuursinstructie van 1636, dienden na het verlies van Brazilië als basisregeling voor de West-Indische koloniën. Daarom staan zij met het Reglement van 1629 in hel Groot-Placcaatboek, Van Grol (1980) p. 25.

7* Van Grol (1980) p. 25.
} 
veroverde gebieden. Bestuur en rechtspraak in die nieuw veroverde gebieden moest worden uitgeoefend volgens de Ordre van Regieringe. Verder kregen de leiders van expedities van de WIC nog aanvullende richtlijnen en reglementen mee van de StatenGeneraal, waarin de verdere details voor het bestuur werden geregeld. Van $\mathrm{Grol}^{79}$ is van mening dat de Compagnie een staatsrechtelijk lichaam was, "door en onder de Staten-Generaal ingesteld en aandeelsgewijze gefinancierd door de commercieelkapitalistische gemeenschap van die dagen."

De WIC werd bij octrooi van 3 juni 1621 door de Staten-Generaal opgericht. De Tachtigjarige Oorlog (1568-1648) was nog in volle gang. De Noordelijke Nederlandse gewesten hadden zich in 1579 op basis van de Unie van Utrecht aaneengesloten tot de Republiek der Verenigde Nederlanden. ${ }^{80}$ Als centraal orgaan van de gevormde statenbond (Unie of Generaliteit) fungeerden de StatenGeneraal, een permanente vergadering van afgevaardigden van de zeven gewesten met elk één stem. In belangrijke zaken was eenstemmigheid vereist. Elk lid was gebonden door een last van zijn Provinciale Gewesten. Wanneer de last niet toereikend was, moest ruggespraak worden gehouden. Dit betekende een absolute invulling van de zeggenschap van de Staten, waardoor de doelmatigheid van het bestuur ernstig werd belemmerd. De gewesten werden al spoedig na het sluiten van de Unie niet meer door een landsheer bestuurd, maar door colleges, Staten (standen). Dit was een gevolg van de ontwikkelingen die plaats vonden na 1581. Men had in dat jaar de landsheer over alle gewesten, de Spaanse Koning Filips II, officieel afgezworen. De Staten-Generaal oefenden toezicht uit op de Oost- en West-Indische Compagnieën. De beide Compagnieen ontleenden hun in sommige opzichten zeer vergaande bevoegdheden aan hun verkregen monopoliepositie in oorlogvoeren, koloniale gebieden verwerven en besturen, slavenhandel en kaapvaart, ${ }^{81}$ etc., door overeenkomsten met de

\footnotetext{
79 Van Grol (1980) pp. 9-13.

* De Monté ver Loren en Spruit (1982) pp. 214220.

1 Kesler, De WIG, 10, 1928, pp. 65-88; Menkman, De WIG, 25, 1943, pp. 65$80 ; 97-116 ; 129-154$. Kaapvaart en zeeroverij worden nogal eens verward. Dat is goed te begrijpen, omdat in de praktijk deze twee bezigheden moeilijk te scheiden waren. Zeeroverij werd vaak beofend onder het mom van kaapvasn. De kaapvaart was een wettelijk erkend bedrijf. Als landen met elkaar in oorlog
} 
Staten Generaal. Voor hun octrooien waren de Compagnieën dus afhankelijk van het Unielichaam. ${ }^{82}$

De WIC bleef ondergeschikt aan en afhankelijk van de Staten-Generaal, maar was zelf tegelijkertijd een regeringslichaam. De Staten-Generaal hadden de WIC staatstaken toebedeeld voor de gebieden, die liggend binnen de grenzen welke in het octrooi waren omschreven, zouden worden veroverd. In het octrooi werd gezegd, dat de Compagnie onder meer 'politie en justitie' mocht instellen en de 'populatie van vruchtbare ende bewoonde quartieren' bevorderen. De eilanden die thans de Nederlandse Antillen en Aruba uitmaken, kwamen hetzij als patroonschappen, hetzij direct als bezittingen van de WIC onder het gezag van de Republiek der Verenigde Nederlanden, vertegenwoordigd door de Staten-Generaal. ${ }^{83}$

Voor de politie en justitie in de West-Indische koloniēn werden door de Staten-Generaal 'onder onze authoriteyt' op 31 oktober 1629 de richtlijnen vastgelegd in de 'Ordre van Regieringe'. Het was als oorlogsinstrument van de Republiek der Verenigde Nederlanden, dat de (Eerste) WIC na het Twaalfjarig Bestand op zoek ging naar een steunpunt in de Kraal. ${ }^{84}$ De Spaanse herovering van Sint Maarten in 1633 betekende niet alleen een verlies voor de Hollandse zoutvaart, het eiland was vanwege zijn ligging ten opzichte van het vasteland ook van strategische waarde.

De toenemende belangen in Nieuw-Holland (Brazilië) en aan de Wilde Kust (kust van Suriname, het huidige Brits- en FransGuyana en Venezuela) vereisten een nieuw steunpunt in de Kraal. In juli 1634 werd Curaçao op de Spanjaarden veroverd. In maart 1644 eiste Pieter Stuyvesant, directeur van de WIC te Curaçao, het gezag van de Spanjaarden over Bonaire op. Dit gebeurde op grond van de Hollandse bezetting van 1631. De Hollanders leden daar in 1644 echter een nederlaag. Direct hierna keerde Stuy-

waren, gaven ze soms aan schippers kaperbrieven uit. Dit was een officiële aanstelling om de kaapvaart te mogen beoefenen. Het doel was om vijandelijke schepen of bezittingen zoveel mogelijk schade toe te brengen. Na de inbeslagname van de Hollandse schepen door de Spanjaarden in 1585, die daar lagen om zout in te nemen, begonnen de Hollanders ook met de kaapvaart in het Caraibisch gebied. De WIC had het recht gekregen om kaperbrieven uit te geven. Zeeroverij daarentegen was een onwettig bedrijf en werd onherroepelijk met de dood gestraft. Meestal voeren de zeerovers onder valse vlag. Zie ook: Wispelwey (1961) pp. 23-26.

- Kunst (1981) p. 41; Koopmans (1987) p. 89.

s Schiltkamp (1969) pp. 117-181.

* De Nederlanders noemden de Caraibische zee, de Kraal of Kralenzee, omdat er zoveel koralen voorkomen, Van Hulzen (1946) p. 22. 
vesant terug naar Nederland. Hij werd benoemd tot DirecteurGeneraal van de nieuw verworven bezittingen namens de WIC en gestationeerd in Nieuw-Nederland. Op Curaçao werd hij vertegenwoordigd door een vice-directeur.

$\mathrm{Na}$ het bewind van Stuyvesant werd de WIC op Curaçao vertegenwoordigd door een Directeur, bijgestaan door een Raad. Aanvankelijk bestond er een rouleersysteem voor schippers als lid van de Raad. Er heersten vaak wantoestanden op het gebied van het personeelsbeleid en er bestond naijver tussen de Directeur en de commandant van oorlogsschepen. De Directeuren konden zeer despotisch optreden tegen hun ondergeschikten, maar moesten zelf voor alles toestemming vragen aan de Kamer van Amsterdam. Corruptie kwam regelmatig voor onder de dienaren van de Compagnie. Bovendien bleef het natuurlijk een probleem de functies van bestuursorgaan en handelslichaam te verenigen. Een ondermeming wil zoveel mogelijk winst maken tegen zo laag mogelijke bedrijfskosten. Een onderneming is dan ook vanzelfsprekend niet zo geīnteresseerd in een onkreukbaar ambtenarenapparaat. De WIC handelde niet anders dan een moderne onderneming en betaalde haar ambtenaren te laag. Dit leidde vaak tot fraude en corruptie en verrijking van de dienaren van de Compagnie. De gedragingen van de Compagniesbedienden leidden weer tot veel klachten van de burgerij aan de Heren XIX en X. ${ }^{85}$

Wil men kennis nemen van de bestuurlijke organisatie van Antilliaanse eilanden in die periode, dan dient vóor alles nagegaan te worden wat daaromtrent in de instructies voor Directeuren (Curaçao) en Commandeurs (Sint Eustatius en Sint Maarten) is bepaald. Deze instructies vormen gedurende ruim anderhalve eeuw de belangrijkste bronnen voor de kennis van bestuur en rechtspraak en verdere overheidstaken. ${ }^{86}$ De benoeming van de Commandeur op de Bovenwindse eilanden geschiedde in de tijd dat deze eilanden nog patroonschappen waren, door de leenheer, de patroon, doch bekrachtiging door de Staten-Generaal bleef ook hier een eis. Na het overgaan van de koloniën in het bezit van de WIC geschiedden de benoemingen uiteraard door de Compagnie. De taak van een Commandeur week in wezen niet af van een

\footnotetext{
is Hartog, Curaçao, deel I, pp. 217-226. Een aantal Directeuren, die voordien bewindvoerders van de WIC waren geweest, zetten hun tegenstanders zonder enige vorm van proces in de gevangenis en persten hun boeten af ter aanvulling van hun tractement. De Eerste WIC werd geleid door de Heren XIX, tijdens de Tweede WIC werd dit hoofdbestuur teruggebracht tot de Heren $X$. 
Directeur op Curaçao.

Met de inname van Curaçao in 1634 ontstond een eerste vorm van Nederlands bestuur op de eilanden. Van bestuur en rechtspraak voor de komst van de Nederlanders op de Antillen is nauwelijks iets bekend. Een bestuursregeling maakte dan ook deel uit van de aan Van Walbeeck (directeur en leider van de expeditie voor de verovering van Curaçao) meegegeven instructies. Als men het octrooi als 'Grondwet' wil zien van de WIC heeft men in de Ordre van Regieringe (OvR) van $1629^{87}$ te maken met haar 'organieke wet', haar uitwerking op de belangrijkste (juridische) terreinen die de Grondwet bestreek. Deze OvR was bedoeld als Grondwet voor alle Nederlandse koloniēn in het Westelijk halfrond. Men vindt daarin regelingen over bestuur en rechtspraak, wetgeving, godsdienst, onderwijs, financiën, militaire aangelegenheden, scheeps- en militair recht, grondpolitiek, regeling van delfstoffen, alsmede bepaalde regels omtrent het recht, dat in de koloniën van toepassing zal zijn. In de OvR ligt de oorsprong van het concordantieprincipe van het recht in Nederland met dat in de Nederlandse Antillen, Aruba en Nederland, alsmede van bet recht tussen de Nederlandse West-Indische koloniën onderling.

In de OvR werd het recht met betrekking tot het strafrecht, personen-, zaken,- en verbintenissenrecht uit de Republiek overgenomen. In het strafrecht, handelsrecht en zeerecht van de Republiek worden invloeden van landsheerlijke wetgeving afkomstig van Filips II en zijn vader Karel V aangetroffen. Zo werd er bij het strafrecht gebruik gemaakt van de foltering (voor zwaardere misdrijven) om een verdachte te laten bekennen, want alleen een schuldige mocht worden gestraft (artikel LV). Bij de meest ernstige misdrijven kon de vraag aan de orde komen of men Romeins recht zou toepassen of de Mozaīsche (de 'goddelijke') wet. Ook kon toegepast worden de oude voor de Duitse staten bestemde wetgeving van keizer Karel V, de Carolina (1532) of een inheemse regeling van het gewestelijk recht. ${ }^{88}$

Artikel LXII van de Ordre gaf het bestuur ter plaatse de mogelijkheid tot het uitvaardigen van lokale wetgeving met betrekking tot huishoudelijke onderwerpen. Goedkeuring achteraf van de Heren XIX was vereist. De OvR regelde dus een aantal belangrij-

n Ordre van Regieringe (1629).

- Kunst (1981) p. 59, met de inheemse regeling van gewestelijk recht bedoelt Kunst kennelijk de beide Criminele Ordonnantiën van 1570 en de Ordonnantie op ' $t$ stuk van de Justitie binnen de steeden ende ten platten landen in Holland van 1580. Zie ook de Instructie voor Brazilië, art. XLDX van 1636, GPB II, p. 695 en p. 1255. 
ke onderwerpen en introduceerde recht uit de Republiek, uit met name de Generaliteitslanden, van delen van het recht, die voor het maatschappelijk leven in de koloniën van gewicht waren. $\mathrm{Zij}$ gaf ook de plaatselijke wetgever ruimte tot regelgeving. De plaatselijke door de Raden van Politie uitgevaardigde wetgeving was omvangrijker dan de wetgeving opgelegd van hogerhand. ${ }^{89}$ Het regeringsreglement van 1629 heeft een lang leven gehad. Het werd voor het Caraibisch gebied in feite eerst vervangen tijdens de regering van Koning Willem $I^{90}$

Sint Maarten werd in 1703 van Sint Eustatius uit, voor de WIC in bezit genomen. Het eiland kwam onder het gezag van de Commandeur van Sint Eustatius, die in 1705 een Vice-Commandeur aanstelde. Zowel voor Saba als voor Sint Maarten hield de ondergeschiktheid aan Sint Eustatius in, dat orders van de Commandeur van het laatste eiland moesten worden opgevolgd. Nadat Sint Maarten eerst in Engelse en daarna in Franse handen was overgegaan, kwam het gezag in 1784 weer aan de WIC, doch de vroegere gezagsverhouding bleef gehandhaafd. Aangezien het opperhoofd te Sint Eustatius officieel de titel Gouverneur kreeg, werd de titel van de functionaris op Sint Maarten door de Heren X op 26 september 1786 gewijzigd in Commandeur, die titel werd op het eiland reeds lang gebruikt. Op Curaçao en Sint Eustatius werd de titel Gouverneur reeds lang gebruikt voor de Directeur en de Commandeur. Saba maakte in ieder geval van 1671 af, deel uit van Sint Eustatius. Op Saba werd een Vice-Commandeur benoemd, die onder de Commandeur van Sint Eustatius het gezag op het eiland uitoefende. De Raad werd benoemd uit een voordracht door de bevolking op te maken. ${ }^{91}$

De Benedenwindse eilanden vielen onder het toezicht van de Kamer Amsterdam, de Bovenwindse eilanden onder de Kamer Zeeland. Amsterdamse kooplieden hadden zich altijd het meest aangetrokken gevoeld tot Nieuw-Nederland dat zij ook hadden gekoloniseerd. De Zeeuwse kooplieden hadden zich gericht op de kust van Guyana met de kleine Antillen. De WIC decentraliseerde het bestuur van de koloniën door het bestuur over Nieuw-Nederland aan de Kamer Amsterdam op te dragen en het bestuur over "den Amazonemond, de Wilde Kust en de Wilde eilanden" aan

Kunst (1981) pp. 57-63, 67, 71, 90, 92-94, 104, 120, 130, 145, 153, 180, 191, 205, 210, 213, 216, 228, 252.

$\mathrm{KB}$ van 14 september 1815,58 .

Schiltkamp (1972) pp. 19-21. 
de de Kamer Zeeland. ${ }^{2}$

In de Ordre of het Regeringsreglement van de Eerste WIC werd voorzien in de vestiging van een hoge en lage regering. De hoge regering was in Brazilië gevestigd, terwijl de directeur van de Curaçaose eilanden met ambtenaren als raden naast zich de zogenaamde lage regering vormde. Deze lage regering was ondergeschikt aan de hoge uit Pernambuco, hoewel van al zijn correspondentie een kopie naar de Heren XIX ging. Deze ondergeschikte verhouding met Nieuw-Holland (Brazilië) eindigde met de val van Recife in 1654. In de tien jaren die verliepen tussen deze val en de verovering van Nieuw-Amsterdam (1664) door de Engelsen werden de Curaçaosche eilanden met Nieuw-Nederland (de Nederlandse kolonie bij het latere New York) tot één bestuurseenheid verbonden. Pieter Stuyvesant, de toenmalige algemeen directeur van deze bestuurseenheid was dit dus ook van Curaçao, Aruba en Bonaire, terwijl te Willemstad een vice-directeur zetelde. Derhalve stond de kolonie Curaçao van 1644-1664 onder het directe gezag van een Vice-Directeur. Men verwachte door centralisering van het gezag een verbeterde opbrengst van de kolonie Curaçao. Voor de vereniging van deze ver uiteenliggende gebieden tot én bestuursgebied was in die tijd goede reden. Curaçao was aangewezen op de invoer van levensmiddelen. Nieuw Nederland kon ze leveren. De Benedenwindse eilanden konden Nieuw Nederland (Amerika) van zout en paarden voorzien en uit het depot van Curaçao konden de Amerikaanse ondernemingen slaven betrekken. De uitwisseling van produkten, de voorziening in elkanders behoeften kon beter door een centraal dan door een gescheiden bestuur behartigd en bevorderd worden, meende Stuyvesant. ${ }^{93}$ $\mathrm{Na}$ de val van Nieuw-Nederland werd de vice-directeur van de Curaçaose eilanden weer Directeur en vormden de drie eilanden Aruba, Curaçao en Bonaire een gesloten bestuurseenheid. ${ }^{94}$

\footnotetext{
$92 \quad$ Van Grol (1980) p. 18.

is Van Hulzen (1946) p. 127.

4 Volgens Schiltkamp was de West-Indische kolonie Curaçao niet ondergeschikt aan de kolonie in Nieuw Nederland. Volgens hem was er slechts sprake van een personele Unie tussen beide koloniēn in de vorm van de persoon van Stuyvesant als Directeur, Schiltkamp (1972) p. 28.
} 
Het bestuur van Curaçao en onderhorige eilanden tijdens de Tweede WIC (1674-1792) was geregeld in een instructie voor Directeur Liebergen, vastgesteld door de Heren $X^{95}$ bij resolutie van 24 augustus $1679 .{ }^{\circ}$ Deze instructie bleef in hoofdzaak gelden tot 1803. De Directeur werd bijgestaan door een Raad, benoemd door de Heren X, waarin vier (later zes) 'Compagnies bedienden' en drie tot vier burgers zitting hadden. De eerste vier leden waren de Directeur, als voorzitter met recht op twee stemmen, ${ }^{97}$ de commissaris van de train en vivres ${ }^{98}$ (belast met het toezicht op de magazijnen), de kapitein-luitenant van de militie en de commissaris van de slavenhandel. De samenstelling van de Grote Raad is herhaaldelijk gewijzigd. Zo kregen de kapitein van de burgerwacht en de vaandrig der militie een plaats in de Raad, terwijl tevens de fiscaal (de Officier van Justitie) ambtshalve zitting had. De Raad was niet alleen Raad van Politie, maar tevens van civiele en criminele justitie. De Raad is verschillend van samenstelling geweest, er zaten schippers in, militairen, aanvoerders van de burgerwacht, slavenhandelaren en andere 'kundige en vroome ingeseetenen'. De belangen van de Compag-

Het bestuur van de Compagnie beruste bij haar 5 Kamers. Een deputatie daaruit vermeerderd met ten minste één lid van de Staten-Generaal, vormde het centraal bestuur, Van Grol (1980) p. 13.

Schiltkamp (1978) pp. 66-72: Instructie voor Nicolaas van Liebergen door de vergaderinge van de Tienen der Generale Geoctroyeerde Nederlantsche WestIndische Compagnie aengestelt tot Directeur over de Curacaosiche Eylanden, 24 augustus 1679 .

97 In de loop der tijd is de taak van de Directeur en de Commandeur in hoofdzaak gelijk gebleven. Wel zijn er verschuivingen in de bevoegdheden opgetreden. De invloed van de Directeur en Commandeur werd minder en de bevoegdheden van de Raad namen toe. Aanvankelijk kon de Raad alleen mar beslissen over zaken die de Directeur of de Commandeur aan de Raad voorlegden. Een tweede wijziging betrof het stemrecht. De dubbele stem welke de Directeur in rechtszaken kon uitbrengen, als de stemmen staskten, is in de instructie van Rodier van 1764 hem uitdrukkelijk ontnomen; Schilikamp (1972) p. 24; De Gaay Fortman, De WIG, 1a, 1919, pp. 441-457.

De Directeur werd bijgestaan door de commissarissen van 'de train en vivres', 'van de militie' en 'van de slavenhandel'. Train, ook geschreven treyn of trein, betekende oorspronkelijk legertros. Onder trainslaven wend verstaan de gezamenlijke huis-en ambachtsslaven. Er was echter ook een commissaris voor de slavenhandel. Wellicht had de train te maken met de op Curaçao verblijvende slaven. De commissaris van de 'vivres' had het toezicht op de voedselmagazijnen van de Compagnie. De commissaris van de train en vivres verving de Directeur indien nodig. De functie van commissaris van de militie hield wasschijnlijk in de uit Brazilië overgenomen titel van controleur of betaalmeester. De garnizoenscommandant was de kapitein (-luitenant) van de militie. De commissaris van de slavenhandel was de laagste in rang, Hartog, Curaçao, deel I (1961) p. 220 e.v. 
nie waren binnen de Raad dan ook het sterkst vertegenwoordigd.

Het aantal burgerleden, dat door de talrijke zaken, die voor de Raad werden gebracht was gegroeid, gaf aanleiding tot ongenoegen bij de Heren X. De belangen van de Compagnie zouden onvoldoende worden behartigd, omdat de burgerleden de meerderheid hadden verkregen in de Raad. Omdat hierdoor de belangen van de Compagnie in het gedrang kwamen werd in 1718 bepaald dat de Raad weer zou bestaan uit ten hoogste drie leden uit de burgerij, de commissaris van de train en militie, de commissaris van de slavenhandel en de kapitein van de militie. Al spoedig werd het aantal leden dat ambtshalve zitting had uitgebreid tot zes. Drie van de zes ambtshalve zitting hebbende leden waren militair. De Directeur zat het college voor. De burgerleden werden alleen bij de behandeling van rechtszaken toegelaten en niet bij de behandeling van zaken van de Compagnie. ${ }^{99}$

Sinds 1738 mochten de 'Compagnie's bedienden' geen handel meer drijven om hun geringe inkomen aan te vullen. De handel van de dienaren der Compagnie had zulke vormen aangenomen, dat het de naijver opwekte van de kooplieden in de kolonie. Dit verbod tot handel drijven ging wel gepaard met een verhoging van de salarissen van de dienaren van de Compagnie. ${ }^{100}$ Ook werden hogere belastingen opgelegd aan de burgerij. Desondanks had de burgerij regelmatig redenen tot klagen over de willekeur van de Directeur en andere dienaren van de Compagnie. Ook tussen de Directeur en de andere leden van de Raad ontstonden nogal eens conflicten, waarbij de Directeur eigenmachtig optrad. ${ }^{101}$ De Compagniesbedienden werden voor drie jaren aangesteld door de bewindvoerders van de WIC; vroegen zij geen ontslag dan werd hun dienstverband stilzwijgend voortgezet. De Directeur diende telkens na afloop van zijn driejarige commissie om verlenging te verzoeken. Tijdens de tweede WIC werd een Directeur voor een jaar aangesteld met de mogelijkheid van verlenging. ${ }^{102}$

De burgerij beschermde zichzelf. Er bestond geen politie, rustverstoorders werden door de burgerwacht zelf in verzekerde bewaring gesteld, andere wetsovertreders werden in handen van de fiscaal gesteld. De militie bewaakte de forten en trad slechts in

\footnotetext{
9 Hamelberg (1901) p. 131.

$100 \quad$ Hamelberg (1901) pp. 147, 148.

101 Hamelberg (1901) p. 151 e.v., gedoeld wordt hier op de Directeur Juan Pedro van Collen (1720-1721 en 1731-1738) en Jan Gales (1738-1740).

102

Hamelberg (1901) pp. 216, 217; Hartog, Curaçao, deel I (1961) p. 224.
} 
hoogst ernstige gevallen op tegen burgers. De burgerij koos uit haar midden haar officieren. De keuze van de kapitein van de burgerij moest worden goedgekeurd door de Heren X, omdat hij uit kracht van zijn ambt zitting had in de Raad en in rang onmiddellijk volgde onder de kapitein-luitenant van de militie. Er was tevens een korps 'vrije mulatten' en een korps 'vrije negers', die de orde handhaafden binnen de eigen bevolkingsgroep. Aan het hoofd van de drie korpsen stond de burgerkapitein. Het korps vrije negers vocht tijdens de slavenopstanden van 1750 en 1795 aan de zijde van het gezag.

In 1717 stelde Directeur Jonathan van Beuningen de zogenaamde Kleine Raad in, bestaande uit vijf Commissarissen, voor rechtspraak in zaken die een bedrag van 300 pesos niet te boven gingen. De Grote Raad trad als beroepsinstantie voor de Kleine Raad op. Artikel 44 van het Regeringsreglement van 1815 introduceerde de scheiding van machten, een proces dat pas in 1869 kon worden voltooid. Aan het hoofd van de eilanden Aruba en Bonaire stonden Commandeurs. Van vertegenwoordiging van de burgerij was hier geen sprake. ${ }^{103}$

De basis van de kennis over taken en bevoegdheden van hoge compagniesdienaren en zeker van de directeur of (vice) Commandeur waren, naast het octrooi en de Ordre van Regieringe, de instructies, die de leiders van de expedities vanuit Nederland meekregen van het bestuur van de WIC, bekrachtigd door de Staten-Generaal. De Directeur riep de vergadering van de Raad bijeen, zat de vergadering voor en zijn stem telde dubbel als de stemmen staakten, dit gold ook voor rechtszaken. De dubbele stem werd hem gegeven toen de Raden van adviseurs tot medebeslissers werden, hetgeen reeds onder Beck (1655-1668) het geval was. ${ }^{104}$ De Directeur of Commandeur van de Bovenwindse eilanden bezat geen dubbele stem, als de stemmen staakten. In 1739 verloor de directeur zijn dubbele stem in de Raad voor rechtszaken, niet voor wat betreft bestuurszaken. ${ }^{105} \mathrm{De}$ invloed van de Raad nam toe en de invloed van de Directeur en de Commandeur verminderde.

Tijdens het gezag van zowel de Eerste- als de Tweede WIC bleef

\footnotetext{
103 Voges (1982) p. 110.

104 Instruktie voor Jacob Pietersz. Tolck, Directeur van Curaçao, 1638, in: Schiltkamp (1978) pp. 3-8; zie ook Schiltkamp (1972) pp. 20.

10s Instructie aan Isaak Faesch, aangesteld tot Directeur over de Eylanden van Curaçao (artikel 6) 1739, in: Schiltkamp (1978) pp. 187-200.
} 
de gezagsstructuur min of meer ongewijzigd. De opdracht om te zorgen voor goede policie en justitie kwam telkens terug in de instructies voor Directeuren en (vice) Commandeurs, waarin ook de raden van Curaçao en de Bovenwinden betrokken werden. Met het belang van de Compagnie op de achtergrond moesten de besturen eventueel via algemene wetgeving waken over de handel, in goederen en mensen, over de scheepvaart, de kaapvaart, de defensie, de openbare orde, de levensmiddelenvoorziening, het markt- en het havenwezen en de zoutraap.

De stadhouder was opperbewindhebber van de Compagnie en Gouverneur-Generaal van de koloniën. Als kapitein-generaal en admiraal-generaal van de Unie oefende hij het hoogste gezag uit over leger en vloot, zowel in als buiten de Republiek.

Bijna twee eeuwen lang is er sprake geweest van én Raad voor Curaçao en onderhorigheden waarin aanvankelijk alle overheidsactiviteiten gebundeld waren, niet alleen bestuur en rechtspraak, maar ook wetgeving, oorlog, handel financiën enz.

De ideeēn van Montesquieu werden in Amerika en Europa al aan het eind van de 18de eeuw uitgewerkt in de verschillende constituties. Van een scheiding van machten was toen in de koloniēn nog geen sprake. Pas in de Regeringsreglementen van 1815 werd uitdrukkelijk bepaald, dat bestuur en rechtspraak gescheiden zouden zijn. De vóór die tijd bestaande Raden behandelden dus zowel de bestuurszaken als de justitiële aangelegenheden. Dit gebeurde meestal door dezelfde leden. Het lidmaatschap van de Gereformeerde Kerk was naast het burgerschap voorwaarde voor benoembaarheid tot raadslid. Door uit de kerk te treden ontkwam men aan een niet gezochte en niet gehonoreerde overheidsfunctie. Als plaatselijk bestuur hebben de Raden een grote rol vervuld bij het tot stand brengen van wetgeving. De Staten-Generaal, het hoofdbestuur van de Compagnie kon door hogere wetgeving de wetgeving van de Raden aanvullen. ${ }^{106}$

De kolonie Curaçao en onderhorigheden stond onder het gezag van een Directeur bijgestaan door een Raad van Politie, waarin militairen, ambtenaren en enkele aanzienlijke burgers zitting hadden. Als meest gebruikelijke titels voor de gezagsdragers 
golden voor het hoofdeiland 'Directeur' of 'Gouverneur' en voor de overige eilanden 'Commandeur'. De Directeur of de Commandeur was in de betreffende kolonie voorzitter van de 'Raad van Policie', het lichaam dat hem bijstond in de uitoefening van het bestuur van de kolonie. Aruba en Bonaire behoorden tot het directoraat van Curaçao. Op elk van deze eilanden trad één Commandeur op als vertegenwoordiger van het gezag. Van een College dat de Commandeur bijstond was op deze eilanden geen sprake. De Bovenwindse eilanden, Sint Eusatius en Sint Maarten, met uitzondering van Saba, dat steeds tot het commandement van Sint Eustatius of Sint Maarten behoorde, kenden wel vanaf het begin van de kolonisatie door de Compagnie naast de Commandeur, een plaatselijk adviesorgaan.

Hierbij dient te worden opgemerkt dat op de Benedenwinden de WIC rechtstreeks het gezag uitoefende. Op de Bovenwinden lag dat anders, daar stichtte de WIC eerst patroonschappen. De eilanden werden in concessie overgedragen aan particulieren, die de verdere kolonisatie op zich namen. De WIC droeg dan slechts zorg voor de defensie en de verscheping van de opbrengsten van de plantages. Daarom vormden ook de burgerleden de meerderheid in de Raden van Politie van Sint Eustatius en Sint Maarten. In de Raad van Politie van Curaçao waren dat de militairen en Compagniesbedienden. Bovendien konden de ingezetenen van de Bovenwinden, anders dan die van de Benedenwinden, participeren in de verkiezing van de Raadsleden. ${ }^{107}$

Tot de bevoegdheden van de Raad, zowel op Benedenwindse als op de Bovenwindse eilanden, behoorden het maken van keuren. Deze bevoegdheid is reeds te vinden in art. LXII van de OvR. De keuren moeten worden goedgekeurd door de Heren XIX of de Heren X. Het bleven echter uitsluitend huishoudelijke zaken van de koloniën waarover de Raad wetgevende bevoegdheid had. Wat de samenstelling van de Raad betreft, schreef de instructie van Tolck (1638) voor, dat naast de Directeur zitting in de Raad zouden hebben: de luitenant over de militie, de commissaris over de koopmanschappen en verder de aanwezige schippers van de schepen en jachten van de Compagnie, 'successivelick na hare ouderdom in den dienst'. Het totale aantal leden in de Raad mocht niet meer dan zeven bedragen.

Het zwaartepunt in de Raad lag steeds bij militairen en 
ambtenaren, dus degenen die in dienst waren van de Compagnie. De invloed van de burgers in de Raad bleef gering, de bevolking had bovendien geen invloed op hun benoeming. $\mathrm{Zij}$ werden door de Directeur (eventueel tezamen met de Raad) aangewezen. Hun benoemingen waren voorlopig, bekrachtiging door de Heren XIX (X), of door de Kamer Amsterdam was noodzakelijk. Schiltkamp merkt op dat Van Grol dan ook terecht spreekt van een 'ambtelijke autocratische oligarchie'. ${ }^{108}$

De rechtsbedeling in Curaçao ontwikkelde zich uit de rechtsbedeling zoals die zich aan boord van de schepen voordeed. De oversten op de schepen behandelden civiele en criminele zaken. Voor de zeemacht gebeurde dit door scheepsraden en voor de landmacht door krijgsraden. De jurisdictie van de scheepsoversten strekte zich niet alleen uit over de aanwezige schepen, maar ook over allen die binnen het betrokken rechtsgebied vertoefden.

Over 'justitiële' zaken ontbrak de kennis bij de Raad vrijwel geheel. Pas in het begin van de $18 \mathrm{de}$ eeuw komen sporadisch gegradueerde Raadsleden voor. In 1784 vroegen de Heren X zich af of het niet dienstig zou zijn 'dat op Essequebo en Demaray alsmede op Sint Eustatius worden aangesteld bequame personen den regten kundig tot praesidenten van de Hove van Justitie.' Tot 1780 hadden de betrokken functionarissen geen juridische opleiding, dit gold in iets mindere mate ook voor de fiscaals. Na 1780 waren de fiscaals op Curaçao over het algemeen gegradueerd. Rechtspraak en bestuur waren zo nauw verweven, dat de fiscaals na opgetreden te zijn als aanklager, ook zitting badden in de Raad ter berechting van de zaak. In 1768 werd de fiscaals verboden om zitting te nemen in de Raad bij afhandeling van rechtszaken. Om het juridisch element in de Raad te versterken had de fiscaal in 1784 op Sint Eustatius tevens de bevoegdheid gekregen om in juridische aangelegenheden als adviseur van de Raad op te treden. Dit werd een ongewenste situatie geacht, daarom werd er reeds in 1787 een eind aan gemaakt en werden de functies van 'fiscaal en advijseur' weer gescheiden. Er werd een aparte adviseur aangesteld naast de fiscaal. Even ongewenst werd geacht dat de Commandeur tevens de functie van fiscaal in zich verenigde, zoals voorkwam op Sint Eustatius. In 1778 besloten de Heren $X$ een afzonderlijk fiscaal aan te stellen 'doordien de verschillende qualiteyten, waarin een Commandeur meede het fiscalaat waernemende, zig bevindt, niet overeenkomstig zijn met de onpartijdigheyd 
waarmede het ampt van regter, hetgeen hij als Commandeur bekleedt, gepaart moest gaan'. De leden van de Raad die op grond van hun ambt zitting hadden, bleven lid van de Raad zolang zij dat ambt uitoefenden. Burgerraadsleden bleven op Curaçao levenslang benoemd. In 1738 stelden de Heren X voor een rooster op te stellen waarbij de drie burgerraadsleden om de beurt jaarlijks zouden aftreden. In plaats van de afgetredene moest dan een nieuw Raadslid worden benoemd. De burgers waren echter over het algemeen zo afkerig van het vele en ondankbare werk als Raadslid, dat zij zelfs een andere godsdienst (de Lutherse) aannamen om zodoende niet in aanmerking te komen voor het Raadslidmaatschap, waarvoor men immers Gereformeerd moest zijn. Niet zeker is of het systeem van periodieke aftreding ooit is toegepast. Het kwam voor dat Raadsleden zelf als verdediger in een bepaalde zaak optraden. Zij waren dan voorzien van de procuratie van de betrokken partij en waren dan niet bevoegd in de Raad zitting te nemen. De Heren $X$ bepaalden daarom in 1762, dat het aan geen Compagniesbediende, die Raadslid was, werd toegestaan een dergelijke procuratie te aanvaarden. De burgerleden mochten dat dus wel.

Directeur Faesch had in 1753 ook de grootste moeilijkheden in het vinden van leden bij het weer instellen van de Kleine Raad. De aangewezen personen werden door hem gedwongen het Raadslidmaatschap te aanvaarden, bij niet aanvaarding van het ambt werden zij bedreigd met verwijdering van het eiland. ${ }^{109} \mathrm{Hij}$ voegde er wel aan toe: 'dat de charge van raadtsheer tegenwoordig op het eiland niet alleen lastig maar ook ruineus voor eenige persoonen is, want sij moeten haar eygene saeken verwaerloosen en jaeren naa malkanderen in den Raad zitten en er konnen dog aan de menschen geen genoegen niet geven'. De Staten-Generaal bepaalden in 1761 dat op het niet aannemen van een functie als

Vergelijk: Kaser (1975) pp. 14, 155, 222; Van Oven (1948) p. 33. De verplichting om openbare ambten te aanvaarden op straffe van verwijdering van het eiland lijkt op het Romeinsrechtelijke begrip 'munus'. De bevolking werd gedwongen bepaalde diensten te verrichten voor de overheid en extra belastingen op te brengen. De persoonlijke vrijheid werd in dienst gesteld van de staatsraison. De Romeinse staat was omstreeks de vijfde eeuw een uiterst strak gereglementeerde samenleving (corpora). Door geboorte werd de plaats van het individu binnen de samenleving bepsald. De dwang tot het uitvoeren van bestuurswerkzaamheden werd met name toegepast in de gemeenteraden (curiales). Die lasten drukten vaak zo zwaar dat men zich aan de 'munera publica' poogde te onttrekken door de woestijn in te vluchten of het klooster in te gaan. De Codex Theodosianus (437) is een compilatie van bestuursrechtelijke wetgeving uil die tijd. 
landraad een boete zou worden opgelegd van 500 pesos en het verbod om andere ambten uit te oefenen. In 1772 werd de boete verhoogd tot 1000 pesos.

De slechte verdiensten van deze functies droegen ook niet bij tot een makkelijke invulling van de benodigde vacatures in de Raad. Daar was echter in Nederland weinig begrip voor, omdat daar de patriciërs door voldoende inkomsten uit hun vermogen wèl functies tegen een geringe vergoeding konden uitoefenen. In de koloniën lag dat echter geheel anders:

"genoegzaam alle de inwoonders hebben aldaar hunne bezigheeden. Wijl zeldzaam naar dezelve [bedoeld is: de kolonie] persoonen gaan, dan om hun fortuijn te maken of ten minsten te verbeeteren. Wijders voor verre 't meest zulk zoort, 't welk niet een eenige der qualificatien bezitten die bequaam regent noodig heeft. Dus kan men zig nooit vleijen de regeeringen der colonien behoorlijk waargenoomen te zien, tenzij men daar aan zoodanige bezoldigingen hegt, die bequame lieden uijt het vaderland daar toeroept of colonisten van de noodige talenten - zoo men die nu en dan mogt vinden - aanmoedigt om die last op hun te neemen en daarvoor eenige der voordeelen op te offeren welke zij door ' $t$ verzuijm hunner tijd daardoor komen te lijden. De behoorlijke bezoldigingen aan die welke de ampten van regeering in de colonien bekleeden, zoude ook nog in een andere betrekking nuttig zijn, te weeten dat die leeden dan zouden kunnen verschijnen met distinctie welke noodig is, om een respect voor de magistraats persoonen in te boezemen. Een zaak van gewigt in de colonien, wijl derzelve inwoonders meestendeels uijt een classe bestaan, bij welke eenige uijterlijke gedaante noodig is om vrees in te boezemen, voorts uit een vermenging mag men zeggen ' $t$ schuim aller Natien, dat zonder enig uijterlijk gelaat in geen band te behouden is. Speciaal is 't dus noodig dat 't Hoofd der Regeering in ijder rivier zoveel inkomen heeft en zulk een wooning bekleedt dat zoo inwoonders als vreemdelingen hun 't noodige respect toedragen, welke die ampten schijnen te vereischen. De behoorlijke bezoldigingen van alle der verdere leeden van den Raad zal ook meerendeels voorkoomen die verlangende greetigheid tot leges van vacatien welke altoos pleegt plaats te moeten grijpen als de regenten de ampten tot hun schade bekleeden, zoo het tot nu hier is geweest." 110

In de OvR werd bepaald dat de justitie, zowel de criminele als de civiele, onpartijdig diende te geschieden, zonder onderscheid 
tussen de personen of hun kwaliteiten en 'soowel voor ende tusschen Spaegnaerden, Portugesen ende andere inwoonders, als die van onze ende andere landen ende natien'. Dit voorschrift werd in de loop der tijden regelmatig herhaald; dat het voorschrift niet steeds is nagekomen lag voor de hand, omdat er verschillend werd geoordeeld over te onderscheiden bevolkingsgroepen. De berechting geschiedde 'naer de natuyrlycke, Goddelycke ende gemeyne rechten ende wetten'. Voor de criminele en de civiele justitie waren in de OvR afzonderlijke bepalingen gegeven. De criminele justitie moest door de Raad worden uitgeoefend in gespannen vierschaar, ${ }^{11}$ op aanklacht van de Advocaat-Fiscaal. Deze had als vervanger een schout, terwijl hij verder 'drie 's Heeren dienaers' onder zich had. Wat de procedure betreft diende te worden gevolgd 'het ordinaris ghebruyck van de Vereenighde Provintien, ende voorts de ghemeene geschreven rechten, die deselve applicerende naer meriten van saecken', een en ander op zodanige wijze, dat de schuldige werd gestraft, zonder teveel gestrengheid.

De civiele justitie werd uitgeoefend door drie commissarissen uit de Raad, die om de drie maanden verwisseld moesten worden. Het toegepaste recht was 'de Ghemeene ordre van de Vereenighde Provintien, ofte soodanige als bij de Vergaderinge van de Negenthiene sal goet gevonden worden'. De procedures dienden snel te worden afgehandeld. Voor zaken boven de $f$ 25,- stond hoger beroep open op de volle Raad, die daarop vonnis zou wijzen, 'an bene, vel male'. De volle Raad besliste in hoogste instantie. De militairen stonden terecht voor een krijgsraad. Daarin hadden zitting de Gouverneur en de legeraanvoerders. Schepelingen werden berecht door een scheepsraad, bestaande uit de generaal, de admiraal en de vice-admiraal, de schout bij nacht en de scheepskapiteinen of schippers. Betrof de misdaad geen zaak die zuiver tot de militaire of scheepsaangelegenheden behoorde, doch waarbij wel militairen of schepelingen waren betrokken, dan werd aan de Raad voor de criminele justitie toegevoegd de generaal en de kapiteinen van de troepen als het militairen betrof en de Gou-

Vierschaar, vroeger de ruimte waarbinnen een rechtsgeding werd gehouden. Deze ruimte werd door vier scharen (banken) ingesloten, vandaar de naam, Algra (1977), p. 658. Gespannen vierschaar betekende dat de ruimte waar recht gesproken werd, afgezet was met een touw om palen, om de schepenen van het overige volk te onderscheiden. Een dingtaal betekende dat als de beklaggde de taal niet meester was, hij zich dan moest laten bijstaan door een taalman, Fruin (1922) p. 120. 
verneur en de scheepskapiteinen als het scheepsvolk betrof.

Als deze voorschriften uit de OvR worden vergeleken met de Directeursinstructies dan kan worden vastgesteld, dat in alle gevallen de justitiële aangelegenheden behoorden tot de bevoegdheden van de Raad. In de instructie voor Tolck ${ }^{112}$ is vermeld dat hij tezamen met de Raad, 'alle civiele ende criminele misdaden ende fortfaicten' diende te berechten. Daarbij moest recht worden gedaan naar de 'artyckelbrief ende voorts naer beschreven rechten, crygsordres, placaten ende costumen van dese landen'. Enige vrijheid om daarvan af te wijken bestond kennelijk, want aan de zojuist geciteerde zin was toegevoegd 'sooveel nae syn beste kennisse ende wetenschap al bevinden te behoorden'. In de instructie van Beck staat vermeld dat indien er militairen moeten worden berecht, de gewone Raad bevoegd was, bestaande uit de Vice-Directeur, de luitenant, de commissaris over de koopmanschappen en de vaandrig. Verdere aanvulling met militairen zoals verlangd in de OvR was niet alleen overbodig, maar zelfs onmogelijk, omdat de militaire commandanten uit het kleine garnizoen reeds q.q. in de Raad zaten. Betrof het een strafzaak tegen een militair of een strafzaak waarbij zowel burgers als militairen waren betrokken, dan moest een vijfde lid aan de Raad worden toegevoegd.

Aanvankelijk werden alleen die zaken behandeld door de Raad, die door de Directeur ter behandeling werden voorgelegd. Er moest 'kort en onvertogen recht, met alle candeur en sinceriteit, zonder eenige haet, gunste of partijschap, aansien van persoon of qualiteiten; zelfs in zaken de Compagnie aengaende' worden gedaan. Tenzij er dringende redenen waren mocht een ter dood veroordeelde niet worden gepardonneerd. Pardon werd gegeven door de Directeur en Raden tezamen met onmiddellijk bericht aan de heren X. De zaken werden voor de Directeur en Raden aangebracht door de Fiscaal, door wie de Directeur 'het recht van de hooge overheid en van de Compagnie' moest laten waarnemen. De Fiscaal trad dus op namens de Staten-Generaal en de WIC. Als de Fiscaal meende in een bepaalde zaak niet te mogen optreden, dan moest hij daarvan kennis geven aan de Directeur en de Raden.

De Directeur was dan bevoegd een ander aan te stellen in de plaats van de Fiscaal. Meestal moest de Fiscaal ook de uitgespro- 
ken vonnissen ten uitvoer leggen. Was de Fiscaal uitgesloten van de zaak, dan executeerde de Directeur het vonnis. Als er geldboeten waren opgelegd of goederen werden geconfisceerd, dan werden deze verdeeld tussen de WIC, de Directeur en Fiscaal tezamen met de aanbrenger, elk kreeg een derde gedeelte. De justitie was geheel een taak van de lokale overheid. Men wenste zich in Nederland niet in te laten met de rechtspraak in de koloniën, ook al werd dat door de Directeur en de Raden of door burgers die zich tekort gedaan voelden bij herhaling verzocht. De Directeur en de Raden beslisten in hoogste instantie. De StatenGeneraal meenden dat zij op grond van artikel 2 van het octrooi slechts bevoegd waren tot revisie.

De instructies voor de Commandeurs op de Bovenwindse eilanden geven ten aanzien van de justitie geen afwijkend beeld te zien ten opzichte van de toestand in Curaçao. Ook het college van Commandeur en Raden op Sint Eustatius besliste in hoogste instantie. Dit college was tevens beroepscollege voor uitspraken in hoger beroep gewezen door de Vice-Commandeur en de Raden van Sint Maarten.

Men probeerde in de 18de eeuw de Raad te ontlasten en de civiele rechtspraak te versnellen. Dat gebeurde door oprichting van de Kleine Raad op Curaçao. Het college van Directeur en Raden werd Grote Raad genoemd. De Kleine Raad werd door Directeur Van Beuningen in 1717 ingesteld en heette voluit: 'Regtbank van mindere questien en verschillen'. Er werden door vijf burger-commissarissen civiele zaken afgedaan, die een bedrag van 300 pesos van achten ${ }^{113}$ niet te boven gingen. De Directeur was voorzitter van de Kleine Raad. Aanvankelijk bediende én secretaris beide Raden maar in 1756 werden de administraties gescheiden en had elke raad zijn eigen secretaris. Van beslissingen

Tol het begin van de 19de eeuw kende men op Curaçao geen andere muntstelsel dan het Spaanse. De belangrijkste munt was de zilveren peso, ook wel gencemd piaster, Spaanse mat, Spaanse daalder, pilaardaalder of patientje. De peso was oorspronkelijk verdeeld in 8 realen en had een waarde van 48 Nederiandse stuivers. In 1826 werd het Nederlandse geldstelsel ingevoerd. De pesos bleef echter wettig betaalmiddel, men kon moeilijk wennen aan het nieuwe betaalmiddel. In 1853 werd het betalingsverkeer verder gesaneerd en de meeste buitenlandse betaalmiddelen werden verboden. Daar er echter een gebrek was aan Nederlandse pasmunt, bleef de bevolking de oude munten als betaalmiddel hanteren. Een verdere regeling van het muntstelsel voor de Benedenwindse eilanden volgde in 1901. Pas in $1943 \mathrm{kreeg}$ de kolonie Curaçao zijn eigen muntstelsel, de Curaçaosche gulden. Bij Landsverordening van 1953 werd een algemeen stelsel voor de Nederlandse Antillen ingevoend; Encyclopedie (1985) pp. 323-326. 
van de Kleine Raad stond hoger beroep open op de Grote Raad, die in hoogste instantie besliste.

Omstreeks 1740 raakte de KJeine Raad in onbruik door geschillen over competentie die tussen de Grote en de Kleine Raad ontstonden. Na de ontbinding van de Kleine Raad in 1746 werden twee extraordinaire Raden benoemd en een fiscaal, die deze zaken moesten afhandelen. Van deze vonnissen was weer hoger beroep opengesteld op de Grote Raad. Ook dit college werd Kleine Raad genoemd. In 1749 besloot Directeur Faesch ${ }^{114}$ tot heroprichting van de Kleine Raad onder de naam 'Bank van Commissarissen van kleyne zaken', een college waarin weer vijf commissarissen zitting hadden. Aangezien de justitie in zijn geheel tot de taak van de Directeur (Commandeur) en Raden behoorde, viel daaronder ook de voluntaire rechtspraak. ${ }^{115}$ Akten van ondertrouw en huwelijk, overdracht en bezwaren van onroerende goederen werden voor dit college verleden. Ook de aanstelling van voogden en curators en de willige condemnatie vond voor de (Grote) Raad plaats.

Voor de voluntaire rechtspraak gaf de OvR weer de nodige richtlijnen. Het passeren van hypotheekakten en akten van overdracht van onroerende goederen moest geschieden ten overstaan van drie commissarissen van de Civiele Justitie, terwijl daarvan een register moest worden bijgehouden door de assessor 'mede conform 't gebruyck van de Vereenighde Provintien' (artikel LX). Op Curaçao en de Bovenwindse eilanden werden deze zaken aanvankelijk door de hele Raad behandeld, doch reeds spoedig rouleerden deze werkzaamheden tussen de raadsleden, van wie er twee werden aangewezen om naast de Directeur of Commandeur zitting te nemen. In het begin van de $18 \mathrm{de}$ eeuw had ook de Directeur geen zitting meer. De Commissarissen van de dingtalen waren twee leden van de Raad die blijkens het reglement van de Grote Raad van 1740 benoemd werden om 'processen en alle andere saken te faciliteeren'. Dat hield in 'het trouwen der bruyden, zoo op het gouvernement als aan particuliere huysen', het afnemen van eden, het optreden als rechter-commissaris bij verhoren van getuigen en verdachten, transacties betreffende onroerende goederen etc.

Met de groei van de koloniën nam uiteraard ook het aantal rechtszaken toe. De klachten over vertraging in de afdoening van

11 De Monté ver Loren en Spruil (1982) p. 144.
} 
zaken waren veelvuldig. In 1750 bepaalden de Heren $X$ dat er elke 14 dagen rechtsdagen moesten worden gehouden. Daar er in de kolonie Curaçao in 1750 maar één secretaris was met zijn beëdigde klerk maakte duidelijk 'dat zij alle collegien tegelijk niet kunnen admitteren'. Ook op de Bovenwinden deden zich dezelfde klachten voor. ${ }^{116}$

$\mathrm{Na}$ de opheffing van de WIC in 1792 waren de eilanden voor korte tijd een kolonie behorende tot de Bataafse Republiek. In 1808 werden zij ingelijfd bij het Engelse koloniale rijk, een situatie die zou voortduren tot het totstandkomen van het Koninkrijk der Nederlanden in 1815. In 1816 werden de eilanden weer aan Nederland overgedragen. De beide West-Indische koloniën kwamen onder het opperbestuur van de Koning en kregen ieder een eigen regeringsreglement.

In het Regeringsreglement van 1815 stond al vermeld dat bestuur en rechtspraak gescheiden zouden moeten worden, maar dat gebeurde feitelijk pas in 1865. Na 1815 werden weliswaar rechtspraak en bestuur gescheiden en ontstonden twee Colleges: de Raad van Politie en de Raad van Civiele en Criminele Justitie, maar in beide colleges zaten dezelfde leden. De Raad bestond uit ambtelijke en burgerlijke leden. De burgerleden werden door de Gezagvoerders gekozen voor een termijn van hoogsten acht jaren. De Raad van Politie in Curaçao bestond na 1815 uit de Directeur/Gouverneur, de Fiscaal en de Controleur Generaal der Financiën, benevens vier burgerleden. De nieuwe Raad van Civiele en Criminele Justitie werd voorgezeten door een president, die meester in de rechten was en benoemd werd door de Koning. Voorts bestond dit College uit de Fiscaal en nog vier leden, die aan dezelfde vereisten moesten voldoen als de 'Raden van Policie, zoo mogelijk echter tegelijkertijd geen Raden van Policie zijnde'. ${ }^{117}$

Ook de kolonie Sint Eustatius kreeg naast de Gouverneur een Raad van Politie, de rechterlijke macht zou worden uitgeoefend door een apart College van Justitie. Het eiland Sint Maarten kreeg zijn eigen plaatselijk bestuur in de vorm van een Raad van Politie, voorgezeten door de Commandeur van dit eiland.

Aruba, Bonaire en Saba bleven geheel ondergeschikt aan het gezag op het hoofdeiland. Verscheidene wijzigingen in het beleid van de regering hebben zich in de loop van de 19 de eeuw voorge-

117 Bordewijk (1911) p. 174; Römer-Kenepa (1983) p. 5. 
daan. Bij iedere wijziging kwamen er veranderingen in de samenstelling en bevoegdheden van de bestaande lichamen van bestuur en werden zelfs nieuwe organen in het leven geroepen. De Raad van Civiele en Criminele Justitie (1815), de Gemeenteraad (1828), de Koloniale Raad (1833) en de nieuwe Raden van Policie na 1865. Ook de titel van de hoogste gezagdrager in de kolonie onderging wijzigingen. In 1815 werd de titel 'Gouverneur-Generaal' gebruikt, daarna 'Directeur', later 'Gezaghebber' en weer later 'Gouverneur'. De titel 'Commandeur' voor de vertegenwoordiger van het gezag op de ondergeschikte eilanden werd in de loop van de negentiende eeuw veranderd in 'Gezaghebber'.

In het Regeringsreglement van 1815 werd voor het eerst de mogelijkheid tot hoger beroep voor de kolonie geopend op een Nationaal Gerechtshof. ${ }^{118}$ Dat werd in 1816 het Hoog Gerechtshof te 's-Gravenhage.

Bij de vereniging met Suriname werd dat het Gerechtshof in Suriname. In 1840 werd beroep op de Hoge Raad mogelijk van civiele vonnissen in eerste aanleg gewezen door het Gerechtshof te Suriname. Na de scheiding behield het Gerechtshof in Suriname de functie van appelinstantie voor de kolonie Curaçao. In 1865 werd deze taak overgenomen door het Hof van Justitie van de kolonie Curaçao. In 1869 werd de Hoge Raad de beroepsinstantie voor zaken door het Hof van Justitie in eerste instantie gewezen.

Artikel 27 van het Regeringsreglement van 1828 gaf aan dat er rechtgesproken werd door een Raad van 'Civiele en Crimineele Justitie' (scheiding van machten in de theorie), een 'Collegie voor de kleine zaken' en door het College van Commercie en Zeezaken. De Regeringsreglementen van 1828 en de Instructie aan de Directeur van 1828 benadrukten de 'onafhankelijkheid van allen politieke invloed' en stelden dat de rechtspraak 'van den kant van

118 Reglement op het beleid van de Regering, het Justitiewezen, den Handel en Scheepvasrt op Curaçao, en onderhoorige Eilanden, gearresteerd bij Koninklijk Besluit van 14 September 1815 no. 58 . Artikel 56 vermeldt de mogelijkheid van 'beroepen op het Geregtshof, dat daartoe bij de Wet zal worden aangewezen', Kunst (1981) noot 340, p. 321. Tevens werd volgens art. 46 van het Reglement op het beleid van de Regering, het Justitiewezen, den Handel en Scheepvaart op de eilanden Sint Eustatius, Sint Maarten en Saba bepaald, dat van vonnissen in eerste aanleg door de Raden van Justitie gewezen, hoger beroep op de Hoge Raad in Nederland mogelijk was. Bij Koninklijk Besluit van 14 mei 1816 werd de mogelijkheid van appel van de West-Indische koloniale zaken opgedragen aan het Hoog Gerechtshof te 's Gravenhage, zolang de Hoge Raad nog niet was ingesteld. In 1869 werd hoger beroep in koloniale zaken op de Hoge Raad mogelijk. 
het administratief gedrag geen stremming mocht ondergaan'. ${ }^{119}$ De kolonie Sint Eustatius en onderhorigheden en Sint Maarten kregen ieder een eigen Raad van Justitie.

Van 1816 tot aan de invoering van het Regeringsreglement van 1833 bestond op Curaçao het College van Commercie en Zeezaken, bedoeld voor alles 'wat betrekking heeft tot commercie en navigatie'. Een lid van de Raad van Politie fungeerde als voorzitter van dit College. De beide andere leden bestonden uit 'geaccrediteerde kooplieden'. Voor zaken boven de $f 300,-$ kon in beroep worden gekomen bij de Raad. Het College werd benoemd op voordracht van de Raad van Politie. De Voorzitter van dit College was een lid van de Raad van Politie. Voor hoger beroep van handels- en zeezaken boven de $f 300$,- moest men zich wenden tot de Raad van Politie.

In 1833 werd de Raad van Justitie omgezet in een 'Regtbank' voor de Kolonie Curaçao en onderhorige eilanden. Het reglement van 1833 kende nog slechts de rechtbank bestaande uit een voorzitter-jurist en zes niet gegradueerde leden en een Commissie bestaande uit drie leden van de rechtbank (commissarissen), die civiele zaken van minder dan $f$ 150,- kon behandelen. Dit was een voortzetting van de Kleine Raad. Artikel 26 stelde dat: "het lidmaatschap der Regtbank vereenbaar is met dat van den Kolonialen Raad"'. Het laatste koninklijke Regeringsreglement van 1848 gaf geen regels meer voor de hoofdlijnen van de rechterlijke organisatie. Het bepaalde slechts dat de Koning daarover verordeningen zou geven of deze zou bekrachtigen.

Het College van Commercie en Zeezaken werd in 1828 een College van Commissarissen tot de Kleine Zaken, het werd in 1833 opgenomen in de Regtbank. Deze Colleges waren gevestigd op Curaçao maar bedienden ook de eilanden Aruba en Bonaire. De Raad van Justitie bleef gehandhaafd op Sint Maarten en bediende Saba en Sint Eustatius. Deze regeling van de rechtspleging duurde tot 1869 , toen kreeg elk eiland een Kantongerecht. In 1919 kwam er een kantongerecht met drie zittingsplaatsen voor de Benedenwindse eilanden. In 1941 werd dit systeem gewijzigd en ontstond het Gerecht in Eerste Aanleg met zittingsplaatsen op alle eilanden. ${ }^{120}$

Het Hoog Gerechtshof te 's-Gravenhage behandelde van 1816 tot 1833 in hoger beroep civiele en strafzaken gewezen in de 
kolonie Curaçao en onderhorigheden en de kolonie Sint Eustatius en onderhorigheden. Sinds 1833 behandelde het Hof van Suriname civiele zaken in hoger beroep van de kolonie Curaçao. Tegen beslissingen in civiele zaken in eerste instantie door het Gerechtshof in Suriname gewezen stond hoger beroep open bij de Hoge Raad.

In 1865 werd het ingestelde Hof van Justitie appelinstantie voor de kolonie Curaçao. Voor zaken in eerste aanleg gewezen door het Hof van Justitie in Curaçao was sinds 1840 beroep op de Hoge Raad mogelijk (géén cassatie). Het beroep in civiele zaken op het Gerechtshof in Suriname bleef in de praktijk tot 1869 bestaan. Voor het hoger beroep in strafzaken bleef de regeling gelden van hoger beroep op het Hoog Gerechtshof in Den Haag.

De Commandeur van elk der eilanden had in bepaalde strafzaken een eigen bevoegdheid. De door hem veroordeelden konden bij de Raad van Politie van de kolonie (bij het Gouvernement) in hoger beroep. Op 30 januari 1824 werden voor Bonaire en Aruba afzonderlijke Reglementen van administratie en bestuur vastgesteld. Daaruit blijkt duidelijk, aldus Bordewijk, "dat de 'Kommandeur' op zijn eiland vrijwel almachtig was en alle zelfregeering der ingezetenen"' ontbrak. In 1865 vervielen de reglementen voor Aruba en Bonaire stilzwijgend. ${ }^{121}$ De Commandeurs van de eilanden kregen een eigen instructie, dat een regeringsreglement in het klein was. De Vice-commandeur op Aruba was belast met met het fokken van ezels en paarden en het beheer van de zoutpan. De Indianen-officier ('kapitein der Indianen') deed allerlei taken, die niet aan andere functionarissen waren toegewezen. Op Aruba ontbrak elke invloed van de ingezetenen op het bestuur. Tot 1821 mochten zich nauwelijks particulieren op Aruba vestigen, de Indianen en kleurlingen die op Aruba woonden waren analfabeet.

Op Aruba fungeerde van 1824 tot 1869 een Vredegerecht, bestaande uit de Commandeur en twee der voornaamste ingezetenen, die magistraten werden genoemd. Zij ontvingen geen bezoldiging. Het Vredegerecht was belast met alle zaken betreffende het politiewezen en met de beslissing van alle tussen ingezetenen gerezen geschillen, die niet van criminele aard waren. Alles ging mondeling en zonder dagvaarding. Het Regeringsreglement van 1824 gaf de gewijzigde positie van Aruba binnen de kolonie weer.

121

Bordewijk (1911) p. 40.

74. De Nederlandse kolonisatie van de West 
Een eerste aanzet tot bestuursparticipatie vond plaats door zittingneming van de gegoede bevolking in het Vredegerecht.

Ook had het Vredegerecht, evenals de latere Raden van Politie, de taak van behandeling der huishoudelijke zaken van het eiland, het verlijden van hypotheek-akten, het transporteren van onroerend goed en dergelijke. ${ }^{122}$ Het Vredegerecht was een wetgevend orgaan, een uitvoerend orgaan en een rechtsprekend orgaan. Tot 1848 werd het opperhoofd van het eiland Commandeur genoemd, daarna kreeg hij de titel van Gezaghebber. In 1848 kwam de Raad van Politie tot stand bestaande uit de Gezaghebber en twee Landraden. Tijdens de vergaderingen van de Raad van Politie mocht het aanwezige publiek meepraten. Een toehoorder-niet lid kon het woord vragen, maar mocht niet stemmen. ${ }^{123}$

Het reglement van 1848 bepaalde dat de onderhorige eilanden werden bestuurd door een Gezaghebber, bijgestaan door een 'Adviseerende Commissie' die uit twee benoemde burgers bestond. ${ }^{124}$ Dit orgaan nam een deel van de taken van het Vredegerecht over. Na 1863 verkreeg de Gezaghebber beperkte rechterlijke bevoegdheden en verloor het Vredegerecht verder aan belang. Het werd in 1869 opgeheven toen op Aruba een kantongerecht werd gevestigd. ${ }^{125}$ Op Bonaire bestond geen vredegerecht maar kon de Commandeur in civiele zaken optreden als arbiter. De opzet van de rechterlijke organisatie is tot 1865 in de koninklijke regeringsreglementen niet al te ingrijpend veranderd, slechts de samenstelling van de colleges wijzigde. Pas in 1869 zou de codificatie worden ingevoerd en zouden bestuur en rechtspraak worden gescheiden. Tevens zou de rechtspraak worden gemoderniseerd en werd in theorie de nadruk gelegd op de scheiding van machten.

Tussen 1863 en 1871 heeft nog een eenvoudige vorm van rechtspraak bestaan, opgedragen aan Districtscommissarissen in Curaçao en Sint Eustatius, aan de Gezaghebbers van Bonaire, Aruba en Saba en een speciale ambtenaar in Saint Martin. Zij

Hartog (1953) pp. 133 e.v.

Van Grol (1980) p. 26. Het West-Indisch begrip landraad moet gezien worden in tegenstelling tot zee- en krijgsragd. De raden van policic of politicke raden behartigden zaken van het land, het territoir. Daarom werden zij landraden genoemd. De term landraad is pas verdwenen bij de Curaçosche Staatsregeling van 1936. Hartog (1961) p. 137.

Bordewijk (1911, p. 67; Hartog (1961) p. 136: de naam 'Commandeur' werd toen veranderd in Gezaghebber. 
hielden zich bezig met eenvoudige zaken bezig en begeleiden de slaven naar de emancipatie na de afschaffing van de slavernij in 1863. Bij het afschaffen van de slavernij had de overheid bepaalde bijzondere rechtsprekende voorzieningen in het leven geroepen. De overheid meende dat door de emancipatie van grote groepen slaven het aantal wetsovertredingen aanzienlijk zou toenemen. Daarom werd het instituut van districtsmeesters of districtscommissarissen ingesteld. Officieel zouden deze districtsmeesters de vroegere slaven begeleiden en voorkomen dat derden misbruik van deze onervaren burgers zouden maken.

De rechtsmacht van de districtsmeester moest zorgen voor snel en goedkoop recht voor eenvoudige burgerlijke zaken en overtredingen. In burgerlijke zaken waren de districtscommissarissen competent tot rechtsvorderingen waarvan het onderwerp de waarde van $f$ 50,- niet te boven ging. De bevoegdheid was 'concilatoir' (op verzoening gericht). Dat hield in dat de districtscommissaris zich beperkte tot de kennisneming der vordering, van het onderzoek der zaak, van de bewijsmiddelen en de verweren en dat hij moest trachten het geschil tussen partijen in der minne af te doen. De rechtsmacht van de districtscommissarissen stoelde in feite op dezelfde grondbeginselen als het 'Vredegeregt' op Aruba. Het reglement voor de districtscommissarissen kende een vorm van prorogatie. Werd dit verzocht, dan was het vonnis verbindend met verdere uitsluiting van de mogelijkheid van hoger beroep. In strafzaken deed de districtscommissaris, behoudens hoger beroep, uitspraak in die gevallen waarin op het feit geen hogere straf was gesteld dan gevangenisstraf van 10 dagen of boeten van niet hoger dan $f$ 50,- hetzij gezamenlijk hetzij afzonderlijk. Op Aruba werden echter niet de districtmeesters met deze bevoegdheid belast, maar de Gezaghebber. ${ }^{126}$ Dit betekende dat vanaf de inwerkingtreding op 1 juli 1863 tot 1 mei 1869 men op Aruba naast een Vredegerecht ook een rechtsprekende Gezaghebber had wier bevoegdheden elkaar overlapten. ${ }^{127}$

Wat de wijze van procederen betreft gaf de OvR richtlijnen. Gevolgd moest worden 'den stijl ende manieren van procederen, bij de Groot Mo: Heeren Staten van Hollant in den jare 1580' vastgesteld. De rechtspraak was nogal chaotisch, men wist in de loop van de tijd niet meer welke wetten toe te passen. Een gebrek aan juridische deskundigheid bij de Raden en het ontbreken van 
een toereikende bibliotheek van de landswetten en juridische handboeken, stonden een goede rechtsbedeling in de weg. Bovendien heeft men er nooit aan gedacht voor de Engels sprekende bevolking van de Bovenwinden de vigerende wetten te vertalen, dat gebeurde pas na de codificatie. Maar daar waar de Raden wel Nederlands spraken was de situatie niet veel beter. Nederland (de Heren X en de Staten-Generaal) had weinig begrip voor de situatie in de kolonie en gaf ook weinig steun. Schiltkamp citeert het Tweede Kamerlid Wintgens, ${ }^{128}$ die op 13 mei 1865 bij de behandeling van de Regeringsreglementen voor de koloniën Suriname en Curaçao ten aanzien van de 'regstoestand (zoo dat woord hier mag worden gebezigd)' pregnant opmerkte:

\footnotetext{
'Wanneer men dat een en ander aldus bijeen zict, dan zou men het kunnen noemen eene verzameling van juridische antiquiteiten en curiositeiten; maar men zegt tevens niet te veel als men, dit alles te zamen genomen ziende, verklaart dat de tegenwoordige toestand is allerellendigst, allertreurigst, ja een ware poel van ongeregtigheid, waaraan hoe eerder hoe beter een einde moet worden gemaakt'. ${ }^{129}$
}

Ingevolge de 'Ordre van Regieringe' van 1629 pasten de rechtscolleges op Curaçao het Oud-Vaderlands recht en het Romeinse recht toe. Daarnaast paste men ook de lokale wetgeving toe. Op Aruba werd echter gezien de beperkte competentie volstaan met de toepassing van lokale wetgeving. Bij de invoering van de codificatie op 1 mei 1869 kwam tevens een nieuwe rechterlijke organisatie tot stand en hielden de Vredegerechten op te bestaan. ${ }^{130}$

De situatie op de Bovenwinden was anders, daar was wel degelijk sprake van volksinvloed op de benoemingen van de Raadsleden. De Bovenwinden waren aanvankelijk voorbestemd als volksplantingen, zij zijn hun bestaan als patroonskolonies begonnen. De patroons waren verplicht bun kolonie onder een Commandeur te stellen. $\mathrm{Zij}$ konden eigen rechtspraak organiseren, van vonnissen van het patroonsgerecht boven vijftig gulden kon in hoger beroep

\footnotetext{
128 Bordewijk (1914) p. 584.

129 Schiltkamp (1972) p. 68.

130 Voges (1982) p. 116.
} 
gegaan worden bij Commandeur en Raden van de Compagnie. ${ }^{131}$ Omdat de Bovenwindse eilanden gedeeltelijk patroonschappen waren geweest had het bestuur zich vrijer van de WIC kunnen ontwikkelen. De oorzaak ligt dus in de aard van de koloniēn, patroonschap en kolonie van de WIC. Ook vond de WIC (en de regering) dat op Curaçao de civiele invloed beperkt diende te blijven, omdat de haven van Curaçao de enige belangrijke haven in het West-Indisch gebied was. Om de haven goed te kunnen verdedigen, dienden de vesting en verdedigingswerken in goede staat te zijn en daartoe had de Gouverneur veel gezag nodig en moest hij niet gehinderd worden door een burgerlijke regering (die uiteraard andere belangen had).

In de Instructie van 29 december 1681 voor Louis Houtkoper en Jacob Munnickhoven, als respectievelijk Commandeur en Commissaris voor Sint Eustatius en Saba was er geen sprake van volksinvloed. Waarschijnlijk was dat te wijten aan de invloed van de WIC, die zich door de aankoop van de helft van het eiland in het bezit van de kolonie had gesteld. In de Instructie van 13 december 1686 voor Commandeur Lucas Schorer werd bepaald dat de Raadsleden zouden worden benoemd uit een voordracht 'van een tripel getal'. Deze voordracht kwam door stemming onder de burgerij tot stand. Deze vorm van zelfbestuur werd door de bewoners van de Bovenwinden zeer belangrijk geacht. Dit kwam tot uiting bij het optreden op Sint Eustatius van de nieuwe Commandeur Everard Raecx in 1728. Zijn instructies bevatte dit voorrecht voor de burgerij weer niet. Toen bleek dat er geen burgerraadsleden zouden worden benoemd, deelden direct enkele burgers de nieuwe Commandeur mee, dat $\mathrm{zij}$ aan hun verworven rechten zouden vasthouden 'selfs met dreygementen'. De Commandeur voldeed terstond aan de verlangens van de burgerij. Voor het hierboven beschreven belangrijke verschil tussen de kolonie

131 Als vertegenwoordiger van de soeverein, de Staten-Generaal, had de WIC het feitelijk eigendom van de grond in de koloniën. Als zodanig had zij de bevoegdheid grond uit te geven aan particulieren. De patroons, die als leenmannen optraden voor de WIC gaven de grond in eigendom uit aan de kolonisten, op voorwaarde dat de grond verbouwd zo's worden. De patroonschappen bestonden van 1636 tot 1682 toen de patroonschappen werden overgenomen door de WIC. De landbouw heef nooit een rol van betekenis gespeeld in de kolonie. De opbrengst van de plantages was voomamelijk bedoeld om in het levensonderhoud van de bewoners van de eilanden te voorzien. Op Curaçao kwamen particuliereen gouvernementsplantages voor. Aruba was nimmer een plantage-eiland. Bonaire werd als een gouvernementsplantage geëxploiteerd. Later verkocht de overheid op Bonaire veel grond aan particulieren. Op de Bovenwindse eilanden ging het om kleinschalige landbouw; Encyclopedie (1985) pp. 380-385. 

aantal oorzaken worden aangegeven.

Op de Bovenwindse eilanden was de belangstelling voor het Raadslidmaatschap hetzelfde als op Curaçao. Ook daar waren de burgers onwillig om Raadslid te worden, terwijl zij door hun medeburgers waren voorgedragen op grond van stemming. Op Sint Eustatius en Sint Maarten schijnt zich de gewoonte te hebben ontwikkeld dat de Raadsleden aftraden bij het aantreden van een nieuwe (Vice-)Commandeur. Ook blijkt uit het rapport van 1791 dat er steeds minder personen de Nederlandse taal beheersten. Op Sint Eustatius ontstond door gebrek aan kennis in zeezaken bij de Raadsleden, een bijzondere rechtspleging. Daar zaken zoals averij, zeezaken, rekeningen en dergelijke nogal moeilijk waren voor de Raad, benoemden de Gouverneur en de Raad drie of vier voorname handelslieden, die de goedkeuring der partijen wegdroegen en die dan fungeerden als arbiters in de zaak 'of de zaak bij beschikking uit de waereld helpen'. Men achtte dit een goede gewoonte, omdat zeezaken een snelle afhandeling vergden en 'de verschillendheid van taelen en reguliere regtspleging allermoeylijkst zouden maken'.

Aruba en Bonaire kregen vanaf 1848 een afzonderlijke Raad van Politie. Voordien vielen ze onder het gezag van Curaçao, waar ook de justiële zaken van de beide eilanden werden behandeld. Aan een meer zelfstandig bestuur voor Aruba en Bonaire zou daarvoor geen behoefte zijn geweest. Er woonden slechts enkele Compagniesbedienden. Omdat Aruba en Bonaire Gouvernementsplantages waren, werd vestiging van vrije lieden er lang tegen gehouden. Pas in de tweede helft van de 18de eeuw werd de toegang voor zelfstandige koloniers vergemakkelijkt. Ook Saba had geen eigen Raad. Er was een Vice-Commandeur als plaatselijk gezagsdrager onder het gezag van Sint Eustatius. Er woonden te weinig mensen om een aantal leden geschikt voor de regering te leveren. Wel zijn burgers van Saba betrokken geweest bij de benoeming van raadsleden op Sint-Eustatius. In de Instructie voor de Commandeur van 28 augustus 1721 werd bepaald, dat de Raden gekozen moesten worden uit 'de opgesetenen' van Sint Eustatius en Saba. In de Instructie van 18 november 1733 kwam deze bepaling niet meer voor.

De functie en betekenis van de Raad van Curaçao is in de periode 1816-1865 sterk verminderd. In de periode 1816-1828 had de Raad van Politie nog echt het karakter van een bestuursorgaan 
dat vele belangrijke besluiten niet alleen voorbereidde, maar ook werkelijk nám. In de periode 1828-1834 nam de zelfstandige wetgevende arbeid van de Raad sterk af. Alle raadsbesluiten moesten worden goedgekeurd door de Gouverneur-Generaal in Paramaribo. Sinds het Regeringsreglement van 1834 was de Koloniale Raad een adviescollege geworden en geen medebesturend college meer. De Gezaghebber kon veel meer zelfstandig doen, zonder de Raad in te schakelen. Het belang van de Koloniale Raad nam tussen 1834 en 1865 steeds verder af. Het lidmaatschap van de Raad werd gezien als een erebetrekking. De leden hadden een ambtskostuum en stelden er ook prijs op dat hen het juiste eerbetoon ten deel viel. Aan het lidmaatschap was geen salaris verbonden, maar wel werd aan de leden een 'douceur' toegekend; in 1827 bedroeg dit bijvoorbeeld $f 100$,- per half jaar. ${ }^{132}$

$\mathrm{Na}$ het aflopen van het octrooi van de Tweede West-Indische Compagnie op 31 december 1791 ging het algebele bestur van de West-Indische koloniën over op de Staten-Generaal. Bij resolutie van 1 juni 1792 bepaalden de Staten-Generaal:

\begin{abstract}
"dat dewijl by Resolutie van haar Hoog. Mog. van den 3 Mey 1792, de overneeming der Actien, Eigendommen en Bezittingen der geweezene Westindische Compagnie, haar volle beslag gekreegen heef, en de zelven daar zyn overgegaan, onder bestier van haar Hoog. Mog., voortaan de Colonien zullen worden gedirigeert door een Collegie onder den naam van Raad van Colonien in de Westindien, hetwelk met zyne Hoogheid den Heere Erfstadhouder, als Gouverneur-Generaal over de Colonien, aan het Hoofd, in naam en van wegens haar Hoog Mog., het generaal bestier zal hebben, ingevolge de Instructie op heeden gearresteert, en agter deeze Resolutie geextendeert sub $n^{0}, 1$ 2."133
\end{abstract}

De WIC werd opgeheven onder een staatsbestel in de Verenigde Nederlandeı, dat zelf ook duidelijk aan vernieuwing toe was. In

\footnotetext{
152 Renkema (1983) pp. 12-15.

133 Bordewijk (1911) p. 21.
} 
de periode 1792-1795 deden zich grote veranderingen voor. De Instructie voor de elf leden tellende Raad der Colonien in de Westindien werd gearresteerd op 1 juni 1792. De taak van de Raad was in art. 10 omschreven:

"Door deezen Raad zullen uit den naam en van wegens haar Hoog Mogende, alle zaaken die tot het generaal bestuur der Colonien en van den Handel en Navigatie, op en van dezelve behooren, worden verhandelt en gereguleert; egter zoodanig, dat het Opperbestuur altoos blyve in den boezem van haar Hoog Mogende." 134

Op 13 november 1792 trad de Raad der Colonien in functie. De Raad der Colonien in de Westindiën heeft na de opheffing van de WIC zijn taak maar kort kunnen uitoefenen, van 1792 tot 1795 . Het centraal bestuur werd uitgeoefend door elf leden, ui" de verschillende gewesten afkomstig. Er traden maar negen leden in fuctie, terwijl in de steden waar de kamers van de WIC gevestigd waren geweest, departementen ${ }^{135}$ voor de Westindische handel werden ingesteld, die ondermeer de belastingen en de recognitiegelden $^{136}$ inden, waarop de Raad aanspraak kon maken.

De Staat had niet alleen de plichten maar ook de rechten van de WIC overgenomen. De Raad moest de grote lijnen van het bewind vaststellen, de correspondentie over de hoofdzaken van het bewind met de koloniën voeren. Verder hield de Raad een generale kas aan, waaruit de kosten van het bestuur in de koloniën en in Nederland betaald moesten worden evenals de rente van de overgenomen aandelen en kredieten van de voormalige Compagnie. Er was dus sprake van een geleidelijke overgang van Compagniebe-

14. Instructie voor den Raad der Colonien in de Westindien, gearresteerd 1 juni 1792, in: Bordewijk (1911) pp. 139-143. Voor de departementen werden Commissarissen tot den Westindische Handel aangesteld. Meer dan 27 mochten er dat niet zijn (w.o. 9 in Amsterdam, 6 in Zeeland, 6 op de Maze, Nooderkwartier 4, Stad en Lande 2). De Raad zou behalve met de Prins als hoofd, uit 11 personen bestaan. Vier uit Holland, 2 uit Zeeland en een uit elk der ander provincies. Het werden er uiteindelijk 9; Kunst (1981) p. 226; Bordewijk (1911) p. 22. Zie ook de Instructie voor Commissarissen tot den Westindische Handel, gearrestcerd 1 Juni 1792 en de Particuliere Memorie voor Johannes de Veer Abrahamszn, Directeur over den Eylande van Curaçao van 11 September 1793, Bordewijk (1911) p. 143 e.v.

135 Zie ook Bordewijk (1911) pp. 143-146: Instructie voor Commissarissen tot den Westindische Handel gearresteerd 1 juni 1792.

136 Onder recognietiegelden werden verstaan de op de grond drukkende lasten zoals akkergeld, canon, hoofdgeld, erfpachtsom of cijns, tienden, de last- en convooigelden en in- en uitvoerrechten; Van Grol (1980) p. 32. 
stuur naar Staatsbestuur. ${ }^{137}$ Op 5 september 1795 hield de 'Colonie-Raad' op te bestaan. ${ }^{138}$

2.6.2 Committé tot Zaken van de Coloniën en Bezittingen (17951801)

Als het verschil tussen beide West-Indische Compagniēn terzijde wordt gelaten, waarbij vooral de invloed van de verschillende Kamers in het geding was, dan veranderde de situatie pas in 1792. Toen werd door de Staten-Generaal het beheer over de overzeese bezittingen toevertrouwd aan een Raad van Koloniën met negen leden, die met de komst van de Bataafse Republiek weer plaats maakt voor een 'Committé tot Zaken van de Coloniën en Bezittingen op de kust van Guinee en Amerika', met 21 leden (1795). Het Committé was een direct gevolg van de revolutie die het oude wilde vervangen. Het opperbestuur berustte bij de 21 leden gezamenlijk, terwijl militaire, huishoudelijke en handelszaken aan drie afdelingen met ieder zeven leden toevielen. Ook een deel van de strafrechtspraak werd opgedragen aan het Committé.

De Staten-Generaal zouden een advocaat-fiscaal aanstellen die de belangen der overheid zou waarnemen bij ambtsmisdrijven, gepleegd door burgers of militairen die aan het Committé onderhorig waren en er door berecht zouden worden. Aan de koloniën werd bericht dat de zittende bestuurders de orde zouden moeten blijven handhaven tot er een charter voor de koloniën zou zijn vastgesteld. Hoewel de afzonderlijke directies van Suriname en Berbice nu werden opgeheven en er dus meer uniformiteit kwam in het koloniaal bestuur, bleek dit veelhoofdig Committé toch niet erg doelmatig. ${ }^{139}$ Dit logge lichaam bestond van 1 november 1795 tot 2 januari $1801^{140}$ en werd op zijn beurt weer vervangen door de 'Raad der Amerikaansche Coloniēn en Bezittingen' met vijf leden (1801), dat gebaseerd was op de de Staatsregeling van 1798.

De Bataafse Republiek sloot met Frankrijk in 1795 het Haags verdrag. Dit hield onder andere in dat Nederland en Frankrijk een aanvals- en verdedigingsverbond sloten. Hierdoor was de Bataafse Republiek bijna voortdurend in oorlog met Engeland. Dit was zeer

Instructie voor den Raad der Colonien in Westindien, gearresteerd 1 Juni 1792, in: Bordewijk (1911) pp. 141-143; Encyclopedie (1985) p. 68.

134 Bordewijk (1911) p. 29.

Wispelweij (1961) pp. 36-39.

Bordewijk (1911) p. 32. 
ongunstig voor de koloniën. In 1795 werden de Bovenwindse eilanden door de Fransen bezet, maar spoedig daarna werden ze weer door de Engelsen veroverd.

Stadhouder Willem V moest uit Nederland vluchten voor de Franse inval en richtte zich in de brieven van Kew, van februari 1795 tot de koloniën. ${ }^{141} \mathrm{Hij}$ gelastte het bewind tijdelijk over te dragen aan de Engelsen. De Staten-Generaal hadden echter de opdracht gegeven de Fransen te gehoorzamen. De voorstanders hiervan waren de Prinsgezinden of Engelsgezinden. De aanhangers van de Bataafse Republiek beoogden het tegendeel en waren Fransgezind, zij hingen de ideeën van de Franse revolutie aan. Directeur (Gouverneur) Lauffer (1796-1803) probeerde buiten het conflict te blijven en wilde voorkomen dat Curaçao door een der oorlogvoerende partijen zou worden bezet. In 1800 veroverden de Fransen Curaçao. Lauffer vroeg toen de Engelse legeraanvoerder Watkins om hulp. De Engelsen stelden voorwaarden, want officieel waren ze met de Bataafse Republiek in oorlog, dus ook met Curaçao. De Engelsen zouden de forten bezetten, maar het plaatselijk bestuur zou ongemoeid worden gelaten. Het eerste Engelse tussenbestuur duurde van 1800-1802. Na de vrede van Amiens (1802) kwam Curaçao weer onder de Bataafse Republiek. Pedro Louis Brion kwam in 1803 naar Curaçao terug en streed tegen de Engelsen toen de oorlog met de Engelsen in 1804 weer uitbrak en wist hen te verdrijven. Door al deze vlagwisselingen ontstond een periode van verwarring, die voortduurde tot 1816 , toen na een Franse inval en twee Engelse tussenbesturen, de koloniēn definitief onder Nederlands gezag terugkeerden. ${ }^{142}$

De Raad der Amerikaansche Coloniën en Bezittingen (18011806)

Het Committé tot Zaken van de Coloniën en Bezittingen werd op 2 januari 1801 weer vervangen door de Raad der Amerikaansche Coloniën en Bezittingen. De Raad der Amerikaansche Coloniën berustte op de Staatsregeling van 1798, die in navolging van Montesquieu de machtenscheiding invoerde. De vertegenwoordigende macht was de hoogste en bracht de volkswil tot uitdrukking. Tevens zouden er een uitvoerende macht en een rechterlijke

i41 De Monté ver Loren en Spruit (1982) pp. 248-261.

142 Hartog (1988) p. 13. 
macht zijn. De uitvoerende macht, het vijf leden tellende Uitvoerende Bewind, was het centrale orgaan voor de koloniēn, dat jaarlijks aan de Vertegenwoordigende Vergadering de nodige gelden diende te vragen voor onder meer onderhoud van de koloniēn en haar defensie.

Twee raden, een voor 'Asiatische Bezittingen en Etablissementen' en een voor de 'Amerikaansche Coloniēn en Bezittingen' zouden het bestuur voeren in een ondergeschikte verhouding tot het Uitvoerend Bewind. De Raad bestond uit vijf leden. Aan de Raad diende volgens de Staatsregeling een uitgebreide instructie gegeven te worden door de Vertegenwoordigende Vergadering en iedere kolonie zou het eerder in het vooruitzicht gestelde charter van het Uitvoerend Bewind ontvangen, deze charters werden echter nimmer ingevoerd. De door de Staatsregeling geëiste raadpleging van de kolonisten kon niet plaatsvinden vanwege de oorlogsomstandigheden, men wachtte op rustiger tijden. Op 11 september 1800 veroverde de Engelsen Curaçao. Na de vrede van Amiëns werd dit gebied in het begin van 1803 door de Engelsen ontruimd en oefende de Raad het opperbestuur over de koloniēn daadwerkelijk uit. Op 1 januari 1807 werd Curaçao weer bij verrassing ingenomen door de Engelsen. De Engelsen ontruimden Curaçao op 4 maart 1816 nadat de teruggave was bepaald bij de tweede vrede van Parijs. ${ }^{143}$

Deze Raad heeft bestaan van 2 januari 1801 tot 29 juli 1806. ${ }^{144}$ Nadat de Bataafse Republiek (1795-1806) in 1806 werd vervangen door het Koninkrijk Holland (1806-1810) maakte Koning Lodewijk Napoleon (1806-1810) een einde aan de collegiale bestuursvorm van de koloniën. Daarmee verdween een vorm van collegiaal bestuur die sinds het begin van de Eerste WIC, 185 jaar had bestaan.

Artikel 36 van de Constitutie van 1806 bepaalde: 'De Bestiering der Koloniën, en van alles wat derzelver innerlijke Regering betreft, behoort bij uitsluiting aan den Koning'. Er werd een Directeur-Generaal benoemd over de zaken van 'Indiën en den Koophandel'. Mr. Paulus van der Heim werd op 29 juni 1806 de eerste minister van Koophandel en Koloniën. Dit 'Ministerie van Koophandel en Kolonien' bestond van 29 juli 1806 tot 8 januari 1808. Het betreffende ministerie werd gewijzigd en ging op in het op 8 januari 1808 ingestelde 'Ministerie van Marine en Kolonien'. Bordewijk (1911) pp. 32-35. 
Dit ministerie functioneerde tot 31 december $1810 .{ }^{145}$ Van 1810 tot 1813 was Nederland bij Frankrijk ingelijfd. ${ }^{146}$

Op 1 januari 1807 viel Curaçao weer in handen van de Engelsen. Het bleef Engels tot 4 maart 1816. Toen Napoleon verslagen was kreeg Nederland bij het Weense Congres, Ceylon, de Kaapkolonie en Essequibo niet terug van de Engelsen. De Antillen werden wel teruggegeven. ${ }^{147}$ Wat er nog van de koloniën over was werd vanuit Parijs bestuurd en beheerd door een 'Division Hollandaise' bij het Franse 'Ministère de la Marine et des Colonies'. ${ }^{148}$ In 1813 (feitelijk 1816) kwam er onder het Koninkrijk der Nederlanden met zijn Ministerie van Koloniën meer stabiliteit. De Grondwet van 1814 bepaalde in art. $35 \mathrm{lid} 3 \mathrm{nog}$ wel dat de 'Souvereinen Vorst de bevoegdheid had een 'Raad van koophandel en kolonien' in te stellen met een collegiale bestuursvorm. De onder Franse invloed verkregen eenheid in het koloniaal opperbestuur werd echter in ere gehouden, wat overigens overeenkwam met

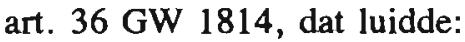

"De Souvereine Vorst heeft, bij uitsluiting het opperbestuur over de kolonien en bezittingen van den Staat in andere werelddeelen."

Die Raad zou dan in de plaats zijn gekomen van een ministerie. En dat lijkt wel logisch, omdat de 'Amerikaansche Raad' ook verdween toen het Ministerie van Koophandel en Koloniën werd ingesteld. Uit het met art. 35 Grondwet (1814) corresponderende artikel 75 van de Grondwet van 1815 was de bevoegdheid tot instelling van een Raad van Koophandel en Koloniën verdwenen. ${ }^{149} \mathrm{Er}$ volgde onder het Nederlandse staatsbestuur een snelle evolutie in de vorm van een aantal Regeringsreglementen, die aanvankelijk bij Koninklijk Besluit $(1815,1828,1833,1848)$ en nadien bij wet (1865) werden vastgesteld. De Bovenwinden

145

Kunst (1981) pp. 228 e.v.; Bordewijk (1911) pp. 35-38 en pp. 154-165.

Nadat Nederland in de loop van het jaar 1810 een onderdeel van Frankrijk was geworden, werd hier op 1 mart 1811 de Franse wetgeving van kracht. Van toen af aan waren de Nederlandse rechterlijke organisatie en strafrechtpleging volledig op Franse leest geschoeid. In 1813 herkreeg Nederland zijn zelfstandigheid, de juryrechtspraak werd afgeschaft, mar de Franse rechterlijke organisatie en strafrechtspleging werd voorlopig gehandhaafd; Bossers (1987) p. 1.

Hartog (1964) en (1961); Encyclopedie (1985) p. 68; Kunst (1981) pp. 225-228.

Projet d'Instruction pour le Gouverneur-Général de l'he de Curaçao etc. Arrêté par Decret du 19 Janvier 1807, in: Bordewijk (1911) pp. 154-165.

Bordewijk (1911) pp. 36-38; Van Hasselt (1979) pp. 172, 224. 
vormden tot 1828 onder Sint Eustatius een aparte eenheid.

\section{Geen revolutie in de koloniën}

Omstreeks 1770 ontstond ook op veel plaatsen in West-Indië een geest van verzet tegen de economische, juridische en sociale omstandigheden in de koloniën. De Noordamerikaanse en later de Franse revolutie hadden daar duidelijk invloed op. Staatsregelingen in de tijd van de Bataafse Republiek van 1798, 1801, 1805, de Constitutionele wetten en de Constitutie van het Koninkrijk Holland van 1806 voor koning Lodewijk Napoleon (die in Nederland in de staatsrechtsgeschiedenis plegen te worden behandeld) bevatten alle één of meer bepalingen over de koloniën. De Staatsregeling van de Bataafse Republiek van 1798, vermeldde dat de koloniēn charters zouden krijgen. ${ }^{150}$ Het idee van charters voor koloniën was van Engelse berkomst. Deze documenten waren de basis van de Engelse koloniēn in Amerika. Zij fungeerden als constitutie van de koloniēn op grond van een maatschappelijk verdrag. Er was voorzien in een ruime mate van zelfbestuur voor de koloniën. Geïnspireerd door Montesquieu was de machtenscheiding ingevoerd. De charters zijn echter nimmer vastgesteld, er volgde een conservatieve reactie op de Franse revolutie en een gedeeltelijk herstel van de voor-revolutionaire regelingen.

De Staatsregeling van 1798 noemde de vertegenwoordigende, uitvoerende en rechterlijke macht. De vertegenwoordigende macht werd geacht de volkswil tot uiting te brengen en was de hoogste macht. Hierin kan de gedachtengang van Rousseau worden teruggevonden. ${ }^{151}$

Bijna tien jaar na de eerste Staatsregeling van de Bataafse Republiek, drong het idee van machtenscheiding gedeeltelijk door op Curaçao. De Raad zou het bestuur niet langer verenigen met de rechtspraak. Het zou echter nog jaren duren, voor het zover was. In $1804 \mathrm{kwam}$ als inleiding tot die splitsing van bestuur en rechtspraak een 'Huishoudelijk reglement van orde voor de Raad van Politie en provisioneel ook Justitie des eylands Curaçao' tot stand. Leden voor een Raad van Politie en voor een Raad van civiele en criminele justitie werden aangewezen. In de verschillende Raden zaten echter vaak dezelfde personen.

\footnotetext{
150 De artt. 251-255 in: Van Hasselt (1987) pp. 70-71.

131 Da Costa Gomez (1935) pp. 1-9.
} 
Herhaaldelijk en uitdrukkelijk werd in de diverse Regeringsreglementen in de periode $1815-1865$ verklaard dat de rechtspraak onafhankelijk was. In de praktijk kwam de scheiding van rechtspraak en bestuur zeer moeilijk tot stand. Dit had verschillende oorzaken. Er was een gebrek aan geschikte personen die de rechterlijke colleges konden bezetten en er bestond een zekere onwennigheid met de machtenscheiding zowel bij de Raad van Politie als bij de justitiële autoriteiten. Ook leefde de (autoritaire) gedachte voort dat in de kolonie de uitvoerende macht superieur was aan de rechterlijke macht. Artikel 46 van het Regeringsreglement van 1815 komt niet verder dan voor te stellen dat de vier leden van de Raad van civiele en criminele justitie 'zo mogelijk' niet tevens raden van politie zijn. Artikel 51 zegt dat geen politiek gezag zich zal bemoeien met de administratie van de Justitie en "veelmin derzelver loop mag stremmen, maar zal de Raad van allen invloed vrij en onafhankelijk regt spreken".

In 1833 werd voor Curaçao bepaald dat het lidmaatschap van de rechtbank verenigbaar was met dat van de Koloniale Raad, het advieslichaam dat nauw bij bet beleid van de regering was betrokken. Voor de Bovenwinden werd zonder omhaal vastgesteld in de betreffende Koninklijke regeringsreglementen van 1833: "De regtspleging wordt uitgeoefend door de zes ingezetenen welke de Koloniale Raad te zamen stellen".

Toen Suriname en de Caraïbische eilanden in 1816 aan Nederland werden teruggegegen, werden de koloniën onderdeel van het Koninkrijk der Nederlanden. De constitutionele opbouw van de Nederlandse staat verschilde veel van de 18de eeuwse Republiek. In de Republiek van de Verenigde Provincies lag de uiteindelijke politieke macht in de handen van rijke kooplieden van de vooraanstaande steden en hun vertegenwoordigers in de Staten-Generaal. Er was sprake van een burgeroligarchie. De Franse bezetting van Nederland had een diepgaande invloed op de staatkundige structuur van het land. Deze veranderde een statenbond in een eenheidsstaat en riep een bureaucratie in het leven met een sterk centraal gezag. In 1815 kregen de kolonie Curaçao en de kolonie Sint Eustatius beide een eigen Regeringsreglement. Sint Eustatius en Sint Maarten kregen ieder een eigen Raad van Politie, Sint Eustatius met een Gouverneur en Sint Maarten met een Commandeur aan het hoofd. Bovendien kreeg Sint Maarten een afzonder- 
lijke Raad van Justitie. ${ }^{152}$ Tevens deden in 1815 twee componenten van de trias politica hun intrede. Hoger beroep van uitspraken van de Raad van Civiele en Criminele Justitie werd opengesteld op een nog aan te wijzen Gerechtshof (art. 56). Artikel 44 bepaalde dat administratie en rechtspraak zouden worden gescheiden. Voor de kolonie Sint Eustatius, Saba en Sint Maarten zou beroep worden opengesteld op de Hoge Raad.

Het Regeringsreglement voor Sint Eustatius, Sint Maarten en Saba van 1815 spreekt in art. 40 evenals het Surinaamse, van appel op de (Nederlandse) Hooge Raad, die overigens pas in 1838 werd ingesteld. Met het in art. 56 van het Curaçaosche Regeringsreglement 1815 bedoelde 'Geregtshof' kan niet anders bedoeld zijn dan de (Nederlandse) Hoge Raad.

Bij $\mathrm{KB}^{153}$ werd bepaald, dat zolang de Hoge Raad niet zou zijn ingesteld, de West-Indische koloniale zaken - deze regeling gold dus voor Suriname en de Antillen - zouden worden behandeld door het Hoog-Gerechtshof te 's-Gravenhage. Dit College zou daarbij de wijze van procederen in het gewone ressort van het Hof in acht nemen. Bij de beoordeling van de zaken zouden evenwel de in de kolonie vigerende wetten worden gevolgd.

\section{$2.9 \quad$ Wetgeving en bestuur}

Koning Willem I kreeg absolute controle over de koloniën. Na het herstel van het Nederlands gezag in West-Indiẽ in 1816 traden bij KB van 14 september 1815 nieuwe regeringsreglementen in werking. Er was nu sprake van een drietal West-Indische koloniën:

- Suriname, onder een Gouverneur-Generaal,

- Curaçao en onderhorige eilanden, eveneens met een Gouverneur-Generaal,

- de Bovenwinden, onder een Gouverneur. ${ }^{154}$

$\mathrm{KB}$ van 14 september 1815, 58. Aruba en Bonaire kregen in 1824 afzonderlijke Reglementen voor administratie en bestuur. De ingezetenen hadden geen inspraak in het bestuur, de Commandeur was almachtig, Hamelberg (1901) pp. 38-40. KB van 14 mei 1816,66 , GBS $1816,9$.

is Het Nederlandse deel van Sint Maarten had een bijzondere positie binnen de kolonie van de Bovenwinden. De Raad van Politie van Sint Eustatius had geen recht op inspectie van de aangelegenheden van Sint Maarten. Op Sint Maarten was een afzonderlijke Raad van Politie en een eigen boekhouder. Bij besluit van 28 maart 1828 werd die bijzondere positie van Sint Maarten nog verder bena- 
Zowel de Grondwet van 1814 (art. 36) en 1815 (art. 61) droegen het opperbestuur van de kolonie bij uitsluiting op aan de Koning. Bij uitsluiting betekende hier zonder inmenging van de volksvertegenwoordiging. ${ }^{155}$ Dit betekende dat de Koning als uitvoerende macht in Nederland ook de wetgevende macht in de kolonie bezat. De Gouverneurs van de koloniēn waren slechts verantwoording schuldig aan de Koning. ${ }^{156}$ De Koning maakte na 1815 ten volle gebruik van zijn macht om de Staten-Generaal buiten koloniale zaken te houden.

De Koning was in de koloniën de wetgever bij Algemene Maatregel van Bestuur, in de vorm van een Koninklijk Besluit (KB). Artikel $60 \mathrm{GW} 1815$ luidde: "De Koning heeft bij uitsluiting het opperbestuur over de volksplantingen en bezittingen van het Rijk in andere werelddelen'. Erg helder was die formule niet. Met name was niet duidelijk wat onder opperbestuur verstaan diende te worden. Viel daar ook de wetgeving voor de kolonie onder of betrof het slechts bestuur, in de zin van uitvoering van wetgeving? De Koning stelde zich echter op het standpunt dat bestuur ruim moest worden geīnterpreteerd. De Koning bezat derhalve de wetgevende en uitvoerende macht in de kolonien.

De Neef ${ }^{157}$ stelde dat Van Hogendorp en Thorbecke meenden dat opperbestuur betekende uitvoering en géén wetgeving en bij uitsluiting zonder inmenging van de oude compagnieēn, maar dit zou dan geen uitsluiting van de Staten-Generaal kunnen inhouden bij koloniale zaken. Die zouden de wetgevende macht in de koloniēn hebben evenals in het moederland. Deze mening wijst De Neef op bovengenoemde gronden, mijns inziens terecht, af.

In de Grondwet van 1848 viel "bij uitsluiting" weg, maar de macht van de Koning bleef feitelijk ongewijzigd, ook al wees Thorbecke sinds 1839 op het onderscheid bestuur-wetgeving. De Grondwet van 1815 en 1848 was onduidelijk op het punt in hoeverre de Koning wettelijke maatregelen kon uitvaardigen zonder medewerking van de Staten-Generaal. Bepaalde onderwerpen waren toebedeeld aan de Koning, andere daarentegen weer aan de

drukt door het te scheiden van Sint Eustatius en Saba en direct te plaatsen onder het algemene bestuur van Nederlands-West-Indiē te Paramaribo, Bordewijk (1911) pp. 39, 47, 49, 57 e.v. en 258; zie ook Paula (1992) pp. 13-15.

Bordewijk is deze mening ook toegedaan. Hij vindt dan ook dat de Regeringsreglementen ingesteld bij KB: "zijn van deze aldus buiten haar ware grenzen gebrachte koninklijke macht een gevolg." Bordewijk (1911) p. 39.

Gastmann (1964).

De Neef (1915) pp. 5-23. 
wetgever. De Code d'Instruction Criminelle eiste dat de rechter in zijn strafvonnis de wet moest noemen waarop de veroordeling rustte. Hierdoor leek het onmogelijk dat de Koning bij AMvB geboden en verboden vaststelde op overtreding waarvan straf kon worden gesteld. Maar de Blanketwet ${ }^{158}$ stelde straf op overtreding van bepalingen gegeven bij algemene maatregel van bestuur, waarop niet bij andere wetten straf was gesteld. De Koning kon nu zonder medewerking van de Staten-Generaal gebods- en verbodsbepalingen uitvaardigen. Koning Willem I maakte ruim gebruik van deze mogelijkheid. Met de invoering van de ministeriële verantwoordelijkheid, waardoor de verhouding tussen parlement en Koning minder gepolariseerd werd, nam het gebruik van de Blanketwet af, maar de bevoegdheid bleef rechtens wel bestaan. De jurisprudentie steunde deze praktijk. ${ }^{159}$

De Hoge Raad veranderde van mening in het befaamd geworden arrest van 13 januari 1879, (Meerenberg). De Hoge Raad overwoog dat, nu nergens bepaald was, wat onder de in de Grondwet vermelde algemene maatregel van bestuur was te verstaan, de vraag hoever de macht des Konings op dit punt strekte, moest worden beantwoord uit het stelsel van de Grondwet ten aanzien van de macht des Konings in het algemeen. Dit stelsel hield een nauwkeurige onderscheid in tussen het gezag toegekend aan de Koning en aan de algemene wetgever. De wetgevende macht was volgens de Grondwet toegekend aan de Koning en aan de StatenGeneraal samen. De macht van de Koning werd met name in de Grondwet genoemd en bestond uit de uitvoerende macht. Tot de uitvoerende macht behoorde bepaaldelijk niet de wetgevende macht. Aan de bevoegdheid van de Koning om zelfstandig, buiten de Staten-Generaal om allerlei wettelijke regelingen vast te stellen was door de HR een eind gemaakt.

De HR volgde hiermee de opvatting van de staatsrechtgeleerde J.T. Buys ${ }^{160}$ die van mening was dat de algemene maatregel van bestuur geen materiële wetgeving (de burgers bindende regelingen) mocht inhouden. Deze bevoegdheid kwam bij uitsluiting aan de wetgever toe, die deze bevoegdheid niet aan de Kroon (of anderen) mag delegeren.

\footnotetext{
138 Wet van 18 maart 1818 , Stb. 12.

199 Van der Pot (1972) pp. 371-373; Luiten (1983) p. 57. Meerenberg arrest, HR 13-1-1879, W. 4330.

160 Buys (1883) pp. 329-351.
} 
Bij de Grondwetsherziening van 1887 werd vastgesteld dat de koninklijke macht tot het uitvaardigen van een besluit met algemene werking op een wet in formele zin moet berusten, als daarin bepalingen worden gemaakt, die door straffen gehandhaafd moeten worden. Er bestaat een duidelijk verschil tussen deze bepaling en de uitkomst van het Meerenbergarrest. De HR had zijn arrest gebaseerd op het onderscheid tussen wetgeving en uitvoering en op het beginsel dat de Koning slechts die bevoegdheden heeft welke hem bij de Grondwet of wet uitdrukkelijk zijn toegekend. Het Grondwetsartikel daarentegen (art. 56 GW 1887) ging uit van de uit de Duitse literatuur afkomstige mening, dat het staatshoofd in beginsel bevoegd is tot regelgeving. Het uitvaardigen van voor de burgers bindende rechtsregelingen was volgens deze opvatting echter zo ingrijpend, dat deze moest steunen op een wet in formele zin (een wet van staatshoofd en volksvertegenwoordiging samen). Een wettelijke bevoegdheidstoekenning was daarom volgens de Grondwetgever van 1887 uitsluitend vereist voorzover de regels die door de regering worden gesteld, strafrechtelijk waren gesanctioneerd. De burger werd daardoor immers rechtstreeks geraakt. De Kroon bleef de bevoegdheid houden, voorschriften te geven, die louter door politiedwang kunnen worden gehandhaafd, of waarop geen sanctie staat. ${ }^{161}$

De situatie in Oost-Indië was er omstreeks 1840 oorzaak van dat de behoefte ontstond om het absolute gezag van de koning ten aanzien van de koloniën te beperken, zeker op financieel gebied. Pas bij de Grondwetsherziening van 1840 werden de StatenGeneraal enigermate ingeschakeld bij de wetgeving voor de koloniën. Toen werd voorgeschreven, dat de staten van ontvangsten en uitgaven van de volksplantingen en bezittingen aan hen zullen moeten worden meegedeeld en dat het gebruik van het batig slot, beschikbaar ten behoeve van het moederland, bij wet zal worden geregeld. De verhouding van ondergeschiktheid aan het moederland veranderde bij de herziening van de Grondwet van 1848 niet. Wat wel veranderde was de verhouding tussen Koning en Staten-Generaal met betrekking tot het bestuur der koloniën.

In 1848 werd de volledige ministeriële verantwoordelijkheid in Nederland ingevoerd waardoor het parlementaire stelsel werd voorbereid. Tot de wijziging van de Grondwet in 1922 luidde artikel 59 GW 1848: 
"De Koning heeft het opperbestuur der koloniën en bezittingen van het rijk in andere werelddeelen. De reglementen op het beleid der regeering aldaar [in de koloniēn] worden door de wet vastgesteld. Het muntstelsel wordt door de wet geregeld. Andere onderwerpen, deze koloniēn en bezittingen betreffende, worden door de wet geregeld, zoodra de behoeften daaraan blijkt te bestaan".

Artikel 60 luidde: "de Koning doet jaarlijks aan de Staten-Generaal een omstandig verslag geven van het beheer dier koloniën en bezittingen en van den staat waarin zij zich bevinden. De wet regelt de wijze van beheer en verantwoording der koloniale geldmiddelen". In het eerste artikel waren de omstreden woorden "bij uitsluiting" vervallen terwijl Koning én Staten-Generaal werden ingeschakeld om het regeringsbeleid mede te bepalen. Wetgeving en rechtspraak zouden zoveel mogelijk overeenkomstig de in Nederland bestaande wetten, door koloniale verordeningen worden geregeld (art. $138 \mathrm{GW}$ 1848). De algemene mening was dat de Regeringsreglementen als een soort Grondwet dienden te worden beschouwd. Na enige mislukte pogingen trad eindelijk in 1865 artikel 59 tweede lid van de Grondwet 1848 in werking. Artikel 59 lid 2 hield in dat de reglementen op het beleid van de regering bij wet moesten worden vastgesteld. ${ }^{162}$ De ontwikkeling om te komen tot een Regeringsreglement voor de koloniën vast te stellen bij wet, werd ernstig bemoeilijkt, omdat er problemen waren ontstaan over de afschaffing van de slavernij.

\section{Bestuur en rechtspraak}

In Nederland woedde tussen 1822 en 1844 een strijd over de onafhankelijkheid van de rechterlijke macht ten opzichte van de uitvoerende macht. In Frankrijk was in de eerste jaren na de revolutie een regeling getroffen waardoor het evenwicht tussen bestuur en rechtspraak kon worden verstoord. $\mathrm{Zij}$ had via de inlijving bij Frankrijk ook Nederland bereikt. Het bestuur kon een aanhangige zaak aan de rechter onttrekken wanneer het meende dat deze onbevoegd was. De Conseil d'Etat besliste daarna of dit al of niet het geval was. Ofschoon deze regeling kort na de bevrijding van de Franse overheersing werd opgeheven, werd zij in 1822 in Nederland hersteld met de koning als beslissende instantie van het 'conflict van bevoegdheid'.

Van 1822 tot 1844 gold in Nederland dit zogenaamde Conflicten- 
besluit. Als de Gouverneur van een provincie kennis kreeg van een procedure bij de gewone rechter tegen het bestuur, in verband met een handeling of besluit van de administratie, moest hij een conflict opwerpen. Daarmede werd de zaak in beginsel onttrokken aan de rechter. De Koning besliste vervolgens over de bevoegdheid van de rechter. Bij een positieve beslissing behandelde de rechter de zaak verder, bij een negatieve beslissing behandelde de Koning het geschil. Dit was in strijd met artikel 165 Grondwet $1815^{163}$ (nu het meest benaderd door art. 112 lid $2 \mathrm{GW}$ ). In 1844 werd in Nederland onder druk van de publieke opinie het zgn. Conflictenbesluit weer ingetrokken. De regeringsreglementen van 1828 voor Curaçao en onderhorigheden en Sint Eustatius en Saba, die slechts een kort bestaan hebben gekend, kenden een soortgelijke regeling. De Directeur en Commandeur hadden de bevoegdheid, de uitvoering van een vonnis of de loop van een rechtsgeding gedurende zes maanden te schorsen, als zij meenden dat door enig rechtsgeding het belang of de veiligheid van de staat benadeeld zou worden. De schorsing duurde totdat de Gouverneur-Generaal te Paramaribo over de kwestie beslist had. In de regeringsreglementen van 1833 ontbrak een dergelijke bepaling. In art. 47 van het Regeringsreglement van 1848 kwam de bepaling over de bevoegdheid van de rechter in een conflict tussen burger en overheid, terug onder de verdergaande bewoordingen: "Wanneer de regter zich de kennisneming toeëigent van zaken die ter beslissing van het administratief gezag behooren, of by andere zeer gewigtige redenen van staatskundig of algemeen maatschappelyk belang, is de Gouverneur bevoegd den loop van het regtsgeding of de uitvoering van het vonnis te schorsen". Artikel 48 van het reglement meldde: "Alle tusschenkomst in zaken van Justitie, niet bij dit reglement of by de wetten toegestaan, is verboden". De Gouverneur vroeg in een conflictsituatie advies van de Rechtbank en van de Koloniale Raad, maar de eindbeslissing berustte bij de Kroon. Kwam er binnen het jaar geen antwoord uit den Haag dan moest het rechtsgeding of de tenuitvoerlegging van het vonnis worden voortgezet. Het bij de wet vastgestelde Regeringsreglement van 1865 gaf geen ruimte meer aan conflicten van attributie. Artikel 160 lid 2 meldde: "Tusschen- 
komst van de Regering in regtszaken is verboden". ${ }^{164}$ Artikel 41 van de Samenwerkingsregeling Nederlandse Antillen en Aruba, ${ }^{165}$ art. 121 lid 2 van de Staatsregeling van de Nederlandse Antillen en art. VI. 2 lid 2 in de Staatsregeling van Aruba herinneren nog aan deze situatie. ${ }^{166}$ In de Nederlandse Grondwet komt een dergelijk artikel niet voor.

\subsection{Samenvoeging tot één kolonie, de periode 1828-1845 (IV)}

In 1828 zond Koning Willem I Commissaris-Generaal Van den Bosch naar de West om de koloniën te inspecteren, maatregelen te nemen tot haar vooruitgang en het bestuur er over te vereenvoudigen. Van den Bosch werd als de persoonlijke afgezant in de rang van commissaris-generaal van koning Willem I naar de West gestuurd met de opdracht een zo breed mogelijk rapport uit te brengen over de economisch rendabele mogelijkheden van de noodlijdende koloniën. ${ }^{167}$

In 1828 werden met het oog op een optimale economische samenwerking tussen de koloniën en bezuinigingen op de kosten van het bestuur, de drie koloniën verenigd onder een GouverneurGeneraal in Paramaribo. ${ }^{168}$ Het eiland Curaçao en onderhorigheden werd bestuurd door een Gouverneur en vijf aan hem ondergeschikte Gezaghebbers. ${ }^{169}$ Alleen het algemeen Regeringsreglement gold voor deze gehele periode. Daarnaast stelde de Commissaris-Generaal Van den Bosch voor beide Antilliaanse koloniën een Regeringsreglement vast. ${ }^{170}$ Het hoogste uitvoerend gezag in

164 Kunst (1981) pp. 261-267.

163 AB 1985, 28, PB 1985, 88.

166 De Rechtsorde (1986) pp. 75 e.v., 131 e.v.

167 Hartog (1988) pp. 18-19.

164 Van Hulzen (1946) pp. 265

169 Memorie van Toelichting by het wetsontwerp van het Reglement der Regeering in de Nederlandsche West-Indische Bezittingen, in: Goslinga (1956) p. 150. Bedoeld wordt het Regeringsreglement van 1848, alhoewel Goslinga dat niet expliciet vermeldt.

170 Reglement op het beleid van de Regeering, het Justitiewezen, den handel en de scheepvaar op Curaçao en onderhoorige Eilanden, vastgesteld door Van den Bosch bij besluit van 7 Februari 1828, in: Bordewijk (1911) pp. 193-203; zie ook: Instructic voor den Directeur (zonder datum), in: Bordewijk (1911) pp. 204211; zie eveneens: Instructie voor den Raad van Policie (zonder datum), opgenomen in: Bordewijk (1911) pp. 211-214, en Instructie voor het Gemeente Bestuur van Curaçao (zonder datum), in: Bordewijk (1911) pp. 214-223. Daar waar geen datum vermeld staat valt af te leiden uil de literatuur dat de totstandkoming in 1828 heeft plaatsgevonden. Ten slotte is nog van belang: Reglement op het beleid der Regering, het Justitie Weezen, den Handel en de Scheepvaart 
de kolonie Curaçao en onderhorige eilanden kwam in handen van een Directeur ondergeschikt aan de Gouverneur-Generaal. De Directeur werd bijgestaan door een Raad van Politie. Sint Eustatius en Saba werden bestuurd door een Commandeur. Sint Maarten werd afgescheiden van eerstgenoemde eilanden en kreeg ook een Commandeur. Beide Commandeurs stonden onder het gezag van de Gouverneur-Generaal.

Curaçao en Sint Eustatius kregen naast de Raad van Politie in 1828 een Gemeenteraad voor plaatselijke aangelegenheden, bestaande uit een President, twee wethouders en vier raadsleden, die benoemd werden door de Commissaris-Generaal. ${ }^{171} \mathrm{Er}$ bestond een duidelijke taakverdeling tussen de Raad van Politie en de Gemeenteraad. De Raad van Politie zou zich met algemene zaken bezighouden en de Gemeenteraden waren belast met de huishoudelijke aangelegenheden van de ingezetenen. De Gemeenteraden functioneerden nauwelijks, omdat zij in alles afhankelijk waren van de Directeur en de Raad van Politie. Bovendien moest daarna de Gouverneur-Generaal in Paramaribo de goedgekeurde besluiten nog arresteren. De Gemeenteraden verdwenen weer in 1833 toen bij $\mathrm{KB}^{172}$ drie nieuwe Regeringsreglementen werden vastgesteld voor de koloniën Curaçao en onderhorige eilanden, Sint Eustatius en Saba, alsmede het Nederlandse deel van Sint Maarten.

De titels Directeur en Commandeur werden gewijzigd in Gezaghebber. Aan elk van de drie Gezaghebbers werd een Koloniale Raad, in plaats van een Raad van Politie, toegevoegd, die echter slechts een adviserende of voorlichtende taak had. De Koloniale Raad van Curaçao was samengesteld uit de Gouverneur, twee ambtenaren en drie burgers. In 1833 kreeg Sint Maarten een eigen Regeringsreglement. De Koloniale Raad van Sint Maarten

op de Eilanden St. Eustatius en Saba vastgesteld door Van den Bosch bij besluit van 28 Juli 1828, in: Bordewijk (1911) pp. 223-233.

171 Van den Bosch werd in 1827 door de Koning als Commissaris-Generaal naar de West gezonden om verslag te doen over mogelijke verbeleringen in het bestuur van de koloniën. Tevens werd Van den Bosch door de Koning blijkens een instructie ook tot Gouverneur-Generaal van de te verenigen kolonies benoemd; Bordewijk (1911) pp. 40-42.

172

$\mathrm{KB}$ van 20-11-1833, 85, Reglement op het beleid der Regering in de kolonie Curaçao en onderhoorige Eilanden, vastgesteld bij Koninklijk besluit van 20 November 1833, 85, in: Bordewijk (1911) pp. 233-246; Reglement op het belcid der Regeering in de Kolonie St. Eustatius en Saba, vastgesteld bij Koninklijk besluit van 20 November 1833, 85, in: Bordewijk (1911) pp. 246-251. Het Reglement op het beleid der Regering in de Kolonie St. Martin is op gelijke datum vastgesteld en komt overeen met de twee zojuist genoemde reglementen; Bordewijk (1911) p. 252. 
en Sint Eustatius en Saba waren samengesteld uit zes 'der meest notabele ingezetenen'. Het ambtelijk element ontbrak. De bevoegdheden van deze Koloniale Raad waren even gering als die van de Koloniale Raad van Curaçao.

Onder de Raad van Politie (1816-1833) en de oude Koloniale Raad (1833-1865) bestond onder de bevolking weinig belangstelling voor het raadslidmaatschap. De situatie was van dien aard dat er zelfs dwingende bepalingen moesten worden gemaakt voor het aanvaarden van het lidmaatschap. Deze situatie veranderde niet door het instellen van de nieuwe Koloniale Raad in 1865 en de afschaffing van de slavernij. ${ }^{173}$

Het in 1828 vastgestelde Reglement van 'Onzen CommissarisGeneraal' Johannes van den Bosch deed de tijdens de WIC gebruikelijke titel van Directeur herleven, om spoedig door die van Gezaghebber te worden gevolgd. De Raad-Fiscaal kreeg de naam van 'Commissaris van politie belast met het publiek ministerie'. Een nieuw rechtscollege, gevormd uit de Raad van Justitie kwam er nog bij, namelijk het 'Collegie voor kleine zaken'. Het in 1828 vastgestelde Reglement van Van den Bosch werd in 1833 vervangen door een nieuw Reglement. Dit Reglement riep een 'Regtbank van Curaçao' in het leven, bestaande uit een president en zes leden. Hierin gingen zowel de Raad van Justitie als het Collegie voor Commercie- en Zeezaken op. Het oordeelde over alle burgerlijkestraf- en handelszaken. Burgerlijke zaken beneden een bepaald bedrag kwamen voor drie leden van de 'Regtbank', de 'Commissarissen tot de kleine zaken', waarop ze konden beslissen, met de mogelijkheid van reauditie (beroep) door de volle rechtbank.

Als openbaar aanklager bij alle overtreding en misdrijven zou de Procureur des Konings optreden, die tevens hoofd van de rechterlijke en administratieve politie werd. Ook kreeg de Procureur des Konings als oudste lid zitting in de Koloniale Raad, het lichaam waarin de Raad van Politie van het eiland Curaçao toen opging.

Ook de drie Bovenwindse eilanden stonden sinds 1816 onder een Gouverneur. ${ }^{174}$ Hoofd van de rechterlijke en administratieve politie in dit Reglement van 1828 werd de Procureur des Konings, die gegradueerd moest zijn (art 20). Hij was belast met het waarnemen van het recht van de hogere overheid en was tevens zaakwaarnemer van het koloniale bestuur, zo dikwijls deszelfs belangen enige rechterlijke beslissing mochten vorderen (art. 22). De

173 Bordewijk (1911) pp. 40 e.v.; Hartog (1961) pp. 1098-1099.

174 De la Try Ellis (1981) pp. 172-174.

96. De Nederlandse kolonisarie van de West 
rechtspleging werd toevertrouwd aan de 'Regtbank' der Kolonie Curaçao en onderhorige eilanden. ${ }^{175}$ De president moest meester in de 'regten' zijn en de ouderdom van 25 jaren hebben bereikt. Het college werd bijgestaan door een griffier, voor wie geen functie eisen worden genoemd (art. 24).

De 'Regtbank' werd in beginsel bevoegd verklaard tot kennisname van alle civiele en criminele zaken. Zaken van geringe importantie werden berecht door drie leden uit de 'Regtbank', Commissarissen tot kleine zaken genoemd (art. 31). De president kon geen Commissaris zijn (art. 32). Van uitspraken van de Commissie was reauditie mogelijk bij de volle 'Regtbank'. De leden die de zaak in eerste aanleg als Commissaris hadden behandeld mochten de zaak niet in reauditie beoordelen (art. 33). Belangrijk waren de bepalingen die voor het eerst voorschreven, dat civiele vonnissen de beweegredenen of motieven moesten vermelden, waarop zij waren gewezen. Voor criminele vonnissen luidde het voorschrift, dat in het vonnis moest worden uitgedrukt en omschreven de misdaad met vermelding van de rechtsgronden, waarop de uitspraak berustte. Nieuw was ook het voorschrift dat de vonnissen met open deuren moesten worden uitgesproken (artt. $37 \mathrm{t} / \mathrm{m}$ 39).

Suriname werd de hoofdkolonie. De rechtspraak werd in Paramaribo geconcentreerd. Het Gerechtshof aldaar fungeerde als appelrechter voor de lokale rechtscolleges op het eiland Curaçao. ${ }^{176}$ Bij de administratieve vereniging van al de West-Indische bezittingen onder één Gouverneur-Generaal in 1828 werd voor de appellen van Suriname de bestaande situatie gehandhaafd. Bij het Surinaamse Regeringsreglement van 1832 werd in art. 30 het GerechtsHof van Suriname aangewezen als Hof van Appel voor de vonnissen bij de rechtscolleges in de overige West-Indische gewesten, in eerste instantie gewezen. Deze situatie duurde voort nadat de in 1845 de samenvoeging weer ongedaan werd gemaakt en werd bevestigd in het Reglement op het beleid der Regering in de kolonie Curaçao van $1848 .{ }^{17}$

175 Dit was de opvolger van de uit het Regeringsreglement van 1815 stammende Raad van Civiele en Criminele Justitie; zie ook Sjiem Fat (1986) noot 26, p. 275.

176 Bordewijk (1911) p. 43.

17 In die tijd was mr. A.M. de Rouville, Procureur des Konings, hij werd op 16 december 1856 benoemd, hij kritiseerde de appelregeling en de lekenrechtspraak en rapporteende aan de Gouvemeur over de naar zijn mening zorgelijke toestand van de rechtsbedeling in de kolonie. Er waren in die tijd rechtbanken op 
Hiermede kwam een eind aan de sedert 1816 bestaande rechtsmacht van het Hoog Gerechtshof te 's-Gravenhage in zaken in de huidige Nederlandse Antillen en Aruba. Voor Curaçao en onderhorigheden vond dit zijn uitwerking in art. 34 van het (Curaçaosch) Regeringsreglement van 1833, dat bepaalde dat van alle bij de volle 'Regtbank' in eerste instantie gewezen definitieve vonnissen in civiele zaken appel zou openstaan op het Gerechtshof in Suriname. Dit werd Koloniaal Appèl genoemd.

Hetzelfde werd voor Sint Eustatius, Sint Maarten en Saba geregeld in art. 27 van het Regeringsreglement voor deze eilanden van 1833, met betrekking tot de door de Raad van Justitie gewezen definitieve vonnissen in civiele zaken. Deze bepalingen traden in werking bij de inwerkingtreding (in 1833) van art. 30 van het Surinaams Regeringsreglement van 1832. Na de instelling van de Nederlandse Hooge Raad in $1838^{178}$ werd het hoger beroep van vonnissen in burgerlijke zaken door het Gerechtshof in Suriname in eerste aanleg gewezen, geregeld bij $\mathrm{KB} .{ }^{179} \mathrm{Bij}$ dit $\mathrm{KB}$ werd een uitvoerig, door de Hoge Raad ontworpen Reglement vastgesteld, waarin de termijnen en de te volgen procesgang in detail werden vastgelegd.

Hoger beroep was alleen toegelaten in zaken die een belang hadden van meer dan $f 100,-$. Daar het hier ging om door het Gerechtshof in Suriname in eerste aanleg gewezen vonnissen, was dit beroep op Curaçao en onderhorigheden en in de Bovenwinden niet van toepassing.

Hoger beroep in strafzaken van vonnissen in eerste aanleg gewezen door het Gerechtshof in Suriname werd niet geregeld. Voor het appel in strafzaken gold dan ook dat tot 1833, toen de Regeringsreglementen van 1833 voor Suriname en voor de Neder-

Curaçao, St. Martin en St. Eustatius; Aruba kende een vredegerecht. Alleen voor de Curaçaose rechtbank gold nog enig vereiste van juridische gegradueerdheid. De Rouville meende dat de vrijheid, zelfstandigheid en onafhankelijkheid van de rechterlijke macht in het gedrang zou komen als de magistraten voortkwamen uit de planters of kooplieden. Hij stelde dan ook een verbetering voor van de rechterlijke organisatie en deed daartoe voorstellen in afwachting van een definitieve regeling bij wet, KB of koloniale verordening. Veel van zijn aanbevelingen werden in het Regeringsreglement van 1865 overgenomen. De verwachte nieuwe burgerlijke wetgeving werd in Nederland opgesteld door een Staatscommissie en een lid van die Commissie moest ter plaatse de met een in de koloniën ingestelde commissie de wetgeving aan de locale omstandigheden aanpassen. De Rouville makte eveneens deel uit van de plaatselijke commissie op Curaçao, zijn opvattingen over de inrichting van de rechterlijke macht zijn daar duidelijk in terug te vinden, Fliek (1969) pp. 8-12.

$179 \quad 11$ januari 1840 , Sib. 1. 
landse Antillen en Aruba in werking traden, de regeling van het $K B$ van 14 mei 1816, dat wil zeggen appel op het Hoog Gerechtshof, Den Haag, van kracht bleef.

Bij art. 1 van het betreffende $\mathrm{KB},{ }^{180}$ werd het appel van de vonnissen in criminele zaken in Suriname, in Curaçao, Sint Eustatius en Sint Maarten gewezen beperkt tot die zaken, welke naar oud-Hollandse strafrechtspleging ordinario modo waren berecht. Daarmede stond in verband de Publicatie van 30 oktober 1837, houdende afkondiging in de kolonie Suriname van het Reglement van 10 oktober 1798 , waarbij werd vastgesteld de manier van procederen tegen zodanige personen, die tot geen confessie der misdaad, hun door de publieke aanklager ten laste gelegd, hadden kunnen worden gebracht.

Weliswaar kon krachtens het Reglement van 1798 ook in extra-ordinarisprocedure op convictie gevonnist worden, maar deze arresten waren niet appellabel. Dit appel bleef volgens Surinaams recht voortbestaan tot 1856 . Toen werd bij $\mathrm{KB}^{181}$ bepaald dat het Gerechtshof aldaar in alle strafzaken bij arrest recht zou spreken. Naar Nederlands recht was het appel reeds eerder vervallen, of had het althans praktisch alle werking verloren, omdat art. 91 van de wet op de Rechterlijke Organisatie van 1838 alleen van hoger beroep in burgerlijke zaken sprak. In Nederland was dus geen rechter aangewezen, die bevoegd was om van hoger beroep in strafzaken kennis te nemen. Het appel van in Curaçao gewezen strafvonnissen was, tegelijk met dat van uitspraken in burgerlijke zaken, bij het Gerechtshof in Suriname gebracht (art. 30 Regeringsreglement Suriname). Dit werd nader geregeld in de artt. 35 en 38 van de Regeringsreglementen van 1833 voor Curaçao en onderhorigheden en voor Sint Eustatius, Saba en voor Sint Maarten. In het Regeringsreglement van 1833 kwam de bepaling uit het Reglement van Van den Bosch (art. 28), die aan de Directeur de bevoegdheid gaf de uitvoering van een vonnis of de loop van een rechtsgeding gedurende zes maanden te schorsen, niet meer voor.

Behoudens enige kleine wijzigingen heeft deze regeling bestaan tot de invoering van de nieuwe wetgeving op 1 mei $1869 .{ }^{182} \mathrm{Bij}$ de beraadslagingen in de Tweede Kamer op 14 november 1900 over aanpassingen van het Regeringsreglement van 1865 met betrekking tot het rechtswezen merkte de geachte

$K B$ van 6 maart 1824,125 .

$\mathrm{KB}$ van 12 mei 1856,25 , GBS 6 .

Stb. 1869,36 , PB 1869, 9 . 
"Het mag wel eens onverbloemd gezegd worden, dat [....] de rechters niet eens de landstaal kennen en zich met tolken moeten behelpen, dat de justitie slecht is en de meeste rechters elke kennis der rechtswetenschap missen, en dus èn de bestuurs- èn de rechterlijke ambtenaren veel te wenschen overlaten. "183

De rechtbanken van Curaçao, Sint Maarten en Sint Eustatius spraken voor een deel met assessoren recht. Dit betekende een vorm van jury-rechtspraak. De Procureur des Konings mr. A.M. de Rouville verzuchtte in een rapport van 1856 aan de Gouverneur:

"Wat beteekent die ééne stem van den voorzitter op een jurij van niet geregistreerden, in een land waar volgens de leer des staatregts, geen jurij te pas kan komen. "184

Ook in 1843 werd de vraag al gesteld 'of de eilandjes St. Eustatius en St. Martin bij eene scheiding [van Suriname] onder het oppertoezigt van Curaçao dan wel in onmiddellijke betrekking tot het Moederland geplaatst zouden behooren te worden'. ${ }^{185} \mathrm{De}$ samenvoeging van de koloniën leidde niet tot 'opbeuring van Curaçao'. Alle pogingen om van Curaçao een produktieve kolonie te maken waren op niets uitgelopen. De verwachte bezuinigingen van de samenvoeging waren eveneens uitgebleven.

Bij $\mathrm{KB}^{186} \mathrm{kwam}$ er een einde aan de administratieve vereniging met Suriname. Tevens werden voor de eerste maal alle eilanden die thans de Nederlandse Antillen en Aruba vormen, onder één bestuur gebracht. In 1845 werd namelijk bepaald dat het bestuur van de kolonie Curaçao en onderhorigheden zich behalve tot Bonaire en Aruba, ook zou uitstrekken tot de eilanden Sint Eustatius, Saba en Sint Maarten. Bij KB werd het Reglement op het beleid van de Regering in de kolonie Curaçao en onderhorigheden

\footnotetext{
$1 * 3$ Bordewijk (19/4) pp. 599 en 304.

i4 Fliek (1969) pp. 8 e.v.

Is Bordewijk (1911) p. 51 .

I* KB 9 april 1845,8 .
} 
vastgesteld. ${ }^{187} \mathrm{Er}$ kwam dus voor het eerst een Regeringsreglement voor alle eilanden. De eilanden kwamen te staan onder het gezag van énn 'Gouverneur van Curaçao en Onderhorigheden', als vertegenwoordiger van de Kroon. Hij oefende het bestuur uit met een Koloniale Raad als adviserend lichaam. De leden van deze Raad (twee ambtelijke en vier niet ambtelijke leden) werden door de Koning benoemd.

De meerderheid van de Raad bestond uit burgers en niet meer uit ambtenaren. De Raadsleden bleven echter onbezoldigd hun functie uitoefenen. De andere eilanden werden als 'Onderhoorigheden' onder het oppergezag van de Gouverneur door een Gezaghebber bestuurd. Aan de Gezaghebber werd een Adviesraad (Raad van Politie) toegevoegd van twee ingezetenen benoemd door de Gouverneur. Het Regeringsreglement van 1848 gaf de hoogste gezagdrager van de zes eilanden de titel van Gouverneur en deze titel is sindsdien gebruikt. Sinds 1848 werd de Commandeur Gezaghebber genoemd. Artikel 47 gaf aan dat de Gouverneur de loop van een rechtsgeding of de uitvoering van een vonnis kon schorsen, terwijl art. 48 aangaf dat alle tussenkomst in rechtszaken verboden was. ${ }^{188}$ Waar in Nederland de conflicten van attributie waren opgelost door intrekking in 1844 van het onwettige $\mathrm{KB}$ van 5 oktober 1822 (het Conflictenbesluit), werd het voor het Curaçaos bestuur gehandhaafd. ${ }^{189}$

$\mathrm{Na}$ de scheiding van Suriname en Curaçao bleef het Ge-

Reglement op het beleid der Regering in de Kolonie Curaçao en onderhoorigheden, vastgesteld bij Koninklijk besluit van 27 Januari 1848, 51, in: Bordewijk (1911) pp. 253-263. Dit voor de ontwikkeling van het staatsrecht onbelangrijk reglement werd door de Grondwet van 1848 provisioneel gehandhaafd. Het werd op 1 januari 1866 door de inwerkingtreding van de wet houdende vaststelling van het Reglement op het beleid der Regeering in de kolonie Curaçao vervangen. Bordewijk was van mening dat bij het Regeringsreglement van 1865 pas de nieuwe rechtsonde werd ingevoend. Bordewijk (1911) p. 71, Da Costa Gomez in: Jeserun e.a. pp. 296-345.

Bordewijk (1911) pp. 1-70; Gedenkboek (1934), pp. 9-105; Sjiem Fal (1986) p. 17. Uit de literatuur blijkt dat de hoogste gezagdrager in de West-Indische koloniën ten tijde van de WIC, Directeur heette. Tijdens de eerste Engelse iijd (1800-1803) werd de functionaris Gouverneur genoemd. Dit was ook het geval tijdens het daaropvolgend Nederlands bewind (1803-1806) en in de tweede Engelse tijd (1807-1816). Na de restauratie van 1816 bestond er tussen 18161820 een Gouverneur-Generaal, van 1820-1828 een Gouverneur, van 1828-1833 een Directeur, van 1833-1848 een Gezaghebber, sedert 1848 Gouverneur genoemd. Sedert 1848 heten de hoogste 'eiland'-functionarissen, de Commandeurs: Gezaghebber, Tot 1920 werd de Gezaghebber door de Kroon benoemd, van 1920 tot 1951 door de Gouverneur, daama weer door de Kroon. Encyclopedie (1985) pp. 206-209; zie cok Hartog (1961) pp. 144-147. 
rechtshof te Paramaribo als hoger beroepsinstantie voor de kolonie Curaçao voortbestaan. Pas bij het Regeringsreglement van 1865 veranderde dit. Toen werd volgens art. 150 van het Regeringsreglement van 1865 , als opperste rechtscollege in de kolonie het Hof van Justitie in Curaçao aangewezen. Op grond van art. 149 van dit Reglement werd de rechtsmacht van de Hoge Raad in Curaçaose zaken geregeld bij wet. De wet ${ }^{190}$ tot voorlopige regeling van de rechtsmacht van de Hoge Raad in West-Indische koloniale zaken, opende hoger beroep vanuit de kolonie Curaçao van vonnissen in eerste aanleg gewezen door het Hof van Justitie, op de Hoge Raad. Hiermede werd de werking van de wet van 1840, die gold voor het Hof te Suriname, uitgebreid tot het Hof van Justitie te Willemstad. ${ }^{191}$

Invloed van de bevolking in het bestuur in Curaçao

Nadat in de Antillen alle eilanden in 1845 tot één kolonie waren verenigd, was het op grond van economische motieven dat de Nederlandse regering een centrale regering voor de Antillen ontwierp. Wat bij bestudering van de Regeringsreglementen van 1848 en 1865 opvalt, is dat de kolonie zo goed als geen autonomie bezat. In alle zaken van enig belang had de Gouverneur dan wel de Koning het laatste woord.

Als Nederlandse koloniën zijn de veranderingen in de organisatie van het bestuur van de koloniën niet los te zien van de Nederlandse Grondwet. Het Regeringsreglement dat in 1865 werd ingevoerd, is te beschouwen als een uitvloeisel van de Nederlandse Grondwetsherziening in liberale zin, die in 1848 plaats vond. Deze wijziging die voorgoed een einde maakte aan het absolutisme van de Vorst, schreef voor, dat de vaststelling van Regeringsreglementen voor de koloniën diende te geschieden door tussenkomst van het wetgevend orgaan, de Staten-Generaal. De vaststelling van de Regeringsreglementen zou niet langer bij KB maar bij wet geschieden. De Raden van Politie deden voor het eerst hun intrede op Aruba en Bonaire op grond van het Regeringsreglement van $1865 .^{192}$

Minister De Waal kon dan ook met enig recht verklaren, dat het Regeringsreglement van 1865 de kolonie volstrekt niet zelf-

\footnotetext{
190 Wet van 4 april 1869 , Stb. 36, PB $1869,9$.

191 Van der Hansz (1984) pp. 6-69.

192 Römer-Kenepa (1983) p. 6.
} 
standig had gemaakt, maar dat het reglement enkel bedoeld was als een opleiding tot autonomie. ${ }^{193}$ Dat er een zekere mate van decentralisatie toen reeds noodzakelijk werd geacht, blijkt uit de vrij uitgewerkte bepalingen, die in 1865 werden opgenomen in het Regeringsreglement. De verschillende eilanden, behalve Curaçao, werden elk afzonderlijk of groepsgewijs bestuurd door Gezaghebbers bijgestaan door twee landraden.

De samenstelling van de Raden van Politie was nieuw. De Landraden werden door de stemgerechtigden gekozen voor een periode van vier jaar, volgens een beperkt census- en capaciteitskiesrecht. Voor het eerst was er sprake van een vorm van kiesrecht in de kolonie. Curaçao kreeg in 1865 géén kiesrecht voor de samenstelling van de Koloniale Raad. De Landraden vormden samen met de Gezaghebber de Raad van Politie, die wegens alle zaken, het eiland betreffende, van bericht en raad zou dienen, schouw zou drijven over wegen en andere openbare werken, alsmede toezicht zou houden op het onderwijs.

Deze Raden hadden voorts de bevoegdheid plaatselijke keuren vast te stellen over alle onderwerpen, die de huishouding van het eiland betroffen. Zij stelden daartoe regels in het belang van de openbare orde, de zedelijkheid en gezondheid. Voor de inwerkingtreding van deze regelingen was echter preventieve goedkeuring van de Gouverneur vereist. Curaçao werd van deze bestuursvorm uitdrukkelijk uitgezonderd.

Omdat het centrale gezag in Willemstad zetelde werd een speciale constructie voor Curaçao gevolgd in art. 135 van het Regeringsreglement van 1865. Dit artikel droeg het maken van plaatselijke keuren voor Curaçao op aan de Koloniale Raad en dus aan een centraal orgaan. Aangezien de eilanden geen eigen budgetrecht hadden, doch ressorteerden onder én centrale begroting, was er eigenlijk alleen maar sprake van een ambtelijke decentralisatie. Pas de wijziging van de Grondwet van 1922 gaf wat meer ruimte voor bestuur in eigen aangelegenheden in de koloniën. Wel was de wetgever er inmiddels toe overgegaan de ingezetenen meer bij het bestuur te betrekken, doch deze beslissing was aan de Koning alleen. Wat hij gegeven had, kon hij, indien hem dat politiek wenselijk en mogelijk voorkwam, uit de volheid van zijn macht weer terugnemen. ${ }^{194}$ Bordewijk ${ }^{195}$ was van mening dat vanwege de onbekendheid van minister Fransen van de Putte met

193

194

195

Sjiem Fat (1986) p. 19.

Oud (1967) p. 12.

Bordewijk (1911) pp. 136, 137.

Invloed van de bevolking in het bestuur in Curaçao .103 
de kolonie Curaçao, de kolonie Suriname alle aandacht kreeg van het parlement. Daardoor zou het Regeringsreglement van 1865 voor Curaçao ook zo weinig inhoud geven aan invloed van de bevolking in het bestuur van de kolonie. Het zou tot 1936 duren voordat in de praktijk een begin werd gemaakt met enige invloed van de bevolking in de Antilliaanse regering.

In Amerika en Europa werden verschillende grondrechten in de loop van de 18de eeuw in de constitutie van ondermeer Nederland opgenomen. Deze grondrechten werden in de praktijk echter niet van toepassing geacht op de gekleurde en zwarte bevolkingen van de Europese koloniën. De slaaf of vrije zwarte werd in die dagen nauwelijks als een vertegenwoordiger van het menselijk ras gezien. Die lage waardering viel ook de kleurlingen ten deel. Daar de slaaf meestal een zwarte huidskleur had en het zwarte ras als minderwaardig werd gezien aan het blanke ras, werden kleurverschillen ook geassocieerd met klasseverschillen. De koloniale maatschappij leek in alle opzichten op een feodale maatschappij. Daar de blanke bestuurder de gekleurde en zwarte burger niet in staat achtte zichzelf te besturen, heeft het ook veel langer geduurd voordat in de kolonie het parlementaire stelsel werd ingevoerd. In het moederland werden de burgerrechten honderd jaar eerder toegekend dan in de kolonie.

\section{Samenvatting en conclusie}

De beide West-Indische Compagnieen, die het bestuur uitoefenden over de koloniēn waren privaatrechtelijke organen met publiekrechtelijke bevoegdheden. Feitelijk beperkte taak van de Compagnie zich tot het vervullen van een deel van de staatstaak, een deel dat door de regering der republiek, ten gevolge van het ontbreken van een behoorlijk georganiseerd centraal gezag, trouwens bezwaarlijk had kunnen worden waargenomen. Handelsbelangen en bestuur waren moeilijk te combineren, deugdelijk bestuur liet ook in die tijd te wensen over.

De beide handelscompagnieën dreven handel en voerden oorlog op eigen risico en bestuurden de kolonie. Een van de belangrijkste bezigheden van de WIC was de slavenhandel. $\mathrm{Cu}$ raçao vormde een doorvoerhaven en stapelplaats voor slaven. Het bestuur werd uitgeoefend op grond van algemene regelgeving, vastgesteld voor de nieuw te veroveren gebieden door de StatenGeneraal van de Republiek der Zeven Verenigde Nederlanden. 
De kolonie stond onder het gezag van een Directeur bijgestaan door een Raad van Politie waarin ambtenaren en enkele aanzienlijke burgers zitting hadden. Als meest gebruikelijke titels voor de gezagsdragers golden voor het hoofdeiland 'Directeur' of 'Gouverneur' en voor de overige eilanden 'Commandeur'. De Directeur of de Commandeur was in de betreffende kolonie voorzitter van de 'Raad van Policie', het lichaam dat hem bijstond in de uitoefening van het bestuur van de kolonie. Helemaal aan het begin van de kolonisatie, in de periode van de kaapvaart, bestond de Raad van Politie van Curaçao uit de Directeur en enkele militairen, aangevuld met eventuele aanwezige schippers van de Compagnieschepen, het getal van zeven leden niet overschrijdend. In een later stadium van de kolonisatie liep het ledental op tot negen personen en werden naast militaire ook civiele dienaren van de Compagnie benoemd, waaraan nog een kleine minderheid van twee of drie leden uit de burgerij werd toegevoegd.

De Raad hield zich niet alleen bezig met besturen, maar ook met rechtspraak in civiele en strafzaken. Dit duurde in theorie van 1634 tot 1815 maar veranderde pas in de praktijk bij de invoering van de codificatie in 1869. Er was geen sprake van scheiding van machten, de rechtspraak kon in die tijd niet onafhankelijk worden genoemd. Vanaf hun kolonisatie waren de eilanden bestuurlijk ondergebracht in een aparte 'Bovenwindse' en 'Benedenwindse' kolonie.

Ook ten tijde van het bestuur van de koloniēn door de WestIndische Compagnieēn kan al gesproken worden van een staatsrechtelijke ontwikkeling, ook al voldeed de gezagsstructuur uiteraard niet aan de eisen die thans gesteld worden aan bestuur, wetgeving en rechtspraak. De basis van de parlementaire rechtsstaat zoals wij die thans in Europa en in de Nederlandse Antillen en Aruba kennen, werd pas in de 19de eeuw in Europa gelegd en zou voor de koloniën pas in 1936 schoorvoetend worden ingevoerd.

De WIC werd eind 1791 opgeheven. In 1792 kwamen de koloniën onder direct bestuur van de Staten-Generaal. De taken van de WIC werden daarna door verschillende collegiale lichamen overgenomen van 1792 tot 1806. Na de opheffing van de WIC werd de Raad van Politie in iets gewijzigde vorm gehandhaafd tot 1833. Met name werden de bestuurlijke en de juridische zaken gescheiden en aan twee afzonderlijke colleges toevertrouwd. Zuiver bestuurlijke taken kwamen te berusten bij de Raad van Politie en de rechtsspraak kwam in handen van een nieuwe in het 
leven geroepen Raad van Civiele en Criminele Justitie.

In de hier besproken koloniale periode 1792-1815 (II) stond het moederland onder Franse invloed. De Franse revolutie had geen invloed op de toekenning van burgerrechten aan de oorspronkelijke bevolking in de kolonie. Ook was er geen sprake van een scheiding van machten. De Franse invloed in Nederland was van belang tijdens de Bataafse Republiek (1795-1806). Die invloed nam verder toe toen Nederland het Koninkrijk Holland werd onder Koning Lodewijk Napoleon (1806-1810). Nederland werd bij Frankrijk ingelijfd van 1810 tot 1813 . In die tijd vielen de koloniën direct onder het Franse gezag.

In de periode 1816-1828 (III) waren er drie West-Indische koloniēn: Suriname, Curaçao en onderhorigheden en Sint Eustatius en onderhorigheden, elk met een eigen Regeringsreglement. De vorst oefende het opperbestuur uit over de koloniën en vaardigde tevens de wetgeving uit voor de kolonie. Hij werd vertegenwoordigd door een Gouverneur, die namens hem de kolonie bestuurde. De andere eilanden werden bestuurd door Gezaghebbers die ondergeschikt waren aan de Gouverneur. Zowel de Gouverneur als elke Gezaghebber werd bijgestaan door een Raad van Politie.

$\mathrm{Om}$ te komen tot een hogere opbrengst van produkten uit de koloniën en de kosten te verminderen werden Suriname, de Bovenwindse- en Benedenwindse kolonie samengevoegd tot én kolonie. Dit duurde van 1828 tot 1845 (periode IV). Op Curaçao werd de Raad van Politie in 1833 omgedoopt tot Koloniale Raad. Ook werden er voor korte tijd gemeenten op Curaçao en Sint Eustatius ingevoerd. Inhoudelijk veranderde er niet veel aan het bestuur. De kolonie bezat nauwelijks bevoegdheid om eigen zaken te regelen. Of de Gouverneur of de Koning hadden het laatste woord. Vanaf 1845 tot 1936 vervulde de Koloniale Raad een dubbele funktie, te weten vertegenwoordiging van zowel het eiland Curaçao als van alle zes eilanden tezamen.

Toen de schaalvergroting slechts bleek te leiden tot nog hogere bestuurskosten werd de samenvoeging van de koloniën in 1845 weer opgeheven. In $1845 \mathrm{kreeg}$ het bestuur een duidelijk gecentraliseerd karakter. De Bovenwindse en Benedenwindse eilanden die nooit eerder als één kolonie waren beschouwd, werden voor het eerst verenigd onder één koloniaal bestuur, gevestigd in Willemstad.

De periode 1845-1865 (V) wordt onderscheiden, omdat in 1865 
het Regeringsreglement bij wet werd ingevoerd, waardoor de macht van de Koning werd ingeperkt en de Staten-Generaal meer invloed kregen in wetgeving en bestuur van de koloniën. Dit geschiedde onder invloed van de veranderde verhouding tussen Koning en parlement in Nederland. In 1848 werd de politieke ministeriële verantwoordelijkheid ingevoerd. Voor de kolonie had dat geen gevolgen. De ministeriële verantwoordelijkheid zou pas bij de Curaçaosche Staatsregeling van 1948 worden ingevoerd. In 1848 werd in de Grondwet bepaald dat de koloniën een Regeringsreglement bij wet zouden moeten krijgen en dat de Koning zich niet langer als alleenheerser in de koloniën zou mogen opstellen. Ook de uitspraak van de HR in het Meerenberg arrest van 1879 versterkte de macht van de Staten-Generaal ten opzichte van de Koning.

De persoonlijke bemoeienissen van de vorst die de koloniën bestuurde verminderde toen het constitutionele koningschap in Nederland tot ontwikkeling kwam onder invloed van de Verlichting. In 1848 werd in Nederland de ministeriēle verantwoordelijkheid ingevoerd. De uitwerking daarvan, de vaststelling en invoering van het eerste Regeringsreglement voor de West-Indische koloniën bij wet zou duren tot 1865 , wegens de economische en staatkundige problemen die Nederland ondervond met de afschaffing van de slavernij in de koloniën.

In de kolonie werd in hoofdzaak recht gesproken volgens oudVaderlands recht. Plaatselijke wetgeving speelde een ondergeschikte rol. De rechtspraak in Curaçao ten tijde van het bewind van de WIC ontwikkelde zich uit de rechtsbedeling zoals die aan boord van de schepen plaats vond. De officieren op de schepen behandelden civiele en criminele zaken. Dit gebeurde vervolgens door de Raad van Politie die civiele en strafzaken behandelde. Bestuur en rechtspraak werden door hetzelfde college uitgeoefend. Rechtspraak en bestuur waren niet gescheiden.

Daar in de koloniale periode het parlementaire systeem nog niet bestond was er geen sprake van een algemeen kiesrecht, gekozen volksvertegenwoordigers en gelijke rechten voor alle burgers. De Verlichting in Europa leidde tot een nieuwe basis voor het staatsrechtelijk gezag en de gedachte dat de bevolking invloed zou moeten hebben in het bestuur. De Verlichting bracht immers het axioma van de monselijke gelijkheid. Uit dit beginsel vloeide de gedachte voort, dat geen individu meer staatkundige rechten mocht bezitten dan een ander. Hiermede was tevens de basis 
gelegd voor de grondrechten, die inhielden dat de staat een aantal rechten ten opzichte van de (blanke) burger moest garanderen. ${ }^{196}$

De Staatsregeling van 1798 bracht de koloniēn direct onder bet gezag van de Republiek. Alhoewel de octrooien van de Compagnie niet meer golden, werd het staatsgezag uitgeoefend op dezelfde manier als voorheen door de Compagnieēn. De verschillende opvolgende Grondwetten van 1814, 1815 en 1840 lieten de soevereiniteit van Nederland op de koloniën onbeperkt gelden. ${ }^{197}$ Ook na de strijd om de oppermacht in de koloniën tussen de Koning en de volksvertegenwoordiging, die ten gunste van de Staten-Generaal werd beslist in 1848 , bleven de machtsverhoudingen als voorheen, maar dan zonder tussenschakel van de WIC.

In het Regeringsreglement van 1865 werd vastgesteld dat de Koloniale Raad, als centraal orgaan voortaan ook de plaatselijke wetgeving voor het eiland Curaçao zou regelen. De leden van de Koloniale Raad werden benoemd door de Koning en niet gekozen. De andere eilanden werden ieder bestuurd door een Gezaghebber met een Raad van Politie, bestaande uit twee Landraden, die uit de burgerij werden gekozen. Een eerste stap op weg naar een staatkundige ontwikkeling van de kolonie zou de instelling zijn van een wetgevende raad naast de Gouverneur, die niet alleen uit hoofdambtenaren bestond, maar ook enige ingezetenen onder zijn leden zou tellen. Dit zou pas in 1865 plaatsvinden.

Concluderend kan gesteld worden dat de invloed van het Nederlands bestuur op het bestuur van de kolonie zeer groot was. Blanke ambtenaren veelal uit het moederland afkomstig bestuurden onder raadpleging van gegoede, blanke kooplieden de kolonie, volgens aanwijzingen van de Directeur/Gouverneur en later de Koning. Het handelsbelang stond voorop. De WIC was immers een privaatrechtelijke onderneming met publiekrechtelijke bevoegdheden.

Kleur speelde een belangrijke rol in de koloniale samenleving. De blanke huidskleur boezemde het meeste gezag in. Kleurlingen en zwarten oefenden geen overheidsfuncties uit.

In de periode 1634-1864 was er alleen op de Bovenwinden enige invloed van de gegoede blanke burgerij op het bestuur, omdat de Bovenwinden oorspronkelijk patroonskolonies waren. Er was geen

$1 \%$ De Monté ver Loren en Spruit (1982) p. 254.

197 Grondwet 1814, art. 36; Grondwet 1815, art. 60; Grondwet 1840, art. 59. 
sprake van scheiding van wetgeving, bestuur en rechtspraak. Tijdens de periode van de beide WIC was het handelsbelang overheersend. Vanaf 1816 was het economisch belang van het moederland doorslaggevend. De mensenrechten en de rechtsbescherming van de burger zoals wij die thans kennen, speelden geen rol van betekenis. De gekleurde en zwarte bevolking verkeerde niet in dezelfde positie als de blanke inwoners van de kolonie. De verhouding burger-bestuur, zoals wij die thans kennen in de democratische rechtsstaat bestond niet. De bevolking had nauwelijks invloed in het bestuur en geen invloed van betekenis op het overheidshandelen.

Bij het Regeringsreglement van 1865 werd een nieuwe samenstelling van de Raden van Politie ingevoerd. De Landraden werden door de stemgerechtigden gekozen voor een periode van vier jaar, volgens een beperkt census- en capaciteitskiesrecht. Voor het eerst was er sprake van een vorm van kiesrecht in de kolonie. Curaçao kreeg in 1865 géén kiesrecht voor de samenstelling van de Koloniale Raad.

Er bestond in de besproken tijdvakken geen scheiding van machten. Wetgeving, bestuur en rechtspraak werden door dezelfde organen uitgevoerd. De opbouw van de staatsorganen verschilde zowel naar vorm en inhoud van de huidige situatie. De binding van de staat aan het recht was arbitrair. In de rechtspraak werd een veelheid aan systemen gehanteerd. Niet altijd was duidelijk welk systeem moest worden toegepast en de kennis van het recht bij de rechtsprekende instanties liet te wensen over. Temeer daar de Raadsleden die ook recht spraken, daarvoor niet opgeleid waren en vaak gedwongen moesten worden het veeleisende en onbetaalde werk van een Raadslid uit te voeren.

Het moderne probleem van het zoeken naar het juiste evenwicht tussen ordening van de samenleving en individuele vrijheid was nog lang niet aan de orde, daar grote delen van de bevolking in Europa in lijfeigenschap verkeerde en in de Nieuwe Wereld de slavernij een belangrijke rol speelde. 


\section{De slavernij in de Nederlandse koloniën}

Omdat de slavernij moeilijk valt in te delen in de tijdscategorieën, zoals aangegeven in hoofdstuk I, wordt de slavernij in een apart hoofdstuk behandeld. De oorzaken en gevolgen van de slavernij in een koloniale samenleving worden uiteengezet. De slavernij in de latere Nederlandse Antillen was minder afschrikwekkend dan in koloniēn met een plantage-economie zoals Suriname, maar heeft desondanks grote invloed gehad op de bestuursstructuur in de kolonie. De sterke segmentatie in de kolon e matschappij, mede onder invloed van de slavernij heeft de maatsch ppelijke en politieke verhoudingen tot op de dag van vandaag in sterke mate beinnvloed. Het onderscheid in rassen en klassen bepaalt tot op de huidige dag de Antilliaanse en Arubaanse samenleving, ook al zijn de scherpe kanten van de rassentegenstellingen verzacht. Voor een goed begrip van de invloed van de slavernij op de vroegere koloniale samenleving en de gevolgen daarvan, zal thans ingegaan worden op het ontstaan van de slavernij, de behandeling van de slaven en de gevolgen daarvan voor de bestaande samenleving. Eveneens zal aandacht worden besteed aan de invloed van de Verlichting en de Franse Revolutie op het ontstaan van de gedachte van vrijheid, gelijkheid en broederschap. Die vrijheid, gelijkheid en broederschap gold wel voor de burgers van het moederland, maar was blijkbaar niet van toepassing op de slaven in de koloniën.

\section{De slavernij}

Slavernij deed reeds kort na de ontdekking van Amerika zijn intrede in het Caraibisch gebied. Pater Bartolomé de Las Casas werd in 1474 geboren als zoon van een edelman. In 1511 werd hij in Santo Domingo tot priester gewijd. De Las Casas bracht het Spaanse Hof in beroering met zijn vurige aanvallen tegen de wreedheid van de veroveraars van Zuid-Amerika. ${ }^{1}$ Door zijn toedoen werden in 1542 de Nieuwe Wetten (Las Nuevas Leyes de las Indias) afgekondigd,

Bartolomé de Las Casas (1969) p. 29. 
die het encomienda systeem ${ }^{2}$ voor Indianen verboden. Deze wetten stuitten onmiddellijk op verbitterde tegenstand van de Spaanse koloniēn in Amerika. De ondernemers verklaarden onomwonden, dat zij op slavenarbeid waren aangewezen. De handel kon alleen tot bloei komen als er gebruik werd gemaakt van slavenarbeid. ${ }^{3}$ De wetten werden niet uitgevoerd. In 1557 antwoordde een lid van de Koninklijke Raad De Las Casas dat de Indianen te laag op de menselijk ladder stonden om het ware geloof te kunnen ontvangen. De Las Casas stelde dat de Spanjaarden in de veertig jaar na de ontdekking van Hispaniola in 1492, meer dan twaalf miljoen Indianen vermoorden, levend verbranden, geroosterd te eten gaven aan hongerende Indiaanse slaven, voor de honden gooiden, als lastdieren gebruikten en in slavernij voerden, om in de goud- en zilvermijnen te werken. ${ }^{4}$ Volgens moderne onderzoekingen zou de 'conquista' alleen al in Mexico negentien miljoen slachtoffers hebben geëist. De Las Casas noemde er vier miljoen; men kan concluderen dat De Las Casas met zijn schattingen aan de voorzichtige kant was.

Nadat een theologische commissie in Spanje, op aandringen van De Las Casas had besloten dat Indianen een ziel hadden en daarom niet in slavernij mochten worden gebracht, werden zwarte slaven uit Afrika aangevoerd. De Republiek en de WIC speelden een belangrijke rol in de slavenhandel. Hierbij moet worden opgemerkt dat lijfeigenschap en slavernij in de 16de eeuw in de West-Afrikaanse rijken een normale levenswijze voor bijna iedere neger was. Door de ontwikkeling van de Europese slavenhandel gingen de gezagdragende leden van de gemeenschap hun onderdanen en krijgsgevangenen niet meer alleen als een klasse zien, maar vooral als een waardeobject. Tegenwoordig gaat men ervan uit dat het totaal aantal slaven dat van de Afrikaanse Westkust naar Amerika verscheept werd rond de 10 miljoen ligt. ${ }^{5}$

2 De veroveraars en de kolonisators kregen in de Spaanse koloniēn Indianen 'toegewezen' (=encomienda) met het doel hen de christelijke leer te onderwijzen. Maar omdat de Indianen de 'encomendoro', persoonlijke diensten en belastingen, verschuldigd waren, bleef er niet veel tijd over om hen op de christelijke weg van de verlossing te brengen. Het ging hier om een vorm van lijfeigenschap, die feitelijk niet verschilde van slavernij; Galeano (1991) p. 58. Ook wordt wel gesproken van het 'repartiamiento'-stelsel; Everett (1993) p. 30.

3 Williams (1970) pp. 30-57; $111-176$.

- Bartolomé de Las Casas (1969) p. 3.

s Everett (1993) p. 42. De meeste verslagen over de Afrikaanse slavenhandel zijn door handelaars geschreven. In 1789 verscheen een indringende autobiografie van een slachtoffer Olaudah Equiano, gedoopt Gustavus Vassa, a.w. p. 56. 
In de $17 \mathrm{de}$ en $18 \mathrm{de}$ eeuw bestond in Nederland reeds lang geen slavernij meer. In West-Indiē daarentegen bestond deze wel. De slavernij was een door de wet geregelde instelling. ${ }^{6}$ In de kolonie Curaçao kwam pas aan het einde van de 18 de eeuw, na de slavenopstand van 1795 een slavenreglement tot stand. De slaaf in Suriname was in verband met het plantagesysteem aldaar een produktiemiddel, in tegenstelling tot de kolonie Curaçao, waar geen plantage-economie bestond en de situatie van de slaven beter was. Voor Suriname werd al in 1686 een slavenreglement uitgevaardigd. In Suriname, zo blijkt uit de regelingen, werden de slaven soms zwaar mishandeld, lichte vergrijpen werden zwaar gestraft. De slavernij in Suriname werd tot het einde van de 18 de eeuw gekenmerkt door een hard en meedogenloos optreden van de slaveneigenaars. De slavenwetgeving was erop gericht zijn produktie zo groot mogelijk te maken, veel bescherming voor de slaaf boden deze reglementen niet.

Curaçao ontleende zijn economische betekenis voor de WIC aan de al dan niet illegale handel in onder andere slaven, met de Spaanse kolonies op het vaste land en met de overige eilanden in het Caraibisch gebied. Later, na de oprichting van een slavendepot op het eiland onder directeur Stuyvesant (1643-1645), ontwikkelde het zich tot centrum van de slavenhandel, waarin de Hollanders tot omstreeks 1715 een belangrijke rol speelden. ${ }^{7}$

De OvR van 1629 bevatte in art. LXI wel een algemene verwijzing over de inrichting van de rechtspleging waarbij gebruik moest worden gemaakt van "de ghemeene ordre van de Vereenighde Provintien, ofte soodanige als by de Vergaderinge van de Negenthiene sal goet gevonden worden', maar geen uitgesproken voorschrift. Bij gebreke aan een regeling voor de slaven werd de negerslavernij direct aan het Romeinse recht gebonden. De Instructie voor de WIC voor 'de landen van Brazil' van 1636, twee jaar na de verovering van

Instructie voor de hooge en lage regeering der West-Indische Compagnie in Brazilië van 23 augusutus 1636, GPB II, pp. 1247-1263. Zie de art. 85 en 86 van deze Instructie; De Monté ver Loren en Spruit (1982).

, Naipaul (1987) heeft als middelpunt van de koloniale geschiedenis zijn geboorteeiland Trinidad genomen, hij beschrijft echter de politieke en economische onlwikkelingen van het koloniale tijdperk in de 16de en 17de eeuw in bet gehele Caraibisch gebied op zeer indringende wijze. Aan het eind van zijn boek is een lijst van geraadpleegede werken en archieven opgenomen (pp. 128-152). Eldoradc, is een legendarisch paleis in Peru, dat volgens een wijdverbreide legende uit puur goud zou zijn gebouwd en door een gouden koning 'el dorado' bewoond. De uildrukking el dorado komt daarvandaan. Het paleis werd nooit ontdekt; Bartolomé de Las Casas (1969). Voor de geschiedenis van de slavenhandel van de WIC zie: Van Brakel (1918) pp. 47-83. 
Curaçao was duidelijk op het gebied van het recht dat op slaven diende te worden toegepast. Artikel LXXXVI van de instructie luidde: "Ende sullen in haar reguard plaetse hebben alle de Wetten ende constitutien, by de ghemyne Rechten [d.i. het Romeinse recht], wegen de Slaven ende onvrye Luyden gestatueerd". 8

In het Romeinse recht verkreeg iemand de status van slaaf door afstamming van een slavin of door krijgsgevangenschap. Het Romeinse recht heeft in zijn meer dan duizendjarig bestaan dat recht aangepast aan de veranderende sociale positie van de slaven. In de eeuwen rond het begin van onze jaartelling is een uitgewerkt juridische casuīstiek ontstaan. Voorzover deze neerslag vond in het Corpus Iuris Civilis werd daarop teruggegrepen voor de behandeling van de slaven in de Europese koloniën. De slaaf werd daarin als voorwerp beschouwd en had geen rechtsbevoegdheid, dus hij had geen eigen vermogen en kon alleen maar voor zijn heer verwerven. Behalve door de dood kon de slaaf zijn positie slechts verbeteren door vrijlating op wettige wijze, de manumissio. De eigenaar van de slaaf stelde hem dan in vrijheid.

In Europa ontstond kerkelijk recht over slavernij, omdat de slavernij in Europa voortduurde tot de negende eeuw, de horigheid bleef voortbestaan tot 1300 . Het christelijk denken bracht enige verzachting in het strenge Romeinse recht met betrekking tot de slavernij, zoals dat in de Nederlandse koloniën werd toegepast. De slaaf op Curaçao was kostbare koopwaar en moest in goede conditie worden gehouden. Verwaarlozing door voedselgebrek en wrede straffen kwamen echter regelmatig voor. ${ }^{9}$ Vanaf het begin van de slavernij zijn in de instructies voor overheidsdienaren en in afzonderlijke publikaties bepalingen opgenomen betreffende de behandeling van de slaven. Deze waren er echter voornamelijk op gericht, ordeverstoringen door slaven of misbruiken door planters tegen te gaan. Van afzonderlijke slavenreglementen, waarin voeding, kleding, arbeidstijden enz. waren geregeld, is pas sprake aan het einde van de $18 \mathrm{de}$ eeuw, met name na de slavenopstand van 1795. In de 19de eeuw,

- Instructie, van de Ho: Mo: Heeren Staten Generael deser Vereenighde Nederlanden, voor de hooge ende lage Regieringe der Geoctroyeerde West-Indische Compagnie, naer dewelcke voorts aen beleyt ende gederigeen sullen worden, alle het bewint ende saecken, met den aenkleven van dien, vervallende, ende noch voor te vallen inde geconquesteerde Captitanien, Steden, Forten ende Plaetsen in Brazil, ende die noch naemaels geconquesteert sullen worden. In den date den 23 Augusti 1636. Groot Placaet-Boek, Inhoudende De Placaten en Ordonnantien van de Hoogh-Mog: Heeren Staten Generael der Vereenighde Nederlanden en de van de Ed: Groot: Mog, Heeren Staten van Hollandt en de West-Vriesland, mitsgaders van de Ed. Mog: Heeren Staten van Zeelandt, (1664); zie ook Goslinga, NWIG, 52, 1977, pp. 1-50. De Gaay Fortman, De WIG, 1a, 1919, p. 455. 
tijdens de langdurige voorbereiding van de emancipatie, werden deze reglementen aangevuld en verbeterd.

Paula ${ }^{10}$ stelde dat de afkomst van de slaveneigenaar de mildheid of de hardheid van het slavenregiem bepaalde:

'There are, briefly speaking, three slave systems in the Western Hemisphere, the British, the American, the Dutch and the Danish were at the one extreme, and the Spanish and the Portuguese at the other. In between these two fell the French. If one were forced to arrange these systems in order of severity the Dutch would seem to stand as the hardest, the Portuguese as the mildest.'

Er hebben drie systemen van slavernij bestaan. Het onderscheid ligt ondermeer in de mate waarin de Christelijke leer, dat alle mensen broeders waren en in geestelijk opzicht elkaars gelijken zijn, in de verschillende landen was doorgedrongen. Deze christelijke leerstelling gold al van oudsher in de Spaans-Portugese moederlanden en werd van daaruit later overgebracht naar de Nieuwe Wereld. Zowel in Europa als in de de Spaans-Portugese koloniēn zorgden de Katholieke Kerk en de wetgeving ervoor, dat de Christelijke leerstelling ook in de praktijk werd gebracht. In deze koloniën konden vrijgelatenen vrij gemakkellijk integreren.

In de Nederlandse koloniën was er een aanmerkelijk verschil tussen vrijgelatenen en vrijgeborenen. Naar de mening van Paula ging in Latijns-Amerika de menselijke persoonlijkheid niet verloren, toen de Afrikaan als slaaf naar de Spaanse en Portugese koloniën werd verscheept. Hij bleef een persoon, ook al was hij slaaf. De Afrikaan verloor weliswaar zijn vrijheid, maar behield zijn recht om eens vrij te worden. De Afrikaan werd in de Spaans-Portugese koloniēn evenmin als een 'roerend goed' beschouwd, zoals dat in de NoordAmerikaanse en Britse koloniën - zelfs bij de wet - werd gedaan en geregeld. De niet-Iberische landen in Europa kenden niet de slaventraditie van Spanje en Portugal; zij bezaten ten tijde van de ontdekkingsreizen ook geen slaven-wetgeving. In hun kolonies werd daardoor met betrekking tot de slavernij niets bij de wet geregeld; de macht van de slaven-eigenaren was onbeperkt. Als niet meer dan een roerend goed had de slaaf geen enkel recht.

Hoetink $^{11}$ stelde dat het verschil in economische ontwikkeling van de kolonie een belangrijke rol gespeeld heeft in de behandeling van de slaven. Zowel Curaçao als Suriname zijn door Nederland

Paula (1992) p. 195, voetnoot 1.

Hoetink (1969), pp. 63 en 178-188.

Behandeling van de slaven in de Nederlandse koloniën .115 
gekoloniseerd, maar hebben een verschillende behandeling van de slaven gekend, omdat Suriname een plantagecultuur had, maar Curaçao niet. Er bestond tussen slaven en slaveneigenaren zeker een afhankelijkheidsrelatie. Wilde de meester zich sociaal en economisch handhaven, dan had hij de arbeid van zijn slaven nodig. De slaven waren voor voeding, kleding en huisvesting afhankelijk van de meester. ${ }^{12}$ Paula is van mening dat in zijn algemeenheid niet gesteld kan worden dat de slaven op Curaçao, wegens het ontbreken van een plantage-economie, geen hard werk hoefden te verrichten. ${ }^{13}$

Meestal verbeterde de behandeling van de slaven pas kort voor de invoering van de emancipatie. Het is goed mogelijk, dat naar aanleiding van de emancipatiegeruchten de slaven onhanteerbaar waren geworden en dat de slavenhouders hun toevlucht namen tot een hardere aanpak. Hierbij lijkt een verband te bestaan tussen het instellen van de Staatscommissie van 1853 ter voorbereiding van de algemene emancipatie en het harder optreden van de slaveneigenaren. De Britten en de Fransen hadden hun slaven immers al vrij verklaard. ${ }^{14}$ Geconstateerd kan worden, dat de slavenreglementen, die golden voor de kolonie Curaçao en de kolonie Sint Eustatius en onderhorigheden gericht waren op het handhaven van orde en tucht onder de slaven. In de betreffende slavenreglementen wordt geen enkele aandacht besteed aan een humane behandeling van de slaven.

In het gehele Caribische gebied werd vrijwel al het werk op de plantages verricht door negerslaven, totdat de emancipatie, hier vroeger en daar later, een eind maakte aan de slavernij. Curaçao vormde op dit punt geen uitzondering; tot 1863 hadden de meeste plantage-arbeiders de status van slaaf. De slaven op Curaçao waren belast met onder andere de verbouw van maĩs en pinda's, de zoutwinning, de oogst van cochenille en aloē, de schoonmaak van putten, herstelwerkzaambeden en de verzorging van het vee. Bonen werden vooral verbouwd door de slaven en 'vrije Lieden' op hun eigen perceeltjes. Was er weinig te doen, dan liet de planter de slaven werkzaamheden verrichten, die hem enige inkomsten verschaften, zoals het vlechten van hoeden. Ook werden slaven verhuurd als werkkrachten voor kortere of langere tijd, of ze moesten zelf werk zoeken. Een vooraf vastgesteld deel van hun inkomsten moesten deze 'geldzoekers' aan de eigenaar afdragen, de rest mochten ze zelf houden. De grootte van de slavenbevolking op Curaçao is moeilijk

Zie ook: Teenstra (1977) pp. 162-171, p. 290.

Paula (1992) pp. 85-88. 
vast te stellen. De opgaven variëren van 2.000 (in 1725) tot 44.000 (in 1747).

Hamelberg meende dat in 1780 de slavenbevolking 13.000 bedroeg. Renkema achtte deze schatting te hoog, maar stelt dat de bronnen weinig houvast bieden. De planters gaven vaak minder slaven op, dan ze bezaten, omdat er belasting over moest worden betaald, het zogenaamde hoofdgeld. Bovendien waren ze slordig in het doorgeven van geboorten en sterfgevallen. In 1857 telde Curaçao 7.036 slaven. Bij de emancipatie in 1863 bleken er op Curaçao 6.684 particuliere en 67 gouvernementsslaven te zijn. Het aantal slaven op Curaçao verminderde door gedwongen verkopen, manumissies en ontvluchtingen van slaven naar Venezuela en Haïti. Het aantal ontvluchtingen lag volgens Renkema op Curaçao echter niet hoog. De meeste slaven woonden op de plantages. De omstandigheden waaronder de slaven moesten leven zijn volgens Renkema beïnvloed door de economische omstandigheden.

Het gezinsleven onder de slaven werd niet bevorderd als gevolg van het verzet van de slaveneigenaars tegen slavenhuwelijken en door de aparte verkoop van moeder en kind, evenals de afzonderlijke verkoop van slaven van een bepaalde plantage op een publieke veiling. Zo konden in tijden van misoogst de slaveneigenaars ter bestrijding van de kosten van levensonderhoud een aantal slaven verkopen. Op de voorgeschreven kleding en hoeveelheid voedsel voor de slaven bezuinigden de slaveneigenaars regelmatig. De slavernij, de werkzaamheden die elke bevolkingsgroep verrichtte en de kombinatie van huidskleur en status leidde tot een kaste-achtige samenleving in de kolonie. In de kolonie 'Curaçao en onderhorigheden' leefden Europeanen, Joden, kleurlingen en Afrikanen gescheiden van elkaar. Vermenging had nauwelijks plaats, waardoor de bestaande vooroordelen van de blanken grotendeels in stand konden blijven. Deze ontwikkeling is van grote invloed geweest op de latere culturele en politieke ontwikkeling van de eilandbevolkingen. De blanke cultuur was normatief. De afschaffing van de slavernij zou niet veel veranderen in de verhoudingen tussen de onderlinge bevolkingsgroepen in de creool$\mathrm{se}^{15}$ maatschappij. Ook de christelijke godsdienst en het onderwijs

Goslinga (1985) pp. 278, 280, 384, 422; Kunst (1981) p. 156; vergelijk Van Dale, woordenboeken Prisma van de geschiedenis, 20 eeuwen geschiedenis in 3000 termen (1991). Met creolen worden bedoeld nakomelingen van Europeanen die in het Caraibisch gebied of Latijns-Amerika zijn geboren. De term wordt ook in meer algemene zin gebruikt voor alle niet-Indiaanse, dus niet oorspronkelijke bewoners van Latijns-Amerika. Vandaar de naam creolen voor Surinaamse negers die afstam- 
ondersteunden de klasseverschillen en hielden het ontstane 'herengedragspatroon' en 'slavengedragspatroon' in stand. De aanwijzingen van de Heren XIX dat de slaven tot kennis van het christelijk geloof moesten worden gebracht, zijn nooit uitgevoerd. De prediking van gelijkheid voor Christus zou wel eens de sociale ongelijkheid, die de slavernij per se inhield, ondergraven kunnen hebben. ${ }^{16}$

\section{De afschaffing van de slavernij}

Nederland speelde geen voortrekkersrol in de afschaffing van de slavernij. Afschaffing zou de koloniale handel ernstig treffen. ${ }^{17}$ Het begin van de anti-slavernij beweging lag in de 18de eeuw in de evangelische bewegingen in Amerika en Engeland. Eerst de 'Quaker revival' van het midden van de 18 de eeuw, gevolgd door de baptisten en methodisten in 1770 en 1780 . Het abolitionisme was ook een manifestatie van de Verlichting. Het waren de Franse filosofen die na een lange tijd van stilzwijgen het debat over de slavernij in het midden van de 18 de eeuw geopend hebben. Voltaire stelde in zijn Candide $^{18}$ de slechte situatie van de slaven in een Nederlandse kolonie, Suriname aan de orde. Opmerkelijk is dat geen enkele vooraanstaande Franse filosoof uit die tijd, zich heeft uitgelaten over de behandeling van de slaven in de Franse koloniën, of ook maar de 'Code Noir' ${ }^{19}$ noemde, die de 'rechtspositie' regelde van de sla-

17 Van Winter, De WIG, 33/34, 1952/1953,pp.61-102. Een bijlage bij het artikel bevat een bronnenlijst van tijdgenoten betreffende de afschaffing van de slavernij in Nederlands West-Indië.

18

Twee reizigers zijn op reis in Suriname. Bij het naderen van de stad treffen zij een neger aan, die zijn linkerbeen en rechtehand mist. Zij vragen de ongelukkige hoe hij in een dergelijke situatie is geraakt. De neger antwoordt: 'Quand nous travaillons aux sucreries, et que la meule nous attrape le doigt, on nous coupe la main; quand nous voulons nous enfuir, on nous coupe la jambe: je me suis trouvé dans les deux cas.'; Voltaire (1983) pp. 76-81. Maar ook Voltaire koesterde een dubbele moraal over de slavenhandel. In 1734 stelde Voltaire in zijn 'Traité de Métaphysique' dat de 'blanken superieur zijn aan negers, zoals de negers superieur zijn aan apen, en de apen aan oesters'. Maar Voltaire had dan ook aandelen in de onderneming van Montaudon, een der grootste reders en slavenhandelarenvan Nantes; NRC-Handelsblad, Weekend-editie, 16 maart 1993; Het fortuin van Nantes, tentoonstelling over de slavenhandel in Nantes.

19 Kunst (1981) pp. 15-19; Sala-Molins (1988) p. 8. De Code Noir is het Franse slavenreglement ingevoerd door Lodewijk XIV in 1685 , uitgebreid en wederom vastgesteld in 1724. De Code Noir regelde de rechtspositie van slaven in de Franse Antillen en Louisiana. Het werd definitief afgeschaft in 1848. De Fransen hebben als eerste grote koloniale mogendheid de rechtspositie van slaven gecodificeerd. SalaMolins heeft de originele tekst overgenomen en van commentaar voorzien. 
ven. ${ }^{20}$ Overigens behandelt ook geen enkel vroeger of tegenwoordig Nederlands staatsrechtelijk of rechtshistorisch handboek van enige importanti $^{21}$ de overzeese gebiedsdelen en de rol die Nederland in de slavenhandel en als kolonisator speelde. Dergelijke handboeken weiden uit over het natuurrecht, de gelijkheid van de burgers, Montesquieu en Rousseau, maar zwijgen over de behandeling en rechtspositie van de slaven in de overzeese koloniēn. Ook in de literatuur is er nauwelijks enig protest te vinden tegen de slavenreglementen in de Nederlandse koloniën.

Ook Hamelberg, de bekende Protestantse geschiedschrijver vindt het onderwerp te beladen en concludeert aldus: "Voorschriften tegen mishandeling der slaven bestonden er; hen te brengen tot kennis van den godsdienst was den predikanten opgedragen, maar toch blijkt het duidelijk, dat de Compagnie in den slaaf vaak den mensch over het hoofd zag, slecht voor hem zorgde uit zuiver eigen belang evenals zij deed voor haar vee. Het lust ons dan ook niet nog verder over deze toestanden uit te wijden, liever keeren wij terug tot gouverneur Kerckrinck" (1686-1692). ${ }^{2}$ Schiltkamp zegt slechts dat de negerslaven evenals de Indianen bescherming genoten ten tijde van het bewind van de opeenvolgende West-Indische Compagnieen, vervolgens laat hij het erbij en stelt:

"Trouwens de slavernij in zijn diverse geledingen is, wat ons land betreft, in meer dan een opzicht nog een donkere bladzijde in onze geschiedenis". ${ }^{23}$

De regelingen voor slaven in de Nederlandse West-Indische kolonie Curaçao zijn, voorzover ze konden worden achterhaald, min of meer

Mc Leod (1987); deze historische roman, geeft een goed (en niet echt opbeurend beeld) van de verhoudingen tussen blanke kolonisten (Nederlanders en voornamelijk Portugese Joden), vrije kleurlingen en slaven in de kolonie Suriname tussen 17701780. De slaven (Aluku's), die de wrede behandeling op de plantages ontvluchtten (marronnage), vestigden zich in het bos en bestookten onder leiding van Baron, Boni en Joli-Coeur vandaar uit de kolonie, om hun hoogste ideaal, leven in vrijheid te realiseren. $Z_{i j}$ werden Marrons genoemd. Hun vrijheidsstrijd zou duren van omstreeks 1650 tot de afschaffing van de slavernij in 1863. Veel slachtoffers vielen, met name aan de zijde van de Marrons (Bosnegers), Goslinga (1979) pp. 114-117 153-160; Sala-Molins (1988). Voor een uitgebreid verslag over de slavernij in Suriname en de Boni-oorlogen zie: Hoogbergen (1992); interessant is ook Naipaul (1988), met name het onderdeel over Suriname. Hij geeft op heldere wijze inzicht in de voormalige koloniale samenlevingen van Trinidad, Brits Guiana, Suriname, Martinique en Jamaica.

Een uitzondering hierop is De Monte ver Loren en Spruit (1982) p. 91.

Hamelberg (1901) p. 78.

Schiltkamp (1972) pp. 10 e.v. 
gelijk aan de Franse 'Code Noir'. ${ }^{24} \mathrm{Ze}$ vermelden behalve in de latere slavenreglementen, geen straffen. De huisslaven (bedienend personeel) hadden het nog het beste. $\mathrm{Zij}$ ontvingen loon en konden zich vaak vrijkopen. De ambachtsslaven werden voor allerlei werk gebruikt en konden ook worden verhuurd. $\mathrm{Zij}$ kregen loon, maar moesten daarvan ongeveer $f 5$,- afdragen aan hun meesters. ${ }^{25}$ De tuin- of veldslaven (plantageslaven) deden het zware werk. Wreedheden zoals op de Engelse en Franse eilanden voorkwamen deden zich op Curaçao niet voor. De slaven van Curaçao stonden dan ook in de omliggende gebieden bekend als 'verwend en brutaal' en brachten daardoor op de slavenmarkt minder op. ${ }^{26}$ De doodstraf werd op Curaçao alleen toegepast wegens moord. Lijfstraffen werden gegeven wegens ongehoorzaamheid en diefstal. Dit gebeurde met de bullepees, zweep of roede. ${ }^{27}$

De Franse 'Code Noir' regelde van 1685 to 1848 de slavernij in de Franse koloniên. ln 1724 werd de Code herzien en sindsdien gold deze ook in de Franse koloniēn in Amerika (Louisiana). De Code van 1685 telt 60 artikelen en die van 1724, 55 artikelen. Inhoudelijk verschillen ze niet veel, Sala-Molins (1988). Goslinga (1956) p. 55. De Gaay Fortman, De WIG, 1a, 1919, p. 455.

Schiltkamp (1978), West-Indisch Plakaatboek, deel I, (1978) 9 juli 1710, Besluit van Beck: Verbod aan negers en mulatten om zich na de taptoe zonder briefje van hun meester op straat te bevinden. Straffen zijn geseling, brandmerking en verbanning, p. 102 e.v. Besluit van Juan Pedro van Collen, Gouverneur van Curaçao, Verbod op het gooien van stenen door negers en mulatten. De straffen op dit delict gesteld zijn: geseling, brandmerking en verbanning, als de getroffene overlijdt wacht de galg, p. 164 e.v. Besluit van Isaac Faesch, Gouverneur van Curaçao 17 oktober 1740 en $24 / 28$ juli 1750 . Reglement voor negers en mulatten. Dit reglement handelt met name over de toenemende gewelddadigheid onder genoemde bevolkingsgroepenen verbiedt hen na 21:00 's avonds zonder reden, zonder briefje van hun meester en zonder lichten zich aldar te bevinden, de straffen zijn dezelfde als hierboven vermeld, $p$. 208 e.v. en p. 270 e.v. Besluit van 7 juni 1741 van Isaac Faesch, verbod van bijeenkomstenvan negersen mulatten. De bedreigde straffen: geseling, brandmerking en verbanning, p. 218. Zie ook een gelijksoortig besluit van Isaacq Faesch van 30 december 1756 (p. 308 e.v.), Straffe, geseling en dwangarbeid. Besluit van Isaak Faesch 8 april 1750, Verbod om vrije negers en mulatten te slaan en hun gronden te misbruiken, straf: 'onze hoogste indignatie', p. 270. Besluit van 22 april 1767 door Jean Rodier, Gouverneur over Curaçao ende desselfs onderhoorige eylanden, Maatregelen tegen baldadigheid op straat van negers en mulatten (zowel slaven als vrijen), waarschuwing aan eigenaars van slaven om de tucht te handhaven, p. 340 e.v. Besluit van Jean Rodier van 26 augustus 1767, Verbod aan inwoners om negers en mulatten die niet hun eigendom zijn aan te houden en op te sluiten, p. 342 e.v. Besluit van Jean Rodier van 14 december 1768 , Maatregelen tegen het verspreiden van geruchten over een slavenopstand (zie ook besluit van Isaak Faesch van 1 augustus 1754, p. 291), p. 351 e.v. Besluit van 6/7 februari 1769: Wij Gouverneur en Raaden des eylands Curaçao, Verbod om goud en zilverwerk of andere goederen van negers en mulatten te kopen of in onderpand te nemen zonder briefje van de eigenaar of onderschout, p. 353 e.v. Besluit van de Gouverneur en de Raad van 3 december 1770 , Voorschriften voor vissers ter voorkoming van het wegvluchten van slaven, p 372. In de Instructie aan Jean Rodier in 1764 wordt hem nog op het hart 
'The slaves in the Guiana colonies were subject to very harsh conditions of enslavement. In many of its aspects, the Dutch slave law resembled the slave law of the French West Indies - a resemblance no doubt due to their common origins of Roman law. But the divorce of law and pratice was as characteristic of the Dutch as of other colonies. In general, the Dutch Company [W]C] like the Danish, regarded the slaves primarily as objects of profit; and the settlers in the Dutch colonies took a similar view. The police regulations which were numerous and often severe, were constantly invoked. Extralegal and illegal punishments were privately inflicted on slaves, especially in the Guiana colonies, where the existence of bands of runaway slaves in the hinterland encouraged a brutal stringency in estate discipline. Fear of the Bush Negro threat increased also the repressive tendencies of public policy. Inhuman punishments were inflicted on slaves not merely by masters privately and illegally but also by the judicial authorities acting under the law. As in the French colonies, a conflict arose between the principle of repression and that of protection; and, on the whole, it was repression that triumphed. At the beginning of the ninetheenth century, there was humane treatment of the slaves because of the abolition of the slave trade, but long after that time very crude punishments were apparantly still in existence and the slaves were looked upon as a sort of cattle. ${ }^{, 28}$

De Franse filosofen hebben een grote invloed gehad op de ontwikkeling van het westerse staatsbestel. De vrijheid die zij voor ieder individu propageerden bleek echter voor wat de slavernij betreft nauwelijks te gelden.

Er zijn dus kennelijk plekken op aarde waar de rede noch natuurlijk, noch redelijk is, meent Sala-Molins in zijn commentaar op de slavernij zoals beschreven door Montesquieu. Hij omschrijft de Verlichtingsfilosofen ook enigermate ironisch als 'Lumières'. Montesquieu gaf het advies aan de koloniale machthebbers dat het niet verstandig was om plotseling door een algemene wet de mogelijkheid te geven grote aantallen slaven de vrijheid te geven, de Repu-

gedrukt toe te zien op een goede behandeling van de slaven. De particuliere slaven moeten net zo behandeld worden als de Compagnieslaven. Voor een beschrijving van de wrede behandeling van slaven door de Engelsen op Trinidad, zie Naipaul (1987) pp. 182-304. Zie ook R.A. Rōmer, Slavemij en Slavenwetgeving in de kolonie Curaçao in: Het oog van de meester (1989) p. 184 e.v. Voor een beschrijving van de wrede behandeling van slaven door de Engelsen op Trinidad, zie V.S. Naipaul (1987). 
bliek zou daardoor in gevaar kunnen komen. ${ }^{29}$ Diezelfde angst speelde trouwens ook in Nederland en is duidelijk te herkennen in het Tweede Rapport der Staatscommissie benoemd bij KB in 1853, tot het voorstellen van maatregelen ten aanzien van de slaven in de Nederlandsche kolonien, de Nederlandsche West-Indische eilanden en Bezittingen ter kuste van Guinea ${ }^{30}$ De Franse revolutie van 1789 bracht mede onder invloed van de 'Lumières' nieuwe ideeën over de universele rechten van de mens. De leus: 'Vrijheid, Gelijkheid en Broederschap' werd een begrip, dat zich niet alleen over geheel Europa verspreidde, maar ook de oceaan overstak naar de Caraibische eilanden. Een neerslag van deze in theorie liberalere opvattingen met betrekking tot slaven in artikel 31 van de Franse regeling voor Curaçao. Daarin stond namelijk dat:

'Quoique d̀ Curaçao comme dans toutes les colonies des Indes occidentales les blancs constituent la classe la plus priviliegé des habitans, il lui est enjoint particulierement de veiller que la classe seconde et mitoyenne des gens libres de la couleur, soit maintenue en leur droits, il identifiera leurs interets autant que possible, avec la première; quand aux Esclaves, il veillera qu'ils ne soient pas maltraitées, et il reglera d'après par les loix dejà existantes, ou par la formation des nouveaux reglemens, sous nôtre approbation leur travail et les punitions qui seront infligées; en observant neanmoins qu'ils soient tenus sous une exacte et rigoureuse discipline; il veillera contre tout acte de cruauté de la par des maitres barbares. Il entretiendra aussi une bonne intelligence avec le peu d'Indiens, qui se trouvent dans la Colonie, et veillera qu'ils soient aucunement vexeé. ${ }^{31}$

Dit was de eerste keer dat in een van de Regeringsreglementen voor de kolonie Curaçao ruim(er) aandacht werd besteed aan de rechten van de niet-Europese bevolking en de slaven. Met het oog op de 'Code Noir' moet hier wellicht alleen in theoretische zin enig belang aan worden gehecht. Artikel 5 in de Instructie voor de GouverneurGeneraal op Curaçao en onderhoorige Eilanden en hetzelfde artikel in de instructie voor den Gouverneur van Sint Eustatius, Saint Martin en Saba vermeldt:

$29 \quad$ Montesquieu, De l'Esprit des lois, liv. 15, chap. 18.

30 Tweede Rapport der Staatscommissie benoemd bij Koninklijk Besluit van 29 November 1853, 66 tot het voorstellen van maatregelen ten aanzien van de slaven in de Nederlandsche kolonien, De Nederlandsche West-Indische eilanden en Bezittingen ter kuste van Guinea (1856).

31 Projet d'Instruction pour le Gouvemeur Général de l'lle de Curaçao etc. Arrêté par Decret du 19 Janvier 1807, in: Bordewijk 1911, pp. 154-165.

122. De slavemij in de Nederlandse koloniën 
"Hij zal zorgen dat noch de naturellen, noch de vrije gekleurde lieden in hunne regten worden benadeeld, maar dezelve zoo veel mogelijk aan de blanke klasse der Ingezetenen attacheren; voorts ontrent de slaven toezien, dat dezelve niet worden mishandeld, doende onder dezelve de behoorlijke discipline en orde observeren." ${ }^{132}$

Artikel 72 van het Regeringsreglement voor de kolonie Curaçao en onderhoorige eilanden van 1833 vermeldt slechts dat de slavenbevolking aanbevolen wordt in de bijzondere zorg van het Koloniaal Bestuur. Het bestuur moet er op toezien dat de belangen van eigenaren worden afgewogen tegen de belangen van een verbetering van de slavenhandel. Artikel 62 van het Reglement op het beleid der Regering in de Kolonie Sint Eustatius en Saba en in het Regeringsreglement voor de Kolonie St. Martin (Sint Maarten) van 1833 heeft exact dezelfde redactie als eerder genoemd artikel 72 .

In het Reglement op het Beleid der Regering in de Kolonie Curaçao en onderhoorigheden van 1848 worden in artikel 59 de slaven wederom aanbevolen in de zorgen van het koloniaal bestuur en moeten "gepaste maatregelen en beraamd, om den stoffelyken en zedelyken toestand der slaven te verbeteren en om de manumissien te doen strekken tot nut der koloniën". Artikel 60 stelt streng: "Het beginsel dat slaven, in regten, als zaken en niet als personen moeten worden beschouwd, blyft afgeschaft." Het artikel was ook nu weer belangrijker in de theorie dan in de praktijk. Ook moest wederom de zedelijke toestand van de slaven worden verbeterd ter voorbereiding van hun emancipatie. Een van de meest probate middelen om dat doel te bereiken zou in de bevordering van normale door de overheid erkende en beschermde gezinsvorming hebben gelegen. Maar die heeft eeuwenlang als hoofdbeletsel gekend dat slaven geen wettig huwelijk mochten sluiten. In 1828 krijgen de slaven de mogelijkheid een wettig huwelijk te sluiten zonder civielrechtelijke gevolgen. Artikel 4 van het Regeringsreglement van 1865 zegt tenslotte: "Sla-

Reglement op het beleid van de Regering, het Justitiewezen, den Handel en Scheepvaart, mitsgaders de instructien voor den Gouverneur-Generaal en den Raad Contrarolleur Generaal op het eiland Curaçao, gearresteerd bij Besluit van Zyne Majesteit den koning in dato 14 September 1815, 58. Deze uitgave begint met het Reglement op het beleid van de Regering voor Suriname en bijbehorende instructien voor den Gouverneur Generaal, den Raad Fiscaal, den Raad Contrarolleur van Financien en den Contrarolleur der Magazijnen. Alle wettelijke regelingen zijn bij hetzelfde KB vastgesteld. Tenslotte beval deze uitgave het Reglement op het beleid der Regering voor St. Eustatius, St. Martin en Saba mitsgaders de instructien voor den Gouverneur der Eilanden St. Eustatius, St. Martin en Saba, den Boekhouder-Generaal op het Eiland St. Eustatius, den Commandeur des Eilands St. Martin, en den Boekhouder aldaar; Bordewijk (1911). 
vernij wordt in de kolonie niet geduld". De slavernij was toen reeds afgeschaft.

Kunst besteedt enige aandacht aan de slavernij in de kolonie Curaçao, maar spreekt slechts over de periode na 1815 in zijn boek 'Recht, Commercie en Kolonialisme in West-Indië' van 1981. Opvallend is wel dat Kunst, die de geschiedenis van de kolonie Curaçao uitgebreid beschreven heeft in zijn boek van 1981 en ook twee kloeke delen heeft gewijd aan de historische ontwikkeling van het recht in 1968, niets over de slavernij zegt. Het enige wat hij daarover opmerkt - is een zijdelingse annotatie, zich daarbij beroepend op Montesquieu, het Romeinse recht en op het eerste Boek van het Nederlandse BW van 1838, artikel 2 luidende:

"1. Allen die zich op het grondgebied van den staat bevinden zijn vrij, en bevoegd tot het genot van burgerlijk rechten.

2. Slavernij en alle andere persoonlijke dienstbaarheden, van welken aard of onder welke benaming dan ook bekend, worden in het rijk niet geduld".

Kunst behandelt het personenrecht van Boek I van het BW, maar verwijst, bij de behandeling van natuurlijke personen slechts naar het Romeinse- en Germaanse recht, die de slavernij kenden. De slavernij speelde in Europa immers een rol tot de negende eeuw. Horigheid werd in Nederland tussen de tiende en twaalfde eeuw afgeschaft. De Romeinen definieerden filosofisch de slavernij als een instelling van het ius gentium, van het recht der volkeren, waardoor een mens tegen de natuur in - aan de heerschappij van een ander wordt onderworpen.

De Franse revolutie had weliswaar de beginselen van vrijheid, gelijkheid en broederschap voor alle burgers gebracht, maar de slavenarbeid in de koloniën bleef de hoeksteen van het economisch bestel. Een slaaf was een belangrijk rechtsobject, geen subject ook al was hij 'persona'. Met het oog op de horigheid ${ }^{33}$ verklaarde art. 2 lid 2 BW 1838 dat de mogelijkheid om de rechtsbevoegdheid van natuurlijke personen te ontkennen of in te perken niet geduld zou worden in het rijk. Met het rijk werd het rijk binnen Europa bedoeld en niet het rijk daarbuiten. Het artikel bedoelde kennelijk alleen de horigheid binnen het rijk in Europa uit te bannen en de slavernij in de koloniën springlevend te laten voortbestaan. Die verklaring geven De Monté ver Loren en Spruit. ${ }^{34}$ 
Het zojuist aangehaalde artikel 2 BW lid 2 kan echter ook zo worden begrepen dat het slechts te maken zou kunnen hebben met de slavernij in de koloniën, omdat slavernij in Nederland niet meer bestond. Aan welke verklaring men ook de voorkeur geeft, beide geven blijk van een dubieuze opstelling van de Nederlandse wetgever.

Het had voor de hand gelegen als Kunst dat causale verband had uiteengezet, maar hij doet dat niet. Hij stelt nog, zonder nader commentaar het volgende:

\begin{abstract}
"Een merkwaardige moeilijkheid leverde sinds de zestiende en zeventiende eeuw de rechtspositie van slaven uit de koloniën op. De hoofdregel dat zij hier te lande komende vrij werden, werd in de tweede helft van de achttiende eeuw door de Staten-Generaal aangevuld; in principe bleven zij vrij, zelfs als zij later in de koloniën terugkeerden. " 35
\end{abstract}

Met geen woord rept Kunst over de slavernij in de Nederlandse koloniën. ${ }^{36}$ Men kan zich niet geheel aan de indruk onttrekken dat Kunst zich gedraagt als de Franse filosofen door de problematiek te ontkennen, want welke slavenhouder die naar Nederland vertrok met een slaaf, zou de slaaf vertellen, dat hij bij betreding van het Nederlandse grondgebied vrij zou worden?

Diephuis $^{37}$ zegt hier nog het volgende over, onder het kopje: 'Van Natuurlijke personen, De mensch als persoon':

"Personen zijn volgens art. $2 \mathrm{BW}$ allen die zich op het grondgebied van den Staat bevinden. ... $\mathrm{Z}_{\mathrm{ij}}$ kent uitdrukkelijk persoonlijkheid toe aan alle menschen, die zich bevinden op het grondgebied, waarover haar gezag zich uitstrekt, om het even van welken maatschappelijke stad, en hetzij ze Nederlanders of vreemdelingen zijn. Zij doet dat op tweeërlei wijze; regtstreeks door de positieve verklaring, dat allen bevoegd zijn tot het genot der burgerlijke regten, en tevens, als tot bevestiging en ontwikkeling daarvan, door de negatieve verzekering, dat geen slavemij of persoonlijke dienstbaarheid voor iemand een beletsel tegen zijne persoonlijkheid zijn kan. Slavernij bestaat hier

Anders G. Diephuis, Het Nederlandsch Burgerlijk Regt, Deel I, J.B. Wolters, 1869, p. 184, noot 5. Volgens Diephuis is de slaaf vrij als hij zijn heer ontvlucht en naar Nederland komt, dit was anders naar vroeger recht, bekrachtigd door een Placcaat van de Staten-Generasl van 23 mei 1776, in Groot Placcaatboek DX, p. S26. Diephuis is echter van mening dat die regeling sinds 1809 als afgeschaft beschouwd mag worden en althans tegenover art. 2 BW krachteloos is. Dit betekent m.i. hetzelfde, in Nederland is de slaaf theoretisch vrij, maar daarbuiten slaaf. Vrijheid is in die opvatting dan kennelijk slechts mogelijk voor de bianke. 
niet, noch eenige andere persoonlijke dienstbaarheid, waardoor de mensch een voorwerp wordt van regten van een ander, waardoor een ander regt op hem heef, gelijk men een regt heeft op eene zaak, die, zij het dan meer of minder volkomen, regtstreeks aan onze magt onderworpen is. Zoodanige persoonlijke dienstbaarheid, welke ook haar aard en hoe haar naam mag zijn, en al heeft zij ook vroeger hier te lande bestaan en bestaat zij elders nog, wordt door onze wet op haar grondgebied niet erkend, noch tengevolge van geboorte of eenige andere oorzaak, noch ook uit kracht eener overeenkomst en van den eigen wil van hem, die zich aldus aan een ander heeft willen onderwerpen; zij wordt in het rijk niet geduld. Hier zijn allen vrij, en als zoodanig bevoegd tot het genot der burgerlijke regten; allen personen, zonder dat hunne persoonlijkheid door eenigen staat van onderwerping geheel of ten deele wordt opgeheven.

Wanneer alzoo een slaaf, uit een land waar slavernij feitelijk bestaat en door het regt erkend wordt, met of zonder zijnen heer, in ons land aankomst, dan is hij met betrekking tot onze wet als persoon vrij te beschouwen, en kan de heer zijn regt als zoodanig hier niet op hem doen gelden. Dit geldt ook dan, wanneer de slaaf zijn heer is ontvlucht en geheel tegen diens wil in ons land is gekomen. Maar zo hij vervolgens dit land weder verlaat, houdt daardoor ook de werking onzer wetsbepaling op, en blijft hij op grond daarvan niet vrij; art. 2 BW heeft zijn verder lot niet verzekerd noch kunnen verzekeren, dit hangt nu weder van de wet, onder wier gezag, en van de omstandigheden af, waarin hij zich bevindt."

Diephuis is echter van mening dat die regeling sinds 1809 als afgeschaft beschouwd mag worden en althans tegenover art. 2 lid 2 BW krachteloos is. Maar dat valt niet erg goed te rijmen met zijn bovenstaande uiteenzetting. De enige conclusie op grond van zijn betoog kan zijn, dat formeel iedereen gelijk is en slavernij niet geduld wordt, maar dat zulks in de praktijk voor (zwarte) slaven anders ligt. Er bestaat duidelijk een onderscheid tussen het grondgebied van de staat binnen en buiten Europa. Ook al geldt het ideaal voor het hele grondgebied en in ieder geval voor blanken, dan nog gelden de feitelijke regels niet voor bepaalde groepen van personen (in casu zwarte slaven). Op Nederlands grondgebied gelden die regels slechts voorwaardelijk voor slaven. De Nederlandse regeling komt dus overeen met het Franse stelsel van de 'Code Noir' zoals uiteengezet door Sala-Molins. In Nederland is de slaaf theoretisch vrij en soms ó́k praktisch vrij, maar daarbuiten slaaf.

De slavernij bracht meer dan zuiver commerciële relaties mee. Curaçaose slaven die hun meesters ontvluchtten, konden zich op het 
eiland zelf niet lang schuil houden en probeerden vaak over te steken naar het vasteland. Werden ze daar gevangen genomen, dan werden ze voor 1751 als regel teruggezonden, maar na dat jaar mochten ze blijven en kregen zelfs de vrijheid indien ze zich lieten dopen. Zo ontstond aan de rand van Coro een hele wijk van vrije negers. 'Las Compañías de negros de Curazao' steunden de slaven van Coro bij hun opstand van 1795 en deelden in hun harde straffen. Was het toeval dat drie maanden later de grootste slavenopstand uit de geschiedenis van Curaçao uitbrak op het eiland? ${ }^{38}$

Op Curaçao kwamen in augustus $1795^{39}$ de slaven in opstand. De opstand werd hardhandig neergeslagen. 29 personen werden terechtgesteld. De leiders van de opstand, Tula en Karpata, werden geradbraakt, in het gezicht geblakerd en onthoofd. Hun hoofden werden op twee staken op het Galgenveld tentoongesteld. De Jezuĩet Alexius Schabel deed in een soort dagboek verslag over de zedeloosheid van de slaven en de meesters. Goslinga schrijft:

'Het huwelijk was de slaaf onbekend, het was immers verboden. Hij leefde als het vee en de eigenar keek alleen maar naar uitbreiding van zijn slavenstapel. Hoe meer kinderen er geboren werden, hoe liever het hem was, en hoe die uitbreiding tot stand kwam, liet de eigenaar koud, zelfs als de kinderen in bloedschande werden verwekt, zelfs als het zijn eigen buitenechtelijk verwekte kinderen waren. Daartegen bestonden geen straffen terwijl daarentegen voor de nietigste kleinigheden soms streng werd gestraft, zoals het geval bewijst van een slavin, die bloedig werd gegeseld, omdat ze wat saus had gemorst. De WIC heeft, zo gaat Schabel verder, niet om het harde slavenjuk enigszins te verzachten hen in kennis gebracht met de ware God. Integendeel, aan hun dor en troosteloos heidendom voegde zij nog toe een hardvochtige en onchristelijke behandeling en propagageerde zij de meest onzedelijke begrippen en levenswijzen of werkte die niet tegen. In de slaaf de medemens erkennen durfden zij niet aan. ${ }^{.40}$

Het zijn deze slavenopstand en de grieven, die door de slaven naar voren waren gebracht, die voor bet bestuur van de kolonie aanleiding

Amigoe, $\bar{N}$ apa, 18 augustus 1990: 'Toela, held of schobbejak?', Herdenking slavenopstand blijft omstreden kwestie, Angel Salsbach maakt een vergelijking met Brion en Bolivar. Toos van Mierlo maakte in 1970 een standbeeld van Toela. $\mathrm{Zij}$ beelde hem af als een fors gebouwde nakke neger. Toen hierover discussie ontstond stelde ze voor hem een schaamlap voor te doen, maar dat was niet aanvaardbaar. Nu staat deze blote Toela ergens in een park in Nederland kou te lijden. Men vond het beeld op Curaçao wel mooi, maar te naskt. Van Soest (1980) p. 6 e.v. op Curaçao een goede behandeling genoten. Zie ook Renkema (1981) pp. 112-143. 
waren om het eerste slavenreglement uit te vaardigen. Dit slavenreglement en de daaropvolgende slavenreglementen erkenden niet zozeer de rechten van de slaven, maar zagen meer op het verzekeren van de openbare orde. Tot 1795 waren de summiere slavenvoorschriften uit de Instructie aan Jean Rodier van 1764 van kracht. Het tweede slavenreglement van 20 november $1795 \mathrm{kwam}$ tot stand na een klacht van 23 slaven tegen hun meester C. Ringeling, die een boete kreeg opgelegd van 500 pesos. De regelingen in het tweede slavenreglement weken niet wezenlijk af van die van het eerste. Enige verandering in de positie van de slaaf bracht deze publicatie niet. De Curaçaosche gemeenschap was er nog niet aan toe.

Een goed voorbeeld van de toen heersende opvatting over de slaaf is de reactie van de Raad van Policie op een voorstel dat pater J. Stöppel in 1817 in een adres aan de Koning deed om de slaven toe te staan een wettig huwelijk aan te gaan. De leden van de Raad reageerden fel hierop en stelden: ' $[\ldots .$.$] de onbeschaafdheid en ruwe$ zeden der slaven leveren zoveel bezwaarnissen op tegen het bevorderen van het huwelijk onder hen, dat wij het als een moeilijke en bijna onmogelijke zaak beschouwen'. Ook de publikatie van 1824 bracht geen wijziging in de positie van de slaaf. Dit reglement greep weer terug op dat van 8 december 1812 en op de publicaties van 6 juni 1761, 2 november 1789, 21 januari 1790 en 23 februari 1791, die over het weglopen van slaven gingen. Zware vergrijpen die schuldigen 'aan meer dan huishoudelijke kastijding onderhevig maken' moesten ter kennis worden gebracht van het Officie-Fiscaal of de districtsmeester.

De sancties voor de slaveneigenaren gesteld op overtreding van deze bepalingen bleven op hetzelfde niveau 'vijftig pezos van achten'. Met het Regeringsreglement van 1828, dat de samenvoeging van Suriname en de West-Indische eilanden tot én kolonie regelde, kwam er enige verbetering in de positie van de slaaf. Artikel 117 van dat Reglement bevatte een waarlijk revolutionaire bepaling, het artikel vermeldt dat "de slaaf is persoon, geene zaak; zijn verhouding tot de zijnen is die van eene onmondigen tot zijnen voogd of curator". ${ }^{41}$ Ook na de publicatie van dit reglement bleef de slaaf echter een verhandelbare zaak. ${ }^{42}$

Menkman, De WIG, 34, 1953, pp. 103-112; Tweede Rapport der Staatscommissie (1856).

42 Römer in: Het oog van de meester (1989) pp. 176-185. Bijlagen: pp. 196-210; Publicatieblad 1795, 28, Slavenreglement. De werkuren werden gereglementeerd, niet meer dan 12 uur per dag mocht er worden gewerkt, de vitzonderingenzijn limitstief omschreven. Ook de minimale voedselrantsoenen werden verplichtend voorgeschreven, de uitgereikte kleding mocht niet op de voedselrantsoenen worden gekort, 
De geschiedenis van de huidige Nederlandse Antillen en Aruba telt vier slavenopstanden, twee op Sint Eustatius (1688 en 1848) ${ }^{43}$ en twee op Curaçao (1750 en 1795). Ook deden zich op de andere eilanden in die periode rellen voor. $\mathrm{Na}$ het eindigen van de asiento' $\mathrm{s}^{44}$ had de Compagnie zelf slavenhalers uitgerust, die de slaven meestal betrokken van St. George d'Elmina. Naar hun plaats van herkomst werden deze slaven Elminaasche of Minaasche negers genoemd. Zij kregen al spoedig een slechte naam, omdat zij zich moeilijk in hun lot schikten. In 1750 kwamen de slaven op Curaçao in opstand onder leiding van de slaven afkomstig uit St. George d'Elmina. Zij waren veel strijdlustiger van aard dan de slaven afkomstig van de kusten van Loango, Congo en Angola. De opstand leidde tot moord en doodslag op andere slaven en brandstichtingen. Vierendertig opstandelingen werden door de scherprechter ter dood gebracht. Op Aruba kwamen de enige drie Minaasche slaven in opstand en vermoorden de zuster van de Commandeur Daniel Nieuwkerk met haar kind. De boosdoeners werden gegrepen, doodgeschoten en verbrand. ${ }^{45}$ Op 21 april 1829 werd de districtsmeester Pieter Lampe vermoord door zijn slaaf Gerard. Voor de moord werd Gerard ter dood veroordeeld. Voor zover bekend zijn dat de enige doodvonnissen die op Aruba is voltrokken. ${ }^{46}$

of tegen hoge prijzen verplicht van de meester worden afgenomen en de Zondagsrust moest in acht worden genomen, ook door de slaven. Ook mochten de slaven niet onnodig hard gekastijd worden. Zie ook Publicatie Slavenreglement 1812 en Publicatie Slavenreglement 1824, Houdende bepalingen ten aanzien der voeding, kleeding, verpleging, huisvesting en afstraffen van slaven. Dit was het eerste reglement wasrin de straffen systematisch zijn ondergebracht. De algemene straffen zijn geseling, kettingboei en dwangarbeid. De meesters konden bij overtreding van de bepalingen bestraft worden met een boete. Paula (1992) pp. 103-126.

4 Assiento of assiente is afgeleid van het Spaanse 'asentar' dat ondermeer een overeenkomst sluiten betekent. Het handelshuis van de Genuezen Domingo Grillo en Ambrosio Lomeline had van de Spaanse koning het alleenrecht verkregen om in Spaans West-Indië slaven te brengen. De Compagnie sloot in 1662 een contract voor levering van 'een goed getal negros' met dit handelshuis af. Deze overeenkomst werd 'assiente" genoemd. Er moest een een agent van de leverancier op Curaçao werden gevestigd om de slaven aan de Compagnie over te geven. Deze agentuur heette 'assiento'. Het assiento was enige tijd in Amsterdam gevestigd; Hamelberg (1901) pp. 73-75; Kesler, De WIG, 9, 1927, pp. 152-160; Van Brakel (1918) pp. 50-59. Voor het assiento van 1662 zie: Van Brakel: 'Accoort om 2000 p. slaven ende meerdere aan Curaçao te leveren', Van Brakel (1918) pp. 61-66. Hamelberg (1901) pp. 165-171.

46 Hartog (1961) p. 215, de plaats waar de moord is gepleegd heet tot nu toe 'Vader Piet'. Eenvoudige misdrijven werden behandeld door het Vredegerecht, dat tussen 1824 en 1869 op Aruba functioneerde en het enige rechterlijke college aldaar was. Van het 'Vredegeregt' zijn behalve de wetgeving ook tien delen notulen bewaard gebleven uit de periode 1828-1869. Deze geven interessante informatie over de verhouding slaven en vrijen; Voges (1982) pp. 107-117. 
De slavenopstanden hebben bijgedragen tot het afschaffen van de slavernij. Het ontstaan van marrongemeenschappen op de Britse eilanden Antigua, Barbados, Dominica en Jamaica en op het vasteland in Guyana, droeg daartoe eveneens bij. In de Franse gebieden kwam marronage voor in Saint Dominique, later Haïti. ${ }^{47}$

In de Nederlandse koloniën kwam marronage in Suriname voor. ${ }^{48}$ De afschaffing van de slavernij in de kolonie Curaçao bleek een moeizaam proces te zijn. Onder invloed van Engeland werd de slavenhandel in het begin van de 19 de eeuw verboden. ${ }^{49}$ In 1807 gebeurde dit in Engeland en in 1814 in Nederland. Tussen dit verbod en de afschaffing van de slavernij lag echter een wereld van verschil. In Nederland kwam de emancipatiebeweging in 1840 op gang. De humanitaire beweegredenen, die aan de afschaffing van de slavernij ten grondslag lagen, stuitten echter voortdurend op de economische bezwaren van de Nederlandse regering. In 1833 schafte Engeland de slavernij af. Frankrijk, dat de emancipatie van de slaven in 1791 inmiddels had teruggedraaid, volgde in $1848 .^{50}$

Een verandering in het denken in de kolonie Curaçao voor wat betreft slavernij en de status van de slaaf vond plaats in 1848 , het jaar waarin de slaven op de Franse eilanden in het Caraibisch gebied hun vrijheid kregen. De moeilijkheden die daardoor ontstonden op het eiland Sint Maarten, dat voor de helft Frans was, maakte dat men zich ook op de Benedenwindse eilanden ging realiseren dat handhaving van de slavernij niet meer mogelijk was. Inmiddels was in Nederland in 1842 een Adres gericht aan de Koning door de 'Nederlandsche Maatschap-

47 Williams (1970) pp. 237-254.

4 Paula (1992). Marrons, zijn niet alleen de Bosnegers van Suriname. Een marron is een slaaf die zich gedurende korte tijd ('petit marronnage') of permanent ('grand marronnage') onttrekt aan het slavernijsysteem waanoe hij rechtens behoort. Grand marronaage is de organisatie van een effectieve eenheid van slaven met het vernogen zich te verdedigen, te voeden en demografisch in stand te houden door aanvulling met nieuwelingen of natuurlijke voortplanting (p. 3). Noonan Jr. (1987) pp. 1-5.

so Paula (1992), zijn proefschrift behelst een sociaal-historische studie over de dubbelzinnige slavenemancipatie op Nederlands Sint Maarten van 1816-1863. Bij de emancipatie van de Franse slaven in 1848, werden ook de slaven op het Franse gedeelte van Sint Maarten bevrijd en dat had bijzondere consequenties voor het Nederlandse gedeelte. $\mathrm{Zij}$ weigerden verder te werken, want zij wilden hun leven niet verder in slavemij voortzetten, dus moesten de slavenhouders en de autoriteiten op het eiland daar een oplossing voor zien te vinden. Dat meenden ze te doen, door concessies te verlenen aan de slaven. Ze beloofden hun, dat ze niet langer als slaven zouden worden behandeld. Ze mochten contracten aangaan met de meesters voor het verrichten van werkzaamheden en heel bijzonder was dat voortaan de wetten van de vrije bevolking voor hen zouden gelden. Dat betrof vooral de strafwetten. 
pij ter bevordering van de Afschaffing van de Slavernij'. De Emancipatie werd echter door de regering zelf ter hand genomen. Bij $\mathrm{KB}^{\mathrm{s}_{1}}$ werd ter voorbereiding van de afschaffing van de slavernij, een Staatscommissie benoemd die de opdracht kreeg maatregelen voor te stellen ten aanzien van slaven in de Nederlandse kolonies. De commissie bracht in 1856 een rapport uit, bestaande uit twee delen, deel I hield zich bezig met Suriname en deel II met de West-Indische kolonies en de bezittingen ter kuste van Guinea. ${ }^{52}$

De veranderde houding ten opzichte van de slavernij vindt men ook terug in de Publicatie van 1857 'houdende bepalingen ten aanzien der voeding, kleeding, verpleging, huisvesting en afstraffen van slaven'.$^{53}$ Het Slavenreglement vangt aan met de vermaning, dat nu de 'Emancipatie' nadert, de slaven daarop moeten worden voorbereid " [...] en hen de voordeelen dier hervorming waardig te maken, het raadzaam geoordeeld wordt hunne zedelyken toestand te verbeteren en hun eergevoel op te wekken, door aan dezelven eene betere behandeling te verzekeren"'. De bepalingen zijn in 1857 veel meer

$K B$ van 29 november 1853,66 .

52 Tweede Rapport der Staatscommissie benoemd bij Koninklijk Besluit van 29 November 1853, 66 tot het voorstellen van mastregelen ten aanzien van de slaven in de Nederlandsche kolonien, De Nederlandsche West-Indische eilanden en Bezittingen ter kuste van Guinea, 's-Gravenhage, bij de Gebroeders van Cleef, 1856. Het rapport bevat als bijlage een ontwerp van wet tot opheffing van het meesterschap op de eilanden Curaçao, Bonaire, Aruba, St. Eustatius en Saba, evenals de MvT daarop. Bijlage $C$ bevat een apart ontwerp van wet 'tot het verleenen van eene tegemoetkoming aan de gewezen eigenaren van slaven op het Nederlandsch gedeelte van het eiland St. Martin en tot het afschaffen van het meesterschap aldaar', benevens de MvT. Het ontwerp bepaalde ook de schadeloosstelling per slaaf aan de meester. Bijlage $\mathbf{K}$ is een nota 'betrekkelijk tot de nopaalkultuur en cochenilleteelt op de Nederlandsche West-Indische eilanden' van de heer R.H. Esser. De bedoeling was om met de teelt van deze produkten de emancipatie der slaven financieel te bestrijden. De conclusie van een der deskundigen was 'dat voortzetting van die kultuur op de Curaçaosche eilanden op den duur geene winsten te verwachten zijn, en dat uitbreiding dasrvan op groote schaal, mij toeschijnt gelijk te staan met geldverspilling, zoo men er winsten in geld mede op het oog heeft'. Met name zou dat niet lukken met vrije personen (te duur), als men beoogt met de bovenvermelde teelt winst behalen concludeerde de betrokken deskundige. De Staatscommissie van $1853 \mathrm{kwam}$ tot de conclusie dat de slavernij op het Nederiandse deel van Sint Maarten daadwerkelijk was afgeschaft, in verband met de emancipatie van de Franse slaven in 1848. De Commissie adviseende dan ook dat de slavenhouders op het Nederlandse deel van Sint Maarten geen recht hadden op schadevergoeding. De slavenhouders op Sint Marten accepteenden dat niet, ze protesteerden heftig. De facto was dus de slavemij afgeschaft op grond van de feitelijke omstandigheden op Sint Maarten, deze praktijk werd achteraf door de wet, die de slavernij afschafte, gedekt. Toen de slaven op het Franse gedeelte vrij werden en de slaven uit het Nederlandse gedeelte in grote getale naar het Franse gedeelte uitweken, probeerde de Nederlandse Gezaghebber de slaven te doen uitleveren. Dit lukte echter niet.

PB 1857, nr. 2. 
uitgewerkt dan in het Reglement van 1824, tevens wordt er ook aan de slaaf een uitkering in geld toegekend. ${ }^{54}$ In Nederland slaagde men er niet in tot overeenstemming te komen omtrent een acceptabele regeling tot schadevergoeding. De slaven zouden zelf moeten opdraaien voor de onkosten, die gepaard gingen met hun emancipatie. ${ }^{55}$ Dit voorstel werd uiteindelijk verworpen. De slavernij werd in de WestIndische koloniën in 1863 afgeschaft. Gouverneur Grol hield ter gelegenheid van dit heuglijk feit een korte rede op 1 juli 1863, waarin hij ondermeer zei:

'Van harte wensch ik U geluk met de weldaad door de vaderlyke zorg des Konings $\mathrm{U}$ geschonken; opregt moogt gij $\mathrm{U}$ erin verheugen, maar gy moet $U$ het voorregt wardig betonen.

Hebt gy in uw vorigen staat $U$ reeds onderseheiden door een stil, rustig gedrag en gehoorzaamheidaan uwe voormalige meesters, thans als vrije menschen - ik durf er vast op te vertrouwen - zult gy steeds ordelyk en ondergeschikt aan het bestuur, uwe pligten als ingezetenen der kolonie betrachten, geregeld werkende tegen een billyk loon, waarover gy naar welgevallen kunt beschikken, tot verzorging van Uzelven en de Uwen. ${ }^{\text {ss }}$

In de gehele Verenigde Staten werd de slavernij in 1865 afgeschaft. ${ }^{7}$ Braziliẽ schafte de slavernij pas in 1888 af. In Venezuela werd de slavernij reeds in 1821 afgeschaft. ${ }^{9 n}$ In de West-Indische koloniën

Van Hulzen (1946) pp. 279-282; Rōmer in: Het oog van de meester (1989) pp. 177 210.

2s Op Curaçao deed zich volgens Renkema, het probleem voor dat er voor de groep geërnancipeerdenalleen een hepasald deel van het jaar werk zou zijn. In 1848 dachien gezaghebber Esser en zijn latere opvolger Rammelman Elsevier dat uitbreiding van de cochenilleteelt in werkgelegenheid voor de geëmaneipeerdenzou kunnen voorzien. Ook werd gedacht aan de asnleg van zoutpannen. Het probleem van de werkgelegenheid voor de vrij to laten slaven was bij de afsehafting van de slevernij in 1863 niat opgelosi. De meeste plantage eigenaars slaagden er echter in hun voormalige slaven ann zich te binden door middel van een paga tera overeenkomst (letterijk het betalen van de grond). De geẽmancipeorde mocht zijn huisjc op de plantage blijven bewonen, een perceeltje grond voor eigen gebruik bewerken, hout kappen, houtskool branden en wat kleinvee houden. In ruil hiervoor mocht de plantage eigenaar van de geämaneipeende vragen dat hij logen beloning en of verstrekking van voedsel een asntal dagen per jaar of per week voor hem werkte. Renkema (1981) pp. 149-153. Wet van den Bsten Augustus 1862, Stbl. 165, houdende opheffing der Slavemy op de eilanden Curaçao, Bonaire, Aruba, St. Eustatius, Saba en St. Martin (Ned. Gedeelte), in: Goslinga (1956) pp. 157-164.

Voor een indringende be schrijving van de slaventransporten maar Amerika zie Johnson (1992). De zwarte auteur kneeg voor dit boek de National Book Award. De roman speelt in 1829, getuige het voorwoord is er veel onderzoek voor verricht in zeemansverhalen en scheepvanrigeschiedenissen. berg (1896) en (1901) pp. 165-170. 
werden in totaal 45275 slaven vrijgelaten, waarvan 33621 in Suriname. De tegemoetkoming aan de slaveneigenaren bedroeg dertig gulden per slaaf, behalve op Sint Maarten. Dit kwam het moederland te staan op $f 11.876 .260$,- waarvan $f 9.864 .360$,- voor Suriname ${ }^{59}$ en $f$ 2.011.900 voor de gezamenlijke huidige Nederlands-Antilliaanse eilanden en Aruba. ${ }^{60}$ Volgens het rapport van Gouverneur J.D. Grol van 10 mei 1864 kwamen op de latere Nederlands-Antilliaanse eilanden 11.211 slaven vrij, waarvan op Curaçao 6.684, Aruba 480, Bonaire 758, Sint Eustatius 1.120, Saba 704 en Sint Maarten 1.465. De totale bevolking van deze eilanden bedroeg in deze tijd ongeveer 30.000 zielen. ${ }^{61}$ In Suriname werd de slavernij niet direkt afgeschaft,

Voor een gedegen verhandeling over de slavernij in Suriname zie: Hoogbergen (1992).

Encyclopaedie van Nederlandsch West-Indië (1914-1917) pp. 635-643; Hoetink (1971) pp. 69-169.

Beckers (1991); Goslinga (1956) en (1992); Römer (1977) p. 15; Visman, NWIG, 55, 1981, pp. 39-51. Voor een (kort) sociologisch en helder overzicht van de vele vormen van slavernij in het verleden en de gevolgen daaarvan in de huidige samenleving zie Foner (1969); Genovese (1974); Hayek (1944). Het laatste boek beschrijft 'een nieuwe vorm van slavernij' economische controle en planning en de oorzaken van dictatuur en onderdrukking, nazisme en socialisme. Het is in die zin van belang, dat slavernij, altijd (mede) een economische oorzaak heeft. Hoetink (1971) en (1973); Den Hollander (1966); Knight (1978), het laatste boek bevat een lijst met aanbevolen boeken over het Caraibisch gebied, gedurende de laatste vijfhonderd jaar (pp. 224233); Mōmer (1975), dit boek bevat gedetailleerde geografische karten van de Europese bezittingen aan de West-Afrikaanse Goud-en Slavenkust in de 17de en 18de eeuw; Walvin (1986); Williams (1975).

Op Curaçao bestond tussen 1871-1875 een weekblad en een school gericht op de verheffing en integratie van ex-slaven. Zowel de missie als Civilisado zetten een beschavingsoffensief in van de ex-slaven. Civilisadó keerde zich tegen de disciplinering van de Katholieke kerk. De organisatie trok door middel van haar weekblad Civilisadó, ten strijde tegen vooroordelen, discriminatie en uitbuiting van de ex-slaven door de hogere klassen in de Curaçaose gemeenschap. De redactieleden waren idealisten en hadden een blind vertrouwen in onderwijs en opvoeding. De Katholieke Missie zag in de oprichters van Civilisadó een gezelschap van godloochenaars, die zich vergrepen aan de gekleurde bevolking van het eiland, dus aan de doelgroep van de missie zelf. De blanke Protestanten en de Joodse kooplieden zagen niets in de verheffing van de gekleurde bevolking. In september 1872 werd een eigen school opgericht die particulier werd gefinancierd. De school was bedoeld voor kinderen, warvan de ouders geen schoolgeld konden betalen. Een overheidssubsidie werd in 1874 geweigerd. Op 31 december 1874 verscheen het laatste nummer van Civilisadó. Ook de school werd opgeheven, omdat er geen inkomsten waren. De negers en kleurlingen ondersteunden het initiatief niet wat voornamelijk uitging van buitenlanders. De meer aanzienlijke kleurlingen distantieerden zich van het initiatief, omdat het hen herinnende aan de groep waaruit zij zelf voortkwamen. Bovendien stond in de jaren zeventig van de vorige eeuw vast, dat de niet-blanke populatie zou worden onderwezen door de Rooms-Katholieke Kerk. De kerk had veel macht en oefende censuur uit op alles wat in druk verscheen. Het educatieve beleid van de RoomsKatholieke Kerk werd gekenmerkt door voorzichtigheid, voorbehoud en geleidelijkheid en leerde niet-blanken hun bescheiden plaats in de door God gestelde maatschappelijke orde. Dit werd door de heersende blanke klasse getolereerd; Abraham-van 
zoals op de Nederlandse Antillen, maar werden de 'slaven' nog 10 jaar onder voogdijschap van de staat geplaatst. Dit staatstoezicht was bedoeld de negers te helpen, tot zij in hun eigen onderhoud konden voorzien.

De vrije neger erfde na de afschaffing van de slavernij de sociale en economische positie van de vroegere slaaf. In de stagnerende economie waren onvoldoende posities beschikbaar, maar ook blokkeerde de raciale factor de weg voor de gekleurde bevolking naar de spaarzame posities. De samenlevingen van de eilanden van de Nederlandse Antillen waren in de tweede helft van de 19de eeuw en het begin van de 20 ste eeuw feodale maatschappijen, waar zich sinds de afschaffing van de slavernij geen structurele veranderingen hadden voorgedaan. De Benedenwindse eilanden ondergingen door de contacten met het vasteland een latineringsproces. De Bovenwinden ondergingen door contacten met de Britse kolonies een sterke Engelse invloed.

Het leenstelsel (of feodaliteit) was het Middeleeuwse systeem van levenslange wederzijdse steun van heer en vazal. Het laat Romeinse begrip 'commendatio', waardoor een man als vazal in dienst van een heer trad verbond zich met het Germaanse begrip van trouw tussen heer en gevolg. 'Hominium, fidelitas, beneficium en feudum' bepaalden de onderlinge relatie tussen heer en vazal. Dienst en trouw vormden de rechtsgrond voor het leen, waarvoor de beleende persoonlijke plichten op zich nam. De heer was verplicht zijn vazal te beschermen. Dit hield ook in, dat indien nodig, de heer voorzag in het onderhoud van zijn vazal. De vazal van zijn kant moest de heer bijstaan met raad en daad, in het bijzonder met krijgsdiensten en geld. Om die diensten te kunnen realiseren werd de vazal bekleed met een leen. Als leenman kreeg hij het vruchtgebruik van een landgoed dat bewerkt werd door horige boeren. Ook verkreeg hij lucratieve rechten, zoals bijvoorbeeld het recht van tolheffing. De leenman op zijn beurt kon weer delen van zijn leen in leen geven (achterleen). In beginsel werd de leenverhouding door de dood van een der partijen beëindigd. Het leen kon niet worden overgedragen worden aan derden. In de 9de eeuw werden de lenen echter erfelijk. Sommige vazallen hadden lenen van meer heren. Toen de leen en ambtsleen de facto en de iure erfelijk werden, verdween de oorspronkelijk bedoelde binding van de adel aan de vorst. In de late Middeleeuwen raakte het leenstelsel in onbruik door de opkomst van de nationale

der Mark (1990). 
monarchieēn met hun huurlingenlegers en gesalarieerde bestuursambtenaren. De laatste feodale rechten werden in Europa in de jaren na de Franse Revolutie afgeschaft. ${ }^{62}$

Feodalisme in meer sociologische zin wordt gebruikt voor een type maatschappij waarin zowel economische als culturele verhoudingen en organisatievormen diepgaand beïnvloed worden door de betrekking leenheer-vazal. Zo'n afhankelijkheidsrelatie bestond tussen slaaf en heer. Het verschijnsel van patronage is eveneens daarop gebaseerd. $\mathrm{Er}$ is in een dergelijke samenleving geen sprake van een rechtsstaat maar van een gunstenstaat. Overheidsmiddelen worden gebruikt om trouwe medestanders van een politieke partij te belonen. De overheid deelt privileges uit. Dit kan geschieden in natura of door het verstrekken van werkgelegenheid bij de overheid. ${ }^{63}$

Zoals hierboven gesteld brachten ook de olie-industrie en het toerisme aan het begin van de twintigste eeuw welvaart, maar de ingebakken feodale verhoudingen verdwenen niet in hetzelfde tempo. $\mathrm{Na}$ de afschaffing van de slavernij waren de slaven weliswaar vrij, maar zij behielden hun lage status binnen de maatschappij. Het bleef moeilijk voor de kleurling of de zwarte om door te dringen in de middenklasse en blanke toplaag. Sommigen zou dat lukken, maar voor de gekleurde en zwarte bevolkingsgroep als geheel bleef verbetering van hun omstandigheden een groot probleem.

Deze achterstelling in hun maatschappelijke positie zou in mei 1969 tot opstand en plundering en brandstichting in Willemstad leiden. Toen staakten 4000 arbeiders voor betere arbeidsvoorwaarden. Op grond van het Statuut van 1954, was Nederland verplicht mariniers te zenden om de orde te herstellen. Deze ingreep in het bestuur van een 'autonoom' land leverde Nederland internationaal ernstige afkeuring op. Hierdoor zou Nederland besluiten dat de voormalige koloniën onafhankelijk moesten worden. Deze politiek zou Nederland 20 jaar lang volhouden. Pas in 1990 zou daar verandering in komen.

De overblijfselen van een feodale maatschappij oefenen nog steeds grote invloed uit in de vorm van het huidige politieke patronagesysteem in de Nederlandse Antillen en Aruba, zoals hierna in hoofdstuk VI nog uitgebreid uiteengezet zal worden. Zoals nog zal blijken zou door het 'verstrekken' van overheidsfuncties het tekort

\footnotetext{
62 Voor een uitgebreide toelichting op het leenstelsel zie: De Monté ver Loren en Spruit (1982) pp. 41-52, 67, 97-106, 107, 109, 259.

63 Klomp (1986); Boissevain (1978); Bax (1976); Friends, Followers and Factions, pp. 1-15, 220; Galjart (1992) pp. 48-63.
} 
van de Arubaanse overheid bij het aanbreken van de Status Aparte in 1986 onverantwoord toenemen. Deze situatie zou het IMF aanleiding geven om Aruba in 1985 te adviseren de overheidsdiensten te rationaliseren en 800 overheidsdienaren met de VUT te laten gaan. Aanzienlijke besparingen werden gerealiseerd, thans (1994) is de situatie als voorheen en zouden opnieuw grote aantallen ambtenaren moeten afvloeien. Op de Nederlandse Antillen doet zich bij de Landsoverheid eenzelfde situatie voor.

Ook is er in de huidige maatschappij sprake van een subtiel racisme, dat selectief werkt bij de sociale mobiliteit. Römer ziet de oplossing in een radicale culturele heroriëntering en integratie in de eigen regio. ${ }^{64}$

Ten slotte moge nog worden opgemerkt dat de omschrijving van het zwarte ras in de loop der jaren is gewijzigd. Ten tijde van de slavernij werd gesproken over blanken en negers. De benaming 'neger' van mensen die tot het zwarte ras behoorden had een negatieve connotatie en is sinds de jaren zestig van deze eeuw in onbruik geraakt. Wel werd als tussenoplossing nog gesproken van het 'negroïde' ras. ${ }^{65}$ Ook die terminologie is echter in onbruik geraakt, onder invloed van de 'Black Power' beweging aan het begin van de jaren zeventig. Thans is het gewoonte om te spreken van het zwarte ras. Behorend tot dat ras zijn alle personen die in etnisch opzicht een Afrikaanse origine hebben. Deze benaming is echter niet zozeer van toepassing op de iemands huidskleur maar duidt veel meer een identiteit aan.

Omdat de nieuw ontdekte kolonies in cultuur moesten worden gebracht waren goedkope arbeidskrachten nodig. Dit waren eerst de Indianen. Toen echter een theologische commissie in Spanje had besloten dat Indianen een ziel hadden en daarom niet in slavernij mochten worden gebracht, werden zwarte slaven uit Afrika aangevoerd. De Republiek en de WIC speelden een belangrijke rol in de slavenhandel.

os Hoetink deelde mij bij brief van 20 december 1991 het volgende mee: "Het woord 'zwart' was in die tijd [bedoeld wordt: na de opstand in Willemstad van 1969] nog niet aanvaardbaar, de benaming 'neger' was niet meer aanvasrdbaar in rapporten, vandaar dat het rapport van de Commissie [bedoeld wordt: de Commssie Römer (1970)], evenals Boeli van Leeuwen dat doet in zijn publikaties aan het begin van de jaren zeventig, spreekt van de 'negroide bevolking'." 
Ook de Nederlanders behandelden in hun koloniën de slaven niet als mensen, maar als koopwaar. De slavernij in de latere Nederlandse Antillen was minder afschrikwekkend dan in koloniën met een plantage-economie zoals Suriname, maar heeft desondanks grote invloed gehad op de bestuursstructuur in de kolonie. De sterke segmentatie in de koloniale maatschappij, mede onder invloed van de slavernij heeft de maatschappelijke en politieke verhoudingen tot op de dag van vandaag in sterke mate beïnvloed. Opvallend is dat geen enkel Nederlands staatsrechtelijk werk van enige importantie aandacht heeft besteed aan de slavernij en de gevolgen daarvan voor de Caraibische delen van het Koninkrijk. De Nederlandse slavenhandel en de slavernij in de Nederlandse koloniēn zijn nimmer systematisch in een staatsrechtelijke context beschreven.

Dat is enerzijds wel begrijpelijk, omdat slavernij een privaatrechtelijk onderwerp is en geen staatsrechtelijk onderwerp. De slavernij heeft echter wel een diepgaande invloed gehad op de staatkundige en politieke ontwikkelingen binnen de koloniale- en post-koloniale maatschappij. Tot op heden is de slavernij alleen besproken door sociologen, antropologen en politicologen, maar niet door (staatsrechtelijke georiënteerde) juristen.

Deze donkere bladzijde in de Nederlandse staatkundige en bestuurlijke geschiedenis wordt blijkbaar angstvallig vermeden. De bovenstaande uiteenzetting beoogt enig licht op die donkere bladzijde te werpen.

De slavenhandel en slavernij duurden driehonderd jaar en hadden een diepgaande invloed op de koloniale maatschappij, waardoor onderscheid naar kleur en de daarmee vaak samenhangende functie en status, bepalend werd. Economische oorzaken leidden tot de slavernij en de slavenhandel en waren onontbeerlijk voor de kolonisatie van de Nieuwe Wereld. De slavernij was tot de 9de eeuw in Europa een algemeen bekend verschijnsel.

De Franse filosofen hebben grote invloed uitgeoefend op de ontwikkeling van het westerse staatsbestel. De vrijheid die zij voor ieder individu propageerden, bleek voor wat de slaven in de koloniën betrof nauwelijks te gelden.

De stelselmatige negatie van (de gevolgen) van de slavernij in zowel de privaatrechtelijke - als staatsrechtelijke - handboeken geeft mijns inziens blijk van een ethisch vacuüm. De interpretatie met betrekking tot art. 2 BW lid 2 (1838) is van die omissie een saillant voorbeeld. De Nederlandse wetgever duldde sinds 1838 geen slavernij meer binnen het rijk, hiermede werd kennelijk alleen beoogd de horigheid in Nederland af te schaffen. Maar horigheid was duidelijk 
wat anders dan slavernij en echte horigheid bestond na 1300 niet meer in Europa. Dus golden de omschreven burgerrechten geformuleerd onder invloed van de Verlichting en uitgedragen na de Franse revolutie alleen voor de blanken binnen het rijk in Europa en voor de blanken in de kolonie. De zwarte bevolking had in de opvatting van de wetgever blijkbaar geen recht op de die voor 'iedere burger' geldende rechten.

$\mathrm{Na}$ de Franse revolutie volgde een herbezinning op het instituut van slavernij. Pas na de slavenopstanden in 1795 op Curaçao, onder invloed van de Franse revolutie, werd enige aandacht besteed aan de leefomstandigheden van de slaven. De ergste wreedheden werden verboden. De slavenreglementen waren echter meer gericht op het handhaven van orde en tucht, dan op het verzekeren van minimale rechten voor slaven. Slaven hadden plichten, maar nauwelijks rechten.

Op grond van de evaluatie-criteria kan worden gesteld dat de invloed van het Nederlands bestuur op het bestuur van de kolonie, in de besproken perioden, overheersend was en bleef. Duidelijk zal zijn dat niet alle evaluatie-criteria op dit onderdeel van de staatkundige geschiedenis kunnen worden gehanteerd. De opbouw van de staatsorganen hield direct verband met het in cultuur brengen van de koloniën en was gericht op het economisch belang van de kolonie voor Nederland. De binding van de staat aan het recht bleef gegrond op het octrooi, de wetgeving vanuit Nederland en de richtlijnen van de Heren XIX of de Heren X. De overheidsmacht bleef in é́n hand, te weten de Raden van Politie (later Koloniale Raad). Het zoeken van het juiste evenwicht tussen ordening van de samenleving en individuele vrijheid was niet aan de orde, zeker niet wat betreft de slaven.

$\mathrm{Zij}$ vielen onder andere regelingen dan de blanken en Indianen. Slaven waren kostbare zaken en geen personen, dus konden niet als zelfstandig rechtssubject optreden, om hun belangen te verdedigen. Regelingen om hun positie te verbeteren werden pas ingevoerd tegen het einde van de slavernij. Op de slaven was met name het Romeinse recht van toepassing en de lokale slavenreglementen. Er was nog geen sprake van het concipiëren of naleven van de mensenrechten in de koloniën. Ook de rechtsbescherming van de slaaf ten opzichte van zijn meester en van de overheid bestond nauwelijks.

In de koloniale maatschappij stonden slaven (zwarten en kleurlingen) onderaan de maatschappelijke ladder. Klasse was synoniem aan kleur. De invloed van de slavernij versterkte die onderlinge verschillen. Slaven hadden uiteraard geen invloed in het bestuur.

Van het zoeken naar het juiste evenwicht tussen ordening van de 
samenleving en individuele vrijheid was, wat de slaven betreft geen sprake. Dit concept was echter in zijn algemeenheid ten tijde van de slavernij voor de meeste burgers onbekend. De blanke protestantse bestuursambtenaren en de handelselite regeerden de facto de kolonie. De invloed van de slavernij bij de toekenning van politieke rechten, plichten en privileges zou lang doorwerken, leidende politici zijn in het Caraibisch gebied tot op de huidige dag in overwegende mate licht van kleur. In de maatschappij wordt een lichte huidskleur ook nu nog veelal als een 'asset' beschouwd en een donkerder kleur als een 'liability', alhoewel dat zelden hard op wordt uitgesproken.

Feitelijk kan het machtsverschil gepaard gaande met kleurverschil ook nu nog worden waargenomen in de dagelijkse betrekkingen tussen mensen in een voormalig koloniale maatschappij. 



\section{De periode van koloniale stabilisa- tie 1865-1936 (VI)}

In het nu volgende hoofdstuk wordt de periode vanaf het Regeringsreglement van 1865 tot 1936 (periode VI) en de periode vanaf 1936 tot de Tweede Wereldoorlog beschreven. Het Regeringsreglement van 1865 wordt uitvoerig toegelicht.

Tevens komt de regeling van de rechtspraak aan de orde, eindelijk wordt een onafhankelijke rechtspraak ingevoerd in de kolonie. De overeenstemming van de wetgeving tussen Nederland en de kolonie (concordantie) wordt besproken.

De banden van de kolonie met opstandelingen in Venezuela leidde regelmatig tot diplomatieke incidenten. Dit had zelfs tot gevolg dat Nederland overwoog de kolonie te verkopen aan Venezulea.

De Grondwet van 1922 voorzag in meer invloed van de bevolking in het bestuur van de kolonie. De Commissie Staal bracht in verband daarmee een rapport uit tot uitvoering van de Grondwetsherziening van 1922 en tot wijziging van het Regeringsreglement van 1865. Deze ontwikkelingen die uiteindelijk pas geconcretiseerd werden in de Curaçaosche Staatsregeling van 1936, worden uitvoerig behandeld, evenals de Curaçaosche Staatsregeling zelf.

Ruime aandacht wordt besteed aan het ontstaan van politieke partijen en de daarmee samenhangende patronage.

Bij wet van 31 mei 1865 werd het Regeringsreglement (RR) van 1865 vastgesteld. ${ }^{1}$ Hiermede werd eindelijk uitvoering gegeven aan bet bepaalde in art. 59 lid 2 van de Grondwet van 1848, dat de StatenGeneraal inschakelde bij het koloniale beleid en medezeggenschap gaf aan de lokale organen. Terwijl het Regeringsreglement van 1848 slechts uit 63 artikelen bestond, omvatte dat van 1865 niet minder dan 190 artikelen. Het Regeringsreglement van 1865 was geènt op de Nederlandse Grondwet van 1848, hetgeen uit de indeling en het opnemen van grondrechten blijkt. Wetgeving en rechtspraak zouden zoveel

$1 \quad$ Stb. 54, PB 1865, 8. 
mogelijk overeenkomstig de in Nederland geldende wetten, door koloniale verordeningen worden geregeld (art. 138). Invoering van de nieuwe wetgeving, waarbij het oude Romeins-Hollandse recht verlaten werd, had te middernacht tussen 30 april en 1 mei 1869 plaats.

Een nieuw instituut dat in 1865 zijn intrede deed in het Regeringsreglement was de Raad van Bestuur, (Hoofdstuk III, de artt. $58 \mathrm{t} / \mathrm{m}$ 66) die als adviserend college, de Gouverneur bijstond in de uitoefening van de uitvoerende macht. Deze Raad bestond uit de Gouverneur als voorzitter, een ondervoorzitter (tot 1901 was dit de ProcureurGeneraal) en drie door de Koning benoemde leden (art. 58). De Raad van Bestuur bestond voornamelijk uit door het moederland uitgezonden hoofdambtenaren, terwijl de Koloniale Raad veelal bestond uit de lokale elite. De Koloniale Raad beraadslaagde over de verordeningen door de Gouverneur aangeboden. De West-Indische gebieden verkregen nu voor de eerste keer een medewetgevend orgaan, in Curaçao: de Koloniale Raad (Hoofdstuk IV, de artt $67 \mathrm{t} / \mathrm{m} \mathrm{98),}$ waarin de leden van de Raad van Bestuur ambtshalve zitting hadden. Acht van de dertien leden van de Koloniale Raad werden door de Koning benoemd (art. 67). De zittingstermijn bedroeg vier jaren (art. 72). De leden van de Koloniale Raad werden niet gekozen door de plaatselijke bevolking. Ook de bevolkingen van de andere eilanden hadden geen invloed op de samenstelling van de Koloniale Raad. Hier deden zich reeds de vraagstukken voor met betrekking tot de samenstelling van de volksvertegenwoordiging en autonomie, die zich voortsleepten tot in de jaren vijftig van deze eeuw en verschillende wijzigingen in de Regeringsreglementen tot gevolg hadden.

Ook Suriname kreeg een medewetgevend orgaan, de Koloniale Staten, waarvan 9 van de 13 leden gekozen werden. ${ }^{2}$ Dit verschil was ontstaan omdat Curaçao een negatief advies had uitgebracht met betrekking tot de invoering van het kiesrecht. Argumenten die werden

Da Costa Gomez (1935) pp. 44-47; Bordewijk (1914)p. 259. Omdat Curaçao in 1682 geen octrooi was geschonken, zoals Suriname wel had gekregen, werd de kolonie Curaçao niet als een volksplanting gezien bij de behandeling van het wetsontwerp voor het Regeringsreglement van 1865. Da Costa Gomez konstateert terecht dat daar waar de Grondwet in 1848 voor het Nederlandse staatsrecht 'een uitsluitend door den Koning benoemd vertegenwoordigend lichaam afschaft, de wet van 1865 voert zulk een lichaam het Curaçaosche staatsrecht binnen' (p. 47). Door de nationaliteitswetgeving van 1892 worden de bewoners van de West-Indische koloniën staatsburgers. Door deze wet werd Nederiand met Curaçao en Suriname één staatsgebied. De uitoefening der staatsburgerschapsrechten vinden evenwel een territoriale beperking met betrekking tot dit gebiedsdeel, door prerogatieven van de Kroon (p. 49). 
aangevoerd waren: de bevolking is er niet rijp voor, het leidt tot onrust en tweespalt, de verbindingen tussen de eilanden zijn slecht, mogelijke dominantie van Curaçao over de andere eilanden, onvoldoende geschikte personen om als afgevaardigden te fungeren en onvoldoende ingezetenen, die voor een redelijk censuskiesrecht in aanmerking komen. Kasteel haalt Hamelberg aan, die van mening was, dat het verlangen naar kiesrecht toe te schrijven was aan ontevredenheid, vooral onder de handelsstand, met de Koloniale Raad, die zijn goedkeuring had gehecht aan te hoge opvoering der uitgaven en daarna ten einde de begroting voor 1895 sluitend te maken zonder 'weer een beroep te doen op Nederlands schatplichtigen', wetsontwerpen tot verhoging der belastingen had aangenomen. Hamelberg vervolgde:

'Meer dan ooit praat thans de een het den ander na; geef ons het recht, onze leden van den K.R. zelf te kiezen; geef ons meer invloed op de behartiging onzer eigen zaken, en de koloniale geldmiddelen zullen beter beheerd en het welzijn der kolonie beter bevorderd worden.

Thans bemoeien de zwarten zich niet met politiek en vragen ook niet om inmenging in regeeringszaken. $\mathrm{Zij}$ leiden een onbezorgd leven, dankbaar voor de orde en rust, die hunne veiligheid van persoon en goederen verzekeren. Doch wijs hun eenmaal den weg, en zij zullen dien betreden. In het begin zullen zij wellicht hunne stem uitbrengen op die blanken of kleurlingen, welke hun door de R.K. geestelijkheid aangewezen worden, of op hen, die er werk van maken, hunne gunst te winnen. Spoedig zullen zij zich echter van hunne macht bewust worden: zij hebben Haïti voor oogen, en zullen zeer goed begrijpen, dat wat dár gedaan werd, ook op Curaçao gedaan kan worden [......]

Het toekennen van het recht tot inmenging in regeeringszaken, waarom hij [de zwarte] niet vraagt, zal hij beschouwen als een teeken van onbekwaamheid in de blanken, om hem verderte blijven besturen [....] Hij zal zich spoedig voorstellen dat het overwicht der blanken slechts op traditioneele ondergeschiktheid zijnerzijds berust [....] De vrijheid, die hij aan Nederland dankt, zal hij zich slechts herinneren met een gevoel van geleden onrecht. ${ }^{3}$

De Minister antwoordde in 1864 :

'waarom aan de ingezetenen van Curaçao alle kiesrecht zal worden onthouden? Het antwoord hierop wordt gegeven door de stellige verklaringen van den Gouverneur en den Kolonialen Raad aldaar, die uit den eigenaardigen toestand van dat eiland en van zijne bevol- 
king, in verband met de voortdurende woelingen in de naburige republieken het besluit trekken en door krachtig vertoog aandringen, dat geen geschenk noodlottiger zou zijn dat dit. Tegenover deze verklaring ware het gewaagd, nu reeds aan die kolonie instellingen te willen opdringen, die altoos later wanneer de publieke geest meer zal zijn ontwaakt en gevormd, zich in het voorgedragen stelsel gemakkelijk zullen laten invoegen. ${ }^{4}$

De eerste Memorie van Toelichting op het wetsontwerp tot wijziging van het Regeringsreglement bracht een saillant punt naar voren:

'Geen andere band houdt hen [de West-Indische eilanden] vereenigd dan de gemeenschappelijke onderhoorigheid aan den Nederlandschen Staat. Eerst sedert betrekkelijk korten tijd maken zij tezamen éen gouvernement uit. Tot de zamenvoeging van al de West-Indische bezittingen onder eenen Gouverneur-Generaal in 1828, had de groep der zoogenaamde bovenwindsche eilanden Eustatius, St. Martin en Saba een eigen gouverneur. De tegenwoordige inrigting, waarbij zij aan het gezag van den gouverneur van Curaçao onderworpen zijn, dagteekend van 1845."

Vervolgens werd de bezwaarlijkheid aangegeven van het zenden van een vertegenwoordiger van de eilanden naar de Koloniale Raad, als men al iemand zou vinden die geschikt is zouden er hoge reiskosten verbonden zijn aan het bijwonen van de vergadering. Bovendien hadden de andere eilanden niets gemeen met Curaçao en zouden er nauwelijks kiesgerechtigden te vinden zijn op de eilanden daar vrijwel niemand de $f 10$,- voor directe belastingen kan opbrengen, die vereist was om te mogen stemmen.

De MvT lichtte het standpunt toe, zonder omhaal van woorden:

'De Koloniale Raad aldaar [in Curaçao], over het ontwerp van 1855 geraadpleegd, heeft zich op de krachtigste wijze daartegen verzet. "Een algemeen kiesregt", zoo leest men in zijn advies, "tot het benoemen van afgevaardigden die beraadslagen moeten over de algemeene belangen van Staat en huishouding, biedt onmiskenbaar de meeste waarborgen die de burger eischen kan, dat de algemeen belangen der ingezetenen warme behartiging zullen vinden. Zal echter dat doel bereikt worden, dan moet er allereerst volksgeest zijn, vaderlandsgezindheid, kennis der algemeene belangen, en dat alles, opdat a priori, zoo al niet met zekerheid, dan toch vermoeden besta, dat de kiezer in zijne keuze en de gekozene in zijne functien het gemeene best bovenaan zullen stellen. In het heden en in een lang

\footnotetext{
$4 \quad$ Bordewijk (1914) p. 214.

s De Gaay Fortman, De WIG, 4, $1922 / 1923$ pp. 533-552 en 537, 6, 1924/1925 pp. 535-560.
} 
verschiet in de toekomst is van dat alles hier niets te wachten. De bevolking, wat den oorspronkelijken landaard van de individuen betreft, is eene agglomeratie uit de meest uiteenlopende bestanddeelen. De groote massa daarvan bezit de eigenschappen niet, die gevorderd worden.

Het eigenlijk Nederlandsch element, met opzigt tot den oorsprong, is verre het kleinste, daarbij door fortuin het minst begunstigde. Bij eventuele emancipatie van de slaven wordt het verschil in verhouding nog grooter. Bij dit alles is het gros der bevolking niet rijp voor de zaak, en wat wel het meeste afdoet, zij wordt door niet éen, althans door de menigte zeker niet, begeerd. ${ }^{6}$

Om te voorkomen dat moeilijkheden ontstonden, was het volgens de MvT beter, dat de Koning de leden van de Koloniale Raad zou benoemen, daar het kiezen van het overkoepelend college ook niet kon worden overgelaten aan de bevolking van Curaçao. De Gouverneur erkende de bezwaren van de Koloniale Raad:

'Hoe meer ik toch dat gewigtige punt heb overwogen - verklaarde hij, - hoe meer ik in de overtuiging bevestigd ben, dat de bevolking dezer kolonie nog niet rijp is voor zelfregering en dat ik mij van een Kolonialen Raad op de thans voorgestelde wijze voor de kolonie meer heil voorstel dan eene zelfregering haar zou kunnen aanbrengen.'

De MvT vermeldde verder: 'De Regering heeft dus gemeend voor de locale bezwaren te moeten bukken aan het verlangen van de Kolonialen Raad voldaan. Trouwens de wijze van zamenstelling van dien raad, hoe gewigtig het punt zij, is niet alles. De raad zal voortaan niet meer bloot adviseren, maar handelen en mede regeren. $\mathrm{Hij}$ zal het doen in het openbaar. De publieke meening zal hem in een vrije drukpers beoordeelen. Daarin bezit men sterke waarborgen. Gelukt de proef in Suriname waar de omstandigheden gunstig zijn te noemen, en openbaart zich dan bij de bevolking van Curaçao en der andere eilanden een waarachtige zucht naar regtstreeksche deelneming in de verkiezing harer vertegenwoordigers, de tijd zal geboren zijn om aan dien wensch te voldoen. ${ }^{7}$

In de Algemene Beschouwingen gaf de regering nog eens aan waarom aan Curaçao geen vertegenwoordigend orgaan kon worden toegestaan, te kiezen door de ingezetenen: minstens vijf leden zouden moeten worden gekozen door de kiesgerechtigden, meende de regering. 'Maar op twintig duizend zielen zijn niet meer dan vijf-en-twintig kiezers te vinden, die voldoen aan de eisen van een mannen-census kiesrecht.

6 Bordewijk (1914) pp. 215, e.v; zie ook de rede over het recht op vrije verkiezingen van Da Costa Gomez in de Staten van 20 december 1938 in: Jesurun e.a. (1993) pp. 22-34

$7 \quad$ Bordewijk (1914) pp. 216 e.v. 
Dergelijke cijfers spreken sterker dan alle redenering.' De regering achtte het verder niet juist een splitsing aan te brengen tussen het algemeen en plaatselijk bestuur op Curaçao. ${ }^{8}$ De keuze voor het benoemen van de leden van de Koloniale Raad werd door de regering nog eens nader onderbouwd in de MvA van 25 januari 1894:

\begin{abstract}
'Aan de leden, die het zonderling noemden dat op het eiland Curaçao de leden van de Kolonialen Raad door den Koning werden benoemd, terwijl op de eilanden Aruba, Bonaire, St. Martin, Sint Eustatius en Saba de landraden door de stemgerechtigde ingezetenen worden gekozen, zou de ondergeteekende willen vragen of zij wel genoeg gelet hebben op het verschil tusschen de functiën van den Kolonialen Raad en van de landraden.

De landraden vormen met den gezaghebber het plaatselijk bestuur op een eiland; de Koloniale Raad daarentegen werkt voor de gehele kolonie. Liet men de leden van de Kolonialen Raad kiezen door den ingezetenen van het eiland Curaçao, de ingezetenen der andere eilanden zouden zich niet zonder reden er over beklagen dat aan een deel der kolonie eene soort van suprematie over de andere deelen gegeven werd. En tegen eene samenstelling van den Kolonialen Raad door verkiezingen op alle eilanden doen zich practische bezwaren gelden.' 9
\end{abstract}

Wel werd de bevoegdheid van de Koloniale Raad in 1865 uitgebreid met de volgende rechten; het petitierecht (art. 96); het recht van initiatief (artt. 93, 94); $;^{10}$ het recht van amendement (art. 90) en het interpellatierecht (artt. 97 en 98). Bovendien zou de Raad voortaan in het openbaar vergaderen (art. 81).

De Koloniale Raad was geenszins tevreden met het bestaande stelsel. De klacht betrof niet de samenstelling van de Raad, maar de begrenzing van zijn bevoegdheden. In 1901 werd het Regeringsreglement gewijzigd. '[....] dien smet van onrijpheid dien men op de inboorlingen van Curaçao heeft gelegd' werd eindelijk weggenomen. ${ }^{11}$ De 13 leden van de Koloniale Raad zouden in het vervolg alleen uit burgers bestaan. De leden van de Raad van Bestuur zouden niet meer ambtshalve lid zijn van de Koloniale Raad. De Raad van Bestuur kan gezien worden als voorloper van de Raad van Advies en de Koloniale Raad als de voorloper van de Staten van de Nederlandse Antillen. ${ }^{12}$

\footnotetext{
Bordewijk (1914) pp. 225 e.v.

Bordewijk (1914) p. 292.

Kasteel (1956) p. 20.

Bordewijk (1914) p. 303.

Sjiem Fat (1986) pp. 18-21.
}

146. De periode van koloniale stabilisatie 1865-1936 (V) 
In de periode 1865 -1936 kon slechts gesproken worden van een surrogaat-autonomie in de kolonie Curaçao. De artikelen 49 (repressief toezicht) en 50 (preventief toezicht) van het Regeringsreglement van 1865 lieten de Nederlandse regering het recht een doorlopend toezicht uit te oefenen op de verordeningen die in Curaçao uit de samenwerking van Gouverneur en Koloniale Raad tot stand kwamen. Aan de Regering werd de gelegenheid geboden in te grijpen door de bepaling dat een koloniale verordening in het algemeen, niet in werking trad, dan nadat de minister had doen weten dat hij er zich mee kon verenigen. Althans dat hij ze niet voor vernietiging voordroeg of wel nadat zes maanden waren verlopen sinds van die verordening aan de minister kennis was gegeven. De Regering had dus feitelijk het recht, de regeling van vrijwel elk onderwerp aan zich te trekken en bij AMvB te regelen. De Gouverneur was slechts verantwoording verschuldigd aan de Koning (art. 21). ${ }^{13}$ Artikel 48 van het Regeringsreglement voorzag in het vervallen van de landsverordening, als dezelfde materie geregeld werd door een wet of een AMvB. Reeds bij de totstandkoming van deze bepaling in 1865 achtte de Raad van State die in strijd met de toekenning van autonomie aan de kolonie. ${ }^{14}$

Het Regeringsreglement van $1865^{15}$ voorzag in een vorm van lokaal bestuur voor alle eilanden, behalve Curaçao. De Minister van Koloniën, Fransen van der Putte meende dat dit laatste niet nodig was met het centrale bestuur gevestigd op Curaçao. De Gouverneur en de Koloniale Raad moesten dus zowel de belangen van de gebele Kolonie behartigen als de plaatselijke belangen van Curaçao.

Op de andere eilanden kwamen de Raden van Politie tot stand, bestaande uit een benoemde Gezaghebber, of onder-Gezaghebber en twee door middel van een beperkt mannen-kiesrecht gekozen Landra-

Paula (1989) pp. 9-11; De Gaay Fortman (1947). Wet van den 31 sten Mei 1865, houdende vaststelling van het reglement op het beleid der regering in de kolonie Curaçao, Stb. 1865, 56. Zie over de totstandkoming en de behandeling in de StatenGeneraal: Bordewijk (1911) pp. 71-136; zie ook Da Costa Gomez. (1935) pp. 70 e.v.; zie voorts Kasteel 1956, in noot 32 op p. 13 vermeldt zij alle wijzigingen met vindplaatsen van het Regeringsreglement van 1865. De Gaay Fortman (1947) p. 9; Luiten (1981) pp. 5 e.v.

is Het eerste hoofdstuk van het RR bevatte bepalingenover het grondgebied der kolonie, toelating en uitzetting van personen, de vrijheid van drukpers en het recht van petitie en dat van vereniging of vergadering. Het tweede hoofdstuk regelde de positie van de Gouverneur. Hoofdstuk drie regelde de bevoegdheden van de Raad van Bestuur en hoofdstuk vier de taken en bevoegdheden van de Koloniale Raad. Hoofdstuk vijf regelde het bestuur van de verschillende eilanden, hoofdstuk zes 'het regtswezen', hoofdstuk zeven de godsdienst, hoofdstuk acht 'de financien', hoofdstuk negen, 'de gewapende magt', hoofdstuk tien het onderwijs, de openbare gezondheid en het armbestuur en hoofdstuk elf de volksvlijt. 
den. De bevoegdheden van de Raden van Politie waren gering. Het Regeringsreglement omschreef de taken limitatief. De Raden mochten plaatselijke keuren maken, maar veel hield dat niet in. Er mochten in die keuren alleen maar voorschriften worden gegeven in het belang van de openbare orde, zedelijkheid en gezondheid. De redactie van art. 129 Regeringsreglement was veel beperkter dan het daarmee verwante artikel 168 uit de Gemeentewet. Bovendien moesten de plaatselijke keuren goedgekeurd worden door de Gouverneur (art. 130).

Naast de beperktheid van de bevoegdheden en de zware vorm van toezicht was er nog een derde factor op grond waarvan gezegd kon worden dat deze vorm van decentralisatie, een vederlichte was. De eilanden buiten Curaçao waren namelijk financieel afhankelijk van het centraal gezag. Een eigen belastinggebied voor de eilanden bestond niet en de begroting kende geen budgetten toe aan de eilanden. Alle uitgaven werden ad hoc aan de eilanden toegekend. Het plaatselijke bestuur stelde tot 1936 weinig voor. De Gouverneur door de Kroon benoemd, bestuurde als vertegenwoordiger van de Koning de kolonie en was met de uitvoerende macht bekleed. Hij had het opperbevel over de in de kolonie aanwezige krijgsmacht (art. 30). Hij benoemde en ontsloeg ambtenaren (art. 35), verleende gratie (art. 39) en stelde na goedkeuring door de Koloniale Raad verordeningen vast (art. 46). Eveneens vaardigde hij, na de Raad van Bestuur te hebben gehoord, besluiten houdende algemene maatregelen, ter uitvoering van wetten, uit (art. 54).

Belangrijk voor het zelfbestuur was dat het Regeringsreglement van 1865 de Adviserende Commissie ${ }^{16}$ verving door de Raad van Politie en dat beperkt stemrecht op de onderhorige eilanden werd ingevoerd. Behalve Curaçao werden alle eilanden bestuurd door Gezaghebbers, die door de Koning werden benoemd (hoofdstuk V: Van het bestuur der verschillende eilanden, de artt. $107 \mathrm{t} / \mathrm{m} \mathrm{136).} .^{17}$

Artikel 31 van het Regeringsreglement van 1848 regelde dat de Gezaghebber van elk eiland een adviserende Commissie kreeg toegevoegd van twee ingezetenen, die op zijn voordracht door de Gouverneur werden benoemd.

17

Opmerkelijk is dat Van Kol zich op bij de beraadslagingen in de Tweede Kamer afvroeg, waarom de Bovenwinden en Benedenwinden in één bestuurlijk verband zouden moeten worden opgenomen. Als grootste bezwaar zag hij dat door de samenvoeging in 1845 Curaçao de andere (armlastige) eilanden moest onderhouden. Van Kol meende dat Nederland de noodlijdende eilanden zou moeten steunen en hen verplichten zo spoedig mogelijk zichzelf te redden. Het gaat niet aan 'dat een overschot op een goed beheerd eiland worde opgeslurpt door het wanbeheer van een ander eiland.' Tevens raadde hij asn ambtenaren minder pompeuse titels te geven en niet te hoge traktementen te betalen. Tegen de scheiding van de Bovenwinden en Benedenwinden pleitte de extra kosten van adminstratie en beheer, volgens minister Cremer. Bordewijk (1914) pp. 549-553. Gelijkluidende financiële motieven waren 
Elke Gezaghebber werd bijgestaan door twee Landraden, die door de stemgerechtigde ingezetenen gekozen waren voor 4 jaar (de artt. $117,118)$. Een koloniale verordening regelde het actieve en passieve kiesrecht voor elk eiland. Het kiesreglement uit 1899 bepaalde dat mannelijke inwoners ouder dan 25 jaar die beschikten over de burgerrechten en onroerende goederen ter waarde van $f 500,-$ ofwel een bepaald militair, ambtelijk of wetenschappelijk verleden hadden de Landraden mochten kiezen. Om de twee jaren trad én Landraad af, die terstond herkiesbaar was. ${ }^{18}$ De landraden vormden samen met de Gezaghebber de Raad van Politie van het betrokken eiland. De Raad kon 'kleine keuren en verordeningen van policie' uitvaardigen, maar deze eerst ter goedkeuring moest voorleggen aan de Gouverneur (art. 130). De Raad van Politie moest jaarlijks een ontwerp-begroting opstellen, maar de Gouverneur paste deze in de centrale begroting van de kolonie. ${ }^{19}$ Evenals de autonomie van de kolonie ten opzichte van het moederland stond de autonomie van de eilanden ten opzichte van het koloniaal bestuur regelmatig ter discussie. In de hoop dat dit tot besparingen zou leiden pleitten zelfs Nederlandse parlementariërs herhaaldelijk voor decentralisatie. Curaçao verdiende een eigen bestuurslaag omdat dit eiland voldoende financiële draagkracht had. In 1917 werd decentralisatie voor Aruba bepleit, opdat de eigen inkomsten van het eiland in hoofdzaak zouden kunnen worden gebruikt voor de voorziening in eigen behoeften. Omdat dit plan de steun van de ministers, Gouverneurs en Gezaghebbers ontbeerde werd het niet geëffectueerd. ${ }^{20}$

\section{Decentralisatio}

Van Kol, Tweede Kamerlid, maakte zich steeds sterk voor een staatsrechtelijk gelijkwaardige positie van de koloniën binnen het Koninkrijk. Hij ergerde zich aan de vele wijzingen van het Regeringsreglement van 1865 , hetgeen de democratie voor de koloniēn niet dichterbij bracht. Tijdens de Algemene beschouwingen op 14 november 1900 werd hij als volgt geciteerd:

ook in 1993 de belangrijkste reden waarom Curaçao een aparte status wenst.

Plante Fébure (1918) p. 163.

19 Bordewijk (1914) pp. 212, 215-217, 222 e.v., 225 e.v., 228 e.v., 257, 285-288, 288a, 292-307, 570; Bordewijk (1911) pp. 9, 67, 258.

20 Plante Fébure (1918) pp. 134 e.v., 146, 178; De Gaay Fortman, De WIG, 4, 1922/1923 p. 545. 
'Hij was van meening dat zij niet waren een kloeke daad van een vooruitstrevend hervormer, doch een geknutsel om een reeds zo oud wetsontwerp, dat driemaal aan de orde gebracht was, nl. in 1892 , 1896 en 1898, thans van de baan te schuiven. Er bleek geen gevoel voor democratie aanwezig; het wetsontwerp was niets dan borduurwerk op een autocratisch stramien en getuigde eerder van redactie dan van werkelijken vooruitgang.

Waar blijft het streven naar decentralisatie? Immers er doet zich een toenemende inmenging van het Moederland gevoelen. Zelfbestuur voor de Kolonie was tot op heden een fictie: Nederland stelt jaarlijks de begrooting vast tot in details. Art. 46 R.R. maakt de Koloniale Staten eenvoudig machteloos, daar de Minister een maatregel der Koloniale Staten in beraad zal houden; dit is autocratisch daar een beroep op de Regeering (in geval van een conflict tusschen de Koloniale Staten en den Gouverneur) gelijk staat aan een beroep op de Minister die ingelicht wordt door den Gouverneur. Wij missen elken stouten geest bij de regeling van het kiesrecht. ${ }^{21}$

Zijn commentaar op het instituut van de Koloniale Raad, zoals ingevoerd bij het Regeringsreglement van 1865 liet aan duidelijkheid niets te wensen over:

'Doordat alle leden van de Koloniale Raad benoemd worden, is het duidelijk, dat zij allen tot de gegoede klasse zullen behooren; dat het personen zijn, die welgevallig zijn in de oogen van den Gouverneur, en even duidelijk is het, dat hierdoor in een land, waar toch al zulk een scherpe scheiding bestaat - de nawerking van de vroegere meesters en slaven - het gevaar groot is voor nepotisme, en groot de kans op behartiging van klassebelangen. Wij weten toch, dat wij in Curaçao te maken hebben met wat men zou kunnen noemen een familieregeering. Het mag wel eens onverbloemd gezegd worden, dat het bestuur daar veel, zo niet alles te wenschen overlaat, dat in die kleine maatschappij nepotisme en gunstelingen-heerschappijregel zijn, dat bijna alle personen van gezag door bloedverwantschap of andere banden aan elkaar verbonden zijn. ${ }^{22}$

In de Tweede Kamer werd tussen 1897 en 1917 veelvuldig aangedrongen op bestuursdecentralisatie in de koloniën. Het wilde echter niet vlotten met decentralisatie. Plante Fébure citeerde de Tweede Kamer daarover:

'In 1907 werd bezuiniging verlangd door ingrijpende wijziging in de bestuursorganisatie; op Curaçao zou het middel moeten worden

21 Geciteerd door Plante Fébure (1918) pp. 98-100; zie ook Bordewijk (1914) pp. 299307.

22

Bordewijk (1914) pp. 303, 304.

150. De perinde van koloniale stabilisatie 1865-1936 (V) 
gezocht in decentralisatie; Minister Fock voorzag daarin geen bezuiniging, tengevolge van de benoeming van plaatselijke hoofden op de eilanden waar de Gezaghebber niet gevestigd was, en door de reisen verblijfkosten van den Gezaghebber; voorts zou de opbrengst van de middelen achteruitgaantengevolge van minder deugdelijk toezicht. Bij de behandeling der begroting van 1909 werd andermaal aangedrongen op decentralisatie en het verleenen van autonomie aan de kleine eilanden, alsmede splitsing der locale en koloniale financien. ${ }^{23}$

Tussen 1906 en 1920 werd diverse gezaghebbers naar hun mening gevraagd over decentralisatie en uitbreiding van de Raad van Politie. In 1907 was Van de Veen Zeppenfeldt tegen invoering van een gemeentebestuur op Curaçao. Bezuinigingen waren er niet van te verwachten en het zou 'aanleiding geven tot allerlei kwesties en haspelarijen van den leden onder elkander benevens vele moeilijkheden met het hoofdbestuur'. In 1918 stelde de Gezaghebber van Aruba dat hij van uitbreiding van de bevoegdheden en van het aantal leden van de van de Raad van Politie met enkele benoemde leden 'weinig goeds' verwachtte, maar dat dit wegens 'de geringen uitgebreidheid der bestuurs- of wetgevende functies van den Raden van Politie [...] ook niet veel kwaad kon'. Ook op Curaçao resulteerde het gebrek aan autonomie in de wens tot decentralisatie.

In 1919 vormde Gouverneur Helfrich een Commissie die moest nagaan of financiële afscheiding van de Bovenwinden zou kunnen leiden tot verlichting van de subsidielasten voor het moederland en een sluitende begroting voor de Benedenwinden. De Raad van Politie op Aruba gaf haar visie op het betrokken voorstel. Weliswaar meende men dat wijziging van de bestuursinrichting wenselijk was voor verkiezing van de Koloniale Raad, maar aan de centrale rol van Curaçao en de eenheid van de Bovenwindse eilanden werd niet getwijfeld. De Raad was voor verkiezing van de Koloniale Raad door middel van een beperkt kiesrecht, daaraan zouden dan ook de onderhorige eilanden moeten deelnemen. De mening van de bevolking over de uitbreiding van de bevoegdheden van de Raden van Politie was verdeeld. Men was in principe voorstander, maar vreesde over onvoldoende inkomsten te beschikken om deze gestalte te kunnen geven. Evenals de Koloniale Raad was Helfrichs commissie voor financiële afscheiding van de Bovenwinden. Die vond echter geen doorgang. ${ }^{24}$

Bordewijk (1914) pp. 295, 30I, 850; De Gaay Fortman (1947) p. 21; Kasteel (1956) pp. 23, 27 e.v.; Alofs (1992) pp. 16 e.v. 
De roep om decentralisatie eindigde voorlopig met de adviezen van de Commissie Staal. De Commissie meende dat een tweedeling van de kolonie niet aanbevelenswaardig was. De Commissie verwachtte van decentralisatie geen geldelijk voordeel, maar stond zelfstandigheid van de eilanden voor, volgens het gemeentemodel..$^{25}$ De uitwerking van de Grondwetsherziening van 1922 en de aanbevelingen van de Commissie Staal lieten tot 1936 op zich wachten. Tussentijds vestigde de olie-industrie zich op Aruba. Door de economische groei die hierop volgde zou juist op Aruba de wens tot verdergaande decentralisatie ontstaan, 'autonomie' genoemd en zelfs tot afscheiding van Curaçao.

\section{Kannibalisme en kiesrecht op Curaçao}

Abraham Mendes Chumaceiro stelde in zijn brochure 'Zal het kiesrecht Curaçao tot het kannibalisme voeren?' van 1895 een census en capaciteitskiesrecht voor. ${ }^{26}$ Het geschrift van Chumaceiro is zeer interessant en geeft een goed beeld van de heersende vooroordelen in die dagen, omtrent het toekennen van kiesrecht aan de bevolking. De brochure is bedoeld als verdediging tegen een artikel van J.H.J. Hamelberg ${ }^{27}$ in het novembernummer van 'Vragen van den Dag', getiteld: 'Het kiesrecht in Curaçao en de afscheiding van de eilanden boven den wind van de kolonie'. Hamelberg wijst het kiesrecht voor Curaçao nadrukkelijk van de hand.

Chumaceiro verwijst naar zijn eerdere brochure van 1879 'Is Curaçao te koop?', waarin hij ook al ijverde voor het verkiezen van de Koloniale Raad. De redenen die Hamelberg aanvoert om Curaçao het kiesrecht te onthouden zijn dat de 1000 Israëlieten (de totale bevolking van Curaçao bestond in 1895 uit 27000 zielen), welvarende kooplieden zijn. Indien een hoge census wordt gekozen voor het

23 Rapport Commissie Staal (1922) p. 11.

24 Chumaceiro (1895). Chumaceiro was geboren in Amsterdam en kwam op 14-jarige leeftijd naar Curaçao, waar zijn vader in 1865 rabbijn bij de Israèlitische gemeente werd. Hij werd zelf praktizijn en toonde steeds veel belangstelling voor politieke en pubtieke angelegenheden. Hij stierf in 1902. Onder vooraanstaande Antillianen schijnt de angst voor zwart overwicht nog groter te zijn geweest, dan die voor katholiek overwicht, doch het was ongetwijfeld de vrees voor de combinatie van beide, zegt Kasteel, die Curaçao zo lang verstoken hield van kiesrecht. Bovendien ging het met het kiesrecht in de omliggende landen ook niet voorspoedig. Kasteel (1956) p. 17 e.v.

27 J.H.J. Hemelberg was de woordvoerder van de Protestantse elite op Curaçao. De protestanten wezen census- of algemeen kiesrecht af, omdat zij niet het risico wilden lopen, dat of de Joden of de negers en kleurlingen teveel invloed zouden krijgen; Fennema (1986) p. 76. 
kiesrecht zou dit volgens Hamelberg een overwegende invloed aan de Joden toekennen. Deze Joden, zullen omdat zij kooplieden zijn hun handelsbelangen zwaarder laten wegen, dan het Curaçaos belang.

\begin{abstract}
'Bovendien zijn zij noch door banden des bloeds, der historie of traditie aan het moederland verbonden. Wordt er daarentegen tot een lagen census besloten, dan valt het kiesrecht in handen van de negers en dan zijn wij er veel erger aan toe: dan is het Troje. Neen, dan wordt Curaçao een tweede Haïti, waar afgodendienst en menschenoffers weer in zwang zijn, dierlijkheid en kannibalisme met al hun afschuwelijkheden weer den teugel vieren.'
\end{abstract}

Chumaceiro geeft, door tal van voorbeelden gestaafd, in zijn betoog aan, dat de Joden zich steeds als Nederlands onderdanen hebben gedragen en veel hebben bijgedragen aan de welvaart van Curaçao en het Koninkrijk. Voor wat betreft het beeld dat Hamelberg van de "diepgezonken en niet te verheffen" zwarte heeft, stelt Chumaceiro, dat 35 jaar na de emancipatie, vrijen en vrijgemaakten in vrede samenleven en dat de afschaffing van de slavernij in het geheel niet tot chaos en wantoestanden heeft geleid. Bovendien geeft hij aan dat de slavenhandel en de vaak zeer slechte behandeling van de slaven, waar ook elke eigen initiatief hardhandig werd gesmoord, niet die mensen oplevert, die zich ontworstelen aan de staat van slavernij. Hamelberg meende namelijk:

'[...] waar het Kaukasische ras eeuwen en eeuwen noodig gehad heeft om tot zijne tegenwoordige geschiktheid van zelfbestuur te geraken, men niet verwachten kan, dat de zwarten, die tot voor 30 jaren in vernederende banden der slavernij verkeerden - een toestand waaruit zij geenszins zichzelven opgeheven hebben, doch waartoe de Christenzin en een gevoel van menschelijkheid van den blanke hen gebracht hebben, - diezelfde geschiktheid aan den dag zullen leggen.'

Chumaceiro vroeg zich af:

'Hoe kan men er den slaaf een verwijt van maken, dat hij zich niet zelf uit de slavernij heeft opgeheven? Eilieve, kon hij dat? Werd hem daartoe de gelegenheid geschonken? Of werd niet veeleer alles in het werk gesteld om die eigen opheffing voor de massa onmogelijk te maken?' Chumaceiro beschrijft wat er gebeurt met de slaven die voor hun rechten opkomen. Hij verwijst hier naar de slavenopstand op Curaçao van 1795. '[.......] de cen (Toela) van onderen op geradbraakt, het aangezicht geblakerd, het hoofd afgchouwen; dan werd een ander (Bastiaan Carpata) op een kruis gebonden om de executie van den eersten aan te zien, alvorens hetzelfde lot te ondergaan; dan werd een derde (Pedro Wakao) na bij de beenen rondom het schavot te zijn gesleept en de handen te zijn afgekapt, hat hoofd met een 
Blanken hebben zwarten in slavernij gebracht, dus zijn de blanken aan de zwarten veel verschuldigd. Naast de afschaffing van de slavernij, moet aan de zwarte even goed onderwijs en ontwikkelingskansen worden verschaft, als aan de blanke. Scherp merkt Chumaceiro op dat de afdoening van een schuld door de blanke (de afschaffing van de slavernij) geen verdienste is. En het past al helemaal niet dat Hamelberg meent de schuldeiser (de zwarte) '[...] die geduldig en gelaten de voldoening der schuld heeft afgewacht te bespotten en te kleinachten'. Ook gaat Chumaceiro in op het gebrek aan zedelijkheid, dat Hamelberg de Curaçaose negerbevolking verwijt en dat uiteraard ook een reden is hen het kiesrecht te onthouden. Hamelberg wijst dan met name op het grote aantal buiten echt geboren kinderen en het gemis aan schaamte, dat 'ene ongetrouwde moeder onder de lagere bevolking van Curaçao bezit.'

Chumaceiro haalt de cijfers aan over het aantal buiten en binnen echt geboren kinderen, zoals vermeld in de koloniale verslagen. Daaruit blijkt dat sinds de emancipatie, het aantal binnen echt geboren en geëchte kinderen aanzienlijk is toegenomen. Grotendeels is dit gebeurd door de goede invloed van de RK kerk. Hamelberg realiseerde zich kennelijk niet dat het slaven niet was toegestaan in het huwelijk te treden. En deze situatie was niet in het leven geroepen door de zwarten zelf, maar door de blanken. Hamelberg geeft kennelijk de onderdrukte zelf de schuld van zijn onderdrukking. Chumaceiro merkt op: 'Curaçao is een garnizoens- en havenplaats, en in zulke plaatsen is de verhouding altijd minder gunstig, wat de zedelijkheid betreft, dan op plaatsen waar geene soldaten liggen en die niet door matrozen bezocht worden.' Ten slotte biedt Chumaceiro een gedegen overzicht van de bestuursvormen van de koloniën in de regio. Daaruit blijkt dat de meeste eilanden wel rijp zijn verklaard voor zelfbestuur. Hieruit trekt Chumaceiro de conclusie dat een gematigd censuskiesrecht (gebaseerd op de te betalen huur) voor Curaçao de oplossing is.

De brochure is zeer belangwekkend omdat het een vernuftig en hoogstaand voorbeeld biedt van de bestrijding van heersende vooroordelen en tevens inzicht geeft in de in die dagen heersende normen en waarden tussen de verschillende bevolkingsgroepen. Tenslotte wordt door Chumaceiro een scherpe analyse gegeven van de oorzaken, die geleid hebben tot het langdurig uitstellen van het invoeren van een begin van een parlementair stelsel in de West-Indische bezittingen. In zijn beschouwingen over het kiesrecht toonde Chumaceiro meer vertrouwen in de ontwikkeling van de geëmancipeerden dan Hamel- 
berg. ${ }^{28}$ Het mocht niet baten, voorlopig zou er de bevolking van Curaçao geen invloed krijgen op het bestuur van de kolonie. De tijd was nog niet rijp.

Tot 30 april 1869 gold in de kolonie Curaçao het Oud-Hollandse en het Romeinse recht. Gouverneur en Raden maakten aanvankelijk het enige rechtscollege op dit eiland uit. Later werd voor mindere questiēn, dat wil zeggen burgerlijke zaken lopende over een gering bedrag, de zogenaamde Kleine Raad aangewezen. Tijdens de Engelse bezettingsperiode werd de oude wetgeving gehandhaafd. In 1816 kwam Curaçao weer onder het Nederlandse gezag. Bestuur en rechtspraak waren toen geregeld volgens het Regeringsreglement van 14 september 1815. De artt. 44 en 46 bepaalden dat de administratie van de Justitie en van die van Politie afgescheiden zou zijn en dat de Raad van Civiele en Criminele Justitie zou bestaan uit een President en vier Raden.

Het Reglement op het beleid der Regering (RR) voor de kolonie Curaçao van 1865 bracht een geheel nieuwe opzet van het rechtswezen, die beoogde een einde te maken aan de vele klachten over de rechtsbedeling en de 'Regtbank' van Curaçao.

Het zesde hoofdstuk van het RR bevatte bepalingen over onteigening, motivering van vonnissen, onschendbaarheid van domicilie en briefgeheim (de artt. 134, 144, 147 en 148). ${ }^{29}$

Het Regeringsreglement van 1865 stelde in artikel 145/2: 'Algemeene verordeningen regelen de wijze, waarop geschillen over bevoegdheid tusschen de regterlijke en andere magten beslist wordt'. Hoofdstuk zes, tweede afdeling: 'Van de zamenstelling der regterlijke macht', regelde de hoofdlijnen voor de rechterlijke organisatie. Artikel 160 stelde: 'Tusschenkomst van de Regering in regtszaken is verboden'. Er zou voor de hele kolonie een opperste Gerechtshof

Zie over de koloniale verhoudingen ook Verton (1984), die zegt: 'In de Caraỉische exploitatie-koloniën (waaronder Curaçao) waren de slaven als gekoloniseerdentegenover de kolonisten in alle opzichten onvrij en machteloos. In deze omstandigheden werd de basis gelegd voor een maatschappij waarin blanken aan de top stonden en zwarten onderaan bleven. Deze indeling zou ook na de afschaffing van de slavernij blijven voortbestaan.' (p. 27).

Sjiem Fat (1986) pp. 20-28 en noot 39, p. 23-276. Hier vermeldt Sjiem Fat dat de vaststelling van een strafwetboek voor Indië in 1866 problemen opleverde. Thorbecke wilde dat dit bij wet zou gebeuren. Fransen van der Putte gaf de voorkeur aan vaststelling bij KB. Dit leidde tot aftreding van het Tweede ministerie Thorbecke. Zie ook Oud (1990) p. 71. 
komen onder de naam van Hof van Justitie met als taak 'de geregelde afdoening en de behoorlijke vervolging van alle misdrijven' (art. $150)^{30}$. De Procureur-Generaal eerder aangeduid als fiscaal, was 'eenen Ambtenaar die het recht van de hoge overheid waarneemt'. Hij werd ook wel als Procureur des Konings aangeduid en leidde als tevoren het Openbaar Ministerie (art. 151). Hij was de vertegenwoordiger van de Staat, of van de kolonie en tevens hoofd van de politie (art. 153). Hij was niet voor het leven benoemd.

In art. 149 van het Regeringsreglement van 1865 werd 'de regtsmagt' van de Hoge Raad in koloniale zaken erkend, nader te regelen bij wet. Bij koloniale verordening (art. 159) zou de inrichting en de samenstelling van de rechterlijke macht worden uitgewerkt.

In afwijking van het in art. 138 en in art. 159 voorgeschrevene, werden krachtens art. $189 \mathrm{RR}$, de inrichting en de samenstelling van de rechterlijke macht geregeld bij Koninklijk Besluit ${ }^{31}$ in het ' $R$ eglement op de inrigting en de zamenstelling der Regterlijke Magt in de kolonie Curaçao'.

Het Hof van Justitie was gevestigd op Curaçao en bestond uit een President, vier leden, van welke twee minstens gegradueerd moesten zijn, drie leden-plaatsvervangers, een PG en een griffier (art. 42). Het nam in eerste aanleg kennis van alle niet aan de kantonrechters ter berechting opgedragen burgerlijke zaken. Over strafzaken vonniste het in eerste aanleg over alle misdrijven waarvan kennisneming niet in eerst aanleg was opgedragen aan de kantonrechter of de Raad van Justitie (de artt. $43 \mathrm{t} / \mathrm{m} \mathrm{46)}$ ). Burgerlijke zaken moesten met drie leden worden behandeld, strafzaken met vier leden (art. 49). Er was op ieder eiland een kantongerecht. ${ }^{32}$

De Raad van Justitie bleef gehandhaafd op het eiland Sint Maarten en bediende eveneens de eilanden Sint Eustatius en Saba. De Raad van Justitie had slechts bevoegdheid in die strafzaken, waarvan de kennisneming niet was opgedragen aan de kantongerechten. De kantongerechten, die in 1868 werden ingevoerd op elk eiland, vonnisten in burgerlijke zaken indien de vordering niet meer bedroeg dan $f 300,-$. Tot hun competentie behoorden verder alle persoonlijke

Artikel 150 luidde: ' $\mathrm{Er}$ is, onder de benaming van het hof van justitic een opperste geregtshof voor de gansche kolonie. Het houdt toezigt op de geregelde afdoening van alle regtsgedingen en de behoorlijke vervolging van alle misdrijven. De voorzitter, de gegradueerde leden en de griffier van het hof van justitie worden door den Koning benoemd, de voorzitter en de leden voor het leven, de griffier tot wederopzeggens toe.' De niet gegradueerde leden zouden uit de stand der groote kooplieden moeten worden gekozen, Bondewijk (1914) pp. 669-671.

PB 1868, 16. 
vorderingen, alle vorderingen tot betaling van grondrenten, erfpachten en dergelijke schuldplichtigheden en alle vorderingen tot opeising van roerende zaken. In strafzaken vonnisten de kantongerechten over alle misdrijven waarop geen zwaardere straf was gesteld dan gevangenisstraf van 6 maanden of geldboete van $f 300,-$. Tegen uitspraken van de kantonrechter stond hoger beroep open op het Hof van Justitie dat gevestigd was op Curaçao. ${ }^{33}$

Beroep in cassatie van door het Hof van Justitie in Curaçao gewezen vonnissen werd pas mogelijk door de 'Wet van den 4den april 1869, tot voorlopige regeling der 'regtsmagt' van den Hoogen Raad der Nederlanden in West-Indische koloniale zaken'. Deze wet trad op 1 mei 1869 in werking. De MvT verwees naar art. 67 van het Surinaamse Regeringsreglement, goedgekeurd bij $\mathrm{KB}^{34}$ Dit artikel bepaalde, dat van alle definitieve sententiēn, door het Hof in Suriname in eerste instantie gewezen, partijen zich konden beroepen op de Hoge Raad te 's-Gravenhage.

Interessant is dat art. 65 van het Regeringsreglement van 1865 luidde: 'Aan de Raad van Bestuur kan, volgens regels bij koloniale verordening te stellen, regtsmagt erlangen in geschillen van bestuur'. Gelijkluidende artikelen zijn thans te vinden in art. 35 van de Staatsregeling van de Nederlandse Antillen, art. IV.3 Staatsregeling van Aruba en art. $76 \mathrm{GW}$. Artikel $76 \mathrm{GW}$ dateert van 1887 en artikel 35 Staatsregeling van de Nederlandse Antillen van het Regeringsreglement van 1865. Meestal volgt de Staatsregeling de Grondwet, maar hier was dat dus andersom. ${ }^{35} \mathrm{Er}$ is nog geen uitvoering gegeven aan het gestelde in art. 65 van het het Regeringsreglement van 1865 . Zowel de Staten van de Nederlandse Antillen als van Aruba hebben sinds 1991 een ontwerp-landsverordening administratieve rechtspraak in voorbereiding.

33 Wetboekenen reglementen voor de kolonie Curaçao, 's-Gravenhage 1868, Aigemeene Landsdrukkerij, hieruit Regtement op inrigting en de zamenstelling der regterlijke magt in de kolonie Curaçao, evenals bepalingen op den overgang van de vroegere tot de nieuwe wetgeving in de kolonie Curaçao. Art. 1 van het eerste boek (personen) luidde: 'Het genot der burgerlijke regten is ona fhankelijk van de stautkundige regten, welke alleen overeenkomstig het Reglement op het beleid der Regering wonden verkregen.' Art. 2 luidde: 'Allen die zich op het grondgebiedvan de kolonie bevinden zijn vrij, en bevoegd tot het genot der burgerlijke regten. Slavernij en alle ander persoonlijke dienstbaarheden van welken aard of onder welke benaming ook bekend, worden in de kolonie niet geduld.' Bij deze gelegenheid verviel het 'Oud-Hollandsche en Romeinse regt' en werden nast bovengenoemde wetten tevens ingevoerd voor de kolonie Curaçıo: het Wetboek van Koophandel, het Wetboek van Burgerlijke Regtsvordering, het Wetboek van Strafregt, het Wetboek van Strafvordering en het Reglement op het Notarisambt. Luiten (1983) p. 125. 
De Regeringsreglementen voor Suriname en Curaçao van 1865 bepaalden in de artt. 128 en $149,{ }^{36}$ dat de rechtsmacht van de Hoge Raad in koloniale zaken zou worden geregeld bij wet. Deze wet was bij de inwerkingtreding van de Regeringsreglementen op 1 januari 1866 nog niet tot stand gekomen. Er werd een voorlopige regeling vastgesteld, waardoor de goede gang der rechtsbedeling voorlopig was verzekerd. Deze voorlopige regeling werd op 4 april 1869 vastgesteld en trad op 1 mei 1869 in werking. Artikel 3 van de wet van 1869 bepaalde dat de PG bij de Hoge Raad in het belang der wet beroep in cassatie kon instellen tegen alle uitspraken in strafzaken, door de Hoven van Justitie in Suriname en Curaçao gewezen.

De op deze voorziening te wijzen arresten zouden geen nadeel kunnen toebrengen aan de rechten door belanghebbenden verkregen. Artikel 2 van de wet bepaalde, dat op de door het Hof van Justitie in Curaçao gewezen en gegeven vonnissen en beschikkingen op rekest in burgerlijke zaken in eerste aanleg, beroep op de Hoge Raad open stond. Aan de PG's bij de Hoven in Suriname en Curaçao was in de wet van 1869 het recht om beroep in cassatie in het belang der wet in te stellen onthouden. De Hoge Raad vond dat een dergelijk beroep alleen toekwam aan de PG bij de Hoge Raad..$^{37}$ Er was dus geen mogelijkheid voor partijen om in cassatie te gaan. Ook civiele cassatie in het belang der wet was niet mogelijk. Dit veranderde niet bij de regeling van 1909. In 1909 werd bovengenoemde voorlopige regeling vervan-

* Bij de Tweede Memorie van Toelichting van 1864 op artikel 128 (Suriname) en art. 149 (Curaçao) zei de minister het volgende: 'Volgens de ontworpen regeling zou in burgerlijke zaken de Hooge Rasd regter in hooger beroep zijn. In strafzaken zou hij regter in cassatie zijn in het belang der wet. Over de vraag, of hij ook in strafzaken regter in cassatie moet zijn op verzoek van partijen, heerschte bij de beraadslagingen over de ontworpen regterlijke organisatie verschil van gevoelen. Ingevolge de bepaling van art. 85 der wet van 31 Mei 1861, houdende eene nieuwe regterlijke inrigting, zal de wet hieromtrent later uitspraak moeten doen.' In het Voorlopig Verslag der Tweede Kamer van 9 juli 1864 werd de vraag gesteld of de Hooge Raad hof van appel, dan wel hof van cassatie in de koloniale zaken zou zijn. Het Voorlopig Verslag der Tweede Kamer van 1 augustus 1893 meldde dat: 'door sommige leden de wenschelijtheid werd betoogd om alle vonnissen in strafzaken van het Hof van Justitie aan cassatie door den Hoogen Raad te onderwerpen. Men herinnerde, dat op deze wijziging ook door de koloniale pers herhaaldelijk is anngedrongen.' De minister was het daar in de Algemene Beschouwingen van 25 januari 1894 niet mee cens, hij wilde 'niet vooruit lopen op een eventuele herziening van de wet van 4 april 1868.' Bij het gewijzigd ontwerp van de wet terzake in 1900 werd de rechtsmacht van de Hoge Raad niet meer bij wet geregeld maar door de Koning. Daaraan werd toegevoegd: 'Bij het inwerking treden van een Koninklijk Besluit betreffende de rechtsmacht van de Hoogen Raad der Nederlanden vervalt, voor zoveel de kolonie Curaçao aangaat, de wet van 4 April 1869' in: Bordewijk (1914) pp. 658-661. Sjiem Fat (1986) pp. 19-28. 
gen bij KB. ${ }^{38}$ Volgens dit KB was hoger beroep op de Hoge Raad toegelaten ten aanzien van vonnissen door het Hof van Justitie in eerste aanleg gewezen. Door ingrijpende wijzigingen in de Rechterlijke Organisatie in de Nederlandse Antillen in 1918 stond hoger beroep op de Hoge Raad praktisch niet meer open, omdat burgerlijke zaken zo goed als steeds in twee instanties werden behandeld en het Hof van Justitie slechts zelden vonnissen in eerste anleg wees. ${ }^{39}$

In 1919 werden de Raad van Justitie en de kantongerechten ontbonden. ${ }^{40}$ Voor de Kantongerechten op elk eiland kwamen in de plaats het kantongerecht van de Benedenwindse-, respectievelijk van de Bovenwindse eilanden, met zittingsplaatsen op de tot hun ressort behorende eilanden. De competentie van de kantonrechter werd in eerste aanleg algemeen. In 1937 werden de Bovenwindse- en Benedenwindse eilanden tot én kanton samengevoegd met een Gerecht in Eerste Aanleg en verschillende zittingsplaatsen. In Nederland is de kantonrechter de rechter in kleine zaken en niet in algemene zaken. Daar de term kantonrechter verwarring schiep, werd gezocht naar een andere naam, vandaar dat sinds 1941 de term 'Gerecht in Eerste Aanleg' wordt gebruikt. ${ }^{41}$ Sindsdien is de inrichting en samenstelling van de rechterlijke macht niet meer inhoudelijk gewijzigd en is te vinden in het Reglement op de Inrichting en de Samenstelling van de Rechterlijke Macht in de Nederlandse Antillen. ${ }^{42}$ De leden van het Hof treden op als Rechter in eerste aanleg en het Hof is voornamelijk appelinstantie geworden.

Omdat dit onderwerp niet meer afzonderlijk wordt besproken, wordt voor een goed begrip de bestaande situatie kort beschreven. Tot aan de Status Aparte van Aruba bestond er én Gerecht in eerste Aanleg voor alle eilanden, met zes zittingsplaatsen. Sinds Aruba de status van Land heeft gekregen binnen het Koninkrijk is de samenstelling en inrichting van de rechterlijke macht geregeld in de Eenvormige Landsverordening op de Rechterlijke Organisatie ${ }^{43}$. Thans is er een Gerecht in Eerste Aanleg in Aruba en een Gerecht in Eerste

KB van 23 februari 1909, Stb. 59, PB 1909, 14.

Van der Hansz (1984) pp. 12 en 13.

De Gaay Fortman, De WIG, 1a, 1919, pp. 85-101. De raden van Justitie op de Bovenwindse eilanden waren onbezoldigd en niet rechtskundig onderlegd.

PB 1941, 60.

PB 1965, 146.

AB 1985, 59 .
}

38 
Aanleg van de Nederlandse Antillen (met vijf zittingsplaatsen). Er is een Gemeenschappelijk Hof voor de Nederlandse Antillen en Aruba. Het Hof houdt zitting op de zes eilanden en is gevestigd op Curaçao. ${ }^{44}$

Reeds vó́r de Tweede Wereldoorlog werd in de West de behoefte aan cassatie gevoeld. Na de Tweede Wereldoorlog werd deze kwestie weer actueel door een verzoekschrift dat door een groot aantal Antilliaanse advocaten op 29 november 1947 werd gericht tot de Minister van Overzeese Gebiedsdelen. Het verzoekschrift bepleitte de wenselijkheid van een volledig beroep in cassatie van Antilliaanse civiele en strafzaken om de rechtszekerheid te verbeteren en de eenheid van de rechtspraak binnen het Koninkrijk te verhogen. Omdat nog niet zeker was hoe de nieuwe rechtsorde vorm zou krijgen, was het niet mogelijk voor de invoering van het Statuut een cassatieregeling in te voeren. De basis voor die cassatieregeling werd gelegd in art. 23 Statuut.

Artikel 23 Statuut bepaalt, dat de rechtsmacht van de Hoge Raad ten aanzien van rechtszaken in de Nederlandse Antillen (en Aruba) wordt geregeld bij Rijkswet. Deze Rijkswet -de Cassatieregeling voor de Nederlandse Antillen- (en sinds 1 januari 1986 voor Aruba) kwam in 1961 tot stand. ${ }^{45}$ Op 1 maart 1965 is deze wet in werking getreden. Cassatie zowel in civiele als in strafzaken is mogelijk, evenals cassatie in strafzaken, in het belang der wet. De Memorie van Toelichting op het ontwerp Cassatieregeling vermeldde als voornaamste voordelen van de invoering van het rechtsmiddel van cassatie voor rechtszaken in de Nederlandse Antillen (en Aruba) dat de justitiabelen daardoor meer rechtswaarborgen zouden verkrijgen en dat de concordantie van rechtspraak, die een complement is van de concordantie van wetgeving, daardoor zou worden bevorderd.

\subsection{Concordantie}

Kunst onderscheidt in de geschiedenis van de eenvormigheid van het recht in Nederland en de West-Indische koloniën vier perioden. Vanaf

4 Fliek (1969) pp. 7-51; Kunst (1981) pp. 267-269, zie ook de desbetreffende regeringsreglementen in Bordewijk (1911).

4s Rijkswet van 20 juli 1961, Stb. 1961, 212. Vanwege de verkrijging van de status van land van Aruba binnea het Koninkrijk is de Cassatieregeling voor de Nederlandse Antillen gewijzigd bij Rijkswet van 12 december 1985, Stb. 660, PB 1986, 21; AB 1986, 12. Zie ook art. 110 Staatsregeling Nederlandse Antillen, Hoofdstuk VI van deSamenwerkingsregelingNederlandse Antillenen Aruba (De rechtsorde, KABNAA, 1986). 
het begin van het Nederlandse bewind over de kolonie was de Ordre van Regieringe de basis voor het toegepaste recht (1).

De Ordre van Regieringe van 1629 gaf reeds aan dat de wettelijke regelingen uit het moederland moesten worden toegepast. De concordantie is aan de Antillen opgelegd toen zij als koloniēn van de Staten-Generaal en de West-Indische Compagnie hun bestaan begonnen. Receptie van ander recht dan wat in het latere Nederland gold heeft niet plaatsgehad. Anders dan in het vroegere Nederlands OostIndiē was er op de eilanden ook geen inheems recht dat van voldoende inhoud en maatschappelijke reikwijdte was om de bevelen van de 'Ordre van Regieringe' ook maar gedeeltelijk terzijde te stellen, of aan te vullen. ${ }^{46}$

Nederland kreeg aan het begin van de negentiende eeuw zijn Frans georiënteerde codificatie (2). De kolonie bleef gebonden aan het oude recht tot het Regeringsreglement van 1865 en de invoering van de Nederlandse codificatie in $\mathbf{1 8 6 9 .}$

In deze tweede periode was dus het codificatiebeginsel op drift, aldus Kunst. In het Regeringsreglement van 1865 werd 'zoveel mogelijk' concordantie opgelegd voor de belangrijkste onderdelen van het geschreven recht (3). Bij de invoering van het Statuut in 1954 (4) werd uitgegaan van de autonomie op wetgevend terrein voor eigen aangelegenheden van de Nederlandse Antillen en bepaalde art. 39 van het Statuut dat belangrijke onderdelen van het recht binnen het Koninkrijk zoveel op gelijke wijze geregeld moeten worden.

Omdat dit onderwerp chronologisch niet goed kan worden ingepast, wordt ten behoeve van de duidelijkheid de huidige situatie met betrekking tot concordantie besproken.

Kunst meende dat de concordantie groot was, terwijl hij tezelf-

Ook Kunneman geeft als zijn mening te kennen dat het concordantiebeginsel al een lange geschiedenis heef en teruggaat to 1629 . Van 1629 tot 1869 was de Ordre van Regieringe op de Nederlandse Antillen en Aruba van kracht als basiswetgeving. Bij de invoering in Nederland van de Franse codificatie was er gedurende een periode van vijftig jaar sprake van discordantic. In deze landen gold immers nog het recht uit de Ordre van vóór de Nederlandse (Franse) codificatie. Na 1869 wordt de concordantie formeel hersteld en opnieuw benadrukt in art. 39 Statuut in 1954. Materieel is er sprake van discordantie en komt er ook weinig terecht van de raadplegingsplicht van art. 39, tweede lid Statuut. De discordantie zal verder toenemen bij de invoering van het (nieuw) BW (NBW) in Nederland, indien wordt nagelaten het NBW ook in Aruba en de Nederlandse Antillen in te voeren. Kunneman maakt (op p. 18) melding van de oprichting van het Hof van Justitie voor de kolonie ex art. 129 van het Reglement op het beleid van de Regering (van 1865). Hij heef deze tekst blijkens voetnool 9 overgenomen uit het voorwoord van Honderd jaar Codificatie in de Nederlandse Antillen (1969). Hierin is een fout geslopen: art. 129 moet zija art. 150, Kunneman (1990) pp. 16-33. 
dertijd voorbeelden geeft, die daaraan grote twijfel doen ontstaan. ${ }^{47}$ Praktisch was er immers na verloop van tijd een groot verschil ontstaan in wettelijke regelingen in Nederland en de West-Indische koloniēn. Dit kwam door een gebrek aan handboeken in de koloniēn, met daarin de vigerende wetten, een gebrek aan deskundige raadsleden, het verschil in belangen van de patroonschappen en de gebieden die direct onder het beheer van de WIC stonden. Bovendien bestond er in Nederland weinig belangstelling voor de verre gebieden en was de WIC in eerste instantie een instrument om oorlog te voeren, gebieden te veroveren, de Nederlandse schatkist te vullen, en de investeringen van de kooplieden in de koloniën rendabel te maken. Ook was er verschil in rechtstoepassing op de Bovenwinden en de Benedenwinden, bijvoorbeeld voor wat betreft het erfrecht. ${ }^{48}$

Artikel 138 van het Regeringsreglement van 1865 stelde dat zoveel mogelijk de in Nederland bestaande wetten bij koloniale verordening in de koloniën moesten worden ingevoerd. In dit artikel werd een gematigd concordantieartikel neergelegd. In de praktijk verschilde en verschilt het toegepaste recht in de Nederlandse Antillen en Aruba aanzienlijk van het toegepaste recht in Nederland. Thans komen art. 39 lid 1 Statuut, art. 4 Samenwerkingsregeling, art. 98 lid 1 Staatsregeling Nederlandse Antillen en art. V.16 Staatsregeling Aruba overeen met de inhoud van art. 138 Regeringsreglement $1865 .^{49}$

Joubert ${ }^{50}$ merkte op, dat sinds de invoering van art. 39 van het Statuut de voormalige kolonie niet meer het moederland moet volgen, maar dat de landen elkaar moeten volgen. In de praktijk betekent dat natuurlijk dat de overzeese rijksdelen Nederland volgen. Joubert is voor hercodificatie (het invoeren van de Nederlandse wetgeving in de Nederlandse Antillen en Aruba), omdat de bestaande wetgeving van 1869 dateert en niet meer voldoet aan de bestaande maatschappelijke eisen. Wel zal dat boek voor boek moeten geschieden. Door partiële wijzigingen gaat het onderlinge verband in de wetgeving verloren en moet het 'rechtersrecht' vaak de plaats van de wetgeving innemen. Hij onderkent de problemen van hercodificatie, zoals rechtsonzekerheid, het gebrek aan menskracht en middelen, maar vindt dat de voordelen tegen de nadelen opwegen.

Bovendien is hij van mening dat concordantie op grond van de

Kunst (1973) pp. 58, 160, 249, 255, 260-261.

4 Op Sint Eustatius werd het schependomsrecht toegepast en op Curaçao het aasdomsrecht bij vererving.

49 Dip (1969) pp. 1-7.

so Jouber (1983) pp. 38, 44 e.v., 53-55. 
traditie, eenheid van rechtspraak in het Koninkrijk en de zich ontwikkelende unificatie tussen onafhankelijke staten geboden is. Eveneens acht hij, indien cassatie gehandhaafd blijft, bij een eventuele onafhankelijkheid, concordantie onontbeerlijk.

Joubert is een voorstander van het gematigd concordantiebeginsel, zoals dat nu in feite ook een rol speelt in de Nederlandse Antillen en Aruba. Voor wat betreft de rechtspraak lopen de wettelijke regelingen in Nederland, de Nederlandse Antillen en Aruba thans nogal uiteen, ook al zijn de historische wortels van het recht binnen het Koninkrijk in beginsel hetzelfde. Sinds de Status Aparte van Aruba is er ook een verschil ontstaan tussen de wettelijke regelingen in de Nederlandse Antillen en Aruba.

Kunneman merkt op, dat bij toenemende discordantie een aantal problemen zijn te verwachten. Hij noemt:

- cassatie bij de Hoge Raad wordt moeilijk,

- de juridische opleiding binnen het Koninkrijk zal teveel onderlinge verschillen gaan vertonen,

- het aantrekken van rechters zal meer moeite gaan kosten,

- de rechtsontwikkeling zal stagneren,

- de rechtsvorming zal aan minder controle onderhevig zijn.

Wellicht is het beter de concordantie-discussie te laten voor wat deze is en de aandacht te concentreren op de mate waarin receptie van Nederlands recht in de Caraïbische delen van het Koninkrijk nuttig is om de kwaliteit van de wetgeving en de rechtspleging te handhaven. ${ }^{51}$

Tratnik $^{52}$ stelde dat het concordantiebeginsel (naar zijn mening meer een vrome wens dan een plicht) geen grond is om het Nieuw Burgerlijk Wetboek (NBW) ${ }^{53}$ op de Nederlandse Antillen en Aruba in te voeren. Hij meent dat invoering moet plaatsvinden, omdat het voor het grootste gedeelte een gesystematiseerde weergave is van het reeds in de West geldende (on)geschreven recht en om te voorkomen dat het recht in de verschillende delen van het Koninkrijk teveel uit elkaar zal groeien. Blijkbaar stellen de Nederlandse Antillen prijs op de toepassing van het concordantie beginsel. In 1961 werden al voorbereidingen getroffen om een nieuw Antilliaans BW tot stand te

\footnotetext{
Kunneman (1990) pp. 20-30.

Tratnik (1992) pp. 137-145.

De nog gehanteerde omschrijving Nieuw Burgerlijk Wetboek (NBW) is sinds de invoering van het NBW in Nederland op 1 januari 1992 niet juist meer. De juiste termininolgie is Burgerlijk Wetboek (BW). Het tot voor kort geldende BW in Nederland dient nu te worden omschreven als BW oud.
} 
brengen. In 1983 werd door de Antiliaanse regering een commissie ingesteld, die een advies moest uitbrengen over de vraag of het nieuwe Nederlandse BW moest worden nagevolgd. ${ }^{54}$

\section{Banden met het vasteland}

De verovering van Curaçao door de Nederlanders bracht geen wezenlijke verandering in de politieke, culturele en godsdienstige banden van het eiland met het vasteland. Spaanse priesters vanuit het bisdom Coro (Venezuela) waaronder de eilanden vielen, bezochten de eilanden regelmatig en hadden een aanzienlijke invloed op de toetreding van de bevolking tot de Rooms-Katholieke kerk. De ontbrandende onafhankelijkheidsstrijd in de Spaanse koloniën bracht vele ballingen en vluchtelingen naar de Antilliaanse kusten, ter voorbereiding van latere opstanden. Francisco de Miranda ${ }^{55}$ ('El precursor') de voorloper van de Venezolaanse onafhankelijkheid, vluchtte na een mislukte poging tot opstand in Coro (1806) naar Aruba. Vier jaar later keerde hij, na een kort verblijf op Curaçao, terug naar Venezuela. Bij de ondergang van de Eerste Republiek Venezuela (1812), vluchtte Simón Bolívar ('El Libertador'), de latere bevrijder van de Spaanse koloniēn op het Zuidamerikaanse continent, naar Curaçao. Veel Curaçaoënaars sloten zich aan bij de strijd. Een strijd, die in hoge mate succesvol zou zijn mede dank zij de grote inzet van twee zonen van Curaçao: Manuel Carlos Piar $^{56}$ en Luis Brion. ${ }^{57} \mathrm{Zij}$ waren beiden Venezolaan geworden.

Van Hansz (1984) pp. 51-54, voorzover informatie voorhanden is nog geen rappor in deze van de Commissie verschenen. Kunneman doet er in zijn artikel in het Lustrumnummer van TAR-Justicia (1990) geen uitsprask over. Naipaul (1987) pp. 162-378.

Encyclopedie (1985) pp. 378 e.v.

Phillippus Lodovicus (Pedro Luis) Brion werd op 6 juli 1782 te Curaçao geboren uit een Nederlandse vader en een Belgische moeder. Op jeugdige leeftijd werd hij naar Nederland gestuurd om zich in de handel te bekwamen. Daar kwam echter niet zoveel van terecht, want in 1799 streed hij onder Daendels in het Batafse legioen tegen de Engelsen en Russen, die een aanval deden op Noord-Holland. De vijand werd afgeslagen, maar Brion raakte in Engelse gevangenschap. Bij de vrede van Amiens kwam hij vrij en reisde terug naar Curaçao. In 1803 werd hij 2de luitenant bij de burgerwacht, Curaçao stond toen onder het bewind van de Bataafse Republiek. De Engelsen vielen in 1804 weer aan, hij wist hun blokkade te breken. In 1805 verdreef Brion de Engelsen van de Kabrietenberg. De rest van zijn leven heefl Brion in dienst gesteld van de onafhankelijkheid van Zuid-Amerika. Hij werd GrootAdmiraal van de Venezolaanse vloot en kaapte Spaanse schepen. Na de onathankelijkheid van Venezuela trok hij zich terug op Curaçao, ziek en ontgoocheld na een conflict met Bolívar en stierf daar in 1821. In 1881 wend zijn stoffelijk overschot op verzoek van president Guzmán Blanco naar Venezuela vervoerd om bijgezet te 
In 1804 en 1805 bevocht Bríon vanuit Curaçao de Engelse aanspraken op het eiland. In 1807 ging Curaçao over in Engelse handen. Bonaire viel in 1804 in Engelse handen en Aruba in 1805. In 1805 nam Bríon deel aan een succesvolle expeditie naar Aruba om de Engelsen op het eiland te verjagen en de inwoners naar Curaçao te evacueren. ${ }^{58} \mathrm{Hij}$ vocht ook in de slag om het eiland Margarita op 2 mei 1816, waarmee de invasie van het vaste land van Venezuela door de opstandelingen was begonnen.

Brion werd naar aanleiding van zijn prestaties bij deze zeeslag benoemd tot admiraal van Groot-Colombia. Groot-Colombia was de door Simón Bolivar gevormde staat die de huidige landen Venezuela, Columbia en Ecuador omvatte. Bolivar benoemde hem kort daarop tot gevolmachtigd minister om met de VS, Mexico en de Nederlandse overheid op Curaçao tot een verdrag te komen tot erkenning van het nieuwe bewind. Op zondag 14 juli 1816 verscheen Bríon met een heel eskader voor de St. Annabaai. Hij wilde in zijn hoedanigheid van gevolmachtigd minister een bezoek brengen, maar werd alleen als privé persoon toegelaten. Dit niet aanvaarden van het nieuw bewind in Venezuela, door Gouverneur-Generaal Kikkert, leidde tot belemmeringen in het scheepvaartverkeer en de bandel met het vasteland, evenals als een verhoogde activiteit van de kaapvaart vanuit Venezuela. Ter gelegenheid van de honderdste verjaardag van Bríons overlijden werd op 27 september 1921 het plein in Otrobanda naar hem vernoemd.

Manuel Carel (Carlos) Piar werd in 1778 op Curaçao geboren. Hij was een belangrijk figuur in de strijd voor de onafhankelijkheid van Venezuela. Hij woonde als jongeman enige tijd in Haîti en nam in 1806 deel aan De Miranda's invasie van Coro en werd in 1811 door hem benoemd tot stafofficier in het revolutionaire leger. In 1814 werd hij generaal. In 1816 werd hij na een aantal succesvolle veldtochten door Bolívar tot bevelhebber benoemd. Piar had zo zijn eigen gedachten over leidinggeven aan een veldtocht, dat viel niet altijd even goed bij Bolívar. Hij ondermijnde diens gezag en werd in september 1817 gearresteerd en door een militaire krijgsraad, onder voorzitterschap van Bríon, veroordeeld tot de dood door de kogel. Piar en Bríon zijn de enige niet-Venezolanen die op het vrijheidsmonument (1956) te Caracas staan afgebeeld. In Willemstad op Punda is een plein naar

worden in het Panteón National in Caracas, waar het thans rust nast het stoffelijk overschol van Bolivar, el Libertador, Wispelweij (1961) pp. 41-43; Encyclopedie (1985) pp. 94 e.v. 
Piar genoemd: Plaza Piar. Zijn standbeeld, volgens het opschrift door de regering en het volk van Venezuela aangeboden, werd op 5 juli 1963 onthuld. ${ }^{59}$ Generaal Francisco de Miranda heeft Aruba tot twee maal toe bezet: van 10 tot 15 april en van 19 augustus tot 25 september 1806. Vanuit Aruba wilde De Miranda, met hulp van de Engelsen, het bestaande Venezolaanse bewind omver werpen. De Engelsen lieten hem echter in de steek en hij vertrok weer van Aruba. ${ }^{60}$ Venezuela onderhoudt nauwe banden met de Benedenwindse eilanden. Jaarlijks worden de grote daden van Simón Bolívar ondermeer herdacht op Curaçao, Piar en Bríon delen in de hulde. Dit geeft Venezuela ook de mogelijkheid de banden met de Benedenwindse eilanden in stand te houden en te versterken. ${ }^{61}$

Tussen 1816-1822 steunde het Nederlandse koloniale bestuur Spanje tegen de voor de onafhankelijkheid vechtende opstandelingen in Venezuela. ${ }^{62}$ In 1822 werd Nederland neutraal. In de strijd om de onafhankelijkheid en de daarop volgende revoluties en contrarevoluties (tussen 1848 en 1870) werd Curaçao regelmatig plaats van asiel- en uitvalsbasis van 'exilados'. Dat betekende dat men vanuit Curaçao het politieke bestel van het nabijgelegen Venezuela kon beinvloeden.

Hartog (1961), pp. 680-682 en 751-753, de onthulling geschiedde door de Venezolaanse minister van onderwijs dr. Reinardo $L$. Mora en de toenmalige voorzitter van de Staten J.A.O. Bikker. Encyclopedie (1985) p. 379. Van Leeuwen (1990) pp. 5761, wijdt een verhaal aan Manuel Piar en Pedro Luis Brion, onder de titel 'History is Bunk'. De Amigoe van 6 juli 1991 meldde dat het Venezolaans congreslid Rondon van mening is dat Venezuela onrecht beging door Piar te fusilleren. Hartog (1953) pp. 100-109.

61 Zie bijvoorbeeld, Amigoe, Ñapa, 26 februari 1994, 'Curaçao is een dorre rots', in dit artikel van de hand van $\mathrm{H}$. Vaders worden ondermeer de roemrijke daden van beide helden in dienst van de Latijns-Amerikaanse vrijheidsstrijd beschreven. In de ontbrande dekolonisatie-oorlogen van de overzeese Spaanse gebieden koos Willem I de zijde van de Spaanse koning, hetgeen de verhouding met de nieuwe machthebbers in Venezuela ernstig belastte. Venezuela had zich in 1811 ona fhankelijk verklaard. Toen Spanje zijn bewind herstelde kreeg de bevrijder Simón Bolívar wel asiel op Curaçao. Na de slag bij Carabobo (1821) werd de definitieve ondergang van het Spaanse imperium in de continentale landen van Amerika duidelijk. Nederland ging toen over op een diplomatie van neutraliteit. Dit leidde tot gevoelige verhoudingen tussen de Benedenwindse eilanden en Venezuela. De 'Monroe' doctrine werd in 1823 door president James Monroe gevestigd en hield in dat als Europese mogendheden Amerikaanse koloniën, die zich onathankelijk hadden verklaard, trachtten te heroveren, dan zouden de VS dit als een onvriendelijke daad jegens zichzelf opvatten. Later werd de doctrine uitgebreid tot een afwijzing van elke vorm van interventie door niet-Amerikaanse mogendheden in het Westelijk Halfrond. Het overschepingsdecreet van president Castro van Venezuelauit 1908 bracht veel schade toe aan de handel van Curaçao. Nederland ondernam in 1908 - ondanks de Monroedoctrine - een vlootactie tegen Venezuela. De twistpunten werden spoedig bijgelegd, maar de diplomatieke verhoudingen bleven tot 1920 verbroken, Van Wehry (1988) pp. 56 e.v., 131 e.v., 136. 
Een factor die de relatie tussen Curaçao en Venezuela altijd bepaald heeft is de geografische ligging van Curaçao, zo vlak voor de kust van Venezuela. Ex-presidenten of toekomstige presidenten vereerden het eiland met een gedwongen bezoek. Simón Bolívar verbleef er als de meest eminente banneling. Juridisch had het opperste bestuur van Curaçao de mogelijkheid om vreemdelingen uit te zetten op grond van verstoring van de rust of openbare orde. Na de slag bij Carbabobo van 24 juni 1821 , waarbij de revolutionairen de strijd wonnen en voortaan nationalen werden genoemd, vluchtten 2000 Spaanse koningsgezinden naar Curaçao. De vluchtelingen vertrokken kort naar hun aankomst naar Cuba, Puerto Rico en Spanje. Ongeacht welk bewind in Venezuela aan de macht was, alle vluchtelingen vonden een gastvrij onthaal op Curaçao. ${ }^{63}$ Curaçao leverde voedsel, wapens en steenkool aan de opstandelingen, hetgeen leidde tot officiële protesten van de Venezolaanse regering aan de Nederlandse regering.

Antonio Guzmán Blanco (1828-1899) die in 1869 vanuit Venezuela uitgeweken was naar Curaçao onderhield de nodige contacten met zijn (liberale) achterban. In 1870 onderschepte de Venezolaanse regering brieven van op Curaçao verblijvende ballingen die revolutionaire plannen maakten. De Venezolaanse regering stelde dat Curaçao als basis diende voor aanvallen op het wettige regime in Caracas en eiste uitlevering van de ballingen.

Het Ministerie van Koloniēn besloot dit verzoek in te willigen wat op Curaçao op veel tegenstand stuitte. De uit te leveren Venezolanen werden als zeer respectabele lieden beschouwd en verkeerden in de hoogste kringen. Bovendien vreesde men dat uitlevering bij een niet onwaarschijnlijke machtsovername in de toekomst de Curaçaose handelsbelangen zou schaden. Steeds moesten zowel de gevestigde regering als haar tegenstanders te vriend worden gehouden. De smokkelhandel leidde een bloeiend bestaan. Zowel de wettige regering als de opstandelingen werden door de Curaçaose handel bediend. Uiteindelijk werd besloten, om gezien de mogelijke ordeverstoringen in Venezuela Guzmán uit te zetten. Dit gebeurde zeer tegen de zin van de Koloniale Raad en de ingezetenen. Guzmán wachtte zijn uitzetting niet af en vertrok heimelijk met medewerking van de autoriteiten. ${ }^{64}$

De uitzetting had tot gevolg dat de revolutie in Venezuela eerder losbarstte dan het plan was geweest. Op Curaçao bleef het onrustig. Terwijl er nog werd nagepraat over de onderschepte brieven begon de Venezolaanse generaal Colina een revolutie voor te bereiden en 
dezelfde Curaçaose handelshuizen die Guzmán Blanco hadden bediend, bedienden nu Colina. Colina verloor echter. Guzmán Blanco was nu president van Venezuela en liep uiteraard niet over van dankbaarheid voor zijn verbanningsoord.

Hij nam wraak op Curaçao door de voor de doorvoerhandel zo belangrijke havens Maracaibo en Vela de Coro te sluiten en nam enkele Curaçaose schepen in beslag. Hij decreteerde bovendien een jaar later een extra heffing van $30 \%$ op alle artikelen afkomstig van maar niet geproduceerd op - de Antillen. Ook trad hij hard op tegen de smokkelhandel vanuit Curaçao. Bovendien werd Nederland gesommeerd om alle kosten te dragen van de krijgshandelingen die waren aangewend om de opstand van Colina te onderdrukken. In Den Haag werd besloten om een oorlogsschip naar Venezuela te sturen om Nederlandse ingezetenen te evacueren en er gingen stemmen op om Curaçao af te stoten. ${ }^{65}$

Plante Fébure maakt in zijn parlementair overzicht gewag van de moeilijke handelssituatie met Venezuela en de reacties van de Tweede Kamer daarop:

'Volgens enkele leden van de II Kamer waren in 1900 de hooge inkomende rechten, die in Venezuela werden geheven van uit Curaçau a fkomstige goederen, doodend voor den handel en de voomaamste oorzaak van den ongunstigen financieelen toestand.

Van Kol vond dat men deze oude koeien gerust in de sloot had kunnen laten liggen; de klachten waren onjuist en onbillijk, daar juist in de laatste jaren de grootste concessie werd verleend welke in langen tijd ten bate van Curaçao door de Regeering van Venezuela was gedaan. Een betere verhouding met Venezuela onder den vrijwel krankzinnigen president Castro was volgens spreker onmogelijk. Opheffing van het door Venezuela geheven uitzonderingsrecht van $30 \%$ zou ongetwijfeld tot den bloei van de Kolonie bijdragen. ${ }^{* 6}$

Van Soest (1980) pp. 10-e.v.; Gedenkboek (1934) pp. 123-139; Goslinga (1975) en (1979) pp. 137-140; Abraham-Van der Mark (1990) pp. 6-8.

so $\mathrm{Na}$ herstel van het Nederlands gezag over Curaçao werd het moeilijk voor opstandelingen uit Venezuela wapens op Curaçao te kopen. Koning Willem I, die zelf zijn troon op legitieme wijze had verkregen, koesterde weinig sympathie voor Bolívar's idealen. Pas in 1822 werd de haven van Curaçao opengesteld voor de schepen der Independenten, nadat het jaar tevoren nog ruim tweehonderd royalisten een toevlucht op Curaçao hadden gevonden na de slag bij Carabobo. Daarna duurde het tot 1829 voordat Nederland de republiek Gran Colombia erkende. Met deze koerswijzigingen had Curaçao weinig van doen, omdat de jonge regeringen in Latijns-Amerika slechts wensten te onderhandelen met ministers in Europa en niet met koloniale ambtenaren. In 1875 werden de diplomatieke betrekkingen tussen Venezuela en Nederland verbroken. In 1914 verkreeg de Koninklijke/Shell Groep een concessie om te boren naar aardolie bij het meer van Maracaibo. In 1920 werden de diplomatieke betrekkin- 
Reeds in 1634 meende de WIC het in dat jaar pas veroverde Curaçao maar te moeten verlaten of verkopen, wegens de tegenvallende baten. Pas in $\mathbf{1 6 5 0}$ werd besloten het eiland voorlopig niet te verlaten. In 1869 gingen er in Nederland opnieuw stemmen op om de kolonie te verkopen. Dit gebeurde steeds als de kolonie meer kostte dan opbracht. De kosten van de emancipatie (afschaffing van de slavernij) waren hoog en de nieuw in te voeren wetgeving was kostbaar. De spanningen bleven voortduren omdat Venezolaanse vluchtelingen op Curaçao nu weer plannen beraamden om het bewind van Guzmán Blanco omver te werpen. De Venezolanen gebruikten Curaçao en Aruba veelvuldig als basis voor hun revolutiepogingen, waardoor Nederland in niet-gewenste moeilijkheden met Venezuela kwam. ${ }^{67}$ In 1875 werden de diplomatieke betrekkingen tussen Nederland en Venezuela verbroken. Het Tweede Kamerlid H.A. des Amorie stelde in 1876 voor Curaçao af te staan aan Venezuela, wegens alle politieke problemen. Nederland en Venezuela hebben hier wel over gesproken, maar er zijn blijkbaar geen serieuze onderhandelingen over een mogelijke verkoop gevoerd.

In februari 1877 richtte Guzmán Blanco een boodschap tot het Venezolaanse Congres met het voorstel Curaçao te kopen. Het was zijn plan Curaçao te versterken en er de zetel van de Venezolaanse regering te vestigen. Hij hoopte daardoor het gevaar van contrarevoluties te bedwingen.

Chumaceiro ${ }^{68}$ reageerde hierop met zijn brochure 'Is Curaçao te koop?' Hij drong in zijn brochure aan op meer zelfbestuur voor de kolonie en meer invloed van de ingezetenen op het plaatselijk bestuur (de Koloniale Raad). Ook zou dan blijken dat de kolonie wel degelijk zijn nut voor het moederland zou blijken te hebben, bovendien had de kolonie voldoende natuurlijke hulpbronnen om haar eigen bestuursapparaat te financieren. Helaas was de bekendheid van het Nederlandse parlement en de Nederlandse regering met de kolonie, uiterst gering, meende Chumaceiro. Het ware aan te bevelen indien de kolonie meer zelfregering had dan thans het geval is, veel dat nu verkeerd is zou dan geheel anders zijn. Wel wenste hij in ieder geval de band met Nederland gehandhaafd te zien.

De Koloniale Raad was uiterst ontstemd over de het voorstel in de

gen weer hersteld, Plante Fébure (1918) pp. 149 e.v., 190 e.v.; Van Soest (1980)

pp. 8-17.

6* Chumaceiro (1879); De Gaay Fortman, De WIG, 3, 1921, pp. 113-144. 
Tweede Kamer de kolonie af te stoten. Het aantal ambtenaren was door de emancipatie op instigatie van Nederland verhoogd, door het invoeren van de nieuwe wetgeving per 1 mei 1869 steeg het aantal ambtenaren verder. En zij moesten allemaal uit de koloniale kas worden betaald. Pas in 1894 werden de betrekkingen met Venezuela weer hersteld om in 1908 weer te worden verbroken.

In 1918 deden opnieuw allerlei geruchten de ronde dat Nederland de kolonie wilde verkopen aan de VS op grond van militair-strategische redenen. ${ }^{69}$ B. Boekhoudt ${ }^{70}$ pleitte in een brochure voor het verkopen van de bezittingen in West-Indiē. Hij vond dat Curaçao teveel geld kostte en meende dat de kolonie 'niet het minste vooruitzicht geeft, dat in de toekomst deze geldelijke offers overbodig zullen blijken.' Verder stelde hij 'dat Curaçao altijd een lastpost is gebleven en zal blijven'. Hoewel Hamelberg deze beweringen bestreed en moeite deed om aan te tonen dat Curaçao allerminst waardeloos was, zal menig Nederlander het toch wel eens zijn geweest met Boekhoudt.

In bet algemeen was men in de kolonie van mening dat het moederland teveel uitgaf ten laste, niet ten behoeve van de kolonie. Verder achtte men het van belang dat de kolonie meer zeggenschap kreeg in eigen zaken. De autonomie die de kolonie bij het Regeringsreglement van 1865 had gekregen was een wassen neus gebleken, omdat de Koloniale Raad niet volledig het budgetrecht had. De steeds dringender wordende eis naar zelfbestuur had met name te maken met het budgetrecht en het financieel beleid. ${ }^{71}$

Plante Fébure geeft de parlementaire debatten over de verkoop van de koloniën als volgt weer:

'Zoo gering was eenige jaren geleden de belangstelling voor Curaçao en zoo weinig lust werd er getoond om aan deze Kolonie flinke hulp te verleenen, dat Van Kol bij de behandeling van het wetsontwerp tot herziening van het Regeerings-Reglement in 1900 uitriep: Mocht er in deze Kamer geen steun gevonden worden om de noodlijdende eilanden te helpen, dat men dan de moed hebbe ze deemoedig af te staan en die Boven- en Benedenwindsche Antillen te verkoopen aan de meestbiedende. Het was een cri de coeur die Van Kol in 1916 uitte, toen hij uitriep: Mocht Nederland niet geneigd zijn jaarlijks enkele tonnen aan Suriname te besteden, laat het dan liever afstand doen van dat Koloniaal bezit en onze Koloniën overdoen aan meer gulle mogendheden. Ik koester persoonlijk dit denkbeeld ten opzichte

Hartog (1961) pp. 736-745, 761, 767-774; Renkema (1976) pp. 1-8. 1918, pp. 1-6.

7 De Gaay Fortman, De WIG, 4, 1922, p. 292.
} 
van Suriname in de verste verte niet, ook omdat wij nu eenmaal daar een historische plicht moeten vervullen. ${ }^{72}$

In 1917 legde de Gouverneur nog een verklaring af in het openbaar dat de Nederlandse regering een dergelijk gedachte volstrekt verwierp. ${ }^{73}$ Pas in 1947 reisde een eerste officiële parlementaire delegatie naar de eilanden. ${ }^{74}$

Begin augustus 1928 kwam een groep Venezolaanse vluchtelingen op Aruba aan. Onder hen bevond zich Rafael Simón Urbina, die zich verzette tegen het bewind van de in 1908 in Venezuela aan de macht gekomen dictator Juan Vicente Gomez. Urbina werd aangehouden en naar Curaçao overgebracht. ${ }^{75}$ Zijn aanwezigheid zorgde voor de nodige onrust onder de op de eilanden wonende Venezolaanse vluchtelingen en hij werd dan ook terstond uitgewezen. Begin juni 1929 keerde Urbina naar Curaçao terug, samen met Antonio Machado en 45 opstandelingen en overviel het aldaar gelegerde garnizoen Nederlandse militairen op 8 juni 1929. Het doel van de overval was het veroveren van wapens om in Venezuela de dictatoriale regering van Juan Vincente Gomez omver te werpen. Er vielen drie doden. Urbina had versterking gekregen van op Curaçao wonende Venezolanen, zodat zijn legertje was aangegroeid tot 150 man. Hij gijzelde Gouverneur Leonard R. Fruytier en garnizoenscommandant Borren toen de laatste weigerde te capituleren en vertrok met een gevorderd schip naar de Venezolaanse kust. Schip en gijzelaars keerden op 9 juni behouden terug.

De gebeurtenissen werden in Nederland hoog opgenomen, onder andere omdat de goede betrekkingen met de olieleverancier Venezuela niet mochten worden geschaad. De diplomatieke betrekkingen waren pas in 1921 hersteld. ${ }^{76} \mathrm{Zo}$ werd Gouverneur Fruytier ontslagen terwijl zijn houding ter plaatse juist werd geacht. De garnizoenscommandant Borre werd veroordeeld tot een dag gevangenisstraf. ${ }^{n}$ De Nederlandse regering trof verdere maatregelen ter versterking van de defensie en benoemde een beroepsofficier, B.W.T. Slobbe tot

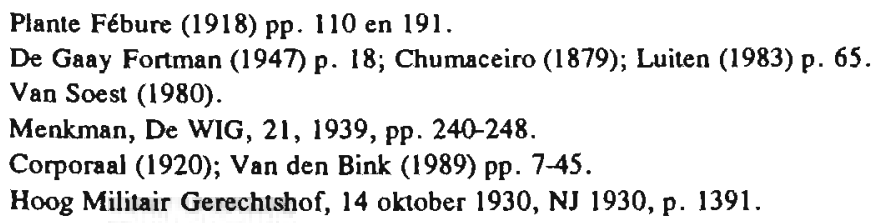


Gouverneur, omdat Nederland meende dat een militaire invloed in deze situatie nuttig zou zijn. ${ }^{78}$

Bij de Grondwetswijziging van 1922 verdween de benaming 'koloniën en bezittingen' uit de Grondwet en werden de overzeese gebiedsdelen met name aangeduid. De nieuwe bepalingen introduceerden naast het begrip opperbestuur het begrip algemeen bestuur. Het opperbestuur bleef bij de Koning, doch het algemeen bestuur zou in zijn naam worden uitgeoefend door de Gouverneur-Generaal in Nederlands-Indië en in Suriname en Curaçao door de Gouverneurs, behalve voorzover de Grondwet of de wet bepaalde bevoegdheden aan de Koning mocht hebben voorbehouden. De wijze van dit algemeen bestuur zou bij de wet worden geregeld. ${ }^{79}$ De Grondwetwijziging van 1922 en de onduidelijke interpretatie van opperbestuur en algemeen bestuur heeft er mede toe geleid 'dat de weg naar de totstandkoming van een geheel of gedeeltelijk aan de Staten verantwoordelijk bestuur effectief werd afgesneden. ${ }^{80}$

Van regeringsreglementen werd niet langer gesproken. Dit woord rook te zeer naar het oude koloniale regiem. In plaats daarvan zou voor elk der gebiedsdelen een staatsinrichting bij wet worden vastgesteld. Ook andere onderwerpen zouden bij de wet worden geregeld, als daaraan behoefte zou blijken te bestaan. Als regel zou

Menkman, De WIG, 11, 1929. pp. 403-411; De Gaay Fortman, De WIG, 12, 19301931, pp. 85-106, 119-146 en De WIG, 12, pp. 510-521; Hartog (1961) pp. 950-975; Encyclopedie (1985) p. 196; Van Soest (1980) pp. 7-13; Van Wehry (1988) p. 137; Justicia (1968) pp. 79-93. J. Sint Jago, 'Revolutie zat Venezolaan Rafael Urbina in het bloed', Amigoe, Ñapa, 30 mei 1992; E. Maduro, 'Overval door Venezolanen in 1929 bracht consternatie', Amigoe, Napa, 11 september 1993.

Wytema (1931) pp. 9 e.v. Daar het de bedoeling was de koloniën zelfbestuur te verlenen naar aanleiding van de gewijzigde Grondwet 1922, was het natuurlijk wel van belang te weten, hoe ver het opperbestuur van de Koning reikte. De schrijvers verschilden sterk van mening. De hoogleraar I.A. Nederburgh was duidelijk: 'De Regeering, dat is de Koning. De macht van de Koning is alomvattend. Zoo was het in 1814 en 200 is het nog.' Duidelijk is dat sinds de Grondwet van 1922 dat opperbestuur niet ook de bevoegdheden tot regelen inhoudt. Wetgeving en bestuur zijn in aparte artikelen geregeld (respectievelijk de artt. 62 en 61 Grondwet 1922) het opperbestuur van de koning is uitgehold en de macht van de Gouverneur (algemeen bestuur) is versterkt, ook al voert hij het algemeen bestuur in 'naam des Konings', dus volgens aanwijzingen van de regering, Wytema (1931) pp. 58 e.v. Wytema stelde dat de regering en de Staten-Generaal toch nog grote moeite hadden bevoegdheid in eigen aangelegenheden over te dragen aan de koloniēn. Zie ook Kasteel (1956) pp. 20 e.v.

- Kasteel (1956) p. 43. 
over de wettelijke regelingen het vertegenwoordigend lichaam van het betrokken gebied worden gehoord. Leidend beginsel zou voorts zijn, dat de regeling van inwendige aangelegenheden van een gebiedsdeel zou worden overgelaten aan aldaar gevestigde organen. De verordeningen van die organen zouden op grond van strijd met de Grondwet, de wet of het algemeen belang bij wet kunnen worden vernietigd, eventueel nadat zij door de Koning waren geschorst.

De Koning stond aan het hoofd van de regering van het Koninkrijk, omdat hij Koning van Nederland was. Zijn positie werd uitsluitend bepaald door de Nederlandse Grondwet, die alleen door de Nederlandse organen kon worden gewijzigd. Hij oefende zijn bestuur uit met medewerking van ministers, die slechts aan de Nederlandse Staten-Generaal verantwoordelijk zijn. Juridisch waren Koning en Staten-Generaal bevoegd, met inachtneming van de daarvoor door de Grondwet voorgeschreven procedure, in die Grondwet iedere wijziging aan te brengen, die zij nuttig oordeelden. De vertegenwoordigende organen der andere gebiedsdelen behoefden daarover zelfs niet te worden gehoord. ${ }^{81}$

In de jaren 1919 en 1920 kwam op het Nederlands deel van Sint Maarten grote ontevredenheid tot uiting over een vermeende achterstelling ten opzichte van de andere eilanden.$^{82}$ In de plaatselijke pers werd propaganda gemaakt voor een afscheiding van de Bovenwinden en voor een eigen Raad van de Bovenwinden. Sint Eustatius en Saba waren het er echter niet mee eens en de afscheidingsbeweging verzandde. Goslinga zegt daar het volgende over:

"The Dutch Leeward Islands, by an irresponsible act of the Dutch Parliament brought under the tutelage of Willemstad, were politically totally dependent on decisions made in far away Curaçao. What aggravated this dependent condition was the fact that economically they were far from prosperous. The three islands, without any institution to voice their opinion - except for the insignificant landra-

i Oud (1967) pp. 13-15.

- Kasteel (1956) pp. 25 e.v. Alle eilanden behalve Curaçao kregen in 1865 een soon gemeenteraad. Raad van Politie genoemd, bestaande uit een Gezaghebber of onderGezaghebber en twee door de mannelijke ingezetenen volgens een beperkt kiesrecht telkens voor vier jaren gekozen Landraden. Tol 1920 had elk eiland, behalve Curaçao, een Gezaghebber benoemd door de Koning. Na 1920 kregen Sint Eustatius en Saba elk een onder-Gezaghebber, administratief afhankelijk van de Gezaghebber van Sint Maarten. Aruba en Bonaire behielden elk een eigen Gezaghebber. Van 1920 tot 1951 was het de Gouvemeur die de Gezaghebbersbenoemde, schorste en ontsloeg en die ook hun instructies vaststelde. Sinds 1951 worden de Gezaghebbers weer benoemd door de Kroon. De verandering in het benoemingsbeleid van 1920 werd aangebracht naar aanleiding van de afscheidingsbeweging op Sint Maarten. 
den in which they were represented - did not trust the Koloniale Raad, which was, as they maintained, not familiar with their problems, and felt abandoned. Socialist member of the Second Chamber Van Kol was almost always their only champion in the Netherlands. The fact that the three Commanders of the Leeward Islands were extremely jealous of their prerogatives and shunned co-operation did not do much for the islands ' plight either. Combined with the hostile attitudes of the inhabitants towards the main island-especially voiced in the local councils - this played a major role in their decision making: the Commander of St. Martin, for instance, refused to improve the saltpan in spite or perhaps because of suggestions from Willemstad, and sabotaged the health action against the hookworm at Simpson Bay. But what especially irritated the people was the fact that most governement employees originated from Curaçao. This irritation went so far that a prominent planter from St. Martin addressed a letter to President Wilson of the USA on the occasion of the purchase of the Danish Antilles. Wilson did not answer. Frustrated this planter, with others, raised his voice to effect a direct relationship with the Netherlands without the Governor of Curaçao as a middleman, the 'los van Curaçaobeweging'. In September 1919 an address was sent tot the Queen, expressing the sad feelings. They wanted their own Raad. The Hague anticipating these demands had already brought the island under one gezaghebber - Commander no longer appointed by Willemstad but by the Colonial Office." 83

Bij deze 'los van Curaçaobeweging', die ook al tussen 1904 en 1908 een rol speelde moet met name gedacht worden aan een administratieve decentralisatie. Ook de Koloniale Raad dacht er in 1923 zo over. De conclusie van de Koloniale Raad was dat de Bovenwinden en Benedenwinden financieel en administratief gescheiden zouden moeten worden. 'Omdat de eilandjes Sint Eustatius, Saba en Saint Martin te onbeduidend waren om in onmiddellijke aanraking met het moederland te worden gebragt', is dat tenslotte de oorzaak geweest van de vereniging van de Bovenwindse en Benedenwindse eilanden tot één kolonie Curaçao en onderhorigheden. Voor de Kolonjale Raad was de scheiding van de Bovenwinden en Benedenwinden geen doel op zich, maar een middel om te komen tot financiële zelfstandigheid. De Koloniale Raad was van mening dat Nederland een historische fout had begaan door twee zulke verschillende gebieden, qua cultuur, taal, economische bedrijvigheid en historische ontwikkeling bij elkaar in één kolonie onder te brengen. De Gaay Fortman was het daar niet mee eens en dacht dat ook die verschillen in én kolonie tot hun recht kunnen komen. De Gaay Fortman merkte op dat de Bovenwinden en Benedenwinden niets met elkaar gemeen mogen hebben, maar dat 
zulks ook gold voor de eilanden onderling. Tevens was De Gaay Fortman van mening dat de door de Koloniale Raad gewenste financiële onafhankelijkheid van Nederland, niet met zich meebracht dat de Bovenwinden en Benedenwinden bestuursrechtelijk van elkaar gescheiden moeten worden, maar dat het beoogde doel ook kan worden bereikt door het verkrijgen van het vrije budgetrecht. ${ }^{84}$

De hierboven geschetste problemen waren uiteraard min of meer voorspelbaar, daar de eilanden niet vertegenwoordigd waren in de Koloniale Raad en de Koloniale Raad zowel de plaatselijke belangen van Curaçao als de centrale belangen van alle eilanden behartigde. In de Koloniale Raad waren de plaatselijke belangen van Curaçao formeel niet vertegenwoordigd, maar kwamen wel aan bod. Het laat zich denken dat de suprematie van Curaçao over de andere eilanden aanleiding gaf tot irritaties. In principe ligt hierin ook de aanleiding tot het afscheidingsstreven van Aruba. De meeste leden van de Koloniale Raad waren bekend met de situatie op Curaçao, maar niet met de problematiek van de andere eilanden. Enige communicatie tussen de eilandelijke Raden en de Koloniale Raad, om deze problemen te voorkomen was door gebrek aan mankracht, middelen, afstand en wederzijdse interesse, niet mogelijk. Toen in 1922 de naam Curaçao in artikel 1 van de Grondwet werd opgenomen als naam voor de hele kolonie, werd in feite een afwijzende beslissing genomen ten aanzien van de kort tevoren geuite wens van de Bovenwindse eilanden zich af te scheiden van Curaçao en de Benedenwindse eilanden. ${ }^{85}$

In 1862 richtten enkele vooraanstaande personen in de Curaçaose gemeenschap een verzoek aan Nederland om beperkt stemrecht. Voor algemeen kiesrecht achtte men de tijd nog niet rijp. Zoals hierboven opgemerkt werd in 1865 in Suriname een beperkt kiesrecht ingevoerd, op Curaçao gebeurde dat bij het Regeringsreglement van 1865 niet. Op 23 mei 1893 zonden 236 ingezetenen van Curaçao een adres aan de Staten-Generaal met het verzoek nogmaals te overwegen of de kolonie geen kiesrecht kon worden toegekend. Zelfs de Koloniale Raad was op zijn standpunt teruggekomen, hoewel de financiële

De Gaay Fortman, De WIG, 4, 1922, pp. 296-299, en 302 e.v. Op 12 september 1919 werd onder leiding van de heren J.C. Waymouth, D.H. Nisbet en A.C. Wathey een betoging gehouden, waarbij besloten werd, een verzoekschrift aan de Koningin te richten, waarin onder andere gevraagd werd on een vertegenwoordiging in de Koloniale Raad en geklaagd werd over de financiële lasten die de 'saamhorigheid' met Curaçao meebracht. Ook klaagde men over de ondergeschikte positie van de Gezaghebber van de drie Bovenwindse eilanden aan de Gouverneur. 
bezwaren nog steeds zwaar telden. ${ }^{86}$

De Nederlandse regering verklaarde het probleem te bestuderen, maar er geen oplossing voor te zien. Naar werd aangenomen waren de aan Suriname gegeven politieke rechten 'geen succes'. ${ }^{87}$ De discussie laaide dertig jaar later weer op, omdat de bewoners van de andere eilanden wel mochten stemmen voor de Raden van Politie, terwijl de bewoners van Curaçao dat niet was toegestaan voor de Koloniale Raad. In 1901 werd in de kolonie Curaçao het ambtshalve lidmaatschap van de Koloniale Raad afgeschaft. Alle leden van de Raad werden door de Koning benoemd. De regel dat de Gouverneur voorzitter was van de Koloniale Raad en de Procureur-Generaal onder-voorzitter kwam te vervallen. Ook werd toen weer uitgebreid besproken of geen kiesrecht kon worden verleend voor de samenstelling van de Koloniale Raad, maar de Gouverneur was er niet voor. ${ }^{88}$ Begrijpelijkerwijs deden er zich regelmatig meningsverschillen voor tussen de Gouverneur en de Koloniale Raad, omdat vaak adviezen van de Koloniale Raad door de Gouverneur niet werden opgevolgd. Dit speelde met name een belangrijke rol bij de begrotingspolitiek. Als de begroting niet sluitend was, dan moest deze goedgekeurd worden bij wet door de Staten-Generaal. Dit was meestal het geval. Van autonomie in eigen aangelegenheden, in beginsel neergelegd in het Regeringsreglement van 1865, kwam nog niet veel terecht. Het bestuur kon immers niet worden heengezonden door de wetgevende macht. ${ }^{89}$

Ook al werd in het Regeringsreglement van 1865 uitgegaan van autonomie, dan is die autonomie echter zinledig zonder zeggenschap over de financiēn, aldus De Gaay Fortman. ${ }^{90}$ Het onvermijdelijke van een subsidie was immers dat de koloniale begroting bij wet moest worden vastgesteld. Daardoor was in de praktijk de toegestane autonomie slechts schijn geworden, omdat door de armlastigheid der koloniēn de begrotingen steeds moesten worden vastgesteld in het moederland. ${ }^{91}$ De Gaay Fortman waarschuwde er nog tegen om het algemeen kiesrecht en de geldelijke onafhankelijkheid van de kolonie als een onverbrekelijk geheel te zien, omdat hij dat 'eene bedenkelijke

\footnotetext{
* Da Costa Gomez (1935) p. 81.

7 De Gaay Fortman, De WIG, 6, 1924/1925, pp. 385-404; Kasteel (1956) p. 15.

* De Gaay Fortman, De WIG, 6, pp. 385-404. De Voz di Pueblo van 18 oktober 1920 deelt nog mee, dat 21 februari 1895 de Koloniale Raad zich met overgrote meenderheid voor de toekenning van het kiesrecht aan de bevolking van Curaçao verklaarde.

* De Gaay Fortman (1947) p. 9 e.v.

so De Gaay Fortman, De WIG, 5, 1923, pp. 533-552.

91 De Gaay Fortman, De WIG, 5, 1923, pp. 535-560.
} 
vereenzelviging van autonomie en budgetrecht' vond.

De Grondwetsherziening van 1922 bracht in de bestaande situatie weinig verbetering. De lijn die in 1848 was gegeven werd doorgetrokken. De gewone wetgeving voor de kolonie berustte niet meer bij de Koning, maar kwam in handen van de Staten-Generaal, die de regeling van inwendige aangelegenheden zou overlaten aan organen ter plekke. ${ }^{2}$ Voorts zou er een scherpere scheiding zijn tussen de bevoegdheden van de Koning en de Gouverneur. Voor zover niet bij de Grondwet of de wet bevoegdheden aan de Koning waren voorbehouden, werd het bestuur in naam van de Koning uitgeoefend door de Gouverneur.

In 1923 richtte de Curaçaosche Vrijheidsbond onder leiding van de Europees-Nederlandse rechter J.A. Schagen een adres aan de Koningin, met het verzoek om beperkt kiesrecht als grondslag voor de samenstelling van de volksvertegenwoordiging. ${ }^{93}$ Het gebrek aan plaatselijke geldmiddelen en mogelijkheden, alsmede de afstand tot Curaçao maakten de bevolking van de overige eilanden vrij apathisch in politiek opzicht. Op Aruba en Bonaire kwam de Raad van Politie slechts enkele keren per jaren bijeen. Wellicht vanwege de relatieve onbeduidendheid van het ambt van Landraad was de belangstelling om het ambt te vervullen of het verlangen het kiesrecht te bezitten evenmin groot. Veel werd overgelaten aan de Gezaghebber, wiens woord op het eiland wet was. Omstreeks de jaren dertig ontstond er ontevredenheid op Aruba wegens gebrek aan beschikking over eigen financiēle middelen en gebrek aan interesse van bet centrale bestuur voor de noden van Aruba. In 1933 zond de Raad van Politie van Aruba een verzoekschrift aan de Koningin. Hierin werd betoogd, dat in de komende Staatsregeling de bevoegdheden van de Raad niet bij koloniale verordening zouden moeten worden vastgesteld en dat instelling van bestuursressorten ook niet op dergelijke wijze moest geschieden. Aruba wenste autonomie, een bevoegdheid onafhankelijk van Curaçao en dacht daarbij aan de bevoegdheid van $B \& W$ in Nederland. De eilanden zouden met meer autonomie "op die wijze

De artikelen 60-62 GW 1922, Van Hasselt (1987) pp. 375-414.

93 In de jaren twintig en dertig bestonden er op Curaçao slechts twee verenigingen die zich soms bezig hielden met politieke onderwerpen. $\mathrm{Zij}$ waren geen politieke partijen, maar meer debatingclubs, wasrin een klein aantal ingezetenen zo nu en dan actuele onderwerpen besprak. De eerste van deze organisaties was de 'Curaçaosche Vrijheidsbond', waarvan de 'Voz di Pueblo' van 1923 tot 1925 het orgaan was. Dit blad bestond van 1916 tot 1928 en was zeer anti-katholiek. De Bond streefde naar 'autonomie voor Curaçao met handhavingvan de saamhorigheid met het moederland'. De tweede vereniging was 'Jong Curaçao', die tussen 1932 en 1935 van zich liet horen in een periodiek dat de 'Onpartijdige' heette. De invloed van de organisatie was gering en viel uiteen door onderling meningsverschil, Kasteel (1956) pp. 38 e.v. 
geen bloode [bedoeld: bloote?] onderhoorigheden blijken te zijn van het hoofdeiland Curaçao." 94

Het bekendste Arubaanse Statenlid was wel de heer J.H.A. ('Henny') Eman (1887-1957), afstammeling van een familie die zich in 1764 op Curaçao en in 1801 op Aruba vestigde en waarvan verscheidene leden een vooraanstaande rol hebben gespeeld in het economische leven en in ambtelijke functies op Aruba. Eman was een van de weinigen die, als hij geen Landraad was, gebruik maakte van het recht in de Raad van Politie het woord te voeren. Ook zijn vader C.H. Eman (1865-1914) had trouwens steeds voor een betere haven op de bres gestaan en leefde in de herinnering van vele Arubanen voort als een onvermoeid promotor van Aruba. J.H.A. Eman was de oprichter van de Arubaanse Volkspartij (AVP). Hij werd in 1921 als Landraad in de toenmalige Raad van Politie gekozen en had vanaf 1941 tot zijn overlijden onafgebroken zitting in de Staten van de Nederlandse Antillen. Hij maakte deel uit van de Ronde Tafelconferentie Nederland, Suriname, Nederlandse Antillen van 1952. C.A. Eman (1916-1967) Shon A, de zoon van 'Henny' Eman was sedert het overlijden van zijn vader voorzitter van de AVP. Hij was van september 1958 tot aan zijn overlijden lid van de Staten van de Nederlandse Antillen en sedert 1951 lid van de Eilandsraad van Aruba. Hij maakte eveneens deel uit van de Ronde Tafel Conferentie van 1948 en die van 1952-1954.

De maatschappelijke veranderingen, door de moderne industrie op Aruba gebracht, waren enorm. De landelijke eenvoudige bevolking, die altijd nogal geïsoleerd had geleefd en een karig bestaan leidde, regelmatig bedreigd door hongersnoden, evolueerde snel. Er was voor iedereen werk, de welstand en de economische bedrijvigheid namen toe. Ook die ontwikkeling leidde er toe dat de Arubanen steeds ontevredener werden over de oude bestuursvorm. ${ }^{95}$

De Commissie Staal (1922)

Ter voorbereiding van uitvoering van de Grondwetsherziening stelde de minister voor Koloniën op 27 april 1922 een Commissie in onder

Kasteel (1956) pp. 28-35, het tussen vierkante haken geplaatste maakt deel uit van het citaat.

93 De landraadsverkiezingscampagnes van Eman waren dikwijls spectaculair, ondat hij zich niet alleen tot de kiesgerechtigde inwoners placht te wenden, maar ook tot andere groepen van de bevolking, van wie hij zichzelf de vertegenwoordiger achtte. Zo plaatste hij in de campagne van 1931, een jaar van economische teruggang. soepketels op een gedeelte van het eiland waar hongersnood heerste en deelde voedsel uit aan de schoolkinderen. Voor een goed inzicht in het dagelijks leven op de eilanden aan het begin van deze eeuw zie: Lampe (1968) en Wernet-Paskel (1992).

178. De periode van koloniale stabilisatie 1865-1936 (V) 
voorzitterschap van G.J. Staal, oud-Gouverneur van Suriname. De Commissie moest de regering adviseren over de wijzigingen die in het Regeringsreglement voor Suriname en Curaçao moesten worden aangebracht in verband met de Grondwetsherziening van 1922 . $^{\text {\% }}$ In haar rapport van 29 maart $1923^{97}$ stelde de Commissie voor de Koloniale Raad te vervangen door de Koloniale Staten als vertegenwoordigend lichaam aan te wijzen. De Staten zouden uit 15 leden moeten bestaan en rechtstreeks gekozen worden. De tijd was echter nog niet rijp voor een algemeen kiesrecht, meende de Commissie. Een mannen-censuskiesrecht wordt voorgesteld, het bedrag van de census werd op minimaal $f 500$,- en maximaal $f 1000$,- gesteld. Ook een zekere verstandelijke ontwikkeling werd als eis gesteld om te mogen kiezen en verkozen te worden. De Commissie meende dat de leden van de Staten in Suriname een vergoeding voor hun werkzaamheden van $f 1000$,- per jaar zouden moeten ontvangen, voor de te verkiezen leden van de Koloniale Staten was dat nog niet aan de orde, zij moesten hun taak nog beginnen. Invoering van het enquêterecht was zinloos, meende een meerderheid in de Commissie. 'De verleende macht, welke slechts ten halve zou kunnen worden uitgeoefend, zou de scherpte van de kritiek ongunstig beïnvloeden en dat in eene samenleving van geringen omvang, waar het persoonlijk element uiteraard op de voorgrond treedt'. De Commissie adviseerde met name om op Curaçao gemeenten in te stellen en die gemeenten autonomie of zelfbestuur in eigen aangelegenheden te geven, zoals ook in Nederlandse gemeenten het geval was. De Commissie sprak zich uit tegen een tweedeling van de kolonie. ${ }^{98}$

De regeling van de decentralisatie diende uitgebreider in het

De opdracht van de Commissie luidde verslag uit te brengen:
'A. omtrent de wijzigingen, welke met inachtneming van de wederzijdse belangen van Moederland en Koloniën, in de Regeeringsreglementen van Suriname en van Curaçao zouden moeten worden aangebracht:
$1^{\circ}$, in verband met de artt. 61, 62 en 62 bis van de Grondwet, zooals die luiden in de wet tot het in overweging nemen van een voorstel van verandering van het Ilde Hoofdstuk der Grondwet;
$2 .^{\circ}$. in verband met instelling van plaatselijke besturen in bevolkingscentra, welke er zich toe leenen om ter voorziening in locale behoeften geheel of ten deele op eigen kracht te steunen;
B. omtrent de mogelijkheden van verwezenlijking van het denkbeeld, om door tijdelijke overbrenging, geheel of ten deele, naar de Staatsbegrooting van bepaalde uitgaven, dan wel op uit een practisch oogpunt aannemelijke andere wijze, voor Suriname en voor Curaçao sluitende koloniale begrootingen te verkrijgen en te behouden.' Verslag van de Commissie van Advies omtrent de herziening van de West-Indische Regeeringsreglementen en begrootingspolitiek (1923) p. 2.
- Rapport Staal (1923) pp. 1-13. 
Regeringsreglement te worden vastgelegd, bovendien moest niet te veel wetgeving worden overgelaten aan de Landswetgever, omdat dan het verwijt zou kunnen worden gemaakt dat Curaçao te veel op de voorgrond zou treden. Voor wat betreft de begroting wilde de Commissie het oude systeem van subsidiëring handhaven, daar zij een begroting van een vastgesteld bedrag voor een bepaalde periode zeer bezwaarlijk achtte. ${ }^{99}$

Het bestuursvoorstel van de Commissie Staal was een bijna getrouwe kopie van de Nederlandse Gemeentewet. Het is interessant te bedenken dat het idee van een gemeentelijke structuur voor de bestuursindeling van de kolonie al sinds 1828-1833 een rol speelde, maar het nooit echt gehaald heeft.

Een gemeentelijke structuur werkt naar mijn mening alleen in een gedecentraliseerde eenheidsstaat van enige omvang. Een staat opgebouwd uit eilanden kent niet dat gemeenschapsgevoel, dat Nederland bijvoorbeeld in het algemeen wel kent, en dat nodig is om als samenbindend element een staatbestel als natie vorm te geven. Hoewel een gemeentelijke structuur niet goed past in het WestIndische staatsdeel, zouden toch ook de Commissie Logemann en de Commissie Van Poelje daaraan hun inspiratie weer ontlenen.

De snelheid waarmee de Commissie Staal zich van haar taak had gekweten, stond in schril contrast met de traagheid die aan de dag werd gelegd in de herziening van de West-Indische Regeringsreglementen. De zonderlinge toestand ontstond, dat terwijl er blijkens artikel 61 van de Grondwet van 1922, in elk der drie buiten Europese gebiedsdelen een vertegenwoordigend lichaam moest zijn, de Staatsregeling die een en ander mogelijk moest maken, pas in 1936 tot stand kwam. Het duurde zolang omdat de decentralisatieregelingen voor Nederlands-Indie meer in de belangstelling stonden. Het de facto uitwerken van decentralisatieregelingen in de kolonie stagneerde wegens onderlinge meningsverschillen in de Koloniale Raad. Wegens kabinetswisselingen en het inwinnen van advies bij de nieuwe Gouverneur van Suriname ontstond verdere vertraging. ${ }^{100}$ Bovendien zag de Koloniale Raad niet zoveel in constitutionele instellingen en kiesrecht. In de omliggende landen waar armoede en onrust heersten bestonden politieke rechten meestal alleen maar op papier. De vooraanstaande Antillianen waren in hoofdzaak geïnteresseerd in

99 Bijlage 1.B van het Rapport Staal bevat de tekst van het Regeringsreglement van 1865 en de voorgestelde wijzigingen daarnaast getypt, de te vervallen onderdelen zijn met een zwarte pen doorgehaald. Het woord kolonie verdwijnt en het hele gebied wordt nog steeds Curaçao genoemd, wel worden de eilanden apart vermeld (art. 1). 
stabiele financiële en handelsrelaties. Bovendien vreesde de Koloniale Raad een zwart overwicht. Ook vanuit de andere eilanden, die economisch niet meetelden was de vraag naar meer invloed in het landsbestuur gering en kwam pas naar voren toen de economische bedrijvigheid toenam. ${ }^{101}$

Eind 1935 verscheen het proefschrift van M.F. da Costa Gomez: ${ }^{102}$ 'Het wetgevend orgaan van Curaçao, Samenstelling en bevoegdheid bezien in het kader van de Nederlandsche koloniale politiek ${ }^{103} \mathrm{Hij}$ gaf een scherpe analyse van het koloniale bestuur in Suriname en de kolonie Curaçao vanaf het bewind van de WIC tot 1935 , vervolgens deed hij aanbevelingen, hoe op grond van de geschiedenis en de wensen van de bevolking in Curaçao de nieuwe staatsinrichting eruit zou moeten zien. Hij stelde: ${ }^{104}$

"Reeds in den aanvang werd de koloniale politiek geheel beheerscht door de overheerschingsgedachte, die een uitvloeisel was van het destijds geldende beginsel, dat de koloniën er waren tot eigen gewin van den overheerscher."

Da Costa Gomez wilde niet zozeer de geschiedenis van het kolonialisme beschrijven, maar de nadruk leggen op het naar zijn mening bestaande 'volslagen rechtsabsenteīsme' in deze verhoudingen; op het stilzwijgen van rechtsbewustzijn en rechtsgevoel.

Kasteel (1956) pp. 17-35.

Moises Frumencio da Costa Gómez, 'Doctoor', werd geboren te Curaçao op 27 oktober 1907 en stierf op 22 november 1966 . Hij studeerde rechten aan de Katholieke Universiteit te Nijmegen en was werkzaam als griffier bij het Hof van Justitie. Hij promoveerde in 1935 in Amsterdam. Hij was sinds 1930 lid van Staten voor de Katholieke Partij. In 1948 richtte hij de Nationale Volkspartij op en had zitting in de Staten voor die partij. In 1942 was hij enige tijd lid van de Buitengewone Raad van Advies. In 1949 was hij enkele maanden voorzitter van hel College van Algemeen Bestuur. Tussen 1946 en 1954 was hij voorzitter van de Antilliaanse delegalies voor de verschillende Ronde Tafel conferenties. Hij was voorzitter van de Regeringsraad van 19 april 1951 tot 8 december 1954. Nadien was hij lid van de Staten en van 1963 tot zijn overlijden Gedeputeerde-Raadslid van Curaçao, Reinders (1989). Da Costa Gomez was katholiek, hoewel van Portugees-joodse afkomst, Fennema (1986) p. 77.

Da Costa Gomez (1935); zie ook Pieters Kwiers (1991) en Jesurun e .a. (1993), deze uitgave bevat een bundeling van een aantal redevoeringen van Da Costa Gomez. Da Costa Gomez (1935) p. 1. 
"Eerst onder den invloed van de natuurrechtsfilosofen en vooral door de revolutionnaire staatsrechtelijke theorieën van 1789 , en de latere ontwikkeling van het rechtsbegrip in tegenstelling met machtsbegrip, is het probleem van den persoon van den inlander en van het staatkundig bestaan van de koloniën ontstaan. De evolutie, die leiden zal zoowel tot verwerping van de oude overhcerschings-commercieele politiek, waarvoor in den verruimden geest geen plaats kan zijn, als tot den ernst der ethische politiek, die hare rechtvaardiging in zich zelve vindt - immers iedere menschelijke handeling en dus ook de politiek en dan ook de koloniale politiek, kan alleen in de ethiek hare rechtvaardiging vinden - wordt theoretisch ingezet in de eerste helft van de $18 \mathrm{e}$ eeuw en tot op heden voortgezet door een groot aantal rationalistische en humane denkers en politici.

Dit begon met de afschaffing van de slavernij. De revolutionaire gelijkheids-theorie heeft tot op heden stand gehouden en meer en meer is deze geestesgesteldheid dit koloniseerendevolk eigen geworden. Deze gelijkheidsgedachtenu, heeft in hare gevolgen een werking naar binnen of een werking naar buiten, een centraliseerend-staatsrechtelijke of een decentraliseerende, federalistische, ja zelfs volkenrechtelijke." 105

Da Costa Gomez gaf hier blijk van een vooruitziende blik, want het Koninkrijk der Nederlanden zou zich later in federale zin ontwikkelen (Eilandenregeling Nederlandse Antillen 1950/1951, Statuut 1954 en Antilliaanse Staatsregeling 1955) met een sterke tendens de bestuursorganen uit het moederland, min of meer aangepast aan de kolonie over te nemen. Da Costa Gomez betreurde het dat de constitutionele charters voor de koloniën, die de Staatsregeling van 1798 in het vooruitzicht stelde niet werden vastgesteld. ${ }^{106}$ Waren ze wel ingevoerd dan had wellicht de kolonie Curaçao niet behoeven te wachten tot de Staatsregeling van 1936 om vrijheid, gelijkheid en broederschap in staatsrechtelijke zin te verkrijgen.

De restauratie had natuurlijk niet alleen in Nederland na 1806 zijn invloed, maar ook in de koloniēn, met dit verschil dat voordat

106 Hij stelt: 'dat het idee van de charters voor de koloniēn in Azië geîmponteend is uit de Engelse koloniale politiek via Frankrijk. Indien dit idee van charters voor de koloniën tot werkelijkheid was geworden en niet een onvervulde belofte was gebleven, zouden wellicht de reactionnaire en onvoldoende reglementen, die na 1798 zijn gemaakt en die zeker de evolutie in het koloniale recht niet hebben bevorderd achterwege zijn gebleven. Koloniale charters plegen een meer vrijzinnigen geest te ademen dan reglementen. Deze documenten fundeerden de Engelsche koloniēn in Noord-Amerika op den grondslag van een maatschappelijk verdrag en hun beteekenis was die van een constitutie in deze koloniēn, in den geest van het "instrument of gove.nement" van 1653 in Engeland zelf. Deze charters hielden in een beschrijving van de staatkundige ordening der Amerikaansche koloniēn, overeenkomende met de staatkundige ordening in Engeland van "selfgovernment".' 
de staatkundige veranderingen de koloniën konden bereiken ze alweer ongedaan gemaakt waren. Nederland heeft nog wel een aantal 'voortvarende' constituties gekend voordat de restauratie intrad, maar de revolutie heeft de koloniën staatsrechtelijk nooit bereikt.

$\mathrm{Da}$ Costa Gomez stelde dat het verschil tussen een bezitting en een staatsdeel is dat de bewoners in een (koloniale) bezitting geen staatkundige rechten hebben en in een staatsdeel wel. De Wet op het Nederlanderschap van 1850 kende aan de bewoners van het Rijk buiten Europa geen staatsburgerschapsrechten toe, Da Costa Gomez achtte dit onjuist daar de koloniale bevolking wel competent geacht moest worden de staatkundige plichten te vervullen. In 1892 wordt door de Wet op het Nederlanderschap de koloniale bevolking in WestIndië gelijkgesteld met de bevolking van het Rijk in Europa en verkregen zij het Nederlanderschap.

Op grond van art. $1 \mathrm{GW} 1848$ moest het overzeese Rijk juridisch als staatsdeel worden gezien, maar de materiële positie van die gebieden was nog steeds die van een exploitatie-kolonie. Het karakter van een staatsdeel werd volgens Da Costa Gomez bepaald door de staatkundige rechten van de bewoners en door het karakter van het territoir. Het territoir was sinds de Grondwet van 1848 staatsdeel. De verdere ontwikkeling van dat staatsdeel had moeten plaatsvinden binnen het gebied, met name het kiesrecht had hen moeten worden toegekend, meende Da Costa Gomez. ${ }^{107}$

Artikel 61 van de Grondwet van 1922 bepaalde, dat de staatsinrichting van Nederlands-Indië, Suriname en Curaçao bij wet zou worden geregeld. Dit gebeurde voor Nederlands-Indië bij de wet van 1925. Suriname en Curaçao hadden die wettelijke regeling nog steeds niet gekregen. Da Costa Gomez meende dat, "[...] daarenboven de intrekking van de regeeringsreglementen dringend noodzakelijk was, aangezien deze niet meer beantwoorden aan den werkelijken toestand van het staatsdeel." 108 Het ontbreken van politieke organisaties achtte hij geen reden om het kiesrecht aan Curaçao te onthouden. "Deze organisaties kunnen alleen daar ontstaan, waar politieke rechten worden toegekend en uitgeoefend." 109 Hij was van mening dat het algemeen kiesrecht niet een evolutie was van een censuscapaciteits-welstands- en ontwikkelings-kiesrecht. "Wanneer een volk, dat geen politieke partijen gevormd heeft, geroepen wordt tot de

io Da Costa Gomez (1935) p. 67.
104 Da Costa Gomez (1935) p. 68.
109 Da Costa Gomez (1935) p. 149.

Da Gosta Gomez en het kiesrech1 .183 
uitoefening van het algemeen kiesrecht kan het niet anders dan zich organiseeren in staatkundige organisaties, waarin de levende staatkundige, rechts- en sociale overtuigingen weergegeven worden." 110 Ook meende hij dat een passief en actief vrouwenkiesrecht moet worden ingevoerd, in tegenstelling tot het voorstel van de Commissie Staal, die alleen het passief vrouwenkiesrecht wenste in te voeren. Hij achtte de vermogenstoestand van de potentiële kiezers volkomen irrelevant voor de toekenning van de kiezershoedanigheid, evenals een bijzondere graad van verstandelijke ontwikkeling. "Hoe men over de mérites van dit algemeen kiesrecht ook moge denken, het is het recht, dat de geest des tijds voor iederen burger vordert. Niet de kleine groep van intellectueelen vormen den staat, maar het geheel der burgers". 111

Mochten geografische bezwaren inderdaad een rol spelen, zoals de regering al bijna 100 jaar hanteerde als argument tegen het invoeren van het algemeen kiesrecht en hieraan twijfelde Da Costa Gomez dan had hij ook daarvoor een oplossing gevonden. "De Bovenwindsche eilanden zouden heel goed een ingezetene van de Benedenwindsche eilanden kunnen kiezen. De partij organisaties, die niet locale, maar algemeene organisaties zijn, zullen die personen als candidaten stellen, die zij als de meest bekwamen beschouwen, ongeacht van welk eiland dezen ingezetenen zijn.",112

Na een lang koloniaal tijdperk luidde de Staatsregeling van 1936 de politieke emancipatie van de Nederlandse Antillen in. Deze wet bereikte pas veertien jaren na de Grondwetswijziging van 1922, het Staatsblad. In 1936 werd het Regeringsreglement 1865 vervangen door de Wet op de Staatsinrichting van Curaçao ${ }^{113}$ en voor Surina-

Da Costa Gomez (1935) pp. 9 en 150.

Da Costa Gomez (1935) p. 94; De Gaay Fortman (1947) p. 37; Gedenkboek (1934) pp. 123-169.

Da Costa Gomez (1935) p. 152.

11 Regeringsontwerp van 19 november 1934, Bijlagen Tweede Kamer, Memorie van Toelichting 4, Wetsontwerp II, Wijziging van het Reglement op het beleid der Regering in de kolonie Curaçao, Zitting Tweede Kamer 1934-1935 (Suriname, Wetsontwerp I). Beschikking van den 16n October 1936, 1683, bepalende de plaatsing in het Publicatieblad van het Koninklijk Besluit van den 15n Augustus 1936 (Stb. 910) bepalende de bekendmaking in het Staatsblad van den tekst der Wet op de Staatsinrichting van Curaçao en tot bepaling van het tijdstip van de inwerkingtreding van de Curaçaosche Staatsregeling, Publicatieblad 1936, 105. De Gaay Fortman is van mening dat de uitvoering van de grondwettelijke bepalingen van 1922 zo lang geduurd heeft omdat er in Nederland weinig belangstelling voor de West 
me door de Surinaamsche Staatsregeling. Deze beide staatsregelingen voor de koloniën kwamen in hoge mate overeen. Voor het eerst was er sprake van een Staatsregeling en niet meer van een Regeringsreglement. Ook het woord 'kolonie' was niet meer passend, meldde de Memorie van Toelichting bij de desbetreffende wetsontwerpen. ${ }^{114}$ Om te voorkomen dat de nieuwe structuur een fiasco werd wegens onbekwaamheid en onenigheid in de Staten, droeg de Staatsregeling de sporen van voorzichtigheid. De Gouverneur kreeg op grond van de Staatsregeling meer macht tegenover het nieuwe wetgevend lichaam (de Staten), dan hij had ten opzichte van de vroegere Koloniale Raad. Bovendien kon hij door zijn bevoegdheid vijf van de vijttien leden te benoemen, een zeer sterke invloed doen gelden op de Staten. Ook de voorzitter en de ondervoorzitter werden door de Gouverneur benoemd. Ondanks de grote verantwoordelijkheid die de Staatsregeling op de Gouverneur legde, werd hij slechts terzijde gestaan door een Raad van Bestuur, door de Koning benoemd. De taak van de leden van de Raad van Bestuur was een neventaak. Zij dienden de Gouverneur van advies. Zij werden 'gekozen' (voorgedragen en benoemd) uit de bevolking zonder enige samenhang met Bestuur en Staten. De belangrijkste wijzigingen in de Curaçaosche Staatsregeling ten opzichte van het Regeringsreglement van 1865 waren:

1. De verdwijning van de benaming kolonie. De Koloniale Raad heette voortaan Staten. Aanvaarding van de naam Sint Maarten in plaats van Saint Martin (art. 1). ${ }^{115}$

2. Het kiesrecht werd ingevoerd. Mede naar aanleiding van uit Curaçao ontvangen adviezen werd slechts een beperkt kiesrecht ingevoerd. Tien leden van de Staten werden gekozen op grond van een beperkt mannen census en capaciteitskiesrecht. Dit gebeurde in Suriname al in 1901. Kiezen mogen slechts mannen van de Nederlandse nationaliteit van 25 jaar of ouder, bovendien moesten zij voldoen aan zekere normen voor ontwikkeling of van fiscaal meetbare welstand (artt. 68, 69 en 71). Vrouwen kregen alleen passief kiesrecht waaraan dezelfde eisen werden gesteld als aan het actieve kiesrecht. Vijf leden werden benoemd door de Gouverneur, een van de vijf was altijd een vertegen-

bestond, De WIG, 24, 1942, pp. 214-226.

114 Memorie van Toelichting, Herziening van het Reglement op het beleid der Regering in de kolonie Suriname (Wetsontwerp I) en herziening van het Reglement op het beleid der Regering in de kolonie Curaçao (wetsontwerp II) 198, p. 2.

ins Sint Maarten heette vanaf het begin van de Nederlandse kolonialisatie van de huidige Nederlandse Antillen en Aruba officieel Saint Martin. 
woordiger van de Shell. ${ }^{116}$ De Statenleden zullen gelijktijdig aftreden. De verdeling van de te kiezen vertegenwoordigers over de eilanden kwam niet voor in de Staatsregeling. Dit werd geregeld in het Kiesreglement, dat de 10 zetels als volgt verdeelde: Curaçao 6, Aruba 2, Bonaire 1 en de Bovenwinden 1.

3. Het recht van de Koning om de regeling van elk onderwerp aan zich te trekken verviel. De bevoegdheden van de Koning worden beperkt tot die welke de Grondwet of de wet hem geeft. Vervanging van Koninklijke besluiten door Algemene Maatregelen van Bestuur (AMvB). De regeling van de toelating en uitzetting van vreemdelingen in Curaçao zal 'voor zoveel noodig' bij algemene maatregel van bestuur geschieden en overigens bij landsverordening. De Staten moeten gehoord worden over ontwerpen van AMvB's en van wetten, uitsluitend of in belangrijke mate $\mathrm{Cu}-$ raçao betreffend. Uitbreiding van de verplichting tot horen van de Raad van Bestuur over de ontwerpen van AMvB's en wetten (art. 63).

4. Teneinde conflicten tussen de niet verantwoordelijke Gouverneur en de Staten te voorkomen, werd een conflictenregeling ingevoerd. ${ }^{117}$ Als tussen Gouverneur en Staten de noodzakelijke overeenstemming (met betrekking tot wetgeving) ontbrak, kon de Gouverneur het ontwerp binnen zes maanden opnieuw aan de Staten aanbieden. Werd opnieuw geen overeenstemming bereikt, dan kon de regeling bij AMvB worden getroffen (art. 100). Voorts kon de Gouverneur zonder medewerking van de Staten verordeningen vaststellen, indien de Staten medewerking weigerden en dringende omstandigheden, een onverwijlde voorziening eisten (art. 101).

5. De bestuurlijke bevoegdheden van de Gouverneur ten opzichte van de Koning werden versterkt. Bestuurde de Gouverneur vroeger met 'stipte inachtneming van 's Konings bevelen', thans luidde de formule: 'met inachtneming van 's Konings aanwijzingen' (art. 29). ${ }^{118}$ De Gouverneur kreeg hierdoor een veel machtiger positie dan voorheen. Ten aanzien van inwendige aangelegenheden konden hem geen richtlijnen meer worden verstrekt. De Gouverneur bezat de uitvoerende macht en kon slechts in beperkte mate door Nederland ter verantwoording

Kasteel (1956) p. 96.

Kasteel (1956) pp. 35-46; de regeling is overgenomenvan art. 89 Indische Staatsregeling.

118 De landvoogd is nog steeds slechts verantwoording aan de Koning schuldig, terwijl de Minister van Koloniën voor het in de Antillen gevoerde beleid verantwoordelijk is aan de Staten-Generaal, Kasteel (1956) p. 21.

186. De periode van koloniale stabilisatie 1865-1936 (V) 
worden geroepen.

6. De mogelijkheid werd geopend verdere decentralisatie bij landsverordening te regelen. Samenstelling en bevoegdheden van in te stellen bestuursressorten zullen nader bij landsverordening worden vastgesteld (artt. 117 en 118).

7. De begrotingspolitiek bleef onveranderd met dien verstande, dat voortaan vaststelling bij de wet zou moeten plaats vinden bij elk tekort op de begroting en niet alleen in het geval van een door rijksbijdrage gedekt tekort.

8. Het recht van benoeming van een aantal hoge ambtenaren onder wie de Procureur-Generaal, ging van de Koning over op de Gouverneur (art. 34).

Zoals bleek uit de hierboven uiteengezette voorstellen van de Commissie Staal week de Staatsregeling af van de regeling die de Commissie Staal had voorgesteld. Er kwam geen volledig gekozen Statencollege. Ook werden geen gemeenten op Curaçao ingevoerd. De voorstellen voor de Staatsregeling van 1936, uitgewerkt en herhaaldelijk gewijzigd, maakten overigens in de loop der jaren ettelijke reizen naar de West, eisten de bemoeienis van niet minder dan vijf Ministers van Koloniën en werden onderworpen aan het oordeel van tenminste vijf Gouverneurs en van de elkaar opvolgende Koloniale Staten van Suriname en Koloniale Raden van Curaçao. ${ }^{119}$

De Staten van Curaçao waren nu een onafhankelijk vertegenwoordigend lichaam met medewetgevende bevoegdheid. Het terugtreden van de Nederlandse organen had vooral tot gevolg, dat de bevoegdheden van de Gouverneur toenamen (art. 29). Een politieke verantwoordelijkheid van de uitvoerende macht aan de Staten voor het gevoerde beleid werd echter niet ingevoerd. ${ }^{120}$ De weerstand bij vele vooraanstaande Curaçaoënaars tegen de invoering van algemeen kiesrecht was verklaarbaar, vooral ook omdat zij van mening waren, dat de vestiging van de olieraffinaderijen en de daarmee gepaard gaande economische opbloei voor een groot deel juist te danken waren aan de rustige politieke toestand. ${ }^{121}$

Volgt men het debat op de Antillen zelf, dan worden de redenen die de bourgeoisie had om zelfs geen censuskiesrecht te wensen, duidelijk. De Curaçaose elite bestond rond de eeuwwisseling uit drie

Kasteel (1956) p. 36. Voor een overzicht zie tevens Van Helsdingen (1956) pp. 4-5.

120 Memorie van Toelichting Herziening van het Reglement op het Beleid der Regering in de kolonie Curaçao (wetsontwerp II) en in de kolonie Suriname (wetsontwerp I), Zitting 1934-1935, 198. PB 1936, 105, Wet op de Staatsinrichting van Curaçao.

121 Kasteel (1956) p. 15.
} 
groepen: een protestantse groep, afstammelingen van de 'dienaren' van de West-Indische Compagnie, een Portugees-Joodse groep, die minstens even oude rechten bezat en een groot deel van de handel beheerste, en een kleine katholieke groep waarvan de geringe omvang werd gecompenseerd door de omvangrijke basis onder de bevolking, die de andere twee groepen moesten ontberen. De protestantse elite stond nu voor een dilemma: een hoge census zou, aldus hun woordvoerder J.H.J. Hamelberg, betekenen dat 'overwegende invloed toegekend zou worden aan de Israëlieten, die in het bij de Kamer van Koophandel geldende kiesstelsel ongeveer de helft van de stemgerechtigden waren'; een lage census zou de Joodse invloed weliswaar neutraliseren, maar dan bestond de kans 'dat reeds terstond de feitelijke overmacht in handen van zwarten en kleurlingen' zou vallen. ${ }^{122}$ Onder die omstandigheden verkoos de protestantse elite geheel van het kiesrecht verstoken te blijven.

In niet-katholieke kring werd de eis van algemeen kiesrecht afgewezen met als voornaamste argument de angst voor katholieke overheersing. De angst had echter ook een racistische ondertoon. Immers vrijwel alle zwarte Antillianen waren door de missie gekerstend en dus katholiek. ${ }^{123}$

Kasteel wees er nog op, dat in 1936 nergens in de aan de Europese mogendheden behorende koloniën in de regio, algemeen kiesrecht was toegekend. ${ }^{124}$ Voorstanders van het kiesrecht, zoals A.M. Chumaceiro, bleven een minderheid. Het zou tot in de jaren dertig duren voordat het kiesrecht op de Antillen serieus ter discussie kwam te staan.

De Curaçaosche Staatsregeling van 1936 bevatte een beperkt census- en capaciteitskiesrecht ${ }^{125}$ voor tien van de vijftien leden van de 'Staten', de andere vijf leden werden door de Gouverneur be-

$124 \quad$ Kasteel (1956) p. 40 noot 40 en p. 41 : "In een hoofdartikel in de 'Onpartijdige' van 15 februari 1935 werd de macht van de nieuwe Gouverneur vergeleken met die der absolute vorsten van vóór en hier en daar ook ná - de Franse revolutie, met die der Russische tsaren of met die der directeuren van de kolonie Curaçao in de tijd van de West-Indische Compagnie. 'In een bespreking van de nieuwe Staatsregeling sprak mr. Eskes over een positie, die "topzwaar" was van macht, over "Menschen, dic Führerneigingen krijgen, wanneer zij over een klein gebied zo zelfstandig de scepter mogen zwaaien'". Hij was van mening dat de ontworpen Staatsregeling de strekking had de landvoogd 'practisch te maken tol alleenheerscher van dit gewest, die met het volste recht zeggen kan: Curaçao, c'est moi'."

12 Censuskiesrecht was gebaseerd op het betalen van een bepaald bedrag aan inkomstenbelasting, capaciteitskiesrecht had te maken met het opleidingsniveau. Dat betekende dat in 1937 ongeveer $6 \%$ van de mannelijke bevolking kon deelnemen aan de verkiezingen; Verton (1973) p. 14.
} 
noemd. De politieke ontwikkeling van de bevolking in de WestIndische kolonie, die men in Den Haag voor ogen had was duidelijk een zeer trage. Met name de almachtige positie van de Gouverneur baarde binnen de Koloniale Raad grote zorgen. Ook Da Costa Gomez was het er niet mee eens. Hij meende dat de positie van de Gouverneur als bestuursambtenaar buiten proporties versterkt werd ten koste van de volksvertegenwoordiging. ${ }^{126}$

W.F.M. Lampe, die diende onder zeven Gouverneurs, geeft een indringend beeld van bet optreden van de Gouverneurs ten opzichte van hun ambtenaren en ten opzichte van de 'onderhorige' eilanden.

"De Gouverneur was omringd door een aantal hoofdambtenaren, die oudtijds door de Kroon werden benoemd en die hij dus niet kon ontslaan en die daardoor ook zelf dictator speelden op hun terrein. Anderzijds kon de gouverneur over hen rapporteren en aangezien het nooit is voorgekomen, dat de minister zijn gouverneur niet dekte, betekende een ongunstig rapport ontslag. Het gevolg hiervan was, dat deze hoofdambtenaren, dictators die zij waren voor hun ondergeschikten, niets anders deden dan de gouverneur naar de mond praten. Op Curaçao waren dit, de administrateur van Financiën, de procureur-generaal, de gouvernementssecretaris, dedirectcurvan Openbare Werken, de inspecteur van het Onderwijs en zelfs de inspecteur der Belastingen. Op de eilanden buiten Curaçao stond de door de Kroon benoemde gezaghebber in eenzelfde positie tegenover de gouverneur als de hoofdambtenaren op Curaçao: almachtig voor wie onder hem stond, stroopsmerend in zijn betrekkingen met de gouverneur. Voor al deze hoge posten kwamen landskinderen niet of slechts zelden in aanmerking. Zelfs ambtenaren van lagere rang werden oudtijds heel vaak van Nederland uitgezonden, zodat de hoge functies helemaal onbereikbaar waren voor de Antillianen. Promotiekansen hadden de landskinderen dus praktisch niet. Gezien deze ondergeschikte positie van het landskind in het ambtelijk apparaat, werd er met hem van hogerhand vrijwel geen rekening gehouden. $\mathrm{Hij}$ werd getolereerd, maar had niets in te brengen.

Enkele Gouverneurs hebben wel de moeite genomen om zich aan te passen en de mentaliteit van onze bevolking te leren kennen, maar anderen bezaten deze bestuursgave in het geheel niet. Hierdoor stond de Gouverneur vroeger altijd op een eerbiedige afstand van het publiek." 127

"Het is, achteraf bezien jammer", merkte Kasteel op, "dat in 1936 niet de politieke stimulans bestond, die zich in de tweede wereldoor- 
log ontwikkelde en die het bij wijziging van de Staatsregeling in 1948 mogelijk maakte, ondanks de nog steeds van kracht zijnde grondwettelijke bepalingen van 1922 , een semi-verantwoordelijk College van Algemeen Bestuur tussen de Gouverneur en de Staten te voegen. Juist in de periode 1936-1945 toen in de Antillen de politieke partijvorming begon, had een dergelijk 'Executive Council' wellicht zeer goede diensten kunnen bewijzen. De adviserende bevoegdheden van de Raad van Bestuur, hoe nuttig zij voor de Gouverneurs en de gemeenschap ook waren, konden geen effect hebben op het publieke politiek besef, omdat de Raad vertrouwelijk adviseerde en geen wettelijke verantwoordelijkheid naar buiten bleek. Hetzelfde gold voor de werkzaamheden der departementshoofden. Noch in Curaçao, noch in Nederland kwam de gedachte aan de instelling van een semi-verantwoordelijk bestuur blijkbaar op. Op Curaçao hield men ook na 1936 het gevoel, dat men in werkelijkheid bestuurd werd vanuit Nederland." 128

Op grond van de Curaçaosche Staatsregeling van 1936 behoorde de vaststelling van het Kiesreglement tot de bevoegdheid van de Landsverordening-wetgever. Alleen voor de eerste keer werd het kiesrecht vastgesteld bij AMvB. Daarna werden alle verdere regelingen en wijzigingen van het kiesrecht overgelaten aan het oordeel van het plaatselijk wetgevend orgaan. Voor het verkiezen van de Statenleden werd het gebiedsdeel in kiesdistricten verdeeld, namelijk het eiland Curaçao, het eiland Aruba, het eiland Bonaire en de Bovenwinden. Het kiesrecht kwam alleen toe aan mannen die de Nederlandse nationaliteit hadden, 25 jaar of ouder waren en jaarlijks een bepaald bedrag aan inkomstenbelasting betaalden. Bovendien werd door de Gouverneur een commissie ingesteld inzake de beslissingen omtrent de graad van verstandelijke ontwikkeling, op grond waarvan plaatsing op de kiezerslijst kon geschieden.

Kasteel (1956) p. 43. Al op 24 juni 1942 pleitte Da Costa Gomez voor meer inspraak in eigen aangelegenhedenen bestuursdecentralisatie, met name voor Aruba. Jesurun e.a. (1993) pp. 76-88. Interessant is dat Da Costa Gomez in een antwoord van 28 oktober op de petitie der Staten van Curaçao, inzake autonomie aangeboden aan Koningin Juliana op 25 juni 1946, Winston Churchill citeert die naar aanleiding van de behandelingvan de constitutie van Transvaal in het Lagerhuis in 1906, al opmerkte dat 'the system of responsible Governement without responsible Ministers has failed wherever and whenever it has been employed.', Jesurun e.a. (1993) p. 101. 
Vóór 1937 was het politiek bewustzijn in Curaçao gering. "Slechts onder ontwikkelde Curaçaoënaars en Nederlandse ambtenaren was sprake van enig politiek leven', zei De la Try Ellis in zijn rapport. ${ }^{129}$ Het eerste Kiesreglement kwam zoals gezegd, bij algemene maatregel van bestuur tot stand, ${ }^{130}$ het kon bij landsverordening worden gewijzigd. Als bekwaamheidseis werd gesteld een ontwikkeling gelijk aan die van zeven jaar ULO onderwijs. Voor de Benedenwindse eilanden was de alternatieve census eis een aanslag in de inkomstenbelasting naar een inkomen van tenminste $f 1200$,-per jaar, $f$ 159,- minder dan in de Staatsregeling gestelde grens (art. 69 Staatsregeling). Hiermede werd beoogd ook werklieden die vakkundig boven de gewone arbeiders uitstaken, stemrecht te geven. Op de Bovenwindse eilanden, waar geen directe belastingen geheven werden, was eigendom van onroerende goederen vereist van tenminste $f 500$,voor Sint Maarten en Sint Eustatius en $f 300$,- voor Saba. Kiesgerechtigden werden ambtshalve op de kiezerslijsten geplaatst, aanmelding was dus niet nodig. Wel moesten de belastingen zijn betaald. Het aantal kiesgerechtigden bedroeg 2.754 personen, waarvan er meer dan 2000 op Curaçao woonden. De totale bevolking bestond uit 91.000 zielen. De belangstelling op de eilanden buiten Curaçao voor de eerste Statenverkiezingen was niet groter dan die voor de landraadverkiezingen, waarvoor op de eilanden trouwens meer kiesgerechtigden bleken te zijn. Op Curaçao waar de meeste kiezers woonden, was de politieke activiteit het grootste.

Op 23 januari 1936 werd de Katholieke Partij (KP) opgericht. Het partijbestuur bestond uit Europese Nederlanders en Curaçaoēnaars uit verschillende sociale groeperingen. De partij had een beginselen actieprogramma en leek veel op de Katholieke Staatspartij in Nederland. Een in augustus 1935 opgerichte Liberale Volkspartij en een in mei 1936 opgerichte Curaçaosche Liberale Partij namen geen deel aan de verkiezingen. De Liberale Partij ontleende veel van haar programma letterlijk aan dat van de Vrijheidsbond in Nederland.

Belangrijk is het hier te vermelden dat bij de eerste verkiezingen de zes eilanden één kieskring vormden, terwijl de 10 leden van de Koloniale Raad met inachtneming van het evenredigheidsbeginsel werden gekozen. Gorsira was van mening dat dit ook in het Antilliaanse staatsrecht paste, daar het lidmaatschap van een vertegenwoordigend lichaam immers strekt tot het waken over het algemeen belang van de gehele bevolking van het hele gebied, waarvoor het betrokken lichaam is ingesteld en niet ter ondersteuning van bepaalde deelbelan-

$130 \mathrm{~KB}$ van 11 maart 1937, 65; PB 1937, 19 en PB 1942, 41. 
gen. Zo wordt een samenwerking gericht op het algemeen belang der gezamenlijke eilanden bevorderd. De eilandenafvaardiging met een bepaald aantal leden per eiland werkt daarentegen een politieke afsplitsing in de hand, aangezien door dit systeem eilandsbelangen behartigd worden. ${ }^{131}$

De verkiezingen vonden plaats op 20 december 1937. Op Curaçao namen twee politieke partijen deel aan de verkiezingen van 1937: de in 1936 opgerichte Katholieke Partij en de in 1937 opgerichte, hoofdzakelijk uit niet-katholieken bestaande, Curaçaosche Politieke Unie. De Katholieke Partij won drie van de zes aan Curaçao toegewezen zetels. ${ }^{132}$ De Curaçaosche Politieke Unie, "waarin zich uitsluitend de bovenste lagen van de Curaçaosche gemeenschap" organiseerden, dus vooral niet-katholieken, was in juli 1937 opgericht. De partij had slechts een 120-tal leden en spleet bij de kandidaatstelling uiteen in een 'Jongerenrichting' of 'Jong-Curaçao-stroming' en het 'Onafhankelijke Verkiezingscomité' of de 'Gematigden', die respectievelijk één en twee zetels verwierven. In 1944 werd de Democratische Partij (DP) opgericht. In 1948 trad er een splitsing op in de partij en werd de Nationale Volkspartij (NVP) opgericht.

Op Aruba werd slechts één politieke partij opgericht: de Katholieke Partij (KP), waarvan de bekendste kandidaat de arts J.R. Arends was, een gezien Arubaan, die zich als lid van de Koloniale Raad en als Landraad de reputatie van gematigd en verstandig politicus had verworven. Hij werd gekozen, evenals de Arubaan J.M. de Cuba van de KP. Voorts werden op Aruba drie individuele kandidatenlijsten opgegeven, waarvan er é́n de naam droeg van de bekende Landraad J.H.A. Eman. Eman was praktisch de enige Arubaanse politicus die, vooral rond landraadverkiezingen, bewust getracht had aanhangers te winnen, met wie hij zo nu en dan bijeenkomsten belegde en voeling hield over de plaatselijke problemen en voorvallen. De eerste verkiezingen hadden plaats op 20 december 1937. Eman werd echter in 1937 niet in de Staten gekozen, omdat velen van zijn aanhangers nog geen kiesrecht bezaten.

Op Aruba werd in 1942 de niet-katholieke Arubaanse Volkspartij opgericht. In diezelfde periode ontstonden de Arubaanse Katholieke Partij (1941) en de Katholieke Unie (1945). Beide partijen verdwenen

131 Gorsira, 'Status aparte ook voor Curaçao en St. Maarten een haalbare kaart', Amigoe, 13 augustus 1992. Gorsira (1913) was van 1951 tot 1968 gezaghebbervan Curaçao. Hij vertegenwoordigde de Antillen als ambassadeur in Costa Rica, Uruguay en Jamaica. Hij maakte deel uit van de Commissie van zeven die het Statuut voor het Koninkrijk hielp voorbereiden en had ook zitting in een commissie, die onderzoek deed nas het functioneren van het politieapparaat. Kasteel (1956) p. 49 
snel van het politieke toneel. De Union Nacional Arubano (UNA) werd in 1946 opgericht en was een gemengde protestantse en katholieke partij. In 1949 splitste de UNA zich in een protestantse (UNA-I of UNA-stad) en katholieke (UNA II of UNA-campo) deel. Bij de Arubanen stonden de verdediging van de Arubaanse belangen voorop en niet zozeer de kerkelijke binding. In 1949 ontstond op Aruba de Partido Patriotico Arubiano, een partij die met name de allochtone Arubanen vertegenwoordigde. Samen met de AVP, de grote voorvechter van een autonoom Aruba, bepaalde de PPA de Arubaanse politieke in de jaren vijftig en zestig. Duidelijke ideologische verschillen tussen de partijen, zowel op Curaçao als Aruba, ontbraken. ${ }^{133}$

Op Bonaire werd een katholieke Europese Nederlander, die zitting had in de Koloniale Raad, bij enkele kandidaatstelling gekozen. Op Bonaire woonden slechts 31 kiesgerechtigden. ${ }^{134}$ Op de drie Bovenwindse eilanden, met een totaal van 1400 kiezers, waren twee kandidaten.

Reeds bij de opening der Staten op 1 april 1938 verklaarde Gouverneur Wouters het plan te hebben een ontwerp in te dienen met de strekking om het kiesreglement zodanig te wijzigen, dat het kiezerscorps zou worden uitgebreid. Het belangrijkste doel van de herziening was uitbreiding van het kiesrecht. Slechts door een soepele toepassing van de hoge eisen van het Kiesreglement ${ }^{135}$ konden de kiezerslijsten van 1937/1938, die de grondslag vormden van de laatste verkiezingen van tien leden van de Staten, in totaal 2754 kiesgerechtigden bevatten op een inwonertal van ongeveer 91.000 zielen. De Gouverneur achtte uitbreiding van het kiezerscorps gewenst om de Staten beter te doen beantwoorden aan hun karakter van vertegenwoordigend lichaam, ingevolge artikel 91 van de Curaçaosche Staatsregeling. Voorts wilde hij voorkomen dat het bij de wet toegekend kiesrecht vanwege het geringe aantal kiezers als het voorrecht van slechts een handjevol kiezers zou worden beschouwd. De veranderingen kwamen erop neer dat iedereen die in de belastingen werd aangeslagen, voor welk bedrag dan ook kiezer zou zijn. Het capaciteitsstelsel zou aldus worden uitgebreid dat iedere man boven de 25 jaar, die lezen en schrijven kon, ook al was dat alleen Papiamentu, aan de verkiezingen deel kon nemen. De examenmethode werd afgeschaft. De niet-katholieke leden in de Staten reageerden fel op het ontwerp tot wijziging van het Kasteel (1956) p. 47.

Curaçaosch Kiesreglement, Stb. 1901, 289; PB 10; PB 1937, $19 \mathrm{j}^{\circ} 41$, daarna is het Kiesreglement nog herhaaldelijk gewijzigd, zie Van Helsdingen (1956) p. 213. 
Kiesreglement. Zij waren bang dat als er meer kiezers kwamen, de katholieke meerderheid (zonder politieke scholing) hen politiek zou onderwerpen. $\mathrm{Zij}$ vreesden zelfs communisme, anarchisme en andere politiek-religieuze stromingen, die via de onwetenden en voor alle invloeden zeer vatbare kiezers bezit zouden gaan nemen van de Staten.

Verder beoogde de herziening de vereenvoudiging van de formaliteiten voor het bekwaamheidskiesrecht, de invoering van een ander stelsel van kiesrecht (lijstenstelsel) en de technische herziening van het Kiesreglement. Het ontwerp tot wijziging van het kiesreglement werd op 3 juni 1938 aangeboden en ontketende een hevige politieke strijd op Curaçao, waarbij de tegenstelling katholiek - niet-katholiek de hoofdrol speelde. Da Costa Gomez was een uitgesproken voorvechter van de uitbreiding van het kiesrecht. De Gouverneur stelde voor de censuseis te verlagen van $f 1200,-$ tot $f 900,-$. De alternatieve capaciteitseis wenste hij te veranderen in het kunnen lezen en schrijven.

Voor Curaçao en Aruba werd het stelsel van evenredige vertegenwoordiging ingevoerd, voor de andere eilanden het meerderheidsstelsel. Het personenstelsel van het eerste kiesreglement zou worden vervangen door een lijstenstelsel. Aan Bonaire en de Bovenwinden werd elk één zetel en aan Aruba en Curaçao werden tezamen acht zetels toegewezen.

In 1937 was tevoren bepaald dat Aruba twee en Curaçao zes zetels zou verkrijgen. De katholieken, die daardoor meer politieke invloed zouden krijgen waren daarmee tevreden. De niet-katholieken achtten een zo uitgebreid kiesrecht voor Curaçao niet wenselijk en zelfs gevaarlijk. Da Costa Gomez steunde de bestuursvoorstellen krachtig. Het ontwerp werd aangenomen met 8 rooms-katholieke leden die voor stemden en 7 niet-katholieke leden die tegen stemden. ${ }^{136}$ De tegenstellingen liepen langs godsdienstige lijnen.

Tussen 1937 en 1940 was geen werkelijke verandering waar te nemen in de staatkundige praktijk of de politieke belangstelling. De voor de verkiezingen opgerichte partijen sliepen spoedig weer in en nieuwe werden niet gevormd. De Statenvergaderingen werden zelden bijgewoond door pers of publiek. De problemen waarmede Bestuur en Staten zich bezighielden waren dezelfde als voorheen, wel namen de te treffen sociale en economische maatregelen in aantal toe. De 
godsdienstige verdeeldheid kwam in de Staten zelden aan de oppervlakte en er viel geen andere op politieke, sociale en economische beginselen gebaseerde blokvorming waar te nemen. Zoals ook in de Koloniale Raad gebruikelijk was geweest, pleitten de vertegenwoordigers van de verschillende eilanden voor hun plaatselijke belangen, wanneer de gelegenheid zich voordeed.

In een Statenrapport van 1940 wezen de Statenleden op de wenselijkheid tot uitwerking van het in artikel 117 van de Staatsregeling neergelegde decentralisatiebeginsel. Alvorens een dergelijke decentralisatieverordening zijn beslag zou kunnen krijgen, achtten zij het wenselijk dat de Gouverneur veelvuldiger dan gebruikelijk op de eilanden buiten Curaçao zou verblijven. ${ }^{137}$

Da Costa Gomez bracht in 1938 zijn staatkundige denkbeelden in de Staten weer naar voren:

'Niet in de verkrijging van volledige autonomie van dit kleine staatsdeel ligt de oplossing zijner staatkundige vraagstukken, maar in het deelnemen aan het staats- en maatschappelijk leven der grotere culturele eenheid, gevormd door het groot verband van de Nederlandse staat. Volledige autonomie zal 't eigen leven van dit gebiedsdeel verstikken, eerder dan vernieuwen. Het moge paradoxaal klinken, niettemin ben ik ervan overtuigd, dat juist in de opneming in de Nederlandse staat, in het zoveel mogelijk opnemen zijner cultuur, het leven onzer eigen gemeenschap kan worden vernieuwd en tot ontwikkeling gebracht.'138

Toen deze rede werd uitgesproken vermoedde wellicht niemand, dat minder dan tien jaar later de Nederlandse Antillen, voor een groot deel geleid door $\mathrm{Da}$ Costa Gomez, krachtig naar volledige autonomie zouden streven. De geciteerde aanhaling geeft intussen wel een inzicht in het ook later in de Antillen voortlevende beginsel van de noodzaak en wenselijkheid tot verbondenheid binnen én Koninkrijk. De daaruit voortvloeiende beperkingen op eigen bestuur en wetgeving, werden lang niet altijd gewaardeerd maar werden aanvaard, als prijs voor de wèl gewaardeerde band. De Staatsregeling was net drie jaren oud, toen de bezetting van Nederland een einde maakte aan de mogelijkheid om onder normale omstandigheden tot een verdere politieke en staatkundige ontwikkeling te komen.

Op zich vormden de Staatsregeling van 1936 en het Kiesregle-

137

Zie rapport van een studiereis van 8 leden van de Staten van Curaçao naar de Bovenwindse eilanden en St. Kitts via Bonaire, Bijlage bij Notulen 1939-40, 22, 1 april 1940, Kasteel (1956) p. 53, noot 180.

Kasteel (1956) p. 54.

De eerste verkiezingen. 195 
ment van 1937 niet zo'n groot verschil met de situatie van vóór 1936, aangezien dezelfde groeperingen waaruit de Gouverneur voorheen de leden van de Koloniale Raad aanwierf, nu kiesgerechtigd waren geworden. De verkiezingen hadden echter wel geleid tot het ontstaan van politieke partijen.

\section{Samenvatting en conclusie}

Periode VI behandelt het tijdvak 1865-1936, alsmede de invoering van de Curaçaosche Staatsregeling. Voor de Nederlandse koloniën zijn de veranderingen in de organisatie van het bestuur van de koloniën niet los te zien van de aanpassingen in de Nederlandse Grondwet. Het Regeringsreglement dat in 1865 werd ingevoerd, is te beschouwen als een uitvloeisel van de Nederlandse Grondwetsherziening in liberale zin, die in 1848 plaats vond. De Raden van Politie deden voor het eerst hun intrede op Aruba en Bonaire op grond van het Regeringsreglement van 1865. De overeenstemming van de wetgeving tussen Nederland en de kolonie is nooit groot geweest. Het Regeringsreglement van 1865 was de eerste koloniale staatsordening die overeenkwam met de Nederlandse Grondwet.

De functie en betekenis van de Raad van Curaçao was in de periode 1816-1865 sterk verminderd. In de periode 1816-1828 had de Raad van Politie nog echt het karakter van een bestuursorgaan dat vele belangrijke besluiten niet alleen voorbereidde, maar ook werkelijk nám. In de periode 1828-1834 nam de zelfstandige wetgevende arbeid van de Raad sterk af. Alle raadsbesluiten moesten worden goedgekeurd door de Gouverneur-Generaal in Paramaribo. Sinds het Regeringsreglement van 1834 was de Koloniale Raad een adviescollege geworden en geen medebesturend college meer. Het belang van de Koloniale Raad nam tussen 1834 en 1865 steeds verder af.

Het Regeringsreglement van 1865 werd ingesteld bij wet, zoals de Grondwet van 1848 eiste, in plaats van bij KB. Daardoor kreeg het parlement zeggenschap in het bestuur van de koloniën. Deze verandering in het bestuur van de kolonie ging ten koste van de macht van de Koning, die sinds 1816 het opperbestuur had gehad over de koloniën. In Nederland was in 1848 de ministeriële verantwoordelijkheid ingevoerd. Het duurde tot 1865 voordat het Regeringsreglement van 1848 werd vervangen, omdat het afschaffen van de slavernij politiek moeilijk te realiseren viel en pas in 1863 plaats vond.

De kolonie 'Curaçao en Onderhorigheden', drong bij de invoering van het Regeringsreglement van 1865 bij Nederland aan op 
invoering van een beperkt kiesrecht voor leden van de Koloniale Raad. Alle eilanden, behalve Curaçao, kregen een Raad van Politie, bestaande uit een Gezaghebber en twee Landraden. De andere eilanden kozen hun Landraden op grond van een beperkt mannenkiesrecht. De Koloniale Raad van Curaçao zou zowel plaatselijke als gezamenlijke aangelegenheden behandelen. Bij de invoering van de Koloniale Raad in Curaçao in 1865 mocht de bevolking van Curaçao haar vertegenwoordigers niet kiezen. Ook de bevolkingen van de andere eilanden hadden geen invloed op de samenstelling van de Koloniale Raad. Hier deden zich reeds de vraagstukken voor met betrekking tot de samenstelling van de volksvertegenwoordiging en autonomie, die zich voortsleepten tot in de jaren vijftig van deze eeuw en verschillende wijzigingen in de Regeringsreglementen tot gevolg badden.

Suriname kreeg tezelfdertijd ook een Koloniale Raad, waarvan negen van de dertien leden werden gekozen op grond van een beperkt mannen-census kiesrecht. Voor de Koloniale Raad van Curaçao werd een gedeeltelijk kiesrecht geweigerd, omdat de Gouverneur en de Koloniale Raad negatief hadden geadviseerd. De mening van de Protestantse elite in Curaçao was dat de voormalige slaven niet in staat zouden zijn het kiesrecht uit toe oefenen, daarvoor waren ze te 'diep gezonken'. Men vreesde tevens voor een Rooms-Katholieke overmacht, omdat de bevolking grotendeels Rooms-Katholiek was. De Joodse handelslieden wilde men ook geen kiesrecht toekennen, omdat ze geen Nederlanders waren en zich niet betrokken zouden voelen bij het bestuur. Ook Da Costa Gomez pleitte voor een algemeen kiesrecht.

Volgens het Regeringsreglement van 1865 werd een Raad van Bestuur ingesteld die de Gouverneur zou bijstaan in zijn taak als uitvoerende macht. Deze voorloper van de Raad van Advies mocht echter alleen van advies dienen. De Raad van Bestuur bestond grotendeels uit hoofdambtenaren uit het moederland en de Koloniale Raad bestond veelal uit de lokale elite. In de Koloniale Raad hadden de leden van de Raad van Bestuur ambtshalve zitting. De vijf leden van de Raad van Bestuur bestonden uit de Gouverneur, de ondervoorzitter en drie leden. De ondervoorzitter, de drie leden van de Raad van Bestuur en de overblijvende acht van de dertien leden van de Koloniale Raad werden door de Koning benoemd.

Een wijziging van het Regeringsreglement in 1901 stelde het ledental van de Koloniale Raad op dertien personen. welke niet uit hoofde van enige functie werden benoemd. het vaste lidmaatschap 
van de Raad van Bestuur werd ingetrokken. Ook de Gouverneur verdween als voorzitter van de Koloniale Raad. De Procureur-Generaal mocht niet meer optreden als ondervoorzitter. Door het ontbreken van eigen vertegenwoordigers van de eilanden buiten Curaçao leek het of in de Koloniale Raad alleen Curaçao was vertegenwoordigd. Joden en Protestanten waren het sterkst vertegenwoordigd in de Koloniale Raad. Dit stemde niet overeen met de samenstelling van de bevolking, die in meerderheid Rooms-Katholiek was.

Tussen 1897 en 1917 werd in de Tweede Kamer veelvuldig aangedrongen op bestuursdecentralisatie in de koloniēn. Het duurde tot de Grondwetsherziening van 1922, voordat de Nederlandse wetgever een begin makte met een regeling die meer invloed moest verschaffen aan de kolonie in het eigen bestuur. Pas bij de invoering van de Curaçaosche Staatsregeling van 1936 zou de decentralisatiegedachte vorm krijgen en werd feitelijk een begin gemaakt met meer zeggenschap van de kolonie in eigen zaken. In het Regeringsreglement van 1865 werden de grondrechten overgenomen uit de Grondwet van 1848.

In 1904, 1908 en in 1919 wenste Sint Maarten een status los van Curaçao, omdat het eiland zich achtergesteld voelde ten opzichte van de andere eilanden. Dit was wel begrijpelijk daar de andere eilanden niet vertegenwoordigd waren in de Koloniale Raad. In de Koloniale Raad werd gedacht aan de bestuurssituatie van vóór 1845, namelijk scheiding van de Bovenwinden en Benedenwinden in de vorm van een administratieve decentralisatie. De suprematie van Curaçao leidde regelmatig tot irritaties van de andere eilanden. De afscheidingsbeweging in Sint Maarten verzandde. De afscheidingsbeweging in Aruba zou vanwege die irritaties vanaf de jaren dertig van de 20 ste eeuw een bloeiend bestaan kennen.

In 1869 werd een nieuwe codificatie ingevoerd en werd het OudHollandse recht in de kolonie afgeschaft. In het Regeringsreglement van 1815 stond al vermeld dat bestuur en rechtspraak gescheiden zouden moeten worden, maar dat gebeurde feitelijk pas in 1865 .

In 1865 werd het ingestelde Hof van Justitie appelinstantie voor de kolonie Curaçao. Voor zaken in eerste aanleg gewezen door het Hof van Justitie in Curaçao was sinds 1840 beroep op de Hoge Raad mogelijk (géńn cassatie). In 1869 werd beroep in cassatie in strafzaken in het belang der wet mogelijk. Met de invoering van de nieuwe codificatie in 1869 kan worden gesteld, dat er tekening begint te komen in de machtenscheiding. De rechterlijke macht is onafhankelijk.

In 1919 werden de Raad van Justitie en de Kantongerechten 
ontbonden. Sinds 1941 bestaat het Gerecht in Eerste Aanleg met de mogelijkheid tot hoger beroep in alle zaken bij het (Gemeenschappelijk) Hof van Justitie en in bepaalde gevallen beroep in cassatie bij de Hoge Raad.

De banden die de kolonie Curaçao onderhield met Venezuela leidden in de $18 \mathrm{de}$ en $19 \mathrm{de}$ eeuw regelmatig tot diplomatieke incidenten. Nederland stelde zich neutraal op in de vrijheidsstrijd van de Spaanse koloniên of steunde Spanje. Deze incidenten deden de vraag ontstaan of de kolonie Curaçao maar niet beter verkocht zou kunnen worden, mede omdat de kolonie teveel kostte en niets opbracht.

Het politieke bewustzijn ontwikkelde zich langzaam. Politieke partijen ontstonden in de jaren veertig. De verhoudingen uit de feodale maatschappij werden opgenomen in het politieke systeem. Bij de verkiezingen wordt iemand gekozen op grond van persoonlijke voordelen die hij de kiezer kan verstrekken. Politieke partijen functioneren niet op grond van een partijprogramma of contributie van hun leden. De gewoonte ontstond dat politieke partijen vaak worden gefinancierd door bet bedrijfsleven. Langzamerhand begint de parlementaire democratie vorm te krijgen.

Het is duidelijk dat in de periode van 1865-1936 de grondrechten nog geen rol van betekenis speelden in de kolonie. Ook de parlementaire democratie was nog niet ingevoerd. Dat betekende dat er nog geen volksvertegenwoordiging bestond zoals in Nederland. In Nederland was in 1917 wel het algemeen kiesrecht ingevoerd. Sinds 1840 bestond in Nederland de strafrechtelijke ministeriële verantwoordelijkheid en sinds 1848 was de Koning onschendbaar en de minister verantwoordelijk. In 1936 was in de kolonie nog geen sprake van het parlementair stelsel. De rechtsbedeling werd tussen 1865 en 1940 beter ingericht, maar er bestonden nog niet dezelfde voorzieningen als in Nederland.

Omdat in de koloniale periode het parlementaire systeem nog niet bestond was er geen sprake van kiesrecht, gekozen volksvertegenwoordigers en gelijke rechten voor alle burgers. Chumaceiro verzette zich al in 1895 tegen de algemeen heersende opvatting dat de bevolking van de kolonie de Koloniale Raad niet zou mogen kiezen op grond van een beperkt census- en capaciteitskiesrecht.

De koloniale verhouding was in wezen een onderlinge relatie van absolute heerschappij en volkomen ondergeschiktheid. De staatkundige ontwikkeling van de kolonie begon met het instellen van een 
adviescollege voor de Gouverneur in 1865 en het invoeren van een beperkt kiesrecht voor het verkiezen van de Landraden op alle eilanden behalve Curaçao. In 1901 werd de samenstelling van de koloniale Raad gewijzigd. Er zouden geen ambtenaren meer zitting hebben in de Raad, alleen nog maar burgers.

De Grondwet van 1922 voorzag in meer invloed van de bevolking in het bestuur van de kolonie. Die inspraak zou moeten worden uitgewerkt in de plaatselijke regelingen. De Commissie Staal bracht daartoe een rapport uit tot uitvoering van de Grondwetsherziening van 1922 en tot wijziging van het Regeringsreglement van 1865 . Uiteindelijk werd het Regeringsreglement van 1865 pas gewijzigd (en de gevolgen van de Grondwetsherziening 1922 verwerkt) in de Curaçaosche Staatsregeling van 1936, maar hetzelfde autoritaire stelsel werd in beginsel gehandhaafd.

Een hogere trap van staatkundige ontwikkeling werd bereikt toen de Curaçaosche Staatsregeling van 1936 een beperkt mannen-kiesrecht invoerde. Tien van de vijftien leden van de Koloniale Raad werden gekozen. De andere vijf leden werden door de Gouverneur benoemd. Algemeen kiesrecht werd niet ingevoerd, maar slechts een censusen capaciteitskiesrecht. Voor vrouwen werd alleen een passief kiesrecht ingevoerd. ${ }^{139}$ Op grond van het preventieve en repressieve toezicht en de grote invloed van de Gouverneur kwam er in de kolonie feitelijk weinig terecht van het bestuur in eigen zaken.

De politieke verantwoordelijkheid van de regering aan de Staten werd niet ingevoerd. De Staten werden grotendeels een onafhankelijk vertegenwoordigd orgaan. Door de grote invloed van de Gouverneur op de benoemingen van de Statenleden, de conflictenregeling en het ontbreken van een algemeen kiesrecht, kon nog niet gesproken worden van een wezenlijk parlementaire structuur. De uitvoerende macht had nog teveel invloed op de volksvertegenwoordiging. De opvattingen over het bestuur van de koloniën waren langzamerhand veranderd. Eigen bestuur werd gezien als een middel om de koloniēn tot bloei te brengen, mits het opperbestuur bij het moederland bleef. Een zekere mate van zelfbestuur werd noodzakelijk geacht om kapitaalsbelegging en ontginning van de eigen bodem mogelijk te maken. De reden hiervoor was, dat geen plaatselijke econonomische ontwikkeling mogelijk was, zonder plaatselijke wetgeving. ${ }^{140}$

140 Zie voor een uitvoerige uiteenzetting over deze gedachtengang Da Costa Gomez in: Jesurun e.a. (1993) pp. 272-295. 
De decentralisatie van bestuurstaken zou uiteindelijk pas plaatsvinden bij de invoering van de Interimregeling en de Eilandenregeling van de Nederlandse Antillen (ERNA) van 1950/1951.

Wanneer deze feitelijke gegevens worden getoetst aan de evaluatiecriteria kan het volgende worden geconcludeerd. De invloed van het Nederlands bestuur op het bestuur van de kolonie was zowel onder het Regeringsreglement van 1865 als onder de Staatsregeling van 1936 zeer groot. Nadat de Koning aan invloed verloor bij de invoering van het Regeringsreglement van 1865 , kreeg de Gouverneur meer invloed. Hij vond geen volksvertegenwoordigend gekozen College tegenover zich en een aan de Staten verantwoordelijk uitvoerend gezag. In feite bleef de Nederlandse invloed even groot, temeer daar het politieke leven op de Antillen pas aan het einde van de jaren dertig tot ontwikkeling kwam. Derhalve bleef de invloed van de burgerij op het bestuur gering. In die zin kon van verdeling van de overheidsmacht volgens Mont esquieu dan ook niet gesproken worden. Bij de eerste verkiezingen was het aantal kiezers gering.

De opbouw van de staatsorganen ontwikkelde zich langzaam naar een parlementaire democratie. De binding van de staat aan het recht kreeg vorm in een codificatie van bet recht in 1869 en de invoering van onafhankelijke rechtspraak. In die zin kreeg de Trias Politica vorm in de kolonie en werd een begin gemaakt met de verdeling van de overheidsmacht. Het zoeken naar het juiste evenwicht tussen ordening van de samenleving en individuele vrijheid was nog geen onderwerp van gesprek of regelgeving.

Alles bleef verder min of meer bij het oude. De komende economische welvaart en het algemeen kiesrecht zouden dat spoedig veranderen. De invloed van de burgers in het bestuur bleef gering. Het concept van de mensenrechten speelde nog geen rol, dus ook het naleven daarvan stond niet in de belangstelling. Wel waren in het Regeringsreglement van 1865 een aantal grondrechten opgenomen. Of die al dan niet werden nageleefd is niet te achterhalen. Deze grondrechten waren gebaseerd op de Nederlandse Grondwet van 1848.

Sinds het rapport van de Commissie Staal uit 1922 wilde Nederland voor de Nederlands-Antilliaanse eilanden steeds een staatsrechtelijke regeling treffen die overeenkwam met de Nederlandse Gemeentewet. Een gemeentelijke structuur werkt alleen maar in een gedecentraliseerde eenheidsstaat van enige omvang. Een 'staat' opgebouwd uit eilanden kent het gemeenschapsgevoel niet dat nodig is om als samenbindend element een staatsbestel als natie vorm te geven. Dit 
gegeven is een van de oorzaken, die tot op de huidige dag van invloed is op het ontbreken van eenheid in het West-Indische rijksdeel. Het blijft gecompliceerd om een Koninkrijksstructuur te ontwerpen, waarmee zowel het Rijk in Europa als de rijksdelen overzee tevreden kunnen zijn.

Klasseverschillen en kleurverschillen bleven in dezelfde verhoudingen bestaan. Van toekenning van politieke rechten aan de gehele bevolking was nog geen sprake, alhoewel de wens daartoe onder de Curaçaose elite al jarenlang leefde. De Staatsregeling van 1936 was een aarzelend begin. 


\section{Geleidelijke dekolonisatie 1936- 1950 (VII)}

Hoofdstuk V behandelt de invloed van de Tweede Wereldoorlog op de toenemende economische zelfstandigheid van het Caraibisch deel van het Koninkrijk (periode VII). De Verenigde Naties (VN) verklaarden aan het begin van de jaren veertig, dat dekolonisatie inhield dat koloniën zelfbestuur zouden moeten krijgen en onafhankelijkheid op termijn. Nederland moest met de internationale mening rekening houden, omdat zij afhankelijk was van de geallieerden om haar gebieden overzee te kunnen behouden.

De Koningin kondigde in haar belangrijke radiorede van 7 december 1942 aan dat het bestaande koloniale staatsverband zou worden gemoderniseerd. Daartoe werd tussen 1942 en 1950 een aantal commissies benoemd. Die commissies hielden zich bezig met het nader uitwerken van de bestuursdecentralisatie, zoals geëist door de Curaçaosche Staatsregeling van 1936. Verder dienden de commissies voorstellen te doen voor een modernisering van het Koninkrijksverband, inhoudende meer invloed voor de koloniën in het bestuur van hun eigen huishouding. De rapporten van deze commissies komen uitgebreid aan de orde.

De meeste politieke partijen ontstonden na de eerste verkiezingen van 1937. De verdere ontwikkeling van de politieke partijen wordt behandeld. Door de politieke bewustwording konden ook de wensen van de bevolking duidelijker naar voren komen.

$\mathrm{Na}$ de oorlog raakte het dekolonisatiestreven in een stroomversnelling door de soevereiniteitsoverdracht van Nederlands-Indie aan Indonesië. De positie van de West-Indische koloniën kon daardoor niet voldoende aandacht krijgen.

Onder invloed van de economische ontwikkeling van Aruba en de politieke bewustwording ontstonden in de jaren dertig al gevoelens van achterstelling en onbehagen ten opzichte van Curaçao. Aruba wenste zich af te scheiden (autonomie) van Curaçao in het nieuwe Koninkrijksverband.

De wijziging van de Grondwet en de Curaçaosche Staatsregeling in 1948 betekende een doorbraak voor het streven naar zelfstandigheid in eigen bestuur van de kolonie. Ook dit streven werd autonomie genoemd. Eindelijk werd feitelijk uitvoering gegeven aan de eis van 
het Regeringsreglement van 1865 , dat het bestuur zoveel mogelijk aan organen ter plaatse zou moeten worden overgelaten. De in hoofdstuk $\mathrm{V}$ besproken periode eindigt met het indienen van de Interimregeling van 1950/1951. Antillen

Veel bevrediging bracht de Staatsregeling van 1936 niet voor degenen die voorstanders waren van het algemeen kiesrecht. Ondertussen waren door de ontwikkeling op sociaal en economisch gebied aan het begin van deze eeuw en door de Tweede Wereldoorlog de wensen van de bevolking van de eilanden om meer zeggenschap in het eigen bestuur te krijgen, groter geworden. Er ontstond een streven naar autonomie, niet alleen voor de Nederlandse Antillen als geheel, maar ook voor de afzonderlijke eilanden. ${ }^{1}$

Omdat de Verenigde Staten zich bij de Europese geallieerden aansloten werd het Caraibisch gebied van groot strategisch belang, met name de olieraffinaderijen. Met hulp van de geallieerden werd het defensie-apparaat verbeterd en werden vele militaire werken uitgevoerd. Zo kregen Bonaire en Sint Maarten een vliegveld. Ook de telefoon- telegraaf- en vliegverbindingen werden aanzienlijk verbeterd. De economische problemen namen toe, zodat steeds meer overheidsbemoeienis nodig werd. Het zelfbewustzijn van de Antillianen groeide door de belangrijke rol die de eilanden vervulden. Het helpen van het winnen van de oorlog was in die tijd de belangrijkste opgave voor de Antillen. Tussen 1939 en 1945 werd bijna elf miljoen gulden vrijwillig aan de oorlogsvoering bijgedragen. De oorlog leidde ertoe dat de Antillianen hun horizon verbreedden. In 1942 schreef de Amigoe:

"De tijd, dat de overzeese gebiedsdelen aanhangsels waren, waar niemand iets van wist, zal na deze oorlog zeker tot het verleden behoren. Reeds thans zien wij een verhoogde belangstelling door herhaalde bezoeken van Ministers en onze wens kan slechts zijn, dat zij langer bleven [.... "'. ${ }^{2}$

Een van de redenen, waarom de Nederlandse regering zich aan de bezetting onttrok om buiten bezet gebied in vrijheid haar gezag uit te oefenen, was vooral het besef haar taak ten aanzien van de overzee-

\footnotetext{
$1 \quad$ Römer-Kenepa (1983) p. 7.

$=\quad$ Kasteel (1956) p. 59, noot 9: Amigoe van 22 oktober 1942.
} 
se gewesten te moeten vervullen, meende Kasteel. ${ }^{3}$ Verschillende malen richtte de Koningin zich in de oorlogsjaren dan ook tot haar onderdanen buiten Europa. In maart 1941 repte de Vorstin voor het eerst van staatkundige hervormingen in Nederland. Aan deze rede herinnerde zij, toen zij zich op 10 mei 1941 voor het eerst speciaa] tot de bewoners van West-Indië wendde, om haar dank en waardering uit te spreken voor de saamhorigheid en offervaardigheid in die gebieden. Zij gaf aan dat de staatkundige hervormingen ook van toepassing zouden zijn op de overzeese gebiedsdelen. Deze belofte was ingegeven door het feit dat de oorlog de positie van de overzeese gebiedsdelen ten opzichte van het moederland principieel gewijzigd had. ${ }^{4}$ Gouverneur Wouters riep de Staten op 16 juni 1941 bijeen en deelde hun, gemachtigd door de Kroon het volgende mee:

"Het ligt in het voomemen van het Opperbestuur om onmiddellijk na de bevrijding van het moederland de aanpassing van de structuur van het Koninkrijk aan de eisch der tijden tot een programmapunt te maken, waarbij de status van Nederlandsch Oost- en West-Indië in overeenstemming zal zijn te brengen met de beteekenis deze gebieden in de rijkseenheid. Van dit programma zal ook het inwendig staatkundig bestel der overzeesche gebiedsdeelen een integreerend deel uitmaken.

Gelegenheid zal worden geschapen om de wenschen en opvattingen ter zake ter kennis van de Kroon te brengen, opdat deze aandachtig overwogen kunnen worden. Het Opperbestuur is voornemens na de bevrijding van het moederland een conferentie van vooraanstaande personen uit verschillende deelen van het Koninkrijk bijeen te roepen, die de Kroon in deze van advies zal dienen."

Met name de autoritaire opstelling van de Gouverneur, de besluitvorming van de Nederlandse regering en het gebrek aan invloed van de Antillen in eigen bestuursaangelegenheden leidden tot veel ongenoegen in de Staten. ${ }^{6}$ De Tweede Wereldoorlog had om meer dan één reden

\footnotetext{
Kasteel (1956) p. 59.

Paula (1989) p. 16.

Kasteel (1956) p. 60.
}

Da Costa Gomez besprak in 1956 het proefschritt van Kasteel. Hij was niet geheel tevreden over haar inspanningen. Da Costa Gomez was het niet eens met de stelling van Kasteel dat onder het Regeringsreglement van 1865 de Gouvemeur verantwoording verschuldigd was aan de Koning, terwijl de Minister van Koloniën verantwoordelijk was voor het in de Antillen gevoerde beleid aan de Staten-Generaal (zie Kasteel, pp. 20 en 42). Hij meent dat de bondigheid van de wet (art. 21 Regeringsreglement 1865) hier bedriegt. Koning en Ministers kunnen niet gescheiden worden in het Nederlandse stelsel van de ministeriële verantwoordelijkheid. De Koning handelt, maar de minister is verantwoordelijk. Tevens gaat Da Costa Gomez in op de naar zijn mening niet altijd noodzakelijke 'Besluiten-regering' van de Gouverneur 
een grote invloed op de politieke situatie op de Antillen, die gedurende vijf jaren in feite 'zelfstandig' waren. In de oorlogsjaren groeide de economie enorm. Nederlandse hoogwaardigheidsbekleders die zich tot 1940 nooit om de Antillen badden bekommerd, vlogen af en aan, nu deze samen met Suriname het enig Rijksdeel bleken dat niet bezet was. Prinses Juliana en Prins Bernhard bezochten de Antillen en "het enthousiasme van de bevolking kende geen grenzen, toen zij deze leden van het geliefde Oranjehuis voor de eerste maal mochten begroeten.' Hierdoor was in Nederland de bereidheid toegenomen de Nederlandse Antillen enige autonomie toe te kennen en het algemeen kiesrecht in te voeren. Die grotere autonomie werd in 1942 toegezegd, in de beroemde decemberrede van Koningin Wilhelmina. ${ }^{7}$

\section{De radiorede van Koningin Wilhelmina}

De hervormingen in het koloniale bestuur, die bij monde van de Koningin werden toegezegd waren niet zozeer het gevolg van de wens naar staatkundige hervormingen of van een bijzondere politieke activiteit op de Antillen. De oorzaken lagen grotendeels elders. In het voormalig Nederlands-Indië was aan het einde van de jaren dertig een sterk nationalisme gegroeid, waarvan de gevolgen langzamerhand tot Nederland begonnen door te dringen. Nederland had zich nooit veel aangetrokken van de mening van andere landen over zijn koloniale politiek. Nu Nederland echter van de geallieerden afhankelijk was om haar gebieden overzee te behouden, telde de mening van met name Engeland en de Verenigde Staten (VS) wel. Temeer daar het Nederlandse bestuur vanuit Engeland werd gevoerd en de Engelsen zich in die tijd intensief bezighielden met de koloniale verhoudingen binnen het Britse Rijk. In de VS ontstond een tendens zich te verzetten tegen alles wat koloniaal was en daarbij werd onder meer het

ex art. 32 Staatsregeling 1936 (dringende omstandigheden), nadat in Europa in 1939 de oorlog was uitgebroken. Naar de mening van Da Costa Gomez was de veelvuldige uitoefening van de exorbitante bevoegdheden van de Gouverneur aanleiding en oorzaak van het ongenoegen in de Staten, dat uiteindelijk op 8 november 1945 leidde tot een dringend telegrafisch verzoek aan Hare Majesteit, om meer autonomie in eigen aangelegenheden. Da Costa Gomez formuleerde zijn kritiek op delicate wijze, daar Annemarie Kasteel de dochter was van de toenmalige Gouverneur, die in de ogen van de Staten buitengewoon autocratisch regeerde. Pas in 1948 werd het autocratisch bestuur van de Gouverneur vervangen door het Nederlandse dualistische bestuursstelsel. Er werd een begin gemaakt met een democratische bewindvoering. Zie ook Van der Pot, bespreking van het proefschrift van Kasteel in: 31, NJB 1956, pp. 47-48 en Felhoen Kraal, De WIG, 37, 1956, pp. 58-60, die beiden lovend over het proefschrift schreven.

$7 \quad$ Kasteel (1956) p. 58; Fennema (1986) p. 78. 
koloniaal beleid van Nederland afgekeurd. De gedachtengang ontstond dat alle onder-ontwikkelde volken onder de voogdij van de Verenigde Naties (VN) zouden moeten worden geplaatst. ${ }^{8}$ Onder de heersende buitengewone omstandigheden kon de Nederlandse regering uiteraard niet overgaan tot het aanbrengen van veranderingen in de bestaande constitutionele verhoudingen, maar zij kwam wel tot de conclusie, dat een openlijke verklaring gewenst was. Er werd een diepgaande discussie gevoerd in welke vorm een dergelijke verklaring moest geschieden. Uiteindelijk werd besloten tot een radiorede, uit te spreken door de Soeverein van het Koninkrijk. Deze vorm waarborgde dat elke twijfel over de draagwijdte voor de toekomst was uitgesloten, terwijl er niet behoefde, noch kon worden getreden in min of meer uitgewerkte plannen van een gewijzigde opbouw van het Koninkrijk. Na de reeds gedane toezeggingen volgde de bekende, door Koningin Wilhelmina gehouden toespraak, op 6 december $1942 .{ }^{9}$ De Koningin beloofde vanuit Londen, aan Suriname en de Nederlandse Antillen grotere zelfstandigheid in eigen aangelegenheden:

"Ik stel mij voor, zonder vooruit te loopen op de adviezen der rijksconferentie, dat zij zich richten zullen op een Rijksverband, warin Nederland, Indonesië, Suriname en Curaçao tezamen deel zullen hebben, terwijl zij ieder op zichzelf de eigen, inwendige aangelegenheden in zelfstandigheid en steunend op eigen kracht, doch met den wil elkander bij te staan, zullen behartigen."

Ook had de Koningin bij haar bezoek aan Washington op 6 augustus 1942 aan het Congres van de Verenigde Staten de richtlijnen van de

Jesurun e.a. (1993) pp. 156-194.

De tekst van de rede van Koningin Wilhelmina van 6 december 1942 komt als Bijlage I voor in het Rapport De la Try Ellis, Pp. 120-122. Vanwege het vigerende tijdverschil komt in de ene bron 6 december voor als tijdstip van de bekende rede van de Koningin, andere bronnen noemen 7 december. Keesings Historisch Archief No. 771, maart 1946, p. 6671: "De regeerings-verklaring van 16 Juni '41 werd vooral te Paramaribo ontvangen met groote koelheid, zoo niet met openlijke vijandigheid en de verklaring van 7 December 1942 maakte geen indruk en werd in Suriname al spoedig gevolgd door een langdurige periode van politieke onrust en vertittering. Suriname en Curaçao hebben zich, vooral sinds den oorlog ontwikkeld tot Amerikaansche gebieden met een Amerikaanschen blik op het leven. Niets verwekt onder de bevolking dieper ontstemming dan de hoogbezoldigde Indische ambtenaren, die volkomen vreemd staan tegenover de Nieutwe Wereld, en niet de minste neiging hebben zich aan haar aan te passen. Een liberale en elastische interpretatie en toepassing van de bestaande stastsregelingen zal in Suriname en Curaçao veel meer bijdragen tot een betere verstandhouding tusschen 'inheemschen' en 'Hollanders', en tot het aanwakkeren van loyaliteit jegens het Moederland, dan hoogdravende verklaringen betreffende toekomstige constitutionele rijkshervormingen, die slechts wantrouwen gaande maken zoolang de bestaande democratische mogelijkheden geïgnoreerd worden ten gunste van een stram koloniaal gezagsbeleid." 
na de oorlog jegens de Nederlandse overzeese gewesten te voeren politiek uiteengezet. ${ }^{10}$

Op de Nederlandse Antillen besefte men dat de vroegere koloniale verhoudingen plaats zouden moeten maken voor het nieuwe beginsel van gelijkwaardigheid binnen een op nieuwe grondslagen te vestigen Koninkrijk der Nederlanden. Het streven om 'baas in eigen huis' te zijn werd dan ook algemener. In het voorjaar van 1942 was al een drietal personen door de Staten benoemd om de Antillen te vertegenwoordigen bij de aangekondigde Ronde Tafel Conferentie (RTC). Korte tijd daarna maakte de regering bekend, dat in de te Londen ingestelde Buitengewone Raad van Advies ook een deskundige ten aanzien van Curaçaose aangelegenheden zitting zou hebben. ${ }^{11}$ Daarvoor werd in juni $1942 \mathrm{Da}$ Costa Gomez benoemd. De voorzitter van de Staten, noemde zijn vertrek naar Londen een historische gebeurtenis, "de eerste daad van medezeggenschap van dit Staatsdeel [...]". ${ }^{12} \mathrm{Hij}$ betreurde het dat er maar én Antilliaan benoemd was in de uit vijftien leden bestaande Buitengewone Raad. ${ }^{13}$

In november 1941 moesten voor de tweede maal verkiezingen worden gehouden, de eerste onder het nieuwe kiesreglement. Nietkatholieke groepen op het eiland Curaçao trachtten te voorkomen, dat deze verkiezingen voortgang zouden vinden. Op geen van de andere eilanden werd tegen de verkiezingen geageerd. Gouverneur Wouters zag geen reden de verkiezingen uit te stellen. Op Curaçao slaagden niet-katholieken er niet in tot partijvorming te komen. De Curaçaosche Politieke Unie had in de loop van de zittingsperiode 1938-1941 feitelijk opgehouden te bestaan, evenals trouwens de andere partijen. ${ }^{14}$ Op Curaçao en Aruba werden echter de Katholieke partijen nieuw leven ingeblazen. Op Curaçao was de Katholieke Partij (KP) dan ook de enige die kandidaten stelde. Op Aruba werden nog drie individuele lijsten ingediend: een lijst Eman, een lijst Van Aggelen, die een groep 'vrije Nederlanders' vertegenwoordigde, alsmede een lijst Aristides Wever. Op Bonaire en de Bovenwinden werd, evenals bij de eerste verkiezingen, slechts één kandidaat gesteld. Van een eigenlijke verkiezingsstrijd was dus alleen op Aruba sprake, waarbij

$10 \quad$ Kasteel (1956) p. 68.

1 Ingesteld bij KB van 21 maart 1942, Stb. C. 26, PB 1942, 101. Artikel 2 lid 4 van het $K B$ bepaalt dat: " $Z 00$ mogelijk zullen tenminste vijf Leden van den Raad zijn deskundigen ten aanzien van de aangelegenheden van Nederlandsch-Indiẽ en twee Leden onderscheidenlijk deskundigen ten aanzien van de aangelegenheden van Suriname en van die van Curaçao". De bedoeling was dat de Raad zou functioneren als een speciale Raad van State voor de herstructurering van het Koninkrijk.

$12 \quad$ Kasteel (1956) p. 63, noot 29.

13 Kasteel (1956) pp. 56-63.

14 Rappor Ellis (1946) p. 67. 
een beroep werd gedaan op het chauvinisme van de Arubaan ten opzichte van de 'Hollander'. Kasteel citeerde met vooruitziende blik ene Albert Balink, die in 1944 een scherpzinnige observatie aan de dag legde over Arubanen: ${ }^{15}$

'Native Arubans are more fanatically attached to their domain than any other citizens of any country we know. A few of them will never be satisfied until Aruba has its own viceroy but the majority are just plainly devoted to the soil where they were born [...].'

De groep Eman verwierf twee zetels. Met de komst van Eman in de Staten, trad een periode in, waarin de vertegenwoordigers van de eilanden met name de belangen van hun geboortegrond verdedigden.

In december 1941 verzochten de Staten aan de Gouverneur een Commissie in te stellen, om een studie te maken en aanbevelingen te doen met betrekking tot de consequente doorvoering van de wijziging door de Staatsregeling gebracht in de wettelijke regelingsbevoegdheid en tot uitwerking van de bepalingen in de Staatsregeling welke betrekking hadden op de bestuursindeling in ressorten. De artikelen 117 en 118 van de Curaçaosche Staatsregeling van 1936 bepaalden dat de instelling van zelfstandige bestuursressorten (decentralisatie) bij landsverordening zou moeten geschieden. De centrale (Antilliaanse) overheid maakte van deze wetgevingsbevoegdheid geen gebruik. Op 5 december 1942 stelde de nieuw aangetreden Gouverneur Kasteel de Commissie Oppenheim in.

Voorzitter Oppenheim memoreerde in zijn antwoordrede ter gelegenheid van de installatie van de Commissie, de waarheid van Thorbecke's woord, 'dat de kracht die van autonomie uit kan gaan, wordt gestuit, wanneer men enkel op centralisatie bedacht is.' Met deze gedachte zou de Commissie zich dan ook aan het werk zetten en streven naar een eigentijds plaatselijk bestuur. ${ }^{16}$

Op 29 februari 1944, bracht de Commissie rapport uit in de vorm van een ontwerp-landsverordening (met toelichting) tot indeling van het gebiedsdeel Curaçao in bestuursressorten en tot instelling van een

\footnotetext{
Is Kasteel (1956) p. 66, noot 41, citeert: 'Albert Balink, Aruba', uit Knickerbocker Weekly, July 24, 1944.

16 Rapport Commissie Oppenheim, antwoordrede Prof. mr. A.S. Oppenheim (p. 2 e.v.).
} 
zelfstandig bestuur in die ressorten als gevorderd door de Curaçaosche Staatsregeling. ${ }^{17}$ De Commissie stelde vast dat de eilanden ondanks de opdracht in het Regeringsreglement van 1865 nog geen autonomie in eigen aangelegenheden hadden gekregen. ${ }^{18}$

Alle eilanden zouden een zelfstandig bestuur krijgen in de vorm van een Eilandsraad en een College bestaande uit een Gezaghebber en tenminste twee en ten hoogste vier Landraden. De Landraden vormden met de Gezaghebber de Raad van Politie op het betrokken eiland. De eilanden zouden hun eigen aangelegenheden verzorgen en daartoe eigen financiën en verordeningsbevoegdheid verkrijgen. Volgens de voorgestelde regeling zou de Raad van Politie Eilandsraad gaan heten.

De Eilandsraad van Aruba zou 11 leden tellen, die van Bonaire 5, van Curaçao 13, van Saba en Sint Eustatius elk 4 en van Sint Maarten (Nederlands deel) 5 leden. De leden van de Eilandsraden zouden door de Nederlandse bevolking van de eilanden worden gekozen volgens een combinatie census-capaciteitskiesrecht. Voor het eerst werd ook voorgesteld het actieve vrouwenkiesrecht in te voeren. Het passieve vrouwenkiesrecht bestond, maar was in Curaçao noch elders op de eilanden in de praktijk gebracht. Er waren geen vrouwen, die een belangrijke politieke functie vervulden. Politiek bedrijven was een mannenzaak.

Het preventieve en repressieve toezicht zou voornamelijk door de Gouverneur worden gehanteerd, de Raad van Bestuur gehoord, en voor een gedeelte door de Staten. Het voorstel beoogde de eilanden zoveel zelfbestuur te geven als onder de Staatsregeling mogelijk en wenselijk was en in de praktijk uitvoerbaar leek.

De bij elk eiland behorende gebiedsdelen (op grond van art. 1 van de Staatsregeling) zouden deel uitmaken van het betrokken ressort. Klein-Curaçao bij Curaçao en Klein-Bonaire bij Bonaire. ${ }^{19}$

17 Ontwerp-Landsverordening tot Indeeling van Curaçao in Bestuursressorten en tot Instelling van Zelfstandig Bestuur in die Ressorten als Gevorderd door de Curaçaosche Staatsregeling (Eilandenreglement), samengesteld door de Commissie ingesteld bij beschikking van 5 December 1942, 7530 (PB 1942, 227) van Zijne Excellentie den Gouverneur (P. Kasteel) van Curaçao, ter bestudering van Staatkundige aangelegenheden, Willemstad (zonder datum). In de Commissie hadden zitting: Prof. mr. A.S. Oppenheim, dr. W. Ch. de la Try Ellis, mr. dr. M.F. da Costa Gomez, dr. W.J. Goslinga, mr. C.F. Gronemeijer, mr. H.A.J. Gijsen en het lid secretaris G.J. Ferguson. De Gaay Fortman (1947) p. 52; Paula (1989) p. 17 e.v.; Luiten (1983) p. 264 e.v.; Kasteel (1956) p. 69 e.v. en p. 145 e.v.; Luiten (1981) p. 7.

1* MvT p. 2, bij het ontwerp van de Commissie Oppenheim.

19 Rapport Commissie Oppenheim. MvT p. 3 en 4. Eigenlijk deed de (plaatselijke) Commissie Oppenheim hetzelfde als de Staatscommissie Staal, maar dan meer in detail, immers de opdracht van de Commissie Oppenheim was de indeling in bestuursressorten verder uit te werken in een ontwerp-landsverordening, terwijl de 
Elk eiland zou een bestuursressort vormen en worden bestuurd naar het voorbeeld van een Nederlandse gemeente met zelfstandig bestuur, zoals Da Costa Gomez het in de vergadering der Staten van 24 juni 1942 uitdrukte - 'de schepping van Thorbecke, de Gemeentewet, die voor de zelfwerkzaamheid van het Nederlandsche volk zulk een krachtige stimulans is geweest'. ${ }^{20}$ De uitzonderlijke positie van Curaçao zou hiermede worden opgeheven.

Autonomie en medebewind zouden worden ingevoerd. Autonomie staat voor zelfstandige wetgevende- en uitvoerende bevoegdheden van de eilanden in eigen huishoudelijke aangelegenheden. Medebewind betekent het (verplicht) medewerken aan regelingen van het hoger gezag, in casu de Landsregering.

De plaatselijke begroting zou worden onderworpen aan de goedkeuring van de Gouverneur. Het geheel kwam neer op een beschikkingsrecht voor de eilanden over eigen financiën met gelegenheid tot belastingheffing, een en ander onder bepaalde door het algemeen belang gevorderde voorwaarden van medezeggenschap van de centrale regering.

De voorzitter van de Eilandsraad zou de Gezaghebber zijn, met alleen raadgevende stem. De Gezaghebber werd voor een periode van 6 jaar door de Gouverneur in zijn functie benoemd. De Landraden zouden door de Eilandsraadleden uit hun midden benoemd worden. Voor de Landraden werd een presentiegelden regeling voorgesteld en geen bezoldiging. De plaatselijke wetgever mocht alle onderwerpen regelen, die de hogere wetgever niet heeft geregeld, voor zover deze onderwerpen behoorden tot de plaatselijke huishouding en de hogere wetgever die bevoegdheid niet had beknot. ${ }^{21}$

De ontwerp-landsverordening werd gepubliceerd en een groot aantal personen sprak er een mening over uit. Veel vertraging werd veroorzaakt, omdat Gouverneur Kasteel zijn mening niet kon bepalen omtrent het rapport en het oordeel van de Nederlandse regering in Londen moest worden afgewacht. Erg positief was dat oordeel niet. Het ontwerp van de Commissie Oppenheim werd vermoedelijk mede in verband met deze kritiek uit Londen niet door de Gouverneur overgenomen en het heeft de Staten dan ook niet bereikt.

Gesteld kan worden dat het een kwalitatief goed rapport was, met een zeer uitgewerkte bestuursregeling voor de eilandsgebieden. Het fundament voor de Eilandenregeling (ERNA) is hier reeds te

\footnotetext{
Commissie Staal die gedachtengang, in hoofdlijnen moest concretiseren, gezien de opdracht neergelegd in de Grondwet van 1922.

Jesurun e.a. (1993) p. 88.

MvT p. 21.
} 


\section{bespeuren.}

In 1946 bood Gouverneur Kasteel de Staten een gewijzigd ontwerp-landsverordening over de indeling van de kolonie in bestuursressorten aan. ${ }^{22}$ De bevoegdheden van de Gouverneur met betrekking tot preventief en repressief toezicht op het doen en laten van de eilandgebieden waren in het gewijzigd ontwerp veel groter dan in het voorstel van de Commissie Oppenheim. ${ }^{2}$ Ook zou het College van Gedeputeerden met de Gezaghebber gewijzigd worden in een College van Burgemeester en Wethouders. Voor deze verandering werd gekozen, "omdat de Gezaghebber ambtenaar van het Centraal Gezag is en de Burgemeester vór alles bestuursorgaan en 'trait d'union' is tusschen het Centraal Bestuur en het plaatselijke." 24

Het gewijzigde decentralisatie-ontwerp werd op 20 februari 1946 aangeboden aan de Staten. ${ }^{25}$ De Staten brachten hun Voorlopig Verslag pas uit op 6 januari 1947. De indruk bestaat dezerzijds, dat de Gouverneur in zijn gewijzigd ontwerp naar de smaak van de Staten te weinig aandacht had besteed aan een aan de Staten verantwoordelijk bestuur en aan vermindering van het gewicht van de positie van de Gouverneur. Uiteindelijk werd het ontwerp door de Staten niet in behandeling genomen, mede in verband met de ontwikkelingen die in 1947 en 1948 op Aruba plaats hadden, met de wijziging van de

Landsverordening tot indeeling van Curaçao in bestuursressorten en tot instelling van zelfstandig bestuur in die ressorten, Willemstad, den 20sten Februari 1946, P. Kasteel, Staten van Curaçao, zittingsjaar 1945-1946-56.

Da Costa Gomez meende dat het ontwerp van de Commissie Oppenheimbeantwoordde aan de wensen van de kolonie tot autonomie en goed in elkaar zat. Die lof had hij niet voor het gewijzigd ontwerp van de Commissie Oppenheim door de Gouverneur en De la Try Ellis. Van de zelfstandigheid van de bestuursressorten was weinig meer overgebleven in het gewijzigd ontwerp. Kennelijk was de Raad van Bestuur bang voor de autonomie. De Raad deelde de Staten mede dat het instellen van verantwoordelijk bestuur zou kunnen leiden tot het spreken over, of erger nog, wensen van een republikeinse staatsvorm. Ook was de Raad van Bestuur bevreesd voor het vertrek van buitenlandse investeerders indien de ministeriële verantwoordelijkheid zou worden ingevoerd. Da Costa Gomez achtte de opvattingen van de Raad van Bestuur 'nogal leuterig'. Openbare Statenvergadering 12 september 1946 in: Jesurun e.a. (1993) pp. 129, 131 en 144-147.

24 Kasteel (1956) p. 146.

2s Sinds de totstandkoming van het Regeringsreglement van 1865 was aangedrongen op bestuursdecentralisatie. Het rapport van de Commissie Staal van 1923 voorzag daarin, evenals het rapport van de Commissie Oppenheim. De onwil van de burgerij zich met bestuurszaken in te laten had historische redenen. Da Costa Gomez no:mt de nawerking van de autoritaire directeuren van de WIC. Ondanks het feit dat het bestuur in 1946 van mening was dat plaatselijke belangen het beste ter plaatse kunnen worden behartigt, meende het bestuur ook dat toezicht nodig was. Da Costa Goni2z. merkte nog op dat het decentraliatie-ontwerp te laat gekomen is, Aruba wenst al afscheiding. Bovendien leven op Curaçao grote bezwaaren tegen het "volgehouden scherpe centrale toezicht"; Da Costa Gomez in: Jesurun e.a. (1993) pp. 305-345. 
staatsregeling in 1948 en met het onderzoek Van Poelje, dat plaats had na de RTC van 1948. Het ontwerp werd op 22 oktober 1948 ingetrokken.

Het Opperbestuur wilde wel de wens naar een 'Gecommitteerde voor Curaçaosche zaken' in Nederland (voorloper van de huidige Gevolmachtigde Minister) honoreren en verzocht de Staten in december 1946, om een voordracht te doen van drie voor de functie geschikte personen. De Staten achtten Da Costa Gomez de beste persoon om de functie te vervullen en hij vertrok dan ook naar Nederland als 'Vertegenwoordiger van Curaçao'. ${ }^{26}$

Het verlangen naar bestuursdecentralisatie kwam in de oorlogsjaren wel zeer sterk naar voren. Enerzijds begon het zich ontplooiende eiland Aruba zijn afhankelijkheid van het centrale bestuur op Curaçao en van de Staten, als een rem op de eigen ontwikkeling te voelen. Anderzijds werden Staten en Bestuur in de oorlog, die zoveel voorzieningen eisten, steeds meer overladen met arbeid. Regelmatig gaf J.H.A. Eman blijk van de ontevredenheid van Aruba over de verouderde bestuursvorm en over de 'makamba's. ${ }^{27}$ Met name dacht hij dan aan de Europees Nederlandse ambtenaren op Aruba en Curaçao.

De eigen bevoegdheden van Gezaghebber en Landraden bleven echter minimaal. Eman drong er dan ook op aan dat Aruba 'autonomie' zou krijgen ten opzichte van Curaçao. Hoe deze 'autonomie' of 'scheiding' juridische werkelijkheid moest worden, werd door Eman nooit nauwkeurig toegelicht. Wel bleek dat hij een status voor Aruba wenste, die staatkundig gelijkwaardig zou zijn aan die van Curaçao, wat eveneens zou betekenen dat Curaçao een eigen eilandsbestuur zou krijgen. Aruba zou een eigen bestuur en eigen financiële middelen moeten bezitten en niet overstemd mogen worden in een de Antillen

26 Curaçaose Staatsregeling, 1948, Stb. I, 204, PB 71, zie met name de vijfde afdeling van het derde hoofdstuk, de artt. 76 en 77, getiteld: Van de Vertegenwoordiger in Nederland. De Vertegenwoordiger zou benoemd worden door de Gouverneur; Kasteel (1956) p. 151.

Terwijl de Arubaan de Europese Nederlander doorgaans met 'hulandés' aanduidt, wordt in Bonaire en Curaçao gesproken van 'makamba'. Deze aanduiding wordt door velen - ten onrechte - als scheldnaam beschouwd. Volgens de schrijver Frank Martinus Arion is dit woord afkomstig van het Kimbundu (een taal van Angola) en is het de meervoudsvorm van kamba = vriend. Kanta guene, (zingen in het 'guene'); het 'guene' heet de oorspronkelijke taal van de slaven uit Afrika te zijn. Het werd ook makamba genoemd. Vooral werkliedjes werden in het guene gezongen. Bekend is de uitdrukking: ' $n$ ' ta ko'i kanta makamba', het mag geen naam hebben, Encyclopedie (1985) pp. 260 en 310. Amigoe, 29 januari 1992, Macamba: betekent laagste bemanningsleden van de houten oorlogsschepen; naam van een negerstam in het oostelijk Kongogebied. Deze stam zou bekend staan als achterlijk en dom, daarom gaven de slaven de blanken deze naam. 'Ta ko'i kanta makamba' betekent vrij vertaald: het is niet veel soeps. 
overkoepelend orgaan, zoals de Staten. Algehele afscheiding van Curaçao, waarvoor Eman in latere jaren ageerde, achtte hij in 1943 nog niet wenselijk. Mede dank zij de inspanningen van Eman werden in de oorlog vele van Aruba's materiële wensen vervuld en kwam de eigen positie van het eiland krachtiger naar voren dan ooit daarvoor het geval was geweest. ${ }^{28}$

In de jaren dertig en veertig werden op de Nederlandse Antillen de eerste politieke partijen opgericht. Deze waren gericht op de bevolking van één eiland. Dit werd mede veroorzaakt door het feit dat de eilanden bij nationale verkiezingen samenvielen met de kiesdistricten, een van de oorzaken van het gebrekkig nationaal bewustzijn op de Nederlandse Antillen. Politieke activiteiten op Curaçao ontplooiden zich in principe op basis van de tegenstelling tussen katholieken en niet-katholieken. De politieke tegenstelling tussen katholieken en nietkatholieken, die op het eerste gezicht een Caraibische variant lijkt van het Nederlandse verzuilde politieke systeem, heeft een diepere achtergrond. Algemeen kiesrecht zou de katholieke bevolkingsmassa tot kiezerskorps maken. De niet-katholieken vreesden dat dit een machtsverschuiving ten gunste van de katholieken zou bewerkstelligen. Arubaanse afgevaardigden gingen zich los van kerkelijke bindingen steeds meer afzetten tegen Curaçao, als het ging om Arubaanse belangen.

De katholieken schaarden zich achter de Curaçaosche R.K. Partij (1936) en de niet-katholieken achter de Curaçaosche Politieke Unie (1937). In december 1944 werd een nieuwe politieke partij opgericht: de Democratische Partij (DP). De DP voerde de verkiezingsstrijd tegen de katholieken op sensationele wijze, in verband met de verkiezingen van 1945. De DP wilde een oppositiepartij zijn. Dit bleek uit haar blad, de 'Democraat', het eerste politieke partijorgaan op Curaçao, dat regelmatig verscheen in oplagen van vele duizenden nummers, die gewoonlijk onmiddellijk uitverkocht waren. In heftige bewoordingen viel de 'Democraat' in het Nederlands en Papiaments zowel de bestuursvorm als het bestuur aan, terwijl de Staten als een 'do-nothing' college werden omschreven, dat een speelbal van de uitvoerende macht zou zijn. Vanwege 'het sullige gedoe' van de Staten, zo meldde de 'Democraat', was dan ook de DP opgericht. De 
DP wenste méér invloed van de bevolking op het bestuur, dat verantwoordelijk zou moeten zijn aan geheel gekozen Staten en vele verbeteringen op sociaal en economisch gebied. Verder streefde de DP naar opheffing van elke vorm van discriminatie op grond van afkomst of ras en scheiding van kerk en staat.

De Katholieke Partij (KP) werd door het optreden van de DP tot nieuw leven geprikkeld en ondersteunde de DP op vele punten. De DP had immers een aantal vooruitstrevende wensen voor Curaçao, zoals eerder verwoord door Da Costa Gomez, overgenomen, maar propageerde die op een fellere en meer uitgesproken manier. Het partijprogramma van de KP kwam in grote lijnen overeen met het programma van de DP.

Het partijprogramma van de KP beoogde eveneens een verantwoordelijk bestuur aan geheel gekozen Staten, opruiming van krotwoningen, invoering van het minimumloon, bevordering en uitbreiding van onderwijs, landbouw, visserij en veeteelt. Verder wilde de KP handhaving en doorvoering van de katholieke staatkundige beginselen, waaronder het hooghouden van het gezag en bestrijding van alles wat het gezag ondermijnt, krachtige gezinspolitiek, bestrijding van de zedenverwildering, bevordering van de Zondagsrust en woekerbestrijding.

Da Costa Gomez meende dat Nederland zijn overzeese gebieden altijd minder goed behandeld had dan andere koloniale mogendheden. Hij sprak zijn vertrouwen uit in de bedoelingen van de Nederlandse regering om na de oorlog dan ook daadwerkelijk een andere koers in te slaan. De politieke activiteit in Curaçao en Aruba voor meer zelfstandigheid in eigen aangelegenheden maakte in 1945 de positie van de Staten en het Bestuur steeds moeilijker. Moest de zich manifesterende onrust als werkelijk in het volk levend worden beschouwd? Kon of moest zij in juiste banen worden geleid? Het toelaten van vrije meningsuiting was altijd een hooggehouden Nederlands beginsel geweest, maar misbruik van deze vrijheid kan schadelijk zijn.

Alles wat 'koloniaal' was, bleek in de oorlogsjaren in de publieke mening slecht geworden; de grondwettelijke basis van een 'koloniaal gezag' scheen aan het wankelen te zijn geraakt, op Curaçao zowel als elders. Gezag werd niet meer zwijgend geaccepteerd, omdat het wettig of historisch was, slechts de volkswil kon gezag nog wettig en rechtvaardig maken. Langzamerhand werd het woord 'autonomie' het symbool van iets zeer begerenswaardig, ook voor velen die de staatkundige betekenis ervan niet begrepen. Deze problemen werden nog gecompliceerd door de binnenlandse en buitenlandse moeilijkhe- 
den die Nederland ondervond met de situatie in Indonesiē. Er waren op de Antillen personen die zich vereenzelfdigden met de naar 'vrijheid snakkende Indonesiërs'.

Ook de begrotingsbehandeling voor 1946 deed politiek veel stof opwaaien. Onder defensie vielen de uitgaven voor de impopulaire Schutterij. De dienstplicht moest maar worden opgeheven. De Staten wensten de gevraagde gelden niet te voteren. De begroting werd afgekeurd, dit leek op een motie van wantrouwen ten opzichte van het Bestuur. ${ }^{29}$

De begrotingskwestie verschafte een programmapunt aan een derde politieke groepering, de Curaçaosche Protestantse Partij (CPP). De CPP werd in oktober 1945 opgericht, vooral met steun van Nederlanders, die tegen algemeen kiesrecht en vóór een beperkte autonomie waren. $\mathrm{Zij}$ verklaarde zich tegen verwerping van begrotingen om redenen buiten de cijfers gelegen.

De algemene principes van de CPP leken op die van de AntiRevolutionaire Partij of de Christelijke-Historische Unie in Nederland. Voor Curaçao wenste zij volledige uitvoering van de Staatsregeling van 1936 en samenwerking tussen Bestuur en Staten op deze basis. Op de kandidatenlijst van de partij stonden voor Curaçao alleen Europese Nederlanders, terwijl hieraan op Aruba een Surinamer werd toegevoegd. De meer behoudende Nederlanders, die in 1945 op de DP hadden gestemd, konden zich op den duur niet verenigen met de latere politiek van de partij. ${ }^{30}$ Hieruit ontstond in 1948 de Curaçaosche Onafhankelijke Partij (COP).

Uit de Curaçaosche R.K. Partij ontstond in 1949 de Nationale Volkspartij (NVP) met als lijsttrekker mr. dr. M. F. da Costa Gomez, die met de leuze 'Baas in eigen huis' de autonomie in de verkiezingsstrijd betrok. ${ }^{31}$

In de periode tussen 1945 en 1955 beheersten twee zaken het politieke toneel: de autonomie en de bestuursdecentralisatie. ${ }^{32}$ De verkiezingen in november 1945, die nog op basis van de zeer beperkte censusregeling werden gehouden, vormden de aanleiding tot verdere partijvorming. Na een aantal vrijwel onmiddellijk gestrande pogingen om op de Antillen geheel naar Nederlands model, een soort PvdA, een soort VVD en een Protestantse Partij op te richten, bleken er uiteindelijk twee levensvatbaar; de Katholieke Partij (KP) en de Democratische

\footnotetext{
$29 \quad$ Kasteel (1956) p. 92 e.v.

3o Rapport Ellis (1946) pp. 60-72.

31 Daal (1988) pp. 68-122.

$32 \quad$ Römer (1977) p. 24.
} 
Partij (DP). De KP was vanuit de Kerk opgezet en leek aan de leiband van de KVP te lopen. Zo schreef de aan de KP gelieerde 'Amigoe' op 12 november 1945 over Indonesië: 'Inmiddels wroet de fascistische Achmed Soekarno voort.' In 'De Democraat', het orgaan van de DP, daarentegen, verscheen op 15 februari een advertentie met de volgende tekst:

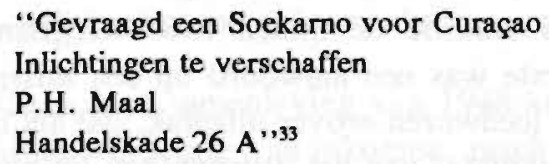

Het was de DP die op het gebied van de koloniale verhoudingen, dichter bij de sociaal-democraten stond dan bij de liberalen. Gegeven het feit dat de enige andere partij een katholieke was, wekt het geen verbazing dat de PvdA al spoedig goede betrekkingen onderhield met de DP, al waren deze betrekkingen gebaseerd op persoonlijke bindingen. De Antilliaanse verhoudingen blijken echter moeilijk met de Nederlandse politieke verboudingen te vergelijken. Daar was in de eerste plaats het feit dat de zeer populaire dr. Da Costa Gomez ('Doctoor') zich bij de KP had gevoegd, hoewel hij zowel op sociaal als op politiek terrein veel progressievere standpunten innam dan de zeer behoudende katholiek hiërarchie op de Antillen. De spanningen die hieruit voortvloeiden leidden er tenslotte toe dat Da Costa Gomez nog voor de eerste algemene verkiezingen een eigen partij oprichtte, de Nationale Volkspartij (NVP). Wat resteerde van de KP ging onder de naam van Katholieke Volkspartij (KVP) de verkiezingen in. De KVP wist zich echter niet te profileren in de verkiezingen van 1949.

Het Nederlandse verzuilingsmodel was op de Antillen ondanks nadrukkelijke pogingen niet aangeslagen. De gematigd nationalistische NVP vertegenwoordigde de gekleurde Curaçaose middenklasse, met als achterban de zwarte Antillianen op het platteland. De progressief liberale DP vertegenwoordigde een gedeelte van de blanke Curaçaose elite en steunde daarnaast op het stadsproletariaat in Willemstad, waaronder een niet gering aantal Surinaamse arbeiders die door de Shell waren aangetrokken. De partijen zouden elkaar te vuur en te zwaard bestrijden. Over én ding waren ze het echter wel eens, de relatie met Nederland was aan herziening toe.

Samen met de AVP, de grote voorvechter van een autonoom Aruba, zou de PPA de Arubaanse politiek in de jaren vijftig en zestig 
De opkomst voor de verkiezingen van 1945 was naar Antilliaanse begrippen enorm. De kiezers maakten echter slechts ongeveer $10 \%$ uit van de mannelijke bevolking. ${ }^{35}$ De belangstelling op de Antillen voor de gewenste staatkundige veranderingen was bij de verkiezingen van 1945 veel groter dan na de verkiezingen van 1937 en 1941. Op 8 november 1945 stuurde de Staten twee telegrammen naar de Koningin. Het eerste was een antwoord op een missive waarin het Opperbestuur zijn leedwezen erover uitsprak, dat het in verband met het spoedeisende karakter van het wetsontwerp tot goedkeuring van het handvest der Verenigde Naties niet in staat was geweest de Antillen hierop te horen. De Staten beklaagden zich hierover en verzochten eerbiedig: 'dat zolang er geen vertegenwoordigers van Curaçao in Nederland zijn, de Staten omtrent alle zaken die Curaçao betreffen, worden gehoord [...]' Het tweede telegram stelde dat in Curaçao algemene ontevredenheid heerste over een bestuursstelsel dat verouderd was en niet meer paste in moderne staatkundige opvattingen. Tevens verzochten de Staten om op hun voordracht vertegenwoordigers van Curaçao in Nederland te benoemen om de belangen van dit staatsdeel voor te staan, alle noodzakelijke inlichtingen daarover te verschaffen en mee te werken aan een volkomen Rijkseenheid. ${ }^{36}$

Op Aruba stelde de Arubaanse Volkspartij (AVP) zich vanaf 1947 op het standpunt van de 'Separación' (afscheiding van Curaçao) en ook de Partido Patriotico Arubiano (PPA), die het vooral moest hebben van het zwarte electoraat, had het zelfbeschikkingsrecht hoog in haar vaandel staan. Bij de eerste algemene Statenverkiezingen in 1948 was de Arubaanse invloed erg groot. Hoewel Aruba maar de helft van de kiesgerechtigden van Curaçao telde, konden op beide eilanden evenveel, namelijk 8 (van de 21) Statenleden worden gekozen. Aan het begin van de jaren vijftig kwam ook op de kleinere eilanden het politieke leven tot bloei. Op Bonaire ontstond in 1949 de Partido Progresista Boneriano (PPB) en in 1953 de Partido Democratico Boneriano (PDB). Dze partijen gingen samen verder in 1954 onder de naam de Partido Progresista Boneriano Uni (PPBU). Samen met de Partido Democratico Boneriano (DP) regeerde de PPBU tussen 1954 en 1966 op landsniveau en eilandsniveau. De Union Patriotico

\footnotetext{
Van Gameren (1991) p. 7.

Kasteel (1956) p. 98 e.v.

Kasteel (1956) pp. 101-104.
} 
Boneriano (UPB) en PDB wisselen elkaar sinds 1975, regelmatig in het bestuur van het eiland af. Op de Bovenwindse eilanden werd de Democratische Partij Bovenwindse Eilanden opgericht (DP, 'Democratic Party Windwards', 1954) en later de Sint Maarten Patriotic Movement en de Windward Islands Peoples Movement (WIPM). ${ }^{37}$

De Curaçaose samenleving van 1948 kenmerkte zich door een zeer ongelijke verdeling van inkomen, macht en aanzien en door geringe stijgingskansen voor de lagere sociale strata. De maatschappelijke bovenlaag werd gevormd door enkele min of meer gescheiden elitegroeperingen: de blanke protestanten, de Sefardische Joden en een langzaam in aantal toenemende groep, meestal licht gekleurde Curaçaoënaars. Deze elites vormden de partijtop in de politieke partijen. Hun aanhang kwam veelal voort uit de lagere sociale strata. De uit de tijd van de slavernij stammende sociale ongelijkheid veranderde nauwelijks door economische vooruitgang. Algemeen kiesrecht bracht verandering in deze situatie. De massa van Afro-Curaçaoënaars kreeg een wat hogere plaats in de machtshiërarchie. Partijtop en kiezersachterban vormden een min of meer blijvend politiek verband (vaak door patronage), dat zich tegen andere politieke groeperingen afzette. Overheidsmiddelen werden aangewend om de stembusuitslagen te beïnvloeden. Voorbeelden hiervan zijn: aanstellingen en bevorderingen in overheidsdienst, voorschotten op het salaris, leningen, studiebeurzen, verstrekking van volkswoningen, het tolereren van achterstand in de betaling van huur voor de volkswoningen, in de betaling van elektra en waterrekeningen, vrije geneeskundige behandeling, onderstand en werkverschaffing. Het ruilen van politieke steun der kiezers tegen voorzieningen van de staat door de partij komt het duidelijkst tot uiting in de verkiezingstijd. Aanpassing van bestuursmaatregelen aan de instandhouding en vergroting van kiezersachterbannen betekende voor een aantal kiezers het verkrijgen van snelle individuele positieverbetering. De grote schaal waarop dit plaatsvond, veroorzaakte een vergrote sociale stijging vanuit de lagere strata. Voortgezet onderwijs voor Antillianen werd met de beëindiging van de koloniale status een feit. Vele Antillianen studeerden in Nederland en de Verenigde Staten. ${ }^{38}$

37 Encyclopedie (1985) p. 388; Klomp (1986); voor een overzicht van alle Statcnleden en hun zittingstermijn in de Staten, zie Paula (1988) pp. 163-173.

38 Verton (1973). 
De vestiging van de olie-industrie op Aruba en Curaçao sinds de jaren twintig betekende het begin van het industriële tijdperk. Een groot deel van de beroepsbevolking was werkzaam in deze bedrijfstak. In het begin van de jaren vijftig verscherpte de concurrentie tussen de olieconcerns. De Shell op Curaçao zag zich genoodzaakt het produktieproces te automatiseren. Tussen 1952 en 1969 daalde het aantal werknemers bij de Shell van 12.500 tot 3.300 , een achteruitgang van $75 \%$. Het voorspel van een naderende economische teruggang, waaruit bleek dat de individuele werknemer geen enkele macht had tegenover de werkgever, deed vele arbeiders in loondienst besluiten om zich te organiseren. Werkgevers bleven zich lange tijd verzetten tegen de vakbondsleiders, die als vertegenwoordigers van de arbeiders optraden. Na een lange periode van conflicten werden zij eindelijk als onderhandelingspartners erkend en kreeg de vakbeweging vaste grond onder de voeten.

De aanwezigheid van steeds meer Europese Nederlanders, Amerikanen en andere buitenlanders, die niet in de Curaçaose maatschappij integreerden, verscherpten de oude tegenstellingen tussen blanke 'heersers' en de gekleurde 'overheerste' autochtone bevolking. Daarnaast waren de bestaande tegenstellingen tussen blank en zwart geenszins verdwenen, die tegenstellingen werden verder versterkt door de grote toevloed van blanken, uit andere milieu's dan de blanken die eerder naar de koloniën waren gekomen. Deze nieuwe veelal tijdelijke inwoners, hadden geen oog voor de Antilliaanse verhoudingen en cultuur en hielden zich afzijdig. Hamelberg, de protestantse historicus, analyseerde in 1894 de verhoudingen tussen de verschillende bevolkingsgroepen. Deze analyse was ook in 1956, zij het in wat andere vorm, nog van toepassing volgens Kasteel. ${ }^{30}$

'De twee rassen staan scherp tegenover elkaar, een emancipatie noch gelijkstelling als leden eener zelfde maatschappij hebben er niets toe bijgebracht, de klove, die hen scheidt, te verkleinen. De blanke ziet in den neger nog steeds zijn voormaligen slaaf; de laatste in den blanke nog steeds zijn vorigen tyrannieken meester, al erkent hij tezelfdertijd diens intellectueele en moreele meerderheid. Den kleurling echter veracht hij. In hem ziet hij een individu, door banden des bloeds aan zijn eigen ras verbonden, dat zich als zijn meester wil gedragen, zonder dat eenig overwicht hem daartoe in zijne oogen het recht geeft. Hij gelooft zeer zeker, dat er van den blanke beter, rechtvaardiger en vriendelijker behandeling te verwachten is dan van 
Afrikaanse afkomst, zelfs al was die maar gedeeltelijk, werd dus niet alleen door de blanken maar ook door de gekleurden als iets minderwaardigs beschouwd. Het woord 'neger' was omstreeks 1859 een zware belediging. Niets wijst erop, dat onder de Antillianen deze gevoelens van ras en stand verdwenen toen de industrie zoveel vreemdelingen naar hun eilanden voerde. Met name de kleurlingen, die in Nederland hadden gestudeerd en daar gemakkelijk werden opgenomen in de maatschappij, werden bij terugkomst naar de Antillen in de jaren veertig en vijfig van deze eeuw, ondanks hun geestelijke groei en verbeterde economische positie, weer geconfronteerd met dezelfde maatschappelijke en psychologische belemmeringen. Daardoor waren zij spoedig geneigd tot verbittering, omdat opname binnen de blanke toplaag voor hen was uitgesloten. Ondanks de snel toenemende welvaart, was het voor de volksklasse zeer moeilijk door te dringen in de middenklasse. ${ }^{41}$

De relatie tussen kiezers en gekozenen werd niet bepaald op grond van een partijprogramma. De politieke keuze van de stemgerechtigde werd gemaakt op grond van persoonlijk voordeel dat de kiezer door zijn stem dacht te kunnen behalen. Het algemeen belang speelde voor de kiezer geen rol. De politieke leiders gaven de kiezers in ruil voor hun stem gunsten en beloften. In veel gevallen kon niet tegemoet worden gekomen aan de verwachtingen van de kiezers. Een kleine groep kiezers kwam wel vooruit door de politieke patronage. ${ }^{42}$ De grote massa bleef daardoor hopen, dat ook zij eens aan de beurt zouden komen en bleef de eigen partij trouw. Door middel van de staatkundige emancipatie en autonomie konden de Antilliaanse politici en met name de Afro-Caraibische bevolkingsgroep in de samenleving politieke macht verwerven. Autonomie bood de kans op bestuursfuncties en politieke macht en daarmee verhoging van zowel inkomen als aanzien voor de politici. Dit gold met name in de jaren vijftig toen

Hamelberg schreef deze verhandeling in 1894, zie: Kasteel (1956) p. 7.

Kasteel (1956) p. 7 e.v.

42 De koloniale samenleving van de 19e eeuw was gekenmerkt door een sociale organisatie, waarin patronage-achtige betrekkingen tussen blanke of lichtgekleurde patronen en donkergekleurde cliënten de voornaamste structurele determinanten vormden. Verton haalt Breman aan die een verklaring geeft over het ontstaan van het patronage systeem (of zo men wil een feodaal systeem). 'De belangrijkste elementen van patronage relaties zijn: ongelijkheid, reciprociteit en het persoonlijk karakter ervan. De patroon geldt als centrum van macht, eigendom en prestige, aan wie cliēnten in afhankelijkheid zijn gebonden. Daarentegen kunnen de laatsten aanspraak maken op bijstand en bescherming, in ruil waarvoor zij tot volgzaamheid en vertoon van eerbied en nederigheid gehouden zijn', Verton (1977) p. 71 e.v. 
de politieke partijen invloed kregen. Deze situatie bestaat ook in de jaren negentig nog min of meer ongewijzigd.

Door de Tweede Wereldoorlog waren de overzeese gebiedsdelen zelfstandiger geworden en kregen zij meer gevoel van eigenwaarde, door die ontwikkeling zou mede de autonomie (behartiging van de eigen huishouding) verder gestalte krijgen. Toen daarbij de economische situatie op Curaçao verslechterde en er geen verbeteringen werden aangebracht in de arbeidssituatie van de autochtone werkende bevolking van Curaçao, zou dat ten slotte leiden tot de gebeurtenissen van 30 mei 1969.

De gebeurtenissen verliepen echter heel anders dan de Nederlandse regering in 1942 voor ogen stond. Wat Nederlands-Indië aangaat bleek het onmogelijk een oplossing te vinden. In 1949 werd een Ronde Tafel Conferentie (RTC) ${ }^{44}$ gehouden tussen Nederland en Nederlands-Indiē, waar ondermeer overeenstemming werd bereikt over een ontwerp-Charter van soevereiniteitsoverdracht, op grond waarvan uiterlijk op 30 december 1949 de volledige soevereiniteit over Nederlands-Indië onvoorwaardelijk en onherroepelijk zou worden overgedragen aan de Republiek der Verenigde Staten van Indonesië, onder erkenning van de laatste als een onafhankelijke en soevereine staat. Vanaf 27 december 1949 behoorde Indonesië niet langer tot het Koninkrijk. Van hetgeen op de RTC werd overeengekomen is praktisch niets verwezenlijkt. Vrijwel onmiddellijk na de soevereiniteitsoverdracht werd de Republiek der Verenigde Staten van Indonesië omgezet in een Republiek Indonesië, een eenheidsstaat. De Unie kwam niet tot leven en werd in 1954 ontbonden. ${ }^{45}$

Nieuw-Guinea was sinds 1828 Nederlands bezit. Van Neder-

43 In de Nederlandse visie betekende dekolonisatie, beëindigen van de staatkundige banden met de voormalige kolonic, Koulen (1985) p. 4. Dit veranderde pas met de 'Schets' van Hirsch Ballin in 1990.

4 De RTC tussen Nederland, Suriname en de Nederlandse Antillen dateert van 1948 en werd bijeengerocpen nadat het accoord op 25 maart 1947 in Linggadjati was bereikt tussen Nederland en Nederlands-Indië. Overeengekomen werd dat het Koninkrijk der Nederlanden zou worden omgezet in een Nederlands-Indonesische Unie, Van Helsdingen (1957) p. 17. 80. 
landse zijde stelde men zich op het standpunt dat de soevereiniteit over het gebied aan het Koninkrijk toebehoorde en niet aan Indonesië. Aan deze toestand kwam een eind door het verdrag dat op 15 augustus 1962 in New York werd gesloten tussen het Koninkrijk en de Republiek Indonesië. Op grond van dit verdrag werd het bestuur over het gebied overgedragen aan Indonesiē, met ingang 1 mei 1963. Hierdoor deed Nederland afstand van de soevereiniteit en het grondgebied. Pas na de overdracht van Nieuw-Guinea zou de weg vrij blijken te zijn voor 'een volwassen verhouding tussen twee onafhankelijke soevereine naties'. ${ }^{46}$

Nadat de Indonesische kwestie was geregeld, kon de aandacht weer feitelijk gericht worden op de situatie in de Nederlandse Antillen. Nederland streefde na de oorlog ten eerste naar staatkundige eenheid onder de eilanden van de ex-kolonie. Desintegratie van het kleine eilandenrijk moest worden voorkomen. Ten tweede vond Nederland het juist om de bestuurden invloed te geven op de bestuurders. De parlementaire democratie zou zijn intrede doen. Ten derde werd technische en financiële hulp verleend met het doel de sociaaleconomische basis van de Antilliaanse samenleving te verbreden. Een overgang naar economische en politieke zelfstandigheid zou daardoor mogelijk worden. ${ }^{47}$

\subsubsection{Commissie De la Try Ellis (1946)}

De Commissie ter voorbereiding van de Rijksconferentie over de nieuwe rechtsorde (onder voorzitterschap van W.Ch. de la Try Ellis) ${ }^{48}$ stelde een onderzoek in naar de in de Nederlandse Antillen heersende opvattingen omtrent de toekomstige staatsrechtelijke verhouding tussen de Nederlandse Antillen, Nederland en Suriname. De Commissie besloot haar onderzoek te houden in de vorm van een enquête. Als leidraad werd hiertoe een vragenlijst met toelichting opgesteld, die in de kranten werd gepubliceerd. Getracht werd de vragen zo te redigeren, dat beantwoording voor velen mogelijk zou zijn. $^{49}$

40

(1989) pp. 147-148, Oud (1967) p. 18; Bosmans (1990) pp. 70-74; Van Goor (1987); Gase (1984); Keesings Historisch Archief, nr. 1578, september/oktober 1961, p. 609 e.v.

47 Verton in: Nos Futuro (1986) pp. 181-193; Koulen (1985).

4 Dr. W.C. de la Try Ellis was ondervoorzilter van de Raad van Bestuur en oudvoorzitter van het Curaçaose Hof van Justitie. De Commissie bestond voor het overgrote deel uit Antillianen van verschillende gezindten, Kasteel (1956) p. 96.

49

Rapport de la Try Ellis, 1946 (in de wandeling afgekort tot Rapport Ellis); de enquêtevragen met toelichting bevinden zich op pp. 73-81. 
Alle inzendingen kwamen van Curaçao, hetgeen de Commissie toeschreef aan het feit dat de belangstelling van Aruba voor de eigen positie binnen het gebiedsdeel groter was dan voor de positie van de Antillen als geheel binnen het Koninkrijk. Op de andere eilanden beperkte de politieke belangstelling zich tot problemen van zuiver lokale aard. Het aantal inzendingen bedroeg 10, het beperkte materiaal noopte de Commissie om in haar rapport een grote plaats te geven aan haar eigen opvattingen. ${ }^{50}$

Het rapport van de Commissie verscheen op 18 mei $1946 .^{51}$ De bestaande staatkundige koloniale verhouding werd door de Commissie in het algemeen onbevredigend en verouderd geacht. De Commissie vond dat als inwendige aangelegenheden van de Antillen, die zaken zouden moeten worden aangemerkt, die niet tot de gezamenlijke belangen zouden worden verklaard. De laatstgenoemde zouden het beste door een gemeenschappelijk orgaan kunnen worden behandeld. De Commissie voorzag moeilijkheden bij het tot uiting doen komen van de gelijkwaardigheid van de delen van het Koninkrijk bij de behartiging van de gezamenlijke belangen. Tevens was de Commissie voorstander van het toekennen van een gelijkwaardige stem aan elk deel van het Koninkrijk bij het beslissen over het al dan niet gezamenlijk zijn van een aangelegenheid, terwijl zij bij de behandeling van gemeenschappelijke zaken elk deel een aantal stemmen zou willen geven. ${ }^{52}$ Een dergelijk orgaan, dat in hoofdzaak wetgevende en controlerende arbeid zou verrichten, zou de naam 'Rijksparlement' krijgen. De taken van dit orgaan zouden beperkt moeten worden tot defensie, buitenlandse zaken, het Nederlanderschap en de Staatsregeling. Alle gebiedsdelen zouden zitting hebben in het vertegenwoordigend orgaan volgens een nader te bepalen verhouding. Bij een geschil of iets een interne aangelegenheid zou zijn of een zaak van het hele Koninkrijk, stelde de Commissie voor dat het Rijksparlement daarover zou beslissen. Elk gebiedsdeel zou dan één stem hebben. Over andere zaken zou elk gebiedsdeel een aantal stemmen

so Rapport Ellis (1946) pp. 81-120.

s Rappor Ellis (1946). In de Commissie werden benoemd: Dr. W. Ch. de la Try Ellis, Dr. C. Süthoff, oud voorzitter van het Hof van Justitie, Mr. E. Cohen Henriquez, conmies ter gouvernementssecretarie en 1 juni 1946, notaris te Willemstad, C.E.B. Hellmund, Landraad op Bonaire, Mr. H.J.M. Hoogeveen, Administrateur bij Financiën, C.W.J. Jonckheer, rechtskundig adviseur bij de Curaçaose Petroleum Industrie Maatschappij (C.P.I.M.) Mr. L.C. Kwartsz, Gezaghebber van Aruba, W.F.G. Mensing, koopmante Willemstad, B.I. Mussenden, Inspecteur der Belastingen, A. van der Veen Zeppenfeldt, Regulier Overste der Paters Dominikanen in het Vicaraat van Curaçao, Pro Vicaris, L.C.M. Kerstens, commies ter gouvernementssecretarie (lid-secretaris), Paula (1989) pp. 18 e.v. 
uitbrengen in verhouding tot zijn betekenis, beoordeelt naar verschillende factoren.

De Commissie achtte invoering van het zuivere parlementaire stelsel vooralsnog onmogelijk wegens de prilheid van het partijwezen, waarop een dergelijk stelsel toch moet rusten. Volgens de Commissie vertoonde de bestaande Curaçaose autonomie drie belangrijke gebreken. De Staten zijn geen zuiver intern orgaan (want een door de Kroon benoemde Gouverneur benoemt een derde deel van de Statenleden aan); de Staten hebben niet alle regelingsbevoegdheid in interne aangelegenheden en de Staten hebben hun wetgevende bevoegdheid alleen in samenwerking met de Gouverneur. Voorgesteld werd door de Commissie, om naast de Gouverneur enkele medebestuurders of vertrouwensmannen door de Staten te doen aanwijzen, waarbij die medebestuurders de plaats zouden innemen van ministers en de Gouverneur die van de Koning in het parlementaire stelsel. Er zou geen individuele ministeriële verantwoordelijkheid zijn, maar het bestuur in volle omvang zou bij dit College van vertrouwensmannen berusten. ${ }^{53}$ Dit College zou Raad van Bestuur heten (de latere Ministerraad). Het orgaan dat op dat moment Raad van Bestuur heette zou Raad van Advies worden. Door deze oplossing te kiezen meende de Commissie conflicten te kunnen voorkomen, omdat de Raad van Bestuur voort zou komen uit de Staten en daardoor gesteund zou worden. ${ }^{54}$

De Commissie begreep wel dat Aruba zich ondergeschikt voelde aan Curaçao. ${ }^{55}$ De Commissie meende echter dat het verlangen van Aruba naar meer zelfstandigheid ten opzichte van Curaçao geen vraagstuk was in het kader van de reconstructie van het Koninkrijk, maar een intern Antilliaans probleem. ${ }^{56}$ Een zelfstandige positie naast Curaçao achtte de Commissie voor Aruba praktisch onmogelijk, althans onwenselijk. ${ }^{57}$

Tegenover de opvattingen van de Commissie De la Try Ellis stelde Da Costa Gomez in een serie lezingen voor de debateerclub Unitas zijn eigen, verdergaande opvattingen: 'zelfbestuur en wetgeving door eigen organen in de gebiedsdelen voor alle inwendige aangelegenheden, zodat alleen staatsbelangen door staatsorganen behartigd zullen

\footnotetext{
53 Rapport Ellis (1946) pp. 91-110; Kasteel (1956) pp. 104-110.

s4 Keesings Historisch Archief N0. 781, p. 6758, Juni 1946, Het rapport der Curaçaosche commissie, politieke opvattingen en wenschen.

Rappont Ellis (1946) p. 79.

Rapport Ellis (1946) p. 90.

Rapport Ellis (1946) pp. 79, 90 e.v.; Kasteel (1956) p. 111 e.v.
} 
moeten worden.' Eveneens had hij een Proeve van een Grondwet voor de Nederlandsche Antillen gemaakt. Gezien zijn lezingen en Proeve stelde Da Costa Gomez zich een nieuw Koninkrijk voor, waarin Curaçao volwaardige eigen organen zou hebben. Directe staatsrechtelijke verhoudingen van ondergeschiktheid tussen Nederlandse en Curaçaose organen zouden niet meer kunnen bestaan, omdat ze in strijd waren met het volledige zelfbeschikkingsrecht van Curaçao. Uit de Proeve sprak een voorkeur voor een presidentieel systeem. Eveneens was hij een voorstander van de instelling van een Hof van appel en cassatie, dat de bevoegdheden zou moeten hebben om wetten van de Nederlandse Antillen aan een eigen constitutie te toetsen. ${ }^{58}$

De nieuwe Staten kwamen begin april 1946 voor het eerst bijeen. Men vond dat het niet verstandig zou zijn af te wachten welke staatkundige stappen de Nederlandse regering zou ondernemen ter uitvoering van de door de Koningin in 1942 gedane belofte. Een Nederlands initiatief leek vanwege de problemen die Nederland met Nederlands-Indië had, voorlopig ook niet aan de orde. Beter leek het de Staten zelf het initiatief te nemen door een delegatie naar Nederland te zenden om daar de staatkundige verlangens van Curaçao kenbaar te maken. Het resultaat was de benoeming van een Commissie (de 'Autonomie-commissie'), die gewapend met een petitie, memorandum en opdracht in samenwerking met een Surinaamse Statenafvaardiging, de wensen van de Staten bij de Koningin en de regering zou voordragen. ${ }^{59}$ De petitie die de Commissie meekreeg voor Hare Majesteit bevatte de volgende punten:

1. zelfbestuur binnen Rijksverband;

2. zonder wijzinging van de Grondwet zou reeds herziening van een aantal artikelen van de Staatsregeling mogelijk gemaakt moeten worden. Die artikelen zouden, hangende de besprekingen over de Rijksconferentie, al ingevoerd kunnen worden;

3. de algemene ontevredenheid over het bestuursstelsel in Curaçao maakt ingrijpende en onmiddellijke veranderingen noodzakelijk, in afwachting van de definitieve reconstructie van het Koninkrijk;

4. hangende de besprekingen dienen de gevraagde wijzigingen aan Curaçao te worden toegezonden, opdat zonder tijdverlies aan

s8 De lezingen zijn zeer helder en geven een duidelijk inzicht in de toen heersende problematiek. Zijn Proeve is ook nu nog interessant. Da Costa Gomez in: Jesurun e.a. (1993) pp. 266-532; De Gaay Fortman (1947) pp. 61 e.v.; Kasteel (1956) pp. 114-121; zie ook: De Gaay Fortman, De WIG, 27, 1946, pp. 257-279.

Kasteel (1956) pp. 121-137. 
het huidige bestuur in Curaçao een einde wordt gemaakt;

5. op voordracht van de Staten van Curaçao dienen adviseurs bij de Nederlandse Regering te worden benoemd, aangezien de Staten de overtuiging hebben dat een nauw cultureel en economisch contact tussen Nederland en Curaçao wenselijk is. ${ }^{60}$

Daarnaast wilde men ook wijziging van de vaststelling van de begroting, van het aangaan van leningen, het kiesrecht en van de benoeming van Statenleden. In Curaçao had men bijvoorbeeld op 125.000 inwoners nauwelijks 4000 kiezers. Het Statencollege kon dus geen afspiegeling van de bevolking worden genoemd. De Raad van Bestuur ontwikkelde ernstige bezwaren tegen de verstrekkende verlangens van de Staten en vond het invoeren van diep ingrijpende wijzigingen niet nodig vóór de Rijksconferentie plaats zou vinden. De Raad was van mening dat de delegatie van Statenleden in Nederland ten onrechte de indruk wekte alsof op Curaçao onhoudbare, dictatoriale toestanden heersten. De delegatie keerde naar Curaçao terug en stelde dat Nederland de autonomie had toegezegd. ${ }^{61}$

In januari 1947 kwam er uit Nederland in de Nederlandse Antillen een Parlementaire Commissie aan (leden uit de Eerste en Tweede Kamer) om zich persoonlijk te oriënteren over de bestaande opvattingen in Suriname en de Nederlandse Antillen. Op de Nederlandse Antillen leefde een sterk verlangen naar autonomie, het behartigen van eigen aangelegenheden door eigen organen, zonder Nederlandse inmenging. De Commissie vatte de wensen van Aruba in haar verslag $^{62}$ als volgt samen:

Van Helsdingen (1957), de inhoud van de petitic is te vinden op pp. 10 e.v. Het antwoord van de Koningin, d.d. 4 oktober 1947, op de petitie van de Statendelegatie is te vinden in Bijlage $J$ van de MvT, 14, bij de wijziging van de Curaçaosche Staatsregeling, zitting der Tweede Kamer 1947-1948, 650; zie eveneens Keesings Historisch Archief No. 783, Juni 1946, p. 6771 e.v.

De Gaay Fortman (1947) pp. 63-69; zie voor de inhoud van het memorandum zie Bijlage II in de Gaay Fortman (1947) pp. 70-71 en Kasteel (1956) pp. 130-132; zie verder ook Kasteel pp. 133-140.

62 Verslag van de Parlementaire Commissie Suriname en de Nederlandsche Antillen, nopens hare bevindingen, Handelingen Tweede Kamer, Zitting 1946/1947, 443; Verslag Commissie Kropman (zie p. 13). Zitting in de Commissie hadden: de heren Bierema, Meijerink, Wagenaar, Logemann, Kropman en de Zwaan. Als secretaris werd benoemd de heer De Nerée tot Babberich, de voorietters van de betrokkenen ontbreken. Het Verslag geeft als de basis voor de herziene verhoudingen binnen het Koninkrijk, de verklaring van H.M. de Koningin van 7 december 1942, Paula (1989) 
1. financiële decentralisatie, waardoor Aruba zelf de beschikking verkrijgt over wat het opbrengt;

2. wijziging van het kiesreglement, zodat een uitgebreider mannenkiesrecht zou kunnen worden ingevoerd;

3. vertegenwoordiging van Curaçao en Aruba in de volksvertegenwoordiging en in andere colleges op gelijke basis;

4. autonomie en zelfbestuur voor Aruba ten aanzien van inwendigen aangelegenheden. ${ }^{63}$

Interessant is dat reeds toen op Curaçao het invoeren van administratieve rechtspraak als urgent werd gezien. Ook zag de Vereeniging van Praktizijns der Nederlandsche Antillen gaarne de cassatierechtspraak weer ingevoerd, die in 1909 voor de Nederlandse Antillen was afgeschaft. De conclusie van de Commissie Kropman aan het eind van haar bezoek was dat het verlangen naar staatsrechtelijke hervormingen gerechtvaardigd was en dat bovendien die verlangens de bevolking zeer na aan het hart lagen. Het kwam de Commissie gewenst voor dat Aruba een status zou krijgen, waardoor het eiland zijn eigen zaken in eigen sfeer binnen het verband van het betreffende gebiedsdeel zal kunnen regelen.

Van der Kuyp en Fingal ${ }^{64}$ waren in 1975 van mening dat de gedachten van de Commissie Kropman toentertijd gingen in de richting van een federale staat waarbij aan het overkoepelende orgaan weinig macht werd gelaten. Vreemd vonden zij daarom de aanbeveling van de Commissie, dat Aruba zijn eigen zaken in eigen sfeer zou kunnen regelen binnen het verband van het gebiedsdeel. De Commissie legde niet nader uit wat onder eigen zaken en eigen sfeer moest worden verstaan en evenmin hoe het verband van het gebiedsdeel eruit zou moeten zien.

Dit is naar mijn mening ook wel logisch. De Commissie kwam poolshoogte nemen, stond niet onwelwillend tegenover de wensen van Aruba en verzamelde de wensen die leefden in Suriname en de Nederlandse Antillen. Uiteraard was het niet het werk van de Commissie een uitgewerkt voorstel te doen. Dat zou gebeuren door de Commissie Logemann en de Commissie Van Poelje.

Intussen werd omtrent de samenstelling van een college van vertrouwensmannen of gecommitteerden (een proto-ministerraad) tussen Gouverneur en Staten vertrouwelijk overleg gepleegd. Het ontwerp van de 'Landsverordening houdende instelling van een

pp. 19-25.

6) Van Helsdingen (1955) p. 116.

o4 Witboek (1975) p. 19. 
College van Gecommitteerden' werd de Staten op 24 mei 1947 aangeboden. De MvT stelde dat het in de bedoeling lag dat een dergelijke proto-ministerraad ervaring op zou kunnen doen met het parlementaire stelsel en dat de ervaring zou leren of de ministeriële

verantwoordelijkheid in volle omvang kon worden ingevoerd. ${ }^{65}$ Het betrokken ontwerp werd nooit afgehandeld. De Staten meenden dat het een 'hol ontwerp' was en dat de vigerende Staatsregeling onvoldoende ruimte bood om aan de bestaande verlangens naar verantwoordelijk tegemoet te komen. In Suriname werd wel een dergelijk College ingesteld.

Een Commissie onder voorzitterschap van W.H. van Helsdingen, ingesteld op 30 augustus 1945 stelde een onderzoek in naar de opvattingen in Nederland omtrent de plaats van de overzeese gebiedsdelen in het Koninkrijk. Dit gebeurde ter voorbereiding van de toegezegde Rijksconferentie. ${ }^{66}$ De Commissie richtte zich met een vragenlijst tot een honderdtal officiële en particuliere instanties. Veel aandacht werd besteed aan Nederlands-Indië, maar daarnaast werden dezelfde vragen, in aangepaste vorm, eveneens voorgelegd aan allerlei personen en instanties bekend met de situatie in West-Indiē. De bedoeling was dat de publieke opinie zou worden gepeild, niet dat er uitgewerkte voorstellen door de Commissie worden aangeboden. Het verslag van de Commissie kwam in december 1941 gereed. Van de honderd aangeschreven instanties stuurden 29 antwoord. Van de 675 verzonden vragenlijsten aan particulieren kwamen 84 ingevulde lijsten terug. ${ }^{67}$ De Commissie vatte de historische staatsrechtelijke ontwikkeling als volgt samen:

"De staatkundige verhouding van Suriname en Curaçao tot het Moederland wordt beheerscht door de vrijwel gelijkluidende staatsre-

Kasteel (1956) p. 143.

66 Verslag Commissie Van Helsdingen (1946); Bijlage II bij het Verslag (289 pagina's). Bijlage I geeft een overzicht van de organen van bestuur en wetgeving in Nederland, met betrekking tot de Overzeesche Gebiedsdeelen, de politieke partijen, de staatsinrichting van India, de Dominions van het Britse Gemeenebest, de bescherming van minderheden in Brits-India, Beknopte beschrijving van de minderhedenbescherming in Midden-Europa, Frankrijk's Overzeesche Gebiedsdeelen, Federale structuur van de USSR, de uitvoerende macht in Zwitserland en Amerika.

67 Verslag Commissie Van Helsdingen (1946) pp. V t/m DX aanbiedingsbrief; hoofdstuk VII houdt zich bezig met Suriname en Curaçao; de andere hoofdstukken houden zich in extenso bezig met Nederlands-Indië. 
gelingen van 1936, welk ingevolge de Grondwetsherziening 1922 tot stand kwamen ter vervanging van het Regeeringsreglement van 1865. In vele opzichten het evenbeeld van de Indische Staatsregeling wijken zij op eenige punten belangrijk af. (Volksvertegenwoordiging, toezicht van de Staten-Generaal op begrooting en financieel beleid, bevoegdheid Kroon ten aanzien van de inwendige aangelegenheden van Suriname en Curaçao). Vanaf het vestigen van het Charter van 1682 , hetwelk de politieke voorwaarden behelsde van het aan de West-Indische Compagnie verleende octrooi, zijn deze Amerikaansche bezittingen anders behandeld dan de Aziatische. Dit vond zijn weerslag in de aanwezigheid reeds in het Charter van 1682, van een volksvertegenwoordiging in min of meer zuiveren vorm, zij het dan dat deze in de 19de eeuw geruimen tijd onderbroken is geweest, toen dit stelsel vervangen werd door een meer autocratischen regeervorm. Onder Van den Bosch (Regeeringsreglement van 1832) vond het oligarchisch-autocratisch stelsel zijn hoogtepunt. In 1865 werd voor Suriname althans het stelsel der vertegenwoordiging hersteld, maar nu in den onzuiveren vorm van een deels gekozen, deels benoemde volksvertegenwoordiging, de Koloniale Staten. Curaçao behield tot 1936 een oligarchischen bestuursvorm, een Gouverneur bijgestaan door een Raad van Bestuur van vijf leden, terwijl voor Suriname en Curaçao gold dat de Kroon bevoegd was alle onderwerpen, welke bij ordonnantie waren geregeld of konden worden geregeld, bij K.B. te mogen regelen. Hieraan is eerst in 1936 een einde gemaakt in aansluiting op de herziene grondwetsartikelen van 1922. De staatsregelingen van 1936 kennen voor beide gebiedsdeelen als vertegenwoordigend lichaam een college van 15 leden - de Staten - waarvan 5 door den Gouverneur worden benoemd. Suriname, dat sinds 1901 een vertegenwoordiging van uitsluitend gekozen leden had gekend, voelde deze wijziging, die met instemming van den Gouverneur en zonder protest van de Staten tot stand was gekomen terwille van de niet kiesgerechtigde minderheden, als een staatsregeling van onrecht "een noodelooze vermindering van den volksinvloed". 68

Uit het verslag van de Commissie bleek ondermeer dat de klacht over de grote bemoeienis van de Nederlandse organen met Curaçaose aangelegenheden algemeen was: ${ }^{69}$

"Men meent dat deze gebiedsdeelen te veel worden geregeerd vanuit de Haagsche bureaux, die naar West-Indische opvattingen veelal willekeurig te werk gaan zonder genoegzamekennis van de werkelijke belangen dezer territoiren".

De Commisie kwam tot de conclusie dat de hervormingen grotendeels zouden neerkomen "op versterking naar binnen van de bevoegdheden

64 Verslag Commissie Van Helsdingen (1946) pp. 56-58.

69 Verslag Commissie Van Helsdingen (1946) p. 58. 
der eigen inheemschen organen, onafhankelijkheid van de Gouverneur, versterking van het gezag en de macht der Staten en uitbreiding van de kiesbevoegdheid, extensief en intensief." 70 Voor Suriname en Curaçao dacht de Commissie aan een Engelse dominion status, maar ook aan een administratieve eenheid "ondanks de mislukking van de historische proef, zij het dan nu een eenheid van twee voor eigen aangelegenheden zelfstandige provincies of ook van twee residentie's." ${ }^{71}$ De Commissie dacht tevens aan een overkoepelend Rijksorgaan en een federale staatsvorm. In het rapport zijn aanzetten te vinden die doen denken aan de staatsvormen zoals uiteengezet in het rapport van de Commissie Staal, het ontwerp-Rijksgrondwet van de Commissie Logemann en het rapport van de Commissie Van Poelje. De fundamenten van het Statuut komen in het rapport van de Commissie Van Helsdingen al naar voren. ${ }^{2}$ Het rapport van de Commissie Van Helsdingen is interessant omdat vele mogelijke staatsvormen worden toegelicht.

Vanaf de jaren dertig manifesteerden zich op Aruba symptomen van onbehagen en achterstellling. De wens naar 'separación' werd politiek naar voren gebracht door J.H.A. Eman. ${ }^{73}$ Toen enige Curaçaose Statenleden in juni 1946 het plan overdachten om zich rechtstreeks tot Nederland te wenden om 'de autonomie' te verkrijgen, achtten zij het noodzakelijk om daarbij ook de steun van Arubaanse volksvertegenwoordigers te hebben. Het verwerven van deze steun was niet zo eenvoudig. De politieke ontevredenheid van de Arubaanse Statenleden richtte zich bijna geheel op de verhouding van Aruba tot het centrale bestuur en de eerste stap naar grotere zelfstandigheid voor Aruba kon pas daadwerkelijk gezet worden, zodra de Staten het in februari 1946 doorde Gouverneur aangeboden Decentralisatie-ontwerp afhandelden.

Hoewel van Arubaanse zijde geen enkele specifieke kritiek op dit ontwerp vernomen werd en verschillende Arubanen jarenlang op de behandeling ervan bleven aandringen, wisten de Curaçaose politici er enige Arubaanse Statenleden toch toe te bewegen de autonomie actie te steunen in ruil voor het gezamenlijk in Nederland naar voren

\footnotetext{
70 Verslag Commissie Van Helsdingen (1946) p. 64.

71 Verslag Helsdingen (1946) p. 65 e.v.

72 Verslag Commissie Van Helsdingen (1946) p. 45 e.v.

73 De kleinzoon van de oprichter van de AVP is Henny Eman die minister-president van Aruba was van januari 1986 tot februari 1989. Hij is tevens voorzitter van de AVP en thans Statenlid (1994), Reinders (1993).
} 
brengen van Arubaanse verlangens. Hierbij was voor Aruba het meest aantrekkelijke nieuwe element de belofte van Curaçao om zich uit te spreken voor een gelijk aantal Statenzetels voor Curaçao en Aruba. Het regeringsontwerp dacht Aruba echter geen gelijk aantal zetels toe. Aruba was van mening dat de schuld voor de ongelijke zetelverdeling toch bij Curaçao lag, dat Aruba eronder wilde houden. Aruba was van mening dat slechts politieke actie op grote schaal hun argumenten kracht zou kunnen bijzetten. Met name het Statenlid Eman ijverde voor de gelijkwaardigheid van de eilanden en de gelijke zetelverdeling. Aruba wenste een volksreferendum en wellicht een algehele afscheiding van Curaçao, waarschuwde Eman in de Staten. Aruba wenste de band met Nederland te behouden, maar los te komen van 'de overheersing' van Curaçao. Die wensen werden nu gedwarsboomd door het regeringsvoorstel inhoudende een ongelijke zetelverdeling.

In juli 1947 dienden 95 Arubanen een verzoekschrift in bij de Raad van Politie tot afscheiding van Curaçao en rechtstreekse plaatsing onder de Kroon. Een petitie met die inhoud werd ook 'aan Hare Majesteit de Koningin overgeseind. ${ }^{74}$ De leuze van dit afscheidingsstreven was 'Aruba Ariba' (Aruba boven). Er werd een Afscheidingscommissie gevormd op initiatief van de Raad van Politie tijdens de openbare vergadering van 17 augustus 1947. Op 7 september was er een grootse volksdemonstratie op Aruba waarbij het afscheidingsstreven werd bevestigd. Sprake van een referendum was er niet. De Gouverneur spoedde zich op 15 september naar Aruba om audiëntie te verlenen aan vijftig Arubanen die daarom hadden gevraagd en stelde dat wat Eman wenste materieel in het veronachtzaamde Decentralisatie-ontwerp was neergelegd. De Gouverneur verwees naar de komende Rijksconferentie en spoorde aan tot een rustig overleg over de voor- en nadelen van afscheiding. De Gouverneur achtte 'zes eilanden apart' een utopie. De Gouverneur beloofde Aruba's wensen in elk geval welwillend en loyaal te bestuderen. ${ }^{75}$ De problematiek van de Arubaanse Separación beweging verplaatste zich uiteindelijk naar naar de RTC's van 1952 en 1954, echter zonder ook daar

74 Keesings Historisch Archief No. 843, augustus 1947, p. 7260. Van Helsdingen, De WIG, 35, 1954, p. 118, meende dat deze beweging door de Commissie van Voorbereiding van de RTC, waarin zitting hadden Da Costa Gomez en Desertine, voor de Nederlandse Antillen, niet hoog werd aangeslagen. De Gezaghebber van Aruba. Kwartsz, schreef op 5 september 1947 aan de Staten dat een scheiding 'funeste gevolgen' voor het gebiedsdeel in het algemeen en voor de eilanden in het bijzonder (namelijk Aruba en Curaçao) zou hebben. Door de zeer 'obstinate houding' van de bevolkingsgroep van Aruba, die hem had afgevaardigd, zag hij zich verplicht voor het lidmaatschap van de Staten te bedanken. Hetzelfde deed het Statenlid V.E. Henriquez; Van Helsdingen (1954) pp. 131-133. 
gehonoreerd te worden.

Op Aruba zelf liep de tegenstelling AVP-PPA steeds hoger op. De AVP zag met lede ogen hoe de PPA aan kracht won, mede door de toestroom van 'import-Arubanen' van de Bovenwinden. De AVP wendde zich bij voorkeur tot de 'landskinderen' en ging zelfs zover om te bepleiten dat in de Eilandsraad overwegend op Aruba geborenen een plaats verdienden te krijgen. In de Staten leidde deze tegenstelling tussen de AVP en de PPA ertoe, dat de AVP hechter aan de NVP en de PPA hechter aan de DP werd geklonken. ${ }^{76}$

\section{Eerste Ronde Tafel Conferentie}

Ter bespreking van de nieuwe grondslagen van het Koninkrijk, stelde de regeringsverklaring van augustus 1947 dat in september de eerste Ronde Tafel Conferentie (RTC) plaats zou vinden tussen Nederland, Suriname en Curaçao (Nederlandse Antillen). De Nederlandse Antillen waren voorbereid op de conferentie. De Staten hadden op 19 december 1947 gesteld dat zij vóór de aanvang van de besprekingen zekerheid wensten ten aanzien van de inlossing van de koninklijke belofte van december 1942. Eveneens eisten zij vó́r de conferentie zekerheid omtrent een aantal vragen, namelijk of Nederland bereid was onmiddellijk de gelijkwaardigheid van Curaçao en Nederland te erkennen en Aruba algehele zelfstandigheid te geven in eigen zaken, wat neerkwam op een Status Aparte. ${ }^{n}$ Aruba wenstte een Status Aparte, dat heette toen autonomie.

De Democratische Partij stemde ermee in aan de conferentie deel te nemen, op voorwaarde dat de delegatie naar Curaçao zou terugkeren, indien de Nederlandse regering zou weigeren de zelfstandigheid van Curaçao te erkennen. De Antilliaanse delegatie vertrok op 14 januari per schip uit Curaçao. Antilliaanse politici trachtten de regering in

76 Reinders (1993) p. 19.

$\pi \quad$ Kasteel (1956) pp. 167-171. Van Helsdingen meende dat de Nederlandse regering verrast was door de eisen van de Antilliaanse delegatie, vlak vóór het begin van de Conferentie. Van Helsdingen achute het een staatsrechtelijk curiosum, "dat vóór de conferentie van personen, die over de toekomstige verhouding overleg gaan plegen, een delegatie disciplinair gebonden wordt en dat er vervolgens twee voorwaarden worden gesteld, de facto erkenning van twee punten, waarover het overleg juist gehouden zou worden. Natuurlijk kon de regering aan de voorwaarden niet voldoen, stelde Van Helsdingen. Het gevolg was dat vier leden van de Antilliaanse delegatie zich de vrijheid voorbehielden om zich van de resultaten van de conferentie te distancięren, Van Helsdingen, De WIG, 35, 1954, p. 119; Van Helsdingen (1957) p. 24. 
Nederland ervan te overtuigen, dat de koninklijke rede belangrijke verwachtingen had gewekt in de Nederlandse Antillen. Hierover kon echter geen eenstemmigheid worden bereikt. De Democratische Partij hield zich stringent aan de opdracht van de Staten en reisde op 26 februari 1948 terug naar de Nederlandse Antillen. De overige leden van de Antilliaanse delegatie, Curiel en Eman die zich niet gebonden voelden aan de opdracht van de Staten, bleven tot aan het slot van de conferentie. ${ }^{78}$

Op de laatste openbare zitting van de RTC op 18 maart 1948 werd een motie aangenomen waarin men de wens uitsprak, de Status Aparte van Aruba te erkennen en te eerbiedigen en waarin om een commissie werd gevraagd die een rapport ter zake moest uitbrengen. ${ }^{79}$

De Panamerikaanse Unie werd in Bogotá gehouden van 30 maart tot 2 mei 1948. Daar bevonden zich waarnemers voor Curaçao en Suriname. De Nederlandse belangen kwamen uitvoerig ter sprake in speciale commissies, die zich bezig hielden met koloniale kwesties. Venezuela bracht onofficieel allerlei argumenten te berde om aan te tonen dat de Benedenwindse eilanden aan Venezuela behoorden. ${ }^{80}$

Van Nederlandse kant werden de onderbandelingen op de RTC gevoerd door een delegatie waarin voor de PvdA de oud-ministers J.W. Alberda en J.H.A. Logemann zitting hadden. De RTC stond vanzelfsprekend onder leiding van J.A. Jonkman, minister van Overzeese Gebiedsdelen (eveneens lid van de PvdA). Alles wees erop dat het PvdA-beleid inzake de Antillen geīnspireerd was door een emancipatiepolitiek welke diende uit te monden in de stichting van een gemenebest. Voor de aanhangers van deze gedachte stond voorop dat de koloniale banden op een fatsoenlijke manier moesten worden vervangen door verhoudingen gebaseerd op vrijwilligheid en gelijkwaardigheid.

Fennema en Henriquez waren van mening dat de PvdA als partij nauwelijks belangstelling had voor de verhouding van de Nederlandse Antillen ten opzichte van Nederland. De standpunten van de PvdA ten opzichte van de koloniën werden in de jaren vijftig bepaald door een bestuurlijke instelling. Fennema en Henriquez kwamen tot een interessante conclusie:

"Ironisch genoeg was er op én punt een opvallende tegenspraak in het beleid ten aanzien van de koloniēn. Waar de Nederlandse regering

$7 \quad$ Daal (1988) p. 122 e.v.; Kasteel (1956) pp. 167-189.
$\approx \quad$ Luiten (1981) p. 7.
$\quad$ Kasteel (1956) pp. 167-182.

234. Geleidelijke dekolonisarie 1936-1950 (VI) 
het streven van de Indonesische Republiek naar een eenheidsstaat scherp afwees en aandrong op een federatief staatsverband, was haar positie ten aanzien van de Antillen precies omgekeerd: men wenste onder geen beding aan Aruba een zelfstandige positie te geven, daarbij voorbijgaand aan het advies van de Commissie Van Poelje, welke was ingesteld ter bestudering van de wensen van Aruba. ${ }^{\prime 81}$

Daarbij moet in overweging worden genomen dat Nederland wel in kon stemmen met een Indonesische Republiek als onderdeel van een Unie met het Koninkrijk der Nederlanden. Dat was in de toenmalige Nederlandse politieke opvatting de enige mogelijkheid om Indonesië te behouden. Bovendien was het grondgebied van Indonesië vele malen groter dan het grondgebied van de toenmalige Nederlandse Antillen. Nederland wilde immers tegen elke prijs de Antilliaanse eilanden bij elkaar houden in één staatkundig verband.

Op grond van de eerste aangenomen motie op de RTC over de afscheiding van Aruba werd op 14 juni 1948 een gemengde Commissie ingesteld onder voorzitterschap van G.A. van Poelje, lid van de Raad van State, ter bestudering van de wensen van Aruba. ${ }^{82}$ Op 19 juni 1948 bracht de Commissie verslag uit. ${ }^{83}$ Het rapport ging uit van

Fenema (1986) p. 81.

82 In de Commissie hadden zitting: Aruba: J.E.M. Arends, J.R. Arends, R.J. Beaujon, J.H.A. Eman, dr. P. Henriquez, L.A.C. Lacle, A.E. Wever en C.H.G. Eman; Curaçao: J.A. Correa, A. Curiel, mr. dr. M.F. da Costa Gomez, dr. W. Ch. de la Try Ellis, C.W.J. Jonckheer en W.F. Mensing; Bonaire: C.E.B. Hellmund; Bovenwindse Eilanden: W.R. Plantz; Nederland: mr. J. van Andel Gzn (tevens alg. secretaris), mr. L.P.M. Loeff en mr. dr. D. Simons, Kasteel (1956) p. 189.

Rapport der Commissie, ingesteld bij Koninklijk Besluit van 14 juni 1948, nr. 29 ter uitvoering van Motie I, aangenomen tijdens de derde openbare vergadering der Conferentie Nederland - Suriname - Curaçao (Commissie Aruba - Curaçao), (Geschriften D, Rapport). De tekst van de genoemde eerste motie bevindt zich op p. I van het rapport. De eerste motie ziet op het verkrijgen van een afzonderlijke status binnen het Koninkrijk voor Aruba. In deze Commissie voorgezeten door Prof, dr. G.A. van Poelje, lid van de Raad van State, hadden zitting voor het gebiedsdeel Curaçao als bewoners van Aruba: J.E.M. Arends, J.R. Arends, R.J. Beaujon, J.H.A. Eman, Dr. P. Henriquez, L.A.C. Laclé, A.E. Wever en als bewoners van het eiland Curaçao: J.A. Correa, A. Curiel, Mr. Dr. F.A. da Costa Gomez, Dr. W.Ch. de la Try Ellis, C.W. Jonckheer, W.F.G. Mensing. Voor het eiland Bonaire: C.E.B. Hellmund, voor de Bovenwindse Eilanden: W.R. Plantz. Tot secretarissen werden benoemd: L.C.M Kerstens en H.A. Hesseling. Ook werd bij KB nog benoemd de heer C.H.G. Eman te Oranjestad. Het rapport zelf bevat als bijlage I een Ontwerp van een landsgrondwet voor de Verenigde Nederlandse Antillen en als Bijlage $\square$ een toelichting op de artikelen van het ontwerp. Zie ook de bijlagen van het rapport die de verslagen van de subcommissies bevatten (Geschriften A - 
1. zelfstandigheid van elk eiland der Nederlandse Antillen;

2. samenwerking in geordend verband waar de belangen van de eilanden dit vereisen;

3. verbondendheid met Nederland in het kader van het zich ontwikkelende Verenigde Koninkrijk. ${ }^{84}$

Het rapport werd uitgebracht in de vorm van een ontwerp van een Landsgrondwet voor de Verenigde Nederlandse Antillen. Deze ontwerp-Landsgrondwet voor de Verenigde Nederlandse Antillen zocht aansluiting bij de structuur van de Nederlandse Provincie- en Gemeentewet. Volgens het ontwerp ${ }^{85}$ zou elk eiland een zelfstandig bestuur hebben, bestaande uit een door de Koning te benoemen Gouverneur, een door de bevolking te kiezen Volksraad en een College van Gedeputeerden. Als overkoepelend orgaan werd gedacht aan een Federale Raad bestaande uit door de Volksraden aangewezen leden. Aruba en Curaçao mochten elk vijf leden aanwijzen, Bonaire twee en elk der Bovenwindse eilanden mocht één vertegenwoordiger aanwijzen. Voorts zou er een Bestuursraad zijn die met de uitvoering van de regelingen van de Federale Raad zou worden belast. Tenslotte zou er een 'commissaris' als vertegenwoordiger van de Koning worden benoemd.

Om schending van belangen van de kleinere eilanden te voorkomen zou een minderheid van vijf leden van de Federale Raad het recht hebben tegen besluiten van de Raad beroep in te stellen op de Koning. De zelfstandige eilanden zouden op een aantal onderwerpen moeten samenwerken. Een voorlopige lijst van 22 onderwerpen werd opgesteld, terwijl ook de Landsgrondwet een aantal bevoegdheden van federale organen opsomde. De overige bevoegdheden zouden berusten

C).

4 Van Helsdingen (1955) pp. 121 e.v. Volgens Van Helsdingen had de regering in de MvT op de Interimregeling duidelijk getoond, dat het rapport Van Poelje als basis voor de Eilandregeling diende. Niet alle artikelen uit het voorstel Van Poelje werden echter overgenomen; ondat het bij het rapport gevoegde ontwerp ingericht is als een ontwerp van een landsgrondwet, nadat de Staatsregeling zou zijn vervallen. De Staatsregeling is echter gehandhaafd (na de wijziging 'Landsregeling' geheten). Van ieder artikel was aangetoond waarom het niet kon worden overgenomen. Van de driedelige Koninkrijksconstructie kon alleen maar worden afgeweken door wijziging van de Grondwet, de regering wilde dat echter toen nog niet. Een verdergaande Grondwetsherziening volgde pas in 1948, toen ingrijpender hervormingen voor de Overzeese Rijksdelen mogelijk werden.

w Rapport Van Poelje (1948) p. 8. 
bij de eilanden, zij het dat de Federale Raad volgens een bepaalde procedure bevoegdheden naar federaal niveau kon overhevelen. Het ontwerp voorzag in de mogelijkheid binnen de eilanden - en hierbij werd vooral aan Aruba en Curaçao gedacht - gemeenteraden in te stellen.

Het ontwerp liet de mogelijkheid open voor de andere eilanden tot een eenvoudiger bestuursinrichting te komen, daar de ontworpen regeling 'rijkelijk zwaar' werd geacht. Het voorstel van de Commissie Van Poelje viel over het algemeen op de eilanden in goede aarde. In verband met de Indonesische problematiek kon de Rijksconferentie waarop dit voorstel moest worden besproken niet doorgaan, bovendien eisten de verkiezingen in de Antillen de aandacht van de politici op. ${ }^{86}$

Nederland vond uiteindelijk de structuur van de Staatsregeling zoals voorgesteld door de Commissie Van Poelje teveel afwijken van de bestaande koninkrijksstructuur. Het plan Van Poelje is in de Nederlandse Antillen uiteindelijk niet aanvaard, omdat het niet meer paste in de inmiddels voortgeschreden onderhandelingen van de conferentie, waarbij een driedelige koninkrijksconstructie werd gehandhaafd. Deze gedachte werd ook neergelegd in art. 209 bij de Grondwetsherziening van 1948. Dit artikel luidde: "Nederland, Suriname en de Nederlandse Antillen vormen een Koninkrijk". Dezelfde gedachte komt thans tot uiting in de preambule van het Statuut. In de in 1951 tot stand gekomen Eilandenregeling Nederlandse Antillen is getracht de desiderata van het rapport Van Poelje zoveel mogelijk te verwezenlijken. ${ }^{87}$

Op grond van de derde RTC-resolutie werd tevens een redactie commissie ingesteld om een ontwerp-rijksgrondwet op te stellen met inachtneming van de door de Conferentie aangenomen beginselen. De redactie-commissie onder voorzitterschap van J.H.A. Logemann (voormalig minister van Overzeese Gebiedsdelen) kwam in oktober 1948 met haar omvangrijke arbeid gereed. De Nederlandse regering was niet zo te spreken over het ontwerp-rijksgrondwet. De voorgestelde structuur was te zwaar. In 1950 bood de Nederlandse regering een schets van een statuut ter bespreking aan in de vorm van een Werkstuk. Deze schets had een heel ander uitgangspunt dan het eerdere ontwerp van de Commissie Logemann. Er zouden geen aparte Koninkrijksorganen komen. De Koninkrijksfunctie zou worden uitgeoefend door Nederlandse organen, aangevuld met vertegenwoordigers van de andere twee landen. De bevoegdheden van het Konink-

* Kasteel (1956) pp. 189-192.

$\Rightarrow$ Croes (1984) pp. 246-254. 
rijk waren limitatief opgesomd. De overige berustten bij de landen. Voor conflictsituaties werd een bijzondere procedure ontworpen. Niet te achterhalen viel, waarom naast de werkzaamheden van de Commissie Van Poelje, de Commissie Logemann soortgelijke bezigheden moest verrichten. Gezien de resoluties en moties lijken het op papier twee geheel verschillende onderwerpen, maar in de praktijk was dit niet zo. Merkwaardig is dat beide commissies, voorzover kon worden nagegaan, geen onderling overleg hebben gevoerd. ${ }^{88}$

Op 8 september 1948 werd in Nederland de Grondwet gewijzigd, waardoor de in de Grondwet bestaande belemmeringen voor een nieuwe staatsrechtelijke structuur van het Koninkrijk werden opgeheven. Het nieuwe veertiende hoofdstuk was met name voor de overzeese gebiedsdelen van belang. In dit hoofdstuk waren belangrijke bepalingen opgenomen nopens de overgang naar de nieuwe rechtsorde voor Nederland, Suriname en de Nederlandse Antillen. ${ }^{89}$ De nieuwe rechtsorde zou volgens de gewijzigde Grondwet in gemeen overleg met en tussen de vertegenwoordigers van de bevolkingen van de drie landen worden gevestigd. $\mathrm{Zij}$ zou bovendien tot stand komen langs democratische weg. Dit betekende dat de nieuwe verhouding diende te worden goedgekeurd door de volksvertegenwoordigingen van Nederland (de Staten-Generaal), Suriname (de Staten) en de Nederlandse Antillen (de Staten). Verder werd bij de gewijzigde Grondwet bepaald dat de drie Landen één Koninkrijk zouden vormen. Tenslotte bepaalde artikel 210 van de Grondwet, dat voor zover de overgang naar de nieuwe rechtsorde voorzieningen vorderde waarbij werd afgeweken van andere grondwettelijke bepalingen, deze voorzieningen bij wet konden worden getroffen. De Interimregeling (1950) was een uitvloeisel hiervan. ${ }^{90}$

Medio 1947 ontvingen de Staten voorstellen voor een nieuwe Staatsregeling vanuit Nederland. Niet in alle opzichten kwamen deze voorstellen tegemoet aan de bestaande autonomie-verlangens. Met name een

\footnotetext{
- Van Helsdingen (1957) pp 17-64.

- Stb. 948-I, 410-413, Grondwet van 1948, met name het veertiende hoofdstuk de art. 208-211, Van Hasselt (1987) pp. 417-467.

o Van Hasselt (1987) pp. 417-464.
} 
bevredigende en scherpe afbakening tussen lands- en koninkrijksorganen kon in verband met de nog niet gewijzigde Grondwet niet worden gegeven. Dat zou pas gebeuren met het invoeren van de Interimregeling en het Statuut. Voorts wilden de Nederlandse Antillen en het Eilandgebied Aruba de voorgestelde zetelverdeling Curaçao 11, Aruba 7 veranderd zien in 8 zetels voor Curaçao en 8 zetels voor Aruba. ${ }^{91}$ Het ontwerp tot wijziging van de Curaçaosche Staatsregeling werd op 21 mei 1948 wet $^{92}$ en trad op 8 juli 1948 in werking. De wet betekende een belangrijke vooruitgang op weg naar de autonomie. De belangrijkste wijzigingen waren:

1. er werd een College van Algemeen Bestuur (C.A.B) ingesteld van maximaal 6 personen, politiek verantwoordelijk aan de Staten voor het gevoerde bestuur (art. $68 \mathrm{t} / \mathrm{m} \mathrm{71}$ ). De leden van het C.A.B. werden benoemd voor eenzelfde periode als de Staten zitting hebben. Het ontwerp van wet sprak nog van een College van Gecommitteerden (de Raad van Bestuur uit de Curaçaosche Staatsregeling van 1936) ${ }^{93}$. Het C.A.B. zou samenwerken met de Gouverneur bij de uitoefening van diens algemeen bestuur over Curaçao. ${ }^{94}$ Formeel bleef de Gouverneur verantwoording verschuldigd aan de Koning (art. 29);

2. afschaffing van de benoeming van Statenleden door de Gouverneur. Alle Statenleden worden voortaan rechtstreeks gekozen (art. 78/2);

3. invoering van het algemeen kiesrecht voor Nederlanders vanaf 23 jaar (art. 79);

4. wijziging van de zogenaamde conflictenregeling. Artikel 100 en 101 (1936) bepaalde dat indien de Gouverneur een ontwerplandsverordening niet goedkeurde, hij het ontwerp binnen zes maanden na dagtekening al dan niet door hem gewijzigd, opnieuw aan de Staten kon aanbieden. Als ten tweede male geen overeenstemming kon worden bereikt en het ontwerp in belangrijke mate andere delen van het Koninkrijk betrof, kon de

92 Beschikking van de 5 de juli 1948,5202 , ter bekendmakingvan het Koninklijk besluit van 25 Mei 1948, houdende bekendmaking van de tekst der Wet op de Staatsinrichting van Curaçao (Curaçaose Staatsregeling, Staatsblad nr. 1 204), Sth. I, nr. 195 , PB 1948, nr. 71, uitgegeven de 7de Juli 1948.

93 Wijziging van de Curaçaosche Staatsregeling (Wetsontwerp II) Bijlage $\mathrm{N}$ van de Memorie van Toelichting, nr. 18, Zitting 1947-1948, 650, art. 29. Het College kan gezien worden als de voorloper van de huidige Raad van Ministers. In 1950 zou de naam van het College gewijzigd worden in Regeringsraad. Bij de Staatsregeling van 1955 zou deze Raad uitgroeien tot Ministerraad.

Kasteel (1956) p. 183. 
regeling geschieden bij algemene maatregel van bestuur. Een dergelijke AMvB kon echter altijd bij landsverordening worden gewijzigd of ingetrokken. Indien de Staten in gebreke bleven een regeling te treffen die in belangrijke mate andere delen van het Koninkrijk betroffen kon de regeling eveneens geschieden bij AMvB, zo bepaalde art. 111;

5. het onttrekken van de algemene verordening voor inwendige aangelegenheden aan de aanwijzing des Konings (art. 29/2);

6. uitbreiding van het aantal zetels in de Staten tot 21 en wijziging van de zetelverdeling; Curaçao 8, Aruba 8, Bonaire 2 en elk der Bovenwindse eilanden 1 (art. 78 de leden 1 en 3);

7. de bevoegdheid om de begroting ook wanneer deze niet sluitend is, zonder interventie van de Nederlandse wetgever vast te stellen (de artt. $119 \mathrm{t} / \mathrm{m} \mathrm{125}$ );

8. de bevoegdheid om bij landsverordening dienstplicht in te stellen (art. 164/2);

9. aanstelling van een vertegenwoordiger in Nederland, (de voorloper van de Gevolmachtigde Minister, de artt. 76 en 77);

10. de Raad van Advies verving de Raad van Bestuur. Tot 1951 bleef deze Raad bestaan uit vijf gewone leden en een buitengewoon lid. ${ }^{95}$

Het eerste C.A.B. kwam met moeite tot stand en hield zich bezig met het vervaardigen van een nieuw kiesreglement, het zag zichzelf meer als een 'intermezzo-college', gezien de spoedige verkiezingen van 17 maart 1949. Het zouden de eerste algemene verkiezingen worden, die veel belangstelling opriepen ook vanwege de ingrijpende zetelverdeling tussen de eilanden. De naam Nederlandse Antillen werd voor het eerst in art. 1 van de Staatsregeling geïntroduceerd, als benaming voor het grondgebied voor Curaçao, waartoe alle zes eilanden behoorden. ${ }^{96}$ Zonder moeilijkheden heeft de overgang van een zeer beperkt census- en capaciteitskiesrecht, naar het algemeen kiesrecht plaatsgevonden. Op 14 oktober 1948 namen de Staten de landsverordening houdende het nieuwe kiesreglement aan, waardoor het mogelijk werd

9s Memoric van Toelichting bij de Wijziging van de Curaçaosche Staatsregeling. 4 (Wetsontwerp I), 3 Ontwerp van Wet, zitting 1947-1948, 650, zie ook bijlage E van de MvT, 9 het Advies van de Staten op de wijzingen van de Staatsregeling. Keesings Historisch Archief No. 836, Juni 1947, p. 7205 en No. 860, December 1947, p. 7402.

* Pas toen bij de Grondwetsherziening van september 1948 de nam van het gebiedsdeel 'Curaçao' gewijzigd werd in Nederlandse Antillen kon bij de totstandkoming van de Interimregeling voor de Nederlandse Antillen in 1950 de benaming 'Curaçao' voor het grondgebied officieel worden vervangen door Nederlandse Antillen. 
op 17 maart 1949 voor het eerst algemene verkiezingen te houden voor een geheel gekozen Statencollege van 21 leden, samengesteld volgens de nieuwe zetelverdeling, waarbij Curaçao en Aruba ieder 8 zetels in de Staten kregen. ${ }^{97}$ De basis voor een politieke tegenstelling op grond van kerkelijke binding verdween en de partijen met een religieus karakter losten geleidelijk op in de nieuw ontstane partijen. ${ }^{98}$ Bij de eerste algemene verkiezingen voor de Staten van 17 maart 1949 kreeg de NVP van Curaçao 4 zetels, de DP kreeg 3 zetels en de KVP 1 zetel. De Arubaanse AVP kwam met 5 zetels in de Staten, de UNA met 3.

Periode VII, het tijdvak 1936-1950, bracht veel veranderingen. Door het gemis aan verantwoordelijk bestuur in de Staatsregeling van 1936 was bet voor de ontstane politieke partijen moeilijk om hun programma's door te voeren. De volksvertegenwoordiging en het bestuur stonden tegenover elkaar als vreemde machten. Het bestuur was niet verantwoordelijk ten opzichte van de volksvertegenwoordiging en het bestuur kon de Staten niet ontbinden. De Staten waren overwegend Curaçaos, het bestuur was overwegend Nederlands. Omdat het bestuur los stond van de bevolking, bestond er weinig begrip van het bestuur voor de noden van de bevolking. Ook de burger had geen band met het bestuur. ${ }^{99}$ Da Costa Gomez vatte de positie van de Staten op saillante wijze samen:

\footnotetext{
"Samengesteld voor 1/3 door den Gouverneur, zonder schadeloosstelling, blootgesteld aan critiek, met een vreemde voertaal, beknot in zijn bevoegdheden, staat het college tegenover een aan hem vreemd bestuur en Opperbestuur. Zijn bevoegdheden ontleent het aan een totaal verouderde wet, die in 1936 tot Staatsregeling werd verklaard."
}

De Staten hadden het zelfs zo moeilijk in hun relatie tot het bestuur dat zij in 1937 enkele jaren het voorbeeld volgden van de Koloniale Raad, die in 1902 begon met vertrouwelijke vergaderingen en niet meer in het openbaar vergaderde.

Met de vaststelling van de Curaçaosche Staatsregeling van 1936 werd

\footnotetext{
$97 \quad$ Kasteel (1956) pp. 193-217.

$98 \quad$ Van Gameren (1991) p. 7 e.v.

99

Jesurun e.a. (1993) p. 348.
} 
een Statencollege ingevoerd, met vijftien leden, waarvan tien van de vijftien leden door kiesgerechtigde burgers werden gekozen. Vijf leden werden door de Gouverneur benoemd. Geen algemeen kiesrecht werd ingevoerd, maar alleen een census- en capaciteitskiesrecht. Voor vrouwen werd alleen een passief kiesrecht ingevoerd.

Veel bevrediging bracht de Staatsregeling van 1936 niet voor degenen die voorstanders waren van het algemeen kiesrecht. Ondertussen waren door de ontwikkeling op sociaal en economisch gebied aan het begin van deze eeuw en door de Tweede Wereldoorlog de wensen van de bevolking van de eilanden groter geworden en ontstond er een streven naar autonomie, niet alleen voor de Nederlandse Antillen als geheel, maar ook voor de afzonderlijke eilanden. De eerste stap in de richting ter vervulling van deze wensen kwam met de Staatsregeling van 1948, waarbij onder andere de volgende vernieuwingen werden ingevoerd: de uitbreiding van het kiesrecht, afschaffing van de benoeming van Statenleden, uitbreiding van het aantal zetels, verandering van de zetelverdeling, de instelling van het College van Algemeen Bestuur en de Staten van de Nederlandse Antillen.

De wijziging van de Curaçosche Staatsregeling (van 1936) in 1948 bracht eindelijk de zelfstandigheid in eigen zaken van de kolonie, waarover het Regeringsreglement van 1865 reeds sprak. Die ontwikkeling was mede beinnvloed door internationale standpunten over dekolonisatie, waarvan Nederland zich tot de Tweede Wereldoorlog weinig had aangetrokken. Na de Tweede Wereldoorlog wilde Nederland de koloniale verhoudingen afschaffen en voormalige koloniën opnemen als een gelijkwaardig deel van het Koninkrijk. Dit was door Koningin Wilhelmina al op 7 december 1942 aangekondigd, onder invloed van Engelse en Amerikaanse opvattingen over dekolonisatie. Met de beroemde rede van Koningin Wilhelmina trad een verandering op in het Nederlandse beleid. Na de oorlog zouden de koloniën een meer gelijkwaardige positie binnen het Koninkrijk tegemoet mogen zien. Vooruitlopend op de nieuwe situatie bestudeerde een aantal commissies de gewenste nieuwe staatkundige structuur voor het Koninkrijk.

Dit waren de commissies Oppenheim (1942), De la Try Ellis (1946), Kropman (1947) en Van Helsdingen (1946). De Nederlandse Antillen streefden naar autonomie, meer zeggenschap in eigen zaken.

Aruba voelde zich sterker op grond van de economische ontwikkeling en streefde al in de jaren dertig naar autonomie of 'separacion'. Aruba wilde los van Curaçao, maar wenste wel binnen het Koninkrijk te blijven. De commissies die zich over dit probleem bogen hadden 
wel begrip voor het Arubaanse streven maar vonden dat een interne Antilliaanse aangelegenheid die niets te maken had met een nieuwe Koninkrijksstructuur. Wel stelden verschillende commissies een federale structuur voor, met als basis de aangepaste Gemeentewet. De Nederlandse regering achtte echter een federale structuur voor het nieuwe Koninkrijk te afwijkend binnen het bestaande staatkundig verband.

Op de Eerste Ronde Tafel Conferentie van 1948 werd een motie aangenomen, waarin de wens van een 'Status Aparte' voor Aruba werd erkend. Nederland wenste echter de Nederlandse Antillen bij elkaar te houden en stond niet positief tegen een 'afscheiding' van Aruba, dat dan directe banden met Nederland wenste.

Om de wensen van Aruba tot autonomie te onderzoeken werd na de RTC van 1947 de Commissie Van Poelje (1948) in het leven geroepen.

Een reeks van regelingen, ingevoerd in de jaren vijftig, waaronder de Interimregeling (1950), de Eilandenregeling van 1951 en het Statuut van 1954, was het resultaat van het streven naar democratie en autonomie. De moderne Colleges van Bestuur: de Ministerraad, de Staten, de Raad van Advies, de Bestuurscolleges en de Eilandsraden kregen in de jaren vijftig hun huidige vorm.

De eilanden hadden vanaf 1634 tot 1833 geen invloed in de verkiezing van de leden van de Raad van Politie van Curaçao. Van 1833-1865 (oude Koloniale Raad) en van 1865-1936 (vernieuwde Koloniale Raad) konden de eilanden geen invloed uitoefenen op de verkiezing van leden van de Koloniale Raad (sinds 1936 Staten). Pas in 1948 werd een algemeen kiesrecht voor de Staten ingevoerd. Curaçao had nimmer als eiland een Raad van Politie gekend. Immers de Raad van Politie van Curaçao bediende ó́k Aruba en Bonaire. Landsbelangen en eilandsbelangen vielen samen. Pas bij de invoering van de Eilandenregeling in 1951 kreeg Curaçao voor de eerste keer een eilandelijk bestuur. Eeuwen vermenging van taken kan echter niet zomaar worden weggepoetst. ${ }^{100}$ eilandelijke belangen. Gedacht kan bijvoorbeeld worden aan de val van het kabinet Liberia-Peters III op 27 oktober 1993. De indruk wordt gewekt of een kabinetscrisis is geforceerd om de Curaçaose politici de gelegenheid te geven op landelijk niveau een eventuele onaangename uitspraak van het te houden referendum niet direct te hoeven uitvoeren. De Curaçaose politici wensen een aparte status voor hun eiland, terwijl een aanzienlijk deel van de Curaçaose bevolking óf onderdeel van Nederland wil worden óf het staatsverband van de Antillen van de Vijf wil behouden. Ook 
De nieuwe Koninkrijksstructuur zou na de oorlog nog geruime tijd op zich laten wachten, daar alle aandacht van Nederland uitging naar de situatie in Nederlands-Indië en de souvereiniteitsoverdracht aan Indonesiē.

Bij de wijziging van de Staatsregeling in 1948 werd de ministeriële verantwoordelijkheid ingevoerd, evenals het algemeen kiesrecht. Alle Statenleden zouden voortaan gekozen worden. Curaçao en Aruba kregen op verzoek van de Staten hetzelfde aantal zetels in de Staten, namelijk acht, ondanks het feit dat Aruba veel minder inwoners had dan Curaçao. In 1948 begon het bestuur van de eigen huishouding vorm te krijgen, evenals de invloed van de burgers in het bestuur. De scheiding van machten was vanaf 1948 een feit.

Vóór 1936 was het politieke bewustzijn binnen de kolonie gering. Voor de eerste verkiezingen in 1937 ontstonden een aantal politieke partijen. De meeste politieke partijen kwamen echter pas tot ontwikkeling na de verkiezingen van 1937. Met de opkomst van de politieke partijen kwam ook de patronage tot ontwikkeling, het verkrijgen van politieke steun op grond van verleende gunsten.

In de periode tussen 1945 en 1955 beheersten twee zaken het politieke toneel: de autonomie en de bestuursdecentralisatie. De verkiezingen van november 1945, die nog op basis van de zeer beperkte censuskiesregeling werden gehouden, vormden de aanleiding tot verdere partijvorming.

De invloed van het Nederlands bestuur op het bestuur van de kolonie nam in theorie af bij de invoering van de herziene Curaçaose Staatsregeling in 1948. De facto zouden de nieuwe verhoudingen zich nog moeten uitkristalliseren. Het algemeen kiesrecht werd ingevoerd, de Statenleden zouden allen rechtstreeks worden gekozen. Er kwam echter nog geen aan de Staten verantwoordelijke regering. De Gouverneur bleef verantwoording verschuldigd aan de Koning. Een niet sluitende begroting zou zonder interventie van Nederland mogen worden vastgesteld.

De opbouw van de staatsorganen en de binding van de staat aan het recht volgens de beginselen van de parlementaire democratie naderde zijn voltooiing, evenals de verdeling van de overheidsmacht volgens het beginsel van de scheiding van machten. De invloed van de burger in het bestuur kwam in theorie tot stand, maar zou zich in

kunnen Nederlandse maatregelen door de kabinetserisis nog even worden uitgesteld. Ondanks de crisis bleef het kabinet zitten. De Statenleden die zeiden geen vertrouwen meer te hebben in het kabinet lieten het kabinet echter desondanks zitten. 
de praktijk nog moeten ontwikkelen.

Het zoeken van het juiste evenwicht tussen ordening van de samenleving en individuele vrijheid was administratiefrechtelijk nog onderontwikkeld. Alhoewel de Commissie Kropman in 1947 al meende dat invoering van administratieve rechtspraak urgent was duurde het tot het begin van de jaren negentig totdat op de Nederlandse Antillen en Aruba een landsverordening Administratieve Rechtspraak zou worden ingediend bij de Staten.

De burgerlijke rechter had evenwel een belangrijke functie in de rechtsbescherming van de burger tegen onrechtmatig overheidsoptreden. De ontwikkelingen in Nederland op dit gebied hadden grote invloed op de rechtspraak in de Nederlandse Antillen. De burgerlijke rechter in de Nederlandse Antillen stelde zich in het algemeen minder terughoudend op in de toetsing van onrechtmatig overheidshandelen dan de rechter in Nederland. De specifieke administratiefrechtelijke rechtsbescherming van de burger tegen overheidshandelen bestond nauwelijks, evenals dat in Nederland het geval was. Daar kwam het denken over de rechtsbescherming van de burger tegen het sterk toenemend overheidshandelen pas aan het eind van de jaren vijftig tot ontwikkeling. De wet Administratieve Rechtspraak Overheidsbeschikkingen werd in Nederland pas in 1976 ingevoerd.

De grondrechten speelden nog niet zo'n belangrijke rol in het staatsrecht als thans (1994) het geval is. De aanpassing van de grondrechten in de Staatsregeling zou pas geschieden in de Staatsregeling van 1955 en liep parallel met de ontwikkeling in Nederland.

Klasseverschillen en kleurverschillen bleven ongewijzigd, maar manifesteerden zich niet, omdat alle aandacht uitging naar een nieuwe Koninkrijksstructuur met meer zeggenschap in eigen aangelegenheden en de wens van Aruba zich los te maken van Curaçao. De klasse- en kleurverschillen zouden zich op hardhandige wijze zichtbaar worden bij de ongeregeldheden in Willemstad in mei 1969. 


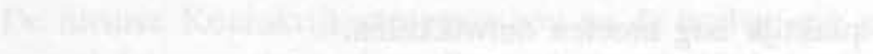

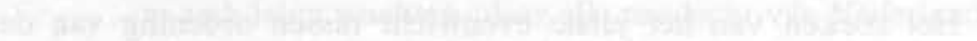

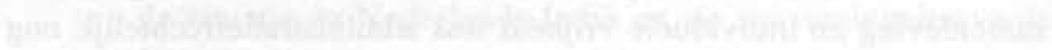

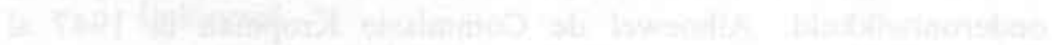

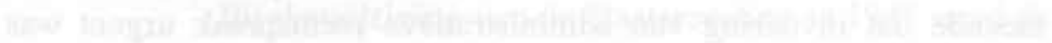
- 
Periode VIII (1950-1986) wordt in drie hoofdstukken behandeld. Hoofdstuk VI beschrijft de periode 1950-1969. Hoofdstuk VII bespreekt het tijdvak 1969-1986 in Antilliaans perspectief. De reden hiervoor is dat de ongeregeldheden van 30 mei 1969 in Willemstad een keerpunt bleken te zijn in het Nederlandse beleid met betrekking tot de Nederlandse Antillen. De ontwikkelingen volgden elkaar snel op. Daarom wordt de periode 1969-1986 apart behandeld. Het handhaven van de orde in Willemstad door Nederlandse mariniers en de negatieve internationale reacties die Nederland daarop kreeg, leidde tot de Nederlandse wens dat Suriname en de Nederlandse Antillen onafhankelijk zouden worden. Hoofdstuk VIII besteedt aandacht aan de strijd voor de Status Aparte van Aruba, vanuit Arubaans perspectief. Die strijd begon in de jaren dertig, zakte in tussen 1950 en 1970 en kwam in de jaren zeventig weer tot bloei om uiteindelijk in met ingang van 1 januari 1986 te leiden tot de felbegeerde Status Aparte.

Hoofdstuk VI gaat in op de wetgeving die de decentralisatie vorm gaf: de Interimregeling en de Eilandenregeling Nederlandse Antillen (ERNA) van 1950 en 1951. Daarna wordt het proces besproken dat geleid heeft tot het Statuut, de Koninkrijksgrondwet. Daarbij was de interpretatie van het zelfbeschikkingsrecht van belang. Het Statuut wordt toegelicht, evenals de veranderde verhouding tussen Gouverneur-Regering en Staten. In 1955 volgt de aanpassing van de Staatsregeling van de Nederlandse Antillen aan het Statuut. Omdat toetsing van de landsverordening aan het Statuut een rol heeft gespeeld in de jaren tachtig en negentig wordt dat bij het Statuut behandeld. Op grond van het Statuut is verschillende keren ingegrepen door de Koninkrijksregering in het bestuur van het Rijk overzee, deze ingrepen worden besproken.

\section{De nieuwe rechtsorde}

Nederland hoopte het voormalig Nederlands-Indiē te kunnen betrekken bij een definitieve regeling van de nieuwe rechtsorde. Dit heeft geleid 
tot de totstandkoming van de Interimregeling van 1950 en $1951 .{ }^{1}$ Toen Koningin Juliana op 27 december 1949 de onafhankelijkheid van Indonesië proclameerde, leek die regeling nog vó́r de inwerkingtreding voor de Nederlandse Antillen, achterhaald te zijn. Voor Nederland bleek de Interimregeling de grondslag voor een definitieve regeling te zijn.

In de loop van 1949 ontvingen de Staten een ontwerp-Interimregeling om vooruitlopend op de nieuwe Koninkrijksstructuur een eigen autonome bestuursinrichting te verwezenlijken. Deontwerp-Interimregeling ging vergezeld van een concept-schets van een Eilandenregeling. Over deze concept-schets waren de Staten teleurgesteld. Zij hadden de uitgangspunten van het rapport van de Commissie Van Poelje niet terug kunnen vinden. De Nederlandse regering stelde zich op het standpunt dat alles wat overgenomen kon worden, ook overgenomen was. De mogelijkheid van eilandelijke grondwetten verviel en de samenstelling van de gezamenlijke organen was anders uitgewerkt. Een aantal vormen die sterk deden denken aan een federale structuur werden vervangen door oplossingen die ontleend waren aan het model van een eenheidsstaat. Uit het rapport Van Poelje werd wel het systeem van de bevoegdhedenafbakening tussen Land en de Eilandgebieden overgenomen. De bevoegdheden van het Land staan dan ook in de ERNA limitatief opgesomd (de artt. 2 en 2A). Alle overige bevoegdheden zouden toevallen aan de Eilanden. ${ }^{2}$ Titel II van de Interimregeling bevatte de wijzingen van de Curaçaosche Staatsregeling van 1936, die zou fungeren als Landsregeling. Onderdeel van de Interimregeling vormde tevens een nog uit vaardigen Eilandenregeling. De Eilandenregeling Nederlandse Antillen (ERNA) kwam in 1951 tot stand.

In de voorgestelde Landsregeling van de ontwerp-Interimregeling bepaalde artikel 126 dat een nadere regeling voor de autonomie van de eilanden moest worden getroffen. Bij algemene maatregel van bestuur (de Eilandenregeling) moest volgens dit artikel worden voorzien in de regeling van de eigen aangelegenheden door de diverse eilanden. In de algemene maatregel van bestuur zou komen te staan welke onderwerpen niet tot de eigen aangelegenheden van het eiland zouden behoren.

De Commissie Plantz (genoemd naar haar voorzitter W.R. Plantz) werd ingesteld om de financiële consequenties van de Eilan-

\footnotetext{
1 De Interimregeling werd gedeeltelijk in 1950 ingevoerd en gedeeltelijk in $1951, \mathrm{~PB}$ 1950,109 en PB 1951, 91.

$2 \quad$ Luiten (1981) pp. 7 e.v.
} 
denregeling te bekijken. ${ }^{3}$ Het Werkbureau Kerstens werd ingesteld bij Gouvernementsbeschikking met de opdracht, de administratieftechnische maatregelen voor te bereiden, nodig in verband met de toekomstige zelfstandigheid van de eilanden. ${ }^{4}$ Zowel de bevindingen van de Commissie Plantz als die van het Werkbureau Kerstens leidden tot belangrijke wijzigingen in het voorontwerp van de Eilandenregeling.

Interimregeling: de Landsregeling van de Nederlandse Antillen (1950)

In de Interimregeling was als Landsregeling opgenomen, de in 1948 gewijzigde Curaçaosche Staatsregeling van $1936 . .^{5}$ De Interimregeling $^{6}$ trad gedeeltelijk in werking op 17 oktober 1950 en voor de rest op 7 februari 1951. De Staatsregeling werd voortaan Landsregeling genoemd. De Interimregeling kon worden gezien als een voorlopig Statuut, met daarin opgenomen de Landsregeling. De Interimregeling moest conform art. 210 Grondwet 1948 worden vastgesteld bij wet waarvoor in de Staten-Generaal een meerderheid van tenminste twee derde van het aantal uitgebrachte stemmen was vereist.

In de Interimregeling werden belangrijke wijzigingen aangebracht. De Nederlandse Antillen mochten hun eigen aangelegenheden zelf gaan behartigen. Er kwam in de Landsregeling een aan de Staten verantwoordelijke Regeringsraad, die samen met de Gouverneur de Landsregering vormde. Geconcludeerd kan worden dat de Interimregeling de positie van de Gouverneur fundamenteel wijzigde. Hier werd namelijk de figuur van de Gouverneur als constitutioneel orgaan geïntroduceerd overeenkomstig de positie die de Koningin in het Nederlandse staatsrecht inneemt. Artikel 12 Interimregeling bepaalde dat de Gouverneur hoofd is van de Landsregering en dat de leden van de Regeringsraad verantwoording verschuldigd zijn aan de Staten.

3 Rapport van de Commissie met de opdracht de financiële consequenties van de zelfstandigmaking der eilanden aan een nauwgezette beschouwing te onderwerpen; ingesteld bij Gouvernementsbeschikking van 9 April 1949, 2910, zoals aangevuld bij Gouvernementsbeschikking van 13 April 1949, 2910b, Curaçaosche Courant N.V. 2382 ' 49.

4 6 juli 1949, 5449. Rapport Kerstens, deel I (264 pagina's) en deel II (264-517); in het Werkbureau hadden zitting de heren: L.C.M. Kerstens, C.J. van den Brink en R. van Hoorn.

3 Zoals gewijzigd bij wet van 21 mei 1948, Stb. I, 195, PB 1948, 71. De Interimregeling, Wet van 28-9-1950, Stb. K 419, PB 1950, 109. Landsregeling, PB 1950, 139.

6 Interimregeling voor de Nederlandse Antillen, Bijlagen 1949-1950, Tweede Kamer der Staten Generaal, 1639, pp. 1-16. 
Artikel 2 Statuut 1954 behield dit beginsel (art. 2 de leden 1 en 2). Deze bepaling vindt men thans ook terug in art. 11 Staatsregeling van de Nederlandse Antillen en art. II.1 van de Staatsregeling van Aruba. De Gouverneur is de plaatsvervanger van de Koning en als zodanig onschendbaar. De Vertegenwoordiger van de Nederlandse Antillen in Nederland heette voortaan Algemene Vertegenwoordiger. ${ }^{7}$ Hij mocht met raadgevende stem deelnemen aan het ministerieel overleg over de aangelegenheden waarbij de Nederlandse Antillen betrokken zijn. Hiermee werd bedoeld de zogenaamde niet-inwendige aangelegenheden (de huidige statutaire Koninkrijksaangelegenheden).

De regeling van eigen aangelegenheden werd volgens art. 63 Grondwet 1948 overgelaten aan organen ter plaatse, tenzij de wetgever een bepaalde regeling aan de Koning had voorbehouden. De bevoegdheid tot ingrijpen van de wetgever was onbeperkt, omdat hetzelfde artikel bepaalde, dat andere onderwerpen door de wet konden worden geregeld zodra de behoefte daaraan bleek te bestaan. In de nieuwe Landsregeling (onderdeel van de Interimregeling) zouden alle inwendige aangelegenheden geregeld worden bij landsverordening (art. II). De conflictenregeling verviel. ${ }^{8}$ In plaats van Curaçao werd nu officieel de naam 'de Nederlandse Antillen' ingevoerd voor dit overzeese deel van het Koninkrijk.'

De Interimregeling was ook van belang voor de eilandelijke autonomie, want krachtens deze regeling zou bij AMvB zelfstandigheid worden verleend aan de eilandgebieden in de vorm van de Eilandenregeling Nederlandse Antillen. Uit de preambule van de Interimregeling blijkt, dat het hier slechts om een tijdelijke maatregel ging. Artikel I bepaalde:

"In afwachting van de vestiging ener nieuwe rechtsorde voor het Koninkrijk bestaande uit Nederland, Suriname en de Nederlandse Antillen, op de grondslag van de uitkomst van het reeds gepleegd en nog te plegen gemeen overleg als bedoeld in het veertiende Hoofdstuk der Grondwet, wordt het bewind in de Nederlandse Antillen gevoerd en worden de betrekkingen tussen Nederland en de Nederlandse Antillen geregeld naar de bepalingen dezer wet."

De gelijke zetelverdeling tussen Aruba en Curaçao had tot protesten van Curaçao geleid, twee verzoekschriften werden in 1949 van Curaçao aan de Koningin verzonden om de gemaakte fout te redresseren. Het tweede rekest was radicaal van toon: of de 8-8 verhouding

\footnotetext{
De Vries, De WIG, 35/36, 1954-1955, pp. 165-173.

Van Helsdingen (1957) p. 83.

Interimregeling, titel D, artikel III, pargraaf 1, PB 1950, 109.
} 
werd gewijzigd óf Curaçao zou zijn eigen weg gaan. De ondertekenaars van het verzoekschrift stond een financiële en economische afscheiding van de Nederlandse Antillen en een directe band met het moederland voor ogen. ${ }^{10}$ Nederland wijzigde toen de zetelverdeling in de Interimregeling in 12-8-1-1 (voor Bonaire en de Bovenwinden), waardoor de Staten, die het wel eens waren met de 8-8 verhouding, zich gepasseerd voelden. De redenen voor de verandering van de zetelverdeling bleken uit de MvT bij de ontwerp-Interimregeling: ${ }^{11}$

"De aandrang tot wijziging van de zetelverhouding vond in 1947 zijn grond in de omstandigheid dat alle belangen van Aruba van uit het centrum werden behartigd. Daardoor voelde Aruba zich afhankelijk van Curaçao. Nu bij de zelfstandigwording van de eilandgebieden de ratio voor de zetelverdeling met een gelijk aantal zetels voor Aruba en Curaçao is komen te vervallen, dient de samenstelling opnieuw te worden overwogen. Door de zelfstandigwording verkrijgen deze eilandgebieden immers de grootst denkbare vrijheid van handelen ten aanzien van eigen lokale aangelegenheden. Deze vrijheid wordt slechts beperkt ten aanzien van die met name te noemen onderwerpen, waarvan ter wille van economische of andere motieven centrale regeling doelmatig is."

De totstandkoming van de Interimregeling werd door Aruba als een zware nederlaag beschouwd. Vooral omdat de Arubaanse aspiraties hierdoor niet konden worden geconcretiseerd. Aruba beschouwde de Interimregeling slechts als een schaduw van autonomie. ${ }^{12}$ De Interimregeling bevatte naast de bepalingen betreffende de regeling van eigen aangelegenheden, slechts provisorisch enige bepalingen over

10 Interimregeling voor de Nederlandse Antillen, Bijlage IV van de Memoric van Toelichting, Algemene Beschouwing van het Statenlid Mr. I.C. Debrot, Kamerstuk 1639 - 7. Debrot laakte de berucht geworden 8-8-2-1-1-1 verhouding en zei: 'Wij stellen vast, dat mocht in het verleden Aruba in verschillende zaken als minderjarige zijn behandeld, dit niet te wijten is aan Curaçao of aan zijn inwoners, maar asn de Staatsregeling en aan de wijze van uitvoering der geldende voorschriften door de ambtenaren.'

11 Memorie van Toelichting, Interimregeling voor de Nederlandse Antillen, Kamerstukken 1639 - 2, 3 met name de artikelsgewijze toelichting bij de paragrafen 70a, 70b en 84, de artikelen 78, 79 en 103a; zie ook stuk $1639-4$, Bijlage I van de MVT, bevattende een toelichting op de kiesdeler bij een zuiver evenredigheidsstelsel; zie ook Witboek (1975) pp. 47-64.

12 Paula (1989) pp. 45 e.v.; zie ook Witboek (1975) pp. 30 e.v. Het is jammer dat de meningen in de Arubaanse Eilandsraad ten tijde van de invoering van de Interimregeling (1950/1951) uiteen liepen. Indien Eman en Yrausquin één lijn hadden getrokken had dat wellicht meer opgeleverd, in de zin van een beter uitgewerkte ERNA met betrekking tot de eilandelijke autonomie. Zeker is dat Nederland toen absoluut geen directe band wilde met één van de eilanden. In ieder geval was de tijd toen nog niet rijp voor een Status Aparte. 
de samenwerking op het gebied van hetgeen in de Interimregeling niet-inwendige aangelegenheden werden genoemd. De definitieve constructie bleef ter regeling voorbehouden an een Statuut.

Eind 1951 bracht minister Van Schaik een bezoek aan Aruba. Doel van dat bezoek was, kennis te nemen van de Arubaanse wensen en verlangens met betrekking tot de Ronde Tafelconferentie. Door de Arubaanse Volkspartij werd de bewindsman een memorandum aangeboden. Onder meer werd daarin gesteld dat Aruba niet geïnteresseerd was in de autonomie van de Nederlandse Antillen of in de vorming van een Koninkrijk nieuwe stijl, tenzij de autonomie van het eiland Aruba ten opzichte van het eiland Curaçao verzekerd zou worden. De wens van het Arubaanse volk was, als zelfstandig volksdeel, onafhankelijk van de Nederlandse Antillen, toe te treden tot het Koninkrijk nieuwe stijl. Indien dit niet kon worden verwezenlijkt, dan zou als minimum de volledige verzelfstandiging van Aruba moeten plaatsvinden, waarna dan Aruba een federatieve overeenkomst zou aangaan met de Nederlandse Antillen. De dan gevormde federatie zou vervolgens vrijwillig toetreden tot het Koninkrijk nieuwe stijl. ${ }^{13}$

In de Interimregeling voor de Nederlandse Antillen was onder de titel “'De Eilandgebieden" een hoofdstuk (V) opgenomen in de Landsregeling, waarin met enkele summiere bepalingen de grondslag werd gelegd voor het eilandelijk zelfbestuur. Dit werd nader uitgewerkt in de Eilandenregeling. Bij Eilandenregeling werd aan de Eilandgebieden zelfstandigheid verleend ten aanzien van de verzorging van eigen aangelegenheden. De Eilandenregeling werd vastgesteld bij Algemene Maatregel van Bestuur. De Kroon had de imperatieve opdracht om voor de Eilandgebieden een 'zelfstandigheid' te creëren met als terrein van werkzaamheden een 'eigen' huishouding. De Staten hadden ook in hun advies over de ontwerp-Interimregeling de nadruk gelegd op het woord 'eigen'. Daardoor zou onomstotelijk vast komen te staan dat het niet ging om decentralisatic, maar om het zelfbeschikkingsrecht van de eilanden. ${ }^{14}$ Van de kant van de Nederlandse Antillen werd een status nagestreefd die veel verder ging dan gemeentelijkeen provinciale autonomie. Gedacht werd aan een onderlinge verbinding op federatieve grondslag in de geest van Van Poelje.

\footnotetext{
13 Paula (1989) p. 46; zie ook Kasteel (1956) pp. 217-228.

$14 \quad$ Kasteel (1956) p. 222.
} 
Door de Nederlandse regering werd in april 1949 een voorontwerp van Algemene Maatregel van Bestuur aan de Staten voorgelegd, betreffende de toekenning van een zekere mate van zelfstandigheid aan de eilanden Aruba en Curaçao. Een en ander had een vertrouwelijk karakter, omdat het nog in het stadium van voorbereiding verkeerde. De voorlegging aan de Staten had alleen de bedoeling een beeld te geven van de wijze waarop de regering zich de toekomstige Eilandenregeling ongeveer had voorgesteld.

De Staten brachten over het voorontwerp een negatief advies uit. Het zou een inbreuk betekenen op de autonomie van de Antillen, ook zou het leiden tot onbestuurbaarheid en ontbinding van het Land. Aruba vreesde in deze constellatie de gewenste zelfstandigheid te moeten ontberen. De Staten vonden de Arubaanse vrees voor benadeling niet terecht. Aruba accepteerde de nederlaag, maar hoopte op het Koninkrijksoverleg. Het herziene (voor)ontwerp werd na het Rapport van de Commissie Plantz en van het Werkbureau Kerstens in 1950 aan de Staten ter advisering aangeboden. Conform de voorstellen van de Aruba-Curaçao Commissie (de Commissie Van Poelje) opende het ontwerp de mogelijkheid een deel van de overheidstaak van de centrale Antilliaanse organen over te dragen aan de eilandsorganen. Als een soort veiligheidsklep voor de gewijzigde 8-8 verhouding wenste met name Aruba een beroepsmogelijkheid tegen de centrale (Antilliaanse) overheid, op een hoger gezag, dit zou een Koninkrijksorgaan moeten zijn, te weten de Kroon. De Kroon zou de status en bevoegdheid van het eiland vaststellen en toezicht uitoefenen op de kwaliteit van de wetgeving. Curaçao en Aruba zouden voortaan hun eigen eilandsverordeningen vaststellen.

De invoering van de Eilandenregeling bij algemene maatregel van bestuur leidde tot vragen bij de parlementaire behandeling. Kamerleden uit beide Kamers uitten hun bezwaren, omdat de Staten-Generaal buiten deze belangrijke wetgeving werden gehouden. $\mathrm{Zij}$ waren van oordeel dat de Eilandenregeling een interne aangelegenheid was van de Nederlandse Antillen en dat vaststelling van de ERNA bij algemene maatregel van bestuur zou kunnen worden gezien als koloniaal optreden. De regering was echter van mening dat deze handelswijze juist was, omdat de Staten en de regering geen bezwaren hadden tegen invoering van de ERNA bij algemene maatregel van bestuur. Ook Aruba wenste dit. Er bestond geen politiek draagvlak in de Antillen om de zelfstandigmaking van de eilanden intern te kunnen 
regelen. ${ }^{15}$

De hoofdbeginselen van de ERNA zijn neergelegd in de Staatsregeling van de Nederlandse Antillen, (de artt. 88-93). ${ }^{16}$ Deze artikelen kunnen slechts gewijzigd worden, nadat de regering van het Koninkrijk haar instemming daarmee heeft betuigd (nu de artt. 44 Statuut en 49 Staatsregeling Nederlandse Antillen). De hoofdpunten uit de ERNA zijn:

1. de ERNA kan worden gewijzigd bij landsverordening overeenkomstig art. 88 Staatsregeling van de Nederlandse Antillen, indien de Staten het ontwerp-landsverordening met goedkeuring van twee derde van het wettelijk aantal zitting hebbende Statenleden hebben aangenomen;

2. de limitatieve opsomming in de artt. 1, 2, en 2A ERNA van de aangelegenheden, die niet tot de zorg van een Eilandgebied behoren;

3. de benoeming en het ontslag van de Gezaghebber door de Koning (art. 91 Staatsregeling Nederlandse Antillen $\mathrm{j}^{\circ}$ art. 63 ERNA);

4. het hoger toezicht van de Koning en de Gouverneur (de artt. 98104 ERNA j $^{\circ}$ art. 92 Staatsregeling Nederlandse Antillen en art. 52 van het latere Statuut);

5. het hoger beroep op de Koning krachtens art. 70 Staatsregeling Nederlandse Antillen en de bevoegdheid van de Kroon om in te grijpen als een eilandgebied onbestuurbaar is geworden of wordt verwaarloosd (art. 93 Staatsregeling Nederlandse Antillen $\mathrm{j}^{\mathrm{o}}$ art. 52 Statuut).

De bedoeling van de ERNA was om de eilanden zelfstandig de eigen zaken te laten regelen. Daarom werd ook een limitatieve opsomming van de bevoegdheden van het centraal gezag opgenomen in de artt. 118-126 Interimregeling (later art. 88 Staatsregeling Nederlandse Antillen, ingevoerd in 1955) en de artt. 1, 2 en 2A ERNA. ${ }^{17} \mathrm{Het}$ omgekeerde gebeurde echter in de praktijk. Op grond van de gekozen overdrachtsmethode van Land naar Eiland, kon de landelijke overheid de bevoegdheid van de eilanden uithollen en regelend optreden op die gebieden. Bestuurlijk toezicht zoals goedkeuring (preventief toezicht) en vernietiging (repressief toezicht) passen niet goed in een 'federa-

\footnotetext{
is Van Helsdingen (1956) pp. 301, 308-311.

16 Artikelen 118-123 oud van de Landsregeling van 1950, zoals opgenomen in de Interimrigeling, Van Helsdingen (1952).

17 Van Helsdingen (1956) p. 288 e.v.
} 
tieve' opbouw, die gebaseerd is op een een limitatieve opsomming van het centraal gezag.

De Nederlandse Antillen streefden tussen 1945 en 1975 naar een meer federatieve structuur. De federatiegedachte is gedeeltelijk uitgewerkt in het Statuut, de Staatsregeling van de Nederlandse Antillen en de Eilandenregeling. De staatsopbouw en staatsinrichting van de Nederlandse Antillen en de ERNA hinkten op twee gedachten. Een aangepaste Gemeentewet regelde het bestuur van de eilanden, met een mager federatief sausje overgoten in de vorm van de artt. 1,2 en 2A ERNA. De staatsinrichting van de Nederlandse Antillen was een kombinatie van federale aspecten en aspecten van de gedecentraliseerde eenheidsstaat, met de nadruk op de gedecentraliseerde eenheidsstaat. Dat lag ook wel voor de hand, omdat de wettenmakers in Nederland geen praktische ervaring hadden met een federaal stelsel. De bestaande Nederlandse regelingen werden aangepast aan het Koninkrijk overzee.

Bij gedecentraliseerde eenheidsstaten (zoals Nederland) heeft men, anders dan in federale stelsels, nooit het oordeel over de doelmatigheid van het bestuur in lokale aangelegenheden principieel aan het hoger gezag willen onttrekken. In Nederland kan de gemeentelijke huishouding op grond van doelmatigheidsoverwegingen door de centrale overheid worden uitgehold als deze regelend optreedt ten behoeve van de gemeenten. Gemeenten hebben de bevoegdheid hun eigen huishouding te regelen, tenzij een hogere overheid daarin voorziet. Tijdens de behandeling van de Interimregeling en van de Eilandenregeling in de Eerste Kamer van de Staten-Generaal sprak minister Van Schaik de gedenkwaardige woorden: 'Wanneer men dit wetsontwerp aanneemt, zal naar mijn mening voor deze gebiedsdelen een gelukkige toekomst aanbreken. ${ }^{18}$ De minister doelde hiermede op de verhouding tussen de eilanden. Zijn woorden zijn echter niet uitgekomen. ${ }^{19}$

De Eilandenregeling ${ }^{20}$ creëerde vier eilandgebieden: Aruba, Bonaire, Curaçao en de Bovenwinden, in tegenstelling tot het voorontwerp dat de instelling van Eilandgebieden wilde beperken tot de twee grootste eilanden. In verband met de overgang van de bestaande oude centralistische structuur naar de nieuwe sterk gedecentraliseerde opzet, moesten veel bevoegdheden aan de eilandgebieden worden

Citaat ontleend aan: Van Helsdingen (1956) p. 314.

Paula (1989) pp. 47-49; Van Helsdingen (1957) pp. 67-95; Luiten (1983) pp. 34 e.v. Eilandenregeling Nederlandse Antillen, tekst van de Algemene Maatregel van Bestuur van 3 maart 1951 (PB 39), zoals deze luidt na de wijzigingen daarin aangebracht bij verschillende landsverordeningen, laatstelijk gewijzigd bij PB 1987, 126, in: $\mathrm{De}$ Rechtsorde (1986). 
overgedragen. De kosten van de decentralisatie bleken echter hoog te zijn en de eilanden beschikten over onvoldoende kader om de overgedragen taken te vervullen. Ook naar de Arubaanse kant bood art. 2 van de ERNA niet die pacificatie die ervan verwacht werd. Eman bleef de wens vertolken van 'separación' bij de definitieve regeling van de rechtsorde van het Koninkrijk. In afwachting van de totstandkoming van die nieuwe rechtsorde werd van Arubaanse zijde aangedrongen op art. 100 van de Interimregeling:

"Indien de belangen der eilandgebieden dit zouden blijken te vorderen, worden bij algemene maatregel van bestuur regelen gesteld omtrent de gevallen waarin, desverzocht, de vaststelling van een door de Staten goedgekeurde ontwerp-landsverordening niet zal geschieden dan na goedkeuring van een in die algemene maatregel aan te wijzen instantie."

Op grond van de Interimregeling en van de ERNA kan niet gesproken worden van een federatief stelsel. ${ }^{21}$ In de ERNA zijn de bevoegdheden van de centrale regering weliswaar limitatief opgesomd, hetgeen als kenmerk wordt gezien van een federale structuur. Anderzijds wordt, zoals in de gedecentraliseerde eenheidsstaat, de organisatie van de Eilandgebieden centraal geregeld. De Eilandgebieden missen de bevoegdheid voor zichzelf een constitutie te maken. Goedkeuring en vernietiging van regelgeving en bestuurlijke maatregelen door een hoger orgaan, medebewind en het ontbreken van een rechterlijk toet-

21 Een bondsstaat of federatie is een vereniging van onathankelijke deelstaten met een overkoepelend orgaan, zoals in de VS. Naast de 50 deelstaten is er ook nog het federale orgaan, belast met het overkoepelend staatsgezag. Met de Commonwealth of Nations (Groot-Brittanië) wordt meer een statenbond bedoeld met een gemeenschappelijke vorst of vorstin, die buiten het eigen land vertegenwoordigd wordt door een Gouverneur-Generaal of een Gouverneur. Dit is bijvoorbeeld het geval in Australië, Canada en Nieuw-Zeeland, deze landen zijn lid van het Britse Commonwealth. Ook republieken (veelal voormalige koloniēn) maken deel uit van het Britse Commonwealth. De staatkundige inrichting van het Koninkrijk der Nederlanden, heeft dus met het Statuut, de Staatsregeling van de Nederlandse Antillen, de Eilandenregeling en de Staatsregeling van Aruba, zowel kenmerken van een federatie, als van een Commonwealth. De basis van de Eilandenregeling is de aangepaste Nederlandse Gemeentewet. Derhalve is het begrijpelijk, dat deze staatsvorm als 'sui generis', eigensoortig wordt aangemerkt. De federatie gedachte is uitgewerkt in het Rapport Staal (1922), het Rapport van de Commmissie Oppenheim (1942) en in het rapport van de Commissie Van Poelje (1948). Het rapport van de Commissie Oppenheim (1942) lijkt veel op de latere Nederlands-Antilliaanse Staatsregeling, maar is niet zo federaal van opzet. Het Statuut voorziet niet in eigen organen voor het Koninkrijk als zodanig. Als Koninkrijksorgaan fungeren de Nederlandse regering en het Nederlandse parlement aangevuld met Antilliaanse of Arubaanse inbreng. Nederland, de Nederlandse Antillen en Aruba zijn de drie Landen binnen het Koninkrijk. De term Koninkrijk slaat dus op het geheel, Van Haersolte (1988) pp. 156-158. 
singsrecht vertonen meer verwantschap met de structuur van een gedecentraliseerde eenheidsstaat. ${ }^{22}$

De verschillen tussen de door de Eilandenregeling geschetste orde, waarin aan de Eilandsraden de zorg voor tal van onderwerpen was toebedacht en de bij de inwerkingtreding daarvan feitelijke situatie waren erg groot. Op Curaçao ontbrak een vorm van lokaal bestuur volledig. Op de andere eilanden leidden de Raden van Politie slechts een marginaal en bloedeloos bestaan. Over de vraag hoe bevoegdheden van het Land naar de Eilandgebieden zouden moeten worden overgeheveld bestonden uiteenlopende opvattingen. De Staten stelden zich op het standpunt dat met de inwerkingtreding van de Eilandenregeling, automatisch alle bevoegdheden bij de eilandelijke organen zouden komen te liggen. Aldus zou een slepende overdracht worden voorkomen en zouden de eilanden onmiddellijk in het volle genot van hun rechten komen.

Dit voorstel werd bestreden zowel door de minister als door de Commissie Plantz en het Werkbureau Kerstens. De overgang naar de nieuwe situatie zou zeer veel juridische en administratieve arbeid eisen. Gedacht zou kunnen worden aan het opsplitsen van de begroting in vijf aparte begrotingen, een toetsing van de gehele wetgeving aan de nieuwe bevoegdheidsafbakening en de splitsing van het ambtenarencorps met alle gevolgen voor hun rechtspositie. Een automatische overgang van bevoegdheden zou tot een volledige chaos moeten leiden. Als alternatief stelden de Commissie Plantz en het Werkbureau Kerstens voor een algehele en gelijktijdige overdracht van bevoegdheden na een bepaalde voorbereidingstijd. Een overdracht aan het begin van een nieuw begrotingsjaar zou dan de minste complicaties geven.

Aangezien de werkzaamheden ter voorbereiding van de overdracht nogal omvangrijk waren, dacht men niet dat dit voor 1952 voltooid zou kunnen zijn. Tegen dit alternatief had de minister bezwaren, omdat het tot gevolg had dat de nieuwe aantredende eilandsraadleden vooralsnog geen zinvolle taak zouden hebben. Voorts was een ernstig bezwaar dat de gehele overdracht zou moeten wachten tot het laatste probleem rond de overdracht zou zijn opgelost. Indien er maar over slechts één kwestie een verschil van mening zou ontstaan, dan zou dat tot vertraging van de gehele overdracht leiden. Vandaar dat besloten werd de overdracht te regelen op de wijze die thans is vastgelegd in Overgangsbepaling $V$ van de Eilandenregeling: 
"1 Bij of krachtens landsverordening wordt het tijdstip bepaald, waarop onderwerpen, ingevolge de artikelen 1 en 2 van de Eilandenregeling tot de zorg van de eilandgebieden behorende, aan deze worden overgedragen, en wordt voor zoveel nodig bepaald, door welke eilandsorganen de bevoegdheden, in wettelijke regelingen betreffende de vorenbedoelde onderwerpen aan landsorganen toegekend, zullen worden uitgeoefend." 23

En zo is de overdracht geregeld op een wijze waarvoor de Staten zo bevreesd waren, beetje bij beetje. Deze overgangsbepaling heeft diep ingrijpende gevolgen gehad voor de verdeling van bevoegdheden tussen Land en Eilandgebieden. Allereerst was het te verwachten gevolg dat de overdracht, nu een tijdslimiet ontbrak, betrekkelijk langzaam zou gaan verlopen. Een veel ernstiger gevolg was dat het gehele systeem van bevoegdheidsverdeling op zijn kop werd gezet. In een afbakening waarin de bevoegdheden van het Land limitatief zijn opgesomd, zou het vrije initiatief komen te liggen bij de eilandgebieden. Men mag regelend optreden ten aanzien van elk onderwerp dat niet expliciet is voorbehouden aan het Land. Door de gekozen overdrachtsmethode hebben de eilanden dat vrije initiatief nooit gekregen. Sinds de eerste overdracht in 1951 van het departement voor Openbare Werken zijn 19 Overdrachtslandsverordeningen tot stand gekomen.

Maar nog steeds zijn niet alle voor overdracht vatbare bevoegdheden aan de eilandgebieden overgedragen. ${ }^{24}$ Gorsira merkte hierover op, dat ook de hoofden van dienst en de betrokken leden van het College van Algemeen Bestuur grote problemen met de overdracht hadden, omdat zij zo hun invloed op de diensten zouden kwijt raken. ${ }^{25}$ Voor een beter begrip wordt in het volgende de ERNA in haar huidige vorm kort besproken. Inhoudelijk is er weinig veranderd aan de ERNA. De hierboven omschreven problematiek speelt nog steeds een rol. De ERNA krijgt de nodige aandacht, omdat deze

Artikel V. 1. Overgangsbepalingenvan de Eilandenregeling, 3 maart 1951 (PB 1951, 39) zoals laatstelijk gewijzigd bij PB 1986, 10, in: De Rechtsorde (1986).

24 Kasteel (1956) p. 251; Luiten (1983) pp. 268-282. Schrage (1968) pp. 8 e.v., gaat in op het intrigerende probleem van de overdrachtsbelasting in het algemeen en met betrekking tot de publieke verkoop van roerende goederen, die van landsverordening, eilandsverordening werd ex Overgangsbepaling III. Bij de herverdelingvan het belastinggebied tussen het Land en de eilandgebieden in 1956 werd een nieuw artikel 2a in de ERNA ingevoegd (PB 1956, 113), dat bepaalde dat de bovengenoemdebelasting weer landsaangelegenhedenwerden. De toen bestaande eilandsverordeningenhielden op te bestaan. Schrage meent dat de Staten nu opnieuw, de betreffende landsverordeningen moeten vaststellen en niet terug kunnen grijpen op 'niet geldige' landsverordeningen.

2s Gorsira (1988) pp. 56 e.v.; zie voor een saillant voorbeeld Van Helsdingen (1963) p. 164. 
Sinds de invoering van de Interimregeling bestond er naast Aruba, Curaçao en Bonaire één Eilandgebied: de Bovenwinden, bestaande uit het Nederlands deel van Sint Maarten, Saba en Sint Eustatius. De Gezaghebber van dit Eilandgebied zetelde op Sint Maarten en werd op de andere twee eilanden vertegenwoordigd door een administrateur. De Eilandsraad van de Bovenwindse Eilanden bestond uit drie per eiland gekozen afdelingen (vijf leden voor elk eiland) ${ }^{26}$ Het Land de Nederlandse Antillen omvat sinds 1983 vijf autonome gemeenschappen of lichamen, die de naam Eilandgebied dragen. Artikel 1 van de Antilliaanse Staatsregeling noemt $z e$ in alfabetische volgorde: Bonaire, Curaçao, Saba, Sint Eustatius en Sint Maarten. Zoals de organisatie van de Nederlandse provincies geregeld is in de Grondwet en de Provinciewet, zo is de organisatie van de Eilandgebieden geregeld in de Staatsregeling van de Nederlandse Antillen en in de Eilandenregeling. De ERNA kan beschouwd worden als een onderdeel van de Nederlands-Antilliaanse constitutie. De tekst van de huidige Staatsregeling gaat grotendeels terug op hetgeen de wetgever destijds bij de Interimregeling heeft vastgesteld. Zo is de huidige ERNA oorspronkelijk vastgesteld bij een algemene maatregel van bestuur uit de interim periode.

Op grond van art. 3 ERNA bestaat het bestuur van een Eilandgebied uit de Eilandsraad, het Bestuurscollege en de Gezaghebber. Men kan deze organen vergelijken met Provinciale Staten, Gedeputeerde Staten en de Commissaris van de Koningin. De Eilandsraad wordt gekozen door de bevolking. De Gezaghebber wordt door de Kroon benoemd. Met de Gedupeerden uit de Eilandsraad vormt hij het Bestuurscollege. Wat de bevoegdheden betreft, is de positie van het Eilandgebied veel zwaarder gewaarborgd dan die van een Nederlandse provincie. Volgens art. 88 Staatsregeling Nederlandse Antillen strekt de overheidstaak van de Eilandgebieden zich namelijk ook uit tot alle onderwerpen die niet bij Statuut, Staatsregeling of Eilandenregeling aan een hoger gezag zijn voorbehouden. De Eilandgebieden doen in bepaalde opzichte denken aan 'deelstaten'. Ze bezitten echter geen eigen staatsregelingen en er is ook geen senaat van vertegenwoordigers van hun besturen. De Eilandgebieden vallen geografisch samen met de kieskringen voor de verkiezing van de Staten, de bevolking van deze 
kieskringen treedt rechtstreeks als kiezerskorps op. ${ }^{27}$

Conform art. 5 van de ERNA bestaat de Eilandsraad van Curaçao uit 21 leden, de Eilandsraad van Bonaire bestaat uit 9 leden, die van Sint Maarten uit 9 leden en de Eilandsraad van Saba en Sint Eustatius elk uit 5 leden (art. 106). De Eilandsraden worden om de vier jaar verkozen door middel van algemeen kiesrecht door de ingezetenen van het Eilandgebied, die de Nederlandse nationaliteit hebben (art. 6ERNA). De mogelijkheid van vervroegde verkiezingen en voortijdige ontbinding is niet aanwezig. De Eilandsraad heeft alle bevoegdheden met betrekking tot regeling en bestuur van de eigen aangelegenheden, voor zover deze niet expliciet aan de Gezaghebber of het Bestuurscollege zijn opgedragen. De bevoegdheid tot regeling wordt door de Raad uitgeoefend door middel van het maken van eilandsverordeningen (de artt. $79 \mathrm{t} / \mathrm{m} \mathrm{85}$ ).

Evenals de Gouverneur en de Statenleden, genieten ook de Eilandsraadleden en de Gezaghebber parlementaire onschendbaarheid (art. 39 en art. 55). Dit houdt in dat zij niet gerechtelijk vervolgbaar zijn voor hetgeen zij in de vergadering zeggen of aldaar overleggen. Evenals bij de Staten is voor het houden van een rechtsgeldige vergadering van de Eilandsraad nodig, dat meer dan de helft van het aantal zitting hebbende leden aanwezig is (quorum). Toch verschillen Staatsregeling en Eilandenregeling met betrekking tot het voorschrift van het quorum in een bepaald opzicht. De Staten mogen onder geen enkele omstandigheid beraadslagen noch besluiten, indien er geen quorum aanwezig is. Is echter bij de Eilandsraad in de eerste vergadering het vereiste aantal leden niet opgekomen, dan wordt een nieuwe vergadering belegd. Wanneer ook op deze vergadering geen quorum aanwezig is, dan roept de Voorzitter een derde vergadering op. Ontbreekt op deze vergadering wederom het vereiste aantal leden, dan kan de vergadering gehouden worden ongeacht het aantal opgekomen leden en zijn de daarin genomen besluiten rechtsgeldig (art. 41).

Het lidmaatschap van de Eilandsraad is onverenigbaar met een aantal in de ERNA genoemde betrekkingen, functies en handelingen (de artt. 12 en 13). Zodra een Raadslid een der onverenigbare functies gaat bekleden, houdt hij op lid van de Raad te zijn en geeft hij hiervan terstond kennis aan de Raad. Doet hij dit niet, dan kan de Raad beslissen dat hij opgehouden heeft lid van de Raad te zijn. Tegen dit besluit kan het Raadslid in beroep gaan bij het Gemeenschappelijk Hof van Justitie van de Nederlandse Antillen en Aruba 
(art. 14) ${ }^{28}$ Op de Nederlandse Antillen hebben Eilandsraadleden nog wel eens problemen om de incompatibiliteiten met betrekking tot familierelaties serieus te nemen. Die situatie heeft aanleiding gegeven tot een aantal interessante rechterlijke uitspraken, evenals de verhouding bestuur en volksvertegenwoordiging en de verkiezingsprocedure. $^{29}$

Bovendien is de positie van de Gouverneur in deze van belang, gezien zijn bevoegdheden met betrekking tot het repressieve toezicht.

Indien een Raadslid een verboden handeling verricht, kan hij door de Eilandsraad worden geschorst. Na onderzoek kan hij door de Gouverneur van zijn lidmaatschap vervallen worden verklaard. Tegen dit besluit kan hij in beroep gaan bij de Koning(in) (art. 15). Een lid van de Eilandsraad mag tevens het lidmaatschap van de Staten bekleden. Wordt dit lid echter benoemd tot Gedeputeerde, dan moet hij het Statenlidmaatschap neerleggen (art. $50 \mathrm{j}^{\circ}$ art. 67). Evenals de gekozen Statenleden moeten ook degenen die tot lid van de Eilandsraad zijn gekozen om te worden toegelaten, hun geloofsbrieven ter goedkeuring overleggen. Anders dan de Staatsregeling schrijft de ERNA een termijn voor binnen welke de geloofsbrieven door de Raad moeten worden onderzocht. Deze termijn is gesteld op dertig dagen na de dag der indiening, wanneer het betreft wegens periodieke (dus na een verkiezing) aftreding inkomende leden en op vijftien dagen na de dag van de indiening, wanneer het betreft tussentijds inkomende leden (art. 18). Wanneer nu deze termijnen verstreken zijn, zonder dat over de toelating een beslissing is genomen, dan beslist het Gemeenschappelijk Hof van Justitie van de Nederlandse Antillen en Aruba daarover. Het Hof doet uitspraak binnen één maand, nadat de

Tot 1 januari 1986 heelte het Gemeenschappelijk Hof: Hof van Justitie van de Nederlandse Antillen. Door het verkrijgen van de Status Aparte binnen het Koninkrijk door Aruba per 1 januari 1986, moest de naam gewijzigd worden.

GEA/Curaçao 22 augustus 1960 (Rosario vs Curaça); HvJ 23 augustus 1960 (De Haseth vs Rosario); HvJ 21 januari 1961 (Rosario vs Eilandsraad Curaçao); HvJ 27 juni 1961 (Rosario vs Curaçao); GEA/St. Maarten 24 oktober 1972 (Johnson vs Bovenwinden); GEA/Curaçao 9 oktober 1977 (bijeenroepen niet beëdigde Staten, Wilson Godell vs Nederlandse Antillen); GEA Curaçao 20 december 1985, Eilandgebied Bonaire vs Nederlandse Antillen, Begrotingen; GHvJ 5 februari 1986, Geloofsbrieven, beschikking; GHvJ 22 december 1986, Hooi/Albert vs Hoofd stembureau, ondersteuning kandidatenlijsten; HvJ 15 oktober 1985, vonnisnr. 311 (Immuniteit in Eilandsraad); GHvJ 5 februari 1986 (Geloofsbrieven); GHvJ 22 april 1986 (Geheime verkiezingen en adhesieprocedure I); GHvJ 20 januari 1987 (Vrij mandaat D); GHvJ 4 oktober 1988 (Uitlatingen Godett); GHvJ 25 oktober 1988 (Notulen Staten); HR 18 november 1988 (Vrij mandaat II): GHvJ 19 oktober 1990 (Jopie Abraham); GEA/NA Curaçao 17 december 1990 (Geheime verkiezingen en adhesieprocedure II). 
stukken ter griftie zijn ontvangen (art. 19). Ook wanneer door de Raad iemands geloofsbrief om de een of andere reden niet is goedgekeurd en hij dus niet als Raadslid wordt toegelaten, kan de niet toegelatene (maar ook elk lid en de Gezaghebber) bij het Hof tegen deze beslissing in beroep komen (art. 19). Vór het aanvaarden van hun betrekking leggen de leden van de Eilandsraad in handen van de voorzitter van de Raad (de Gezaghebber) de eed van trouw af (art. 22).

Bij Eilandsverordening wordt de wijze van verkiezing van de leden van de Eilandsraad, de vaststelling de uitslag der verkiezing en de wijze van inzending der geloofsbrieven aan de Raad geregeld. ${ }^{30}$ De Eilandsraad maakt de Eilandsverordeningen, die hij nodig acht in het belang van het eilandgebied (autonomie) (art. 24). De Gezaghebber zit de Eilandsraad voor en heeft daarin adviserende stem (art 69). Hij is echter geen lid van de Raad. De Eilandsraad wordt in zijn werkzaambeden bijgestaan door de secretaris van het Eilandgebied. De secretaris is voor een groot deel van zijn taak ondergeschikt aan de Eilandsraad. Daarom is benoeming, schorsing en ontslag van de secretaris, niet zoals te doen gebruikelijk bij eilandsambtenaren, in handen gelegd van het Bestuuurscollege (art. 60), maar van de Eilandsraad zelf (art. 25).

De Gezaghebber wordt door de Koning benoemd voor de tijd van zes jaren (art. 63). Hij is voorzitter van de Eilandsraad, voorzitter en tevens lid van het Bestuurscollege (art. 47). Voorts werkt hij mee aan de uitvoering van de taak van de Gouverneur als orgaan van het Koninkrijk en volgt daarbij diens aanwijzingen op (art. 67). Ook heeft hij een functie in het kader van het hoger toezicht. Eilandsverordeningen, Eilandsbesluiten houdende algemene maatregelen (b.a.m.) en beschikkingen van eilandsorganen dienen steeds door hem te worden onderzocht op strijdigheid met Rijkswetten, Algemene Maatregelen van Rijksbestuur, met internationale overeenkomsten, en met het algemeen belang van het Koninkrijk (artt. $98 \mathrm{t} / \mathrm{m} \mathrm{104}$ ). Tevens staat hij de Gouverneur bij als orgaan van het Land. Zo moet hij meewerken aan de uitvoering van Landsverordeningen en Landsbesluiten h.a.m., indien daarin de Gezaghebber als uitvoerend orgaan wordt aangewezen (art 67). Hij draagt zorg voor de uitvoering van wettelijke regelingen, indien het Bestuurscollege daarin niet voorziet

30 Voor de Nederlandse Antillen is dat het Kiesreglement Staten en Eilandsraden. Landsverordening van de lste marn 1973, houdende bepalingen betreffende hel kiesrecht en de verkiezingen van de Staten van de Nederlandse Antillen en van de leden van de Eilandsraad, PB, 1973, 27, zoals gewijzigd bij Landsverordening van de Iste april 1977, PB 1977, 91. Voor Aruba is dat de Landsverordening van 3 november 1987, AB 1987, 110 , de zogenaamde Kiesverordening. 
(art. 68). Hij is belast met taken in het hoger toezicht van het Land op het Eilandgebied (art. 68) en hij is plaatselijk hoofd van de politie (art.73). ${ }^{31}$

De Gedeputeerden worden door de Eilandsraad verkozen. De Gedeputeerden behoeven geen lid te zijn van de Eilandsraad (art. 47). Wel schrijft de Eilandenregeling voor dat tenminste de helft van het aantal Gedeputeerden door de Raad uit zijn midden wordt gekozen (art. 47). Uitgangspunt is dat de Gedeputeerden voor de gehele duur van de zittingsperiode van de Eilandsraad worden verkozen. De leden van het Bestuurscollege dragen een collectieve verantwoordelijkheid voor het gevoerde bestuur jegens de Eilandsraad. Indien een Gedeputeerde niet meer het vertrouwen van de Raad geniet, kan hij door de Raad van zijn functie vervallen worden verklaard. Deze vervallen verklaring kan slechts worden uitgesproken door de Raad, nadat de procedure gevoerd is, zoals omschreven in art. 50a ERNA.

Het Bestuurscollege houdt zich op de eerste plaats bezig met het dagelijks bestuur van het Eilandgebied (art 57). Voorts heeft het Bestuurscollege een taak als medebewindsorgaan van het Land (art. 68). Wetgeving wordt bij eilandsverordening (artt. $24 \mathrm{j}^{\circ}$ art. $79 \mathrm{t} / \mathrm{m} \mathrm{85}$ ) of eilandsbesluit houdende algemene maatregelen (h.a.m.) vastgesteld, beschikkingen bij eilandsbesluit (art. 57). Art. 62 ERNA spreekt over de politieke verantwoordelijkheid van het Bestuurscollege voor diens daden jegens de Eilandsraad. De Gezaghebber, handelend als lid van het Bestuurscollege, deelt volledig in deze verantwoordingsplicht, al kan deze verantwoordingsplicht niet tot gevolg hebben, dat hij door een uitspraak van de Eilandsraad van zijn functie vervallen wordt verklaard. Een bepaling analoog aan art. 62 ontbreekt in het derde hoofdstuk van de Eilandenregeling over de Gezaghebber. Daaruit zou kunnen worden afgeleid, dat de Gezaghebber geen verantwoording verschuldigd is aan de Eilandsraad, indien hij een zelfstandige bevoegdheid uitoefent, dus niet als lid van het Bestuurscollege. Deze opvatting kan echter niet worden aanvaard in een democratisch stelsel. De Gezaghebber dient desgevraagd de Eilandsraad te informeren over de door hem genomen beslissingen en de motieven die hem tot die beslissingen hebben gebracht. Indien de Raad niet van de juistheid van het gevoerde beleid overtuigd is, kan dat echter ook hier niet

31 Zie voor deze taken eveneens het Reglement voor de Gouvemeur van de Nederlandse Antillen, Stb. 1985, 674; PB 1986, 30, de art. 23 en $24 \mathrm{j}^{\circ}$ de artt. 92 Staatsregeling Nederlands Antillen en 52 Statuut; zie ook het Reglement voor de Gouverneur van Aruba, Stb. 1985; 671, AB 1986, 3, zoals gewijzigd bij Rijkswet van 18 december 1985, Stb. 672, AB. 1986, 5. Eerder genoemde artikelen zijn van toepassing behalve art. 92 Staatsregeling Nederlandse Antillen, in: De Rechtsorde (1986).

Eilandenregeling (ERNA, 1951).263 
leiden tot het hanteren van machtsmiddelen van de kant van de Raad. Voor zover de Gezaghebber gehandeld heeft volgens instructies van hoger gezag, kan hij daarop niet door de Eilandsraad worden aangesproken. Politieke controle op die instructies dient plaats te vinden op het niveau waarop die instructies zijn gegeven. ${ }^{32}$

Opgemerkt kan worden dat het bestuurlijk toezicht een doorbreking vormt van de zelfstandigheid van de Eilandgebieden. Wat ook ontbreekt is een bewaking van de verdeling van competenties tussen Land en Eilanden door de onafhankelijke rechter. De beantwoording van de vraag of een daad van formele wetgeving de in de Staatsregeling afgesproken en in de ERNA neergelegde verdeling van bevoegdheden respecteert is uitsluitend voorbehouden aan de landswetgever. De Antilliaanse rechter acht zich onbevoegd landsverordeningen te toetsen aan de Staatsregeling. ${ }^{33}$

\subsubsection{De ERNA: geen zelfstandigheid voor de eilanden}

De ERNA bracht voor Aruba geen eigen status los van Curaçao en rechtstreeks onder de Kroon en ook geen zelfstandigheid binnen een federatie zoals door Van Poelje voorgesteld, maar het eiland werd een rechtslichaam van lagere orde binnen een eenheidsstaat, te vergelijken met een Nederlandse gemeente. De visie van Yrausquin bleek de juiste: de Interimregeling had verworpen moeten worden door de Staten van de Nederlandse Antillen. Eerst had de zelfstandigheid van de eilanden geregeld moeten worden. Het vertrouwen van Eman in de Kroon bleek ongefundeerd. De hoofdrol in de afscheidingsbeweging ging vervolgens over van de Staten van de Nederlandse Antillen naar de Eilandsraad van Aruba. Op 15 januari 1952 nam de Eilandsraad van Aruba een motie aan waarin wederom de wens tot afscheiding van Curaçao naar voren wordt gebracht. Opnieuw noemde de Nederlandse regering het argument in strijd met de Grondwet. De minister van Overzeese Gebiedsdelen Kernkamp merkte op dat de Grondwet geen andere uitleg toeliet dan dat het Koninkrijk zal bestaan uit drie rijksdelen, Nederland, Suriname en de Nederlandse Antillen. Was eenmaal het Statuut tot stand gekomen dan zou de regering bij de eerstvolgende Grondwetsherziening het voorstel doen het XIV Hoofdstuk van de Grondwet te laten vervallen,

$32 \quad$ Luiten (1983) pp. 271-280; Braam (1988); Van Helsdingen (1983); De Rechtsorde (1986).

33 Van Rijn, Naar een constitutioneel toetsingsrecht voor de Nederlandse Antillen? (1991); Luiten, Teleurgestelde verwachtingen (1981). 
zodat dan de wettelijke belemmering voor een eventuele andere Koninkrijksvorm zou zijn opgeheven. De minister voegde daar nog aan toe dat als de belemmering zou zijn opgeheven dat niet betekende, dat Aruba alsnog zich kon afscheiden van de Nederlandse Antillen. De Nederlandse regering had daartegen overwegende bezwaren. Mocht echter Aruba na de inwerkingtreding van de ERNA alsnog een status buiten de Nederlandse Antillen wensen dan kon dit via het Statuut worden verwezenlijkt. ${ }^{34}$

Van Helsdingen merkte in 1954 op dat de ERNA, drie jaren na de inwerkingtreding, wel het een en ander verbeterd had op het gebied van de overdracht van taken van de centrale regering naar de eilanden, de scheiding van het belastinggebied en de personeelspolitiek. Bij zorgvuldige lezing achtte hij het beeld echter niet positief. ${ }^{35} \mathrm{De}$ oorspronkelijke bedoeling van de ERNA was dat alleen Aruba en Curaçao autonomie zouden verwerven en dat de kleinere eilanden dat niet zouden krijgen. ${ }^{36} \mathrm{Hij}$ meende dat het bedoelde voorontwerp gesneuveld was als gevolg van de overmatige invloed die de kleine eilanden in 1949 in de Staten hadden. ${ }^{37}$

De ERNA was volgens Bongenaar ${ }^{38}$ vooral opgezet als een instrument om tussen de rivaliserende eilanden Aruba en Curaçao een evenwicht te bereiken, met name om aan Aruba binnen de toen bestaande verhoudingen zoveel mogelijk interne autonomie te geven. Hij achtte de ERNA onevenwichtig van structuur en vindt het niet juist dat alle eilanden dezelfde bestuursvorm hadden gekregen in de ERNA. De Commissie Oppenheim met het ontwerp Eilandenreglement van 1944 en de Commissie Van Poelje met het ontwerp Landsgrondwet van 1948 gingen in die gelijkwaardigheid nog verder. Die uniformerende tendens was echter wel voor de hand liggend omdat bovengenoemde regelingen alle min of meer waren afgeleid van de Nederlandse Gemeentewet, die in beginsel voor alle gemeenten in Nederland, groot of klein van toepassing was.

Bongenaar meende dat als de ERNA loyaal was uitgevoerd volgens de beoogde doeleinden, er geen ideale, maar wel een werkbare situatie was ontstaan. Hij deelde de mening van Luiten dat de overdracht van de voorziene landsbevoegdheden naar de eilanden niet

\footnotetext{
34 Witboek (1975) pp. 33-36.

35 Van Helsdingen, De WIG, 35, 1954, pp. 72-90; zie ook Van Helsdingen, De WIG, 32, 1951, pp. 193-205; Van Helsdingen, WIG, 32, 1951, pp. 193-205; Van Helsdingen (1955) pp. $124 \mathrm{e.v}$.

36 Van Helsdingen (1957) p. 83.

37 Van Heldsingen (1963) pp. 22 e.v.

38 Bongenaar (1989) pp. 1-42, met name pp. 2-5.
} 
met voldoende spoed en loyaliteit door de Landsregering en ambtenaren was voorbereid en uitgevoerd. ${ }^{39}$

Ook voor de kleine eilanden bracht de ERNA geen gelijkwaardigheid. Aan die gelijkwaardigheid werd afbreuk gedaan door beperking van de financiële armslag. Artikel 110 ERNA ging hierin het verste, door te eisen dat de jaarlijkse begroting van de eilandgebieden aan goedkeuring bij landsverordening was onderworpen, tenzij de begroting geen nadelig saldo vertoonde. Tot op heden kampen Bonaire, Saba en Sint Eustatius altijd met een nadelig saldo. Ondanks de ook aanwezige positieve geluiden over de ERNA gingen er ook stemmen op om de kleine eilanden in te delen bij Aruba en Curaçao.

Het Statenlid Morkos achtte de regeling van art. 110 ERNA verwarrend. Hij noemde in 1953 die regeling: 'un cos sin pia y sin cabez' (een zaak zonder kop of staart) en hij stelde voor om aan alle eilandbesturen het volle vertrouwen te schenken met betrekking tot de tekorten op de jaarlijkse begroting, ofwel de ERNA te wijzigen en de eilandelijke begrotingen in de landsbegroting op te nemen. De kleine eilanden zouden dan onderdelen moeten worden van Aruba en Curaçao of pleegkinderen van de Antilliaanse Regeringsraad.

Ook decentralisatie ${ }^{40}$ van wetgevende en bestuurlijke taken naar de kleine eilanden was een probleem, omdat er een groot gebrek aan kader bestond. In het Rapport Dip $^{41}$ kan men nalezen tot welke consequentie de Bonairiaanse autonomie inzake de wetgeving met betrekking tot het haven-en loodswezen heeft geleid. Op Bonaire waren de schulden van het Eilandgebied in 1971 zo hoog opgelopen bij het hospitaal, de benzinepompen en de bouwmaterialenleverancier, dat gedreigd werd verdere dienstverlening te staken. Op Sint Maarten was men in de jaren zestig volstrekt onmachtig gebleken om een deugdelijke grondpolitiek te voeren. De Staten konden niets anders doen dan machteloze waarschuwingen uiten, die niet verhinderden dat het Bestuurscollege gronden occupeerde die aan anderen toebehoorden, al was niet duidelijk, bij gebrek aan deugdelijke openbare

Luiten (1981).

4. Voor een uitgebreide toelichting op het begrip decentralisatie en de Antilliaanse decentralisatiegeschiedenis, zie Van Peet (1984); hij geeft onder andere als advies ter verbetering van de decentralisatie: sterkere druk vanuit Nederland, andere decentralisatiewetgeving en meer financiële middelen (p. 108).

$4 \quad$ Rapport Dip (1984) pp. 29 e.v. De ontoereikende wetgeving kwam aan het licht bij de Soponata-affaire op Bonaire. Het ging hier om de aansprakelijkheid van het Eilandgebied Bonaire voor schade veroorzaakt door onjuist handelen van een loods. HR 7 mast 1986, NJ 1987, 266; zie ook Bongenaar (1983) pp. 1, 16 en 22-25, m.n. p. 17 en noot 85 op p. 31 , vervolg: (1983) pp. $49-84$, m.n. pp. 75 e.v.; van dezelfde auteur de noot onder het vonnis van het HvJ in het TAR april 1984, pp. 102 e.v. 
registers, aan welke anderen. Ook had tegelijkertijd een grootscheepse uitverkoop van grond aan vreemdelingen plaats.

Duidelijk is dat politieke autonomie niet kan functioneren zonder economische en administratieve autonomie. Dat betekent dat een eilandelijke bestuurslaag veel geld kost. Ook een zekere politieke rijpheid is nodig en daarin zijn Aruba en Curaçao beter geslaagd dan de kleine eilanden, er bestaat daar een redelijk niveau van wetgeving en bestuur. ${ }^{42}$

Door de in de Staatsregeling vastgestelde zetelverdeling konden de kleine eilanden in de Staten een grote invloed uitoefenen. Na de Status Aparte van Aruba werd de zetelverhouding in de Staten ex art. 44 Staatsregeling Nederlandse Antillen: Curaçao 14, Bonaire drie, Saba en Sint Eustatius elk 1 lid en Sint Maarten drie leden. Omdat Aruba en Curaçao onderling zo verdeeld waren hadden zij de politieke steun van de kleine eilanden nodig. Maar die steun had natuurlijk zijn prijs, de grote eilanden mochten zich niet al te zeer bemoeien met de gang van zaken op de kleine eilanden. Het ligt dus voor de hand dat een poging om de kleine eilanden hun autonomie te ontnemen in het huidige Nederlands-Antilliaanse staatsverband niet zal lukken. De kleine eilanden klaagden geregeld dat zij hun autonomie onvoldoende konden realiseren wegens het ontbreken van de over te dragen bevoegdheden door de Landsregering. Daarom was er vaak kritiek van de kleine eilanden op de Landsregering en wensten de kleine eilanden zich regelmatig los te maken van de macht van Curaçao.

Gedurende de jaren zeventig en tachtig brachten de kleine eilanden steeds naar voren, dat zij een directe staatsrechtelijke band met Nederland wensten. Volgens Bongenaar liepen de Bovenwinders nooit echt warm voor een Antilliaans staatsverband. Elke oplossing achtten zij beter dan een 'Curaçaose' regering. Om de situatie nog ingewikkelder te maken, was er ook sprake van een ondermijning van het Landsgezag door de kleine eilandgebieden. De kleine eilanden weigerden nogal eens gelden af te dragen aan het Land, op grond van een afgekondigde landsverordening. De conclusie van Bongenaar is dat de eilandelijke autonomie (dus de ERNA) verbeterd moet worden, met invloed van de kleine eilanden op het centrale bestuur. ${ }^{43}$ Tot dusverre kon de eilandelijke autonomie voorzien in de ERNA niet worden gerealiseerd. 
De Tweede Ronde Tafelconferentie kwam in 1952 in Den Haag bijeen om te komen tot een definitieve regeling van de nieuwe rechtsorde. Bij de voorbesprekingen voor de RTC in de Nederlandse Antillen en Suriname in 1951, werd niet langer uitgegaan van het concept van de Commissie Van Poelje. Het ontwerp stond met eigen Koninkrijksorganen, te ver af van de historisch gegroeide verhouding tussen de Eerste en Tweede Kamer van de Staten-Generaal. Bij die besprekingen werd uitgegaan van een Schets voor een Statuut regelende de status van Suriname en de Nederlandse Antillen in het Koninkrijk der Nederlanden. De Schets ${ }^{44}$ zag af van het scheppen van aparte Koninkrijksorganen. Zij gaf aan hoe Suriname en de Antillen bij de behandeling van gemeenschappelijke aangelegenheden konden deelnemen aan de bestaande Nederlandse organen. De algemene vertegenwoordigers namen deel aan het ministerieel overleg en in de Raad van State voor de behandeling van aangelegenheden, waarbij Suriname dan wel de Antillen betrokken waren. De Kamers der StatenGeneraal zouden uitgebreid worden met vertegenwoordigers van beide Rijksdelen voor de behandeling van dergelijke aangelegenheden.

De bevoegdheden van het Koninkrijk werden limitatief opgesomd, de overige bevoegdheden berustten bij de landen. Voor conflictsituaties werd een bijzondere procedure ontworpen. Op 28 februari 1950 werd de Schets voor een Statuut naar de West gezonden. De Landsregeringen moesten zich terzelfdertijd buigen over de ontwerp Interimregeling en de ontwerp-ERNA. Op 11 februari 1952 brachten de gemachtigden van de drie landen hun ontwerp-Statuut in de vorm

Werkstuk door de gemachtigdenvan Nederland, Suriname en de Nederlandse Antillen aan de Regering aangeboden, bestemd om te dienen als basis van bespreking op de eerlang te houden Conferentie tot opstelling van een ontwerp van een Statuut voor het Koninkrijk, 11 Februari 1952 (Keesings Historisch Archief, nr. 1079 februari 1952, pp. 9859 en 9861). De gemachtigden voor de Nederlandse Antillen waren: mr. dr. M.F. da Costa Gomez, dr. W.Ch. de la Try Ellis en mr. N. Debrot. Zie ook Conferentie Nederland, Suriname, Nederlandse Antillen, 's-Gravenhage 1952. Dit verslag begint met een systematisch overzicht van de staatkundige ontwikkeling in de West. Het algemeen deel bevat nog een chronologisch overzicht van de geschiedenis en economie van de Nederlandse Antillen. Het oorspronkelijke plan om de conferentie in de loop van 1950 weer bijeen te roepen kon niet worden uitgevoerd omdat de Interimregeling voor de Nederlandse Antillen eerst op 7 februari van kracht werd. Nadat de Interimregeling en de Eilandenregeling waren ingevoerd, restte nog een nieuwe constructie van het Koninkrijk. Er volgde nu weer een vooroverleg voor het vervolg van de RTC, waar als gemachtigden voor de Nederlandse Antillen zitting hadden: de heren Da Costa Gomez en De la Try Ellis. Deze commissie van gemachtigden heeft het Werkstuk van 11 februari 1952 vervaardigd dat voor het vervolg van de RTC de basis vormde. 
van een Werkstuk ${ }^{45}$ uit. Op 3 april 1952 werd de Tweede RTC officeel geopend.

Op het Werkstuk volgde het ontwerp-Statuut van 13 mei 1952 en tenslotte de aangepaste versie van het ontwerp-Statuut van 6 februari 1954. Tijdens de Conferentie stelde met name Suriname zich kritisch op tegenover het door Nederland ingediende Werkstuk. Het ontwerpStatuut sprak niet van het 'zelfbeschikkingsrecht' van de landen, wat tegelijkertijd het recht inhield zich af te scheiden van de nieuwe rechtsorde. Suriname protesteerde dat het ontwerp-Statuut niet meer was dan de continuering van de koloniale banden. De Antillen namen genoegen met het ontwerp en steunden Nederland in de discussie met Suriname.

In de inleiding van dit ontwerp werd gezegd dat door de ontwikkelingen in Indonesiê de nieuwe rechtsorde nogal op zich had laten wachten en dat hangende de oplossing van de Indonesische kwestie de Interimregeling was ingevoerd, die Suriname en de Nederlandse Antillen autonomie verleende. Vervolgens meldde de inleiding van het ontwerp-Statuut ${ }^{46}$ dat van de beginselen van de ontwerp-Rijksgrondwet van de Commissie Logemann niet was afgeweken. Het (ontwerp) Statuut beoogde aan Suriname en de Antillen autonomie en medezeggenschap te geven. Wel was afgeweken van de instelling van een aantal nieuwe (overkoepelende) staatsinstellingen, zoals de Commissie die had voorgesteld.

“De Regering heeft gestreefd naar een sobere en eenvoudige regeling. Bij het overleg, dat in het bijzonder de toenmalige Vice-President met vele personen en instanties heeft gevoerd, is het de Regering gebleken, dat ook bij velen in Suriname en de Nederlandse Antillen de voorkeur uitgaat naar een eenvoudige opzet. Vermeden moet worden, dat voor de aangelegenheden van het Koninkrijk teveel een beroep wordt gedaan op personen in Suriname en de Nederlandse Antillen, waardoor deze aan de Surinaamse en Antilliaanse samenleving, die aan hun werkkracht grote behoefte heeft, min of meer

4s Werkstuk, a.w. In de toelichting op het Werkstuk werd aangegeven, dat afgestapt was van eerdere voorstellen, het werd van belang geacht dat de bestaande staatsrechtelijke instellingen zoveel mogelijk zouden worden gehandhaafd en niet door nieuwe organen moesten worden vervangen. De kempunten van het Werkstuk waren: zelfstandigheid zoals geregeld in de Landsregeling en samenwerking. Samenwerking tussen de Koninkrijksonderdelen zou moeten worden geregeld in een eigen charter met de naam Statuut.

a.w., p. 6. 
zouden worden onttrokken. Vermeden moet worden een zodanige inrichting van het Koninkrijk, dat zijn organen niet voldoende snel en elastisch kunnen functioneren en dat kosten ontstaan, die niet noodzakelijk zijn. Tenslotte achtte zij het van belang, dat de bestaande staatsrechtelijke instellingen van het Koninkrijk zoveel mogelijk worden gehandhaafd en niet door nieuwe organen worden vervangen". 47

Zoals blijkt uit het beknopt verslag van de Conferentie 1952 stelde de Nederlands-Antilliaanse delegatie aan de hand van het OntwerpStatuut van 13 mei 1952 een lijst van geschilpunten vast. De tweede RTC waarop naar aanleiding van het Werkstuk beslissingen zouden worden genomen, verliep aanvankelijk voorspoedig, maar stokte op een tweetal Surinaamse bezwaren:

- het voortgezet overleg bood niet de garantie voor onpartijdige besluitvorming door de beslissende rol die de Nederlandse Minister-President daarin speelde;

- Suriname wenste voorts het zelfbeschikkingsrecht in de preambule van het Statuut op te nemen. ${ }^{48}$

Een kleine Commissie wist hierover een accoord te bereiken en de Conferentie werd voortgezet. Tijdens de Conferentie kwam het Arubaanse afscheidingsstreven ter tafel. Nederland en Suriname vonden dit afscheidingsstreven een inwendige aangelegenheid van de Nederlandse Antillen en dus niet aan de orde. Eman verliet daarop de vergadering en Da Costa Gomez liet weten dat hij zijn verdere medewerking aan de Conferentie zou onthouden als geen aandacht zou worden besteed aan het Arubaanse streven. De Conferentie werd op 29 mei 1952 onderbroken en verdaagd. ${ }^{49}$ De Conferentie zou een

a.w. p. 4. Met het werkstuk werd het ontwerp-Statuut bedoeld, Van Helsdingen (1957) p. 154.

4 Beknopt verslag der deelneming van de Nederlandse Antillen aan de Conferentie Nederland-Suriname-Nederlandse Antillen, Vervolg. Curaçaosche Courant N.V., Willemstad, 1954. Het Verslag is ondertekend door de Voorzitter der NederlandsAntilliaanse delegatie, mr. dr. M.F. da Costa Gómez.

19 Op 15 maart 1952 was door de Eilandsraad van Aruba een Commissie rapport goedgekeurd, dat een ontwerp van een Landsgrondwet voor de Verenigde Nederlandse Antillen inhield. Dit ontwerp had het ontwerp-Van Poelje als basis. 'De regering', meldt Van Helsdingen zuinig, 'had reeds verklaard, dat bedoeld ontwerp op goede gronden niet geheel kon worden gevolgd, doch dat met de hoofdbeginselenterdege rekening was gehouden. De Nederlandse regering wilde alleen onder zeer dringende omstandigheden wijzigingen anbrengen in de Landsregeling en de ERNA.' Het motief van de gehele actie van Aruba was kennelijk herstel van de 8-8 verhouding in de Staten, dan wel het verkrijgen van pariteit tussen Aruba en Curaçao langs andere weg. Dit blijkt duidelijk uit de uitlatingen van J.H.A. Eman in de Staten. 
Commissie aanwijzen, die zich verder moest bezig houden met de samenstelling van een ontwerp-Statuut, dat minder problemen zou veroorzaken binnen de Surinaamse- en de Nederlands-Antilliaanse delegaties. Wellicht, meende men, was de voorbereiding van de Conferentie niet degelijk genoeg geweest. Bovendien was de ERNA in de Antillen nog niet op bevredigende wijze uitgevoerd. Slechts de dienst Openbare Werken was overgedragen aan het Eilandgebied Curaçao.

Omdat het zelfbeschikkingsrecht een allesoverheersende rol speelde en speelt in de Nederlandse Antillen en Aruba, zal aan de uitleg van het begrip hierna de nodige aandacht worden gegeven. De uitleg van het begrip heeft niet op eenduidige wijze plaatsgevonden. De interpretatie van het zelfbeschikkingsrecht vormt een verbindende schakel tussen de jaren vijftig, zeventig en negentig met betrekking tot de staatkundige structuur van de Nederlandse Antillen en Aruba. Ingevolge de VN resoluties 1514,1541 en 2526 zijn de wijzen waarop het zelfbeschikkingsrecht kan worden uitgeoefend: de vrije associatie of integratie met een onafhankelijke staat, de vestiging van een soevereine of onafhankelijke staat of het verwerven van welke ander politieke status dan ook, waartoe in vrijheid door een volk wordt besloten. ${ }^{\text {so }}$

Het recht van zelfbeschikking kent ook beperkingen. In het algemeen geldt dat een koloniaal volk zijn toekomst vrijelijk kan bepalen, als eenheid die werd gevormd door de vroegere koloniale grenzen. Dit zelfbeschikkingsrecht wordt nogal eens betwist bij zeer

Reeds in de eerste vergadering van de Staten in de nieuwe samenstelling van 21 februari 1951, dreigde hij 'nu zullen de poppen gaan dansen. U kunt verwachten, dat de Eilandenregeling een middel van obstructie in de hand van Aruba zal worden!' En de heer Geerman profeteerde: 'Aruba neemt nimmer genoegen met een Eilandenregeling zolang het overkoepelend lichaam niet berust op de basis van gelijkheid en gelijkwasdigheid tussen Aruba en Curaçao. Wie zich de moeite getroost de notulen van de Staten door te lopen zal bemerken dat de heer Eman de afscheiding van Aruba propageerde waar hij maar meende die leuze te pas te kunnen brengen.' Ter conferentie in 1952 was wel een poging gedasn tot overeenstemming te komen. De Antilliaanse delegatie stelde namelijk een sub-commissie in ter bestudering van de onderlinge verhouding tussen het Antilliaanse rijksdeel en de eilandgebieden, onder voorzitterschap van Prof. W.C.L. van der Grinten. Een voorstel tot wijziging van de Eilandenregeling is daarvan niet het gevolg geweest, Van Helsdingen (1955) p. 126 e.v.

so Kuyper en Kapteyn, Self-determination, in: International Law in the Netherlands (1980) pp. 201, 205-206, 213-217. Het referendum over de staatkundige toekomst van Curaçao, Rapport van de Referendum Commissie Curaçao, 23 augustus 1993, p. 18. 
kleine gebieden. De VN kende deze gebieden het zelfbeschikkingsrecht niet toe, omdat het zelfbeschikkingsrecht niet gold voor delen van gekoloniseerde gebieden, dit was met name om te voorkomen dat Staten op gevaarlijke wijze zouden worden gefragmentariseerd. ${ }^{51}$

In 1951, vlak na de inwerkingtreding van de Interimregeling staakte de Nederlandse regering de jaarlijkse rapportage over de economische, sociale en educatieve omstandigheden in Suriname en de Nederlandse Antillen aan de Verenigde Naties (VN). Op grond van art. 73 sub e van het Handvest van de Verenigde Naties zijn lidstaten die gebieden besturen, waarvan de volkeren nog niet zelfbesturend ('self-governing') zijn, verplicht regelmatig te rapporteren over de stand van zaken in hun gebieden aan de VN. Nederland meende dat rapportage niet meer nodig was, omdat de overzeese gebiedsdelen reeds een grote mate van zelfbestuur hadden verkregen met de invoering van de Interimregeling.

Nederland had de grootste moeite om tegenover de Verenigde Naties aannemelijk te maken dat de overzeese gebiedsdelen een volledige staatkundige emancipatie zouden verwerven. ${ }^{52}$ Naar de mening van de Nederlandse regering had de Algemene Vergadering van de VN zich zonder enige grond de competentie toegekend te beoordelen of een gebied al dan niet zelfbesturend was geworden. Die bevoegdheid kwam alleen de Nederlandse regering toe, meende de minister van Buitenlandse Zaken, J.W. Beijen, en wel in gemeen overleg met het betrokken gebied zelf. De verhouding tussen de delen van het Koninkrijk moest als een inwendige aangelegenheid worden beschouwd, welke zich de jure aan internationale bemoeiing onttrok, maar de facto diende met de reacties in de VN steeds min of meer rekening te worden gehouden. ${ }^{53}$

si Meijers (red.), Volkenrechtelijke aspecten van Antilliaanse ona fhankelijkheid (1980) pp. 139-146 en Moenir Alam: pp. 147-153.

s2 Ministerie van Buitenlandse Zaken, Suriname en de Nederlandse Antillen in de Verenigde Naties (VN, 1952), voorwoord. Ook de Zuid-Amerikaanse Staten hadden zich sinds de Conferentie van Bogota van de Pan-Amerikaanse Unie van 1948 tos taak gesteld aan de athankelijkheid van niet zelfbesturende gebieden binnen hun sferr vallende, een einde te maken. De Pan-Amerikaanse Unie zag ongaame dat nietzelfbesturende gebieden als zij zelfbestuur krijgen, óók nog een band onderhouden met een in ander werelddeel gelegen moederland. Het Nederlandse beleid ten aanzien van de nieuwe verhoudingen met de West, zoals uiteengezet door Nederland aan de $\mathrm{VN}$, werd in deze uitgave uiteengezet en werd ook aangeboden aan de Staten van de Nederlandse Antillen en Suriname; pp. 7, 24.

ss Ministerie van Buitenlandse Zaken, Suriname en de Nederlandse Antillen in de Verenigde Naties (1954) voorwoord. De Resolutie van de VN aangenomen door de Achtste Algemene Vergadering op 27 november 1953 geeft aan hoe kan worden beoordeeld of een gebied al dan niet zelfbesturend is. Een van de genoemde factoren (annex deel 2) geeft aan dat als landen er voor kiezen in een associatieverband met 
Met de totstandkoming van het Statuut in 1954 was voor Nederland de zelfbeschikking van de overzeese gebiedsdelen een voldongen feit. Daaruit concludeerde Nederland, dat, nu de Nederlandse Antillen en Suriname gelijkberechtigd waren binnen het Koninkrijk der Nederlanden, de rapportageplicht aan de VN was vervallen. De vertegenwoordigers van de Nederlandse Antillen en Suriname onderschreven deze Nederlandse zienswijze. Veel leden van de VN vonden dat Nederland in de meeste zaken nog duidelijk het overwicht had, ondanks de in het Statuut genoemde zelfstandigheid en gelijkwaardigheid. De VN hadden met name bezwaren tegen het Statuut, omdat het zelfbeschikkingsrecht erin ontbrak en daarmee het recht van secessie (afscheiding) voor Suriname en de Nederlandse Antillen.

Pas na veel onderling overleg erkenden de VN in 1955 het Statuut als de beëindiging van de koloniale status en namen een resolutie aan, waarin Nederland werd ontslagen van de rapportageplicht. Tekenend was wel dat de resolutie met 21 stemmen vóór, 10 stemmen tegen en maar liefst 33 onthoudingen werd aangenomen. ${ }^{54}$ Nederland stelde zich op het standpunt dat het tegen het vaste Nederlandse beleid zou zijn om een partner te verhinderen het Koninkrijk te verlaten, indien deze zulks wenste. ${ }^{55}$ Deze situatie leidde wel tot een jarenlange discussie over de vraag of de Nederlandse Antillen en Suriname als 'non-selfgoverning' of als autonoom moesten worden beschouwd en in hoeverre beide landen nog gebruik konden maken van het zelfbeschikkingsrecht. ${ }^{56}$

In 1952 werd namelijk door de Algemene Vergadering van de Verenigde Naties bepaald dat verdragen inzake de rechten van de mens een bepaling zouden bevatten over het zelfbeschikkingsrecht voor alle

het moederland te blijven, zij altijd kunnen opteren voor een verandering van die status. Uit die factoren zou ook afgeleid kunnen worden dat het moederland het recht heeft de politieke status van het (niet) zelfbesturend gebied te wijzigen, p. 56.

4 Zie voor een uitgebreide toelichting: Suriname en de Nederlandse Antillen in de Verenigde Naties, Verslag van de handelingen der Zesde Algemene Vergadering (November 1951-Februari 1952) terzake van het beëindigen door Nederland van de rapportage over de West-Indische Rijksdelen, Ministerie van Buitenlandse Zaken, (1952). Voor een heldere toelichting op de gebeurtenissen, zie: Kapteyn (1982); Van Gameren (1991)p. 13. Voor de tekst van de Resolutie zie: Ministerie van Buitenlandse Zaken, Suriname en de Nederlandse Antillen in de Verenigde Naties (1956) p. 171. In dit verslag zijn de stemverhoudingen niet vermeld. Opvallend is trouwens dat de weergave van de Nederlandse regering over het dekolonisatieproces hier en daar nogal geflatteerd zijn.

ss Ministerie van Buitenlandse Zaken, Suriname en de Nederlandse Antillen in de Verenigde Naties, September-December (1956) p. 108; Koulen (1985) p. 39.

so Paula (1989) pp. 87-93; Keesings Historisch Archief, nr. 1155, augustus 1953, p. 10780 en nr. 1169 november 1953, pp. 10950 e.v. 
volkeren. Bovendien zou in deze verdragen worden opgenomen, dat staten die verantwoordelijk zijn voor het beheer van niet zelfbesturende gebieden, de verwezenlijking van dit recht met betrekking tot de volkeren van deze gebieden zouden moeten bevorderen. Tenslotte aanvaardde de AV in 1960 de verklaring inzake de toekenning van onafhankelijkheid aan koloniale landen en volkeren. ${ }^{57}$ Onafhankelijkheid werd in deze verklaring gezien als vanzelfsprekende uitkomst, zo niet als enig doel van het zelfbeschikkingsrecht van de niet-zelfbesturende gebieden en alle andere gebieden, die nog geen onafhankelijkheid hadden verkregen. Direct na de dekolonisatieverklaring in 1960 werd echter met Nederlandse steun een resolutie aangenomen waarmee de opvatting, dat het dekolonisatieproces zijn einde slechts kon vinden in onafhankelijkheid, werd afgezwakt. Krachtens deze resolutie (1541) wordt een niet-zelfbesturend gebied in drie gevallen geacht volledig zelfbestuur te hebben bereikt:

- het worden van een soevereine, onafhankelijke staat,

- vrije associatie met een onafhankelijke staat,

- integratie met een onafhankelijke staat.

In 1970 werd hieraan toegevoegd dat zelfbeschikking ook kan worden gerealiseerd door 'the emergence into any other political status freely determined by a people'. ${ }^{58}$ Het dekolonisatiebeleid van Nederland is dus beïnvloed door de internationale ontwikkelingen. Ook de veranderde economische en strategische belangen van de koloniale mogendheden in de regio hebben het dekolonisatiebeleid beīnvloed. Eveneens

Resolutie 1514 van 14 december 1960; 'The Declaration on the Granting of Independence to Colonial Countries and Peoples'. De inhoud van deze resolutie kan aldus worden geïnterpreteerd, dat elke vorm van staatsverband van koloniēn, afwijkend van onafhankelijkheid onaanvaardbaar is. Op 15 december 1960 heeft de AV van de VN een gematigde resolutie aangenomen: Resolutie 1541. Deze resolutie hield in dat ook andere vormen van dekolonisatie mogelijk zijn, naast onathankelijkheid. Resolutie 2625 (XXV) van 24 oktober 1970, bevestigt deze gedachtengangnadrukkelijk. Dekolonisatie kan volgens deze resolutie ook inhouden hechtere banden met het moederland. Inmiddels is het recht op zelfbeschikking uitgegroeid tot een regel van positief recht. Nota AVP: Doño di nos propio destino, Aruba en haar recht op zelfbeschikking (1990). Het zelfbeschikkingsrecht is het recht, binnen het kader van het dekolonisatieproces, dat de bevolking van een niet onathankelijk gebied heeft om zelf te beslissen over haar toekomstige staatkundige (politieke en juridische status), Akehurst (1987), p. 290; zie ook Starke (1989) pp. 123-125. Het recht van zelfbeschikking behoeft niet in te houden dat een voormalige kolonie onathankelijk moet worden, het kan ook inhouden een min of meer vergaande vorm van integratie met het moederland.

s Koulen (1985) pp. 14 e.v.; Baehr (1976) pp. 188-200. Handvest van de Verenigde Naties, hoofdstuk XI, Verklaring betreffende niet-zelfbesturende gebieden (de arth. 73 en 74) en hoofdstuk XI, Internationaal Trustschapsstelsel (de artt. 75-85). 
zijn de naoorlogse opvattingen van vooral de VS, van invloed geweest, die afwijzend stonden tegen het bezitten van koloniën en het toenemend nationalisme in Nederlands-Indië. ${ }^{59}$

De Surinaamse delegatie naar de Tweede RTC, waarin het nationalistisch element, gesteund en gedragen door het volk, de overhand kreeg, eiste vastlegging van het zelfbeschikkingsrecht in de preambule. Met name het zelfbeschikkingsrecht, dat Suriname in de nieuwe Koninkrijksregeling wenste, met als consequentie het recht van secessie, lag moeilijk in Nederland. Suriname verstond onder het zelfbeschikkingsrecht mede het recht van permanente secessie. Door het aldus geĩnterpreteerde begrip vast te leggen in de preambule van het Statuut, wenste de Surinaamse delegatie tot uitdrukking te brengen, dat het Statuut de verdere staatkundige ontwikkeling van Suriname niet zou afsnijden. Het recht van secessie was volgens Nederland niet begrepen in het officiële recht van 'self-determination', zoals geregeld in het Handvest van de Verenigde Naties. Bovendien meende Nederland dat erkenning van een permanent recht van secessie in strijd was met de Grondwet en het koninkrijk op losse schroeven zou zetten. ${ }^{\infty}$

De terughoudendheid van Nederland om aan de Verenigde Naties verdere inlichtingen te verstrekken op grond van art. 73 sub e van het Handvest van de Verenigde Naties ${ }^{61}$, was de reden waarom de vertegenwoordigers van de drie rijksdelen, in november 1952 in New York bijeenkwamen. Vooral Suriname wenste dat er duidelijk zou worden gesteld, welke draagwijdte een eventuele erkenning van het zelfbeschikkingsrecht voor Suriname en de Nederlandse Antillen zou hebben. In de afwijzing van het recht van secessie vond Nederland de Nederlandse Antillen aan zijn zijde. ${ }^{62}$ De Antilliaanse regering stelde onder meer dat naar haar opvatting het zelfbeschikkingsrecht niet inhield het recht zelve om een koninkrijk op te bouwen en te niet te doen en voorts, dat zij zich niet kon verenigen met een rechtsopvatting, die inhield een zelfde rechtsgrond voor binding en ontbinding. Belangrijkste conclusie van dat overleg was, dat het Statuut niet het eindpunt van de ontwikkelingen tussen de drie rijksdelen behoefde te zijn. In de preambule van het Statuut zou het zelfbeschikkingsrecht

39 Koulen (1985) pp. 35-47; Baehr (1976) pp. 188-200; Kuyper, Kapteyn (1980) pp. 150-218, m.n. p. 201.

so Het vinden van een algemeen aanvaarde definitie van het zelfbeschikkingsrecht is tot op heden niet tot stand gekomen. Secessie en revolutie is volgens het internationale recht een onwettige daad: Jonkers, De WIG, 34, 1953, pp. 148-156; Kastee] (1956) p. 266 e.v.

61 Paula (1989) pp. 87-93.

62 Karamat Ali (1989) pp. 102 e.v. 
van Suriname en de Nederlandse Antillen tot uitdrukking worden gebracht. ${ }^{63}$ Uiteindelijk zou het recht van zelfbeschikking niet in het Statuut worden genoemd, maar wel worden erkend. Karamat Ali merkte naar aanleiding daarvan nog op dat het uitgerekend Nederland was, dat in de zestiger jaren het eerst aandrong op onafhankelijkheid van de overzeese rijksdelen.

Over de formulering van het zelfbeschikkingsrecht in het Memorandum van New York $^{64}$ rees al snel verschil van interpretatie. In Nederland begreep men niet dat minister Kernkamp, minister van Overzeese Rijksdelen aan Suriname en de Nederlandse Antillen een permanent recht van afscheiding had beloofd. De regering meldde begin 1953 bij monde van Minister-President Drees, dat er geen sprake kon zijn van opneming van het zelfbeschikkingsrecht in het Statuut.

De Antilliaanse delegatie had zoals gezegd echter een duidelijk standpunt in deze kwestie ingenomen. De erkenning van het recht van zelfbeschikking hield niet in het recht de bestaande verbondenheid eenzijdig te beëindigen, doch de mogelijkheid (tot beëindiging van de bestaande verbondenheid) moest volgens de in de Nederlandse Antillen heersende opvattingen kunnen worden ingeroepen. Evenals de Surinamers waren ook de Antillianen van mening dat de nieuwe rechtsorde een radicale omzetting moest zijn van de bestaande historische staatkundige verhoudingen in een rechtsorde, waarin de belangen der landen geregeld zouden worden in vrijwillige samenwerking. Suriname meende dat op grond van het Memorandum het zelfbeschikkingsrecht zo kon worden geïnterpreteerd, dat een Koninkrijksdeel kon uittreden door een wijziging van het Statuut zonder dat andere Rijksdelen dit zouden kunnen tegenhouden. Op 30 juni 1953 werd in Den Haag meegedeeld dat het principe van het zelfbeschikkingsrecht in de preambule van het Statuut zou worden opgenomen. Het recht van secessie was in het begrip zelfbeschikkingsrecht niet inbegrepen, want een vrijwillig aangegane verbondenheid kon niet eenzijdig worden beëindigd. Wijziging van het Statuut zou niet te moeilijk worden gemaakt. Gehoopt werd dat Suriname tot een gerijpt inzicht kon komen en evenals de Antillen de opvatting zou koesteren, dat op het recht van secessie geen Koninkrijk kan worden gebouwd. ${ }^{65}$

In januari 1954 kwamen de besprekingen binnen een kleine RTC weer

\footnotetext{
63 Keesings Historisch Archief, nr. 1120, novenber/december 1952, p. 10357.

a Van Helsdingen (1957) pp. 189-249; Kasteel (1956) p. 268 e.v.

os Keesings Historisch Archief, nr. 1150, juni/juli 1953, pp. 10717e.v.; Kasteel (1956) p. 270.
} 
op gang in Willemstad en vervolgens in Paramaribo. Er werd gezocht naar een basis om de eigenlijke RTC voort te zetten. De Arubaanse wens tot afscheiding van Curaçao was nog steeds een heet hangijzer. Professor R. Kranenburg kwam enkele maanden later naar Aruba om een studie te maken van het Arubaanse afscheidingsstreven. Zijn advies strookte niet met de Arubaanse verlangens, daar hij van mening was dat de Grondwet slechts de rijksdelen Nederland, de Nederlandse Antillen en Suriname kende. ${ }^{60}$

De Nederlandse regering was niet bereid een voorstel in te dienen om de Grondwet te wijzigen. ${ }^{67}$ Uit de besprekingen van de kleine Commissie kwam tenslotte het door de drie landen aanvaarde Ontwerp-Statuut van 6 februari $1954 .{ }^{68}$ Op 24 juni 1954 volgde het Ontwerp van Wet tot aanvaarding van een Statuut voor het Koninkrijk der Nederlanden. ${ }^{69}$ Op 20 mei 1954 werd de RTC in Den Haag

Notulen Eilandsraad Aruba, Bijlage bij de Notulen, 1954-1955, 15, 12 mei 1955. De tekst van het rapport Kranenburg is volledig afgedrukt in de Amigoe, dagblad voor de Nederlandse Antillen van 28 juli 1954. De kop boven het artikel luidt: 'Professor Kranenburg acht separacion niet mogelijk; bij absolute scheiding blijft niets van de Landsregeling over.'

6) Conferentie Nederland-Suriname-Nederlandse Antillen, Ontwerp-Statuut, 6 Februari 1954. In de toelichting op het Ontwerp-Statuut wordt het volgende opgemerkt: 'Het eerste deel betreft de Rijksband zelf, die tussen de landen bestaat. Deze Koninkrijksaangelegenheden zijn een gemeenschappelijke zaak van de landen en staan in het Statuut limitatief opgesomd. Op deze wijze wordt de autonomie der landen zeker gesteld. Het tweede deel betreft de onderlinge verhouding der landen als autonome eenheden. Het derde deel handelt over de autonome sfeer der landen'. Zie ook: Beknopt Verslag der deelneming van de Nederlandse Antillen aan de Conferentic Nederland-Suriname-Nederlandse Antillen, vervolg, Willemstad, Curaçaosche Courant N.V., 1954.

Keesings Historisch Archief, nr. 1193, april/mei 1954, pp. 11235-11238.

Ontwerp van Wet, Aanvaarding van een statuut voor het Koninkrijk der Nederlanden, Zitting 1953-1954,3517. Ln dit wetsontwerp bevindt zich als bijlage no 4 bij de MvT het verslag van de openbare vergadering van de Conferentie Nederland-SurinameNederlandse Antillen van donderdag 3 juni 1954. Op deze vergadering werd uiteindelijk overeenstemming bereikt over het ontwerp-statuut, na het voorwerk van de kleine commissie. Het Voorlopig Verslag (No. 5) meldt op blz 2: 'Enkele leden [van de delegaties op de RTC] waren zeer verheugd over het resultaat van het gemeenschappelijk overleg, noemdenhet Statuut en vernuflig politiek document, [andere delegatieleden meenden dat het Statuut] een vasg en duister staatsrechtelijk stuk [was]'. De regering zei in de Memorie van Antwoord (No. 7, blz. 7): 'Uiteraard verliest ook de Regering niet uit het $00 \mathrm{~g}$, dat het Statuut niet allereerst een volkomen logisch opgesteld Staatsstuk is, zoals door sommige leden terecht opgemerkt, en dat de praktijk zal moeten uitwijzen of het Statuut een hanteerbaar instrument zal blijken te zijn. Te dien aanzien koesteren zij met deze leden goede verwachtingen voor de toekomst. Het doet de Regering leed, dat de vreugde over het resultaat van het overleg wordt getemperd door de mening van enkele leden, dat het Statuut vaag en duister zou zijn. Sommige leden, die geheel afwijzend tegenover het Statuut staan, gaan blijkbaar uit van de veronderstelling uit, dat Suriname en de Nederlandse Antillen voltedige ona thankelijkheid begeren. Deze leden gaan intussen uit van een onjuiste praemisse. Suriname en de Nederlandse Antillen hebben immers bij herhaling 
voortgezet. Op 3 juni werd de slotvergadering gehouden. ${ }^{70}$ Op de slotvergadering voerde ondermeer C.A. Eman het woord over het Arubaanse afscheidingsstreven. ${ }^{71}$ Op 15 december 1954 werd de nieuwe rechtsorde door Koningin Juliana bevestigd. ${ }^{2}$ In de Nederlandse Antillen vond de plechtige afkondiging plaats op 29 december 1954. Het Statuut ${ }^{73}$ was een feit. Het kwam tot stand langs democratische weg in elke der drie landen. Dit betekende voor Nederland aanvaarding van het Statuut door de beide Kamers der Staten-Generaal met ten minste twee derden der uitgebrachte stemmen. Datzelfde gold voor Suriname en de Nederlandse Antillen. In tweede lezing was een volstrekte meerderheid in de Staten nodig (art. 61 Statuut).$^{74}$

Bij de beschrijving van het Statuut wordt uitgegaan van de huidige situatie (1994), tevens wordt echter de geschiedenis van het Statuut verhaald, dat levert voor de chronologische volgorde geen problemen $o p$, omdat de huidige situatie de werking van het Statuut niet wezenlijk heeft veranderd. De belangrijkste aanpassingen van het Statuut vonden plaats naar aanleiding van de onafbankelijkheid van Suriname in 1975 en het verkrijgen van de Status Aparte van Aruba per 1 januari 1986. Van 1954 tot 1957 bestond het Koninkrijk uit drie

uitdrukkelijk verklaard, dat zij geen onafhankelijkheid begeren, doch handhaving van een band met het Koningshuis en met Nederland.'

In Keesings Historisch Archief, nr. 1199, juni 1954, pp. 11307, 11309 en 11310 bevindt zich een overzicht van alle ontwikkelingen die tot het Statuut hebben geleid tussen 1942 en 1954 . Ook wordt de tekst vermeld van het Ontwerp-Statuut, waarover overeenstemming is bereikt. Op 16 juni 1954 wordt het Ontwerp-Statuut door de Tweede Ksmer goedgekeurd, idem nr. 1204, juli 1954, p. 11369 en 11370 . Prof. Oud had onder meer bezwaar tegen art. 5 Statuut in samenhang met art. 55 Statuut derde lid, waardoor naar zijn mening de troonopvolging ondergeschikt werd aan het Statuut, omdat hierover met gewone meerderheid zou kunnen worden beslist.

" Na een historische schets van Aruba's streven om 'baas in eigen huis' te zijn, hield Eman een pleidooi voor de federatieve ophouw van de Nederlandse Antillen als overgangsperiode, die uiteindelijk zou moeten resulteren in de volwaardige erkenning van de zelfstandigheid van de Arubaanse bevolking in de besluitvorming over de staatkundige toekomst van het eiland. Beknopt Verslag der deelneming van de Nederlandse Antillen aan de Conferentie Nederland-Suriname-Nederlandse Antillen, Vervolg, Willemstad, Curaçaosche Courant N.V., 1954, pp. 27 e.v. Zie ook Van Helsdingen (1954) pp. 72-90 en (1955) pp. 124 en 125-133.

7 Keesings Historisch Archief, nr. 1126, december 1954, pp. 11635, 11637. Ter gelegenheid van deze gebeurtenis werd een postzegel van 10 cent uitgegeven. Idem, nr. 1128, december 1954 pp. $11662-11666$. Op deze pagina's wordt de rede van de Koningin vermeld; Van Helsdingen (1957) pp. 189-249.

7 Stbl. 1954, nr. 596, PB 1954, 121; Van Helsdingen (1957) pp. 1-165.

74 Van Helsdingen (1957) pp. 578-628; Logemann, NJB, 1952, pp. 309-319. 
landen, tussen 1975 en 1986 uit twee landen en sinds 1986 weer uit drie landen.

De hoogste regeling binnen het Koninkrijk is het Statuut. Het Statuut bestaat uit een plechtige preambule en vijf paragrafen. Paragraaf 1 (de artt. $1 \mathrm{t} / \mathrm{m} \mathrm{5}$ ) bevat algemene bepalingen. In paragraaf 2 wordt de behartiging van de Koninkrijksbelangen geregeld (de artt. $6 \mathrm{t} / \mathrm{m}$ 35). Paragraaf 3 gaat over bijstand, overleg en samenwerking van de landen onderling (de artt. $36 \mathrm{t} / \mathrm{m} \mathrm{40}$ ). Paragraaf 4 bevat een aantal bepalingen over de staatsinrichting van de landen (de artt. $41 \mathrm{t} / \mathrm{m} \mathrm{53}$ ) en paragraaf 5 besluit met de overgangs- en slotbepalingen (de artt. $54 \mathrm{t} / \mathrm{m} \mathrm{62}$ ). De grondgedachte van het Statuut is dat de landen de eigen belangen zelfstandig behartigen en dat zij op voet van gelijkwaardigheid zich verplichten tot verzorging van de gemeenschappelijke belangen en tot het verlenen van wederzijdse bijstand. Aangezien de wens tot autonomie bepalend was in de totstandkoming van het Statuut, zijn de gemeenschappelijke belangen in het Statuut limitatief opgesomd in art. 3. De toelichting op art. 3 van het Statuut zegt:

\begin{abstract}
"Wat Koninkrijksaangelegenheden zijn, is limitatief in het Statuut opgesomd. In dit artikel zijn niet alle Koninkrijksaangelegenheden genoemd. Ook elders in het Statuut vindt men deze. In de loop van de tijden kan de wenselijkheid blijken ook andere zaken tot Koninkrijksaangelegenheden te bestempelen. De beslissing hiertoe kan echter slechts in gemeen overleg tot stand komen. In lid 2 is dit tot uitdrukking gebracht. Daarbij is artikel 55 van overcenkomstige toepassing verklaard, hetgeen wil zeggen, dat de aanwijzing van een aangelegenheid tot Koninkrijksaangelegenheid geschiedt bij Rijkswet, welke op dezelfde wijze tot stand komt als een wijziging van het Statuut. De Koning keurt een desbetreffend ontwerp van wet dus niet goed dan na aanvaarding door Suriname en de Nederlandse Antillen bij landsverordening". ${ }^{75}$
\end{abstract}

Logemann stelde in 1952 al de 'epineuse' vraag of er binnen het Koninkrijk 'nieuwe stijl' wel sprake kon zijn van gemeenschappelijke belangen. Hij meende van niet.

De drie landen liggen te wijd uiteen, in politiek, economisch en cultureel verschillend milieu; zij bergen te wijd verscheiden bevolkingen. De eenheid van het Koninkrijk berust niet op het feit, dat zijn burgers in én gemeenschap zijn verenigd. De objectieve factoren ontbreken en het wordt ook niet als zodanig gevoeld, noch overzee noch in Nederland. 
De samenhang van het Koninkrijk zou volgens Logemann dan ook gevonden moeten worden in de bijstand van Nederland aan de Nederlandse Antillen en Suriname. ${ }^{76} \mathrm{Zijn}$ epineuse vraag is ook in de huidige jaren negentig nog actueel.

Het aantal limitatief opgesomde Koninkrijksaangelegenheden is in het Statuut aanzienlijk kleiner dan in de Interimregeling (de artt. 3 en 43). ${ }^{77}$ In de betrekkelijk ingewikkelde en niet altijd even heldere bepalingen in het Statuut kunnen de volgende categorieën Koninkrijksregelingen worden onderscheiden:

1. wijzigingen van het Statuut, inclusief het verklaren dat andere dan in het Statuut genoemde onderwerpen tot aangelegenheden van het Koninkrijk behoren. Het voorstel moet door de Staten van de landen worden aanvaard, hetzij in twee lezingen, hetzij in eerste en enige lezing, mits met twee derde van de uitgebrachte stemmen (de artt. 3 en 55 Statuut);

2. regelingen met betrekking tot aangelegenheden van het Koninkrijk, die bij Rijkswet worden vastgesteld en die op Aruba en/of de Antillen gelden. De Gevolmachtigde Minister neemt deel aan het overleg in de ministerraad van het Koninkrijk. De Staten worden in de gelegenheid gesteld hun oordeel te geven (de artt. $15 \mathrm{t} / \mathrm{m} 18$ Statuut);

3. regelingen over aangelegenheden van het Koninkrijk die in de Nederlandse Antillen of Aruba niet zullen gelden, maar die Aruba en/of de Antillen wel raken. De Gevolmachtigde Minister neemt deel aan de het overleg in de ministerraad van het Koninkrijk (de artt. 11 en 12 Statuut);

4. regelingen over Koninkrijksaangelegenheden, die in de Nederlandse Antillen en Aruba niet gelden en die Aruba en/of de Antillen niet raken. De regeling geschiedt bij wet of gewone AMvB (art. 14 lid 3 Statuut).

Indien een te treffen regeling niet zal gelden voor Aruba of de Antillen, dan kan deze worden vastgesteld bij gewone wet of AMvB (art. 14 derde lid), dus uitsluitend door Nederlandse organen. Om te

Voor een vergelijking tussen de Lnterimregeling en het Statuut zie: Van Helsdingen (1956) pp. 33-35. 
voorkomen dat Aruba en de Antillen, door de limitatieve opsomming en door de mogelijkheid van vaststelling van regelingen voor Koninkrijksaangelegenheden van het Koninkrijk bij gewone wet of AMvB te weinig zouden worden betrokken bij de behartiging van de gemeenschappelijke belangen, is een speciale regeling ontworpen. Artikel 11 Statuut bepaalt welke regelingen worden geacht Aruba en de Antillen te raken. Ook kunnen de regeringen van Aruba en de Antillen aangeven, welke andere onderwerpen hun Land raken (art. 11 lid 6).

De Gevolmachtigde Minister van de Nederlandse Antillen wordt door de regering van de Nederlandse Antillen benoemd. De Gevolmachtigde Minister van Aruba wordt door de Arubaanse regering benoemd. De regeringen van de landen dragen de verantwoordelijkheid voor het handelen van hun Gevolmachtigde Minister. De Gevolmachtigde Minister staat in een mandaatsverhouding tot zijn regering. Crince le Roy ${ }^{78}$ is van mening dat de Gevolmachtigde Minister alleen zijn regering kan binden, als hij ook de gevoelens van zijn regering vertolkt. ${ }^{79}$ De Gevolmachtigde Minister neemt volledig deel aan het overleg in de ministerraad en aan de vergaderingen van de vaste colleges en bijzondere commissies uit de raad, indien aangelegenheden van het Koninkrijk die zijn land raken aan de orde komen. Indien de Gevolmachtigde Minister zich in het belang van zijn land tegen een voorziening verklaart, zal deze voor Aruba of de Antillen niet gelden, tenzij de verbondenheid van Aruba of de Antillen met het Koninkrijk zich daartegen verzet (art. 12 lid 1). ${ }^{80}$

De besluitvormingsregels tonen dat de Arubaanse- en Antilliaanse participatie in regelingen over Koninkrijksaangelegenheden gering is. Veel van die regelingen worden buiten Aruba en de Antillen of hun vertegenwoordiger om genomen. Als de Staten al bij de besluitvorming worden betrokken, is hun oordeel niet beslissend. De Gevol-

78 Crince le Roy (1962) pp. 962-964

79 Van der Pot/Donner/Prakke (1989) pp. 704-706. Voor de historische ontwikkeling van het instituut van de Gevolmachtigde Minister, zie: De Vries, De WIG, 35/36, 1954-1955, pp. 165-172.

* Deze situatie deed zich eind 1992 voor, toen Nederland er bij de Nederlandse Antillen en Aruba op aandrong dat het Verdrag van Stratsburg, ook genoemd het verdrag inzake Wederzijdse Administratieve Bijstand in Belastingzaken (WABB) zou gelden voor de Nederlandse Antillen en Aruba. Indien het verdrag tevens zou gelden voor de Nederlandse Antillen en Aruba zou dat nadelig zijn voor de off-shore. mr. C. Dip was van mening dat met een beroep op art. 25 lid 1 Statuut medegelding van het verdrag voor de Nederlandse Antillen en Aruba kon worden voorkomen. Dit is echter niet het geval. Artikel 12 lid 1 Statuut geeft de doorslag. Het belang van het Koninkrijk zal altijd de overhand hebben. Amigoe 25 november 1992. 
machtigde Minister staat alleen tegenover een groot aantal Nederlandse ministers. Om enige compensatie te geven is in artikel 12 Statuut de procedure van voortgezet overleg geopend. Dit voortgezet overleg vindt plaats tussen de Minister-President van Nederland, twee ministers, de Gevolmachtigde Minister en een door de betrokken Landsregering aan te wijzen persoon. In plaats van deze persoon kan desgewenst ook de Gevolmachtigde Minister van het andere Land deelnemen. De Landsregeringen hebben in dat geval het recht een minister uit hun midden naar het voortgezet overleg af te vaardigen, die dan raadgevende stem heeft (art. 12 lid vier Statuut). Het Statuut heeft het voortgezet overleg zo gestructureerd, dat de drie Nederlandse ministers (inclusief de Minister-President) de twee andere deelnemers kunnen overstemmen.

De toelichting op het Statuut formuleert dat op delicate wijze en stelt over de Caraïbische deelnemers aan het voortgezet overleg: " $\mathrm{Zij}$ kunnen slechts overstemd worden, indien de Minister-President hun zienswijze niet kan delen". ${ }^{81}$ De Koninkrijksministerraad is vervolgens gebonden aan de uitslag van het voortgezet overleg (art. 12 lid 5 Statuut). De procedure van voortgezet overleg wordt zoveel mogelijk vermeden. Deze procedure toont duidelijk de onevenwichtigheid in de machtsverhoudingen tussen de landen. Zou er vaak van deze procedure gebruik worden gemaakt, dan zou dat de onderlinge verhoudingen tussen de Koninkrijkspartners te zeer belasten. Voorzover bekend heeft tot dusver slechts eenmaal voortgezet overleg plaatsgevonden, waarbij de Antilliaanse Gevolmachtigde Minister werd overstemd. Het betrof de benoeming van een nieuwe Gouverneur, kort na de opstand in Willemstad van 1969. De Antilliaanse regering had Minister-President Jonckheer voorgedragen. Binnen de Koninkrijksministerraad bestonden daartegen echter ernstige bezwaren. Jonckheer zou teveel als vertegenwoordiger van het blanke koloniale regiem worden gezien. Tegen de wil van de Antilliaanse regering werd toen Leito tot Gouverneur benoemd. ${ }^{82}$

De op zich al niet zo heldere grens tussen Koninkrijk en landen wordt nog verder vertroebeld door de artt. 43 lid 2, 50 en 51 Statuut. Artikel 43 lid 2 verklaart dat als de fundamentele menselijke rechten en vrijheden, de rechtszekerheid en de deugdelijkheid van bestuur niet voldoende worden gewaarborgd, het Koninkrijk (Nederland) kan ingrijpen.

"De Rechtsorde (1986) p. 27.

c Reinders (1993) p. 79; Encyclopedie p. 207, Leito was wasmemend Gouverneur van 1969-1970 en Gouvemeur van 1970-1983. 
Op grond van art. 50 kunnen wettelijke regelingen van de Nederlandse Antillen en Aruba door de Gouverneur bij de Kroon worden voorgedragen voor vernietiging, indien er strijd bestaat met een hogere regeling, of met een belang van het Koninkrijk.

Als een bestuursorgaan in de Nederlandse Antillen of Aruba niet voldoende voorziet in hetgeen volgens een hogere regeling moet worden uitgevoerd, kan door het Koninkrijk in die taak worden voorzien op grond van een algemene maatregel van rijksbestuur. ${ }^{83}$ wijziging van het Statuut

Het hoogste orgaan binnen het Koninkrijk is de Koning(in), die de regering voert over het Koninkrijk en over de drie landen. In verband met de onmogelijkheid haar bevoegdheden thans zowel op Aruba als op de Antillen feitelijk uit te oefenen wordt zij in de West vertegenwoordigd door een Gouverneur. (Sinds de Status Aparte van Aruba in 1986 heeft Aruba als Land binnen het Koninkrijk ook een Gouverneur gekregen). De bevoegdheden en verplichtingen van de Gouverneur als vertegenwoordiger van de Koning(in) als hoofd van de Koninkrijksregering worden geregeld bij Rijkswet of AMvRB (Reglement voor de Gouverneur). ${ }^{84}$ Daarnaast is de Gouverneur tevens vertegenwoordiger van de Koning als hoofd van de Landsregering. In deze laatste functie hoeft hij geen richtlijnen te volgen van de Koninkrijksregering, maar is hij onschendbaar staatshoofd en wordt zijn positie beheerst door bepalingen van de Staatsregeling. De Koning als hoofd van de Koninkrijksregering wordt bijgestaan door de Raad van Ministers voor het Koninkrijk. Dit is de Nederlandse ministerraad, aangevuld met een door de regering van Aruba of de Nederlandse Antillen benoemde Gevolmachtigde Minister. Beide landen hebben dus ieder hun eigen Gevolgmachtigde Minister.

De Raad van State van het Koninkrijk, het orgaan dat aan de Kroon advies uitbrengt bij de totstandkoming van Rijkswetten en AMvRB, bestaat uit de Nederlandse Raad van State, desgewenst aangevuld met een door de Arubaanse of Antilliaanse regering

83 Voor een uitgebreide toelichting op het ingrijpen van het Koninkrijk op grond van art. 43 Statuut, zie: Van Aller (1992) pp. 8-16.

24 Reglement voor de Gouverneur van de Nederlandse Antillen, Stb. 1985, 674; PB 1986, 30. Reglement voor de Gouverneur van Aruba, Stb. 1985, 671, AB 1986, 3, zoals laatstelijk gewijzigd bij Rijkswet van 18 december 1985, Stb. 672, AB, 1986, 5 . 
Wettelijke regelingen omtrent Koninkrijksaangelegenheden, die op Aruba of de Antillen zullen gelden, worden bij Rijkswet of AMvRB vastgesteld. Het ontwerp wordt door de Koninkrijksregering toegezonden aan de Staten-Generaal en aan de Staten.

Koninkrijksaangelegenheden genoemd in artikel 3 van het Statuut zijn: de handhaving van de onafhankelijkheid en de verdediging van het Koninkrijk, de buitenlandse betrekkingen en het Nederlanderschap. Koninkrijksaangelegenheden zijn eveneens de regeling van ridderorden, alsmede de regeling van vlag en wapen van het Koninkrijk, de regeling van de nationaliteit van schepen en het stellen van eisen met betrekking tot de veiligheid en navigatie van zeeschepen, het toezicht op de algemene regels betreffende toelating en uitzetting van vreemdelingen en tenslotte de uitlevering. Deze onderwerpen vloeien voort uit het feit dat de landen in éen rechtsorde zijn verbonden. Ook kent het Statuut onderwerpen, waaromtrent een plicht tot bijstand, overleg en samenwerking geldt. Het betreft hier bevoegdheden die behoren tot de sfeer van de landen, maar waarover men toch samenwerking wenst te hebben.

Het samengaan in één rechtsorde is alleen mogelijk als er binnen die rechtsorde een zekere samenwerking en onderling overleg wordt nagestreefd. ${ }^{86}$ Om de onderlinge samenwerking gestalte te geven kunnen gemeenschappelijke organen worden opgericht (art. 37 Statuut). Ook kan men onderlinge regelingen treffen (art. 38). Dit geschiedt in de vorm van een Rijkswet of AMvRB, met dien verstande dat de regeling de instemming behoeft van beide landen. Deze paragraaf over onderlinge bijstand, overleg en samenwerking bevat ook het concordantiebeginsel op grond waarvan bepaalde rechtsgebieden zoveel mogelijk op overeenkomstige wijze moeten worden geregeld (art. 39). Vonnissen en authentieke akten, afkomstig uit én der landen kunnen in het gehele Koninkrijk ten uitvoer worden gelegd (art. 40). Paragraaf 4 (de artt. $41 \mathrm{t} / \mathrm{m} 53$ van het Statuut) bevat een aantal voorwaarden, waaraan de staatsinrichting van de landen moet voldoen. On-

* Artikel 13/2 Statuut biedt de mogelijkheid een Arubaan of Antilliaan te benoemen tot staatsraad in buitengewone dienst, indien geadviseerd moet worden door de RvS over een Arubaanse of Antilliaanse kwestie. Dit is in 1958 gebeurd. Om gebruik te maken van deze mogelijkheid zijn een aantal wettelijke regelingen op Koninkrijksniveau getroffen. Zie Van der Pot/Donner/Prakke (1989) p. 706, noot 25.

* Kranenburg (1956) pp. 873 e.v., anders: Logemann (1956), Pp. 141 e.v.; zie reactic hierop van Böhtlingk (1956) p. 411 e.v. en weerwoord van Logemann (1956) pp. 554 e.v. Zie ook Van der Pol (1956) pp. 672 e.v. en 705 e.v. 
danks de autonomie van de landen moeten er waarborgen voor een zekere democratie en rechtsstatelijkheid bestaan. Het Statuut stelt een aantal minimale eisen. Genoemd worden: een geschreven constitutie, de wijzigingsprocedure van de Staatsregeling (art. 42), de verwezenlijking van de fundamentele menselijke rechten en vrijheden, de rechtszekerheid en de deugdelijkheid van het bestuur, alsmede de waarborging daarvan door het Koninkrijk (art. 43), de bevoegdheden van de vertegenwoordigende lichamen van de landen, alsmede een aantal randvoorwaarden waaraan een kiesstelsel moet voldoen. Teneinde deze minimale waarborgen te kunnen garanderen geeft het Statuut ook een aantal machtsmiddelen, zoals art. 50 dat een vernietigingsrecht geeft aan de Koning, van wetgevende en bestuurlijke maatregelen, die in strijd zijn met de belangen, waarvan de behartiging aangelegenheid van het Koninkrijk is. Volgens art. 42 vindt de staatsinrichting van Nederland regeling in de Grondwet, die van de Nederlandse Antillen en Aruba in de Staatsregelingen van die landen. De Staatsregelingen kunnen gewijzigd worden bij landsverordening.

De Staatsregeling van de Nederlandse Antillen kreeg pas de status van landsverordening in $1954 .{ }^{87} \mathrm{Bij}$ bestudering van de toelichting op art. 42 lid 2 Statuut blijkt dat bij de invoering van het Statuut de Staatsregeling werd aangepast aan de nieuwe rechtsorde. ${ }^{88}$ Dit betekende dat tussen 1865 en 1954 het Regeringsreglement van de kolonie Curaçao en onderhorigheden (1865), respectievelijk de Curaçaosche Staatsregeling (1936), de Curaçaose Staatsregeling (1948) en de Landsregeling van de Nederlandse Antillen (1950) bij wet konden worden gewijzigd. Sinds de invoering van het Statuut in 1954 moet de Staatsregeling bij landsverordening gewijzigd worden. De Nederlandse invloed op wetgeving en bestuur van de kolonie was aanzienlijk verminderd. Er is niet gekozen voor de naam 'Grondwet' maar voor de 'Staatsregeling', om verwarring te voorkomen, omdat de Nederlandse Grondwet ingevolge het Statuut gedeeltelijk Grondwet van het gehele Koninkrijk is.

Het aanbrengen van wijzigingen in het Statuut geschiedt bij Rijkswet, aldus art. 55. Het voorstel moet door de drie landen zijn aanvaard. In Nederland geschiedt dat bij gewone wet, behalve indien de herziening een afwijking van de Grondwet oplevert. Dan geldt art. 55 lid 3 Statuut. Aanvaarding in Aruba en de Nederlandse Antillen geschiedt bij landsverordening met tweederde der uitgebrachte stemmen. Wordt deze drempel niet gehaald, maar wel een gewone meerderheid, dan

Zie hiervoor de Overgangs- en slotbepalingen van het Statuut, met name art. 59. 
kan binnen een maand het voorstel worden aanvaard bij gewone meerderheid in tweede lezing. De bepaling is in zoverre merkwaardig, dat de vereisten om het Statuut te wijzigen voor Aruba en de Nederlandse Antillen lichter zijn, dan de vereisten tot wijziging van de Staatsregeling. (Art. VII/1 lid 2 van de Staatsregeling van Aruba geeft aan dat een wijziging van de Staatsregeling slechts kan worden goedgekeurd met $2 / 3$ van het aantal zitting hebbende leden). De Staatsregeling van de Nederlandse Antillen bepaalt in art. 149 lid 2 dat wijziging van de Staatsregeling alleen kan worden goedgekeurd met 2/3 van het aantal uitgebrachte stemmen. En dat terwijl het Statuut een regeling is van de hoogste orde in de Koninkrijksstructuur. Deze betrekkelijk eenvoudige procedure tot wijziging van het Statuut is echter met opzet gekozen om het de landen mogelijk te maken, indien gewenst, de Statuutsrelatie te beëindigen en onafhankelijk te worden. In ieder geval is met deze bepaling vastgelegd, dat beslissingen over de staatkundige toekomst van de (ei)landen alleen met instemming van de Staten kunnen worden genomen. Dit is een uitgangspunt dat men in Nederland in de discussie over de onafhankelijkheid van de eilanden gemakshalve wel eens over het hoofd ziet.

Tussen 1865 en 1950 had de Gouverneur een zeer grote macht in het bestuur van de kolonie. De macht van de Koning werd door het Meerenbergarrest van 1879 beperkt, maar dit gold niet voor de macht van de Gouverneur. Toen in 1936 de Curaçaosche Staatsregeling werd ingevoerd kreeg de Gouverneur meer macht dan hij onder het Regeringsreglement van 1865 bezat, omdat de macht van de Nederlandse regering inzake wetgeving en bestuur werd beperkt. De Gouverneur benoemde vijf van de vijftien leden van de Koloniale Raad, hij was slechts verantwoording verschuldigd aan de Koning. Een aan de Staten verantwoordelijke uitvoerende macht (de ministeriële verantwoordelijkheid) zou pas in $1950 \mathrm{bij}$ de Interimregeling worden ingevoerd. De macht van de Gouverneur werd nog versterkt doordat in de Koloniale Raad veelal ambtenaren zaten, die door de Gouverneur werden aangesteld, geschorst en ontslagen.

De in de jaren veertig gevoelde noodzaak tot hervorming van interne Antilliaanse staatsrecht en herbezinning over de positie van de Gouverneur was boven alle twijfel verheven. ${ }^{89}$ Het rapport van de 
Commissie De la Try Ellis van 1946 gaf blijk van een veelheid van denkbeelden over dit onderwerp. Zo werd het idee geopperd twee Gouverneurs te benoemen, een voor Koninkrijksaangelegenheden, verantwoordelijk aan de Kroon en een voor landsaangelegenheden, die dan verantwoordelijk zou zijn aan de Staten. De Commissie De la Try Ellis wees dit voorstel af, daar zij problemen vreesde door een mogelijke bevoegdhedenoverschrijding van beide functionarissen. Dip vroeg zich af, of die mogelijkheid zich in de huidige situatie niet evenzo zo kunnen voordoen, daar waar de twee functies verenigd zijn in één persoon. Hij had gelijk omdat met het invoeren van de AMvRB voor Sint Maarten in het voorjaar van 1993, wegens het ontbreken van behoorlijk bestuur, de moeilijke positie van de Gouverneur evident was. ${ }^{90}$ Evenmin kon de Commissie vrede hebben met de gedachte van een gekozen Gouverneur naast een door de Kroon te benoemen Gouverneur. Bovendien zou de figuur van een gekozen Gouverneur wel zeer sterk gaan in de richting van een republikeinse staatsvorm. Ook werd nog voorgesteld tussen de Gouverneur en de volksvertegenwoordiging verantwoordelijke personen in te voegen. Deze constructie zou overigens bij de wijziging van de Curaçaosche Staatsregeling in 1948 worden ingevoerd. ${ }^{91}$

De Commissie De la Try Ellis wenste nog geen aan de volksvertegenwoordiging verantwoordelijke uitvoerende macht, omdat het parlementair stelsel door een gebrek aan partijvorming nog niet ontwikkeld was. Derhalve kon ook de ministerièle verantwoordelijkheid niet functioneren. Bij een conflict tussen de volksvertegenwoordiging en de uitvoerende macht, zouden de Staten dan ontbonden moeten worden. De Commissie zag dat als een gevaar voor een stabiele bestuursvoering. Bovendien zou de functie van de Gouverneur in een dergelijk stelsel slechts een representatieve zijn, daardoor zou het Gouverneursambt aan gezag inboeten. ${ }^{92}$ De Interimregeling van 1950 maakte een einde aan de tot dusverre bestaande koloniale verhoudingen. De ministeriële verantwoordelijkheid werd eindelijk een feit.

De ministeriële verantwoordelijkheid, zoals bekend, werd in Nederland ingevoerd als uitvloeisel van de onschendbaarheid van de Koning. De onjuiste regeringsdaden van de vorst werden toegerekend

Besluit houdende enkele tijdelijke voorzieningen in het bestuur van het eilandgebied Sint Maarten van de Nederlandse Antillen, de Minister voor Nederlands-Antilliaanse en Arubaanse Zaken, 14 augustus 1992, nr. 37629; zie hierop het advies van de Raad van State, 's-Gravenhage 18 september 1992, nr. WO1.92.0363/K. De officiële regeling is te vinden in Stb. 1993, 72.

$92 \quad$ Rapport Ellis (1946) pp. 177-183. 
aan zijn ministers, die hem dan verkeerd hadden geadviseerd, immers kritiek op de vorst is niet goed mogelijk, want dat zou kunnen worden opgevat als belediging van de koninklijke majesteit. Dit resultaat van een ontwikkeling, die zich afspeelde binnen een monarchale staatsvorm werd met de invoering van de Interimregeling in 1950 zonder meer in het Antilliaanse staatsrecht overgeplant. Dit achtte Dip niet logisch. Aan invoering in het Antilliaanse staatsrecht van het instituut van verantwoordelijke ministers naast een uit het koloniale staatsrecht afkomstige door de Kroon benoemde, Gouverneur bestond geen behoefte. "Zij geeft tevens blijk van een duidelijk gebrek aan gevoel voor staatkundige psychologie", aldus Dip. ${ }^{93}$

Het Statuut van 1954 en de daaraan aangepaste Staatsregeling van 1955 brachten in de bestaande regeling nauwelijks enige verandering. De Interimregeling ging er vanuit dat er in de Nederlandse Antillen eenzelfde verhouding tussen de Gouverneur en de ministers mogelijk is, als in Nederland tussen de Koningin en de ministers. De Commissie De la Try Ellis had die opvatting al afgewezen, met het zeer steekhoudende argument dat de Gouverneur in de Antillen nimmer als regeringshoofd de plaats van de Koning zou kunnen innemen. Hij zou in interne zaken slechts een representatieve rol kunnen spelen en nimmer het morele gezag kunnen veroveren, dat de Kroon in Nederland bezit. Juist zijn functie als Koninkrijksorgaan heeft hem in staat gesteld invloed uit te oefenen op het interne Antilliaanse staatsrecht, niet zijn functie als regeringshoofd. Dit blijkt ook weer uit zijn taak bij het repressieve en preventieve toezicht als Koninkrijksorgaan bij de invoering van de AMvRB voor Sint Maarten in $1993 .{ }^{94}$

De Gouverneur kan als hij niet mee kan gaan met de verantwoordelijke minister en er toch een voorziening geboden is, de minister niet tussentijds ontslaan, zoals in Nederland wel kan als tenminste de betrokken minister de verantwoordelijkheid wil dragen voor een dergelijke beslissing van de Koning. De minister neemt dan ontslag. Tot tussentijds ontslag van een minister op politieke gronden in de Nederlandse Antillen kan alleen worden overgegaan als de minister voor die beslissing van de Gouverneur de verantwoordelijkheid wil dragen, daarnaast is voor ontslag nodig dat de Gouverneur gebleken

C.E. Dip, Gouverneur en minister in het Antilliasnse staatsrecht (1976) p. 101. Besluit houdende enkele tijdelijke voorzieningen in het bestuur van het eilandgebied Sint Maarten van de Nederlandse Antillen, de Minister voor Nederlands-Antilliaanse en Arubaanse Zaken, 14 augustus 1992, nr. 37629; zie hierop het advies van de Raad van State, 's-Gravenhage 18 september 1992, nr. WO1.92.0363/K. De officiële regeling is te vinden in Stb. 1993, 72. 
is dat de betrokken minister het vertrouwen van de Staten niet meer bezit. Hij mag dat echter niet zelf onderzoeken. De Gouverneur heeft nog het middel van art. 21 Reglement voor de Gouverneur om de impasse aan de Kroon voor te leggen. De constitutionele Koning kan dan zijn mening over het probleem gemotiveerd naar voren brengen. De Gouverneur is voor zijn handelen als Koninkrijksorgaan gerechtelijk vervolgbaar, dat is hij niet als regeringshoofd van het Land. ${ }^{95}$ Ook daarin verschilt zijn positie dus van het onschendbare staatshoofd. Tevens is het Gouverneursambt niet erfelijk, hij wordt voor zes jaar benoemd met slechts één mogelijke verlenging van zes jaar.

Op 12 december 1976 handelde de Gouverneur volgens Dip ${ }^{96}$ correct door aan de Staten een kopie van een brief voor te leggen van de Minister-President, die de Gouverneur meedeelde dat de Ministerraad had besloten de samenwerking met de drie MEP-ministers te beëindigen. De Gouverneur verzocht de Staten hem mee te delen of de betrokken ministers het vertrouwen van de Staten nog bezaten. De MEP was over deze handelwijze zeer ontstemd, sprak van een staatkundige trouvaille en meende dat de collega ministers geen bevoegdheid hebben om over hun medebestuurders te oordelen, zo'n oordeel kwam uitsluitend toe aan de Staten. Volgens de MEP handelde de Gouverneur inconstitutioneel, daar hij lijdelijk diende af te wachten tot hem gebleken was, dat de ministers het vertrouwen van de Staten niet langer bezaten. Tevens zou een minister ook moeten kunnen worden ontslagen als hij in strijd handelt met een besluit van de Ministerraad. Naar de mening van de Mininster-President in deze kwestie handelde de Gouverneur weliswaar onder de verantwoordelijkheid van een minister, maar hij behoudt zijn zelfstandig beoordelingsvermogen en als zodanig heeft hij invloed op tal van regeringsbeslissingen.

In Nederland ligt de verhouding tussen de Koningin en de regering duidelijk vast. De Koningin en de minister treden naar buiten toe als één orgaan op. In de Nederlandse Antillen en Aruba is dat niet het geval en wordt de Gouverneur regelmatig in de pers ernstig gekritiseerd of aangevallen door parlementariërs en ministers. Deze afbakening van bevoegdheden tussen de vertegenwoordiger van het Nederlandse staatshoofd en de Staten wordt ook wel de interne werking van het Statuut genoemd. De problematiek van de interne werking van het Statuut kan in de beginfase na de invoering van het Statuut,

95 De artt. 9, 10 en 11 Reglement voor de Gouverneur.

\% Dip (1976) p. 105. 
worden geillustreerd aan de hand van twee conflicten. De kwestie Van der Meer en de kwestie De Wit, die zich voordeden in het kabinet Jonckheer I (1955-1958). Het ging over de verhouding Staten-Minister-Gouverneur. De ministeriele verantwoordelijkheid in de Nederlandse Antillen kreeg door deze conflicten de kans zich te concretiseren.

In 1951 bepaalde de Landsregeling, zoals opgenomen in de Interimregeling, dat de Gouverneur hoofd was van de Landsregering en de leden van de Regeringsraad verantwoordelijk waren aan de Staten. Dit betekende dat de ministers niet verantwoordelijk waren aan de Gouverneur, maar aan de Staten. De Gouverneur mocht dus alleen datgene zeggen waarvoor de regering bereid was de verantwoordelijkheid te dragen. Op 13 mei 1952 had Gouverneur Struycken de ministeriële verantwoordelijkheid al geweld aan gedaan door in zijn openingsrede van de Staten een opmerking te maken over het geringe aantal aanwezige Statenleden. Wel was de lezing van de Gouverneur vóóraf door de regering goedgekeurd. Maar dat nam niet weg dat de Gouverneur dit niet had mogen zeggen. De Gouverneur heeft, zoals Bagehot dat reeds in 1867 uitdrukte met betrekking tot de Engelse Koning: 'the right to be consulted, the right to encourage, the right tot warn. ${ }^{97}$ Maar dit alles zonder dat eventuele conflicten tussen de Gouverneur, de Staten of de regering naar buiten komen.

De kwestie Van der Meer uitte zich in 1957 als een conflict tussen de Gouverneur en het Kabinet. De Minister van Volksgezondheid en Sociale Zaken, S.W. van der Meer zou de post van Justitie gaan behartigen wegens een reorganisatie in het Kabinet. Hij weigerde echter zijn praktijk als advocaat neer te leggen. Gouverneur Struycken meende dat een advocatenpraktijk niet te verenigen was met het ambt van Minister van Justitie. De zaak liep hoog op en werd met de Koninkrijksregering besproken. Aftreden van de Gouverneur leek onvermijdelijk. Er werd een tijdelijke oplossing gevonden, welke dat was weet niemand, maar zowel de Gouverneur als Minister Van der Meer bleven aan. Kort daarop verliet Struycken Curaçao en werd Minister van Binnenlandse Zaken van Nederland. De regering werd op verzoek van Da Costa Gomez geïnterpelleerd over de staatsrechtelijke positie van de Gouverneur en over de vraag of deze kon weigeren hem voorgelegde conceptlandsverordeningen of besluiten te ondertekenen. Het antwoord was dat de Gouverneur dat in beginsel niet kan weigeren, tenzij een minister voor die weigering de verant- 
woordelijkheid wil dragen. Minister Van der Meer trad in 1959 af wegens de affaire De Wit en is daarna nog jaren werkzaam geweest als advocaat op Curaçao.

De affaire De Wit speelde van 1957 tot 1959. De Wit, die sinds 1940 op Curaçao woonde, had als journalist naar het oordeel van de landsregering voor het land schadelijke artikelen geschreven. Hij had een kritisch artikel overgenomen uit het Amerikaanse weekblad 'Time' over de Venezolaanse vakbeweging. De Antilliaanse regering nam hem dit kwalijk, omdat hij daardoor de goede betrekkingen met Venezuela zou vertroebelen. De hele economie van de Nederlandse Antillen was naar het oordeel van de landsregering immers afhankelijk van de olietoevoer van Venezuela. Minister van Justitie Van der Meer gaf in mei 1957 aan de Procureur-Generaal W.C. van Binsbergen opdracht De Wit uit te wijzen. Dit was mogelijk omdat De Wit als Europese Nederlander op basis van een verblijfsvergunning in de Antillen verbleef. De Wit tekende administratief beroep aan (beroep op de Gouverneur), maar het kabinet wees dit af. De Gouverneur weigerde toen het besluit dat de uitspraak in beroep bevatte, te bekrachtigen omdat hij het in strijd achtte met de fundamentele rechten, waarvan de waarborging een aangelegenheid van het Koninkrijk is. Door de Koninkrijksregering van zijn weigering in kennis te stellen maakte de Gouverneur de zaak tot Koninkrijksaangelegenheid. De Antilliaanse Raad van Ministers achtte de Gouverneur echter niet tot weigering bevoegd. De zaak liep na Nederlandse bemiddeling met een sisser af. Het kabinet-Jonckheer zei het conflict aan de kiezers te willen voorleggen en schreef vervroegde verkiezingen $u^{4} .^{98} \mathrm{Kort}$ na de verkiezingen die geen duidelijkheid brachten, verliet De Wit uit eigen beweging de Nederlandse Antillen. ${ }^{99}$ Dit is een voorbeeld van een situatie dat de Gouverneur als Landsorgaan verplicht is zijn handtekening onder een besluit te zetten, maar dit op grond van zijn bevoegdheid als Koninkrijksorgaan toch zou kunnen weigeren. Gouverneur Koolman van Aruba weigerde in januari 1994 een aantal

Kritisch over de hantering van het onbindingsrecht om deze reden is Dip in: De ontbinding van de Staten (1975) pp. 22-23, zie ook Luiten (1983) pp. 102-103. Keesings Historisch Archief, nr. 1353, mei 1957, p. 13252 e.v. Naar aanleiding van het conflict De Wit, heeft de Minister van Economische Zaken en Welvaartszorg dr. E.J. van Romondt op 13 mei zijn ontslag ingediend. Volgens de Nieuwe Rotterdamse Courant van 9 mei 1957 'doel A. de Wit niets anders dan de ondergang van de Antillen voorspellen, vooral naar aanleiding van de recente ontwikkelingen op bet gebied van de arbeidsverhoudingen'. Na het ontslag van Minister Van Romondt zegde zijn partij, de Curaçaose Onafhankelijke Partij (COP) de medewerking aan de regering op. Zie ook nr. 1369, september 1957, p. 13504.
} 
benoemingsbesluiten te tekenen. ${ }^{100}$

Sinds de affaire De Wit betracht de Gouverneur in de uitoefening van zijn Koninkrijksbevoegdheden uiterste terughoudendheid, want zijn handelen als Koninkrijksorgaan heeft onwillekeurig repercussies op zijn positie als niet zelfstandig handelend Landsorgaan. Aangezien de positie van de Gouverneur als Landsorgaan uit constitutioneel oogpunt de doorslag dient te geven, zal de Gouverneur alles doen om een conflict te vermijden. Toch geeft de Koninkrijks-'pet' aan de Gouverneur een ander gewicht in de interactie met de Antilliaanse of Arubaanse ministers dan aan de Koningin in de vergelijkbare Nederlandse situatie. Uiteindelijk was het gevolg van de affaire De Wit dat de Gouverneur in het Antilliaanse staatsbestel hem voorgelegde ontwerp-landsverordeningen en landsbesluiten moet tekenen en dit niet kan weigeren. Zijn functie is als die van een staatshoofd, althans in zijn relatie tot regering en Staten. ${ }^{101}$

Op grond van de scheiding van machten zoals Montesquieu die voorstond (de Trias Politica) gaat de Nederlandse Grondwet uit van de gedachte dat de rechter de grondwettigheid van de formele wet niet mag beoordelen. Dit beginsel is neergelegd in art. 120 Grondwet. ${ }^{102}$ In recente jurisprudentie is uitgemaakt dat de 'onschendbaarheid van de wet' ook geldt voor het Statuut. Formele wetten mogen niet worden getoetst aan het Statuut. Volgens art. 49 Statuut kunnen bij rijkswet regels worden gesteld omtrent de verbindendheid van wetgevende maatregelen van de landen, die in strijd zijn met het Statuut, een internationale regeling, een rijkswet of een algemene maatregel van rijksbestuur. Het toetsingsrecht van de rechter ten aanzien van wettelijke maatregelen aan Koninkrijksrecht is dus niet in het Statuut zelf geregeld, maar overgelaten aan de rijkswetgever. De toelichting op art. 49 van het Statuut verklaarde dat het niet raadzaam leek hieromtrent in het Statuut zelf te voorzien. Het onder-

Amigoe, 3 januari 1994; het ging voomamelijk om benoemings- en bevorderingsbesluiten. De functic van de Gouverneur als Koninkrijksorgaan botste hier met zijn functie als Landsorgaan. Van Rijn (1993) pp. 115-119. De Gaay Fortman, De WIG, 39, 1959, pp. 1-27; Dip (1976) p. 103.

Artikel 120 Grondwet luidt: "De rechter treedt niet in de beoordeling van de grondwettigheid van wetten en verdragen". Beelaerts van Blokland (1868). 
werp lag te controversieel. ${ }^{103}$ Vrij snel na de inwerkingtreding van het Statuut ontbrandde de discussie over de vraag of de rechter ook zonder nadere regeling door de rijkswetgever bevoegd was formele wetgeving aan het Statuut te toetsen of dat een rijkswet deze bevoegdheid eerst moest vastleggen. ${ }^{104}$

Het duurde tot 1988 , voordat deze vraag aan de rechter werd voorgelegd. ${ }^{105} \mathrm{De}$ in 1988 ingevoerde Harmonisatiewet in Nederland leidde ertoe dat studenten die langer dan zes jaar studeerden hun beurs kwijt raakten. Overgangsbepalingen ontbraken. Een aantal studenten voelde zich gedupeerd en wendde zich tot de rechter met een beroep op het in art. 43 Statuut neergelegde rechtszekerheidsbeginsel. Volgens de rechter hield art. 49 Statuut geen toetsingsverbod in. De rechter oordeelde dat de wet in formele zin getoetst mocht worden aan het Statuut. De Hoge Raad dacht daar anders over. Het feit dat art. 49 Statuut de oplossing van de toetsingskwestie delegeerde, interpreteerde de Hoge Raad als een teken van verzet van de toenmalige Nederlandse regering tegen de invoering van een recht van toetsing aan het Statuut. De Hoge Raad achtte van doorslaggevend belang dat sinds de afkondiging van het Statuut nimmer een wettelijke maatregel aan het Statuut is getoetst. In zoverre kan worden gezegd dat in het Koninkrijksrecht sprake is van een traditie van niet-toetsing, die overeenstemt met hetgeen ingevolge art. 120 Grondwet in Nederland voor de rechter geldt. ${ }^{106}$ Ook in de Nederlandse Antillen werd toetsing aan het Statuut na het Harmonisatiewetarrest al snel beproefd. Een drietal werknemers had bezwaren tegen een landsverordening die hen met terugwerkende kracht van hun aanspraken op een vakantieuit-

Het Werkstuk regelde onder punt 38 lid 1 de onverbindendheid van landsregelingen in elk der landen, als er strijd bestond met internationale regelingen, het Statuut, rijkswerten of algemene maatregelen van rijksbestuur. Hicronder vielen ook de Grondwet en de constituties van de landen. De situatie zou dan ontstaan dat de rechter wet en Grondwet zou moeten toetsen aan het Statuut, terwijl hij de wet niet zou mogen toetsen aan de Grondwet. Logemann achte toetsing aan het Statuut noodzakelijk om de rechtszekerheid te versterken en meende dat de redenen voor het toetsingsverbod die voor Nederland golden (het primaat van de controle van de volksvertegenwoordiging) op Koninkrijksniveau niet opgingen. De regering nam het voorstel niet over, "omdat zij de opvattingen omtrent de verhouding van tractaat en latere wet niet voldoende uitgekristalliseerd achte". Logemann, NJB, 1952, p. 319. Van Helsdingen (1957) pp. 505-509; Logemann (1955) pp. 433-441; Van den Bergh (1955) pp. 221-227.

President Rb. 's-Gravenhage 11 augustus 1988, AA 1988, pp. 776 en 778; HR 14 april 1989, AB 1989, 207, AA 89, pp. 578-529. Voor een duidelijk inzicht in de geschiedenis van het toetsingsrecht, zie de conclusie van A-G Mok bij het arrest van de HR, onderdeel 5 . Statuut van het Koninkrijk. 
kering had beroofd. De werknemers vroegen net als de Nederlandse studenten aan de rechter deze landsverordening onverbindend te verklaren wegens strijd met het in art. 43 Statuut neergelegde rechtszekerheidsbeginsel. Maar zowel de rechter in eerste aanleg ${ }^{107}$ als het Gemeenschappelijk Hof van Justitie ${ }^{108}$ wezen deze vordering af onder verwijzing naar de uitspraak van de Hoge Raad in het Harmonisatiearrest. Vanwege het verbod van toetsing van formele wetgeving aan het Statuut moet worden aangenomen dat toetsing van formele wetgeving aan rijkswetten en algemene maatregelen van rijksbestuur evenmin mogelijk is. ${ }^{109}$

\section{Toepassing van de AMvRB op grond van grove verwaarlozing}

Op 30 januari 1960 werd op verzoek van de Antilliaanse regering en op grond van art. $93^{110}$ van de Staatsregeling Nederlandse Antillen, voorzien in het bestuur van het eilandgebied Curaçao op grond van een Algemene Maatregel van Rijksbestuur (art. 51 Statuut). Er woedde toen een heftig conflict tussen de Eilandsraad en het Bestuurscollege van Curaçao. Het BC werd ontslagen en de gezaghebber M.P. Gorsira werd in zijn eentje met de uitvoerende taken belast en handelde volgens aanwijzingen van de Minister van Algemene Zaken van de Nederlandse Antillen. De Eilandsraad behield haar bevoegdheden.

De aanleiding tot de AMvRB was de gerezen onbestuurbaarheid van het Eilandgebied Curaçao wegens een gebrek aan vertrouwen tussen het Bestuurscollege (BC) en de Eilandsraad. Het Bestuurscollege van Curaçao had geen meerderheid meer en er werd dan ook prompt in de Eilandsraad een motie van wantrouwen aangenomen tegen het BC, welke het College, gevormd uit de oppositie, naast zich neerlegde. Vanaf dat moment voerde de meerderheid van de Eilandsraad een verbitterde strijd om aan het College het besturen zoveel mogelijk onmogelijk te maken. De Eilandsraad weigerde onder andere

GEA-NA/Curaçao 18 december 1989, in: Van Aller/Van Rijn (1992) p. 639 e.v. GHvJ 4 september 1990, Antonia/Paulina vs het Eilandgebied Curaçao, Van Aller/Van Rijn (1991/1992) pp. 634 e.v.

Van Rijn (1991) pp. 16-27; Heringa en Zwart, NJB, 1990. pp. 631-633; Van Maarseveen, NJB, 1990, pp. 625-626; Flinterman en De Winter, NJB, 1990, pp. 627-630; Bongenaar (1985) pp. 249-273 en (1986) pp. 22-36 en pp. 199-222; zie ook Van der Pot/Donner/Prakke (1989) pp. 714 e.v.

Dit artikel luidt: 'Wanneer de regeling en het bestuur van de huishouding van een eilandgebied grovelijk worden verwaarloosd kan een algemene maatregel van Rijksbestuur de wijze bepalen, waarop in het bestuur wordt voorzien.' Logemann (1969) pp. 245-253. De verwantschap met art. 153 lid 4 Grondwet (thans art. 132 lid $5 \mathrm{GW}$ ) komt duidelijk naar voren. 
de begroting voor 1960 te behandelen, alsmede een leningsvoorstel, dienend om in de uitgeputte kasmiddelen te voorzien. Daardoor kwam ook de betaling van de ambtenarensalarissen in het gedrang. Niets hielp om het BC te doen aftreden. Toen de salarissen van de gedeputeerden werden ingehouden, vertrok er slechts én, de COP Gedeputeerde P.J. Evertsz. De overige Gedeputeerden bleven zitten. Zij beriepen zich op art. 47 lid 2 van de ERNA. Zij waren immers gekozen 'voor de gehele duur' van een zittingsperiode. Op verzoek van de Nederlands-Antilliaanse regering werd op 30 januari 1960 een AMvRB afgekondigd, die het $\mathrm{BC}$ ontsloeg. Nadat het $\mathrm{BC}$ was verdwenen, kon de AMvRB worden ingetrokken, wat de Eilandsraad de handen vrij gaf om een nieuw BC te kiezen. Dat College werd op 21 juli 1960 gekozen. Op 22 juli 1960 werd de werking van de AMvRB beëindigd. ${ }^{11}$

Op grond van art. 43 lid 2 Statuut werd ten tweede male ingegrepen door Nederland, naar aanleiding van de ongeregeldheden van 30 mei 1969. ${ }^{112}$ Tweehonderd Nederlandse mariniers werden naar Curaçao gestuurd om samen met de daar gestationeerde vierhonderd mariniers de orde te handhaven. Opvallend is dat, hoewel de Antilliaanse regering zelf om het Koninkrijksingrijpen vraagt, er uiteraard altijd toch een ware polemiek ontstaat, waarbij de termen 'kolonialisme' en 'bevoogding' niet van de lucht zijn. In april 1992 vroeg de Antilliaanse premier M. Liberia-Peters de Koninkrijksregering om militaire bijstand, naar aanleiding van de stakingen van het onderwijzend personeel en de politie. Het verzoek werd ingewilligd. Er was echter alleen een verzoek om hulp van een deel van de aanwezige militairen op Curaçao. De 150 mariniers op Aruba zijn niet in paraatheid gebracht. De bijstand bleek niet nodig te zijn. In de pers werd hierop nauwelijks gereageerd.

Dit lag echter anders met het onder 'curatele stellen' van Sint Maarten, de tweede AMvRB, die onder vigeur van het Statuut van 1954

De rechtmatigheid van het intrekken van de salarissen van de gedeputeerden is voor de rechter uitgevochten. Het HvJ deed op 21 november 1961 uitspraak; Van Voon (1962) pp. 537-579; Logemann (1960) pp. 245-253; Keesings Historisch Archief, nr. 1493 februari 1960, p. 15490 en nr. 1516, juli 1960, p. 15858 e.v. H.C. Walters, Ingezonden stuk in de Amigoe 14 september 1992 naar aanleiding van de afgekondigde AMvRB ter sanering van de bestuurlijke problematiek op Sint Maarten. Deze laatste AMvRB heeft zeer veel publiciteit ontketend.

112 Uiteraard speelden (en spelen) de artt. 41 lid 2 en 43 lid 2 Statuut, evenals de artt. 50 en 51 Statuut een belangrijke rol in een dergelijke situatie. Hier werd ingegrepen op grond van art. 43 lid 2 Statuut. Arrikel 93 Staatsregeling Nederlandse Antillen speelt hier geen rol. 
werd afgekondigd om in te grijpen in het bestuur van de Nederlandse Antillen. ${ }^{113}$ Vanwege de systematiek wordt thans kort ingegaan op de AMvRB voor Sint Maarten. De bestuurlijke en financiële situatie op Sint Maarten liet al jaren te wensen over. ${ }^{114}$ Op 9 juli 1992 deelde de minister van Antilliaanse en Arubaanse Zaken, Hirsch Ballin mede, dat de Koninkrijksministerraad met onmiddellijke ingang had besloten, Sint Maarten in de 'staatsrechtelijke houdgreep' te nemen, om verdere bestuurlijke en financiële chaos te voorkomen. De Landsregering had niet eerder krachtdadig ingegrepen op Sint Maarten, want als A.C. Wathey (DP) zijn steun aan de regeringscoalitie zou intrekken, ontviel de politieke basis aan het kabinet en zouden wellicht nieuwe verkiezingen moeten worden gehouden. De staatkundige houdgreep wordt algemeen als 'koloniaal' gekarakteriseerd, omdat Nederland wel het recht heeft in te grijpen in Sint Maarten, terwijl dit omgekeerd niet mogelijk is, wat werd opgevat als 'eenrichtingsverkeer', aldus een politiek waarnemer ${ }^{115}$ De deugdelijkheid van bestuur moest worden hersteld. De basis voor de uitgevaardigde AMvRB vormden de artt. 92 derde lid en art. 93 van de Staatsregeling van de Nederlandse Antillen.

Artikel 43 Statuut eist dat elk land binnen het Koninkrijk de fundamentele menselijke rechten en vrijheden, de rechtszekerheid en de deugdelijkheid van bestuur verzorgt. Het waarborgen daarvan is een Koninkrijksaangelegenheid. De mogelijkheid om een ongewenste toestand te redresseren, waardoor de rechtsstaat in gevaar komt in de Nederlandse Antillen of Aruba, staan vermeld in de artt. 50 en 51 Statuut, namelijk schorsing en vernietiging door de Koninkrijkskroon of een AMvRB. Het gaat dan met name om Koninkrijksbelan-

NRC-Handelsblad, 6 april 1992.

11 Amigoe 21-5-1992, 22-5-1992, 23-5-1992, 3-6-1992, 5-6-1992, 20-6-1992. Claude Wathey, leider van de DP, meldde dat hij geen enkel heil zag in de uitvoering van de aanbevelingen van het rapport van de Commissie Pourier: Amigoe, 22 juni 1992. 1 juli 1992. Ook de Commissie Bakhuis waarschuwde in 1979 al voor de bestuurlijke chaos die op Sint Maarten dreigde. Een belangrijke oorzaak voor de nu ontstane impasse, is het gebrek aan daadkracht in Willemstad. Volgens het rapport Pourier werden slechte besluiten van het bestuur op Sint Maarten niet voor vernietiging bij de Gouverneur voorgedragen uit vrees dat de DP van Sint Maarten, die geleid werd door machthebber Claude Wathey, zich uit het Antilliaanse kabinet zou tenugtrekken. In een politiek klimaat waarin de belangen zo zijn verstrengeld, worden de uitgangspunten van het Statuut voor het Koninkrijk - rechtmatigheid en deugdelijkheid - een farce; NRC Handelsblad 3-8-1992 en 11-8-1992. Zie ook de Inleiding van Memorie van Toelichting KABNA begroting 1993, pp. 7-9; Gorsira: 'Staatsrechtelije houdgreep niet onrechtmatig, preventieve maatregelen niet uitgesloten', Amigoe, N̄apa, 19-9-1992.

11) NRC Handelsblad 1 en 11 juli 1992. Amigoe 24 juli en 25 juli 1992, 'Hirsch Ballin legt weifelend advies Antilliaanse regering naast zich neer.' De kranten schreven in juni, juli, augustus, september en oktober 1992 dagelijks over deze problematiek. 
gen. Naast deze algemene voorziening in het Statuut bestaat de bijzondere bepaling in de artt. 92 derde lid en 93 van de Staatsregeling Nederlandse Antillen. In de Grondwet bestaat een analoge bepaling in art. 132 lid 5. Deze artikelen worden alleen toegepast in een abnormale situatie. Normaal kan worden volstaan met repressief toezicht. De AMvRB die ten aanzien van Sint Maarten werd getroffen is repressief van aard, omdat de ingreep is genomen als gevolg van de wanordelijke situatie aldaar en niet ter voorkoming daarvan. Er is dus geen sprake van preventief toezicht, waardoor de zelfstandigheid van het land of het eiland wordt aangetast. In dat verband kunnen wel preventieve maatregelen worden getroffen, zo luidde de officiële verklaring. In feite ging het echter wel degelijk om preventief toezicht. Voor Aruba zou in een dergelijke situatie alleen art. 51 Statuut van toepassing kunnen zijn.

De Raad van State (RvS) van het Koninkrijk was naar aanleiding van de ontwerp AMvRB van mening dat er conflicten konden ontstaan tussen de Gezaghebber en de Gouverneur en de Gouverneur en de Landsregering. De RvS meende dan ook dat het te overwegen viel om dan beroep op de regering van het Koninkrijk open te stellen. Tevens was de Raad van mening dat de bevoegdheden van de Gouverneur met betrekking tot goedkeuring niet eenduidig waren. Niet duidelijk was wanneer de Gouverneur als Landsorgaan goedkeurde en wanneer als Koninkrijksorgaan. Het was niet evident wat er moest gebeuren indien de Gouverneur en de verantwoordelijke Landsminister van mening verschilden over een te nemen maatregel. ${ }^{116}$ Artikel 5 het vijfde lid gaf voor het BC binnen een termijn van dertig dagen een beroepsmogelijkheid op de Kroon, voor het geval dat de Gouverneur aan een wettelijk besluit zijn goedkeuring onthoudt. ${ }^{117}$

Met ingang van 25 februari 1993 werd de AMvRB voor Sint Maarten ingevoerd. De Gouverneur stelde vooraf als orgaan van het Koninkrijk de Antilliaanse Ministerraad in kennis van het voornemen om een vernietigingsbesluit te nemen. De Ministerraad kon dan beoordelen of er gronden aanwezig zijn voor preventief toezicht. Als dat zo is, zal het besluit worden genomen door de Antilliaanse regering, waarbij de Gouverneur optreedt als orgaan van het Land. In alle andere gevallen treedt hij op als orgaan van het Koninkrijk. In beginsel geldt de maatregel voor een jaar, maar er zal worden $/ \mathrm{K}$.

117 Besluit van 2 februari 1993, houdende enkele tijdelijke voorzieningen in het hestuur van het eilandgebied Sint Maarten van de Nederlandse Antillen, Stb. 1993, 72. 
geëvalueerd of verlenging noodzakelijk is. ${ }^{118}$

Precies honderd jaar na de historische Grondwetsherziening van 1848 , waarbij de ministeriële verantwoordelijkheid in de Grondwet werd vastgelegd, onderging de Nederlandse Grondwet opnieuw een wijziging waar geschiedenis mee werd gemaakt. Nederlands-Indië zou onder de naam 'de Verenigde Staten van Indonesië' een onafhankelijke Staat worden, maar die Staat en het Koninkrijk der Nederlanden zouden zich verenigen tot de Nederlands-Indonesische Unie met behoud van ieders onafhankelijkheid en soevereiniteit. Deze Unie zou op 'eigen naam' aan het internationale rechtsverkeer deelnemen. Formeel kwam de Nederlands-Indonesische Unie tot stand, maar het als groots bouwwerk geconstrueerde lichaam bleek doodgeboren.

Nauwelijks was in 1954 de mislukking van deze Unie erkend, of een project op kleinere schaal kwam van de grond, maar met beter resultaat. In een bepaald opzicht is de invoering van het Statuut te beschouwen als een herhaling van het plan dat met de NederlandsIndonesische Unie werd beoogd. Ook bij de inwerkingtreding van het Statuut werd een gedeelte van het Koninkrijk der Nederlanden afgesplitst, dat daarvoor een afzonderlijk onderdeel vormde met een afzonderlijke (koloniale) status. Dat onderdeel werd als gelijkwaardige partner aanvaard en opgenomen in een nieuwe hogere eenheid. In de Oost ging het echter om én partner, maar in de West om twee.

Het nieuwe Koninkrijk der Nederlanden omvatte drie staatkundige verbanden: Nederland, Suriname en de Nederlandse Antillen. De nieuwe rechtsorde met de West kwam dus tot stand nadat die met de Oost was mislukt. Maar beide stamden uit een gezamenlijke opzet. Het was de bedoeling geweest dat zij tegelijkertijd in werking zouden treden. De volgorde was eerder andersom bedoeld, eerst de nieuwe eenheid met Suriname en de Nederlandse Antillen en daarna trapsgewijs het grotere en hogere verband met de Unie. Deze opzet was neergelegd in het veertiende hoofdstuk van de Grondwetswijziging van 1948.

Bij de invoering werd het vernieuwde Koninkrijk aangeduid met 'het Koninkrijk der Nederlanden'. Daarmee was al onmiddellijk een akelig misverstand geschapen, omdat het Koninkrijk al sinds 1815 zo heette. Zonder de kwestie scherp te stellen ging men ervan uit dat er dus altijd nog maar één Koninkrijk was, het oude maar gereorgani- 
seerde Koninkrijk, dat voor de vastelandszaken de Grondwet had behouden en voor de contacten met de West een Statuut had gekregen. Dit leidde dan ook in 1962 tot vragen in de Kamer van de Surinaamse gedelegeerden, die van mening waren dat een Rijkswet niet door een gewone vergadering van de Tweede Kamer kon worden behandeld, maar zou moeten worden behandeld door een Tweede Kamer in zitting bijeen volgens het Statuut.

Weliswaar is met het Statuut de kiem gelegd voor de samenwerking van de drie op voet van gelijkwaardigheid verbonden Staten, maar overigens is de partner Nederland in beduidende mate overwicht blijven behouden. De aparte Koninkrijksorganen volgens bet Statuut bleken in overwegende mate Nederlandse staatsorganen te zijn, ook al bedoelde het vijfde lid van art. 86 Grondwet van 1948 een afzonderlijk Koninkrijk met eigen organen in het leven te roepen. Die uitwerking kon echter niet worden doorgevoerd omdat de Unie met Indonesië de facto niet kon worden geconcretiseerd. ${ }^{119}$

Ook heeft de rechtspersoonlijkheid van het 'nieuwe' Koninkrijk tot verwarring aanleiding gegeven. Artikel 1 Boek 2 BW geeft een opsomming van publiekrechtelijke rechtspersonen. De Staat is rechtspersoon. De organisatorische verbanden die de staatstaak uitoefenen hebben over het algemeen geen rechtspersoonlijkheid. Het statutaire Koninkrijk der Nederlanden heeft geen privaatrechtelijke rechtspersoonlijkheid, omdat het Koninkrijk geen subject van privaatrechtelijke rechten of verplichtingen kan zijn. Het Koninkrijk heeft wel publiekrechtelijke rechtspersoonlijkheid. De samenstellende delen van het Koninkrijk: de Staat der Nederlanden, het Land de Nederlandse Antillen en het Land Aruba zijn publiekrechtelijke rechtspersonen met privaatrechtelijke rechtspersoonlijkheid. ${ }^{20}$

Gerlings, NWIG, 48, 1971, pp. 135-155.

120 Zie: Van der Grinten (1991) p. 161; Het Koninkrijk der Nederlanden als zodanig heeft volgens de gezaghebbende schrijvers geen privaatrechtelijke rechtspersoonlijkheid, omdat deze grondwettelijke Staat geen eigen vermogen heeft. Dit betekent dat nimmer een rechtsvordering tegen het Koninkrijk kan worden ingesteld. Een rechtsvordering zal moelen worden ingesteld tegen één der Landen. Zie Hof 'sGravenhage, 3 februari 1958, NJ 1958, 434, Erven Eman vs het Koninkrijk der Nederlanden en de Staat der Nederlanden (de procedure werd gevoerd tegen het statutaire Koninkrijk der Nederlanden), Van Helsdingen, Het Statuut (1957) p. 457. Volkenrechtelijk gezien is het Koninkrijk drager van rechten en plichten. In staatsrechtelijk opzicht bezien is voor het naleven van volkenrechtelijke verplichtingen de privaatrechtelijke rechtspersoonlijkheid niet vereist; Statuut voor het Koninkrijk, Nederlandse Staatswetten, Editic Schuurman en Jordens, I-III, Deel III (1988) pp XXII $t / m$ XXV. 
Met de totstandkoming van het Statuut heeft het Nederlandse constitutionele recht een ingrijpende wijziging ondergaan. Sinds 1813 was de Grondwet de hoogste regeling in het Koninkrijk, waaraan alle andere vormen van regelgeving ondergeschikt waren. Voortaan wordt deze positie ingenomen door het Statuut. De Grondwet komt op de tweede plaats, zij dient de bepalingen van het Statuut in acht te nemen (Statuut art. 5 tweede lid). Het Statuut bracht de juridische bevestiging en vormgeving van de belangrijke politieke ontwikkelingen sinds de Tweede Wereldoorlog in de relatie tussen Nederland, Suriname en de Nederlandse Antillen. Het smeedde deze landen samen in een nieuwe, vrijwillig aangegane, gezamenlijke rechtsorde.

Geconstateerd kan worden dat het uiteindelijk resultaat aanzienlijk afwijkt van wat aanvankelijk in 1948 werd afgesproken: een federale structuur, theoretisch zuiver van opzet, maar naar te voorzien viel in de praktijk te omslachtig en te weinig soepel functionerend. In plaats daarvan kwam men uit bij een model dat enerzijds uitging van de in het veertiende hoofdstuk van de Grondwet van 1948 neergelegde voorwaarden, maar anderzijds gericht was op een praktische toepassing, rekening houdend met de feitelijke situatie van grote fysieke afstand tussen Nederland en de andere partners en het onderscheid in bevolkingsaantal en draagvlak. ${ }^{121}$ De totstandkoming van het Statuut was een niet geringe prestatie. Rekening moest worden gehouden met in Nederland bestaande wensen, waar het afstand nemen van Nederlandse zeggenschap en Nederlandse bestuursmodellen nog lang niet vanzelfsprekend werd gevonden, én met de wensen van de landen overzee, waar een grote gevoeligheid bestond voor het zichtbaar maken in de nieuwe constructie van de zelfstandigheid en gelijkwaardigheid van de landen. Dat leidde tot een ingenieus in elkaar gezet stelsel met een sterke nadruk op formele gelijkwaardigheid, maar toch tegelijk met een feitelijk overwicht in de besluitvorming bij de Nederlandse organen. Het is dan ook onvermijdelijk dat de Statuutsconstructie 'les défauts de ses qualités' vertoont. ${ }^{12}$

De belangrijkste punten in het Statuut waren dat er nu voor het eerst een scherpe bevoegdheidsverdeling ontstond tussen het Koninkrijk en de samenstellende delen van het Koninkrijk. Het Statuut legt

$121 \quad$ Polak (1966) pp. 7-45; Luiten (1983) p. 69.

122 In 1956 werd de Grondwet aangepast aan de nieuwe rechtsorde. De artt. 69, 70 en 71 , die vanouds op het bestuur van de overzeese rijksdelen betrekking hadden, konden nu worden geschrapt. Ingevoegd werd een nieuw artikel 213, waarin de mogelijkheid werd geopend de tekst van de Grondwet bij wet met het Statuut of met een wijziging van het Statuut in overeenstemming te brengen; Van Helsdingen, De WIG, 35, 1955, pp. 182-191. 
sterk de nadruk op de formele gelijkwaardigheid van de Landen, maar inhoudelijk hebben Nederlandse organen een feitelijk overwicht in de besluitvorming. Door de 'inspraak' van de Gevolmachtigde Minister is de invloed van de Koninkrijksdelen overzee in Koninkrijksaangelegenheden verzekerd. De besluitvorming inzake wetgeving en bestuur betreffende het Koninkrijk kan door de Caraibische landen niet geblokkeerd worden.

Om de naleving van de grondrechten, deugdelijk bestuur en financieel beheer te verzekeren, werd hoger toezicht op de wetgeving en het bestuur van de Koninkrijksdelen overzee vastgelegd. Dit kon zowel preventief als repressief toezicht zijn. De Koninkrijksregering kan zowel preventief als repressief toezicht uitoefenen ten aanzien van de Caraïbische landen, deze maatregelen kunnen door de Koninkrijksregering niet aan Nederland worden opgelegd. ${ }^{123}$ Een gemis is dat de Rijkswetgever nagelaten heeft een mogelijkheid te scheppen voor toetsing van formele wetgeving aan het Statuut. ${ }^{124}$

Ruim 20 jaar heeft het Statuut ongewijzigd gefunctioneerd. Naar aanleiding van de ongeregeldheden in Willemstad in 1969, werden omstreeks 1970 zowel in Nederland als overzee meer en meer geluiden vernomen, die de Statuutsrelatie ter discussie stelden. ${ }^{125}$ In Suriname leidde dit tot het verbreken van de statutaire band en volledige onafhankelijkheid in 1975. De ontwikkelingen in Suriname bekoelden in de Nederlandse Antillen de lust om onafhankelijk te worden, voor zover al aanwezig. In de jaren na 1975 eiste binnen de Koninkrijksrelatie het streven van Aruba naar verwezenlijking van het zelfbeschikkingsrecht de meeste aandacht op. Aruba werd op 1 januari 1986 een afzonderlijk Land binnen het Koninkrijk. De medewerking van Nederland aan het creëren van een 'Status Aparte' voor Aruba ging niet van harte, omdat vrees bestond voor verdere fragmentatie van de Antillen. Daarom werd onder krachtige Nederlandse aandrang tevens in het Statuut vastgelegd dat ten aanzien van Aruba de rechtsorde, neergelegd in het Statuut, met ingang van 1 januari 1996 zou eindigen (art. 62 Statuut). Aruba werd op termijn juridisch onafhankelijk verklaard. Deze 'koppelverkoop' werd door Aruba

Janus (1993) pp. 33-92, zie met name pp. 40-43.

Van Rijn (1993) pp. 93-125.

Ter gelegenheid van de viering van het eerste lustrum van de ondertekening het Statuut op 15 december 1959 werd op initiatief van de juweliersfirma Spritzer en Fuhrmann (Curaçao en Aruba) een penning uitgegeven. De penningen waren verkrijgbaar in brons, zilver en goud. De drie gestileerde vogels stellen de drie parners van het Koninkrijk voor; de golven de saamgebondenheid van de Koninkrijksdelen en de Oranjebloesem symboliseert het Huis van Oranje. De tekst op de penning luidde: 'Vrij heet wat zich gebonden weet'. Keesings Historisch Archief, nr. 1486 , december 1959 , p. 15374.

Evaluatie Statumt . 301 
morrend aanvaard, omdat men er op zichzelf geen behoefte aan had de Statuutsrelatie te verbreken. ${ }^{126}$

Met de inwerkingtreding van het Statuut vervielen de eerste en derde titel van de Interimregeling. Dit was vastgelegd in art. 58 van het Statuut. De tweede titel kon niet tegelijkertijd vervallen, want zij bevatte de Landsregeling. Aangezien deze bij landsverordening zou moeten worden gewijzigd, heeft deze tweede titel volgens art. 57 van het Statuut de status van landsverordening gekregen. Conform art. 42 lid 1 van het Statuut hebben de Nederlandse Antillen gebruik gemaakt van de mogelijkheid om de Landsregeling Staatsregeling te noemen. In het eerste hoofdstuk van de Staatsregeling wordt het grondgebied van de Antillen aangeduid: de vijf eilandgebieden (art. 1) zijn Curaçao en Klein Curaçao, Bonaire en Klein Bonaire, Saba, Sint Eustatius en Sint Maarten (Nederlandse deel).

Bij landsverordening van 11 februari $1983^{127}$ werd het eilandgebied de Bovenwindse eilanden gesplitst in drie afzonderlijk eilandgebieden: Saba, Sint Eustatius en Sint Maarten, elk met een Eilandsraad en een Bestuurscollege bestaande uit een Gezaghebber en twee Gedeputeerden. Artikel 2 van de Staatsregeling van de Nederlandse Antillen noemt de regelingen, die in de Nederlandse Antillen geldig zijn. Genoemd worden het Statuut, de overeenkomsten met andere mogendheden en met volkenrechtelijke organisaties, voorzover zij in de Nederlandse Antillen van toepassing zijn en de algemene verordeningen.

Voorts bevat het eerste hoofdstuk van de Staatsregeling van de Nederlandse Antillen, bepalingen over uitlevering van vreemdelingen, over toelating en vestiging alsmede uitzetting van Nederlanders (bij landsverordening te regelen met inachtneming van art. 3 lid 1 onder f Statuut). De Staatsregeling bevat enkele voor de burgers zeer belangrijke fundamentele rechten (op grond van de Grondwet van 1948). ${ }^{128}$

Het tweede hoofdstuk van de Staatsregeling is gewijd aan de Gouverneur. De positie van de Gouverneur als Koninkrijksorgaan is

Gerlings, NWIG, 48, 1971, pp. 135-155; Tien jaar Statuut, NWIG, 44, 1965, pp. 4-74; Borman (1988) p. 3 e.v.

127 PB 1983, 20.

128 Voor een vergelijkend overzicht van de huidige grondrechtenartikelen in de Arubaanse en Nederiands-Antilliaanse Staatsregeling, zie De Rechtsorde (1986) p. 43 , noot 28 . 
geregeld in het Reglement voor de Gouverneur. Zijn positie als hoofd van de landsregering is geregeld in de Staatsregeling (de artt. $11 \mathrm{t} / \mathrm{m}$ 27). Het derde hoofdstuk van de Staatsregeling behandelt de Raad van Advies, de Raad van Ministers en de Gevolmachtigde Minister (de artt. $32 \mathrm{t} / \mathrm{m}$ 37). De Raad van Advies is in 1948 in de plaats gekomen van de vroegere Raad van Bestuur. De Raad van Advies is te vergelijken met de Raad van State in Nederland. De Raad van Ministers vormt met de Gouverneur de regering van het Land. Hoofdstuk vier betreft de Staten (de artt. $44 \mathrm{t} / \mathrm{m}$ 87). De leden van de Staten worden rechtstreeks door de kiezers gekozen in vrije en geheime verkiezingen.

Elk eilandgebied vormt een kieskring (art. 44). De Gouverneur benoemt voor elke zitting van de Staten een voorzitter en een ondervoorzitter uit een voor ieder afzonderlijk door de Staten in te dienen voordracht van twee leden (art. 56). De gewone zitting wordt jaarlijks op de tweede dinsdag van mei geopend. De wetgevende macht van de Staten, samen met de constitutionele Gouverneur is geregeld in de artt. $67 \mathrm{t} / \mathrm{m} 87$. Hoofdstuk vijf betreft de eilandgebieden (artt. 88 $\mathrm{t} / \mathrm{m}$ 93) en de plaatselijke gemeenschappen (de artt. $94 \mathrm{t} / \mathrm{m}$ 96) aan de instelling van zelfstandige plaatselijke gemeenschappen is tot dusverre nooit uitvoering gegeven. De Eilandenregeling (ERNA) regelt de zelfstandigheid van de verzorging van de eigen aangelegenheden van de eilandgebieden ten opzichte van het Land. De volgende hoofdstukken zijn achtereenvolgens gewijd aan: het rechtswezen

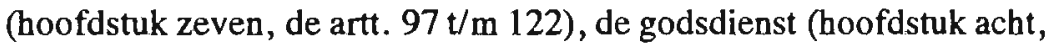
de artt. $123 \mathrm{t} / \mathrm{m} \mathrm{127}$ ), de financiën (hoofdstuk negen, de artt. $128 \mathrm{t} / \mathrm{m}$ 134), de defensie (hoofdstuk 10, de artt. $135 \mathrm{t} / \mathrm{m} \mathrm{138}$ ), het onderwijs, de openbare gezondheid en het armbestuur (hoofdstuk elf, de artt. 139 $\mathrm{t} / \mathrm{m}$ 142), de volksvlijt (hoofdstuk twaalf, de artt. $143 \mathrm{t} / \mathrm{m} \mathrm{147)}$ ). Verschillende artikelen alsmede de indeling in hoofdstukken zijn ontleend aan de tekst van de Nederlandse Grondwet van 1972. In de Defensiewet voor de Nederlandse Antillen en Aruba ${ }^{129}$ zijn de bepalingen van de artt. $30 \mathrm{t} / \mathrm{m} 34$ Statuut nader uitgewerkt. ${ }^{130}$ De verdediging van Nederland, de Nederlandse Antillen en Aruba is een aangelegenheid van het gehele Koninkrijk. Er is dus maar een krijgsmacht voor het gehele Koninkrijk en de dienstplichtigen in de Nederlandse Antillen en Aruba vervullen hun dienstplicht bij de onderdelen van die krijgsmacht die zich in deze landen bevinden.

129

t30 Paula (1989) pp. 52-66; Van Helsdingen (1956) pp. 1-40; Luiten (1983) pp. 69-74; Van der Pot (1989) pp. 697-729. 
Periode VIII wordt in drie hoofdstukken behandeld. Het eerste hoofdstuk (VI) van de beschreven periode (1950-1969) maakt duidelijk dat Nederland na de oorlog Nederlands-Indiē hoopte te behouden. Deze omstandigheden maakten het onmogelijk de nieuwe rechtsorde in te voeren. In afwachting van een definitieve regeling kwam de Interimregeling tot stand. Achteraf bleek de Interimregeling toch de basis voor een definitieve regeling (het Statuut van 1954) te zijn.

Tegelijk met de Interimregeling werd de ERNA ingevoerd. De Interimregeling wijzigde de voor Aruba gunstige gelijke zetelverdeling met Curaçao in 12 zetels voor Curaçao en 8 voor Aruba. Bij de invoering van de ERNA kreeg Curaçao voor de eerste keer een eilandelijk bestuur.

Aruba had grote moeite met de invoering van gewijzigde zetelverdeling, evenals met de invoering van de Interimregeling en de Eilandenregeling, die niet aan de autonomiegedachte van Aruba tegemoet kwam. Aruba hoopte dat de autonomie geregeld zou worden door het Statuut. De Staatsregeling werd nu Landsregeling genoemd en maakte een integraal onderdeel uit van de Interimregeling.

Het zelfbeschikkingsrecht speelde in de onderhandelingen over het Statuut een belangrijke rol. De Nederlandse Antillen wensten meer zelfstandigheid dan Nederland bereid was toe te staan. De Nederlandse Antillen zagen een federatie op grond van zelfstandige eilanden als een goede mogelijkheid, terwijl Nederland een Eilandenregeling wenste op grond van de Gemeentewet, met preventief en repressief toezicht op wettelijke en bestuurlijke maatregelen. De enige concessie die aan de federale gedachte werd gedaan, was de duidelijke opsomming van Landstaken. Alle overblijvende bevoegdheden zouden aan de eilanden toekomen.

Het zelfstandig bestuur van de eilanden heeft nooit goed gefunctioneerd, omdat de Landsregering de in de Eilandenregeling gegeven bevoegdheden, niet aan de eilanden overdroeg. Binnen de ERNA hadden de eilanden een grote mate van zelfstandigheid kunnen bereiken als het Land de voorziene taken had overgedragen aan de eilanden. Daar de eilanden geen ervaring hadden in zelfbestuur is het begrijpelijk dat die overdracht in het begin stagneerde. Maar in een later stadium had die overdracht wel kunnen geschieden. Dat zou echter hebben betekend dat een groot aantal Landsambtenaren op andere eilanden zou moeten worden gestationeerd. Daar bijna alle Landsdienaren afkomstig waren van Curaçao, zagen zij zich ongaarne van Curaçao overgeplaatst worden. De oorzaak van de stagnatie van overdracht van Landstaken lag dus niet zozeer in een ontoereikende 
Eilandenregeling, maar meer in de uitvoering van de regeling door het Land.

Als de ERNA zou zijn uitgevoerd zoals voorzien, zou dat de rivaliteit tussen Curaçao en Aruba grotendeels hebben kunnen opheffen en niet in een later stadium hebben behoeven te leiden tot de eis voor Status Aparte van Aruba. Dat blijkt ook uit de onderhandelingen op de RTC over de invoering van het Statuut en de interpretatie van het zelfbeschikkingsrecht, zoals hierboven uiteengezet.

Het Statuut werd in 1954 ingevoerd. Het werd vrijwillig door de drie Landen aanvaard. Er kwamen geen aparte Koninkrijksorganen. De Koninkrijksorganen werden gevormd door het Nederlandse parlement en de Nederlandse regering, met inspraak van de Nederlandse Antillen. Het Statuut paste binnen het bestaande Nederlandse staatsrechtelijke systeem. Een federatieve opbouw met overkoepelende organen week daar teveel vanaf. Een diepgaande herziening van het staatsrechtelijk bestel in federatieve zin bleek voor Nederland niet aanvaardbaar. Het Statuut werd uiteindelijk niet gebaseerd op een federale constitutie, maar evenmin kon worden gesproken van een volkenrechtelijk samenwerkingsverband. De drie partners zijn geen soevereine staten, maar drie landen binnen één staatsverband. De soevereiniteit berust bij het Koninkrijk der Nederlanden. Het Statuut is staatsrechtelijk gezien een regeling van geheel eigen aard. Van een federatie is geen sprake, omdat de drie samenstellende delen van het Koninkrijk, Nederland, Aruba en de Antillen de facto niet gelijkwaardig zijn. De Koninkrijksbelangen worden immers behartigd door Nederlandse organen, die voor die gelegenheid aangevuld worden met een Arubaansof Antilliaans element. Van een volkenrechtelijk samenwerkingsverband is ook geen sprake, aangezien Suriname en de Antillen bij de totstandkoming van het Statuut niet onafhankelijk wilden worden en ook volkenrechtelijk geen staat werden. Er bestaat geen rechterlijke controle op de verdeling van bevoegdheden. De Koninkrijkswetgever beslist zelf over eventuele conflicten naar aanleiding van de competentieverdeling tussen de landen en het overkoepelend orgaan. Bovendien bestaat er een zekere hiërarchische verhouding tussen de twee omdat er toezicht mogelijk is vanwege het Koninkrijk op het doen en laten van de landen.

Het Statuut heeft federale trekken. Er is immers sprake van drie autonome landen, die vrijwillig samenwerken in een verband, dat eigen organen heeft en waarin de bevoegdheidsverdeling zodanig is geregeld, dat de bevoegdheden van het overkoepelend orgaan limitatief zijn opgesomd, terwijl alle overige bevoegdheden aan de afzon- 
derlijke landen toekomen. Binnen de door het Statuut gecreëerde rechtsorde behartigen de landen zelfstandig hun eigen belangen. De gemeenschappelijke belangen worden op voet van gelijkwaardigheid. verzorgd en de landen verlenen elkaar wederkerig hulp en bijstand. $\mathrm{Er}$ is sprake van een regeling 'sui generis', die niet valt onder te brengen in de gangbare categorieën.

De artikelen 50 en 51 stellen het Koninkrijk in staat maatregelen te treffen ten aanzien van de Antillen en Aruba als de bepalingen van het Statuut niet worden nageleefd. Die regeling geldt niet voor het Europese deel van het Koninkrijk. De artikelen 50 en 51 Statuut bevatten een vorm van curatele, waarvan men zich kan afvragen of zij in de huidige tijd nog aanvaardbaar is. Zij doorbreekt de gedachte van gelijkwaardigheid, omdat de curatele niet voor Nederland geldt.

Op grond van art. 49 Statuut kunnen bij rijkswet nadere regels worden gesteld omtrent de verbindendheid van wetgevende maatregelen van de landen die in strijd zijn met het Statuut, een internationale regeling, een rijkswet of een algemene maatregel van rijksbestuur. De rijkswetgever heeft nagelaten het rechterlijke toetsingsrecht van wettelijke maatregelen aan Koninkrijksrecht te regelen.

Toetsing van de formele wet aan internationale regelingen is sinds de jaren zestig mogelijk. Toetsing aan de Staatsregeling en het Statuut werd in het Nederlandse staatsrechtelijke bestel steeds als onmogelijk gezien. De volksvertegenwoordiging wordt nog beschouwd als de instantie, die het laatste woord dient te hebben over de verbindendheid van de wetgeving en niet de rechter. Dit komt overeen met de Trias Politica gedachte, dat de hoogste macht bij het volk ligt. En het volk wordt in een parlementaire democratie vertegenwoordigd door de volksvertegenwoordiging, die de regering controleert.

De Hoge Raad heeft tot op heden toetsing aan het Statuut afgewezen, op grond van de overweging dat nooit aan het Statuut getoetst is. Dit zou kunnen veranderen in de toekomst, omdat in Nederland stemmen opgaan om formele wetten te kunnen toetsen aan hoofdstuk I van de Grondwet, waarin de grondrechten staan vermeld. Toetsing van de formele wet aan de Staatsregeling van de Nederlandse Antillen of de Grondwet is niet mogelijk. In Aruba kan de formele wet (de landsverordening) sinds 1 januari 1986 wel getoetst worden aan hoofdstuk I van de Arubaanse Staatsregeling: de grondrechten. Zo treedt dus onder invloed van de praktijk een verandering in het denken op over de werking van de machtenscheiding. In deze heeft het Koninkrijk overzee een voorbeeldfunctie.

Het Statuut leidde tot een andere invulling van het ambt van Gouverneur. Nadat de volledige ministeriële verantwoordelijkheid in 1948 
was ingevoerd kostte het tijd om de verhouding tussen Gouverneur en regering en Gouverneur en Staten te concretiseren. De Gouverneur was de vervanger van het staatshoofd in het Koninkrijk overzee. Hij was onschendbaar, de ministers waren verantwoordelijk. Het ambt van Gouverneur werd meer ceremonieel van aard. De onbeperkte macht van de Gouverneur werd door de werking van het parlementair stelsel meer in overeenstemming gebracht met heersende opvatting over het functioneren van het staatshoofd binnen de Nederlandse staat.

In Nederland ligt de verhouding tussen de Koningin en de regering duidelijk vast. De Koningin en de minister treden naar buiten toe als én orgaan op. In de Nederlandse Antillen en Aruba en Aruba is dat niet het geval en wordt de Gouverneur ook nu nog regelmatig in de pers ernstig gekritiseerd of angevallen door parlementariërs en ministers. Dit onderdeel van de werking van het parlementair stelsel is dus nog niet uitgekristalliseerd.

De Landsregeling van 1950 werd in 1955 aangepast aan het Statuut en volgde inhoudelijk de Nederlandse Grondwet. De Landsregeling kreeg weer de naam van Staatsregeling. De bevolking van het Koninkrijk overzee bezat dezelfde grondrechten als andere Nederlanders en de invloed van de burgers kon gestalte krijgen in de werking van het parlementaire stelsel. De scheiding van machten, met name de relatie tussen de Gouverneur en de regering en tussen de Gouverneur en de Staten kreeg vorm door een aantal conflicten die zich voordeden.

De hierboven besproken periode, met name de invoering van de Interimregeling, de ERNA, het Statuut en de Staatsregeling van de Nederlandse Antillen zijn van groot belang geweest voor de parlementaire democratie. In de Interimregeling werden belangrijke wijzigingen aangebracht. De Nederlandse Antillen mochten hun eigen aangelegenheden zelf gaan behartigen. Er kwam in de Landsregeling een aan de Staten verantwoordelijke Regeringsraad, die samen met de Gouverneur de Landsregering vormde. Geconcludeerd kan worden dat de Interimregeling de positie van de Gouverneur fundamenteel wijzigde. Hier werd namelijk de figuur van de Gouverneur als constitutioneel orgaan overeenkomstig de positie die de Koningin in het Nederlandse staatsrecht inneemt, geïntroduceerd. Artikel 12 Interimregeling bepaalde dat de Gouverneur hoofd is van de Landsregering en de leden van de Regeringsraad verantwoordelijk zijn aan de Staten. Artikel 2 Statuut 1954 behield dit beginsel (art. 2 de leden 1 en 2). Deze bepaling vindt men thans ook terug in art. 11 Staatsregeling van de Nederlandse Antillen en art. II.1 van de Staatsregeling 
van Aruba. De Gouverneur is de plaatsvervanger van de Koning en als zodanig onschendbaar. De invloed van het Nederlands bestuur op het bestuur van de Nederlandse Antillen, nu een zelfstandig land binnen het Koninkrijk was sterk verminderd.

De parlementaire democratie was volwassen geworden. De opbouw van de staatsorganen en de binding van de staat aan het recht was grotendeels gelijk aan de Nederlandse staatsrechtelijke situatie. De Trias Politica was volledig ingevoerd. De invloed van de burgers in het bestuur is verzekerd, de noodzaak tot het naleven van de mensenrechten binnen het Koninkrijk werd duidelijk vermeld in het Statuut. De rechtsbescherming van de burger tegen de overheid moest evenals in Nederland, grotendeels bij de burgerlijke rechter worden verzocht.

Worden de evaluatie-criteria getoetst aan het bestudeerde materiaal dan is duidelijk dat eindelijk een rijke oogst kan worden binnen gehaald. Er zijn echter haken en ogen, want is er met in de invoering van de parlementaire democratie wind gezaaid en moet er storm geoogst worden? Het Antilliaanse standpunt ${ }^{131}$ over bet zoeken van het juiste evenwicht tussen ordening van de samenleving en individuele vrijheid wordt subtiel weergegeven door een citaat van Henriquez uit de MvT van de Interimregeling:

"De Antilliaanse gemeenschap is anders samengesteld en heeft een andere traditie dan de Nederlandse. In elke gemeenschap leeft echter de drang naar vrijheid. Deze drang is de laatste jaren in het begrip autonomic tot uiting gekomen. Hiermede beoogde men meer vrijheid voor de koloniale gemeenschap. Doch niet zelfstandigheid en vrijheid voor het land (autonomie) is uiteindelijk het hoogste goed. Ook niet de vrijheid en het recht voor de bevolking om haar eigen regering aan te wijzen (democratie). Doch veeleer de vrijheid voor het individu, die gepaard gaat met het besef van gelijkheid, eenheid en verbondenheid in de gemeenschap.

In een gemeenschap, waar dit laatste besef door heterogeniteit der bevolking, door ondemocratische traditie, door verschillen in kleur en verspreiding voor de verschillende eilanden niet voldoende aanwezig is, kan invoering van autonomie leiden tot het aan de macht komen van die individuen, die instede van met besef van gelijkheid en eenheid, bezield zijn met die gevoelens van machtswellust (zowel in reactionnaire als revolutionnaire richting), eigenbelang, haat wantrouwen en rassendiscriminatie ook, en vooral indien zij het tegendeel met kracht beweren, dat zij de gemeenschap tot een chaos 
zullen leiden en de democratie tot anarchie.

Dat de Interimregeling een overneming inhoudt van het West-Europese parlementaire stelsel voor de interne aangelegenhedender Antillen wordt met een zekere voldoening gezien, doch de vraag is juist of doorvoering dier constructie niet een parlementair-democratische regeringsvorm schept in een gemeenschap, die slechts door het opgelegde Nederlands Koloniale Staatsrecht als gemeenschap is geconstrueerd. De Nederlandse Antillen bezitten geen parlementaire traditie. Een parlementaire democratie wordt niet bij de wet geschonken. Evenmin kan een democratisch voelende volksgemeenschapbij de wet in het leven worden geroepen. Evenals de opbouw van een democratisch en vrije gemeenschap afhangt van sociologische en psychologische factoren, evenzo hangt de instelling van een parlementair-democratische regering af van politieke gebruiken en tradities. In een jonge gemeenschap, waar obstructie, rechtsmisbruik en bedrog als bruikbare politieke handelswijzen worden aangewezen, in zo een gemeenschap moeten de uitwassen van het parlementarisme, dat toch aan zekere regels en discipline gebonden moeten zijn, gecontroleerd worden door een orgaan, dat ingeval van onregelmatigheid kan optreden tegen misbruik van recht, tegen obstructie en rechtsverdraaiing. Hiertoe zou een administratiefrechtelijk orgaan in het leven geroepen moeten worden."

Henriquez legde reeds toen profetisch de vinger op de zere plek, deugdelijk bestuur is sinds de invoering van de Interimregeling nog steeds een probleem. De oorzaken zijn duidelijk en zijn ook in 1994 nog actueel. ${ }^{132}$

Klasseverschillen en kleurverschillen zijn in theorie opgeheven, alle burgers hebben gelijke politieke rechten gekregen. Die verschillen werken echter praktisch nog steeds door in de Antilliaanse maatschappij, zoals in het volgende hoofdstuk nog betoogd zal worden. Klasseverschillen en kleurverschillen vinden hun oorsprong in de slavernij. In die zin heeft de slavernij in de post-koloniale maatschappij kennelijk vaststaande, moeilijk te doorbreken patronen en opvattingen doen ontstaan. 


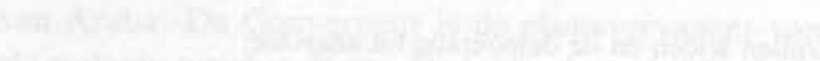

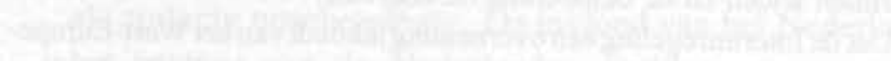

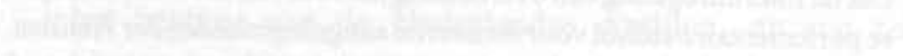

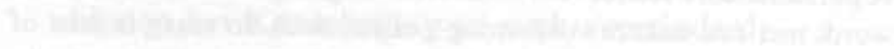

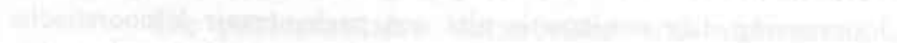

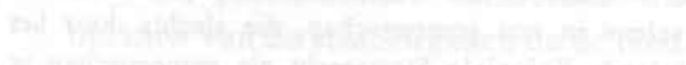

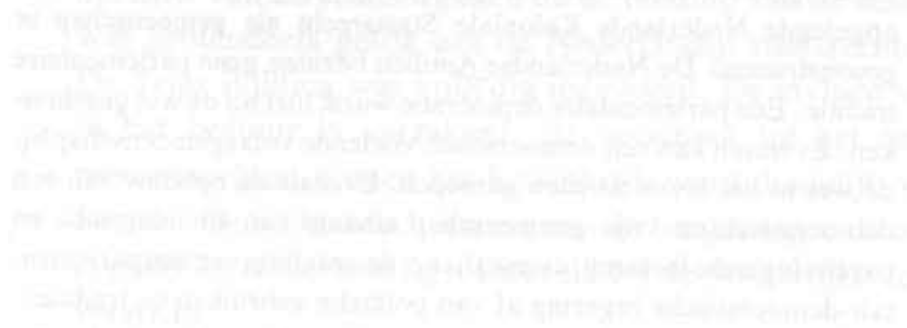

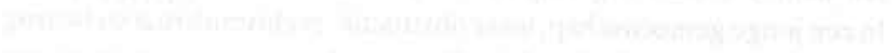




\section{Ongeregeldheden en ongewenste onafhankelijkheid}

Hoofdstuk VII beschrijft de politieke en maatschappelijke oorzaken en gevolgen van de ongeregeldheden van 30 mei 1969 in Willemstad (periode VIII 1950-1986). Op grond van het Statuut was Nederland verplicht mariniers te sturen om de orde te herstellen. Het Nederlandse ingrijpen leidde tot internationale afkeuring. Nederland vreesde voor herhaling van ongeregeldheden, die niet door Nederlands ingrijpen zouden kunnen worden voorkomen, daar het Koninkrijk overzee autonoom was in eigen aangelegenheden. Om onoplosbare situaties te voorkomen drong Nederland aan op een spoedige onafhankelijkheid van de voormalige koloniën. Noch de bevolking van de Nederlandse Antillen, noch de politici van de Nederlandse Antillen wensten onafhankelijk te worden. De Surinaamse politici zouden wel gevoelig blijken voor de door Nederland uitgeoefende druk. Suriname zou in 1975 onafhankelijk worden.

De staatkundige rapporten van Boeli van Leeuwen, en Jeukens komen aan de orde, evenals enige onderzoeken naar de wensen van de bevolking over de staatkundige toekomst van de Nederlandse Antillen door Koot en Verton.

Naar aanleiding van de ongeregeldheden in Willemstad en de Nederlandse wens om de eilanden in een Antilliaanse federatie te verenigen, verscherpte het afscheidingsstreven van Aruba. Deze ontwikkelingen worden besproken, evenals de werkzaamheden van de zestig personen tellende Koninkrijkscommissie die de onafhankelijkheid van Suriname en de Nederlandse Antillen moest voorbereiden.

De twee grootste partijen op Curaçao, de DP en de NVP bestreden elkaar in de jaren vijftig en zestig op leven en dood. Sinds de invoering van het algemeen kiesrecht in 1948 gaven de verkiezingsuitslagen steeds hetzelfde beeld te zien. De NVP bemachtigde ongeveer $45 \%$ van de stemmen, de DP $35 \%$ tot $40 \%$. Door coalities met de Arubaanse PPA en de zetelhouder van Bonaire of de Bovenwindse eilanden te vormen, lukte het de DP steeds terug te keren als rege- 
ringspartij op het centrale bestuursniveau van de Nederlandse Antillen. De DP wenste ook de bestuursmacht op eilandelijk niveau uit te oefenen. De NVP was een partijcombinatie aangegaan met de Curaçaosche Onafhankelijke Partij (COP), een in 1948 opgerichte en in aanhang altijd klein gebleven partij.

In de concurrentie met de NVP/COP ging de DP steeds verder in het gebruik maken van overheidsmiddelen om de stembusuitslagen te beïnvloeden. Het ruilen van politieke steun der kiezers tegen voorzieningen kwam het duidelijkst tot uiting in de verkiezingsstrijd. Zo trachtte de DP volmachten te verkrijgen. Het percentage van stemmen bij volmacht liep in de loop van de jaren zestig zelfs op tot boven de $10 \%$. Ook het belachelijk maken, beledigen, belasteren en beschuldigen van politieke tegenstanders behoorde en behoort tot het schouwspel dat rondom de verkiezingen wordt gevoerd. Tevens slaagde de DP erin om vanuit haar positie als landsbestuurder, ontwikkelingsprojecten van het NVP/COP eilandsbestuur te vertragen. De DP stelde alles in het werk de NVP/COP iedere kans om aan de wensen van haar kiezers tegemoet te komen, te ontnemen. Op deze wijze zou de NVP/COP in aanhang achteruitgaan en kon de kiezersachterban ertoe bewogen worden op de DP te stemmen.

De feitelijke totstandkoming van een deel van de uitvoerende bestuursmacht van de eilandelijke overheden, vastgelegd in de ERNA van 1950/1951, was afhankelijk van de overdracht van deze bevoegdheden door het Land aan de eilandgebieden. Deze overdracht werd door de Landsregering gestagneerd. De NVP/COP elite kon hierdoor bijna geen bestuursmaatregelen aan de eigen achterban aanbieden. En dit terwijl juist in de jaren zestig de economische achteruitgang om zich heen greep en armoede en werkloosheid had gebracht voor veel Afro-Curaçaoënaars.

Land en eiland leefden in de jaren vijftig en zestig op voet van oorlog. Het overheidsapparaat werd een wapen in de hand van de winnende politieke groepering. Tegen deze gang van zaken verzette zich de Union Reformista Antilliano (URA), een afsplitsing van de NVP/COP, die in 1965 was opgericht. Bij de Statenverkiezingen van 1966 verkreeg eindelijk de DP een meerderheid en verloor de NVP haar dominante positie. Radicale jongeren traden als kritische intelligentsia naar voren en uitten hun mening in tijdschriften als Kambia (Verandering) en Vitó (Slavenopzichter). Vitó stond onder redactie van de onderwijzer Stanley Brown, die een belangrijke rol zou spelen bij de gebeurtenissen van 30 mei 1969. Deze tijdschriften verwoordden de heersende kritiek rond de gang van zaken op politiek, economisch en sociaal gebied. Groeiende bewustwording, organisatie van 
de arbeiders door vakbonden en toenemende ontrevedenheid over de economische achteruitgang en de bestaande situatie vormden een aanzet tot protest. De URA kwam op voor het landsbelang en verwierp de politieke patronage omdat die in strijd was met de regels van de democratie. Algemene ontevredenheid onder de arbeiders werd door het protest der lagere ambtenaren en onderwijzers omgezet in daden. Dat gaf een schok van herkenning in de achterhoede, die zag dat werknemers die het zoveel beter hadden dan de achtergebleven Afro-Curaçaoēnaars hun eisen op die wijze ondersteunden. Toen in mei 1969 de achterhoede op de been kwam, werd het ontbrandingspunt bereikt. De achtergebleven bevolkingsgroepen waren niet meer te stoppen. ${ }^{1}$

De staatsrechtelijke verhouding tussen Nederland en de Nederlandse Antillen stond in de jaren vijftig en zestig niet ter discussie. Dit veranderde echter na de gebeurtenissen van 30 mei 1969. De directe aanleiding tot de gebeurtenissen op 30 mei 1969 was gelegen in het arbeidsconflict tussen het bedrijf Werkspoor Caribbean (Wescar) en de Curaçaosche Federatie van Werknemers (CFW). De vakbonden vonden nog weinig erkenning op Curaçao. Werkgevers zagen de opkomst van het vakbondswezen als een bedreiging. De cao-onderhandelingen in 1968 tussen Wescar en de CFW verliepen voor wat betreft de loondifferentiatie niet naar wens en de besprekingen werden door de CFW in maart 1969 afgebroken. Op 6 mei 1969 liep de vigerende cao af. Wescar besloot gezien de situatie, met werknemers na 6 mei 1969 individuele arbeidsovereenkomsten af te sluiten. Dit leidde tot felle reacties van de CFW. Op 6 mei riep de vakbond een staking uit, die na gedeeltelijke voldoening aan de eisen van de vakbond op 9 mei werd opgeheven. De loononderhandelingen leidden echter niet tot een voor beide partijen bevredigend resultaat. De vakbond kondigde een staking aan voor 27 mei 1969, waarop de directie van Wescar aanzegde een ieder die 28 mei niet op het werk zou verschijnen te zullen ontslaan. Deze aanzegging leidde tot een explosieve situatie. Intussen nam de arbeidsonrust op het eiland verder toe. Spontane betogingen vonden op 27,28 en 29 mei plaats.

Verton (1977) pp. 77-86; Van Gameren (1990) pp. 10 e.v.; De Kuyperstichting (1971) p. 19, voetnoot 25, noemt als oorzak voor de ongeregeldheden in Willemstad de volgende reden: 'Hoewel de directe aanleiding van het oproer en brandstichten in Willemstad gelegen was in een arbeidsconflict, waren de diepste oorzaken onder andere gelegen in de structurele werkloosheid, de grote kloof tussen rijk en arm, en de in diverse takken van de overheidsdiensten bestaande vriendjespolitiek'. Het rapport verwijst voor de conclusie naar het rapport van de Commissie Römer. 
De onrust en de ongeregeldheden bereikten vroeg in de avond van 30 mei een hoogtepunt bij een massabetoging met ongeveer duizend man bij Post V, een van de toegangen tot het Shell terrein. De betoging, die tot grote ongeregeldheden zou leiden, begon om 29 mei om 21.50, onder leiding van Stanley Brown, onderwijzer en redacteur van het weekblad 'Vito' en Wilson 'Papa' Godett, voorzitter van de Algemene Havenunie. De volgende ochtend braken de onlusten uit. Papa Godett deelde mee dat de havenarbeiders tot een sympathiestaking hadden besloten. Tijdens de ongeregeldheden werd Papa Godett ernstig gewond door een politiekogel, waardoor de agressiviteit van de menigte een hoogtepunt bereikte. De vakbondleiders hadden daarvoor reeds hun greep op de menigte verloren, daarin in niet geringe mate bijgestaan door een excessief gebruik van rum door de betogers.

Diezelfde dag kwamen partijen tot een principe-accoord over de nieuw af te sluiten cao. De staking werd opgeheven. Maar inmiddels was het onheil geschied. De emoties waren hoog opgelopen, Willemstad brandde, er werd geplunderd. Nederlandse mariniers werden ingezet om het oproer te bedwingen. Op 5 juni trad de regering af. De rust keerde betrekkelijk snel weer in Willemstad, maar niet op het politieke vlak. ${ }^{2}$

De regering Petronia kwam na moeizame onderhandelingen tot stand. Het Akkoord van Kralendijk werd getekend op 23 november 1969. Dit Akkoord was een beginselverklaring van de Democratische Partij, de PPA van Aruba, de Frente Obrero y Liberacion 30 di Mei, de DP Bovenwindse Eilanden en de Partido Obrero Boneriano tezamen met de de Partido Progresista Boneriano Uni. Op het gebied van sociale voorzieningen voor werknemers zou onder meer een minimumloonregeling worden ingevoerd, evenals een pensioenregeling, een Algemene Ziektewet voor de gehele Antilliaanse bevolking en een ontslagregeling. Ook werd men het eens over de instelling van de wettelijke verplichting tot erkenning van de vakbonden door de werkgevers en een wettelijke vertegenwoordiging van werknemers- en werkgeversor-

2 De Amigoe wijdde op I mei 1994 een speciale Ñapa aan de gebeurtenissen van 1 mei 1969 en stelde ondermeer dat de werknemers 25 jaar na dato niet veel verder waren. Het themanummer bevatte interviews met ondermeer Ewald Ong A Kwie, destijds voorzitter van de Wescarvakbond; A.F. Paula, hoogleraar aan de Universiteil van de Nederlandse Antillen; Hubert van Grieken, ondememer en Dito Abbad, architect. Paula meende dat de mei-onlusten een gevolg waren van een mondiale gezagscrisis. Sterke drank speelde een belangrijke rol tijdens de onlusten. Als gevolg daarvan wordt nog steeds gedurende de verkiezingsdag van overteidswege een algehele drooglegging afgekondigd. 
ganisaties, de invoering van een Algemene werkeloosheidverzekering voor alle werknemers en de herziening en aanpassing van de Arbeidswetgeving. ${ }^{3}$

Groepen uit de intelligentsia traden kort na de onlusten in contact met de vakbondsleiders om te trachten het vakbondsfront om te zetten in een politiek front. Dat ging moeizaam daar ook de vakbonden verdeeld waren. Amador Nita, ${ }^{4}$ de tweede man van de Algemene Havenunie richtte de Frente Obrero y Liberacion 30 di Mei (Frente) op. Op de lijst stonden Godett, Nita en Brown. Nita en Godett als radicale vakbondsleiders en Brown als een radicale intellectueel, waren direct betrokken geweest bij de mobilisatie van protest en verzet onder de arbeiders. De verkiezingen van 5 september 1969 werden een groot succes voor de nieuwe arbeiderspartij.

De schok die door de Curaçaose gemeenschap was gegaan leidde ook tot een heroriëntatie op de staatkundige toekomst. Naar aanleiding

Akwerdo di Kralendijk, Gobierno di Antiyas Hulandes, Curaçaosche Courant, 1970, vertaling in het Nederlands, Engels en Spaans.

Nita was ondermeer secretaris van de Havenunie en was tevens intellectueel en schrijver. Hij was een bewonderaar van Voltaire en Rousseau en schreef de romantische bestseller 'Marinanita', 21 korte verhalen, 8 sociaal-politieke geschriften en tal van kranten- en tijdschriftartikelen. In 1954 schreef hij 'De sociale wensdroom van het landskind in de gelijke delen van het Koninkrijk'. De hele oplaag werd door de Shell opgekocht en vernietigd. Keesings Historisch Archief, juli 1970 p. 412. Volgens het voorwoord bij de vierde druk uit 1969, met dezelfde titel werd het boekje voor het eerst in 1952 uitgegeven. De Shell wordt inderdaad niet gunstig afgeschilderd. Nita brengt de positie van de zwarte Antilliaan onverbloemd in beeld en die weergave zal ongetwijfeld de Shell niet zijn uitgekomen. De C.P.I.M. betaalde de Antilliaanse arbeiders slecht in tegenstelling tot de Nederlandse medewerkers, 'de tropenadel' zoals Nita ze noemt. Vaak deden Antillianen en Nederlanders hetzelfde werk, maar Antillianen kregen veel minder betaald. Naar het ordeel van Nita meenden de Nederlanders dat het landskind niet de juiste mentaliteit had om een hoge en verantwoordelijke functie te bekleden. Nita vreesde dat zijn kritiek als 'communistisch' zou worden ervaren door de Nederlandse gemeenschap. 'De Nederlander is de grootste strijder voor de rechten van de arbeider, maar hier in de Antillen merkt men daar in het geheel niets van', stelt Nita. Hij weet de marxistische theorie van de onderdrukking en uitbuiting van de arbeidersklasse mooi te verbinden met hoofdstuk 12 vers 4 van het Evangelie van Lucas: 'En ik zeg u mijnen vrienden, vreest u niet voor degenen, die het lichaam doden, en daama niets meer kunnen doen'. Hij meent dat de sociale problematiek snel verbetering behoeft. Ook haalt hij de omverwerping van het Nederlands bewind in Nederlands-Indië aan, waar 'het ging om de bevrijding van miljoenen arbeiders welke als koelie's in de plantsge's voor een hongerloon als slaven werden uitgebuit'. Het geschrift komt in deze tijd zachtmoedig over. Ik acht het ook onder de toenmalige verhoudingen onbegrijpelijk dat Shell de gehele oplage heeft vernietigd. De beschreven feiten, voor wat betreft de ongerechtvaardigde verschillen in behandeling en beloning van de Nederlandse- en Antilliaanse werknemer, zijn mede daarom zeker juist.

Verton (1977) p. 93 
van de ongeregeldheden werden de Staten ontbonden en verkiezingen gehouden. De nieuwe Staten waren het er met de regering over eens, dat een begin moest worden gemaakt met de noodzakelijke voorbereidingen. Uiteindelijk moesten de Nederlandse Antillen een zelfstandige plaats innemen in de rij der volkeren.

De gevoelens over een onafhankelijkheid op korte termijn waren ambivalent. In Aruba leidde de actualisering van de staatkundige problematiek en de vrees zonder Nederlandse steun een tweederangs positie in een onafhankelijke Antilliaanse staat te moeten innemen tot de oprichting van de Movimiento Electoral di Pueblo (MEP) in 1971.

Al snel bleek dat de arbeiderspartij Frente Obrero, eenmaal regeringspartij geworden, het systeem niet wilde veranderen, maar binnen het systeem mogelijke veranderingen wilde doorvoeren, met behulp van patronage. De structuur-hervormers binnen de Frente, voornamelijk bestaande uit de intelligentsia en volgelingen van Stanley Brown, keerden zich teleurgesteld af van de Frente Obrero. De samenwerking tussen arbeiders en intellectuelen was ten einde. Terug naar de URA kon niet, deze partij was opgegaan in de partij NVP-U. In 1971 werd er door de strijders voor een ander politiek systeem weer een 'eigen' partij opgericht, de Movimiento Antyas Nobo (MAN). Deze partij kan worden beschouwd als geestverwant en opvolger van de URA.

Op 26 februari 1970 werd een parlementaire commissie benoemd door de Staten, die tot taak had het uitwerken van de staatkundige positie van de Nederlandse Antillen, waarin met name de eilandelijke zelfstandigheid verder moest worden geconcretiseerd. Deze gedachtengang werd nog eens herbaald in de regeringsverklaring van het kabinet-Petronia van 25 mei $1970 .^{6}$ Uit de regeringsverklaring van het kabinet-Isa, afgelegd in de Antilliaanse Staten op 25 februari 1971 , bleek dat de regering van mening was dat verandering in de staatkundige verhoudingen alleen op bilaterale basis kon plaatsvinden en dat Nederland niet eenzijdig de onafhankelijkheid kon opleggen. ${ }^{?}$

De gebeurtenissen brachten veranderingen op gang zowel in Curaçao als in Aruba en Nederland. Op politiek gebied volgde de vorming van nieuwe politieke partijen, op niet traditionele basis. Op economisch gebied kregen de handel en het toerisme op Curaçao harde klappen. Toeristen en andere kooplustigen, alsmede mogelijke investeerders werden afgeschrikt door de gebeurtenissen van 30 mei. Het Noord- 
Amerikaanse toerisme, gevoelig voor alles wat naar 'revolutie' zweemt, trok naar Aruba en Sint Maarten. De economische onafhankelijkheid die hiervan het gevolg was, zou de hang naar autonomie van deze twee eilanden doen toenemen. ${ }^{8}$

\title{
Rapport van de Commissie Römer
}

\section{Bij Landsbesluit ${ }^{9}$ werd een gemengde Nederlands-Antilliaanse Com- missie ingesteld om:}

\begin{abstract}
"een diepgaand onderzoek in te stellen naar de achtergronden en beweegredenen, welke geleid hebben tot de onlusten welke op $30 \mathrm{mei}$ 1969 op Curaçao hebben plaatsgehad, zomede de toedracht en de maatschappelijke gevolgen daarvan en de Regering terzake rapport uit te brengen en aanbevelingen te doen."
\end{abstract}

De Commissie bestond uit personen die geen binding hadden met politieke partijen, vakbonden of werkgeversorganisaties. De Commissie meende dat er van een beraamde samenzwering tot plundering, brandstichting en omverwerping van de regering geen sprake was. Ook vond de Commissie geen bewijs van directe buitenlandse inmenging. De Commissie was van mening dat ondanks de bestaande raciale

- Zie over het succes van de Frente in 1973 en 1975 en de samenwerking van de Frente en de MAN: Rōmer (1975) pp. 253-263. Römer stelt terecht 'that the unequal distribution of material affluence follows the racial line'. Hij verklaan het succes van de Frente voor een deel uit raciaal bewustzijn en tevens als een demonstratic van klasse solidariteit van een gedepriviligeerde (zwarte) groep in de maatschappij met haar leiders, die uit de eigen groep afkomstig waren. Papa Godett en zijn politieke medestanders kwamen eveneens uil de lagere klasse en waren gekleurd. Ook de vakbond CFW gaf het advies op de Frente te stemmen. Voordien badden de vakbonden zich nooit met de politiek beziggehouden. Deze veranderde opstelling van de CFW had te maken met een machtsstrijd tussen de vakbond en de regerende partij. Römer besluit met een belangrijke gevolgtrekking: 'Racialism in Curaçao seems to have an overtone of nationalism and in the case of Frente Obrero is not aimed at an elimination of the whites from society but at better accomodation of the black population within the existing socio-economic structure.' Bij de ongeregeldheden werd de autochtone blanke bevolking met rust gelaten en richtte de vermielingen zich op ondernemingen en bezittingen van Askenazische Joodse ondememers, Portugese, Libanese en Syrische winkeliers en tijdelijk op Curaçao werkzame Nederlanders en Amerikanen. Zie ook Römer (1976) pp. 192-204. 16 oktober 1969, PB 1969, 27. 'Aanleiding om deze commissie in het leven te roepen is de overtuiging van de regering, dat slechts een op wetenschappelijke grondslag berustende analyse betrouwbare aanwijzingen kan verschaffen voor eventuele kours en structuurverandering', aldus de minister. 'Zijn de corzaken wetenschappelijk vastgesteld, dan mag men aannemen, dat de verantwoordelijke instanties alles in het werk zullen stellen om de oorzaken van het onbehagen weg te nemen', Keesings Historisch Archief, maart 1970, pp. 142, 143. 
problemen, het raciale element geen dominerende rol heeft gespeeld bij de gebeurtenissen van 30 mei. Het Wescarconflict was geen geïsoleerde gebeurtenis, maar de climax in een reeks van arbeidsconflicten. De vakbonden waren tegen het inroepen van militaire bijstand geweest, maar de algemene reactie onder de bevolking was dat door het optreden van de mariniers erger was voorkomen. De vakbonden wilden echter ook hun ongenoegen uitspreken over het gebrek aan een sociaal-economisch beleid van de regering. De vakbonden achtten het zeer kwalijk dat de regering het zo ver had laten komen dat zij zichzelf slechts door gewapende hulp van buitenaf in stand kon houden en de door de vakbonden gewenste wijzigingen in het maatschappelijk bestel had belemmerd, althans vertraagd.

De Commissie verklaarde dat de Antilliaanse houding ten opzichte van Nederland ambivalent was. Nederland werd verweten kolonialistisch te handelen door in te grijpen en tegelijkertijd werd Nederland verweten niet eerder te hebben ingegrepen. Verder was de Commissie van mening dat de strijd tussen het Land en het eilandgebied Curaçao over ontwikkelingsprojecten niet had bijgedragen tot goede onderlinge verhoudingen. De kwaliteit van het ambtenarencorps was ondergraven door het patronagesysteem. Het beleid van de overheid met betrekking tot de ambtenaren, zeker voor wat betrof de bezoldigingsregeling in 1968 kenmerkte zich niet door inzicht in de aldaar heersende frustraties.

De vakbonden gaven nooit stemadviezen uit en hielden zich buiten de politiek. De arbeider bleef echter de speelbal van de partijen die in onderlinge strijd naar zijn hand dongen. Daar er een alternatief ontbrak en de arbeiders het spel begonnen te doorzien leidde dit tot nog grotere frustraties. De kritische, jonge intelligentsia, vaak opgeleid in Nederland richtte zich met felle kritiek tegen het overheidsoptreden en het gemis aan sociale verantwoordelijkheid. Dit kwam sterk tot uiting in het weekblad Vitó. De aanvallen van Vitó op de regering, handel en industrie hadden langzamerhand een ontoelaatbare agressiviteit bereikt, volgens de Commissie. Dit had tot gevolg, dat de uitgever en redacteur Stanley Brown na 30 mei 1969 voor opruiing werd vervolgd en veroordeeld. ${ }^{10}$

10 Hij was al eerder veroordeeld wegens in het openbaar de menigte toespreken op de openbare weg, zonder vergunning, HvJ 6 februari 1968, Stanley Brown vs OvJ, Opruiende luifelrede. De toespraak was bedoeld om mevrouw Brown te verdedigen, die een klap van een politie-agent had gekregen. Die toespraak had met vergaderen niets van doen. Een beroep op noodweer-exces ging niet op, daartoe was een toespraak niet het juiste middel. Stanley Brown werd op 30 juli 1969 wegens bedreiging en brandstichting veroordeeld tot 10 maanden gevangenisstraf, met een 
Al deze factoren droegen bij tot het scheppen van een atmosfeer, die bevorderlijk was voor het ontstaan van onlusten. In het begin van de jaren zestig werden bij de Shell, die de belangrijkste inkomstenbron voor de eilandelijke economie vormde, arbeidsbesparende produktiemethoden ingevoerd. Hierdoor kreeg de economie op Curaçao een harde klap en steeg de structurele werkloosheid onder invloed van de inkrimpende betekenis van de olie-industrie. De vakbonden hadden te kampen met een gezagscrisis in hun gelederen, waardoor de onderhandelingen over de cao ook niet soepel konden verlopen. De Commissie meende dat de vakbondleiders zich niet realiseerden hoe de menigte zou reageren op de door hen zelf opgeroepen onverantwoorde agitatie. De sociale voorzieningen schoten tekort en de verwijdering tussen regering, volken vakbeweging had zorgwekkende vormen aangenomen. Hierdoor en door de slechte communicatie konden de tegenstellingen zich verscherpen.

De Commissie Römer deed een aantal aanbevelingen in de vorm van politieke alternatieven voor de Nederlandse Antillen. De Commissie droeg twee mogelijkheden aan, of een politieke afscheiding van Nederland 6 f een permanente economische ondersteuning van Nederland. De Commissie hield er rekening mee dat onderdelen van de huidige federatie een eigen weg zouden gaan. Tevens dacht zij aan een mogelijke aansluiting van de Bovenwinden bij de ministaatjes van het Britse Commonwealth en aansluiting van de Benedenwinden bij Venezuela. Aansluiting van de blanke en licht gekleurde bevolking bij Venezuela zou geen probleem zijn. Assimilatie voor de 'negride' bevolking echter wel. De Commissie meende echter dat het etnische bezwaar als 'quantité négligeable' kon worden beschouwd, bezien vanuit Venezolaans oogpunt. Voor Curaçao en Bonaire zou dat echter

proeftijd van drie jaar. De Officier van Justitie zei in zijn requisitoir dat een van de oorzaken van de gebeurtenissen van 30 mei, de stelselmatige campagne van 'Vito' is geweest. Stanley Brown was hoofdredacteur van 'Vito' en leider van de Frente Obrero. Met name het artikel van 24 mei onder de kop 'Open brief aan Tauber en andere kwaadwillige kapitalisten' werd door de rechter beschouwd als een bedreiging met brandstichting. Eén van de zaken van de heer Tauber brandde tijdens de gebeurtenissen van 30 mei af. Brown werd echter vrijgesproken van opruiing, die hem ook ten laste was gelegd. Zowel het $\mathrm{OM}$ als de verdediging tekenden beroep aan tegen de uitspraak van de rechter. Op 11 september werd Brown door het Hof van Justitie (HvJ) veroordeeld tot 4 maanden, met aftrek van voorarrest, Keesings Historisch Archief, oktober 1969, pp. 618-621 en februari 1970, pp. 91 e.v. Hoe het verder ging met oud-revolutionair Stanley Brown valt te lezen in de Amigoe, Ñapa van 28 april 1990. Hij zegt daarin dat hij 20 jaar lang een 'betaalde werkloze' is geweest. Hij ging naar een overheidskantoor maar had geen werk te doen. Naar zijn mening gebeurde dat op grond van represailles vanwege zijn woelige woorden en daden als jongeman tijdens de mei-dagen van 1969. Hij werkt sinds 1990 als coördinator van een werklozenproject. 
wel een bezwaar zijn. De Benedenwinden zouden zich ook kunnen aansluiten bij Trinidad en Tobago, daar zaten echter zowel etnische als economische bezwaren aan vast. Ook kon gedacht worden aan aansluiting van Aruba bij Venezuela of bij Nederland en Curaçao en Bonaire bij Trinidad en Tobago.

Ten slotte zag de Commissie een oplossing in een soevereine federatie van de $A B C$ eilanden. De Bovenwinden konden dan rechtstreeks aan Nederland worden gebonden. De Commissie besloot haar rapport met vier pagina's aanbevelingen voor de gehele Antilliaanse samenleving. De volgende aanbevelingen waren onder meer van belang:

- de politie moet op verantwoorde en professionele wijze haar taak kunnen uitoefenen;

- bezinning op de onduidelijke taakverdeling tussen de centrale regering en de eilandgebieden is noodzakelijk;

- de invloed van partijpolitiek op ambtenarenbenoemingen is onwenselijk;

- patronage moet zoveel mogelijk worden voorkomen;

- belediging van personen en volksgroepen dient te worden vervolgd;

- er dient nauwlettend acht te worden geslagen op de economische ontwikkelingen en de arbeidsverhoudingen moeten in evenwicht zijn;

- $\quad$ sociale wetgeving is dringend noodzakelijk;

- meer vertegenwoordigers van de negride bevolking moeten in verantwoordelijke bestuursposten worden benoemd. ${ }^{11}$

In het rapport van de Commissie Römer werden voor het eerst de economische consequenties betrokken bijde onafhankelijkheidsproblematiek. Er bestond veel kritiek op het feit dat de Commissie pas een jaar na de gebeurtenissen haar verslag uitbracht.

Vijf jaar na 30 mei 1969 kwam Römer op deze gebeurtenissen terug. ${ }^{12}$ Römer was het niet eens met de samenzweringstheorie die

Rapport Römer (1970). De Commissie stond aanvankelijk onder leiding van dr. A.F. Paula, verder hadden zitting: mej. drs. B.E. Dougle, mr. W.R. Boom, ir. R.A. Hodgson, Prof. dr. H. Hoetink, drs. R.A. Römer, Prof. dr. J.D. Speckman en Jhr. mr. G. Witsen Elias. Secretaris was drs. R.H.A.M. Baron van Hövell tot Westerflier. Na vertrek van dr. A.F. Paula als voorzitter werd drs. R.A. Römer tot voorzitter benoemd. Zie ook Römer (1977) pp. 74-78. Paula bleek omstreden als voorzitter, omdat hij zowel adviseur was van premier Ciro Kroon als van Vitóvoortrekker Stanley Brown. Na dreigementen van Vitó-aanhangers trad hij terug als voorzitter, Amigoe, Ñapa, 1 mei 1994. 
wel naar voren is gebracht om de ongeregeldheden te verklaren. De oorzaak daarvan werd binnen de eigen gemeenschap gezocht, namelijk in de 'Black Power' beweging. Black Power was de titel van een boek van de bekende negerschrijver Richard Wright, een reisverslag opgedragen aan de onbekende Afrikaan, het verscheen in 1954. Römer stelde dat in de strijd om gelijke burgerrechten van de negers in de Verenigde Staten de benaming 'Black Power' voor het eerst werd gebruikt door Stokely Carmichael tijdens de in 1966 gehouden Meredithmars door Mississipi.

\begin{abstract}
"Deze strijdkreet werd later door hem en andere vrijheidsstrijders nader gepreciseerd en wel in tweeërlei betekenis: dat de zwarte mens in de Verenigde Staten zichzelf moet bevrijden van de onderdrukking van het interne kolonialisme in zijn eigen land en dat de volken van de Derde Wereld zich moeten bevrijden van de nog bestaande (externe) koloniale invloeden. Naast een politieke had het begrip ook een culturele inhoud, namelijk de bewustwording van de Amerikaanse neger van zijn Afrikaans verleden en culturele erfenis. In het Caraibisch gebied, waar het probleem van de burgerrechten van de neger niet speelde en de politieke macht reeds grotendeels in handen was van het gekleurde deel van de bevolking, werd de inhoud anders gedefinieerd. 'Black Power' in het Caraïbisch gebied keerde zich vooral tegen de 'white economic structure', tegen de overheersende positie dus van de blanke op economisch gebied.

Ook in de 'februari revolutie' van Trinidad in $1970 \mathrm{kwam}$ dit duidelijk naar voren. In de retoriek en ideologie van de beweging werd toen 'black' gedefinieerd in de termen van de sociaal-economische positie. Indien men van deze inhoud van het begrip 'Black Power' uitgaat, dan waren er bij het verschijnsel 30 mei ongetwijfeld ook 'Black Power' elementen werkzaam geweest." 13
\end{abstract}

Maar van buitenlandse agitatoren was in de Nederlandse Antillen geen sprake geweest. De bestaande concrete sociaal-economische omstandigheden en de achterstandssituatie van de gekleurde bevolking in eigen land, leverden een geschikte voedingshodem voor een 'Black Power' bewustzijn Caraibische stijl.

Römer stelde vervolgens de interessante vraag of een herhaling van de gebeurtenissen van 30 mei mogelijk zou zijn, daar de sociaaleconomische situatie van de gekleurde bevolking nauwelijks verbeterd is. De positie van de vakbonden ten opzichte van de werkgevers is sinds 30 mei aanzienlijk versterkt. Ook de inspraak van de vakbonden via de Sociaal Economische Raad is toegenomen, zij kunnen thans zelf hun vertegenwoordigers voor benoeming voordragen. 
De DP-PPA regeringen waren sinds 1954 onafgebroken aan het bewind. Ondanks het feit dat zij sedert 1954 op basis van periodieke algemene verkiezingen waren tot stand gekomen, werd die politieke constellatie langzamerhand als een semi-dictatuur beleefd. Het oligarcheringsproces, dat zich binnen deze partijen manifesteerde in het steeds weer terugkeren van dezelfde figuren op dezelfde posten, had dit beeld nog versterkt. Er werden na 1969 door de politiek verbeteringen aangebracht in de positie van de arbeiders. Dat gebeurde mede onder verantwoordelijkheid van de Frente, de arbeiderspartij die ontstaan was naar aanleiding van de gebeurtenissen op 30 mei. De werklozen vormden echter nog steeds een vergeten categorie. Grote groepen, meestal jongeren, bevonden zich in deze situatie. Na jarenlang zonder werk te zijn geweest, moesten zij zich wel aan de situatie aanpassen. Dit ging gepaard met het verlies van gevoel voor eigenwaarde en arbeidsbereidheid. Ook bestond er geen vertrouwen meer in de maatschappij, die geen plaats voor hen wist in te ruimen. De individuele houding die hieruit ontstond kon er een zijn van óf berusting of verzet. De algemene houding in de Curaçaose samenleving was en is die van "Es ku Dios ke" (Gods wil geschiede), een religieus gewortelde vorm van defaitisme, dat in menig feodale maatschappij in Latijns-Amerika ook wordt aangetroffen. ${ }^{14}$ De in de geseculariseerde Curaçaose samenleving opgegroeide jongere werklozen zijn echter minder geneigd tot deze vorm van berusting. Hun houding is veel meer die van ontevredenheid met de gang van zaken en draagt een grote ontvankelijkheid in zich voor verzet tegen de bestaande orde. Ook het leven in een consumptiemaatschappij wakkert de 'hoop-factor' aan. In feite wenst elke Curaçaoënaar een 'middle class way of life'.

\footnotetext{
“De mogelijkheid van een herhaling van een 30 mei-achtige uitbarsting zal afhangen van de mate, warin de regering erin zal slagen cen perspectief te scheppen voor een toekomst, waarin ook aan de behoeften van deze kwetsbare categorieën tegemoet zal worden gekomen."'
}

Römer kwam tot de conclusie dat in ieder geval naast de boven omschreven maatregelen het ook van essentieel belang is te streven naar een rechtvaardiger verdeling van sociale en culturele goederen. Materiële welvaart alleen brengt geen oplossing. Zij schept een mens die consumeert en niet creëert. De verdeling van sociale en culturele schaarse goederen acht hij nog schrijnender dan de ongelijke verdeling 
van de materiële goederen. De neger-arbeider wordt in de Antilliaanse maatschappij nog steeds niet voor vol aangezien. Hij is voor velen nog het kinderlijke wezen, dat blij te maken is met kostbaar speelgoed, als Miami-auto's (grote Amerikaanse auto's), televisietoestellen en transistorradio's. Dat de vlucht in deze statussymbolen een compensatie kan vormen voor ondervonden frustraties in de intermenselijke relaties, wordt nog onvoldoende onderkend. Het onderwijs zou een belangrijke rol kunnen spelen in het versterken van de mobiliteit van deze groepen. Het huidige, naar Nederlandse voorbeeld opgezet onderwijs achtte Römer onvoldoende toegesneden op de Antilliaanse bevolking.

Naar mijn mening legde Rōmer onvoldoende nadruk op de vicieuze cirkel die ontstaat als een kind uit een achterstandmilieu komt, waarin de ouders het nut van onderwijs onvoldoende inzien. Als er geen stimulans vanuit de thuissituatie voor onderwijs is, zal geen enkele vorm van onderwijs het beoogde doel bereiken. Terecht geeft Rōmer aan dat een aanvaardbaar ontwikkelingspeil van de bevolking onontbeerlijk is voor een goed functioneren van de democratie. Hij haalt hier de Jamaicaanse pedagoog John Figueroa aan die opmerkte: ' $[\ldots]$ ignorant citizens will participate ignorantly, inefficiently and destructively in their governement'. ${ }^{15}$ Hij gaf naar mijn mening echter onvoldoende aan dat de thuissituatie van doorslaggevend belang is in de schoolprestaties van een kind. De neger-arbeider moet zich een volwaardig lid van de maatschappij kunnen voelen en daarom moet zijn emancipatie voltooid worden. ${ }^{16}$ De hier bedoelde emancipatie lijkt nog steeds niet voltooid te zijn. Dat blijkt wel uit de grote groep ongeschoolde Antilliaanse jongeren, die naar Nederland vertrekt en zich daar niet kan handhaven en in moeilijkheden komt. ${ }^{17}$

Zie ook De Sola (1979) pp. 49-58.

Eind 1992 klaagde de hoofdcommissaris van politie in Amsterdam E. Nordholt, dat er aanwijzingen bestonden dat Antilliaanse criminele jongeren onder druk (van de Antilliasnse overheid) naar Nederland kwamen. Deze uitlatingen in de Nederlandse en Antilliaanse pers leidde tot grote commotie en verwijten over en weer. Naar aanleiding van de uitlatingen van de hoofdcommissaris heefl de Binnenlandse Veiligheidsdienst (BVD), begin 1993, een onderzoek taten uitvoeren. De conclusies van dit onderzoek zijn geheim. Minister Dales van Binnenlandse Zaken wilde alleen kwijt, dat er geen aanwijzingen zijn dat de Antilliaanse overheid actief betrokken is bij het verhuizen van genoemde jongeren naar Nederiand. Wel achtte de minister de situatie in de Antillen met betrekking tot het optreden van de politie, het gevangeniswezen en de Sociale Dienst onaanvaardbaar. NRC Handelsblad, 8 juli 1993. 
De reden waarom relatief veel aandacht is besteed aan de onlusten van 30 mei 1969 is dat deze gebeurtenissen zowel staatsrechtelijk als economisch grote invloed hebben gehad. Staatsrechtelijk leidden de onlusten tot grote vastberadenheid in het Nederlandse beleid om de dekolonisatie te voltooien. Suriname en de Nederlandse Antillen moesten onafhankelijk worden. Tevens beïnvloedden de ongeregeldheden de toeristenindustrie en de buitenlandse investeringen in negatieve zin. De oorzaken van de onlusten lagen ondermeer in de achterstandssituatie van de zwarte bevolkingsgroep. Veel verbetering is er sinds de Jonlusten in de bestaande situatie niet opgetreden, dus dat betekent dat een potentiële brandhaard in de Antilliaanse maatschappij aanwezig is, die met de huidige slechte financiële situatie van het Land en het Eilandgebied Curaçao (1994) weer een aanleiding zou kunnen vormen voor een hernieuwde uitbarsting in de toekomst.

Onder invloed van de ongeregeldheden veranderde aan het begin van de jaren zeventig, het standpunt van Nederland ten aanzien van de overzeese gebiedsdelen. Nederland toonde zich vanaf dat moment actief voorstander van het zelfbeschikkingsrecht met als gewenst uiteindelijk resultaat de onafhankelijkheid van Suriname en de Nederlandse Antillen.

Deze gewijzigde opstelling wordt wel toegeschreven aan de afgenomen bereidheid van Nederland langer verantwoordelijkheid te dragen voor zaken overzee, een verantwoordelijkheid die krachtens het Statuut, eventueel ingrijpen in de interne verhoudingen van de Antillen en Suriname met zich meebracht. Met de onlusten in Willemstad in 1969 werden de omvang en consequenties van deze verantwoordelijkheid goed duidelijk. Nederland was op grond van het Statuut verplicht militair in te grijpen, maar besefte tegelijkertijd dat ze geen enkele invloed kon uitoefenen op de situaties die een ingrijpen door Nederland vereisten. In internationale kringen bestond bovendien weinig waardering voor deze verplichting tot militaire bijstand en de praktische gevolgen daarvan. G.M. Nederhorst stelde in het debat in de Tweede Kamer, ten aanzien van de gebeurtenissen op Curaçao: 'De vraag laat zich, stellen, of de ervaring niet leert, dat wij het initiatief moeten nemen om het Statuut, dat ons onredelijke verplich- 
In 1961 hadden besprekingen plaats gevonden tussen de Koninkrijkspartners over eventuele wijziging van het Statuut, naar aanleiding van de affaire De Wit. De Nederlandse Antillen wensten toen geen wijziging van het Statuut. Een reden hiervoor kan zijn geweest dat in deze periode een ernstig conflict was gerezen tussen de Antilliaanse regering en het $\mathrm{BC}$ van Curaçao. De hulp van de Koninkrijksregering moest worden ingeroepen, die bij AMvRB het BC buiten werking stelde. De Antilliaanse regering had zich hiermede in een moeilijke positie gebracht, omdat het zelf inroepen van hulp niet samen gaat met protesteren tegen ingrijpen van Nederland in interne zaken. Het is begrijpelijk dat de Nederlandse Antillen in 1961 geen verandering van het Statuut wensten.

Het eerstvolgende gezamenlijk regeringsoverleg na 1961 werd op 29 en 30 januari 1970 in Willemstad gevoerd naar aanleiding van de val van het kabinet-Pengel in Suriname en de ongeregeldheden in Willemstad. Onderwerp van bespreking tussen de Koninkrijkspartners was officieel 'een gedachtenwisseling aangaande de onderlinge staatkundige verhoudingen'. Dit volgens de Nederlandse regering om de mening van de Nederlandse Antillen en Suriname over het Statuut te vernemen. De mogelijkheid werd onderzocht of het Statuut de ruimte bood tot meer zelfstandigheid van de Antillen en Suriname. Deze vraag werd bevestigend beantwoord. Men kwam kort daarna overeen dat een begin moest worden gemaakt met de aanloop naar de zelfstandigheid van Suriname en de Nederlandse Antillen. Besloten werd een gezamenlijke commissie in te stellen om keuzemogelijkheden te formuleren voor uitvoerbare staatkundige- en volkenrechtelijke alternatieven. ${ }^{19}$ Uit de tekst van het uiteindelijk te Willemstad opgestelde Protocol bleek een passieve houding van Nederland. Nederland wilde rekening houden met de mening van de Nederlandse Antillen

Fennema (1986) p. 90. Politiek gezien was er in Nederland, vóór de gebeurtenissen van 30 mei 1969 nauwelijks enige belangstelling voor de Nederlandse Antillen, pp 78, 87, 90. Handelingen Tweede Kamer 1969, 2996.

In 1971 bracht een Commissie van de Adviesraad van de Doctor Abraham Kuyperstichting (ARP) een rapport uit geheten: 'Naar nieuwe verhoudingen'. Als bijlage I is opgenomen het Protocol van Willemstad. De Kuyperstichting (1971) p. 25, noot 35, bevat een belangrijke conclusie van het Protocol van Willemstad: 'dat de bewindslieden voorts van oordeel zijn dat, ter handhaving van de huidige rechtsorde de in het statuut neergelegde bepalingen inzake de verantwoordelijkheden van de koninkrijksregering ten volle moeten functioneren'. Hiermede werd bedoeld dat de Koninkrijksregering een grote verantwoordelijkheidd roeg voor het goed functioneren van de komende besprekingen over de voorgenomen ona fhandelijkheid. De Commissie van de Kuyperstichting begreep evenals de regering niel goed wat met deze verantwoordelijkheid werd bedoeld. 
en Aruba over de toekomstige staatkundige verhoudingen. Tevens stelde het Protocol, dat als Suriname en de Antillen onafhankelijk zouden worden er overeenkomsten moesten worden gesloten tussen Suriname, de Antillen, de VS en Venezuela, met betrekking tot noninterventie en het bewaren van de soevereiniteit. ${ }^{20}$

Fernandes Mendes $^{21}$ was van mening dat aan de rellen in Willemstad teveel gewicht werd toegekend. Men kwam in het Protocol van Willemstad overeen dat de onderlinge samenwerking binnen het Statuut zou worden verstevigd. Desondanks meende Nederland dat Suriname en de Nederlandse Antillen onafhankelijk moesten worden. Fennema en Henriquez ${ }^{22}$ stelden:

"In het Nederlandse verkiezingsprogramma van de PvdA in 1971 werd dan ook voor het eerst weer een alinea aan de Antillen gewijd: 'Nederland neemt het initiatief tot een conferentie met Suriname en de Nederlandse Antillen met het doel het Rijksverband te beëindigen. En in Keerpunt 1972, verkiezingsprogramma en tevens 'regeerakkoord' van de progressieve drie (PvdA, D '66 en PPR), werd zelfs gesteld dat Suriname en de Nederlandse Antillen vó́r 1976 onafhankelijk zouden worden. Wat Suriname betreft zou dat lukken, maar de Antillen wilden niet meewerken aan zoveel voortvarendheid."

De verhouding tussen Nederland en de Nederlandse Antillen onderging niet te ontlopen veranderingen. Nederland zag zich gedwongen de reeds gedane benoeming van ex-Minister-President Efraim Jonckheer tot Gouverneur te herroepen. ${ }^{23}$ De Rijksregering benoemde

De Kuyperstichting (1971).

Femandes Mendes (1989) pp. 68-71.

Fennema (1986) p. 90.

Keesings Historisch Archief, maart 1970, pp. 151-153: 'Er waren zelfs stemmen die de mei-onlusten in direct verband brachten met de benoeming van Jonckheer tot gouvemeur. In een door ons aangehaald interview van het Parool met de Curaçaose vakbondsleider Hubert Rojer verklaarde deze dat de arbeiders door de benoeming van Jonckheer pas beseften dat zij door een familiecian bestuurd werden.' Ook de Frente Obrero was die mening toegedaan. Aan Koningin Juliana werd een telegram gestuurd ondertekend met 'black power'. Daarin werd gezegd dat herstel van de dictatuur van de dynastie Jonckheer met behulp van Nederland niet meer zal worden geaccepteerd door de zwarte bevolking van Curaçao. Deze telegrammen maakten de samenwerking binnen de coalitie moeilijk, omdat de DP deze uitingen afkeurde. Uiteindelijk besloot de Koninkrijksregering na een intern appel procedure ex art. 12 Statuut de benoeming van dr. Jonckheertot Gouverneur in te trekken. De Antilliaanse regering vond dat Jonckheer wel tot Gouverneur kon worden benoemd en dat de oppositie van een kleine groep, de Frente Obrero niet de doorslag mocht geven. De Nederlandse deelnemers en de Gevolmachtigde Minister van Suriname waren echter tijdens het intern appel van mening dat er terecht of ten onrechte een politieke controverse was ontstaan en dat aan het vereiste dat een Gouverneur boven en buiten de partijen moest staan niet meer werd voldaan. Dit veranderde niet toen dr. Jonckheer aangaf zich al sinds midden 1967 uit de Antilliaanse politiek te hebben 
In september 1970 werd een conferentie gehouden in Den Haag. Het doel van de conferentie was om na te gaan of aanvullende afspraken over de staatkundige verhoudingen noodzakelijk waren en om de uitvoering van de eerder gemaakte afspraken te evalueren. Afgesproken werd een een tri-partite commissie in te stellen, die tot taak had een aantal realiseerbare staatkundige en volkenrechtelijke alternatieven te formuleren voor de bestaande verhoudingen. Deze commissie werd ingesteld bij KB van 5 januari 1972 en stond bekend als Koninkrijkscommissie. ${ }^{24}$

Eind augustus 1971 bracht een delegatie van de Vaste Commissie voor Suriname en de Nederlandse Antillen van de Eerste en de Tweede Kamer een bezoek aan de Nederlandse Antillen en besprak daar het Statuut met de Staten. De indruk door de delegatie gewekt, was dat de onafhankelijkheid voor de deur stond, ook al werd dat ontkend door Van Lier, lid van de PvdA en lid van de parlementaire delegatie. $^{25}$ Wel moesten de Antillen op korte termijn zelfstandig worden, maar dat zou niet behoeven in te houden dat de banden met Nederland verbroken zouden moeten worden ${ }^{26}$ Het leek erop of Nederland het initiatief had genomen, omdat een initiatief van de Nederlandse Antillen te lang uitbleef.

In november 1971 werd door Curaçaose politici besloten tot de oprichting van de Commissie Staatkundige Structuur Curaçao (CSSC) als Antilliaanse sectie van de nog op te richten Koninkrijkscommissie, waarvan al sinds het Protocol van Willemstad sprake was. Deze adviescommissie van de eind 1971 opgerichte Nederlands-Antilliaanse sectie van de Koninkrijkscommissie ${ }^{27}$ kwam begin januari 1971 bijeen. In de besloten vergadering van deze commissie bleek, dat bij vrijwel alle partijen op de Nederlandse Antillen de intentie bestond de band tussen de zes eilanden te behouden. Aruba gaf echter te

\footnotetext{
teruggetrokken.

24. Fernandes Mendes (1989) p. 74.

as De Kuyperstichting (1971) p. 19. De delegatie bestond uil mr. Th. van Lier (PvdA), voorzitter, mej. J. van Leeuwen (ARP), mr. J.A. Mommersteeg (KVP), dr. K. van Dijk (VVD), A. de Goede (D'66), H. Pors (DS'70), J.B. Broeksz (PvdA), F.T. van der Maden (KVP) en D. Rijnders (CHU).

26 Van Gameren (1991) pp. 35 e.v.

27 Koninkrijkscommissies zijn voorbereidende ambtelijke commissies ingesteld door de Koninkrijksregering, ter voorbereiding van een RTC, Toekomstconferentie etc. Deze commissies waren en zijn gemengd, hetgeen betekent dat een Koninkrijkscommissie bestond en bestaat uit een Nederlandse-, (Surinaamse,-) Antilliaanse,- en nu een Arubaanse sectie.
} 
kennen dat zij alleen aan een federatie deel wilde nemen als de eilanden politiek en financieel-economisch zelfstandig zouden zijn. Op 31 januari 1972 werd in de Eilandsraad van Aruba met algemene stemmen een motie aangenomen die als volgt luidde:

"Het eilandgebied Aruba is bereid mee te werken aan een Antilliaanse federatie, ${ }^{28}$ waaraan de eilanden vrijwillig deelnemen, uitgaande van de volgende punten:

1. de erkenning van de zelfstandigheid van Aruba als deelstaat van de te vormen federatie;

2. der erkenning en waarborging van het recht van de deelstaten tot vaststelling van hun eigen constitutie (constitutionele autonomie);

3. de erkenning van het principe dat de bevoegdheden van het Centrale Federale gezag tot stand komen krachtens vrijwillige delegatie door de deelstaten." 29

Dit was tevens het standpunt van de MEP. Kon de federatie van de Nederlandse Antillen in een staatsrechtelijke verband met Nederland niet gerealiseerd worden, dan was de MEP voorstander van een onafhankelijk Aruba met staatsrechtelijke of volkenrechtelijke banden met Nederland en volkenrechtelijke banden met de andere eilanden van de Nederlandse Antillen. De federatiegedachte was geen lang leven beschoren op Aruba. Curaçao zou immers gezien het aantal inwoners altijd de overhand hebben. Aruba dacht toen aan rechtstreekse banden met Nederland, maar Nederland gaf te kennen geen voorstander van versplintering van de Nederlandse Antillen te zijn. De MEP was echter van mening dat het een heilig recht was van de Arubaanse samenleving zelf over de eigen toekomst te beslissen.

Eind februari 1973 werd door Arubaanse Eilandsraad unaniem een door de MEP ingediende motie aangenomen, waarin de Koninkrijkspartners Nederland, Suriname en de Antilliaanse eilanden verzocht werd, het recht van Aruba om over haar eigen lot te beslissen te erkennen en eerbiedigen. De Gaay Fortman, Minister van Suri-

Verton (1978) p. 775. In de Curaçaose visie op een federatie zouden de bevoegdheden van het centrale gezag tot stand komen krachtens vrijwillige delegatie van de deelstaten. Een wijziging in de bevoegdheden tussen Land en Eilandgebieden zou tot stand kunnen komen op basis van overeenstemming op federaal niveau. Aruba legde echter in haar visie op een federatie de beslissingsmacht niet op federaal niveau maar op het niveau van de deelstaat. Door middel van 'opwaartse delegatie' zouden een aantal competenties vrijwillig aan het federale niveau worden toegekend. Curaçao zag het federale niveau als het hoogste niveau van wasruit na overeenstemming een 'neerwaartse delegatie' van bevoegdhedennaar de eilandelijke deelstaten zou kunnen plaatsvinden. Aruba wees de Curaçaose visie scherp af en schrapte sindsdien het woord 'federatie' uit zijn woordenboek en wenste nog slechts de 'Status Aparte'. Paula (1989) p. 70. 
naamse en Antilliaanse Zaken noemde het MEP-streven voor een Status Aparte onrealistisch. In het Kabinet Evertsz dat in 1973 optrad, droeg de MEP regeringsverantwoordelijkheid, zij beschouwde de decentralisatie van overheidstaken als een aanloop naar de Status Aparte. Om daarover duidelijkheid te krijgen werd op initiatief van de MEP een eilandelijk topoverleg georganiseerd, waarbij de volgende belangrijke vragen moesten worden beantwoord:

1. Hoe zullen de toekomstige inter-eilandelijke verhoudingen worden, staatsrechtelijk - of volkenrechtelijk, in welke vorm en wat zijn daarvan de financiële consequenties?

2. Welke taken moeten aan de nieuwe eilandenconstellatie worden toebedeeld, welke taken kunnen gedecentraliseerd worden naar de eilanden en welke financiële gevolgen heeft dat?

3. Moeten de eilandelijke bestuursorganen met het oog daarop niet reeds gewijzigd worden?

Op de top werd afgesproken dat ieder eiland zijn eigen lot zou mogen bepalen en dat de andere eilanden dat niet zouden tegenwerken. Het streven van de MEP hield de centrale regering dermate bezig dat zowel de regering Evertsz, als de regering Martina, waaraan de MEP deelnam van 1979 tot 1981 , nauwelijks de lopende zaken kon afhandelen. Daarom werd de MEP in het kabinet-Rozendal (1977) bewust buiten de deur gehouden.

In december 1975 verklaarde Gilberto François ('Betico') Croes dat als Nederland niet mee wilde werken aan een Status Aparte, Aruba deze eenzijdig zou uitroepen. Ook zocht een Arubaanse delegatie in Costa Rica, New York en Venezuela steun voor het afscheidingsstreven. ${ }^{30}$

Rapporten Van Leeuwen, Venezolaanse aanspraken en verdere onderzoeken

In december 1970 verscheen het verslag ${ }^{31}$ van W.C.J. van Leeuwen dat hij in opdracht van de parlementaire Statuutscommissie had opgesteld. In deze Commissie waren alle politieke partijen uit de Staten vertegenwoordigd. De bedoeling was dat in de Commissie een gezamenlijk standpunt werd geformuleerd, dat zou kunnen dienen als

Paula (1989) pp. 71-74.

(Boeli) W.C.J. van Leeuwen was jarenlang secretaris van de Eilandsraad van Curaçao. Tevens is hij jurist en een bekend Antilliaans schrijver. Van Leeuwen (1970). 
uitgangspunt voor de wijziging van het Statuut. Van Leeuwen beschreef in zijn rapport op sociologische en juridische wijze de ontstane staatsrechtelijke situatie in het Caraībisch gebied en met name de problemen van ministaten. Van belang is hoe staten die in dit gebied onafhankelijk werden, zich ontwikkelden: dictatoriaal of democratisch. Een belangrijke conclusie uit het verslag was dat het vormen van een eenheidsstaat van eilanden een schier onmogelijke zaak lijkt.

Het Statuut zag Van Leeuwen als een staatsrechtelijk contract tussen de samenstellende delen van het Koninkrijk der Nederlanden, tevens Koninkrijksgrondwet, gezagsstructuur en gezagsverhouding. De zwakke punten in het Statuut, zoals de theoretische gelijkwaardigheid van de Landen, de quasi federatieve opbouw van het Statuut en de geringe zelfstandigheid van de eilanden worden toegelicht. Als voorbeeld van een geschikt federatief samenwerkingsverband zag Van Leeuwen het Uniestatuut met Indonesie. ${ }^{32}$ Daarin was een verhouding vorm gegeven die heel dicht bij de dominion-status ligt.

Nederlandse staatsrechtelijke instituties zijn verknipt en pasklaar gemaakt voor de eilanden. De grootste fout die ooit gemaakt is in het verleden is de bestemming van Curaçao als zetel van de Centrale Regering. Had men de Centrale Regering op Bonaire gezet, dan was daarmee veel onheil voorkomen. Een belangrijk punt uit het rapport was ook de analyse over de kleinst mogelijke schaal waarop een eiland staatsrechtelijk kan functioneren. " Ergens is 'a law of diminishing returns', waardoor op een bepaald moment het systeem kapot loopt op de realiteit". Van Leeuwen bedoelde hiermee dat een bepaalde grootte van een land noodzakelijk is om economisch te kunnen overleven. Hij was van mening dat een band met Nederland voor de eilanden samen, in bepaalde combinaties of afzonderlijk, te verkiezen is boven een band met Noord-Amerika of Venezuela.

Van Leeuwen kwam met een aantal suggesties om de zelfstandigheid van de eilanden in eigen zaken te vergroten en de onderlinge tegenstellingen te verminderen. Hij stelde de ontwikkeling van de eilanden centraal. De belangrijkste kenmerken van de federatie die hij voorstelde zijn: een bilaterale verhouding tussen twee onafhankelijke soevereine staten en samenwerking op het terrein van buitenlandse betrekkingen, defensie, financiën, economische samenwerking en samenwerking op cultureel gebied, onderwijs en rechtsbedeling. De samenwerking zou moeten geschieden op grond van overeenstemming tussen de partijen. 
Gorsira $^{33}$ was van mening dat de tegenstellingen tussen de eilanden versterkt zijn, door de wijziging in de zetelverdeling van de Staten in 1948. Het politiek insularisme werd door eilandelijke afvaardigingen geïntroduceerd. De stemmen van de kiezers van de verschillende eilanden kregen in het eenheidsparlement verschillende waarden. Voordien waren de verschillende politieke partijen op alle eilanden actief en maakten zij lijstverbindingen op politiek-ideologische basis. Deze door Nederland niet voldoende doordachte wijziging van de zetelverdeling speelt de politiek in de Nederlandse Antillen nog steeds parten. De integratie van de zes eilanden tot een politieke eenheid werd er in grote mate door bemoeilijkt.

De socioloog-politicoloog P.C. Verton, hield vlak voor de Eilandsraadverkiezingen van 1971, een lezersenquête naar de mening van de bevolking over de gewenste staatkundige structuur. ${ }^{34}$ De enquête werd op inititatief van de Amigoe di Curaçao voorgelegd aan de abonnees van de Amigoe di Curaçao, Amigoe di Aruba en Amigoe di Bonaire. Het ging hier om een a-selecte steekproef. Het overgrote deel van de respondenten koos voor een lossere band met Nederland, maar wilde de staatkundige band met Nederland niet verbreken. Geen respondent koos voor onafhankelijkheid terwijl de politieke partijen toch regelmatig de wens tot onafhankelijkheid te kennen badden gegeven. Er bestond duidelijk een verschil in opvatting over de staatkundige toekomst van de Nederlandse Antillen tussen de politieke partijen en de kiezers. ${ }^{35}$

Het grote verschil tussen het rapport van de Commissie Römer en het Verslag Van Leeuwen was, dat het laatste geen alternatieven bood met betrekking tot de verhouding met Nederland. Bovendien meende Van Leeuwen dat de oplossing van het probleem van de zelfstandigheid gezocht moest worden in de onderlinge verhouding tussen de eilanden. Zij stemden op één punt overeen, het Statuut zou moeten worden gewijzigd; hoe, dat vermeldde de historie niet. ${ }^{36}$ Het onderzoek van Verton gaf eveneens aan dat het Statuut gewijzigd zou moeten worden. Alleen het Rapport van de Commissie droeg de mogelijkheid van onafhankelijkheid aan.

\footnotetext{
33 Gorsira (1988) pp. 51-64.

34 Verton (1973).

3s Verton (1971) pp. 58 e.v. bevat de lezersenquête; Van Gameren (1991) pp. 29-32

36 Van Gameren (1991) p. 31.
} 
In de inleiding van zijn tweede rapport ${ }^{37}$ stelde Van Leeuwen dat sinds de totstandkoming van het Statuut (1954) de eilanden niet geleerd hebben elkaar bij te staan. De blik was naar binnen gericht. Het Statuut sneed alle politieke contacten met de buitenwereld af. Immers: defensie, buitenlandse betrekkingen en nationaliteit bleven voorbehouden aan Nederland (het Koninkrijk) op grond van het Statuut. De aandacht van de Nederlandse Antillen moest gericht zijn op een gemeenschappelijk doel, een analyse van de (Nederlandse) buitenlandse politiek ten aanzien van Venezuela en de gevolgen daarvan voor de Nederlandse Antillen. De gunstige ligging van Curaçao en Aruba voor de kust van Venezuela genoot altijd al de warme belangstelling van Venezuela. Alhoewel Nederland ontkende het voornemen te koesteren eenzijdig de onafhankelijkheid op te dringen aan Suriname en de Nederlandse Antillen, wenste Nederland wel zelfstandig initiatieven tot overleg over wijziging van de staatkundige status te kunnen ontwikkelen.

Mommersteeg van de KVP sprak zelfs luchtig over 'latente aanspraken van Venezuela' op de Nederlandse Antillen. Op deze uitspraak wilde Mommersteeg verder begrijpelijkerwijs niet ingaan. De parlementaire Commissie die in september 1971 een bezoek bracht aan de Nederlandse Antillen en Suriname concipieerde een rapport. De belangrijkste zinsnede uit dat rapport luidde, volgens Van Leeuwen:

"Gezien de geografische spreiding van de eilandgebieden lijkt het niet onmogelijk dat van een onafhankelijke staat bestaande uit de Bovenwindse en de Benedenwindse eilanden op langere termijn geen

Van Leeuwen (1972); zie voor een bespreking van het rapport: Van Aller (1991), naar aanleiding van deze publikatie deelde Prof. Hoetink (lid van de toenmalige Commissie Römer) mij bij brief van 20 december 1991 het volgende mee: "Het is zeker juist dat Boeli [Van Leeuwen] in zijn position paper van 1972 en bij andere gelegenhedenook mondeling zich verzet heef tegen het zelfs maar aan de orde stellen van nauwere samenwerking, laat staan politieke aansluiting bij Venezuela. Onze commissie heeft deze mogelijkheid als één van allerlei denkbare altematieven wél aan de orde gesteld. Daarbij zijn in ons rapport de kosten en baten van elk van deze hypothetische alternatieven uitvoerig besproken. De teneur van ons rapport is echter duidelijk, dat voortgezette binding aan en samenwerking met Nederland véruit de voorkeur verdiende en verdient. De gronden daarvoor - en die tegen bijvoorbeeld aansluiting bij Venezuela - zijn dezelfde als die welke Boeli naderhand ook zou hanteren. De situatie op Curaçao in 1969 was er één waarin talrijke radicale opties met klem en fors werden verdedigd, en waarin voortgezette binding aan Nederland door degenen die de 'onlusten' hadden geleid of die als hun intellectuele gidsen optraden, volstrekt van de hand werd gewezen. Het lag daarom - zeker psychologisch - voor de hand dat onze commissie al deze opties 'head-on' behandelde en serieus nam; daarom ook begon ze met de meest extreme 'alternatieven' om vervolgens de balans op te maken en deze extreme opvattingen met kJem van redenen af te wijzen." 
sprake kan zijn. In dat geval zou gedacht kunnen worden aan aansluiting bij andere soevereine staten, waarbij een 'Koninkrijk nieuwe stijl' slechts één der mogelijkheden en zeker niet de meest voor de hand liggende zou kunnen zijn". 38

Voor de Bovenwinden was het nog niet zo eenvoudig om uit te maken welke soevereine staten het rapport op het oog heeft. Voor de Benedenwinden was de zaak duidelijk: alleen Colombia en Venezuela kwamen vanwege hun geografische ligging in aanmerking. 'Tussen een staatsrechtelijke verhouding, zoals die nu bestaat en een volkenrechtelijke met totale onafhankelijkheid is slechts én tussenstation: de gemenebestverhouding, hoe rekbaar dit begrip ook langzamerhand is geworden.' Van Leeuwen meende dat de Venezolaanse politiek erop gericht is aanspraak te maken op met name de Benedenwinden en dan meer specifiek Aruba en Curaçao. De relatie van de Nederlandse Antillen met Venezuela was altijd een haat-liefde verhouding. In de loop der eeuwen zijn familiebetrekkingen en commerciēle banden tussen de landen ontstaan. Op de eilanden leeft de bevolking grotendeels met een 'Europees normbesef'. Van Leeuwen meende dat Nederland nogal beducht was voor migratie van de 'negroïde volksmassa', waarover het rapport ' 30 mei 1969' repte. Hij heeft geen goed woord over voor het rapport van de Commissie Römer. 'Het is voor dit volk niet wenselijk dat het de Venezolaanse soevereiniteit verkrijgt', verklaarde hij. De reeds jarenlang bestaande sociaalculturele en economische penetratie door Venezuela, van met name de Benedenwinden is algemeen bekend. Naar zijn opvatting zal Venezuela geen openlijke stappen nemen vór het economisch een goede greep heeft op de eilanden. Daarna zal Venezuela zo mogelijk langs geleidelijke en vreedzame weg, via artikel 15 van zijn Grondwet, de rol van Nederland trachten over te nemen. Nederland zou hier niet afkerig tegenover staan. ${ }^{39}$

3s De Kuyperstichting (1971) p. 31.

39 In 1942 gedurende de Tweede Wereldoorlog, zijn President Medina Angarita van Venezuela en President Roosevelt van de VS overeengekomen, dat indien de Nederlandse Antillen van soeverein gezag zouden wisselen, Venezuela het eerste land zou zijn om soevereiniteit over deze eilanden uit te oefenen. In 1960 heeft het Venezolaanse Congres de Venezolaanse grondwet herzien en het huidige artikel 15 opgenomen, dat de integratie met het grondgebied van de Venezolaanse staat toestaat van elk willekeurig eiland gelegen voor de kust van Venezuela. Oorspronkelijk was dit artikel bedoeld om de incorporatie van Rupunini (Essequibo) in Venezuela in 1960 te vergemakkelijken. Tijdens de zeventiger jaren is Venezuela begonnen met een actieve politiek ter bevordering van zijn belangen in het Caribisch gebied. Voor wat betreft Aruba en de Nederlandse Antillen was de Venezolaanse aanwezigheid onder andere gericht op een duidelijke vergroting van haar culturele invloed, door op deze eilanden een permanente aanwezigheid te creëren van Venezolaanse culturele 
Ook het rapport van het Institute of Social Studies (ISS) ${ }^{40}$ maakte melding van eventuele wensen van Venezuela tot meer invloed in de Benedenwinden. Het rapport stelde dat indien Aruba onafhankelijk zou worden vóor de totstandkoming van het grensafbakeningsverdrag, dit de volkenrechtelijke en politieke positie van Aruba zeer moeilijk zou maken, zeker bij een eenzijdige onafhankelijkheidsverklaring van Aruba. Het leek de onderzoekers niet onmogelijk dat Aruba steeds meer in de invloedssfeer van Venezuela zou komen, hetgeen tot aansluiting bij Venezuela zou kunnen leiden. Een directe Venezolaanse bedreiging zagen de onderzoekers echter niet. Zowel Venezuela als Amerika hebben belang bij een zo ordelijk en veilig mogelijk verloop van het proces naar Aruba's onafhankelijkheid. Zolang dit gebeurt in overleg met Nederland, zullen beide staten het resultaat van deze onderhandelingen respecteren. Alleen in onvoorziene omstandigheden - langdurige en ernstige ongeregeldheden, een militant radicaal bewind, dat steun zou verlenen aan guerilla-bewegingen elders - zou ingrijpen door één van beide staten verwacht kunnen worden. Maar wanneer de onafhankelijkheid van Aruba, tegelijkertijd met volkenrechtelijke banden met Nederland en de overige Antillen tot stand zou komen, bestaat de mogelijkheid de territoriale integriteit van ieder der Antillen bij verdrag met Venezuela, de VS en Nederland te regelen.

Van Soest ${ }^{41}$ meende dat Venezuela toch wel belangstelling voor de Benedenwinden heeft.

"De doelstellingen welke Venezuela voor ogen heeft in haar buitenlands beleid ten aanzien van de Nederlandse Antillen zijn nooit expliciet geformuleerd in officiële uitspraken; de fraaie volzinnen zijn eerder verhullend dan openbarend. De gebeurtenissen van de laatste jaren wijzen evenwel in dezelfde richting. Blijkbaar stelt Venezuela zich ten doel de Nederlandse Antillen of - althans de drie benedenwindse eilanden voor haar kust, gezamenlijk of afzonderlijk - door zo veelzijdige en innige banden aan zich te binden, dat zij na het verbreken van de staatkundige banden met Nederland zonder twijfel of discussie verder tot de Venezolaanse invloedssfeer zullen worden gerekend. Caldera herinnerde er bijvoorbeeld graag aan dat Curaçao

instituten. Tezelfdertijd was het beleid gericht op de bevordering van de onafhankelijkheid van Caribische eilanden. Bij het bezoek van H.M. Koningin Beatrix aan Venezuela in 1987 is voor het eerst door Venezuela meegedeeld, dat prijs wordt gesteld op een Nederlandse anwwezigheid in de regio, om de stabiliteit en veiligheid in de regio en voor haar kust te garanderen. Zie ook AVP-nota (1990) pp. 22-37. ISS-Rapport (1978) pp. 86-89.

4 Van Soest (1980) pp. 18-23; zie ook Kikker (1977) p. 111 en Hoetink (1980) pp. 43 e.v. 
en Aruba vroeger delen van de provincie Venezuela waren geweest.

Andres Pérez zag in het Venezolaanse en Antilliaanse volk een 'espiritualmente un solo pueblo'."

Verder merkte Van Soest op dat er nimmer een grote affiniteit bestond tussen de Afro-Curaçaoënaar en de Venezolaanse bevolking. De betrekkingen over en weer speelden en spelen zich in hoofdzaak af tussen de blanke elitelaag in beide landen. De immigratiewetten in Venezuela zijn discriminerend ten opzichte van negers. Op de ministeries in Caracas zijn geen donker gekleurde Venezolanen te vinden op hoge posten. Op Curaçao is naar de mening van Van Soest ook het inzicht doorgebroken dat de overgrote meerderheid van de Curaçaose bevolking zowel qua uiterlijk als qua sociaal-culturele erfenis meer verwantschap vertoont met de bewoners der vroegere plantagekoloniën in de Caribische zee, dan met de hispano-indiaansnegroïde bevolking van Venezuela. ${ }^{42}$

\section{Rapporten Jeukens (1971 en 1977)}

Het eerste rapport van H.J.M. Jeukens dat hij in opdracht van de regering van de Nederlandse Antillen maakte, geeft informatie over de heersende staatsrechtelijke problemen sinds de afkondiging van het Statuut. Ook het Statuut van het Koninkrijk deed volgens Jeukens een nieuwe structuur ontstaan.

"De 'soevereiniteit' van de eilanden of hun 'constitutionele autonomie' is de uitdrukking van de gedachte dat in het Antilliaanse staatsbestel het eilandelijk karakter voorop staat en dat de gemeenschappen van de eilandgebieden een veel zwaarder accent hebben in het geheel, dan welke provincie in Nederland ook. Het functioneren van het landsbestuur moet berusten op de samenwerking van de eilandgebieden. Maar het is irreëel deze begrippen tot uitgangspunt te nemen voor een procedure, welke moet leiden tot het verleggen van bevoegdheden in het bestuur van land naar eilandgebied. Deze methode zou zich niet ontwikkelen uit maar naast, zo niet tegen, de bestaande rechtsorde in".

Een federatie van onderaf opbouwen (zoals Van Leeuwen voorstelde) was niet langer mogelijk, aldus het eerste rapport Jeukens. ${ }^{43} \mathrm{De}$ belangrijkste conclusie van Jeukens was dat meer aandacht zou moeten worden besteed aan de verder uitwerking van de decentralisa-

Van Soest (1980) pp. 25-33.
$4 \quad$ Rapport Jeukens (1977) p. 7. 
tie, aan een tweekamerstelsel en aan een gelijkwaardige vertegenwoordiging van politieke partijen in het Bestuurscollege. Voor wat betreft de 'Separación' was Jeukens van mening dat ook gezien het Rapport Kranenburg van 12 mei 1954, afscheiding van Aruba onmogelijk is. Dit zou betekenen dat alle onderwerpen van art. 2 ERNA voor de ongedeelde verantwoordelijkheid van Aruba zouden komen. Met alle technische bijstand die Nederland dan zou moeten leveren, ziet hij dat als een stap terug in de ontwikkeling naar zelfbestuur. Bovendien zou ook na een staatsrechtelijke 'Separación' overleg van de Nederlandse regering met de Antilliaanse regering over Aruba toch nodig blijven, immers de materiële relaties tussen Aruba en het overig deel van de Nederlandse Antillen zouden blijven bestaan.

Verder was Jeukens van mening dat van de politieke organen van de centrale overheid slechts het vertegenwoordigend lichaam, de Staten, een duidelijke electorale legitimatie bezit, nu dit lichaam rechtstreeks wordt gekozen op basis van een algemeen mannen en vrouwenkiesrecht.

\footnotetext{
"De samenstelling van de Staten, die 22 leden telde, wordt beheerst door twee bepalingen in de Staatsregeling die weliswaar niet met elkaar in strijd zijn, doch mocilijk met elkaar te verzoenen zijn. Terwijl art. 67 van de Staatsregeling immers voorschrijft dat de Staten het gehele volk van de Nederlandse Antillen vertegenwoordigen, gaat art. 44 uit van een eilandelijk gestructureerde samenstelling. Dit artikel bepaalt namelijk dat elk der Eilandgebieden een kieskring vormt en kent vervolgens aan het eilandgebied Bonaire drie leden toe, aan Curaçao veertien, Sint Maarten drie en Saba en St. Eustatius elk één lid."
}

Dit beginsel van eilandelijke vertegenwoordiging was van invloed zowel op het functioneren van de Staten als op het functioneren van de ministers. In de praktijk profileerden vooral de uit Curaçao afkomstige Statenleden en ministers zich als vertegenwoordigers van het geheel. Bij degenen die afkomstig zijn van de andere eilanden, proefde men daarentegen voortdurend - "is het omdat de vrees voor achterstelling door Curaçao bij hen overheerst?"' - dat zij zich primair beschouwen als vertegenwoordigers van hun eiland.

Door Jeukens was in 1971 aan de Antilliaanse regering het voorstel gedaan om een tweekamerstelsel in te voeren waarbij de ene kamer rechtstreeks zou worden gekozen door het gehele volk en de andere zou worden samengesteld op basis van de indeling in Eilandgebieden. Op deze wijze zouden de hiervoor genoemde beginselen het 'landelijke' en het 'insulaire' van elkaar worden losgekoppeld. Hij verwachtte dat dit voorstel zou kunnen leiden tot het ontstaan van politieke partijen die zich over de hele Antillen aan het electoraat 
zouden presenteren en dat de rechtstreeks gekozen kamer een exponent zou kunnen zijn van het nationaal Antilliaans staatsrecht.

Het voorstel is echter nimmer door enige Antilliaanse regering in overweging genomen, terwijl latere ontwikkelingen de insulaire gevoelens juist hebben versterkt. ${ }^{44}$

Het tweede rapport Jeukens was een uitgebreide uitwerking van het eerste rapport in het licht van een planmatige voorbereiding van de onafhankelijkheid van de Nederlandse Antillen, zoals ook de regering van de Nederlandse Antillen dit in de jaren zeventig wenste. ${ }^{45}$ In deze periode stuurde Nederland nog aan op de onafhankelijkheid van de Nederlandse Antillen en Suriname. Voordat daartoe het Statuut gewijzigd kon worden, moest zekerheid bestaan omtrent de staatskundige vorm waarin de Nederlandse Antillen zouden samenwerken in een staatkundig verband.

De onderzoeksopdracht van de Antilliaanse regering aan Jeukens, was de uitwerking van een verdergaande zelfstandigheid van de eilanden en behelsde de eerste fase op weg naar de onafhankelijkheid. In de tweede fase zou vanuit de interne zelfstandigheid van de eilanden een nieuw samenwerkingsverband tussen de eilanden tot stand worden gebracht. In de derde fase zou de voorbereiding voor de onafhankelijkheid worden afgerond. Jeukens behandelde twee hoofdmogelijkheden, te weten een geheel andere staatsrechtelijke of volkenrechtelijke orde en als tweede mogelijkheid, aanpassingen van de staatsrechtelijke structuur binnen hetgeen in het Statuut mogelijk is.

Als uitgangspunt werd bij de eerste mogelijkheid gedacht aan de soevereiniteit van de eilanden (deze gedachtengang werd aangehangen door de MEP). De voorstanders daarvan dachten aan een federatiestructuur van de eilanden. Elk eiland zou dan een eigen constitutie moeten hebben, voordat de onafhankelijkheid kon worden ingevoerd. Als voorbeeld werd gedacht aan de VS.

Jeukens meende dat het beter was de bestaande rechtsorde te handhaven zodat de eilanden in één staatsverband met elkaar verbonden zouden blijven. Binnen de bestaande rechtsorde moest gezocht worden naar mogelijkheden om de eilanden meer zelfstandigheid te verlenen. Het rapport zag weinig heil in een vorm van decentralisatie

\footnotetext{
Dip (1990) pp. 509 e.v.

Ten aanzien van deze problematiek hadden de regeringen van Nederland en de Nederlandse Antillen een gezamenlijke Commissie ingesteld teneinde een integraal sociaaleconomisch en cultureel ontwikkelingsplan voor de Nederlandse Antillen op te stellen in verband met de planmatige voorbereiding van de ona fhankelijkheid. Dit geschiedde bij $K B$ van 26-11-1976, 15 .
} 
door overdracht van bevoegdheden van landsniveau naar eilandsniveau. Een andere benadering verdiende de voorkeur. De interne bestuursstructuur van de eilandgebieden zou moeten worden versterkt. De Staatsregeling en de ERNA zouden moeten worden samengevoegd. Het administratief hoger toezicht zou moeten worden afgeschaft en vervangen door een rechterlijke controle van een 'federale' rechter. Dit zou kunnen geschieden door het bestaande Hof van Justitie van de Nederlandse Antillen. Ook zou het wellicht mogelijk zijn het toezicht op Koninkrijkswetgeving, landswetgeving en eilandsverordeningen en eilandsbeschikkingen aan de onafhankelijke rechter te laten en niet door een hoger bestuursorgaan te doen geschieden.

Samenvattend kan worden gesteld dat Jeukens de eilandelijke soevereiniteit te eenzijdig en te riskant vond. Hij meende dat de eilanden in én staatsrechtelijk verband met elkaar verbonden moesten blijven en dat binnen de bestaande rechtsorde gezocht moest worden naar mogelijkheden om de eilanden een grotere zelfstandigheid te verlenen.

Duidelijk was in ieder geval wel dat door de opstelling van Nederland na 30 mei 1969 de politieke partijen in verwarring waren geraakt en dat zij niet echt de onafhankelijkheid wensten. De consistente lijn sinds de jaren vijftig was dat de bevolking van de Nederlandse Antillen nimmer, met zelfs maar een geringe meerderheid, de banden met Nederland heeft wilden verbreken. Dat was ook de reden waarom de Antilliaanse politici zich niet bezig wilden houden met de onafhankelijkheid. De onafhankelijkheid kwam in de Staten nauwelijks ter sprake en in de Eilandsraden in het geheel niet. Ook het rapport van de Commissie Römer is nauwelijks aan de orde geweest in de Staten en dit gold ook voor het Verslag van Van Leeuwen en het onderzoek van Verton. ${ }^{46}$

J.H. van der Kuyp, thans advocaat op Aruba, was hoofd van de voormalige afdeling Wetgeving en Constitutionele Zaken van het Eilandgebied Aruba, tevens secretaris van de Arubaanse grondwetscommissie, Eilandsraadlid en Gedeputeerde voor de MEP van het Eilandgebied Aruba. Hij reageerde op het Werkdocument van Jeukens. ${ }^{47}$ Voor de Arubanen was de regeling van de toekomstige staatkundige structuur veel belangrijker dan de onafhankelijkheid. De Arubanen waren niet tevreden met hun minderheidspositie in de Antilliaanse Staten. Naar zijn mening verzwakte het voorstel van Jeukens de positie van Aruba nog verder. Met name omdat in Jeu-

46 Van Gameren (1991) p. 42

4 Van der Kuyp (1977) pp. 150-152 en (1975) pp. 1246-1251. 
kens' voorstel de Staten werden gekenschetst als een volksvertegenwoordiging met het element van een eilandsvertegenwoordiging. Van der Kuyp meende dat de situatie juist omgekeerd is. Hij sluit zijn reactie af met een pregnante conclusie

\footnotetext{
“[...] het Curaçaosche electoraat is de sjeik en de electoraten van de andere eilanden zijn de haremdames. De sjeik gaat naar bed met wie hij belieft. Zolang de Nederlandse politici en juristen niet kunnen inzien dat het Arubaanse electoraat weigert om de rol van haremdame te spelen, zal er geen oplossing gevonden worden." 4
}

De MEP achtte het rapport Jeukens volstrekt achterhaald. Inmiddels was de politieke druk van het Arubaanse nationalisme zo sterk geworden dat mogelijke nadelen van de onafhankelijkheid moeilijk bespreekbaar werden, omdat men dan al gauw gezien werd als tegenstander of zelfs vijand van het Arubaanse volk. Er was zelfs sprake van intimidatie. ${ }^{49}$

Betico Croes zei daarover het volgende: “De Arubaan die kiest voor de federatie is een landverrader". Betico Croes doelde hier in het bijzonder op de PPA politici. Er was zelfs al sprake van een eventuele gewapende strijd, een aantal MEP-leden deed aan intensieve lichaamstraining. "Ik zie de tijd komen dat we tot acties moeten overgaan. Ik zal bet uiterste doen om gewapende strijd te voorkomen. Maar als we gedwongen worden, dan zie ik ergere acties dan vorig jaar. Het kan mij mijn leven kosten, maar ik ga door het vuur. Ik kan in mijn geweten niet aan een federatie meewerken. Ik zal alles, alles doen om de onafhankelijkheid te bereiken. Ook een wapenstrijd als die daarmee gepaard moet gaan". 50

De Koninkrijkscommissie

Het eerste beraad van de voltallige Koninkrijkscommissie vond plaats in Den Haag, eind maart 1972. Deze had tot taak alternatieven te formuleren voor nieuwe staatkundige verhoudingen tussen de lan-

Kleurenbijlage Vrij Nederland (1978) p. 31.

ISS-Rapport (1978) pp. 103 e.v.

Kleurenbijlage Vrij Nederland (1978); Verton (1978) en (1978A). De positie van de MEP was zeer belangrijk in de jaren '70. Bij de Eilandsraadverkiezingenin 1971 verkreeg de MEP 34\% van de stemmen, in 1973 was dat $56 \%$ en in $197560 \%$, Verton a.w. p. 772. Wat ook een rol speelde bij het Arubaanse afscheidingsstreven was dat de schade van de 30 mei gebeurtenissen, begroot op $\$ 50$ miljoen, ook met Arubaanse bijdragen zou moeten worden betaald. Naar de mening van Verton hadden de 30 mei gebeurtenissen een sneeuwbaleffect op het Arubaanse afscheidingsstreven, Verton, (1978) p. 774. 
den. ${ }^{31}$ Er werd besloten tot de splitsing van de commissie in twee werkgroepen, een staatsrechtelijke werkgroep en een voor volkenrechtelijke kwesties.

De Arubaanse Eilandsraad eiste op 14 augustus 1972 opschorting van de werkzaamheden van de Koninkrijkscommissie, totdat er helderheid zou bestaan over de inter-eilandelijke relaties. Daartoe zou een inter-eilandelijk topoverleg moeten worden gehouden, hetgeen pas in augustus 1974 plaats had. De meeste leden van de Antilliaanse sectie van de volkenrechtelijke werkgroep meenden dat de Nederlandse Antillen onafhankelijk moesten worden. Voor de Arubaanse leden was een volkenrechtelijke samenwerking slechts een tweede keuze, indien het behoud van staatsrechtelijke banden niet te verwezenlijken viel, was Aruba bereid een volkenrechtelijke samenwerking te accepteren. De Koninkrijkscommissie vergaderde van 28 augustus tot 2 september 1972 te Paramaribo en daar kwamen de tegenstellingen tussen Curaçao en Aruba pas goed aan het licht. De AVP en de PPA wisselden nog al eens van mening en waren soms voor en soms tegen de Status Aparte. Alleen de MEP stelde de staatkundige problematiek centraal, ook in de verkiezingen voor 3 augustus 1973. Op centraal niveau was er wel belangstelling voor de onderlinge eilandelijke relaties bij onafhankelijkheid maar nauwelijks voor de economische relaties. ${ }^{52}$

Op 13 februari 1973 werd aan de leden van de Antilliaanse sectie van de Koninkrijkscommissie het concept-Statuut aangeboden, dat door Nederlandse deskundigen was vervaardigd en dat door de Nederlandse staatsrechtelijke werkgroep bij de besprekingen over de toekomstige staatkundige status als voorstel tot een overgangsregeling zou worden aangeboden. Dit 'Licht Statuut' zou als overgang dienen naar een algehele onafhankelijkheid, waarvoor de Landen eenzijdig door middel van een landsverordening of wet zouden kunnen kiezen. Door Nederland werd de indruk gewekt dat de onafhankelijkheid van de Nederlandse Antillen zou worden doorgedrukt, ondanks geruststellende verklaringen van Nederland, die het tegendeel moesten bewijzen. De reacties van de Antilliaanse sectie waren negatief, maar ze hadden zelf geen alternatief voorstel aan te bieden. Het leek erop of de Antilliaanse sectie door interne verdeeldheid een machteloos praatorgaan was geworden.

Eind februari 1973 wist de Antilliaanse sectie van de Koninkrijkscommissie alsnog een gezamenlijk standpunt te formuleren, het Licht Statuut werd verworpen. Het Licht Statuut, zo meende de

st Van Gameren (1991) p. 48: Fernandes Mendes (1989) p. 74 e.v.
s2 Van Gameren (1991) pp. 48-54. 
sectie, was een landmijn, zodra de Antillen een verkeerde stap zouden doen zou Nederland de staatsrechtelijke band opzeggen. De Antilliaanse sectie opteerde voor een Gemenebest op volkenrechtelijke basis met vóóraf duidelijke onderlinge afspraken over garanties van Nederlandse steun, tussen Nederland en de Nederlandse Antillen, met betrekking tot de daarvoor in aanmerking komende terreinen. Ook de leden binnen de sectie die de voorkeur gaven aan staatsrechtelijke banden opteerden voor een Gemenebest-regeling, als tweede keuze.

Op 1 maart 1973 verklaarde de voorzitter van de Antilliaanse sectie Evertsz van de NVP-U dat de Antillen het meeste gebaat zouden zijn met een band tussen Nederland en de Nederlandse Antillen in de vorm van een Gemenebest, tijdens de overgangsperiode. De weg naar de onafhankelijkheid zou gefaseerd moeten worden afgelegd. Op lange termijn kon dan integratie in de eigen regio plaatsvinden. Gezien de zuigkracht van Venezuela moest de band met Nederland gehandhaafd blijven, totdat, naast de lijn Caracas-Willemstad, meer lijnen in de regio ontwikkeld zouden zijn. De afwachtende houding van de Nederlandse Antillen was door de Nederlandse activiteiten verdwenen en het leek erop dat de Antillen op weg waren naar de onafhankelijkheid.

De conferentie van de Koninkrijkscommissie, die van 12 tot en met 23 maart 1973 in de Antillen werd gehouden bevestigde die tendens. De Antillen presenteerden een eensgezind, constructief en vooral realistisch standpunt. Nederland zou wel de buitenlandse betrekkingen en de defensie moeten blijven behartigen. Ook diende er een oplossing te worden gevonden voor de grote schuldenlast van bijna $10 \%$ van de begroting, het verminderen van de aanzienlijke werkloosheid was van belang, het onderwijssysteem was niet aangepast aan de lokale situatie en er bestond een groot tekort aan deskundig personeel op allerlei gebied.

Op de conferentie spraken de MEP-leden zich echter uit voor het behoud van staatsrechtelijke banden met Nederland, net nu de Antillen eensgezind de onafhankelijkheid voorstonden, indien aan de bovengenoemde garanties werd voldaan. Omdat Aruba niets met Curaçao te maken wilde hebben sloeg de stemming om en verdween de Antilliaanse eensgezindheid als sneeuw voor de zon. Tijdens de bijeenkomst van de Koninkrijkscommissie op Aruba organiseerde de MEP een manifestatie vóór de Status Aparte van Aruba, terwijl de Nederlandse delegatie, evenals de PPA en de AVP zich niet achter het MEP-standpunt konden stellen. In zekere zin hielp het mislukken van de Koninkrijksconferentie de Antillen om de onafhankelijkheid, 
waarom zij duidelijk niet zaten te springen, nog even uit te stellen.

In mei 1973 verscheen een rapport van de Nederlandse politieke partijen PvdA, Politieke Partij Radicalen (PPR) en Democraten 66 (D66). Deze partijen zagen niets in een tijdelijk Gemenebest en wensten zo snel mogelijk algehele onafhankelijkheid voor Suriname en de Nederlandse Antillen.

Bij de Statenverkiezingen van augustus 1973 werd de MAN die zich het duidelijkst had uitgesproken over de onafhankelijkheid van de kaart geveegd, waaruit kan worden geconcludeerd, dat de Curaçaose bevolking afwijzend stond ten opzichte van onafhankelijkheid. Op Aruba veroverde de MEP 5 van de 8 Statenzetels, werd de AVP weggevaagd en veroverde de PPA de resterende 3 zetels. De MEP wilde bij het opdringen van de onafhankelijkheid door Nederland uit het Antilliaanse verband stappen en staatsrechtelijke banden met Nederland onderhouden, liefst als vierde partner in het Koninkrijk. Het is begrijpelijk dat de MEP deel wilde uitmaken van de regering om de staatkundige doelstellingen van Aruba te realiseren. Evertsz wantrouwde de Nederlandse regering en meende met Aruba sterker te staan. Het leek er ook inderdaad op, dat zeker na de verklaringen van de progressieve politieke partijen in Nederland, Nederland niet langer als een koloniale natie wilde worden gezien. Zolang de Antillen nog geen eenheid vormden kon Nederland de Antillen niet laten vallen en met de MEP in de regering viel er voor die eenheid niet te vrezen.

Inmiddels was er ook een nieuw ministerie van Staatkundige Structuur Eilandgebieden (DSSE) ontstaan, onder verantwoordelijkheid van de MEP. Op 19 december 1973 werd in de Staten van de Nederlandse Antillen de motie 'aparte status' van de MEP, met een overweldigende meerderheid aangenomen. Deze motie hield in dat elk eilandgebied baas in eigen huis was en zich te allen tijde kon beroepen op de aparte status. De motie zei echter niets over afscheiding van Aruba van de Nederlandse Antillen. Dat is zeker de oorzaak geweest dat de motie op algemene instemming kon rekenen. De motie kwam neer op grotere autonomie van de eilandgebieden ten opzichte van de centrale regering.

De Frente kwam met een ontwerp-landsverordening ter goedkeuring van het afscheidingsstreven van Aruba. Dit ontwerp moest duidelijkheid brengen ten aanzien van de Antilliaanse onafhankelijkheidsproblematiek, waardoor de Antillen desnoods zonder Aruba naar onafhankelijkheid zouden kunnen streven. Dit mislukte. Het ontwerp werd pas behandeld in het zittingsjaar 1978-1979. De Antilliaanse regering kwam eind januari 1974 met een regeringsverklaring waarin 
een standpunt werd ingenomen met betrekking tot de gewenste staatkundige structuur van de Nederlandse Antillen. De regering was niet eerder met een standpuntbepaling gekomen, omdat zij het eindadvies van de Koninkrijkscommissie had willen afwachten. De regering stelde zich op het standpunt dat voorafgaande aan de onafhankelijkheid, de interne Antilliaanse verhoudingen duidelijk moesten zijn en een aantal garanties dienden te worden verkregen van Nederland. De lijst van gewenste garanties was zo lang dat het duidelijk was, dat het jaren zou duren voordat alles geregeld was. De Nederlandse Antillen hadden zelf het initiatief genomen, omdat tegen elke prijs vermeden moest worden dat Nederland de onafhankelijkheid zou opleggen, voordat de Nederlandse Antillen daarvoor klaar waren. De vertragingsstrategie had in ieder geval gewerkt. Het uit nood geboren 'nationale gevoel' van de politieke partijen maakte weer plaats voor onderlinge rivaliteit. Hoe de politieke partijen de onafhankelijkheidsproblematiek zouden aanvatten was nog verre van duidelijk. ${ }^{53}$

Op 19 februari 1974 verklaarde Premier Evertsz in de Staten, dat de Antilliaanse regering vasthield aan een planmatige voorbereiding van de onafhankelijkheid. Nederland moest ook de benodigde garanties geven, voordat de Nederlandse Antillen zich voor de onafhankelijkheid zouden uitspreken. Daar waar de Antillen gehoopt hadden voorlopig niet over de onafhankelijkheid te hoeven denken, veranderde deze situatie ingrijpend door de verklaring van Suriname. Voorkomen moest worden dat Nederland een spoedige onafhankelijkheid zou afdwingen. Met de opstelling van de MEP valt deze uitspraak van Evertsz moeilijk te rijmen. De MEP had immers steeds gesteld het Antilliaans verband te willen verlaten en een aparte status te wensen. De MEP wilde helemaal geen snelle onafhankelijkheid, maar opteerde voor een directe band met Nederland. Zou daarentegen de onafhankelijkheid snel worden doorgedrukt dan kon de MEP de Status Aparte wel vergeten, omdat dan afscheiding veel moeilijker zou worden. Omstreeks maart 1974 maakte de MEP duidelijk dat zij haar streven niet opzij zette, maar de 'Status Aparte' anders interpreteerde. Alle eilanden moesten zoveel mogelijk onafhankelijk van elkaar worden en daarna samenwerken in een supranationaal verband op basis van vrijwilligheid.

Bij de opening van het zittingsjaar 1974-1975 memoreerde Gouverneur Leito nogmaals dat de onafhankelijkheid van de Antillen niet 
mocht worden opgedrongen zonder voldoende garanties. En ook al wenste Suriname onafhankelijkheid dan was dat een zuiver Surinaamse aangelegenheid en hield dat niet in dat de Antillen geen staatsrechtelijke banden met Nederland zouden kunnen houden. Eerst zou de zelfstandigheid van de eilanden onderling moeten worden gerealiseerd, dan zou een samenwerkingsverband voor de eilanden moesten worden uitgewerkt en vervolgens zou de voorbereiding voor de onafhankelijkheid dienen te worden afgerond. Nederland moest zich niet schuldig maken aan koloniaal gedrag door de onafhankelijkheid op te dringen. De Antilliaanse regering volgde dezelfde lijn als de Curaçaose partijen. Evertsz verklaarde in een gesprek met het ANP van eind april 1974, dat hij de status aparte van Aruba altijd had begrepen als de wens tot veel meer autonomie. Dit viel slecht bij de MEP, die eiste dat de status aparte van Aruba centraal zou staan op de komende Koninkrijksconferentie. Hierop reageerde Evertsz weer door te stellen dat de regeringsverklaring nergens meldde dat er een status aparte voor Aruba moest komen. De onderlinge verhoudingen tussen de partijen verslechterden verder. De MEP accepteerde veel om in de regering te kunnen blijven. De Nederlandse druk op de Antillen om onafhankelijk te worden nam af, dus nam de rivaliteit tussen de politieke partijen weer toe, omdat een eensgezinde Antilliaanse houding minder noodzakelijk bleek.

Tussen 26 en 29 augustus 1974 vond eindelijk het eerste eilandelijke topoverleg plaats, waarom de Arubaanse Eilandsraad al in augustus 1972 had gevraagd. De polarisatie tussen de politieke partijen nam op dit overleg verder toe. De AVP had zich aan de zijde van de MEP geschaard, met name omdat de Curaçaose partijen zich in februari 1972 hadden uitgesproken voor een gedecentraliseerde eenheidsstaat in republikeinse vorm volgens het systeem 'one man one vote'. Daardoor ontstond het gevaar dat het ene eiland het andere zou kunnen overheersen. Op grond daarvan sprak de AVP zich uit tegen een Antilliaanse federatie en vond dat het concept moest worden bijgesteld. Tot op dat moment had echter geen enkele Antilliaanse politieke partij concreet uitgewerkt, hoe zo'n federale republiek er dan wel uit zou moeten zien en wat daarvan de financiële consequenties zouden zijn. Ook was niet echt duidelijk wat de MEP precies bedoelde met de 'Status Aparte', omdat dat concept nogal aan verandering onderhevig was geweest.

Toen het overleg op 18 november 1974 werd voortgezet op Bonaire, presenteerde de MEP maar liefst drie verschillende interpretaties van de Status Aparte. Naast het model waarin Aruba als soevereine natie los van de rest van de Antillen staatsrechtelijke banden met Nederland, Suriname en de Nederlandse Antillen wenste, 
waren er twee nieuwe modellen bijgekomen. Het eerste model kwam neer op een Gemenebest, bestaande uit Nederland, Aruba, de Antillen en Suriname (indien nog niet onafhankelijk) met volkenrechtelijke banden, waarbij Aruba een onafhankelijk deel in het Gemenebest zou zijn. De onderlinge samenwerking zou geregeld worden in verdragen, terwijl de externe defensie, het buitenlands beleid, een economische gemeenschap en een monetaire unie onder de gemeenschappelijke taken zou vallen. De Koningin zou aan het hoofd van het Gemenebest staan.

Het tweede model was een Gemenebest tussen de Antilliaanse eilanden. Dit Gemenebest zou dan weer in een Gemenebest met Nederland moeten worden opgenomen. In dit voorstel was de Koningin hoofd van het Gemenebest, hoofd van het samenwerkingsverband en hoofd van de staat Aruba. Aruba zou in alle drie de modellen een soevereine natie zijn. Daar Nederland een aparte status voor Aruba had afgewezen stelde de MEP alles in het werk om toch haar ideaal te realiseren. De Antilliaanse partijen, behalve de PSD hielden opnieuw vast aan de Antilliaanse federatie en de MEP kwam met drie Status Aparte modellen.

$\mathrm{Koot}^{54}$ had grote vraagtekens bij de houding van de PSD. Hij meende dat Isa, de partijleider van de PSD, gedacht moet hebben dat de onafhankelijkheid van Curaçao een interessant verkiezingsthema was. De keuze van de PSD zou niet door idealistische motieven zijn ingegeven, maar door electorale overwegingen, aldus Koot. Wellicht was de PSD echter alleen maar realistisch, daar de problemen tussen de eilanden onoplosbaar leken. Er ontbrak immers nog steeds een degelijke analyse van de financiële consequenties van de toekomstige onderlinge eilandelijke verhoudingen. Het eilandelijk overleg had nog steeds geen concrete resultaten opgeleverd.

Tussen 18 en 21 mei 1975 kwamen de drie premiers van de Koninkrijksdelen in Den Haag bijeen om de onafhankelijkheidsproblematiek te bespreken. De Nederlandse Minister-President Den Uyl stond uiterst welwillend tegenover de wens tot onafhankelijkheid van Suriname en de conferentie werd beëindigd met een slotverklaring

Koot (1975) pp. 13 en 34. Uit dit onderzoek bleek dat Antilliaanse onathankelijkheid door het merendeel van de Antillianen niet werd gewenst, ook al spraken politieke leiders zich duidelijk uit over de wens tot onathankelijkheid. Alleen bij de MEP kiezers was een krappe meerderheid in 1975 vóór de onathankelijkheid. De meesten onder hen vereenzelvigden echter een staatkundige onafhankelijkheid met de status aparte. Minister-President Evertsz kon, aldus Koot, tevreden zijn over zijn beleid. dat erop gericht was eerst economische zekerheid en politieke veilighsid te waarborgen, alvorens over een opheffing van het Statuut met de Nederlandse regering te gaan praten. Het onderzoek van Koot, wees uit dat de meerderheid van de Antillianen zijn beleid lijkt goed te keuren. Zie ook Koot (1985) p. 722. 
dat het Statuut eind 1975 niet meer voor Suriname zou gelden. De Nederlandse Antillen hoefden (nog) niet onafhankelijk te worden. De commissie had alleen op een aantal deelonderwerpen geadviseerd en was er niet in geslaagd een advies over de Antillen uit te brengen. De commissie telde teveel leden (60) en had een weinig preciese taakstelling. De Koninkrijkscommissie stierf een min of meer zachte dood en kreeg op 4 juli 1974 als aanvullende taak het Surinaamse streven naar onafhankelijkheid als uitgangspunt te nemen. Dat betekende dat alle aandacht werd besteed aan de komende onafhankelijkheid van Suriname. ${ }^{5 s}$

Het derde eilandelijk topoverleg had plaats van 12 tot 16 februari 1975 op Curaçao. Dit overleg kan het best worden beschreven als chaotisch. De organisatie was slecht, de meningen liepen zeer uiteen. De eilanden verkeerden in de unieke situatie " dat zij het onafhankelijk worden van Suriname met alles wat daaraan verbonden was als toeschouwer op de eerste rij konden gadeslaan. Zij konden van de fouten die daar gemaakt werden leren en op grond van deze fouten de strategie bepalen bij de onderhandelingen met Nederland." 56

De Curaçaose partijen met uitzondering van de PSD, waren niet verder gekomen dan zich uit te spreken voor een Antilliaanse federale republiek en de MEP had drie verschillende status-aparte modellen voorgesteld. De partijen die altijd het duidelijkst waren geweest over de onafhankelijkheid van de Antillen, de Frente en MAN kwamen samen op een lijst onder de naam Frente. De Frente liet duidelijk merken, dat er nu genoeg gepraat was en dat er besluiten moesten worden genomen. Als de eilanden niet bij elkaar konden blijven, dan moest Aruba zich maar afscheiden, dat was beter dan de bestaande situatie, waarin de MEP de regering doorlopend dwarsboomde.

De MEP bleef op haar standpunt staan. Aruba moest los van de Antillen komen te staan en zou op volkenrechtelijke basis samenwerken met de andere eilanden. Een politieke eenheid met de andere eilanden werd met grote stelligheid afgewezen. Ook de MEP kwam echter niet met sociaal-economische plannen. Tevens was niet duidelijk welke staatkundige verhouding de MEP in de toekomst met Nederland wenste. De PPA en de AVP wensten wel een samenwerking met de andere Antilliaanse eilanden. De PPA opteerde voor een

ss Fernandes Mendes (1989) p. 74.

\6 Van Gameren pp. 71-88.

346. Ongeregeldheden en ongewenste onafhankelijkheid 
federatie met autonome eilandgebieden, een standpunt waarvan nimmer was afgeweken, aldus PPA-voorzitter Max Croes. De eensgezindheid tussen de Curaçaose partijen NVP-U, DP, MAN en Frente, die leek te bestaan was in de verkiezingsstrijd geheel verdwenen. De PSD en de MEP waren binnen de Antilliaanse regering voorstanders van desintegratie van de Nederlandse Antillen. De eilandgebieden moesten volledige autonomie verkrijgen en op de door de eilanden gewenste terreinen zou federale samenwerking moeten plaats vinden.

De Eilandsraadverkiezingen van 25 april 1975 gaven op Curaçao grote verschuivingen te zien. De combinatie Frente/MAN behaalde 8 van de 21 zetels. De PSD, die voor het eerst deelnam aan de verkiezingen kreeg 3 zetels, de NVP-U leed verlies en behaalde 6 zetels, de DP behaalde 4 zetels. Bij de Eilandsraadverkiezingen op Aruba behaalde de MEP 13 zetels, van de overige zetels kreeg de PPA er 7 en de AVP 1. De MEP vormde in haar eentje het Bestuurscollege $(\mathrm{BC})$, de 'eilandsregering'.

In de periode 1969-1975 werd door Verton ${ }^{57}$ onderzoek gedaan naar de wens van de Antilliaanse bevolking ten aanzien van de toekomstige staatkundige structuur. Uit dit onderzoek bleek dat vrijwel niemand zich uitsprak voor de Nederlandse Antillen als een onafhankelijk land. Ook de Nederlandse antropoloog-socioloog Koot publiceerde in 1975 een onderzoek naar de wens van de Antilliaanse bevolking naar de onafhankelijkheid. ${ }^{58}$ Uit het onderzoek kwam naar voren dat slechts $14 \%$ van de Curaçaose bevolking en $28 \%$ van de Arubaanse bevolking voor de onafhankelijkheid was. ${ }^{59}$ Verder bleek uit het onderzoek dat $73 \%$ van de Curaçaoënaars en Arubanen bevreesd waren voor de gevolgen van de onafhankelijkheid op korte termijn. Slechts $18 \%$ zag de tijd na eventuele onafhankelijkheid met vreugde tegemoet. $6 \%$ tenslotte dacht dat alles ongeveer hetzelfde zou blijven. Werkzoekenden oordeelden nog het gunstigste over de onafhankelijkheid. Koot was van mening, dat werklozen zich in hun uitzichtloze situatie vastklampten aan de onafhankelijkheid. Het grootste percentage pessimisten over de toekomst van de Antillen werd gevonden in de hoogste sociaal-economische klasse. $\mathrm{Zij}$ verklaarden zeer angstig te

$\begin{array}{ll}\text { s7 } & \text { Verton (1973). } \\ \text { s8 } & \text { Koot (1975). } \\ \text { s9 } & \text { Koot (1975) p. } 18 .\end{array}$ 
zijn voor de onafhankelijkheid. ${ }^{60}$ Wellicht kan de verklaring hiervoor gevonden worden in het feit dat hoogopgeleiden met goede banen het meeste te vrezen hebben van een staatkundige verandering, omdat hun positie dan bedreigd zou kunnen worden en hun verworven rechten zouden kunnen worden aangetast.

De MEP was de enige partij met meer voorstanders dan tegenstanders voor de onafhankelijkheid. $39 \%$ van de aanhangers van de MEP waren voor de onafhankelijkheid en $38 \%$ tegen. De kiezers waren alleen geïnteresseerd in de vermindering en opheffing van de invloed van Curaçao op Aruba. De sociaal-economische consequenties van de onafhankelijkheid speelde een geringe rol in de afweging. De tegenstanders van de onafhankelijkheid bij de MEP waren wel sterk voor de Status Aparte maar vonden een opheffing van het Statuut een te groot economisch risico. Van de PPA-stemmers sprak niemand zich uit vó́r de onafhankelijkheid en was $66 \%$ absoluut tegen. ${ }^{61}$ Van de Arubaanse respondenten sprak niemand zijn voorkeur uit voor het AVP standpunt, namelijk samenwerking met de andere eilanden. Het onderzoek vond plaats in maart 1974, de AVP had in augustus 1973 een groot verlies geleden ten opzichte van de vorige verkiezingen en behaalde niet meer dan 1300 stemmen (ongeveer $1 \%$ van het totaal). Koot vroeg zich ook af of de partij nog wel enige aanhang had. ${ }^{62}$

Vastgesteld kan worden dat door het onderzoek van Koot de anti-onafhankelijkheidspolitiek van het kabinet Evertsz werd ondersteund, een groot deel van de bevolking stond achter die politiek. De MEP wenste nog steeds de Status Aparte, maar wat dat precies inhield was niet duidelijk, ook niet bij de MEP aanhang. Wel duidelijk was dat de onafhankelijkheid voorlopig nog niet voor de deur stond. Dat was immers niet in bet belang van de Antilliaanse bevolking, temeer daar de regering niet kwam met oplossingen voor de economische problematiek.

Renkema ${ }^{63}$ vatte nog eens alle in het verleden gedane pogingen om de kolonie af te stoten samen, in drie gevallen door verkoop en in het vierde geval door het aandringen op onafhankelijkheid door Nederland:

- $\quad 1634$, de kolonie leverde te weinig op en kostte teveel;

- 1869, idem, de kosten van de emancipatie waren hoog en de

Koot (1975) pp. 22 e.v.; Van Gameren (1991) pp. 9-97.

Kool (1975) pp. 96 e.v.

Kool (1975) p. 6.

Renkema (1976) pp. 1-8.

348. Ongeregeldheden en ongewenste onafhankelijkheid 
nieuw in te voeren wetgeving was kostbaar;

- 1879 , de Venezolanen gebruikten Curaçao en Aruba veelvuldig als basis voor hun revolutiepogingen, waardoor Nederland in niet-gewenste moeilijkheden met Venezuela kwam;

- 1917-1918, de VS zouden vanwege militair-strategische redenen Curaçao willen kopen;

- 1969 en daarna, de druk van Nederland tot onafhankelijkheid van de Nederlandse Antillen na de ongeregeldheden in 1969.

De wens van Nederland om de kolonie los te laten, werd veelal ingegeven door de hoge kosten die de kolonie Nederland bezorgde. Toen een dergelijke situatie zich in 1869 voordeed stelde het lid van de Koloniale Raad A. Jeserun op 5 maart 1869 voor een adres te richten aan de Tweede Kamer. Hij lichtte zijn voorstel in de vergadering van de Raad onder meer als volgt toe: 'van de bevolking der kolonie $[\ldots . .$.$] zal nimmer de stem uitgaan om te verzoeken dat$ Curaçao van Nederland worde losgemaakt'. Bij de behandeling van de (tekortschietende) begroting in 1870 sprak het lid van de Koloniale Raad N. Rojer de volgende gedenkwaardige woorden: “dat zolang een Oranje Koning der Nederlanden zou zijn, de Nederlandse wapenspreuk 'Je Maintiendrai' zou luiden en niet 'Ik zal loslaten' .' Renkema vergeleek de situaties uit 1869, 1879, 1917-1918 en 1969 met elkaar en constateerde dat in de eerste drie gevallen Nederland zich druk maakte over de financiën, maar dat zulks niet het geval was nu bleek dat de Nederlandse Antillen onafhankelijk moeten worden, zij zich bezorgd maakten over de financiele gevolgen van de onafhankelijkheid. Zou de geldstroom nog wel blijven vloeien na de onafhankelijkheidsdatum en zouden de contacten met de EEG, 6ók een belangrijke geldschieter, wel gehandhaafd blijven?

Het Engelse koloniale systeem komt in veel opzichten overeen met het Nederlandse systeem. ${ }^{64}$ De Engelsen lieten over het algemeen meer invloed van de plaatselijke bevolking toe op de koloniale regering dan Nederland. De strijd om een algemeen kiesrecht in de kolonie Curaçao is daar een saillant voorbeeld van. De vorming van de West-Indische federatie in 1958 stond in het teken van dekolonisatie. De Britse regering wilde na het einde van de Tweede Wereldoorlog de Britse koloniën 'dominionstatus' verlenen, dit betekende 
autonomie in interne en externe aangelegenheden. Tevens hield het in gelijkwaardigheid met de andere leden van het Britse 'Commonwealth'. Vertaald naar de Nederlandse Koninkrijkssituatie betekende dat onafhankelijkheid binnen een licht federaal verband. Velen, zowel in het Caraibisch gebied als in Engeland waren van mening dat slechts een federatie of een bepaalde vorm van politieke samenwerking essentieel was voor de creatie van een staat met overlevingskansen. Met name omdat de afzonderlijke eilanden gezien de kleinschaligheid en de armoede niet als afzonderlijke staten zouden kunnen overleven. Diezelfde gedachtengang heeft ook altijd overheerst in het Nederlands koloniaal beleid en werd onlangs nog naar voren gebracht in de Tweede Kamer bij de behandeling van de begroting van Antilliaanse en Arubaanse Zaken. ${ }^{65}$

Engeland wenste dat de Caraïbische entiteiten meer met elkaar zouden samenwerken. Die hechtere samenwerking kwam uiterst moeizaam tot stand, daar de eilanden altijd meer contact hadden onderhouden met het moederland dan met elkaar. Bovendien speelde een belangrijke rol dat relatief rijke eilanden zoals Jamaica en Trinidad bang waren opgezadeld te worden met de problemen van de arme eilanden. Ook wilden de eilanden niet graag hun macht afstaan aan een federatie. Jamaica stapte in 1961 uit de federatie en werd in 1962 onafhankelijk.

In augustus 1962 besloot Trinidad samen met Tobago ook zelfstandig onafhankelijk te worden, daar zij niet in federaal verband de lasten wilde dragen van de arme eilanden. De federatie werd in mei 1962 formeel opgeheven. De federale gedachte speelde nog wel een rol bij de acht kleine eilanden, maar het kwam er niet meer van. In 1966 werd Barbados onafhankelijk. De andere kleine eilanden met uitzondering van Montserrat en Belize, die Britse koloniën bleven, verenigden zich in een semi-autonoom verband met Engeland, waarbij Engeland verantwoordelijk is voor hun defensie en buitenlandse betrekkingen. Guyana dat geen onderdeel vormde van de federatie werd onafhankelijk in 1966. Grenada verliet in 1974 het autonome verband met Engeland en werd onafhankelijk.

Van der Kuyp geeft een aantal redenen aan waarom de federatie al na drie jaren in 1961 mislukte. Er bestond een gebrek aan een allesbepalende ideologische gebondenheid tussen de verschillende eilanden. Verder zouden koloniale tendensen de gemeenschappelijke achtergronden van de eilanden niet tot hun recht hebben laten komen, waardoor federale samenwerking mislukte. Naar de mening van Van 
der Kuyp was de oorzaak van de mislukking bet feit dat de federale constitutie een federatie had willen construeren op grond van puur eilandelijke organisaties, zowel de politieke partijen als de Kamers van Koophandel en dergelijke waren eilandelijke organisaties. Wil een federatie goed werken dan moet er loyaliteit bestaan ten opzichte van de deelstaat en ten opzichte van het geheel. En dit kan nimmer plaats vinden als de loyaliteit alleen maar bij de eilanden ligt.

Van der Kuyp haalt Singham aan die stelt dat de Caraibische maatschappij en familiestructuur overwegend autoritaire personen heeft geproduceerd. ${ }^{66}$ Zo'n autoritaire persoon wordt een politieke held, die de massa controleert door zijn persoonlijke binding met hen. De politieke partij speelt een ondergeschikte rol. Het is geen kaderpartij die afhankelijk is van betalende leden. De bovenomschreven knelpunten gelden ook voor de Nederlandse Antillen, dus zal een Antilliaanse federatie nooit werken. De vrees voor een (democratische) overheersing van Curaçao is duidelijk. Dit bepaalt ten dele ook zijn kijk op de West-Indische federatie en het mislukken daarvan. Toch is zijn analyse de moeite van het overdenken zeker waard, daar in Nederland regelmatig weer de roep gehoord wordt om een Antilliaanse federatie, die gezien de geschiedenis van de Nederlandse Antillen weinig kans van slagen lijkt te hebben. ${ }^{67}$

\section{Verdere vertraging van het proces tot de Antilliaanse onafhanke-} lijkheid

Van 17 tot en met 20 maart 1975 was er inmiddels in Den Haag een topberaad gehouden tussen de Koninkrijkspartners over de toekomstige staatkundige toekomst van Suriname. De Antilliaanse situatie kwam daarbij in het gebeel niet aan bod. Premier Evertsz kwam na het beraad tot de conclusie, dat na het uittreden van Suriname uit het Koninkrijksverband de Antilliaanse sectie van de Koninkrijkscommissie een geheel andere taak diende te krijgen. De Antilliaanse sectie moest een veel bredere samenstelling krijgen, naast politici moesten ook vertegenwoordigers van maatschappelijke instellingen zoals werkgevers en vakbonden worden opgenomen. Evertsz wilde absoluut niet dat de Antillen in hetzelfde snelle tempo als Suriname onafhankelijk zouden worden.

Van 9 tot en met 19 juni 1975 bracht een Nederlandse parlementaire delegatie een bezoek aan de Nederlandse Antillen om onder meer

6) Zie voor de situatie van dekolonisatie in het Caraibisch gebied ook: Koulen (1985). 
de toekomstige staatkundige verhoudingen te bespreken met de Antilliaanse Statenleden. Alle partijen bleven bij de ingenomen standpunten. Een uitspraak van de PvdA-er Franssen zorgde nog voor de nodige opschudding. Tijdens een discussie met MEP-partijleider Betico Croes kwam Franssen tot de uitspraak, dat 'u de onafhankelijkheid per aangetekende brief thuis bezorgd zou kunnen krijgen'.

Verton ${ }^{68}$ stelde dat de Nederlandse parlementaire delegatie in 1975 geconfronteerd werd met afwijkende visies van de Antilliaanse politici die nu opeens geen onafhankelijkheid op korte termijn meer wensten, terwijl in 1971 en 1975 de Nederlandse parlementaire delegaties op spoed aandrongen en geen duidelijke afwijkende meningen over die stellingname had gehoord. In 1975 oefende de parlementaire delegatie geen druk uit tot een snelle onafhankelijkheid. De uit zijn verband getrokken opmerking van Franssen was een welkome aanleiding voor de Antilliaanse regering om een vertragingstactiek te voeren. De Nederlandse regering had immers duidelijk te kennen gegeven dat de datum van de onafhankelijkheid door de Antillen zelf bepaald zou mogen worden en zolang de Antillen zich niet serieus bezighielden met de onafhankelijkheid, kon van enige druk ook geen sprake zijn. Bovendien had de Nederlandse regering zich geheel gericht op de Surinaamse onafhankelijkheid. ${ }^{69}$ Dat kwam de Antilliaanse politici ook goed uit, omdat ze alles in het werk stelden niet aan de Nederlandse wens tot onafhankelijkheid tegemoet te komen.

Frente-vertegenwoordiger Martina meende na afloop van het bezoek van de parlementaire delegatie, dat een conservatieve groep de onafhankelijkheid wilde tegenhouden en geen verantwoordelijkheid wilde dragen voor het aanvaarden van de soevereiniteit. Martina meende dat het volk niet zozeer bang was voor de onafhankelijkheid, maar meer dat de bestuurders de zaak niet goed zouden besturen. De Frente wilde die verantwoordelijkheid echter wel dragen. Maar nog steeds werd de onafhankelijkheid niet concreet en planmatig voorbereid.

Daar Nederland stelselmatig weigerde staatsrechtelijke banden met Aruba aan te knopen, voelde Aruba zich gedwongen de onafhankelijkheid te kiezen, omdat Aruba niet langer in het Antilliaanse verband wilde blijven. Op 10 september 1975 verklaarde Betico Croes in de Staten, dat Aruba besloten had de onafhankelijkheid te aanvaarden. Zowel met Nederland als met de Nederlandse Antillen wilde

\footnotetext{
68 Verton (1977).

69 Van Gameren (1991) p. 101; Verton (1977) pp. 193 p. 268, noot 6.
} 
Aruba volkenrechtelijke banden onderhouden. Nu werd duidelijk wat Aruba met de Status Aparte bedoelde. Op 11 september 1975 namen de Staten een motie aan, die overeenkwam met de op 19 december 1973 aangenomen 'Status Aparte' motie. Opnieuw werd in de motie het beginsel onderschreven, dat elk eiland het onvervreemdbaar recht had om de eigen staatkundige toekomst te bepalen.

Door de motie van 11 september 1975 kwam de 'Status Aparte' kwestie in een stroomversnelling terecht, waardoor de oorspronkelijke tegenstanders hun tegenwerking maar opgaven. De Nederlandse regering had immers steeds verklaard dat tijdens de onderhandelingen over de onafhankelijkheid de Antillen als een eenheid moesten blijven optreden. Dit betekende dat rationeel gesproken de kans van slagen van het Arubaanse streven naar een Status Aparte nihil was, zodra de Nederlandse Antillen onafhankelijk zouden zijn geworden. Door deze ontwikkelingen zou in ieder geval de onafhankelijkheid weer verder worden uitgesteld en dat was precies, wat de meeste politieke partijen wensten. ${ }^{70}$

Op 13 december 1975 kondigde premier Evertsz in de Staten aan, dat de eerste fase voor de verwezenlijking van de Antilliaanse onafhankelijkheid zou beginnen, inhoudende de regeling van de interne structuur tussen de eilanden. Aruba zou geen deel uitmaken van het Antilliaans verband, meldde de MEP nogmaals. Evertsz noemde geen datum voor de onafhankelijkheid maar kon dank zij het onderzoek van Koot wel de mening van de bevolking naar voren brengen. Het was de eerste keer dat Evertsz zijn vertrouwen in de Nederlandse politici uitsprak. Half november 1975 vertrok een MEP delegatie op eigen initiatief naar Venezuela om steun te verkrijgen voor het Arubaanse afscheidingsstreven en om daarover bilaterale afspraken te maken. Dit viel slecht bij de NVP-U de coalitiepartner van de MEP, in de Antilliaanse regering. Evertsz vond het bezoek ongehoord, omdat daardoor de bevoegdheden zowel van de Centrale Antilliaanse - als van de Koninkrijksregering voor wat betreft het buitenlands beleid, met voeten werden getreden. ${ }^{71}$ Door deze actie vervreemdde de MEP zich van de Curaçaose partijen, die vonden dat het gedrag van de MEP duidde op een gebrek aan respect voor het centrale gezag. Bovendien had de MEP zich niets aangetrokken van de Nederlandse eis om de eenheid van de eilanden te bewaren en als Aruba erin zou slagen de onafhankelijkheid te verkrijgen, zou dat ook de onafhankelijkheid voor de Antillen met rasse schreden nader brengen en dat wensten de 
Onder de kop: "De MEP is de vijand van de Antillen", werd door de NVP een pamflet verspreid, waarin een felle aanval werd gedaan op de MEP en op de partijleider Betico Croes. Betico Croes werd uitgemaakt voor een racist en fascist. Tijdens de op 12 december 1975 gehouden vergadering van de Ministerraad werd de samenwerking tussen de NVP-U en de MEP officieel door premier Evertsz opgezegd. Diezelfde dag vertrok een MEP-delegatie naar Panama om ook daar het idee van de Status Aparte uit te dragen. De regering Evertsz besloot op 12 december een brief aan Gouverneur Leito te sturen, met het verzoek de drie MEP-ministers ontslag te verlenen. De aangevoerde argumenten waren dat de MEP de desintegratie van de Nederlandse Antillen in de hand werkte, waardoor zij het welzijn van het Land niet bevorderde. Bovendien hadden de betreffende ministers buiten de regering om bezoeken aan buitenlandse mogendheden gebracht en daar overleg gepleegd over interne Antilliaanse zaken, waardoor zij de integriteit van de Nederlandse Antillen ernstig in gevaar hebben gebracht.

Staatsrechtelijk wellicht niet geheel juist, aangezien het parlement het vertrouwen in de Ministers behoort op te zeggen en dat ontslag niet behoort te geschieden op grond van een verzoek van de Ministerraad aan de Gouverneur. De bestaande situatie was echter nogal ingewikkeld, daar de voorzitter de Staten bijeen moest roepen voor een uitspraak dienaangaande en het voorzitterschap was nu juist in handen van de MEP. De MEP was echter van mening dat de hele regering moest aftreden en dat de Staten moesten worden ontbonden en er nieuwe verkiezingen moesten worden gehouden. De MEPvoorzitter Frans D. Figaroa weigerde dan ook de Staten bijeen te roepen. De Gouverneur wees erop dat op grond van art. 38 tweede lid, van de Staatsregeling van de Nederlandse Antillen, de Gouverneur de bevoegdheid had een minister tussentijds te ontslaan. Dan moest echter wel vaststaan dat de Staten geen vertrouwen meer hadden in de betrokken minister en moest de Raad van Advies worden gehoord. De Gouverneur drong er bij de Statenvoorzitter op aan, zo spoedig mogelijk de Staten bijeen te roepen om een uitspraak te doen in de aan de orde zijnde aangelegenheid. Figaroa riep de Staten op 29 december 1975 bijeen. Met veertien stemmen vóór en nul tegen namen de Staten een motie van wantrouwen aan tegen de drie MEPministers. ${ }^{73}$

Van Gameren (1991) p. 107.
$73 \quad$ Paula (1991) pp. 74 e.v.

354. Ongeregeldheden en ongewenste onafhankelijkheid 
De Antilliaanse eenheid was verbroken, de MEP had minder mogelijkheden de onafhankelijkheid uit te dragen, nu de partij geen regeringsverantwoordelijkheid meer droeg. ${ }^{74}$ De onafhankelijkheid was voor onbepaalde tijd uitgesteld en alle aandacht zou zich voorlopig op de Status Aparte regeling van Aruba richten. ${ }^{75}$

De op 5 januari 1972 ingestelde Koninkrijkscommissie had als opdracht gekregen om alternatieven voor de bestaande constitutionele betrekkingen tussen de drie landen voor te bereiden. De commissie bestond uit een Surinaamse, Antilliaanse en Nederlandse sectie, tezamen ongeveer 60 personen. De Antilliaanse sectie werd voorgezeten door R.A. Römer, de Nederlandse sectie had als voorzitter $H$. Hoetink. De commissie was een typisch voorbeeld van het sociaal-democratisch initiatief. ${ }^{76}$ Fennema zegt over de werkzaamheden van de commissie het volgende:

\begin{abstract}
"En het produkt was navenant. Gebaseerd op een indrukwekkende hoeveelheid economische gegevens, samengevat in een statistische appendix van zestig pagina's, is het rapport in feite een schets van een sector-structuurbeleid voor de Nederlandse Antillen. Het gehele rapport ademt de econometrische traditie van Tinbergen. Veelvuldig wordt geklaagd over het gebrek aan beschikbaar statistisch materiaal. Het rapport dat uitdrukkelijk uitgaat van de 'basic needs'-gedachte die destijds in sociaal-democratische kring veel aanhang had, pleit voor een drastische reorganisatie van het overheidsapparaat, minder projekthulp en meer hulp gericht op het versterken van de produktieve structuur van de Antillen. Het is in zeer veel opzichten een doorwrocht werkstuk vol goede bedoelingen; in die zin kan het beschouwd worden als 'het afscheidscadeau' van de regering Den Uyl. Helaas hebben de politieke en economische ontwikkelingen in Nederland en op de Antillen van na 1980, de uitvoerbaarheid van de voorgestelde plannen sterk verminderd." $n$
\end{abstract}

De Commissie kwam viermaal in plenaire zitting bijeen. Na het advies over een aantal deelonderwerpen betreffende de uiteindelijke onafhankelijkheid van Suriname kreeg de commissie een andere taakstelling. Op 4 juli 1974 kreeg de commissie de opdracht zich

$74 \quad$ Van Gameren (1991) p. 114.

75 Van Gameren (1991) pp. 90-114.

76 Fennema (1986) p. 91.

7 Rapport van de Gemengde Commissie van Deskundigen, een integraal beleidskader voor de Nederlandse Antillen in de jaren ' 80 , Staatsuitgeverij, 's-Gravenhage, 1979. 
alleen nog maar bezig te houden met de onafhankelijkheid van Suriname. ${ }^{78}$ De redenen hiervoor waren dat toen in Suriname het kabinetArron meedeelde te streven naar volledige onafhankelijkheid in 1975 alle aandacht op de Surinaamse onafhankelijkheid werd gericht. De commissie zou nog slechts rapporteren over een aantal onderwerpen samenhangend met de onafhankelijkheid van Suriname. In het najaar van 1974 kwam de voltallige Koninkrijkscommissie nog tweemaal bij elkaar en beide keren stond de onafhankelijkheid van Suriname centraal. De Antilliaanse sectie trad min of meer op in de rol van waarnemer.

Zowel De Gaay Fortman als Den Uyl lieten in augustus 1974 weten, dat de Antillen zelf zouden mogen bepalen wanneer de onafhankelijkheid zou moeten ingaan. Ook mochten de Antillen voorstellen doen omtrent de nieuwe samenwerking met Nederland, na de uittreding van Suriname. De te ontwerpen nieuwe regeling zou dan gezien kunnen worden als een voorlopige handhaving van het Statuut in afwachting van de planmatige voorbereiding van de Antilliaanse onafhankelijkheid. Wel wenste de Nederlandse regering de Antillen in één verband te zien en niet de vijf overblijvende eilanden en Aruba apart. Betico Croes reageerde fel op deze uitlatingen, beschuldigde Nederland van kolonialisme en gaf duidelijk te kennen, dat Aruba niet binnen een Antilliaanse federatie kon en wilde functioneren.

Uit het rapport ${ }^{79}$ van de Koninkrijkscommissie over de op handen zijnde Surinaamse onafhankelijkheid bleek duidelijk dat de Nederlandse houding ten opzichte van de Antilliaanse onafbankelijkheid was veranderd. Het rapport behandelde de onafhankelijkheid van Suriname, de Antilliaanse onafhankelijkheid kwam niet ter sprake. De voor Suriname ontworpen regeling zou niet model staan voor de Nederlandse Antillen. De Antillen kregen dus alle tijd om de onafhankelijkheid voor te bereiden, een datum werd niet genoemd. Met grote moeite slaagde men erin de geplande datum van de Surinaamse onaf-

7* Fernandes Mendes (1989) pp. 74 e.v.

79 Koninkrijkscommissie ter voorbereiding van alternatieven voor de huidige staatkundige verhoudingen tussen Nederland, Suriname en de Nederlandse Antillen, Ingesteld bij Koninklijk besluit van 5 januari 1972, nr. 1 met aanvulling van de taakomschrijving bij Koninklijk besluit van 4 juli 1974, nr. 7; Rapport ter voorbereiding van de onafhankelijkheid van Suriname, 's-Gravenhage, oktober 1974. De voorzitter van de Nederlandse sectie van de Koninkrijkscommissie was mr. J. van der Hoeven, van de Surinaamse sectie was dat mr. E.I. Karamat Ali en van de Nederlands-Antilliaanse seclie was dat mr. C.E. Dip. Zie ook Van Gameren (1991) pp. 80-88; voor de Grondwet van Suriname zie: Munneke (1990). 


\section{Samenvatting en conclusie}

In de jaren vijftig en zestig stonden regeringspartijen en oppositie vijandig tegenover elkaar, evenals land en eiland. Het overheidsapparaat werd een wapen in de hand van de winnende politieke partij. Overheidsinvloed werd gebruikt om de politieke medestanders te belonen. Op grond daarvan ontstonden coalities van dezelfde partij op landsniveau en eilandsniveau. Deze samenhang tussen eilandelijke en landelijke politiek had een intensivering van de patronage tot gevolg. Overheidsmiddelen werden niet zelden gebruikt om politieke medestanders te belonen. De overheidsmiddelen kwamen evenwel niet aan de meest behoeftigen in de Curaçaose maatschappij ten goede (het zwarte electoraat).

Patronage wordt versterkt omdat de Caraỉbische maatschappij en familiestructuur overwegend autoritaire personen produceren. Zo'n autoritaire persoon wordt een politieke held, die de massa controleert door zijn persoonlijke binding met hen. Een dergelijke leider mag ook niet worden gekritiseerd. De politieke partij speelt een ondergeschikte rol. Het is geen kaderpartij die afhankelijk is van betalende leden. Het zijn de persoonlijke contacten die tellen. De burgers hebben dan ook niet allen op gelijkwaardige wijze toegang tot de overheidsmiddelen. Deze verschijnselen leiden weer tot rechtsongelijkheid, vooroordelen en rechtsonzekerheid. De politieke patronage speelt nog steeds een belangrijke rol in de Nederlandse Antillen en Aruba en heeft in 1993 weer geleid tot zware druk van Nederland op het Koninkrijk overzee om deugdelijk bestuur in te voeren of ingrijpen van Nederland te gedogen.

De achtergestelde economische en sociale positie van de zwarte arbeiders en de kritische houding van de intelligentsia, die veelal in Nederland had gestudeerd en de gevoelens van ontevredenheid verwoordde, gaven aanleiding tot de ongeregeldheden in Willemstad van mei 1969. De rijkelijk vloeiende rum speelde bij de intensivering van de ongeregeldheden een niet onbelangrijke rol.

De ongeregeldheden in Willemstad hadden tot gevolg dat de

* Handelingen, Tweede Kamer der Staten-Generaal, Zitting 1975-1976, 5, 21-23 oktober 1975, Beēindiging statulaire band met Suriname; Handelingen Eerste Kamer der Staten-Generaal, 3, 27-28 oktober 1975, Beēindiging van de statutaire band met Suriname, Fernandez Mendes (1989). 
Antilliaanse politiek meer aandacht besteedde aan de economische situatie van de werknemers in de olie-industrie en de toename van de werkloosheid, ontstaan door arbeidsbesparende maatregelen van de Shell trachtte te bestrijden. De vakbonden werden geaccepteerd door de werkgevers, als serieuze onderhandelingspartners, al ging dat niet van harte. Sociale wetgeving werd ingevoerd, zoals een minimumloonregeling, een pensioenregeling, een Algemene Ziektewet voor de gehele Antilliaanse bevolking en een ontslagregeling.

Naar aanleiding van de onlusten bracht de Commissie Römer een rapport uit, waarin de oorzaken van de ongeregeldheden werden aangegeven. De Commissie noemde ook mogelijke staatkundige modellen voor de Nederlandse Antillen. De voorkeur van de Commissie ging uit naar een band met Nederland. De mogelijkheid van aansluiting van de Benedenwinden bij Venezuela en de Bovenwinden bij Trinidad en Tobago werd genoemd. Van die mogelijkheden werden de voordelen en nadelen aangegeven. Ook werd gedacht aan een soevereine federatie van de Antilliaanse eilanden. De Commissie achtte het belangrijk dat de zwarte bevolking meer invloed zou krijgen in het bestuur van Curaçao. Ook wees de Commissie op de negatieve invloed van politieke patronage en het daaruit voortvloeiende veel voorkomende gebruik van belediging van personen en volksgroepen in de pers. De invloed van partijpolitiek op ambtenarenbenoemingen zou geminimaliseerd moeten worden.

Het Nederlandse militaire ingrijpen en de internationale reactie daarop leidde tot de Nederlandse opvatting dat Suriname en de Nederlandse Antillen zo snel mogelijk onafhankelijk moesten worden. De druk van Nederland op Suriname en de Nederlandse Antillen om onafhankelijk te worden werd op de Nederlandse Antillen niet met instemming begroet. De Nederlandse Antillen deden er alles aan om die ongewenste situatie te voorkomen. $\mathrm{Zij}$ aanvaardden alleen in theorie de onafhankelijkheid, die op planmatige wijze en gefaseerd zou moeten worden ingevoerd. Daarbij werd gedacht aan een Antilliaanse federatie.

Van Leeuwen zocht de oplossing van de Antilliaanse problemen in meer zelfstandigheid voor de eilanden in een federatieverband. Gorsira wijtte de bestaande problematiek aan het kiesstelsel, daardoor zijn de Staten teveel een orgaan geworden dat eilandbelangen vertegenwoordigt. In de jaren ' 70 was eventuele aansluiting bij Venezuela een belangrijk onderwerp van discussie. In het algemeen was men tegen aansluiting bij Venezuela.

Jeukens was een voorstander van een verdere federalisering van 
de Nederlandse Antillen langs de weg van decentralisatie door bijzondere (lands)wetten. Tevens zou er een twee-kamerstelsel moeten komen, bestaande uit een rechtstreeks door de gehele bevolking gekozen kamer en een federale kamer. Aruba verzette zich daartegen, omdat gezien de bevolkingsgrootte, Curaçao altijd een meerderheid zou vormen binnen een federatie en niet alleen de andere eilanden, maar ook Aruba zou kunnen overstemmen. Aruba zag op die grond af van ondersteuning van de federatie en verwees daarbij naar de mislukking van de West-Indische federatie in 1961. Als er een te groot onderscheid in eilanden is, zou een federatie niet werkbaar zijn, omdat gelijkwaardigheid alleen in naam bestaat en de grote eilanden, de kleine economisch zwakke eilanden moeten ondersteunen.

Het blijkt tot op heden onmogelijk te zijn om eilanden in een natie te verenigen, omdat eilandbewoners 'nationalistisch' denken met betrekking tot hun eigen eiland, maar niet met betrekking tot een groter geheel. De tegenstellingen tussen de eilanden werden versterkt door de wijziging van de zetelverdeling van de Staten in 1948. Het politiek insularisme werd door eilandelijke afvaardigingen geīntroduceerd.

De stemmen van de kiezers van de verschillende eilanden kregen in het eenheidsparlement na 1954 verschillende waarden. Voordien waren de verschillende politieke partijen op alle eilanden actief en maakten zij lijstverbindingen op politiek-ideologische basis. Na 1954 werd de integratie van de zes eilanden tot een politieke eenheid in grote mate bemoeilijkt. Het nationalistisch eilandsdenken en de noodzaak tot een groter economisch geheel om onafhankelijk te kunnen overleven werken elkaar tegen.

Behalve het specifieke eilandsdenken wordt een samenwerking tussen de eilanden, daar waar het om het algemeen belang gaat, ook bemoeilijkt door patronage, omdat politici eerst hun 'eigen' eilandsmensen zullen helpen, mits van de 'juiste' partij.

Toen Suriname de Nederlandse wens tot onafhankelijkheid onderschreef waren de Nederlandse Antillen bevreesd dat de door Suriname gewenste onafhankelijkheid zou leiden tot de Antilliaanse onafhankelijkheid. Nederland gaf hierop na uitgebreide onderhandelingen te kennen dat een Surinaamse onafhankelijkheid niet zou behoeven te leiden tot een Antilliaanse onafhankelijkheid, indien de Nederlandse Antillen, zich daartoe nog niet in staat voelden.

Ten slotte werden de besprekingen over de al dan niet in te voeren onafhankelijkheid voor de Nederlandse Antillen en in welke vorm dan wel, opgeschort en werd alle politieke aandacht binnen het 
Koninkrijk gericht op de onafhankelijkheid van Suriname. De in 1972 ingestelde Koninkrijkscommissie die tot taak had staatsrechtelijke en volkenrechtelijke alternatieven aan te dragen voor een ander Koninkrijksverband voor de Nederlandse Antillen en Suriname kreeg in 1974 een aangepaste opdracht. De commissie zou zich alleen nog maar bezig houden met de onafhankelijkheid van Suriname. Dat betekende dat de Nederlandse Antillen tijdelijk verschoond zouden zijn van de Nederlandse druk om onafhankelijk te worden. De Nederlandse Antillen hadden bereikt dat de Surinaamse onafhankelijkheid niet zou worden gekoppeld aan een Antilliaanse onafhankelijkheid en dat de Antillen zelf zouden kunnen beslissen over het tijdstip van onafhankelijkheid.

Naar aanleiding van de ongeregeldheden in Willemstad en de Nederlandse wens van een Antilliaanse federatie, verscherpte het afscheidingsstreven van Aruba. De MEP van Betico Croes zou hier een belangrijke rol in spelen. De Antilliaanse situatie zou na de regeling van de Surinaamse onafhankelijkheid weer aan de orde komen.

Gesteld kan worden dat de onlusten staatsrechtelijk hebben geleid tot grote vastberadenheid in het Nederlandse beleid om de dekolonisatie te voltooien. Tevens beïnvloedden de ongeregeldheden de toeristenindustrie en de buitenlandse investeringen in negatieve zin. De oorzaken van de onlusten lagen met name in de achterstandssituatie van de zwarte bevolkingsgroep. Veel verbetering is er sinds de onlusten in de bestaande situatie niet opgetreden, dus dat betekent dat een potentiële brandhaard in de Antilliaanse maatschappij aanwezig is, die met de huidige slechte financiële situatie van het Land, het Eilandgebied Curaçao en sinds 1993 ook het Land Aruba, weer een aanleiding zou kunnen vormen voor een hernieuwde uitbarsting in de toekomst.

Indien de evaluatie-criteria in ogenschouw worden genomen dan lijkt in eerste instantie dat aan alle criteria wordt voldaan. Immers de invloed van het Nederlands bestuur op het bestuur van de voormalige kolonie is gering. De Nederlandse Antillen regelen hun eigen aangelegenheden. De opbouw van de staatsorganen en de binding van de staat aan het recht is voortreffelijk geregeld, evenals de verdeling van de overheidsmacht. De inspraak van de burger in het bestuur staat vast, alhoewel de zwarte bevolkingsgroep was ondervertegenwoordigd in de regering en de Staten.

Het zoeken van het juiste evenwicht tussen ordening van de samenleving en individuele vrijheid was vastgelegd in het Statuut, de Staatsregeling van de Nederlandse Antillen en de ERNA. De proble- 
men deden zich zoals altijd in de praktijk van het dagelijks leven voor.

Hetgeen Henriquez in 1949 had voorzien uitte zich in de vorm van patronage, het vooropstellen van eilandsbelangen en niet van landsbelangen. Uit met name de Engelse dekolonisatie bleek dat eilanden heel moeilijk in een staatsverband vallen onder te brengen, zeker als zij grote verschillen vertonen in economische importantie.

De overheidsmiddelen werden nogal eens gebruikt om politieke medestanders te belonen. De praktijk van de parlementaire democratie moest wortel schieten. Klasseverschillen en kleurverschillen manifesteerden zich op indringende wijze tijdens de ongeregeldheden in Willemstad in 1969. Toen bleek ook dat de zwarte bevolkingsgroep niet had meegedeeld in de groeiende welvaart. Overheidsinvloed en privileges werden een wapen in handen van de regerende partijen. 


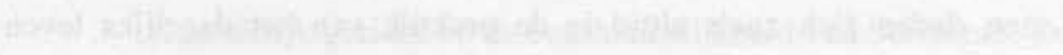

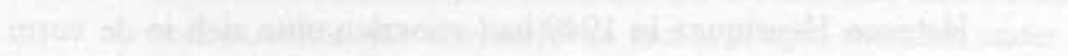

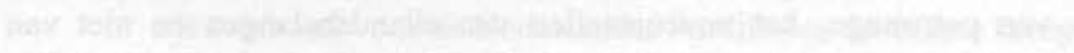
10
0

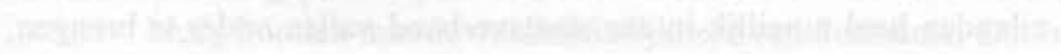

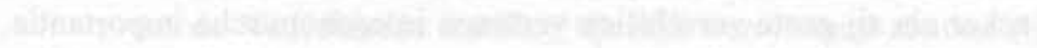

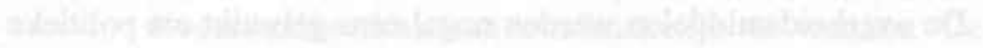

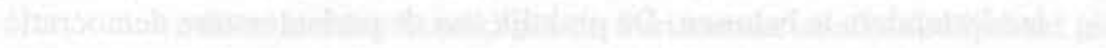
The

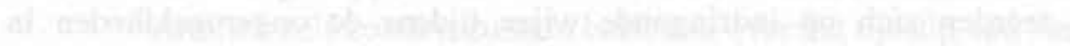

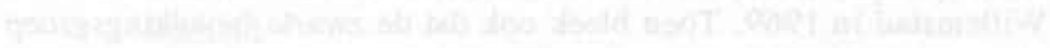

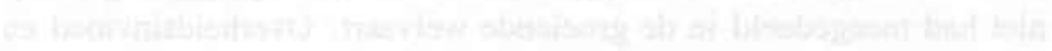

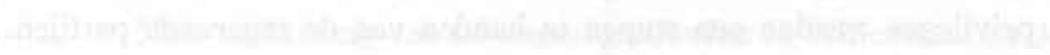


Hoofdstuk VIII beschrijft in extenso het 'Separación' streven van Aruba en de gevolgen daarvan op het Antilliaanse verband, bezien vanuit een Arubaans perspectief. Het afscheidingsstreven (in de jaren dertig en veertig uitgedragen door Henny Eman) wordt weer nieuw leven ingeblazen in de jaren zeventig door Betico Croes, leider van de MEP. Een aparte status voor Aruba past echter niet in het Nederlandse beleid voor de voormalige kolonie. Nederland oefent druk uit op de Nederlandse Antillen om als eenheid onafhankelijk te worden. Het onduidelijke Nederlandse beleid ten aanzien van de staatkundige toekomst van de Nederlandse Antillen wordt uiteengezet, evenals de opvattingen op de Nederlandse Antillen over de in te voeren onafhankelijkheid.

Naar aanleiding van het Arubaanse afscheidingsstreven en de mogelijke gevolgen daarvan op staatkundig gebied wordt in 1977 door het Institute of Social Studies een onafhankelijk onderzoek uitgevoerd naar de levensvatbaarheid van een gescheiden dekolonisatie. Dit rapport wordt besproken. In 1978 wordt een eventuele afscheiding van Aruba bespreekbaar en wordt een Koninkrijkswerkgroep opgericht die de gevolgen van een Arubaanse afscheiding op het Antilliaanse verband zal moeten onderzoeken en alternatieven aandragen voor een staatsrechtelijk - dan wel volkenrechtelijk samenwerkingsverband tussen de eilanden. Deze ontwikkeling wordt uiteengezet.

De door Aruba naar voren gebrachte staatkundige modellen komen aan de orde en de inhoud van een Gemenebest 'sui-generis' wordt verduidelijkt. De interpretatie van het zelfbeschikkingsrecht: elk eiland zal de eigen toekomst mogen bepalen, is een belangrijke conclusie van de Koninkrijkswerkgroep in 1980 en werd vastgelegd op de RTC in 1981.

Op 1 september 1981 ontstond een breuk in de NederlandsAntilliaanse coalitie tussen de MEP en de andere coalitie-partners, wegens meningsverschillen over de olierijkdommen in de wateren rond Aruba. Het binnen twee dagen gevormde nieuwe kabinet, zonder de MEP dringt dan ook bij Nederland aan op een spoedig te houden topoverleg. 
Eind oktober 1981 heeft in Den Haag het topoverleg plaats tussen Nederland, de Nederlandse Antillen en een delegatie van de Arubaanse Eilandsraad. Het overleg resulteert in de oprichting van een Gemengde Commissie Toekomst Antillen. Het rapport van de Commissie wordt besproken.

$\mathrm{Na}$ veel onderling overleg tussen Nederland, de centrale Antilliaanse regering en de eilanden, alsmede het uitoefenen van internationale druk door Aruba, wordt op de RTC van 1983 besloten tot een Status Aparte voor Aruba, met onafhankelijkheid op termijn. Aruba zal per 1 januari 1996 onafhankelijk worden. De voorziene onderlinge samenwerkingsregeling tussen de eilanden in de vorm van een Unie zal uiteindelijk niet tot stand komen. Besloten wordt tot een nogal vrijblijvende Samenwerkingsregeling. Aruba ontwerpt een moderne Staatsregeling naar het voorbeeld van de Nederlandse Grondwet. Deze regelingen worden besproken. Bij de verkiezingen van 1983 doet zich een ongelukkig schietincident voor waarbij Betico Croes werd gewond, dit leidt weer tot het doodschieten van een jeugdige AVP supporter door een MEP aanhanger. Het schietincident waarvan Betico Croes het slachtoffer wordt, leidt tot een grote verkiezingsoverwinning voor de MEP. Op 1 januari 1986 zal de aparte status voor Aruba ingaan, de bedoeling is met Betico Croes als eerste premier van het Land Aruba.

Reeds in de jaren dertig, kwam onder leiding van J.H.A. (Henny) Eman $^{1}$ de afscheidingsbeweging op gang, onder het motto: 'Aruba voor de Arubanen'. ${ }^{2}$ In de jaren dertig en veertig waren er veel immigranten van de andere eilanden naar Aruba gekomen, om in de

1 De grootvader van de huidige leider van de AVP, Henny Eman richtte in 1942 de Arubaanse Volkspartij op. Op de sokkel van zijn standbeeld bij het Kabinet van de Gouverneur staat te lezen: 'Defensor di pueblo, pionir di e gran lucha pa autonomia' (verdediger van het volk, pionier van de grote strijd voor autonomie).

Zie voor een goed overzicht van de geschiedenis van de Arubaanse Status Aparte beweging, ook wel aangeduid als 'separashon': A.G. Croes (1983) pp. 28-31. Het Witboek (1975) heeft het motto van Betico Croes meegekregen: 'Niet het land dat er kolonies op na houdt, bedrijt kolonialisme van het ergste soort, mar het land dat afstand wenst te doen van zijn kolonies onder oplegging van een staatkundige structuur welke niet in overeenstemming is met de wil van het volk'. Dit was ook de gedachtengang van Henny Eman. Het Witboek geeft een uitstekend overzicht van de gevoelens van de Arubanen met betrekking tot de Afscheidingsbeweging. Voor de denkwijze van Henny Eman zij verwezen naar de pp. 1-64. In het Witboek is ondermeer gebruik gemakt van de notulen van de Statenvergaderingen en Eilandsraadvergaderingen van die dagen. 
olie-industrie te werken. $\mathrm{Zij}$ waren de allochtonen. De op Aruba geboren Nederlanders, die al generaties op het eiland gevestigd waren, werden als autochtonen gezien, de 'yiu di tera', de landskinderen. De verhouding tussen 'echte' en 'niet echte' Arubanen verschoof in de jaren zeventig en tachtig van deze eeuw ten gunste van de echte Arubanen. Deze ontwikkeling vond plaats onder invloed van een afslanking in de olie-industrie toen duizenden arbeidsmigranten het eiland verlieten. Dit proces werd nog versterkt door de sluiting van de Lago in 1985. Nog altijd wonen er op Aruba ten minste vijfentwintigduizend (van de zestigduizend) mensen die niet als volwaardig Arubaans landgenoot erkend worden. ${ }^{3}$ Naast de toenemende invloed van 'buitenlanders' door immigratie leidde ook de gunstige economische positie van Aruba tot de wens van Aruba zich losser van Curaçao te maken.

Alofs en Merkies ${ }^{4}$ menen dat de Separación beweging eigenlijk al in de jaren dertig begon toen Nederland het Regeringsreglement van 1865 wilde wijzigen. Ook in 1933 uitte Aruba al de wens tot decentralisatie, toen de Raad van Politie op Aruba de Kroon verzocht de kolonie te reorganiseren op basis van het Nederlandse gemeentemodel met een grotere autonomie voor de verschillende eilanden. De redenen die hiervoor werden genoemd waren de bestuursproblemen waarmee men kampte als gevolg van de grote bestuursafhankelijkheid van Curaçao en de enorme maatschappelijke veranderingen, die zich voordeden sinds de komst van de olie-industrie.

Noch de Staatsregeling van 1936, noch de Staatsregeling van 1948 brachten een wezenlijke vooruitgang op weg naar de autonomie. ${ }^{5}$ Het werk van de Commissie Oppenheim (1942) kon worden gezien als een streven om tegemoet te komen aan de wensen naar meer zelfstandigheid van Aruba. Dit gold ook voor het rapport van de Commissie Van Poelje (1948). Bij de herziening van de Staatsregeling van $1948 \mathrm{kreeg}$ Aruba hetzelfde antal zetels in de Staten als

3 Voor een verantwoorde studie naar wie nu een echte Arubaan is zie: Alofs en Merkies (1990). Het interessante aan deze studie is dat het de culturele en economische ontwikkeling van de verschillende bevolkingsgroepenop Aruba op inzichtelijke wijze duidelijk maakt, vanaf de kolonialisatie van de Spanjaarden en Nederlanders tot het jaar 1990, toen Aruba de Status Aparte binnen het Koninkrijk der Nederlanden, sinds 1-1-1986, had verkregen.

$+\quad$ Alofs en Merkies 1990) p. 80 e.v.

s Kasteel (1956) p. 32: 'Met name het gebrek aan beschikking over eigen middelen speelde een rol. De Raad van Politie was van mening dat de bevoegdheden van de Koloniale Raad niet langer bij koloniale verordening zouden moeten worden geregeld en dat instelling van bestuursressorten ook niet op een dergelijke wijze zou moeten geschieden. De Raad van Politie dacht hierbij aan de rechten en bevoegdheden toegekend aan Burgemeesters en Wethouders in Nederland. 
Curaçao, te weten $8,{ }^{6}$ maar bij de invoering van de Interimregeling (1950) werd deze voor Aruba gunstige zetelverdeling weer teniet gedaan.

Henny Eman stelde zich sinds het begin van de jaren veertig op als een voorvechter van decentralisatie-wetgeving. Hieronder werd verstaan het overdragen van landstaken aan de eilanden. Terwijl Curaçao zich met Da Costa Gomez voorbereidde op de autonomie ten opzichte van Nederland, bepleitte Eman de zelfstandigheid van Aruba ten opzichte van Curaçao.

De Arubaanse PPA sloot zich qua politieke gedachtengang in 1954 aan bij de DP van Curaçao. Op landsniveau werd er samengewerkt door de politieke elites van Aruba en Curaçao. Waar zich voorheen Statenleden en bloc inzetten voor Arubaanse belangen ten opzichte van Curaçaose, stelde zich nu een Arubaans/Curaçaose regeringscoalitie als concurrerende elite tegenover een Arubaans/Curaçaose oppositie-coalitie. Tegenstellingen tussen eilandelijke politieke leiders werden daarmee verlegd naar de eilandelijke kiezersachterbannen. De kiezers moesten bij Statenverkiezingen hetzij op de partij van de regeringscoalitie stemmen, hetzij op de partij van de oppositie. In 1947 kreeg Eman de Arubanen nog bij honderden de straat op om voor de Separación te demonstreren. In de periode na 1954, lukte het zijn AVP niet de verkiezingen overtuigend te winnen met leuzen als 'Aruba Ariba' (Aruba boven) en 'Lucha Arubiano' (de Arubaanse strijd). De PPA beschikte als regeringspartij over de patronagemiddelen en vele economisch afhankelijke Arubaanse kiezers kozen federale 'eieren' in plaats van insulaire leuzen voor hun stem. ${ }^{\text {? }}$

De acceptatie van de Interimregeling in 1950 door Eman was voor Yrausquin en zijn achterban aanleiding om uit de AVP te stappen en de Partido Patriotico Arubiano (PPA) op te richten. Naar de mening van Yrausquin werd in de Interimregeling niets vastgelegd over de

6 Oud-minister J.A. Jonkman, die de portefeuille 'Overzeesche Gebiedsdelen' beheerde van 3-7-1946 tot 7-8-1948, maakte zich toen in de Eerste Kamer sterk voor grotere zeggenschap van Aruba en pleitte voor statutaire erkenning van de mogelijkheid tot afscheiding van een der Antililasnse eilanden van de Nederlandse Antillen en het aangaan van een 'afzonderlijke betrekking' met Nederland, Wehry (1988) p. 170. Wehry achtte Jonkmaneen ver vooruitziende statsman. Volgens het ISS rapport (1978) p. 27 zijn er overeenkomslen te bespeuren tussen de separaciónbeweging van Eman in de jaren ' 40 en de MEP in de jaren ' 70 . In beide gevallen stuitten aanvankelijk zeer gematigde eisen - bestuurlijke decentralisatie - constitutionele autonomie voor de eilanden en een federaal verband - af op het vanzelfsprekend centralistisch denken en handelen in Den Haag en Willemstad. Door het niet serieus nemen van de Arubaanse wensen, ontstonden sterke emoties en radicaliseerde de afscheidingsbeweging op Aruba.

7 Verton (1977) pp. 195 en 196. 
verlangde bestuurlijke zelfstandigheid van Aruba. Ook de ERNA (1951) bracht niet die zelfstandigheid die Aruba zich bad gewenst. Op grond van de ERNA waren vier eilandgebieden ingesteld, die elk wel een grotere mate van autonomie kregen dan voorheen, maar deze was eerder te vergelijken met de gemeentelijke autonomie in Nederland dan met de zelfstandigheid van een deelstaat in een federatie. De ERNA wijkt alleen in zoverre af van de Gemeentewet dat in artikel 2 en 2a een opsomming wordt gegeven van bevoegdheden die niet tot de zorg van het eilandgebied behoren. Maar dat is wel een uitgebreide lijst van bevoegdheden. ${ }^{8}$ Het administratief toezicht zoals geregeld in de ERNA wekte ook wrevel in Aruba, met name door de wijze waarop de Gezaghebber zijn bevoegdheden hanteerde. ${ }^{9}$

Als tegenwicht voor de AVP richtte een aantal Europese Nederlanders en Arubanen de Union Nacional Arubiano (UNA) op. Deze partij wierp zich op als confessionele (katholieke én protestantse) partij, die een brede maatschappelijke achterban nastreefde onder (intellectuele) kringen in de stad en de stemgerechtigde immigranten, met name de Europese Nederlanders, ook wel Hollanders genoemd. Tijdens de eerste algemene verkiezingen van $1949 \mathrm{kreeg}$ de AVP vijf zetels in de Eilandsraad en de UNA kreeg de resterende drie. Op Aruba beheerste de AVP de Eilandsraad en op landsniveau participeerde ze in regeringscoalities met de Curaçaose NVP en enkele kleinere partijen. ${ }^{10}$

Op initiatief van Eman werd op de Eilandsraadvergadering van 15 maart 1952 met 16 tegen 5 stemmen een motie aangenomen om de invloed van de immigranten te beperken. Voortaan zou de meerderheid van de Eilandsraadszetels door Arubanen moeten worden bezet, 'welke laatsten dan geacht werden te bestaan uit allen die op Aruba waren geboren en degenen, die buiten Aruba uit Arubaanse ouders ter wereld kwamen, mits ze Nederlanders waren'. ${ }^{11}$ Een van de ernstige grieven van de separatisten was dat door de stijgende welvaart de grotere financiële bijdragen van Aruba aan de koloniale begroting niet werden gecompenseerd door een grotere invloed van

* Het ISS-Rapport (1978) heeft als motto meegekregen, de idealen zoals verwoord door J. Yrausquin in 1947: 'Deze beweging zou zeker niet zo het accent leggen op afscheiding, indien onze Hooge Regeering in Nederland meer diligentie had getoond bij de inlossing van hare belofte en het Bestuursapparaat in Willemstad meer gevoel had getoond voor de belangen van Aruba', p. iii, zie ook p. 6 e.v.

9 In zijn rapport van 1977 stelt Jeukens dan ook voor het hiērarchisch hoger toezicht te vervangen door een systeem van rechterlijke controle, waarbij toetsing aan het algemeen belang zou moeten vervallen, Rapport Jeukens (1977) pp. 37-42.

Alofs (1990) p. 85 e.v.; Kasteel (1956) p. 244.

Kasteel (1956) p. 244; Alofs (1990) pp. 85 e.v.; Hartog (1953) p. 424. 
Aruba. ${ }^{12}$ De gevolgen van de 30 mei-beweging in 1969 bleken een sneeuwbaleffect te hebben op de drang naar afscheiding op Aruba. ${ }^{13}$ De angst voor blijvende overheersing van Curaçao heeft zeker bijgedragen hebben tot een actualisering van het afscheidingsstreven na 1969. De afwijzing van de Separación-gedachte door Curaçao en Nederland heeft evenzeer een radicalisering van de beweging in de hand gewerkt. Deze situatie werd nog versterkt doordat de Lago allerlei overheidstaken ter hand nam, zoals het op grote schaal bouwen van huizen in San Nicolas, het opzetten en uitvoeren van de benodige infrastructuur zoals de aanleg van wegen en havens, verder zorgde de Lago voor een wasserij, voor supermarkets en sportfaciliteiten. Er werd in 'de Colony' een ziekenhuis gebouwd en in 1935 startte de Lago een eigen beroepsopleiding. ${ }^{14}$

Bij het opzetten van een eigen Arubaans ambtenarenapparaat werd een groot aantal Hollandse en Curaçaose hoofdambtenaren aangetrokken, die een directe bedreiging vormde voor de oude lokale bestuurlijke elite. Vooral de Europese Nederlanders moesten het in dit verband ontgelden. ${ }^{15}$ " Het adjectief 'Hollands' diende vooral om de patriottische gevoelens van de Arubanen aan te wakkeren, hetgeen niet overmatig moeilijk bleek". ${ }^{16}$

Alofs en Merkies tonen overtuigend aan dat de Separación-beweging een poging was, om na het verlies van het economische en het bestuurlijke monopolie in ieder geval de politieke arena onder controle te houden. Nationalisme was het antwoord op de bijzonder snelle veranderingen op het eiland, die ten koste waren gegaan van de oude maatschappelijke verhoudingen en de machtsposities van de autochtone bevolkingsgroepen. ${ }^{17}$ De welvaart van veel plattelanders bleef dan ook sterk achter bij die van de olie-immigranten uit het Caraibisch gebied. Ook in deze kringen wierp Eman zich op als de 'vox populi, vox Dei' en bediende hij zich van een politieke stijl, die zich keerde tegen de Afro-Caraíbische immigranten en die hierdoor een racistische ondertoon had. De groep Eman won al in 1941 de verkiezingen,

\footnotetext{
$12 \quad$ Kasteel (1956) p. 34 e.v.

13 Verton (1978) p. 774.

$14 \quad$ Alofs en Merkies (1990) pp. 61-79.

is Kasteel (1956) p. 71.

$16 \quad$ Kasteel (1954) p. 65.

17 Kleurenbijlage Vrij Nederland (1978) pp. 5 en 7. De PPA werd door veel blanke autochtone Arubanen van het platteland gezien als de partij waar de negers de hoofdrol spelen. De MEP makkte een eind aan de PPA-overheersing en gaf Aruba weer anzien in de wereld. Betico is een van hen, een jongen uit de knoek. Politiek wordt op Aruba niet in de vergaderzaal bedreven, zoals in Nederland in de Tweede Kamer, maar op straat en op bruiloften, partijen en begrafenissen, VN, p. 9.
} 
omdat "die haar liefde voor Aruba het luidst had verkondigd". ${ }^{18}$ Henny Eman verloor de aanhang voor zijn Separación-beweging toen hij een compromis over de zetelverdeling met Curaçao accepteerde in 1950. Betico Croes was zich van dat feit buitengewoon goed bewust. Het verklaart voor een groot deel zijn latere geringe bereidheid tot compromissen. Zijn onbuigzaamheid is zijn behoud als leider geweest. ${ }^{19}$

Een in Nederland wonende groep Antillianen vroeg na '30 mei 1969' als eerste om onafhankelijkheid van de Nederlandse Antillen. Op 1 juni 1969 hield een menigte van zo'n 400 personen, grotendeels bestaande uit Antilliaanse studenten, een protestdemonstratie in Den Haag. $\mathrm{Zij}$ hadden van de gebeurtenissen op Curaçao vernomen, protesteerden tegen het inzetten van mariniers om de ongeregeldheden de kop in te drukken en eisten de Antilliaanse onafhankelijkheid. Tegelijkertijd diende de Partij van de Arbeid (PvdA) een motie in, waarin om beëindiging van het Statuut werd gevraagd. Deze motie vond bijval. Arends, de fractieleider van de AVP stuurde een telegram naar de PvdA, waarin hij namens zijn partij ontbinding van het Statuut van het Koninkrijk en een zelfstandige positie van Aruba buiten het Antilliaans verband eiste. ${ }^{20}$

In 1969 werd de PPA-politicus Petronia - met Curaçaose achtergrond - de eerste (en laatste) Arubaanse minister-president van de Nederlandse Antillen en de eerste zwarte premier. Een gebeurtenis die over het algemeen werd gezien als een reactie op de kritiek van de 30 mei-beweging, die van mening was dat het zwarte deel van de bevolking geen mogelijkheid had hoge posities te verkrijgen. Aruba en Curaçao vervreemdden verder van elkaar toen Aruba niet wilde meebetalen aan de herstelwerkzaamheden van de onlusten, omdat Aruba deze beschouwde als een puur Curaçaose aangelegenheid. Verder ontstonden problemen bij de benoeming van de Gouverneur. Aruba wenste ex-premier Jonckheer als Gouverneur. De Afro-Curaçaoënaar Leito, die door Nederland werd benoemd was voor Aruba niet acceptabel. Deze gebeurtenissen leidden tot heropleving van de oude Separaciónidealen. ${ }^{21}$

In plaats van de aandacht te richten op de federatieve opbouw van de Nederlandse Antillen gaf de PPA voorrang aan het verbreden van

\footnotetext{
Kasteel (1954) p. 66; Alofs (1990) p. 101 e.v.

Kleurenbijlage Vrij Nederland (1978) p. 32.

Van Gameren (1991) p. 21; Paula (1989) p. 69.

Reinders (1993) p. 343 e.v.
} 
de basis van de eilandelijke economie in verband met vertrek van de Eagle $^{22}$ en de automatisering bij de Lago. ${ }^{23}$ Vooral de komst van het toerisme kan worden toegeschreven aan de PPA. Het cruisetoerisme werd bevorderd. Ook probeerde de overheid het verblijfstoerisme en de industrie te ontwikkelen. In 1957 en 1959 werden de eerste twee luxe hotels gebouwd, die konden profiteren van een 'taxholiday'. ${ }^{24}$

Eind oktober 1969 werd de 'Comishon Pro Separashon di Aruba' opgericht. Haar eerste openbare optreden was het organiseren van een demonstratie tijdens een bezoek aan Aruba van minister Bakker, belast met Surinaamse en Antilliaanse Zaken. De demonstratie trok ongeveer 500 belangstellenden. ${ }^{25}$

Ook de Curaçaose Frente Obrero was van mening dat de Nederlandse Antillen onafhankelijk moesten worden. De NVP/COP vond dat de eilanden autonomer ten opzichte van elkaar en de centrale regering moesten staan en de gemeenschappelijke belangen in federatief verband moesten worden geregeld. De ERNA en de Staatsregeling zouden dienovereenkomstig gewijzigd moeten worden. De DP vond dat de staatsrechtelijke band met Nederland gewijzigd moest worden in een volkenrechtelijke band, waarmee zij pleitte voor de opheffing van het Statuut. Wel wilde de DP tegelijkertijd een versteviging van de economische, sociale en culturele banden met Nederland. De URA nam tegen de verwachtingen in een zeer behoudend standpunt in, terwijl de partij jarenlang had gestreden voor een grotere autonomie van de Nederlandse Antillen. Toen Nederland duidelijk te kennen gaf dat onafhankelijkheid op korte termijn zou moeten worden gerealiseerd, stelden de meeste politieke partijen zich overigens terughoudend op.

Deze raffinaderij was een zelfstandig onderdeel van de Koninklijke Shell, de Compañia Mexicana de Petrole et Aguila SA. Aguila betekent arend, vandaar de naam Arend Petroleum Mastschappij. In de wandeling meestal met de Engelse term 'Eagle' aangeduid. In het begin van 1953 werden alle bezigheden bij Eagle gestakt, Alofs (1990) p. 64 en Hartog (1953) p. 319. Op 31 december 1960 werd de naam gewijzigd in: 'Shell Nederlandse Antillenverkoopmaatschappij NV', Encyclopedie (1985) p. 41.

23 De Lago Petroleum Corporation kwam in 1924 naar Aruba, Hartog (1953) pp. 305 e.v.

Alofs (1990) pp. 118 e.v. en 124.

Paula (1989) p. 69. 
$\mathrm{Na}$ het op gang komen van het dekolonisatieproces kon de bestaande patronage $^{26}$ toenemen omdat de invloed van de eigen Antilliaanse politici toenam en deze meer dan ooit controle kregen over de openbare middelen waar voorheen het moederland het beheer over voerde. Verton beschrijft patronage als volgt:

"Het basispatroon van de electorale relaties was dat van kiezers, die een $\mathrm{min}$ of meer persoonsgerichte relatie aangaan met de leider in wie ze vertrouwen hebben. Dat vertrouwen sloeg voor een niet gering deel op de hulp, die men achteraf van hem verwachtte. Hulp, die in principe sociaal-economische vooruitgang voor de kiezer of zijn familie inhield. Zolang de politieke leider daarvoor kon zorgen, of overtuigend beloofde dat die vooruitgang zou komen, zou hij op handen worden gedragen." ${ }^{27}$

Verton (1977) pp. 58-86, 104-110: 'Het ging in de relatie kiezer en partijleider veelal om een band met charismatische trekken. Enkele typerende uitspraken in dit kader: "De geliefdheid van de politieke leider bij het volk maakt uit of men voor hem stemt. Vertrouwen in een partijleider is de enige basis voor een stembusoverwinning. Wie het hardst schreeuwt, krijgt het domme volk achter zich"' (p. 105). Kleurenbijlage Vrij Nederland (1978); de leider helpt: 'Zoals alle Caraibische leiders kan ook Betico Croes zich alleen maar handhaven, wanneer hij voldoende mensen het gevoel kan geven dat hun individuele voorspoed door hem persoonlijk wordt bevorderd. In het Aruba van vór de olie werd het leven beheerst door een omvangrijk stelsel van patronage verhoudingen. Een in hongersnood verkerende eilandbewoner was voor overleving aangewezen op de hulp van een beschermer, doorgaans een wat gefortuneerd familielid. Dat was de 'shon', die als tegenprestatie wellicht enige diensten vroeg, maar in ieder geval onderdanigheid. De olie kwam en de tijden veranderden. Wat bleef was de ingebakkenovertuiging dat men voor hulp op iemand was aangewezen. En dat is de politieke leider van vandaag. Het verstrekken van persoonlijke gunsten en het ontvangen van persoonlijke macht is van groot belang om de politieke macht te behouden. In het Arubaanse politieke systeem is het tevens van belang dat de degene die de meeste macht binnen de partij heef, degene is die de meeste voorkeurstemmen op zich verzameld heeft. Van het aantal stemmen dat een politicus op zijn persoon heeft verzameld hangt zijn positie binnen de partij af.'

Verton (1977) p. 105: 'Onderhoud aan overheidskantoren wordt opgespaard tot in de verkiezingstijd. Een schildersjob voor een paar stemmen.' Tegen de verkiezingen wordt vaak een of andere maatregel getroffen, zoals het invoeren of verhogen van het weduwen- en wezenpensioen (p. 107). 'Achterstallige waterrekeningen worden vereffend in ruil voor de volmachten van de hele familie. In het ziekenhuis werden voor $f 5$,- volmachten van patienten gekocht.' (p. 108). Na de verkiezingen komen veel kiezers hun loyaliteitspremie incasseren van de politici, die zij in het zadel hebben geholpen. De beloften aan velen gedaan leiden tol gunsten aan weinigen. De staatkundige structuur zet verkiezingswinst om in bestuursmacht, die pas bij de volgende verkiezing kan worden aangetast. Voor de Statenverkiezingen van Aruba in 1993 werd een koortsachtige werkzaamheid ten toon gespreid in het onderhoud van wegen en kregen de ambtenaren, sinds de bevriezing van 1988, voor het eerst weer vakantiegeld uitbetaald. Op de pp. 116 en 117 geeft Verton voorbeelden van het in hechtenis nemen van leiders van de oppositie op grond van gefingeerde beschuldigingen, voor de verkiezingen in 1962, 1966 en 1969. Volgens Verton, speelt 
$\mathrm{Koot}^{28}$ meende dat patronage in geheel Zuid-Amerika voorkomt. Hij zag patronage als een gevolg van het ontbreken van een economische middenklasse in een land. De feodale verhoudingen zijn in LatijnsAmerika nooit doorbroken, zoals in Europa wel gebeurde, door de opkomende burgerlijke handelsklasse. Een stabiel politiek klimaat kan alleen dan ontstaan als er een evenwicht bestaat tussen de verschillende klassen in de maatschappij. Is er een min of meer rechtvaardige verdeling van inkomen, dan hebben corruptie, politieke patronage en criminele invloed veel minder kans om een voet aan de grond te krijgen. Schrills noemde naast een rechtvaardige inkomensverdeling voor de bevolking, een gegarandeerd minimuminkomen, een goede algemene ontwikkeling en het verstrekken van de juiste informatie door de overheid aan de burgers. ${ }^{29} \mathrm{Klomp}^{30}$ geeft een heldere analyse over het verschijnsel. $\mathrm{Zij}$ komt tot de conclusie dat patronage alleen zal kunnen verdwijnen als de lagere klasse voor een groot deel zal zijn opgenomen in de middenklasse, waarin de waarden en normen overheersen dat politiek dient te worden uitgeoefend ten behoeve van het algemeen belang en niet ten behoeve van persoonlijke belangen.

Politieke patronage heeft zich op de Nederlandse Antillen en Aruba pas kunnen ontwikkelen na de invoering van het algemeen kiesrecht in 1948. De 'shons ${ }^{31}$ hadden voordien geen behoefte aan

het ministerie van Justitie een steeds belangrijke rol in de 'détoumement de pouvoir' van de landsregering met de bedoeling oppositiepartijen reeds bij de verkiezingen uit te schakelen.' Politieke tegenstanders op eilandsniveau werden gedwarsboomd door de kraan van de financiële hulp dicht te draaien (p. 121).

Koot (1975) p. 4. Het partijwezen op de Nederlandse Antillen en Aruba wordt nog steeds gekenmerkt door een oligarchische partijstructuur, er bestaan persoonlijke relaties tussen kiezers en gekozenenen partijvorming geschiedi zonder programmatische grondslag. Een belangrijke grondslag voor patronage lijk mij de grootte van een gemeenschap. Het is jammer dat sociologisch (Nederlands) onderzoek naar patronage zich altijd schijnt te richten op Latijns-Amerika of een afgelegen bergdorp in Italie. Het zou interessant zijn een dergelijk onderzoek uit te voeren in een aantal kleine (Limburgse) gemeenten. Minister Dales van Binnelandse Zaken waarschuwde in 1992 al tegen 'machtsbederf' in het binnenlands bestuur. In eenvijfde van de Nederlandse gemeenten is in de afgelopen vijf jaar opgetreden tegen cormptie onder ambtenaren en bestuurders. Het NRC-Handelsblad en de Rijksuniversiteit Leiden onderzochten het toenemend machtsbederf, NRC-Handelsblad, Weekend-editie, 1 fehruari 1994: 'Voor smeergeld moet je elkaar vertrouwen.' Schrills, Onze politieke mentaliteit, een gevaar voor de democratie in: Nos Futuro (1986) pp. 147-162.

Klomp (1986) 'Politics on Bonaire', met name hoofdstuk V, dat oorzakenen gevolgen van patronage behandelt vanuit een antropologisch/sociologisch/politicologisch standpunt, p. 185.

31 Shon betekent heer, oorspronkelijk was deze benaming de aanspreektitel van de meester in de slaventijd. De slaaf werd altijd met zijn voornaam aangesproken. De slaaf diende echter de meester en zijn familieleden, benevens alle personen van 
trouwe volgelingen, daar de belangrijke posities voorbehouden waren aan blanke protestanten en zij daarvoor de steun van de rest van de bevolking niet nodig hadden. Verder is politieke patronage mede versterkt door de segmentatie van de maatschappij naar kleur, op grond van die indeling zijn ook de politieke partijen meestal gestructureerd. De aandacht van de kiezer gaat naar de leider van de partij (personalisme) in plaats van naar politieke partijprogramma's, daden van politieke partijen of ideologieën. Daar leden van een politieke partij geen contributie betalen, zijn de politieke partijen aangewezen op financiering door het bedrijfsleven, dat daarvoor weer 'gunsten' verwacht in de vorm van contracten van - en leveringen aan - de overheid.

Zo wordt het patronagesysteem van twee kanten versterkt. ${ }^{32}$ Een voorbeeld van patronage is het nog even snel benoemen van ambtenaren, voordat een nieuwe politieke partij op het regeringspluche plaats neemt. Bloedverwantschap, vriendschapsrelaties en partijloyaliteit, zowel afzonderlijk als in onderlinge samenhang spelen een rol bij beslissingen, waar slechts zakelijke, bestuurlijke motieven de doorslag zouden moeten geven. De afhankelijkheid van lokale politici van hun kiezers en het feit dat anonimiteit van beslissingen in kleine samenlevingen haast onmogelijk is, leggen een zware druk op het overheidshandelen. Door de kleinschaligheid en het gebrek aan anonimiteit worden bestuurders teveel op hun vingers gekeken en moeten zij te vaak primair als politici handelen. Dit gedrag is dan gericht op het verwerven of behouden van macht en niet op hetgeen bestuurlijk wenselijk zou zijn. Kleinschaligheid werkt kennelijk ook op politiek gebied een sterke sociale controle in de hand en beperkt daarmee ook de bestuurlijke bewegingsruimte. ${ }^{33}$

Op den duur zal de politiek 'zuiverend' optreden, maar voordat een dergelijk proces intreedt, zal de patronage onaanvaardbare grenzen hebben bereikt. Plato's concept om de staat zo in te richten, dat alleen 'de besten' regeren is dan ook praktisch niet uitvoerbaar. Met name 'de besten' kunnen vaak geen weerstand bieden aan corruptie en fraude. De opgave is veel meer te voorkomen dat slechte en incompetente bestuurders te veel schade aanrichten. Het parlement en de kiezer hebben een belangrijke taak in het wegsaneren van 'onwaardige

\footnotetext{
dezelfde sociale status met 'shon' aan te spreken. Later werd 'shon' de aanspreektitel voor alle personen die men respecteert en als van hogere sociale rang erkent. De Gouverneur werd aangeduid met 'Shon Grandi', Encyclopedie (1985) p. 431.

32 Galjart (1992) Antropologische Verkenningen, pp. 48-63.

33 Römer (1982), pp. 100 e.v.
} 
elementen'. Zo uit de democratie zich óḱk door het schandaal. Een effectieve controle van de regering is alleen mogelijk door de oppositie en dat kan alleen als er parlementaire onschendbaarheid bestaat. De politiek in de Nederlandse Antillen en Aruba wordt voor een groot deel beheerst door het wederzijds beledigen van politici van een andere partij. ${ }^{34}$ Dat betekent dat de oppositie scherpe en niet altijd terechte kritiek heeft op de regeringscoalitie en andersom..$^{35}$ Castillo beschrijft in Nos Futuro, ${ }^{36}$ dezelfde problematiek politicologisch, hij acht het bestaande politieke systeem dictatoriaal.

Omdat de DP op centraal niveau tussen 1954 en 1969 slechts kon regeren dank zij de steun van de Arubaanse PPA, kon Aruba bij de verdeling van overheidsgelden steeds een meer dan evenredig deel eisen. In die situatie was er voor een afscheidingsbeweging geen materiële basis. Het separatisme zou pas in de jaren zeventig met de MEP onder leiding van Betico Croes weer opleven. Juist in de overgangsjaren toen de PPA op Aruba de hegemonie van Henny Eman overnam kwam de patronage in deze partij tot volledige ontwikkeling. Tussen 1967 en 1973 brokkelde de machtspositie van de PPA af. De dood van Yrausquin en de nadelen van de jarenlange onrust in de partijtop werden steeds duidelijker. ${ }^{37}$

In de jaren zeventig zou de Status Aparte-beweging, de tegenstelling tussen autochtonen en allochtonen en met name die tussen autochtone blanke plattelands-Arubanen en allochtone Afro-Caraïbische Arubanen opnieuw vorm geven. Daarbij speelde de verslechterde politieke verhoudingen tussen Aruba en Curaçao een belangrijke rol. ${ }^{38}$ De jaren zeventig en tachtig werden gekenmerkt door de tweede golf van staatkundig separatisme in de vorm van Betico Croes' Status Aparte-beweging, de uitbreiding van de toeristenindustrie en van het ambtenarenapparaat, benevens de ondergang van de olieindustrie in 1985.

4. Vanaf 23 februari 1994 is in de Nederlandse Antillen een landsverordening ingevord die de strafrechtelijke verantwoordelijkheid van ministers en leden van het BC regelt, Amigoe 24 februari 1994. Tevens overweegt minister van Justitie Rōmer een landsverordening in te voeren die op politieke belediging een boete stelt van NAf. 25.000, Amigoe 25 februari 1994. De PAR wil corruptie vermijden door hun kandidaten inzage te laten geven in hun persoonlijke financiën, vóór en na hun ambtstermijn als Statenlid of minister, Amigoe, 17 februari 1993.

3o Van Aller (1992).

36 Castillo, Ons politiek systeem, hervorming of dictatuur (1986) pp. 129-146.

37 Alofs (1990) pp. 124-128.

3. Alofs (1990) p. 151 . 
In 1971 richtte ex-onderwijzer en AVP gedeputeerde van onderwijs Gilberto F.(Betico) Croes een nieuwe politieke partij op, de Movimiento Electoral di Pueblo (MEP). De MEP zette zich met name in voor de emancipatie van de autochtone plattelandsbevolking van Aruba. ${ }^{39}$ Croes wilde Aruba aanvankelijk tot een zelfstandige deelstaat van een te vormen Antilliaanse federatie maken, ${ }^{40}$ waarmee hij de idealen van Juancho Yrausquin en die uit het rapport Van Poelje nieuw leven dacht in te blazen. In 1971 deed de MEP onmiddellijk mee met de Eilandsraadverkiezingen en behaalde tot ieders verrassing $30 \%$ van de stemmen, te weten zeven van de eenentwintig zetels.

In het begin van dat jaar was het 'Verslag' van Van Leeuwen verschenen. Hij bepleitte daarin constitutionele autonomie voor ieder eiland en een federale staatsvorm voor de Antillen, waarin het hoger toezicht op de eilandgebieden zou komen te vervallen en plaats zou maken voor constitutionele en wettelijke toetsing door een Hof van Justitie. ${ }^{41}$ Dit rapport had veel invloed op de ontwikkeling van het denken van de MEP.

In januari 1972 werd door de Eilandsraad van Aruba een door de MEP geïnspireerde motie aangenomen over de herziening van de staatsrechtelijke banden van Aruba met de overige eilanden. ${ }^{42} \mathrm{De}$ AVP wilde in de zeventiger jaren samenwerken met de concurrende partij, de PPA. Dit beschouwde Croes als verraad aan de Status Aparte gedachte. De positie van de MEP werd steeds sterker, niet alleen vanwege Croes' staatkundige voornemens, maar meer nog omdat hij de eerste politicus was die de plattelands-Arubanen een alternatief bood ten opzichte van de gevestigde partijen en uitdrukking

Alofs (1990) pp. 3-8.

40 Verkiezingspamflet MEP, 1971, 'Vox populi vox dei', daarop wordt met betrekking tot de federatie het volgende vermeld: ' $E$ territorianan insular mester ta INDEPEN. DIENTE riba terreno politico y financiero-economico, sin cu un isla ta domina e otro. Un Federacion mester ser encarga cu algun interesnan comun. E fondonsn necesario lo bini di e islanan, a base di un acuerdo entre e islanan. E lasonan historico cu Hulanda lo ser manteni, si e circumstancianan actual no cambia radicalmente.' (De eilandgebieden moeten ONAFHANKELUK worden op politiek en financieeleconomisch gebied, zonder dat één eiland de andere domineer. Een federatie zal moeten worden belast met de gemeenschappelijke belangen. De noodzakelijke basis daarvoor zal moeten komen van de eilanden, op grond van overeenstemming tussen de eilanden. De historische banden met Nederland moeten worden gehandhaafd, als de huidige omstandigheden zich niet ingrijpend wijzigen [vertaling HBvA].

4. Van Leeuwen (1971).

42 Witboek (1975) pp. 68 e.v. 
gaf aan de gevoelens van tenachterstelling tegenover de elitaire en allochtone bewoners van Oranjestad en San Nicolas. Zo werden ter legitimatie van de wens tot afscheiding van Curaçao, de Latijnsamerikaanse identiteit en de Indiaanse afstamming van de autochtone bevolking benadrukt en afgezet tegen tegen het Afro-Caribische karakter van de Curaçaose samenleving. ${ }^{43}$

Van de interne Arubaanse tegenstellingen tussen de MEP en de PPA maakte Nederland dankbaar gebruik. ${ }^{44}$ Betico Croes reageerde op de Nederlandse afwijzing van een aparte status voor Aruba, door niet langer deel te nemen aan de Koninkrijksbesprekingen en met de organisatie van een volksmanifestatie in Oranjestad op 18 maart 1973, vlak voor een bijeenkomst van de Koninkrijkscommissie op Aruba. De overweldigende opkomst van 6000 tot 8000 mensen bracht een Nederlands commissielid tot de suggestie om de afscheiding van Aruba te realiseren door middel van een appèl op het zelfbeschikkingsrecht. ${ }^{45}$ Met de wens voor een Status Aparte binnen een Gemenebest ging de MEP de Statenverkiezingen in. ${ }^{46}$ De PPA stelde hiertegenover het federatieve Antilliaanse model. De verdeeldheid tussen Aruba en Curaçao kwam ook tot uiting in de Antilliaanse sectie van de Koninkrijkscommissie. De discussie concentreerde zich niet langer op de onafhankelijkheid van de Antillen, maar had zich verplaatst naar de interne Antilliaanse verhoudingen.

De bekendmaking van het 'Licht Statuut' in februari 1973 door de Nederlandse sectie van de Koninkrijkscommissie zorgde voor grote opschudding onder de Antilliaanse politici. Zij hadden het gevoel dat Nederland zich binnen korte tijd wilde ontdoen van de band met de Antillen. Hierop wist de Antilliaanse sectie van de Koninkrijkscommissie binnen twee weken een gezamenlijk standpunt te formuleren. Alle partijen behalve de MEP leken het eens te zijn over een Gemenebest-verbouding. In mei 1973 kwam in Nederland een links-georienteerde regering aan de macht. De Antilliaanse politici vreesden een

\footnotetext{
$43 \quad$ Alofs (1990) p. 522; Reinders (1993) p. 344.

4 Witboek (1975) p. 82.

4s Bedoeld wordt hier art 1 lid 1 van de 'International Convenant on Civil and Political Rights' luidende: 'All people have the right of self determination. By virtue of that right they freely determine their political status and freely pursue their economic, social and cultural developement.' De brandende vraag blijtt naar mijn mening wel, hoe vaak het zelfbeschikkingsrecht kan worden toegepast en hoe een volk wordt gedefinieerd, in dit geval als hel Antilliaanse volk of heeft elk eiland een eigen volk? Deze laatste interpretatie is niet de algemeen gangbare in het volkenrecht, maar kan natuurlijk athankelijk van de heersende waarden en normen daarover in de wereldgemeenschap anders worden geïnterpreteerd; zie ook Witboek (1975) p. 75 e.v.

t6 ISS-Rapport (1978) pp. 10-14; Witboek (1975) p. 74; Van Gameren (1991) p. 116 e.v.
} 
verharding van het Nederlandse standpunt ten aanzien van de Antilliaanse onathankelijkheid.

Bij de verkiezingen van de Staten in 1973 brak de MEP verder door. De AVP verloor al haar zetels aan haar 'splinterpartij'. De PPA veroverde slechts drie van de acht Statenzetels en erkende het MEP standpunt als de mening van het volk. De MEP verwierf 5 van de 8 Arubaanse zetels. Daarmee was de MEP een potentiële coalitiepartner voor de Curaçaose partijen geworden. Vanaf mei 1973 maakte de MEP deel uit van de Landsregering. De aantredende regering Evertsz van de Nederlandse Antillen, maakte in haar regeringsverklaring geen melding van de soloplannen van Aruba. Wel loodste de MEP enkele belangrijke moties door de Staten met betrekking tot het zelfbeschikkingsrecht van de eilanden. Na de overwinning van de MEP bij de Statenverkiezingen maakte de tegenstelling Curaçao - Aruba plaats voor de tegenstelling Curaçao - MEP.

$\mathrm{Na}$ het bekend worden van het voornemen van de de Surinaamse regering in 1974 om vóór 1976 de onafhankelijkheid te verkrijgen, vreesden de Antilliaanse politici, dat ook de Nederlandse Antillen in 1975 onafhankelijk zouden moeten worden. Indien deze vooronderstelling juist zou zijn, zouden de Antillen de planmatige voorbereiding van de onafhankelijkheid kunnen vergeten. Op grond van deze gebeurtenis vormden de Antilliaanse regering en de politieke partijen een eensgezind front en maakten Nederland duidelijk dat de Antilliaanse problematiek van een geheel andere orde was dan de Surinaamse, om zodoende de dreigende onafhankelijkheid te blokkeren. Met name de economische garanties voor de onafhankelijkheid werden uitvoerig besproken. Het nationale gevoel hield echter niet lang stand. De PSD én van de regeringspartijen kwam eind april 1974 met de verklaring dat zij streefde naar een onafbankelijk Curaçao. De Antilliaanse regering had te snelle conclusies getrokken. De Nederlandse regering bleek bereid te zijn de Antillen de tijd te gunnen de onafhankelijkheid planmatig voor te bereiden. De Nederlandse regering eiste wel dat de voorbereiding van de onafhankelijkheid constructief moest worden aangepakt en dat de Antillen als eenheid zouden blijven optreden. Aparte staatsrechtelijke banden met Aruba achtte Nederland en de Antilliaanse regering onaanvaardbaar. De druk die de Antilliaanse partijen hadden gevoeld was verdwenen, maar daarmee ook het nationale gevoel. De onderlinge tegenstellingen laaiden weer op en een spoedige overeenkomst over de inter-insulaire verhoudingen, de eerste fase in de planmatige voorbereiding van de onafhankelijkheid leek er niet meer in te zitten. 
Tussen 26 en 29 augustus 1974 vond het eerste eilandelijke topoverleg plaats op Aruba, waarom de Arubaanse Eilandsraad in augustus 1972 al om had gevraagd. In dit overleg bleek dat de AVP zich ook aan de kant van de MEP had geschaard, omdat de Curaçaose partijen zich in februari 1972 hadden uitgesproken voor een gedecentraliseerde eenheidsstaat in republikeinse vorm volgens het systeem 'one man one vote'. Door dit systeem kon het ene eiland het andere overheersen. Zolang de Curaçaose partijen niet terugkwamen op dit voornemen, zou de AVP zich blijven uitspreken tegen een Antilliaanse federatie. Zowel de MEP als de AVP wensten een aparte status voor Aruba. Het eilandelijk topoverleg maakte duidelijk dat met uitzondering van de MEP, de AVP en de PSD alle politieke partijen een blijvende band tussen de eilanden wensten. Alle delegatieleden wilden verder een sterke decentralisatie van het centrale gezag doorvoeren. Bij het vervolg van het eilandelijk topoverleg op 18 november 1974 op Bonaire kwam de MEP met drie verschillende interpretaties van de status aparte. Naast het model waarin Aruba als soevereine natie los van de rest van de Nederlandse Antillen staatsrechtelijke banden met Nederland, Suriname en de Nederlandse Antillen zou onderhouden, werden nog twee Gemenebest-modellen gepresenteerd.

Het eerste model bestond uit het Gemenebest Nederland, Suriname, de Antillen en Aruba, die onderling volkenrechtelijke banden zouden onderhouden. Het tweede Gemenebest-model bestond uit de Antilliaanse eilanden. Het Antilliaanse Gemenebest zou dan weer Gemenebest-banden onderhouden met Nederland. In alle drie modellen zou Aruba een soevereine natie vormen. De Antilliaanse partijen, behalve de PSD hielden vast aan de republikeinse federatie. Het derde eilandelijke topoverleg van 12 tot en met 15 februari 1975 leverde ook geen nieuwe gezichtspunten op. De tegenstelling tussen Curaçao en de MEP leken onoplosbaar. ${ }^{47}$ Gesteld kan worden dat de Antilliaanse politici hier niet ontevreden mee waren. Zolang de Antillen geen eenheid vormden kon Nederland zich niet van de Antillen ontdoen.

Nederland was niet bereid om een Status Aparte voor Aruba te accepteren en vond dat de Antillen zich daarom moesten concentreren op de inter-eilandelijke staatkundige verhoudingen. Dit bleek op de vergadering van de Koninkrijkscommissie ter voorbereiding van de onafhankelijkheid van Suriname en van de Nederlandse Antillen in Paramaribo. De MEP opteerde toen voor een Gemenebest bestaande uit vier deelgenoten: Nederland, Aruba, de overige Antillen en 
Suriname. De Koningin zou aan het hoofd van dit Gemenebest staan. Aruba zou een onafhankelijke staat worden met een premier als hoofd van de Ministerraad. Dit was het afscheidingsideaal in de trant van de Separación van de oude Henny Eman.

Op 11 september 1975 onderschreven alle partijen een motie, waarin de MEP om de Status Aparte van Aruba vroeg. De politici wisten, dat dit de definitieve politieke desintegratie van de Nederlandse Antillen tot gevolg zou hebben. Zij gingen echter uit van een Nederlandse weigering, omdat Nederland steeds had verklaard dat de Nederlandse Antillen een eenheid moesten vormen. De Antilliaanse politici hadden de standvastigheid van Croes en zijn MEP onderschat. Als Aruba de onafhankelijkheid zou weten te realiseren zou dat ook de snelle herstructurering van de staatkundige verhoudingen tussen de andere eilanden moeten volgen.

Inmiddels had Aruba medio november 1975 geprobeerd bilaterale afspraken met Venezuela te maken over een aparte status van Aruba. Twee MEP ministers uit het kabinet Evertsz maakten deel uit van de Arubaanse delegatie naar Venezuela. Dit viel niet in goede aarde bij de centrale regering die vasthield aan een Antilliaanse federatie.

Voordien was er een incident geweest met de Arubaanse vlag en weigerde Aruba belasting af te dragen aan het Land. Op bevel van de Gouverneur moest de Gezaghebber alsnog de belastinggelden afdragen aan het Land. De samenwerking tussen de NVP en de MEP werd er niet beter op. Premier Evertsz zegde op 12 december 1975 de samenwerking tussen de MEP en NVP officieel op. Op diezelfde dag reisde een MEP-delegatie onder leiding van Betico Croes naar Panama om steun te verkrijgen voor de Status Aparte van Aruba.

De NVP-U stuurde aan op een kabinetscrisis. Op 29 december namen de Staten een motie van wantrouwen aan tegen de drie MEP ministers Efraim de Kort, 'Watty' Vos en Hendrik Croes. ${ }^{48}$ Met steun van de meeste politieke partijen in het Antilliaanse parlement, werd de MEP uit de regering gezet. Een snelle Antilliaanse onafhankelijkheid was van de baan. Geruchten gingen dat Nederland had aangedrongen op een regeringscrisis en het buitenspel zetten van de MEP om het eilandelijk nationalisme van Aruba te beteugelen. ${ }^{49}$ De MEP ver-

\footnotetext{
48 Paula (1989) pp. 74 e.v; Van Gameren (1991) p. 115 e.v.

49 Dit werd door minister Van der Stee ten stelligste ontkend: 'Laat ik heel duidelijk zeggen dat het Koninkrijk geen bemoeienis heeft gehad met de breuk in het kabinet Evertsz, waar het de MEP betreft. Ook door minister De Gaay Fortman is dit eerder nadrukkelijk ontkend'. Tweede Kamer, 17 mei 1978, p. 2424, beleidsdebat Nederlandse Antillen, waarbij tevens aan de orde was het Verslag van een mondeling
} 
dween uit de Landsregering. Over de wijze waarop de MEP uit het kabinet werd gewerkt valt politiek en staatsrechtelijk bet nodige op te merken. Na de verwijderijg van de MEP volgde een reconstructie waarbij de tegenstander van de MEP, de PPA als coalitiepartner werd aangezocht. De MEP verweet de Gouverneur inconstitutioneel gedrag. Van Rijn ${ }^{50}$ merkte daarover het volgende op.

"Het verzoek van de Gouverneuraan de Staten [of de MEP-ministers nog het vertrouwen genoten van de volksvertegenwoordiging] moet op grond van de werkwijze van het parlementair stelsel inderdaad als constitutioneel worden beschouwd, maar op een andere wijze dan de MEP meende. Inconstitutioneel was niet dat de Gouverneur zijn medewerking verleende aan een ontslagvergunning van de MEPministers uit de boezem van de regering, maar het feit dat de Gouverneur zelfstandig handelde. Hij had zelf het initiatief genomen de Staten te benaderen.

Zulks is echter in strijd met het beginsel van de ministeriële verantwoordelijkheid. Deze strekt zich uit over alle handelingen van Gouverneur, ook die in het kader van art. 39 lid 2 Staatsregeling Nederlandse Antillen. De ontslagverleningsbevoegdheid berust bij de regering als samenwerkingsverband van de Gouverneur en de ministers. Voordat de regering tot het verlenen van ontslag kan overgaan moet inderdaad blijken dat de betreffende minister niet meer het vertrouwen van de Staten geniet. De verantwoordelijke ministers bepalen echter wat dit 'blijken' inhoudt. Hebben zij redenen om aan te nemen dat een meerderheid van de Statenleden geen vertrouwen meer in de betrokken minister meer heeft, dan is dit voldoende. Vragen zij de Gouvermeur derhalve een ontslag te ondertekenen, dan is deze daartoe gehouden. Voor het ontslaan van een minister moeten de resterende ministers tenslotte verantwoording a fleggen tegenover het parlement. Op deze wijze blijkt dan definitief of het ontslag van de weggestuurde minister juist is geweest. Zo niet, dan kan een vertrouwenscrisis ontstaan, hetgeen het einde van het hele kabinet betekent.

Deze sanctie zal voorkomen dat individuele ministers binnen een kabinet lichtvaardig worden ontslagen. Artikel 39 lid 2 Staatsregeling van de Nederlandse Antillen moet dus zo worden uitgelegd dat materieel geen verschil bestaat met de werking van de ongeschreven vertrouwensregel in Nederland."

De hierboven beschreven problematiek is grotendeels toe te schrijven aan de dubbele functie van de Gouverneur, hij is naast Landsorgaan бók Koninkrijksorgaan. Over het standpunt van Van Rijn valt derhal-

overleg over een werkbezoek van de Minister voor Nederlands-Antilliaanse Zaken aan de Nederlandse Antillen (14800-IV, 12). 
ve te twisten.

Na de breuk in de Landsregering nam de MEP voor de Eilandsraadsverkiezingen van 1975 de Status Aparte-idee weer op. Dit leidde tot een grote verkiezingsoverwinning; $60 \%$ van de kiesgerechtigden op Aruba steunden de MEP, die 13 van de 21 zetels in de Eilandsraad verkreeg. Opnieuw werd door Aruba in Den Haag de wens te kennen gegeven een apart rijksdeel binnen het Koninkrijk te worden. Nederland bleek daartoe beslist niet bereid te zijn. Daarop kondigde Betico Croes namens de MEP aan dat Aruba in 1981 een onafhankelijke staat zou worden, die uitsluitend op volkenrechtelijke basis banden met Nederland en de overige Antillen zou kunnen en willen aangaan. Om zijn woorden kracht bij te zetten organiseerde Betico Croes op 25 maart 1977 een referendum, waarin de Arubanen zich uit konden spreken over hun staatkundige wensen. Hoewel er bij het referendum sprake was van een slechte vraagstelling, een relatief lage opkomst van ongeveer $80 \%$ en een groot percentage ongeldige stemmen van rond de $10 \%$, kon uit de uitslag worden opgemaakt dat $57 \%$ van de stemgerechtigde Arubanen achter de MEP-plannen stond. De vraagstelling van dit referendum luidde of men voorstander was van een onafhankelijk Aruba of voorstander van Aruba als deelstaat van een te vormen onafhankelijke Antilliaanse federatie. ${ }^{51}$ Wat een dergelijke

Het referendum werd bij Eilandsbesluit houdende algemene matregelen van 19 januari 1977 vastgesteld en afgekondigd in het Afkondigingsblad van Aruba (1997, 2). Staatkundig is het niet juist om een dergelijke regeling te treffen bij Eilandsbesluit h.a.m. Dat had moeten gebeuren bij Eilandsverordening. Het Antilliaanse en Arubaanse recht kent geen mogelijkheid een referendum te houden. Het ontbreken van een basis in de geschreven constitutie vereist dat het besluit door regering en parlement wordt genomen. Vaststelling bij Eilandsverordening maakt het ook mogelijk de voorschriften van het Kiesreglement van toepassing te verklaren, Van Rijn, Referendum Curaçao, Preliminaire opmerkingen, juli 1993 en Gilhuis (1981) pp. 32, 33, 286, 289. Het Eilandsbesluit h.a.m. bestond uit 83 artikelen en werd op 20 januari 1977 afgekondigd. Het trad ook die dag in werking. Verder zijn 8 bijlagen toegevoegd. Bijlage 1 geeft het model van de oproepingskaart aan. Bijlage 4 geeft het stembiljet weer, voorzien van een tekening. Zie ook Officieel Verslag van het referendu m bij wijze van Opiniepeiling betreffende de toekomstige staatkundige status van Aruba, gehouden op 25 maan 1977; H. Figaroa, Voorzitter van het Hoofdstembureau voor het Referendum bij wijze van opiniepeiling. Bij de stemming van het referendum diende de kiezer een keuze te maken uit twee staatkundige mogelijkheden, die als volgt geformuleerd en toegelicht waren: 'Aruba onafhankelijk': indien men deze optie kiest, betekent het dat men van mening is dat Aruba een onafhankelijke staat moet worden. De keuze voor de tweede mogelijkheid 'Aruba deelstaat van een te vormen onafhankelijke Antilliaanse federatie', houdt in, dat men kiest voor Aruba als deelstaat en onderdeel van een te vormen Antilliaanse federatic, die een onathankejijke staat zal zijn. Van de 37.346 stemgerechtigdenverklaarden niet minder dan $21.418(82 \%)$ zich voor de onathankelijkheid van Aruba en 1085 kiezers $(4,51$ \%) stemde voor de federatie, dus voor het behoud van de band met de overige 
federatie zou inhouden werd overigens niet verder gespecificeerd. De Nederlandse minister voor Antilliaanse Zaken De Gaay Fortman bleef op het standpunt staan dat de Nederlandse Antillen alleen een toekomst hadden als ze alle zes bij elkaar bleven. ${ }^{52}$

Bij de op 17 juni 1977 gehouden Statenverkiezingen boekte de MEP ten opzichte van 1973 geen winst, omdat na een intern conflict, de Rubianonan Uni pa Bienestar di Aruba (RUBA) als afsplitsing van de MEP was opgericht. Dit was de afsplitsing geleid door Rancho ${ }^{53}$ politicus Vos en twee allochtone politici Richardson en Gomez. ${ }^{34}$ Het is vanuit de Arubaanse visie begrijpelijk dat de MEP zich afsplitste van de AVP, omdat de jongere generatie geen ruimte kreeg voor haar denkbeelden binnen de partij. Vanwege interne concurrentie gebeurde dat ook met de afsplitsing van de RUBA van de MEP. ${ }^{55}$

De MEP behaalde in 1977 weer 5 van de 8 Statenzetels. De overige drie gingen naar de PPA. Op Curaçao werden de Statenzetels over de drie partijen DP, NVP-U en Frente verdeeld, die respectievelijk zes, drie en drie zetels kregen. De grootste partij, de $\mathrm{DP}^{56}$ had al

eilanden van de Nederlandse Antillen, 3669 kiezers brachten een ongeldige stem uit en 11.222 kiezers maakten geen gebruik van hun stemrecht. ISS-Rapport (1978) p. 14; Verton (1978A), pp. 771-778, m.n. 775 e.v.; Van Gameren p. 121.

33 Rancho is een wijk in Oranjestad, gelegen achter het gebouw van de Dienst Openbare Werken (DOW) en strekt zich uit van de omgeving bij de Paardebaaistraat tot achter de Weststraat. Op die plaats werden in de koloniale tijd paarden, schapen en geiten gefokt voor het gouvemement.

s4 Reforma, pa progreso di nos Isla, Organo di Reformistanan Uni pa Bienestar di Aruba, funda dia 13 di Maart 1977', verkiezingsprogramma 1977. Uit het programma blijkt dat de RUBA sociaal-democratische beginselen aanhing, die in hoofdlijnen overeenkwamen met de MEP. Met name de gelijkheid van alle burgers wordt benadrukt. Overheidsdictatuur wordt niet geduld. Voor wat betreft de staatkundige structuur wilde de RUBA de banden met Nederland aanhouden. Als het niet anders kan is de RUBA voor een ona fhankelijk Aruba, maar wel na een adequate voorbereidingsperiode.

ss In 1993 richtte de zoon van Betico Croes, Glenbert Croes de Organisacion Liberal Arubiano (OLA) op, omdat hij geen leidende rol kon vervullen binnen de MEP.

s6 Nota van de Democratische partij, met betrekking tot de overgangsperiode naar de ona fhankelijkheid, 11 februari 1980. De DP ging in haar nota uit van het zelfbestuur en de gelijkwaardigheid van elk der eilanden. Alle eilanden zouden in één staatsverband bij elkaar moeten blijven. Ook was de DP van mening dat de bestaande zetelverdeling nimmer had geleid tot 'overruling' van een eiland door een ander eiland. De PSD was die laatste mening ook toegedaan en stelde in haar nota ten aanzien van de discussienota Janus "een overgangsperiode voor de Nederlandse Antillen" van februari 1980, dat de zogenaamde overmacht van Curaçao in de Staten te maken had met 'het willen zien van spoken'. "De Curaçaose Statenleden hebben nimmer zonder leden woonachtig in een der andere Eilandgebiedenquorum gevormd, zij hebben nimmer een parlementaire meerderheid gevormd waarop een Regering kon steunen en zij hebben nimmer zonder hulp van Statenleden uil de overige 
laten weten dat zij onder geen enkele voorwaarde mee wilde werken aan een desintegratie van de Nederlandse Antillen. ${ }^{57}$

De Gouverneur zou op basis van de verkiezingsuitslagen Betico Croes tot (in)formateur van een kabinet hebben kunnen benoemen. Zijn partij had $62,5 \%$ van de voor Aruba haalbare zetels verworven. De zittende premier S.G.M.(Boy) Rozendal van de DP werd echter benoemd om politieke redenen, daar de centrale regering de MEP niet meer als regeringspartner wenste. In de zomer van 1977 sloten DP, NVP-U en PPA, alle drie voorstanders van een federatie tussen de Antilliaanse eilanden, een regeringscoalitie. Omdat de MEP aangaf dat Aruba uiterlijk in maart 1981 uit het Antilliaans verband te willen treden wenste formateur Rozendal de MEP niet in de coalitie op te nemen. De MEP zou pas in het interim-kabnet Pourier weer terugkeren in de Staten, samen met de PPA en de AVP. ${ }^{58}$

Betico Croes, zeer ontstemd door het weren van zijn partij uit de centrale regering, riep de Arubaanse bevolking op, zich te verzetten tegen het onrecht dat Aruba werd aangedaan. Croes beklaagde zich over de keuze van de formateur bij de Nederlandse regering. De Eilandsraad vroeg op grond van art. 26 ERNA een gesprek aan met de Nederlandse regering. ${ }^{59}$ Minister De Gaay Fortman liet echter weten dat Nederland bij het eenmaal ingenomen standpunt bleef en dat over wijziging van de Staatsregeling uitsluitend zou worden gesproken tussen de regeringen van Nederland en de Nederlandse Antillen. De Gaay Fortman verklaarde verder dat het benoemen van de formateur het prerogatief van de Gouverneur is als landsorgaan en niet als koninkrijksorgaan, het ging hier immers om zuiver interne aangelegenheden van de Nederlandse Antillen. Tevens zou een onafhankelijkheidsverklaring van Aruba het stopzetten van de ontwik-

eilanden besluiten tot stand gebracht." Kennelijk was Janus onder de indruk geraakt van het geweeklaag van Arubaanse zijde over de Curaçaose meerderheidspositie en had zwaar geleund op het rapport Jeukens en op het model-Kapteyn, meende de PD. De PSD zag niets in een pariteit tussen Aruba en Curaçao tijdens de overgangsfase. J.A.B. Janus had als deskundige toegevoegd aan de Nederlandse sectie van de KWG een discussienota uitgebracht over de eventuele inlassing van een overgangsperiode van de Nederlandse Antillen naar de post-statutaire situatie. Deze nota werd behandeld op de vierde plenaire vergadering van de KWG van 7 t/m 11 januari 1980 op Aruba. Rapport KWG (1980) p. 12. Ook de discussienota van de Juridische werkgroep over een samenwerking tussen de eilanden "het model Kapteyn", dat werd omschreven als "een mini-EG" kon geen genade vinden in de ogen van de Antilliaanse politici. Zie nota Kapteyn, 14 februari 1979 en Amigoe, 11 februari 1980.

Reinders (1993) p. 137.

59 Artikel 26 ERNA luidt: 'De eilandsraad is bevoegd de belangen van het eilandgebied voor te staan bij de Koning, bij de Staten-Generaal, bij de Gouverneur en bij de Staten"; Van Wehry (1988) p. 155. 
kelingsbijdragen tot gevolg hebben.

Op grond van de bestaande staatkundige structuur waren de politieke elites op Curaçao in staat een politieke groepering van Aruba, die meer aanhangers op de been had gebracht, dan welke andere partij tevoren, volkomen te negeren. Dat de PPA als eilandelijke minderheidspartij aan de Landsregering deelnam, leidde op Aruba tot grote beroering. ${ }^{60}$ De MEP werd niet in de regeringscoalitie opgenomen, maar de PPA wel. Alle drie de partijen waren voorstander van de federatie-gedachte. In de regeringsverklaring stelde de nieuwe Landsregering een herziening van de staatkundige structuur voor, met een Unie van de Nederlandse Antillen als centraal samenwerkingsorgaan van zes gelijkwaardige eilanden. In feite behelsden deze voorstellen een herhaling van het Curaçaose model van federatievorming. ${ }^{61}$ De Curaçaose politieke eliten waren dan ook niet geneigd om in gesprek te treden met de Arubaanse afscheidingspartners.

De uitvoering van het dekolonisatiestreven van de Nederlandse regering vond sinds de jaren vijftig plaats door overleg met de centrale (Lands)regering. Den Haag wilde zelfbestuur toekennen aan de hele kolonie als Aruba de afscheidingseis zou laten vallen. Den Haag sprak dus met de Landsregering en niet met politici op eilandsniveau. De MEP-voormannen ervoeren dat toen ze na december 1975 geen deel meer uitmaakten van de Landsregering. Nederland wilde wel meewerken aan een staatkundige herstructurering en stelde daartoe de staatrechtsgeleerde Jeukens ter beschikking van de Antilliaanse regering. Jeukens werkte een decentralisatie volgens 'Curaçaos' model uit. De Arubaanse afscheidingsleiders verwierpen de voorstellen van Jeukens omdat ze waren gebaseerd op de door hen steeds verworpen uitgangspunten.

Den Haag was noch na het Arubaanse referendum, noch na de herhaalde MEP meerderheid bij de Statenverkiezingen van juni 1977 bereid het Arubaanse afscheidingsstreven als een verschijnsel te beschouwen waaraan politieke consequenties moesten worden verbonden. Dat veranderde in augustus 1977. Aruba greep toen naar een machtig wapen: internationale publiciteit.

Op 10 augustus 1977 werd onder de leiding van Betico Croes een demonstratieve optocht gehouden. Nadat twee vakbondsleiders wegens opruiïng tegen PPA-leiders in voorlopige hechtenis waren genomen, werden door de MEP solidariteitsbetogingen georganiseerd en vonden stakingen plaats. Op 11 augustus 1977 trof een algemene staking het 
hele eiland, politie en stakers raakten slaags en de situatie escaleerde, de telefoon- en telexverbindingen met de buitenwereld werden verbroken en de luchthaven werd gesloten voor alle verkeer. Door de stakingen stagneerden de electriciteitsvoorzieningen. Amerikaanse toeristen, ontriefd door het uitvallen van de airco's, konden het eiland niet verlaten. Onder de gevangen genomen vakbondleiders bevond zich de voorzitter van de Independent Oil Union Workers of Aruba (IOUWA), de vakbond van de Lago arbeiders. De grootste vakbond van Aruba, de Federacion di Trahadornan di Aruba (FTA), hield zich afzijdig, omdat deze organisatie de samenstelling van de Landsregering geen kwestie vond, waarmee een vakbond zich diende in te laten.

Er werd een aanslag gepleegd op de auto van het van de PPA afgescheiden Statenlid G. Guilermo Trinidad (door wie is nooit vastgesteld). De MEP reageerde op de aanslag met solidariteitsbetogingen, er braken stakingen uit, schepen uit Curaçao werden niet meer gelost. De MEP kondigde ook een boycot af van op Curaçao geproduceerde produkten. Vanwege de ongeregeldheden, zag de centrale regering zich genoodzaakt oproerpolitie naar Aruba te sturen.

Paula $^{62}$ merkte op dat de gemoederen onder de Arubaanse bevolking mogelijk verder verhit raakten door de politieversterking, die tot grote ergernis van de Arubanen van Curaçao werd uitgezonden. Zwaar bewapende politieversterkingen marcheerden als bezetters door het centrum van Oranjestad. Nadat een jeep, waarin een neef van Betico Croes zat, werd beschoten en deze aan zijn been werd gewond, nam de animositeit tegen de Curaçaose politie sterk toe. Deze houding van Aruba werd op Curaçao weer bijzonder kwalijk genomen. Op Aruba en ook in Den Haag beseften beleidsmakers toen dat de volgende fase uit gewapende strijd zou bestaan. De verhouding tussen Curaçao en Aruba verslechterde verder. Het lot van de 'Antillen van de zes' leek hiermee bezegeld. Veel later zou Betico Croes onthullen dat er in augustus 1977 brieven waren gestuurd naar Cuba, de Verenigde Staten, Columbia en Venezuela met een verzoek om hulp voor de Arubaanse strijd, omdat Nederland geen aandacht wilde schenken aan de gerechtvaardigde verlangens van Aruba.

Het Tweede Kamerlid H.A.A. Molleman, die in augustus 1977 op Aruba verbleef drong er na terugkomst in Nederland bij de Nederlandse regering op aan om rechtstreeks met Aruba te praten, voordat er 'gekke dingen' zouden gebeuren. Blijkbaar veranderde zijn kijk op de situatie de houding van de Nederlandse regering. 
In september 1977 werd als gevolg van een hernieuwd beroep van de Eilandsraad van Aruba op art. 26 ERNA in Den Haag overleg gevoerd tussen vertegenwoordigers van de Koninkrijksregering en de Eilandsraad van Aruba over de wens van het Arubaanse volk het zelfbeschikkingsrecht te verwezenlijken en op grond daarvan de onafhankelijkheid voor te bereiden. Ook kwam het waarborgen van de fundamentele rechten zoals vastgelegd in art. 43 van het Statuut aan de orde. ${ }^{63}$ Schoorvoetend kwam er verandering in de houding van de Nederlandse regering. Het Arubaanse streven werd serieus genomen.

Daarna volgde op 19 en 20 april 1978 in Willemstad voortgezet overleg tussen de Koninkrijksregering, de regering van de Nederlandse Antillen en de Eilandsraad van Aruba. Dit overleg leidde tot het Protocol van Willemstad van 20 april 1978. Daarin werd vastgelegd dat de Antilliaanse regering de uitwerking van de voorgenomen decentralisatie en herstructureringsplannen van de Nederlandse Antillen voortvarend ter hand zou nemen. Eveneens zou een Koninkrijkswerkgroep (KWG) worden ingesteld. Op 1 november 1978 werd overeenstemming bereikt over de samenstelling van de KWG. De KWG onder voorzitterschap van B.W. Biesheuvel, werd in december 1978 ingesteld. Deze moest een inventarisatie maken van de mogelijke samenwerkingsvormen tussen Aruba, de Nederlandse Antillen en Nederland. De KWG werd ingesteld om een oplossing te vinden voor de staatkundige problemen van Aruba. De wederzijdse besprekingen leidden tot een verandering in de Nederlandse opvatting over het Arubaanse afscheidingsstreven. De volgende besluiten werden genomen:

1. de regering van de Nederlandse Antillen zal een intereilandelijk overleg entameren over decentralisatie en herstructureringsplannen (het zogenaamde Antilliaans Spoor);

2. de Koninkrijksregering zal een werkgroep instellen, die de mogelijke relaties tussen de Nederlandse Antillen, de eilanden van de Nederlandse Antillen en Nederland zal inventariseren (het zogenaamde Koninkrijksspoor);

3. Aruba zal constructief aan dit overleg deelnemen. ${ }^{64}$

63 Paula (1989) p. 75 e.v.

s4 Het Protocol van Willemstad van 20 april 1978, in: Rapport van de Koninkrijkswerkgroep (1980) p. 165 e.v. De Koninkrijkswerkgroep werd opgericht bij KB van 2 december 1978, 75, Zie ook Besluit houdende instelling van een werkgroep ter inventarisatie en onderzoek van mogelijke relaties tussen de Nederlandse Antillen, de eilanden van de Nederlandse Antillen en Nederland en de Nota van Toelichting op dit KB; zie ook Bijlage B, pp. 167-170. 
In 1978 werd niet alleen besloten tot de instelling van de Koninkrijkswerkgroep, maar ook tot de instelling van een Antilliaanse werkgroep, het zogenaamde Antilliaans Spoor. Het Antilliaans Spoor, stond onder het voorzitterschap van de minister van Staatkundige Structuur van de Nederlandse Antillen en was samengesteld uit politici van alle eilanden. De Antilliaanse werkgroep hield zich bezig met de problematiek van decentralisatie en herstructurering. Daarnaast was er in Aruba de Raadscommissie Onafhankelijkheid Aruba, waarin zitting hadden de raadsleden en vertegenwoordigers van de geestelijkheid handel en vakbonden. Minister Van der Stee verklaarde na de besprekingen, dat Nederland was afgestapt van het tot dan toe geldende standpunt dat de kwestie van de onafhankelijkheid van Aruba, een interne Antilliaanse aangelegenheid was. Het was een Koninkrijksaangelegenheid geworden. ${ }^{65}$ In het kader van de doorbraak, bereikt tijdens de besprekingen van september 1977, werd het eerste onafhankelijke onderzoek naar de levensvatbaarheid van een gescheiden dekolonisatie van Aruba uitgevoerd, door medewerkers van het Institute of Social Studies (ISS). De onderzoekers kwamen tot de conclusie dat Aruba's onafhankelijkheidsstreven ten opzichte van Curaçao tenminste 'begrijpelijk' was en dat een gescheiden dekolonisatie niet onmogelijk was. De onderzoekers constateerden dat de roep om volledige onafhankelijkheid slechts een middel was om te worden gehoord. Aruba wilde liever los van Curaçao dan onafhankelijk worden van Nederland. ${ }^{66}$ Het ISS-rapport bevatte de conclusies van een onderzoek naar het afscheidingsstreven van Aruba en de mogelijke gevolgen daarvan op staatkundig gebied.

"Wanneer we de ontwikkeling van de standpunten van met name de MEP - van federatie via status aparte en gemenebest tot onafhankelijkheid - nader bezien blijkt het steeds te gaan om het verkrijgen van waarborgen voor bestuurlijke zelfstandigheid. In een federatie, waar

Tweede Kamer, 17 mei 1978, beleidsdebat Nederlandse Antillen, pp. 2389-2431. Mito Croes (AVP) werd geciteerd in een artikel uit de Beurs- en Nieuwsberichten van 10 april 1978 waarin hij commentaar gaf op het ISS rapport: 'We hebben hier weer een rapport over onze interne staatkundige structuur, opgesteld door buitenlandse deskundigen, die even langs zijn geweest'. De PPR vertegenwoordiger merkte op: 'Wij hebbengeen hasst. Wat ons betreft krijgen de Antillen hun onafhankelijkheid noch per telegram, noch per luchtpost'. Tweede Kamer-lid H. Waltmans was geen voorstandervoor een status aparte voor een der eilanden, daar zodoende de kolonisatie zou worden voortgezet tot in de eenentwintigste eeuw (pp. 2394 en 2395). In het algemeen waren de Kamerleden toch nog van mening, dat onafhankelijkheid voor de Nederlandse Antillen de meest aangewezen weg was. De ongelukkige uitlating 'onafhankelijkheid desnoods per luchtpost', was van drs. Franssen, ISS-rapport (1978) p. 24; Paula (1989) pp. 75-78. 
de bestuursvorming en de samenstelling van bestuurlijke organen ten dele berust op het 'one man one vote' beginsel, is een dergelijke waarborg niet te vinden. Wanneer 'status aparte' voor Nederland niet aanvaardbaar blijft, lijkt dan uitsluitend 'onafhankelijkheid' over te blijven. Maar die onafhankelijkheid wordt dan meteen weer geclausuleerd, omdat naar behoud van speciale banden wordt gestreefd, o.a. op het gebied van de rechtspraak, nationaliteit, defensie, de buitenlandse betrekkingen en eventueel zelfs het staatshoofd."

Het rapport adviseerde dat een volkenrechtelijke constructie niet op een 'one man one vote' beginsel hoefde te berusten. Het was zeker mogelijk een 'supranationale' staatkundige structuur te ontwerpen waarbij de Antillen é́n staat in volkenrechtelijke zin vormden en waarin waterdichte garanties voor bestuurlijke zelfstandigheid voor Aruba zouden zijn opgenomen. Het model van de Europese Gemeenschap, misschien aangevuld met enige elementen uit de Zwitserse staatsstructuur, zou daarbij als voorbeeld kunnen dienen. Bovendien zou een recht op afscheiding kunnen worden opgenomen. ${ }^{67} \mathrm{De}$ volgende conclusies werden in het rapport getrokken:

1. Een eenzijdige onafhankelijkheidsverklaring van Aruba zou in vele opzichten grote schade aan de Arubaanse economie berokkenen. Gedacht kon worden aan de onderhandelingen met Venezuela over de olieraffinaderijen, het opdrogen van de Nederlandse hulp, de te verwachten moeilijkheden door gebrek aan erkenning, waarbij de meeste landen zullen afwachten hoe Nederland zal reageren. Ook zou interventie van andere landen kunnen worden uitgelokt. ${ }^{68}$

2. Onafhankelijkheid, na onderhandelingen binnen het Koninkrijk, zou ook niet zonder pijn en moeite kunnen worden gerealiseerd. Dit alternatief zou vooral betekenis hebben voor de economische politiek met name betreffende invoerrechten, het vestigingsbeleid voor bedrijven; voor het toelatingsbeleid van vreemdelingen; voor justitie en politie en voor enkele aspecten van de buitenlandse betrekkingen.

II ISS-Rapport (1978) pp. 28 e.v. en 83-87.

6. Curaçao en Aruba waren van strategisch belang voor de aanvoer van olieprodukten van en naar Amerika. De eilanden zijn verder ook voor Venezuela van belang omdat ze op de vaarroute liggen van de grote Venezolaanse olietankers. Bovendien liggen de Nederlandse Antillen en Aruba in 'de achtertuin van de Verenigde Staten'. De Nederlandse Antillen en Aruba zijn voor Amerika van strategisch belang in de natuurlijke verdedigingsgordel van het Panamakanaal. Amerika wenst in deze gebieden daarom een stabiel politick klimaat en zou zeker ingrijpen, indien daartoe aanleiding zou bestaan. 
In juni 1978 bezocht een parlementaire delegatie de Nederlandse Antillen. Haya van Someren ${ }^{69}$, senator voor de VVD en een van de delegatieleden, trok uit dit bezoek een aantal conclusies. Zij constateerde dat de Arubaanse opvatting over een onafhankelijkheid 'sui generis' het volgende inhield:

"Achter dit Latijn verschuilt zich het volgende onafhankelijkheidsmodel: de Arubanen behouden een Nederlands paspoort, de Nederlandse cassatierechtspraak, Nederlandse externe defensie, via Nederland een affiliatie met de EG, een Nederlands paspoort en ten slotte ontwikkelingssamenwerking. Wat voor iedere Arubaan volstrekt vaststaat is dat men los wil van Curaçao, dat men primair als de boze kolonisator ziet. Op de drie Bovenwindse eilanden bestaat eenzelfde vrees voor Curaçao als op Aruba. Op de door de Nederlandse delegatie gehouden hoorzittingen werd duidelijk, dat men ten eerste geen vertrouwen heeft in de plaatselijke bestuurders, dat men die zelfs vreest, ten tweede dat de haat ten opzichte van Curaçao zeker zo groot is als op Aruba. Er werd dringend gevraagd bij 'Holland' te mogen blijven onder de 'Queen'. Een zanger zong: 'Independency what a hell would that be'."

Van Someren concludeerde dat de Nederlandse Antillen onmogelijk onafhankelijk konden worden in de bestaande vorm, zij konden niet worden ondergebracht in een federatie, laat staan in een eenheidsstaat. Wel was Van Someren van mening dat met voortvarendheid een ontwikkelingsproces zou moeten worden ingezet om de Nederlandse Antillen op eigen benen te laten staan. Over elk model viel te praten. $\mathrm{Zij}$ gaf drie redenen aan waarom de besprekingen tussen Nederland en de Nederlandse Antillen vaak zo moeizaam verliepen.

"Ten eerste is er een verschil tussen het Nederlandse denken en handelen en het Latijns-Amerikaanse denken en handelen in de Nederlandse Antillen. Ten tweede wordt het West-Europese begrip onafhankelijkheid te strikt gehanteerd. Ten slotte bestaat er onvoldoende begrip in Nederiand voor het verleden en heden in het Caribisch gebied, waar de machtigen uit het verleden (en heden) Engeland, Frankrijk, de VS en Nederland namaak-culturen tot stand brachten die de aanwezige cultuur van het Caribisch eigene gesmoord hebben." 
Zij benadrukte nog eens het standpunt dat door Röling en Meijers ${ }^{\text {To }}$ naar voren werd gebracht. Als Aruba los wil van Curaçao zou dit moeten gebeuren vóór het moment waarop de Antillen onafhankelijk worden van Nederland. Daarna is volgens Meijers afscheiding vrijwel onmogelijk. De eilanden hebben weliswaar een recht op zelfbeschikking. Maar dit gaat volgens het volkenrecht verloren op het tijdstip dat de Antillen als geheel onafhankelijk zijn geworden. De Verenigde Naties hebben zich op het standpunt gesteld dat de eenheid van onafhankelijk geworden ex-kolonies moet worden gehandhaafd. Er zouden anders over de hele wereld verzoeken van minderheden om erkenning van het zelfbeschikkingsrecht komen. In zulke problemen zou de VN zich niet willen storten, meende Meijers. ${ }^{71}$

Amigoe, 10 september 1980. Tevens meenden Röling en Meijers, twee vooraanstaande Nederlandse volkenrecht-geleerden, dat ook Nederland het zelfbeschikkingsrecht heeff. Op grond daarvan kan de ona fhankelijkheidde Antillen worden opgelegd. $E_{r}$ is geen volkenrechtelijke regel die dat verbiedt. Als Nederland zich van Texel wil ontdoen, kan niemand dat met een beroep op het volkenrecht belemmeren. Hetzelfde geldt voor de Antillen, die nu eveneens nog deel uitmaken van het Koninkrijk der Nederlanden. Beide hoogleraren meenden dat het opleggen van de onathankelijkheid geen schending van het zelfbeschikkingsrecht is. Het zou echter wel een unicum zijn als Nederland de onafhankelijkheid zou opleggen. In de geschiedenis zijn geen voorbeelden te vinden van een moederland dat een ex-kolonie tegen de zin van de bevolking onafhankelijk verklaarde. Moreel achtten zij het niet juist als Nederland een dergelijke maatregel zou treffen. Juridisch kan het wel.

Voor een heldere uiteenzetting over de interpretatie van het recht op zelfbeschikking door de Nederlandse regering en het parlement zie Kuyper en Kapteyn in: International law in the Netherlands (1980) pp. 213-218. Kuyper en Kapteyn laten zich niet uit over het zelfbeschikkingsrecht van Nederland. Van der Grinten (1986) hangt eveneens de opvatting aan dat Nederland het zelfbeschikkingsrecht heefl en de band met de Nederlandse Antillen of Aruba kan verbreken als deze landen geen orde op zaken weten te stellen, als het Openbaar Ministerie en de politie onder partijpolitieke invloed zouden komen, of als de Nederlandse Antillen en Aruba onvoldoende openstaan voor de Nederlandse cultuur en taal en discrimineren ten opzichte van Europese Nederlanders, pp. 236-238. 
Op 30 augustus 1980 werd het eindrapport van de $\mathrm{KWG}^{\text {T3 }}$ aan de Landsregeringen en de besturen van de Eilandgebieden aangeboden. In het eindrapport werd het zelfbeschikkingsrecht van de eilanden gedefineerd als "het recht van de bevolking van elk eiland om zelf zijn politieke toekomst te bepalen'. ${ }^{74}$

"In zijn algemeenheid is het recht tot zelfbeschikking een afgeleide van her beginsel van de volksouvereiniteit. Naties en burgers van naties hebben het recht om over hun eigen politieke status te beslissen (vgl. art. 55 Handvest der Verenigde Naties). Op 19 december 1947 stelden de Staten der Nederlandse Antillen een opdracht vast voor de delegatie der Nederlandse Antillen naar de Ronde Tafelconferentie, inhoudende dat 'het een natuurlijk recht van de bevolkingen dezer eilanden is om uit het staatsrechtelijk verband te treden'. Op 19 december 1973 hebben de Staten der Nederlandse Antillen verklaard dat 'het een onvervreemdbaar recht van iedere volksgemeenschap is, en derhalve van elk der eilanden van de Nederlandse Antillen, om de eigen staatkundige toekomst te bepalen'. " "75

Deze verklaring werd herhaald in een motie van de Staten van de Nederlandse Antillen van 12 september 1975. In september 1978 werd door de Tweede Kamer der Staten-Generaal bij de behandeling van de Mensenrechtenverdragen van New York 1966 een motie aangenomen, waarin tot uitdrukking werd gebracht dat de samenstellende

In de Koninkrijkswerkgroep hadden 26 personen zitting: de voorzitter was mr. B.W. Biesheuvel benevens de leden aangewezen door de Nederlandse regering: mr. G.W. van Barneveld Kooy, drs. J.Ph. Elzerman, mr. H. Gritter, mr. P.J.G. Kapteyn, A.C. Lamers, gen.maj.b.d., drs. J. Weitenberg. De regering van de Nederlandse Antillen had de volgende leden aangewezen; C. Gomes Casseres, B.A. M.A., mr. N.E. Henriquez, mr. T.M. Monzón, A.J. Muyale, dr. R.A. Römer, U.L. Schotborg. Het Eilandgebied Aruba wees de volgende leden asn: G.F. Croes, mr. J.H.A. Eman, N.O. Oduber, E.J. Vos. Het Eilandgebied Bonaire wees als lid aan: mr. G.A. Soliana. Het Eilandgebied Curaçao vaardigde af: J.A.O. Bikker, R. Elhage, drs. E.N. Kleinmoedig, W.S.S.D. Lourens, G. de Paula. Door de drie afdelingen van het Eilandgebied de Bovenwindse eilanden werden de volgende leden afgevaardigd: afdeling Saba: W.E. Johnson; afdeling Sint Eustatius: R.A. Berkel; afdeling Sint Maarten: mr. ing. E. Voges. Als adviseurs die als waamemers de vergadering bijwoonden werden benoemd: mr. B.H. Adamen mr. P.D.O. Denz. Tenslotle hebben onder meer de volgende deskundigen assistentie verleend: M.R. Croes R.A., mr. J.A.B. Janus, mr. C.J.G. Olde Kater, mr. C.I. Plantz, drs. A. Russchen en N. de Waard, kol.b.d., Rapport van de Koninkrijkswerkgroep (1980). Rapport van de Koninkrijkswerkgroep, Naar nieuwe vormen van samenwerking, ingestled bij KB van 2 december 1978, nr. 75 (1980). Rapport van de Koninkrijkswerkgroep (1980) p. 16.

75 a.w. p. 45. 
delen van het Koninkrijk na gemeen overleg een soevereine beslissing kunnen nemen ten aanzien van de staatkundige structuur. ${ }^{76}$ Het was duidelijk dat de deskundigen het zelfbeschikkingsrecht zagen als de keuze van de verschillende eilanden om hun eigen weg te volgen naar de onafhankelijkheid. Er was toen nog geen sprake van de mogelijkheid dat de Nederlandse Antillen binnen het Koninkrijk zouden blijven in een mogelijk andere vorm dan de bestaande. ${ }^{\pi}$ Merkwaardig was

a.w. p. 46; zie ook Crawford (1979) pp. 370-377. In september 1978 boekte Betico Croes in de Tweede Kamer een belangrijke winst. Door middel van een Kamerbreed ondersteunde motie legde de Tweede Kamer vast dat alle mogelijkheden betreffende de staatkundige toekomst voor de Nederlandse Antillen open stonden, tot de onathankelijkheid van Aruba toe. Croes was naar Nederland gereisd om anwezig te zijn bij de debatten over de goedkeuring van de VN verdragen over politieke en burgerlijke rechten. Door de aangenomen motie Roethof stond vast dat de aanvaarding van de VN verdragen door niemand kon worden uitgelegd als een uitspraak dat de zes eilanden van de Nederlandse Antillen in de vorm waarin ze sinds de totstandkoming van het Statuut in 1954 samenwerkten, tegen elke prijs in stand zou moeten blijven. Het VN-verdrag stond noch een staatsrechtelijke regeling, noch een volkenrechtelijke in de weg. Deze motie was belangwekkend, omdat de hele Tweede Kamer eigenlijk vond dat de Antilliaanse eenheid behouden moest blijven. Dat makte het Nederlands beleid ook zo oninzichtelijk, omdat de Nederlandse politiek zowel steun had betuigd aan het Arubaanse afscheidingsstreven als aan premier Rozendal die de eenheid van de Antillen wilde bewaren. $\mathrm{Na}$ de motie zou de Nederlandse politiek een eenduidig standpunt moeten innemen, aldus PPR Kamerlid Waltmans. Een motie van Croes die vroeg om erkenning van het Arubaanse zelfbeschikkingsrecht moest hij weer intrekken. De hete hangijzers lagen nu bij de in te stellen Koninkrijkscommissie, die een jaar de tijd zou krijgen om de problematiek te bestuderen en een eindrapport uit te brengen. Amigoe, 6 oktober 1978.

Conferentie van de Nederlandse Antillen, de eilanden van de Nederlandse Antillen en Nederland, stenografisch verslag. De problemen over de interpretatie van het zelfbeschikkingsrecht bleken ook op RTC gehouden van maandag $16 \mathrm{t} / \mathrm{m}$ woensdag 25 februari 1981 in Den Haag, pp. 17-32. Algemeen aanvaard is zeker dat zelfbeschikking ook kan inhouden het kiezen van een andere status dan onathankelijkheid. Het begrip volk is moeilijk af te bakenen. Dat geldt niet alleen voor het Arubaanse volk, dat zich wil afscheiden van de Nederlandse Antillen, mar ook voor afscheidingsbewegingen zoals die van de Koerden, Ibo's en de Basken. Over het algemeen wordt ervan uitgegaan dat voormalige kolonies binnen hun koloniale grenzen als geheel onathankelijk worden. Dit was de mening van Kleinmoedig van de Curaçaose delegatie. Betico Croes ontkende deze stelling en was van mening dat het recht van alle eilanden op zelfbeschikking was erkend door de KWG. Elstak (p. 21) gaf aan dat onder het interne zelfbeschikkingsrecht wordt verstaan het recht van een staat om, als een geconstitueerde natie een eigen regeringsvorm te kiezen. Onder het externe zelfbeschikkingsrecht wordt verstaan het recht van een volk on zijn eigen status in de wereldgemeenschap te bepalen. Dit kan geschieden in de vorm van ona fhankelijkheid, associatie of integratie. Volgens Kapteyn (pp. 24 en 25) zouden de Antillen in 1954 al een keer het zelfbeschikkingsrecht hebben uitgeoefend. De Kleinmoedig meende vervolgens dat ook Nederland het zelfbeschikkingsrecht heeft uitgeoefend, waarop Kapteynzei dat Nederland dat al deed in 1579. Het was duidelijk dat de delegaties het eens waren over de conclusic dat elk eiland het recht van zelfbeschikking heeft, maar wanneer dat 'verbruikt' is wordt niet aangegeven. Voor de recente Arubaanse opvalting over het zelfbeschikkingsrecht: zie de uitgebreide uiteenzetting van A.G. Croes en R.R. Croes in de AVP-nota (1990). Deze nota stelde 
dat de Nederlandse regering eind 1978 bij de behandeling van het Verdrag van de Verenigde Naties over de politieke en burgerlijke rechten, verklaarde het zelfbeschikkingsrecht van Aruba niet te willen erkennen. Dat zou volgens de Nederlandse uitleg van de Dekolonisatieverklaring van de VN uit 1960 "de nationale eenheid ontwrichten." ${ }^{78}$ Zowel door minister Van der Stee als door de motie van de Tweede Kamer werd Aruba verzekerd dat de weg naar de onafhankelijkheid niet was afgesloten.

Aruba en de Nederlandse Antillen zouden gefaseerd naar de onafhankelijkheid worden gevoerd, aldus het eindrapport van de KWG. Aruba mocht dat los van de Antillen doen, maar in een zo hecht mogelijk samenwerkingsverband met de Nederlandse Antillen op volkenrechtelijke basis en een soort Gemenebestrelatie met Nederland.

Het rapport van de Koninkrijkswerkgroep was als deskundigenrapport bedoeld, dat materiaal moest aandragen voor op een RTC te nemen politieke beslissingen. ${ }^{79}$ De Koninkrijkswerkgroep adviseerde de RTC het zelfbeschikkingsrecht van elk der eilanden uitdrukkelijk te erkennen. Wanneer de eilanden gezamenlijk of afzonderlijk zouden kiezen voor de onafhankelijkheid, zou van de Nederlandse kant steun moeten worden verleend voor het verkrijgen van volkenrechtelijke erkenning. Onder het zelfbeschikkingsrecht werd hier verstaan, het recht van de bevolking van elk eiland om zelf zijn politieke toekomst te bepalen. De Antilliaanse leden van de werkgroep stelden zich op het standpunt dat onafhankelijkheid niet behoefde te betekenen, dat de band met Nederland zou worden verbroken. De eilanden zagen de uitoefening van het zelfbeschikkingsrecht op de volgende manier:

- Aruba wenste onafhankelijkheid met een zo hecht mogelijk samenwerkingsverband op volkenrechtelijke basis met de andere eilanden en een soort Gemenebestrelatie met Nederland;

- Bonaire wenste in een zo hecht mogelijk staatsrechtelijk samenwerkingsverband te blijven met de Nederlandse Antillen en gaf

dat Aruba het zelfbeschikkingsrecht nog niet verbruikt heef, daar Aruba de 'Status Aparte' niet kon verkrijgen zonder onder Nederlandse druk toe te stemmen in onathankelijkheid, dus was er geen sprake van een vrije keuze (pp. 22-37). Paula (1989) p. 77.

79 Tijdens de eerste plenaire vergadering van de KWG werden drie werkgroepen uil haar midden ingesteld, één voor juridische onderwerpen, één voor financieeleconomische onderwerpen en één voor functionele onderwerpen. Voor de gevolgen van een mogelijk staatsrechtelijk Antilliaans federatief verband of een volkenrechtelijk Antilliaans samenwerkingsverband van de onathankelijke entiteiten: Curaçao, Aruba, Bonaire en de Bovenwinden, zie het Rapport van de studiegroep Juridische onderwerpen van juli 1979. 
de voorkeur aan het behouden van een staatsrechtelijke band met Nederland;

- Curaçao gaf de voorkeur aan de vorming van een bondsstaat van de zes eilanden;

- De Bovenwindse eilanden gaven de voorkeur aan het behouden van een staatsrechtelijke band met Nederland.

Hoe de overkoepelende samenwerking tussen de eilanden onderling zou moeten plaatsvinden werd niet concreet uitgewerkt. Wel zou dit moeten geschieden op basis van art. 88 derde lid, ${ }^{80}$ van de Staatsregeling van de Nederlandse Antillen. Evenmin vond concrete uitwerking plaats van de uiteindelijke samenwerkingsrelatie met Nederland. Wel werd uitgegaan van een speciale relatie met Nederland in de zin van ontwikkelingssamenwerking, culturele samenwerking, onderwijs, cassatierechtspraak, belangenbehartiging in het buitenland en bijstand inzake defensie, omdat Nederland bij onafhankelijkheid hier niet direct in wil voorzien. Deze samenwerking met Nederland zal tezijnertijd in een verdrag moeten worden uitgewerkt. Ook zouden veel meer landstaken moeten worden overgedragen aan de eilanden. In de eerste fase zouden de eilanden zelfstandiger gaan functioneren, het hoger toezicht van het landsbestuur op het eilandsbestuur zou worden afgeschaft. Er zou een Hof voor de rechtspraak worden ingesteld die over geschillen tussen de eilanden onderling en tussen de eilanden en het centraal bestuur zouden beslissen. Naast verdere decentralisatie onder een ongewijzigd Statuut moesten wijzigingen in de Staatsregeling en in de ERNA worden aangebracht. In de tweede fase zou een wijziging van het Statuut moeten plaatsvinden teneinde Aruba een aparte status te geven (vergelijkbaar met de positie van Suriname vóór de onafhankelijkheid) alsmede het totstandbrengen van een samenwerkingsverband tussen de entiteiten als beoogd in de eindsituatie.

Het hoger toezicht op wetgevende maatregelen op landsniveau en Koninkrijksniveau zou moeten worden vervangen door het voordragen van deze regelingen ter vernietiging aan het tijdens de overgangsperiode op te richten Constitutioneel Hof. ${ }^{81}$

* Artikel 88 derde lid van de Staatsregeling van de Nederlandse Antillen luidt: 'Niet tot de zorg van de eilandgebieden behoren de onderwerpen, waarvan de regeling ingevolge de Staatsregeling of ingevolge het Statuut voor het Koninkrijk bij Rijkswet of algemene maatregel van Rijksbestuur moet of kan geschieden. De Eilandenregeling bepaalt, welke onderwerpen voorts niet tot hun zorg behoren en kan de regeling van bepaalde onderwerpen, welke volgens deze Staatsregeling bij landsverordening behoren te geschieden, aan de eilandsverordening overlaten.'

s Rapport van de Koninkrijkswerkgroep (1980). 
Terwijl Aruba zoveel mogelijk bevoegdheden aan de eilandelijke instanties wilde doen toekomen, propageerde Curaçao de gezamenlijke aanpak van zoveel aangelegenheden als mogelijk was. Conform de inhoud die hij gaf aan het begrip de Nederlandse Antillen en zijn organen, ging Betico Croes ervan uit, dat er voor Aruba geen hoger gezag bestond dan de Eilandsraad. De Antilliaanse Staten dienden daaraan ondergeschikt te zijn. Als gevolg daarvan eiste de MEP-leider dat de 8 Arubaanse Statenleden reeds in 1983 door de Arubaanse Eilandsraad moesten worden gekozen, terwijl Curaçao en de kleinere eilanden de directe verkiezingen voor de Staten zouden handhaven. Deze getrapte verkiezingen voor de Staten in 1983 stelde de MEP in de KWG als voorwaarde om de voorgestelde overgangsfase van de Arubaanse onafhankelijkheid te aanvaarden. Reeds in de periode die vooraf ging aan de onafhankelijkheid, wenste Aruba tot uitdrukking te brengen dat niet de Staten maar de Eilandsraad voor Aruba het belangrijkste bestuursorgaan was. De Arubaanse Statendelegatie moest dan ook een weerspiegeling zijn van de samenstelling van de Arubaanse Eilandsraad. Zou aan de wensen van Aruba geen gehoor worden gegeven dan zou Aruba zich met de hulp van Nederland bilateraal onafhankelijk verklaren. Curaçao kreeg niet de benodigde steun van Nederland, die de Arubaanse eis zowel 'aanvaardbaar' als 'praktisch uitvoerbaar' achtte.

Het gemengde systeem van Statenverkiezingen werd door Nederland gezien als een technische zaak die de democratische spelregels geen geweld aandeed. Bovendien was het departement dat met constitutionele aangelegenheden was belast gevestigd op Aruba en zodoende in staat alles naar eigen hand te zetten. ${ }^{82}$

\section{Ronde Tafel Conferentie}

De RTC tussen de Nederlandse regering, de Antilliaanse regering en de Eilandgebieden van de Nederlandse Antillen, begon 16 februari 1981 in Den Haag. Het doel van de RTC was de toekomstige staatkundige structuur van de Antillen en de relatie met Nederland aan de orde te stellen. In tegenstelling tot de eerdere RTC's waren de hoofdrolspelers op de RTC van 1981, naast de Nederlandse delegatie, niet de centrale overheid van de Nederlandse Antillen, maar de eilandsbesturen. Op grond van de agenda van de RTC bleek reeds de grote invloed van Aruba op de gang van zaken: 
- decentralisatie, het zelfbeschikkingsrecht van de eilanden, de opsplitsing van de Bovenwinden in drie eilandgebieden, een nieuwe structuur voor ontwikkelingssamenwerking;

- een niet overeenstemmingsclausule, dit betekent dat elk eiland een bepaald gewicht in de schaal moet kunnen leggen, zodat het niet mogelijk is dat een meerderheid van één Eiland in de Staten wordt weggestemd over zaken die van vitaal belang zijn voor het eiland;

- de zetelverdeling in de Staten, de herziening van het kiesreglement, de technische wijziging van het Statuut, hoger administratief toezicht (het Land), gemengde Statenverkiezingen, synchronisatie van Staten- en Eilandraadsverkiezingen, de mogelijkheid tot ontbinding van de Eilandsraden;

- de instelling van een Constitutioneel Hof en de vormgeving van de noodzakelijke samenwerking tussen de eilanden. ${ }^{83}$

Reeds in een vroeg stadium van de besprekingen toonde Aruba zich verontrust over de Curaçaose plannen om geen beslissingen te nemen over de staatkundige herstructurering van de Antillen. De RTC van 1981 gaf Aruba niet de zekerheid, dat het omstreeks 1991 onafhankelijk zou worden. Aruba opteerde voor onafhankelijkheid in dat jaar, tenzij de Arubaanse bevolking te zijner tijd anders mocht beslissen. ${ }^{84}$ De RTC bleef er in meerderheid bij, dat pas over een jaar of tien over de Arubaanse onafhankelijkheid kon worden beslist. Premier Martina meende dat er grote onrust zou ontstaan op het eiland Curaçao, indien beslissingen zouden worden genomen zonder inspraak van de sociale groepen in de gemeenschap. Minister Van der Stee probeerde Aruba te overtuigen door te stellen, dat alle eilanden, gedurende een zekere overgangsperiode een eenheid zouden vormen. Wie tussentijds opstapte, hoefde volgens de bewindsman niet op Nederlandse steun te rekenen. Toch toonde Betico Croes zich tevreden. Immers voor het eerst werd formeel vastgelegd dat elk eiland het zelfbeschikkingsrecht had. Verder zegde hij toe dat het Bestuurscollege van Aruba een consultatief referendum zou houden, over de vraag, of Aruba in de tweede zitting van de RTC definitief accoord moest gaan met een overgangsperiode van 10 jaar.

3) Stenografisch verslag van de RTC, verslag van de eerste zitting van $16 \mathrm{~V} / \mathrm{m} 25$ februari 1981, p. 7.

- Stenografisch verslag van de eerste zitting van de RTC van maandag $16 \mathrm{t} / \mathrm{m}$ woensdag 25 februari 1981 , p. 158. 
De kwestie van de Arubaanse onafhankelijkheid bleek steeds opnieuw een terrein te zijn vol (onvoorziene) moeilijkheden. Bekend was bijvoorbeeld dat Venezuela de hele ontwikkeling met argusogen volgde en geen avonturen zou dulden aan eigen kust. Ook Nederland hechtte veel belang aan het intact blijven van het Antilliaans verband, uit angst later met de kleinere eilanden opgescheept te zitten, indien zij het niet zouden aandurven met Curaçao als onafhankelijke staat de toekomst in te gaan. Het Koninkrijk piekerde er dan ook niet over om Aruba een aparte status te geven, meldde minister Van der Stee ter RTC in 1981. Hij meende dat dit zou leiden tot soortgelijke eisen van de andere eilanden. ${ }^{85}$ De RTC verliep niet volgens plan. De oorspronkelijke bedoeling was dat na de eerste zitting een rustpauze van vijf weken zou worden ingelast, waarin de raadsleden voeling zouden kunnen houden met hun achterban. Er zou van 30 maart $t / m$ 3 april een tweede zitting volgen. Vanwege de gerezen meningsverschillen bleef de RTC beperkt tot de eerste zitting. ${ }^{86}$

Nederland wenste uitdrukkelijk vast te houden aan de koppeling van de realisatie van een Status Aparte binnen het Koninkrijk en een latere onafhankelijkheid van Aruba. In augustus 1981 vroeg de MEP van zijn coalitiepartners in de centrale regering; MAN, DP (Curaçao) en UPB, om de Staatsregeling van de Nederlandse Antillen als het ware opzij te schuiven voorzover het Aruba betrof daar Aruba alle zeggenschap wenste over de bodemrijkdommen rond Aruba. Bij de formatie van het kabinet Martina, na de verkiezingen in juli 1979 was afgesproken dat driekwart van de opbrengst aan het eiland toekwam waar olie werd gevonden en een kwart aan de centrale regering in Willemstad. De MEP wilde dat Aruba zelf de toestemming voor olieexploratie aan oliemaatschappijen zou geven, een eis waarmee het kabinet Martina niet accoord ging. Men kon het niet eens worden over het Petroleum Protocol, de drie MEP-ministers dienden daarop op 1 september 1981 hun ontslag in en de MEP Statenleden trokken hun steun aan het Kabinet Martina in. Het kwam op 1 september 1981 tot een breuk in de Nederlands-Antilliaanse coalitie. Het kabinet verloor de benodigde regeringsbasis. Op 3 september was een nieuwe coalitie gevormd, zonder Aruba. Het nieuwe kabinet wilde zo snel mogelijk helderheid verkrijgen over de toekomstige staatkundige ontwikkeling van de Nederlandse Antillen en met name de positie van Aruba daarin. Het kabinet drong dan ook bij Nederland op een spoedig te houden topoverleg.

Paula (1989) p. 79. 
Op 9 september 1981 aanvaardde de Arubaanse Eilandsraad een motie met de strekking om op grond van artikel 26 ERNA besprekingen te voeren en concrete afspraken te maken met de betrokken instanties over de realisering van de onafhankelijkheid van Aruba. Eind oktober 1981 vond in Den Haag het topoverleg plaats tussen Nederland, de Nederlandse Antillen en een delegatie van de Arubaanse Eilandsraad.

De Arubaanse delegatie onder aanvoering van Betico Croes bood de Koninkrijksregering een nota ${ }^{87}$ aan waarin gesproken werd van een onafhankelijk Aruba in een Gemenebestrelatie met Nederland. Van Nederland werd verwacht dat het waarborgen zou verstrekken op het gebied van defensie, steun voor aansluiting bij internationale organisaties, hulp bij het aangaan van buitenlandse betrekkingen, behoud van het cassatierechtspraak van de Hoge Raad der Nederlanden en hulp uit de ontwikkelingsfondsen. De mogelijkheid werd in dit verband nog opengelaten om de Nederlandse vorstin als symbolisch staatshoofd aan te houden. In dezelfde nota kwam ook de republikeinse staatsvorm ter sprake met aan het hoofd een Minister-President, die tevens staatshoofd zou zijn. Ook de mogelijkheid van een associatieverdrag werd besproken. ${ }^{88}$ Onder een Gemenebest 'sui generis' verstond

Arubasnse nots voor het overleg ex art. 26 ERNA met de regering van het Koninkrijk der Nederlanden alsmede voor het overleg met de Staten-Generaal, oktober 1981.

Tussen mei 1974 en juli 1981 kwamen de vertegenwoordigers van de eilanden tien keer bijeen om over de gewenste staatkundige structuur te spreken. Uit de eerste bijeenkomst kwamen vier mogelijke constructies naar voren: een eenheidsstaat, een gedecentraliseerde eenheidsstaat, een federale structuur en een volkenrechtelijke structuur, waaronder een constructie 'sui generis' (nota van H.S. Croes, juli 1981). Deze nota bevatte een decentralisatie-plan. Zie ook de nota's van H.S. Croes van oktober 1981 en 4 april 1982, 'Planmatige en gefaseerde verwezenlijking van de onafhankelijkheid van Aruba conform alternatief II uit de Arubaanse nota van oktober 1981'. In deze nota was de mogelijkheid van een associatie-overeenkomst van Aruba met het Koninkrijk verder uitgewerkt. De status van geassocieerd gebied met het Koninkrijk zou Aruba een beperkte internationale status moeten geven. Het geassocieerde gebied moest het recht hebben zonder inmenging van buiten zijn eigen interne rechtsorde te structureren. Bij de aanvang van de associatiefase zouden de Arubaanse constitutie, alsmede de daarop gebaseerde wettelijke regelingen in de plaats treden van de constitutionele regelingen van het Koninkrijk. In de associatie-overeenkomst van Aruba met het Koninkrijk zouden buitenlandse betrekkingen en defensie moeten worden geregeld. Aruba zou dan een onathankelijke staat in statu nascendi zijn. Zie ook Rapport van de Gemengde Commissie (1982) pp. 64-69. Over het algemeen ging de voorkeur van de leden van de Commissie, als voorbereiding op de onafhankelijkheidvan Aruba, uit naar een aparte status en niet naar een associatieovereenkomst. De leden Evertsz, Pourier en Voges wilden een korte periode een aparte status gedogen (p. 73). De geassocieerde staat moet niet worden verward met de aparte status van een land binnen een staatkundig verband. Bij een aparte status blijft een land onderdeel van het corspronkelijke staatsverband. Een geassocieerde staat daarentegen maakt geen deel uit van het vroegere staatsverband en heeft de status zoals bedoeld in resolutie 1541 van de Algemene Vergadering van de Verenig- 
Aruba:

"het creëren van banden tussen Aruba en het Koninkrijk der Neder-
landen, die zowel naar vorm als naar inhoud zodanig zijn dat de door
Aruba gewenste Gemenebest-constructie een inhoud zal hebben van
meer dan zuiver volkenrechtelijke aard."

Het overleg resulteerde in de oprichting van een Gemengde Commissie Toekomst Antillen. ${ }^{90}$ De Commissie moest een rapport samenstellen over de gevolgen die de Arubaanse onafhankelijkheid kon hebben voor de Nederlandse Antillen, voor Aruba zelf, voor de andere eilanden en voor de verhouding met Nederland. Dit rapport zou als basis dienen voor een te zijner tijd te houden RTC. De RTC zou pas worden gehouden als de Commissie haar rapport zou hebben uitgebracht. Nederland verzette zich niet langer tegen een Arubaanse onafhankelijkheid..$^{91}$

In de Tweede Kamer vielen opeens andere geluiden te beluisteren over de 'eenheid en ondeelbaarheid' van de Nederlandse Antillen. Van Zeil, vaste voorzitter van de Tweede Kamercommissie voor Antilliaanse Zaken, meende medio 1981 dat een Gemenebest sui generis mogelijk moest zijn. Hij dacht hierbij aan maximale zelfstandigheid voor de eilanden met een nauwe onderlinge samenwerking en eventuele eigen relaties met Nederland. Ook in socialistische kring vond men nu dat onafhankelijkheid niet tegen de wens van de Nederlands-Antilliaanse bevolking kon worden opgelegd.

In het overleg van de Gemengde Commissie, ook wel Commissie van Zeven genoemd (vanwege de zeven deskundigen, drie Nederlanders en vier Antillianen), werd besloten te kiezen voor een andere benadering van de problematiek. Niet langer werd een integrale oplossing

de Naties (1960), Koulen (1985) p. 48 noot 20.

Arubaanse nota ex art. 26 ERNA (1981) pp. 4, 5. Zie ook nota: Samenwerkingsvormen tussen Aruba en de overige samenstellende delen van het Koninkrijk in de eindsituatie, afdeling Wetgeving en Constitutionele Zaken (W.C.Z.) 8/13 oktober 1981. Voor de Gemenebestconstructie werd verwezen naar het Uniestatuut zoals dat was gepland voor het Koninkrijk der Nederlanden en de Republiek der Verenigde Staten van Indonesië. oktober 1982 gepubliceerd: Rapport van de Gemengde Commissic (1982). Van Gameren (1991) pp. 121-123. 
nagestreefd, maar het Arubaanse probleem moest worden opgelost. ${ }^{92}$ De Commissie kreeg de volgende taakopdracht:

a. te rapporteren over de vraag welke gevolgen de onafhankelijkheid van Aruba kan hebben voor de Nederlandse Antillen, voor Aruba zelf, voor de andere eilanden van de Nederlandse Antillen en voor de verhouding [van de Nederlandse Antillen] met Nederland;

b. de nodige aandacht te schenken aan een planmatige verwezenlijking van de onafhankelijkheid van Aruba;

c. te onderzoeken in welke positie en eindsituatie als gevolg van het onafhankelijk worden van Aruba, de overige eilanden, gezamenlijk of afzonderlijk, zouden komen te verkeren;

d. te onderzoeken hoe een samenwerkingsverband kan worden gevormd tussen Aruba en de overige eilanden, zo hecht en duurzaam dat de voorwaarden aanwezig zijn voor een vruchtbare relatie met Nederland. ${ }^{93}$

Nederland bepaalde de toon van de besprekingen door te kennen te geven de zelfstandigheid van Aruba ten opzichte van de Antillen te zien als een overgangsfase naar de algehele onafhankelijkheid (Aruba wilde liever deel blijven uitmaken van het Koninkrijk). De Koninkrijksregering besliste dat de onafbankelijkheid van de vijf eilanden buiten beschouwing moest blijven. De Antillen 'van de Vijf' gaven te kennen de losmaking van Aruba niet te zullen dwarsbomen. De Commissie kwam zes keer bijeen. De Commissie besloot tijdens de tweede bijeenkomst deskundigen te vragen een aantal deelstudies te verrichten over de gevolgen van de onafhankelijkheid van Aruba op financieel, economisch en bestuurlijk terrein en op terreinen als buitenlandse zaken, defensie, rechtsorde, nationaliteit en ontwikkelingssamenwerking. In november 1982 bracht de Commissie verslag uit. Voor wat betreft de taakopdracht onder $\mathrm{a}$ en $\mathrm{b}$ werd als leidraad voor de discussies gehanteerd de door het lid H.S. Croes ingediende

92 Rapport van de Gemengde Commissie Toekomst Antillen, november 1982. De inleiding van het rapport geeft op p. 4 de redenen aan, die hebbengeleid tot instelling van de Gemengde Commissie. De Commissie bestond uit de volgende zeven leden: mr. B.W. Biesheuvel, mr. M.A. Pourier, mr. H.S. Croes, M.P. Gorsira, Prof. dr. A.J.F. Köbben, drs. Th.A.J. Meijs en mr. ing. E. Voges. Tevens was lid van de Commissie: J.M.G. Evertsz, hij verving Gorsira. Het lid Voges diende een nota ter bespreking in over een samenwerkingsverband in Unievorm. Het lid Croes stelde nog twee andere vormen van samenwerking voor: parallelle en concordante wetgeving.

93 Rapport van de Gemengde Commissie (1982); Instellingsbesluit, op grond van art. 10 Statuut, KB 14 januari 1982 nr. 8. 
nota. In de nota was aangegeven hoe Aruba zijn onafhankelijkheid zag en welke relaties Aruba met de Nederlandse Antillen, Nederland en het Koninkrijk voorstond. Op vrijwel geen enkel punt werd overeenstemming bereikt. Het enige punt waar men het wel over eens scheen, was de 'Status Aparte' van Aruba. De overige Nederlandse Antillen zouden die 'Status Aparte' gedogen als korte overgangsperiode naar de onafhankelijkheid van Aruba. Het rapport werkte de federatieve samenwerkingsvorm concreter uit, door aan te geven welke onderwerpen in een federale grondwet geregeld zouden moeten worden. De grondrechten, een democratische staatsvorm, de samenwerking(splichten) en een geschillenregeling waren de belangrijkste onderwerpen, die in de federale grondwet geregeld zouden moeten worden. ${ }^{94}$ Enkele van de conclusies uit het rapport waren:

- Een onafhankelijk Aruba zal een eigen rechtsorde moeten creëren. Op het tijdstip van de intrede van de onafhankelijkheid zal Aruba moeten beschikken over een eigen Grondwet, waarin de belangrijkste elementen van het nieuwe staatsbestel zijn opgenomen. Bij het onafhankelijk worden van Aruba zal de reorganisatie van het bestuur voltooid moeten zijn, aangezien Aruba op dat moment - in principe - alle bestuurlijke taken die het ingevolge de constitutie dient te behartigen, zelfstandig moet kunnen verrichten.

- Samenwerking op het terrein van de regelgeving tussen de Nederlandse Antillen en Aruba is naar het oordeel van de Commissie om verscheidene redenen aan te bevelen.

- De vijf eilanden zullen zich nader moeten beraden over de vraag of de gewijzigde omstandigheden consequenties hebben - en, zo ja welke - voor de staatkundige structuur van de Nederlandse Antillen.

- Wanneer Aruba tot op het ogenblik van de onafhankelijkwording deel uitmaakt van de Nederlandse Antillen, dan heeft de onafhankelijkheid van Aruba geen gevolgen voor de wetgeving van bet Koninkrijk, aangezien het geen zelfstandig onderdeel van het Koninkrijk is. Wanneer Aruba, voorafgaande aan de onafhankelijkwording, de status van land binnen het Koninkrijk zou verkrijgen, dan zal bezien worden welke consequenties dit heeft voor de Rijkswetten en zullen deze voor zover nodig gewijzigd moeten worden. 
Over de samenwerkingsvormen tussen Aruba en de Antillen in de overgangsfase kon geen overeenstemming worden bereikt. In het eindadvies kon de Commissie hierdoor nog altijd geen onafhankelijkheid als einddoel adviseren als Aruba niet zou deelnemen aan een duurzaam samenwerkingsverband met de Nederlandse Antillen in het kader van de Unie. ${ }^{95}$ Nederland opteerde nog steeds voor de 'eenheid en ondeelbaarheid' van de Antillen op weg naar de onafhankelijkheid. Een radicale wijziging in de opstelling van de Nederlandse Antillen trad op in de discussies in 1982 in de Commissie. De vier Antilliaanse leden verklaarden dat onder 'eindsituatie' van de eilanden, die zouden overblijven na het uittreden van Aruba geen onafhankelijkheid mocht worden verstaan. ${ }^{96}$ Nederland stelde zich op het standpunt dat het recht van zelfbeschikking zou moeten resulteren in onafhankelijkheid voor de Nederlandse Antillen. De Antilliaanse vertegenwoordiging meende dat het zelfbeschikkingsrecht ook in kon houden, het bestendigen van de staatsrechtelijke banden met Nederland. De vraag bleef nu of elk eiland afzonderlijk onafhankelijk kon worden, of dat het zelfbeschikkingsrecht slechts het Land van de Nederlandse Antillen en Aruba betrof. ${ }^{97}$ Uiteindelijk sloot de Neder-

Rapport van de Koninkrijkswerkgroep (1980) p. 72.

* Dip (1990) pp. 516 e.v. Dip vermeldt in noot 16 (p. 517) het volgende over het rapport, de pp. 77 en 78 . Het gestelde op p. 78 van het rapport, waar gesproken wordt van de 'te zijner tijd bij de onafhankelijkheid van de vijf andere eilanden te treffen maatregelen, is in tegenspraak met hetgeen op p. 77 wordt gezegd ten aanzien van de uitkomst van het zelfbeschikkingsrecht.' Dit betekent dat op p. 77 nog gerept wordt van een zelfbeschikkingsrecht, inhoudende dat als Aruba onathankelijk werd, de rest van de Nederlandse Antillen dat ook zou moeten worden. Pagina 78 daarentegen geeft een uitleg van het zelfbeschikkingsrecht waaruit blijkt dat onafhankelijkheid van Aruba niet noodzakelijkerwijs onathankelijkheid voor de andere eilanden zal behoeven in te houden. Elk overblijvend eiland zal zelf de keuze mogen maken voor de gewenste bestuursstructuur.

r) Kapteyn (1982) pp. 181-187. Kapteyn meende in 1982 dat het zelfbeschikkingsrecht in beginsel slechts de landen toekwam en niet de afzonderlijke eilanden. 'Als we de drager van het zelfbeschikkingsrecht onder het dekolonisatierecht van de VN definiëren als de meerderheid binnen een algemeen geaccepteerde politieke eenheid, dan wordt deze politieke eenheid zonder twijfel gevormd door het Land: de Nederlandse Antillen.' Kapteyn stelde echter dat er twijfel kan rijzen over deze definitie. Meerderheidsbeslissingen veronderstellen echter een redelijke mate van saamhorigheidsgevoel. Dit ontbreekt in hoge mate binnen de Antilliaanse maatschappij. Ook het insularisme, de geografische verspreiding van de eilanden, de splitsing in twee taalgemeenschappen, zo niet culturen (Boven- en Benedenwinden) drukken hun stempel op het politieke leven. Landelijke politieke partijen ontbreken. Kapteyn kwam tot de conclusie dat onathankelijkheid voor elk eiland a fzonderlijk mogelijk is en ook naar maatstaven van het dekolonisatiebeleid van de $\mathrm{VN}$ acceptabel is. Zou echter een of meer eilanden van de Benedenwinden zich los van de overige eilanden, ona fhankelijk verklaren, dan is het risico niet denkbeeldig dat op zo'n eiland historische claims zullen worden gelegd. Kapteyn was de voorzitter van de Coördinatie-commissie die conform conclusie-punt 32 van de RTC van maart 1983, erop moest toezien dat de 
landse regering zich bij het standpunt van de Antilliaanse regering aan en erkende zij het zelfbeschikkingsrecht van elk der eilanden. ${ }^{98}$

Bij de totstandkoming van het Regeringsreglement van 1865 schreef de toenmalige Nederlandse Minister van Koloniën: "Geen andere band houdt hen verenigd dan de gemeenschappelijke onderhorigheid aan de Nederlandsche Staat" . ${ }^{99}$ En in feite is sindsdien de situatie ongewijzigd. Volgens het VN dekolonisatiebeleid van het 'non-disruption principe', zou Aruba tot in lengte van dagen deel uit moeten maken van een staatsverband door Curaçao gedomineerd, als de Nederlandse Antillen een soevereine staat zouden worden. Deze VN-lessen hebben de Arubaanse leiders ter harte genomen. Daarom werd de prijs voor de status aparte, onafhankelijkheid op termijn, ook door Aruba geaccepteerd. De los-van-Curaçaobeweging, werd mede door de druk die Nederland na 1970 uitoefende op de Antillen om onafhankelijk te worden, een onafhankelijkheidsbeweging.

Naar aanleiding van het overleg tussen de Koninkrijkspartners op 26 en 27 oktober 1981 werd van 7 t/m 13 maart 1983 de RTC vervolgd. $\mathrm{Er}$ moesten beslissingen worden genomen over de toekomstige staatkundige structuur van Aruba en de Nederlandse Antillen. Tijdens de te houden RTC moest het programma voor de losmaking van Aruba uit de Antillen worden vastgesteld. De Nederlandse delegatie naar de conferentie verklaarde bij het begin van de conferentie dat het Statuut door Nederland nooit gezien werd als de eindfase in de ontwikkeling van de staatkundige verhouding tussen de rijksdelen. Benadrukt werd nogmaals dat in Nederland de mening overheerste dat de Nederlandse Antillen onafhankelijk zouden moeten worden. Wel was Nederland van mening dat een overgangsfase noodzakelijk was, waarin de onafhankelijkheid planmatig kon worden voorbereid. Ook werd nogmaals benadrukt dat het wenselijk zou zijn indien de zes eilanden, na een overgangsperiode, in één verband onafhankelijk zouden worden. ${ }^{100}$

\section{RTC besluiten zouden worden uitgevoerd.}

Te vinden op p. 7 van het stenografisch verslag van de Conferentie van de Nederlandse Antillen, de eilanden van de Nederlandse Antillen en Nederland, $7 \mathrm{v} / \mathrm{m} 12$ maar 1983, 's-Gravenhage, 1983.

Bordewijk (1914) p. 3.

Toespraak R.F.M. Lubbers, 7 maart 1983 bij het begin van de RTC, KABNA, BDS 070383. Opmerkelijk is dat Lubbers in verband met de onathankelijkheid van de Antillen en Aruba, ók spreekt van een de iure onathankelijk Nederland (p. 5). Op de RTC werden ook de conclusies besproken van de werkgroep juridische en 
Op 10 februari had het georganiseerde bedrijfsleven op Aruba er met klem voor gepleit op de RTC geen tijdstip vast te leggen voor volledige onafhankelijkheid van het eiland. In een brief van de Kamer van Koophandel en Nijverheid en van de Arubaanse Vereniging voor Handel en Industrie werd verzekerd dat de mening van die organisaties werd gedeeld door "een zeer grote meerderheid van de Arubaanse bevolking. Wij vragen de Nederlandse regering en het parlement op te houden met Aruba en de overige eilanden voortdurend te bedreigen met een geforceerde onafhankelijkheid. We hebben aan Suriname gezien waartoe doordrukken kan leiden". ${ }^{101}$

Om uit de patstelling te geraken namen de Minister-President van Nederland, Lubbers en de Minister van Antilliaanse Zaken, De Koning, tijdens de RTC de teugels strak in handen. Aan het einde van het overleg hadden de deelnemers van het overleg een lijst van 33 punten aangelegd, die voor een deel tegenstrijdig waren en voor een deel verwezen naar een nadere uitwerking van probleemaspecten. Nadrukkelijk stelde Nederland dat deze lijst in zijn geheel door alle partners geaccepteerd of verworpen zou moeten worden. Werd het stuk verworpen, dan zou het staatkundig emancipatieproces in een

institutionele zaken, de werkgroep monetaire samenwerking en boedelscheiding en het rapport van de Gemengde Commissie Toekomst Antillen (G.C.T.A.). Betico Croes memoreerde in zijn toespraak op de RTC dat het precies 50 jaar geleden was (7 maart 1933) dat de Raad van Politie van Aruba een petitie zond aan de koningin om meer zeggenschap in eigen aangelegenhedente verkrijgen. Ook twijfelde Betico Croes er niet aan dat indien Van Poelje nog in leven zou zijn, hij de volgende wijze woorden zou hebben gesproken: 'de geschiedenis heeft mij vrijgesproken'. Tevens overlegde de Arubaanse delegatie afschrift van een uitgebreide motie van de Eilandsraad van Aruba yan 24 februari 1983, waarin verwezen werd naar ondermeer de volgende documenten: de moties van de Staten van de Nederlandse Antillen van 19 december 1973 en 12 september 1975, alsmede de motie van de Eilandsraad van Aruba waarin tot uitdrukking werd gebracht de rechtvaardige wens van het Arubaanse volk zijn eigen politieke status te bepalen. Ook werd overlegd het resultaat van het referendum van 5 maart 1977, de motie van de Eilandsraad van 18 augustus 1977 , 8785, waarbij om een gesprek ex art. 26 ERNA werd gevraagd. Verder speelden een rol de moties van de Eilandsraad van Aruba van 9 september 1976, 9943, en van 13 december 1978, 13866 (beide met betrekking tot diversificatie van de economie), de motie van de Arubaanse Eilandsraad van 13 juni 1978 betreffende de instelling van een breed samengestelde commissie, die de onafhankelijkheid moest voorbereiden en verwezenlijken, het resultaat van de besprekingen in september 1977 , het Protocol van Willemstad van 20 april 1978, de motic van de Eilandsraad van Aruba d.d. 12 juli 1978, 8624 (over de gelding van de Mensenrechtenverdragen van 1966) en de motie Roethof van september 1978, 13932, R. 1037, 17. De bedoeling van breed opgezette motie was om aan te geven dat de Arubaanse delegatic de taak had met de status aparte en de onathankelijkheid op termijn van Aruba terug te komen van de RTC. De uitwerking van de samenwerking in de overgangsfase werd puntsgewijs en uitgebreid toegelicht in de motie.

101 Kessings Historisch Archief, mei 1983, p. 283. De pp. 283-286 bevatten de 33 conclusiepunten van de RTC, overgenomen uit de Staatscourant. 
uitzichtloze en wellicht eindeloze impasse geraken, waarbij overleg de eerste jaren of decennia geen oplossing zou kunnen bieden. Ongetwijfeld heeft deze pressie ertoe bijgedragen dat iedereen accoord ging met de 'besluitenlijst', zoals ze in de dagelijkse omgang genoemd werd. ${ }^{102}$ De onderlinge samenwerking tussen de eilanden vormde een probleem. Gezien de grote onderlinge meningsverschillen had de Commissie van Zeven daar geen concrete uitspraken over kunnen doen. Ook de Werkgroep voorbereiding RTC had zich daar nauwelijks over uitgelaten. ${ }^{103}$

Tussen de MEP-leden en de overige leden van de Arubaanse delegatie bestonden principiële meningsverschillen over de toekomstige samenwerkingsverbanden met name over de bevoegdheden en personele samenstelling van de Unie-organen. Ingevolge art. 19 van de consensus-punten zou op het tijdstip dat Aruba de Status Aparte verkreeg, een Unie tussen de resterende Nederlandse Antillen en Aruba worden aangegaan. Het Unieverdrag zou gemodelleerd worden naar de bepalingen van de artt. 21 en volgende van de conclusiepunten en op grond van art. 20 daarvan, ook naar de Proeve van een Unieverdrag van de hand van J.A.B. Janus, die in bijlage IV bij het rapport van de Gemengde Commissie Toekomst Antillen opgenomen was. ${ }^{104}$

Tussen de overige Antilliaanse eilanden en Nederland bestond een zekere spanning omdat de vijf eilanden vreesden dat de afscheiding en uittreding van Aruba door Nederland zou worden gebruikt om ook de rest van de Antillen uit het Koninkrijk te zetten. Reeds aan het begin van de RTC gaven de vijf eilanden te kennen dat de toekomstige relaties tussen Aruba en de rest van het Koninkrijk geen invloed mochten hebben op hun eigen toekomstige relaties met Nederland.

Conclusiepunt 28 bevatte de wens om de minder draagkrachtige eilanden bij te staan in het handhaven van een behoorlijk bestuursni-

Stenografisch verslag van de Conferentie, gehouden van maandag $7 \mathrm{t} / \mathrm{m}$ zaterdag 12 maart 1983, Bijlage 'Definitief voorstel van de voorzitter' bevat de 31 conclusiepunten, pp. 97-100, Paula (1989) pp. 79-86.

Protocol, Werkgroep voorbereiding Ronde Tafel Conferentie, 24 februari 1983. Dit Protocol wordt ook wel het Protocol van Mito (A.G. Croes) genoemd. Hij was tijdens de onderhandelingen de minister van Justitie en van Staatkundige Structuur Eilanden. De Werkgroep was ingesteld bij Landsbesluit van 7 januari 1983, 1 en zou er naar streven om gemeenschappelijke standpunten te formuleren voor de te houden RTC van $7 \mathrm{l} / \mathrm{m} 12$ maart 1983. Er werd zeven keer vergaderd.

104 Stenografisch verslag van de conferentie gehoudenvan maandag 7 tot en met zaterdag 12 maan 1983. Definitief voorstel van de voorzitter over de conclusiepunten, pp. 97-100. De Unie werd omschreven in de conclusiepunten $19 \mathrm{~V} / \mathrm{m}$ 22; Bongenaar (1983) pp. 49-84, met name pp. 76 e.v. 
veau. Nederland zou dit garanderen door een herschikking van de middelen bestemd voor de ontwikkelingssamenwerking. Daartoe zou een Solidariteitsfonds worden opgericht, dat de bestaande landsbijdrage aan de eilandsbegrotingen van de minder draagkrachtige eilanden zou vervangen. Op de RTC kon geen overeenstemming worden bereikt over de juiste verdelingen van de bijdragen in het fonds door Nederland, de Nederlandse Antillen en Aruba. Met name Nederland wilde een geringe bijdrage leveren aan het in te stellen Solidariteitsfonds. Nederland achtte het ondersteunen van de minder draagkrachtige eilanden, een Antilliaanse en Arubaanse zaak. ${ }^{105}$

Op de RTC werd besloten dat Aruba een Status Aparte zou krijgen gedurende tien jaar, die in zou gaan op 1 januari 1986. Daarna zou het eiland definitief kiezen voor onafhankelijkheid in 1996. In besluit twee ${ }^{106}$ was echter een onduidelijkheid geslopen die door de partijen verschillend geïnterpreteerd werd, omdat daarin een ontsnappingsclausule leesbaar was. Er was in besluit twee sprake van toetsing van de wens van het Arubaanse volk, voordat de onafhankelijkheid daadwerkelijk van kracht zou worden. Herhaaldelijk hadden de Nederlandse politici echter al te kennen gegeven wel degelijk 1996 te beschouwen als de definitieve datum van Arubaanse uittreding.

"Het is in dit verband met name van belang een ten aanzien conclusie 2 van de RTC van 1983 bestaand misverstand uit de weg te ruimen. De betekenis die de Nederlandse regering destijds aan deze conclusie hechtte was de volgende. Voor Nederland was de onafhankelijkheid van de Nederlandse Antillen en Aruba een vaststaand einddoel. $\mathrm{Er}$ werd, in ieder geval wat Nederland betreft, geen toetsingsconferentie afgesproken om te bezien of de onafhankelijkheid van Aruba al dan niet zou moeten doorgaan en op welke voorwaarden er eventueel van afgezien zou kunnen worden, maar om te bepalen of de onafhankelijkheid van Aruba wellicht op een ander moment zou moeten ingaan. De RTC-afspraken zijn - wat Nederland betreft - gemaakt in het perspectief van de onafhankelijkheid niet alleen van Aruba, maar ook van de Nederlandse Antillen." 107

Rapport van de Gemengde Commissie (1982) pp. 91 e.vị Stenografisch verslag van de RTC van $7 \mathrm{U} / \mathrm{m} 12$ mart 1983, pp. 30-36.

Besluit twee luidde: 'Voor $1996 \mathrm{zal}$ een toetsingsconferentie worden gehouden tussen het Koninkrijk en Aruba om de datum van de onathankelijkheid van Aruba eventueel nader te bezien in het licht van de staatkundige ontwikkelingen tussen de landen van het Koninkrijk. Hiermee wordt in geen enkel opzicht vooruit gelopen op deze staatkundige ontwikkelingen'.

107 KABNAA: Voorstel van rijkswet tot wijziging van het Statuut voor het Koninkrijk der Nederlanden in verband met het voortzetten van de in het Statuut neergelegde rechtsorde ten aanzien van Aruba, Tweede Kamer, vergaderjaar 1991-1992, 22593 
Fernandes Mendes merkte over de toetsingconferentie op dat de duidelijkheid die art. 62 Statuut poogde te scheppen enigszins werd vertroebeld door de afspraak dat de datum van de onafhankelijkheid van Aruba op een voor 1996 te houden toetsingsconferentie eventueel nader zou worden bezien 'in het licht van de staatkundige ontwikkelingen tussen de landen van het Koninkrijk'. ${ }^{108}$ Deze zinsnede bleek zich voor een meerduidige uitleg te lenen. De interpretatie van het kamerlid Wiebenga (VVD), overigens gedeeld door andere kamerfracties en de regering, klonk niet onaannemelijk. Volgens Wiebenga sloot de zinsnede 'staatkundige ontwikkeling tussen de landen van het Koninkrijk' uit dat:

a. economische ontwikkelingen tot heroverweging of vertraging van de onafhankelijkheidsdatum hoeven te leiden;

b. verslechterde politieke ontwikkelingen in het Caraỉbisch gebied de onafhankelijkheidsdatum in een nieuw licht behoren te plaatsen.

Alleen ontwikkelingen in het Koninkrijk, bijvoorbeeld wanneer de Antillen zouden besluiten in dezelfde periode onafhankelijk te worden, konden tot uitstel aanleiding geven. Overigens was de interpretatie van Wiebenga niet terug te vinden in stukken van de RTC; het was een invulling achteraf die niet door alle partijen werd geaccepteerd. De Arubaanse politici meenden bijvoorbeeld eensgezind dat de toetsingsconferentie een ruimere betekenis diende te hebben. Een volksraadpleging zou volgens hen de datum van de onafhankelijkheid nog kunnen beïnvloeden. ${ }^{109}$

Nederland hield vast aan de onafhankelijkheid. Naar mijn mening is de redactie van conclusiepunt twee niet gelukkig, er kon uit afgeleid worden dat éérst een toetsingsconferentie moet worden gehouden, voordat kon worden bepaald wanneer Aruba onafhankelijk zou worden. Ik ben van mening dat de Nederlandse verklaring pas achteraf geēxpliciteerd is. Feitelijk blijft het de vraag hoeveel procent van de bevolking van Aruba de prijs van de onafhankelijkheid heeft willen betalen voor het verkrijgen van de Status Aparte. Het was typerend voor de verhoudingen, dat op Aruba de oppositiepartijen

(R 1433) 1-2. Het gaat hier om het zogenaamde 'schrappingsvoorstel' van art. 62 Statuut. Bij het Koninkrijksoverleg in mei 1991 werd tussen de Koninkrijkspartners overeengekomen dat Aruba binnen het Koninkrijk zou kunnen blijven.

109 Zie ook: Fernandes Mendes, NJB 1984, pp. $73-79$ en pp. 723-724; Wilms, NJB 1984, pp. 721-722: Pedroli, NJB 1984, pp. 722-723. 
stelden dat de MEP Aruba uit het Koninkrijk had laten zetten, terwijl de MEP er de nadruk op legde dat de strijd om de Status Aparte eindelijk gewonnen was en Aruba nu snel definitief van het juk van Curaçao bevrijd zou zijn. Toch was het iedereen duidelijk dat vooral Nederland zijn zin had gekregen, omdat de Status Aparte inderdaad aan de onafhankelijkheid was gekoppeld. ${ }^{110}$

Op Aruba vond een zekere stabilisatie van de politieke verhoudingen plaats. Tot 1985 bleef de MEP de absolute meerderheidspartij. De grootste verkiezingsoverwinning van de MEP vond plaats bij de Eilandsraadverkiezingen van 29 april 1983. Een schietpartij op zondag 28 april 1983, é́n dag voor de verkiezingen besliste de verkiezingsstrijd. In een moment van paniek liet een Curaçaose politieagent zijn dienstpistool afgaan tijdens een (illegale) verkiezingsoptocht van de MEP. De agent had eerst een waarschuwingsschot gelost en trof daarna Betico Croes in de buik. Na enkele dagen verpleging op Aruba werd de zwaar gewonde Croes naar Miami overgevlogen. Tot aan zijn dood zou Croes hinder blijven ondervinden van zijn verwondingen. Na het incident werd de politieman en zijn gezin 'op vakantie' gestuurd naar Curaçao, waarvan hij afkomstig was. Door het brute optreden van de agent was getracht een einde te maken aan de vrijheidsstrijd van een volk, aldus de MEP. De echtgenote van Croes had al meteen verklaard dat " de aanslag een goed voorbereid complot was en dat de agent van hogerhand opdracht tot schieten had gekregen'. Hiermee bedoelde de familie Croes vooral de AVP-minister van Justitie Gonzalez. Croes beschouwde de schietpartij als een complot tegen de onafhankelijkheidsstrijd van Aruba. ${ }^{111}$ De politieagent die betrokken was bij het schietincident werd niet strafrechtelijk vervolgd. Het Openbaar Ministerie (OM) achtte niet bewezen dat de politieman het schot, dat Betico Croes in de buik trof, opzettelijk had afgevuurd, of dat de politieman schuld had aan het afgaan van zijn dienstpistool. ${ }^{112}$

Naar aanleiding van het schietincident werd een onderzoekscommissie van de politie ingesteld. De commissie kwam met een zeer omvangrijk rapport, waaruit bleek dat het schietincident mede veroorzaakt

110 De door het verkrijgen van de Status Aparte van Aruba noodzakelijk geworden wijziging van het Statuut vond plaats door middel van een Rijkswet van 22 juli 1985 , die in werking trad op 1 januari 1986, Stb. 1985, 452, PB 1985, 102, 1985, AB 35; Pronk (1991) p. 27.

111 Ofschoon Croes en de MEP sindsdien consequent hebben gesproken over een aanslag op zijn leven is deze bewering nooit bewezen.

112 Keesings Historisch Archief, mei 1984, p. 287; idem juni 1984, p. 364. 
was door het hinderen van politieagenten in de uitoefening van hun functie. De agent die het fatale schot zou hebben gelost verkeerde in een moeilijke situatie, daar hij bedreigd werd door MEP-aanhangers die een verboden auto-optocht wilden houden, waardoor moeilijkheden zouden kunnen ontstaan met AVP-aanhangers, die ook een autooptocht hielden. Een groot aantal MEP-aanhangers was onder invloed van alcoholhoudende dranken, zeer geëmotioneerd en wilde niet luisteren naar de aanwijzingen van de politie. Ook het politierapport stelt dat niet is komen vast te staan dat de kogel die Betico Croes raakte uit het dienstpistool van de betrokken agent is gekomen. Het interpellatierapport bevatte geen stukken over het strafrechtelijk onderzoek. ${ }^{113}$ De gemoederen waren zeer verhit na het schietincident en er onstonden vechtpartijen tussen de MEP-aanhangers en AVP-aanhangers. De spanningen namen toe toen een zestienjarige AVP-aanhanger, F.R. Tromp, op 29 april 1983 'per ongeluk' werd doodgeschoten door een MEP-aanhanger. ${ }^{114}$ Betico Croes ontvluchtte het ziekenhuis waar hij verbleef en vertrok naar Miami, toen AVPaanhangers zich opmaakten tot represailles tegen zijn persoon. Bij zijn afscheid als Gouverneur sprak Leito waarschuwende woorden in verband met de extreme reacties. ${ }^{115}$

Noch de opmars van Henny Eman's AVP, noch de PPA, noch de nieuwe partij Partido Democratico Arubiano (PDA) waren bestand tegen het effect van de schietpartij. De AVP verloor bijna 2.000 stemmen, de PPA bleef opnieuw steken op drie zetels en de PDA haalde de kiesdrempel niet. De MEP behaalde ruim 20.000 stemmen en daarmee dertien zetels in de Eilandsraad.

Van 13 tot 29 januari 1984 bracht een Nederlandse parlementaire delegatie onder leiding van het PvdA Kamerlid J.A. van Kemenade een werkbezoek aan de eilanden. Na terugkeer in Nederland zei Van

Interpellatie-Rapport 1 juli 1983. Dit rapport werd gebruikt in de Staten, om de Minister van Justie te ondersteunen in zijn antwoorden op de gestelde vragen, het rapport bevatte de uitkomsten van het politieonderzock.

De dader werd wegens doodslag veroordeeld tot negen jaar gevangenisstraf, Gerecht in eerste aanleg 8 juni 1984, nr. 1498; HvJ 29 januari 1985, nr. 8, HR 15 november 1985, nr. 78.813 A. De HR vernietigde het vonnis van het HvJ en wees de zaak terug. omdat het Hof de verweren van de verdachte: noodweer en noodweer-exces, onvoldoende gemotiveerd had verworpen. GHvJ 4 maart 1986, nr. 23. De verdachte was met zijn auto versierd met MEP-stickers, vergezeld van enige vrienden, allen in het bezit van een vuurwapen en onder invloed van alcohol houdende dranken, een rondje gaan rijden in een stadsgedeelte, dat bekend stond als het bolwerk van de AVP. Beklaagden hadden het willens en wetens op een gevaarlijke situatie laten aankomen. Derhalve faalde het beroep op noodweer en noodweer-exces, aldus de rechter. 
Kemenade dat Curaçao bang was dat het na de afscheiding van Aruba uit het Antilliaanse staatsverband de verantwoordelijkheid voor de overblijvende vijf eilanden als een molensteen om de nek kreeg en dat er daarom op Curaçao steeds nadrukkelijker gepraat werd over een aparte status voor dit eiland. De oorspronkelijke opzet van Nederland was een hecht samenwerkingsverband tussen de Nederlandse Antillen en Aruba in de vorm van een Unie, compleet met gemeenschappelijke regering, parlement en andere wezenlijke instituten. Langs die weg probeerde Nederland nog een soort federatieve staatsvorm in stand te houden tussen Aruba en de Nederlandse Antillen. Het duurde niet lang voordat de eilanden, die na 1 januari 1986 samen de Nederlandse Antillen zouden blijven vormen, zich begonnen te realiseren dat een gestructureerde gelijkwaardigheid zowel hun eigen ontwikkeling als die van Aruba zou blokkeren. Mede om die reden werd de RTC afspraak voor het aangaan van een Unie-verband met Aruba na 1986, tijdens het eilandelijk Topoverleg van 26 tot 29 juni 1984 , van de hand gewezen. De directe aanleiding tot de definitieve afwijzing van de Unie, was het verzoek van de MEP-leider Betico Croes, aan Nederland om pressie uit te oefenen, desnoods via de ontwikkelingshulp of anderszins, om zo uitvoering te bewerkstelligen van alle RTC afspraken. De centrale regering zette weinig vaart achter de voorbereidende werkzaamheden, in verband met met de Arubaanse afscheiding. Om die reden werd de Antilliaanse regering zowel door Aruba als door Nederland beticht van het voeren van een vertragingspolitiek met de bedoeling de afscheiding van Aruba tegen te werken. ${ }^{116}$

Op 31 oktober 1984 deelde de Amerikaanse oliemaatschappij Exxon mee dat de exploitatie van de Lago Oil \& Transport Company Ltd. per 31 maart 1985 zou worden beëindigd wegens grote verliezen. Venezuela die de Exxon had gesubsidieerd door middel van een preferentieel prijzensysteem, kon dat gezien de wereldwijde recessie niet langer volhouden. De sluiting van de Lago zou catastrofale gevolgen hebben voor de Arubaanse economie. Sinds de jaren twintig van de 19de eeuw bepaalde de Lago grotendeels de economie van Aruba. Aruba zou niet in staat zijn om de economische gevolgen van de sluiting van de Lago op eigen kracht op te vangen. De werkgelegenheid zou dramatisch teruglopen evenals de overheidsinkomsten.

116 Naar de mening van Paula klaagde ook Prof. Jos Kapteyn, voorzitter van de Coördinatie-commissie die tot taak had toe te zien op de uitvoering van de RTC conclusies, meermalen dat er weinig of geen vooruitgang werd gemaakt in de voorbereidende werkzaamheden. Paula (1989) a.w. pp. 84 e.v. 
Nederlandse begrotingshulp leek dan ook onvermijdelijk, Aruba dacht hierbij aan de kwijtschelding van de ontwikkelingsschulden. Op grond van deze gebeurtenissen vroeg Aruba om overleg ex art. 26 ERNA.

Dit overleg in aanwezigheid van de minister voor Antilliaanse Zaken J. de Koning, vond plaats op 9 november 1984 . Voor de kwijtschelding van schulden was onvoldoende ruimte op de begroting van KABNA, bovendien achtte De Koning dat een laagwaardige besteding van ontwikkelingsgeld. Ook een tijdelijke emigratie van Arubanen naar Nederland leek de minister geen goede oplossing, gezien de negatieve gevolgen die dat zou kunnen opleveren, zoals het vertrek van de meest vakbekwame mensen. Bovendien zou een massale emigratie van Arubanen naar Nederland spanningen op kunnen leveren tussen de verschillende bevolkingsgroepen op grond van het cultuurverschil en zou dat weer kunnen leiden tot het stellen van toelatingseisen aan Antilliaanse en Arubaanse Nederlanders. ${ }^{117}$ Uiteindelijk leidde de sluiting van de Lago tot grote problemen voor Aruba. Als gevolg van de economische neergang zou koortsachtig worden gezocht naar diversificatie van de economie. Dit zou leiden tot aanzienlijke vergroting van de hotelsector. Daar er teveel hotels zijn gebouwd en een aantal hotels niet konden worden afgebouwd wegens faillissement van de aannemer is Aruba daardoor financieel en economisch weer in de problemen geraakt. Op deze ontwikkelingen zal nader worden ingegaan in het volgende hoofdstuk.

Naar aanleiding van de uittreding van Aruba uit het Antilliaanse verband werd vele malen vergaderd door Nederland, de Nederlandse Antillen en overblijvende eilanden van de Nederlandse Antillen. Met name de problematiek van het Solidariteitsfonds viel niet eenvoudig te regelen. Het eerste overleg tussen het land en de vijf eilanden werd gehouden op 2 en 3 april 1984 op Curaçao. ${ }^{118}$ Aan de orde kwam

117 Woordelijk verslag van de vergadering tussen de Koninkrijksdelegatie en de Arubaanse delegatie ex artikel 26 Eilandenregeling Nederlandse Antillen, gehouden te Curaçao in de Statenzaal op 9 november 1984, uitgave van het Departement Staatkundige Structuur Eilanden (DSSE), 1984.

118 Bij Landsbesluit van 14 mart 1984, 1, PB 1984, 25 werd een Topoverleg bijeengeroepen van de Nederlandse Antillen en de eilandgebieden Bonaire, Curaçao, Saba, Sint Eustatius en Sint Maarten ter uitwerking van de consensuspunten 6 en 13 van de RTC, die van $7 \mathrm{t} / \mathrm{m} 12$ maart in Nederland was gehouden. De punten 6 en 13 regelden de Status Aparte van Aruba en de herstructurering van de Nederlandse Antillen. Bij Landsbesluitvan 9 september 1983, 1 was een werkgroep van financieel- 
onder andere het Solidariteitsfonds. Aan het einde van het overleg werd een resolutie aangenomen die eraan herinnerde, dat ter vervanging van de bestaande landsbijdrage aan de begrotingen van de minder draagkrachtige eilanden een Solidariteitsfonds zou worden opgericht. De middelen daarvoor zouden ter beschikkingen worden gesteld door de Nederlandse Antillen, Aruba en Nederland. Verder spraken de deelnemers aan het overleg hun ongerustheid uit over de geringe bereidheid van Nederland substantieel bij te dragen in het Solidariteitsfonds. ${ }^{119} \mathrm{Op}$ het overleg tussen de centrale regering en de eilanden van 26 tot 29 juni op Sint Maarten werd de nieuwe zetelverdeling in de Staten als volgt geregeld: Curaçao 14, Bonaire 3, Sint Maarten 3 en Saba en Sint Eustatius ieder 1 zetel. ${ }^{120}$ Op het overleg tussen het Land de Nederlandse Antillen en de vijf eilanden op 9 augustus 1984 op Bonaire werd besloten dat de Nederlandse Antillen tenminste $5 \%$ van hun totale ontvangsten zouden bijdragen in het Solidariteitsfonds. ${ }^{121}$

Het overleg met de Koninkrijksdelegatie, de Raad van Ministers en de eilandsdelegaties werd gehouden op 21 augustus 1984. Minister De Koning gaf aan dat Nederland niet meer dan $10 \%$ in het Solidariteitsfonds wilde bijdragen. ${ }^{122}$ Tevens zei De Koning dat Nederland niet zou meewerken om landstaken ten behoeve van de minder draag-

economisch deskundigen opgericht. Deze werkgroep moest op grond van de conclusiepunten 17, 25, 26, 27 en 31 van de RTC van 1983 advies uitbrengen aan de regering van de Nederlandse Antillen en aan de Eilandsraad van Aruba inzake het voortgezet overleg over de genoemde onderwerpen. Het ging om economische en monetaire samenwerking tussen de Nederlandse Antillen en Aruba, het invoeren van een eigen Arubaanse munt, de boedelscheiding tussen de Nederlandse Antillen en Aruba en de verdeling van eventuele netto-opbrengsten uit de exploitatie van de zeebodenurijkdonmen. De Werkgroep besloot op 20 september 1983 het Internationaal Monetair Fonds (IMF) om advies te vragen over monetaire samenwerking en het invoeren van de Arubaanse munt. Het IMF gaf gehoor aan het verzoek en bracht in mei 1984 een rapport uit: Netherlands Antilles, 'Issues related to the Formation of a Monctary Union in the Netherlands Antilles'. Dat rapport is opgenomen als bijlage 4 in het rapport van de Werkgroep Financieel-economische deskundigen van juli 1984, getiteld: Monetaire samenwerking in de Unie van de Nederlandse Antillen. Woordelijk Verslag van het Topoverleg tussen de Nederlandse Antillen en Bonaire, Curaçao, Saba, Sint Eustatius en Sint Maarten. Gehouden te Curaçao in de Staten der Nederlandse Antillen op 2 en 3 april 1984. Het verslag dateert van 4 mei 1984. Zie ook het rapport van de Gemengde Commissie Toekomst Antillen (1982) pp. 91 e.v; Stenografisch verslag van de RTC van $7 \mathrm{t} / \mathrm{m} 12$ maart. 1983, pp. 30-36. Besluitenlijst d.d. 28 juni 1984, Topoverleg Sint Maarten (TOSM) 84/13, TOSM 84/14; Paula (1989) p. 84.

121 Woordelijk verslag van het Topoverleg tussen de Nederlandse Antillen en Bonaire, Curaçao, Saba, Sint Eustatius en Sint Maarten, in Hotel Bonaire op 9 augustus 1984. Woordelijk verslag van het Topoverleg inzake de uitwerking van het Solidariteitsfonds tussen de Koninkrijksdelegatie, de Raad van Ministers en de delegaties van de eilandgebieden, gehouden op 21 augustus 1984 in de Statenzaal der Nederlandse Antillen, p. 6. Het verslag is gedateerd 10 september 1984. 
krachtige eilanden te financieren. Dit gold uiteraard ook voor de begrotingstekorten van de eilanden. De ontwikkelingsgelden waren bestemd voor de ondersteuning en de economische ontwikkeling en niet voor het wegwerken van begrotingstekorten. Dat zou de eilanden alleen maar meer afhankelijk maken. Boven de gebruikelijke 175 miljoen gulden stelde Nederland extra 40 miljoen op jaarbasis ter beschikking om een bufferfonds te vormen (een verhoging van ongeveer 23\%). Van dit bedrag zou de herstructurering van Aruba en de Antillen van de Vijf moeten worden betaald. Aruba meende dat Nederland 50\% moest bijdragen, de resterende 50\% moest worden bijgedragen door de Nederlandse Antillen en Aruba in de verhouding $35 \%$ en $15 \%$. De Antillen wensten dat Nederland $40 \%$ zou bijdragen terwijl de Nederlandse Antillen ook financiering vroegen voor het fonds 'overige kosten', waarmede 30 miljoen gemoeid was. ${ }^{123}$

Op 8 en 9 februari 1985 werd weer overleg gevoerd tussen Nederland, de Nederlandse Antillen en Aruba. Het belangrijkste onderwerp op de agenda was het Solidariteitsfonds. Ook werd nog gesproken over de Samenwerkingsregeling. Er kon geen accoord worden bereikt over de verdeling van de bij te dragen middelen in het Solidariteitsfonds. Nederland hield vast aan zijn laatste voorstel te weten een verdeling van de voeding van het Solidariteitsfonds tot een maximum van 24 mln Nederlands-Antilliaanse florijnen (NAf) als volgt verdeeld:

Aruba $\quad 15 \%$

Nederlandse Antillen 45\%

Nederland $\quad \underline{10 \%}$

Totaal $\quad 70 \%$

De resterende $30 \%$ moest als volgt worden verdeeld:

\begin{tabular}{|c|c|}
\hline Aruba & $10 \%$ (totaal \\
\hline Nederlandse Antillen & $10 \%$ (totaal \\
\hline Nederland & $10 \%$ (totaal \\
\hline Totaal & $\overline{30 \%}$ (totaal \\
\hline
\end{tabular}

De MEP ging in 1985 akkoord met Nederland inzake de volgende verdeelsleutel: Aruba 25\%, Nederland 20\% en de Antillen 55\%. De

123 Woordelijk verslag van het Topoverleg inzake de uitwerking van het Solidariteitsfonds tussen de Koninkrijksdelegatie, de Raad van Ministers en de delegaties der eilandgebieden, gehouden in de Statenzaal op 21 augustus 1984 van de Nederiandse Antillen. Paula (1989) p. 85 e.v. 
AVP en de PPA op Aruba, benevens Curaçao distantieerden zich van het MEP-Nederland akkoord. De impasse werd in beginsel doorbroken, omdat Sint Maarten zich als 'donor' in plaats van als ontvanger opwierp, waardoor alleen Bonaire, Saba en Sint Eustatius voor een bijdrage uit het Solidariteitsfonds in aanmerking kwamen. ${ }^{124}$

\section{De Samenwerkingsregeling Nederlandse Antillen en Aruba}

Op de in 1983 gehouden RTC werd afgesproken dat er zowel op staatkundig als economisch terrein een hechte vorm van samenwerking tussen de scheidende partners (Aruba en de Nederlandse Antillen) zou blijven bestaan. ${ }^{125}$ Dit zou gebeuren in de vorm van een Unie, maar het Unieplan werd van Antilliaanse zijde getorpedeerd. Onderhandeld werd over minder vergaande vormen van economische samenwerking tussen partijen. De uiteindelijke samenwerking werd vastgelegd in de Samenwerkingsregeling Nederlandse Antillen en Aruba. ${ }^{126} \mathrm{Het}$ is een onderlinge regeling zoals bedoeld in art. 38 eerste lid van het Statuut. Uit de toelichting op de Samenwerkingsregeling blijkt dat behoud van maximale zelfstandigheid voorop stond. Binnen dit kader werd zo mogelijk gestreefd naar samenwerking. ${ }^{127}$ Deze samenwerking was ook ter geruststelling van Nederland, dat samenwerking had verordonneerd. ${ }^{128}$

Hoofdstuk I van de Samenwerkingsregeling, de artt. $1 \mathrm{t} / \mathrm{m} 3$ bevatten de algemene bepalingen. Hoofdstuk II, de artt. $4 \mathrm{t} / \mathrm{m} 8$, omschrijven de aangelegenheden die voorwerp zijn van samenwerking en de mate van samenwerking. De Samenwerkingsregeling voorziet niet alleen in samenwerking op economisch terrein, maar ook in een

Paula (1989) p. 85 e.v.

Rapport van de Koninkrijkswerkgroep (1980) p. 17; Conclusiepunten nrs. 7 en 22 van de RTC van 1983; MvT, Samenwerkingsregeling, pp. 2 en 3.

Stb. 1985, 542, PB 1985, 88 en AB 1985, 28. De Samenwerkingsregeling bestaat uit 75 artikelen, verdeeld over zeven hoofdstukken. Aan de eigenlijke regeling zijn verder vijf protocollen gehecht over bijzondere onderwerpen: luchtvaar, scheepvart, exploratie van de zeebodemrijkdommen, telecommunicatie en metereologische dienstverlening, die dezel fde rechtskracht hehbenals de Samenwerkingsregelingzelf, maar waarvoor een lichtere wijzigingsprocedure geldt conform an. 38 eerste lid Statuut. De protocollen zijn tot stand gekomen op grond van art. 37 eerste lid en tweede lid onder $f$ van het Statuut. Zie ook Aangepaste tekst concept Samenwerkingsregeling met bijbehorende Protocollen, zoals aangepast, 21 mei 1985, Departement Staatkundige Structuur Eilanden. Dit was een werkstuk van de Gemengde JuridischeInstitutionele Werkgroep.

27 Fernandes Mendes (1986) p. 76; Toelichting bij de Ontwerp-Samenwerkingsregeling Nederlandse Antillen en Aruba, p. 12.

Rapport van de Gemengde Commissie (1982) p. 95 e.v. 
gezamenlijke regeling van de rechterlijke organisatie. Op economisch terrein is over het algemeen slechts voorzien in een informatie- en overlegplicht en een streven naar gelijkvormige concordante wetsbepalingen. Er bestaan verschillende niveaus van samenwerking. Artikel 4 eerste lid van de Samenwerkingsregeling noemt de categorie van onderwerpen waarbij verplicht moet worden samengewerkt. Dit moet geschieden bij eenvormige landsverordening en de betreffende onderwerpen zijn genoemd in art. 5 .

Het tweede lid van art. 4 geeft de categorie angelegenheden weer, die zoveel mogelijk op overeenkomstige wijze moeten worden geregeld. De nadere uitwerking van die categorie is geregeld in art. 6. Artikel 4 derde lid geeft de aangelegenheden weer waarover de Ministeriële Samenwerkingsraad moet worden gehoord. Artikel 7 regelt die aangelegenheden. Artikel 4 vierde lid noemt de categorie aangelegenheden waarbij een informatie en overlegplicht van de Landen ten opzichte van elkaar bestaat. In art. 8 zijn de betreffende aangelegenheden nader omschreven. Hoofdstuk III regelt de Ministeriële Samenwerkingsraad in de artt. $9 \mathrm{t} / \mathrm{m} 16$, hoofdstuk IV de totstandkoming van eenvormige landsverordeningen in de artt. $17 \mathrm{t} / \mathrm{m}$ 27, hoofdstuk V het Constitutioneel Hof in de artt. $28 \mathrm{t} / \mathrm{m} 39$ en de rechterlijke organisatie wordt geregeld in hoofdstuk VI, de artt. 40 $\mathrm{t} / \mathrm{m} 66$.

Het aantal en de aard van de onderwerpen die aan de zelfstandige regelingsbevoegdheid van de Landen zijn onttrokken suggereert een grotere gebondenheid van de Landen, dan waarvan in werkelijkheid sprake is. ${ }^{129}$ Voor de meeste gebieden op het financieeleconomisch, monetaire en fiscale vlak is voor de laagste trap van samenwerking gekozen. Op een tiental niet onbelangrijke beleidsterreinen kunnen de Landen echter niet zelfstandig beslissen, maar moet regelgeving door de Ministeriële Samenwerkingsraad (de Raad of MSR) worden geïnitieerd (art. 7) zoals:

- het burgerlijk-, straf-, faillissements- en tuchtprocesrecht;

- de instelling en samenstelling van het Constitutioneel Hof en de rechterlijke macht;

- de rechtsbescherming voor ambtenaren bij geschillen aangaande hun rechtspositie, voorzieningen voor geschillen in de fiscale sfeer;

- de geschillenbeslechting naar aanleiding van conflicten die ontstaan bij de toelating en vestiging van beroepsgroepen.

Zie ook Fernandes Mendes (1986) p. 76 e.v. 
De besluitvormingsprocedure in de Raad en de aanvullingsbevoegdheid ten aanzien van deze onderwerpen welke aan de Landen is overgelaten stelt echter zowel Aruba als de Nederlandse Antillen in staat uiteindelijk ook op deze terreinen een eigen koers te varen. De Samenwerkingsregeling derogeert voor de daarin genoemde terreinen aan de Staatsregelingen van de Nederlandse Antillen en Aruba. Het constitutionele karakter blijkt uit de bijzondere procedure waarbij telkens een meerderheid van tweederde van de aanwezige parlementariërs uit beide parlementen, die overigens zelfstandig vergaderen, is vereist (art. 74 derde lid). ${ }^{130}$ Deze procedure is zwaarder dan bij de toepasselijke regels voor wijziging van de Staatsregeling, waarbij immers de tot wetgeving bevoegde organen der Landen geheel in eigen hand hebben of en in hoeverre wijziging zal plaatsvinden.

Artikel 2 van de Samenwerkingsregeling draagt de Landen op bij wetgeving en bestuur de bepalingen van de Samenwerkingsregeling in acht te nemen. Blijkens art. 36 van de Samenwerkingsregeling heeft het Constitutioneel Hof de exclusieve bevoegdheid wettelijke bepalingen der Landen die in strijd zijn met de Samenwerkingsregeling buiten toepassing te laten. Het Hof heeft niet de bevoegdheid te oordelen over een eilandelijk wetgevingsprodukt.

De bevoegdheden van de Ministeriële Samenwerkingsraad (Raad of MSR) zijn geregeld in hoofdstuk II, de artt. $9 \mathrm{t} / \mathrm{m} \mathrm{16}$. De Raad is het enige orgaan waarin tussen de twee landen overleg wordt gevoerd en waarin over gemeenschappelijke onderwerpen besluiten worden genomen. Zes bewindslieden maken deel uit van de Raad, elk Land wijst er drie aan, waaronder in elk geval de beide premiers, waarvan er één om de zes maanden het voorzitterschap van de Raad vervult (art. 10). De staatsrechtelijke betekenis van de Raad is gering en wordt in de MvT zoveel mogelijk geminimaliseerd. De Raad is geen naar buiten werkend staatsrechtelijk orgaan, maar meer een ontmoetingspunt der regeringen. ${ }^{131}$

Dit is een merkwaardige stelling daar het 'geminimaliseerde' orgaan wel bevoegd is bindende en exclusieve besluiten te nemen over: ${ }^{132}$

Zie art. 149 lid twee Staatsregeling Nederlands Antillen; of tweederde van het aantal zitting hebbende leden, art. VII.1 tweede lid Staatsregeling Aruba.

in Fernandes Mendes (1986) p. 79. 
- de benoeming van de President van het Constitutioneel Hof;

- benoeming en ontslag van rechter-plaatsvervangers in eerste aanleg en de griffier van het Gemeenschappelijk Hof van Justitie;

- bepalingen omtrent de hoogte van de invoerrechten en accijnzen en de toelating en vestiging van beroepspersonen. ${ }^{133}$

De Raad legt geen verantwoording af voor het gevoerde beleid aan de Landsparlementen. Zou er wel een zodanige plicht bestaan dan zou dit een statusverhogend effect hebben voor de positie van de Raad en dat achtten partijen ongewenst. ${ }^{134}$ Besluiten in de Raad kunnen slechts met eenparigheid van stemmen worden genomen (art. 12).

De vaststelling van de tekst van een voorstel voor een eenvormige (gelijkluidende regeling in beide Landen) landsverordening is een der

Artikel 5 onder $7^{\circ}$ SWR is onderwerp geweest van recente jurisprudentie, zie Van Aller in: TAR-Justicia (1992) pp. 235-251; GEA 27 november 1991, vonnis nr. 1429 behorend bij KG nr 191, 1991, Deira/Wickland vs het Land Aruba. De vragen die in deze zaak van belang waren zijn: was de rechter bevoegd een uitspraak te doen over de Samenwerkingsregeling, daar deze taak is voorbehoudenaan het Constitutionele Hof. Bovendien kunnen burgers geen zaak voorleggen aan het Constitutioneel Hof. En vervolgens moest de vraag worden beantwoord of het RTC conclusiepunt 26 sub 5 uit 1983 een rechtsbeginsel was, dat directe werking heef en de landen bindt. In eerste aanleg meende de rechter dat de dreigende verwijdering van Deira getoetst kon worden aan art. 5 lid 7 van de Samenwerkingsregeling, die regeling bevat direct werkende bepalingen en is een bijzondere wet die derogeert aan de LTU. In zijn uitspraak van 16 juni 1992 was het Gemeenschappelijk Hof van Justitie (GHvJ) van mening dat deze opstelling van de rechter in Eerste Aanleg onjuist was. Het $\mathrm{GHvJ}$ oordeelde dat het recht van vrije toelating en vestiging op alle eilanden ook na de Status Aparte voor beroepspersonen was gehandhasfd. Dit achtte de rechter een beginsel van Antilliaans staatsrecht van voor 1986, dat kan wordengezien als een burgerschapsrecht met grondrechtelijketrekken. Afspraken over beroepspersonen waren op de RTC van 1983 vastgesteld in conclusie punt 26 sub 5. Deira werd geacht een beroepspersoonte zijn, ook al werkte hij in loondienst. Onder beroepspersonen werden voondien verstaan vrije beroepsbeoefenaars, zoals artsen en advocaten. In de uitspraak van het GHvJ kwam een niet eerder voorgekomen supersnelle ontwikkeling van een grondrecht door middel van gewoonterecht tot stand. De Hoge Raad bevestigde het vonnis van het GHvJ: HR 12 november 1993, Land Aruba vs Deira/Wickland Oil. Op grond van conclusiepunt 26 overeengekomen op de RTC in 1983, bestaat er een beginsel van Antilliaans staatsrecht met grondrechtelijke trekken, dat inhoudt dat beroepspersonen van de Antilliaanse eilanden en Aruba ongeclausuleerd toegang hebben tot de verschillendelanden, zolanger geen eenvormige landsverordening is die de administratieve rechtsbescherming regelt op grond van de LTU.

MvT, p. 16. 
belangrijkste besluiten die de Raad neemt, de procedure daarvoor is geregeld in hoofdstuk IV de artt. $17 \mathrm{t} / \mathrm{m} \mathrm{27}$. De ontwerptekst van een eenvormige landsverordening wordt door de parlementen van beide landen behandeld. Wijst én van de parlementen het wetsvoorstel af, dan is het daarmee van de baan. Alleen de Raad is bevoegd een ontwerp eenvormige landsverordening in te dienen (art. 18, tweede lid). De parlementen kunnen wel een initiatief ontwerp aan de Raad zenden (art. 18, eerste lid). Het is echter de Raad die beslist of een initiatief voorstel ter behandeling aan beide parlementen wordt voorgelegd. Een door de Staten van een of beide Landen geamendeerd wetsvoorstel komt terug bij de Raad, die beraadslaagt over de wijzigingen. Het al dan niet gewijzigde voorstel wordt door de Raad dan voor de tweede keer bij de Staten ingediend. Dit voorstel kan door de Staten dan alleen nog in zijn geheel worden goedgekeurd of afgekeurd (art. 21).

Sinds Aruba uit het landsverband van de Nederlandse Antillen is getreden en een zelfstandig Land vormt binnen het Koninkrijk, regelt de Eenvormige Landsverordening (EVL) ${ }^{135}$ de rechtspraak met betrekking tot de geschillen tussen de Landen. Artikel 12 van de EVL geeft het Constitutioneel Hof de uitsluitende bevoegdheid in geschillen tussen de Landen over:

a. de toepassing en interpretatie van de Samenwerkingsregeling Nederlandse Antillen en Aruba;

b. de verenigbaarheid van besluiten van de Ministeriële Samenwerkingsraad met de Samenwerkingsregeling;

c. de verenigbaarheid van wettelijke regelingen en besluiten van de landen met de Samenwerkingsregeling.

Het Constitutioneel Hof, vindt zijn uitwerking in hoofdstuk V. Het Hof zal bestaan uit 5 leden waarvan tenminste drie leden, waaronder de President, zijn gerecruteerd uit de gelederen van het Gemeenschappelijk Hof van Justitie. De overige twee leden hoeven geen beroepsrechter te zijn, doch worden benoemd op grond van hun specifieke deskundigheid. ${ }^{136}$ De benoeming der leden geschiedt door de Gouverneur. Door de Gouverneur van elk der Landen worden elk 
twee leden benoemd. Tenminste én lid dient op voordracht van het Gemeenschappelijk Hof te worden benoemd, terwijl de President van dat Hof (tevens het vijfde lid) wordt benoemd door de MSR. Het ontslag geschiedt ook door de Gouverneur en wel op dezelfde gronden als het ontslag van de rechters bij het Gemeenschappelijk Hof. Het Constitutioneel Hof heeft ook twee plaatsvervangende leden, deze beide leden worden benoemd door de Gouverneur van elk der Landen. De leden worden benoemd voor een periode van tien jaren. (Deze periode is gelijk aan de periode waarin Aruba binnen het Koninkrijk der Nederlanden een aparte status zal behouden). De inrichting, samenstelling en bevoegdheid van het Constitutionele Hof dienen alsnog bij Eenvormige landsverordening nader te worden geregeld. ${ }^{137}$ Behalve de Eenvormige Landsverordening op de Rechterlijke Organisatie zijn er geen Eenvorminge Landsverordeningen tot stand gekomen tussen beide Landen. Dit betekent dat zolang er geen geschillen rijzen, het Constitutioneel Hof nog niet feitelijk ingesteld is. Het Constitutioneel Hof is gevestigd in Aruba en heeft zitting in de Nederlandse Antillen en Aruba.

De regeling van de rechtspleging zowel in eerste als in tweede instantie is een gemeenschappelijke taak van beide landen en is nader geregeld in hoofdstuk VI, de artt. $40 \mathrm{t} / \mathrm{m}$ 66. Dit betekent een verruiming van wat op de RTC in 1983 was afgesproken; toen was alleen samenwerking in tweede instantie voorzien. ${ }^{138}$ De aparte status van Aruba behelst dus geen verandering in de rechtsmacht van het Hof, dat voor de gerechten in eerste aanleg rechters uit zijn midden kiest (art. 58). Om praktische redenen is gekozen voor de indienststelling van deze rechters bij het Land de Nederlandse Antillen. De kosten zullen onderling verdeeld moeten worden. Beide Landen hebben een Gerecht in Eerste Aanleg. Dat van de Nederlandse Antillen is gevestigd op Curaçao, zijn rechtsgebied strekt zich uit over alle Eilandgebieden van de Nederlandse Antillen.

Het Gemeenschappelijk Hof is gevestigd op Curaçao en kan zitting houden op Aruba en in elk Eilandgebied van de Nederlandse 
Antillen. ${ }^{139}$ Het Gemeenschappelijk Hof heeft twee ProcureursGeneraal (PG), voor elk Land één (art. 60). De Haagse politici hebben zich lang verzet tegen een eigen PG voor Aruba, omdat zij bevreesd waren voor de sterke politieke beïnvloeding van deze justitiële autoriteit. Het Openbaar Ministerie (OM) is niet gemeenschappelijk in tegenstelling tot het Hof van Justitie, maar is landelijk opgezet. Elke PG ressorteert onder zijn eigen Minister van Justitie. In het belang van de rechtszekerheid moet er zorg voor worden gedragen dat er voldoende waarborgen zijn opdat de eenheid van het vervolgingsbeleid van de Procureurs-Generaal bij het Gemeenschappelijk Hof van Justitie wordt bevorderd, hun rechtspositie wordt versterkt en de kansen op competentiegeschillen worden geminimaliseerd. ${ }^{140}$ De Ministers van Justitie van beide Landen blijven bevoegd om instructies aan hun respectievelijke PG's te geven. ${ }^{141}$

Als gevolg van de landelijke opzet heeft de organisatie van het OM grote wijzigingen ondergaan. Zo is thans de Officier van Justitie (OvJ) hoofd van het parket in Eerste Aanleg geworden. De andere leden van het $\mathrm{OM}$ bij dat Gerecht zijn bij het vervullen van hun functie gelijkwaardig, doch zijn in hun ambtsbetrekking ondergeschikt gemaakt aan de OvJ, hoofd van het parket. Zij zijn bevoegd binnen de landsgrenzen waar zij zijn benoemd. Die benoeming en ook het ontslag van die leden geschiedt bij Landsbesluit van het Land bij welk Gerecht zij worden benoemd. Dit gebeurt op voordracht van de betreffende PG.

Ieder der PG's kan de ander ter terechtzitting (hoger beroep) waarnemen. Hiermee is enigszins tegemoet gekomen aan de Nederlandse wens om het $\mathrm{OM}$ bij het Gemeenschappelijk Hof als een eenheid met gezamenlijke verantwoordelijkheid te laten optreden. Ten aanzien van beleidszaken geldt die vervanging of waarneming niet. Dat zou zich ook niet goed verdragen met de eigen ministeriële verantwoordelijkheid van elk Land op dit gebied. In beleidszaken

Pietersz (1986) pp. 105-110, m.n pp. 106 e.v. Pietersz meent dat ten aanzien van schorsing van een lid van de rechterlijke macht een merkwaardige bepaling is opgenomen in art. 55 vierde lid en art. 56 vierde lid. Daarin wordt gesteld dat wanneer de Ministeriële Samenwerkingsraad (MSR) van oordeel is dat een der genoemde redenen voor ontslag asnwezig is, de MSR bevoegd is de betrokken ambtenaar in afwachting van de beslissing van de Koning of Hoge Raad te schorsen en in de waameming van diens ambl te voorzien. Hier is sprake van een rechtstreekse inmenging van het bestuur in aangelegenheden van de rechterlijke macht. Pietersz. acht dit in strijd met de Trias Politica. Hij is van mening dat de schorsing moet geschieden door de Gouverneur, nadal de gevoelens daaromtrent van het Gemeenschappelijk Hof zijn ingewonnen.

141 Fernandes Mendes (1986) pp. 82 e.v. 
wordt de betreffende PG vervangen door een ander lid van het OM van dat Land. Voor de leden van het OM bij de Gerechten in Eerste Aanleg, dat zijn dus de OvJ's, zijn de ambtenarenregelingen van de Landen waarin zij optreden, van toepassing. Met uitzondering van de benoeming en het ontslag geldt dit ook voor de Advocaten-Generaal der beide Landen. De rechtspositie van de PG is bij Eenvormige Landsverordening op de Rechterlijke Organisatie, geregeld. De benoeming van de PG en ook het ontslag geschiedt na overleg met de Gouverneur van het betrokken land door de Koning (art. 63). De aanbevelingslijst wordt niet zoals bij de leden van het Gemeenschappelijk Hof opgemaakt door de MSR maar door de Gouverneur. Op zijn verzoek maakt het Hof een aanbevelingslijst op, waarvan de Gouverneur (gemotiveerd) mag afwijken (art. 61).

Artikel 63 lid noemt voor de PG tevens een nieuwe ontslaggrond namelijk de gebleken ongeschiktheid voor de functie, anders dan uit hoofde van ziekte of gebreken. Deze ontslaggrond is ingevoerd om een impasse te voorkomen bij ernstige en blijvende meningsverschillen tussen een PG en zijn regering (Minister van Justitie). Om misbruik van deze ontslaggrond te voorkomen zijn enkele waarborgen in de ontslagprocedure ingebouwd. ${ }^{142}$ De samenwerking tussen de Nederlandse Antillen en Aruba is alleen succesvol geweest voor wat betreft de rechterlijke organisatie. ${ }^{143}$ Op andere gebieden is er nauwelijks enige samenwerking tot stand gekomen. Kennelijk werkt de vrijwillige samenwerking niet.

\section{De Arubaanse Staatsregeling}

De Staatsregeling van Aruba werd door de Eilandsraad van het Eilandsgebied Aruba vastgesteld bij Eilandsverordening van 9 augus-

142

143

Eenvormige Landsverordening op de Rechterlijke Organisatie, Hoofdstuk V, de griffie, de artt. 22 t/m 27; Pietersz (1986) p. 107 e.v.

PB 1985, 170, AB 1985, 59. Volgens Bongenaar hebben de Nederlandse Antillen wel een Eenvormige Landsverordening Constitutioneel Hof, PB 1985, 173. Dit kan echter naar mijn mening alleen maar een landsverordening zijn, daar er geen procedure is gevolgd die de Samenwerkingsregeling voorschrijft voor een Eenvormige Landsverordening, Bongenaar(1986)p.90. Aruba heeft géén regeling daaromtrent getroffen, dus kan er geen sprake zijn in casu van een Eenvormige Landsverordening inzake het Constitutioneel Hof. Naar mijn mening vergist Bongenaar zich. Een Eenvormige Landsverordening Constitutioneel Hof komt ook niet voor in de Editie Schuurman en Jordens, Nederlandse Staatswetten, Statuut voor het Koninkrijk der Nederlanden, deel III, bijgewerkt tol 1 augustus 1990 . Wel kan het een regeling zijn op grond van art. 2 tweede lid Samenwerkingsregeling. 
tus $1985 .{ }^{144}$ De Arubaanse Staatsregeling is vervaardigd naar het model van de Nederlandse Grondwet van 1983 en natuurlijk heeft de Staatsregeling van de Nederlandse Antillen ook de nodige invloed uitgeoefend. ${ }^{145}$ De staatsinrichting van Aruba is in het algemeen gelijk aan die van de Nederlandse Antillen. Beide Landen van het Koninkrijk hebben dezelfde organen: Gouverneur, Regering, Raad van Advies, Ministerraad (in de Nederlandse Antillen Raad van Ministers geheten), Staten en Algemene Rekenkamer. Hun burgers genieten dezelfde fundamentele en grondrechten en zijn aan dezelfde plichten onderworpen. Wel zijn er een aantal verschillen te noemen tussen de staatsinrichting van Aruba en de Nederlandse Antillen. Aruba heeft een gecentraliseerde bestuursvorm, de Nederlandse Antillen kennen een meer gedecentraliseerd bestuur, zoals neergelegd in hoofdstuk vijf van de Staatsregeling van de Nederlandse Antillen en in de ERNA. De Staatsregeling telt in totaal 123 artikelen verdeeld over zeven hoofdstukken. De indeling van de Staatsregeling is als volgt:

AB 1985, 26, naar aanleiding van de verkrijging van de status van Land door het Eilandgebied Aruba, werd tevens het Statuut aangepast bij rijkswet van 22 juli 1985, Stb. 425, PB 102, AB 35. Ook werd de Staatsregeling van de Nederlandse Antillen aangepast bij landsverordening, PB 1985, 69 en werd de ERNA bij landsverordening met de nieuwe situatie in overeenstemming gebracht, PB 1985, 67. De regeling over de besluitvorming van de Arubaanse Staatsregeling in de Eilandsraad was vastgesteld bij Rijkswet van 20 juni 1985, Stb. 370, AB 33, PB 94: Enige overgangsbepalingen in verband met het verkrijgen van de hoedanigheid van land in het Koninkijk door Aruba. Na het aannemen van het ontwerp werd door de Gezaghebber de Eilandsraad ex. art. 5 Overgangsbepalingen ontbonden en werden verkiezingen uitgeschreven voor de Staten. Dit is de enige keer dat een Eilandsraad ontbonden werd! Omdat Aruba zelf nog niet alle benodigde wetgeving had, werd een groot aantal regelingen overgenomen van de Nederlandse Antillen. Hiervoor werden twee specifieke regelingen getroffen: de Landsverordening algemene overgangsregeling wetgeving en bestuur (met bijlage), AB 1985, 30, AB 1987, G.T. 2. 'G.T.' betekent Geldende Tekst en ziet op een overgenomen regeling van de Nederlandse Antillen, die voor Aruba is aangepast, die regeling krijgt na aanpassing de toevoeging G.T. De bijlage van de algemene overgangsregeling bevat 794 overgenomen wettelijke regelingen. Tevens werd een Landsverordening bijzondere overgangsbepalingenvastgesteld, $A B$ 1985,60 . In deze regeling werden een aantal termen en artikelen uit bestaande eilandsverordeningen en overgenomen wettelijke regelingen gewijzigd.

Deze regelingen benevens de in deze verhandeling over de Staatsregeling van Aruba genoemde regelingen en daamaast de Kiesverordening (AB 1987, 110), de Landsverordening bekendmaking en inwerkingtreding (AB 1985, 54 inhoudende regeling van het Afkondigingsblad en de Landscourant), het Landsbesluit bekendmaking wettelijke regelingen (AB 1981, 1) en het Landsbesluit regeling Landscourant (AB 1986, 21) zijn te vinden in: Pronk (1988).

145 De Nederlandse Grondwet van 17 februari 1983, (Stb. 1983, 70, PB 1983, 24) en de Staatsregeling van de Nederlandse Antillen van 29 maar 1955 (PB 1955, 32, laatstelijk gewijzigd PB 1986, 68). 


$\begin{array}{ll}\text { Hoofdstuk I } & \text { Grondrechten } \\ \text { Hoofdstuk II } & \text { Regering } \\ \text { Hoofdstuk III } & \text { Staten } \\ \text { Hoofdstuk IV } & \text { Raad van Advies, Algemene Rekenkamer en } \\ & \text { Vaste Colleges van Advies } \\ \text { Hoofdstuk V } & \text { Wetgeving en Bestuur } \\ \text { Hoofdstuk VI } & \text { Het rechtswezen en de rechterlijke macht } \\ \text { Hoofdstuk VII } & \text { Slotbepalingen. }{ }^{146}\end{array}$

Een bewerking van de artikelsgewijze toelichting op de Arubaanse Staatsregeling is te uitgebreid om te worden opgenomen. ${ }^{147}$ Wel zullen de belangrijkste verschillen tussen de Staatsregeling van de Nederlandse Antillen en de Arubaanse Staatsregeling worden aangegeven. Evenals de Nederlandse Grondwet schenkt Aruba veel aandacht aan de grondrechten. Behalve de in hoofdstuk I opgesomde grondrechten kent de Arubaanse Staatsregeling: de vrijheid van levensovertuiging, de vrijheid van betoging, het recht op eerbiediging van de persoonlijke levenssfeer en het recht op onaantastbaarheid van het lichaam. Deze laatstgenoemde rechten staan niet in de Staatsregeling van de Nederlandse Antillen. Volgens de Staatsregeling van Aruba heeft de rechter de bevoegdheid wettelijke voorschriften (bijvoorbeeld een landsverordening) te toetsen aan de grondrechtbepalingen van de Staatsregeling (artt. I.22, VI.4). voor het overige geldt het toetsingsverbod van de landsverordening aan de Staatsregeling (art. VI.4). Die toetsingsbevoegdheid aan de grondrechten heeft de rechter noch in de Nederlandse Antillen, noch in Nederland. De meeste van deze rechten zijn echter gewaarborgd in de internationale mensenrechtenverdragen, die mede van toepassing zijn in de Nederlandse Antillen. De rechter heeft in de Nederlandse Antillen toetsingsbevoegdheid op grond van die verdragen en niet op grond van de Staatsregeling.

Evenals voor de wijziging van de Staatsregeling van de Nederlandse Antillen is voor de wijziging van de Staatsregeling van Aruba een gekwalificeerde meerderheid in de Staten van Aruba vereist. In de Nederlandse Antillen bedraagt deze meerderheid twee derden van het aantal uitgebrachte stemmen, in Aruba twee derden van het aantal zitting hebbende Statenleden. Voor de Arubaanse Staatsregeling geldt dus een zwaardere wijzigingsprocedure (de artt. VII.1 en 149 lid 2

146

147 Voor een artikelsgewijze toelichting zie Van Aller in: Pronk en Croes (1993). De behandeling volgt de uiteengezette indeling en vergelijkt tevens de Arubaanse Staatsregeling met de Staatsregeling van de Nederlandse Antillen en de Nederlandse Grondwet. 
Staatsregeling Nederlandse Antillen).

De Staatsregeling van de Nederlandse Antillen wijdt een afzonderlijk hoofdstuk aan de Gouverneur, in de Arubaanse Staatsregeling is dat niet het geval. Niet de Gouverneur maar de Koningin wordt als deelgenoot in de regering genoemd (art. II.1). Daar waar de Gouverneur optreedt als hoofd van de Landsregering is in de Arubaanse Staatsregeling de term Gouverneur steeds vervangen door regering (bijvoorbeeld art. V.1). De bevoegdheden van de Gouverneur van Aruba als orgaan van het Koninkrijk zijn geregeld in het Reglement voor de Gouverneur van Aruba. ${ }^{148}$

De bepalingen van de Raad van Advies verschillen in beide Staatsregelingen nogal van elkaar. De Raad van Advies van Aruba bestaat maximaal uit vijf leden, in de Nederlandse Antillen bestaat dit college tenminste uit vijf leden, waarvan een ondervoorzitter. In de Antilliaanse Staatsregeling is de voorzittersfunctie gereserveerd voor de Gouverneur. In Aruba wordt éen van de vijf leden benoemd tot voorzitter. De Raad van Advies van Aruba kent geen buitengewone leden.

Een lid van de Raad van Advies van Aruba kan deze functie voor hoogstens zeven jaren bekleden. In de Nederlands Antillen is dat vijf jaren. In Aruba kunnen naast de regering 66 k de Staten het advies van de Raad vragen. De adviezen van de Arubaanse Raad van Advies zijn in beginsel openbaar, voorzover zij niet in strijd zijn met het belang van het Land of het Koninkrijk. Artikel V.19 van de Arubaanse Staatsregeling kent een specifieke bepaling die de overheid verplicht tot openbaarheid in de uitvoering van haar taak (art. V.19). Deze bepalingen kent de Antilliaanse Staatsregeling niet.

De Arubaanse Ministerraad maakt, anders dan de Raad van Ministers van de Nederlandse Antillen geen deel uit van de regering. Het zijn de ministers, die met de Koningin, vertegenwoordigd door de Gouverneur, de regering van Aruba vormen. De Arubaanse staatsregeling legt hiermede de nadruk op de individuele ministeriële verantwoordelijkheid. De Staatsregeling van Aruba kent aan de Minister-President een bijzondere positie toe. Die positie komt ondermeer tot uiting in de bepaling dat naast het overleg dat gevoerd moet worden met de Staten over de benoeming van de ministers, over de benoeming van de Minister-President afzonderlijk overleg is vereist. Dit houdt in dat aan de Staten de naam van de te benoemen Minister-President moet Sib. 1985, 672, AB 1986, 5. 
worden opgegeven. De Minister-President wordt evenals de andere ministers bij landsbesluit benoemd en ontslagen (art. II.2). In de Nederlandse Antillen daarentegen wordt de Minister-President als voorzitter van de Raad van Ministers aangewezen bij beschikking van de Raad.

De Staatsregeling van Aruba schrijft verplichtend voor, dat een minister die niet langer het vertrouwen van de Staten heeft, zijn ambt ter beschikking moet stellen. Hoewel een dergelijke verplichting niet in de Antilliaanse Staatsregeling is opgenomen, vloeit zij voort uit het parlementaire stelsel. Weigert de minister af te treden, dan zal zowel in Aruba als de Nederlandse Antillen de minister door de Gouveraeur (regering) ontslagen worden, tenzij besloten wordt tot ontbinding van de Staten.

Anders dan in de Nederlandse Antillen kan in Aruba het maximum aantal te benoemen ministers (negen) zelfs niet bij landsverordening gewijzigd worden (art. II.6 lid twee). Het instellen van ministeries geschiedt in Aruba bij landsverordening, dus met medezeggenschap van de Staten.

Een Statenlid in Aruba heeft een volledige dagtaak, hij ontvangt een bezoldiging. Daarom kan en Statenlid van Aruba ook niet tegelijk actief dienend ambtenaar zijn (art. II.3). De Statenleden van de Nederlandse Antillen oefenen hun functie parttime uit en ontvangen een schadeloosstelling. De Arubaanse Staten bestaan uit 21 leden, de Staten van de Nederlandse Antillen kennen 22 leden. De aanvang van het nieuwe zittingsjaar van de Staten van Aruba is vastgesteld op de tweede dinsdag van september. In de Nederlandse Antillen is dat de tweede dinsdag in mei. In Aruba moet uiterlijk op de tweede dinsdag in september de begroting zijn ingediend. In de Nederlandse Antillen is dat 1 augustus. De Staatsregeling van Aruba kent niet het verschil tussen gewone en buitengewone Statenzittingen. Ook mist de Arubaanse Staatsregeling een bepaling, zoals vermeld in de Antilliaanse Staatsregeling, die de Gouverneur het recht geeft de Staten in buitengewone zitting bijeen te roepen (art. 66 Staatsregeling Nederlandse Antillen).

De voorzitter en de ondervoorzitter van de Staten van Aruba worden voor de gehele zittingsduur benoemd (vier jaren). In de Nederlandse Antillen worden zij benoemd voor slechts een zitting (een jaar). Bij de bepaling van het quorum in de Staten van Aruba moet rekening worden gehcuden met de helft van het aantal zittinghebbende leden. Er wordt rekening gehouden met bestaande vacatures. Voor het bepalen van het quorum in de Staten van de Nederlandse Antillen moet rekening worden gehouden met de helft van het (totaal) aantal 
leden, waaruit de Staten bestaan. In Aruba is het vragenrecht vastgelegd in de Staatsregeling (art. III.17).

De bepalingen in beide Staatsregelingen betreffende het kiesrecht zijn in het algemeen gelijk. Slechts op het gebied van de uitsluitingsgronden wijken ze af. In navolging van de Nederlandse Grondwet bevat de Staatsregeling van Aruba minder uitsluitingsgronden voor de uitoefening van het kiesrecht. ${ }^{149}$ Het lidmaatschap van de Staten kent meer onverenigbare betrekkingen (incompatibiliteiten) dan het lidmaatschap van de Staten van de Nederlandse Antillen. Een ambtenaar in actieve dienst kan geen Statenlid zijn, dit geldt ook voor een lid van de rechterlijke macht, de Procureur-Generaal en de AdvocaatGeneraal bij het Gemeenschappelijk Hof van Justitie.

De wijze waarop in Aruba een landsverordening tot stand komt verschilt niet van de procedure in de Nederlandse Antillen. Alleen wordt voor een aantal handelingen in beide Staatsregelingen een afwijkende terminologie gebruikt. In Aruba heet het proces dat leidt tot de totstandkoming van een landsverordening door Staten en regering gezamenlijk: vaststelling (art. V.1.). In de Nederlandse Antillen wordt dan gesproken van het uitoefenen van de wetgevende macht (art. 67 lid 2). Nadat de Staten van Aruba een ontwerp-landsverordening hebben goedgekeurd geschiedt bekrachtiging door de regering (art. V.2). In de Nederlandse Antillen geschiedt vaststelling van een ontwerp-landsverordening na verkregen goedkeuring van de Staten, door de Gouverneur (art. 18 lid 1).

In Aruba vindt de bekendmaking (afkondiging) van landsverordeningen en landsbesluiten houdende algemene maatregelen plaats in het Afkondigingsblad (AB). In de Nederlandse Antillen is dat het Publicatieblad (PB). Wanneer in een landsverordening de datum van inwerkingtreding niet is vermeld, dan treedt volgens de Staatsregeling van de Nederlandse Antillen de landsverordening in werking met ingang van de dertigste dag na die van de uitgifte van het PB waarin zij is afgekondigd. Deze regeling ontbreekt in de Arubaanse Staatsregeling, maar is te vinden in de Landsverordening Bekendmaking en inwerkingtreding. ${ }^{150}$

De Arubaanse Algemene Rekenkamer ontleent haar bevoegdheid direct aan de Staatsregeling (de artt. IV.5 t/m IV.8). Bij de Rekenka-

Vergelijk de artt. III.7 Arubaanse Staatsregeling en 46 Staatsregeling van de Nederlandse Antillen.

150

AB 1985, 54; art. 7 bepaalt dat indien een datum voor de inwerkingtreding van de regeling ontbreekt, dit gebeurt met ingang van de vijfliende dag na de datum van bekendmaking. Zie ook art. V.8 Staatsregeling Aruba, daarin wordt bepaald dat de inwerkingtreding van landsverordening bij landsverordening nader wordt geregeld. 
mer van de Nederlandse Antillen is dat niet het geval.

De weinige bepalingen die in de Staatsregeling van Aruba voorkomen over de Gevolmachtigde Minister van Aruba in Nederland komen in het algemeen overeen met die in de Staatsregeling van de Nederlandse Antillen over de Gevolmachtigde Minister van de Nederlandse Antillen. In Aruba bestaan meer incompatibiliteiten ten aanzien van de functie, dan op de Nederlandse Antillen (art. II.10). De bevoegdheden die beide Gevolmachtigde Ministers aan het Statuut ontlenen zijn hetzelfde. ${ }^{151}$

De jaren 1984 en 1985 waren voor Aruba op politiek gebied moeilijk. Er kwam een eind aan de heerschappij van de MEP. Dit was niet verwonderlijk gezien de ontwikkelingen van de jaren daarvoor. In 1975 ontstond de eerste splinterpartij van de MEP toen 'Watty' Vos en twee andere leden van de MEP, Richardson en Gomez de RUBA oprichtten. Hierdoor ontstond een versmalling van de etnische basis van de MEP, omdat Vos veel stemmen uit West-Oranjestad meenam. Richardson en Gomez namen de stemmers uit San Nicolas met zich mee. De RUBA werd gezien als de MEP voor donkere Arubanen. De positie van donkergekleurde politici en aanhangers binnen de MEP werd steeds problematischer. Die problematiek was niet alleen terug te voeren op raciale tegenstellingen, maar ook op het feit dat Watty Vos de belangrijkste concurrent van Betico Croes was geworden binnen de MEP. ${ }^{152}$

De eerste nieuwe partij die in de jaren tachtig aan het politieke front verscheen was de Partido Democratico Arubiano (PDA) onder leiding van L.S. Berlinski. In 1983 was de partij kort voor de verkiezingen opgericht, uit ontevredenheid over het regeringsbeleid van de MEP. In 1983 haalde de partij de kiesdrempel niet, omdat, de MEP na het gewond raken van Betico Croes in 1983 haar grootste verkiezingszege behaalde. Hierdoor stagneerde ook de aanwas van de AVP.

Het politieke beleid van de MEP werd steeds exclusiever. 'Wie niet voor is, is tegen' verwoordde de politieke sfeer op Aruba. 'Niet voor' betekende niet voor de Status Aparte en tégen de MEP, tégen

\footnotetext{
191 Het Kabinet voor Nederlands Antilliaanse Zaken, dat de desbetreffende Nederlandse Minister ondersteunt, heet sinds de invoering van de aparte status voor Aruba: Kabinet voor Nederlands-Antilliaanse en Arubaanse Zaken (KABNA is nu KABNAA, maar wordt nog steeds regelmatig als KABNA geschreven); Bongenar (1986) p. 93. 
Betico Croes en dus ook tégen Aruba en de Arubanen. Politieke geschillen werden teruggebracht tot dit ene punt en de staatkundige strijd kreeg alle politieke aandacht. De MEP eigende zich - begrijpelijkerwijs - de Status Aparte toe, maar ging in de ogen van velen te ver toen zij, vanaf 1976, jaarlijks de eilandelijke feestdag van volk en vlag ging vieren op 18 maart, - de dag waarop in 1948 de eerste massabijeenkomst ter onderstreping van de wensen tot grotere zelfstandigheid had plaatsgevonden.

In 1985 werd de Arubaanse vlag en het volkslied op 18 maart, met steun van de MEP meerderheid in de Eilandsraad aanvaard. ${ }^{153}$ De nationale feestdag, de vlag en het volkslied werden door de oppositie gezien als typische MEP-fenomenen en niet als nationale symbolen. Thans (1994) lijkt 18 maart meer een feestdag te zijn geworden voor de gehele bevolking.

Ook met het uitwerken van de besluitenlijst van de RTC en de voorbereidingen van de Status Aparte verloor de MEP aan populariteit. Van de nagestreefde economische, monetaire, politieke en justiële samenwerking met de 'Antillen van de Vijf' kwam weinig terecht. Slechts het Gemeenschappelijk Hof van Justitie en het Soldariteitsfonds, waar de arme eilanden Bonaire, Sint Eustatius en Saba mee onderhouden moesten worden, werden geregeld. Op Aruba zelf had de MEP grote moeite met het vervangen van de dubbele bestuurslaag (eilands- en landsambtenarij) door één enkele laag. Alleen de keuze voor de toekomstige Gouverneur verliep zonder veel incidenten. Net als aan het einde van de PPA jaren namen de geruchten over politieke patronage toe. Deze zou meer en meer op corruptie zijn gaan lijken en steeds vaker ten goede komen aan de partijtop en de eigen familie.

Zelfs Betico Croes zette bij velen zijn populariteit op het spel door zich op 20 december 1985 te laten benoemen tot 'Algemeen Adviseur van het Bestuurscollege', waardoor zijn macht ongekend groot werd. In de Kleurenbijlage van Vrij Nederland van 1978 wordt het voorbeeld aangehaald van J\&J, Jossy Croes en Jossy Luydens. Samen vormden zij de Algemene Dienst, die ressorteerde onder de Algemeen Adviseur Betico Croes. De Algemene Dienst droeg net zomin verantwoordelijkheid voor het bestuursbeleid, als de Algemeen Adviseur. Ambtelijk bestonden zij niet, maar alle verzoeken gingen via hun Dienst. Verzoeken van MEP-leden werden toegewezen, van niet MEP-leden meestal niet. De ingewijden kregen beurzen voor studies waar reeds 'stops' op stonden, banen waarvoor men niet 
geschikt was en dergelijke. Zonder dat hij enige serieuze parlementaire verantwoording hoefde af te leggen kon Betico Croes al zijn gedeputeerden controleren en de gehele politiek naar zijn hand zetten. Jossy Mansur, redacteur van verschillende kranten op Aruba merkte daarover op:

"De schaduw van de toekomst verkilt reeds nu ons eiland. Reeds heerst de wil van één man over de wet, reeds is het grondwettelijk gezag vervangen door de willekeur. Te vaak heb ik het in andere landen zien gebeuren, om niet te geloven dat het hier ook kan. Jamaica, Brits-Guyana, het is er op dezelfde manier begonnen". ${ }^{154}$

Het gerezen wantrouwen groeide nog meer toen eind 1984 bekend werd dat er bij de eilandsfinanciën maar liefst een tekort was van 340 miljoen Antilliaanse guldens was ontstaan. Dit geld was in enkele jaren tijd zonder duidelijke begrotingsplanning of afrekeningen uit de eilandskas verdwenen. Feitelijk leek dit geld opgegaan te zijn aan patronage ten behoeve van de stemmenwinst. Grote demonstraties waren het gevolg en het openlijk verzet tegen de partij die voorheen vrijwel alle massabijeenkomsten zelf georganiseerd had, groeide.

De naderende ondergang was vervolgens zichtbaar in het toenemend aantal conflicten van de MEP met een aantal belangrijke bestuurders en politici. Ex Mep-er en Gezaghebber Bislip en Eilandssecretaris Booi richtten samen met Kelly de 'Accion Democratico Nacional' (ADN) op na conflicten met Croes en de MEP over de regels van de democratie en de bevoordeling van de partijelite. In 1983 was Kelly gezien het stemmenresultaat de tweede man van de MEP. Deze partij haalde haar stemmen ongetwijfeld ook uit de traditionele achterban van de MEP en was dan ook een serieuze concurrent in de strijd om de autochtone stemmen.

Het meeste had de MEP echter te lijden van de sluiting van de Lago door Exxon en het gebrek aan vertrouwen dat de bevolking had in de MEP als partij die het economisch herstel moest brengen. Het sluiten van de Lago betekende dat de overheidsinkomsten met $40 \%$ daalden. Het was Betico Croes niet gelukt om de Lago open te houden, hetgeen Minister-President Liberia-Peters wel gelukt was in een vergelijkbare situatie, door de hulp van Nederland in te roepen en de gevolgen van de sluiting van de Shell-raffinaderij, zoveel mogelijk te beperken. Medio 1985 werd de Venezolaanse maatschappij Isla opgericht, die de raffinaderij in Curaçao vijf jaar voor eigen 
rekening zou exploiteren.

Ook had men weinig vertrouwen in de economische herstelpolitiek van de MEP. De partij sprak teveel over extra hulp van Nederland en de tijdelijke emigratie van duizenden Arubanen naar Nederland. Er werd te weinig gereageerd op de herstructureringsvoorstellen van het IMF. De herstructureringsvoorstellen hielden in verhoging van belastingen en invoerrechten, het ontslaan van overtollige ambtenaren en het flink in salaris korten van de resterende ambtenaren. Ook zou er een soldariteitsheffing moeten worden ingevoerd, waaraan de werknemers moesten bijdragen om het ecnonomisch herstel te financieren.

De IMF-adviezen hielden voor de Arubaanse bevolking een verlaging van de levensstandaard in van $30 \% .{ }^{155}$ De MEP vestigde haar hoop teveel op de activiteiten van projectontwikkelaar Melchior, die van mening was dat Aruba zich zoveel mogelijk als een onafhankelijke natie moest presenteren. ${ }^{156}$ Dit was in strijd met de adviezen

Alofs (1990) p. 169.

136 Keesings Historisch Archief, juni 1989, pp. 357-360en p. 364. De tot Belg genaturaliseerde Nederlander Melchior had in februari 1985 een contract met het toenmalige Bestuurscollege van Aruba gesloten 'aangasnde het verrichten van studies inzake de toekomstige werkgelegenheid en inkomstenbronnen voor Aruba'. Voor zijn onderzoek kreeg Melchior 1 miljoen dollar van de Nederiandse regering. In januari 1986 kwam hij met zijn rapport. Het rapport ging ervan uit dat Aruba in 1996 onathankelijk zou zijn, Melchior vond ook dat Aruba zich zoveel mogelijk als een ona fhankelijke natie moest presenteren. De onathankelijkheid leverde een probleem op, omdat de regering Eman eerst nog een referendum wilde laten houden over de onafhankelijkheid. Indien aan allerlei randvoorwaarden was voldaan zag Melchior vele mogelijkheden, waarvoor hij zei menig investeerder te kunnen aantrekken. Tegen betaling van een additioneel honorarium van 1 miljoen dollar, wilde Melchior de regering wel adviseren en zijn kennis en contacten aanwenden om potentiële investeerders aan te trekken. Het rapport was omstreden, omdat Aruba als 'een onafhankelijke staat in wording' een hoog loonpeil had, een lage produktiviteit door een gebrek aan industriële ervaring, een beperkte thuismarkt en een beperkt arbeidspotentieel, benevens een 'post Lago-trauma', zoals het rapport vaststelde. Maar daarom waren er fondsen nodig om potentièle investeerders aan te trekken. Want Melchior constateerde wel dat er extra hoge risico's verhonden waren aan het doen van investeringen in Aruba. Als Aruba onathankelijk zou worden kon het ook een beroep doen op de internationale fondsen. zoals de EEG, het ontwikkelingsfondsvan de VN, regionale samenwerkingsverbandenen de OPEC. Het vragen van steun had echter alleen maar zin als Aruba de internationale organisaties duidelijk wist te maken op welke manier men de gelden op een zinvolle manier dacht te besteden. Daartoe diende een 'integraal stimuleringsplan voor de economie' te worden ontwikkeld. Melchior dacht ook een Mijnbouwmaatschappij op te richten om onderzoek te doen naar de winning van natuurlijke grondstoffen, hij dacht hierbij aan goud. Ook zag Melchior wel wat in de introductie van een gouden munt, winning van olie en gas en het opzetten van een kuuroord voor chelatie-therapie. De Tweede Kamer sprak een vernietigend oordeel uit over het rappon van Melchior en kritiseerde minister De Koning, die zich positief had uitgelaten over de voorstellen van Melchior. De Kamer wees elke verdere bemoeiing van Melchior met Aruba af. Op 6 november 
van het IMF. ${ }^{157}$ Bovendien speculeerde de MEP teveel op de overname van de Lago door andere maatschappijen, zonder dat er concrete resultaten op tafel kwamen, in plaats van zich in te spannen voor de herstructurering van de economie en sanering van het overheidsapparaat.

In juli 1985 braken protesten en stakingen uit tegen de herstructurering van het onderwijs. De plannen werden ingetrokken, maar de partij verloor veel van haar aanhang. De acceptatie van de onafhankelijkheid droeg uiteindelijk bij aan de (tijdelijke) ondergang van de MEP in 1985. De 'opgedrongen onafhankelijkheid' in combinatie met de in 1986 ingevoerde Solidariteitsheffing van $8,2 \%$ aan de werknemers deed de populariteit van de MEP dalen. Op Aruba liepen de reacties op de onderhandelingsresultaten sterk uiteen. De MEP stelde de strijd om de Status Aparte eindelijk gewonnen te hebben, terwijl de oppositiepartijen haar verweten de onafhankelijkheid te hebben geaccepteerd. Zij wezen erop dat het altijd gegaan was om de zelfstandigheid ten opzichte van Curaçao en niet om onafhankelijkheid buiten het Koninkrijk.

De laatste Eilandsraadverkiezingen en feitelijk de eerste Statenverkiezingen werden gehouden op 22 november 1985 . Voor de verkiezingen werd al duidelijk dat de oppositiepartijen bereid waren gezamenlijk de MEP uit het Bestuurscollege te wippen en samen een nieuw Bestuurscollege te vormen. Duidelijk was dat de AVP, onder leiding van Henny Eman, de partij was die Betico Croes het Minister-Presidentschap wilde ontnemen. "Henny Eman wierp zich hierbij op als de Arubaanse Ruud Lubbers". ${ }^{158}$ Door de AVP was gekozen voor een zakelijke opstelling in de verkiezingsstrijd "pa un Aruba nobo", temeer daar de herinneringen aan de gewelddadigheden van $1983 \mathrm{nog}$ vers in het geheugen lagen en de AVP geweldadigheden wilde voorkomen. Behalve het schietincident, waarbij Betico Croes betrokken was, was er toen ook een jongen van 15 jaar met een AVP vlag door twee MEP-leden doodgeschoten. Er zou niet 'gescholden' worden of aan de prestaties op staatkundig terrein door de MEP worden getwijfeld, maar doordacht kritiek worden geleverd op de sociaal-economische politiek van de partij. In plaats van het emotionele nationalisme van Betico Croes en de MEP moest een 'no-nonsense'

1986 moest minister De Koning erkennen, dat het contract tussen Aruba en Melchior niets concreets had opgeleverd. 
opstelling, gericht op economisch herstel door Henny Eman en de AVP, de kiezer worden aangeboden.

De MEP stelde in haar verkiezingsvoorbereidingen opnieuw de Status Aparte en haar leider centraal. 'Betico Ministro Presidente', was het motto van de MEP, die door grote auto-optochten en massabijeenkomsten opnieuw de absolute meerderheid in de volksvertegenwoordiging wilde halen. De partij had reeds twee vergunningen voor auto-optochten aangevraagd: één vóór de verkiezingen en één vlak daarna om de verwachte overwinning te vieren. Croes was vol vertrouwen dat hij erkenning zou krijgen van 'zijn' volk voor het feit dat hij uiteindelijk de Status Aparte voor elkaar had gekregen. 'Nos lider a cumpli status aparte', stond overal op de verkiezingsborden te lezen. De MEP-campagne verliep wat minder goed, dan andere jaren, zeker vergeleken met die van de AVP, die kennelijk over veel meer geld beschikte van het bedrijfsleven. Maar Henny Eman miste wat Croes in overvloed had: charisma en een perfecte bespeling van de publiciteit en van de sentimenten van de kiezers. Croes afficheerde zich als een eenvoudige zoon van Aruba, die zijn gezinsleven en zijn gezondheid verwaarloosde om het volk te kunnen dienen. ${ }^{159}$ Zoals voorheen de dominantie van Curaçao in het voordeel van de separatisten had gewerkt, zo werkten in 1985 de economische crisis en de dreiging deze 'onafhankelijk' te moeten oplossen, in het nadeel van de MEP. ${ }^{160}$ Beide partijen meenden als overwinnaar uit de strijd te zullen komen en hadden beide al vergunning gevraagd om na de verkiezingen een overwinningsoptocht te mogen houden.

De MEP bleef de grootste partij. Betico Croes alleen kreeg 8.879 stemmen. Het totale aantal behaalde stemmen voor de MEP bedroeg slechts 13.793 stemmen, goed voor acht zetels, maar wel 7.005 stemmen minder dan tijdens de verkiezingen van 1983. De grote winnaar was de AVP, die ruim 3.000 stemmen won en met zeven zetels slechts én zetel minder kreeg dan de MEP. De overige drie partijen PPA, PDA en ADN kregen ieder twee zetels. De PPA bleef dankzij de goede resultaten in San Nicolas de derde partij met 4.493 stemmen. De PDA en ADN haalden ieder tussen de 3.000 en 4.000 stemmen, voornamelijk in en rond Noord (een Arubaans district). Het grootste verlies had de MEP geleden in Oranjestad. Maar zelfs in het bolwerk en de bakermat van de partij, Santa Cruz, had men één kwart van de stemmen verloren. Jonge stemmers hadden de MEP sterk gemeden en alleen in de leeftijdsgroep boven de veertig bleef de MEP de grootste partij.

\footnotetext{
159 Keesings Archief, december 1985, pp. 782 e.v.

$160 \quad$ Alofs (1990) p. 525.
} 
De verenigde oppositiepartijen schoven Betico Croes en zijn MEP na dertien jaren terug in de oppositiebanken. Het gevolg van de verkiezingsresultaten was dat niet Betico Croes maar Henny Eman formateur werd en na 1 januari 1986 de eerste Minister-President van het Land Aruba werd en dat alle partijen, behalve de MEP, ministers in het nieuwe kabinet leverden. Op 1 januari 1986 liep de geschiedenis van het Eilandgebied Aruba als onderdeel van de Nederlandse Antillen af en begon de geschiedenis van het Land Aruba, als derde partner binnen het Koninkrijk der Nederlanden. ${ }^{161}$

In november 1985 deed Koot nogmaals een onderzoek naar de wensen ten aanzien van de onafhankelijkheid van de Curaçaose en Arubaanse bevolking en de Curaçaose politieke partijen. Slechts $10 \%$ van de Arubaanse en $12 \%$ van de Curaçaose ondervraagden zei voorstander te zijn van de onafhankelijkheid. De meeste Arubanen wilde wel de Status Aparte, maar verwierpen het idee van de onafhankelijkheid. Op beide eilanden werd als reden hiervoor opgegeven het geringe vertrouwen in de economische overlevingskansen. Op Aruba was eveneens een niet onaanzienlijke groep bang voor dictatoriale neigingen van MEP-bestuurders. De verkiezingsuitslag in november 1985 waarbij de MEP de absolute meerderheid zou verliezen, gaf dit ook duidelijk aan. ${ }^{162}$ De viering van de Status Aparte tijdens de jaarwisseling was sober gehouden vanwege de slechte economische situatie. De viering werd overstemd door het bericht dat Betico Croes tijdens een auto-ongeluk enkele uren voor het ingaan van de Status Aparte zwaar gewond was geraakt. Croes was tegen een lantaarnpaal gereden, had talloze inwendige breuken en kneuzingen opgelopen en was daardoor in een diepe coma terecht gekomen. De meest charismatische politicus uit de Arubaanse geschiedenis zou niet meer bij kennis komen en na elf maanden verpleging op Aruba, in de Verenigde Staten en in Nederland stierf Betico Croes op 26 november $1986 .{ }^{163}$

Een duidelijk inzicht in de parlementaire behandeling en de wetgevende arbeid ten behoeve van de Status Aparte geeft Borman (1986). Hij voorspelde al de komende fragmentarisatic van de 'Antillen van de $\mathrm{Vijf}_{\mathrm{ij}}$. Zie voor een prognose van de Arubaanse toekomst: De Jong in: Netherlands Yearbook of International Law (1989) pp. $71-89$. zie Verton in: Nos Futuro, pp. 195-208; Koot, Internationale Spectator (1985) pp. 721-727. 
Het Arubaanse streven naar autonomie ontstond in de jaren dertig naar aanleiding van de toevloed van 'niet-autochtone Arubanen' naar Aruba om te werken in de olie-industrie. Dit streven naar decentralisatie, autonomie, 'separashon' of 'separación' werd versterkt door de opbloeiende economie. Aruba verzette zich tegen de 'overheersing' van Curaçao.

Noch de Staatsregeling van 1936, noch de Staatsregeling van 1948 brachten Aruba de gewenste zelfstandigheid. De rapporten van de Commissie Oppenheim en de Commissie Van Poelje waren bedoeld om een oplossing te vinden voor de Arubaanse wensen binnen een gemoderniseerd staatsverband. De Nederlandse regering meende geen uitvoering te kunnen geven aan conclusies van de rapporten, die een federale structuur voorstelden. Een federale structuur met eigen overkoepelende organen week teveel af van de bestaande Koninkrijksstructuur en paste slecht in een gedecentraliseerde eenheidsstaat, zoals Nederland sinds 1815 is.

Bij de herziening van de Staatsregeling van 1948 kreeg Aruba hetzelfde aantal zetels als Curaçao in de Staten, te weten 8 , maar bij de invoering van de Interimregeling (1950) werd deze voor Aruba gunstige zetelverdeling weer teniet gedaan. De afbakening tussen landelijke en eilandelijke bevoegdheden zou pas plaatsvinden in de ERNA.

Henny Eman van de AVP stelde zich sinds bet begin van de jaren veertig op als een voorvechter van decentralisatie-wetgeving. Terwijl Curaçao zich met Da Costa Gomez voorbereidde op de autonomie ten opzichte van Nederland, bepleitte Eman de zelfstandigheid van Aruba ten opzichte van Curaçao.

De acceptatie van de Interimregeling in 1950 door Eman was voor Yrausquin en zijn achterban aanleiding om uit de AVP te stappen en de Partido Patriotico Arubano (PPA) op te richten. Naar de mening van Yrausquin werd in de Interimregeling niets vastgelegd over de verlangde bestuurlijke zelfstandigheid van Aruba.

Ook de ERNA (1951) bracht niet die zelfstandigheid die Aruba zich had gewenst. In de ERNA werden vier eilandsgebieden ingesteld, die elk wel een grotere mate van autonomie kregen dan voorheen, maar deze was eerder te vergelijken met de gemeentelijke autonomie in Nederland dan met de zelfstandigheid van een deelstaat in een federatie.

In de vijftiger jaren was het Henny Eman Sr. die een lans brak voor radicale decentralisatie en pleitte voor een echte federatieve 
opbouw van de Nederlandse Antillen, alles gericht op opheffing van de 'onderhorigheid' aan Curaçao. 'Separación' was het trefwoord. De band met Nederland bleef daarbij voorop staan, iets wat door de meerderheid van de Arubanen steeds als vanzelfsprekend en wenselijk werd gezien. De leiders van de Separación konden echter niet worden vrijgepleit van het inspelen op zekere etnische en raciale ressentimenten, waarbij het blanke-Indiaanse, 'echt Arubaanse' werd gesteld tegenover het zwarte van de Curaçaoënaars en het blanke van de Hollanders.

De jaren vijftig werden gekenmerkt door de constante strijd van de AVP en de PPA. Dankzij de rol van de PPA in de landscoalitie, die tot 1969 duurde, werd Aruba niet echt overvleugeld. Daardoor bleven de centrifugale krachten in de onderlinge eilandsbetrekkingen redelijk in evenwicht. De AVP, ook eilandelijk in de oppositie in die jaren, hield de fakkel van de Separación brandende. Na 1969 wijzigde de situatie drastisch. De neergang van de PPA zette door. De AVP werd steeds nationalistischer, 'mei 1969' vervreemdde Aruba van Curaçao.

De jaren zeventig en tachtig werden gekenmerkt door de tweede golf van staatkundig separatisme in de vorm van Betico Croes' Status Aparte-beweging, door de uitbreiding van de toeristenindustrie en van het ambtenarenapparaat, benevens de ondergang van de olie-industrie in 1985. In de jaren zeventig benadrukte de afscheidingsbeweging de tegenstelling tussen autochtonen en allochtonen en met name het onderscheid tussen autochtone blanke plattelands-Arubanen en allochtone Afro-Caraibische Arubanen. Daarbij speelde de verslechterde politieke verhoudingen tussen Aruba en Curaçao een belangrijke rol. De MEP wenste een federatie van de Nederlandse Antillen, met Aruba als een zelfstandige deelstaat, maar herzag dit standpunt toen zij zich realiseerde dat in een federatief verband Curaçao altijd de overhand zou hebben. De MEP opteerde toen voor directe banden met Nederland (een Status Aparte). Toen Nederland dat niet wilde accepteren koos Aruba voor een Gemenebest bestaande uit Nederland, Suriname, de overige Antillen en Aruba. De MEP stond in deze opvatting alleen in Aruba. De PPA, als regeringspartij ondersteunde het Antilliaanse federatie model. Nadat de MEP in 1973 overtuigend de verkiezingen won, kon haar standpunt aan gezag winnen en sloot de AVP zich aan bij het standpunt van de MEP.

De periode februari 1974 - februari 1975 kan in twee duidelijke fases worden verdeeld. Na het bekend worden van het voornemen van de de Surinaamse regering in 1974 om vóór 1976 de onafhankelijkheid te verkrijgen, vreesden de Antilliaanse politici dat ook de Nederlandse 
Antillen in 1975 onafhankelijk zouden moeten worden. Indien deze vooronderstelling juist zou zijn, zouden de Antillen de planmatige voorbereiding van de onafhankelijkheid kunnen vergeten. Op grond van deze gebeurtenis vormden de Antilliaanse regering en de politieke partijen een eensgezind front en maakten Nederland duidelijk dat de Antilliaanse problematiek van een geheel andere orde was dan de Surinaamse, om zodoende de dreigende onafhankelijkheid te blokkeren.

Het nationale gevoel hield echter niet lang stand. De PSD één van de regeringspartijen kwam eind april 1974 met de verklaring dat zij streefde naar een onafhankelijk Curaçao. De Antilliaanse regering had te snelle conclusies getrokken. De Nederlandse regering bleek bereid te zijn de Antillen de tijd te gunnen de onafhankelijkheid planmatig voor te bereiden. De druk die de Antilliaanse partijen hadden gevoeld was verdwenen, maar daarmee ook het nationale gevoel. De onderlinge tegenstellingen laaiden weer op en een spoedige overeenkomst over de inter-insulaire verhoudingen, de eerste fase in de planmatige voorbereiding van de onafhankelijkheid leek er niet meer in te zitten. De Antilliaanse regering achtte een afscheiding van Aruba uit het Antilliaanse verband onaanvaardbaar. De drie eilandelijke topoverleggen tussen augustus 1974 en februari 1975 brachten de oplossing niet dichterbij, temeer daar Aruba de nadruk bleef leggen op een soevereine status buiten het Antilliaanse verband.

De AVP en de PPA waren niet duidelijk over de Status Aparte tijdens de Statenverkiezingen van augustus 1973. De Arubaanse bevolking liet duidelijk merken dat zij achter het centrale verkiezingsthema van de MEP (de Status Aparte) stond. De AVP kreeg geen Statenzetel en de PPA kreeg er maar drie. De overige vijf Statenzetels gingen naar de MEP. Na de overwinning van de MEP bij de Statenverkiezingen maakte de tegenstelling Curaçao - Aruba plaats voor de tegenstelling Curaçao - MEP.

In 1977 werd een referendum gehouden in Aruba, waar de bevolking werd gevraagd of zij onafhankelijk wilde worden of het Antilliaanse staatsverband wilde continueren. De meerderheid koos voor een onafhankelijk Aruba. De verhouding tussen de andere regeringspartijen en de MEP verslechterde, omdat alle aandacht wat Aruba betrof gericht diende te zijn op het afscheidingsstreven van Aruba. Pas nadat Aruba de internationale pers had gemobiliseerd voor haar afscheidingsstreven en er ernstige stakingen op Aruba uitbraken, was Nederland bereid politieke consequenties te verbinden aan de Arubaanse wens tot afscheiding. 
In het kader van de doorbraak, bereikt tijdens de besprekingen van september 1977, werd het eerste onafhankelijke onderzoek naar de levensvatbaarheid van een gescheiden dekolonisatie van Aruba uitgevoerd, door medewerkers van het Institute of Social Studies (ISS). De onderzoekers kwamen tot de conclusie dat Aruba's onafhankelijkheidsstreven ten opzichte van Curaçao tenminste 'begrijpelijk' was en dat een gescheiden dekolonisatie niet onmogelijk was. De onderzoekers constateerden dat de roep om volledige onafhankelijkheid slechts een middel was om te worden gehoord. Aruba wilde liever los van Curaçao dan onafhankelijk worden van Nederland. Het ISS-rapport adviseerde dat een volkenrechtelijke constructie niet op een 'one man one vote' beginsel hoefde te berusten. Het was zeker mogelijk een 'supranationale' staatkundige structuur te ontwerpen waarbij de Antillen één staat in volkenrechtelijke zin vormden en waarin waterdichte garanties voor bestuurlijke zelfstandigheid voor Aruba zouden zijn opgenomen. Het model van de Europese Gemeenschap, misschien aangevuld met enige elementen uit de Zwitserse staatsstructuur, zou daarbij als voorbeeld kunnen dienen. Bovendien zou een recht op afscheiding kunnen worden opgenomen.

Naar aanleiding van diezelfde besprekingen werd een Koninkrijkswerkgroep (KWG) ingesteld. Deze moest een inventarisatie maken van de mogelijke samenwerkingsvormen tussen Aruba, de Nederlandse Antillen en Nederland. In bet eindrapport van de KWG werd het zelfbeschikkingsrecht van de eilanden gedefinieerd als het recht van de bevolking van elk eiland om zelf zijn politieke toekomst te bepalen. Dit is een ongebruikelijke uitleg van het zelfbeschikkingsrecht. Internationaalrechtelijk wordt het zelfbeschikkingsrecht gezien als een recht dat een volk toekomt en niet aan een onderdeel van een land. Zo zou het zelfbeschikkingsrecht wel aan de Nederlandse Antillen als geheel toekomen, maar niet aan de afzonderlijke eilanden.

Volgens het VN dekolonisatiebeleid van het 'non-disruption principe', zou Aruba tot in lengte van dagen deel uit moeten maken van een staatsverband door Curaçao gedomineerd, als de Nederlandse Antillen een soevereine staat zouden worden. Deze VN-lessen hebben de Arubaanse leiders ter harte genomen. Daarom werd de prijs voor de status aparte, onafhankelijkheid op termijn, ook door Aruba geaccepteerd. De los-van-Curaçaobeweging, werd mede door de druk die Nederland na 1970 uitoefende op de Antillen om onafhankelijk te worden, een onafhankelijkheidsbeweging.

Op de RTC van 1981 werd de interpretatie van het zelfbeschikkingsrecht nog eens vastgelegd. Vastgesteld kan worden, dat ook al is het een ongebruikelijke uitleg van het zelfbeschikkingsrecht, het 
de Koninkrijkspartners natuurlijk vrij staat een dergelijke opvatting over het zelfbeschikkingsrecht te hebben en uit te voeren.

Op 1 september 1981 ontstond een breuk tussen de MEP en de andere regeringspartijen. Op 3 september was een nieuwe coalitie gevormd, zonder de MEP. Het nieuwe kabinet wilde zo snel mogelijk helderheid verkrijgen over de toekomstige staatkundige ontwikkeling van de Nederlandse Antillen en met name de positie van Aruba daarin. Het kabinet drong dan ook bij Nederland op een spoedig te houden topoverleg.

Eind oktober 1981 vond in Den Haag het topoverleg plaats tussen Nederland, de Nederlandse Antillen en een delegatie van de Arubaanse Eilandsraad. Het overleg resulteerde in de oprichting van een Gemengde Commissie Toekomst Antillen. In november 1982 bracht de Commissie verslag uit. Op vrijwel geen enkel punt werd overeenstemming bereikt. Het enige punt waar men het wel over eens scheen, was de 'Status Aparte' van Aruba. De overige Nederlandse Antillen zouden die 'Status Aparte' gedogen als korte overgangsperiode naar de onafhankelijkheid van Aruba. Het rapport werkte de federatieve samenwerkingsvorm concreter uit, door aan te geven welke onderwerpen in een federale grondwet geregeld zouden moeten worden. De grondrechten, een democratische staatsvorm, de samenwerking(splichten) en een geschillenregeling waren de belangrijkste onderwerpen, die in de federale grondwet geregeld zouden moeten worden.

Over de samenwerkingsvormen tussen Aruba en de Antillen in de overgangsfase kon geen overeenstemming worden bereikt. In het eindadvies kon de Commissie hierdoor nog altijd geen onafhankelijkheid als einddoel adviseren als Aruba niet zou deelnemen aan een duurzaam samenwerkingsverband met de Nederlandse Antillen in het kader van de Unie. Nederland opteerde nog steeds voor de 'eenheid en ondeelbaarheid' van de Antillen op weg naar de onafhankelijkheid.

Op de RTC van 1983 werd besloten dat Aruba voor een periode van tien jaren een aparte status zou krijgen, ingaande op 1 januari 1986. Daarna zou het eiland definitief kiezen voor onafhankelijkheid in 1996. Op de RTC werd ook afgesproken dat er tussen de Nederlandse Antillen en Aruba een hecht samenwerkingsverband in de vorm van een Unie moest worden gerealiseerd. Die samenwerking werd kort daarna afgewezen vanwege de dwang die erachter zat. Uiteindelijk kwam de Samenwerkingsregeling tot stand. De daarin in voorziene samenwerking is erg vrijblijvend en werkt eigenlijk alleen maar voor de gezamenlijke rechtspleging van de beide Landen. 
Aruba stelde een moderne Staatsregeling op, die naar het voorbeeld van de Nederlandse Grondwet van 1983 werd geconcipieerd. Het verschil met de Nederlandse Grondwet is dat de landsverordening (de formele wet) kan worden getoetst aan hoofdstuk I van de Staatsregeling (de grondrechten).

Op Aruba vond een zekere stabilisatie van de politieke verhoudingen plaats. Tot 1985 bleef de MEP de absolute meerderheidspartij. De grootste verkiezingsoverwinning van de MEP vond plaats bij de Eilandsraadverkiezingen van 29 april 1983. Een schietpartij op zondag 28 april 1983, één dag voor de verkiezingen besliste de verkiezingsstrijd. In een moment van paniek liet een Curaçaose politie-agent zijn dienstpistool afgaan tijdens een (illegale) verkiezingsoptocht van de MEP. De agent had eerst een waarschuwingsschot gelost en trof daarna Betico Croes in de buik. Dit leidde tot een dodelijk schietincident, waarvan een jeugdige AVP-supporter het slachtoffer werd. Het politieke geweld tijdens verkiezingen is nog steeds een zorgwekkend fenomeen, zoals bleek uit de Statenverkiezingen van januari 1993, waarbij weer een dode viel te betreuren.

Bij de laatste Eilandsraadverkiezing van 22 november 1985 verloor de MEP haar meerderheid. De MEP had veel van haar populariteit zien verdwijnen door (verplicht) voor de onafhankelijkheid te kiezen en gebruik te maken van patronage. Een tekort van 340 miljoen gulden in de Eilandskas eind 1984 deed de partij ook geen goed. Eveneens had de MEP veel te lijden van de sluiting van de Lago. De tot dan toegejuichte staatkundige toekomstige veranderingen verloren hun glans door de schok van de wankel gebleken basis van de eilandseconomie. Ook kwam de MEP niet met goede initiatieven voor economisch herstel, meenden de andere Arubaanse politieke partijen.

De coalitie wenste de MEP dan ook buiten het Bestuurscollege en de Staten te houden. Henny Eman werd de eerste premier van het Land Aruba tot grote spijt van Betico Croes. Op de dag van de ingang van de Status Aparte kreeg Betico Croes een ernstig auto-ongeluk dat op 26 november 1986 tot zijn dood leidde.

De toepassing van de evaluatie-criteria op deze periode geven een merkwaardig beeld te zien. De invloed van Nederland op de toekomstige staatsinrichting is in theorie niet groot. De facto worden de Nederlandse Antillen echter door Nederland tegen hun zin naar de onafhankelijkheid geleid. De opbouw van de staatsorganen is weer een punt van heftige discussie, maar nu in de vorm van al of niet een Antilliaanse federatie. De binding van de staat aan het recht laat in de praktijk te wensen over. Soms heeft de regering moeite een 
uitspraak van de rechter op te volgen. De rechterlijke macht wordt regelmatig vermanend in de pers toegesproken, als een uitspraak de uitvoerende macht niet aanstaat. In de pers pogen politici elkaar het leven moeilijk te maken, door elkaar over en weer te beledigen en vervolgens een kort geding aan te spannen om hun naam te zuiveren. De verdeling van de overheidsmacht komt door deze processen onder druk te staan. Het zoeken van het juiste evenwicht tussen ordening van de samenleving en individuele vrijheid leidde ertoe dat deugdelijk bestuur sinds het einde van de jaren tachtig een belangrijk beleidsissue van de Koninkrijksregering is geworden. Het naleven van de mensenrechten en de rechtsbescherming van de burger tegen de overheid behoeven daarom ook regeling bij (eenvormige) landsverordening. Het voornemen daartoe bestaat al sinds het einde van de jaren tachtig.

De burgers hebben invloed in het bestuur door middel van algemene, vrije en geheime verkiezingen. De verkiezingscampagnes leidden in toenemende mate tot geweldpleging. Klasseverschillen en kleurverschillen deden in Aruba een verscherpt nationalisme ontstaan, waarbij de autochtone blanke plattelands-Arubaan zich kon afzetten tegen de allochtone Afro-Caraibische (import) Arubaan. De gevoelens van achterstelling en overheersing die Aruba koesterde ten opzichte van het overwegend zwarte en gekleurde Curaçao, werden versterkt door de politieke ontwikkelingen. Ook op Aruba hebben 'blanke' Arubanen de facto meer 'rechten' en 'privileges' dan de donker gekleurde Arubaan. De hogere functies bij de overheid en in het bedrijfsleven zijn in overwegende mate licht ingekleurd. 


\section{Politieke ontwikkelingen als ge- volg van de Status Aparte}

Hoofdstuk IX beschrijft de economische en politieke situatie van Aruba en de Nederlandse Antillen, na de Status Aparte (periode IX). Het overlijden van Betico Croes aan de vooravond van de invoering van de Status Aparte heeft veel invloed op het politieke krachtenveld. De Statenverkiezingen van 1989 en 1993 komen aan de orde. Er wordt kort ingegaan op de verdiensten van het kabinet-Eman (19861989) en het kabinet-Oduber I (1989-1993). Vervolgens komt de herstructurering van de Antillen van de Vijf aan de orde.

De Antillen van de Vijf moeten na de uittreding van Aruba uit het Antilliaans verband een modus vivendi vinden. De staatkundige vorm van de overgebleven eilanden van de Nederlandse Antillen is een zaak die alle partners van het Koninkrijk aangaat. De modellen en meningen die naar aanleiding van de nieuwe ontwikkelingen tussen 1983 en 1994 naar voren worden gebracht, passeren de revue. Een aantal knelpunten in de bestaande staatkundige Antilliaanse structuur vereist de nodige aandacht. Het ongelijke gewicht van een stem tijdens de verkiezingen, op grond van het bestaande kiesstelsel zal altijd de suprematie van Curaçao opleveren. Dit versterkt weer het insularisme tussen de eilanden, waardoor het onmogelijk lijkt tot een voor elk eiland aanvaardbaar Antilliaans verband te komen. Tevens is dat de reden waarom een overkoepelend orgaan die de taken kan uitvoeren, die de kleine eilanden zelf niet kunnen realiseren, altijd zo problematisch is geweest. Deze knelpunten worden uiteengezet. Ook wordt de ontwikkeling behandeld die heeft geleid tot een verandering in het Nederlands beleid over de gewenste onafhankelijkheid van Aruba en de Nederlandse Antillen. Van belang voor Aruba is het schrappen van art. 62 Statuut, dat vermeldt dat Aruba per 1 januari 1996 onafhankelijk zal worden. Als de Nederlandse Antillen en Aruba voorlopig niet onafhankelijk worden en binnen het Koninkrijk willen blijven, dan kan dat blijkbaar alleen als aan een aantal Nederlandse eisen wordt voldaan. Uiteengezet wordt welke eisen dat zijn.

De Nederlandse regering kondigt in maart 1993 aan een Toekomstconferentie te willen houden om een nieuwe Koninkrijksstructuur vast te stellen. Geen der partijen heeft zich goed voorbereid op 
de conferentie, de standpunten van de verschillende eilanden liggen ver uiteen. Nederland biedt de Antilliaanse eilanden, geheel onverwacht, een Status Aparte aan, onder stringente voorwaarden. Het voorstel van Lubbers, neergelegd in een 'synthese-document' is mager gemotiveerd en veroorzaakt de nodige commotie op de Nederlandse Antillen en in de Nederlandse pers. De inhoud van de voorstellen van Premier Lubbers komt ter sprake evenals de Antilliaanse en Arubaanse reacties daarop. Aangekondigd wordt dat in juni 1993 een vervolgconferentie zal worden gehouden, waarop volgens Nederland concrete beslissingen moeten worden genomen. Gezien de grote onderlinge meningsverschillen tussen de Koninkrijkspartners stagneert de tweede Toekomstconferentie en wordt onderling overleg gepleegd tussen de eilanden en Nederland. Zoals het zich thans laat aanzien, zal de nieuwe Koninkrijksstructuur nog geruime tijd op zich laten wachten. Deze ontwikkelingen worden in extenso beschreven.

\section{Economische en politieke ontwikkelingen}

De economische vooruitzichten voor zowel Aruba als Curaçao verslechterden in 1985 plotseling. De oliebedrijven op beide eilanden waren in de financiële problemen geraakt en dreigden de raffinaderijen te sluiten. Op basis van een studie ter sanering van de Arubaanse economie en de overheidsuitgaven werd door het IMF een aanzienlijke verhoging van de inkomstenbelasting, importheffingen en benzineprijs geadviseerd. Als Aruba zich wilde onderwerpen aan de voorstellen van het IMF, dan wilde Nederland begrotingshulp ter waarde van 110 miljoen gulden in het vooruitzicht stellen. Bij dit alles werd Aruba geconfronteerd met een crisisheffing van $10 \%$, die in oktober 1985 werd opgelegd door de Antilliaanse regering. Door de sluiting van de Lago gingen 900 banen verloren. Als gevolg hiervan raakten bij de toeleveringsbedrijven nog eens 1.300 mensen hun baan kwijt. ${ }^{1}$ De Status Aparte ging van start met een zeer smalle economische basis.

De vraag rond de wenselijkheid van de onafhankelijkheid van Aruba in 1996 werd veel besproken. De AVP was zeer ontstemd dat de MEP de onafhankelijkheid op termijn had geaccepteerd. De economische crisis volgend op de sluiting van de Lago en het voorbeeld van de mislukte onafhankelijkheid van Suriname beïnvloedden het denken over de onafhankelijkheid op Aruba sterk. De naderende onafhan-

$1 \quad$ Reinders (1993) p. 346 e.v. 
kelijkheid deed de buitenlandse investeringen afnemen. Ook was men bevreesd voor een penetratie van de drugsmaffia in regeringskringen, (zoals in Cuba, Colombia, Panama en de Bahamas) en voor staatsgrepen zoals in Suriname. ${ }^{2} \mathrm{Al}$ in het regeerprogramma van het kabinetEman (1986-1989) viel te lezen dat ondanks art. 62 Statuut, waarin de onafhankelijkheid van Aruba op termijn was vastgelegd, de Arubaanse bevolking zelf de datum van de onafhankelijkheid zou moeten bepalen, door middel van een referendum. ${ }^{3}$

Bij de viering van de Status Aparte op 18 maart 1986 zei de econoom H. Mehran van het Internationaal Monetair Fonds (IMF), dat het belangrijk was dat Aruba ook na 1996 deel uit zou blijven maken van het Koninkrijk der Nederlanden. Zonder de politieke binding met het moederland zou het eiland beperkt blijven in zijn ontwikkelingsmogelijkheden. Volgens Mehran aarzelden veel investeerders op dat moment al, omdat zij niet wisten hoe de politieke toekomst na 1996 zou zijn. De traditionele band met Nederland garandeerde rechtszekerheid en democratie, hetgeen volgens de IMFdeskundige voor investeerders belangrijker was dan wat dan ook. ${ }^{4}$ De jaren na 1985 brachten Aruba weinig rust. De gespannen verhouding tot Curaçao en de Antillen van de Vijf bleef bestaan. Een groot luchtvaartconflict van april tot juni 1986 en het uitblijven van de voorgenomen samenwerkingsregelingen leken hiervan te getuigen.

In 1989 bracht de Aruba Trade \& Industry Association (ATIA) een rapport ${ }^{5}$ uit, waarin de organisatie aangaf dat onafhankelijkheid voor Aruba in 1996 niet haalbaar was. De reden hiervoor was, dat economisch gezien het eiland niet klaar was voor de onafhankelijkheid. Aruba had zelf een ontoereikende deviezenvoorraad om voldoende te kunnen inkopen. Het overheidsapparaat was onvoldoende toegerust om de onafhankelijkheid te kunnen dragen en het Land had geen gunstige liquiditeitspositie. De Status Aparte voldeed goed om Aruba economisch weer op peil te brengen en moest voorlopig dan ook gehandhaafd blijven, vond de ATIA. Nadat de belastingvrijdommen en hotelgaranties die het Land Aruba heeft verstrekt verlopen zijn, zou pas kunnen worden vastgesteld of de hotelprojecten rendabel waren en welke inkomsten de overheid uit deze bronnen kan verkrijgen. Ten slotte waren de kosten voor een onafhankelijk Aruba nooit berekend. Vanwege de sluiting van de Lago was veel kader naar

\footnotetext{
Alofs (1990) pp. 525 e.v.

Reinders (1993) p. 349.

Keesings Historisch Archief, juni 1989, p. 360.

ATLA, De redenen waarom 1 januari 1996 niet haalbaar is voor de onafhankelijkheid van Aruba (juni 1990) en Amigoe, 5 juni 1990, "Onathankelijkheid in 1996 onhaalbare zaak voor Aruba."
} 
elders vertrokken, waardoor een en ernstig tekort aan professionele krachten was ontstaan, met name bij de overheid. Bovendien was Aruba's geopolitieke situatie van dien aard, dat landen in de regio over zouden kunnen gaan tot inmenging, ongewenste beïnvloeding en annexatie. Aanpassing van het Statuut leek de ATIA een betere oplossing dan onafhankelijkheid.

Het kabinet-Eman leidde Aruba na de verlening van de Status Aparte op 1 januari 1986. Dit kabinet was een coalitie, die werd gevormd door de AVP (met zeven zetels in de Staten), de ADN (twee zetels in de Staten) en de PPA (twee zetels in de Staten). Het kabinetEman probeerde de economische situatie te verbeteren door tal van maatregelen te treffen. Op 19 augustus 1987 namen de Staten van Aruba de Petroleumlandsverordening ${ }^{6}$ aan, waardoor kon worden begonnen met de uitgifte van concessies. Ook de overige Antilliaanse eilanden konden hun rechten laten gelden op eventuele bodemschatten, zoals werd vastgelegd in de Samenwerkingsregeling. De CanArub Gold Development NV een Canadees-Arubaans bedrijf kreeg van de Arubaanse regering toestemming drie jaar lang te zoeken naar goud en andere mineralen op het eiland. Tot op heden (1994) heeft dat niets opgeleverd.

Ook kreeg Aruba in 1988 de Investeringsbank, een speciale bank voor investeringen in projecten die de ontwikkeling van het eiland een sterke impuls moesten geven en waarvoor grote en langlopende leningen nodig waren. Een van de grootste aandeelhouders was de Nationale Investeringsbank in Den Haag, die ook een belangrijke rol speelde in de leiding van de nieuwe bank. President van de Arubaanse Investeringsbank werd $\mathrm{H}$. Mehran, die een hoge functie bij het Internationaal Monetair Fonds (IMF) had bekleed. ${ }^{7} \mathrm{Net}$ als op de Antillen kwam een afvloeiingsregeling voor ambtenaren tot stand, in de vorm van een lumpsumregeling. De pensioengerechtigde leeftijd werd verlaagd van 60 naar 55 jaar, waardoor $10 \%$ van het ambtenarenbestand van 4.500 zou afvloeien. Het overheidstekort kon aanzienlijk verminderd worden. De Nederlandse begrotingssteun werd vooral

6 Petroleumverordening Zeegebied Aruba, 27 auguatua 1987, AB 89.

7 Keesings Historisch Archief, juli 1989, p. 424. Hassanali Mehran was hoofd van de MF delegatie, die op verzoek van de de regering van de Nederlandse Antillen in 1984 technische assistentic verleende in verband met de oprichting van een Centrale Bank in Aruba; Rapport IMF, Netherlands Antilles, Issues related to the Formation of a Monetary Union in the Netherlands Antilles, prepared by Reza VaezZadeh and Philine Lachman, May 1984. Interessant is dat door zijn contacten veel investeringenvoor Aruba konden worden aangetrokken. De Landsregering van Aruba was echter na verloop van tijd minder blij met zijn inspanningen, temeer daar Betico Croes zijn eigen adviseurs uit Nederland aantrok. Mehran nam toen zijn ontslag; gesprek met A.G. Croes, 5 oktober 1993. 
gebruikt om de hotelbouw te financieren. In 1987 werd de Solidariteitsheffing teruggebracht van $8,2 \%$ tot $4 \%$. Per 1 januari 1989 kon de heffing worden afgeschaft. In $1988 \mathrm{kwam}$ ook de wetgeving tot stand die de Arubaanse Vrijgestelde Vennootschap (AVV) introduceerde, een constructie die vooral was bedoeld om buitenlandse investeerders aan te trekken in de sfeer van de financiële dienstverlening. ${ }^{8}$

De overgang van eilandsbestuur naar landsbestuur verliep niet soepel. Op de eerste Statenzitting konden de geloofsbrieven van de gekozen Statenleden niet worden behandeld, omdat de MEP niet aanwezig was. Deze situatie bleef voortbestaan totdat het Gemeenschappelijk Hof van Justitie de geloofsbrieven onderzocht en de beëdiging van de Statenleden kon plaatsvinden op 12 februari $1986 .{ }^{9}$

Op 12 augustus 1986 viel de PDA van Berlinski uiteen. Tijdens een rumoerig verlopen vergadering in Oranjestad stapten enkele prominente leden van de partij op, nadat een vertrouwenscrisis rond de persoon van Berlinski een climax had bereikt. ${ }^{10}$ De vertrouwensbreuk was ontstaan naar aanleiding van de vermeende verdenkingen van Berlinski met betrekking tot het vragen van steekpenningen. Het programma van de PDA van 1986 vermeldt op pagina 13 onder het kopje 'Relacion interno' de wens om te komen tot een procedure van 'impeachment', inhoudende dat als een regeringsfunctionaris misbruik maakt van zijn bevoegdheden, hij moet vertrekken. En dat nu wilde Berlinski niet.

\section{Reinders (1993) p. 354 e.v.}

GHvJ 5-2-1986, onderzoek geloofsbrieven door het Hof.

Keesings Historisch Archief, juni 1989, p. 362, juli 1989, p. 425; Reinders (1993) p. 350 e.v. Op 4 juli 1986 diende de minister van Economische zaken Berlinski van de PDA zijn ontslag in wegens vermeende corruptie. Tegen hem liep een justitieel onderzoek. Geruchten circuleerden dat de AVP hier de hand in zou hebben gehad, omdat Berlinski de Lago wilde openhouden en daartoe ondertandelingen voerde en de AVP dat niet wilde. De AVP wenste op het Lago terrein een hotel en sportcomplex aan te leggen. De crisis in de PDA zou zijn 'uitgelokt' door de AVP. De AVP vormde samen met de PDA en de ADN de regering, een motie van wantrouwen met 11 stemmen voor, 7 tegen en 2 (PDA) onthoudingen werd tegen Berlinski aangenomen. E.(Don) Mansur, werd minister van Economische Zaken, hij was dat ook al geweest in de tijd dat de MEP de absolute meerderheid had. Op 3 juli 1987 veroordeelde de rechter op Aruba Berlinski tot een boete van $f 7.500$,- wegens een poging tot het aannemen van steekpenningen. Bovendien werd Berlinski ontzet uit zijn recht openbare ambten te bekleden voor de periode van vijf jaar. Op 19 januari $1988 \mathrm{sprak}$ het GHvJ van de Nederlandse Antillen en Aruba Berlinski in hoger beroep vrij, omdat de aangevoerde feiten niet wethig en overtuigend bewezen waren. 
Onder de personen die voor het partijlidmaatschap bedankten behoorden de twee Statenleden van de PDA, Arturo Oduber en Servito Thijsen, die tevens ondervoorzitter van de Staten was. Na afloop van de vergadering lieten de dissidenten doorschemeren dat $\mathrm{zij}$ hun parlementszetels niet ter beschikking zouden stellen, maar een eigen fractie zouden vormen. De partij die onder andere door beide Statenleden werd opgericht was de Accion Democratico '86 (AD '86). Onder de naam van deze nieuwe partij presenteerden beide Statenleden zich in het Arubaanse parlement. Naar aanleiding van de ontstane situatie spande de PDA een kort geding aan om haar zetels terug te krijgen. Het Gerecht in Eerste Aanleg achtte de eis niet ontvankelijk en het GHvJ weigerde de gevraagde voorziening. De HR was van mening dat het volk deze Statenleden had gekozen en dat daar partijafspraken niet aan kunnen afdoen." "Een dergelijke afspraak moet voorshands voor nietig worden gehouden wegens strijdigheid met de, ingevolge additioneel art. XI Staatsregeling van Aruba, geldende bepalingen van het Nederlands-Antilliaans kiesreglement, die van publieke orde zijn en voor zulk een afspraak geen ruimte laten', stelde het GHvJ en de HR ondersteunde dat standpunt.

Op 5 januari 1987 deelden de twee Statenleden van de PPA, H.A. Werleman en V.R. Jansen, Gouverneur Tromp mee dat zij het vertrouwen in 'één van de ministers' van het kabinet Eman opzegden. De twee parlementariërs wilden het kabinet-Eman blijven steunen, maar eisten het vertrek van hun partijgenoot, de minister van Verkeer Benny Nisbet, wegens eigenmachtig optreden. Vervolgens deelde Nisbet, tevens partijleider van de PPA, beide dissidenten mede, dat zij geschorst waren en dat zij noch als Statenlid, noch als lid van de partij verklaringen mochten afleggen. Op 23 januari diende Nisbet zijn ontslag in bij de Gouverneur. Werleman en Jansen bleven deel uitmaken van de Staten, zij het niet meer namens de PPA. Zij zaten voortaan als 'onafhankelijken' in het parlement en richtten de Partido Patriotico Nacional op (PPN). Nisbets plaats in het kabinet werd ingenomen door A.G. Bermudez.

"GHvJ 20 januari 1987 en HR 18 november 1988, NJ 1990, 564, Antillenzaak, Nietige verkiezingsafspraken. Overeenkomst tussen politieke partij en haar kandidaten voor verkiezingen Eilandsraad Aruba, (inmiddels: de Staten van Aruba), inhoudende dat een zetel in de Staten geldt als partijzetel (gebonden aan lidmaatschap van de partij). Nietigheid wegens strijd met het in de Staatsregeling neergelegde beginsel van vrij mandaat, welk beginsel de publieke orde betreft. Nietigheid van afspraak die in strijd is met de van publieke orde zijnde bepalingen van het indertijd geldende Kiesreglement, zie AB 1989, 185. 
Op 25 juni 1987 deelde de minister van Openbare Werken P.P. Kelly, Gouverneur Tromp mee dat zijn partij, de ADN zich zou terugtrekken uit de regering en dat hij zijn ontslag als minister zou aanbieden. Oorzaak van het conflict was dat Kelly tegenover een journalist enkele opmerkingen over Eman had gemaakt, waaronder de mededeling dat de AVP zich in de Arubaanse Ministerraad nogal arrogant gedroeg. Dat gesprek was op de band opgenomen en in handen van de AVP gespeeld, die daarop had meegedeeld geen vertrouwen meer te hebben in een samenwerking met Kelly. Een bemiddelingspoging van Mansur en Bermudez leverde niets op. Nadat de ADN haar steun aan de regering Eman had ingetrokken, beschikte het kabinet in de Staten over 11 van de in totaal 21 parlementszetels, 7 van de AVP, 2 van de $A D$ ' 86 en twee van de onafhankelijke voormalige PPA leden Werleman en Jansen. Tot opvolger van Kelly werd F.A.J. Booi benoemd, die behoorde tot AD '86.

Op 18 oktober 1988 stelde de Gouverneur op voordracht van de Minister-President, Minister van Algemene Zaken, het Landsbesluit vast, waarbij werd besloten de Staten van Aruba te ontbinden en nieuwe verkiezingen te houden op 6 januari 1989. Aan dit besluit lagen twee overwegingen ten grondslag. In de eerste plaats werd overwogen dat als gevolg van de politieke verschuivingen er gegronde redenen bestonden te twijfelen aan de representativiteit van de Staten. Ten tweede wilde het kabinet-Eman de inspanningen van de afgelopen drie jaren en de resultaten die daarmee bereikt waren electoraal verzilveren, nu het noodprogramma van het kabinet-Eman was voltooid, om zo versterkt uit de stembusstrijd tevoorschijn te komen. Bij de ontbinding van de Staten was geen sprake van een conflictsituatie, of van een reguliere ontbinding. Wel bestond er twijfel aan de representativiteit van de Staten. Naar de mening van Janus ${ }^{12}$ ging

Janus (1989) m.n. p. 27. Vier Statenleden van de PDA en PPA waren immers uit de partij getreden, maar wel blijven zitten. Dat betekende dat bijna een vijfde van het totaal aantal Statenleden zitting had voor politieke groeperingen die niet het mandaat van de kiezers hadden verkregen. Janus acht dit een bedenkelijke situatie voor de parlementaire democratie, temeer omdat deze partijen nog deel uitmaakten van het kabinet Eman en dus nog regeermacht uitoefenden. Janus merkt op dat het kabinet wel lang gewacht heeft om het gebrek aan representativiteit aan de kiezers voor te leggen. Gedeeltelijk was daarvoor een valide excuus, omdat de Kiesverordening pas op 18 november 1987 werd vastgesteld. Maar dat betekent niet dat daarna nog bijna een jaar behoefde te worden gewacht om verkiezingen uit te schrijven. De 'electorale reden' om tot een ontbinding van de Staten over te gaan 
het hier om een terechte ontbinding, die echter te laat kwam en waarbij op de achtergrond motieven meespeelden, die uit staatsrechtelijk oogpunt bezien niet geheel zuiver waren. ${ }^{13}$

In 1948 werd het ontbindingsrecht in de Staatsregeling van de Nederlandse Antillen opgenomen. Dip ${ }^{14}$ achtte het ontbindingsrecht als middel tot conflictoplossing tussen regering en Staten louter theorie. De grote solidariteit tussen kabinet en parlementaire meerderheid was zijns inziens overbekend en werd nog versterkt door het feit dat steeds het overgrote deel van de Statenleden bestond uit ambtenaren in actieve dienst. Sinds de invoering werd het ontbindingsrecht vijf maal gehanteerd, in 1954, 1958, 1969, 1979 en 1982. Geen enkele maal geschiedde dit om een conflict tussen regering en de parlement tot een oplossing te brengen. De Kwaadsteniet die zijn proefschrift wijdde aan Kamerontbinding was van mening dat ook ontbinding valt onder de ministeriële verantwoordelijkheid. ${ }^{15}$

Op 24 oktober diende minister Booi zijn ontslag in en zegden de Statenleden van de partij waartoe minister Booi behoorde, AD '86, hun steun aan het kabinet op, waardoor het kabinet nog maar over 9 van de 21 parlementszetels beschikte, te weten 7 van Emans AVP en de twee zetels van Werleman en Jansen, die hun Statenzetel behielden en aanbleven voor de nieuwe partij, de Partido Patriotico Nacional (PPN). AD '86 zegde de steun aan het kabinet op, omdat het besluit tot ontbinding van de Staten en het uitschrijven van nieuwe verkiezingen zonder overleg met $\mathrm{AD}$ ' 86 was genomen. De oppositiepartijen MEP, ADN en AD '86 vroegen daarop de Gouverneur een zakenkabinet te benoemen totdat er op 6 januari 1989 verkiezingen werden gehouden. Een meerderheid in de Staten, die overigens de vervroegde verkiezingen toejuichte, was het met het demissionair

is beslist geen rechtsgeldige grond om tot ontbinding over te gaan.

13 Zie voor de geschiedenis van de kamerontbinding: Beekman (1973) en Van der Burg (1981). Over het algemeen zijn de staatsrechtgeleerden het er over eens dat tot een ontbinding van de Tweede Kamer of van de Staten kan worden overgegaan als er sprake is van een conflict tussen het parlement en de regering, of een conflict tussen de beide Kamers onderling, dan wel een conflict in de boezem van de regering. Ook kan worden overgegaan tot ontbinding indien getwijfeld kan worden aan de representativiteit van de volksvertegenwoordiging. Er behoeft dan geen sprake te zijn van een conflict tussen regering en volksvertegenwoordiging. Tegenwoordig wordt het ontbindingsrecht nauwelijks meer gehanteerd om een conflict tussen parlement en regering op te lossen, maar veeleer om een conflict tussen coalitiepartners binnen een kabinet op te lossen.

$14 \quad$ Dip (1975) p. 15.

is Zie voor de Nederlandse situatie: De Kwaadsteniet (1968) pp. 253-261; Van der Pot/Donner/Prakke(1989)pp. 496-507; Witteveen (1988)pp. 1237e.v.; Oud (1987); Koekkoek (1989) pp. 877 e.v.; Beekman (1973) pp. 379 e.v; Prakke (1977) p. 401 e.v., m.n. p. 404, nool 12 . 
aanblijven van het kabinet-Eman niet eens. In een motie van 2 november 1988 werd aangedrongen op de installatie van een zakenkabinet. De motie werd gericht aan het constitutioneel hoofd van regering, de Gouverneur! Janus vroeg zich af of een ieder zich wel realiseerde dat met de verkrijging van de Status Aparte de Eilandsraad, het Bestuurscollege en de Gezaghebber, niet zozeer zijn vervangen door de Staten, de regering en de Gouverneur, maar dat men in feite geheel nieuwe organen heeft gekregen, die in volstrekt andere verhoudingen tot elkaar staan. Janus gaf dan ook aan dat kritiek die geuit werd op de Gouverneur, met name door de MEP, blijk gaf van een ernstig gebrek aan besef van de positie van de Gouverneur. De Gouverneur heeft buiten zijn bevoegdheden bij kabinetsformaties, zelfstandig geen staatsrechtelijke bevoegdheden. Hij dient dan ook niet in politieke discussies te worden betrokken, aldus Janus. Waar er een kabinet zit, zij het demissionair, had de motie zich moeten richten tot de leden van dit kabinet, die politiek verantwoordelijk zijn voor hun aanblijven en niet tot de Gouverneur. Het zakenkabinet kwam er overigens niet.

Janus stelde de vraag of wanneer er een ontbindingsbesluit ter tafel ligt, de volksvertegenwoordiging het kabinet nog weg kan krijgen. Met andere woorden hadden de ministers, nu de Staten hun aanblijven niet in het algemeen belang achtten, wederom naar de Gouverneur moeten gaan en deze moeten vragen met spoed van hun taken te worden ontheven en een interimkabinet te laten formeren? Janus beantwoordde die vraag ontkennend. Door een ontbindingsbesluit wordt een kabinet materieel demissionair. Het einde van de zittingsperiode is in zicht. De formele demissionaire status volgt door de ontslagaanvrage ter gelegenheid van de verkiezingen welke op korte termijn zullen plaatsvinden. Het ontbindingsbesluit maakt de Staten materieel demissionair. Een dergelijk kabinet kan nog door een motie van wantrouwen zijn ontslag vragen en ook kan een minister van een materieel en formeel demissionair kabinet nog zeer wel ogenblikkelijk naar huis worden gestuurd. Wel is Janus van mening dat dit alleen acceptabel is bij zeer ernstig falen van de betrokken bewindspersoon. Is een kabinet echter formeel demissionair dan kan daarin door de volksvertegenwoordiging geen verandering meer worden gebracht. Immers een kabinet dat reeds ontslag heeft gevraagd, kan men niet meer bedreigen met een tot aftreden dwingend wantrouwensvotum. Ook heeft het kabinet geen greep meer op de Kamer, omdat het de 
De verkiezingen van 6 januari 1989 leidde tot acht zetels voor de AVP en tien voor de MEP. Van de politieke partijen die de 'aanleiding' voor de ontbinding waren, haalde alleen de PPN één zetel. AD ' 86 verdween van het toneel. Wat dat betrof schortte er dus inderdaad iets aan de representativiteit van de Staten. ${ }^{17}$

Toen in 1989 na het kabinet Eman het kabinet-Oduber was aangetreden, verzocht Minister-President Oduber twee hoogleraren staatsrecht om een oordeel over het ontbindingsbesluit van de Staten. ${ }^{18}$ De Minister-President legde twee vragen voor:

1. Is het ontbindingsrecht gehanteerd op een wijze die volgens Nederlandse verhoudingen juist is en zo nee, wat zijn dan de gevolgen van een dergelijk besluit?

2. Kan de Gouverneur - gezien de Nederlandse verhoudingen - een ontslagaanvrage van de ministers, gedaan naar aanleiding van het ontbindingsbesluit, in beraad blijven houden indien het parlement uitdrukkelijk de steun aan het demissionaire kabinet onthoudt, maar die steun wel wil geven aan een ander kabinet? Met andere woorden mocht de Gouverneur toen het kabinet formeel demissionair was overleg voeren over een nieuw te vormen kabinet?

Van der Burg en Burkens kwamen tot de conclusie dat de conflictontbinding in deze situatie niet kon worden aangemerkt als een constitutioneel oirbaar middel van de regering tot ontbinding van de Staten. ${ }^{19}$ Het ging immers om een termijnontbinding en niet om een conflictontbinding. De constitutionele gewoonte zou moeten worden ingevoerd dat slechts tot ontbinding van de Staten mag worden overgegaan als de Gouverneur advies heeft ingewonnen van dezelfde adviseurs als die bij kabinetsformaties worden geraadpleegd. Van der Burg en

16 In gelijke bewoordingen: Prakke (1977) m.n. p. 404.

17 Janus, TAR-Justicia (1989) pp. $23 \mathrm{l} / \mathrm{m} 34$

14 Van der Burg en Burkens, Open brief aan de Minister-president van Aruba (1990) pp. 41-46.

19 De beide hoogleraren achten het ontbindingsbesluit van 18 oktober slecht voorbereid. Het hesluit kwam tot stand op dezelfde dag als waarop de Ministerraad over de voordracht beraadslaagde. Het onderwerp was niet op de agenda geplaatst en minister Booi verbleef in Nederland. Gezien de emst van de situatie was er alle reden geweest de Gouverneur in de gelegenheid te stellen zijn 'right to be consulted' en zijn 'right to warn' uit te oefenen. Daarvoor was echter nauwelijks tijd daar Premier Eman al op 17 oktober in een boodschap tot het Arubasnse volk had verklaard dat de ministers nieuwe verkiezingen wensten. 
Burkens beantwoordden de tweede vraag dus bevestigend. Van der Burg $^{20}$ stelde dat de Koning ook in het geval van een echte conflictontbinding verplicht is om de fractievoorzitters te raadplegen en om ontbinding te weigeren indien een meerderheid van de Kamer er tegen zou zijn.

Prakke $^{21}$ was van mening, dat een dergelijke handelwijze in strijd lijkt te zijn met het karakter van een conflictontbinding.

Janus $^{22}$ was het met de visie van beide hoogleraren niet eens, daar naar zijn mening de politieke situatie op Aruba noopte tot een ontbinding, ook al speelden onzuivere motieven bij het besluit tot ontbinding van de Staten een rol. Janus meende dat Van der Burg en Burkens het ontbindingsrecht zien als een recht van (de meerderheid) van het parlement, een soort van zelfontbinding en niet als een zelfstandig door de regering te hanteren bevoegdheid. Voor de opvatting van Van der Burg en Burkens is geen grond te vinden in de staatsrechtelijke literatuur.

Het was opmerkelijk dat Van der Burg en Burkens in de hen voorgelegde situatie geen gebrek aan parlementaire representativiteit vermochten te ontdekken. Jammer genoeg ging het advies ook niet in op de overwegingen die hebben geleid tot het ontbindingsbesluit. Naar mijn mening konden die maar gedeeltelijk de toets der kritiek doorstaan en het was interessant geweest daar de mening van beide hoogleraren op te mogen vernemen. ${ }^{23}$

$20 \quad$ Van der Burg (1981).

$21 \quad$ Van der Pot/Donner/Prakke (1989) p. 506, noot 31.

22 Janus (1989) pp. 14-19.

23. Naar de mening van Janus gaan Van der Burg en Burkens ten onrechte vit van een conflictontbinding. Er was ten tijde van het ontbindingsbesluit nog geen conflict, dat deed zich pas later voor. Er was immers duidelijk sprake van een gemis aan representativiteit van de volksvertegenwoordiging. Janus constateent dat de partijloyaliteit hier minder diep geworteld is dan in Nederland. Hij acht het een kwestie van politieke ethiek, dat een parlementariêr wanneer hij de partij verlaat waarvoor hij ais volksvertegenwoordiger gekozen is zijn zetel in het vertegenwoordigend lichaam opgeeft. 'Bedenkelijk voor de parlementaire demoeratie wordt het naar mijn oordeel wanneer deze volksvertegenwoordigerskunnen beslissen over het lot van een kabinet of via hun geestverwanten in het kabinet regeermacht kunnen uitoefenen.' Het overlopen in de landen van het Koninkrijk is een politick probleem, waarvoor het recht geen oplossing biedt. Dit bleek ook ten aanzien van de naar AD '86 overgelopen Statenleden. Hun oorspronkelijke partij, de PDA eiste in rechte dat zij hun Statenzetels zouden opgeven. De PDA baseerde deze eis op een voor de verkiezingen met haar kandidaten gesloten overeenkomst, inhoudende dat deze de door hen verworven zetels weer zouden opgeven, wanneer ze zouden bedanken voor het lidmaatschap van de PDA. Tot en met de Hoge Raad kreeg de PDA nul op het rekest omdat een dergelijke overeenkomst in strijd werd geacht met het in de Statsregeling neergelegde beginsel van het vrije mandaat, welk beginsel de publieke orde betref. Het arrest van de Hoge Raad (d.d. 18 november 1988) is geannoteerd in dezelfde zin door Van der Burg (AB 1989, afl. 20, d.d. 20-5-1999, nr. 185). 'Met evenveel 
Onder het kabinet-Eman onderging de Arubaanse economie een ware metamorfose en werd het toerisme uitgebouwd tot de economische peiler; waarop het eiland leek te kunnen steunen. Het gebrek aan arbeidsplaatsen sloeg om in een tekort aan arbeidskrachten en gevreesd werd voor een oververhitting van de economie. Ondanks zijn economische prestaties werd Eman bij de vervroegde herverkiezingen van januari 1989 niet herkozen. De redenen voor zijn nederlaag waren ontevredenheid over vermoedelijk de afstandelijke manier van politiek bedrijven en zijn sociaal-economische politiek. Bovendien was het de come-back van de MEP, die Eman de voet dwars zette. De MEP kreeg 24 stemmen te weinig om de meerderheid van elf zetels in het Arubaanse parlement te bezetten. Haar verkiezingsstrategie bleek zeer succesvol; de partij moest het werk van de overleden leider voortzetten. Hiertoe werd Croes' jongere broer en evenbeeld Rudy Croes op de verkiezingslijst geplaatst. Alhoewel hij een nieuweling op het politiek toneel was, werd hij na Henny Eman de grootste stemmentrekker van het eiland. ${ }^{24}$ Samen met de ADN en de PPA kon Nelson Oduber zijn eerste kabinet vormen, terwijl Henny Eman opnieuw plaats kon nemen in de oppositiebanken. De verkiezingen leidden tot een onverwacht resultaat van acht zetels voor de AVP en tien voor de MEP, de PPN behaalde één zetel. AD '86 verdween van het toneel. ${ }^{25}$ Het kabinet-Oduber kwam aan de macht bestaande uit de MEP, de ADN (1 zetel) en de PPA (1 zetel). De vervroegde verkiezingen hadden voor de AVP uitgepakt als een historische vergissing. ${ }^{26}$

\section{De samenwerking tussen Aruba en de Nederlandse Antillen}

Op het gebied van de handel en industrie vlotte de samenwerking tussen Aruba en de Nederlandse Antillen niet erg. Per 1 januari 1986 had Aruba de marktbescherming voor Antilliaanse produkten sterk verminderd. Als reactie daarop hadden de Antillen de protectie van de op Aruba vervaardigde produkten, zoals auto-accu's en de in

recht', stelt Janus, 'zou men kunnen stellen dat crossing the partyline de publieke orde aantast bijv. in het geval dat een andere partij een partijverlater betere politieke vooruitzichten biedt'. Tevens constateert Janus dat de publieke orde in het (latere) advies van Van der Burg en Burkens geen rol heeft gespeeld.

De Arubaan stemt emotioneel en niet rationeel. Het electoraat meende dat het toch niet geheel terecht was dat Betico Croes, de grote voorvechter voor een aparte status van Aruba, niet de eerste Minister-President van Aruba was geworden. De uitslag van de verkeizingen kan worden gezien als (postuum) eerbetoon aan Betico Croes. Janus (1989) pp. 23-34. 
licentie vervaardigde Marlboro sigaretten laten vervallen. De Antillen vonden tevens dat het Gemeenschappelijk Hof van Justitie in strijd was met art. 43 Statuut, dat inhield dat ieder der Landen zorg droeg voor de eigen rechtspraak. Bovendien waren alle rechters in Antilliaanse dienst, ook al werkten ze op Aruba. Wanneer Aruba toch onafhankelijk zou worden in 1996, dan was het raadzaam, aldus Don Martina, de premier van de Antillen, om Aruba maar vast te laten wennen aan een eigen rechterlijke macht.

In april 1986 ontstonden problemen met betrekking tot de landingsrechten van de ALM, omdat Aruba de ALM sinds 1 januari 1986 beschouwde als een buitenlandse onderneming. De Nederlandse regering was van mening dat de ALM een nationale luchtvaartmaatschappij was en dat daarom tussen de eilanden het speciale cabotagerecht, het vliegrecht op een binnenlandse route, gold. Aruba bleef het oneens met deze opvatting. Op 1 mei gaf premier Martina opdracht alle vluchten van de ALM op Aruba te staken. Diezelfde dag besloot Aruba een eigen luchtvaartmaatschappij op te richten. Op 4 juni gelastte de Arubaanse rechter de Antilliaanse regering binnen 24 uur toestemming te geven voor de vluchten van en naar Aruba. Met zijn uitspraak kwam de rechter tegemoet aan een eis van de hotelketen Divi Hotels NV die een kort geding had aangespannen tegen de Antilliaanse regering. De hotelketen voelde zich benadeeld door de beslissing van de regering van de Antillen om de ALM-vluchten van en naar Aruba stop te zetten. Amerikaanse toeristen aan wie een reis was verkocht met daarin een verblijf op zowel Aruba als Bonaire, moesten worden teleurgesteld, omdat de ALM haar charterovereenkomst met de hotelketen niet meer kon nakomen als gevolg van het vliegverbod.

In het vonnis stelde de rechter dat noch de Antilliaanse regering noch de Arubaanse regering de ALM kon verbieden op Aruba te vliegen. Zolang er geen nieuw luchtvaartverdrag was, gold de samenwerkingsovereenkomst tussen de Landen. Dat was het luchtvaartprotocol dat door beide Landen aanvaard was bij de Arubaanse afscheiding op 1 januari 1986. Met ingang van 7 juni 1986 vloog de ALM weer op Aruba. ${ }^{27}$

Op 12 juli 1986 namen de Antilliaanse Staten een motie aan waaruit bleek dat de bestaande wettelijk vastgelegde Samenwerkingsregeling tussen Aruba en de Antillen op de helling moest. Een Antilliaanse 
evaluatie van de eerste zes maanden van deze regeling had tot de conclusie geleid dat er meer nadelen dan voordelen aan vast zaten. Ondanks andere afspraken was de Ministeriële Samenwerkingsraad slechts één keer bijeen geweest. Aruba had Antilliaanse verzoeken voor meer dergelijke vergaderingen ter invulling van samenwerkingsprotocollen op specifieke terreinen niet gehonoreerd. Minister De Koning meldde bij een bezoek aan Curaçao op 17 juli 1986, ter voorbereiding van een Topconferentie van de drie regeringen dat afschaffing van de Samenwerkingsregeling door Nederland uiterst ernstig zou worden opgenomen en ernstige consequenties zou hebben. De Koning was van mening dat in ieder geval de Samenwerkingsregeling gehandhaafd moest blijven vanwege het functioneren van het Gemeenschappelijk Hof van Justitie. Voor wijziging van de Samenwerkingsregeling was immers instemming van Nederland nodig (art. 74 lid 5 Samenwerkingsregeling). Op 9 en 10 september 1986 besloten Curaçao, Bonaire, Sint Maarten, Sint Eustatius en Saba dat zij de bestaande Samenwerkingsregeling met Aruba afwezen. De Antilliaanse premier voegde hieraan toe, dat de eilanden niet goed konden functioneren met de door Nederland van bovenaf opgelegde regeling. Martina wilde de bestaande regeling opheffen en op basis van vrijwilligheid bepalen op welke terreinen samenwerking in het voordeel was van beide partijen.

Van 29 september tot 2 oktober 1986 vond in Den Haag een tripartite overleg plaats over de gerezen problematiek. Na moeizame onderhandelingen ondertekenden Aruba, de Nederlandse Antillen en Nederland op 2 oktober een protocol van conclusies betreffende de luchtvaart. De belangrijkste conclusie was dat alle drie de Rijksdelen binnen de grenzen van het Statuut en de Samenwerkingsregeling autonoom waren regelingen te treffen met betrekking tot luchtvervoer. Verder werd afgesproken dat de Samenwerkingsregeling zou worden herzien. De eenheid van rechtspraak en het Gemeenschappelijk Hof van Justitie bleven bestaan, maar de overige punten van samenwerking zouden minder zwaar worden gereglementeerd. ${ }^{28}$

Al op 1 april 1987 zei premier Eman bij aankomst in Nederland voor overleg dat hij de Nederlandse regering formeel zou voorstellen de onafhankelijkheid van Aruba per 1 januari 1996 niet te laten doorgaan. ${ }^{29}$ De onzekerheid over de Arubaanse staatkundige toekomst

\footnotetext{
28 Reinders (1993) pp. 256-258.

3 Zie ook: Amigoe, 14 oktober 1989; Johan P. Sjiem Fat: "Aruba is niet gebaat bij onathankelijkheid in 1996"; Amigoe, 26 maart 1990, "AVP: status aparte moet gehandhaafd". In een artikel in het NRC Handelsblad van 23 juli 1984 schreef L.A.
} 
had een negatieve invloed op het investeringsklimaat. ${ }^{30}$ De onafhankelijkheid was opdrongen in ruil voor de Status Aparte, aldus Eman. De Tweede Kamerleden W. de Kwaadsteniet (CDA) en J.G.C. Wiebenga (VVD) verklaarden echter dat het Statuut geen stukje papier was, dat maar naar believen kon worden gewijzigd. Volgens Wiebenga werd het investeringsklimaat op Aruba, waar Eman zo bezorgd over was, juist negatief beïnvloed door pogingen de onafhankelijkheid telkens ter discussie te stellen. ${ }^{31}$ Bij het jaarlijks januari-overleg tussen de drie parlementaire delegaties in Oranjestad drong de Nederlandse delegatie bij de Arubaanse partners weer sterk aan op meer aandacht voor de komende onafhankelijkheid.

De Arubaanse regering zag de noodzaak niet in om op dat moment overleg met Nederland te voeren over de wijze waarop het Land in 1996 onafhankelijk zou moeten worden. Eman meende dat een discussie over de onafhankelijkheid afleidde van de hoofdtaken van de regering: economische heroriëntatie en de Status Aparte. ${ }^{32}$

De economische groei en de oplopende tekorten van de overheden bleken aan het begin van de jaren negentig een zware wissel te trekken op de deviezenvoorraad van de Nederlandse Antillen. De toenemende begrotingstekorten werden grotendeels monetair gefinancierd, hetgeen leidde tot hoge tekorten op de lopende rekening van de betalingsbalans. Geconstateerd kan worden dat de Centrale Regering in liquiditeitsmoeilijkheden dreigde te komen gezien de bestaande schuld van 2.5 miljard gulden. Voor Aruba lag dat anders, maar daar zou op termijn de hotelgarantieproblematiek tot dezelfde gevolgen leiden. De afgegeven overheidsgaranties in Aruba, voor wat betreft de exploitatie en bouw van bepaalde hotels leidden tot ongerustheid in de Tweede Kamer. ${ }^{33}$ Dat bleek uit de vragen gesteld door de

Struik, dat het veel beter is dat de Antillen gezamenlijk autonoom worden dan dat Aruba de Status Aparte krijgt. Bovendien geeft hij duidelijk uiting aan de toen heersende politieke mening: "de Antillen moeten onathankelijk worden". Hij stelde die onathankelijkheidsgedachte wel ter discussie. Zoutendijk, Eerste Kamerlid voor de VVD stelde voor de Bovenwindse eilanden overzeese gebiedsdelente maken. Zie ook G.P. Hoefnagels in NRC Handelsblad van 6 juli 1984, "Bilateraliteit moet leidende principe zijn in de verhouding met de Antillen". Uit dit artikel blijkt dat het in Nederland was doorgedrongen dat de Antillen niet tegen hun zin, onathankelijk wilden worden.

30 Zie ook Verton (1986) pp. 181-193.

$31 \quad$ Keesings Historisch Archief, juni 1989, pp. 364 e.v.

32 Keesings Historisch Archief, juli 1989, pp. 425 e.v.

33 Vaststelling van de begroting van de uitgaven en ontvangsten van Hoofdstuk IV (kabinet voor de Nederlands-Antilliaanse en Arubaanse Zaken, KABNAA) voor het jaar 1992, Lijst van vragen, vastgesteld 14 oktober 1991 Lijst van antwoorden, ontvangen 22 oktober 1991, Tweede Kamer, vergaderjaar 1991-1992, 22300 IV, 
leden van de Vaste Kamercommissie voor Nederlands-Antilliaanse en Arubaanse Zaken aan Minister Hirsch Ballin over de consequenties van de in het verleden afgegeven hotelgaranties door de Arubaanse overheid. De financiële problemen betroffen het Golden Tulip Hotel, het Ramada Renaissance Hotel, het Beta Hotel en het Plantation Bay Hotel, die beide nog moesten worden afgebouwd. Indien door de betrokken banken een substantieel beroep zou worden gedaan op de afgegeven overheidsgaranties, zouden de financiële problemen voor Aruba onoplosbaar zijn. Vandaar ook dat Nederland hulp verleende in de vorm van het verkrijgen van een lening van 75 miljoen dollar ten behoeve van de financiering van de afbouw van de hotels.

De Commissie Biesheuvel bracht over die problematiek een vertrouwelijk rapport uit, naar aanleiding waarvan mevrouw E.G. Terpstra (VVD) opmerkte dat het nog erger was als de Kamer had gedacht. Niet alleen Aruba zat in de boot, ook Nederland zat in de boot. Mevrouw Terpstra verwees naar art. 29 Statuut, dat stelt dat voor het garanderen of aangaan van een buitenlandse geldlening toestemming van de Koninkrijksministerraad nodig is. Mevrouw Terpstra merkte nog op dat bij een cumulatie van zoveel garanties en leningen, waarbij tevens wellicht sprake was van het witwassen van drugsgelden, strikt juridisch op grond van het Statuut geen financiële toets mogelijk kan zijn, maar dat er strijd kan ontstaan met de belangen van het Koninkrijk ex art. 29 lid twee van het Statuut. Ook wees Mevrouw Terpstra op de dramatisch dalende bezettingsgraad in de hotels; voor 1991 was die $68.9 \%$ en de cijfers over 1992 zagen er nog slechter uit. Zij verwoordde de zorgen van de Kamer in het algemeen over de schuldenlast van de Nederlandse Antillen van 2.5 miljard gulden, de problematische bestuurssituatie op Sint Maarten en de hotelproblematiek van Aruba. De Minister antwoordde hierop dat de schade voor wat betreft de niet afgebouwde hotels in Aruba zo snel mogelijk getemporiseerd diende te worden, daar de schade zou kunnen oplopen tot het gigantische en ondraaglijke bedrag van 233 miljoen dollar. Die schade, zo stelde hij, zal in belangrijke mate onvermijdelijk blijken. Tijdens de Contactplanbijeenkomst in Nederland in 1992 was F.B. Flanegin van mening:

“dat de Koninkrijksregering conform artikel 29 Statuut, de door de Arubaanse regering verstrekte garanties had goedgekeurd zonder grondige verificatie van de economische haalbaarheid van de projec-

nrs. 5 en 7 en Lijst van antwoorden bij de begrotingsbehandeling KABNAA 1993, 22800 rV, nr. 6 en nr. 7. Zie ook het verslag van de Parlementaire Contactplanvergadering, Staten-Generaal, vergaderjaar 1992-1993, 22 850, nrs. 40 en I, pp. 93-108. 
ten. Ons baserend op het genoemde artikel 29 , zijn wij van oordeel dat Nederland mede verantwoordelijkheid dient te dragen voor de claims die thans aan de Arubaanse regering worden voorgelegd als gevolg van die garanties."

J. Franssen (VVD) was het daar helemaal niet mee eens. Hij verklaarde: " $U$ heeft een intern financieel-huishoudelijk probleem". ${ }^{34}$ Naar aanleiding van deze problematiek werd in januari 1993 door Hirsch Ballin een onderzoekscommissie ingesteld. De commissie moest onderzoeken hoe de Arubaanse besluitvorming met betrekking tot het afgeven van de garanties tot stand was gekomen. Tevens zou de commissie indien nodig, voorstellen moeten doen om de besluitvorming over geldleningen in het buitenland te verbeteren en te bezien of in dat kader art. 29 Statuut zou moeten worden aangepast. De conclusie van de commissie in haar eindrapport was dat bij de garantieverlening niet altijd voldoende begeleiding, toezicht en controle aanwezig was. Ook was de besluitvorming voor nieuwe hotelprojecten niet altijd even zorgvuldig afgewogen en werd de geplande hotelbehoefte niet systematisch bewaakt. Bovendien werd geen onderzoek gedaan naar de betrouwbaarheid van de aangezochte buitenlandse aannemers en ingeschakelde banken en verzekeringsinstellingen. De Koninkrijksregering keurde de garantieverklaring goed zonder een inhoudelijk onderzoek. Nederland heeft er nooit enige twijfel aan laten bestaan dat noch Nederland, noch het Koninkrijk aan de garanties gebonden zijn, maar alleen het Land Aruba zelf. Het kabinet-Oduber I was die mening niet toegedaan en meende dat Nederland zich ook tegenover Aruba gecommitteerd had. Dit standpunt werd nog eens herhaald in een motie van de Staten van mei 1991. Daar de financiers waarschijnlijk niet op de hoogte waren van de beperkte betekenis van de goedkeuring van de Koninkrijksregering meende de commissie te moeten betwijfelen of het Koninkrijk in deze geen medeverantwoordelijkheid droeg.

Gezien het bovenstaande deed de commissie een aantal aanbevelingen, die kort samengevat inhielden dat bij een voorgenomen project de haalbaarheid in economische, juridische en financiële zin zou moeten worden onderzocht. Eveneens zou de betrouwbaarheid en financiële draagkracht van de ingeschakelde aannemers, banken en verzekeringsinstellingen dan dienen te worden onderzocht. Er zou 
voldoende toezicht en controle moeten worden uitgeoefend op de voortgang van een project en ook externe accountantscontrole was noodzakelijk.

Daar de Tweede Toekomstconferentie van juni 1993 aanstaande was, toen de commissie haar rapport uibracht wilde zij geen uitspraak doen over de eventuele aanpassing van art. 29 Statuut tussen Aruba en Nederland, omdat gezien de uitkomsten van de eerste Toekomstconferentie gehouden in maart 1993 het hele Statuut herzien zou moeten worden. ${ }^{35}$

\section{De Arubaanse Statenverkiezingen van 8 januari 1993}

Het eerste kabinet-Oduber besteedde veel aandacht aan de sociale woningbouw, infrastructuur en sanering van de overheidsfinanciën. Dreigend hingen de meer dan 520 miljoen overheidsgaranties afgegeven voor de hotelbouw boven het eiland.

De economische crisis werd verder bedwongen sinds in oktober 1990 het kabinet-Oduber erin slaagde om de olie-industrie op het eiland te herintroduceren. Het Amerikaanse bedrijf Coastal raffineert op het voormalige Lago-terrein olie en heeft ook een olie-overslagstation in gebruik genomen. Ondanks de bezwaren rond de verdere overbelasting van de arbeidsmarkt en de ongunstige milieu-, loon-, en belastingafspraken met Coastal betekende de komst van Coastal een verbreding van de basis van de eilandeconomie.

Aan de verkiezingen voor 1993 deden negen politieke partijen mee. ${ }^{36}$ PPA-politicus Toppenberg overleed op 14 januari 1993 door

Rappon van de Onderzoekscommissie Besluitvorming Garantieproblematiek Aruba, 18 juni 1993. In de commissie hadden zitting: F.G. Kordes, mr. E.J. Numann, M.R. Croes R.A, mr. E.J.E. Mohamed, die mr. A.J. Swaen verving, secretaris van de commissie was mr. B. Nieuwenhuizen.

* 1. Accion Democratico Nacional(ADN) van Pedro Pablo Kelly;

2. De Arubaanse Volkspartij (AVP) van Henny Eman;

3. Convergencia Royalista Nacional (CORONA), van mr. Helen Lejuez, een nieuwe partij;

4. Movimiento Electoral di Pueblo (MEP) van Nelson Oduber;

5. Organisacion Liberal Arubiano (OLA) van Glenbert Croes, een nieuwe partij;

6. Partido Aruba Nobo (PAN) van Marco Marlin, een nieuwe partij;

7. Partido Democratico Arubiano (PDA) van dr. Leonard S. Berlinski;

8. Partido Patriotico Arubiano (PPA) van Benny Nisbet;

9. Partido Patriotico Nobo (PPN) van Eddy Werleman.

Amigoe 12 en 13 januari 1993. Premier Oduber liet op de verkiezingsdag nog weten dat hij bang was voor een aanslag op zijn leven, daar er twee Columbianen zouden zijn ingehuurd om hem van het leven te beroven. De premier verklaarde dat "een regen van kogels werd afgevuurd" toen hij op de verkiezingsavond thuis aan het uitrusten was. "Ik werd gelukkig niet geraakt door de kogel die door het raam 
mishandeling bij een gevecht op 8 januari, door een AVP aanhanger. Hij zou zijn overleden aan een miltruptuur, die in het ziekenhuis niet onderkend zou zijn. Dit bericht leidde tot beschuldigingen van onderlinge bedreigingen van de MEP en de AVP aan elkaars adres. ${ }^{37}$ De verkiezingen leverden geen duidelijke winnaar op. De MEP en de AVP behaalden beide 9 zetels.

De ATIA gaf aan een groot voorstander te zijn van een zakenkabinet met de MEP en de AVP. "De komende vier jaren moeten problemen van nationale aard worden opgelost, voordat ze ontaarden in ongecontroleerde spanningsvelden, met alle gevolgen van dien.' Er moest overeenstemming worden bereikt op Koninkrijksniveau, over de toekomstige staatkundige toekomst van Aruba. De overheidsgaranties en de afbouw van de hotels moesten zo spoedig mogelijk worden geregeld. De bouw van deze hotels werd in 1990 gestaakt, wegens faillissement van het Italiaanse bouwbedrijf. Er moesten meer deviezen-genererende projecten worden aangetrokken, de financiën van het Land moesten beter beheerst worden en de basis van de economie moest verbreed worden. Verder zouden de sociale spanningen kunnen worden bedwongen door een voortvarend huisvestingsbeleid en arbeidsmarktbeleid, verlaging van de kosten van het levensonderhoud, een stringent toelatingsbeleid van vreemdelingen en bestrijding van criminaliteit.

suisde", vertelde de premier naar anleiding van de aanslag die op hem was gepleegd. De volgende dag trok de premier zijn verklaring weer in en weet het aan een foute berichtgeving van de kranten, er zouden alleen ruiten zijn ingegooid bij familieleden elders.

Amigoe, 15 januari 1993. In de Amigoe van 18 januari 1993 verscheen een ingezonden schrijven van een groep verontruste Arubanen in Nederland. De groep is van mening dat uitgezocht moet worden waar de Af1. 60.000 ,- zijn gebleven, die uit het Arubahuis zijn vendwenen en wenst bestrijding van de ambtelijke comptie en fraude bij het Arubahuis. Amigoe 19 januari 1993: H. Habibe Croes, cen Arubaan wonend in Nederland, zond een ingezonden stuk naar de Amigoe onder de titel: 'Arubsanse tragedia'. Naar aanleiding van de incidenten bij de verkiezingen en de dasaan voorafgaande campagne gaf hij aan dat het ondoordacht en gevaarlijk is om bij verkiezingscampagnesop ongenuanceerdewijze een beroep te doen op de volkssentimenten. Naar zijn mening blijkt daaruit dat Aruba nog helemaal niet rijp is voor de ons fhankelijkheid. 'Door een louter emotioneel nationalisme heeft men een gezonde integratie tegengewerkt. Zelfs de sluiting van de Lago in 1985 was voor de polititci geen aanleiding om op nationaal niveau te gaan samenwerken. Eenheid naar buiten kan moeilijk optreden, omdat partijpolitiek gekibbel (uitmondend in agressiviteit en pogingen tot moord) deze in de weg staan. Een gemeenschappelijk referentiekader schijnt mede door gebrek aan geestelijke volwassenheid, nog steeds te ontbreken. Het is jammer dat de tijd en de politieke rust, die door Nederland zijn gecreēerd niet beter benut worden.' 
De Kamer van Koophandel (KvK) waarschuwde voor het verlies van waarden en normen en constateerde dat de verkiezingscampagne niet op de juiste wijze was verlopen, de berichtgeving in de pers had daar zeker toe bijgedragen. Tevens maakte de $\mathrm{KvK}$ melding van pogingen tot afpersing van zakenlieden en de vrije beroepsbeoefenaars. ${ }^{38} 26$ januari 1993 werd ex-premier Oduber door de Gouverneur benoemd tot formateur. ${ }^{39}$ Uiteindelijk bleek de OLA geen deel uit te willen maken van het tweede kabinet-Oduber. Dat betekende 'een magere zetelverdeling' voor de nieuwe regering. De MEP, PPA en ADN sloten een principe overeenkomst over de vorming van een nieuwe regering op basis van een 11-10 zetelverhouding in de Staten. Op 8 februari 1993 kwamen de Staten in de nieuwe samenstelling bijeen."

\section{Politieke ontwikkelingen in de Antillen}

Op 8 januari 1989 verklaarde Martina dat het de voorkeur verdiende als Curaçao zelfstandig zou worden en dat het geen zin had te werken aan een eenheid van vijf Antilliaanse eilanden. Het zoeken naar een samenwerkingsvorm waarin alle eilanden zich konden vinden was volgens hem een gebed zonder einde. Nederland was nog steeds van mening dat gebruikmaking van het zelfbeschikkingsrecht automatisch moest leiden tot onafhankelijkheid van de Antillen. ${ }^{41}$ De PNP zag een federaal staatsverband met de overige vier Antilliaanse eilanden niet meer zitten nu Sint Maarten onafhankelijk wilde worden. In Curaçao werd omstreeks 1989 de roep steeds sterker om evenals Aruba een aparte status binnen het Koninkrijk te verwerven.

Nederland bleef bij zijn standpunt van een Antilliaans staatsverband van de vijf eilanden en suggereerde zoveel mogelijk taken en bevoegdheden van de Landsregering naar de eilanden af te stoten. $\mathrm{Na}$ de uitreding van Aruba uit het Antilliaans verband, werd door de Antilliaanse politiek nog steeds gezocht naar een werkbaar staatkundig verband tussen de overgebleven eilanden. Ook drong Nederland bij Aruba aan op voorbereidingen voor de onafbankelijkheid in 1996.

39 Amigoe, 26 januari 1993.

40 Amigoe, 4 februari 1993, 'Felle kritiek MEP, ADN en PPA op OLA, Magere zetelverdeling bij formatie tweede kabinet Oduber'. Amigoe, 5 februari 1993, 'Drie coalitiepartners sluiten overeenkomst nieuwe regering'; 'Onathankelijkheidsdatum eerste punt in principe-regeerakkoord'.

\$1 De Tweede Kamer was in 1983 uiteraard nog van mening dat Aruba het zelfbeschikkingsrecht had uitgeoefend door definitief te kiezen voor onafhankelijkheid in 1996, Handelingen Tweede Kamer, vergaderjaar 1983-1984, 18 001, hoofdstuk IV, nr. 2, p. 2. 
Aan Aruba werd gevraagd zich nader te beraden op een in 1989 door het Arubaanse kabinet naar voren gebrachte Gemenebestconstructie. De interne herstructurering van de Nederlandse Antillen stagneerde, ondanks een hausse aan rapporten, standpuntbepalingen en uitlatingen van Nederlandse en Antilliaanse politici tussen 1983 en $1990 .^{42}$ In het nu volgende onderdeel komen deze rapporten, meningen en modellen uitgebreid aan de orde.

De meningen van de Nederlandse deskundigen De Gaay Fortman, Van der Grinten en Hoetink worden eerst behandeld. Vervolgens worden de Antilliaanse rapporten behandeld. De rapporten die zich bezighielden met de herstructurering van de Antillen van de Vijf waren achtereenvolgens het rapport 'Gezamenlijk of gescheiden voortbestaan' van de werkgroep Dip uit 1983. De bevindingen van de Werkgroep Herstructurering Nederlandse Antillen: 'Modellen voor een nieuwe staatkundige structuur' dateerden van 1987. Hierop volgde in 1988 een discussiepaper: 'Naar een nieuwe taakverdeling tussen Land en Eiland'. Uit 1990 dateerde het 'Draaiboek Decentralisatie', een gezamenlijke inventarisatie van het Land en het Eilandgebied Curaçao. In datzelfde jaar verscheen de 'Schets' van minister Hirsch Ballin. Aan deze rij voegde de directeur van het kabinet van de Gouverneur op Curaçao, Janus zijn Unie-model toe. Tevens komt een aantal meningen van deskundigen over een gewenste Koninkrijksstructuur ter sprake.

De Gaay Fortman ${ }^{43}$ gaf onder de titel: 'Laat de Antillen met rust' in 1985 zijn mening over de staatkundige toekomst van de Nederlandse Antillen. Hij was van mening dat nu Aruba een eigen status binnen het Koninkrijk had gekregen, dat tevens inhield dat Aruba een zekere verantwoordelijkheid hield voor de andere eilanden. De aparte status die Aruba zich ten opzichte van de andere eilanden had verworven, was tijdelijk van aard, ze was immers bedoeld als een overgangsstatus naar volledige zelfstandigheid. Bij het toekennen van de Status Aparte werd art. 62 opgenomen in het Statuut. Dit artikel verwoordde het 
zelfbeschikkingsrecht waarvan Aruba gebruik maakte door definitief te kiezen voor de onafhankelijkheid in $1996 .^{44}$ De Gaay Fortman bracht naar voren dat een voormalige koloniale mogendheid de onafhankelijkheid niet mag opdringen aan een voormalige kolonie die nog tot haar staatsverband behoort. Dit is in strijd met art. 1 van het Verdrag van New York (1966) inzake burgerrechten en politieke rechten. Het zelfbeschikkingsrecht betekent niet, dat een voormalige koloniale mogendheid met een beroep daarop een voormalige kolonie buiten de deur zou kunnen zetten tegen de zin van de bevolking. Artikel 62 van het Statuut, dat de verplichte onafhankelijkheid regelt, verdraagt zich dan ook niet met art. 1 Verdrag van New York. ${ }^{45}$

Van der Grinten ${ }^{46}$ reageerde op de uitlatingen van De Gaay Fortman en gaf als zijn mening te kennen dat een verdere opsplitsing van de Nederlandse Antillen moet leiden top het einde van de band met het Koninkrijk. Hij betreurde het dat door het verkrijgen van de Status Aparte door Aruba, de Nederlandse Antillen in twee mini-staatjes uiteen deed vallen. De Nederlandse regering en het Nederlandse parlement "zijn bezweken voor de Arubaanse druk, waartegen Curaçao geen sterke tegendruk gaf." Van der Grinten was van mening dat het zelfstandige Land Aruba de verhoudingen in het Koninkrijk compliceert. Nederland had alleen maar aan de wens van Aruba toegegeven omdat de Nederlandse Antillen zich hiertegen niet verzetten. Hij vond het beter als door het uittreden van Aruba uit het Antilliaanse staatsverband ook direct de staatsrechtelijke band met Nederland was verbroken. Daardoor zou er dan een redelijke kans was geweest dat Aruba binnen het Antilliaanse verband was gebleven. Van der Grinten was het dan ook helemaal niet eens met de Gaay Fortman, Aruba in 1996 de keuze te laten al of niet in het Koninkrijk te blijven. De definitieve beslissing was dat de statutaire band met Aruba in 1996 moest worden beëindigd en dat diende ook te gebeuren. Wel kon Aruba er voor opteren terug te keren binnen het Antilliaanse staatsverband in 1996.

Tevens vond hij de opvatting van De Gaay Fortman dat art. 1 van het Verdrag van New York, inzake burgerrechten en politieke rechten inhoudt, dat een moederland niet de bevoegdheid heeft de banden met een voormalige kolonie te verbreken onjuist. Nederland heeft dat zelfbeschikkingsrecht ook en kan de relatie met de voormalige kolonie beëindigen.

\footnotetext{
$4 \quad$ Zie over het zelfbeschikkingsrecht ook: Fernandes Mendes (1984) m.n. p. 73.

4s De Gaay Fortman (1985).

46 Van der Grinten (1986).
} 
Van der Grinten gaf aan dat Nederland volkenrechtelijk bevoegd is eenzijdig de Koninkrijksband met de Nederlandse Antillen en Aruba te verbreken. In het bijzonder drie gronden kunnen een rechtvaardiging zijn om de juridische band met de Nederlandse Antillen te verbreken:

1. Indien de Nederlandse Antillen geen orde op zaken kunnen stellen is dat een deugdelijke grond om de staatsrechtelijke relatie te verbreken. De economische situatie laat te wensen over en de loonstandaard is te hoog in vergelijking met de omliggende landen. Het ambtelijk apparaat is excessief uitgedijd met name door partijpolitieke benoemingen. Begrotingssteun achtte Van der Grinten uit den boze, want daardoor worden de noodzakelijke maatregelen niet genomen. Regering en Staten moeten hun verantwoordelijkheid willen dragen.

2. Indien het Openbaar Ministerie en politie onder invloed van partijpolitiek de fundamentele rechten van de burgers zouden aantasten.

3. Indien de Nederlandse Antillen binnen het Koninkrijk willen blijven en de Nederlandse nationaliteit willen behouden zullen zij zich open moeten stellen voor de Nederlandse cultuur. Onderwijs moet in het Nederlands worden gegeven en er mag niet gediscrimineerd worden ten aanzien van Europese Nederlanders.

Verder meende Van der Grinten, gezien de geringe bestuurskracht van de kleine eilanden, dat er bij een herstructurering gedacht zou moeten worden aan een sterk centraal gazag met beperkte taken voor de eilandsbesturen. De begrotingssteun aan de Nederlandse Antillen zou bez̈indigd moeten worden, omdat economische noodzakelijke beslissingen daardoor verder worden uitgesteld.

Van der Grinten wilde voorlopig de Antillen van de Vijf wel 'met rust laten', zoals De Gaay Fortman verlangde, maar dan alleen als voldaan werd aan de drie bovengenoemde punten. Het overzeese deel van het Koninkrijk moet naar behoren functioneren, zo niet dan moet de Koninkrijksband beëindigd worden. De tolerantie die Nederland ten opzichte van Aruba heeft betoond, moet niet herhaald worden, indien de Nederlandse Antillen nog verder zouden desintegreren. Indien de Nederlandse Antillen dit wensen, dan moet ook tegelijkertijd de Koninkrijksband worden verbroken. ${ }^{47}$

67 Van der Grinten (1986) pp. 231-238, nawoord van De Gaay Fortman, met name de pp. 237 e.v. 
Van der Grinten vond blijkbaar dat de Nederlandse mening over de gewenste staatkundige structuur van de voormalige kolonie de doorslag geeft. Het is opvallend dat weinig Nederlanders het Antilliaanse perspectief als uitgangspunt voor hun analyse nemen. Zijn conclusie dat Nederland 6ók het zelfbeschikkingsrecht heeft in de zin van eerder genoemd art. 1 Verdrag van New York, lijkt mij onjuist. Dat artikel is duidelijk bedoeld voor landen die zuchten onder het bewind van een andere mogendheid en dat is voor Nederland zeker niet het geval. Bovendien was het zelfbeschikkingsrecht van de eilanden duidelijk erkend in het rapport van de Koninkrijkswerkgroep uit 1980. Daarin werd ook alleen maar gesproken van het zelfbeschikkingsrecht van de eilanden en niet van Nederland. Dat zelfbeschikkingsrecht werd nog eens bevestigd op de RTC van $1981^{48}$ en op de RTC van 1983.

Ten slotte lijkt het ook onjuist uit te gaan van een sterke centrale regering en weinig taken voor de afzonderlijke eilanden. Dit is in strijd met de gedachte die al sinds 1865 in het Regeringsreglement voorkomt: zelfstandigheid in eigen zaken voor de eilanden, hetgeen uiteindelijk ook is vastgelegd in de Eilandenregeling van 1951, het Statuut van 1954 en de Staatsregeling voor de Nederlandse Antillen van 1955. Bovendien zou het gevaar in het geheel niet denkbeeldig zijn dat landsbelangen grotendeels eilandsbelangen van Curaçao zouden blijken te zijn. Alle eilanden behalve Curaçao hebben altijd het gevoel gehad, dat zij achtergesteld werden, omdat in Curaçao de centrale regering was gevestigd. Alle rapporten en onderzoeken uitgaande van de wens van de bevolking en analyses van de vraag waarom Nederlandse maatregelen in de West niet werkten, pleiten tegen de opvattingen van Van der Grinten.

Ook het beëindigen van begrotingssteun lijkt mij niet de aangewezen weg. Wel kan er naar mijn mening een betere controle worden uitgeoefend op de besteding van de overgedragen middelen. Van der Grinten doet het voorkomen alsof het Koninkrijk geen enkele zeggenschap heeft op de Antillen en Aruba. Gezien de mogelijkheden op grond van het Statuut en het hanteren van de begrotingssteun lijkt mij dat er voldoende ruimte aanwezig is voor de Koninkrijksregering invloed uit toe oefenen op het interne Antilliaanse en Arubaanse politieke beleid. men een brief van de minister voor Nederlands-Antilliaanse Zaken Van der Stee, d.d. 4 madr 1982 aan de voorzitter van de Gemengde Commissie, B.W. Biesheuvel. Hierin wordt expliciet nogmaals het zelfbeschikkingsrecht van de eilanden erkend zoals vastgelegd op de RTC van februari 1981. 
Hoetink $^{49}$ merkte in 1986 op dat een federatie van meerdere eilanden kennelijk alleen kan bestaan als éńn ervan véruit dominant is. Hoetink merkte verder op dat tijdens de RTC waarop de Status Aparte van Aruba werd behandeld, niet alleen de onafhankelijkheid van dit eiland per 1996 werd afgedwongen, maar er werd, méér dan vragenderwij]s, gesuggereerd dat per die datum ook de Antillen van de Vijf onafhankelijk zouden behoren te zijn. Daarbij werd een volkenrechtelijke samenwerkingsvorm, een 'gemenebest sui generis', vooralsnog niet nader uitgewerkt, in het vooruitzicht gesteld. Tezelfdertijd wilde Nederland wel de aard, vorm en inhoud van de toekomstige samenwerking tussen Nederland nauwkeurig voorschrijven. Een dergelijke Nederlandse houding wekte verwarring.

Sinds het vertrek van de Shell van Curaçao nam de feitelijke en potentiële invloed van Venezuela toe, zowel politiek als economisch en zeker voor wat betreft de Benedenwinden. Als de Antillen van de Vijf willen overleven als 'onafhankelijke' staat dan zouden in ieder geval met een of meer derde landen verdragen moeten worden afgesloten over defensie, opleidingen en gespecialiseerde menskracht. Ook meende Hoetink dat er meer eilandelijke autonomie zou moeten komen, maar dan wel met meer bestuurskracht en doelmatigheid op de eilanden.

Hij haalde hier weer De Gaay Fortman aan, die suggercerde dat het nuttig is om na te gaan hoe de decentralisatie in de koloniale tijd was geregeld. De Gezaghebbers van de eilanden hadden toen een grote zelfstandigheid ten opzichte van het centrale bestuur in Willemstad. De Gaay Fortman was van mening dat in de koloniale regeringsreglementen aanwijzingen te vinden zouden zijn voor een eenvoudiger regeling van decentralisatie, dan die welke de Koninkrijkswerkgroep voorstelde.

Het is mij onduidelijk welke ideeën omtrent decentralisatie De Gaay Fortman en Hoetink in dit geval voor ogen stonden. Bij bestudering van de Regeringsreglementen bleek dat bestuur en rechtspraak in de koloniale tijd zeer met elkaar verweven waren. De bevolking had weinig invloed in het bestuur, de Gezaghebber en de landraden regelden alle zaken die zij in het belang van het eiland nuttig achtten en die hen binnen het Regeringsreglement waren toegestaan. Verder had de Koning de hoogste macht.

Dat een simpele decentralisatieregeling de voorkeur verdient is begrijpelijk. Dan moet echter, wel duidelijk zijn wát precies met decentralisatie wordt bedoeld en welke consequenties decentralisatie 
heeft, met name voor de kleine eilanden. De Soponata-affaire van Bonaire is een voorbeeld van de ongewenste gevolgen van decentralisatie, die kunnen ontstaan als onvoldoende deskundigheid en bestuurskracht op het eiland voorhanden zijn. ${ }^{50}$ De gegroeide verhoudingen sinds de koloniale tijd, zijn vanwege de invoering van de democratie en het parlementaire stelsel ook delicater geworden. Het moederland kan de andere landen binnen het Koninkrijk niet meer de wet voorschrijven. Bovendien moet rekening gehouden worden met de (inter) eilandelijke cultuur en gevoelens. ${ }^{51}$ Antillen

Herstructurering van het Antilliaans staatsverband was noodzakelijk geworden door het uittreden van Aruba, concludeerde Dip $^{52}$ Dit werd ook voorgeschreven door conclusiepunt $13^{53}$ van de RTC van 1983. In de Nederlandse Antillen werd dat geïnterpreteerd als een opdracht om in het bijzonder te onderzoeken of de verticale machtenscheiding van de artikelen 2 en 2 A ERNA moest worden gehandhaafd en of de wijze van verzorging van de lands- en eilandstaken niet op een doelmatiger wijze en met minder kosten kon geschieden.

De wijze waarop de artikelen 2 en $2 A$ van de ERNA zijn gestructureerd, geeft aan de staatsrechtelijke ordening van de Nederlandse Antillen een federale inslag en verleent aan de eilandgebieden veel meer waarborgen dan het stelsel van de Nederlandse Gemeentewet. De Nederlandse rijkswetgever is te allen tijde bevoegd een onderwerp te regelen, waardoor de wetgevende bevoegdheid van de gemeente automatisch wordt beperkt.

HR 7 maart 1986, NJ 1986, 266, Sociedade Portugesa de Navios Tanques Lida, Lissabon (Soponata) vs het Eilandgebied Bonaire.

si Hoetink in: Bongenaar (1986) pp. 4 e.v.

s2 Dip (1990) p. 514.

33 Conclusiepunt 13 luidde: 'Nederland en de Nederlandse Antillen verienen hun medewerking aan de in verband met het intreden van de status aparte van Aruba noodzakelijke wijzigingen van het Statuut voor het Koninkrijk der Nederlanden, de Staatsregeling van de Nederlandse Antillen en andere relevante regelingen. De wijzigingen van de Staatsregeling zullen worden gerealiseerd in twee landsverordeningen die gelijktijdig en wel op het tijdstip van de intreding van de status aparte van Aruba in werking zullen treden. De ene landsverordening regelt de uittreding van Aruba uit het Antilliaanse staatsverband, terwijl de andere landsverordening de noodzakelijke herstructurering van het nieuwe Antilliaanse staatsverband van de vijf eilandgebiedenvastlegt. Bij de nieuwe samenstelling der Staten wordt als uitgangspunt genomen dat elke der eilandgebieden in de Staten vertegenwoordigd zal zijn.' 
De in 1983 ingestelde Werkgroep Dip had tot taak de regering van de Nederlandse Antillen en de vijf zonder Aruba overblijvende eilandgebieden te adviseren over de herstructurering van de Nederlandse Antillen. De werkgroep presenteerde reeds in januari 1984 een aantal modellen als alternatief voor de vigerende staatsrechtelijke structuur (het rapport Dip). ${ }^{54}$ Deze verschillende bestuurlijke modellen werden gepresenteerd, elk voorzien van een overzicht van de bestuurlijke en financiële consequenties. De voorkeur van de werkgroep ging uit naar een model, dat de huidige centrale bestuurslaag afschafte, door de landstaken zoveel mogelijk aan Curaçaose eilandsorganen (Eilandsraad en Bestuurscollege) op te dragen, voorzover nodig aangevuld met vertegenwoordigers van de andere eilandgebieden. Gedacht werd aan een soort statutair systeem zoals voorgesteld in art. 17 van het Statuut. De Staten worden gevormd door de Eilandsraad van Curaçao, aangevuld met gevolmachtigde ministers en/of bijzondere gedelegeerden van de andere eilanden. Het rapport wekt de indruk, dat de kleine eilanden, minder invloed in de landsregering zullen hebben dan thans en dat Curaçao een wel zeer dominante plaats zal in gaan nemen.

Deze dominante plaats achtte Curaçao noodzakelijk, omdat Curaçao vreesde in een staatsverband van de Antillen van de Vijf, de financiële last voor de kleine eilanden te moeten dragen. Een overeenkomstige situatie deed zich voor in de regio met de 'Federation of the West-Indies', die om die redenen in 1962 ontbonden moest worden. ${ }^{55}$ Aan het mislukken van de West-Indische Federatie zal hierna nog de nodige aandacht worden besteed.

Het Rapport Dip beschreef zes modellen met de nodige varianten. Vier modellen gaan uit van een staatsrechtelijk verband van de Antillen van de Vijf, waarbij de RTC-consensuspunten kunnen worden uitgevoerd. Twee modellen vallen buiten het RTC kader. Interessant is dat met name die modellen die niet overeenkomen met de RTC-conclusiepunten een belangrijke rol zouden spelen bij de Toekomstconferentie van maart 1993. De gepresenteerde modellen hielden kort weergegeven het volgende in:

34 'Gezamenlijk of gescheiden voortbestaan', Rapport van de werkgroep ingesteld bij Landsbesluit van 9 september 1983, PB 1983, nr.1, Curaçвo, 1984 ('Rapport Dip'). Mr. C.E. Dip was voorzitter van de werkgroep; in de werkgroep hadden verder zitting: mr. N.G. Navarro, drs. J. Buys, mr. A.G. Croes, mr. A.F.M. Torres; Croes (1984).

ss Croes (1984) pp. 261 e.v. 
1. voortzetting van de huidige staatsinrichting met enige noodzakelijke aanpassingen ten einde te verhinderen dat de kleine eilanden te weinig invloed op het centrale bestuur kunnen uitoefenen;

2. veel sterkere decentralisatie, zodat voor de centrale overheid nog slechts een minimaal pakket van bevoegdheden overblijft;

3. afschaffing van de huidige centrale bestuurslaag door de landstaken zoveel mogelijk aan Curaçaose eilandsorganen op te dragen, voor zover nodig met enige aanwas vanuit de andere eilanden. Met name zouden hierdoor de overheidskosten aanzienlijk kunnen worden verlaagd. Deze variant bevat vier reductie modellen, de werkgroep Dip geeft de voorkeur aan het tweede reductiemodel, hetgeen inhoudt dat de eilandsraden worden samengevoegd. In verenigde vergadering optredend vormen zij dan het Statencollege, dat dan in totaal 49 leden telt in de verdeling Curaçao: 21, Bonaire: 9, Sint Maarten: 9, en Saba en Sint Eustatius elk 5 zetels; ${ }^{56}$

4. recentralisatie;

5. enige bijzondere oplossingen, al dan niet onder handhaving van het Antilliaanse staatsverband, in het eventueel negatieve geval gepaard gaande met een Status Aparte voor Curaçao.

6. Deze mogelijkheid is wel uitgewerkt maar niet in extenso, omdat onafhankelijkheid van elk eiland nog geen aanvaardbaar alternatief is.

Voortzetting van de bestaande staatsinrichting van de Antillen was na het uittreden van Aruba nogal kostbaar geworden. Vandaar dat ook alle staatkundige voorstellen werden doorgerekend op kosten en baten door het Departement van Staatkundige Structuur. In beginsel werd gekeken naar de modellen die pasten binnen de RTC afspraken van 1983. ${ }^{57}$ Het reduceren van een bestuurslaag evenals centralisatie, dat ook tot het opheffen van een bestuurslaag kan leiden, leverde de grootste kostenbesparingen op. ${ }^{58}$

Een belangrijk gedeelte van het rapport was gewijd aan de 'reductiemodellen'. Deze hebben vooral betrekking op de volksvertegenwoordiging, de regering en de uitvoering. Voor wat betreft reductie ten aanzien van de volksvertegenwoordiging gaf het rapport Dip vier varianten. ${ }^{59}$ Het eerste model hield in een samenvoeging

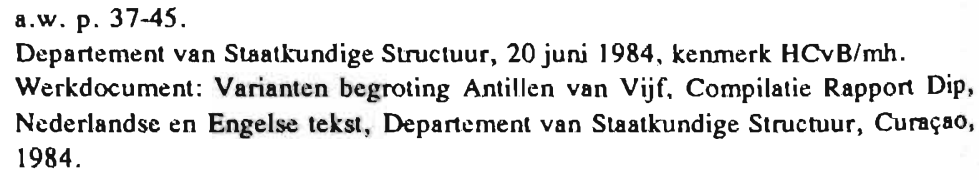


van alle Eilandsraden, die in verenigde vergadering optredend, het Statencollege vormen. Dit leverde een zetelverdeling op, die voor Curaçao onaanvaardbaar was. In het tweede model werd een deel van de leden van de Eilandsraden door de raden aangewezen als landelijke vertegenwoordiger. Bij deze constructie zou de kwestie van zetelverdeling uiteraard weer een rol spelen. De volgende twee modellen gingen meer de kant op van het laten samenvallen van de Staten met de Eilandsraad van Curaçao. De Staten zouden worden gevormd door de Eilandsraad van Curaçao, aangevuld met Gevolmachtigde ministers en/of bijzondere gedelegeerden van de andere eilanden.

Het rapport Dip achtte het tweede reductiemodel (van variant 3) het meest raadzaam en besteedde daaraan ook de meeste aandacht. Ten aanzien van de landelijke - indirect gekozen - volksvertegenwoordiging werd hierbij een suggestie gedaan voor een zetelverhouding van: Curaçao 12, Bonaire 3, Sint Maarten 3, Saba en Sint Eustatius 1.

De werkgroep achtte het juist dat Curaçao de boventoon voerde, als tenminste door de niet-overstemmingsclausule een beveiliging kon worden ingebouwd. Het rapport stelde dat een minister die tevens Gedeputeerde is, niet ontslagen behoort te kunnen worden. ${ }^{60}$ Gezien de feitelijke verhoudingen zouden de Gedeputeerden van Curaçao tevens met de functie van Landsminister moeten worden belast. De voorzitter van het Bestuurscollege van Curaçao wordt MinisterPresident. De overige eilanden hebben in de ministerraad elk een toehoorder zonder stemrecht. Slechts één minister is niet tevens een gedeputeerde van Curaçao. Hij wordt als minister zonder portefeuille benoemd, in overleg met een politieke partij, die op een of meer van de eilanden werkzaam is en in de Staten is vertegenwoordigd. Dit voorstel betekende zonder twijfel een achteruitgang voor de kleine eilanden. Ook het inbouwen van een intern raadsappel en de rechtspraak van een Constitutioneel Hof kunnen dit niet veranderen. De rechter zal immers alleen de rechtmatigheid van de besluitvorming kunnen toetsen en niet de doelmatigheid en op het gebied van de doelmatigheid doen zich met name de politieke conflicten voor.

De werkgroep onthield zich in haar rapport zoveel mogelijk van politieke argumenten voor het ene of andere model. Op grond van financiële en personele overwegingen en met het oog op de noodzaak om de kwaliteit van wetgeving en bestuur zo hoog mogelijk te houden, koos de werkgroep zelf duidelijk voor model III en achtte zij aan de modellen I en II grote bezwaren verbonden. De politici op 
de Antillen kozen voorlopig voor model I op het Topoverleg (1984). Naar de mening van de werkgroep was na de uittreding van Aruba, niet langer voldaan aan de noodzakelijke voorwaarden om van de overblijvende eilanden een federatie te vormen. Met Aruba erbij zouden beide eilanden een federatie hebben kunnen dragen. ${ }^{61}$ Bongenaar ${ }^{62}$ ondersteunde de mening van de werkgroep en stelde:

"De veronderstelling dat er na 1 januari 1986 vijf gelijkwaardige eilandgebieden met tegen elkaar opgewassen autonome eilandgebieden kunnen bestaan is ridicuul."

Bongenaar ${ }^{63}$ meende dat de Arubaanse afscheiding de Nederlandse Antillen niet alleen een tragische maar ook een dodelijke slag had toegebracht. Het Land steunde op de twee grootste eilanden Curaçao en Aruba, die elkaar min of meer in evenwicht hielden. Beide hadden afzonderlijk en ten opzichte van elkaar een politiek en economisch draagvlak, dat voldoende was om de overige vier eilanden plaats te bieden. ${ }^{64}$

Hij achtte de verdeling van de Statenzetels over de overblijvende Antilliaanse eilanden in de verhouding 14-3-3-1-165 zeer onredelijk. Gezien de politieke verhoudingen kon een meerderheidspartij met medewerking van de kleine partijen buiten de regering worden gehouden. Die kleine partijen eisten voor hun steun natuurlijk een beloning en dat kon leiden tot ongewenste politieke concessies. Bongenaar meende dat Curaçao de Status Aparte moest krijgen. Armlastige maar autonome eilanden vertroebelen de besluitvaardigheid van de centrale regering. Hij achtte een verdere decentralisatie uit den boze, maar beveelt wel een minder rigide competentieverdeling aan tussen het Land en de eilanden. De landswetgever zou de bevoegdheid moeten hebben eilandsaangelegenheden te regelen, indien de eilanden dat nalaten. ${ }^{60}$

61 Rapport Dip (1984) p. 17.

62 Bongenaar (1986) p. 42.

6s Bongenaar (1986) pp. 16-52.

a Amigoe, 6 november 1989, 'AVP: te houden referendum dient beslissend te zijn, particulier bedrijfsleven wenst voortzetting Status Aparte, Groeiende oppositie op Aruba tegen het onathankelijkheidsstreven', Amigoe, 7 december 1989, 'AVP: PPA heeft over 1996 nieuw standpunt', Amigoe, 13 december 1989, 'Brief voor Den Haag, Conclusie gebaseerd op grondige studie, Overleg van Nederland met Aruba over staatkundige structuur moet uitgesteld', Amigoe, 28 december 1989, 'Na verklaring premier, AVP-leider Henny Eman: ons standpunt bevestigd, Volk Aruba moet beslissen over zijn eigen toekomst'. zowel Bonaire als Sint Maarten en voor Saba en Sint Eustatius elk 1 zetel.

Bongenaar (1986) pp. 42 e.v. 
De werkgroep 'Herstructurering Nederlandse Antillen' ontwikkelde in 1987 een aantal modellen, waaronder een zogenaamd fusie-model. Dat model zou later in de Schets van Hirsch Ballin (1990) worden toegepast. Het fusie-model van 1987 was bedoeld voor een Antillen van vijf eilandgebieden, terwijl het Hirsch Ballin-model voor de twee te vormen combinaties Curaçao/Bonaire en Sint Maarten/Saba/Sint Eustatius bedoeld was.

In het fusie-model van de werkgroep werden op Curaçao alle Lands- en Eilandstaken verricht door een samengesmolten apparaat en bestond er geen onderscheid meer tussen de beide taken. De Landsregering en de Staten, waarin ook de eilanden buiten Curaçao zouden zijn vertegenwoordigd, behartigen niet alleen de Landstaken, maar tevens de Curaçaose eilandelijke taken. ${ }^{67}$ Dit voorstel leek overeen te komen met de situatie van Curaçao in de koloniale tijd (vanaf 1865 tot 1936/1948), toen de overkoepelende Koloniale Raad, ook de lokale wettelijke regelingen van het eiland Curaçao vaststelde. ${ }^{68}$ De voorstellen van beide werkgroepen zijn nimmer in de Staten of in de Eilandsraden principieel ter discussie gesteld. ${ }^{69}$

Werkgroep Herstructurering, Nederlandse Antillen, Modellen voor een nieuwe staatkundige structuur, voorlopig rapport ten behoeve van het Topoverleg op Bonaire op 24 en 25 februari 1987. Op dat Topoverleg werd vastgesteld dat het noodzakelijk was om de bestuursapparaten op Curaçao in elkaar te schuiven. Tevens werd geconcludeerd dat een vergaande decentralisatie naar de andere eilanden dan Curaçao geen haalbaar alternatief was. Het rapport behandelt drie modellen, het Koninkrijksmodel het fusie-model en het gedifferentieerde decentralisatie-model. In het Koninkrijksmodel wordı de Land soverheiden de Eiland soverheidvan Curaçao samengesmolten tot een geheel. De Eilandsraad van Curaçao aangevuld met vertegenwoordigers van de Eilandsraden van de andere eilanden vormen de Staten. Verder blijft alles hetzelfde. In het fusie-model treedt ook vereniging van beide organen op, maar de Landsregering behartigt dan tevens de eilandelijke aangelegenheden van Curaçao. In dit model is de positie van Curaçao overheersend. De Eilandsraad van Curaçao fuseert met de Staten. In het decentralisatie-model blijf alles bij het oude, maar worden de taken van de Handsoverheid vermindert. Het rapport lijkt een voorkeur te hebben voor het decentralisatie-model. Dat is trouwens het enige model dat nader is uitgewerkt.

Werkgroep Herstructurering. Naar een nieuwe takverdeling tussen Land en Eiland, november 1988, Vervolgens publiceerde de werkgroep in 1988 een discussiepaper onder de titel 'Naar een nieuwe taakverdeling tussen Land en Eiland.' Dit discussiepaper is een nadere uitwerking van het decentralisatiemodel. In juli 1990 verscheen een nader rapport met betrekking tot decentralisatie van het Land samen met het Eilandgebied Curaçao. Zeker dit laatste rapport lijkt een praktische voorbereiding op de Status Aparte van Curaçao. Commissies Reorganisatie en Efficiêntiebevordering Land en Eilandgebied Curaçao, Binnenlandse Zaken: J. Bernadina en Sectie Organisatie en Informatie, Stafbureau Eilandgebied Curaçao: G.Th. Sulvaran, juli 1990. 
A.G. Croes ${ }^{70}$ bracht het probleem van het 'gezamenlijk voortbestaan' helder in beeld. Hij gaf aan dat een der grootste problemen van het Antilliaanse bestel het onderbrengen was van kleine en grote eilanden in één staatsrechtelijke structuur. De problematiek spitste zich vooral toe op de vraag boe men een staatsrechtelijke eenheid kan construeren zodat minderheden (de kleine eilanden) in het centrale parlement, de Staten, niet in het niets verdwijnen. Van oudsher probeerde men op de Antillen het probleem van twee kanten te benaderen:

1. het zoveel mogelijk decentraliseren van bevoegdheden, dat wil zeggen zoveel mogelijk beslissingen laten nemen door de eilandgebieden;

2. voor de beslissingen op centraal niveau 'safe-guards' formuleren bij besluitvorming ten behoeve van minderheden.

Dergelijke 'safe-guards' kunnen zich voordoen als het eisen van:

- $\quad$ eenstemmigheid of unanimiteit;

- meerderheid van stemmen of overstemming (overstemming kan zich ook voordoen als bepaalde partijen een vetorecht hebben, het kan dan leiden tot een onbeperkt gehanteerd vetorecht en anarchie);

- overwicht van numerieke minderheid;

- $\quad$ autoriteit of eenhoofdige beslissing;

- beslissingen afhankelijk maken van het lot.

Een voorbeeld van een beveiliging van minderheden door overstemming kwam bij de Interimregeling tot stand. De zetelverdeling in de Interimregeling werd Curaçao 12, Aruba 8, Bonaire 1 en de Bovenwindse eilanden gezamenlijk 1 zetel. Deze regeling gold tot de uittreding van Aruba uit het Antilliaanse verband. Als beveiliging tegen de dominante positie van Curaçao werd bij de Interimregeling gekozen voor:

- een gemitigeerd tweekamerstelsel (met eventueel nog, op verzoek van een bepaalde minderheid, het vereiste van goedkeuring door de Koningin) en een alternatief dat, indien dit werd verzocht door $3 / 4$ van de leden welke gezamenlijk een eilandgebied vertegenwoordigden, een onderwerp bij eilandsverordening in 
De voorstellen die werden aangedragen in verband met de uittreding van Aruba, zijn varianten op de voorstellen aan het einde van de jaren veertig. Een vaststaand gegeven bij alle voorstellen is zoveel mogelijk overdracht van bevoegdheden van de centrale overheid aan de eilandgebieden. Het rapport Jeukens zou volgens Croes nog een bijdrage kunnen leveren bij de herstructurering van de Antillen van de Vijf. ${ }^{71}$ Croes ging vervolgens in op het rapport Dip, waaraan hij zelf meewerkte. De werkgroep Dip was van mening dat het intern statenappel misbruikt kon worden door de van de kleinste eilanden afkomstige Statenleden. Croes stelde daar tegenover dat deze Statenleden in de voorgestelde zetelverdeling de besluitvorming niet kunnen blokkeren. Hij meende verder dat het intern statenappel en de niet overstemmings-clausule slechts betrekking konden hebben op de totstandkoming van landsverordeningen en niet op materiële wetgeving. Een beroepsregeling op de Kroon leek in de huidige omstandigheden vrijwel onmogelijk, meende Croes, daar het welhaast ondenkbaar is dat Nederland nu nog geneigd zal zijn zich te mengen in interne Antilliaanse zaken met doorkruising van de statutaire bevoegdheidsafbakening.

\section{De mislukking van een eilanden federatie}

Er bestond een grote overeenkomst tussen de Antilliaanse situatie van de Zes en de situatie zoals die bestond ten tijde van de kortstondige West-Indische Federatie (1959-1962). Deze federatie omvatte tien

Croes denkt hierbij vooral aan de zogenaamde 'non-overrulingsclausules',opgenomen in het rapport van april 1977, uitgebracht aan de Nederlands-Antilliaanse Regering (Rapport Jeukens 1977, p. 10). De Koninkrijkswerkgroep heeft dankbaar gebruik gemaakt van de suggesties van Jeukens op dit gebied (Rapport Koninkrijkswerkgroep 1980 m.n. par. 3.1. en 5.3.1). Met de niet-overstemmingsclausule wordt bedoeld dat het niet voldoende is bij een besluitvormingsprocedure dat de meerderheid van de Statenleden voor een voorstel stemt, maar dat tevens nodig is dat de meerderheid van de onderscheiden eilandelijke Statenvertegenwoordiging voor het voorstel stemt. Dit zou echter de besluitvorming vrijwel onmogelijk maken. Op p. 124 van het Rapport van de Koninkrijkswerkgroep wordt een aantal onderwerpen genoemd waarbij de meerderheid van een eilandelijke Statenventegenwoordiging dient voor te stemmen. Daarnaast vindt de Koninkrijkswerkgroep dat gezien het grote verschil in inwoneraantal, de kleine eilanden de Statenvertegenwoordiging van Aruba of Curaçao niet mogen overstemmen. Deze clausule zou niet automatisch moetengelden, maar toepassing moeten krijgen nadat een gemotiveerde en uitdrukkelijke verklaring daartoe is afgelegd door de helft van de Arubaanse, respectievelijk de helft van de Curaçaose Statenleden, dan wel van alle door de kleine eilanden gekozen vertegenwoordigers. 
eilanden, ver van elkaar, die een staatsrechtelijke band met het moederland hadden. Binnen de federatie hadden Jamaica en Trinidad tezamen $77 \%$ van het bevolkingsaantal en $83 \%$ van de landoppervlakte. Deze eilanden brachten ook $82 \%$ van de staatsinkomsten op. De oorzaken die tot een mislukking van de West-Indische Federatie hebben geleid, kunnen tevens als criteria worden gehanteerd om de voorgestelde Antilliaanse modellen te toetsen op hun haalbaarheid. Het verschil in opvatting hoe de federatie te besturen tussen de grote en de kleine eilanden van de West-Indische Federatie werd steeds groter en bleek tenslotte onoverbrugbaar.

De ontevredenheid in de West-Indische Federatie nam nog toe door de disproportionaliteit van de vertegenwoordiging in het federale parlement. $^{n}$ Alhoewel besloten was dat de federale constitutie de eerste vijf jaren niet geamendeerd zou worden vroegen Jamaica en Trinidad al spoedig om een wijziging van de zetelverdeling. ${ }^{73}$ Vrijwilligheid en samenwerking zijn van doorslaggevend belang wil een federaal samwerkingsverband slagen.

Bovendien werd de houding van Jamaica ten opzichte van de federatie bepaald door de vrees dat Engeland de federatie steunde, om zo de verantwoordelijkheid voor de kleinere eilanden af te wentelen op Jamaica. Na twee jaar was Jamaica ervan overtuigd dat deze vrees gerechtvaardigd was en verliet de federatie. Hierna verliet Trinidad de federatie, die toen in 1962 werd ontbonden.

De vrees dat een Antilliaanse federatie nooit zou kunnen slagen, omdat er een te groot verschil in bevolkingsaantal en oppervlakte van de verschillende eilanden bestond, sprak ook uit het rapport Dip. De last voor elk Antilliaans samenwerkingsverband zou op Curaçao komen te liggen, meende zowel Dip als Croes. Uit het rapport Dip bleek dat als voor Curaçao een bepaalde constellatie niet nuttig is, het dan zinloos is om aan een dergelijke constructie te werken.

In 1989 bestond in de Nederlandse politiek de opvatting dat er twee mogelijkheden waren voor het handhaven van de band tussen Nederland en de eilanden. Een nieuwe volkenrechtelijke relatie, een variatie

72 Zie Croes (1984) p. 266. noot 38. Men had gekozen voor een tweekamerstelsel bestaande uit een Senaat van 19 leden en een huis van Afgevaardigdenvan 45 leden. De Senaat was samengestelduit 1 afgevaardigdevan Montserrat, en 2 afgevardigden voor den andere eenheden. In het Huis van Afgevaardigden kreeg Jamaica 17 zetels, Trinidad en Tobago 10, Barbados 5 en de overige 2 met uitzondering van Montserrat, dat 1 zetel kreeg.

73 Croes (1984) p. 266, noot 39. Het Huis van Afgevaardigden werd uitgebreid tot 64 zetels. Jamaica kreeg zo 30 zetels en Trinidad en Tobago 15. 
op een Gemenebestconstructie, of de staatsrechtelijke constructie met een aan te passen Statuut. De Gemenebestrelatie ging uit van een volkenrechtelijke band tussen Nederland, de Nederlandse Antillen en Aruba, als onafhankelijke partners. Ook Suriname zou tot dit Gemenebest toe kunnen treden, indien de Surinaamse regering dat zou wensen. In de staatsrechtelijke variant zouden de eilandgebieden meer bevoegdheden krijgen. De verplichte samenwerking met Nederland zou beperkt moeten worden tot de buitenlandse betrekkingen, de handhaving van de onafhankelijkheid, de verdediging van het Koninkrijk en de wetgeving op het Nederlanderschap.

De verdere samenwerking tussen de Koninkrijksdelen zou op grond van overeenkomsten kunnen worden geregeld. Het preventieve en repressieve toezicht zou worden afgeschaft, evenals de mogelijkheid van het Koninkrijk om in te grijpen bij situaties zoals thans genoemd in art. 43 Statuut. Indien een Koninkrijksdeel op dit gebied ernstig tekort zou schieten, dan zou op grond van een speciale procedure het Koninkrijksverband met dat Gemenebest-lid beëindigd kunnen worden.

In beide varianten werd wel gedacht aan een regeling over het Nederlandse 'absorptievermogen' met betrekking tot (kansarme) rijksgenoten. Alternatieven voor een migratiestop, zoals de studiefinanciering vanuit Nederland in de Nederlandse Antillen en Aruba zelf beschikbaar stellen en remigratie bevorderen, werden aangedragen. ${ }^{74}$

Wie vertolkt de mening van het volk

Koot $^{75}$ sprak in 1989 zijn verbazing uit over het feit dat de mening van de bevolking zo weinig meetelde in de discussie over de 'Antillen van de Vijf'. Begin 1988 deden de Curaçaose Kamara Syndical (een overkoepelende vakbond) en de Universiteit van de Nederlandse Antillen een steekproefgewijs onderzoek onder de bevolking van de vijf eilanden. De respondenten werden tweemaal geïnterviewd met een tussenperiode van zes weken. Voor het tweede gesprek kregen alle respondenten de uitslagen van de eerste ronde toegestuurd, alsmede samenvattingen van de gesprekken met de politieke leiders en de bevolking. Er bleken zich grote verschillen voor te doen tussen verwachtingen van de politieke leiders en die van de bevolking. In

\footnotetext{
74 Rapport van de Partijcommissie Nederlandse Antillen en Aruba, Visie van de PudA op de toekomst van ons Koninkrijk Il, juni 1989. De PvdA was van mening dat de immigrantenstroom van de Rijksdelen overzee beperkt zou moten worden, pp. 1-15, 20.

79 Koot (1989).
} 
de periodes dat de enquête werd gehouden had Wathey in december 1987 juist verklaard dat Sint Maarten een Status Aparte wilde en die zo snel mogelijk wenste om te zetten in onafhankelijkheid. De MAN van Don Martina was nog steeds voor handhaving van het Antilliaans staatsverband, desnoods met vier eilanden en de PNP van Maria Liberia-Peters wilde de Status Aparte voor Curaçao. De politieke leiders meenden dat hun partij-standpunt op de Nederlandse Antillen de meerderheid zou halen. De bevolking dacht daar anders over.

In februari 1988 was op Curaçao $63 \%$ van de bevolking voor een Antillen van de Vijf, $23 \%$ wenste een aparte status voor Curaçao en $14 \%$ wenste een Antillen van Vier, Drie of Twee. Van degenen die een Status Aparte nastreefden, was een ruime meerderheid (69\%) er tegen om de andere Antilliaanse eilanden nog enige voorzieningen te leveren. $96 \%$ van de respondenten gaf aan voorstander te zijn van een blijvende band met Nederland. De voorstanders waren wel verdeeld over de kwestie hoe die relatie vorm moest krijgen.

Op de vraag welke staatkundige relaties met Nederland gewenst waren wilde $41 \%$ van de respondenten op Curaçao de huidige situatie handhaven, $38 \%$ wenste een lossere band en $21 \%$ wilde een provincie van Nederland worden. Onder het handjevol tegenstanders van behoud van een staatkundige band met Nederland opteerde een minderheid voor een volledige onafhankelijkheid en vrijwel niemand voor een staatkundige relatie met Venezuela of de Verenigde Staten. De meerderheid van de respondenten zou zich willen aansluiten bij een Caraibische Federatie. Onder de tegenstanders van een staatkundige band met Nederland waren relatief gesproken zeer veel hoogopgeleiden, ook de werkenden waren oververtegenwoordigd.

Bij de tweede ronde in april 1988 werd op Curaçao nog overtuigender gekozen voor een Antillen van de Vijf: 79\%. De verschuivingen deden zich vooral voor in de lagere sociaal-economische milieus. De meerderheid van de respondenten koos voor het terugdringen van de rol van de centrale regering en dus voor verzelfstandiging van de eilanden. Onder de voorstanders voor het verzelfstandigen van Curaçao waren degenen met de hogere opleiding en hogere inkomens oververtegenwoordigd. De band met Nederland wilde $99 \%$ handhaven. Op Bonaire, Saba en Sint Eustatius lagen de percentages voor een Antillen van de Vijf nog hoger, in eerste ronde: $71 \%, 83 \%$ en $84 \%$. In tweede ronde was dat $98 \%, 93 \%$ en $85 \%$. Voor het behoud van de band met Nederland was het percentage op de kleine eilanden tussen de 96 en $99 \%$

Op Sint Maarten waren de uitkomsten verschillend. In eerste ronde was 37\% voor een Antillen van de Vijf, in tweede ronde was dat $45 \%$. Het streven naar autonomie op Sint Maarten was sterk. In 
eerste ronde wenste $77 \%$ een constructie met Saba en Sint Eustatius, maar zonder Curaçao. $40 \%$ wilde in eerste en tweede ronde de staatkundige band met Nederland handhaven, $26 \%$ wilde een lossere staatkundige band en $34 \%$ wilde dat Sint Maarten een provincie van Nederland werd. De boodschap is duidelijk, stelde Koot: " autonomie ten opzichte van Curaçao, maar met behoud van een band met Nederland' '. Het Status Aparte-streven op Sint Maarten is het sterkste onder de hoogopgeleiden, de beter betaalden en de middelbare leeftijdsgroepen. In de Caraibische literatuur wordt steeds benadrukt dat samenwerkingsrelaties tussen de eilanden vanwege het sterke insularisme gedoemd zijn te mislukken. Zo'n zelfde constatering is ook regelmatig gedaan voor de Nederlandse Antillen. "Wil men dan toch graag bij elkaar horen, omdat men zich etnisch, cultureel en historisch verwant voelt?"' Het lijkt er niet op, stelde Koot met nadruk.

\footnotetext{
"Men is bang een onzekere economische en politieke toekomst tegemoet te gaan. Deze angst is ook de belangrijkste drijfveer om een staatkundige band met Nederland te behouden. De gebeurtenissen op andere Caraïbische eilanden, maar zeker in Suriname, vormen voor menig Antilliaan een afschrikwekkend voorbeeld van de wijze waarop de rechtszekerheid en economische weerbaarheid teniet kunnen worden gedaan. "76
}

Veel Antillianen wantrouwden de Nederlandse politici, vanwege ondermeer het sterk wisselende Nederlandse beleid tegenover de Antillen in de laatste decennia. Verscheidene kabinetten namen sterk afwijkende standpunten in en er werden beslissingen genomen, waarop de Nederlandse politici later weer terugkwamen. Koot besloot zijn uiteenzetting met de belangrijke conclusie dat:

\begin{abstract}
"indien Nederland de Antilliaanse wensen zou respecteren, dat dan tevens geëist mag worden dat de Antilliaanse politici ook de wensen van de eigen bevolking serieus nemen. Wanneer de politici zich beter zouden voorbereiden, zouden zij zich ook wat minder angstvallig tegenover Nederlandse politici kunnen opstellen. Want dan kan vanuit een sterke positie onderhandeld worden".
\end{abstract}

Het zou wenselijk zijn als met Nederland lange termijn afspraken zouden kunnen worden gemaakt over de toekomstige status van de Nederlandse Antillen, in plaats van bij elke wisseling van een kabinet in Nederland weer met nieuwe wensen en opties van Nederland te 
worden geconfronteerd. ${ }^{77}$ De Antillen zijn meer gericht op Europa. Ondanks de wellicht 'annexerende' bedoelingen van Venezuela zijn er goede mogelijkheden tot een intensievere samenwerking van de Nederlandse Antillen met Venezuela, ter stimulering van de Antilliaanse economie. De leidende rol, die Venezuela in de regio wil spelen, kan profijt opleveren voor de Antillen, Nederland en Venezue1a. ${ }^{78}$

\section{Schets voor een Gemenebestconstitutie voor het Koninkrijk der Nederlanden}

$\mathrm{Na}$ een periode van relatieve staatsrechtelijke rust, werd sinds begin 1990 druk gespeculeerd over aanpassing van het Statuut aan de eisen des tijds. Dan moest echter wel duidelijk zijn of de Nederlandse Antillen en Aruba binnen afzienbare tijd de onafhankelijkheid dienden te realiseren. ${ }^{79}$ Op 15 november 1989 werd minister De Koning opgevolgd door de minister van Justitie E.M.H. Hirsch Balllin. Hij had duidelijk een andere mening dan zijn voorgangers en wilde rekening houden met de wensen van de Koninkrijksdelen in de West. De nieuwe minister voor Nederlands-Antilliaanse en Arubaanse Zaken presenteerde op 12 maart 1990 een Schets van een Gemenebestconstructie voor het Koninkrijk der Nederlanden. ${ }^{80}$ Hierin werd een

$\pi \quad$ Koot (1985) pp. 724 e.v.

7* Verton (1986) met name pp. 201-207. In 1986 werden de vier Shell bedrijven voor Afl. 1,-per stuk verkocht aan de Petroleos de Venezuela SA (PDVSA). De raffinaderij heet nu ISLA NV en is voor 5 jaar verhuurd aan de PDVSA. Om de raffinaderij open te houden en de joint-venture van Curaçao met de Venezolaanse mastschappij mogelijk te maken, heef Curaçao afgezien van aan eventuele latere milieuschadeclaim. Op Curaçao werd zo een dreigende sociaal-economischecrisis afgewend. Voor enige interessante overwegingen met betrekking tot de soms ambivalente Antilliaanse relatie met Venezuela, zie Bongenaar (1986). Kennelijk leeft de mogelijke stastkundige relatie met Venezuela nog steeds. Of de PDVSA het ISLA contract zal willen verlengen, zal afhangen van de winstmogelijkheden. In 1985 gaven geoplitieke overwegingen de doorslag. Nu zullen dat winstmages en economische overwegingen zijn, Amigoe 19 maart 1994.

7 Amigoe, 3 november 1989, 'Antillen willen nog geen onathankelijkheid'. Amigoe, 13 november 1 1-1989, 'Vermoedelijk deelname aan Statenverkiezingen, Streven van nieuwe partij: een "Status Provinciaal" . Amigoe, 9 december 1989, 'DP: De Antillen mogen niet uit elkaar vallen'.

* Hirsch Ballin (1989); Amigoe, 22 januari 1990, 'Uitspraken over GemenebestConstitutie, Pers in Nederland: Hirsch Ballin heeft de Haagse politici verrast'. Amigoe, 8 februari 1990, 'Minister Hirsch Ballin en de toekomst van de West, We hebben een gemeenschappelijk heden'; KABNAA (1990): Schets voor een Gemenebestconstructie voor het Koninkrijk der Nederlanden; NRC Handelsblad, 24 maar 1990, 'Aruba en Antillen blijven in Koninkrijk'; Amigos, 24 mart 1990, 'Schets Hirsch Ballin: Antillen en Aruba kunnen in Koninkrijk blijven'. 
staatsrechtelijke Gemenebestconstructie (een aangepast Statuut) voorgesteld. Met deze Schets werd de West een blijvende Koninkrijksrelatie aangeboden. Over onafhankelijkheid van de Nederlandse Antillen en Aruba werd niet meer gerept. De huidige Nederlandse Antillen zouden in twee Koninkrijksdelen opgesplitst worden: éen Land de Benedenwinden, bestaande uit de eilandgebieden Curaçao en Bonaire en één Land de Bovenwinden, bestaande uit de eilandgebieden Sint Maarten, Sint Eustatius en Saba. Deze twee nieuwe Koninkrijksdelen (Landen) zouden tezamen met het Land Aruba en Nederland het Koninkrijk der Nederlanden vormen. Het bestuur van Curaçao kon Bonaire onder zijn hoede nemen en het bestuur van Sint Maarten kon de zaken van de andere Bovenwindse eilanden regelen. Op Curaçao en Sint Maarten kon dan één bestuurslaag worden opgeheven. Dit betekende dat op Curaçao en Sint Maarten het landsen eilandsbestuur in elkaar zouden opgaan. ${ }^{81}$

De Schets bracht niet werkelijk iets nieuws. Het grote belang van de voorgestelde regeling was dat de Nederlandse Antillen en Aruba niet meer onafhankelijk behoefden te worden als ze dat niet wilden. De Schets kon worden gezien als een projectie op landsniveau van de bestuursorganisatie op statutair niveau, waar de Koninkrijksregering bepaalde taken voor de Nederlandse Antillen en Aruba behartigt. ${ }^{82}$ In de Schets werd ook aangegeven dat een eiland of een Land het Koninkrijksverband zou moeten kunnen verlaten, als uitoefening van het recht op zelfbeschikking. Een procedure daarover zou moeten worden opgenomen in het vernieuwde Statuut. ${ }^{83}$

In de Nederlandse Antillen en Nederland werd het voorstel voor een Gemenebestrelatie sui generis van Hirsch Ballin met gemengde

82 Amigoe, 12 juli 1990, 'Toekomst moet uitwijzen of solidariteit bestaat, Mr. Harold Munneke over nota Hirsch Ballin: Tweedeling Antillen krampachtige poging ter voorkoming desintegratie'; Reinders (1993) pp. 276-282.

In de AVP-nota (1990) wordt de vraag gesteld (p. 23 e.v.) of Aruba gebruik heeft gemaakt van het zelfbeschikkingsrecht door te opteren voor de Status Aparte als tussenstation naar de ona fhankelijkheid en hierdoor dit recht heeft verwerkt. In dit proces kunnen, na de jaren vijflig drie historische momenten worden onderscheiden: het referendum van 1977, de RTC van 1983 en de wijziging van het Statuut van 1985. De nota komt tot de conclusie dat het unilateraal koppelen door Nederland van de Status Aparte aan onafhankelijkheid in strijd is met de uitoefening van het zelfbeschikkingsrecht volgens het internationaal recht. Volgens het internationaal recht moet het volk van het land dat gebruik maakt van het zelfbeschikkingsrecht, vrij zijn de opties te bepalen en zonder beïnvloeding door het moederland uit deze opties een keuze kunnen maken. 
gevoelens ontvangen. ${ }^{84}$ Dip vond de Schets niet haalbaar daar $\mathrm{Cu}-$ raçao daarin niet voldoende naar voren kwam als een autonome entiteit. ${ }^{85}$ Het Tweede Kamerlid Wiebenga ${ }^{86}$ gaf te kennen dat de Schets tot 'veel politiek gekrakeel' geleid had in de Eerste en Tweede Kamer.

"Hoe wil de minister Curaçao weigeren, wat hij Aruba wel wil toestaan, namelijk een aparte status binnen het Koninkrijk, als eindmodel. Het beleid van Hirsch Ballin lijdt aan innerlijke tegenstrijdigheid, want Nederland wenst die verbrokkeling niet. Wiebenga zag ook niets in een apart Bovenwinds Land, gezien het 'wanbestuur' op Sint Maarten."

Hij achtte een rustige en planmatige ontwikkeling van onderen af, beter dan een model opgelegd vanuit Nederland. Hoefnagels, Eerste Kamerlid van D66 was van mening dat het Statuut gehandhaafd moest worden en dat de Antillen in een lichte Unie zouden moeten samenwerken en verdere decentralisering van landstaken naar de Eilanden noodzakelijk is. ${ }^{87}$

A.G. Croes verklaarde in een nota voor de $\mathrm{AVP}^{88}$ in 1990 dat de partij de banden met Nederland wilde behouden en daartoe ook aanknopingspunten zag in de Schets. Hij constateerde dat de discussies over de staatkundige toekomst van de Nederlandse Antillen en Aruba een cyclisch verloop hebben, daar in de jaren negentig het denkbeeld van een licht-Statuut weer onderwerp van gesprek is, net

4 Amigoe, 12 september 1990, Munneke stelde dat de voorgenomen tweedeling van de Antillen, zoals in de Schets van Hirsch Ballin uiteengezet, naar zijn mening een krampachtige poging tot voorkoming van desintegratie van de Antillen van de Vijf is. In het algemeen wordt de term Gemenebest gebruikt voor de relaties tussen soevereine staten, dus voor volkenrechtelijke relaties. In de Schets wordt deze term gebruikt voor de samenstellende delen van de soevereine staat: het Koninkrijk der Nederlanden.

s Hirsch Ballin sloot zich gedeeltelijk aan bij de adviezen van de Commissie Dip. Deze Commissie opperde indertijd de mogelijkheid om het landsbestuur als zodanig af te schaffen. Het bestuur van Curaçao kon dan met enige inspraak van de andere eilanden taken voor die andere eilanden uitvoeren; Dip (1991) p. 47.

* J.C.G. Wiebenga, 'Vijftig jaar na begin van Nederlandse dekolonisatiebeleid, De West geen modellen dicteren', NRC Handelsblad, 28 mart 1991, Amigoe, 27 oktober 1992, 'Forse kritiek op Hirsch Ballin inzake staatkundige politiek'.

$n$ Amigoe, 15 mei 1990, 'Hoefnagels in beleidsdebat Nederlands-Antilliaanse en Arubaanse Zaken: Spring je over de hond, dan spring je over de staar' en Amigoe 29 februari 1992, 'Hoefnagels (D '66): Minister voorbarig met loslaten onathankelijkheid Aruba'.

- Croes (1990), zie ook AVP-nota, waarin het zelfbeschikkingsrecht van Aruba nader wordt toegelicht en wasrin wordt vastgesteld dat Aruba het recht op zelfbeschikking nog niet heeft verwerkt. 
als in de jaren zeventig. Met een 'verlichting' van het Statuut wordt dan bedoeld dat de verantwoordelijkheid van het Koninkrijk ten aanzien van een aantal Koninkrijksaangelegenheden zal vervallen en dat de voormalige Koninkrijksaangelegenheden, Landsaangelegenheden zullen worden. De Nederlandse Antillen moesten in de jaren zeventig en tachtig onder Nederlandse druk de onafhankelijkheid gaan voorbereiden. Het ontwerp licht Statuut uit $1973,{ }^{89}$ paste toen geheel binnen de Nederlandse opvattingen: onafhankelijkheid van de voormalige koloniēn. Er werd een landsburgerschap geïntroduceerd en Nederland zou het buitenlands beleid blijven behartigen, maar niet de defensie. Dit ontwerp was echter voor Suriname en de Nederlandse Antillen onaanvaardbaar, zodat het nimmer in bespreking kwam.

Croes acht blijvende banden met het Koninkrijk noodzakelijk, maar niet in de vorm van een licht Statuut zoals in 1973 door Nederland voorgesteld. De mogelijkheid van preventief en repressief ingrijpen door het Koninkrijk in Landsaangelegenheden bleef nodig, omdat interne instabiliteit vaak automatisch een uitnodiging betekent voor interventie van buiten. Hij wees op de systematische penetratie van de internationale drugshandel in de hoogste regeringskringen in landen zoals Cuba (1989), Bahamas (1988), Suriname (1986), Panama (1987), Turks en Caicos Islands (1986), Haïti (1987) om van Columbia maar niet te spreken, waar de drugsmaffia een staat binnen de staat vormt. Nederland kan, volgens Croes op grond van art. 43 tweede lid Statuut verantwoordelijk worden gesteld voor de interne situatie in Aruba en de Nederlandse Antillen. Het garanderen van fundamentele mensenrechten in de landsgrondwet garandeert niet het daadwerkelijke voortbestaan van de rechtsstaat. Het gaat bij interne kwetsbaarheid meer om mentaliteit dan om wetsteksten. Garanties voor rechtszekerheid en het naleven van de mensenrechten kunnen ook in een volkenrechtelijke band niet gegarandeerd worden. Daarom moeten in een eventueel licht Statuut de artt. 43 lid twee, 44, 50 en 51 Statuut worden gebandhaafd: te weten effectieve waarborging van de rechtszekerheid en het preventief en repressief toezicht.

Als de belangrijkste staatsrechtelijke ontwikkeling in de jaren tachtig zag Janus de erkenning van het zelfbeschikkingsrecht voor alle Antilliaanse eilanden afzonderlijk. Met een beroep op het zelfbeschik- 
kingsrecht verliet Aruba het Antilliaanse staatsverband en verwierf een zelfstandige status binnen het Koninkrijk. Op grond van dat zelfbeschikkingsrecht eisten Curaçao en Sint Maarten eenzelfde status. De onafhankelijkheid die Nederland de Nederlandse Antillen zo gaarne wilde verstrekken versterkte de bestaande middelpuntvliedende krachten en beïnvloedde het herstructureringsproces negatief, meende Janus en anderen met hem. ${ }^{90}$ Door de starre opstelling van Nederland over de onafhankelijkheidskwestie werd ook het politiek insularisme versterkt. "Het opdringen van de onafhankelijkheid verdraagt zich niet met de essentie van het zelfbeschikkingsrecht. Een Status Aparte voor Curaçao en Sint Maarten past niet in de Schets van Hirsch Ballin." Een verdere versnippering van de Antillen achtte hij een heilloze weg.

Janus wees er verder op, dat er nooit een serieuze probleemanalyse is gemaakt van de knelpunten, die de eilandbesturen concreet ervaren. Het bestuurlijk herstructureringsproces en de overdracht van landstaken naar de eilanden is ernstig gestagneerd. ${ }^{91}$ Die probleemanalyse zou plaats moeten vinden, voordat aan een nieuwe staatkundige structuur wordt gedacht. Daarom was hij van mening dat het voorstel van Hirsch Ballin, de problemen van de Nederlandse Antillen niet oplost, maar verplaatst. De Schets liet teveel ruimte voor inmenging van Nederland in zaken van het Caraïbisch gedeelte van het Koninkrijk, dat zou nog meer het geval zijn indien alle eilanden een Status Aparte zouden krijgen. "Een duurzame staatsrechtelijke relatie is alleen dan haalbaar, wanneer de landen hier zonder al te veel Nederlandse inmenging hun eigen boontjes doppen."

De door Nederland gewenste hechte samenwerking tussen de Nederlandse Antillen en Aruba kwam niet tot stand. De Samenwerkingsregeling Nederlandse Antillen en Aruba bleef grotendeels een dode letter. Niet valt in te zien dat een samenwerking tussen de Benedenwindse en de Bovenwindse eilanden meer inhoud zal hebben en op deze manier de Nederlandse bemoeienis zal kunnen beperken. ${ }^{92}$

B.W. Biesheuvel en J.A.B. Janus, 'Erkenning zelfbeschikkingsrecht hoeft niet tot onathankelijkheidte leiden, Nederland trekt zicht weinig aan van de Antillen', NRC Handelsblad, 2 oktober 1989.

9 Bongenaar (1983) pp. 1-35.

92 Amigoe, Ñapa, 24 maart 1990: 'J.A.B. Janus, Aparte status voor elk eiland niel haalbaar, Voorstel Hirsch Ballin is overwegen waard, Herstructurering Antillen is een gepasseerd station'. Mr. J.A.B. Janus was van 1983 tot 1993 directeur van het Kabinet van de Gouverneur van de Nederlandse Antillen. 
Janus $^{93}$ stelde een Unie van eilanden van de Nederlandse Antillen voor. Uitgangspunt was de eilanden zoveel mogelijk ruimte te bieden voor hun eigen ontplooiing en alleen die taken op centraal niveau te laten behartigen, waarvan een behartiging op dit niveau min of meer noodzakelijk was. ${ }^{94}$ Janus had al eerder een Unievoorstel gelanceerd in 1983 als samenwerkingsmodel voor de Nederlandse Antillen en Aruba. ${ }^{95}$ Ook Bonaire pleitte regelmatig voor een Unie van vijf autonome eilanden. 96

Het staatsrechtelijk sleutelwerk zou moeten worden vervangen door een analyse van de bestuurlijke problemen van de Antillen, meende ook Munneke. ${ }^{97}$ Een van de grootste problemen was het beheer van de financiën. "Wanneer ieder eiland wat de financiën betreft zijn plaats weet, is een belangrijke steen des aanstoots in de intereilandelijke verhoudingen weggenomen". Hij zag meer in een associatieconstructie, te regelen in de Nederlandse Grondwet, dan in een aangepast Statuut in de vorm van een Gemenebest. Met een associatieclausule in de Grondwet zou sneller en soepeler kunnen worden ingespeeld op veranderde politieke inzichten van de bestuurlijke organisatie. De Nederlandse Grondwet is makkelijker te wijzigen dan het Statuut. Omdat ook Curaçao en Sint Maarten voor een Status Aparte opteerden leek het plan van Hirsch Ballin al bij voorbaat niet haalbaar. De financiēle solidariteit van Nederland met de Nederlandse Antillen is

93 Amigoe, 26 juni 1990.

4 J.A.B. Janus, 'Eilandenregeling zou moeten verdwijnen, Synchronisatie verkiezing conditio sine qua non, Unie van Eilanden mogelijk alternatief voor Nederlandse Antillen', Amigoe, 26 juni 1990. Voor de basisgedachte zie Rapport Gemengde Commissie (1982) pp. 131-138, voor Proeve van een Unieverdrag van de Nederlandse Antillen en Aruba, van de hand van mr. J.A.B. Janus.

9s Stenografisch verslag van de conferentie gehoudenvan maandag 7 tot en met zaterdag 12 maart 1983, Definitief voorstel van de voorzitter over de conclusiepunten, pp. 97-100. De Unie werd omschreven in de conclusiepunten $19 \mathrm{t} / \mathrm{m} \mathrm{22}$; Bongenaar (1983) pp. 49-84, met name pp. 76 e.v.

Amigoe, 3 september 1991, 'Status Aparte voor alle eilanden, Bonaire komt mel nieuw unie-voorstel' en Amigoe, 14 november 1992, 'Bonaire pleil voor unie van vijf autonome eilanden'.

9 Deze conclusie van Munneke wordt ondersteund door een bericht in de Amigoe van 28 december 1992, stellende dat 'Den Haag direcl in zee gaat met de afzonderlijke eilanden, ter verstrekking van financiële hulp'. Het zou hier gaan om het hersturcturcringsfonds nieuwe stijl. Gezien de stijgende begrotingstekorten van de eilanden moeten de uitgaven worden beperkt en de inkomsten verhoogd. Nederland zal de tekorten niet overnemen want deze schuldensanering is de verantwoordelijkheid van de Antillen zelf. 
groot. De onderlinge solidariteit tussen de Nederlands-Antilliaanse eilanden daarentegen voldoet niet aan de Nederlandse verwachtingen en aan de verwachtingen van de kleine Antilliaanse eilanden. Er bestaat geen financiële solidariteit tussen de eilanden onderling.

Munneke zag als meest waarschijnlijk toekomstscenario een Engelse constructie van de meer draagkrachtige eilanden als autonome 'associated states' en de financieel minder gezonde als 'dependencies'. $^{98}$

Ook Fernandes Mendes ${ }^{99}$ was van mening dat de Gemenebestplannen van Hirsch Ballin niet of uiterst moeilijk uitvoerbaar waren. De eilanden zouden een betere kans hebben om in een integratief staatsrechtelijk verband, de zelfstandigheid in economisch en politiek opzicht te bereiken. Het uittreden van Curaçao en Sint Maarten zou het ongecontroleerde einde van het Antilliaans staatsverband betekenen. Fernandes Mendes stelde als alternatief voor een hecht samenwerkingsverband van de Antillen van de Vijf met Nederland en Aruba. Onafhankelijkheid zou de eerste 30 tot 50 jaren niet overwogen behoeven te worden. Een aparte status voor de andere eilanden past hier niet in. Indien Aruba niet onafhankelijk zou worden, diende Aruba de mogelijkheid te worden geboden opnieuw toe te treden tot het Antilliaans staatsverband.

Pourier ${ }^{100}$ was van mening dat splitsing van de Nederlandse Antillen in twee kernen misschien in de verre toekomst onvermijdelijk zou zijn, maar thans op veel bezwaren zou stuiten. Sint Maarten had al moeilijkheden genoeg met zichzelf, het zou zeker niet in staat zijn om voor Saba en Sint Eustatius te zorgen. Saba en Sint Eustatius maakten zich zich pas in 1983 los van Sint Maarten en zouden er zeker niet voor voelen onder ongunstiger voorwaarden weer bij Sint Maarten te worden gevoegd. Wel is de onafhankelijkheid van Sint Maarten voorlopig in de ijskast terecht gekomen, vanwege de tanende macht van Wathey. De andere eilanden binnen het Antilliaanse

Munneke (1990); Amigoe 12-9-1990 'Toekomst moet uitwijzen of solidariteit bestaat, mr. Harold Munneke over nota Hirseh Ballin: Tweedeling Antillen krampachtige poging ter voorkoming desintegratie'. Fernandes Mendes (1990) pp. 1190-1197; Amigoe, 13 september 1990, 'Mr. Fernandes Mendes, Haags belang bij Gemenebest, Nederland wil niet blijven zitten met kleine eilandjes'.

Amigoe, 21 april 1990, M.A. Pourier, 'Alleen Aruba heeft profijt van voorstel Hirsch Ballin, Antillen van vijf blijt voor Curaçao voordelig'; Amigoe, 31 december 1992 'Pourier: "Boeman" Nederland door Antillen gecreēerd, Als een stel verwarde lora's'; Amigoe. Napa, 14 september 1991 'Mr. Gerard Tellers, De echtscheidingsbrief is al de deur uit, Curaçao moet los van de andere eilanden'. 
verband vormen een rem op de besluitvaardigheid van Curaçao, zeker gezien de dubbele bestuurslaag. Pourier stelde voor Curaçao haar eigen aangelegenheden autonoom te laten regelen. Naar de mening van Pourier moest bij een samenwerkingsverband tussen de Antillen van de Vijf in ieder geval rekening worden gehouden met de volgende knelpunten:

- de eilandelijke autonomie moest worden uitgebreid, vooral op sociaal-, economisch-, en onderwijs terrein;

- gebieden van gemeenschappelijke zorg moesten (naast de verplichtingen uit hoofde van het Koninkrijk) rechtspleging, rechtshandhaving, wetgeving op diverse gebieden, belastingheffing, monetaire zaken, onderwijsdiploma's en dergelijke, blijven gehandhaafd;

- financiering van deze gemeenschappelijke zaken zou moeten komen uit een gemeenschappelijke pot, waaraan ieder eiland op grond van de bevolkingsomvang bijdraagt. De bijdragen voor de kleinere eilanden, uitgezonderd Sint Maarten moeten uit het Solidariteitsfonds komen;

- De centrale regering en het parlement zouden worden gevormd uit delegaties van de eilandsregering c.q. Eilandsraad. In verband met de afgenomen bevoegdheden van de centrale regering en het parlement kan de samenstelling van de volksvertegenwoordiging ongewijzigd blijven.

Pourier zag nog wel mogelijkheden voor een Antillen van de Vijf. Voor samenstelling van de Ministerraad zou kunnen worden gekeken naar de EEG-procedures, waar grotere landen meer invloed hebben dan kleinere landen. Bovendien achtte hij het nuttig als een kleine Commissie bestaande uit vertegenwoordigers van de eilanden, de landszaken eerst grondig zou voorbereiden, alvorens zij in de Ministerraad zouden worden behandeld. Kleine eilanden die op bepaalde gebieden de bestuurskracht missen, zouden op eilandelijk niveau met Curaçao of Aruba kunnen samenwerken op grond van een samenwerkingsovereenkomst. Curaçao of Aruba zouden tegen betaling uit het Solidariteitsfonds bepaalde diensten voor de kleine eilanden kunnen verrichten. 
In 1992 stelde Van Rijn ${ }^{101}$ voor dat elk eiland een Status Aparte zou krijgen. Op de zes eilanden bestond geen verschil van mening over de onderwerpen, die daarnaast gezamenlijk met Nederland moesten worden behartigd: rechtszekerheid, deugdelijk bestuur, waarborgen voor de rechtsstaat en democratie, een goede rechtspleging, alsmede defensie en buitenlandse betrekkingen. Een nieuwe Koninkrijksstructuur zou bovendien duidelijkheid moeten brengen over culturele betrekkingen, financiële bijstand en ontwikkelingssamenwerking. ${ }^{102}$

Alle herstructureringsvoorstellen uit de laatste jaren worstelden met twee problemen, aldus Van Rijn:

- hoe kan aan de afzonderlijke eilanden een grotere zelfstandigheid jegens het Land worden verleend;

- bestaat er een alternatief voor de inefficiënte en kostbare dubbele bestuurslaag op Curaçao?

De conclusie van de rapporten was over het algemeen: alleen Curaçao kan op verantwoorde wijze de gedecentraliseerde taken van het centrale niveau behartigen. De andere eilanden konden maar beperkt landstaken absorberen en verantwoord uitvoeren. Van Rijn achtte het noodzakelijk, dat Nederland rekening zal houden met de wensen van de overzeese gebiedsdelen. Die wensen moeten dan wel ondubbelzinnig vaststaan en als middel daartoe, stelde hij voor een referendum te houden, om vast te stellen of de bevolking van de Antillen een aparte status wenst voor hun afzonderlijke eilanden. Want ook al hadden alle politieke partijen op Curaçao verklaard een Status Aparte te willen, uit onderzoeken van Verton en Koot bleek dat de wensen van de burgers vaak niet strookten met die van de politici. Mochten alle eilanden een aparte status wensen dan nog blijft onderlinge samenwerking noodzakelijk, om de kleine eilanden te verzekeren van een behoorlijk bestuur. Deze samenwerking zal Curaçao niet onnodig moeten belasten. Nederland zou hierin een belangrijke taak kunnen vervullen, vooropgezet dat zulks ook uitdrukkelijk gewenst wordt.

A.B. van Rijn, 'Naar een nulsituatie om iets nieuws op te bouwen, Status Apare voor alle eilanden: een staatsrechtelijke uitdaging', Amigoe, 23 december 1992.

Amigoe, 27 januari 1993; Bonaire pleitte bij monde van UPB Gedeputeende Ramoncito Booi van Bonaire, voor een samenwerking van de vijf Antillianse eilanden in een Unie-model. De vijf eilanden zouden dan de Status Aparte verkrijgen en een gemeenschappelijk parlement. Dit voorstel lijkt op het model III van de werkgroep Dip, met de Uniegedachte van Janus en gesteund door de gedachten van Pourier mul de zegen van Fernandes Mendes. Het voorstel zoals geformuleerd door Van Rijn leefde in voorafgaande jaren ook op Bonaire. 
Van Rijn achtte samenwerking noodzakelijk voor rechtspraak en wetgeving op het gebied van het burgerlijk recht, strafrecht, handelsrecht en procesrecht. Verder zouden de Antillen, ook als zij uiteen zouden vallen, moeten samenwerken in een monetaire en douane-unie met een vrij verkeer van personen, kapitaal en goederen. Tevens zou moeten worden samengewerkt op het gebied van het buitenlands beleid en op het gebied van de verplichtingen die voortvloeien uit internationale verdragen, die ook de Antillen raken.

De bestaande Samenwerkingsregeling werkt niet vanwege de ingewikkelde besluitvormingsprocedures en het feit dat de besluitvorming via nationale Arubaanse en Antilliaanse organen loopt. De vrijwilligheid van de samenwerking heeft niet tot enige eenvormige wetgeving geleid. Indien vrijwillige samenwerking niet zou kunnen plaatsvinden, zou naar andere mogelijkheden gezocht kunnen worden. Een gemeenschappelijk parlement van de vijf eilanden lijkt dan onontkoombaar. Van Rijn wenst wel een mogelijkheid voor de kleine eilanden om het numerieke overwicht van Curaçao bet hoofd te bieden, wellicht in de vorm van een geclausuleerd vetorecht. De samenwerking zou geen federatie kunnen zijn, want dat is niet de bedoeling van een Status Aparte. De samenwerking zou meer confederaal moeten zijn. Ieder eiland zou in beginsel de Status Aparte moeten krijgen en directe banden met Nederland aangaan. Samenwerking tussen de eilanden zou moeten worden afgedwongen, indien noodzakelijk. Dit zou op Koninkrijksniveau moeten worden geregeld. Artikel 38 Statuut is daarvoor te vrijblijvend. Er zou een aparte regeling moeten worden geschapen in het Statuut. Het hoger toezicht zou aan het Koninkrijk moeten opgedragen worden.

Zonder een vorm van intereilandelijke samenwerking kunnen de eilanden geen Status Aparte verkrijgen. Een aparte status voor elk eiland zou zeker een grotere bemoeienis van Nederland betekenen, zowel in positieve zin als in negatieve zin.

Hirsch Ballin ${ }^{103}$ bleef vasthouden aan zijn beleid zoals verwoord in de Schets en meende dat een verdere opsplitsing van de Nederlandse Antillen niet goed hanteerbaar zou zijn. Dit zou de genadeslag

Tekst lezing minister Hirsch Ballin aan de Universiteit van de Nederlandse Antillen d.d. 10 september 1990. Amigoe, 11 september 1990. 'Gemenebest-schets niet zaligmakend, Hirsch Ballin schept ruimte voor Antilliaans alternatief'. Amigoe, 15 september 1990, 'Ernst Hirsch Ballin: Elementaire voorzieningen houden ons bij elkaar'. 
betekenen voor de kleine eilanden. Bovendien wenste Den Haag niet de verantwoordelijkheid voor deze eilanden toegeschoven te krijgen. ${ }^{104}$

In juli $1990 \mathrm{kwam}$ premier Oduber (MEP) tot overeenstemming met de Nederlandse regering en deelde bij terugkomst uit Nederland mee, dat de onafhankelijkheidsdatum van 1 januari 1996 uit het Statuut zou worden geschrapt. ${ }^{105}$ Tevens werd overeengekomen dat het Statuut gemoderniseerd zou worden, er zoveel mogelijk taken van Landsniveau naar Eilandsniveau zouden worden overgedragen en dat het Solidariteitsfonds wettelijk geregeld zou moeten worden. Curaçao streefde nog steeds naar een aparte status, maar wilde wel met de andere eilanden samenwerken. ${ }^{106}$ Dit alles overziende kan worden vastgesteld dat de herstructurering praktisch weinig had opgeleverd. De theorie had vele staatkundige modellen aangedragen maar hieraan werd politiek gezien nauwelijks aandacht besteed.

Karamat $\mathrm{Ali}^{107}$ reageerde op het veranderde Nederlandse beleid en stelde dat het juist van belang is dat voormalige koloniale gebieden onafhankelijk worden. Hij dacht daarbij duidelijk aan Suriname.

"Het is algemeen bekend, dat in voormalige koloniale gebieden de nationalistische voortrekkers er doorgaans niet in slagen de actieve betrokkenheid van het merendeel van de bevolking te realiseren bij activiteiten, gericht op de verwerving van de onafhankelijkheid. De ongenuanceerde mening pleegt dan post te vatten dat het overgrote deel van de bevolking de onafhankelijkheid zou afwijzen op grond

Amigoe, 28 oktober 1989, Onafhankelijkheidsdatumkan wordengeschrapt'; Amigoe, 24 maart 1990, Amigoe, 15 mei 1990, 'Hoefnagels (D66) in beleidsdebat NederlandsAntilliaanse en Arubaanse Zaken, Spring je over de hond, dan spring je over de staart, (salto kacho, salta su rabu)'. Amigoe, 23 mei 1990, 'Eerste Kamer kritisch over "Schets" van Hirsch Ballin'; Amigoe, 12 september 1990, 'Hirsch Ballin stelt grens aan claims ona fhankelijkheid" "; Amigoe 24 maart 1990, 'Schets Hirsch Ballin: Antillen kunnen in Koninkrijk blijven'.

Van Gameren (1991) pp. 123-127; Aruba, Noticiero Oficial di Gobierno, oktober 1990; Volkskrant, 22 mei 1990 'Aruba-beleid Hirsch-Ballin geeft Betico Croes posthuum gelijk, B. Wilms bespreckt het nieuwe dekolonisatiebeleid van Lubbers III'; NRC Handelsblad, 'Akkoord met Antillen en Aruba over Koninkrijksstatuut'. Bij KB van 1991, Stb. 454 is met inachtneming van art. 10 Statuut een gemengde ambtelijke werkgroep ingesteld met als taak de voorbereiding van de vereenvoudiging en modernisering van het Statuut van het Koninkrijk der Nederlanden, genaamd: 'Gemengde Commissie werkgroep modernisering Statuut'. De werkgroep zal ten hoogste uit tien leden bestaan. Reeds in mei 1992 werden terzake doende voorstellen van de werkgroep verwacht, gezien echter het opleggen van de AMvRB asn St. Maarten moest de werkgroep zich bezinnen over met name het hoger toezicht, waarvan werd gedacht dat het zou kunnen worden opgeheven in het nieuwe Statuut. Karamat Ali (1989) pp. 104 e.v. Hij heeft zijn bijdrage niet voor niets een motto meegegeven van Kipling: "He travels the fastest, who travels alone". 
Karamat Ali achtte dit een 'selffulfilling prophecy' en was van mening dat Curaçao zeker de juiste mogelijkheden en instelling heeft om onafhankelijk te worden. De Antillianisering is zover voortgeschreden, dat de band met Nederland symbolisch is geworden. Het Nederlands is een vreemde taal. Het 'di nos e ta' (het volkseigene) demonstreert een duidelijk gevoel van nationaal bewustzijn. Hij verwees bij zijn opvatting niet naar de onderzoeken van Verton en Koot die duidelijk aangaven dat de overgrote meerderheid van de Antilliaanse en Arubaanse bevolking de onafhankelijkheid niet wenste.

Karamat Ali stelde verder dat het nog nergens gelukt is een eertijds koloniale economie tot ontwikkeling te brengen vanuit het Europese moederland en met toepassing van het aldaar geldend normenkader. Ten slotte betoogde Karamat Ali dat de Antillen en Aruba hun eigen ontwikkeling ter hand zouden moeten nemen en dat Nederland zich daaromtrent afstandelijker zou moeten opstellen. Te verstrekken financiële middelen zouden projectmatig moeten worden verstrekt en gezamenlijk of door Nederland moeten worden beheerd. Het sociaal-economisch beleid zou echter door de Landen zelf moeten worden bepaald op grond van een zo breed mogelijke consensus. Verder zou bij onafhankelijkheid een toescheidingsovereenkomst ${ }^{108}$ een nationaliteitsregeling moeten inhouden, om een 'run' op het moederland te voorkomen bij een aangekondigde onafhankelijkheid. De oorzaak van de Nederlandse angst voor een instroom van een groot aantal immigranten uit de overzeese gebiedsdelen is volgens Karamat Ali te wijten aan discriminatie en toenemend racisme in Nederland. Indien veel Antillianen en Arubanen naar Nederland zouden vertrekken kan de eigen economie niet in stand worden gehouden of verder worden ontwikkeld. Wellicht zou daarom tijdelijk voor een dubbele nationaliteit moeten worden gekozen. ${ }^{109}$ De opvatting van Karamat Ali komt lijkt niet op de gepercipieerde werkelijkheid van de Antilliaanse en Arubaanse bevolking te kunnen steunen. Alhoewel met de Schets de dreiging van een spoedige onafhankelijkheid voor de Nederlandse Antillen en Aruba verminderd leek,

Toescheidingsovereenkomst inzake nationaliteiten tussen het Koninkrijk der Nederlanden en de Republiek Suriname, Paramaribo, 25 november 1975, Tractatenblad, 28, 1975, nr. 1 en de Overeenkomst tussen het Koninkrijk der Nederlanden en de Republiek Suriname inzake het verblijf en de vestiging van wederzijdse onderdanen, Paramaribo. 25 november 1975, 29, 1975, nr. 1. Amigoe, 22 december 1989, 'Met Suriname als voorbeeld, mr. M.D. van Aller: Gevolgen onathankelijkheid zakelijk onder ogen zien'. 
dacht de meerderheid van de Nederlandse politici daar genuanceerder over. De onafhankelijkheid speelde nog steeds op de achtergrond een belangrijke rol, er was immers nog niet serieus gesproken over het schrappen van art. 62 Statuut.

Gorsira maakte duidelijk dat onafhankelijkheid voor de Nederlandse Antillen een slechte zaak zou zijn. ${ }^{110}$ Nederland erkende het zelfbeschikkingsrecht van alle eilanden. Er werd toen weliswaar geen rekening gehouden met de volkenrechtelijke consequenties van die beslissing, maar dat neemt niet weg dat duidelijke afspraken met Nederland zijn gemaakt. ${ }^{111}$ Uitdrukkelijk werd vastgesteld bij de besprekingen met de Commissie van Zeven dat als Aruba de onafhankelijkheid zou doorzetten, dat niet inhield dat de Antillen 6́6k onafhankelijk zouden moeten worden, maar dat een dergelijke beslissing ook niet uitgesloten zou kunnen worden. De politieke lijn met betrekking tot de overzeese gebiedsdelen wijzigde met de Schets van minister Hirsch Ballin, de ontwikkelingen in Suriname droegen daartoe ook bij.

Gorsira meende derhalve dat daarom Nederland het 'verstotingsrecht' niet zou mogen uitoefenen, de Nederlandse bevolking zou die gedachtengang nu ook niet ondersteunen. Hij kon zich niet voorstellen:

"dat een land dat voortdurend tegen dictaturen waar ook ter wereld opkomt, dat altijd klaar staat om recht en billijkheid in alle continenten te verdedigen, zal goedvinden dat zes kleine eilanden, minder bedeelde eilanden - waarmede Nederland al drie eeuwen in tijden van voor- en tegenspoed verbonden is geweest - tegen hun wil uit het Koninkrijk zouden worden gezet, met alle mogelijke gevolgen van dien."

Indien Nederland in onderling overleg en op grond van een behoorlijke kostenberekening aan de zes eilanden had overgelaten te bepalen hoe ver ze hun autonomie wilden doorvoeren, zou Aruba waarschijnlijk het separación-avontuur bespaard zijn gebleven. Ook Gorsira bracht een aantal mogelijke staatkundige opties voor de Antillen van de Vijf naar voren, die elementen bevatten van de voorstellen van

110 Gorsira (1989) m.n. pp. 62 e.v.

111 Zie ook Röling, Moenir Alam, Post en Van der Veen in: Meyers (1980); zie ook: Papers presented at the Symposium on International Relations in the Caribbean, Curaçao, January 24-26, 1974, sponsored by the Institute of International Relations, University of the West-Indies, Saint Augustine, Trinidad and Hogeschool van de Nederlandse Antillen, Curaçao. 
Croes, Pourier en Munneke. ${ }^{112}$ Als reactie op de Schets stelde Gorsira dat in de Gemenebest-constructie de verzorging van bepaalde onderwerpen aan het Gemenebest kon worden overgelaten, maar in principe zijn de geassocieerde leden onafhankelijk en kunnen daarom de behartiging van rechtszekerheid, deugdelijk bestuur, waarborgen voor de rechtsstaat en democratie, een goede rechtspleging, alsmede defensie en buitenlandse betrekkingen elk moment afstoten. ${ }^{113}$ Dat zou betekenen dat de rechtsstaat in gevaar zou kunnen komen. Gorsira probeerde daarom dit probleem te ondervangen en meende een oplossing te vinden in de Engelse Gemenebeststructuur.

'The British Commonwealth of Nations' is sinds 1926 de aanduiding van het Britse Rijk, waarin de Dominions en Ierland als gelijkberechtigde leden naast het moederland staan. In principe zijn dus alle leden van het Gemenebest onafhankelijk en kunnen krachtens verdragen bepaalde zaken behartigen. De Antilliaanse eilanden en Aruba willen vooralsnog geen onafhankelijkheid maar een wijziging in hun onderlinge verhouding en op grond daarvan een andere verhouding met het moederland. Naast een kroongewest in de zin van het Britse 'Commonwealth' dacht Gorsira ook aan de mogelijkheid van een eenheidsstaat van de Nederlandse Antillen met Nederland. Daarbij verwees hij naar het Franse systeem en concludeerde dat het verkrijgen van een andere status binnen het Koninkrijk, zoals bijvoorbeeld 'kroongewest' geen inlijving is. Van inlijving kan geen sprake zijn, de eilanden zijn al onderdeel van het Koninkrijk.

Gorsira lijkt een voorkeur te hebben voor een integratie van de Antilliaanse eilanden binnen het Koninkrijk in de vorm van een aparte status voor Curaçao en Aruba. De kleine eilanden zouden overzeese gebiedsdelen kunnen worden.

De observaties van Dip in 'Realiteit en fictie in het proces van de staatkundige herstructurering van de Nederlandse Antillen' ${ }^{114}$ zijn van belang om te bepalen welk staatkundige structuur voor de Nederlandse Antillen politiek haalbaar en reëel is. Modellen zijn theoretische constructies, die uitgaan van een gewenste, ideale situatie en niet van de vaak onhandelbare praktijk. In zijn artikel besprak Dip een aantal ficties. Wordt er geen rekening gehouden met de weerbarstige

M.P. Gorsira 'Status Aparte ook voor Curaçao en St. Maarten haalbare kaart, Exgezaghebber sleutelt aan nieuwe rechtsorde tussen Nederland en de zes eilanden', Amigoe, 13 augustus 1992.

M.P. Gorsira 'De nieuwe rechtsorde, Een regeling van staatsrechtelijke of volkenrechtelijke aard?', Amigoe, 3 maat 1990. Dip (1991). 
praktijk dan zullen de modellen afgewezen worden. Dip stelde in de eerste plaats dat een Antilliaans- en/of Arubaans staatsverband van enige duurzaamheid zich niet verdraagt met het zelfbeschikkingsrecht van de eilanden. Vier van de vijf eilanden hebben blijkens conclusiepunt 6 van de RTC van 1983 zich het recht voorbehouden om ieder moment voor onafhankelijkheid of uittreding uit het Antilliaans verband te kiezen. Een samenwerking tussen de vijf eilanden kan niet op zo'n wankele basis zijn gebouwd.

"Het is niet voor niets dat het dikwijls als een essentiële voorwaarde voor een federale structuur wordt gezien, dat de deelstaten der federatie geen recht van secessie hebben en dat de federale overheid evenmin het recht heeft een deelstaat uit te sluiten".

Indien decentralisatie zou worden overwogen, waarvan al zolang gedacht wordt dat het de problemen van de eilanden zou kunnen oplossen, dan zou ook aan een federatie kunnen worden gedacht. Dip was de mening toegedaan dat federalisering ook een vorm van decentralisatie was, "in die zin dat bij de eerste door een regeling in de constitutie wordt getracht een bepaalde verhouding tussen de macht van het centrale gezag en die van de andere overheden te institutionaliseren en aldus een optimale graad van decentralisatie te waarborgen".

Decentralisatie en federalisme hebben beide tot doel om overbeidsmacht te spreiden. Het federalisme onderscheidt zich van decentralisatie, doordat het die decentralisatie wil vastleggen in de Grondwet. Dit is ook het systeem van de artt. 2 en 2a ERNA. De bedoeling van decentralisatie is om de overheid op Lands- en Eilandsniveau efficiënt te laten werken. Daar de politieke omstandigheden voor een federatieverband sinds het einde van de jaren tachtig, niet meer aanwezig zijn, ligt decentralisatie voor de hand. Verruiming van de bevoegdheden van de Eilandgebieden zou kunnen gebeuren door wijziging van de artt. 2 en 2a ERNA, maar zou ook kunnen geschieden door een ruimer gebruik van medebewind, verruiming van de financiële middelen van een Eilandgebied en vermindering van preventief en repressief toezicht door het Land. Voordat er sprake zou kunnen zijn van een nieuwe staatkundige structuur, zou zorgvuldig moeten worden bestudeerd welke taken naar de Eilandgebieden kunnen worden gedecentraliseerd en welke taken de Landsregering moet blijven regelen. Dip achtte dan ook wijziging van de artt. 2 en 2a ERNA niet opportuun. Het schrappen van de artt. 2 en 2a ERNA leek Dip niet verstandig, want dan verliezen de Nederlandse Antillen als rechtsgemeenschap hun bestaansgrond. 
Hij was het dan ook niet eens met de suggestie uit het rapport van het Bureau Staatkundige Structuur Eilandgebied Curaçao, die daarentegen voorstelde juist de artt. 2 en 2a ERNA te schrappen. ${ }^{115} \mathrm{Na}$ schrapping zou de basis voor het verlenen van hulp en bijstand van Curaçao aan de kleine eilanden kunnen worden ontleend aan art. 88 vierde lid Staatsregeling Nederlandse Antillen. Op grond van dit artikel kunnen gemeenschappelijke regelingen worden getroffen ter behartiging van bepaalde aangelegenheden. Gezien het feit dat de eilanden in één staatsverband leven zal er altijd een aantal taken centraal moeten worden geregeld. Zo'n samenwerkingslandsverordening kan geen verplichting tot samenwerking inhouden. Daarom is het art. 88 lid 4 ook onbruikbaar om ontstane hiaten in de wetgeving op te lossen. Dat artikel vormt geen goede basis voor een staatsrechtelijke structuur, het heeft niet de strekking om krachtens gemeenschappelijke regeling in te stellen organen en lichamen te belasten met de verzorging van onvoldoende begrensde belangencomplexen. Namelijk in beginsel alle onderwerpen genoemd in de artt. 2 en 2a ERNA. Bovendien kunnen de genoemde taken grotendeels niet worden gedecentraliseerd, daar het toch niet de bedoeling kan zijn dat elk eiland afzonderlijk en zelfstandig het geldwezen, deviezenverkeer, de wetgeving op het gebied van het burgerlijk recht, strafrecht, belastingheffing, sociale verzekeringen etc. zou gaan regelen.

Daarnaast merkte Dip dat er ook onduidelijkheid bestaat over de betekenis van de gehanteerde terminologie, 'decentralisatie' werd in vele modellen genoemd als dé oplossing. Maar wat daarmee nu precies werd bedoeld bleef onduidelijk. Ging het om de toekenning van bevoegdheden in medebewind aan de eilandbesturen met betrekking tot onderwerpen van landszorg, of was het de bedoeling dat bepaalde landstaken door verdere wijzigingen van de artt. 2 en 2 a van de ERNA onder de zorg van de Eilandgebieden werden gebracht? Deze laatste vorm van decentralisatie zou het Antilliaans verband in het hart treffen. Dip meende dat decentralisatie van medebewindstaken heel goed mogelijk kan zijn zonder wijziging aan te brengen in de artt. 2 en 2a ERNA. Daartoe gaf hij de volgende aanbevelingen:

1. Er moet worden uitgegaan van de realiteit en niet van ficties.

2. Er moet duidelijkheid zijn over de betekenis van begrippen zoals: 'bestuurslaag', 'decentralisatie' en 'federalisering'. 
3. Curaçaose politici moeten aangeven wat zij precies met een Status Aparte voor Curaçao bedoelen, als zij niet de Status Aparte van Aruba wensen te reproduceren.

4. Zowel Curaçao als de Landsregering moeten zich realiseren dat een Antillen van de Vijf als staatsrechtelijke eenheid, staatsrechtelijke en financiële consequenties heeft voor zowel de Antillen als voor Curaçao.

5. De kleine eilanden dienen zich te realiseren dat bij een Antillen van de Vijf, waaronder Curaçao als grootste eiland, nimmer sprake kan zijn van een machtsevenwicht tussen de delen. Wel is het mogelijk dat bepaalde waarborgen kunnen worden ingebouwd in het belang van de kleine eilanden.

6. Een nieuw staatsrechtelijk verband kan niet gebaseerd zijn op gemeenschappelijke regelingen tussen de Nederlandse Antillen en de eilanden onderling.

\section{Federale staatsvormen}

De behandelde modellen en meningen van deskundigen, hebben ook een aantal problemen, waaraan de deskundigen niet altijd aandacht besteden. Het invoeren van een federaal stelsel vereist basisvoorwaarden waaraan voldaan moet zijn. Het kiesstelsel in de Nederlandse Antillen versterkt de eilandbelangen en werkt samenwerking, eenheid en natievorming tegen. Daarom zal in het onderdeel 9.16 worden ingegaan op de vereisten om met vrucht een federaal stelsel te kunnen invoeren en op de knelpunten van het Antilliaanse kiesstelsel.

Volgens Polak ${ }^{116}$ is federalisme een vorm van politieke organisatie, waarbij mensengroepen die oorspronkelijk zelfstandig waren, zich aaneensluiten, omdat zij op een gegeven ogenblik tot het inzicht zijn gekomen, dat zij onderling van elkaar afhankelijk zijn. Het is ook voorgekomen, dat grote, centraal geleide staten tot een lossere organisatievorm zijn overgegaan, omdat het fysiek en technisch onmogelijk bleek de uitoefening van alle staatsfuncties centraal te doen plaatsvinden. Met een confederatie of statenbond wordt bedoeld samenwerking tussen verschillende soevereine staten op grond van een verdrag. Bijvoorbeeld de Republiek der Verenigde Nederlanden en Amerika van 1781-1787. Er is wel een centrale instantie, maar deze coördineert slechts en heeft geen beslissende bevoegdheden, uittreding is altijd mogelijk (voormalige USSR). Sommige bondsstaten 
zijn ontstaan uit statenbonden waar het ontbreken van een sterk centraal gezag als een gemis werd gevoeld (VS, Zwitserland). Staten verenigen zich tot een statenbond of confederatie wanneer zij met elkaar een verdrag sluiten en daarbij aan een gemeenschappelijk gezagsorgaan de uitoefening van hun bevoegdheden toevertrouwen. Deze zullen meestal bestaan in de leiding van de buitenlandse betrekkingen, het in standhouden van een krijgsmacht, het voeren van oorlog en de beslechting van geschillen tussen de aangesloten leden. Het bondsorgaan zal over het algemeen een soort gezantenconferentie zijn, waarheen iedere staat vertegenwoordigers, voorzien van instructies, afvaardigt, terwijl ieder lid één stem uitbrengt.

In een statenbond blijft dus de centrale wil afhankelijk van de wil van de afzonderlijke eenheden. Het verdrag waarop de statenbond rust kan gezien worden als een vorm van contract. Het contract kan beëindigd worden en een staat kan uit de overkoepelende organisatie treden. Het samenwerkingsverband hangt dus voortdurend af van de goede wil van de deelnemers.

In de bondsstaat of federatie is enerzijds sprake van min of meer zelfstandige deelstaten, anderzijds van een federaal gezag. Als ideale vorm van politieke organisatie wordt het federalisme gekenmerkt door harmonie en onderlinge solidariteit. Het heeft de strekking om verhoudingen van ondergeschiktheid te vervangen door die van nevengeschiktheid, dwang van boven door wederkerigheid, onderling begrip en aanpassing, bevel door overreding en macht door recht. De federale constitutie regelt de bevoegdheidsverdeling tussen de twee soorten gezagsdragers, zij hebben elke ook een eigen sfeer van zeggenschap. Omdat ook de bevoegdheid van de federale wetgever afhangt van de Grondwetsbepaling en de interpretatie daarvan is het van belang dat in een federaal systeem een onpartijdige instantie het laatste woord heeft in zaken van Grondwetsinterpretatie. Meestal is dat dan ook niet aan de wetgever zelf overgelaten, maar aan de rechter; deze kan dan wetten, ook federale wetten, onverbindend verklaren wegens strijd met de federale Grondwet.

Een federatie had naar mijn mening wellicht in een eerder stadium kans van slagen kunnen hebben, bijvoorbeeld om tegemoet te komen aan het 'autonomiestreven' van Aruba. Thans zijn de omstandigheden zozeer gewijzigd door de dreigende desintegratie van de Antillen, dat alle basisvoorwaarden om met enige kans van slagen een federatieve staatsvorm voor de Nederlandse Antillen en Aruba te creëren, zijn komen te vervallen. 
In een gedecentraliseerde eenheidsstaat als Nederland is het mogelijk dat kleine territoriale eenheden over betrekkelijk verreikende bevoegdheden beschikken ten aanzien van hun interne aangelegenheden. Het verschil met de bondsstaat is enerzijds, dat de centrale wetgever, binnen zekere grondwettelijke grenzen, de omvang van die bevoegdheden kan uitbreiden of beperken, anderzijds dat er een zekere mate van toezicht van de centrale overheid is op het reilen en zeilen van de kleinere verbanden. Hierbij kan gedacht worden aan toezicht van de provincies op de gemeenten, toezicht van de Kroon op de provincies, toezicht van het Land op de eilanden en toezicht van de Gouverneur als Koninkrijksorgaan op het Land en op de Eilanden. Typerend voor decentralisatie is de bevoeghedentoedeling aan kleinere verbanden.

Vergelijkt men de bevoegdheidsverdeling inzake wetgeving een bestuur tussen de organen van provincies, gemeenten en eilanden enerzijds en die tussen regering, parlement en Staten anderzijds, dan vallen twee verschillen op:

1. Is op rijksniveau (en landsniveau) het bestuur niet aan de StatenGeneraal (en aan de Staten) maar aan de regering als een volledig en zelfstandig uit te oefenen bevoegdheid opgedragen, op provinciaal en gemeentelijk (en eilandelijk) niveau is het bestuur in beginsel opgedragen aan Provinciale Staten respectievelijk de Gemeenteraad (en de Eilandsraad). Het aan Gedeputeerde Staten en B\&W (en het Bestuurscollege) opgedragen 'dagelijks bestuur' is geen volledig en zelfstandig uit te oefenen bevoegdheid. De hoogste bestuursbevoegdheid blijft aan Provinciale Staten respectievelijk de Gemeenteraad (en de Eilandsraad), aan wie ook het verrichten van de verschillende belangrijke bestuurshandelingen is voorbehouden, zie bijvoorbeeld de artt. 170-173 Gemeentewet. en de art. 24 en 57 ERNA.

2. Hebben op rijksniveau en landsniveau regering en Staten-Generaal (en Staten) tezamen de wetgevende macht, op provinciaal, gemeentelijk en eilandelijk niveau is de wetgevende macht toegekend aan Provinciale Staten, de Gemeenteraad respectievelijk de Eilandsraad (art. 24 ERNA) zonder dat medewerking van Gedeputeerde Staten, B\&W of het Bestuurscollege (BC) is vereist. De verdeling van bevoegdheden tussen regering en Staten-Generaal respectievelijk de Staten is mede de basis waarop het 'dualisme' tussen deze twee organen berust. Zij hebben ieder een eigen taak. Bovendien zijn ministers geen lid 
van de Staten-Generaal of de Staten en zij hoeven besluiten van het parlement respectievelijk de Staten niet uit te voeren als zij daarvoor geen verantwoordelijkheid kunnen dragen. Gedeputeerden zijn tevens lid van Provinciale Staten en wethouders zijn tevens lid van de Gemeenteraad. Leden van het BC kunnen ook lid zijn van de Eilandsraad. De colleges van Gedeputeerde Staten, B\&W en het BC moeten de besluiten van Provinciale Staten, de Gemeenteraad en de Eilandsraad uitvoeren (art. 57 ERNA).

De leden van het college van Gedeputeerde Staten zijn tezamen en ieder afzonderlijk verantwoording verschuldigd aan Provinciale Staten voor het door het college gevoerde bestuur. Hetzelfde geldt voor het college van B\&W en het Bestuurscollege (art. 62 ERNA). Het GHvJ deed een interessante uitspraak over dit onderwerp. De rechter vergeleek op grond van art. II.6 vierde lid Staatsregeling van Aruba, de bevoegdheden van de Ministerraad van Aruba met de vroegere collegiale verantwoordelijkheid van de Eilandsraad van Aruba. ${ }^{117}$ In beginsel gelden deze verplichtingen ook voor de Commissaris van de Koningin en de burgemeester. De Commissaris is naast provinciaal orgaan ook rijksorgaan (art. $126 \mathrm{GW}$ en zijn ambtsinstructie). Voor zijn beleid als rijksorgaan is hij geen verantwoording schuldig aan Provinciale Staten. Dit komt overeen met de functie van de Gouverneur als Koninkrijksorgaan, daarvoor is hij verantwoording verschuldigd aan de Koninkrijksregering en niet aan de Landsregering.

In de provincie en de gemeente en ook bij de eilanden is de verantwoordingsplicht niet gekoppeld aan de vertrouwensregel. Gedeputeerde Staten, B\&W en het BC besluiten als college (zie art. 5 jo 47 Provinciewet en art. 1 jo 98 Gemeentewet en art. 62 ERNA), daarin past niet dat een individueel lid waarin het vertrouwen is opgezegd moet heengaan. $\mathrm{Er}$ is op dit niveau geen onschendbaar staatshoofd, rond wiens bevoegdheid zich het gewoonterecht (vertrouwensregel) heeft gevormd. Als er ontslag wordt verleend moet dat geschieden door Provinciale Staten, de Gemeenteraad of de Eilandsraad. De vraag wanneer ontslag kan worden verleend is uitputtend geregeld in de Provinciewet, Gemeentewet en de ERNA. Een gedeputeerde kan van zijn betrekking worden vervallen verklaard indien hij het vertrouwen van de Raad niet heeft op grond van art. 50a ERNA. Uit deze vergelijking volgt dat de nadruk in de Antilliaanse Staatsre-

117

Gerecht in Eerste Aanleg in kort geding 5 oktober 1988, Windsurfing Aruba NV vs het Land Aruba en GHvJ 18 april 1989, Het Land Aruba vs Windsurfing Aruba NV. 
geling en de ERNA toch veel sterker werd gelegd op de eenheidsstaat, naar het Nederlands model, dan op een federale structuur. Met de bestaande Antilliaanse Staatsregeling en de ERNA, waarin opgenomen het hoger toezicht, het verschil in grootte en bevolking van de eilanden, het vigerende kiesstelsel, het bestaande insularisme en het ontbreken van de wens tot een intensieve samenwerking lijkt een federaal samenwerkingsverband vooralsnog niet mogelijk. Een Antilliaanse gedecentraliseerde eenheidsstaat behoort zeker niet tot de mogelijkheden.

Naast de onduidelijkheid over de gewenste staatkundige structuur, vormt de werking van het kiesstelsel in de Antillen een groot probleem. Daarom wordt dit probleem apart besproken, omdat vele deskundigen van mening zijn dat wil een Antilliaans staatkundig verband goed kunnen werken, daarvoor de regeling van het kiesstelsel van doorslaggevend belang is.

Het rapport De la Try Ellis ${ }^{118}$ wees erop dat bij de Staatsregeling van 1936 een beperkt mannen-census kiesrecht werd ingevoerd, nader te regelen door een kiesreglement. Dit kiesreglement kwam tot stand bij Algemene Maatregel van Bestuur. ${ }^{119}$ Anders dan het huidige kiesreglement, huldigde het Kiesreglement van 1937 niet het lijstenstelsel maar het meerderheidsstelsel. De wetgever ging van de gedachte uit dat als het meerderheidsstelsel werd gevolgd, het vrijwel zeker zou zijn dat alle zetels door de volkspartijen zouden worden bezet. Omdat de vorming van politieke partijen met vaste programma's nog in een beginstadium verkeerde en politieke scholing ontbrak onder de meeste kiezers, werd een personenstelsel ingevoerd. In elk van de kiesdistricten Bonaire en Bovenwinden viel één plaats te vervullen; in de districten Curaçao en Aruba samen acht. Volgens het Kiesreglement werden zes zetels aan Curaçao toebedeeld en twee zetels aan Aruba. Vervolgens werd de wens tot uitbreiding van het kiesrecht uitgewerkt en werd het Kiesreglement gewijzigd. Het personenstelsel uit het Kiesreglement van 1937 werd vervangen door een lijstenstelsel met waarborging voor Bonaire en de Bovenwindse Eilanden van én zetel, Aruba en Curaçao kregen samen acht zetels (in de verhouding zes/twee). Voor Aruba en Curaçao werd het evenredigheidsstelsel ingevoerd, voor Bonaire en de Bovenwinden

118 Rapport Ellis (1946) p. 60.

119 AMvB van 11 maart 1937, 65, PB 41. 
het meerderheidsstelsel. ${ }^{120}$

Het bestaande kiesstelsel op de Nederlandse Antillen werkt desintegratie en versterking van deelbelangen in de hand. Het heeft ook bijgedragen tot het mislukken van een natievorming in de Nederlandse Antillen. De eilanden-afvaardiging met een vast aantal leden per eiland werkte een politieke afsplitsing in de hand, daar de eilandvertegenwoordiging beheerst werd door het eiland-belang. ${ }^{121}$

Ondanks de principiële bezwaren tegen de eilanden-afvaardiging, werd in 1948 als gevolg van een transactie tussen twee op Curaçao en Aruba gevestigde partijen voor het eerst in de Staatsregeling vastgelegd, dat elk eiland een bepaald aantal zetels zou krijgen. De betrokken partijen beloofden elkaar na de verkiezingen te steunen bij de vorming van een nieuwe regering. De Koninkrijksregering volgde het advies van de Staten op en voerde de eilanden-vertegenwoordiging in. In de Staatsregeling werd vastgelegd dat de Staten uit 21 leden zouden bestaan: 8 zetels voor Curaçao, 8 voor Aruba, Bonaire kreeg 2 zetels en elke der Bovenwindse eilanden kreeg 1 zetel. In deze constructie werd Curaçao benadeeld en kregen de minder draagkrachtige eilanden onevenredig veel invloed, hetgeen niet in overeenstemming was met het aantal op de eilanden uitgebrachte stemmen. In de verkiezingen worden stemmen geacht een gelijke waarde te hebben. Maar deze democratische vereisten ontbraken in bet kiesstelsel van 1948.

In 1985 werd de Statenvertegenwoordiging gewijzigd vanwege de uittreding van Aruba uit het Antilliaanse verband. Elk eiland vormt een kiesdistrict. Curaçao kiest 14 leden, Bonaire 3 evenals Sint Maarten. Saba en Sint Eustatius kiezen elk één Statenlid. Op de eilanden Curaçao, Bonaire en Sint Maarten worden de leden van de Staten volgens het evenredigheidsstelsel gekozen. Op Saba en Sint Eustatius waar één zetel is te behalen, gaat de zetel naar de partij die de meeste stemmen heeft behaald. De nieuwe zetelverdeling werd niet volgens bet evenredigheidsstelsel vastgesteld. Nogmaals werd de eilanden-afvaardiging gekozen voor de centrale wetgevende macht. Deze zetelverdeling is wederom in het voordeel van de kleine, minder draagkrachtige eilanden. Het schijnt nog steeds niet te zijn doorgedrongen, dat de eilanden-afvaardiging het politiek samenbrengen van de eilanden in hoge mate tegenwerkt. Als voorbeeld geeft Gorsira een overzicht van de in 1990 gehouden Statenverkiezingen. De discrepan-

\footnotetext{
120 Rapport Ellis (1946) pp. 60-71.

121 M.P. Gorsira, 'Status Aparte ook voor Curaçao en St. Maarten haalbare kaart, Exgezaghebber sleutelt aan nieuwe rechtsorde tussen Nederland en de zes eilanden', Amigoe, 13 augustus 1992.
} 
tie is duidelijk zichtbaar:

$\begin{array}{lc}\text { Curaçao: } & 72.925 \text { stemmen (14 zetels) } \\ \text { Bonaire: } & 5.244 \text { stemmen ( } 3 \text { zetels) } \\ \text { Sint Maarten: } & 8.007 \text { stemmen ( } 3 \text { zetels) } \\ \text { Sint Eustatius: } & 722 \text { stemmen ( } 1 \text { zetel ) } \\ \text { Saba: } & 672 \text { stemmen ( } 1 \text { zetel ) }\end{array}$

Hieruit blijkt, dat elk van de veertien aan Curaçao toegekende zetels 5208 kiezers vertegenwoordigt. Het ondemocratische karakter van deze zetelverdeling blijkt duidelijk uit deze cijfers, de politieke invloed van de kiezers van de verschillende eilanden is niet gelijk.

Janus $^{122}$ meende dat enerzijds kiezers niet of nauwelijks invloed kunnen uitoefenen op de politieke samenstelling van het te vormen kabinet, noch op de kandidaten die door de partijen worden aangewezen voor de diverse ministersportefeuilles. Anderzijds wordt echter door Nederlandse en Antilliaanse politici, het uiteindelijke resultaat van de formatie gekritiseerd en geconcludeerd dat de Nederlandse Antillen geconfronteerd worden met instabiele en weinig daadkrachtige regeringen. Ook een krachtige oppositie kan niet bestaan binnen het huidige kiessysteem. Het creëert minderheden, die na de verkiezingen gaan onderhandelen om een meerderheid te vormen. Dit wordt in de hand gewerkt door de noodzaak tot het vormen van een uit meerdere partijen bestaand coalitie-kabinet. Om de genoemde problemen het hoofd te bieden, zou een ander kiesstelsel moeten worden geïntroduceerd, dat in plaats van minderheden meerderheden creēert. Het organiseren van landelijke partijen, die met een lijst op alle eilanden opereren lijkt uitgesloten, derhalve zal het moeilijk zijn een kiessysteem te ontwerpen, waarin een partij de absolute meerderheid heeft. Janus achtte dan ook de invoering van verkiezingen in twee rondes ${ }^{123}$ de moeite van het overwegen waard. Janus verwees hierbij naar Castillo's voorstel voor een gemengd kiesstelsel inhoudende:

- $\quad$ Aan de eerste verkiezingsronde nemen alle partijen deel, aan de tweede slechts de twee grootste partijen. De winnaar van de tweede ronde krijgt de helft van het aantal zetels plus twee toegewezen en zal zo kunnen regeren zonder dat een coalitiekabinet gevormd behoeft te worden.

\footnotetext{
122 Janus (1988) met name pp. 75-78.

123 Deze gedachtengang werd naar voren gebracht door Oscar Castillo van Kousa Komun, Castillo (1986) pp. 129-145.
} 
- De resterende zetels worden op basis van evenredigheid, overeenkomstig de resultaten van de eerste ronde onder de overige partijen verdeeld.

Het voorstel van Castillo hield in dat de kleine eilanden niet of nauwelijks vertegenwoordigd zullen zijn in de Staten. Dat achtte Janus in strijd met het tot nu toe algemeen aanvaarde uitgangspunt dat alle eilanden in de Staten vertegenwoordigd moeten zijn en volgens de formatie-instructie van de Gouverneur, liefst ook in de regering. Janus was van mening dat hetzelfde systeem gevolgd zou moeten worden bij de gelijktijdig te houden verkiezingen voor de Staten en de Eilandsraden.

Geconcludeerd kan worden dat er veel kritiek is geweest op het heersende kiessysteem en het daaruit voortvloeiende systeem van kabinetsformaties. Voorstellen om dit te veranderen waren er de afgelopen jaren regelmatig te horen. ${ }^{124} \mathrm{Bij}$ het bespreken van een nieuwe rechtsorde, moet zeker het kiessysteem onderwerp van gesprek zijn. Wil men het kiessysteem veranderen en dat zou mogelijk zijn als de dubbele bestuurslaag wordt opgeheven, dan is een dergelijke gelegenheid daartoe geschikt.

Op grond van het bovenstaande kan worden gesteld dat een tepaalde vorm van centraal gezag zal moeten worden gehandhaafd, zolang de eilanden binnen het Koninkrijk blijven. Dat een samenwerkingsverband van de Antillen van de Vijf moeilijk tot stand zal komen als Curaçao een meerderheidspositie opeist is wel duidelijk. Een federatief verband is thans gezien de heersende politieke opvattingen, niet goed mogelijk. Een confederatief samenwerkingsverband behoort wel tot de mogelijkheden. Een dergelijk samenwerkingsverband zou ook wel op enige politieke steun kunnen rekenen. Het nadeel van een dergelijk samenwerkingsverband is dat een aangesloten staat altijd kan uittreden. Dat betekent dat gezien de heersende politieke verhoudingen op de Antillen en Aruba, alleen een meer verplichtend confederatief verband zou werken, daar anders partijen elkaar over en weer zouden kunnen chanteren en bijvoorbeeld hulp en bijstand onthouden als bepaalde beslissingen al dan niet in hun voordeel zouden zijn. Curaçao en Aruba hebben duidelijk gemaakt dat zij geen verantwoordelijkheid meer willen dragen voor de kleine eilanden, dat is ook de opzet van de Status Aparte. Zolang de eilanden binnen het Koninkrijk blijven en ondersteuning van Nederland verwachten, zou het voor de 
hand liggen, dat óók van de eilanden gevraagd kan worden dat zij enige solidariteit met elkaar aan de dag leggen.

Een dergelijk samenwerkingsverband zou tevens meer politieke steun kunnen verwerven, als de financiën van de eilanden direct met Nederland zouden kunnen worden geregeld en de samenwerking meer verplichtend zou kunnen worden vastgelegd. Haalbaar lijkt tot op heden het model Dip III in samenwerking met de Unie van Janus en de regeling van directe financiering op Eilandsniveau met Nederland. Tevens dient te worden nagegaan welke Landsbevoegdheden wel naar de kleine eilanden kunnen worden gedecentraliseerd en welke niet. Ten slotte kan dan gezien het streven naar een Status Aparte van Curaçao, deze worden verleend, daar Curaçao voldoende bestuurskracht bezit om die taken gedecentraliseerd uit te voeren. De kleine eilanden hebben dat niet. De kleine eilanden zullen derhalve een gemeente van Nederland moeten worden of indien dat politiek niet haalbaar is bediend moeten worden via de Unie van Janus.

Intussen was nog steeds niets geregeld over de schrapping van art. 62 Statuut. Aruba wilde dat graag geregeld zien. Sinds april 1992 zijn twee voorstellen van Rijkswet ${ }^{125}$ in behandeling bij de volksvertegenwoordigingen van de Landen van het Koninkrijk. Een voorstel behandelde het schrappen van de onafhankelijkheidsdatum. Het tweede voorstel ging over de bijdragen van de Landen aan het Solidariteitsfonds. ${ }^{126}$ Beide voorstellen werden vooruitlopend op de

Wijziging van het Statuut voor het Koninkrijk der Nederlanden in verband met het voortzetten van de in het Statuut neergelegde rechtsorde ten aanzien van Aruba, Tweede Kamer vergaderjaar 1991-1992, 22593 (R 1433) nrs. I-2. Zie ook Beleidsdebat over onderwerpen rakende het Kabinet van Nederlands-Antilliaanse en Arubaanse Zaken, Voorlopig Verslag van de Vaste Commissie voor NederlandsAntilliaanse en Arubaanse Zaken, vastgesteld 12 maart 1991 en de daarop aansluitende Memorie van Antwoord van de Minister, ontvangen 3 mei 1991, Eerste Kamer, vergaderjaar 1990-1991, $21800 \mathrm{IV}$, de nrs. $210 \mathrm{en} \mathrm{nr.} \mathrm{210a,} \mathrm{Schets} \mathrm{en} \mathrm{wijziging}$ artikel 62 . Uit het onderdeel betreffende de wijziging van art. 62 Statuut blijkt duidelijk dat de Minister de wijziging koppelt aan een bevredigende oplossing van de verwachte bijdragen aan het Solidariteitsfonds.

126 Staten-Generaal, vergaderjaar 1986-1987, 19 620, nr. 30 en I. Tweede Ksmer, vergaderjaar 1991-1992, 22 594, 1433. Uit de Handelingen van de Tweede Kamer blijkt heel duidelijk dat het schrappen van art. 62 Statuut wordt gekoppeld aan cen afdoende regeling voor het Solidariteitsfonds. Handelingen Tweede Kamer, Nederlands-Antilliaanse en Arubaanse Zaken, 14 en 15 november 1990, TK 23 en idem 30 oktober 1991, TK 17. p. 17-892 en 893. J.C.G. Wiebenga (VVD), voorzitter van de Contactplanbijeenkomst in 1992, gaf die samenhang nog eens duidelijk weer, zie Staten-Generaal vergaderjaar 1992-1993, 22850 , nrs. 40 en 1, p. 21 . In diezelfde 
algehele herziening van het Statuut gedaan. De herziening van het Statuut zal nog geruime tijd op zich laten wachten, daar over het voorstel tevens een 'brede maatschappelijke discussie' in Nederland zal worden gevoerd. De financiële bijdragen aan het Solidariteitsfonds werden door Nederland gekoppeld aan een nieuwe Koninkrijksstructuur. De Memorie van Toelichting (MvT) ${ }^{127}$ op het schrappingsvoorstel stelde dat het de uitdrukkelijke wens van Aruba was, dat de keuze voor een onafhankelijke status in het Statuut zou worden opgenomen. De voorgestelde artikelen 58, 59 en 60 Statuut hielden in dat Aruba bij landsverordening kan verklaren dat de statutaire rechtsorde wordt beëindigd. Dit voorstel moet in de Staten worden aangenomen met een tweederde meerderheid van het aantal zitting hebbende leden. Vervolgens moet binnen zes maanden daarna een referendum worden gehouden over de door de Staten reeds goedgekeurde landsverordening. Als een meerderheid van de bevolking de goedgekeurde landsverordening ondersteunt, wordt bij koninklijk besluit de statutaire band met Aruba beëindigd. Voor de Nederlandse Antillen is een dergelijke regeling nog niet getroffen vanwege de onzekere toekomstige staatkundige structuur. Daarom blijft voor de

Contactplanvergadering, die gehouden werd in Den Haag ging A.G. Croes nog eens uitgebreid in op het zelfbeschikkingsrecht, pp. 23-26, 39 en 63-75. Wiebenga verwoorddeopnieuwhet Nederlandse standpuntover het zel fbeschikkingsrecht: 'Geen zes statusjes aparte van zes eilanden'. In de pp. 26-32 en 94 e.v. probeerden de AVP en de MEP interne parlementaire meningsverschillen te ventileren. In deze vergadering gaf senator Hoefnagels van D '66 te kennen dat een provinciestatus voor de Nederlandse Antillen het overwegen waard was, a.w. p. 36. Mevrouw M.J.C.A. van Ermen, senator (PvdA) verklaarde dat ook al had Minister Hirsch Ballin een afspraak gemaakt met Aruba om artikel 62 Statuut te schrappen, dat niet betckende dat het parlement met die afspraak zonder meer akkoord zou gaan. Zie ook de Slotverklaring van 5 juni 1992, pp. $138 \mathrm{~lm} 158$ en de hier ook opgenomen Voorbereidende Notities van de Staten van Aruba, Nota staatkundige aangelegenheden, pp. 162-166 en de Minderheidsnota AVP, pp. 166-172. Zowel de MEP als de AVP waren van mening dat Aruba het zelfbeschikkingsrechthad behouden, na het verzoek tot schrapping van artikel 62 Statuut. Voor wat betreft het Solidariteitsfonds wilde Aruba niet meer bijdragen dan $25 \%$ met een plafond van 1,5\% van de Arubaanse inkomsten. De AVP diende bij dit overleg naar aanleiding van de nota van de MEP een minderheidsnota in en stelde daarin ondermeer dat een voorjaarsmotie van de MEP, daterend uit 1990 nog rept van het leiden van Aruba naar de ona fhankelijkheid. Naar aanleiding van deze motie werd namens de coalitie door de heer H.R. Croes een brief gezonden naar de VN, waarin werd gesteld dat Nederland gebruik makte van 'dispicable tactics of economic strangulation....' om Aruba's onathankelijkheid te traineren. De AVP sprak haar vreugde uit over het feit dat de coalitie van mening was veranderd en ook de Status Aparte wil handhaven, p. 166.

$\mathrm{VgI}$. Kamerstukken II 1990-1991, 21800 IV nr. 14. Deze stukken geven het Koninkrijksoverleg weer gehouden op 27 en 30 mei 1991 te 's-Gravenhage. De Koninkrijkspartners bevestigden toen over een weer hun wens om de constitutionele banden van het Koninkrijk voort te zetten. Zie tevens Tweede Kamer, vergaderjaar 1991-1992, 22593 (R 1433) nr. 3. 
Nederlandse Antillen en Nederland artikel 55 Statuut van kracht dat regelt dat verandering van de statutaire verhoudingen in onderling overleg moet geschieden.

De reactie van de Staten van Aruba ${ }^{128}$ op het schrappen van de onafhankelijkheidsdatum was zeer positief. De Staten spraken zich niet uit voor het tweede voorstel. De Staten van de Nederlandse Antillen $^{129}$ spraken zich evenmin uit over het tweede voorstel en meenden dat het eerste voorstel eerst besproken zou moeten worden tussen de Koninkrijkspartners en de eilanden van de Nederlandse Antillen. De Tweede Kamer was in meerderheid van mening dat Aruba wel binnen het Koninkrijk kan blijven als de samenwerking met de Nederlandse Antillen verbetert en Aruba zich betrokken opstelt ten opzichte van de Nederlandse Antillen.

De Memorie van Antwoord (MvA) ${ }^{130}$ stelde dat nu Aruba duidelijk had gemaakt niet alleen pro forma deel uit te willen maken van het Koninkrijk, er een Toekomstconferentie nodig was.

De meeste politieke partijen in Nederland waren blijkens het Voorlopig Verslag (VV) van mening dat het schrappen van de onafhankelijkheidsdatum een goede zaak was. Het voorstel betreffende het Solidariteitsfonds was kort en nietszeggend, niemand wijdde er dan ook enige aandacht aan. Verbazingwekkend was dat de MvA tevens meldde dat de Samenwerkingsregeling tussen de Nederlandse Antillen en Aruba goed werkte, maar desondanks toch over een aanpassing van de regeling zou moeten worden beraadslaagd.

Naar aanleiding van het wijzigingsvoorstel van het Statuut valt op dat het niet nuttig en efficiënt is om twee verschillende methodes te hanteren om verandering te brengen in het Koninkrijksverband. Bovendien is het merkwaardig om éérst een landsverordening aan te nemen met de strekking dat Aruba onafhankelijk zal worden en vervolgens een referendum te houden. Er staat een fatale termijn genoemd in het voorgestelde artikel 60 Statuut. Nadat de hierboven omschreven procedures zijn gevolgd en de landsverordening is vastgesteld, evenals uiteraard de aangepaste constitutie, zal hoogstens één maand na die datum de onafhankelijkheid intreden. Terugkomen op het besluit kan dan niet meer. Ook al heeft Aruba daarop kennelijk

Tweede Kamer, vergaderjaar 1991-1992, 22593 (R 1433) nr. 6; zie ook A.G. Croes, Op de grenzen van het Statuut, lezing voor de A.J.V., A.J.V. Nieuwsbrief, 1992/4, pp. 18-23; 1993/2, pp. 18-21.

130 Zie: Voorlopig Verslag Tweede Kamer, vergaderjaar 1991-1992, 22593 (R 1433) nr. 5, De MvA heeft nog geen nummer, de MvA is tevens de nota naar aanleiding van het verslag van de Staten van de Nederlandse Antillen en van het verslag van de Staten van Aruba. 
aangedrongen, dan zou toch de bestaande regeling voorlopig gehandhaafd kunnen blijven.

Het Statuut wordt in sommige opzichten reeds geruime tijd als verouderd ervaren. Zowel Nederland als Aruba hebben een moderne Staatsregeling, daarom werd het voor de hand liggend geacht, ook de basisregeling voor de Koninkrijksverhoudingen te moderniseren. Om voorstellen voor te bereiden voor een vereenvoudigd en gemoderniseerd Statuut met een versterkte nadruk op democratische en rechtsstatelijke waarborgen heeft de Koninkrijksregering een ambtelijke werkgroep ingesteld. Die instelling vond plaats na herhaald overleg tussen de Koninkrijkspartners in 1991. De eerste opdracht van de werkgroep was het opstellen van een Proeve met een toelichting van een vernieuwd Statuut. Het was daarbij de bedoeling deze Proeve te beschouwen als een, door ambtelijke deskundigen opgesteld en door de regering van het Koninkrijk openbaar te maken discussiestuk, vergelijkbaar met de in 1966 verschenen Proeve van een nieuwe Nederlandse Grondwet. Deze Proeve kwam begin 1993 gereed en ging uit van de bestaande verhoudingen binnen het Koninkrijk en de vigerende statutaire rechtsorde. Nu deze ontwikkelingen zijn achterhaald door de eerste Toekomstconferentie in maart 1993 werd de Proeve niet officieel gepubliceerd. ${ }^{131}$

9.18 Nederlandse en Antilliaanse opvattingen over de Koninkrijksverhoudingen

De Schets werd uitgebreid besproken in de Tweede Kamer, ook andere staatkundige modellen speelden in de discussie een rol. De Kamerleden waren van mening dat de Nederlandse Antillen en Aruba de staatsrechtelijke band met Nederland alleen konden voortzetten, indien aan een aantal voorwaarden zou worden voldaan. Die voorwaarden lagen op het democratisch-rechtsstatelijk terrein en hielden in: een stabiele samenleving, naleving van de grondrechten een toereikende rechtsbedeling, vermindering van de criminaliteit en vooral een sanering van de overheidsfinanciën. Dit werd door Hirsch Ballin al sinds 1990 duidelijk gesteld en deze opvatting werd met grote eensgezindheid door beide Kamers gedeeld. De VVD bij monde van Wiebenga noemde de Schets van Hirsch Ballin 'onbesuisd', maar 
wilde dat later wel elastisch herzien in 'verfrissend' ${ }^{132}$ In de debatten naar aanleiding van de begrotingsbehandeling van KABNAA vroeg de VVD met klem om meer toezicht op de financiën en om versterking van de controlerende taak.

Het CDA zag de Nederlandse Antillen het liefst verenigd in een Unie. Indien dat niet mocht lukken wenste het CDA hooguit een tweedeling van de Nederlandse Antillen in een Bovenwinds land en een Benedenwinds land. Het toekennen van een aparte status aan Curaçao deed de Kamerleden vrezen voor een verdere versnippering. "Wat moeten wij dan met de kleine eilanden?", voeg J.G.H. Krajenbrink (CDA) zich af tijdens de begrotingsbehandelingen op 29 en 30 oktober 1991. Mevrouw E.G. Terpstra achtte het eindmodel van zes aparte eilanden met voor elk eiland speciale banden met Nederland onwenselijk. Hirsch Ballin beaamde dit. Op 30 oktober nam de Tweede Kamer een motie aan over de zorgwekkende bestuurlijke situatie in Sint Maarten en verzocht de minister om in overleg met de regering van de Nederlandse Antillen over te gaan tot het invoeren van bijzondere bestuurlijke voorzieningen. Met name tijdens de begrotingsbehandeling 1993 werd veel aandacht besteed aan de problematiek van emigratie naar Nederland van Antilliaanse en Arubaanse jongeren, zonder vooruitzichten. Een toelatingsregeling voor Antillianen en Arubanen werd overwogen. Tijdens de begrotingsbehandeling op 27 oktober 1992 gaf Wiebenga als zijn mening te kennen, dat een Unie nog steeds zijn voorkeur had, maar dat ook te denken viel aan het model van een 'departement d'outre mer'. Hirsch Ballin bleef bij zijn mening dat het verder opsplitsen van de Nederlandse Antillen in drie, vier of vijf landen onhanteerbaar was. De minister zegde toe met de Kamer nog nader overleg te plegen over de agenda, de opzet en de inzet van Nederland bij de Toekomstconferentie. ${ }^{133}$ De basis voor het synthese-voorstel van premier Lubbers was echter gelegd.

Handelingen Tweede Kamer, Nederlands-Antilliaanse en Arubaanse Zaken, vergaderjaar 1992-1993, KABNAA begroting 1993, 27 oktober 1992, TK 14, p. 14 917 en 923.

Handelingen Tweede Kamer, Nederlands-Antilliaanse en Arubaanse Zaken, 14 en 15 november 1990, TK 23; Idem Tweede Kamer, vergaderjaar 1991-1992, 29 oktober 1991, TK 16, idem, vergaderjaar 1992-1993, 27 oktober 1992, TK 14. Zie ook Parlementair Contactplan, Nederland-Nederlandse Antillen-Aruba, Ontmoeting 1989, tweede deel (25 september-2 oktober 1989) en de Rijksbegroting 1993, Hoofdstuk IV, Nederlands-Antilliaanse en Arubaanse Zaken. Bij deze parlementaire gedachtenwisselingen die regelmatig plaatsvinden kunnen van Antilliaanse en Arubaanse zijde de wensen op staatkundig gebied naar voren worden gebracht. 
Op 2 februari 1993, vlak voor de te houden Toekomstconferentie van 9 maart 1993, deed minister Hirsch Ballin een nieuw voorstel. De Bovenwindse eilanden zouden een provincie van Nederland kunnen worden. De Bovenwindse eilanden zouden dan in een federatieverband met elkaar moeten samenwerken. Deze staatkundige variant vormde een onderdeel van meerdere geopperde mogelijkheden, die vermeld stonden in een brief, die de minister aan het kabinet had geschreven. ${ }^{134} \mathrm{Om}$ de situatie nog ingewikkelder te maken kwamen de senatoren Hoefnagels en Vis van D66 met het voorstel om elk Antilliaans eiland een Status Aparte te geven en er vervolgens een Kroongewest van te maken. Hoefnagels en Vis achtten dit voorstel geen nieuwe vorm van kolonialisme.

\footnotetext{
"Iedere constructie die niet neerkomt op volstrekte ona fhankelijkheid, zal altijd enige afhankelijkheid inhouden. Het zelfbeschikkingsrecht van de eilanden wordt door deze constructie niet aangetast. De Antilliaanse eilanden zijn minder afhankelijk van Nederland, dan Nederland van de EEG. Een bestuurslaag verdwijnt, daarom spreken wij ook van overdracht van die taken welke de bestuursmogelijkheid van de gewesten te boven gaat".
}

Op 13 en 14 januari 1992 werd op Curaçao een miniconferentie gehouden van de Eilandsraden, de Centrale Regering en de Nederlandse Regering. Deze conferentie was de eerste gelegenheid sinds de RTC van 1983, waarbij de problematiek van de staatkundige structuur van de Nederlandse Antillen aan de orde werd gesteld in een overleg waaraan alle betrokken partners deelnamen. Zowel de toekomstige staatkundige structuur als de problemen met betrekking tot deugdelijk bestuur werden besproken. De Eilandgebieden van de Nederlandse Antillen brachten hier wederom hun verschillende wensen over een staatkundige band binnen het Koninkrijk naar voren. Alle delegaties van de Eilandsraden hielden vast aan hun eerder ingenomen standpunten. Curaçao wenste een zelfstandige positie als Land binnen het Koninkrijk en wilde vanuit die positie samenwerken met de andere vier eilanden. Bonaire opteerde voor de positie van Land binnen het Koninkrijk en streefde naar een hecht samenwerkingsverband tussen de eilanden in de vorm van een (lichte) Unie. Sint Maarten wilde zowel de positie van Land binnen het Koninkrijk als de onafhankelijkheid. Sint Eustatius zag het liefst dat de Antillen van de Vijf blijven voortbestaan. Saba koos voor een status aparte provincie binnen het Koninkrijk'. 
binnen het Koninkrijk. ${ }^{135}$

Het is jammer dat de zes eilanden niet met gezamenlijke goed voorbereide alternatieven kwamen voor de Toekomstconferentie. Indien de eilanden zoals op het Topoverleg op Bonaire van februari 1993 uitgesproken, meer autonomie wensten dan gaat dat rechtstreeks in tegen de uitkomsten van het Rapport Dip en wreekt hier zich dat de rapporten van de laatste jaren nooit zijn besproken binnen de Staten. Ook op het Topoverleg kon geen eenduidig Antilliaans standpunt worden bereikt om tijdens de Toekomstconferentie voor te leggen. Augustin Diaz vatte het resultaat van het Topoverleg pregnant samen: "Er was geen standpunt en ook geen consensus". ${ }^{136}$

Oostindie ${ }^{137}$ meende dat de nieuwste Nederlandse voorstellen geen blijk gaven van neo-kolonialisme. Daar leek het natuurlijk wel op. Indien Nederland bepaalde eilanden een provincie status wilde verstrekken, dan was er geen sprake meer van decentralisatie maar meer van centralisatie. Het was duidelijk dat als de Nederlandse Antillen en Aruba binnen het Koninkrijk wilde blijven, Nederland daaraan stringente eisen stelde. Nederland was blijkbaar voornemens het falende bestuur op de Nederlandse Antillen krachtdadig ter hand te nemen. Dat zou kunnen gebeuren in de vorm zoals voorgesteld door Van Rijn en nader uitgewerkt door Hoefnagels en Vis. ${ }^{138}$

135 Eerste Kamer, Vaststelling van de begroting van de uitgaven van hoofdstuk IV (Kabinet voor Nederlands-Antilliaanse en Arubaanse Zaken) voor het jaar 1992, Memorie van Antwoord, ontvangen 24 januari 1992, vergaderjaar 1991-1992, 22 300 IV, nr. 176a; zie ook Tweede Kamer, vergaderjaar 1991-1992, 22300 IV nr. 12.

136 Beurs-en Nieuwsberichten, 11 februari 1993.

137 Oostindie (1992) meent dat de Schets rekolonisatie inhoudt en vraagt zich af of strenger toezicht op de overzeese gebiedsdelen wel past in de opzet van het huidige Statuut, waarin de landen autonoom hun eigen aangelegenheden behartigen. Bovendien is hij van mening dat impliciet de gevolgen van de 'Antillianisering' sinds de jaren ' 70 als teleurstellend worden gezien in de optiek van Hirsch Ballin. De kwaliteit van het landsbestuur en het eilandsbestuur zou te wensen over laten. Indien de invloed van Nederland in de West zal toenemen, zou dat kunnen leiden tot toenemende spanningen. Oostindie voorspelt een verdere desintegratie van de Nederlandse Antillen. De vorm waarin dat zal gebeuren zal, weet hij, nog een harde strijd opleveren. Het nieuwe Statuut zal de West meer integreren in het Koninkrijk, dan voorheen het geval was. Het artikel besluit met de essentie van de vraag waarom de Nederlandse Antillen en Aruba (nog) niet ona thankelijk willen worden: 'The Dutch presence will guarantee a relatively favourable, economic profile, territorial integrity and stable democracy' (p. 119).

Amigoe, 3 februari 1993, 'Hoefnagels en Vis (D '66): Elk Antilliaans eiland een Kroongewest van Nederland', 'Commentaar, Steen in de vijver', 'Wij hebben, een suikeroompje nodig, Saba niet afwijzend tegen voorstel SSS-eilanden provincie of Kroongewest'. In dezelfde Amigoe wordt melding gemaakt van de politieke boodschap van de nieuwe politieke partij van Augustin Diaz, de Partido Demokrat Outentiko (PDO of ook wel D.O '92). Deze partij wil de Antillen van de Vijf behouden. 
Nederland stelt jaarlijks $\mathbf{4 5}$ miljoen aan onwikkelingsgelden voor de Antillen en Aruba beschikbaar. Het getuigt van goed bestuur om vast te kunnen stellen of die gelden ook efficiënt en doelmatig worden gebruikt. Dit zou betekenen handhaving van het preventieve en repressieve Koninkrijkstoezicht. Indien de Antillen en Aruba er niet in zouden slagen hun begrotingstekorten zelf te financieren, blijft dit toezicht hard nodig. Dit impliceert een vergrote invloed van Nederland, maar dat kan passen in de veranderende verhoudingen en hoeft geen nieuwe kolonisatie in te houden, daar het gebruikelijk is dat verantwoording moet worden afgelegd van ontvangen bedragen aan sponsors. Met rekolonisatie wordt bedoeld verrijking van het moederland en daarvan is al lang geen sprake meer, tussen de Nederlandse Antillen, Aruba en Nederland.

Kort voordat de Toekomstconferentie van maart 1993 zou plaatsvinden gaf G.R. Booi, ${ }^{139}$ adviseur van de politieke partij Provincie Antilliaanse Nederlanders (PAN), een aantal knelpunten aan, die de kern van de zaak raken. Zijn artikel komt erop neer dat de Nederlandse Antillen steeds afhankelijker zijn geworden van Nederland, door het eigen tekortschietend bestuur, met name voor wat betreft de steeds groeiende begrotingstekorten. Zelfs voor begrotingshulp wordt nu al bij Nederland aangeklopt, terwijl de bedoeling van ontwikkelingshulp toch is dat de eilanden onafhankelijker worden.

\begin{abstract}
"Dat gedonder over structuur, de bestuurslagen, de trek van werklozen en criminelen naar Nederland, gesjoemel met Nederlandse paspoorten, het crimineel gedrag van Antillianen in Nederland, verzet in Nederland tegen Antillianen, allerlei verwijten aan het adres van Nederland, onwil/onkunde van de Antilliaanse politici, corruptie, projecten die niet lopen, het wordt Nederland teveel. Het is heel begrijpelijk dat het zo niet door kan gaan. Er moeten knopen worden doorgehakt, want Nederland heeft het zelf al moeilijk genoeg. Zouden de eilanden bij elkaar blijven dan maken zij een kans om ook als onafhankelijke natie het hoofd boven water te houden, maar dat willen de eilanden niet. Bovendien zou onafhankelijkheid betekenen dat de levensstandaard niet onaanzienlijk zou dalen en dat willen de Antillianen 6ók niet. De eilanden hebben steeds meer moeite zichzelf te besturen, maar willen ook niet dat Nederland ingrijpt. 'Nederland mag alleen betalen en voor de rest niet mopperen'."
\end{abstract}

Booi dacht aan twee mogelijkheden: onafhankelijkheid met een gouden handdruk of de status van provincie van Nederland. 
"Men is op de eilanden niet serieus bezig, omdat moedertje Nederland toch altijd weer klaar staat om te helpen als het fout gaat. Op deze wijze zullen de eilanden nooit zelfstandig worden. Indien de eilanden tot onafhankelijkheid gedwongen worden moeten zij samen werken en serieus te werk te gaan, anders verzuipen ze. Ze hebben dan ook geen moederland meer die ze van alles kunnen verwijten als het fout gaat, want dan hebben ze het helemaal zelf gedaan."

Voor wat betreft de status van provincie merkte Booi op dat de eilanden al door Den Haag bestuurd worden via de lokale regeringen. Waarom die onofficiële situatie dan niet reguleren, dat spaart geld en moeite. Bovendien kunnen Antillianen dan op hun eiland blijven als ze werkloos worden, omdat de sociale voorzieningen op de Antillen zullen verbeteren als de Antillen een provincie van Nederland worden. Nederland hoeft zich niet meer te ergeren aan 'acclimatiserende Antillianen' en de Antillianen wordt discriminatie bespaard.

\section{De Toekomstconferentie}

De Toekomstconferentie werd op 8, 9 en 10 maart 1993 gehouden op Curaçao. De toespraak die premier Lubbers ${ }^{140}$ hield bij de opening van de Toekomstconferentie gaf al aan hoe de stukken die hij later zou presenteren eruit zouden zien. Hij toonde zich in zijn rede zeer bekommerd over de werkloosheid, financiële tekorten, criminaliteit en normvervaging, zowel op de eilanden als in Nederland. De nieuwe zakelijkheid en de strenge aanpak die ook in Nederland worden toegepast (zonder veel succes overigens), doordrenkten zijn openingsrede, die niet uitblonk door inzicht in de Caraibische problematiek. De boodschap was duidelijk. Eerst orde in eigen huis scheppen, daarna kan er gesproken worden over samenwerking en hulp. Het was al vroeg duidelijk dat het geen soepel verlopende Conferentie zou worden. Nederland wilde het vooral hebben over de waarborgen voor een deugdelijk bestuur, waaronder de financiën. Voor de Nederlandse Antillen en de eilanden lag de nadruk op de staatkundige herstructurering. Tenslotte wilde Aruba vooral spreken over de bestendiging van de Status Aparte, zonder opgelegde samenwerkingsverbanden. 
Een vertrouwelijk stuk $^{141}$ van Nederlandse zijde uitgereikt op de Toekomstconferentie gaf aan wat Nederland bedoelde met 'deugdelijk bestuur'. Als eerste stelde het stuk dat de Koninkrijksband alleen kan worden voortgezet indien de beginselen van de democratische en sociale rechtsstaat in de Antillen en Aruba worden gehandhaafd. Deze beginselen zijn voorwaarden voor de voortzetting van de rechtsorde van het Statuut ten opzichte van Aruba en het Solidariteitsfonds. Duidelijk werd vervolgens gesteld dat de Antillen en Aruba hun eigen verantwoordelijkheid moeten dragen. Derhalve kon het betalen van schulden niet langer worden uitgesteld of monetair worden gefinancierd. De steeds weerkerende begrotingstekorten vormen een groot probleem voor de Nederlandse Antillen en Curaçao. De vraag is hoe het Land en het eilandgebied een dergelijke buitenproportionele schuld hebben kunnen opbouwen. Middelen tot correctie van ongewenste situaties mogen niet onbenut worden gelaten. Er zal meer aandacht moeten worden aan onderwijs, versterking van het bestuur, verbetering van de financiële huishouding en rechtshandhaving. De overheden moeten jegens hun burgers verantwoording aanvaarden voor deugdelijk bestuur: geen eigenmachtige regeerders, maar verantwoordelijke ambtsdragers. De nadruk wordt gelegd op de taken van de Statenleden. Een van de staatsrechtelijke grondregels is immers dat niemand een bevoegdheid kan uitoefenen zonder dat op die uitoefening controle bestaat. De patronage ${ }^{142}$ wordt gezien als een belemmerend effect op de deugdelijkheid van bestuur. Ook zouden consequenties moeten worden verbonden aan parlementaire controle op het bestuurshandelen, evenals de controle van de Algemene Rekenkamer en de Accountantsdiensten.

Verder diende openheid omtrent het besluitvormingsproces binnen de overheid te bestaan en moesten overheidsbeslissingen gemotiveerd zijn (algemene regels van bestuursrecht). ${ }^{143}$ Een onaf-

14 Hernieuwd vertrouwen in de toekomst, de Nederlandse inbreng in de Toekomstconferentie met de Nederlandse Antillen en Aruba. Merkwaardigerwijs was dit stuk niet bij de officiële stukken zoals die beschikbaar waren na de Toekomstconferentie, via de officiële kanalen.

De Beurs- en Nieuwsberichten van 29 september 1993 geeft als commentaar op de aangekondigde bezuinigingsmaatregelnen, dat de regering Oduber daarvoor ten onrechte de afgegeven garanties voor de hotelbouw aangeeft. De Beurs meent dat het gaat om de ongeveer 1500 politieke benoemingen, wasronder bevorderingen die gedaan zijn tijdens het bewind Oduber. Dat legt een zwasr beslag op de overheidsmiddelen, een bedrag van 100 miljoen florijnen op jaarbasis word genoemd. Er zou niet alleen sprake zijn van een financiēle crisis maar ook van een morele crisis, die onoplosbaar is.

Zie het voorstel van wet Algemene wet Bestuursrecht, Kluwer Studenteneditie nr. 16. Het is hoogst ongebruikelijk dat voorstellen in wetsedities worden opgenomen, maar gezien het belang van het wetsvoorstel is dat gebeurd; zie ook Bijloos (1990). 
hankelijke klachtenbehandeling en de mogelijkheid van toetsing in het kader van (administratieve) rechtspraak werden van wezenlijk belang geacht. Die ontbrekende regelingen in de Nederlandse Antillen en Aruba zouden zo spoedig mogelijk moeten worden ingevoerd. Gewezen werd op regelingen in de Nederlandse en Arubaanse wetgeving die deze onderwerpen gedeeltelijk regelen en op gewenste verbeteringen in het bestuur van de Nederlandse Antillen en Aruba:

- $\quad$ in de Grondwet zijn dat de artikelen 105, derde lid, 107, tweede lid, 108 en 110 van de Grondwet;

- $\quad$ in de Staatsregeling van Aruba zijn dat de artikelen V.13, V.17 en V.19;

- ingevolge art. 14 Statuut jo art. 43, tweede lid kunnen bij rijkswet regels worden gesteld betreffende de waarborgen van de rechten van de mens, de rechtszekerheid en de deugdelijkheid van bestuur;

- in dat kader zullen ook de overheidsfinanciën beter beheersbaar moeten worden en moet de gelijke behandeling van mannen en vrouwen worden geïmplementeerd;

- het toezicht op de deugdelijkheid van bestuur vanwege het Koninkrijk zal moeten worden versterkt en genuanceerd;

- er moet een deskundigencommissie worden ingesteld, die jaarlijks rapporteert over de naleving van de gemeenschappelijke beginselen van het Koninkrijk, in de drie landen. Deze commissie moet met name rapporteren over de naleving van de mensenrechten, de rechtszekerheid en de deugdelijkheid van bestuur, inclusief het financieel beheer. Dit college kan aanbevelingen doen tot verbetering, indien zulks gewenst is. Indien die aanbevelingen niet worden gevolgd, zou de Koninkrijksregering daarin moeten voorzien;

- $\quad$ indien de financiën niet beheersbaar zijn zou het Koninkrijk kunnen ingrijpen op grond van een overeenkomstige constructie van art. 12 Financiële-Verhoudingswet. ${ }^{144}$

Hier ligt uiteraard met name een taak voor de Statenleden. Een voorbeeld daarvan is de oproep van Rufus Mc William aan de Statenleden van de Nederlandse Antillen toch vooral aanwezig te zijn bij de

14 Financiële-Verhoudingswet 1984, wet van 22 december 1983, Stb. 650, tot vaststelling van de Financiële-Verhoudingswet 1984, zoals deze wet gewijzigd is bij de Wetten van 24 december 1986, Stb. 678 en 679, Kluwer Stduenteditie nr. 26A. Artikel 12 houdt in dat een gemeente die tekort schiet in het financieel beheer onder toezicht wordt geplaatst van de Kroon, totdat de financiēn zijn gesaneerd. Dat moet binnen een periode van drie jaar plaats vinden. 
Statenvergaderingen om hun taken als gekozen volksvertegenwoordigers uit te voeren en het verzuim te matigen. ${ }^{145}$

De bedoeling was dat er op de Conferentie gesproken zou worden over het schrappen van artikel 62 Statuut, waarin de komende onafhankelijkheid van Aruba staat vermeld. Dat toch zeer belangrijke punt kwam nauwelijks aan de orde. Premier Lubbers presenteerde als voorzitter van de Conferentie een 'synthese-document,' ${ }^{146}$ inhoudende: autonomie voor alle eilanden, samenwerking en gemeenschappelijkheid. Alle eilanden kregen de status aparte in de schoot geworpen, zonder enige argumentatie die deze belangrijke Nederlandse beleidswijziging verklaarde. Curaçao zou én bestuurslaag krijgen en de banden van de kleine eilanden zouden nader met Nederland worden geregeld.

De Gouverneur zou Koninkrijksorgaan moeten blijven, het hoger toezicht zou eveneens gehandhaafd worden, tevens was rechterlijke toetsing voorzien. Dit is een opvallend gegeven daar hoger toezicht over het algemeen niet passend wordt geacht naast een rechterlijke constitutionele toetsing.

Het Gemeenschappelijk Hof van Justitie (GHvJ) de ProcureurGeneraal (PG), de Centrale Bank en de Rekenkamer zouden Koninkrijksorganen moeten worden. De vraag rijst dan onmiddellijk of dat met de rechtspraak en de PG's in Nederland óók zou gebeuren. Een in te voeren rijkswet zou de deugdelijkheid van bestuur moeten waarborgen. De Antilliaanse en Arubaanse munt zou gekoppeld

Deze ongewenste situatie doet zich natuurlijk ook in Nederland voor, zie De Goede (1965) over het vereiste quorum in de Kamer om rechtsgeldig te mogen besluiten. artikel 67 Grondwet. Dit artikel is vergelijkbaar met artikel III.16 van de Staatsregeling van Aruba en artikel 62 van de Staatsregeling van de Nederlandse Antillen. Het verhaal beschrijft het 'onuitroeibaar kwaad' van het grote verzuim van Tweede Kamerleden bij vergaderingen. Ernstige bezwaren tegen het grote verzuim van Kamerleden werden al geuit in 1875, 1914 en 1961. In 1875 werd er op gewezen dat de Kamerleden maar 'een schadeloosstelling' kregen van $f$ 2000,-per jaar 'dat is natuurlijk geenszins een prikkel, om zich geheel aan de landszaken te wijden, te minder daar zij eerst verbeurd wordt, wanneer men gedurende een geheele zitting afwezig is gebleven. De leden die niet bemiddeld zijn, kunnen van een paar duizend gulden niet leven.' De lage lonen, zo meldt het Algemeen Handelsblad van 12 februari 1875 , leiden tot het grote verzuim en de werkstaking der leden. Als men niet wenst dat alleen vermogende lieden de natie vertegenwoordigen is het wenselijk dat de Grondwet op dat punt wordt aangepast. Gezien de veelvuldige afwezigheid der leden lijdt ook de wetgevende arbeid hieronder, omdat de leden nauwelijks tijd hebben de stukken te lezen, daar zij zich met andere zaken moeten bezighouden om in hun levensondethoud te voorzien.

Synthese-document, Een vernieuwde staatkundige- en rechtsorde (concept ter bespreking) nr. 080392. Amigoe, 9 maart 1993, 'Impasse in onderhandelingen na synthese-voorstel Lubbers, Autonomie maar met strakke Nederlandse hand.' 
moeten worden aan de Europese EMU.

Vanwege de structurele begrotingstekorten zou nader toezicht nodig zijn. Daartoe zou de taak van de Algemene Rekenkamer versterkt moeten worden en zouden de Antilliaanse en Arubaanse Rekenkamers op moeten gaan in de Nederlandse Rekenkamer.

Een Algemene Maatregel van Rijksbestuur (AMvRB) ex art. 43 tweede lid Statuut werd het Koninkrijk overzee in het vooruitzicht gesteld, vanwege de structurele begrotingstekorten, de ondeugdelijkheid van bestuur en het onaanvaardbare niveau van criminaliteit. ${ }^{147}$

Bestuurlijke geschillen tussen de eilanden onderling en de eilanden en het Koninkrijk zouden moeten worden voorgelegd aan de Raad van State. De schrapping van artikel 62 werd weer aan een regeling voor het Solidariteitsfonds gekoppeld.

De toelating van Europese Nederlanders in de Nederlandse Antillen en Aruba zou mogelijk moeten zijn, behoudens enkele beperkingen met betrekking tot een strafrechtelijke verleden en het ontbreken van middelen van bestaan. Dit zou nader moeten worden geregeld bij rijkswet. In Nederland worden Antilliaanse en Arubaanse Nederlanders zonder meer toegelaten, was het argument.

Kennelijk toch enigermate geschrokken van de voorspelbare reacties van de andere Koninkrijkpartners werkte de premier zijn voorstel bij. Op 10 maart kwam Lubbers met een tweede voorstel getiteld: 'Naar vernieuwde staatkundige verhoudingen in het Koninkrijk'. ${ }^{148}$ Deze versie was bedoeld voor overleg met de delegatieleiders. Uit het tweede voorstel viel af te leiden dat ook Sint Maarten de aparte status zou kunnen krijgen, mits er orde op zaken werd gesteld. Eventuele inter-eilandelijke geschillen zouden worden voorgelegd aan een in te stellen Kamer van het Gemeenschappelijk Hof van Justitie. De Raad van State zou niet meer worden ingeschakeld. De administratieve rechtsbescherming van de burger en de openbaarheid van bestuur zouden zo spoedig mogelijk daadwerkelijk geregeld moeten worden. Het kiesrecht en de verkiezingsprocedure zouden bij rijkswet moeten worden geregeld. Ingrijpen bij rijkswet in de regelingen over het kiesrecht lijkt een vergaande inmenging in landszaken.

Tevens werd geïmpliceerd dat voor de Nederlandse Antillen en Aruba bij eenvormige landsverordening het Nieuw Burgerlijk Wetboek en de nieuwe wetboeken van strafrecht en strafprocesrecht moet worden doen we dat zelf.

148 Conclusies Toekomstconferentie 8, 9 en 10 maart 1993 Curaçao (eerste versie ten behoeve van overieg met de delegatieleiders); 'Naar vernieuwde staatkundige verhoudingen in het Koninkrijk'. 
moeten worden ingevoerd. Deze exercitie zal belangrijke kosten met zich meebrengen, waarover niets werd gezegd. Gebeurt die invoering van de nieuwe wetgeving niet dan kan daarom bij rijkswet worden verzocht, ó6 door Nederland. Daar invoering van een AMvRB als een uiterst middel werd gezien, zou er een in theorie lichtere sanctie met een in de praktijk gelijke werking worden ingevoerd; de 'aanwijzing'. De aanwijzing zou worden vastgesteld indien de waarborgen neergelegd in artikel 43 Statuut niet worden nageleefd. De sanctie in de vorm van een aanwijzing zou een beroepsmogelijkheid kennen op een daartoe in te stellen Kamer bij de Raad van State. Bij rijkswet ingevolge artikel 3 Statuut zouden de uitgangspunten voor de toelating en uitzetting van Nederlanders moeten worden geregeld. Gelijkluidende uitzonderingscriteria voor vrij personenverkeer zullen worden bevorderd.

Helemaal aan het einde van de voorstellen van Lubbers kwam het onderwerp waarover de Conferentie had moeten gaan: het schrappen van artikel 62 Statuut. Op zo kort mogelijke termijn zou de bestaande positie van Aruba bij rijkswet moeten worden vastgesteld en 'verankerd' in het Statuut. De overname van de bestaande schuld van 2.5 miljard florijnen zou verdeeld moeten worden over de verschillende entiteiten die uit de Nederlandse Antillen zouden voortkomen.

Een tweede (afsluitende) Toekomstconferentie zou worden gehouden in juni 1993, maar stagneerde wegens grote onderlinge meningsverschillen tussen de Koninkrijkspartners. Er volgde overleg tussen Nederland en de eilanden. Voordat Nederland verder wilde praten over een nieuwe staatkundige structuur zullen de Nederlandse Antillen en Aruba Nederland echter duidelijk moeten maken dat zij ernst maken met financiële sanering van de overheidstekorten en invoering van deugdelijk bestuur.

Voordat Nederland verdere onderhandelingen wilde voeren kreeg Curaçao op 19 november 1993 de mogelijkheid een referendum ${ }^{149}$ te

Voor een uitgebreide verhandeling over het referendum zic: F.A. Bijvoet, Directe volkswetgeving, referendum en volksinitiatiefrecht (1925). Bijvoet is het niet eens met Kranenburg die een referendum gecombineerd met decentralisatic van wetgeving een goed middel acht om de niet functionerende parlementaire democratie te verbeteren. Bijvoet ziet niets in het referendum. "De doorsnee-Hollander staat tegenover de politiek onverschillig; wordt hij enoe gedwongen, zich er mede bezig te houden, hij laat zich meeslepen door parijen en demagogen. Men moet niet het volk iets willen opdringen, wat het niet past en waarom het bovendien niet vraagt. Zoodra een doorsnee-Hollander zich op het politieke terrein begeeft, laat zijn aangeboren kalmte, zekerheid, helderheid van oordeel en scherpzinnigheid hem veelal in den steek, om voor kortzichtigheid, bekrompenheid, fanatisme en egoisme plaats te maken". Bijvoet achtte het Zwitserse volk wel geschikt voor de politiek 
houden over de gewenste staatkundige toekomst. Het is interessant de voorbereiding en uitvoering van het Curaçaose referendum te vergelijken met het Arubaanse referendum uit $1977 .{ }^{150}$

\section{Samenvatting on conclusie}

Het lijkt of de staatkundige geschiedenis van de Nederlandse Antillen en Aruba een aaneenschakeling is geweest van gemiste kansen door Nederland. Wederzijds onbegrip tussen Nederland en de Nederlandse Antillen en tussen de Nederlandse Antillen en Aruba leidden tot frustraties en spanningen. In 1933 had de Arubaanse Raad van Politie bescheiden wensen. Men zou toen tevreden zijn geweest met de rechten en bevoegdheden van burgemeester en wethouders in Nederland.

Het uiteindelijke resultaat van de RTC van 1948 voor wat betreft de Arubaanse wensen werd vastgelegd in een motie en een resolutie. Op grond van de motie werd de Commissie Van Poelje ingesteld, die onderzoek zou doen naar de uitvoerbaarheid van de wensen van Aruba. De Commissie bracht in 1948 een rapport uit dat in de Nederlandse Antillen goed werd ontvangen. Het rapport stelde een Antilliaanse federatie voor met een federale raad waarin Curaçao en Aruba een gelijk aantal afgevaardigden zouden hebben. Dit rapport werd niet door de Nederlandse regering overgenomen, zoals bleek uit de aanbieding aan de Antilliaanse Staten van de ontwerp-Interimregeling in 1949. De spanningen liepen tussen 1948 en 1951 verder op, omdat Nederland de zetelverhouding in de Staten tussen Curaçao en Aruba, die bij de wijziging van de Staatsregeling in 1948 was gesteld op 8 voor Curaçao en 8 voor Aruba, wilde veranderen.

Er bestond niet alleen een conflict tussen Aruba en Curaçao, ook bestond er verschil van mening tussen de AVP en de PPA in Aruba over de invoering van de Interimregeling. De ERNA bood niet de gewenste zelfstandigheid voor Aruba. De Arubaanse frustraties bleven voortleven en werden nog eens vastgelegd in een motie van de

en het referendum, mar het Nederlandse volk duidelijk niet. Het referendum past niet in de historische en traditionele ontwikkeling van het Nederlandse volk, was zijn eindconclusie, pp. 202-203.

150

Het houden van een referendum op Curaçao werd geregeld bij Eilandsverondening van 21 september 1993, AB 1993, 19. Het referendum werd gehouden op 19 november 1993. Zie voor een uitgebreide toelichting op de procedure: het referendum over de staatkundige toekomst van Curaçao, Rapport van de Commissie Referendum Commissie Curaçao, Curaçao 23 augustus 1993. De leden van de Commssie waren: ir. G.A. Abbad; dr. N. Driss; prof. dr. P.C. Gilhuis; J.H. Jacobs, drs. L.C.G. Moenir Alam, dr. A.B. van Rijn, secretaris. 
Eilandsraad van 15 januari 1952 . Ook de besprekingen over het Statuut brachten Nederland niet tot andere gedachten. De rivaliteit tussen Curaçao en Aruba liet zijn sporen na in het Statuut. Zie bijvoorbeeld art. 44 lid 2 inzake de wijziging van de zetelverdeling in de Staten en wijziging van de Eilandenregeling.

Naar aanleiding van 30 mei 1969 ontstond in Nederland de opvatting dat de voormalige koloniën onafhankelijk moesten worden. Noodgedwongen moest de 'West' zich bezinnen op nieuwe Koninkrijksverhoudingen. Op 31 januari 1972 nam de Arubaanse Eilandsraad een motie aan, waarin uiteen werd gezet dat Aruba als deelstaat onderdeel wil uitmaken van een Antilliaanse federatie. De uitvoering hiervan zou mede afhangen van de vormgeving van de interne Antilliaanse structuur. Er was dus sprake van een duidelijke terugkeer naar het idee van algehele afscheiding zoals twintig jaar eerder bepleit. Het Arubaanse enthousiasme voor een Antilliaanse federatie bekoelde snel toen duidelijk werd dat de Curaçaose politieke partijen dachten aan een onafhankelijke federale republiek met een 'one man one vote' systeem. De Arubaanse angst om vervolgens ten eeuwige dage onderdeel te blijven uitmaken van zo'n onafhankelijke federale republiek speelde in de verdere ontwikkelingen een belangrijke rol.

Nadat Aruba de Status Aparte had verkregen bleef de AVP gekant tegen de realisering van de RTC-besluiten uit 1983, zij zag het behoud van de Status Aparte als doel. Ook de andere politieke partijen waren niet gelukkig met de koppeling van de aparte status aan de onafhankelijkheid.

Tijdens haar regeerperiode (1985-1989) weigerde de AVP daar echter met Nederland over te spreken, omdat de economische heropbouw alle aandacht opeiste. Met het aantreden van het kabinet-Oduber en het kabinet-Lubbers II in Nederland, beide in 1989, trad een verandering op in het denken over de Koninkrijksverhoudingen na 1996. Onder de nieuwe minister van Nederlands-Antilliaanse en Arubaanse zaken, Hirsch Ballin, voltrok zich een omwenteling in het Nederlands denken ten aanzien van de onafhankelijkbeid van Aruba en de Antillen.

Zowel Aruba als de Nederlandse Antillen konden als zij dat wensten in het Koninkrijksverband blijven. Interne en externe bedreigingen van de verworven welvaart en democratie vragen om een beveiliging, die slechts het Koninkrijk kan bieden. Indien echter de Nederlandse Antillen en Aruba voorlopig niet onafhankelijk zouden worden en binnen het Koninkrijk wilden blijven, dan kon dat alleen als aan een aantal Nederlandse eisen werd voldaan. Nederland achtte met name de naleving van de fundamentele mensenrechten van belang, evenals 
de instandhouding van de rechtsstaat en democratie. ${ }^{151}$ Daarbij speelde ook een rol dat de schuldenlast van de Nederlandse Antillen zou moeten worden gesaneerd. Ook de hotelgaranties van Aruba leggen een zware last op de beschikbare middelen.

Geconstateerd kan worden dat partijpolitieke conflicten op regeringsniveau, die op zich niets met de staatkundige structuur van doen hebben steeds weer tot polarisatie en stagnatie hebben geleid. Daardoor kunnen de Nederlandse Antillen en de eilanden geen eenduidige standpuntbepalingen aan Nederland voorleggen. Hierdoor wordt het ook voor Nederland heel moeilijk aan redelijke wensen te voldoen, mede omdat zo vaak van mening wordt veranderd. Daar waar Nederland sinds de jaren negentig duidelijk blijk geeft te willen voldoen aan de wensen van de Nederlandse Antillen en Aruba wordt dat bemoeilijkt door de interne Antilliaanse politieke conflicten en de slechte financiële en economische vooruitzichten van zowel de Nederlandse Antillen als Aruba. De politieke geschiedenis van de laatste vijftig jaar geeft in ieder geval geen reden voor overmatig optimisme om ervan uit te gaan dat in de toekomst betere en snellere resultaten te bereiken zouden zijn. A.G. Croes ${ }^{152}$ verwoordt dit pregnant door in verwondering het verleden te bezien waarbij hij het gevoel krijgt "weinig meer te kunnen doen dan proberen deze krachten te kanaliseren totdat - na vijftig jaar - hopelijk het proces zover is gevorderd dat een stabilisatie is ontstaan.

Een aantal knelpunten in de bestaande staatkundige Antilliaanse structuur vereiste de nodige aandacht. Het ongelijke gewicht van een stem tijdens de verkiezingen, op grond van het bestaande kiesstelsel zal altijd de suprematie van Curaçao inhouden. Dit versterkte weer het insularisme tussen de eilanden, waardoor het onmogelijk leek tot een voor elk eiland aanvaardbaar Antilliaans verband te komen. Tevens was dat de reden waarom een overkoepelend orgaan die de taken kan uitvoeren, die de kleine eilanden zelf niet kunnen realiseren, altijd zo problematisch was. Aan een reflectie op deze problematiek kon nauwelijks aandacht worden besteed, omdat partijpoltieke

Voor een goed inzicht over de inhoud van de rechtsstaat zie: De rechtsstaat herdacht, E.M. Middel en K.F. Schuiling (red), (1989), zie met name de bijdrage van J. van der Hoeven, pp. 1-9; M. Scheltema, pp. 11-25; D.J. Elzinga, pp. 43-61; M.C. Burkens, pp. 63-71; J.W.M. Engels, pp. 73-85. Voor de vraag of het zinvol is de term rechtsstaat te gebruiken als beschrijving van een reēel bestaande staat zie: J. Griffiths, pp. 87-103; H.B. Winter, pp. 223-236; A.J. Bok, pp. 267-281; D.J. Hutten, pp. 283-296. 
conflicten, zoals altijd de aandacht afleiden van deze onderwerpen. Bovendien zou een wijziging van het kiesrecht inhouden dat de invloed van de kleine eilanden in de Landsregering en Staten zou afnemen en dat was onbespreekbaar.

Een bepaalde vorm van centraal gezag zal moeten worden gehandhaafd, zolang de eilanden binnen het Koninkrijk blijven. De kleine eilanden kunnen landstaken niet zelfstandig uitvoeren. Daarom is decentralisatie van landsbevoegdheden naar de eilanden zonder nader onderzoek of de benodige bestuurskracht aanwezig is, zinloos. Dat een samenwerkingsverband van de Antillen van de Vijf moeilijk tot stand zal komen als Curaçao een meerderheidspositie opeist is wel duidelijk. Een federatief verband is thans gezien de heersende politieke opvattingen, niet goed meer mogelijk, ondermeer omdat Curaçao gewantrouwd wordt door de andere eilanden. Een confederatief samenwerkingsverband behoort wel tot de mogelijkheden. Een dergelijk samenwerkingsverband zou ook wel op enige politieke steun kunnen rekenen. Het nadeel van een dergelijk samenwerkingsverband is dat een aangesloten staat altijd kan uittreden. Dat betekent dat gezien de heersende politieke verhoudingen op de Antillen en Aruba, alleen een meer verplichtend confederatief verband zou werken, daar anders partijen elkaar over en weer zouden kunnen chanteren en bijvoorbeeld elkaar hulp en bijstand zouden kunnen onthouden als bepaalde beslissingen al dan niet in hun voordeel zouden zijn. Curaçao en Aruba hebben duidelijk gemaakt dat zij geen verantwoordelijkheid meer willen dragen voor de kleine eilanden, dat is ook de opzet van de Status Aparte.

Zolang de eilanden binnen het Koninkrijk blijven en ondersteuning van Nederland verwachten, zou het voor de hand liggen, dat $66 \mathrm{k}$ van de eilanden gevraagd kan worden dat zij enige solidariteit met elkaar aan de dag leggen.

Een dergelijk samenwerkingsverband zou tevens meer politieke steun kunnen verwerven, als de financiēn van de eilanden direct met Nederland zouden kunnen worden geregeld en de samenwerking meer verplichtend zou kunnen worden vastgelegd. Haalbaar lijkt tot op heden het model Dip III. Dit model hield in een vergaande decentralisatie met een gehele of gedeeltelijke eliminering van een bestuurslaag. De Staten zouden integreren met de Eilandsraden. Dit zou gecombineerd kunnen worden met het Uniemodel van Janus en de regeling van de ontwikkelingsgelden op Eilandsniveau met Nederland. Tevens dient te worden nagegaan welke Landsbevoegdheden wel naar de kleine eilanden kunnen worden gedecentraliseerd en welke niet. 
Ten slotte kan dan gezien het streven naar een Status Aparte van Curaçao, deze worden verleend, daar Curaçao voldoende bestuurskracht bezit om die taken gedecentraliseerd uit te kunnen voeren. De kleine eilanden hebben dat niet. De kleine eilanden zullen derhalve moeten kiezen voor een samenwerkingsverband met Nederland of indien dat politiek niet haalbaar is zouden zij overkoepelende taken in samenwerking met Curaçao of Aruba kunnen regelen. Ook zouden die taken door een overkoepelend instantie kunnen worden uitgevoerd.

Onder invloed van het Nederlandse aanbod op de Toekomstconferentie van maart 1993 is de discussie van een Antilliaans verband op het ogenblik na de achtergrond verschoven en overweegt elk eiland welke keuze moet worden gemaakt voor de toekomstige verhoudingen. Totdat voorlopig beslist zal zijn over de toekomstige status van Curaçao zullen de andere eilanden hun keuze opschorten. Welke beslissing door de afzonderlijke eilanden ook genomen zal worden, deze zullen de bestaande problematiek niet oplossen. In welke vorm dan ook zullen de eilanden met elkaar moeten samenwerken. En hoe die samenwerking eruit zal moeten zien, staat nog niemand voor ogen. Daar zowel de financiële situatie van de Nederlandse Antillen als van Aruba zorgwekkend is, wordt door vele burgers privé naar voren gebracht dat "Nederland maar orde op zaken moet komen stellen". De politici denken daar anders over. Het getuigt niet van een politiek doordachte strategie Nederland regelmatig te betichten van kolonialisme en van gebrek aan begrip voor de culturele verschillen van de Koninkrijksdelen overzee en vervolgens bij opkomend geldgebrek Nederland medeverantwoordelijk te stellen. Er bestaat dan ook duidelijk een discrepantie tussen een groot deel van de bevolking en de politici over de efficiëntie en deugdelijkheid van bestuur. Door al deze commotie zijn de bestuursperikelen van Sint Maarten op de achtergrond geraakt, maar ook daar is de bestuurlijke situatie niet rooskleurig.

In juni 1993 zou een vervolg-conferentie worden gehouden, waarop volgens Nederland concrete beslissingen moesten worden genomen. Vanwege de grote onderlinge meningsverschillen tussen de Koninkrijkspartners stagneerde de tweede Toekomstconferentie.

Op grond van de criteria voor evaluatie kan het volgende worden vastgesteld. De invloed van het Nederlands bestuur op het bestuur van de Nederlandse Antillen en Aruba lijkt weer toe te nemen. Dat behoeft echter met de gewijzigde opvattingen over dekolonisatie geen probleem te zijn. Het zelfbeschikkingsrecht kan ook worden uitgeoefend als gekozen wordt voor incorporatie van een eiland binnen Nederland. Het is dan vanzelfsprekend, gezien de staatkundige 
opbouw van Nederland dat er dan een aanmerkelijk grotere invloed van Nederland op het eilandsbestuur zal zijn te verwachten. Dat kan voordelen en nadelen hebben. Die voor- en nadelen zullen tegen elkaar moeten worden afgewogen.

Het Antilliaanse en Arubaanse staatsverband is een parlementaire democratie met feodale trekken. Dit komt tot uiting in het gebruik van overheidsmiddelen om politieke medestanders van de regeringspartijen te belonen voor hun steun. Deze handelwijze kan leiden tot excessen, zoals een topzwaar overheidsapparaat. Met de bestaande begrotingstekorten van zowel de Antilliaanse als de Arubaanse overheid levert het surplus van overheidsdienaren grote financiële problemen op.

De scheiding van machten binnen het Antilliaans en Arubaans staatsverband geeft aanleiding tot discussie. De wetgevende en uitvoerende macht worden geacht hun bevoegdheden op dualistische wijze uit te oefenen. Dat betekent dat beide machten hun eigen bevoegdheden hebben en niet dat er een toenemende vermenging van taken ontstaat. De Staten leveren soms het beeld op van een goedkeurend comité voor de regeringsinitiatieven. Tevens geeft de regering regelmatig blijk van groot ongenoegen als de rechter een uitspraak doet die de regering niet bevalt. Dit speelt met name een rol bij de rechterlijke uitspraken met betrekking tot politieke belediging. ${ }^{153}$ Daardoor komt

Van Aller en Van Rijn, Jurisprudentie bundel Publickrecht Nederlandse Antillen en Aruba 1951-1991, Universiteit van de Nederlandse Antillen en Universiteit van Aruba, editie 1991 en supplement 1992:

GEAC 25 mei 1964, Eilandgebied Curaçao vs NA, JPB p. 23 (Preventieve censuur, tv),

HvJ 6 februari 1968, Stanley Brown vs OvJ, JPB p. 27 (Opruiende luifelrede),

HvJ 19 april 1983, JPB p. 79 (Teatro Foro),

HvJ 11 oktober 1983, Ultimo Noticia vs Wout, JPB p. 100 (Belediging, openbare taak pers, publieke persoonlijkheid),

HvJ 18 oktober 1983, Mansur vs Favi, JPB p. 110 (Belediging, openbare laak pers), HvJ 10 september 1985, Ultimo Noticias vs Frank Martinus, JPB p, 166 (Belediging),

HvJ 15 oktober 1985, Kelly vs Oduber, JPB p. 185 (Belediging),

HvJ 19 november 1985, Denz vs Curaçaosche Drukkerij, JPB p. 200 (Belediging),

GHvJ 19 januari 1988, De Veer Chain Theatres vs Land Aruba, JPB p. 378 (Televisieuitzend-concessie),

GHvJ 4 oktober 1988, Godett vs Martina, JPB p. 436 (Belediging, parlementaire onschendbaarheid, Godett vs. Martina),

GHvJ 9 januari 1990, JPB p. 586 (Antilliaanse Televisiemij. vs O.C. Behilia),

GHvJ 21 augustus 1990, Arends vs Oduber, JPB p. 624 (Afluisteren en belediging), GHvJ 18 september 1990, Mansur vs Croes, JPB p. 659 (Belediging),

GHvJ 9 oktober 1990, Behilia vs Antilliaanse Televisiemaatschappij, JPB p. 685, GHvJ 17 april 1991, Kelly vs Croeze, JPB p. 732 (Belediging),

GEA/Aruba 11 februari 1991, Geluidsbandjes, JPB p. 893. 
de binding van de staat aan het recht in gevaar, omdat politieke opportuniteit op gespannen voet staat met de rechtszekerheid en het legaliteitsbeginsel. Het legaliteitsbeginsel eist immers dat alle beslissingen van de overheid moeten steunen op de wet en dat iedere burger voor de wet gelijk moet worden behandeld.

Het juiste evenwicht tussen ordening van de samenleving en individuele vrijheid staat onder druk. Dat is een belangrijke reden waarom Nederland behoorlijk bestuur eist van de Antilliaanse en Arubaanse overheid en ondermeer met spoed de invoering van een landsverordening administratieve rechtspraak, benevens een landsverordening Openbaarheid van bestuur tegemoet ziet. Ook de rechtspraak zou daarom Koninkrijksaangelegenheid moeten worden. De Koninkrijksregering (Nederland) kan dit eisen op grond van art. 43 lid 2 van het Statuut. Elk der landen draagt zorg voor de verwezenlijking van de fundamentele menselijke rechten en vrijheden, de rechtszekerheid en de deugdelijkheid van bestuur. Het waarborgen van de zojuist genoemde kenmerken van de rechtsstaat is aangelegenheid van het Koninkrijk.

Daarbij is het wel van belang in het oog te houden dat de normen en waarden van de rechtsstaat aan het verschuiven zijn. Historisch kan de ontwikkeling van de nachtwakersstaat naar de verzorgingsstaat worden onderscheiden. De Nederlandse Grondwet en de Arubaanse Staatsregeling geven in hun grondrechten catalogi de gedachte van de verzorgingsstaat weer. Door de economische stagnatie en de vluchtelingenstromen in Europa is de verzorgingsstaat al een aantal jaren aan erosie onderhevig. Er zijn duidelijke empirische tendensen te onderkennen die wijzen op een ontwikkeling naar een liberale rechtsstaat, gebaseerd op het marktmechanisme, waarbij verworven rechten van burgers onder druk komen te staan en de verzorgingsstaat wordt afgebouwd. De nadruk die Nederland legt op het handhaven van de rechtsstaat in de Nederlandse Antillen en Aruba is mede beïnvloed door die ontwikkeling. ${ }^{154}$

De burgers van de Nederlandse Antillen en Aruba hebben invloed in het bestuur van hun Land, de oppositie speelt echter niet de rol die noodzakelijk is in een parlementaire democratie, omdat regeringspartijen de neiging hebben de oppositie niet serieus te nemen. Politici rechtsstaat herdacht (1989). 
steken veel tijd in het voeren van korte gedingen over wederzijds beledigende uitlatingen. De grondrechten worden in het algemeen nageleefd, maar behoeven op punten verbetering op het gebied van de toelating en uitzetting van vreemdelingen. ${ }^{155}$

Klasseverschillen en kleurverschillen worden thans (1994) niet openlijk en hardop naar voren gebracht als onderscheidende factor binnen de Antilliaanse en Arubaanse samenleving, maar zij spelen wel een belangrijke rol en zullen zeker weer scherpe scheidingslijnen te zien geven, als de economische situatie verder verslechtert, de werkloosheid toeneemt, de ontevredenheid van de burgers stijgt en de Nederlandse invloed toeneemt. ${ }^{156}$ Alle Nederlandse burgers die tevens landskinderen zijn hebben gelijke rechten. Vanwege patronage hebben sommige landskinderen meer privileges dan andere landskinderen. Sommige bevolkingsgroepen hebben ook nu nog een ruimere toegang tot privileges dan andere groepen binnen de samenleving.

Zie met name de uitspraken over toelating en uitzetting in Van Aller/Van Rijn (1991) GEA/Aruba 30 juni 1993, vonnis 910, AR: $120 / 93$ KG. Parra vs het Land Aruba. Parra werd uitgezet terwijl zijn verzoek om toelating in behandeling was bij de Dienst Openbare Orde en Veiligheid (DOOV). Het KG ter voorkoming van zijn uitzetting/verwijdering mocht hij niet bijwonen. De zaak werd uitgesteld tot 21 juni 1993 en door tussenkomst van ondermeer de gemachtigde van het Land kon hij terugkeren naar Aruba. De rechter oordeelde dat Parra in Aruba mocht blijven totdat beslist was over zijn werk- en verblijfsvergunning. Tot zolang mocht hij ook werkzaam blijven als loodgieter. Hij was ten onrechte uitgezet.

Beurs-en Nieuwsberichten, 30 september 1993: "Jacques Veeris in blad, Willemstad en Den Haag niet adekwaat gereageerd op 30 mei"; in de rubriek FORSAvisie (landelijk steunpunt voor Antilliaanse en Arubaanse organisaties in Nederland. Twintig jaar na de volksopstand van 1969 op Curaçao wordt het hele koninkrijk weer opgeschud door onrust en scherp protest. In de voorhoede van de kansarme Curaçaö̈naars lopen nu de zonen èn dochter (!) van de opstandelingen van toen. Ze trekken een spoor van vaak harde criminaliteit van Willemstad tot Amsterdam. Hun eis luidt nog steeds: 'Pan i rēspect'..... hun boodschap: Niemand bekommert zich echt om onze toekomst. Men is er na 1969 niet in geslaagd echte ontwikkelingskansen te scheppen op sociaal economisch gebied voor de bevolkingsgroep díe reeds eeuwen in een achtergestelde positie verkeer. Veeris bepleit compassie en zelfredzaamheid. 



\section{Een les uit het verleden: een (con)federale structuur}

De criteria voor evaluatie zoals vermeld in hoofdstuk I waren als volgt geformuleerd:

- de invloed van het Nederlands bestuur op het bestuur van de kolonie;

- de opbouw van de staatsorganen en de binding van de staat aan het recht;

- de verdeling van de overheidsmacht;

- het zoeken van het juiste evenwicht tussen ordening van de samenleving en individuele vrijheid;

- de verhouding burger-bestuur, waarbij inspraak van de burgers in het bestuur, het naleven van de mensenrechten en de rechtsbescherming van de burger tegen de overheid van belang zijn;

- tevens werden klasseverschillen, kleurverschillen en de invloed van de slavernij bij de toekenning van politieke rechten, plichten en privileges in elke periode onderzocht.

Sinds 1954 zijn de Antillen en Aruba een parlementaire democratie. Op de RTC van 1983 werd het zelfbeschikkingsrecht van alle eilanden erkend. Vanaf 1986 heeft ook Aruba de status van Land binnen het Koninkrijk. Het verkrijgen van de Arubaanse Status Aparte is de eerste 'overwinning' van een Koninkrijksdeel op Nederland, ooit behaald. De prijs daarvoor was hoog: ongewenste onafhankelijkheid op termijn. In de Schets van Minister Hirsch Ballin van 1990 werd de wens de Nederlandse Antillen in én staatsverband bijeen te houden losgelaten. De innerlijke tegenstrijdigheid in het Nederlandse beleid is ontstaan toen Nederland wel het zelfbeschikkingsrecht van de afzonderlijke eilanden erkende, maar de juridische consequenties daarvan slechts in beperkte mate wilde aanvaarden. Het zelfbeschikkingsrecht houdt immers niet alleen onafhankelijkheid in, maar ook alternatieven zoals integratie, associatie of enige andere vrijelijk bepaalde politieke status, zoals bijvoorbeeld een Status Aparte. Dat zelfbeschikkingsrecht moet door de Koninkrijkspartners worden 
erkend met inachtneming van de belangen van de andere eilanden en landen. Het zelfbeschikkingsrecht is geen absoluut recht en moet op een redelijke manier met inachtneming van de gerechtvaardigde belangen van anderen te goeder trouw ten uitvoer worden gelegd, meende Janus. ${ }^{1} \mathrm{Hij}$ is tevens van mening dat een autonome status binnen het Koninkrijk geweigerd kan worder aan het eiland dat naar de maatstaven van het Statuut de taken en bevoegdheden van een Land niet kan realiseren.

De slechte financiële situatie van de Nederlandse Antillen en Aruba leidde ondermeer tot de Nederlandse eisen van deugdelijk bestuur aan de Antilliaanse en Arubaanse landsbesturen, indien de Landen deel willen blijven uitmaken van het Koninkrijk. Het parlement wordt geacht de mening van het volk weer geven. De uitslag van het Curaçaose referendum, dat werd gehouden op 19 november 1993, gaf aan dat de mening van de politici sterk afweek van de mening van het volk over de gewenste staatkdundige structuur. Dat was niet eerder zo duidelijk en empirisch toetsbaar gebleken.

De staatsvorming van de Nederlandse Antillen en Aruba is nog steeds in ontwikkeling, zoals aanpassing van waarden en normen, onder invloed van de politieke en sociale omstandigheden in de staatsvorming altijd een rol speelden. De invloed van het Nederlands bestuur op het bestuur van de Nederlandse Antillen en Aruba lijkt weer toe te nemen. Dat behoeft echter met de gewijzigde opvattingen over dekolonisatie geen probleem te zijn. Het zelfbeschikkingsrecht kan ook worden uitgeoefend als gekozen wordt voor incorporatie van een eiland binnen het Nederlandse staatsverband. Het is dan vanzelfsprekend, gezien de staatkundige opbouw van Nederland dat er een aanmerkelijk grotere invloed van Nederland op het eilandsbestuur en landsbestuur zal zijn te verwachten. Dat kan voordelen en nadelen hebben. Die voor- en nadelen zullen tegen elkaar moeten worden afgewogen. Problemen kunnen in een vroeg stadium worden herkend en zoveel mogelijk worden vermeden door minimalisatie van de naijlende effecten. Duidelijk is dat de criteria in de gewijzigde opvattingen over dekolonisatie in hun tegendeel kunnen omslaan, zonder dat deze omslag echter als onaanvaardbaar zou moeten worden aangemerkt.

Janus, Het Statuut voor het Koninkrijk der Nederlanden: terugblik en perspectief, preadvies voor de staatsrechtconferentie (1993) p. 23. 
Het evenwicht tussen ordening van de samenleving en individuele vrijheid staat onder druk. Dat is een belangrijke reden waarom Nederland behoorlijk bestuur eist van de Antilliaanse en Arubaanse overheid en ondermeer met spoed de invoering van een landsverordening administratieve rechtspraak, benevens een landsverordening Openbaarheid van bestuur tegemoet ziet. Ook de rechtspraak zou daarom Koninkrijksaangelegenheid moeten worden.

De Koninkrijksregering (Nederland) kan dit eisen op grond van art. 43 lid 2 van het Statuut. Elk der landen draagt zorg voor de verwezenlijking van de fundamentele menselijke rechten en vrijheden, de rechtszekerheid en de deugdelijkheid van bestuur. Het waarborgen van de zojuist genoemde kenmerken van de rechtsstaat is aangelegenheid van het Koninkrijk.

De burgers van de Nederlandse Antillen en Aruba hebben invloed in het bestuur van hun Land, de oppositie speelt echter niet de rol die noodzakelijk is in een parlementaire democratie, omdat regeringspartijen de neiging hebben de oppositie niet serieus te nemen. Politici steken veel tijd in het voeren van korte gedingen over wederzijds beledigende uitlatingen. De grondrechten worden in het algemeen nageleefd, maar zouden kunnen worden verbeterd op het gebied van de toelating en uitzetting van vreemdelingen. ${ }^{2}$

\section{Een prognose}

Op grond van de bestaande machtsverhoudingen binnen het Koninkrijk, de evaluatie-criteria en de toetsing daarvan aan de probleemstelling van hoofdstuk I kan worden vastgesteld dat de voormalige kolonie, Nederland in het verleden pecuniaire problemen opleverde. Ook in de huidige tijd is de economische ontwikkeling van de Nederlandse Antillen en Aruba een voorwerp van grote zorg voor de Koninkrijksregering. Daarbij moet worden opgemerkt dat ook al zijn de Nederlandse Antillen en Aruba politiek vrij om hun eigen weg te gaan, de economische afhankelijkheid nieuwe 'koloniale' verhoudingen kan scheppen.

2 Zie met name de uitspraken over toelating en uitzetting in Van Aller/Van Rijn (1991) GEA/Aruba 30 juni 1993, vonnis 910, AR: 120/93 KG. Parra vs het Land Aruba. Parta werd uitgezet terwijl zijn verzoek om toelating in behandeling was bij de Dienst Openbare Orde en Veiligheid (DOOV). Het KG ter voorkoming van zijn uitzetting/verwijdering mocht hij niet bijwonen. De zaak werd uitgesteld tol 21 juni 1993 en door tussenkomst van ondermeer de gemachtigde van het Land kon hij terugkeren naar Aruba. De rechter oordeelde dat Parra in Aruba moche blijven totdat beslist was over zijn werk- en verblijfsvergunning. Tot zolang mocht hij ook werkzaam blijven als loodgieter. Hij was ten onrechte uitgezet. 
Volgens Caraibische maatstaven bevinden de Nederlandse Antillen en Aruba zich in een gunstige situatie. Hun economie is wel steeds in hoge mate afhankelijk geweest van Nederlandse ontwikkelingshulp, bood daarnaast weinig diversificatie en was onevenwichtig van aard. Uit alle onderzoekingen van de laatste 15 jaren bleek duidelijk dat de meerderheid van de bevolking van de Nederlandse Antillen en Aruba geen onafhankelijkheid wensten. Opvallend was dat politici regelmatig een tegengestelde opvatting daarover koesterden, met name in de jaren zeventig en tachtig. Sinds het eind van de jaren tachtig accepteert Nederland dat de Nederlandse Antillen en Aruba voorlopig niet onafhankelijk willen worden. Tevens ziet Nederland geen overwegende bezwaren meer om te komen tot een verdere opsplitsing van de Nederlandse Antillen. Nu onafhankelijkheid voor geruime tijd van de baan lijkt te zijn en de Koninkrijkspartners plechtig hebben verklaard dat zij gezamenlijk verder willen, heeft een gemengde commissie reeds een Proeve van een vernieuwd Statuut vervaardigd. Door deze ontwikkelingen en het opstellen van een nieuwe Koninkrijksconstitutie zal de oriëntatie van de Nederlandse Antillen en Aruba op Nederland toenemen.

De redenen waarom Nederland van mening veranderde over de gewenste onafhankelijkheid van de Nederlandse Antillen en Aruba zijn nogal uiteenlopend van aard. De ongeregeldheden van 1969 speelden in de laatste 10 jaren geen rol van betekenis meer in de Nederlandse wens tot onafhankelijkheid voor de Caraibische Koninkrijksdelen. Alhoewel Antilliaanse politici de voortzetting van de Nederlandse anwezigheid van cruciaal belang achtten, ervoeren Nederlandse politici de laatste overblijfselen van een voormalige koloniaal rijk wellicht als een lastig, maar niet als een onoverkomelijk probleem. Een jaarlijks bedrag van ongeveer 300 miljoen gulden aan ontwikkelingshulp is essentieel, bezien vanuit Antilliaans en Arubaans standpunt. Deze financiële verplichtingen vormen geen onoverkomelijke post op de Nederlandse begroting, maar leidden wel tot groeiende Nederlandse parlementaire kritiek, irritatie en de wens om meer van deze middelen te kunnen inzetten voor Nederland zelf, temeer daar Nederland reeds enkele jaren kampt met een economische recessie en de bestedingsbeperking harde offers vraagt van de Nederlandse burgers. De legitimatie van de gevoteerde gelden vraagt veel meer parlementaire aandacht en daarmede ook de tekortkomingen in het overheidsbeleid van de Nederlandse Antillen en Aruba.

Vele ongeschoolde Antillianen en Arubanen weken uit naar Nederland en ondervonden grote aanpassingsproblemen. Bovendien bleken de arbeidsmogelijkheden voor deze groep gering, waardoor deze jongeren vaak in het criminele circuit terecht kwamen. Dit leidde 
in Nederland tot een toenemende angst voor massa-emigratie, zoals zich eerder voordeed vanuit Suriname. De mogelijkheid voor emigratie van Antillianen en Arubanen naar Nederland is voor hen essentieel gezien de beperkingen van de lokale arbeidsmarkt. Een toenemende emigratie van Antillianen en Arubanen naar Nederland wordt door de Nederlandse politiek niet met vreugde geconstateerd, maar het levert politiek nog geen overwegende bezwaren op.

Ten slotte speelde het politieke proces een belangrijke rol. Nederlandse politieke partijen waren lange tijd de mening toegedaan dat dekolonisering alleen maar eervol kon worden afgesloten door onafhankelijkheid van de voormalige koloniën. Het was duidelijk dat verandering in de politieke beleidsopvattingen een moeizaam proces was. In 1990 deelde de Koninkrijksregering mee dat het punt van de onafhankelijkheid eindelijk van de agenda van het Koninkrijksoverleg zou worden verwijderd. Van groter belang was dat Aruba niet langer zou worden gedwongen om in 1996 onafhankelijk te worden. Dit was een belangrijke en onverwachte verandering in de Nederlandse politieke opvattingen. Na moeizame onderhandelingen stemde Nederland slechts met de grootste tegenzin in met de Arubaanse Status Aparte. Nederland stelde echter als voorwaarde voor het ingaan van de Status Aparte per 1 januari 1986, dat Aruba als prijs voor de opsplitsing van het Antilliaanse verband, in 1996 onafhankelijk moest worden. De Arubanen konden niets anders doen dan hiermee accoord gaan, zij het zeer tegen hun zin in. Deze 'package deal' werd neergelegd in art. 62 Statuut. Vanaf het begin stuitte deze regeling op grote weerstand binnen de Arubaanse samenleving. Arubaanse politici verzetten zich tegen het tweede deel van art. 62. In tegenstelling tot de staatsrechtelijke positie van de Nederlandse Antillen was de staatsrechtelijke opstelling van Aruba op dit punt twijfelachtig. Aruba had immers 'vrijwillig' toegestemd in het verkrijgen van de Status Aparte, met als voorwaarde onafhankelijkheid op termijn. Daarom vormde de Nederlandse beleidswijziging met betrekking tot een definitief en in eerste instantie ongeclausuleerd uitstel van de Arubaanse onafhankelijkheid ook een duidelijke aanwijzing voor een ingrijpende verandering in de Nederlandse politieke opvattingen ten opzichte van de staatkundige Caraïbische Koninkrijksdelen.

De Antilliaanse en Arubaanse bevolking, evenals uiteindelijk de politiek hebben zich altijd met kracht tegen onafhankelijkheid verzet, zij profiteerden daarbij in grote mate van de geringe omvang van hun grondgebied. Dat maakte het gemakkelijker voor Nederland om af te zien van het opleggen van een ongewenste onafhankelijkheid aan 
de Nederlandse Antillen en Aruba. De Nederlandse beleidswijziging werd verder in de hand gewerkt door de trieste post-koloniale geschiedenis van Suriname. Voorstanders van onafhankelijkheid vroegen zich af of onafhankelijkheid inderdaad de eilanden in staat zou stellen een evenwichtige en stabiele economische en politieke koers te varen en bij zou dragen tot zelfstandigheid en zelfredzaamheid van de eilanden. Ironisch genoeg was de Surinaamse mislukking een onverwachte zegen voor de Nederlandse Antillen en Aruba in hun strijd tegen de Nederlandse wens om onafhankelijk te worden.

Ten slotte speelden druk van buitenaf een rol. Met name de Verenigde Staten en Venezuela wensten geen politieke en economische instabiliteit in het Caraibisch gebied en oefenden druk uit op Nederland de status quo te handhaven. Een machtsvacuüm zou tot zeer ongewenste gevolgen kunnen leiden, zeker gezien de toenemende invloed van de drugskartels in Latijns-Amerika, het witwassen van drugsgelden en de handel in verdovende middelen.

$\mathrm{Nu}$ Nederland heeft toegegeven aan de wens van de Nederlandse Antillen en Aruba, voor wat betreft de onafhankelijkheid en de wellicht te verwachten opdeling van de Nederlandse Antillen, eiste Nederland meer invloed in Antilliaanse en Arubaanse zaken. In de Schets van minister Hirsch Ballin uit 1990 werd het definitieve uitstel van de onafhankelijkheid gekoppeld aan strenge voorwaarden betreffende deugdelijk bestuur en sanering van de overheidsfinanciën. Deze strenge aanpak geeft aan dat Nederland bereid is belangrijke concessies te doen aan de Nederlandse Antillen en Aruba, maar dat zal gepaard gaan met uitgebreide maatregelen. Dit bleek ook duidelijk uit de voorstellen van Minister-President Lubbers tijdens de Toekomstconferentie in maart 1993 en de daarop volgende bilaterale gesprekken.

De Nederlandse eis van behoorlijk bestuur leidde tot geschokte reacties van de Nederlandse Antillen en Aruba. En zoals zo vaak in het verleden werd gerefereerd aan driehonderd jaren koloniale onderdrukking. Nederlandse parlementariërs waren daar in het verleden gevoelig voor. Thans is de Nederlandse volksvertegenwoordiging niet langer bereid, die beschuldiging te aanvaarden voor jarenlang tekortschietend overheidsbeleid in de Nederlandse Antillen en Aruba. Hirsch Ballin verwoordde dat op Hegeliaanse wijze door op een bijeenkomst ter herdenking van de slavernij te stellen dat Nederland geenszins neo-koloniaal handelt. Integendeel binnen het Koninkrijk staat: 
'betrouwbaar, overzichtelijk, consistent en democratisch bestuur centraal. En dat is de antithese van de slavernij, waarin de willekeur centraal stond. Wij zoeken juist waarborgen tegen willekeur. Stond in het kolonialisme de ongelijkheid centraal, nu gaan wij uit van de principiële gelijkwaardigheid van de partners. In het Koninkrijksoverleg zullen de culturele verschillen gezamenlijk overstegen dienen te worden. Het Koninkrijksgevoel heeft alles te maken met een gevoel van consensus, omdat wij samen dat Koninkrijk nieuwe stijl gaan vormen. $^{.3}$

Dat Koninkrijksgevoel kan niet eenzijdig worden opgelegd door Nederland. Gerechtvaardigde wensen van de Nederlandse Antillen en Aruba zullen binnen dat Koninkrijksgevoel moeten verwerkelijkt kunnen worden. De gewenste consensus kan niet door Nederland worden gedicteerd. Er zal sprake moeten zijn van een 'vrijwillige' consensus. Temeer daar Nederland altijd onverschillig leek te staan ten opzichte van de staatkundige wensen van de Nederlandse Antillen en Aruba. Het alleen maar op verzoek de gaten in de begroting vullen is geen teken van daadwerkelijke betrokkenheid. Uit de Nederlandse reacties op de wensen uit de (voormalige) kolonie bleek niet dat die wensen serieus werden genomen. Er werd nimmer een brede maatschappelijke discussie over gevoerd. Een van de belangrijkste oorzaken daarvoor was ongetwijfeld het algemene gebrek aan politieke en juridische belangstelling en het gebrek aan deskundigheid over de Nederlandse Antillen en Aruba. De laatste jaren is de politieke en juridische belangstelling voor de Nederlandse Antillen en Aruba wat toegenomen, alhoewel het gemiddeld Nederlandse staatkundige handboek er weinig belangstelling voor aan de dag legt.

Het toekomstige Nederlandse beleid zal vrijwel zeker leiden tot een vermindering van de Antilliaanse en Arubaanse autonomie, indien de Nederlandse Antillen en Aruba niet met aanvaardbare tegenargumenten komen. Het preadvies van Van Rijn over de nieuwe staatkundige structuur van het Koninkrijk is daar een voorbeeld van, evenals de goede voorbereiding van het referendum over de toekomstige staatkundige structuur van Curaçao. Nederland wenst onder geen beding te spreken over een nieuwe Koninkrijksstructuur vóórdat de Antilliaanse en Arubaanse overheid de door Nederland gewenste geachte maatregelen heeft ingevoerd en gewaarborgd. Een nieuwe Koninkrijksstructuur zal dan welhaast moeten leiden tot een tamelijk 'autoritair' Statuut. Dat betekent dat de wensen van de Nederlandse

Staatscourant, 15 juli 1993, 132, p. 2. Amigoe, 12 juni 1993: Hirsch Ballin: geen plaats voor schaamte en rancune, "Koninkrijksgevoel is antithese van slavemij in zoeken naar waarborgen tegen willekeur". 
Antillen en Aruba alleen maar een rol zullen spelen voorzover die niet te maken hebben met de tekortschietende overheidsfinanciēn en de waarborging van behoorlijk bestuur.

De laatste drie jaren heeft het Nederlandse parlement gezocht naar middelen om de autonomie en zelfredzaamheid van de Nederlandse Antillen en Aruba te versterken. De noodzaak voor modernisering en professionalisering van het falende overheidsbestuur werd door Nederland steeds belangrijker geacht. Het recente en vroegere Antilliaanse en Arubaanse overheidsoptreden heeft in Nederland tot toenemende irritatie geleid. Verbetering van de overheidssector zou moeten plaatsvinden door structurele en langdurige Nederlandse professionele ondersteuning. Impliciet houden de Nederlandse voorstellen een vernietigend oordeel in over de 'Antillianisering'. Het vervangen van Nederlandse deskundigen door Antillianen op alle niveaus van de overheidssector en de private sector was een belangrijk uitgangspunt van het Antilliaans overheidsbeleid sinds de jaren 70 . Kennelijk wenst Nederland thans deze ontwikkelingen (gedeeltelijk) terug te draaien.

Het is verleidelijk om te constateren dat de Nederlandse voorstellen 'rekolonisatie' betekenen. De aantrekkingskracht van de voorstellen is dat op lange termijn professionalisering van het overheidsapparaat zal resulteren in een toenemende zelfstandigheid en een grotere zelfredzaamheid van de Nederlandse Antillen en Aruba. Dit vooruitzicht is inderdaad slechts op (zeer) lange termijn te realiseren. Ondertussen zou toenemende Nederlandse invloed kunnen leiden tot een ongewenste druk op de Antilliaanse en Arubaanse overheid. Bezien vanuit het Nederlandse standpunt is het te rechtvaardigen dat de Caraỉbische partners betalen om onderdeel te kunnen blijven vormen van het Koninkrijk der Nederlanden en daarvoor een deel van hun bestaande autonomie inleveren. Toenemende Nederlandse bemoeienis zal ook leiden tot meer verplichte ondersteuning bij de rechtspraak en de rechtsbedeling.

Nederland heeft bij herhaling verklaard ontevreden te zijn over de praktische uitwerking van de Antilliaanse politieke opvattingen en de gevolgen daarvan op de uitoefening de Antilliaanse autonomie. Deze stijgende ontevredenheid blijkt uit de voorgestelde maatregelen met betrekking tot de Antilliaanse en Arubaanse autonomie, op de Toekomstconferentie in maart 1993 en op de bijeenkomsten tussen Nederland en de eilanden in juni 1993. Nederland legt immers een direct verband tussen deugdelijk bestuur en een nieuwe Koninkrijksstructuur. Ook werd door Nederland bij herhaling verwezen naar de politieke cultuur van de eilanden, de kleinschaligheid en de 
daardoor beperkte politieke horizon van de politici. Deze verwijzingen kunnen ook worden gezien als een suggestie dat ingrijpen van buitenaf (Nederland) noodzakelijk is om verbetering aan te brengen in het tekortschietende overheidsoptreden. Verder Nederlands ingrijpen wordt vergemakkelijkt omdat de onbeheersbare bestuurssituatie in Sint Maarten een maatregel van toezicht uiteindelijk noodzakelijk maakte. Voordat Nederland tot deze maatregel overging hadden zowel het eilandsbestuur van Sint Maarten alsmede het landsbestuur ruim de tijd gehad orde op zaken te stellen.

De laatste jaren is bij het toekennen van ontwikkelingsgelden de praktijk ontstaan dat de donorlanden de eis stellen van 'deugdelijk bestuur' aan de ontvangende landen. Als hieraan niet voldaan kan worden wordt geen ontwikkelingshulp verstrekt. Het is dus geen overspannen of onredelijke Nederlandse eis die aan de Antilliaanse en Arubaanse overheid wordt gesteld. Bovendien is het ook een standaard voorwaarde van het IMF om in nood verkerende overheden bij te staan met zachte leningen. ${ }^{4}$

De brandende vraag is ten slotte welke invloed deze omstandigheden zullen hebben op de staatsrechtelijke toekomst van de Nederlandse Antillen en Aruba. Een wetenschappelijk verantwoorde vooronderstelling wijst in de volgende richting:

- onafhankelijkheid is van de baan;

- de voormalige Nederlandse Antillen zullen zoeken naar een aanvaardbaar samenwerkingsverband en zullen wellicht toch gedeeltelijk desintegreren; over de gewenste bestuursvormen zal nog een harde strijd worden gevoerd, die een tiental jaren in beslag zal nemen;

- $\quad$ artikel 62 Statuut wordt geschrapt;

- de Nederlandse aanwezigheid zal worden versterkt.

Ondanks het feit dat Nederland van officiële zijde de nadruk zal leggen op de Antilliaanse en Arubaanse autonomie zal toch de

- Document of Intemational Monetary Fund, SM/86/257, Kingdom of the NetherlandsAruba, Staff Report for the 1986 Article Four Consultation, October 17, 1986. Zie eveneens Staff reports IMF, SM/85/21 (1/22/85 en $2 / 13 / 85)$ en SM/85/24 (1/25/85); 15 november, 1988, SM/88/250/; 30 november 1988, SM/88/260, met name pp. 21-23; SM/90/234, 27 december, 1990, pp. 5-9, 14-22. Drs. D.H. Baarh, directeur van het Departement voor Buitenlandse Betrekkingen van Aruba, deelde mij dit mee. Hij wordt daar regelmatig mee geconfronteerd tijdens internationale bijeenkomsten in het kader van de Verenigde Naties, gesprek 14 oktober 1993. Voor een overzicht van de (koloniale) monetaire politiek van de Nederlandse Antillen (en Aruba) zie: Van Soest (1978). 
toenemende Nederlandse aanwezigheid en bemoeienis met het Antilliaanse en Arubaanse bestuur de indruk wekken dat er sprake is van een sluipende rekolonisatie. Het bestaande Statuut was bedoeld als een tussenstation naar onafhankelijkheid. Een Statuut nieuwe stijl zal ongetwijfeld een verdere integratie met Nederland inhouden en zeker geen toenemende decentralisatie van bestuur voor de eilanden betekenen. Het nieuwe Statuut zal stellig voor wat betreft de economische stabiliteit en de vooruitzichten voor buitenlandse investeringen een aanmerkelijk betere garantie bieden dan onafhankelijkbeid. Het zal wat dat betreft nog gunstiger zijn dan het huidige Statuut dat ervan uitging dat de voormalige koloniēn op weg waren naar de onafhankelijkheid. Toenemende Nederlandse invloed in interne Antilliaanse en Arubaanse zaken zou echter kunnen leiden tot wrevel en onlustgevoelens. Politici en hogere ambtenaren die als eersten een beperking van hun macht en gezag zullen ondervinden, zullen van die onlustgevoelens zeker blijk geven. Dergelijke kritiek is reeds naar voren gebracht door de belangrijkste politieke partijen in de Nederlandse Antillen en Aruba. Het is niet ondenkbaar dat zich in de toekomst, naar aanleiding hiervan, onrust en ongeregeldheden zullen voordoen. Gedurende de laatste tien jaren was lokale ontevredenheid over het Antilliaanse en Arubaanse overheidsoptreden voornamelijk gericht op de lokale politici.

Als het Nederlands professionaliseringsstreven er echter in slaagt de noodzakelijke en veel te lang uitgestelde saneringsmaatregelen in de Nederlandse Antillen en Aruba uit te voeren binnen bet overheidsapparaat en veel ambtenaren zullen worden ontslagen, kan dat leiden tot grote ontevredenheid ten opzichte van Nederland. Bovendien kan de zich uitbreidende Nederlandse invloed ook leiden tot het omgekeerde van het 'Antillianiseringsproces'. Een opvallende groei van Nederlandse ambtenaren zou zich kunnen voordoen, die door Antillianen en Arubanen zou kunnen worden ervaren als een ernstige belemmering van hun carrière-mogelijkheden. Römer heeft al gewezen op het ontstaan van een dergelijke 'anti-macamba' houding, met name in de jaren veertig en na 30 mei $1969 .^{5}$

Tevens kan een toenemende Nederlandse anwezigheid leiden tot negatieve bij-effecten, zoals een stijging van de onroerend-goedprijzen en de huren en het ontstaan van een dubbele salarisstructuur voor lokale werknemers en Nederlandse specialisten. Ook zou de

s Rōmer, Korsow (1967); Römer, Un Pueblo na kaminda (1979) pp. 64 en 116 e.v. Rōmer stelt hier dat de agressie van de volksmassa zich in 1922 (bootwerkersconflict, waarbij de lonen werden verlaagd door de werkgever) en in 1969 richtte tegen nietCuraçaose ondernemers. 
Nederlandse koloniale arrogantie (en racisme) zich weer kunnen manifesteren, die gedurende de laatste tientallen jaren verdween of werd onderdrukt. De belangrijkste verandering onder een nieuw Statuut zal voorlopig ongetwijfeld van economische aard zijn. De Europese integratie zal zeker de Nederlandse Antillen en Aruba meer aan Nederland en Europa binden dan aan Latijns-Amerika.

Op dit ogenblik hebben de Nederlandse Antillen en Aruba een vrijwel onbeperkte toegang tot de EEG. Omdat zowel de huidige als de verwachte economische situatie van de Caraïbische Koninkrijksdelen aanmerkelijk beter zal zijn dan de algemene economische vooruitzichten in het Caraibisch gebied, zullen de Nederlandse Antillen en Aruba een aantrekkelijk bestemming blijven voor (illegale) buitenlandse werknemers. Zowel de overheid van de Nederlandse Antillen als Aruba proberen deze toevloed van buitenlandse werknemers te beperken. Nu Europa één 'natie' wordt zonder binnengrenzen, zal ook Nederland van de Caraibische Koninkrijkspartners eisen dat immigratie zal worden beperkt. Deze ontwikkelingen zullen verdere integratie in Latijns-Amerika bemoeilijken. Voorlopig zullen de Nederlandse Antillen en Aruba nog op Europa georiënteerd blijven, geïntegreerd binnen het Koninkrijk der Nederlanden. ${ }^{6}$

Nederland wenste een afsluitende Toekomstconferentie in december 1993. De Nederlandse wens om alles geregeld te hebben vór het eind van het jaar werd door politieke motieven ingegeven. In 1994 zijn de Kamerverkiezingen. Blijkens het gehouden referendum over de staatkundige toekomst van Curaçao op 19 november 1993 koos $74 \%$ van de kiezers voor de Antillen van de Vijf. ${ }^{7}$ Dit betekende een nederlaag voor de Curaçaose politici. Premier Liberia-Peters stelde de uitspraak van het volk te zullen eerbiedigen. $\mathrm{Zij}$ wenste direct

6 Oostindie (1992) pp. 225-247. Het woord natie moet hier niet in de gebruikelijke zin worden opgevat. Het begrip natie duidt gewoonlijk op één volk. Binnen Europa bestaan uiteraard grote taal- en cultuurverschillen. Gesproken zou kunnen worden van een federatie in wording.

Amigoe, 20 november 1993; “Curaçao kiest voor Antillen, Stemadvies politieke partijen resoluut afgewezen." Optie A kreeg 73,6\%, optie B behalde 17,9\%, optie C kreeg 8\%, optie D haalde slechts 0,5\%. De Grupo Pro Antia Restruktura (PAR) en de vakbondscentrales SKK en Kamara Sindikal voerden de laatste weken een kennelijk geslaagde campagne. De overwinning deed PAR voorzitter Miguel Pourier geëmotioneerd uitroepen: "Als het moet ga ik de politiek in en zal ik tol asn mijn dood blijven vechten voor de Antillen." Er werden 66052 geldige stemmen uitgebracht. Niet alle eilanden zijn even gelukkig met de Curaçaose keuze, want Curaçao blijft de overhand houden. Dezelfde problemen van staatkundige aard die zich in de jaren zeventig en tachtig voordeden zullen in de komende jaren (opnieuw) moeten worden opgelost. Zie ook Eindverslag van de Referendum Commissie Curaçao, Eilandgebied Curaçao, 28 december 1993. 
onderhandelingen te beginnen met de eilanden. De uitslag van het referendum is zeker beīnvloed door de slechte financiële situatie van Aruba. ${ }^{8}$ Dat is ook wel begrijpelijk, omdat in het Protocol naar aanleiding van de besprekingen ingrijpende maatregelen worden opgesomd, die moeten worden genomen, als Aruba de noodzakelijke medewerking wenst om art. 62 tijdig uit het Statuut te laten verdwijnen.

De omslag in het denken van de meeste burgers op Curaçao van een Status Aparte naar een Antilliaans verband deed zich pas voor in de laatste weken voor het referendum. ${ }^{9}$ De geplande afsluitende Toekomstconferentie werd na het bekend worden van de uitslag van het referendum uitgesteld. Minister Hirsch Ballin gaf als reactie op de uitslag dat Nederland een verdere desintegratie van de eilanden nooit heeft gewenst, maar tegemoet wilde komen aan de staatkundige wensen van de eilanden. ${ }^{10}$

De Antilliaanse eilanden zagen in de maatregelen voorzien in het Arubaanse Protocol een ernstige beperking van de eigen autonomie. Met andere woorden, de Status Aparte is gén garantie voor een betere toekomst en levert ook geen bescherming op tegen Nederlands ingrijpen. De in het Protocol genoemde maatregelen waren van Nederlandse zijde al eerder aangekondigd tijdens de Toekomstconferentie in maart 1993. Nederland en Aruba kwamen in oktober 1993 in een Protocol overeen dat art. 62 Statuut zal worden geschrapt als aan een aantal voorwaarden voor deugdelijk bestuur wordt voldaan. Belangrijk was de afspraak dat op Aruba de MEP en de AVP zouden samenwerken om met de steun van een brede politieke basis de

De toekomstige vechoudingen tussen Nederland en Aruba, Communiqué naar aanleiding van de besprekingen tussen Nederland en Aruba in Den Haag van 16 tot 21 oktober 1993, Protocol ter invulling van het Resumé van de bilaterale gesprekken Aruba-Nederland op 24, 25 en 26-6-1993, KABNA, 21 oktober 1993. Amigoe, 11 november 1993. De Aruba Hotel \& Tourism Association (AHATA) was van mening dat het Arubaanse politieke systeem gebaseerd is op de gedachte dat Statenleden en ministers he: belang van een politieke partij vertegenwoordigenen niet het Landsbelang. Tevens hekelde de AHATA het patronage systeem.

Amigoe, 16 november 1993. Stanley Brown, de activist van de opstand van $30 \mathrm{mei}$ 1969 ging zelfs zover door te kiezen voor optie C, aansluiting bij Nederland, de gehate kolonisator. Hij stelde: "De nieuwe machthebbers (de Antillianen) zijn dezelfde bombarol blijven vervullen. (Een bomba is een bevoorrechte negerslaaf die de baas speelde over de andere slaven en in feite aan de kant van de blanke shon stond). Ik ben niet veranderd, de wereld is anders geworden en daar pas ik mij bij aan. In 1989 heeft het communisme verloren en het materialisme gewonnen. Zonder materiële zekerheden hebben we geen eigenwaarde, geen moraal, geen ethiek en geen cultuur."

10 Minister Hirsch Ballin in een vraaggesprek met de Radio Wereldomroep, 20 november 1993. 
gerezen financiële problemen het hoofd te kunnen bieden. Daartoe was ook naast premier Oduber de oppositieleider Eman naar Nederland uitgenodigd om te overleggen over het Protocol. Het Arubaanse parlement stemde in met het Protocol, maar de uitvoering stagneerde wegens problemen die de MEP met haar achterban had over samenwerking met de AVP.

Het Protocol hield verder in dat de rechtspleging in Koninkrijksverband zal moeten plaatsvinden. Intensivering van de samenwerking binnen het Koninkrijk zal geschieden op het gebied van grensoverschrijdende criminaliteit en op het gebied van toelating en uitzetting. Tevens zal een strak toezicht van Koninkrijkswege op de financiële situatie van het Land moeten worden uitgeoefend. Met spoed zal de landsverordening Administratieve Rechtspraak moeten worden ingevoerd. Dit geldt ook voor een landsverordening Openbaarheid van bestuur en een landsverordening die de onafhankelijke klachtenregeling in verband met politieoptreden regelt. ${ }^{11}$ Voor wat betreft de regeling van de openbaarheid van bestuur wordt met name verwezen naar de financiering van politieke partijen. Voor verticale geschillen van bestuur zal een beroepsmogelijkheid worden geopend op de Raad van State, als intensief politiek overleg niet tot een oplossing leidt. Men kan zich niet aan de indruk onttrekken dat een AMvRB zowel voor Aruba als de Nederlandse Antillen in het verschiet ligt. De begrotingsproblematiek wordt met de dag groter.

\section{Een oplossing op termijn: de staatsrechtelijke federatie}

De gemiste kansen tussen Nederland en de overige rijksdelen om tot een voor alle partijen bevredigende staatkundige structuur te komen zochten de oplossing in een vergaande decentralisatie, veelal in een (con)federaal samenwerkingsverband. In de staatkundige ontwikkeling van de Nederlandse Antillen en Aruba vallen daarbij drie dingen op als men het heden vanuit het verleden beschouwt.

$11 \quad$ Er bestaat een landsbesluit h.a.m. van 8 juni 1988, ter uitvoering van art. 3, zevende lid, van de Landsverordening Politieoptreden (AB 1988, 18) AB 1988, 71. 
Ten eerste is er reeds lang sprake van de federatiegedachte. ${ }^{12}$ Toen de Nederlandse Antillen daar serieus over dachten wilde Nederland een federatie niet in overweging nemen. Toen Nederland eindelijk zover was wilde de Nederlandse Antillen een federatie niet meer overwegen. Bovendien werd de federatie afgewezen onder verwijzing naar de mislukking van de West-Indische federatie. Sommige samenwerkingsvormen die eerst niet bleken te werken kunnen op de langere termijn een oplossing bieden. Aruba en Curaçao hadden het zo druk met zichzelf en dachten alle problemen te hebben opgelost als zij alleen voor zichzelf hoefden te zorgen. $\mathrm{Na}$ een briljante start blijkt de financiële situatie van Aruba bijna even slecht als die van Curaçao. Dat betekent dat alleen de eigen zorgen dragen ook niet de oplossing is. Door de nadruk te leggen op de eigen problemen en daarvan de oorzaak grotendeels te zien in de gedwongen samenwerking met de andere eilanden dacht niemand meer aan de voordelen van een samenwerkingsverband in een Unieverband ${ }^{13}$ dan wel in een staatkundige federatie.

Munneke in: Federalisme (1992) pp. 58-79. In zijn bijdrage aan deze bundel schetst Munneke de naoorlogse federale constructies die ontworpen werden voor het Koninkrijk der Nederlanden. Munneke constateert dat een federaal naoorlogs staatsverband niet ontstond en dat voor reanimatie van de federale gedachte de geschikte voorwaarden niet aanwezig zijn. Als oorzaken voor het falen van de federale constructie voor het Koninkrijk der Nederlanden noemt Munneke: de ongelijke machtsverhoudingentussen de verschillende partners, rechterlijke overbescheidenheid bij toetsingsvraagstukken, tolerantie van factoren die de rechtsstaat ondermijnen en en het feit dat samenwerking geen financieel voordeel oplevert. De uitslag van het referendum van 19 november 1993 zal wellicht ook Munneke tot andere gedachten brengen. Zie ook: Wheare (1960). Het Britse Commonwealth werd in 1916 door sommigen gezien als een 'Commonwealth of Nations' in de zin van een federale unie. Dit stemde niet overeen met de werkelijkheid, daar Engeland voor alle landen binnen het Britse Commonwealth de defensie en buitenlandse betrekkingen regelde (p. 3 en 4). Sinds 1919 wordt het huidige begrip van het Britse Commonwealth gezien als een Koninkrijk opgebouwd uit autonome landen. Het Koninkrijk der Nederlanden heeft sinds 1954 dezelfde staatsrechtelijke uitgangspunten. Vile (1961); Emmerich (1971).

Ook Janus is van mening dat de aanpak van Lubbers tijdens de eerste Toekomstconferentie niet gelukkig was. In plaats van een gemeenschappelijke inventarisatie. analyse en oplossing van de problemen koos Lubbers met de presentatie van zijn Synthese-document voor de eenzijdige aanpak. Voor een overheveling van landstaken naar het Koninkrijk is wijziging van het Statuut nodig en dus de instemming van de drie Landen binnen het Koninkrijk. Janus is nog steeds van mening dat een samenwerkingsverband van de eilanden de voorkeur zou verdienen, Beurs-en Nieuwsberichten, 6 november 1993. Voor de goede orde zij opgemerkt dat er in de Nederlandse Antillen en Aruba veel meer politiek en staatsrechtelijk door deskundigen uiteengezet wordt in de dagbladpers dan dat zulks in Nederland het geval is. Behalve een juridisch tijdschrift (TAR-Justicia) is er geen wetenschappelijk forum. Voor een goed begrip van de recente onderlinge politicke en staatkundige verhoudingen is daarom ondermeer veel gebruik gemaakt van artikelen uit de dagbladpers. 
Ten tweede is de Gemeentewet steeds een belangrijke basis geweest voor het Eilandsbestuur. Ook al was de Nederlandse Gemeentewet aangepast voor de Antillen en was er daarom al kritiek op, toch bevat het een goed bestuurssysteem voor kleinere eenheden binnen een groter verband. Bovendien lag het falen van de ERNA niet zozeer aan het systeem van de ERNA maar aan het niet in een vroegtijdig stadium overdragen van landsbevoegdheden aan de eilanden. Tevens vielen gezien het vigerende kiessysteem landsbelangen niet meer te scheiden van eilandsbelangen, hetgeen nog versterkt werd door partijpolitieke conflicten. Daarom zal ook de beste oplossing voor de heersende bestuursproblematiek op korte termijn zijn een aantal instrumenten uit de nieuwe Gemeentewet aan te reiken voor de Nederlandse Antillen en Aruba binnen het Koninkrijk nieuwe stijl. Op langere termijn kan dan gedacht worden aan een vrijwillig samenwerkingsverband tussen de eilanden.

Ten derde valt niet te ontkennen dat er binnen de oorspronkelijk Nederlandse Antillen twee eilanden bestonden die aanmerkelijk groter waren dan de andere vier eilanden en daarom in een staatsrechtelijk systeem meer gewicht zouden moeten hebben. In het systeem van de ERNA werden alle eilanden gelijk behandeld, maar dat leidde niet tot de oplossing van de bestuursproblemen en het doorbreken van het insularisme. Thans zijn er twee eilanden Curaçao en Aruba die in beginsel voldoende bestuurskracht hebben om een land binnen het Koninkrijk te vormen. De andere vier eilanden zullen dat nooit kunnen. Dat betekent dat de eilanden verschillend behandeld zullen moeten worden, niet omdat het ene eiland minder zou zijn dan het andere eiland, maar omdat grote verschillen bestaan tussen de eilanden naar inwonertal en naar het aantal kiesgerechtigden.

Kleine eilanden bebben feitelijk onvoldoende bestuurskracht om alle landstaken uit te kunnen voeren. Er zijn echter tendensen om hetgeen gemeenschappelijk is gegroeid te handhaven en het is mogelijk dat gemeenschappelijk gegroeide te vernieuwen. Veel slechter dan het nu is kan het niet worden. Het ligt dan ook voor de hand dat Nederland thans de eilanden de mogelijkheid geeft om met Nederland een eigen relatie aan te gaan. Daarnaast is het noodzakelijk dat Nederland in plaats van alleen maar financiële hulp ook technische bijstand verleent in de uitvoering van het openbaar bestuur.

Bovendien ontbreekt iedere basis voor een kiesstelsel, waarin de gezamenlijke eilanden als één kiesgebied fungeren. Alle politieke partijen zijn eilandgebonden. In ieder geval zal in welk kiesstelsel dan ook voorkomen moeten worden dat én eiland de absolute meerderheid in de nationale (gezamenlijke) volksvertegenwoordiging zal 
hebben. Zou een gezamenlijke volksvertegenwoordiging opnieuw worden overwogen en die kans is toegenomen gezien de uitslag van het referendum op Curaçao, dan zou het aantal zetels van Curaçao gelijk kunnen zijn aan het aantal zetels van de andere eilanden. ${ }^{14} \mathrm{Er}$ zou gekozen kunnen worden tussen een aangepast evenredigheidsstelsel of een districtenstelsel. Bij een kiesstelsel kan gekozen worden voor een evenredige representatie van alle stromingen binnen de maatschappij, dat is het Nederlandse systeem. Dit zal leiden tot coalitieregeringen. Wil men echter in een land de nadruk leggen op een stabiele regering dan zal de keuze van de kiezer moeten worden beperkt door het beginsel van evenredige vertegenwoordiging los te laten. Gedacht kan dan worden aan een districtenstelsel.

Op grond van de referendumuitslag is nog niet zeker hoe de staatkundige structuur van de Nederlandse Antillen zich zal ontwikkelen. Het is mogelijk dat de kleine eilanden (Saba en Sint Eustatius) alsnog voor een directe band met Nederland kiezen. De voorkeur van Bonaire gaat uit naar een unie met Curaçao maar het geslonken politieke vertrouwen in de landelijke politici kan Bonaire ook tot andere gedachten brengen.

In het verleden dook steeds weer de federatieve bestuursvariant op. Dat was niet voor niets. Eilanden kunnen blijkbaar niet in een eenheidsstaat worden ondergebracht. Maar een staatsrechtelijk of volkenrechtelijk federatief verband 'sui generis' behoort wel tot de mogelijkheden op langere termijn. De referendumuitslag wijst daar op. Een samenwerkingsverband tussen de eilanden op vrijwillige basis is een aanvaardbare oplossing voor de Antilliaanse eilanden en Aruba, willen zij hun eigenheid bewaren en de voordelen smaken van een relatie met Europa en Latijns-Amerika. Hierbij kan dan gedacht worden aan een staatsrechtelijk (federatief) verband van de eilanden, dat ondergebracht in een aangepast Statuut binnen het Koninkrijk functioneert. Ook kan gedacht worden aan een onafhankelijke Antilliaanse federatie die een associatie-verband met Nederland afsluit. Weliswaar zijn de Antillen en Aruba ook gericht op Latijns-Amerika en voelen zij zich daarmee verwant, maar de onstabiele politieke constellaties in Latijns-Amerika vormen geen navolgenswaardig voorbeeld voor de Nederlandse Antillen en Aruba. De droeve geschiedenis van de Surinaamse dekolonisatie illustreert dat op onbarmhartige wijze. Onafhankelijkheid en chaos creëren voor een volk zeer moeilijke levensomstandigheden. 
Tegen de recente huidige politieke ontwikkelingen in blijkt uit onderzoek naar alle voorgestelde bestuursstructuren voor de Antilliaanse eilanden uit het verleden, dat objectief gezien de beste bestuursstructuur voor de Nederlandse Antillen en Aruba een federatief samenwerkingsverband is. Daarbij behoeft niet direct gedacht te worden aan een volkenrechtelijke (soevereine) federatie, maar aan een 'staatsrechtelijke' federatie 'sui generis' voor de Nederlandse Antillen en Aruba samen, binnen het Koninkrijk. Nu de eilanden binnen het Koninkrijk wensen te blijven, heeft Nederland harde eisen gesteld aan de deugdelijkheid van bestuur. De eisen zullen zoals hierboven betoogd zeker leiden tot een andere beleving van de eigen Antilliaanse en Arubaanse autonomie en een toenemende invloed van Nederland in de Koninkrijksdelen overzee. Dit proces zal versterkt worden indien Curaçao vroeger of later een autonome status doorzet en de andere eilanden hun relatie met Nederland apart regelen.

Veelvuldig en langdurig is van Antilliaanse en Arubaanse zijde betoogd dat de eilanden niets gemeen hebben met elkaar en dat zij slechts gedwongen zijn samengevoegd in een Antilliaans staatsverband op grond van toevallige kolonisatie. ${ }^{15}$ Maar het is ongetwijfeld zo dat de eilanden toch meer met elkaar gemeen hebben dan zij dat met Nederland hebben, dat bleek immers weer uit de uitslag van het referendum op Curaçao.

Ingrijpen in de eilandelijke autonomie is veel gemakkelijker voor Nederland te realiseren bij elk eiland afzonderlijk dan dat zulks het geval zou zijn bij een federatieve structuur van de eilanden.

Daarenboven kunnen in het huidige tijdsgewricht noch grote noch kleine landen elkaar negeren. Vrijwillige of gedwongen onderlinge hulp en bijstand in de regio is noodzakelijk. Gebeurt dat niet goedschiks dan gebeurt dat kwaadschiks zoals de politieke praktijk in het Caraibisch gebied laat zien. Al die gemiste kansen wijzen op de lange termijn in de richting van een federatie, omdat binnen een dergelijke structuur eilanden van verschillende grootte kunnen samenwerken. Als de eilanden onderling niet willen samenwerken zullen zij in een andere constellatie die veel minder gunstig is voor hun eigen ontwikkeling daartoe worden gedwongen. De keuze voor een federatief model lijkt daarom geen moeilijke, ook al zijn de voordelen

Rapport Jeukens (1977) p. 13; Nota inzake de toekomstige staatkundige structuur en een daaraan voorafgaande overgangsperiode, Bureau Staatkundige Structuur Eilandgebied Curaçao (zonder datum, uit de context kan worden afgeleid dat het hier gaat om een nota uit 1980) p. 1. De Statiaanse vertegenwoordiger had op het eilandelijk topoverleg van 25 tot 27 februari 1980 gesteld: "We cannot unite what God has already divided." Deze uitspraak kan ook worden aangepast in de zin van:

"United we stand, divided we fall". 
daarvan nu tijdelijk uit het oog verloren. Het getuigt van een volwassen politieke ontwikkeling om die wil tot samenwerking te concretiseren. De kleine eilanden kunnen immers maar een beperkt aantal taken zelfstandig afhandelen.

Curaçao en Aruba als grootste eilanden zouden de kleine eilanden tegen verrekening kunnen bijstaan in die aangelegenheden die zij zelf niet kunnen uitvoeren. ${ }^{16}$ Daarbij kan dan gedacht worden aan technische bijstand door een goed functionerend en eenvoudig bestuursapparaat in de vorm van een gemeenschappelijk orgaan. Elk samenwerkingsverband zal moeten berusten op de wil van de eilanden om samen te werken. Daarbij behoeven zij hun zelfstandigheid niet te verliezen. Het samenwerkingsverband zal permanent en duurzaam moeten zijn en gebaseerd moeten zijn op onderling vertrouwen.

Afscheiding zal niet mogelijk moeten zijn tenzij onder zeer dringende omstandigheden, omdat daarmee anders voor het minste of geringste politieke geschilpunt over en weer gedreigd zal worden. Alleen al vanuit financieel-economisch oogpunt is samenwerking noodzakelijk. De huidige Samenwerkingsregeling kan als uitgangspunt dienen. In een dergelijke federale constructie zullen de volgende onderwerpen duidelijk geregeld moeten worden:

1. afbakening van federale en eilandelijke bevoegdheden;

2. constitutionele autonomie;

3. rechterlijke controle op verticale bestuursgeschillen, toetsing van landsverordeningen en eilandsverordeningen aan de Staatsregeling (de grondrechten), de Samenwerkingsregeling en het Statuut. Dit betekent wel als men deze weg in wil slaan, dit vergaande consequenties zal hebben voor de functie van de rechter;

4. al dan niet hoger toezicht van het land op het eilandgebied en van het Koninkrijk op het land;

5. tweekamerstelsel, waarbij een kamer samengesteld is op basis van het aantal inwoners van de eilanden (op grond van direct kiesrecht ${ }^{17}$ op alle eilanden, gebaseerd op een gematigd propor-

Zie Decentralisatieplan, 29 december 1980, p. 52 e.v. Van belang is dat samenwerking kan leiden tot besparingen.

17 Voor een uiteenzetting over het kiesrecht zie: Donner (1967); Elzinga (1989). Het is juist te bedenken dat in Nederland als een van de oorzaken van de politieke malaise de evenredige vertegenwoordiging wordt gezien. In de Nederlandse Antillen werd als een der oorzaken van de soms moeilijk functionerende staatsorganen (regering en volksvertegenwoordiging op Landsniveau en Eilandsniveau) nu juist het systeem van niet evenredige vertegenwoordiging genoemd. Wellicht zou ook nog gedacht kunnen worden aan de $5 \%$ regeling. Geen partij mag vertegenwoordigd zijn in de volksvertegenwoordiging als zij niet tenminste $5 \%$ van de stemmen heeft behaald. Bovendien zou een vorm van een districtenstelsel kunnen worden ingevoerd, Gielen 
tioneel systeem). Deze kamer zou kunnen fungeren als de nationale volksvertegenwoordiging. De andere kamer zal worden samengesteld op basis van pariteit ${ }^{18}$ van de eilanden (indirect te verkiezen). Is het Landsniveau blijvend vervallen binnen de Nederlandse Antillen, dan is alleen een federale kamer noodzakelijk, samengesteld op grond van pariteit van de eilanden;

6. rigide federale constitutie of Samenwerkingsregeling en rigide eilandsconstituties, vanwege de daarin gewaarborgde grondrechten. Die basisgrondwet kan alleen worden gewijzigd met een gekwalificeerde meerderheid van de volksvertegenwoordiging van alle eilanden. Aanpassing van het Statuut zal dan op termijn noodzakelijk zijn;

7. indien nodig synchronisatie Statenverkiezingen en Eilandsraadverkiezingen;

8. eventueel herziening van de positie van de Gezaghebber, die thans fungeert als autonoom eilandsorgaan, eilandelijk medebewindsorgaan, landsorgaan en Koninkrijksorgaan;

9. zonodig integratie van de Staatsregeling van de Nederlandse Antillen en de ERNA.

Alhoewel formeel gesproken hoger toezicht niet past in een federale structuur is handhaving daarvan gezien de huidige situatie noodzakelijk. Hierbij wordt tevens voorgesteld rechterlijke toetsing in te voeren. Dit betekent dat als op termijn een federaal staatsrechtelijk samenwerkingsverband politiek mogelijk wordt, kan worden bezien of hoger toezicht nog langer moet worden gehandhaafd. In dat stadium zou de ERNA kunnen worden omgewerkt naar een eilandelijke constitutie wellicht naar het model van de Arubaanse Staatsregeling.

Het is duidelijk dat het Koninkrijk en met name Nederland worstelt met een groot probleem. Als de eilanden samen blijven, bestaat er een kans dat ze als onafhankelijke staat kunnen overleven, zij het met een veel lagere levensstandaard. Begrijpelijkerwijs vinden de eilanden dat geen aantrekkelijke optie. De eilanden hebben echter steeds meer moeite zich zelf te besturen, maar tegelijkertijd willen ze ook niet dat Nederland ingrijpt. De laatste jaren trekt het minst ontwikkelde deel van de bevolking naar Nederland. Door de etnische en cultuurverschillen komen hoe langer hoe meer botsingen voor met

(1968) pp. 55-56.

Rapport Jeukens (1977) pp. 49-64. 

1993 op Curaçao werd gehouden bood de bevolking de keuze uit vier opties:
A. deel uit te blijven maken van de Nederlandse Antillen;
B. een autonoom land binnen het Koninkrijk der Nederlanden te worden (de status aparte, zoals Aruba die heeft) ${ }^{30}$
C. deel van Nederland te worden;
D. onafhankelijkheid. ${ }^{21}$

Naar aanleiding van het te houden referendum werden op Curaçao verhitte discussies gevoerd over de meest gewenste optie. Er ontstond een aanzienlijke aanhang voor optie $C$, ondermeer verwoordt door

T. Croes (1992) pp. 47-51; R. Croes en L. Moenir Alam in: The Dutch Caribbean (1990) pp. 81-101; Gilhuis (1981); Amigoe, 20 oktober 1993, "De referendumbal ligt in het veld, Professor Gilhuis: 'Uitstel referendum zou politiek nog meer vertrouwen kosten'."

Het Nederlandse weekblad Elsevier vroeg in juni 1993590 bewoners van Curaçao naar hun mening over de toekomstige staatkundige structuur. $58,3 \%$ van alle ondervraagden vond dat Curaçao geen status aparte moest krijgen, zelfs al zouden de overheidsfinanciēn op orde zijn gebracht en de misdaad teruggedrongen. 24,8\% was het hiermee oneens. $85 \%$ van de ondervraagden wees onathankelijkheid van de hand. Slechts $31,3 \%$ had vertrouwen in de Antilliaanse regering, 46,3\% was niet tevreden met de regering Liberia-Peters. Maar 27,8\% sprak zijn vertrouwen uit in het eilandsbestuur, weinig tot geen vertrouwen had $43,7 \%, 28,5 \%$ had geen mening, Amigoe, 8 juni 1993; Amigoe 21 oktober 1993, "Psychologisch effect niet te onderschatten, Betrian ziet autonome status als een noodzakelijke fase".

Eilandsverordening houdende bepalingen betreffende een op 19 november te houden referendum over de staatkundige toekomst van het eilandgebied Curaçao, AB 1993, 19; Het referendum over de staatkundige toekomst van Curaçao, Rapport van de Referendum Commissie Curaçao, 23 augustus 1993. Uit een onderzoek van de Universiteit van de Nederlandse Antillen bleek, dat de strijd zal gaan tussen optie B of C, Amigoe, 24 september 1993. Indien Curaçao voor aansluiting bij Nederland zou kiezen dan blijkt daaruit een radicale afwijzing van de plaatselijke politiek. Daarom had de politiek ook grote moeite met deze optie en probeerde deze te elimineren, Amigoe, 20 september 1993. Het Statenlid Winston Lourens noemde optie C 'een historische en emancipatorische dwaling' om deze mogelijkheid te betrekken in de vraagstelling van het referendum, Amigoe, 6 september 1993. Voor alle zekerheid had Curaçao al een Proeve van een Grondwet voor Curaçao vervaardigd, die aangeboden werd aan de Nederlandse regering. De Staatsregeling van Aruba heeft daarvoor model gestaan, Amigoe, 31 augustus 1993. Ook de PNP was fel tegen optie C gekant, 'dat zou de uitverkoop zijn van de strijd die Doktoor ds Costa Gomez heeft gestreden heef voor de autonomie van de Antillen'. Aansluiting bij Nederland zou leiden tot een tweederangs burgerschap, Amigoe, 8 september 1993. Ook de premier Maria Liberia-Peters (PNP) was deze mening toegedaan, Amigoe, 9 september 1993. 
Booi. ${ }^{22}$ Degenen die voor optie $\mathrm{C}$ waren meenden dat de eilanden te verwend en te veeleisend waren geworden. Er werd teveel kritiek op Nederland geuit, met name als Nederland niet direct met de benodigde financiën klaar stond om de oplopende overheidstekorten weg te nemen. Booi zag twee mogelijkheden, onafhankelijkheid per postwissel of de provinciale status. Nederland moet te vaak de schade van het wanbeleid van de overheid herstellen. Indien de eilanden in het Koninkrijk willen blijven zal echter de Nederlandse eis van behoorlijk bestuur omgezet moeten worden in de verantwoordelijkheid daarvoor van de Antilliaanse en Arubaanse overheid. Sanering van de overheidsfinanciën is een eerste vereiste voor behoorlijk bestuur. Op Curaçao kreeg optie A op het laatste moment een royale meerderheid van $74 \%$. Een samenwerkingsverband zou dan ook kunnen worden overwogen met maximalisering van de voordelen en minimalisering van de nadelen, die een samenwerkingsverband tussen de eilanden ongetwijfeld zal opleveren.

De vormgeving van deugdelijk bestuur vraagt het meest dringend om een oplossing en zal daarom in de volgende uiteenzetting nader worden uitgewerkt. De concretisering van de uitwerking van deugdelijk bestuur houdt in: de controle op het bestuur, de bescherming van de burger tegen overheidshandelen, het recht op inspraak en nieuwe vormen van hoger toezicht en de criteria daarvoor.

Al die tegenstrijdige belangen en stromingen kunnen het beste worden verenigd in de vorm van hoger toezicht in een 'tweetrapsraket' model. Samenwerkingsmogelijkheden tussen de eilanden op termijn kunnen pas overwogen worden, als de eilanden daar zelf de voordelen van kunnen inzien.

De bestaande op te lossen problemen zijn duidelijk. Deugdelijk bestuur kan alleen worden gerealiseerd met behulp van Nederland. In Nederland is de Gemeentewet aangepast aan de eisen des tijds. Onderdelen uit de Gemeentewet met name voor wat betreft 'positief' toezicht zouden ook in de Nederlandse Antillen en Aruba kunnen worden ingevoerd. Worden aanbevolen maatregelen door het verant-

22 "Nederland moet Antillen direct gaan besturen", Volkskrant 3 mart 1993; G.R. Booi is leraar te Willemstad; Amigoe, 20 oktober 1993, "Glenn Booi: optie C garandeert goed investeringsklimast, Culturele vrijheid betekent weinig met een lege maag'". 
woordelijk orgaan niet genomen, dan kan of het Land of de Koninkrijksregering ingrijpen. Zo blijft de verantwoordelijkheid daar waar deze hoort: bij het Eiland of het Land en is ook direct duidelijk, welke instantie in gebreke blijft. Bovendien zou een rechterlijke controle mogelijk moeten zijn indien repressief toezicht wordt toegepast. Op grond van de huidige bestuurscrisis in zowel de Nederlandse Antillen en Aruba is versterkt toezicht en een wezenlijke ondersteuning van Nederland nodig bij de groei naar een volwassen parlementaire democratie in de Nederlandse Antillen en Aruba. Het grootste probleem hierbij is het sluitend maken van overheidsinkomsten en uitgaven. Nederland volstond meestal met het zenden van ontwikkelingsgelden, maar heeft niet daadwerkelijk samen met de Arubanen en Antillianen gezocht naar methoden om praktische kennis en deskundigheid op dat gebied over te dragen.

De instrumenten neergelegd in het ontwerp nieuwe Gemeentewet $^{23}$ zouden kunnen worden aangepast voor de Nederlandse Antillen en Aruba. Deze instrumenten kunnen een vorm van toezicht opleveren die aan de bestaande autonomie geen geweld aandoet. Deze vormen van toezicht kunnen worden gecombineerd met een rechterlijke controle $^{24}$ op verticale bestuursgeschillen. Op het gebied van de rechtspraak en het financiële toezicht zou intensief kunnen worden samengewerkt met Nederland. Op deze wijze hoeft de eilandelijke autonomie niet teveel geweld te worden aangedaan en krijgen de eilanden alle mogelijkheden voor zichzelf te bewijzen dat zij in staat zijn de parlementaire democratie op volwassen wijze vorm te geven in een relatie met Nederland, die zij zelf hebben gewenst. Deze ontwikkelingen zullen moeten worden vastgelegd in het Statuut. De autonome status van Aruba leidde tegen de verwachtingen in niet tot een aanzienlijke vermindering van de bestuursproblemen. Nederland eiste strenge maatregelen, deze Nederlandse opstelling zal ongetwijfeld binnen de Nederlandse Antillen en Aruba leiden tot een grotere bewustwording dat vrijwillige samenwerking tussen de eilanden mogelijk is. Voorafgaande aan die samenwerking kunnen de eilanden zelf bepalen welke landstaken in het algemeen belang van de eilanden

Voorstel Gemeentewet, Voorstel van wet houdende nieuwe bepalingen met betrekking tot gemeenten (nr. 19403 ) met vergelijkende overzichten van de artikelen van het voorstel met de huidige wet en van de huidige wet met het voorstel. Met ingang van 1 januari 1994 is de nieuwe Gemeentewet in werking getreden.

24 Indien het hoger toezicht zou worden afgeschaft dan zou slechts een incidentele rechterlijke controle overblijven, die afhankelijk zal zijn van het al of niet aanhangig kunnen maken van een procedure. Ook zal die toetsing beperkt zijn, omdat zij geen toetsing aan het algemeen belang inhoudt. Rapport Jeukens (1977) pp. 38 en 39, zie voor een interessante uiteenzetting over rechterlijke toetsing in plaats van hoger toezicht: pp. 39-41.

546. Een les uit het verleden: een (con)federale structuur 
kunnen worden overgedragen. ${ }^{25}$

De kwaliteit van het bestuur in een staat bepaalt voor een groot deel het welbevinden van zijn burgers. Openbaar bestuur kan worden gedefinieerd als alles wat de overheid doet, met uitzondering van rechtspraak en van wetgeving in materiele zin. Konijnenbelt ${ }^{26}$ definieert het bestuursrecht als "het recht betreffende de actieve overheidsbemoeiing"'. De overheid als zodanig is een verzamelnaam en is niet feitelijk. We kunnen alleen de beslissingen van concrete mensen en organen 'zien'. Deugdelijk bestuur houdt in dat de overheid een ieder voor de wet gelijk behandelt en geen privileges verleent. Het bestuurshandelen mag niet willekeurig zijn en moet op de wet zijn gebaseerd. Ook mag de overheid van zijn bevoegdheden geen ander gebruik maken dan de wet voorschrijft. De besluiten van de overheid dienen voorts op inzichtelijke, zorgvuldige en gemotiveerde wijze te worden genomen. Een beleid dat de overheid voert mag niet zonder meer worden gewijzigd, dat is in strijd met de rechtszekerheid, bovendien moet de overheid toezeggingen aan een burger gedaan in beginsel nakomen. Tevens moet de burger de mogelijkheid hebben zich tot de onafhankelijke rechter te wenden indien hij door de overheid in zijn belang is geschaad. Ten slotte dient de overheid de algemene middelen ten behoeve van zijn inwoners op een doelmatige en juiste wijze te beheren en toezicht en advies van de daartoe aangewezen constitutionele organen te accepteren. Deugdelijk bestuur moet kunnen worden getoetst aan de algemene beginselen van behoorlijk bestuur. Deugdelijk bestuur houdt naast juiste regeltoepassing, óók goed management in. De kenmerken van goed management zijn:

1. de dienstverlening naar de burger toe is optimaal, de staat is er voor de burger en niet andersom;

2. de bestuurder en ambtenaar stellen hun deskundigheid in dienst van de burger;

3. bestuur heeft mensen tot doel en geen dingen, het bestuur functioneert doelmatig en efficiēnt.

Naast deze belangrijke kenmerken van bestuur moeten ook tekortkomingen binnen het systeem worden herkend en verbeterd. Laurence Peter $^{27}$ heeft daartoe het Peterprincipe ontwikkeld. Dit principe

Zie Decentralisatieplan, 29 december 1980 van de hand van mr. P.D.O. Denz, Directeur Departement Staatkundige Structuur. Zie ook Decentralisatieplan Nederlandse Antillen, Departement Staatkundige Structuur, mr. H.S. Croes, juli 1981. Van Wijk/Konijnenbelt (1990) pp. 1, 31, 35-55. 
verklaart hoe individuen binnen een organisatie omhoogstreven tot zij hun niveau van incompetentie hebben bereikt. Helaas is dat niveau van incompetentie het niveau waarop velen zich gewoonlijk bevinden. Dit kan leiden tot frustraties en vluchtgedrag van medewerkers, afname van efficiency van de organisatie. Overheidsbureaucratieên vertonen dat beeld nogal eens. Het plafond van de ene mens is immers soms de vloer van de ander. Het Peterprincipe beoogt een verklaring te geven voor het feit dat zoveel dingen verkeerd gaan en waarom veel mensen incompetent zijn. Wat het Peterprincipe doet voor het individu doet de Peterpyramide voor het systeem. De Peterpyramide laat zien hoe hele systemen (organisaties) kunnen uitgroeien tot hun niveau van incompetentie en hoe dit kan worden vermeden. Bureaucratieēn hechten meer waarde aan interne harmonie dan aan dienstverlening.

Bezuinigingen leiden tot grootschaligheid, waarvan men aanneemt dat het kostenverminderend werkt. Maar grootschaligheid vraagt meer coördinatie, regelaars en denkers en steeds minder mensen die het werk uitvoeren, dus wordt de dienstverlening nog slechter, een voorbeeld daarvan was het debâcle van het vervaardigen van een fraudebestendig paspoort door de Nederlandse regering. Bovendien hoe groter de bureaucratie, hoe groter de fouten zijn die gemaakt worden en hoe moeilijker het is een fout te corrigeren. Een verantwoordelijk persoon valt dan meestal niet te vinden. De overheidsorganisatie zou wat de dienstverlening betreft nog wel wat kunnen leren van het bedrijfsleven. ${ }^{28}$

Na de Verlichting in de $17 \mathrm{de}$ en $18 \mathrm{de}$ eeuw, toen allerwegen in het Westen gezocht werd naar een passende vorm van parlementaire democratie, probeerde men corruptie te voorkomen door de regering te laten controleren door een volksvertegenwoordiging. Daarnaast ontstond de onafhankelijke rechterlijke macht. Deze vorm van 'checks and balances' is de basis van de rechtsstaat en houdt in dat regeerders evenals de geregeerden gelijk zijn voor de wet. Daarom moeten wetten ook opgeschreven (gecodificeerd) worden, dit is het zogenaamde legaliteitsbeginsel. Het legaliteitsbeginsel of beginsel van de wetmatigheid van bestuur houdt in dat overheidsbevoegdheden te herleiden zijn tot de (Grond)wet. Tevens bevordert het legaliteitsbeginsel daardoor een gelijke behandeling van de burgers. Iedereen behoort immers voor de wet gelijk te worden behandeld. Ook de 
staatsorganen zijn aan de wet onderworpen. ${ }^{20}$

De democratie, de heerschappij van het volk, kan alleen dan goed functioneren als zowel de regering als de volksvertegenwoordiging de wet toepassen en de rechterlijke uitspraken accepteren, óók als een vonnis voor hen niet altijd even positief uitvalt. De regering en de volksvertegenwoordiging behoren iedere burger gelijk te behandelen, niemand te bevoordelen en geen stemmen te verzamelen door het uitdelen van gunsten, dat ondermijnt de rechtsstaat. Ook ambtsdragers zijn onderworpen aan de wet.

In het bedrijfsleven trekt een organisatie vaak een tijdelijke trouble-shooter aan in crisis-situatie om de onaangename beslissingen tot sanering te nemen. Zo wordt de tijdelijke manager 'de zondebok', de eigen mensen krijgen geen vuile handen en er kan met een schone lei worden begonnen. Nederland is zelfs bereid die onaangename rol te spelen, een mogelijkheid bij uitstek om deugdelijk bestuur in te voeren.

Orndat Nederland zo de nadruk legt op deugdelijk bestuur als voorwaarde voor het voortbestaan van de Koninkrijksband is naast inzicht in wat deugdelijk bestuur dan wel is en de basis daarvan, óók duidelijkheid vereist over de controle op - en de naleving van - dat deugdelijk bestuur. ${ }^{30}$

Het parlementaire systeem kent een verdeling van macht binnen de staat, over de wetgevende macht, de uitvoerende macht en de rechterlijke macht. In de parlementaire democratie is de macht niet bij én orgaan gelegen. Deze verdeling van macht moet voorkomen dat die macht verwordt tot willekeur en de overheid de eigen burgers zou gaan onderdrukken. In het parlementaire systeem wordt dat altijd aanwezige gevaar in toom gehouden door de Trias Politica, ${ }^{31}$ de verdeling van macht over drie instanties te weten: de volksvertegenwoordiging, de uitvoerende macht en de rechterlijke macht die proberen elkaar in evenwicht te houden door een wederzijdse contro-

Van Wijk/Konijnenbelt, pp. 35-55.

30 Burkens, Kummeling, Vermeulen (1992) zie met name hoofdstuk 1 pp. 6-7; hoofdstuk 2, pp. 9-27; hoofdstuk 3, pp. 29-125, hoofdstk 4, pp. 127-183. Voor de imporantie van een referendum: zie de pp. 183-186. Opvallend is dat in dit boek in het geheel geen gewag wordt gemaakt van de overzeese delen van het Koninkrijk. Het voorbeeld bij uitstek is de Amerikaanse Constitutie, vastgesteld in mei 1787 en aangenomen in maart 1789; Constitution of the United States and the 26 amendements to the Constitution, The 1993 Information Please Almanac (1993) pp. 617-629. 
le. Daardoor kunnen willekeur, nepotisme en dictatuur worden voorkomen. De controle van de volksvertegenwoordiging op het bestuurshandelen en de controle van de rechter op datzelfde handelen zijn daarbij van groot belang. Controle op de handelingen van het bestuur kan geschieden door:

1. Toezicht van Staten op het handelen van de regering. Dit kan plaatsvinden in het overleg tussen Staten en regering tijdens het totstandkoming van regelgeving. Het kan gebeuren door het vragen van inlichtingen en het stellen van mondelinge en schriftelijke vragen door Statenleden aan de minister (de artt. III.17 en MII.18 Staatsregeling van Aruba). Tevens kan gebruik worden gemaakt van het recht van enquête (art. III.19 Staatsregeling van Aruba), het recht van amendement (art. V.19 Staatsregeling van Aruba) en het begrotingsrecht (art. V.12 Staatsregeling van Aruba).

2. Controle door de Algemene Rekenkamer en de Centrale Bank.

3. Controle door de (administratieve) rechter.

4. Controle door openbaarheid en inspraak.

5. Hoger toezicht (de artt. 43, 44, 48, 50, 51, 52, 53 Statuut, art. 88 Staatsregeling Nederlandse Antillen, Eilandenregeling Nederlandse Antillen (ERNA) de artt. $98 \mathrm{t} / \mathrm{m} 104$ en de artt. 21, 22 en 23 van het Reglement voor de Gouverneur van respectievelijk de Nederlandse Antillen en Aruba. Zowel het Land als de Eilandgebieden kunnen verplicht worden medewerking te verlenen aan regelingen van een hoger orgaan (bijvoorbeeld de Koninkrijksregering). Dit wordt medebewind genoemd.

De invloed van de administratie op de rechten en belangen van de burger is enorm. Burgers kunnen door overheidshandelen rechtstreeks in hun bestaanszekerheid worden aangetast. Met rechtsbescherming tegen de overheid wordt bedoeld:

1. Het geheel van juridische mogelijkheden om klachten over besluiten en handelingen van de overheid voor te leggen aan een rechterlijk orgaan of eventueel daaraan voorafgaand een administratief beroepsorgaan dat het geschil bindend zal moeten beslissen.

2. De voorzieningen ter bescherming van rechten en belangen van de burger die niet gericht zijn op de beslissing van geschillen 
zijn: regelingen van het recht op inspraak en informatie.

Vanaf de jaren zestig is in Nederland de vraag om inspraak groot geweest. Onder inspraak wordt verstaan: het proces waarbij individuele burgers of groepen uit de bevolking hun mening kenbaar maken omtrent voorgenomen of voorgesteld beleid, langs de weg van door de overheid geregelde procedures. Inspraak waarbij individuele belangenbehartiging voorop staat, wordt wel aangeduid als 'preventieve rechtsbescherming'. Hieronder wordt verstaan: de juridische mogelijkheid die de burger heeft om zijn belangen onder de aandacht van de overheid te brengen, waar het betreft de voorbereiding van bestuurlijke beslissingen en handelingen. Dat gebeurt bijvoorbeeld op grond van de wet Ruimtelijke Ordening in Nederland. Inspraak in beperkte zin opgevat betekent dat een burger zijn belangen kan bepleiten. In ruime zin opgevat kan er sprake zijn van participatiedemocratie (referendum). Inspraak is nuttig als er geen beroepsmogelijkheid is, het kanaliseert conflicten en vermindert beroepsprocedures. Ook versterkt het de democratische legitimatie van bepaalde overheidsbesluiten. Inspraak houdt geen recht in op meebeslissen of gelijk krijgen. Hooguit heeft de burger er recht op dat er naar hem wordt geluisterd. Aruba en de Nederlandse Antillen kennen geen wetgeving waarbij inspraak en rol speelt.

Wel is een andere vorm van inspraak bekend in Aruba en de Nederlandse Antillen, namelijk het referendum over de uitoefening van het zelfbeschikkingsrecht. Hiervan is gebruik gemaakt in 1977 toen Aruba de mening van de bevolking wilde weten over een mogelijke onafhankelijkheid of voortzetting van het staatsverband met de Nederlandse Antillen. Ook op Curaçao wilde de Eilandsraad in 1992 de mening van de bevolking polsen over een nieuwe staatkundige structuur. Het referendum in de Nederlandse staatsrechtelijke geschiedenis is een onbekend verschijnsel. De nu voorgenomen wijziging van het Statuut in verband met het schrappen van art. 62 Statuut voorziet in een referendum, indien Aruba uit het Koninkrijksverband wil treden. Dit is de eerste keer dat in de staatkundige geschiedenis van het Koninkrijk het referendum wordt vastgelegd voordat een wettelijke regeling van kracht kan worden. Wel is merkwaardig dat eerst de betrokken landsverordening moet worden aangenomen en dan pas het referendum zal worden gehouden. Dit zou manipulatie van het referendum kunnen inhouden. 
Het houden van een referendum heeft ook nadelen. De mogelijkheid bestaat dat het volk iets anders wil dan de regering en/of politici. De brede Maatschappelijke Discussie over kernenergie in Nederland was daar een saillant voorbeeld van. De Nederlandse regering heeft zich niets aangetrokken van de mening van het volk over kernenergie, omdat de uitkomst niet strookte met het regeringsbeleid. Hier was met recht sprake van inspraak zonder enige invloed, waardoor de democratische legitimatie van het beleid geenszins versterkt werd. Het enige wat versterkt werd, waren de frustraties van de burgers en dat werkt anti-democratische stromingen in de hand. Soms is het horen een voorwaarde voor het vervolgens kunnen instellen van bezwaar en beroep. Ook biedt het recht van beroep een zekere garantie voor het serieus nemen van de inspraak.

De essentie van de rechtsstaat houdt in dat ook de overheid gebonden is aan de wet en haar bevoegdheid slechts kan uitoefenen op grond van de wet. Dat betekent dat elke burger gelijk is voor de wet en niet de ene burger boven de andere burger mag worden bevoordeeld of benadeeld. Juiste politieke beslissingen en een adequaat bestuur zijn gebonden aan het recht en dienen daaraan te worden getoetst. Het instellen van een nationale Ombudsman zou kunnen bijdragen aan de deugdelijkheid van bestuur. Ook zou kunnen worden gedacht aan een nationale Mensenrechtencommissie. Een dergelijk instituut zou goed kunnen functioneren in Nederland, de Nederlandse Antillen en Aruba. Ieder land zou zijn eigen commissie in het leven kunnen roepen. Deze commissie zou de regering kunnen adviseren over de knelpunten inzake de uitvoering van de fundamentele rechten en op grond daarvan richtlijnen kunnen geven. Tevens zou de commissie individuele klachten kunnen behandelen en de uitkomst daarvan kunnen publiceren. Dat zou een betere procedure zijn dan het afdwingen van naleving op grond van art. 43 van het Statuut. ${ }^{32}$

Vele besluiten van een gedecentraliseerd orgaan zijn onderworpen aan repressief toezicht. Zie bijvoorbeeld de artt. $98 \mathrm{t} / \mathrm{m} 104$ Eilandenregeling Nederlandse Antillen (ERNA), de artt. 48, 50 en 51 Statuut

32 C. Flinterman is hoogleraar staats- en internationaal recht aan de Rijksuniversiteit van Maastricht. Hij sprak in zijn lezing op 31 maar 1993 aan de Universiteit van Aruba over de mensenrechten en de bestuurspraktijk. Voor het handelen van bestuursambtenaren verwees Flinterman naar de 'Code of Conduct for Law Enforcement Officials', adopted by the General Assembly of the United Nations, resolution $34 / 169$ of 17 December 1979. 
(bestuur). Van belang zijn ook de artt. 20, 21 en 22 van het Reglement voor de Gouverneur. Preventief toezicht houdt in toezicht vooraf, te weten voordat het betrokken besluit in werking treedt. De betrokken regelingen treden niet in werking voordat dat daartoe toestemming of goedkeuring is verleend. Dit gebeurt door machtiging of goedkeuring van een hoger bestuursorgaan. Repressief toezicht is toezicht achteraf (na het nemen van het besluit) door schorsing of vernietiging van dat besluit door het toezichthoudend orgaan. Dit wordt 'spontane' schorsing of 'spontane' vernietiging genoemd. Deze vorm van repressief toezicht moet wel worden onderscheiden worden van het rechtsmiddel van een verzoek tot schorsing of vernietiging dat een burger kan instellen tegen een besluit van de overheid. De Koninkrijkskroon heeft een ruime beleidsvrijheid bij schorsing en vernietiging.

De burger kan door een verzoek tot vernietiging aan de Koninkrijksregering een besluit van hogerhand uitlokken. Spontane vernietiging houdt in een vorm van toezicht van hogerhand, dat tot gevolg heeft dat aan een besluit van een lager overheidslichaam de rechtskracht wordt ontnomen door een besluit van een hoger overheidsorgaan, zonder dat het vernietigde besluit hiervoor behoeft te zijn voorgedragen door de Gezaghebber of de Gouverneur (vandaar de benaming 'spontaan'). ${ }^{33} \mathrm{De}$ Kroon is voor het Koninkrijk belast met het repressieve toezicht als hoogste instantie. In de Nederlandse Antillen en Aruba loopt de vernietigingsprocedure via de Gouverneur en de Gezaghebber, er is dan geen sprake meer van een spontaan vernietigingsrecht. De Koninkrijksregering beslist. Het spontane vernietigingsrecht kan tevens worden opgevat als een uitwerking van het petitierecht. Er is geen recht op vernietiging. Er bestaat een recht op antwoord op het verzoek.

Geconstateerd kan worden dat de Landen formeel gelijkwaardig zijn binnen het Koninkrijk, maar materieel zijn het Land de Nederlandse Antillen en het Land Aruba te vergelijken met een Nederlandse gemeente.

Het uitoefenen van toezicht door een hoger bestuursorgaan op een lager bestuursorgaan vormt een belangrijke functie binnen de Neder-

Vóór de invoering van de wet Administratief Beroep Overheidsbeschikkingen (AROB) in 1976 kwam het regelmatig voor dat een burger de Kroon om spontane vernietiging van een overheidsbesluit verzocht. 
landse parlementaire democratie. Deze vorm van toezicht is zoals eerder gesteld ook vastgelegd voor de Nederlandse Antillen en Aruba. Dit hoger toezicht wordt uitgeoefend op Eilandsniveau door het Land met medewerking van de Gezaghebber en op Landsniveau door de Gouverneur. ${ }^{34}$ Zowel de Gezaghebber als de Gouverneur treden in deze op als toezichthoudend Koninkrijksorgaan.

Bestuurlijk toezicht is het uiterste middel om orde op zaken te stellen en dat geldt zeker voor het Koninkrijkstoezicht. Elke vorm van toezicht doorbreekt immers de autonomiegedachte. Toezicht kan noodzakelijk zijn daar waar het kleinschaligheid betreft, dit is het geval in Nederland (voor de provincies en gemeenten), de kleinschaligheid speelt een nog grotere rol in de Nederlandse Antillen en Aruba. Bestuurlijk toezicht dient in beginsel repressief te zijn. Ingrijpen achteraf vereist elke keer een actief optreden door het Koninkrijk. De drempel is hoog. Bij preventief toezicht is echter eerder sprake van routine, hetgeen drempelverlagend werkt. Toestemming vooraf heeft bovendien sterker het karakter van curatele dan ingrijpen achteraf, dat in strijd is met de geest van het Statuut. Preventief toezicht tast de essentie van de autonomie sterker aan.

Nieuwe vormen van bestuurlijk toezicht dienen wel met de grootste terughoudendheid te worden ingevoerd. Bestaande mogelijkheden binnen het kader van de artt. 50 en 51 Statuut zouden moeten worden toegepast. Maatregelen op grond van deze artikelen zouden aan de rechter ter toetsing kunnen worden voorgelegd om het toezichthoudend karakter van deze maatregelen te verzachten. Een dergelijke vorm van constitutionele toetsing zou de acceptatie en daarmee de praktische inzetbaarheid van deze bevoegdheden ten goede komen. Constitutionele toetsing zou bij voorkeur moeten geschieden door het Constitutioneel Hof of door een speciale administratiefrechtelijke 'Caraỉbische' kamer van de Raad van State. ${ }^{35}$

De bevoegdheden met betrekking tot bestuurlijk toezicht, die in de artt. 92 en 93 Staatsregeling Nederlandse Antillen aan de Koninkrijksregering zijn toegekend, moeten worden gezien in de verhouding Land - Eilandgebieden. Die verhouding zou kunnen worden omgezet in een Koninkrijksverhouding en aangepast aan een gemoderniseerde

Zie hiervoor ondermeer Statuut art. 43, lid 2; art. 50 en 51 Statuut; Grondwet art. 132; Staatsregeling van de Nederlandse Antillen art. 92 en 93; Eilandenregeling Nederlandse Antillen de arth. 85 en $98 \mathrm{Vm}$ 104; Reglement voor de Gouverneur van de Nederlandse Antillen en Reglement voor de Gouverneur van Aruba de arth. 15 Vm 24.

is Vergelijk de artt. 278 e.v. van de Gemeentewet, editie Schuurman en Jordens 4-Ia, 1994. 
toezichthoudende functie in een daarop afgestemd Statuut. Dit gemoderniseerde toezicht zou dan kunnen worden toegepast als een Land of Eilandgebied het plaatselijk bestuur grovelijk verwaarloost. Constitutionele toetsing zou mogelijk moeten worden gemaakt, om na te gaan of voor bet ingrijpen vanwege het Koninkrijk voldoende grond aanwezig is.

Het is duidelijk dat toezicht de autonomie van de Landen of Eilandgebieden bedreigt, zeker als financieel toezicht analoog aan de regeling in art. 12 van de Nederlandse Financiële Verhoudingswet 1984 wordt uitgeoefend. Daarom is een zorgvuldige constitutionele afweging van de in het geding zijnde belangen ook noodzakelijk, vóórdat een dergelijke regeling wordt ingevoerd. De rapporten van de Antilliaanse of Arubaanse Rekenkamer of het rapport van én in te stellen Koninkrijksrekenkamer zouden van doorslaggevend belang moeten zijn, om een maatregel van toezicht toe te passen.

De Statuutsperiode van 1954 tot heden heeft echter laten zien dat het gebrek aan deugdelijk bestuur, zowel op landsniveau als op eilandsniveau tot grote problemen heeft geleid. Dat betekent dat de autonomie beperkt zal moeten worden als de overheidsfinanciën gedurende langere tijd onvoldoende worden beheerd. Maar dat hebben de betrokken overheden zelf in de hand, als zij op financieel-economisch gebied een juist beleid voeren, behoeft het Koninkrijk niet in te grijpen. Autonomie houdt verantwoordelijkheid in, als die verantwoordelijkheid niet wordt gedragen is toezicht aanvaardbaar. Een vrijwillig toezicht in de vorm van een gemeenschappelijke regeling op grond van art. 38 lid Statuut lijkt onvoldoende. De bestaande Samenwerkingsregeling, die al buitengewoon vrijwillig is, wordt reeds veelvuldig als 'te zwaar' beoordeeld door de Nederlandse Antillen en Aruba.

Het is immers algemeen gebruikelijk dat donorlanden van de ontvangende landen behoorlijk bestuur eisen, is dat niet verzekerd dan worden geen ontwikkelingsgelden verstrekt. Ook het IMF stelt strenge voorwaarden aan leningen die het verstrekt.

Het excuus van staatsrechtelijke autonomie is onvoldoende om het langdurige ontoereikende beheer van' de overheidsmiddelen te rechtvaardigen. Indien de Nederlandse Antillen en Aruba bij voortduring financiële injecties nodig hebben vanwege het Koninkrijk dan zullen zij streng toezicht moeten accepteren, evenals gemeenten in Nederland of (staats)bedrijven die toezicht van de regering of een bank moeten accepteren bij een slechte bedrijfsvoering, uitstel van betaling of een dreigend faillissement.

Om het toepassen van hoger toezicht ook inhoudelijk te kunnen toetsen werd aandacht besteed aan de discussies over de nieuwe 
Gemeentewet in Nederland en de ook daar bestaande bezwaren tegen dat toezicht. De voor de nieuwe wet ontwikkelde meetinstrumenten worden bestudeerd en aangepast aan de Caraibische situatie om zo te komen tot een werkbare formule die ook voor tegenstanders van toezicht aanvaardbaar kan zijn.

In de MvT op de nieuwe Gemeentewet ${ }^{36}$ wordt een aantal redenen naar voren gebracht voor de noodzakelijkheid van hoger toezicht op de gemeenten. Deze criteria worden onderzocht en aangepast voor de situatie van de Nederlandse Antillen en Aruba. Dit is gebeurd om twee redenen.

Ten eerste is de bestuursstructuur van de Nederlandse Antillen en Aruba sterk beïnvloed door de Gemeentewet. Daarbij moet wel worden vastgesteld dat de autonomie van de Landen en de Eilandgebieden in theorie veel groter is dan de autonomie van de Nederlandse gemeenten. In de praktijk beschikken veel Nederlandse gemeenten echter gezien hun schaalgrootte over meer bestuurskracht dan bijvoorbeeld de Antilliaanse eilanden. Ook de bestaande politieke cultuur kan bijdragen aan onvoldoende bestuurskracht van het Land of het Eiland.

Ten tweede bestaat er binnen het Koninkrijk consensus over de zorgwekkende financiële situatie van het Land de Nederlandse Antillen en het Land Aruba. Het bestuur van Sint Maarten werd aan een verscherpt hoger toezicht onderworpen. Hirsch Ballin, de minister van Nederlands-Antilliaanse en Arubaanse Zaken, wil alleen maar spreken over een nieuwe Koninkrijksstructuur, het schrappen van art. 62 Statuut en een aangepast Statuut als de landen waarborgen kunnen geven dat deugdelijk bestuur meer aandacht krijgt van de overheid en de volksvertegenwoordiging. Een aangepaste en moderne vorm van toezicht lijkt daarvoor het meest efficiënt, zeker als daarbij de autonomie van beide overzeese Rijksdelen in acht wordt genomen en een rechterlijke controle vooraf mogelijk is. Toezicht zal beter voldoen dan rechterlijke toetsing. Rechterlijke toetsing kan alleen een

Zie de Gemeentewet, editie Cremers, Gemeentewet met vermelding van administratief- en burgerrechtelijke jurisprudentie, met name art. 185 , schorsing en vernietiging. In het voorstel Gemeentewet (nr. 19403) opgenomen in dezelfde Cremers editie na het register op de Gemeentewet (Supplement 50, december 1990) is een nieuwe titel V opgenomen, bestaande uit hoofdstuk XVI en XVII, het toezicht op het gemeentebestuur (de artl. 259-281). Daarin is ook de terminologie gemoderniseerd. Preventief toezicht heet nu toezicht vooraf. De nieuwe Gemeentewet werd ingevoerd op 1 januari 1994, Stb. 1993, 610. De tekst is geplaatst in Stb. 1993, 61; Editie Schuurman en Jordens, Gemeentewet, 4-Ia, 1994. 
rechtmatigheidstoetsing zijn en geen doelmatigheidstoetsing van het overheidsbeleid. In de dagelijkse bestuurspraktijk kunnen de meeste problemen beter worden gehanteerd door een doelmatigheids- en rechtmatigheidstoetsing, hetgeen hoger toezicht kan bewerkstelligen, dan door alleen maar een rechterlijke toetsing.

Het hoger toezicht kan preventief (vooraf) of repressief (achteraf) plaatsvinden. Preventief toezicht houdt ondermeer in: goedkeuring, ontheffing, machtiging en de verklaring van geen bezwaar. De MvT op het ontwerp Gemeentewet spreekt een voorkeur uit voor de goedkeuringsbevoegdheid. Het bezwaar van preventief toezicht is het structurele karakter ervan. Het nodigt als het ware het hogere bestuursorgaan uit tot een voortdurende bemoeienis met het beleid van de lagere overheid. Het kan tevens leiden tot te grote afhankelijkheid, doordat het lager orgaan uit angst voor vertraging als gevolg van onthouding van goedkeuring, bereid is verdergaande concessies te doen dan het strikt genomen aanvaardbaar acht. Indien grote risico's zich zouden voordoen in bijzondere gevallen, waarbij niet met een repressief toezicht kan worden volstaan, is preventief toezicht, mits geregeld bij of krachtens de wet aanvaardbaar. Repressief toezicht vindt plaats door schorsing of vernietiging van een overheidsbesluit door een hogere instantie.

In een aantal gevallen zal toezicht zelfs een voorwaarde zijn om op verantwoorde wijze tot decentralisatie over te gaan. De rampzalige gevolgen die een gebrek aan toezicht kunnen opleveren bleken uit de Soponatazaak. ${ }^{37}$ Toezicht werkt meestal 'negatief', omdat een bepaald bestuurshandelen ongedaan wordt gemaakt of wordt belet. Men kan ook een 'positieve' vorm van toezicht vastleggen in de wet, zoals de aanwijzing, de uitnodiging om een besluit te nemen en het opleggen van toezicht. Het is echter onjuist deze vormen als toezicht aan te merken, omdat het 'positieve toezicht' geen toezicht is, maar gebaseerd is op de regels van medebewind.

Aangezien deze instrumenten in hun toepassing grote overeenstemming vertonen met toezicht is de MvT op het voorstel Gemeentewet van mening dat desondanks regels van medebewind aangemerkt moeten worden als 'positief toezicht'. Thans kent de Gemeentewet

HR 7 maart 1986, NJ 1987, 1. Soponata vs Eilandgebied Bonaire. Het ging in deze kwestie om de overdracht van bevoegdheden van het Landsniveau naar het Eilandgebied Bonaire en om de aansprakelijkheid van het Eilandgebied Bonaire voor schade veroorzaakt door onjuist handelen van een loods. De overdracht leidde tot onzorgvuldige wetgeving, zie ook Bongenaar in: Justicia 1983, p. 1 e.v. en van dezelfde auteur de noot onder het vonnis van het $\mathrm{HvJ}$ in het Tijdschrift voor Antilliaans Recht, april 1984, p. 102 e.v. 
nauwelijks vormen van positief toezicht. Medebewind is ook geen veel toegepast middel in de Nederlandse Antillen. Aan 'positief toezicht' kan vooral behoefte bestaan wanneer een lager orgaan zelf niet wil overgaan tot de vaststelling of wijziging van een krachtens medebewind verplichte verordening of plan, terwijl de toezichthoudende overheid dit wel noodzakelijk vindt. Preventief en repressief toezicht bieden hier geen soelaas. In dergelijke gevallen zijn positieve toezichtinstrumenten nodig, zoals de aanwijzing of de uitnodiging om een verordening of een plan vast te stellen.

Ook kan gedacht worden aan lichtere vormen van beïnvloeding zoals de mededelingsplicht, het verplicht overleg en het verplicht advies. Wel dient het positief toezicht geclausuleerd te worden, opdat de hogere overheid alleen in zeer uitzonderlijke gevallen de beleidsvrijheid van het lager orgaan kan aantasten. Indien daaraan voldaan is en er waarborgen tegen misbruik zijn ingebouwd (zoals beroep bij de Kroon) behoeft positief toezicht geen grote bezwaren te ontmoeten. Bovendien is bij positief toezicht de verantwoordelijkbeid voor de uiteindelijk te nemen beslissing op zeer duidelijke wijze tot uiting gebracht.

Teneinde het deugdelijk bestuur aan te scherpen op de Nederlandse Antillen en Aruba zou het aan te bevelen zijn het 'positieve toezicht' te versterken. Wel zou daardoor de positie van de Gouverneur als Koninkrijksorgaan en Landsorgaan en van zijn assistent, de Gezaghebber als Koninkrijksorgaan en Eilandsorgaan problematisch kunnen worden, gezien het politieke klimaat van de Nederlandse Antillen en Aruba. Om verwarring te voorkomen en de betrokken functionarissen niet in een moeilijk parket te brengen is het van belang dat het positieve toezicht duidelijk bij of krachtens landsverordening, AMvRB of Rijkswet wordt geregeld. Waarschijnlijk zal het positieve toezicht voor de Nederlandse Antillen en Aruba beter werken, dan het preventieve toezicht, zeker als daar financiële sancties aan zouden zijn verbonden.

Met name het preventieve en positieve toezicht betekenen een duidelijke inmenging in de Landelijke en Eilandelijke autonomie. Slechts op grond van krachtige argumenten zal naast het algemene repressieve toezicht van de Koninkrijkskroon een andere vorm van toezicht kunnen worden geaccepteerd. Op Koninkrijksniveau zou kunnen worden vastgesteld dat preventief toezicht alleen zal geschieden bij AMvRB of bij Rijkswet op grond van een aantal criteria, voldoende gemotiveerd en met de mogelijkheid van een rechterlijke controle. Het preventief toezicht in welke vorm dan ook zou moeten worden getoetst aan de volgende criteria: 
- de mogelijkheid en haalbaarheid van een 'geïntensiveerd' repressief toezicht of een duidelijke motivering waarom het repressieve toezicht onvoldoende resultaten oplevert;

- aanvaardbaarheid van de verschillende toezichtmotieven;

- randvoorwaarden voor preventief en positief toezicht;

- het niveau waarop het toezicht moet worden uitgeoefend;

- mogelijkheid voor het Land of het Eiland de wijze van uitoefening van het toezicht te beīnvloeden;

- de wenselijkheid van toetsingsnormen;

- algemene gedragsregels voor de toezichthouder;

- procedurele voorschriften voor de wijze waarop bepaalde vormen van toezicht moeten worden toegepast;

- evaluatie van de werking en de resultaten van het voorafgaande toezicht.

Voorzover een ontwikkelde visie met betrekking tot voorafgaand toezicht niet in een wet kan worden vastgelegd zou een dergelijke visie op grond van de hierboven genoemde criteria wel als richtsnoer moeten dienen voor wetgeving die toezicht regelt. De motieven voor de invoering van toezicht moeten helder zijn. Motieven voor toezicht, vertaald vanuit het ontwerp Gemeentewet naar de Antilliaanse en Arubaanse situatie kunnen zijn:

- coördinatie: voorkomen/oplossen van belangenconflicten tussen Land en Eiland;

- beleidsbewaking: afstemming van het beleid van het Eiland op het Land, of van het Land op het Koninkrijk. Terughoudendheid met preventief of positief toezicht is geboden. Excessen kunnen meestal afdoende worden bestreden op grond van repressief toezicht. Indien een wettelijke regeling specifiek op coördinatie is gericht kan preventief of positief toezicht in een medebewindsregeling aanvaardbaar zijn;

- beleidsbewaking: afstemming van het beleid van een lager orgaan op dat van een hoger orgaan. Gaat het om autonome bevoegdheden dan kan er geen sprake zijn van preventief toezicht. De autonome taakbehartiging veronderstelt immers dat het Koninkrijk en het Land de behartiging van de desbetreffende taak overlaten aan de Eilanden en zelf dus geen beleid ter zake voeren. Wel kunnen op grond van een bepaald Koninkrijks- of Landsbelang dat krachtige bescherming verdient en niet geheel afhankelijk dient te zijn van plaatselijke inzichten, bepaalde taken in medebewind worden geregeld. Dat kan gebeuren door het stellen van bepaalde normen, waarbij aan de Eilanden een 
ruime beleidsvrijheid wordt gelaten. In zo'n geval kan preventief of positief toezicht redelijk zijn. Een medebewindsplicht, eventueel met een termijnstelling waarbinnen een Landsbesluit of een Eilandsbesluit niet in werking mag treden, zal in veel gevallen voldoende zijn. De hogere overheid krijgt immers op deze wijze ruimschoots de gelegenheid het desbetreffende besluit aan de gestelde normen te toetsen en het besluit zonodig voor te dragen voor vernietiging;

- $\quad$ kwaliteitsbewaking: controle op de deugdelijkheid, de technische kwaliteit van het besluit. Aan het motief van kwaliteitsbewaking ligt de veronderstelling ten grondslag, dat de kwaliteit van het ambtelijk apparaat van de hogere overheid beter zou zijn dan dat van het Land of het Eiland. Of dat zo is zal van de omstandigheden afhangen. Het beleid dient erop gericht te zijn dat de bestuurskracht van het Land en het Eiland voldoende is toegerust. Preventief of positief toezicht moet indien noodzakelijk spaarzaam worden toegepast. Lichtere vormen van beïnvloeding zullen eerst moeten worden uitgeprobeerd, zoals verplicht advies vragen aan bepaalde Landsinstanties, Koninkrijksinstanties of andere terzake kundige instanties;

- financiële motieven: bevordering van een gezond en evenwichtig financieel beleid van de Eilanden en het Land. Vanouds ging het hier om het reeds door Thorbecke genoemde motief: 'Voorkomen dat de vermogenstoestand van de gemeente wordt geschaad door de kortzichtigheid van het zittende bestuur'. De gemeenten waren in het midden van de negentiende eeuw financieel nagenoeg onafhankelijk van de centrale overheid. De eigen beleidsruimte van de lagere overheden is echter met het inkrimpen van het eigen belastinggebied en de toenemende tekorten steeds verder teruggedrongen.

De positie van de Nederlandse Antillen en Aruba heeft zich altijd onderscheiden van de positie van de Nederlandse gemeenten, omdat de voormalige kolonie vanaf zijn ontstaan regelmatig met financiële tekorten werd geconfronteerd. Dit vond vaak plaats door onbegrip voor de situatie ter plaatse van de autoriteiten in het moederland, de slechte honorering van de bestuursambtenaren en de geringe mogelijkheden voor economische bedrijvigheid. Indien de Eilanden in een aangepaste bestuursstructuur zullen worden opgenomen, met een status aparte of provinciale status, dan nog zal decentralisatie van Landsbevoegdheden moeten samengaan met voldoende bestuurskracht zowel wat menskracht, deskundigheid als financiën betreft. Een zekere mate van sturing is echter gewenst, gezien de deplorabele 
toestand van de financiēn van de overzeese rijksdelen, temeer daar de nu ontstane situatie niet van vandaag of gisteren is.

Voorkomen moet worden dat de Landsfinanciēn of Eilandsfinanciën in een uitzichtloze situatie geraken. Wettelijk verplichte uitgaven moeten niet te laag op de begroting worden opgenomen. Sanering van het overheidsapparaat kan daar een bijdrage aan leveren. Bovendien moet er meer inzicht komen in de uitgaven van de Landsoverheid en de Eilandsoverheid. Ook zou Nederland specifieke uitkeringen kunnen doen op grond van duidelijke onderbouwde projecten. In deze specifieke situatie zou daarom een vorm van preventief toezicht gekoppeld kunnen worden aan de aanbevelingen van de Nederlands-Antilliaanse en Arubaanse Rekenkamer en het financieel beleid van de overheid in de voorgaande perioden. Hiermede zou wel zeer spaarzaam omgegaan dienen te worden. Via normstelling bij of krachtens wet kan het financiële overheidsbeleid worden bijgesteld. Aanvullend preventief toezicht kan wel worden gerechtvaardigd indien lagere overheden door hun beslissingen de uitgaven van het Koninkrijk, van elkaar of van derden kunnen beinnloeden.

Een te stringent toezicht moet echter worden vermeden, omdat dat in het algemeen zal leiden tot een bureaucratische rompslomp bij de toezichthouder, hetgeen weer leidt tot een onevenredig beslag op de beperkte middelen en tot vermindering van verantwoordelijkheidsbesef en initiatief bij de lagere overheden. De ervaringen in de verschillende beleidssectoren en de koloniale geschiedenis van de Nederlandse Antillen en Aruba, zoals in de voorgaande hoofdstukken beschreven staven de relevantie van deze stelling;

- rechts- en belangenbescherming van de burger: dit motief wordt gevonden bij administratief beroep, dat ook als een vorm van toezicht kan worden beschouwd en in Nederland ook bij de goedkeuring van verordeningen en plannen. Dit toezicht zal marginaal moeten zijn, zeker in de gevallen waarin de regeling door de volksvertegenwoordigende organen wordt vastgesteld. Zolang deze gedecentraliseerde regelgeving en planning binnen de grenzen van de wet blijft, moet immers in beginsel worden aangenomen dat zij geen onaanvaardbare aantasting van de rechten en belangen van de burgers vormt. In de gevallen waarin de democratisch tot stand gekomen regelgeving en planning van de lagere overheden op willekeur lijkt of anderszins de belangen van bepaalde groepen van burgers op onaanvaardbare wijze aantast, kan de hogere overheid wel besluiten dergelijke regels 
of plannen niet te handhaven. De achtergronden van een eventueel optreden van de hogere overheid is dan een zekere bescherming van minderheden en van fundamentele beginselen van behoorlijk bestuur waarmee ook bijgedecentraliseerde wetgeving rekening moet worden gehouden. Belangrijke wetgeving kan worden gebonden aan een plicht tot mededeling (al dan niet met opschortende werking) of verplicht overleg of advisering. De vraag is of in de bestaande situatie met repressief toezicht kan worden volstaan en of niet ook een vorm van preventief of positief toezicht noodzakelijk is, nu de Landsverordening Administratieve Rechtspraak in beide Landen op zich laat wachten. ${ }^{38}$

Gezien de hierboven uiteengezette aanbevelingen en dan met name die ter versterking van het hoger toezicht, kunnen de volgende vragen worden gesteld:

- Hoe zouden de vernieuwde staatkundige verhoudingen er uit moeten zien om zo goed mogelijk inhoud te geven aan het verlangen naar autonomie?

- Hoe zou in de vernieuwde staatkundige verhoudingen de taakverdeling moeten zijn tussen Koninkrijksorganen, de organen van de Landen en de organen van de Eilanden?

- Hoe kunnen waarborgen geschapen worden voor de kwaliteit van het bestuur?

Meer autonomie houdt ook meer verantwoordelijkheid in. De rechtsstaat, de beginselen van democratie, de fundamentele rechten en de betrouwbaarheid van bestuur moeten gewaarborgd zijn. Om dit te realiseren zal meer tijd nodig zijn. De landen die voor een autonome status hebben geopteerd kunnen die krijgen, binnen de rechtsstatelijke grenzen zoals besproken op de conferentie. Dat betekent dat in Curaçao de Landsoverheid zal worden afgeschaft. Bonaire, Saba en Sint Eustatius zullen in een samenwerkingsverband met Curaçao en/of Aruba worden opgenomen.

Een andere mogelijkheid is een rechtstreekse band met Nederland, die eventuele band zal nog nader moet worden uitgewerkt. Intereilandelijke geschillen zouden kunnen worden voorgelegd aan een Bestuurlijke Kamer van het Gemeenschappelijk Hof van Justitie. besturen, Tweede Kamer, vergaderjaar 1985-1986, 19403, nr. 3. 
Deze aanbevelingen kunnen óók worden toegepast indien toch een samenwerkingsverband tussen de Antilliaanse eilanden (en Aruba) tot stand zou kunnen komen. De uitslag van het referendum wijst daarop. Ook al zou een samenwerkingsverband in de nabije toekomst mogelijk blijken, dan nog zullen er vele problemen moeten worden overwonnen om een werkbaar samenwerkingsverband te kunnen construeren.

Duidelijk is dat de bestuursproblemen zo groot zijn geworden dat ingrijpen door Nederland welhaast onvermijdelijk is geworden. De politieke verhoudingen in de Nederlandse Antillen en Aruba liggen zo gecompliceerd, dat ingrijpen door een 'buitenstaander' (Nederland) niet te voorkomen lijkt. Deze conclusie wordt versterkt door de bestaande politieke constellatie op de Nederlandse Antillen, waar de Landsregering mogelijk ondeugdelijk bestuur van een der Eilanden in stand laat om de coalitiepartner(s) van de Landsregering niet te contrariëren. Het toezicht van het Land op het Eilandsbestuur functioneert vaak niet zoals het zou moeten. Indien het bestuur op Landsniveau niet voldoet, kan alleen de Koninkrijkskroon ingrijpen. Daartoe zijn medebewind en de verschillende vormen van toezicht de beste middelen. Als de Landen en de Eilanden geen deugdelijk bestuur kunnen waarborgen zal meer autonomie alleen maar leiden tot een vergroting van de reeds bestaande bestuursproblemen. Wellicht kan toezicht tot een minimum worden beperkt als binnen de nieuwe staatkundige verhoudingen het Land of het Koninkrijk meer gebruik zou maken van een aangepaste en moderne vorm van medebewind. Ook al is de Gemeentewet als rolmodel voor de ERNA aan veel kritiek onderhevig geweest, toch kan een aantal aanbevelingen uit de nieuwe Gemeentewet bijdragen aan een flexibele mogelijkheid om binnen Koninkrijksverband te komen tot een aanvaardbare manier van invulling van de nieuwe Koninkrijksverhoudingen. Naast bepaalde vormen van toezicht zal een mogelijkheid van rechterlijke toetsing moeten worden ingevoerd voor ingrijpende maatregelen van toezicht.

Geconcludeerd kan worden dat de rijksregering er verstandig aan zou doen bij geconstateerd wanbestuur van een (ei)landsbestuur, de statutaire toezichtsinstrumenten te hanteren. Als de stille diplomatie of de openbare discussie niet werkt kan gebruik worden gemaakt van de vernietigingsbevoegdheid en de bevoegdheid tot het treffen van voorzieningen bij taakverwaarlozing. Het vragen van verantwoording krijgt immers pas reliëf als de Koninkrijksregering bereid is onverant- 
woordelijkheid te sanctioneren door de toepassing van hoger toezicht. Aanstellingsbesluiten van zich misdragende ambtsdragers zijn niet onschendbaar. Een verantwoording vragende Koninkrijksregering heeft om zo te zeggen een motie van wantrouwen achter de hand. De Koninkrijksregering beschikt over machtsmiddelen die een verontruste burger die een misstand aan de kaak wil stellen niet heeft. Sterker nog, een dergelijke burger heeft in een kleinschalige omgeving waar de politiek alom tegenwoordig is, een behandeling als politieke dissident te vrezen. Een dergelijke behandeling kan echter dragelijk worden, indien men het vertrouwen heeft dat petities bij het eindverantwoordelijkheid dragende gezag zinvol zijn. Munneke omschrijft dit heel spits: "indien de rijksregering verantwoordelijk bestuur wil zien, dan is vanuit staatsrechtelijk oogpunt het recept eenvoudig: vraag verantwoording en stel verantwoordelijk." De politieke boodschap van de Nederlandse regering aan de Antillen en Aruba is duidelijk: óf men wordt onafhankelijk of men accepteert waarborgen voor deugdelijk bestuur. ${ }^{39}$ In die zin zit Nederland in feite nog op het oude spoor. Onafhankelijkheid voor de Nederlandse Antillen en Aruba (op termijn). Willen de overzeese rijksdelen binnen bet Koninkrijk blijven, dan zal het Nederlandse toezicht worden verscherpt. Onder de huidige omstandigheden houdt dit echter geen kolonisatie in, maar afleggen van verantwoordelijkheid door de landsbesturen en eilandsbesturen voor het door hen gevoerde beleid. Autonomie houdt verantwoordelijkheid in en daarvan kunnen de bestuurders van de rijksdelen in de West zich niet ontdoen, noch voor wat betreft de eigen bevolking, noch voor wat betreft de Koninkrijksregering. De kern van dekolonisatie is nu juist de eigen verantwoordelijkheid willen en kunnen dragen en $66 \mathrm{k}$ bereid zijn daarvoor verantwoording af te leggen.

De lezer zal het ongetwijfeld duizelen van alle meningen en modellen, die hiervoor aan de orde zijn geweest. Om de staatkundige toekomst van de Nederlandse Antillen en Aruba te kunnen bepalen is een objectieve zakelijke afweging van de voor-en nadelen van verschillende mogelijke staatsrechtelijke samenwerkingsverbanden nodig. Daarnaast kan de staatkundige ontwikkeling niet begrepen worden als niet ook affiniteit bestaat met het Antilliaanse, Arubaanse en Nederlandse politieke denken over de Koninkrijksstructuur en dan in onderlinge vaak tegenstrijdige context bezien. 
Het verleden heeft die structuur sterk bepaald. Het Antilliaanse en Arubaanse politieke denken is beïnvloed door de kolonisatie, de eilandelijke en landelijke beeldvorming over de gewenste staatkundige structuur, hooglopende emoties over vermeende overheersing van het ene eiland ten opzichte van het andere eiland en een grote financiēle afhankelijkheid van Nederland. Ook speelt de ambivalente verhouding met het moederland een belangrijke rol.

Thans is een omslagpunt bereikt, waarbij de centrifugale krachten ontketend door het recente Nederlandse beleid, de Nederlandse Antillen en Aruba ver van elkaar dreigen te verwijderen. Nederland heeft die verwijdering nooit gewenst en de uitslag van het referendum in Curaçao heeft die centrifugale ontwikkeling voorlopig afgeremd. Hoe de door Curaçao gewenste samenwerking gestalte zal krijgen is nog niet duidelijk. De commissies die de gewenste samenwerking gestalte moeten gaan geven behoeven geen nieuw ei van Columbus uit te vinden. Alle informatie is er al. Alle mogelijke en onmogelijke problemen zijn reeds geanalyseerd en alle gewenste en ongewenste oplossingen zijn reeds aangedragen. Volstaan kan worden met alle oude nota's uit de bibliotheek te halen en daaruit de gewenste oplossing op te zoeken en aan te passen aan de bestaande situatie. Munne$\mathrm{ke}^{40}$ noemt dit het leerstuk van de protocolmatigheid van bestuur. Het vereist het bijhouden van kasten vol met vergaderstukken en krantenknipsels. Als al die verzamelde achtergrondinformatie en opgeslagen kennis selectief zou worden toegepast dan hebben de nog te benoemen commissies een sinecure.

Welk stelsel men ook zal kiezen, de essentie van het stelsel zal worden bepaald door de werking van het systeem in de praktijk en die is grotendeels afhankelijk van de gegroeide politieke cultuur. Willen de Nederlandse Antillen en Aruba 'deugdelijk bestuur' realiseren en gelijkwaardige partners blijven binnen het Koninkrijk der Nederlanden dan zullen de landsregeringen en de eilandsbesturen zelf de noodzakelijke veranderingen in het overheidsbestuur en de politieke cultuur moeten invoeren en handhaven. Indien dat gebeurt zal Nederland ook voor de rijksdelen overzee de wapenspreuk 'Je Maintiendrai' willen handhaven, inplaats van 'Ik zal loslaten'. 


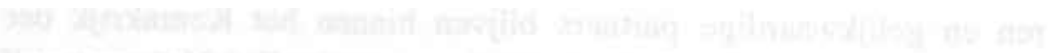

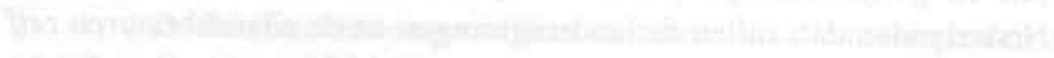

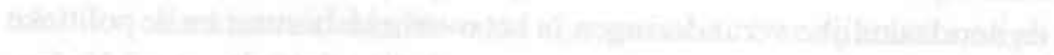

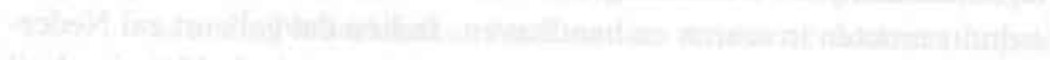

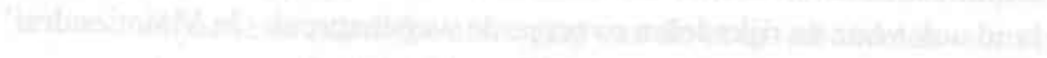

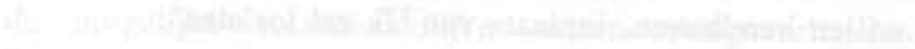




\section{Summary}

This study of the political and constitutional development of the former Dutch colonies in the Caribbean concerns its transformation from a colony into a parliamentary democracy.

An attempt has been made to show what actually happened in the 'Netherlands Antilles' and what lay underneath the words and actions of the Antillians and the Dutch who were most instrumental in determining the course of events. It has, therefore, been necessary throughout the entire study to relate the political and constitutional evolution to the economic, sociological and cultural development in the Antilles, while a historical survey supplies the perspective for understanding the significance of what took place between 1634 and 1994.

The first chapter provides an explanation of the scientific foundation and execution of this study, as well as a clarification on the framework for the historical perspective. The propositions to be answered by this study were formulated as follows:

1. To what extent did the Dutch colonial government and the constitutional development of the state of the Netherlands influence the existing constitutional order of the Netherlands Antilles and Aruba?

2. Which influences in the past caused the 'Status Aparte' of Aruba?

3. Is it possible to draw conclusions from the answers on the propositions 1 and 2 and to make and present scientifically sound recommendations for a future generally, acceptable constitutional order of the Kingdom of the Netherlands?

The constitutional history of the colonies Curaçao and dependencies and Sint Eustatius and dependencies - since 1845 Curaçao and dependencies, and since 1948 the Netherlands Antilles - is discussed mostly in chronological order.

A division is made according to important constitutional changes. For better reference the constitutional history of the colony is divided into certain time intervals which brought considerable constitutional 
changes.

Period I deals with the time interval 1634-1792. In 1792 the government of the West India Company was terminated.

Period II covers the years $1792-1815$, in this period the Netherlands were moreless under French rule.

Period III includes the years 1815-1828; period IV the years 1828-1845 and period $V$ the years $1845-1865$. In these periods the Dutch State governed the colony and tried to implement another form of government in order to decrease the amount of money the Netherlands had to pay in governing the upkeep of the colony. It was understood that colonies ought to yield a profit. In 1865 Governmentregulations were introduced by law and no longer by a Sovereign decree.

Period VI covers the years $1865-1936$. In 1865 the colony was granted a beginning of democracy, this became more evident in the first real constitution for the Netherlands Antilles in 1936.

Period VII discusses the years 1936-1950. In this period a parliamentary democracy slowly emerged. In 1951 the Netherlands Antilles possessed all the outward aspects of a modern democracy.

Period VIII covers the years 1950-1986, when Aruba became an autonomous territory within the Kingdom of the Netherlands and period IX deals with the years 1986-1993, when the remaining islands of the Netherlands Antilles were searching for a new constitutional constellation within the Kingdom. An analysis of every period will be executed according to the following criteria:

- the influence of the evolution of Dutch government on the colonial government;

- the evolution of the organs of the state in the Netherlands and its influence on the governmental institutions in the colony and the practice of the rule of law in the colony;

- the division of power within the state, the influence of the 'Trias Politica' on the government of the colony;

- the influence of the people on the legislature of the colony;

- the influence of human rights on the governement of the colony, especially on the treatment of slaves;

- the distribution of the law in the colony;

- the impact of slavery, colour differences and class differences in granting political rights, obligations and privileges to the nonwhite inhabitants of the colony.

- the influence of the previous criteria on the present constitutional structure of the Kingdom. 
After a historical outline an educated guess is presented on the future of the Kingdom of the Netherlands and the reasons for the expected development. In the colonial era the Dutch presence in the colonies was very significant. Until 1948 there existed hardly any influence of the population in the governement of the colony. In the future Dutch influence might increase again. Not to colonize the former colonies anew, but to support the Netherlands Antilles and Aruba in becoming self-sufficient in governing their own territories.

\section{The origin of overseas expansion, period I}

Period I deals with the interval 1634-1792 when the West India Company ruled the colonies. Holland ventured to reach the tropical antipodes not only because their nemesis, Philip II of Spain, annexed Portugal and forbade the Dutch entry to Lisbon. The United Netherlands were a nation of merchants, a brokerage house for northern Europe, and it wanted to get to the source of tropical wealth itself. Dutch navigators and traders knew the location of the fabled Indies, they were well acquainted with Portuguese achievement at sea, and counted among their members individuals who had worked for the Portuguese. After 1585 the trade with the west coast of Africa developed. This was promoted by the fact that a great many business relations between Portuguese and Dutch traders existed, notably with regard to the Brazilian trade. The States-General of the Dutch Republic played an active part in supervising the African and American trade. Thus in 1614, they issued a 'General Charter', according to which those discovering new passages, ports, or countries were to be allowed to profit for from their discoveries for a certain period of time without competition from other Dutch traders.

During the seventeenth century the Dutch extended their influence in the Caribbean by means of superior naval strength, use of armed intervention which was often ruthless, by shrewd politicking and exploitation of local differences. It became apparent to the Dutch that al these separate ventures did little to promote welfare. So in 1621 a contract was concluded which in effect merged individual enterprises into one West India Company, better known under its Dutch acronym as the WIC.

The framework of the organization and the powers of this body were broadly analogous with those of the United East India Company (VOC) established in 1602. The WIC was not an unqualified success.

From the very start the WIC had to respect all sorts of vested interests, while at the same time conducting a continuous struggle against 
captains and merchants who tried to evade its monopoly.

The trade of the English, the French and the Dutch in the Caribbean area in the wake of the Spanish, had originally a commercial, but later on also a strategic purpose, namely the interception of the treasures with which Spain financed her wars against rising new nations. The Netherlands found a harbour in Curaçao which offered an excellent refuge and which gave the island ideal opportunities for establishing an emporium for the traffic of slaves and goods. St. Eustatius was also favourably situated for this purpose. The hunt for salt, tobacco, and Spanish merchantmen formed the principal attraction of the islands in the Caribbean Sea. Salt and dyewood from the islands of the Leeward Group, off the Venezuelan coast, were in great demand.

The later so-called 'Netherlands Antilles' - consisting of the islands of Curaçao, Aruba and Bonaire (Leeward Group), all lying off the South American mainland, and to the north the very small islands of St. Martin (partly French, the Dutch part called Sint Maarten), St. Eustatius (Statia) and Saba (Windward Group) - had a central Dutch administration for more than three centuries. Period I is discussed at the start of chapter II and continues with the periods II-V.

\section{Colonization, periods II-V}

Period II discusses the space of time 1792-1815, a time of revolution and restoration, when the colonies were directly governed by the Dutch State. The Netherlands endeavoured to reduce the costs of governing the colonies in this period, however to no avail. In period III, 1815-1828 the colonies were governed by the King. From 1828 till 1845 (period IV) the colonies, including Suriname were united under one Governor-General, representing the King, with a view to reducing the costs of governing them. As this did not work the colonies were divided again in 1845 and the six Caribbean islands were joined together in one colony. From the end of the Napoleonic period until the introduction of the Government-regulations of 1865 constitutional modifications were repeatedly made, among others those required first for the union of Suriname and the Antilles and in 1845 for their division. Period V concerns the time period 1845-1865.

The second chapter covers the years 1634-1793, 1792-1815, 1815-1828, 1828-1845 and 1825-1865. The government of the colony by means of a Company with limited liability, the West India Company (WIC) under the supervision of the Republic of the United Nether- 
lands (1634-1792) is considered first. The WIC exercised governmental authority at the same time. In due course the government of the State of the Netherlands and the King in the colony is explored. One may freely state that the inhabitants of the colony did not have any influence oin the government of the colony. The colony was autocratically ruled by the officers of the WIC and later on by the representative of the King. There existed no division in the power of the state officials. All main legislature was ordained by the Dutch government. In the colony the Council, de Raad van Politie, which made the local rules, also executed them. In that same capa- city and composition the Council administered justice. Chapter II deals with the periods I-V.

\section{Slavery and the slave trade}

Slavery existed in the Dutch colonies from 1634 till 1863. As this institution did not very well fit in one period it was decided to consider slavery separately in chapter III. The implications of slavery for the colonial society are indeed penetrating. The influence on the structure of the colonial society was of a very definite nature, slavery left strong marks on the present society of the Caribbean islands. Although slavery was a subject regulated by civil law it had an enormous effect on class relations and therefore was eminent in structuring constitutional and political relations in the colony. So far all textbooks on Dutch state- and governmental law utterly ignore slavery and its aftermath in the former Dutch colonies. An omission not lightly to be excused, it seems.

Slavery and the slave trade were already well established when Europeans first called upon Africa to obtain labour necessary to come into possession of the treasures which the newly discovered land on the other side of the Atlantic promised to yield. Since then the African negro, brought over as a slave from his native country, or born in slavery in the colonies, has during three centuries supplied the manpower required for the economic development of the new world.

For the Dutch the slave traffic became a no longer generally despised business, but a very profitable and as soon as they had acquired important interests in tropical America and had driven the Portuguese from West-Africa, a very risky one. In the seventeenth century foreign colonies also depended on Dutch trade and capital for their supply of slaves and for the disposal of the products procured by the labour of the blacks. 
Local colonial regulations nor metropolitan legislation could protect the slaves from harsh treatment and ruthless masters in times when violence and cruelty were deemed suitable means in maintaining order and discipline, and in administering criminal justice, also in free society. The Dutch were not known for their benevolent treatment of slaves.

In the Netherlands the question of slavery never met with a real and practical interest of large strata of society. The public at large was rather indifferent to the case of the slaves. Abolition of slavery had become necessary after the English had liberated their slaves in 1833 and the French in 1848 , and so hardly anybody in Holland and even in Suriname dared to declare himself against the principle of emancipation.

The British and French example were very reluctantly followed. The Dutch government had made inquiries into the possibilities of emancipation without costs to the State but with a compensation to the proprietors of plantations. It took the Dutch government ten years to pass the bill for the emancipation of the slaves.

In the colonial society colour nearly always corresponded with class and status. This did not change much, although in the course of time the former colony became a member of the Kingdom of the Netherlands on equal footing with Holland. How prominent 'colour' still is, became evident in the riots on Curaçao, on May, 30, 1969. It also became manifest in the struggle for Arubian independence ('autonomy') from Curaçao. The Arubians generally mistrusted the inhabitants of Curaçao, because their complexion is darker than most Arubians who pride themselves on their Indian ancestry. This colour division, often ignored and officially discarded still rules the relations between the races and classes to a large extent.

\section{Stable colonial government, period VI}

Period VI deals with the stabilization of the colonial government between 1865 and 1936. The Government-regulations of 1865 meant a modernization of the public institutions. Curaçao and dependencies were granted a nominated Koloniale Raad (Colonial Council). The Government-regulations were revised several times, the most important revision being the adjustment in 1936 by which the influence of the population on the government proceedings was enhanced.

Since 1865 the colonies had the right of budget which however was subject to certain restrictions. The most important of these restrictions 
was that if the budget showed a deficit its approval should take place in the Netherlands.

There was hardly an affair in which the Crown or the Parliament would not have the last word.

An era of unprecedented prosperity and population growth resulted from the establishment of oil-refineries on Curaçao (1915) and Aruba (1924). Within three decades after these industries were established, the population of Curaçao doubled and the population of Aruba more than trebled mainly from the influx of foreign labour. The standard of living rose to a higher level than on any other West-Indian island; agriculture always small scale because of arid soil and poor transport, was mostly abandoned. Considerable modification of the Antilles social structure resulted from greater prosperity, increased population, improved educational facilities and social conditions. Aruba and Curaçao became 'boomtown' communities and part of the twentieth century industrialism, while the presence of great numbers of European Dutch and other foreigners disturbed the traditional set social patterns.

As a result of the introduction of limited suffrage in 1936 for two thirds of the fifteen seats in the Legislative Council, popular influence was increased. The Royal Governor retained a wide range of powers, however, so did the Dutch Crown and parliament, despite the fact that the Antilles became economically self-supporting in 1929. The emergence of political parties focussed on personalities rather than on principles.

Party organization, then as now, has been consistently characterized by its looseness. Almost every one of the many political parties depended for its action on one or a few personalities who appeal to the voters at election-time, but who are generally too overburdened with other work to maintain contacts with the electorate at other times. ${ }^{1}$ Chapter IV analyses period VI (1865-1936).

\section{Decolonization, period VII}

Period VII analyses the time between 1936 and 1950 , when decolonization emerged and the former colonies slowly progressed to a status of equal membership with the Netherlands in the Kingdom. The influence of the Second World War, in which the West-Indies re-

Kasteel (1956) pp. 325-329.

Summary .573 
mained the only unoccupied part of the Netherlands Kingdom, was very important for the start of decolonization. Politically, this period has been increasingly characterized by a widespread desire for change, partly due to economic factors such as the enormously increased costs of living, diminished trade because of shipping and dollarshortages, and the scarcity of labour. Political parties started agitating for 'autonomy': a wholly elected legislature, universal suffrage, responsible government and abolishment of the power of Dutch organs to intervene in internal Antillian affairs. They based their demands on the promise of Queen Wilhelmina in December 1942 that relations between Holland and its overseas territories would be altered to a basis of voluntary association and self-government in internal affairs.

After the Second World War the difficulties in Indonesia accounted for the fact that the introduction of the new jurisdictional order envisaged in the speech of H.M. the Queen had to be postponed. In 1948 several important modifications were introduced into Government-regulations. A semi-parliamentary responsibility of the people's representation (Staten) to be elected by general suffrage was created. In the same year a revision of the Constitution of the Netherlands was effected which abrogated constitutional objections against further reforms.

Increased political rivalry between Curaçao and Aruba, resulted in a redistribution of seats in the legislature giving these islands equal representation despite their disparity in population. The new division was mainly based on the consideration that both islands were financially self-supporting. Curaçao-voters, however, soon started complaining about their small electoral value in relation to the inhabitants of the other islands. A round-table conference was held in 1948.

Aruba expressed the wish to be 'independent' of Curaçao and to enter into a direct relation with the Netherlands. In order to meet this wish as far as might be considered reasonable, extensive and thorough negotiations took place resulting in a settlement for the Antilles in which a very large measure of independence within the whole of the Netherlands Antilles, was granted to each island or "island territory". The three smaller islands of the Windward Group were considered to form one "island territory". The underlying principle was that the islands would get: 
1. their own organs for their internal affairs,

2. their own finances,

3. a competence of their own.

The reforms of 1948 did not prove to be very satisfactory in practice. As a result, a second series of reforms occurred in 1950/1951. Fully responsible government was introduced. Another redistribution of seats in the legislature followed, granting Curaçao additional representation. The Dutch power to interfere in internal Antillian affairs was abolished. A foundation for future cooperation between Holland, the Antilles and Suriname and the provisional regulations of the relationship between these three territories was established. Complete autonomy in internal affairs was enforced by law in 1951. Island-regulations were introduced in 1951, granting the islands a territorial autonomy. Chapter $\mathrm{V}$ analyses period VII.

\section{Responsible Government, period VIII}

Period VIII (1950-1986) deals with the realization of the 1954 Kingdom Charter, incorporating the new structure of the Kingdom of the Netherlands. In 1952 a Round-Table Conference was necessary to discuss the final jurisdictional order for the Kingdom. The conference had to be adjourned because of differences of opinion for which a solution could not be found at that time. The reforms were completed with the realization of a Charter (Statuut) for the Realm, by which the new jurisdictional order was established in 1954. The Statuut served as a constitution for a Kingdom consisting at that time of three 'equal' partners, the Netherlands, Suriname and the Netherlands Antilles, each autonomous in internal affairs. Only defense, international relations and a mutual guarantee for democracy and 'decent government' were defined as Kingdom matters and as such were for all practical purposes to be dominated by the Dutch administration.

The Charter sets forth the procedure for the conduct of 'Kingdom-affairs' which are restrictively enumerated. It contains the basic rights and duties of each of the three autonomous territories and guarantees of good government, the rule of law and certain fundamental human rights and duties. Approved by a qualified majority of the parliaments of each of the three territories, this Charter was proclaimed the supreme law of the Kingdom on December 15, 1954.

Each territory, however has its own constitution and its own jurisdiction. The impression could be created that the Kingdom of the Netherlands is a federation. This however is not the case as the 
Crown can suspend or nullify land or island ordinances and other resolutions and dispositions in case of contradiction with the international law or regulations, with a law or with a royal resolution or with the general interest of the Kingdom. Each territory has a Legislative Council, a Council of Ministers, a Judiciary and a Government Advisory Council. The Netherlands Antilles consist of five island territories. Each island has its own Island Council, Administrative Council and a Lt. Governor. The Netherlands Antilles and Aruba (since 1986) each have a Governor appointed by the Crown. The Governor is the head of state representing the Queen, he also acts as an organ of the Kingdom watching the general interests of the Kingdom in accordance with the provisions related to his activities and with due observance of the King' ${ }^{2}$ instructions. The Netherlands Antilles and Aruba each have a Minister Plenipotentiary in the Netherlands representing their interests in the Dutch parliament and the Dutch government. Each territory is independent in looking after its own interests. Not one of the specific territories constituting the Kingdom of the Netherlands is the competent instance to maintain international relations, only the Kingdom has that competence. Chapter VI also looks into the consequences of responsible government. In this chapter period VIII is covered until 1969, the year general unrest on Curaçao changed the political relations within the Kingdom.

\section{Independence granted, but not wanted, period VIII (continued)}

Chapter VII relates the political causes and constitutional consequences of the events that occurred on May 30, 1969. Popular unrest in Willemstad on Curaçao unexpectedly led to rioting and looting. In accordance with the 1954 Statuut of the Kingdom Dutch marines were called to reestablish order. As they did, the world press documented a European military intervention in an 'autonomous' former colony. Nobody liked this. The Dutch had felt themselves obliged to intervene. Now they were denounced for neo-colonialism. For the next two decades, 'May 1969' was the main reason for the Netherlands to insist on independence for the Netherlands Antilles and so the Dutch were unwillingly reinforcing centrifugal tendencies that were leading to a breakup of the six-island state, which at all costs the Netherlands wanted to keep together. Mainly for ideological reasons

2 For King can be read Crown, this is a modemized description more fitting in the present parliamentary system in Western Europe. 
successive Dutch governments tried hard to shed the former Dutch Caribbean colonies, which should become independent long before the end of this millennium. Linked to this interpretation was the conviction that the Dutch would impose 'voluntary' independence on these islands, just as they had done on Suriname. Suriname became independent in 1975, the post-independence history of Suriname is not encouraging.

The government of the Netherlands Antilles had a different attitude. Self-determination according to the Antillians could very well signify the deliberate choice not to attain full independence. This means that the Kingdom relations as defined in the 1954 Statuut should be considered as enduring, unless all partners involved opted for a change of the status quo. Chapter VII analyses the Antillian and Dutch opinions on independence (period VIII till 1986).

8. Aruba's struggle for 'autonomy' within the Kingdom, period VIII (continued)

No matter how sound the formal construction of the Dutch Kingdom may have seemed at that time, it did not ameliorate the underlying insular animosities in the Netherlands Antilles, existing since the 1930s. On the contrary the issue of Aruba's place in the Kingdom reemerged at the outset of the 1970s with more vigor than before. Next to Curaçao, Aruba is the most densely populated island. The Aruba issue essentially stemmed from the combination of a deep fear of political domination by Curaçao and of the consequences emanating from the emancipation of the black proletariat in Curaçao.

Since the 1930s the political elite of Aruba had strongly feared that any constitutional arrangement with Curaçao would de facto entail political domination by Curaçao, because of the latter's larger population. The frustrations stemming from the bureaucratic, centralized structure in Curaçao, which was inherited from the direct government by the metropolis before 1954 bolstered this perception.

The economic development process in the Antilles, especially since the end of the 1960s, had highlighted the fierce competition between Aruba and Curaçao, to the point that the existing conviction in Aruba still holds the progress of the islands to be mutually exclusive. Also the social tensions that erupted in Curaçao, particularly after May 1969, had un unsettling effect in Aruba, causing fear that these tensions could have spillover effects adversely influencing its 
moderately blossoming economy. ${ }^{3}$

Since the early 1970 s Aruba engaged in a struggle against the federal government which, after sixteen years, on the first of January 1986, resulted in the so called 'Status Aparte', which granted Aruba a modified independent status within the Kingdom of the Netherlands. This status stipulates that Aruba is no longer part of the Netherlands Antilles but is granted prerogatives within the Kingdom identical to those of the Antilles. This Status was achieved on the condition, imposed by the Netherlands, that Aruba would become independent in 1996. Since the 'Status Aparte' of Aruba, the three partners in the Kingdom are: the Netherlands, the Netherlands Antilles and Aruba. Chapter VIII deals with period VIII (1950-1986) till the 'Status Aparte' for Aruba was obtained. This chapter analyses the Arubian opinion on the subject of an autonomous status within the Antillian constitutional context.

9. Readjustment of the structure of the Kingdom after the 'Status Aparte', period IX

As a kind of penalty for their splitting the six-island state, the Arubians grudgingly had to accept another amendment to the Statuut: their full independence as of January 1, 1996. This package deal was resented by the Arubians and as soon as the separation of the Curaçao dominated Netherlands Antilles had materialized, Arubian politicians started to militate against the second phase of the convenant. Unlike the Netherlands Antillian juridical position, the Arubian position was disputable at best. The fact that in 1990 the Dutch administration declared its willingness to postpone Arubian independence for an indefinite time was a clear indication of the change in Dutch policy regarding its Caribbean legacy.

In the first few years after Aruba gained its separate status a certain amount of tension could be observed between that memberCountry and the Antilles, in particular in the field of civil aviation policy. Mutual relations have improved since then. The judicial cooperation between the Antilles and Aruba is working well. The collaboration on the drafting of uniform legislation for the two countries has not procured any legislation so far.

It cannot be said that the federation of the Netherlands Antilles has become more balanced now that Aruba has left. Referring to their 
right of self-determination confirmed at the 1983 Round Table Conference, various islands (mainly St. Maarten and Curaçao) have since then considered it necessary to raise the question of their future constitutional structure. New constitutional arrangements between the islands seem to be urgently needed. Since Aruba left the Antillian constellation the remaining islands have proposed all kinds of mutual relations, but so far they could not agree on any of them. The islands did not want to become independent.

The Antilles, a self-determining partner within the Kingdom, still feels that full independence is not an attractive alternative to the present situation, at least not until the islands state has attained a higher level of viability. With regard to international law, in particular from the viewpoint of the right of self-determination, at present the conclusion can be drawn that independence is not the only option open to non-self governing and other dependent territories. Although the famous United Nations General Assembly Declaration on Decolonization in 1960 was based on the idea of independence as the obvious outcome, if not the only goal, of the right to self-determination, later resolutions have abandoned this idea. A dependent territory can also attain full self-government by means of free association or integration with an independent State. The emphasis is on the free choice of the peoples concerned.

Since the Dutch have yielded to the issues of independence and the fragmentation of the Netherlands Antilles, they claim a stronger say in Antillian and Arubian affairs. In his 1990 'Schets', minister Hirsch Ballin linked the (indefinite) postponement of independence to firm regulations which should impede further changes of the status quo within the Kingdom. Any partner should be either in or out. This 'take it or leave it' approach suggests that the Dutch are willing to make considerable concessions, but will not refrain from imposing restrictions. This will lead to a reduction of the Antillian and Arubian autonomy within the Kingdom. Considering the outcome of the first conference on the future of the Kingdom in March 1993 and the contents of the aide-memoire of June 1993 in preparation of the second conference, this regulations and restrictions on autonomy are mandatory conditions for a restruction of the Kingdom.

On the first conference all Antillian islands were granted a separate status, much to their surprise. However, it became clear that very specific restrictions would be imposed by the Dutch government before the desired new structure within the Kingdom could be obtained. The imposition of this restructuring of the former Netherlands Antilles would imply a rather authoritarian start of the new Statuut period. Such a start would clearly qualify the pious statement in the 
Schets to 'take the wishes and longings [of the Antillians] in consideration as far as possible.

In the last three years subsequent Dutch state papers and the minutes of parliamentary meetings elaborated on ways for the Netherlands Antilles and Aruba to enhance their autonomy and self-reliance. The need for 'modernization' and 'professionalization' of public management emerged as a recurring theme. One senses a growing Dutch irritation over past and present performance of the Dutch Caribbean public sector. The increase in quality of the public sector is to be contrived by structural and long-standing assistance of Dutch specialists. Implicitly, however, one could read in these proposals a devastating comment on the policy of 'Antillianization' which has been a guideline for all Antillian governments since the early 1970s. This policy aimed at substituting Antillians for Dutch professionals at all levels of both the public and the private sectors. Now, for the Dutch policy makers, the pendulum apparently must swing back.

The change in Dutch policy has not primarily been inspired by economic or strategic reasons. Where Antillian politicians perceived continued Dutch presence as crucial, Dutch politicians may have thought of these last remnants of empire as a nuisance, but at least a minor one. An annual quarter of a billion Dutch guilders of development aide is crucial from an Antillian perspective. It is not critical to the Dutch. And while the migration outlet to the Netherlands may be essential for Antillians, additional Antillian immigration for Dutch policy makers is no welcome prospect, but neither is it a nightmare. Thus Antillian politicians and the electorate, both firmly opposed to independence, have benefitted from the very smallness of their societies, which made it easier for the Dutch to stop pestering them with the menace of unsolicited independence. In addition, the disillusion in Suriname's post-independence record did much to sober those who felt independence would provide the islands with a fresh impetus to attain economic and political viability and self-reliance. Ironically therefore, the Suriname debacle was a remote blessing for the Antilles. Finally, outside interests, particularly the US and Venezuela, may have put a mounting pressure on the Dutch not to relinquish these territories. The geopolitical risks of a power vacuum may have inspired such pressure; and more recently, problems associated with narcotrafficking and money-laundering have assumed major importance.

It is tempting to read 'recolonization' in these Dutch proposals. The persuasive long-term prospect offered is that professionalization will result in increased self-reliance and greater viability. Yet this prospect 
seems to be indeed long-term. Meanwhile Dutch assistance could put mounting pressure on the Antillian and Arubian public sector. From the Dutch perspective, it is justifiable that their Caribbean partners pay for being 'allowed' to remain within the Kingdom by relinquishing some of their previous autonomy. Growing Dutch involvement will also extend to more 'assistance' in the legal system and the administration of justice.

The Dutch are discontented over the previous decades of autonomy in internal affairs. This growing discontent transpires in the proposed regulations and restrictions on the autonomy of the Netherlands Antilles and Aruba, as put forward on the conferences on the future of the Kingdom and the aide-memoire of Prime-minister Lubbers of June 1993. Telling is the strong connection the Dutch are making between 'good government' and a new Kingdomcharter. Likewise, occasional allusions to the political culture of the islands, the islands being on such a small-scale and therefore restricting the scope for policy making by local politicians, may be read as a suggestion that outside (Dutch) interference is needed to make things work. In this regard, persistent rumors and indications of public sector corruption, money-laundering and narcotrafficking in Sint Maarten have now facilitated a Dutch involvement.

Higher supervision was imposed on Sint Maarten in mid-1992. First based on an Interim Provision of the Council of Ministers of the Kingdom and afterwards through the ' $A M \nu R B$ ' (General Measure of the Kingdom Government) for the duration of one year. This Measure provided preventive supervision by the Governor on decrees by an island organ, in case these decrees had considerable administrative and financial implications. The Measure has been effective as an instrument to prevent serious forms of undesirable government acts, however it was not effective to improve the quality of administration permanently. Actually the Sint-Maarten Government is not considered capable of continuing the ongoing process of administrative improvement on its own. A different provision with far-reaching powers for a special Lieutenant Governor is contemplated for a period of two years. ${ }^{4}$

One could conclude that Dutch patience with its partners has run out. The Dutch and West-Indian political opinions on the issues of good government and the restructuring of the Kingdom differ to a large extent. But this does not mean that the Dutch wishes can be ignored

Rapport van de Commissie Evaluatie Hoger Toezicht Sint Maarten, januari 1994. 
much longer. This might have been a good strategy in the 1980s, but another mood is prevailing in Dutch government and parliament. A more successful strategy nowadays would be to negotiate the Dutch demands. It also is of no use any longer to threaten the Dutch by becoming independent, that is if the Netherlands Antilles and Aruba do not wish to become independent in the near future. The Dutch will gladly grant full independence if the Netherlands Antilles or Aruba so desire. In the past the Antillians could considerably influence the Dutch policy to their advantage by using the argument of three hundred years of colonial repression. That argument is now considered obsolete by the Dutch, as they do not want to accept that argument as an excuse for long-standing mismanagement of the public sector.

If the Antillians and Arubians do not wish to negotiate, the Dutch might very well impose unilateral restrictions on both WestIndian partners of the Kingdom. Dutch MP's declared to be willing to impose restrictions on the unlimited entrance of Antillians and Arubians to the Netherlands. They also consider a cut-down in development-aid to the Caribbean part of the Kingdom.

The question arises where this will place the former Netherlands Antilles in the next decade? An educated guess points to the following scenario:

- independence is off;

- the former Dutch Antilles will further disintegrate, on the modalities a hard battle will be fought, which might take more than ten years;

- the Dutch presence will be reconfirmed.

Government policies and decisions with far reaching implications for the Netherlands Antilles and Aruba must be made with the approval of the population of the Netherlands Antilles and Aruba. It is essential that the population approves of the policy of their representatives. The referendum held on Curaçao in November 1993 indicated a strong preference of the population for an Antillian federation of the five islands. This contradicted the political opinion on Curaçao, which was in favour of a separate status for the island. On the other islands a referendum will be held in the near future, giving the population of an island the possibility to voice their wishes on a new Antillian constitutional relation.

It is, however, conceivable that due to the outline of the Dutch government the former unitary state of six islands of the Netherlands Antilles will eventually split into at least three independent entities. 
With independence postponed indefinitely and the formulation of a new constitution of the Kingdom on its way, orientation of the Dutch Caribbean islands to the metropolis is even more acute. ${ }^{5}$

A new Kingdom Charter is necessary as article 62 thereof stating Aruba will become independent per January 1, 1996, has to be eliminated, now that all parliaments concerned agreed to the amendment of article 62 to that effect. The new Kingdom Charter will certainly include heavy restrictions on financial mismanagement and will support and implement the rule of law within the Kingdom. But the islands will have every possibility to govern themselves. If they will not comply with the guarantees of good government specified in the Charter of the Kingdom the Kingdom itself will take over.

The conclusion of this study might be that constitutional problems rise anew but that their causes lie in the past and that a constitutional past casts long shadows. A lot can be learnt from that past so that costly and painful (constitutional) misunderstandings might be anticipated, as prevention is better than a powerless cure.

The motto of the weapon of the Kingdom reads: 'Je maintiendrai' (I will maintain). It applies to the Kingdom as a whole, nonetheless some caution is warranted or the motto might become: 'I will abandon'.

Chapter IX analyses period IX (1986-1993) the present constitutional position of the Kingdom with its predicaments and divines from the past which political and constitutional dilemmas should be recognized, envisioned and settled. Chapter $\mathrm{X}$ presents suggestions for a new Kingdom Charter on these pressing issues. These suggestions mainly incorporate a different approach of the Kingdom Government in Kingdom-matters and the implementation of higher supervision by legislature of the Kingdom Government.

Whenever the Netherlands Antilles or Aruba neglects its responsibilities or do not comply with Dutch indications for 'good government' as stated in the Kingdom Charter, the higher organ will inform the lower organ and a conference might be immediately convened to discuss the matter. The higher organ will invite the lower organ to take certain necessary measures. If no agreement is reached on resolving the matter, any of the two parties can appeal to an independent Constitutional Court, which will have the right to issue binding and final rulings and/or non-binding recommendations, for instance

Oostindie (1992). 
a specially created branch of the Kingdom Government Advisory Council (Raad van State).

If after a specified period these conditions or the recommendations or rulings of the Court are not observed the higher authority will implement the required adjustments, resolutions or dispositions, eventually by a General Measure of the Kingdom Government.

It is clear that the existing serious economic and financial problems in the Dutch Caribbean will not correct themselves and that imaginative and creative actions in problem solving and crisis management - a field in which the Dutch Caribbean lacks the necessary experience - should be encouraged. Aruba and the Netherlands Antilles believe that in order for these actions to have a certain degree of success, clarity should exist on the future constitutional status of the Dutch Caribbean. They deem clarity on this matter indispensable in order to attain those instruments and conditions, such as investments and tranquility, to enable the construction of a solid foundation for the future. The Netherlands are of a different opinion, they first want structural adjustment reforms, before they are willing to contemplate a reform of the Kingdom Charter.

As the Netherlands only just began to realize that independence could not be forced upon the Dutch Caribbean they never paid much attention to supporting the Netherlands Antilles and Aruba in becoming self-sufficient in governing their own territories. The existing problems cannot be solved by imposing Dutch technical assistance without including domestic talent and management. It does not answer to substitute domestic management for expatriate management. The necessary skills must be obtained from training domestic civil servants and managers mainly in their own country, in order to achieve a real civil service reform. Otherwise expatriate help might turn out to be a destructive force instead of a constructive power. The challenge is to keep safeguarding principles and the right of initiative and autonomy of the Caribbean partners within the Kingdom at the same time, and to respond to new positive developments in 'good government' as well. ${ }^{6}$

When the new legal order for the Kingdom is conceived, the Dutch Caribbean ought to be granted a more effective participation and involvement in the government of the Kingdom. These adjustments seem essential to counterbalance the increasing Dutch influence in the Dutch Caribbean.

The Courier, Africa-Caribbean-Pacific-European Community, September-October 1993. Dossier: Development Policies, pp. 48-86. 
In the long run even a federation between the islands might become possible again. The islands indeed have more in common which each other than they have with the Netherlands proper. If the islands will be able to perceive such a notion, they might see the profits of joining forces and living together. This certainly does not mean that there will suddenly be an ongoing honeymoon between the islands. But there are advantages as the small scaleness of the islands will not permit one island to survive on its own. So far an asymmetrical federal structure did not meet with the approval of Aruba. In the present Antillian constitutional system the smaller islands have a political influence far beyond their relative importance. For their own benefit the islands might learn to trust each other in the future, as it is impossible nowadays for any country to live in splendid isolation. The future seems hopeful as the referendum on Curaçao indicated a strong preference for an Antillian federation of the five islands. 


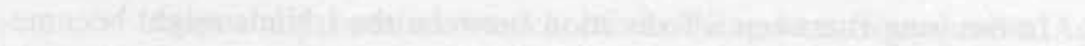

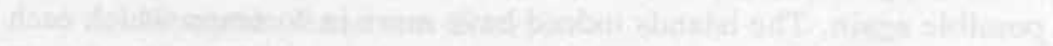

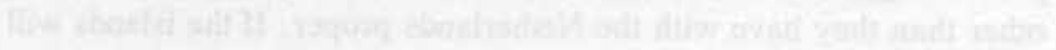

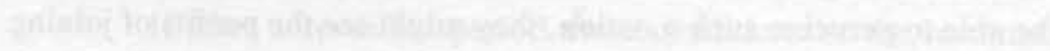

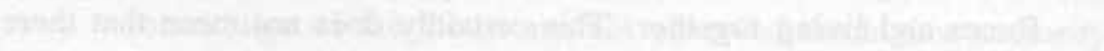

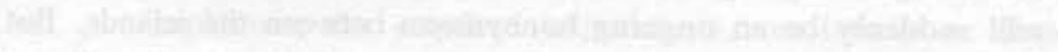

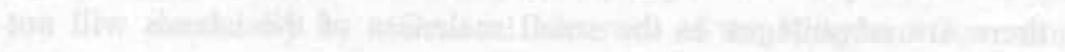

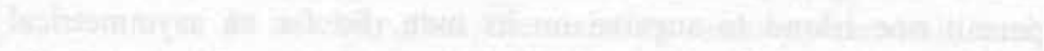

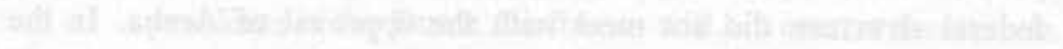

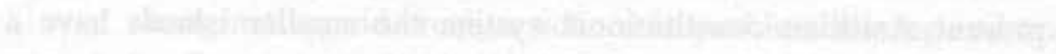

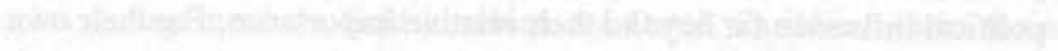
F.

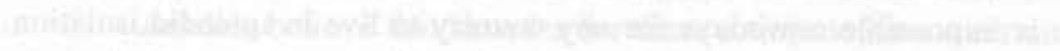

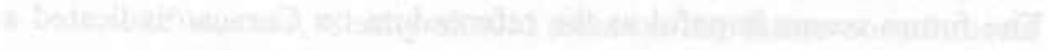

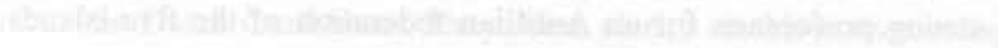

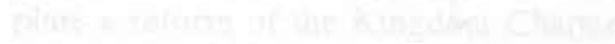




\section{Bronnen}

Aide Memoire, kenmerk 93MOO4622, brief van Minister-President Lubbers d.d. 15 juni 1993, voorbereiding Toekomstconferentie 24-26 juni 1993.

Aller, H.B. van, Rijn, A.B. van m.m.v. Lemans, M.W.J. Jurisprudentie bundel Publiekrecht Nederlandse Antillen en Aruba 1951-1992, Universiteit van de Nederlandse Antillen en Universiteit van Aruba, editie 1991 en supplement 1992.

AVP-nota, 'Doño di nos propio destino', Aruba en haar recht op zelfbeschikking, Nota van de politieke partij AVP, Aruba, 1990.

AVP: 'Naciemento di nos pais Aruba', dedica na e celebracion di e prome lustro di Status Aparte, maart 1991.

Besluit van 30 augustus 1991, houdende instelling van een gemengde ambtelijke werkgroep met als taak de voorbereiding van de vereenvoudiging en modernisering van het Statuut voor het Koninkrijk der Nederlanden [Gemengde werkgroep modernisering Statuut], Stb. 1991, 454.

Bestuursrecht, nieuwe teksten van de Algemene wet bestuursrecht, Gemeentewet, Provinciewet, Wet op de Raad van State, wet BestuursrechtspraakBedrijfsorganisatie, wet Milieubeheer, Beroepswet, Ambtenarenwet 1929, Kluwer, Deventer, 1993.

Bordewijk, H.W.C., Handelingen over de Reglementen op het Beleid der Regering in de koloniën Suriname en Curaçao, 's-Gravenhage, Martinus Nijhoff, 1914.

Code of Conduct for Law Enforcement Officials, adopted by the General Assembly of the United Nations, resolution 34/169 of 17 December 1979.

Commissies Reorganisatie en Efficiëntiebevordering Land en Eilandgebied Curaçao, Binnenlandse Zaken: J. Bernadina en Sectie Organisatie en Informatic, Stafbureau Eilandgebied Curaçao: G.Th. Sulvaran, juli 1990. Werkgroep Herstructurering. Naar een nieuwe taakverdelingtussen Land en Eiland, november 1988; Naar een nieuwe taakverdeling tussen Land en Eiland, 1988.

Conclusies Toekomstconferentie 8, 9 en 10 maart 1993 Curaçao (eerste versie ten behoeve van overleg met de delegatieleiders); 'Naar vernieuwde staatkundige verhoudingen in het Koninkrijk'. 
Constitution of the United States and the 26 amendements to the Constitution, The 1993 Information Please Almanac, Houghton Mifflin Company, Boston, 1993, pp. 617-629.

Contactplan, Parlementair Contactplan, 's-Gravenhage, 1989.

Decentralisatieplan, 29 december 1980, P.D.O Denz, Directeur Departement Staatkundige Structuur.

Dertig mei 1969, Rapport van de Commissie tot onderzoek van de achtergronden en oorzaken van de onlusten welke op 30 mei 1969 op Curaçao hebben plaatsgehad, De Wit, Oranjestad [ca. 1970].

Groot Placaet Boek [GPB], Inhoudende: De Placaten en Ordonnantien Van de Hoogh-Mog: Heeren Staten Generael der Vereenighde Nederlanden, en de van de Ed: Groot Mog: Heeren Staten van Hollandt en de West-Frieslandt, mitsgaders van de Ed: Mog. Heeren Staten van Zeelandt, 's-Gravenhage, by Hillebrant van Wouw, Ordinaris Drucker van de Hoogh-Mog: Heeren Staten Generaal der VereenigdheNederlanden, 1664, byeen gebracht door Cornelis Cau, I-IX; Octrooi WIC, GPB I, pp. 579-582, pp. 595-596, GPB II, pp. 585-590, GPB III, pp. 13291330, pp. 1333-1343, GPB VII, pp. 1581; Ordre van Regieringe soo in Policie als Justitie in de 'plaetsen verovert ende te veroveren in West-Indiën. In den date den 13 October 1629', GPB II, pp. 1235-1247; Ordre voor Brazilië 1636, GPB II, pp. 1247-1264.

Hasselt, van, Nederlandse Staatsregelingen en Grondwetten, Samsom, Alphen aan den Rijn, 1987.

Helsdingen, W.H. van, Peyl, Th.J. van der, Het Statuut van het Koninkrijk der Nederlanden, Staatsuitgeverij, 's-Gravenhage, 1957.

Helsdingen, W.H. van, De Staatsregeling van de Nederlandse Antillen van 1955, Staatsdrukkerij, 's-Gravenhage, 1956.

Helsdingen, W.H. van, De Eilandenregeling Nederlandse Antillen met toelichting, 's-Gravenhage, Staatsuitgeverij, 1963.

Hernieuwd vertrouwen in de toekomst. De Nederlandse inbreng in de Toekomstconferentie met de Nederlandse Antillen en Aruba (maart 1993), vertrouwelijk stuk van de Nederlandse delegatie ten behoeve van de besprekingen.

Instruktie voor Jacob Pietersz. Tolck, Directeur van Curaçao, 1638, Amsterdam, West-Indisch Plakaatboek, Schiltkamp, J.A., en Schmidt, J.Th de, (red), Publikaties en andere wetten alsmede de oudste resoluties betrekking hebbende op Curaçao, Aruba, Bonaire I-II, 1638-1782, S. Emmering, Amsterdam, 1978, I, pp. 3-8.

Instruktie voor Matthias Beck, Vice Directeur van Curaçao, Bonaire en Aruba, 8 juni 1655, West-Indisch Plakaatboek, Schiltkamp, J.A., en Schmidt, J.Th de, (red), Publikaties en andere wetten alsmede de oudste resoluties betrekking 
hebbende op Curaçao, Aruba, Bonaire I-II, 1638-1782, S. Emmering, Amsterdam, 1978, I, pp. 52-59.

Instructie voor Isaack Faesch, aangesteld tot Directeur over de Eylanden van Curaçao, 20 november 1739, Amsterdam, West-Indisch Plakaatboek, Schiltkamp, J.A., en Schmidt, J.Th de, (red), Publikaties en andere wetten alsmede de oudste resoluties betrekking hebbende op Curaçao, Aruba, Bonaire I-II, 1638-1782, S. Emmering, Amsterdam, 1978, I, pp. 1873-201.

Instructie voor den Raad der Colonien in de Westindien, gearresteerd 1 juni 1792, Bijlage I in Bordewijk, 1911, pp. 139-143.

Koninklijk Besluit van 18 september 1868,18 , waarbij is vastgesteld de nieuwe wetgeving van de kolonie Curaçao.

Leeuwen, W.C.J. van, De Nederlandse Antillen tussen Nederland en Venezuela, Position-paper, Drukkerij Scherpenheuvel, Willemstad, 1972.

Leeuwen, W.C.J. van, Verslag aan de Staten van de Nederlandse Antillen omtrent onze toekomstige staatkundige structuur, Drukkerij Scherpenheuvel, Willemstad, 1970.

Luiten, W.A., Antilliaanse Staats- en Administratiefrechtelijke jurisprudentie, UNA, Willemstad, 1981 .

Ministerie van Buitenlandse Zaken, Suriname en de Nederlandse Antillen in de Verenigde Naties I, November 1951-Februari 1952, Staatsdrukkerij en Uitgeverij, 's-Gravenhage, 1952, 28.

Ministerie van Buitenlandse Zaken, Suriname en de Nederlandse Antillen in de Verenigde Naties II, December 1952-Juli 1953, Staatsdrukkerij en Uitgeverij, 'sGravenhage, 1954, 36.

Ministerie van Buitenlandse Zaken, Suriname en de Nederlandse Antillen in de Verenigde Naties, September-December 1955, III, Staatsdrukkerij en Uitgeverij, 's-Gravenhage, 1956, 41.

Octroy of fundamentele Conditien, onder weleke haer Hoogh. Mog. ten besten ende voordeele van de Ingezetenen dezer landen, de Colonie van Suriname hebben doen vallen in de handen ende onder de directie van de Bewindhebberen van de Generale Nederlantsche Geoctroyeerde West-Indische Compagnie. In date 23 September, 1682, in: B.E. Colaçao Belmonte, Over de hervorming van het Regeringsstelsel in Nederlandsch West-Indië, P.H. van den Heuvel, Leiden, 1857.

Officieel Verslag van de stemming van het referendum bij wijze van opiniepeiling, betreffende de toekomstige staatkundige status van Aruba, gehouden op 22 maart 1977, H. Figaroa, voorzitter van het Hoofdstembureau voor het Referendum bij wijze van opiniepeiling, Hoofdstembureau, Eilandgebied Aruba, [z.u., z.j.] 
Ontwerp Landsverordening tot indeeling van Curaçao in bestuursressorten en tot instelling van zelfstandig bestuur in die ressorten (Eilandenreglement), Staten van Curaçao, zittingsjaar 1945-1946-56, met de Memorie van Toelichting op het ontwerp, Willemstad, 20 februari 1946.

Patroonschap verleend aan Joseph Nunes de Fonseca alias David Nassy, 'Vrijheden ende exemtien op het Eylandt Curaçao, Amsterdam, 22 februari 1652, Amsterdam, West Indisch Plakaatboek, Schiltkamp, J.A., en Schmidt, J.Th de, (red), Publikaties en andere wetten alsmede de oudste resoluties betrekking hebbende op Curaçao, Aruba, Bonaire I-II, 1638-1782, S. Emmering, Amsterdam, 1978, I, pp. 50-53.

Paula, A.F., (red.), 1795, De slavenopstand op Curaçao, een bronnenuitgave van de origineleoverheidsdocumenten, CentraalHistorisch Archief, Willemstad, 1974.

Placcaat van de Staten-Generaal van 23 mei 1776, in Groot Placcaatboek IX, p. 526. Dit placcaat regelde de rechtspositie van de slaaf als hij zijn heer ontvluchtte en naar Nederland kwam. Hij werd dan niet vrij.

Proeve van een Unieverdrag van de Nederlandse Antillen en Aruba, van de hand van mr. J.A.B. Janus, zie Rapport Gemengde Commissie (1982) pp. 131-138.

Proeve van een vernieuwd Statuut voor het Koninkrijk der Nederlanden, Gemengde werkgroep modemisering Statuut, aangeboden aan minister Hirsch Ballin op 18 maart 1993, niet officieel gepubliceerd. Deze werkgroep werd ingesteld bij KB van 30 augustus 1991, Stb. 1991, 454.

Pronk, P., en Croes, P.E., Basisregelingen uit het Arubaanse Staats- en Administratief recht, I-II, 1988. ${ }^{1}$

Pronk, P., en Croes, P.E., Basisregelingen uit het Arubaanse Staats- en Administratief recht, I-II, $1993 .^{2}$

Protocol, Werkgroep voorbereiding Ronde Tafelconferentie, Willemstad, 24 februari 1983 ['Protocol van Mito'].

Publicatie tot afschaffing van de slavenhandel, PB 1819, 22.

Publicatie van enige artikelen uit de instructien voor het Vredegeregt en de districtsmeesters, mitsgaders van het reglement van administratie der armenkas op het eiland Aruba, 26 november 1824, PB 1824, 86.

Rapport der Staatscommissie benoemd bij Koninklijk Besluit van 29 November 1853, 66 tot het voorstellen van maatregelen ten aanzien van de slaven in de Nederlandschekolonien, De NederlandscheWest-Indische eilanden en Bezittingen ter kuste van Guinea, I-II,'s-Gravenhage, bij de Gebroeders van Cleef, 1856.

Rapport Commissic Oppenheim. Ontwerp Landsverordening tot indeeling van Curaçao in bestuursressorten en tot instelling van zelfstandig bestuur in die ressorten als gevorderd door de Curaçosche Staatsregeling (Eilandenreglement), 
samengesteld door de Commissie ingesteld bij beschikking van 5 December 1942, 7530 (PB 1942, No. 227 van Zijne Excellentie den Gouverneur van Curaçao ter bestudecring van Staatkundige aangelegenheden), Willemstad, 1944.

Rapport Ellis, Rapport van de Commissie De la Try Ellis, tot onderzoek en bestudeering van de in het staatsdeel Curaçao levende politieke opvattingen en wenschen ter voorbereiding van de Rijksconferentie, 's-Gravenhage, Algemene Landsdrukkerij, 1946.

Rapport R. Kranenburg, over de mogelijke afscheiding van Aruba van de Nederlandse Antillen, Notulen Eilandsraad Aruba, Bijlage bij de Notulen 19541955, 15, 12 mei 1954 en Amigoe, 28 juli 1954.

Rapport van H.J.M. Jeukens aan de Regering van de Nederlandse Antillen omtrent enige staatsrechtelijke vraagstukken, Tilburg, april 1971.

Rapport van H.J.M. Jeukens aan de Nederlands-Antilliaanse regering inzake alternatieven voor de huidige staatsrechtelijke structuur van de Nederlandse Antillen, Tilburg, 1977.

Rapport Römer, Rapport van de Commissie tot onderzoek van de achtergronden en oorzaken van de onlusten welke op 30 mei 1969 hebben plaatsgehad, $30 \mathrm{Mei}$ 1969, de Wit NV, Aruba, 1970.

Rapport van de Koninkrijkswerkgroep, Naar nieuwe vormen van samenwerking, Staatsuitgeverij, 's-Gravenhage, 1980.

Rapport van de Gemengde Commissie Toekomst Antillen, Staatsuitgeverij, 'sGravenhage 1982 .

Rapport van de werkgroep ingesteld bij art. 6 van het Landsbesluit van 9 september 1983, 1, onder voorzitterschap van C.E. Dip, 'Gezamenlijk of gescheiden voortbestaan', Departement van Staatkundige Structuur, 20 juni 1984.

Rapport van de Referendum Commissie Curaçao. Het referendum over de staatkundige toekomst van Curaçao, 23 augustus 1993.

Rapport van de Onderzoekscommissie Besluitvorming Garantieproblematiek Aruba, 18 juni 1993.

Rapport van het Werkbureau ter voorbereiding van de administratief-technische maatregelen in verband met de zelfstandigmaking der eilanden, I-II, [Werbureau Kerstens, z.u., Willemstad, ca 1950].

Rechtsorde, De rechtsorde van het Koninkrijk der Nederlanden, de Basisregelingen, officiële toelichting op art. 3 van het Statuut, Uitgave van het Kabinet voor Nederlands-Antilliaanse en Arubaanse Zaken, SDU, Den Haag, 1986.

Reglement op het beleid van de Regering, het Justitiewezen, den Handel en Scheepvaart, mitsgaders de instructien voor den Gouverneur-Generaalen den Raad 
Contrarolleur Generaal op het eiland Curaçao, gearresteerd bij Besluit van Zyne Majesteit den koning in dato 14 September 1815,58 . Te 's-Gravenhage en te Amsterdam bij de Gebroeders van Cleef, met Privilegie, 1815. Deze uitgave begint met het Reglement op het beleid van de Regering voor Suriname en bijbehorende instructien voor den Gouverneur Generaal, den Raad Fiscaal, den Raad Contrarolleur van Financien en den Contrarolleur der Magazijnen. Alle wettelijke regelingen zijn bij hetzelfde $\mathrm{KB}$ vastgesteld. Tenslotte bevat deze uitgave het Reglement op het beleid der Regering voor St. Eustatius, St. Martin en Saba mitsgaders de instructien voor den Gouverneur der Eilanden St. Eustatius, St. Martin en Saba, den Boekhouder-Generaal op het Eiland St. Eustatius, den Commandeur des Eilands St. Martin, en den Boekhouder aldaar; Bordewijk (1911).

Reglement op de manier van procederen voor het College van Commercie en Zeezaken op het eiland Curaçao van 27 juni 1816, PB 1816, 6.

Reglement van Administratie en Bestuur op het eiland Aruba, gearresteerd door den Gouverneur van Curaçao en onderhoorige eilanden, bij dispositie van den 31 sten december 1823, 857, gepubliceerd te Curaçao, den 30sten Januarij 1824, PB 1823, 67

Reglement op de manier van procederen voor het Vredegeregt op het eiland Aruba van 17 november 1824 , PB 1824, 81 .

Reglement op het beleid van de Regeering, het Justitiewezen, den handel en de scheepvaart op Curaçao en onderhoorige Eilanden, vastgesteld door Van den Bosch bij besluit van 7 Februari 1828, Bordewijk (1911) Bijlage VIl, pp. 193-203, zie ook de Instructie voor den Directeur (zonder datum) opgenomen als Bijlage VIII in Bordewijk (1911) pp. 204-211, zie eveneens de Instructie voor den Raad van Policie (zonder datum), opgenomen als Bijlage IX in Bordewijk (1911) pp. 211-214 en Instructie voor het Gemeente Bestuur van Curaçao (zonder datum), opgenomen als bijlage $X$ in Bordewijk (1911) pp. 214-223. Daar waar geen datum vermeld staat valt af te leiden uit de literatuur dat de totstandkoming in 1828 heeft plaatsgevonden. Reglement op het beleid der Regering, het Justitie Weezen, den Handel en de Schcepvaart op de Eilanden St. Eustatius en Saba vastgesteld door Van den Bosch bij besluit van 28 Juli 1828, in Bordewijk (1911) Bijlage XI, pp. 223-233.

Reglement op het beleid der Regering van de Nederlandsche West-Indische Bezittingen (Vastgesteld bij K.B. van 21 Juli 1828, 222. G.B. 1828 No. 3), Bijlage C, bij A.J. van der Houven van Oordt, Regeeringsreglement van Suriname, E.J. Brill, Leiden, 1895.

Reglement op het beleid der Regering in de kolonie Curaçao en onderhoorige Eilanden, vastgesteld bij Koninklijk besluit van 20 November 1833, 85, Bordewijk (1911) Bijlage XII, pp. 233-246, Reglement op het beleid der Regeering in de Kolonie St. Eustatius en Saba, vastgesteld bij Koninklijk besluit van 20 November 1833, 85, Bordewijk (1911) Bijlage XIII, pp. 246-251. Het Reglement op het beleid der Regering in de Kolonie St. Martin is op gelijke datum vastgesteld en komt overeen met de twee zojuist genoemde reglementen, Bijlage XIV in 
Reglement op het beleid der Regering in de Kolonie Curaçao en onderhoorigheden, vastgesteld bij Koninklijk besluit van 27 Januari 1848, 51, in Bordewijk (1911) Bijlage XV, pp. 253-263.

Samenwerkingsregeling, PB, 1985, 88; AB 1985, 28 en de toelichting daarop.

Synthese-document van de hand van premier R.F.M. Lubbers, Een vernieuwde staatkundige en rechtsorde, basis voor de bespreking op de Toekomstconferentie van 8, 9, 10 maart 1993.

Statuut voor het Koninkrijk der Nederlanden, bewerkt door W.W. Timmers, Nederlandse Staatswetten, I-III, Editie Schuurman en Jordens, W.E.J. Tjeenk Willink, Zwolle, 1988, met aanvullingen, bijgewerkt tot 1 augustus 1990.

Toescheidingsovereenkomst inzake nationaliteiten tussen het Koninkrijk der Nederlanden en de Republiek Suriname, Paramaribo, 25 november 1975, Tractatenblad, 28, 1975, 1 en de Overeenkomst tussen het Koninkrijk der Nederlanden en de Republiek Suriname inzake het verblijf en de vestiging van wederzijdse onderdanen, Paramaribo, 25 november 1975, Tractatenblad 29, 1975 , 1 .

Verdrag tot herstel van de diplomatieke betrekkingen tussen Nederland en Venezuela, KB 11 maart 1921, Stb. 1921, 301, Justicia, 4, pp. 79-93.

Verslag van de Commissie Staal, Verslag van de Commissie van Advies omtrent deherzieningvan deWest-Indische Regeeringsreglementenen begrootingspolitiek, [z.u., z.p.], 's-Gravenhage, 1923.

Verslag Commissie Kropman, Verslag 2 (1947), Verslag van de Parlementaire Commissie Suriname en de Nederlandsche Antillen, nopens hare bevindingen, Handelingen Tweede Kamer, Zitting 1946/1947, 443.

Verslag Van Helsdingen, Verslag van de Commissie van onderzoek naar de opvattingen in Nederland omtrent de plaats van de overzeesche gebiedsdelen in het Koninkrijk, ingesteld bij ministerieel besluit van 30 augustus 1945 (Commissie Van Helsdingen), Rijksuitgeverij, 's-Gravenhage, 1946.

Verslag, Beknopt verslag der deelneming van de Nederlandse Antillen aan de Conferentie Nederland-Suriname-Nederlandse Antillen, Curaçaosche Courant N.V., Willemstad, 1954.

Verslag, Conferentie van de Nederlandse Antillen, de eilanden van de Nederlandse Antillen en Nederland, stenografische verslag van de eerste zitting gehouden van maandag 16-25 februari 1981 te 's-Gravenhage.

Voorstel van Rijkswet tot wijziging van het Statuut voor het Koninkrijk der Nederlanden in verband met het voortzetten van de in het Statuut neergelegde rechtsorde ten aanzien van Aruba, Tweede Kamer zitting 1991-1992, 22593, nrs. 
Wet van den 8sten Augustus 1862, Stb. 165, houdende opheffing van de Slaverny op de eylanden Curaçao, Bonaire, Aruba, St. Eustatius, Saba en St. Martin (Ned. Gedeelte).

Wet van den 31 sten Mei 1865, Stb. 56, houdende vaststelling van het reglement op het beleid der regering in de kolonie Curaçao. 


\section{Geraadpleegde literatuur}

Abraham-Van der Mark, E., Civilisadó, een weekblad en een school gericht op de verheffing en integratie van ex-slaven in de kolonie Curaçao, UNA Cahier, 33, 1990.

Adam, B.H., De wetgeving betreffende Koninkrijksaangelegenhedenin 1960, 35 , NJB 1961, pp. 903-904.

Akehurst, M., A Modern Introduction to International Law, Allen and Unwin, London, $1987 .^{6}$

Algemene Maatregel van Rijksbestuur (AMvRB), Besluit van 2 februari 1993, houdende enkele tijdelijke voorzieningen in het bestuur van het eilandgebied Sint Maarten van de Nederlandse Antillen, Stb. 1993, 72.

Algra, N.E., en Janssen, H.C.J.G., Rechtsingang, Een oriëntatie in het recht, Wolters-Noordhoff, Groningen, $1983,{ }^{10} 1992 .{ }^{13}$

Algra, N.E., Gokkel, H.R.W., Fockema Andrea, Rechtsgeleerd handwoorden boek, H.D. Tjeenk Willink, Alphen aan den Rijn, $1990 .^{6}$

Alkema, E.A., Foreign relations in the Netherlands Constitution of 1983, Netherlands International Law Review, The Hague, 31, 1984, pp. 307-331.

Aller, H.B. van, College staatsrecht 18 november 1992, naar aanleiding van het Koninklijk bezoek, Universiteit van Aruba, Oranjestad, 1992.

Aller, H.B. van, De vrijheid van meningsuiting en het onschendbaar beledigen, UA Cahier, 4, Oranjestad, Aruba, 1992.

Aller, H.B. van, Een koekje van eigen deeg, Coomans-Eustatia, M. (red.), Dric Curaçaose schrijvers in veelvoud, Boeli van Leeuwen, Tip Marugg, Frank Martinus Arion, Walburg Pers, 1991.

Aller, H.B. van, De staatkundige toekomst van Aruba en de Nederlandse Antillen. Modellen en meningen, Symposiumbundelten behoeve van het Symposium van de Universiteit van Aruba ter voorbereiding van de Toekomstconferentie, gehouden op 5 maart 1993, Universiteit van Aruba, 1993.

Aller, H.B. van, De zaak Deira, een heet hangijzer, TAR-Justicia, 1992, pp. 235251.

Alofs, L., Van Separación tot Status Aparte, De Gids, 1990.

Alofs, L., Merkies, L., Ken ta Arubiano? Sociale integratie en natievorming op Aruba, Antillen Working Papers 15, Koninklijk Instituut voor Taal-Landen Volkenkunde, Leiden, 1990.

Antilliana. Verzameld werk van Dr. W. Ch. de la Try Ellis, Spruit, J.E. en Voges E., (red.), Universiteit van de Nederlandse Antillen, De Walburg Pers, 1981.

Apeldoom, L.J., van, Inleiding tot de studie van het Nederlandse recht, N.V. Uitgeversmaatschappij, W.E.J. Tjeenk Willink, Zwolle, 1966. ${ }^{16}$

Attali, J., 1492, Schuyt \& Co, Haarlem, 1992.

Aristotle, The Politics, Penguin Classics, 1962 [vele herdrukken, 1987]. 
Aristotle, Ethics, Penguin Classics, 1955 [vele herdrukken, 1987].

Balen, W.J. van, Ons Gebiedsdeel Curaçao, H.D. Tjeenk Willink \& Zoon's, N.V., Haarlem, 1938.

Baudet, H., Fennema M., e.a., Het Nederlands belang bij Indië, Aula Paperback 90, Het Spectrum, Utrecht/Antwerpen, 1983.

Bax, M., Harpstrings and Confessions. Machine Style Politics in the Irish Republic, Van Gorcum, Assen/Amsterdam, 1976.

Beekman, H., Ongeschreven staatsrecht en kamerontbinding, 48, NJB 1973, pp. 397-403.

Beekman, H.J.M., Smit, C.Th., Object en methode van de staatsrechtwetenschap, in: Object en methode van de staatsrechtwetenschap, Staatsrechtconferentie 1982, Ars Aequi Libri, Nijmegen, 1982, pp. 96-108.

Beelaerts van Blokland, G.J.T., De onschendbaarheid van de wet, S.C. van Doesburgh, Leijden, 1868.

Belinfante, A.D., Object en methode van de staatsrechtbeoefening, in: Object en methode van de staatsrechtwetenschap; Staatsrechtconferentie 1982, Ars Aequi Libri, Nijmegen, 1982, pp. 1-24.

Belinfante, A.D., De Reede J.L., Beginselen van Nederlands staatsrecht, Alphen aan den Rijn, 1987.

Benjamins, H.D. en Snelleman, J.F., (red.), Encyclopaedie van Nederlandsch West-Indiē, Martinus Nijhoff, 's-Gravenhage/N.V. v.h. E.J. Brill, Leiden, 1914-1917.

Bergh, G. van den, Beschouwingen over het toetsingsrecht, 26, NJB 1951, pp. 417-425.

Bergh, G. van den, Het Statuut en het toetsingsrecht, 30, NJB 1955, pp. 221-227.

Bergh, G. van den, Statuut, Rijskwet, Grondwet en Wet, 30 NJB 1955, pp. 703706.

Biesheuvel, B.W. en Janus, J.A.B., Erkenning zelfbeschikkingsrecht hoeft niet tot onafhankelijkheid te leiden, Nederland trekt zich weinig aan van de Antillen, NRC Handelsblad, 2 oktober 1989.

Bijkerk, M., Caribiaans Manifest, M. Bijkerk, MAS Productions, Bonaire, Nederlandse Antillen, 1990.

Bijloos, A.W.M., De Algemene wet Bestuursrecht, Tjeenk Willink, Zwolle, 1990. Bink, M.J. van den, Olie op de golven. De betrekkingen tussen Nederland/Curaçao en Venezuela gedurende de eerste helft van de twintigste eeuw, De Bataafsche Leeuw, 1989.

Böhtlingk, F.R., Logemann, J.H.A., Het wetsbegrip in Nederland, Samsom, Alphen aan den Rijn, 1966.

Boissevain, J., Friends of Friends. Networks, Manipulators and Coalitions, Basil Blackwell, Oxford, 1978. ${ }^{2}$

Bondam, P.A.C., De cassatieregeling voor de Nederlandse Antillen, 40, NJB 1965 pp. 201-209.

Bongenaar, K.E.M., Een plus een is drie of vier, Enige beschouwingen over de status van Landsverordeningen betreffende de aan de zorg der eilandgebieden overgedragen onderwerpen en van eilandsverordeningen betreffende aan het land voorbehouden aangelegenheden, Justicia, 11, 1983, pp. 1-35; 49-84.

Bongenaar, K., Rijkswet en rechterlijke toetsing. Een gemiste kans voor het Statutaire recht?, TAR-Justicia, 6, 1985, pp. 249-237; 7, 1986, pp. 22-36; pp. 199-222. 
Bongenaar, K., De overlevingskansen van de Antillen van de Vijf, vanuit staatkundig en staatsrechtelijk perspectief, in: UNA cahier, 23 (1986) pp. 16-52.

Bongenaar, K., Hoetink, H. en Weitenberg, J., De overlevingskansen van de Antillen van de Vijf, een analyse van de integrerende en desintegrerende. krachten in de intereilandelijke betrekkingen, UNA-cahier, 23, september 1986.

Bongenaar, K.E.M., Enige overpeinzingen bij de voorgenomen continuering en herstructurering van de Nederlandse Antillen, in: Nos Futuro (1986) pp. $25-50$.

Bongenaar, K.E.M., De staatsrechtelijke gevolgen van Aruba's afscheiding voor de Nederlandse Antillen, TAR-Justicia, 1986, pp. 86-104.

Bongenaar, K.E.M., Een vondeling aan de poort der Antilliaanse maatschappij, in: Het oog van de meester (1989) pp. 1-42.

Bongenaar, K., Vreemde eend in de bijt of beste paard van stal? Het vóór en tegen van de cassatierechtspraak van de Hoge Raad in 'Antillenzaken', TAR-Justicia, 1989, pp. 90-113.

Bongenaar, K.E.M., Le pluralisme juridique aux Antilles Neerlanda ises, Netherlands Reports to the thirteenth Intemational Congress of Comparative Law, Montreal 1990, T.A.M. Asser Instituut, The Hague, pp. 1-17.

Bongenaar, K., De Schets van een Gemenebestconstitutie voor het Koninkrijk der Nederlanden, Enig commentaar op de nota van minister Hirsch Ballin, in: Uní ku UNA (1991), pp. 1-21.

Bok, A.J., Rechter contra wetgever: toetsing van geschreven aan ongeschreven recht, De rechtsstaat herdacht (1989) pp. 267-281.

Boogaart, E. van den, Drooglever, P.J. e.a., Overzee, Nederlandse koloniale geschiedenis 1590-1975, Fibula/Van Dishoeck, Haarlem, 1982.

Boom, W.R., De cassatieregeling voor de Nederlandse Antillen, Justicia, 1965 , p. 29-38.

Bordewijk, H.W.C., Ontstaan en Ontwikkeling van het Staatsrecht van Curaçao, 's-Gravenhage, Martinus Nijhoff, 1911.

Borman, C., Na Grondwetsherziening ook Statuutsherziening? in: Gegeven de Grondwet, (CZW-bundel) 1988, pp. 3-18.

Bomnan, C., Aruba, Land in het Koninkrijk, AA, 1986, pp. 361-369.

Bossers, G.F.M., 'Welk eene natie, die de jurij gehad heeft, en ze weder af schaft!': de jury in de Nederlandse rechtspraktijk (1811-1813), Eburon, Delft, 1987.

Braam, H.L., Beknopt leerboek van de Staatsinrichting van de Nederlandse Antillen, De Wit Stores N.V., Aruba, 1988. ${ }^{7}$

Brakel, S. van, De Hollandsche Handelscompagnieën der zeventiende eeuw, hun onstaan - hunne inrichting, 's-Gravenhage, Martinus Nijhoff, 1908.

Brakel, S. van, Bescheiden over den slavenhandel der West-Indische Compagnie, Economisch Historisch Jaarboek. Bijdragen tot de Economische Geschiedenis van Nederland, De Vereeniging Het Nederlandsch Economisch Historisch Archief, Martinus Nijhoff, 's-Gravenhage, IV, 1918, pp. 47-83.

Buckley, R.N., Kwetsbare eilandstaatjes in het Caribisch gebied, Internationale Spectator, 1985, pp. 495-496. 
Burg, F.H. van der, Kamerontbinding in een periode van grote sociale onrust. Beantwoording rechtsvraag Staatsrecht, AA, 1981, pp. 34-37.

Burg, F.H. van der en Burkens, M.C., Namens, Tijdschrift over vertegenwoordiging en democratisch bestuur, 5, 1990, pp. 41-46.

Burkens, M.C. Grondwet en beslissingssysteem, Staatsrechtconferentie 1981, Ars Aequi Libri, Nijmegen, 1981, pp. 33-72.

Burkens, M.C., Problemen van de rechtsstaat in: De rechtsstaat herdacht (1989) pp. 63-71.

Burkens, M.C., Kummeling, H.R.B.M., Vermeulen, B.P., Beginselen van de democratische rechtsstaat, Inleiding tot de grondslagen van het Nederlandse staats-en bestuursrecht, W.E.J. Tjeenk Willink, Zwolle, 1992.

Buys, J.T., De Grondwet, Toelichting en kritiek, I-II, Gouda Quint, Arnhem, 1883.

Bijvoet, F.A., Directe volkswetgeving, referendum en volksinitiatiefrecht, H.J. Paris, Amsterdam, 1925.

Castillo, O.H., Ons politiek systeem, hervorming of dictatuur, in: Nos Futuro (1986) pp. 129-145.

Chumaceiro, A., Is Curaçao te koop?, Belinfante, 's-Gravenhage, 1879.

Chumaceiro, A.M., Zal het kiesrecht Curaçao tot het kannibalisme voeren?, A. Bethencourt \& Zonen, Curaçao, 1895.

Condorcet, Beschouwingen over de negerslavernij, vertaling M. Fennema, G. Karsten-van der Giessen, Heureka, Weesp, 1989.

Coopmans, I., Bescherming van het parlement, maatregelen tegen de orde verstorende en revolutionnaire afgevaardigden, H.J. Paris, Amsterdam, 1929.

Costa Gomez, M.F. da, Het wetgevend Orgaan van Curaçao, Samenstelling en bevoegdheid gezien in het kader van de Nederlandsche koloniale politiek, H.J. Paris, Amsterdam, 1935.

Costa Gomez, M.F. da, Dr. A. Kasteel's studie over de staatkundige ontwikkeling der Nederlandse Antillen, Christoffel 1956, pp. 65-73; pp. 119-127

Corporaal, K.H., De internationaal rechtelijke betrekkingen tusschen Nederland en Venezuela, 1816-1920, Eduard Ydo, 1920.

Couwenberg, S.W., Staatsrecht en economische macht, Staatsrechtconferentie 1975, Universiteit van Amsterdam, 1975, pp. 1-82.

Couwenberg, S.W., Ontwikkeling en actuele problematiek der politicke partijen als primaire constitutionele machts factoren, Tijdschrift van Overheidsadministratie (TvO) 15, 1989, pp. 188-192.

Crawford, J., The Creation of States in International Law, Clarendon Press, Oxford, 1979.

Crince le Roy, R., Het mandaat van artikel 8 Statuut, 37, NJB 1962, pp. 962-964.

Croes, A.G., De weg naar Status Aparte, Lantèrnu, 1, 1983, pp. 28-31.

Croes, A.G., Gezamenlijk voortbestaan? Hoe dan?, in: Koperen poly fonie (1984) pp. 246-266.

Croes, A.G., Op de grenzen van het Statuut, lezing voor de Antilliaanse Juristen Vereniging, A.J.V. Nieuwsbrief, 1992/4, pp. 18-23; 1993/2, pp. 18-21.

Croes, R., en Moenir Alam, L., Decolonization of Aruba within the Netherlands Antilles, The Dutch Caribbean, Prospects for Democracy, Betty SedocDahlberg (ed.), Centre for Latin Studies, University of Florida Gainesville, USA, Gordon and Breach, New York, Philadelphia, London, Paris, Montreux, Tokyo, Melbourne, 1990. 
Croes, T., Referendum and Democracy, in: Information cycle on the planned referendum in Curaçao (1992) pp. 47-51.

Daal, L.H., Schouten, T., Antilliaans verhaal, Geschiedenis van Aruba, Bonaire, Curaçao, Saba, St. Eustatius en St. Maarten, De Walburg Pers, Zutphen, 1988.

Diephuis, G., Het Nederlandsch Burgerlijk Regt, I-II, J.B. Wolters, 1869.

Dijke A., Hulst, H. van, Terpstra, L., Mama Soltera. De positie van 'alleenstaande' Curaçaose en Arubaanse moeders in Nederland, Migrantenuitgeverij Warray, 's-Gravenhage.

Dip, C.E., Is het Landsbesluit van de 2de Augustus 1971, no 6 (PB 1971 no. 116) inderdaad onbevoegd genomen?, Justicia, 7, 1971, pp. 65-72

Dip, C.E. , Enige beschouwingen rond artikel 2 van de Antilliaanse Staatsregeling, Antilliaans Juristenblad, 23, 1973, pp. 927-945.

Dip, C.E., De ontbinding van de Staten, Hogeschool van de Nederlandse Antillen, Willemstad, 1975.

Dip, C.E., Gouverneur en minister in het Antilliaanse staatsrecht, in: Lustrum van een ideaal (1976) pp. 96-120.

Dip, C.E., Kent de Staatsregeling het codificatiebeginsel?, in: Honderd Jaar Codificatie (1969) pp. 1-7.

Dip, C.E., De Gouverneur als wetgever, in: Een decennium later, UNA/Kluwer, Willemstad/Deventer, 1982, pp. 55-74.

Dip, C.E., De politieke structuur van de Nederlandse Antillen en de relatie tot Nederland, De Gids, 153, 1990, pp. 509-517.

Dip, C.E., Realiteit en fictie in het proces van staatkundige herstructurering van de Nederlandse Antillen, in: Uní ku UNA (1991) pp. 41-57.

Donner, A.M., Iets over kiesstelsels, Mededelingen der Koninklijke Nederlandse Akademie van Wetenschappen, Afdeling Letterkunde, Nicuwe Recks, 30, 5, N.V. Noord-Hollandsche Uitgevers Maatschappij, Amsterdam, 1967.

Donner, A.M., De Grondwetsherziening, Inleidende opmerkingen over staatsrecht en politiek, Staatsrechtconferentie 1981, Ars Aequi Libri, Nijmegen, 1981, pp. 1-9.

Donner, A.M., Object en methode van het staatsrecht, in: Object en methode van de staatsrechtwetenschap, Staatsrechtconferentie 1982, Ars Aequi Libri, Nijmegen, 1982, pp. 25-63.

Drooglever, P.J., Colonial Empire: Historical Outline and Some Legal Aspects, I, Sijthoff \& Noordhoff, Alphen aan den Rijn, 1980, Oceana Publications Inc. Dobbs Ferry, N.Y., pp. 103-165.

Eigeman, J.A., Indiē en het Koninkrijk, 's-Gravenhage, 1928.

Ellis, J.W., Rechter en verordening in het Antilliaanse Staatsrecht, Antillaans Juristenblad, 1952, pp. 19-25,

Ellis, J.W., e.a., De zelfstandigheid der Eilandgebieden, een bijdrage tot herziening der Eilandenregeling Nederlandse Antillen, Eilandgebied Curaçao, 1954.

Ellis, J.W., Gorsira, M.P., Nuyten, F.C.J., De zelfstandigheid der eilandgebieden. Een bijdrage tot herziening der Eilandenregeling Nederlandse Antillen, Eilandgebied Curaçao, Willemstad, 1954.

Elzinga, D.J., Het Nederlandse kiesrecht, W.E.J. Tjeenk Willink, Zwolle, 1989. 
Elzinga, D.J., Wisse, C., De parlementaire fracties, Wolters-Noordhoff, Groningen, 1988.

Elzinga, D.J., De democratische rechtsstaat als ontwikkelingsperspectief, Over machtsregulering als ontwikkelingslijn in: De rechtsstaat herdacht (1989) pp. 43-61.

Elzinga, D.J., Warmelink, H.G., Het Nederlandse parlementaire stelsel, Ars Aequi Libri, Nijmegen, 1993.

Emmerich, H., Federal Organization and Administrative Management, The University of Alabama Press, 1971.

Encyclopaedie van Nederlandsch West-Indië, Benjamins, H.D., en Snelleman, J.F., (red.), Martinus Nijhoff, 's-Gravenhage, N.V. v.h. E.J. Brill, Leiden, 1914-1917.

Encyclopedie van de Nederlandse Antillen, Palm, J.Ph. de, (red.), De Walburg Pers, Zutphen, 1985.

Engels, J.W.M., Rechtsstaat en staatsrecht, De rechtsstaat herdacht (1989) pp. 73-85.

Everett, S., Slavernij, door de eeuwen heen, Walburg Pers, Zutphen, 1993.

Felhoen Kraal, J., Boekbespreking proefschrift Annemarie Kasteel, De WIG, 37, 1956, pp. 58-60.

Fennema, M., Henriquez, R., De sociaal democratie en de Nederlandse Antillen, Het zevende jaarboek voor het democratisch socialisme, de Arbeiderspers, 1986.

Fennema, M., Racisme en politieke theorie, in: Een Bleek Bolwerk, racisme en politieke strategie, Hisschemōller, M., (red.), Pegasus, Amsterdam, 1988.

Fernandes Mendes, H.K., De Status Aparte van Aruba, een bekeken zaak?, NJB 59. 1984, pp. 73-79.

Fernandes Mendes, H.K., Aruba en de Antillen, Naar een nieuwe samenwerking, TAR-Justicia, 1986, pp. 75-85.

Fernandes Mendes, H.K., Ona thankelijkheid en parlementair stelsel in Suriname, Hoofdlijnen van een nieuw en democratisch staatsbestel, Tjeenk Willink, Zwolle, 1989.

Fernandes Mendes, H.K., Het Nederlands Gemenebest: een theoretische constructie, 65, NJB 1990, pp. 1190-1197.

Fliek, F.C., Het Reglement op de inrichting en samenstelling van de Rechterlijke Macht, in: Honderd jaar Codificatie (1969) pp. 7-51.

Flinterman, C., Winter, R.E. de, Een 'Court-packing plan' voor Nederland? Over concentratie van rechterlijk toetsingsrecht bij één instantie, 65, NJB 1990 , pp. 627-630.

Fockema Andrea, S.J., De NederlandseStaat onderde Republiek, Verhandelingen der Koninklijke Nederlandse Akademie van Wetenschappen, Afd. Letterkunde, Nieuwe Reeks, 78, 3, Noord-Hollandsche Uitgevers Maatschappij, Amsterdam, $1974 .^{6}$

Foner, L. and Genovese, E.D., (eds.), Slavery in the New World, Prentice-Hall, Inc., Englewood Cliffs, New Jersey, 1969.

Friedrich, C.J., The philosophy of law in historical perspective, The University of Chicago Press, Chicago \& London, 1963.

Friends, Followers and Factions. A reader in Political Clientelism, Schmidt, S.W., Scott, J.C., Landé, C., Guasti L., (eds.), University of California Press, Berkeley/Los Angeles/London, 1977.

Fruin, R., Geschiedenis der staatsinstellingen in Nederland tot den val der 
Republiek, bewerkt door H. T. Colenbrander, Martinus Nijhoff, 's-Gravenhage, $1922 .^{2}$

Fuller, L.L., The Morality of Law, New Haven/London, Yale University Press, 1972.5

Gaay Fortman B. de, De rechtsbedeeling op de bovenwindsche eilanden en de herziening van de rechterlijke macht en van de rechtspleging in de kolonie Curaçao, De WIG, 1a, 1919, pp. 85-101.

Gaay Fortman B. de, Curaçao tegen het einde van de West-Indische Compagnie, De WIG, 1a, 1919, pp. 441-457.

Gaay Fortman B. de, De voortgang der Nederlandsche West-Indische eilanden, De WIG, 3, 1921, pp. 113-144.

Gaay Fortman, B. de, Over de bestuursinrichting van Curaçao, De WIG, 4, 1922 , pp. 289-304, pp. 533-552; 5, pp. 535-560; 6, pp. 385-404.

Gaay Fortman B. de, Een bladzijde uit de geschiedenis van Curaçao, De WIG, 6, 1924, pp. 169-178.

Gaay Fortman B. de, Hoe Cantz'laar gouverneur van Curaçao werd, De WIG, 7, 1925, pp. 145-152.

Gaay Fortman B. de, De landbouwplannen van den gezaghebber Van Raders, De WIG, 7, 1925, pp. 353-367.

Gaay Fortman B. de, Een aanvulling op Bordewijks 'Ontstaan en ontwikkeling van het staatsrecht van Curaçao', De WIG, 7, 1926, pp. 505-506.

Gaay Fortman B. de, De oprichting der Curaçaosche schutterij Curaçao, De WIG, 8, 1926, pp. 97-118.

Gaay Fortman B. de, Gouverneur Cantz'laar en de bloedige gebeurtenis van 1 juni 1824, De WIG, 8, 1926, pp. 341-356.

Gaay Fortman, B. de, Curaçao en onderhoorige eilanden, 1816-1828, De WIG, $9,1927 / 1928$, pp. $1-16,49-66,97-110,241-264,363-378,417-432,497$ 518, 561-574; 10, 1928/1929, pp. 1-10.

Gaay Fortman, B. de, De West-Indische Maatschappij, De WIG, 11, pp. 307-315.

Gaay Fortman B. de, De verrassing van Willemstad, 8 juni 1929, De WIG, 12, 1930-1931, pp. 85-106, 119-146, 510-521.

Gaay Fortman, B. de, De bestuursinrichting van Curaçao, in: Gedenkboek Nederland-Curaçao (1634-1934).

Gaay Fortman B. de, Twee verzoekschriften aan den koning over de landbouwpolitiek van gouverneur Van Raders in Curaçao, De WIG, 18, 1937, pp. 321329.

Gaay Fortman B. de, Aanvulling van Encyclopaedie van Nederlands West-Indië: bestuursregeling van Curaçao, De WIG, 24, 1942, pp. 214-226.

Gaay Fortman B. de, Nieuwe gegevens over de inbezitneming van Curaçao op den Nieuwjaarsdag van 1807, De WIG, 25, 1943, pp. 193-247.

Gaay Fortman B. de, De Kolonie Curaçao onder Engelsch bestuur van 1802 tot 1816, De WIG, 26, 1945, pp. 229-246.

Gaay Fortman B. de, De nieuwjaarsdag van 1807, De WIG, 27, 1946, pp. 254255.

Gaay Fortman B. de, Politieke beschouwingen over Curaçao, De WIG, 27, 1946, pp. 257-279.

Gaay Fortman B. de, Toelating, verblijf, vestiging en uitzetting in de Nederlandse Antillen: het geval De Wit, De WIG, 39, 1959, pp. 1-27.

Gaay Fortman, B. de, Schets van de politieke geschiedenis der Nederlandsche Antillen in de twintigste eeuw, uitgeverij W. van Hoeve, 's-Gravenhage 
1947.

Gaay Fortman, W.F. de, Laat de Antillen met rust, Christen Democratische Verkenningen, 1985, 12, pp. 553-554.

Galeano, E., De aderlating van een continent, vier eeuwen economische exploitatie van Latijns-Amerika, Kritiese Bibliotheek Van Gennep, Amsterdam, 1980.

Galjart, B., Politieke vriendschapals beschermingsmechanisme. Een beschouwing over micro-sociologische relaties met macro-sociologische gevolgen in: Patronage, clientelisme en vriendschap, Banck, G., Trouwborst, A. (red.), Antropologische Verkenningen, 11, 2, 1992.

Gameren, R.J.S. van, Met onbekendebestemming, Discussies over ona fhankelijkheid in de Nederlandse Antillen, doctoraalscriptie Nieuwste Geschiedenis, Katholieke Universiteit Nijmegen, Nijmegen, 1991.

Gase R., Misleiding of zelfbedrog. Het Nederlands beleid ten aanzien van Nieuw Guinea, In den Toren, Baam, 1984.

Gastmann, A.L., The place of Surinam and the Netherland Antilles in the political and constitutional structure of the Kingdom of the Netherlands, Columbia University, Michigan, UMI Dissertation Information Service, 1964.

Gedenkboek Nederland-Curaçao 1634-1934, J.H. de Bussy, Amsterdam, 1934. [Uitgegeven ter herdenking van de driehondjarige vereeniging van Curaçao met Nederland. Het gedenkboek is samengesteld door een Commissie Nederland-Curaçao 1634-1934. De Commissie was ingesteld op initiatief van het Algemeen Nederlandsch Verbond en van de Koninklijke Vereeniging Oost en West. [Waarschijnlijk heeft de secretaris van de Commissie F.H.A. van der Burgh de redactie gevoerd].

Geggus, D., The Haitian Revolution, in: The West Indian Slave Laws of the Eighteenth Century (1991) pp. 402-418.

Geiser, H.J. e.a., Legal Problems of Caribbean Integration, A Study on the Legal Aspects of Caricom, Sijthoff, Leiden, Trinidad and Tobago, 1976.

Genovese, E.D., Roll Jordan Roll, The World the Slaves made, Pantheon Books, New York, 1974.

Gerbenzon, P., Algra, N.E., Voortgangh des reechtes, Samsom/H.D. Tjeenk Wllink, Alphen aan den Rijn, $19877^{\circ}$

Gerlings, H.J.M., Het Koninkrijksstatuut, Nieuwe WIG, 48, 1971, pp. 135-157.

Gerlings, H.J.M., Nederland, Suriname en de Nederlandse Antillen, souvereine staten, Nieuwe WIG, 50, 19751, pp. 3-6.

Gielen, W.J.G.M., Over kiezen en kiesstelsels, Uitgeverij Van der Laan, Heiloo, 1968.

Gilhuis, P.C., Het referendum, Een rechtsvergelijkendestudie, Samsom, Alphen aan den Rijn, 1981.

Goede, B. de, Aan de hand van de Grondwet, De Haan/Van Loghum Slaterus, Amhem, 1965.

Goor, J. van, Indië/Indonesië, Van kolonie tot natie, HES Uitgevers, Utrecht, 1987.

Gorsira, M.P., De Staatkundige Emancipatie van de Nederlandse Antillen, Staatsdrukkerij- en Uitgeverijbedrijf, 's-Gravenhage, 1950. 
Gorsira, M.P., De Gezaghebber, zijn taak en positie in ons staatsbestel, Scherpenheuvel, Willemstad, 1958.

Gorsira, M.P., Zelfbeschikkingsrechten Status Aparte, Enige beschouwingenover de toekomstige relatie tussen Nederland en het Caraibisch deel van het Koninkrijk, in: Het oog van de meester (1989) pp. 51-64.

Gorsira, M.P., De nieuwe rechtsorde, Een regeling van staatsrechtelijke of volkenrechtelijke aard?, Amigoe, 3 maart 1990.

Gorsira, M.P., Status Aparte ook voor Curaçao en St. Maarten haalbare kaart, Ex-gezaghebber sleutelt aan nieuwe rechtsorde tussen Nederland en de zes eilanden, Amigoe, 13 augustus 1992.

Goslinga, C.Ch., Emancipatie en emancipator. De geschiedenis van de slavernij op de Benedenwindse eilanden en van het werk der bevrijding, Van Gorcum, Assen, 1956.

Goslinga, C.Ch., Juan de Ampuès, vredelievende Indianenjager, De WIG, 37, 1957, pp. 169-187.

Goslinga, C.Ch., The Dutch in the Caribbean and on the Wild Coast, 1580-1680, Van Gorcum \& Comp., Assen, 1971.

Goslinga, C.Ch., Curaçao and Guzmán Blanco, a case study of small power politics in the Caribbean, Martinus Nijhoff, 's-Gravenhage, 1975.

Goslinga, C.Ch., Papachi Sassen, drie onrustige jaren op Curaçao: 1870-1873, Nieuwe WIG, 46, 1977, pp. 105-149.

Goslinga, C.Ch., Curaçao as a slave trading center during the war of the Spanish Succession, 1702-1714, Nieuwe WIG, 52, 1977, pp. 1-50.

Goslinga, C.Ch., A short history of the Netherlands Antilles and Surinam, Martinus Nijhoff, The Hague/London, 1979.

Goslinga, C.Ch., The Dutch in the Caribbean and in the Guianas, 1680-1791, Van Gorcum, Assen/Maastricht, 1985.

Goslinga, C.Ch., The Dutch in the Caribbean and in Surinam, 1791/5-1942, Van Gorcum, Assen/Maastricht, 1990.

Goslinga, C., Sjons en slaven, Primavera Pers, Leiden, 1992.

Gould, R.T., Unexplained Facts, Enigmas and Curiosities, The landfall of Columbus, Bell Publishing Company, New York, 1965 [reprint] 1980.

Goveia, E.V. The West Indian Slave Laws of the Eighteenth Century, H. Beckers \& V. Shepherd (eds.), Caribbean Slave Society and Economy, A Student Reader, IRP, Kingston, Jamaica and James Currey London, 1991.

Granzotto, G., Christoffel Columbus, een biografie, Kwadraat, Utrecht, 1992. Griffiths, J., Bestaat de rechtsstaat? in: De rechtsstaat herdacht (1989) pp. 87-103.

Grinten, W.C.L. van der, De toekomst van de Nederlandse Antillen, Christen Democratische Verkenningen 1986, 6, pp. 231-238, met nawoord van W.F. de Gaay Fortman.

Grinten, W.C.L. van der, Het Koninkrijk der Nederlanden, TAR-Justicia, 1991, 2, pp. 53-64.

Grinten, W.C.L. van der, met medewerking van J.M.M. Maijer, Handleiding tot de beoefening van het Nederlands Burgerlijk Recht, Vertegenwoordiging en Rechtspersoon, De Rechtspersoon, Asserserie, W.E.J. Tjeenk Willink, Zwolle, 1991.

Grol, G.J. van, De grondpolitiek in het West-Indische Domein der Generaliteit, Algemeene Landsdrukkerij, 's-Gravenhage, Emmering, Amsterdam, 1934 [herdruk 1980]. 
Groot, A.D. de, Methodologie, Grondslagen van onderzoek en denken in de gedragswetenschappen, Uitgeverij Mouton, 's-Gravenhage, 1981.

Groot, G.R. de, Tratnik, M., Nationaliteitsrecht, Tjeenk Willink, Zwolle, 1984.

Haan, J.C. de, e.a., (red.), Nederlanders over de zeeēn, 350 jaar Nederlandsche koloniale geschiedenis, Uitgeverij W. de Haan, Utrecht, 1940.

Haersolte, R.A.V. van, Inleiding tot het staatsrecht, Tjeenk Willink, Zwolle, 1988.

Hakkenberg, A., Van probleem analyse naar structuur, Stedebouw en Volkshuisvesting, 1981, pp. 126-133.

Hall, G. M., Saint Domingue, in: H. Beckers \& V. Shepherd (eds.), Caribbean Slave Society and Economy, 1991.

Halley, A., Is Cassatierechtspraak wel wenselijk?, TAR-Justicia, 1980, 1, pp. 5-10.

Hamelberg, J.H.J., De Nederlanders op de West-Indische Eilanden, I-Ill, Bijdrage tot de Jaarverslagen van het Geschied-, Taal-, Land- en Volkenkundig Genootschap der Nederlandsche Antillen, De Bussy, Amsterdam, 19011909, [herdruk Emmering, Amsterdam, 1979].

Hamelberg, J.H.J., De Slavenopstand op Curaçao in 1795, Jaarlijksch Verslag van het Geschied-, Taal-, Land- en Volkenkundig Genootschap, De Bussy, Amsterdam, 3, 1899, pp. 120-148.

Hamelberg, J.H.J., De verkoop der kolonie Curaçao, De Indische Mercuur, 22 maart 1918.

Hansz, R. van der, Civiele rechtspraak door de Hoge Raad voor de Nederlandse Antillen in verleden en heden, in: Hoge Raad bedankt?, Cassatieregeling en onafhankelijke Antillen, Drukkerij ALEVO, Delft, Universiteit van de Nederlandse Antillen, Willemstad, Curaçao, Nederlandse Antillen, pp 669.

Hardenberg, L., De Hoge Raad en Overzees Recht, art. 23 Statuut jo. art. 99 R.O., 36, NJB 1961, pp. 923-930 en 36, NJB 1961, pp. 942-946.

Hartog, J., Aruba zoals het was, zoals het werd, van de tijd der Indianen tot op heden, D.J. de Wit, Aruba, 1953. ${ }^{2}$

Hartog, J., Luis Bríon, De Wit N.V. Stores, Aruba, 1968.

Hartog, J., De banden tussen Oranje, de Nederlandse Antillen en Aruba, De Walburg Pers, Zutphen, 1988.

Hartog, J., Curaçao, van kolonie tot autonomie, D.J. de Wit, Aruba/Nederlandse Antillen, 1961.

Hartog, J., De Bovenwindse Eilanden, De Wit N.V. Stores, Oranjestad, Aruba, 1964.

Haseth, C. de, Over de executies van de slavenopstand van 1795, Kristòf, 1985, pp. 5-11.

Hayek, F.H., The Road to Serfdom, Phoenix Books, The University of Chicago Press, 1944.

Heijden, E.J.J., van der, Handboek voor de naamloze en besloten vennootschap, bewerkt door W.C.L. van der Grinten, W.E.J. Tjeenk Willink, Zwolle, 1989."

Helsdingen, W.H. van, Handelingen over de Reglementen op het Beleid der Regering in de koloniēn Suriname en Curaçao, Martinus Nijhoff, 'sGravenhage, 1914. 
Helsdingen, W.H. van, De zelfstandigheid der eilandgebieden in de Nederlandse Antillen, De WIG, 32, 1951, pp. 193-205.

Helsdingen, W.H. van, Voorlopigebalans over de uitvoering van de Eilandenregeling van de Nederlandse Antillen, De WIG, 35, 1954, pp. 72-90.

Helsdingen, W.H. van, Aruba en de Separación, De WIG, 35, 1954, pp. 113-134, 1955, pp. 233-234.

Helsdingen, W.H. van, Het Statuut voor het Koninkrijk der Nederlanden, De WIG, 35, 1955, pp. 182-191.

Heringa, A.W., Zwart, T., De wetgever en het toetsingsrecht, NJB 65, 1990, pp. 631-633.

Het oog van de meester, Opstellen aangeboden aan mr. C.E. Dip, ter gelegenheid van zijn afscheid als Raadsadviseur belast met de leiding van het Centraal Bureau voor Juridische en Algemene Zaken; Delden, M.PH. van, Grüning, C.M. en Jonis-Kleinmoedig, E.E., (red.), Stichting Wetenschappelijke en Culturele Publicaties, Curaçao, N.A., 1989.

Hillebrand Bosch, H., Zelf-beschikkingsrecht, NJB 53, 1978, pp. 183-184.

Hirsch Ballin, E.M.H., De wetenschap van het constitutionele recht, in: Object en methode van de staatsrechtwetenschap, Staatsrechtconferentie 1982, Ars Aequi Libri, Nijmegen, 1982, pp. 64-95.

Hirsch Ballin, E.M.H., Het Koninkrijk in de Caribische Zee, Christen Democratische Verkenningen, 1989, 11, pp. 463-471.

Hirsch Ballin, E.M.H., Schets voor een Gemenebestconstructie, Kabinet voor Nederlands-Antilliaanse- en Arubaanse Zaken, 1990.

Hoetink, H., Slavery and Race Relations in the Americas, An Inquiry into their Nature and Nexus, Harper and Row, New York, 1973.

Hoetink, H., Caribbean Race Relations, A Study of Two Variants, Oxford University Press, London, 1971.

Hoetink, H., De overlevingskansen van de Antillen van de Vijf, in: UNA-cahier, 23,1986 , pp. 2-14.

Hoetink, H., Schipperen tussen a fhankelijkheden, De Nederlandse Antillen en hun plaats in de Caraibische regio, Volkenrechtelijke aspecten van Antilliaanse onafhankelijkheid, Tjeenk Willink, Alphen aan den Rijn, 1980, pp. 33-50.

Hoetink, H., Race Relations in Curaçao and Surinam, in: Slavery in the New World, Foner, L. and Genovese, E.D. (eds.), Prentice-Hall, Inc., Englewood Cliffs, New Jersey, 1969, pp. 178-188.

Hoetink, H., Het patroon van de oude Curaçaosche samenleving, De Wit Stores, Aruba, 1971.

Hoeven, J. van der, Koninkrijksrecht en constitutioneel recht, Rechtsgeleerd Magazijn Themis, 1959, pp. 375-389.

Hoeven, J. van der, Staatsrecht en economische macht, Staatsrechtconferentie 1975, Universiteit van Amsterdam, 1975, pp. 85-120.

Hoeven, J. van der, De rechtsstaat herdacht, in: De rechtsstaat herdacht (1989) pp. $1-9$.

Hollander, A.N.J. den, e.a., De plurale samenleving, begrip zonder toekomst?, Boom, Meppel, 1966.

Honderd Jaar Codificatie in de Nederlandse Antilen, Schiltkamp, J.A., Sjiem Fat, P.V., Wijnholt, M.R. (red.), N.V. Uitgeversmaatschppij S. Gouda Quint/D. Brouwer en Zoon, Arnhem 1969. 
Hoogbergen, W., De Bosnegers zijn gekomen! Slavernij en Rebellie in Suriname, Prometheus, Amsterdam, 1992.

Hullu, J. de, Memorie van den Amerikaanschen Raad over de Hollandsche bezittingen in West-Indië in Juli 1806, De WIG, 4, 1922, pp. 387-398.

Hutten, D.J., Regelgeving door de rechter in: De rechtsstaat herdacht (1989) pp. 283-296.

Hulzen, J. van, Onze West-Indische Geschiedenis, uitgeverij W. van Hoeve, 'sGravenhage, 1946.

Information cycle on the planned referendum in Curaçao, Cova, E., Marcha, V., Moenir Alam, L., (eds.), University of the Netherlands Antilles and Kamara Sindikal, Willemstad, March 1992.

International Relations in the Caribbean, Papers presented at the Symposium on International Relations in the Caribbean, Curaçao, January 24-26, 1974, sponsored by the Institute of International Relations, University of the WestIndies, Saint Augustine, Trinidad and Hogeschool van de Nederlandse Antillen, Curaçao, 1974.

ISS-Rapport, Aruba en de onafhankelijkheid: achtergronden, modaliteiten en mogelijkheden: een rapport in eerste aanleg, Benthem van den Bergh, G., Braun, O., Hilhorst, J.G.M., Laar, A.J.M. van der, (red.) Institute of Social Studies, Den Haag, 1978.

Janus, J.A.B., De Ontbinding van de Staten van Aruba; Nogmaals: de ontbinding van de Staten van Aruba, TAR-Justicia, 1989, pp. 14-19; pp. 23-34.

Janus, J.A.B., Kabinetsformaties in de Nederlandse Antillen, in: Het oog van de meester (1989) pp. 65-96.

Janus, J.A.B., Eilandenregelingzou moeten verdwijnen, Synchronisatieverkiezing conditio sine qua non, Unie van Eilanden mogelijk alternatief voor Nederlandse Antillen, Amigoe, 26 juni 1990.

Janus, J.A.B., Staatsrechtelijke ontwikkelingen in de jaren tachtig. Een terugblik, TAR-Justicia, 1990, pp. 77-91.

Janus, J.A.B., Het Statuut voor het Koninkrijk der Nederlanden: terugblik en perspectief, in: Naar een nieuwe structuur voor het Koninkrijk, Staatsrechtconferentie 1993, W.E.J. Tjeenk Willink, Zwolle, 1993, pp. 33-92.

Jesurun, E.A.V., (red): Hendrikse, M.C., Opdat wij niet vergeten, Gedenkboek Mr. Dr. Moses F. da Costa Gomez, Den Haag/Willemstad, 1993.

Johnson, Ch., Slavenroute, Arena, Amsterdam, 1992.

Jong, M.W. de, Napel, H. ten, Nederlandse Antillen en Aruba, Koninklijk Instituu, voor de Tropen/Novib/SDU uitgeverij, 1988.

Jong, H.G. de, Aruba, a separate 'country' within the Kingdom of the Nether lands on its way to independence, Netherlands Yearbook of International law, Martinus Nijhoff, 20, 1989, pp. 71-89.

Jonkers, A., Hoofdtrekken van de ontwikkeling van Suriname en de Nederlandse Antillen, De WIG, 34, 1953, pp. 113-159.

Joubert, E.L., Dienen de Nederlandse Antillen de Nederlandse hercodificatie te volgen?, diësrede UNA 1982, Miscellanea luridica Antiliana, Opstellen ter gelegenheid van de tweede diësviering van de Societas luridica Antiliana, Jongbloed \& Zoon, 's-Gravenhage/Leiden, 1983, pp. 37-70.

Joubert, G.S., Strafrechtspleging anno 1790 op St. Eustatius, Latèrnu, 1. 1983. pp. 8-11.

Kant, 1., Prolegomena, 1783, Boom, Meppel/Amsterdam, 1979.

Kapteyn, P.J.G., De Nederlandse Antillen en de uitoefening van het zelfbeschik- 
kingsrecht, Mededelingen der Koninklijke Nederlandse Academie van Wetenschappen, Afd. Letterkunde, Nieuwe Reeks, deel 45, 6, B.V. NoordHollandsche Uitgeversmaatschappij, Amsterdam, 1982, pp. 159-187.

Karamat Ali, E.I., De Nederlandse Antillen, Aruba en de onafhankelijkheid, in:

Het oog van de meester (1989) pp. 97-112.

Kaser, M., Das Römische Privatrecht. Handbuch der Altertumswissenschaft,

Zweiter Abschnitt, Die nachklassischen Entwicklungen, I-II, C.H.

Beck'sche Verlagbuchhandlung, München, $1975^{2}$

Kasteel, A., De Staatkundige ontwikkeling der Nederlandse Antillen, Uitgeverij

W. van Hoeve, 's-Gravenhage/Bandung, 1956.

Kesler, C.K., Willem Usselinex en de oprichting van de Westindische Compagnie, De WIG, 3, 1921, pp. 65-78.

Kesler, C.K., Het Assiento, De WIG, 9, 1927, pp. 152-160.

Kesler, C.K., Boekaniers en flibustiers, De WIG, 10, 1928, pp. 65-88.

Kikkert, O.H., en Bekman, A.A.M., Drempelvrees, Een boek over Curaçao aan de vooravond van de onafhankelijkheid, Van Gorcum, Assen/Amsterdam, 1977.

Kleurenbijlage Vrij Nederland, Verhey, E., Westerloo, G. van, De heilige strijd van een verheven volk, juli 1978.

Klomp, A., Politics on Bonaire, Van Gorcum, Assen/Maastricht, 1986.

Knappert, L., Geschiedenis van de Bovenwindsche eilanden in de $18 \mathrm{e}$ eeuw, I-III, Martinus Nijhoff, 's-Gravenhage, 1932.

Knight, F.W., The Caribbean, The Genesis of a Fragmented Nationalism, Oxford University Press, New York, 1978.

Koekkoek, A.K., Het aftreden van het kabinet Lubbers, 64, NJB, 1989, pp. 877 883.

Kol, H. van, Naar de Antillen en Venezuela, A.W. Sijthoff, Leiden, 1904.

Komdeur, W., Cassatierechtspraak en onafhankelijkheid, TAR-Justicia, 1981, 2, pp. 150-151.

Koopmans, T., Compendium van het staatsrecht, Kluwer, Deventer, $1992 .^{6}$

Koot, W., Onafhankelijkheid door Antillianen gewenst?, Onderzoek naar de oorzaken en gevolgen van de migratie van Surinamers en Antillianen naar Nederland, Rapport 5, Antropologisch-Sociologisch Centrum, Universiteit van Amsterdam, 1975.

Koot, W., Ringeling A., Migranten in de Nederlandse samenleving. De Antillianen, D. Coutinho, Muiderberg, 1984.

Koot, W., Na Aruba ook Curaçao onafhankelijk?, Internationale Spectator, 1985 , pp. 721-727.

Koot, W., Tempel-Schoorl, C., Marcha V., Alleen of samen. Wat wil ons volk?, ISOR, Utrecht, 1988.

Koot, W., De Antillen en Aruba op weg naar 1996, Internationale Spectator, 1989, pp. 98-103.

Koperen polyfonie, Linker, O.B., Reinders, A. en Reijntjes, J., (red), [Bij het $121 / 2$-jarig bestaan van de Juridische faculteit van de Universiteit van de Nederlandse Antillen, Opstellen aangeboden ter gelegenheid van zijn afscheid aan Prof. W.R. Boom], Universiteit van de Nederlandse Antillen, Willemstad, 24, 1984.

Kortmann, C.A.J.M., De Grondwetsherziening 1983 en 1987, Deventer, 1987

Koulen, I., Verton, P. en Silberie, R., Dilemma's van dekolonisatie en ontwikkeling: Ontwerpen voor onderzoek, UNA Cahier 9, UNA, Willemstad, 1985. 
Kousa Komun, Outonomia. Punto di diskushon den konferensia pa futuro, Willemstad, Intergrafia N.V., aprel 1993.

Kranenburg, R., Het gebied van de rijkswetgever, 31, NJB 1956, pp. 873-875.

Kranenburg, R., Het Nederlands Staatsrecht, met medewerking van J.L. Kranenburg, H.D. Tjeenk Willink en Zoon N.V., Haarlem, 1958. ${ }^{8}$

Koulen, I., Europa en het Caraibische gebied, UNA-Cahier, 9, Willemstad, 1985.

Kunneman, F.B.M., De herziening van het vermogensrecht op de Nederlandse Antillen, TAR-Justicia, 1990, pp. 16-33.

Kunst, A.J.M, Receptie en Concordantie van Recht, De invloed van het Nederlandse Recht op dat van de Nederlands Antillen, diesrede 10-9-1973, Uitgave van de Rechtshogeschool van de Nederlandse Antillen, 1973.

Kunst, A.J.M., De handel in slaven en de slavernij op de Nederlandse Antillen, Kristòf, 1975, pp. 162-178.

Kunst, A.J.M., Recht, Commercie en Kolonialisme in West-Indiē, De Walburg Pers, Zutphen, 1981.

Kuyp, J.H. van der, Het werkdocument Jeukens of het hinken op twee gedachten, 52, NJB 1977, pp. 150-152.

Kuyp, J.H. van der, Het politieke regime van de Nederlandse Antillen in de knoop, 50, NJB 1975, pp. 1246-1251.

Kuyp, J.H. van der, De West-Indische Federatie: Een mislukte poging tot Caraibische samenwerking, Miscellanea Iuridica Antiliana, Opstellen ter gelegenheid van de tweede diesviering van de Societas luridica Antiliana, Jongbloed \& Zoon, 's-Gravenhage/Leiden, 1983, pp. 89-119.

Kuyper, P.J. en Kapteyn, P.J.G., A Colonial Power as Champion of Selfdetermination: Netherlands state practice in the period 1945-1975, Ill, Sijthoff \& Noordhoff, Alphen aan den Rijn, 1980, Oceana Publications Inc. Dobbs Ferry, N.Y., pp. 149-218.

Kuypers, G., Grondbegrippenvan politiek, Politicologie als wetenschapvan macht en beleid, van de mens als producent van gevolgen, Wie bereikt wat voor wie, hoe en wanneer, Aula boeken, Het Spectrum, Utrecht/Antwerpen, 1976.

Kuyperstichting, De, Naar nieuwe verhoudingen, De Staatkundige toekomst van Suriname en de Nederlandse Antillen, rapport uitgebracht door een commissie van de Adviesraad van de Doctor Abraham Kuyperstichting, Den Haag, 1971 ('De Kuyperstichting').

Kwaadsteniet, W. de, Het recht van Kamerontbinding, Kluwer, Deventer, 1968.

Lagerberg, C.S.I.J., Onvoltooid verleden tijd, de dekolonisatie van Suriname en de Nederlandse Antillen, Nijmegen, Instituut voor Ontwikkelingsvraagstukken (IVO) 1989, pp. 191-197.

Lampe, W.F.M., In de Schaduw van de Gouverneurs, De Wit, Aruba, 1968.

Land L. van der, (red), Repertorium der politiek, Elsevier, Amsterdam/Brussel, 1953.

Las Casas, Bartolomé de, Kort Relaas van de verwoesting van de West-Indische Landen. oorspronkelijk Sevilla 1552, de Arbciderspers, Amsterdam, 1969.

Laurence, P., De Peterpyramide, waarom staat de top op zijn kop?, Veen BV, Utrecht/Antwerpen, 1986.

Leeuwen, B. van, Geniale Anarchie, In de Knipscheer, Amsterdam, 1990.

Lewis, G.K., The Growth of the Modern West Indies, Monthly Review Press, New York, 1968. 
Locke, J., The Works of John Locke, I-V, Two Treatises of Government, 1823 [reprint Scientia Verlag Aalen, 1963].

Locke, Over het staatsbestuur, Boom, Meppel, Amsterdam, 1988.

Logemann, J.H.A., Het nieuwe staatsrecht, NJB 25, 1950, 1, pp. 1-7.

Logemann, J.H.A., Het komende Statuut voor het Koninkrijk, NJB 27, 1952, 14, pp. 309-319.

Logemann, J.H.A., Toetsing van rijksregelingen in de Nederlandse Antillen, NJB 30,1955 , pp. 569-572.

Logemann, J.H.A., Het Staatsrecht van Indonesië, het formele systeem, N.V.

Uitgeverij W. Van Hoeve, 's-Gravenhage, Bandung, 1955 . $^{3}$

Logemann, J.H.A., De hiërarchie der wettelijke regelingen in het Statuut, NJB 30, 1955, pp. 433-441.

Logemann, J.H.A., Wat moet bij rijkswet worden geregeld?, NJB 1956, 31, pp. 141 [reactie hierop van F.R. Böhtlingk, 31, NJB 1956, pp. 672; en reactie hierop van Logemann: pp. 705].

Logemann, J.H.A., Het Antilliaanse staatsrecht in beroering, NJB 35, 1960, pp. 245-253.

Los Santos, E.B.N. de, Toetsing van landsverordeningen, Antilliaans Juristenblad, 1951, pp. 90-93.

Lustrum van een ideaal, Opstellen ter gelegenheid van het eerste lustrum van de Hogeschool van de Nederlandse Antillen, 1971-1976, Dip, C.E., Kunst, A.J.M, Römer, R.A., (red.), Hogeschool van de Nederlandse Antillen, Willemstad, 1976. Luiten, W.A., Concordantie en Cassatie, in: TARJusticia, 1980, 1, pp. 11-16.

Luiten, W.A., Een inleiding tot het Antilliaanse staatsrecht, UNA, Willemstad, 1983.

Luiten, W.A., Teleurgestelde verwachtingen, diesrede UNA, Willemstad, 1981.

Luiten, W.A., Een ivoren toren of een glazen kast, in: Het oog van de meester (1989) pp. 121-136.

Maarseveen, H.Th.J.F. van, Minsteriēle verantwoordelijkheid, NJB 40, 1965, pp. 495-507.

Maarseveen, J.F. van, Politiek recht, opvolger van de het staatsrecht?, N.V. Uitgeversmaatschappij, Kluwer, Deventer, 1971.

Maarseveen, H. van, Toetsing een politiek non-probleem?, NJB 65, 1990, pp. 625-626.

Martha, R.S.J., De schendbaarheid van landsverordeningen, Universiteit van de Nederlandse Antillen, 1988.

Mc Leod, C., Hoe duur was de suiker?, uitgeverij VACO, Paramaribo, 1987.

Menkman, W.R., Moederlandscheverantwoordelijkheiden Westindische autonomie, De WIG, 11, 1930, pp. 403-411.

Menkman, W.R., Slavenhandel en rechtsbedeeling op Curaçao op het einde der 17e eeuw, De WIG, 17, 1935, pp. 11-26.

Menkman, M.R., Van de verovering van Curaçao tot de vrede van Munster, De WIG, 18, 1936, pp. 161-183.

Menkman, M.R., De Nederlanders in de Caraibische wateren: een nabetrachting, De WIG, 18, 1936, pp. 213-219.

Menkman, M.R., Urbina, De WIG, 21, 1939, pp. 240-248.

Menkman, M.R., Zuidamerikaansche piraterie en onze bovenwindsche eilanden voor vijf kwart eeuw, De WIG, 25, 1943, pp. 65-80, 97-111, 129-154. 
Menkman, W.R., Nederlandsche en vreemde slavenvaart, De WIG, 26, 1944, pp. 97-110.

Menkman, W.R., Het eerste Nederlandsche bestuur van Curaçao, De WIG, 29, 1948, pp. 328-332.

Merton, R.K., Social Theory and Social Practice, The Free Press, New York, London, 1986.

Middel, E.M., Schuiling, K.F., (red.), De rechtsstaat herdacht, W.E.J. Tjeenk Willink, Zwolle, 1989.

Miscellanea iuridica Antilliana, Opstellen ter gelegenheid van de tweede diesviering van de Societas Iuridica Antilliana, Palm, R.O.L., Martis, E.H.J., (red.), Jongbloed, 's-Gravenhage, 1983.

Moenir Alam, L.C.G., Commentaar, in: Meijers (1980) pp. 147-153.

Montesquieu [Charles de Secondat de la Brède, baron van Montesquieu], De l'Esprit des Lois, I, 1757, [herdruk, GF Flammarion, 1979].

Monté ver Loren, J.Ph. de, Spruit, J.E., Hoofdlijnen uit de ontwikkeling der rechterlijke organisatie in de Noordelijke Nederlanden tot de Bataafse omwenteling, Kluwer, Deventer, $1982 .^{6}$

Munneke, H.F., Een Gemenebestconstitutie voor het Koninkrijk der Nederlanden, de strijd tegen de bestuurlijke desintegratie op de Antillen, Tijdschrift van Overheidsadministratie (TvO), 1990, 16, pp. 348-352.

Munneke, H.F., De Surinaamse constitutionele orde sinds 1975. De grondwet van 1975, een staatsrechtoverzicht anno 1985 en de grondwet van 1987, voorzien van een staatsrechtelijk commentaar, Ars Aequi Libri, Nijmegen, 1990.

Munneke, H.F., Riezebos, C., Tang van der G.F.M., Federalisme, Publikaties van de Staatsrechtkring, W.E.J. Tjeenk Willink, Zwolle, 1992.

Munneke, H.F., Deugdelijk bestuur en zelfbeschikking in het Caraibisch Koninkrijksdeel, NJB 68, 1993, pp. 857-858.

Meijers, H., (red.), Volkenrechtelijke aspectenvan Antilliaanseona fhankelijkheid, Tjeenk Willink, Alphen aan den Rijn, 1980.

Naipaul, V.S., The Loss of El Dorado, Penguin, 1987.

Nripaul, V.S., The Middle Passage, Penguin, 1988.

Neef, A.A.J. de, De Regelingsbevoegdheidvan de Kroon voor de Koloniēn, A.H. Kruyt, Amsterdam, 1915.

Nederveen Pieterse, J., Wit over Zwart, Beelden van Afrika en Zwarten in de Westerse Populaire Cultuur, Uitgegeven ter gelegenheid van de tentoonstelling: Wit over Zwart in het Tropenmuseum van 16 december 1989 tot en met 21 augustus 1990. Koninklijk Instituut voor de Tropen, Amsterdam, Stichting Cosmic Illusion Productions, Amsterdam, NOVIB, Den Haag, 1990.

Nita, A.P., De sociale wensdromen van het landskind in de gelijke delen van het nieuwe koninkrijk, Curaçaosche Courant, Willemstad [1969]. ${ }^{4}$

Noonan, J.T., Jr., Persons as central, TAR-Justicia, 1987, 1, pp. 1-5.

Nos Futuro, Wegen naar een toekomst voor de Nederlandse Antillen, Lieuw, G.H, Algra T., Evers R., (red.), Universiteit van de Nederlandse Antillen/De Walburg Pers, 1986.

Oostindie, G., The Dutch Caribbean in the 1990's: Decolonization, recolonization?, Annales des Pays d' Amérique Latine et des Caraibes, 1992, pp. 225 247. 
Oostindie, G.J., The Dutch Caribbean in the 1990's: Decolonization or Recolonization, Caribbean Affairs, 5, 1992.

Oostindie, G.J., Caraibische dillema's in een 'stagnerend' dekolonisatieproces, inaugurele rede, 18 januari 1994, KITLV Uitgeverij, Leiden, 1994.

Oud, P.J., Het Constitutioneel Recht van het Koninkrijk der Nederlanden, I-II, Tjeenk Willink, Zwolle, I, $1967,{ }^{2}$ II, $1970 .{ }^{2}$

Oud, P.J., Honderd jaren, Staatkundige vormgeving in Nederland, I-II, bewerkt door J. Bosmans, Van Gorcum, Assen/Maastricht, 1987.

Oudeschans Dentz, F., Het Nederlanderschap in Suriname en Curaçao, I-II, De WIG, 9, 1927, pp. 131-136; WIG 16, 1934, p. 205.

Oudeschans Dentz, F., Hoe het eiland Sint Maarten werd verdeeld, De WIG, 13, 1931, pp. 163-164.

Oudeschans Dentz, F., De inbezitneming van het Fransche gedeelte van Sint Maarten door de Nederlanders, De WIG, 15, 1933, pp. 280-281.

Oven, J.C. van, Leerboek van het Romeinsch Privaatrecht, E.J. Brill, Leiden, $1948 .^{3}$

Parry, J.H., Sherlock, P., A Short History of the West-Indies, The Macmillan Press Ltd., London and Basingstoke, Third edition 1976.

Passerin d'Entrèves, A., The notion of the State, An Introduction to Political Theory, Oxford University Press, $1969 .^{2}$

Patronage, clientelisme en vriendschap, Banck, G., Trouwborst, A. (red.), Antropologische Verkenningen, 11, 2, 1992.

Patterson, O., The Sociology of Slavery, An Analysis of the Origins, Develop ment and Structure of Negro Slave Society in Jamaica, Rutherford, Madison, Teaneck, Fairleigh Dickinson University Press, London, 1975.

Paula, A.F., 50 jaren Staten van de Nederlandse Antillen, 1938-1988, Willemstad, 1988.

Paula, A.F., Hoofdmomenten uit de Staatkundige Ontwikkeling van de Nederlandse Antillen 1865-1986, Lantèrnu 9, Willemstad, 1989.

Paula, A.F., Van slaaf tot quasi-slaaf, Een sociaal-historische studie over de dubbelzinnige slavenemancipatie op Nederlands Sint-Maarten 1816-1863 [proefschrift Utrecht] Centraal Historisch Archief, Curaçao, 1992.

Paula, A.F., 'Vrije' slaven. Een sociaal-historische studie over de dualistische slavenemancipatie op Nederlands Sint-Maarten 1816-1863, Centraal Historisch Archief/Universiteit van de Nederlandse Antillen/De Walburg Pers, 1993 [handelseditie van het hierboven genoemde proefschrift].

Pedroli, W.J., De Status Aparte van Aruba: 1-1-11986 is wel degelijk een keerpunt!, 59, NJB 1984, pp. 722-723.

Peet, H.P. van, De besluitvorming over de decentralisatie van landstaken op de Nederlandse Antillen, UNA-Cahier 7, Universiteit van de Nederlandse Antillen, Caraibische Afdeling, Koninklijk Instituut voor Taal-, Land- en Volkenkunde, CARAF, Stichting voorCulturele Samenwerking,STICUSA, 1984.

Peters Th.J., Waterman Jr. R.H., Excellente ondernemingen, Kenmerken van succesvol management, Veen uitgevers, Utrecht/Antwerpen, 1983. 
Peters T., Austin N., A passion for excellence, the leadership difference, Fontana/Collins, 1986.

Pieters Kwiers, G.T., De Eenvormige Landsverordening, TAR-Justicia, 1986, pp. 273-278.

Pieters Kwiers, H.G.M., Ideal Politiko di Dr. Da Costa Gomez, Scherpenheuvel, Willemstad, 1991.

Pietersz, R.F., Gevolgen van de Status Aparte van Aruba voor de rechterlijke organisatie, TAR-Justicia, 1986, pp. 105-110.

Plante Fébure, J.M., West-Indiē in het Parlement, 1897-1917, bijdrage tot Nederlands koloniaal-politieke geschiedenis, Martinus Nijhoff, 's-Gravenhage, 1918.

Plato, Verzameld werk, I-V, III, De Staat, pp. 69-517, De Staatsman, pp. 519611, IV, De Wetten, pp. 93-613, De Nederlandsche Boekhandel, Antwerpen/AMBO BV, Baarn, $1980 .^{3}$

Poelgeest L. van, Preadvies. Toetsing van de wet aan de Grondwet in Nederland, Vereniging voor de vergelijkende studie van het recht van België en Nederland, W.E.J. Tjeenk Willink, Zwolle, 1991.

Polak, M.V., Federale Staatsvormen, Samsom, Alphen aan den Rijn, 1966.

Pool, J. de, Zo was Curaçao, oorspronkelijk uitgegeven in 1935 in Santiago de Chile onder de titel 'Del Curaçao se va'; [Nederlandse vertaling in de Antilliaanse cahiers, 1960], S. Emmering, Amsterdam, 1985. ${ }^{2}$

Post, H.H.G., Veen, J.H. van der, Discussieverslag, in: Meyers (1980) pp. 154156.

Pot, C.W. van der, Handboek van het NederlandscheStaatsrecht, Tjeenk Willink, Zwolle, 1940.

Pot, C.W. van der, De Grondwetsherziening van 1956, 31, NJB 1956, pp. 673 681; pp. 705-712.

Pot, C.W. van der, Boekaankondigingen, bespreking van: De Staatsregeling van de Nederlandse Antillen van 1955 van W.H. van Helsdingen en bespreking van het proefschrift van $A$. Kasteel, de staatkundige ontwikkeling der Nederlandse Antillen, 31, NJB 1956, pp. 47-48.

Pot, C.W. van der, Handboek van het Nederlandse Staatsrecht, bewerkt door A.M. Donner, W.E.J. Tjeenk Willink, Zwolle, 1972. ${ }^{9}$

Pot, van der, Donner, Handboek van het Nederlandse Staatsrecht, bewerkt door L. Prakke m.m.v. J.L de Reede, G.J.M. van Wissen, W.E.J. Tjeenk Willink, Zwolle, 1989. ${ }^{12}$

Pourier, M.A., De Antillen van de Vijf, toekomst of dood spoor, in Uní ku UNA (1991) pp. 235-243.

Prakke, L., Demissionair kabinet en kamerontbinding, 52, NJB 1977, pp. 401407.

Prakken, A.B.J., De Bovenwindsche eilanden der kolonie Curaçao, De WIG, 1b, 1920, pp. $401-412$.

Pronk, P., Staatsinrichting van Aruba, VAD, Aruba, 1991.

Race and Class in Latin America, Mörner, M., (ed.), Columbia University Press, 1971.

Reijntjes, J.M., Cassatie en herziening in Antilliaanse strafzaken, UNA boekenreeks 27, UNA, Willemstad, 1984. 
Remmelink, J., De Hoge Raad ook in de toekomst nog een bindend element in ons koninkrijk?, gastcollege, 19-9-1990 gehouden voor de Universiteit van Aruba, Gouda Quint BV, 1990.

Reinders, A., Politieke geschiedenis van de Nederlandse Antillen en Aruba 19501993, De Walburg Pers, 1993.

Renkema, W.E., Anno 1869, Curaçao los van Nederland? Dat nooit, Kristòf, 1976, pp. 1-7.

Renkema, W.E., Het Curaçaosche plantagebedrijf in de negentiende eeuw, De Walburg Pers, Zutphen, 1981.

Renkema, W.E., De samenstelling van de Raad van Policie en de Koloniale Raad van Curaçao, 1816-1865, Lantèrnu, 1, 1983, pp. 12-18.

Renkema, W.E., Bronnen van ons verleden. Een Curaçaos adres tegen het Regeringsreglement van 1848, Lantèmu, 1, 1983, pp. 42-43.

Rijn, A.B. van, Naar een constitutioneel toetsingsrecht voor de Nederlandse Antillen?, TAR-Justicia, 1991, pp. 16-27.

Rijn, A.B. van, Enkele aanbevelingen met betrekking tot het Koninkrijkstoezicht, ten behoeve van de cyclus deugdelijk bestuur, 3 maart 1993.

Rijn, A.B. van, Naar een nulsituatie om iets nieuw op te bouwen, Status Aparte voor alle eilanden, een staatsrechtelijke uitdaging, Amigoe, 23 december 1992.

Rijn, A.B. van, De nieuwe structuur van het Koninkrijk door een Caraibisch venster bezien, Een voorwaarde voor bestuurlijke vernieuwing, in: Naar een nieuwe structuur van het Koninkrijk, Staatsrechtconferentie 1993, W.E.J. Tjeenk Wiilink, Zwolle, 1993, pp. 93-125.

Ritter, S.F., Asina 'ki pueblo a vota atravers di cincuenta aña, [z.u., z.p., 1987]. Roelofsen, C.G., The Netherlands until 1813, I, International Aspects, Sijthoff \& Noordhoff, Alphen aan den Rijn, 1980, Oceana Publications Inc. Dobbs Ferry, N.Y., pp. 1-42.

Röling, B.V.A., Volkenrechtelijke notities betreffende het recht van zelfbeschikking, in: Meyers (1980) pp. 133-146.

Römer, R.A., Naar de voltooiing van de Emancipatie, Beschouwingen naar aanleiding van het verschijnsel 30 mei, Van Dorp, 1974.

Römer, R.A., Race and class in political perspective. The Case of Frente Obrero, Kristòf, 1975, pp. 253-263.

Römer, Sociale stratificatie en sociale mobiliteit in de Curaçaose samenleving, in: Lustrum van een ideaal, Opstellen ter gelegenheid van het eerste lustrum van de Hogeschool van de Nederlandse Antillen, Hogeschool van de Nederlandse Antillen, 1976.

Römer, R.A., Het slavenverzet, Kristòf, 1976, pp. 181-189.

Römer, R.A., (red.), Cultureel Mozaiek van de Nederlandse Antillen, De Walburg Pers, Zutphen, 1977.

Römer, R.A., Emancipatie en democratie. Twee complementaire processen, Kristof, IV, 1977, pp. 74-78.

Römer, R.A., Een volk op weg = Un pueblo na kaminda: een sociologisch historische studie van de Curaçaose samenleving, De Walburg Pers, Zutphen, 1979. 
Römer, R.A., De ministaat. Problemen van kleinschaligheid, in: Een decennium later, W.A. Luiten, R.A. Rōmer, J.E. Spruit (red.), Opstellenbundel ter gelegenheid van het 10 jarig bestaan van de Faculteit der Rechtsgeleerdheid van de UNA, UNA/Willemstad/Kluwer/Deventer, 1982, pp. 89-105.

Römer, R.A., Het Caraibisch gebied. Een terreinverkenning, rede uitgesproken ter gelegenheid van de aanvaarding van het ambt van gewoon hoogleraar, aan de Universiteit van de Nederlandse Antillen, 4 maart 1982, UNA, Willemstad, 1982.

Römer, R.A., Slavernij en Slavenwetgeving in de kolonie Curaçao, Stichting Wetenschappelijke en Culturele Publicaties, Curaçao, 1989.

Römer-Kenepa, N.C., De Colleges van Bestuur van de Nederlandse Antillen, Lantèmu, 1, 1983, pp. 3-7.

Römer-Kenepa, N.C., Betekenis van de Raad van Policie van Bonaire, Lantèrnu, 1, 1983, pp. 20-27.

Rosenthal U., e.a., Openbaar Bestuur, organisatie, beleid en politieke omgeving, H.D. Tjeenk Willink, Alphen aan den Rijn, 1977.

Rousseau, J.J., Du contrat social, 1762, précédé de la Démocratie selon Rousseau par. J.P. Siméon, Éditions du Seuil, 1977.

Ruiter, D.W.P., de, e.a., Staatsrechtwetenschap en Politicologie, een onderzoek in het licht van de algemene staatsleer, Staatsrechtconferentie 1983, Ars Aequi Libri, Nijmegen, 1983,pp. 1-37.

Sabine G.H., Thorston T.L., A history of Political Theory, Bryden Press, Hinsdale, Illinois, USA, 1973.`

Sala-Molins, L., Le Code Noir, ou la calvaire de Canaan, Presses Universitaires de France, 1988.

Scheltema, M., De rechtsstaat in: De rechtsstaat herdacht (1989) pp. 11-25.

Schiltkamp, J.A., Bestuur en rechtspraak in de Nederlandse Antillen ten tijde van de West-Indische Compagnie, in: Honderd jaar Codificatie (1969) pp. 117-183.

Schiltkamp, J.A., en Schmidt, J.Th de, (red.), West Indisch Plakkaatboek, I-II, S. Emmering, Amsterdam, 1978.

Schmelzer, W.K.N., Economische macht binnen de maatschappelijke en staatkundige verhoudingen, Staatsrechtconferentie 1975, Universiteit van Amsterdam, 1975, pp. 121-159.

Schrage, H.J.J., Staatkundig novum, Antilliaans Juristenblad 1967-1969, 18, 1968, pp. 3-4.

Schrieke, B.J.O., Heemstra, M.J. van, Ons Koninkrijk in Amerika, West-Indiē, W. van Hoeve, 's-Gravenhage, 1947.

Schrills, J.M.R., Onze politieke mentaliteit: een gevaar voor de democratie, in: Nos Futuro (1986) pp. 147-162.

Simons, G.J., Beschrijving van het eiland Curaçao, uit verschillende bronnen bijeen verzameld, Osterwolde, 1868, [herdruk. S. Emmering, Amsterdam en De Wit N.V, Aruba, 1986].

Sjiem Fat, P.V., Aanpassing Antilliaanse Wetgeving aan Cassatieregeling gewenst, Justicia, 1968, pp. 1-5.

Sjiem Fat, P.V., Biba Willem Sassen, De Procureur-Generaal Mr. W.K. Sassen Jz., Curaçaos rechtsleven in de 19de eeuw, De Walburg Pers, 1986.

Sjiem Fat, P.V., Arubaans (en Antilliaans) rechtsleven, 1950-1990, Drukkerij Alberga, N.V., Paramaribo, Suriname, 1990. 
Smit, W., De Hoge Raad, cassatierechter ook voor de Nederlandse Antillen, TAR-Justicia, 1981, pp. 278-281.

Soest, J. van, Olie als water. De Curaçaose economie in de eerste helft van de twintigste eeuw, Hogeschool van de Nederlandse Antillen/Centraal Historisch Archief, 1976.

Soest, J. van, Trustee of the Netherlands Antilles. A history of money, banking and the economy with special reference to the central Bank van de Nederlanse Antillen 1828 - 6 February - 1978, Bank van de Nederlandse Antillen, Curaçao, 1978.

Soest, J. van, De betrekkingen tussen Curaçao en Venezuela. Een historische analyse, UNA, Willemstad, 1980.

Sola, J.H. de, Ten years thereafter, Kristòf, V, 1979, pp. 49-58.

Sondaal, H.M.M., Dutch Treaty Practic, Treaties with the Netherlands Antilles and Aruba, Netherlands Yearbook of International Law, Martinus Nijhoff, The Hague, 1988,19 , pp. 229-237.

Starke, J.G., Introduction to International Law, Butterworths, London, 1989.

Tak, P.J.P., Rechtsvorming in Nederland, een inleiding, Open Universiteit, Samsom/H.D. Tjeenk-Willink, 1987.

Taunay, J.P., Wat zal de vertegenwoordiging doen ten opzichte van het aanhangig ontwerp Regerings-reglementvoor West-Indië, De Erven Loosjes, Haarlem, 1864.

Teenstra, M.D., De Nederlandsch West-Indische eilanden, Curaçao, St. Maarten, St. Eustatius, Saba, I-II, C.G. Sulpke, 1837, [herdruk S. Emmering, Amsterdam, 1977].

Therborn, G., What does the Ruling Class do when it rules?, NLB, London, 1978.

Therborn, G., Ideologie en macht, SUA, Amsterdam, 1982.

Thomassen, J.J.A., Politicologie en Staatsrecht, Staatsrechtconferentie 1983, Ars Aequi Libri, Nijmegen, 1983, pp. 73-102.

Thorbecke, J.R., Staatsinrichting en staatsbestuur, bewerkt door J.P. Duyverman, N.V. UitgeversmaatschappijS. Gouda Quint/D. Brouweren zoon, Amhem, 1968.

Tratnik, M., De jurist in Aruba en in de Nederlandse Antillen en het NBW, TARJusticia, 1992, pp. 137-145.

Uní ku UNA, Opstellen aangeboden aan Prof. mr. W.C.L. van der Grinten, ter gelegenheid van zijn afscheid als gastdocent aan de UNA, Joubert, E.L., e.a. (red.), Tjeenk Willink, Zwolle, 1991.

Veen, P., Sociale psychologie toegepast, van probleem naar oplossing, Samsom reeks psychologie en samenleving, Alphen aan den Rijn/Brussel, 1985.

Verhey, E., en Westerloo, G. van, Kleurenbijlage Vrij Nederland, De heilige strijd van een verheven volk, juli 1978.

Versteeg, A.H., Toen woonden Indianen op Aruba, Archologisch Museum Aruba, 3, 1991 .

Verton, P., Aruba en de dekolonisatie van de Nederlandse Antillen, Internationale Spectator, 1978, pp. 771-778.

Verton, P.C., Politieke macht in koloniale samenlevingen, UNA cahier, 28, 1984.

Verton, P.C., Afhankelijkheid en ontwikkeling van de Nederlandse Antillen, in: Nos Futuro (1986) pp. 195-208. 
Verton, P.C., Wat vindt u van de toekomstige band met Nederland?, in: Nos Futuro (1986) pp. 181-193.

Verton, P.C., Kiezers en politieke partijen in de Nederlandse Antillen, Aruba, 1973.

Verton, P.C., Politieke dynamiek en dekolonisatie, de Nederlandse Antillen tussen autonomie en onafhankelijkheid, Samson, Alphen aan den Rijn, 1977.

Vile, M.J.C., The Structure of American Federalism, Oxford University Press, 1961.

Visman, M.A., Van slaaf tot plantagehouder: een aspect van het $18 \mathrm{e}$ eeuws plantagewezen op Curaçao, Nieuwe WIG, 55, 1981, pp. 39-51.

Voges, E., Het Vredegeregt op Aruba, in: Een decennium later, Opstellenbundel ter gelegenheid van het 10 jarig bestaan van de Faculteit der Rechtsgeleerdheid, UNA/Kluwer, 1982, p. 110-117.

Voltaire [François Marie Arouet], Candide ou l'optimisme, 1759, [herdruk, Librairie Générale Française, 1983].

Voort, P.P.C.H. van de, Détournement de pouvoir door de wetgever, 37, NJB 1962, pp. 537-579.

Vranken, J.B.M., De betrekkelijke waarde van een juridische methodenleer voor de rechtspraktijk, Een beeld van recht, Ars Aequi, jaargang 28-11, december 1979 , pp. 819-835.

Vries, F.P. de, Enige aspecten van de Nederlands-Antilliaansevertegenwoordiging in Nederland, De WJG, 36, 1956, pp. 165-173.

Vroom C.W., Stevens F.C.J. e.a. Organisatiesociologie, 6, Vuga-boekerij, 'sGravenhage, 1978.

Wachter, B., De Rijkswet van 20 juli 1961 houdende Cassatieregeling voor de Nederlandse Antillen en hercodificatie van het Nederlands Burgerlijk recht, TAR-Justicia, 1981, pp. 265-269.

Waddell, D.A.G., The West Indies and the Guianas, Prentice Hall, Inc., Englewood Cliffs, New Jersey, 1967.

Wageningen, G.J., van, Is het Landsbesluit van de 2 de Augustus 1971 no. 6 (P.B. 1971 no. 116) onbevoegd genomen en dus van rechtswege nietig?, Justicia, 7, 1971, pp. 33-35.

Walvin, J., Slavery and the Slave Trade, A Short Illustrated History, Macmillan, 1986.

Wehry, G.A.M. van, Nederland en het Caraibisch bekken, Clingendael Cahiers, Meijer en Siegers bv, Oosterbeek, 1988.

Wehry, G.A.M. van, The Netherlands and the Caribbean region, Internationale Spectator, 1989, pp. 696-674.

Weitjens, W.M.A., Het bestuur van de Bovenwindsche Eilanden, De WIG, 13, 1931, pp. 231-239.

Wels, C.B., The Foreign Relations of The Netherlands between 1813 and 1945 , I, Sijthoff \& Noordhoff, Alphen aan den Rijn, 1980, Oceana Publications Inc. Dobbs Ferry, N.Y., pp. 43-102.

Wernet-Paskel, L., Ons eilandje Aruba, Walburg Pers, Zutphen, 1992

Wheare, K.C., The Constitutional Structure of the Commonwealth, Oxford University Press, 1960.

Williams, E., The Negro in the Caribbean, 1942 [reprint 1975], ${ }^{3}$ Negro University Press, Westport, Connecticut, USA. 
Williams, E., From Columbus to Castro, The History of the Caribbean, 14921969, Harper and \& Row Publishers, New York/Evanston/San Francisco/ London, 1970.

Wilms, B.J.Th.G., De Status Aparte van Aruba: een bekeken zaak, nogmaals bekeken, 59, NJB 1984, pp. 721-722.

Wilms, B.J.Th.G., Het staatkundig emancipatieproces binnen het Caraibisch gedeelte van het Koninkrijk der Nederlanden. Aruba een 'case-study', [z.u.] Aruba, juli 1985 .

Winter, H.B., Wetgeving en wetsevaluatie, een Siamese tweeling, Over de legaliteitseis en de aanvullende werking van wetsevaluatie in: De rechtsstaat herdacht (1989) pp. 223-236.

Winter, J.M. van, De openbare mening in Nederland over de afschaffing der slavernij, De WIG, 34, 1953, pp. 61-102.

Wispelwey, TH.J.M., Steunend op eigen kracht, Willemstad, [ca. 1961].

Witboek, Het Witboek over de Status Aparte, Van der Kuyp, J.H., Fingal, H.R. (red.), Departement Staatkundige Structuur Eilanden, 1975.

Witteveen, W.J., De brede marges van het staatsrecht, Staatsrechtconferentie 1983, Ars Aequi Libri, Nijmegen, 1983, pp. 38-72.

Witteveen, W.J., Het negatieve vertrouwensvotum, 63, NJB, 1988, pp. 1237.

Wytema, H.J., Opperbestuur en Algemeen bestuur over Nederlandsch-Indië, Suriname en Curaçao, J.B. Wolters, Groningen/Den Haag/Batavia, 1931. 



\section{Personenregister}

Alberda, J.W., 234

Alofs, L.J., 365, 368

Amorie, H.A. des, 169

Ampués, Juan Martinez, de, 35

Arends, J.R., 192

Arends, A.M., 369

Athualpa, 36

Bakker, J.A., 370

Beck, M., 61, 68

Beijen, J.W., 272

Berlinski, L.S., 427, 445

Bermudez, A.R., 446-447

Beuningen, J, van, 61, 69

Biesheuvel, B.W., 386

Binsbergen, W.C. van, 291

Bislip, P., 429

Blanco, A.G., 43, 167, 168, 169

Boekhoudt, B., 170

Bolivar, S., 164, 167

Bongenaar, K.E.M., 265, 267, 470

Booi, F.A.J., 429, 447

Booi, G.R., 509, 545

Bordewijk, H.W.C., 14, 103

Bosch, J. van den, 42, 94, 96, 99, 230

Bríon, P.L., 83, 164

Brown, S.C., 314, 316, 318

Burg, F.H. van der, 450

Burkens, M.C., 450

Buys, J.T., 90

Caldera, R., 334

Carmichael, S., 321

Castillo, O.H., 374, 500

Castro, C., 168

Chumaceiro, A.M., 152, 169, 188, 199

Colina, L., 167

Colón, Diego, 37

Columbus, Christoffel, 22, 33, 36-37

Cortéz Hernando, 36

Crince le Roy, R., 281

Croes, G.F.(Betico), 329, 339, 352, 356, 360, 363, 364, 369, 374-376, 379, 
$381,383,385,395,396,398,408,427,431,435,439,441$

Croes, A.G., 472-473, 480, 491, 518

Croes, H.S., 379,400

Croes, J., 428

Croes, Maximo, 428

Croes, R.R., 452

Cuba, J.M. de, 192

Curiel, A., 234

De Las Casas, B., 111

Da Costa Gomez, M.F., 181, 184, 189, 194, 195, 208, 211, 213, 215-217, $225,241,270,290,366$

De la Try Ellis, W.Ch., 191, 223, 498

De Miranda, F., 164

De Monté ver Loren J.Ph., 124

De Wit, 290, 291, 292

Diaz, A.M., 508

Diephuis, G., 125

Dip, C.E., $287-289,448,466,480,491$

Drees, W., 276

Eman C.A., 178, 278

Eman, C.H., 178

Eman, J.H.A., sr. 178, 192, 209, 213, 231, 234, 256, 264, 270, 363, 364, $366,374,379,433,434$

Eman, J.H.A., jr. 441, 444, 446, 447, 448, 452, 454, 455, 537

Evertsz, J.M.G., 295, 342, 343, 351, 353, 379

Faesch, 1., 65, 70

Fennema, M., 234, 326, 355

Ferdinand van Aragón, 33

Fernandes Mendes, H.K., 326, 407, 484

Figaroa, F.D., 354

Figueroa, J., 323

Filips II, 37, 38, 53, 56

Fingal, H.R., 228

Flanegin, F.B., 456

Fock, C., 151

Fransen van de Putte, I.D., 103, 147

Franssen, J., 352, 457

Fruytier, L.R., 171

Gaay Fortman, W.F. de, 174, 176, 328, 356, 382, 383, 461, 465

Godett, W., 314

Gomez, J.V., 171

Gomez, D., 382, 427

Gonzalez, H.E., 408

Gorsira, M.P., 191, 258, 294, 331, 490, 499

Goslinga, C.Ch., 127, 173

Goveia, E.V., 121

Grinten, W.C.L. van der, 461-464 
Grol, G.J. van, 64

Grol J.D., 133

Guzmán, A., 167

Hamelberg, J.H.J., 117, 119, 143, 152, 170, 188, 220

Heim, P. van der, 84

Helfrich, O.L., 151

Helsdingen, W.H. van, 229, 265

Henriquez, R., 234, 326

Henriquez, E.C., 308, 361

Hirsch Ballin, E.M.H., 17, 296, 456, 461, 471, 478, 482, 487, 505, 507, $517,530,556$

Hoefnagels, G.P., 480, 507-508

Hoetink, H., 115, 355, 461, 465

Hogendorp G.K. van, 89, 56

Houtkoper, L., 78, 49

Isa, R.J., 345, 216

Isabella van Castilië, 33

Jansen, V.R., 446

Janus, J.A.B., 405, 447, 449, 451, 461, 482, 500, 526

Jeserun, A., 349

Jeukens, H.J.M., 335, 336, 338, 358

Jonckheer, E., 282, 326, 369

Jonkman, J.A., 234

Joubert, E.L. 162

Karamat Ali, E.L., 276, 488, 489

Karel V, 37, 56

Karpata, 127

Kasteel, A., 143, 188, 189, 205, 209, 220

Kasteel, P.A., 209, 211, 212

Kelly, P.P., 429, 447

Kemenade, J.A. van, 409

Kerckrinck, W., 119

Kernkamp, W.J.A., 264, 276

Kikkert, A., 165

Klomp, A., 372

Kol, H. van, $100,149,168,170,174$

Konijnenbelt, W., 547

Koning J. de, 404, 411, 412, 454, 478

Koningin Juliana, 248, 278

Koningin Wilhelmina, 207, 242

Koolman, O., 291

Koot, W., 345, 353, 372, 433, 475, 477, 486, 489

Kort, E.M. de, 379

Krajenbrink, J.G.H., 506

Kranenburg, R., 277

Kunneman, F.B.M., 163

Kunst, A.J.M., 124, 125, 160, 161 
Kuyp, J.H. van der, 228, 338, 350

Kwaadsteniet, W. de, 448, 455

Lampe, W.F.M., 189

Lampe, P., 130

Lauffer, J.R., 83

Leeuwen, W.C.J. van, $330,332,335,338,358,375$

Leito, B.M., 282, 327, 343, 354, 369, 409

Liberia-Peters, M.P., 295, 429, 476, 535

Liebergen, N., 59

Lier, Th. van, 327

Lodewijk Napoleon, 15, 84, 106

Logemann, J.H.A., 234, 237, 279

Lonvilliers, R., 48

Lubbers, R.F.M., 404, 442, 506, 513, 530

Luiten, W.A., 265

Luydens, J., 428

Maal, P.H., 217

Machado, A., 171

Mansur, D.E., 447

Mansur, J., 429

Marco Polo, 32

Martina, D.F., 352, 396, 453, 454, 460, 476

Me William, R.F., 512

Meer, S.W., van der, 290

Mehran, H., 443, 444

Meijers, H., 390

Melchior, L, 430

Merkies, L., 365, 368

Molleman, H.A.A., 385

Mommersteeg, J.A., 332

Montesquieu, 8, 62, 83, 86, 119, 121, 124, 201, 292

Morkos, E.J., 266

Munneke, H.F., 483, 491, 564, 565

Munnickhoven, J., 78

Napoleon, 85

Nederhorst, G.M., 324

Neef, A.A.J., de, 89

Nieuwkerk, D., 129

Nisbet, B.J.M., 446

Nita, A.P., 315

Oduber, A.A., 446

Oduber, N.O., 450, 452, 460, 488, 537

Ojeda de, Alonso, 22, 37

Oostindie, G.J., 508

Oppenheim, A.S., 209 
Paula, A.F., 115, 116, 385

Paus Alexander VI, 34

Pérez, C.A., 335

Peter, L., 547

Petronia, E.O., 314, 369

Philips, J., 49.

Piar, M.C., 164

Pizarro, Francisco, 36

Plante Fébure, J.M., 168

Plantz, W.R., 248

Plato, 373

Poelje, G.A. van, 213, 235, 252, 264

Polak, M.V., 494

Pourier, M.A., 484, 485, 491

Prakke, L., 451

Ptolomaeus, 32

Raders, R.F. van, 41

Raecx, E., 78

Renkema, W.E., 117, 348

Richardson, R.R.H., 382, 427

Rijn, A.B. van, $380,486,508,531$

Ringeling, C., 128

Rodier de la Bruguière, J.I.C., 128

Rodney, G.B., 47

Rojer, N., 349

Röling, B.V.A., 390

Römer, R.A., 136, 321, 322

Rousseau, Jean-Jacques, 86, 119

Rouville, A.M. de, 100

Rozendal, S.G.M., 383

Sala-Molins, L., 121, 126

Schabel, A., 127

Schagen, J.A., 177

Schaik, J.R.H. van, 252, 255

Schiltkamp, J.A., 64, 77, 119

Schorer, L., 78

Schrills, J.M.R., 372

Slobbe, B.W.T. van, 171

Soest, J. van, 334

Someren-Downer, G.V. van, 389

Spruit, J.E., 124

Staal, G.J., 179

Stee, A.P.J.M.M., 387, 393, 396

Stöppel, J., 128

Struycken, A.A.M, 290

Stuyvesant, P., 54, 55, 58, 113

Terpstra, E.G., 456, 506

Thijsen, S.S., 446 
Thomas, M., 48

Thorbecke, J.R., 89, 209

Tolck, J.P., 63

Toppenberg, R.G., 458

Tratnik, M., 163

Trinidad, G.P., 385

Tromp, F.R., 409

Tromp, F.B., 447

Tula, 127

Urbina, R.S., 171

Uyl, J.M. den, 345, 356

Veen Zeppenfeldt, B.E. van de, 151

Verton, P.C., 331, 338, 347, 352, 486, 489

Vespucci, Amerigo, 37

Vis, J.J., 507, 508

Voltaire, 118

Vos, E.J., 379, 382, 427

Waal, E. de, 102

Walbeeck, J., 56

Wathey, A.C., 296, 484

Watkins, F., 83

Werleman, H.A., 446

Wiebenga, J.G.C., 407, 455, 480, 505

Willem I, 42, 57, 88, 94

Willem V, 83

Willem van Oranje, 38

Wouters G.J.J., 193, 205, 208

Wright, R., 321

Yrausquin, J.E., 264, 366, 374, 375, 434

Zeil, P.H. van, 399

Zeppenfeldt, 151 


\section{Zakenregister}

Accion Democratico '86, 446

Actief vrouwenkiesrecht, 210

ADN, 429, 447

Advocaat-fiscaal, 47, 173, 542

Afscheiding 108, 339

Algemeen kiesrecht, 244, 372

Algemene Havenunie, 314

ALM, 453

AMvRB, 2, 284, 294, 514

Antilliaans Spoor, 387

Antilliaanse Staatsregeling, 182

Arubaanse Katholieke Partij, 192

Arubaanse Staatsregeling, 422

Arubaanse Volkspartij, 178, 192

Asiento's, 129

Associatie-verband, 540

ATIA, 443, 459

Autonomie, 103, 211, 213, 252, 434, 477, 541, 554, 564

AVP, 340, 344, 364, 366, 369, 375, 378, 409, 436, 442, 447, 459, 480,

516,536

AVV, 445

Bataafse Republiek, 15, 29, 71, 82, 84, 86, 106

Benedenwindse eilanden, 25

Bestuurscollege, 260

Black Power, 90, 136, 321

Blanketwet, 90

Bondsstaat, 495

Bovenwindse eilanden, 25

Buitengewone Raad van Advies, 208

C.A.B., 239,240

CanArub Gold Development NV, 444

Centralisatie, 508

Coastal, 45, 458

Cochenille-cultuur, 42

Code d'Instruction Criminelle, 90

Code Noir, 118, 120, 122, 126

Codificatie, 198

Collegie van Commercie en Zeezaken, 73, 96

College van Commissarissen tot de Kleine Zaken, 73

Collegie voor kleine zaken, 96 
Commandeur, 28, 63

Commendatio, 4, 134

Commissie Biesheuvel, 223, 287, 456

Commissie De la Try Ellis, 223, 243, 287

Commissie Kropman, 228

Commissie Logemann, 180, 228, 231, 237, 269

Commissic Oppenheim, 209, 211, 365, 434

Commissie Plantz, 248, 253

Commissie Römer, 317, 319, 320, 331, 338, 358

Commissie Staal, 141, 152, 180, 187, 201, 231

Commissie Van Helsdingen, 231

Commissie Van Poelje, 180, 228, 231, 237, 238, 248, 268, 365, 375, 434, 516

Committé tot Zaken van de Coloniën en Bezittingen op de Kust van Guinea en America, 29, 82, 83

Concordantie, 56, 161

Concordia, 48

Concordantiebeginsel, 284

Confederatie, 494

Conflicten, 305

Conflictenbesluit, 92, 101

Conflictenregeling, 186, 239, 250

Conflictontbinding, 450

Constitutioneel Hof, 394, 415, 418

Constitutionele toetsing, 554

Controle op het bestuur, 549

Conquista, 36, 112

Coro, 164

Creoolse maatschappij, 117

CPIM, 43

CSM, 43

Curaçao en onderhorigheden, 30

Curaçaosche Federatie van Werknemers, 313

Curaçaosche Liberale Partij, 191

Curaçaosche Onafhankelijke Partij, 216

Curaçaosche Politieke Unie, 192, 208, 214

Curaçaosche Protestantse Partij, 216

Curaçaosche R.K. Partij, 214

Curaçaosche Staatsregeling, 141, 185, 190, 196, 198, 209, 239, 286

Decentralisatie, $103,152,198,252,266,335,337,359,365,386,396,434$, $465,492,493,496,508,519,534,557,560$

Dekolonisatie, 17, 19, 203, 242, 274, 324, 350, 360, 361, 520, 564

Dekolonisatiebeleid, 437

Democratische Partij, 192, 214

Democratische Partij Bovenwindse Eilanden, 219

Dertig mei 1969,312

Deugdelijk bestuur, $511,522,526,536,541,545,547,556,558$

Directeur, 28, 63, 96

Districtscommissarissen, 7548

DP, 311 
Drugsmaffia, 443

Dualisme, 496

Eagle, 370

Eenheidsstaat, 496

Eenvormige landsverordening, 418

Eilandenregeling Nederlandse Antillen, 19, 182, 201, 247, 259

Eilandsraad, 210, 211, 233,259-264

Encomienda, 112

ERNA, 248, 253, 256, 267, 304, 312, 360, 367, 370, 434, 516, 539, 563

Evaluatie Statuut, 298

Federale staatsvorm, 231

Federalisme, 494

Federatie, 252, 264, 305, 320, 328, 335, 350, 360, 367, 439, 495, 516, 539, 540

Fiscaal, 59, 370

Frente Obrero y Liberacion, 314, 370

FTA, 385

Geloofsbrieven, 445

Gemeenschappelijk Hof van Justitie, 260, 418, 562

Gemeenteraad, 72, 95, 496

Gemeentewet, 180, 539, 545, 556, 559, 563

Gemenebest, 341, 345, 363, 376, 378, 398, 491

Gemengde Commissie Toekomst Antillen, 364, 399, 438

Gerecht in Eerste Aanleg, 159, 419

Gevolmachtigde Minister, 213, 281

Gezaghebber, 96, 106, 259

Gouverneur, 63, 106, 286

Grondrechten, 104

Grondwet, 196

Grote Raad, 70

Haags verdrag, 82

Handvest, 275

Harmonisatiewet, 293

Heerlijkheid, 46

Hof van Justitie, 72, 156, 198

Hoge Raad, 72, 90, 102, 156, 160, 293

Hoger beroep, 159

Hotelgaranties, 456

IMF, 334, 363, 387, 430, 442, 533, 555

Incompatibiliteiten, 426

Institute of Social Studies, 334, 336, 363, 387, 437

I.zsularisme, 441, 518

Interimregeling, 201, 238, 247, 251, 256, 264, 272, 287, 304, 366

Investeringsbank, 444

IOUWA, 385

ISS-rapport, 437 
Kabinet-Eman, 441, 452

Kabinet-Oduber I, 441

Kabinet-Lubbers II, 517

Kabinet-Oduber, 159, 452, 517

Kantongerechten, 156, 157, 159, 199

Katholieke Partij, 191, 208, 215

Katholieke Unie, 192

Katholieke Volkspartij, 217

Kiesrecht, 200

Kiesreglement, 498

Kleine Raad, 69, 155

Koloniale Raad, 72, 87, 93, 95, 103, 106, 108, 142, 146, 175, 179, 185, 241,286

Koloniale Staten, 179

Kolonisatie, 541

Koninkrijk, 106

Koninkrijk Holland, 15, 29, 84, 86, 106

Koninkrijksaangelegenheden, 280

Koninkrijkscommissie, 327, 340, 343, 346, 355, 360

Koninkrijksregering, 440, 464, 499, 527

Koninkrijkstoezicht, 2

Koninkrijkswerkgroep, 363, 387, 393, 437, 464

Kraal, 54

Kroongewest, 491, 507

$\mathrm{KvK}, 460$

Kwestie De Wit, 290, 325

Kwestie Van der Meer, 290

Lago, 45, 368, 370, 410, 429, 442

Landraad, 103, 108, 177

Landsregeling, 250

Landsverordening Administratieve Rechtspraak, 537

Landsverordening Bekendmaking en inwerkingtreding, 426

Landsverordening Openbaarheid van Bestuur, 537

Leenstelsel, 134

Legaliteitsbeginsel, 522

Liberale Volkspartij, 191

Licht Statuut, 340, 376, 481

Lodewijk Napoleon, 86

Luchtvaartprotocol, 453

Makamba, 213

MAN, 342

Marronage, 130

Medebewind, 211, 558

Meerenbergarrest, 90, 91, 107, 286

MEP, 289, 328, 337, 339, 342, 343, 344, 363, 374, 375, 378, 395, 408, $427,435,442,452,459,536$

Ministerie van Koophandel en Koloniën, 15

Ministerie van Marine en Koloniën, 15

Ministeriële Samenwerkingsraad, 415 
Ministeriële verantwoordelijkheid, 107, 244, 286

Ministerraad, 225

Movimiento Antyas Nobo, 316

Movimiento Electoral di Pueblo, 316

Nationale Volkspartij, 192, 216

Nederlands-Indiē, 222

Nederlandse Antillen, 250

Nieuw-Amsterdam, 58

Nieuw-Guinea, 222

Nieuw-Holland, 24, 54, 58

Nieuw-Nederland 24, 58

NVP, 311,312

Octrooi, 28, 52, 54, 61, 69, 80

OLA, 460

Olie-industrie, 220

Onafhankelijkheid, 355, 356, 359, 393, 442, 462, 528

Onlusten, 314, 315, 317, 319, 324, 358, 360

Ontbindingsrecht, 448,451

Oost-Indische Compagnie, 23

Openbaar Ministerie, 420

Ordre van Regieringe, $28,52,56,58,61,161$

Parlementaire onschendbaarheid, 260

Partido Democratico Arubiano, 409

Partido Democratico Boneriano, 218

Partido Obrero Boneriano, 314

Partido Patriotico Arubiano, 193, 218

Partido Patriotico Nacional, 446

Partido Progresista Boneriano, 218, 314

Patronage, $7,135,136,141,219,221,244,313,316,318,320,357,358$, $359,361,366,371-374,428,439,511,523$

Patroon, 45

PDA, 427, 445

Petroleum Protocol, 397

Plakkaat van Verlatinge, 38

Positief toezicht, 557, 562

PPA, $311,340,366,374,375,380,434,436,446,516$

Preventief toezicht, 297, 553, 557, 561

Proeve van een Unieverdrag, 405

Proeve van een vernieuwd Statuut, 505

Protocol, 536

Protocol van Willemstad, 326, 386

Provinciale status, 560

PSD, 345, 378, 436

Raad-Fiscaal, 96

Raad der Amerikaansche Coloniën en Bezittingen, 82

Raad der Colonien, 15, 29, 81

Raad van Advies, 146, 197, 225, 240 
Raad van Bestuur, 142, 148, 190, 197, 210, 225, 240

Raad van Civiele en Criminele Justitie, 71, 106, 155

Raad van Justitie, 88, 96, 156, 159

Raad van Koloniën, 15, 41, 82

Raad van Politie, 28, 32, 59, 62, 71, 79, 86, 95, 105-108, 148, 196, 516

Raad van State, 96, 147

Radiorede, 203

Rapport Dip, 266, 467, 473, 508

Rapport Jeukens, 473

Rapport Kranenburg, 336

Rechtspersoonlijkheid, 299

Rechtspraak, 107

Rechtszekerheidsbeginsel, 293

Recife, 24

Recognitiegelden, 81

Referendum, 381, 384, 396, 436, 486, 503, 515, 526, 531, 535, 536, 540, 551,565

Regeringsraad, 249

Regeringsreglement, 87, 101, 107, 185, 196, 210, 286

Regeringsreglement van $1865,14,21$

Reglement voor de Gouverneur van Aruba, 424

Regtbank, 73, 96

Repressief toezicht, 297, 552, 557, 562

Republiek der Verenigde Nederlanden, 15, 23, 53

Republiek der Verenigde Staten van Indonesië, 222

Republiek Indonesiè, 222

Rijkswet, 284

Ronde Tafel Conferentie, 178, 208, 222, 233, 243, 268

RTC, 363, 393, 395, 406, 414, 464, 492, 516, 525

RUBA, 382

Samenwerkingsregeling, 413, 438, 453, 482, 542

Schepenbank, 47

Schets voor een Gemenebestconstructie, 17, 461, 471, 478, 482, 489, 505, 525,530

Schout, 47

Separación, 218, 231, 242, 336, 363, 365, 379, 435

Shell, 43, 217, 220

Sint Eustatius en onderhorigheden, 30

Sint Maarten Patriotic Movement, 219

Slavernij, 19, 92

Solidariteits fonds, 406, 412, 488, 511

Solidariteitsheffing, 445

Soponata, 466, 557

Staatsregeling Nederlandse Antillen, 19, 259, 297, 302, 360, 370

Staten, 185, 284

Staten-Generaal, 28, 80, 82, 89, 105, 108, 175, 284

Statenbond, 494

Status Aparte, 17, 18, 159, 233, 243, 267, 301, 305, 340, 343, 348, 353, $375,397,428,436,441,442,455,482,502,517,519,525,536,560$

Statuut, 19, 135, 182, 239, 273, 278, 288, 304, 330, 332, 335, 337, 360, 
$394,414,487,488,505,511,517,534$

Suriname, $30,300,301,345,356,359,475,530$

Toekomstconferentie, $1,3,7,18,458,505,510,515,520,530,532$

Toetsing, 301, 306

Toetsingsrecht, 292

Toezicht, 200, 210, 481, 545

Trias Politica, 292, 549

Twaalfjarig Bestand, 39

Tweede Wereldoorlog, 203, 205, 222, 242

Unie, $298,410,480,483,487,507,538$

Unie van Utrecht, 38, 53

Union Nacional Arubiano, 193, 367

Union Reformista Antilliano, 312

Venezuela, 478

Verdrag van Alcobaça, 33

Verdrag van Concordia, 48

Verdrag van Tordesillas, 34

Verenigde Naties, 203, 275

Verlichting, 107

Vierschaar, 46

Vitó, 312

Voortgezet overleg, 282

Vrede van Amiens, 83

Vrede van Londen, 49

Vredegerecht, 74

VVD, 389

Weense Congres, 85

Werkbureau Kerstens, 249, 253

Werkgroep Dip, 467

Werkgroep Herstructurering Nederlandse Antillen, 471

Werkspoor Caribbean, 313

West-Indische Compagnie, 15, 21, 23, 104

West-Indische Federatie, 349, 467, 474, 538

Wet op het Nederlanderschap, 183

WIC, $23,39,40,44,51,53,55,78,80,96,107,108,162,181$

Wilde Kust, 24, 54, 219

Windward Islands Peoples Movement, 219

Zakenkabinet, 448

Zelfbeschikking, 402, 479

Zelfbeschikkingsrecht, 6, 252, 271, 273, 304, 376, 390, 392, 393, 396, 462, $479,481,490,492,525,551$

Zoutwinning, 39 
Dit boek behandelt de staatkundige ontwikkeling van de Nederlandse Antillen en Aruba van 1634 tot 1994

De geschiedenis van de koloniale staotkundige ontwikkeling is zoseel miogelijk chronologisch weergegeven aan de hand van tijdsperioden, warin zich bijzondere staotkundige ontwikkelingen voordeden.

De Europese expansic in de zestiende ecuw en de Tachtigjarige oorlog met Spanje leidden tot de verovering van de latere Antilliaanse cilanden door de West-Indische Compagnie. Vanaf 1816 stonden de koloniēn ander bet gezag van de Nederlandse staat. Van een autocratisch geregeerd wingewest werden de koloniền langramerhand een gelijkwuardig onderdecl van het Koninkrijk:

Dere ontwikkeling werd afgesloten mer de in oering van het Staruut in 1954. De dekolonisatic en de vele rapporten over de gewenste staatkundige structuar van de Antilliaanse cilanden verschaffen inzicht in de vrocgere en bestaande staatkundige en besturulifke problemen.

Hoewel Nederland sinds 1969 voor de Antillen. de onafhankelijkheid wenste: wilden de Antillen dat toen nog niet. In 1986 kreeg Aruba derelfide status als de Nederlandse Antillen binnen het Koninkrijk. De overblijvende Antilliaanse cilanden roeken sindsdien naar een nicuwe staatkundiy verband. Omdat Nederland ontevreden is over het eigen bestur van de West-Indische delen van het Koninkrijk neemt de Nederlandse invloed toe. Sommigen vien dat als 'rekolonisatie'.

Het Statuur is aan vernieuwing toe. In dit boek worden aambevelingen gedaan voor een nieuwe Koninkrijksstructuur: 